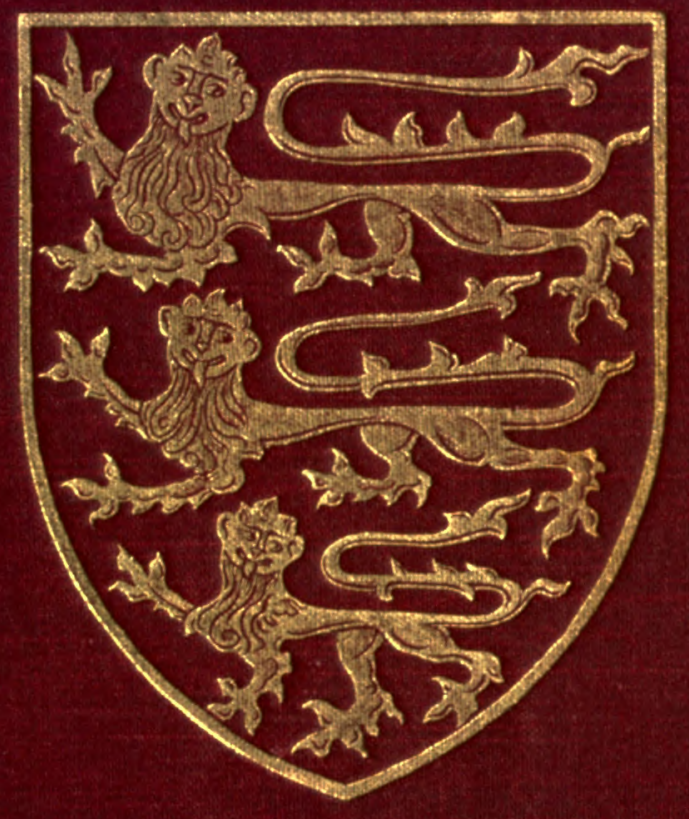




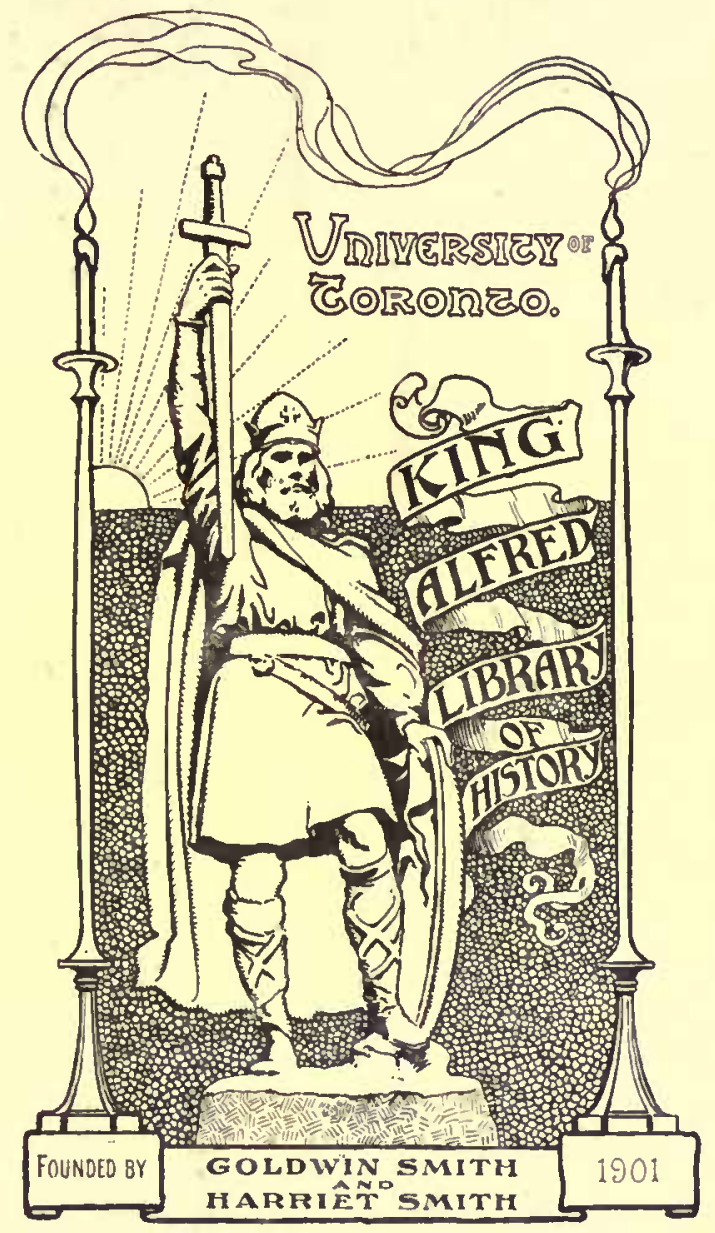





The Victoria Ibistorn of the

Countíes of England

EDITED BY H. ARTHUR DOUBLEDAY

AND WILLIAM PAGE F.S.A.

\section{A HISTORY OF ESSEX}

VOLUME I 

A HISTORY OF ESSEX IN
FOUR VOLUMES EDITED
BY H. ARTHUR DOUBLEDAY
AND WILLIAM PAGE F.S.A. 


\section{THE \\ VICTORIA HISTORY \\ OF THE COUNTIES \\ OF ENGLAND \\ ESSEX}

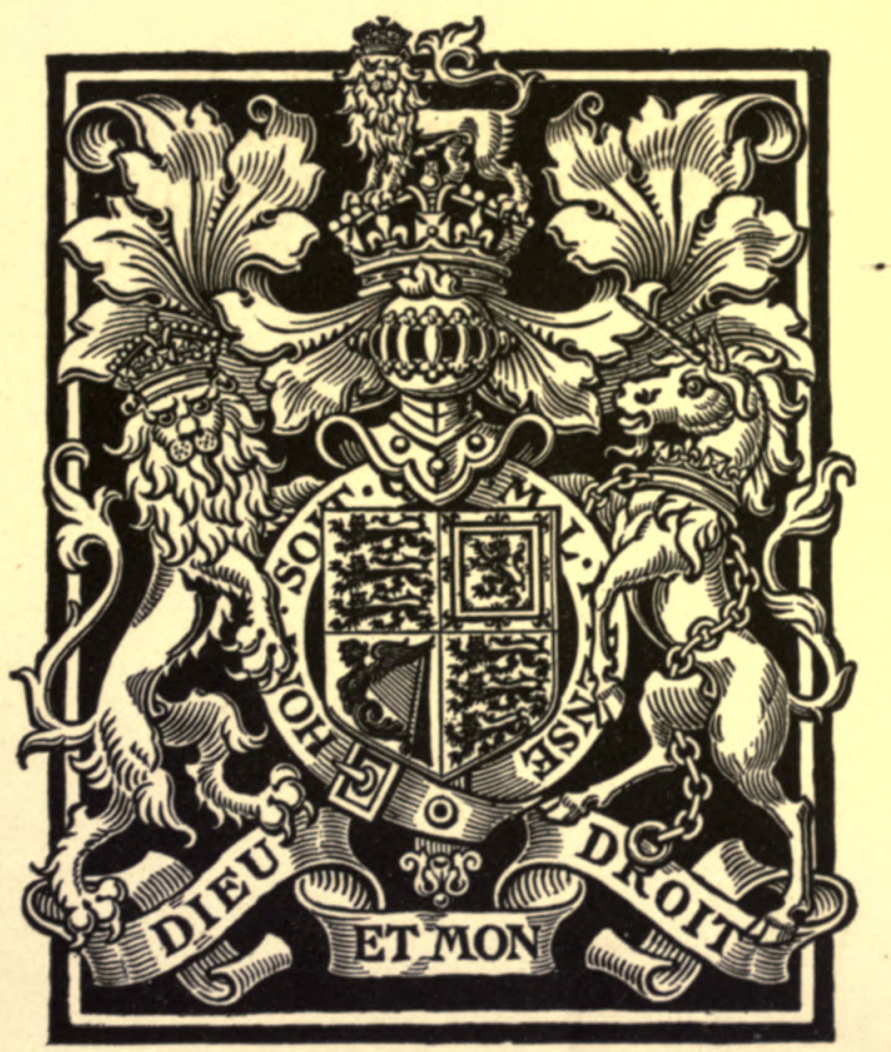

$$
\frac{59733}{2476703}
$$

WESTMINSTER

ARCHIBALD CONSTABLE

AND COMPANY LIMITED 
This History is issued to Subscribers only

By Archibald Constable Eo Company Limited and printed by Butler E Tanner of Frome and London 


\author{
INSCR I B E D \\ TO THE MEMORY OF \\ HER LATE MAJESTY \\ QUEEN VICTORIA \\ WHO GRACIOUSLY GAVE \\ THE TITLE TO AND \\ A C C E P T E D T H E \\ DEDICATION OF \\ THIS HISTORY
}




\section{THE ADVISORY COUNCIL OF THE VICTORIA HISTORY}

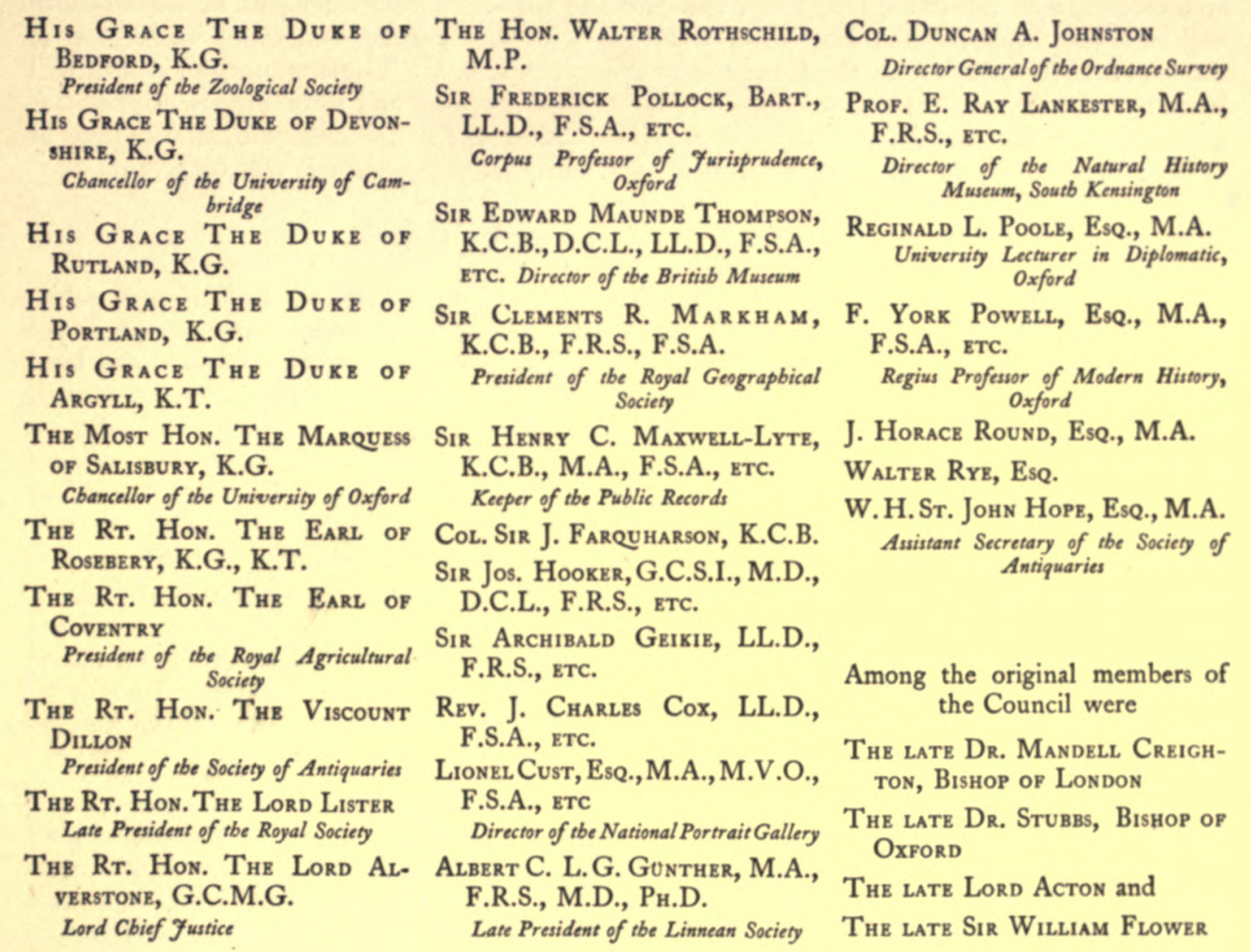
General Editors of the Series $\left\{\begin{array}{l}\text { H. Arthur Doubleday } \\ \text { William Page, F.S.A. }\end{array}\right.$

\section{GENERAL ADVERTISEMENT}

The Victoria History of the Counties of England is a National Historic Survey, which, under the direction of a large staff comprising the foremost students in science, history, and archæology, is designed to record the history of every county of England in detail. This work was, by gracious permission, dedicated to Her late Majesty Queen Victoria, who gave it her own name. It is the endeavour of all who are associated with the undertaking to make it a worthy and permanent monument to her memory.

Rich as every county of England is in materials for local history, there has hitherto been no attempt made to bring all these materials together into a coherent form.

Although from the seventeenth century down to quite recent times numerous county histories have been issued, they are very unequal in merit; the best of them are very rare and costly; most of them are imperfect and all are now out of date. Moreover they were the work of one or two isolated scholars, who, however able, could not possibly deal adequately with all the varied subjects which go to the making of a county history. 
In the Victoria History each county is not the labour of one or two men, but of several hundred, for the work is treated scientifically, and in order to embody in it all that modern scholarship can contribute, a system of co-operation between experts and local students is applied, whereby the history acquires a completeness and definite authority hitherto lacking in similar undertakings.

\section{THE SCOPE OF THE WORK}

The history of each county will be complete in itself, and its story will be told from the earliest times, commencing with the natural features and the flora and fauna. Thereafter will follow the antiquities, pre-Roman, Roman and post-Roman ; a new translation and critical study of the Domesday Survey ; articles on political, ecclesiastical, social and economic history ; architecture, arts, industries, biography, folk-lore and sport. The greater part of each history will be devoted to a detailed description and history of each parish, containing an account of the land and its owners from the Conquest to the present day. These manorial histories will be compiled from original documents in the national collections and from private papers. A special feature will be the wealth of illustrations afforded, for not only will all buildings of interest be pictured, but the coats of arms of past and present landowners will be given.

\section{HISTORICAL RESEARCH}

It has always been, and still is, a reproach to us that England, with a collection of public records greatly exceeding in extent and interest those of any other country in Europe, is yet far behind her neighbours in the study of the genesis and growth of her national and local institutions. Few Englishmen are probably aware that the national and local archives contain for a period of 800 years in an almost unbroken chain of evidence, 'not only the political, ecclesiastical, and constitutional history of the kingdom, but every detail of its financial and social progress and the history of the land and its successive owners from generation to generation.' The neglect of our public and local records is no doubt largely due to the fact that their interest and value is known to but a small number of people. But this again is directly attributable to the absence in this country of any endowment for historical research such as is to be found among other cultured nations. The government of this country has always left to private enterprise work which our continental neighbours entrust to a government department. It is not surprising, therefore, to find that although an immense amount of work has been done by individual effort, the entire absence of organization among the workers and the lack of intelligent direction has robbed the results of much of their value.

In the Victoria History, for the first time, a serious attempt is made to utilize our national and local muniments to the best advantage by carefully organizing and supervising the researches required. Under the direction of the Records Committee a large staff of experts is engaged at the Public Record Office in calendaring those classes of records which are most fruitful in material for local history, and by a system of interchange of communication among local editors each county gains a mass of information which otherwise would be lost.

\section{THE RECORDS COMMITTEE}

$\begin{array}{ll}\text { Sir Edward Maunde Thompson, K.C.B. } & \text { C. T. Martin, B.A., F.S.A. } \\ \text { Sir Henry Maxweli-Lyte, K.C.B. } & \text { J. Horace Round, M.A. } \\ \text { W. J. Hardy, F.S.A. } & \text { S. R. Scargill-Bird, F.S.A. } \\ \text { F. Madan, M.A. } & \text { W. H. Strvenson, M.A. } \\ \text { F. Maitland, M.A., F.S.A. } & \text { G. F. Warner, M.A., F.S.A. }\end{array}$

Many archæological, historical and other societies are assisting in the compilation of this work; and local supervision and aid are secured by the formation in each county, of a County Committee, the president of which is in nearly all cases the Lord Lieutenant.

The names of the distinguished men who have joined the Advisory Council are a guarantee that the work will represent the results of the latest discoveries in every department of research. It will be observed that among them are representatives of science; for the whole trend of modern thought, as influenced by the theory of evolution, favours the intelligent study of the past and of the social, institutional and political developments of national life. As these histories are the first in which this object has been kept in view, and modern principles applied, it is hoped that they will form a work of reference no less indispensable to the student than welcome to the man of culture. 
Family History will, both in the Histories and in the supplemental volumes of chart pedigrees, be dealt with by genealogical experts and in the modern spirit. Every effort will be made to secure accuracy of statement, and to avoid the insertion of those legendary pedigrees which have in the past brought discredit on the whole subject. It has been pointed out by the late Bishop of Oxford, a great master of historical research, that 'the expansion and extension of genealogical study is a very remarkable feature of our own times,' that 'it is an increasing pursuit both in America and England,' and that it can render the historian useful service.

Heraldry will also in this Series occupy a prominent position, and the splendours of the coat-armour borne in the Middle Ages will be illustrated in colours on a scale that has never been attempted before.

The general plan of Contents, and the names of the Sectional Editors (who will co-operate with local workers in every case) are as follows :-

Natural History.

Geology. By Clement Reid, F.R.S., Horace B. Woodward, F.R.S., and others

Palæontology. Edited by R. Lydekker, F.R.S., etc.

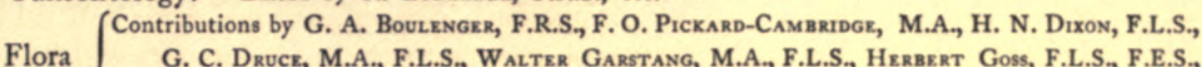
Fauna $\begin{aligned} & \text { R. I. Pocock, Rev. T.R. R. Steasing, M.A., F.R.S., etc., B. B. Woodward, F.G.S., F.R.M.S., } \\ & \text { etc., and other Specialists }\end{aligned}$

Prehistoric Remains. Edited by W. Bord Dawriks, D.Sc., LL.D., F.R.S., F.S.A.

Roman Remains. Edited by F. Haverrixıd, M.A., F.S.A.

Anglo-Saxon Remains. Edited by C. Hercules Read, F.S.A., and Reginald A. Sмith, B.A.

Ethnography. Edited by G. LaURence Gomme, F.S.A.

Dialect. Edited by Joszpr Wright, M.A., Ph.D.

Place Names

$\left.\begin{array}{l}\begin{array}{l}\text { Folklore } \\ \text { Physical Types }\end{array}\end{array}\right\}$ Contributed by Various Authorities

Domesday Book and other kindred Records. Edited by J. Horsce Round, M.A.

Architecture. By Various Authorities. The Sections on the Cathedrals and Monastic Remains Edited by W. H. St. John Hope, M.A.

Ecclesiastical History. Edited by R. L. Pootr, M.A.

Political History. Edited by W. H. Stevenson, M.A., J. Hognce Round, M.A., Pror. T. F. Tout, M.A., JaMEs TAit, M.A., and C. H. Firth, M.A.

History of Schools. Edited by A. F. LEAcн, M.A., F.S.A.

Maritime History of Coast Counties. Edited by J. K. Lavgrton, M.A., and M. Oppenherm

Topographical Accounts of Parishes and Manors. By Various Authorities

History of the Feudal Baronage. Edited by J. Horace Round, M.A., and Oswald Barron, F.S.A.

Family History and Heraldry. Edited by Oswald Barron, F.S.A.

Agriculture. Edited by Sir ERnest Clarkr, M.A., Sec. to the Royal Agricultural Society

Forestry. Edited by Jонn Nisket, D.Овс.

Industries, Arts and Manufactures

Social and Economic History

Persons Eminent in Art, Literature, Science

By Various Authorities

Ancient and Modern Sport. Edited by the Duke of Beaufort

Hunting

Shooting

Fishing, etc.

Cricket. Edited by Home Gordon

Football. Edited by C. W. Ascock

Bibliographies

Indexes

Names of the Subscribers

\section{ILLUSTRATIONS}

Among the many thousands of subjects illustrated will be castles, cathedrals and churches, mansions and manor houses, moot halls and market halls, family portraits, etc. Particular attention will be given to the beautiful and quaint examples of architecture which, through decay or from other causes, are in danger of disappearing. The best examples of church brasses, coloured glass, and monumental effigies will be depicted. The Series will also contain 160 pictures in photogravure, showing the characteristic scenery of the counties. 


\section{CARTOGRAPHY}

Each History will contain Archæological, Domesday, and Geological maps; maps showing the Orography, and the Parliamentary and Ecclesiastical divisions; and the map done by Speed in 16 10. The Series will contain about four hundred maps in all.

\section{FAMILY HISTORY AND HERALDRY}

The Histories will contain, in the Topographical Section, manorial pedigrees, and accounts of the noble and gentle families connected with the local history ; and it is proposed to trace, wherever possible, their descendants in the Colonies and the United States of America. The Editors will be glad to receive information which may be of service to them in this branch of the work. The chart family pedigrees and the arms of the families mentioned in the Heralds' V isitations will be issued in a supplemental volume for each county.

The Rolls of Arms are being completely collated for this work, and all the feudal coats will be given in colours. The arms of the local families will also be represented in connection with the Topographical Section.

In order to secure the greatest possible accuracy in the descriptions of the Architecture, ecclesiastic, military and domestic, a committee has been formed of the following students of architectural history, who will supervise this department of the work :-

\section{ARCHITECTURAL COMMITTEE}

J. BILSON, F.S.A., F.R.I.B.A.

R. BLOMFIELD

Harol.d Brakspear, A.R.I.B.A.

Prof. BaldWin Brown

Arthur S. Flower, F.S.A., A.R.I.B.A.

GroRge E. Fox, M.A., F.S.A.

J. A. Gотсн, F.S.A., F.R.I.B.A.
W. H. ST. JoHn Hope, M.A.

W. H. KNowles, F.S.A., F.R.I.B.A.

J. T. MicklethWaite, F.S.A.

Roland Paul

J. Horace Round, M.A.

Percy G. Stone, F.S.A., F.R.I.B.A.

ThaCKeray TURNeR

A special feature in connection with the Architecture will be a series of coloured ground plans showing the architectural history of castles, cathedrals and other monastic foundations. Plans of the most important country mansions will also be included.

The issue of this work is limited to subscribers only, whose names will be printed at the end of each History. 



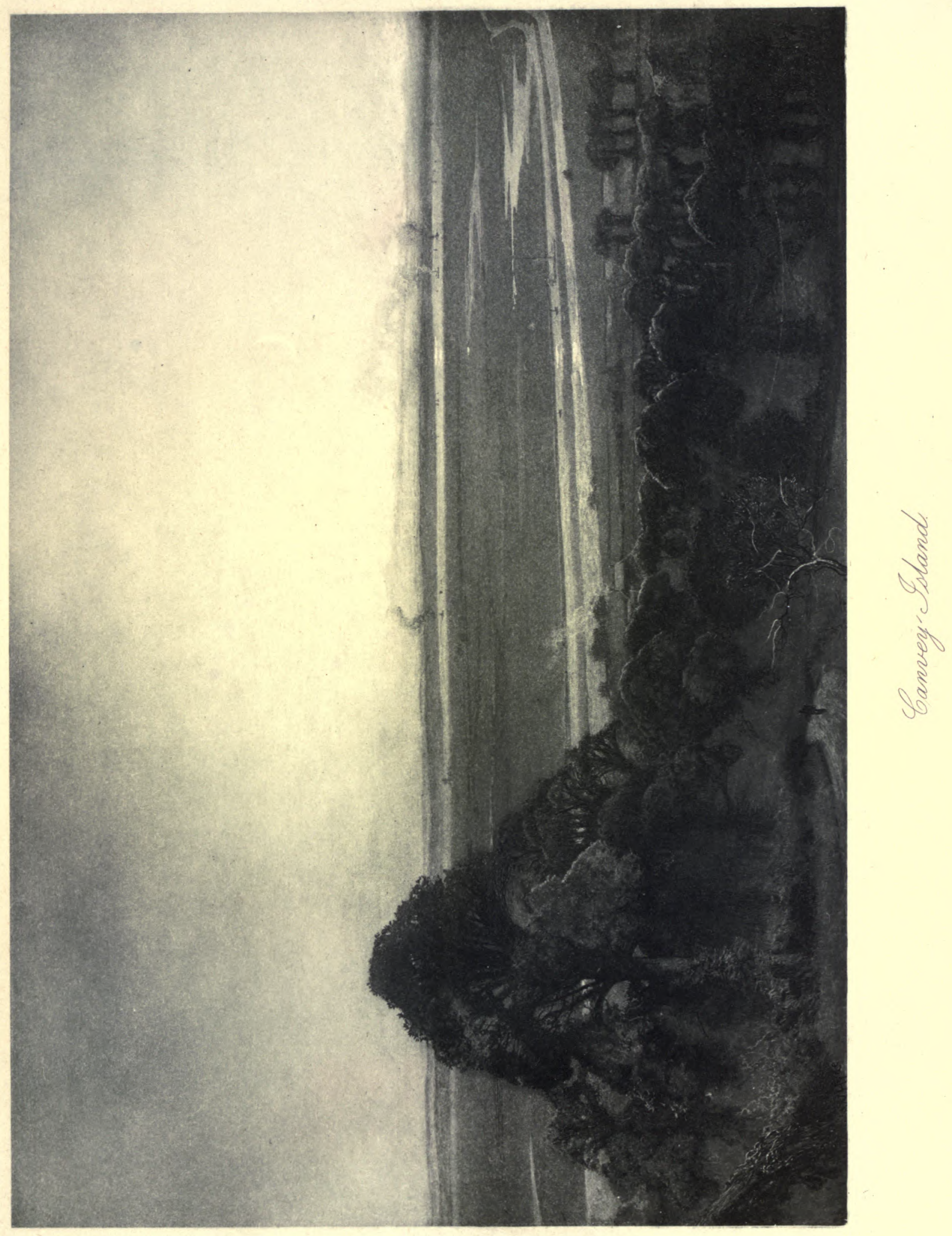




\section{THE \\ VICTORIA HISTORY \\ OF THE COUNTY OF \\ ESSEX}

VOLUME ONE

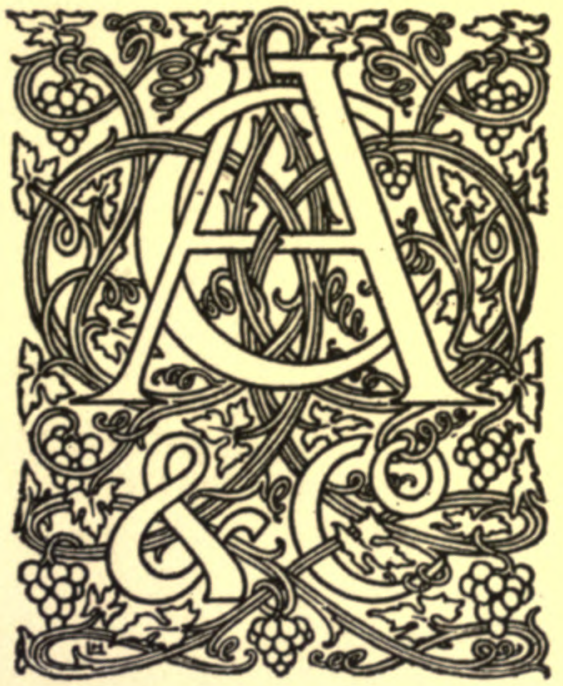

WESTMINSTER

2 WHITEHALL GARDENS

I9O3 
vas

$$
\begin{aligned}
& D A \\
& 670 \\
& E 7 V_{6} \\
& V .1
\end{aligned}
$$




\section{County Committee for Esgex}

\section{THE RT. HON. THE EARL OF WARWICK Lord Lieutenant, Chairman}

The Rt. Hon. The Lord Claud J. Claude E. Egerton-Green, EsQ., M.A., HamiLton

J.P., D.L.

The Rt. Rev. The Lord Bishop of St. E. A. Fitch, EsQ., F.L.S., F.E.S. Albans

The Rt. Hon. The LoRd Rayleigh

The RT. Hon. The LoRd Hawkesbury John Lewis FFYTChe, EsQ., F.S.A., J.P., D.L. The Rev. F. W. Galpin, M.A., F.L.S.

A. R. Goddard, EsQ.

The Rt. Hon. Sir Joseph C. Dimsdale, BarT., M.P.

The Rt. Hon. James Round, M.P.

I. C. Gould, Eso.

Horace G. Egerton Green, EsQ., J.P., D.L.

Hugh E. Hoare, EsQ.

The Hon. Charles Hedley Strutt, M.P. Thomas Vincent Holmes, EsQ., F.G.S., Sir Thomas L. H. Neave, Bart.

Sir Walter Gilbey, Bart. M.A.I.

Sir James Blyth, Bart.

Sir Edmund du Cane, K.C.B.

David Howard, Esq., D.L.

Eliot Howard, EsQ., J.P., D.L.

Henry Joslin, EsQ., J.P., D.L.

Admiral Sir William G. Luard, K.C.B. Sir H. Seymour King, K.C.I.E., M.P.

The Rt. Rev. The Bishop of Colchester The Rt. Rev. The Bishop of Barking

The Worshipful The Mayor of ChelmsFORD

The Worshipful The Mayor of ColCHESTER

The Worshipful The Mayor of Harwich The Worshipful The Mayor of Maldon

Col. George Bramston Archer-Houblon, J.P.

James Bailey, EsQ., M.P., J.P.

Commander Kelso, R.N., J.P., D.L.

The Rev. J. W. Kenworthy

Frank Landon, Eso.

Henry Laver, Esq., F.S.A., F.L.S.

Col. A. R. M. Lockwood, M.P., J.P.

Grorge Alan Lowndes, EsQ., J.P., D.L.

James H. A. Majendie, Esq., M.P., J.P., D.L.

Wilson Marriage, EsQ., J.P.

R. Meldola, EsQ., F.R.S., F.R.A.S., F.C.S.

Major F. L. Nathan, R.A.

W. Nocton, EsQ., J.P.

The Rev. Canon C. F. Norman, M.A., J.P.

Christopher W. Parker, Esq., J.P., D.L.

Thomas Barrett-Lennard, EsQ., J.P., D.L. James N. Paxman, EsQ., J.P.

The Rev. R. E. Bartlett, M.A.

G. F. Beaumont, Eso., F.S.A.

Charles E. Benham, Esq.

J.Timbrell Pierce, Ese., F.R.G.S., J.P., D.L.

The Rev. Lewis N. Prance, M.A.

J. Horace Round, Esq., D.L.

W. Gurney Benham, EsQ., J.P.

G. S. Boulger, Ese., F.L.S., F.G.S.

A. W. Ruggles-Brise, EsQ., J.P., D.L.

J. C. Shenstone, EsQ., F.L.S.

E. N. Buxton, EsQ.

Frederic Chancellor, EsQ., F.R.I.B.A.

Miller Christy, EsQ., F.L.S.

R. Beale Colvin, EsQ., J.P., D.L.

Grorge Courtauld, Esq., J.P.

The Rev. Cecil Deedes, M.A.

Charles Brogden Sperling, EsQ., J.P., D.L.

C. F. D. Sperling, EsQ., J.P.

Col. Nevill Tufnell, J.P., D.L.

Col. J. L. Tufnell-Tyrell, J.P., D.L.

W. Chapman W aller, EsQ., F.S.A.

James F. T. Wiseman, EsQ. 


\section{CONTENTS OF VOLUME ONE}

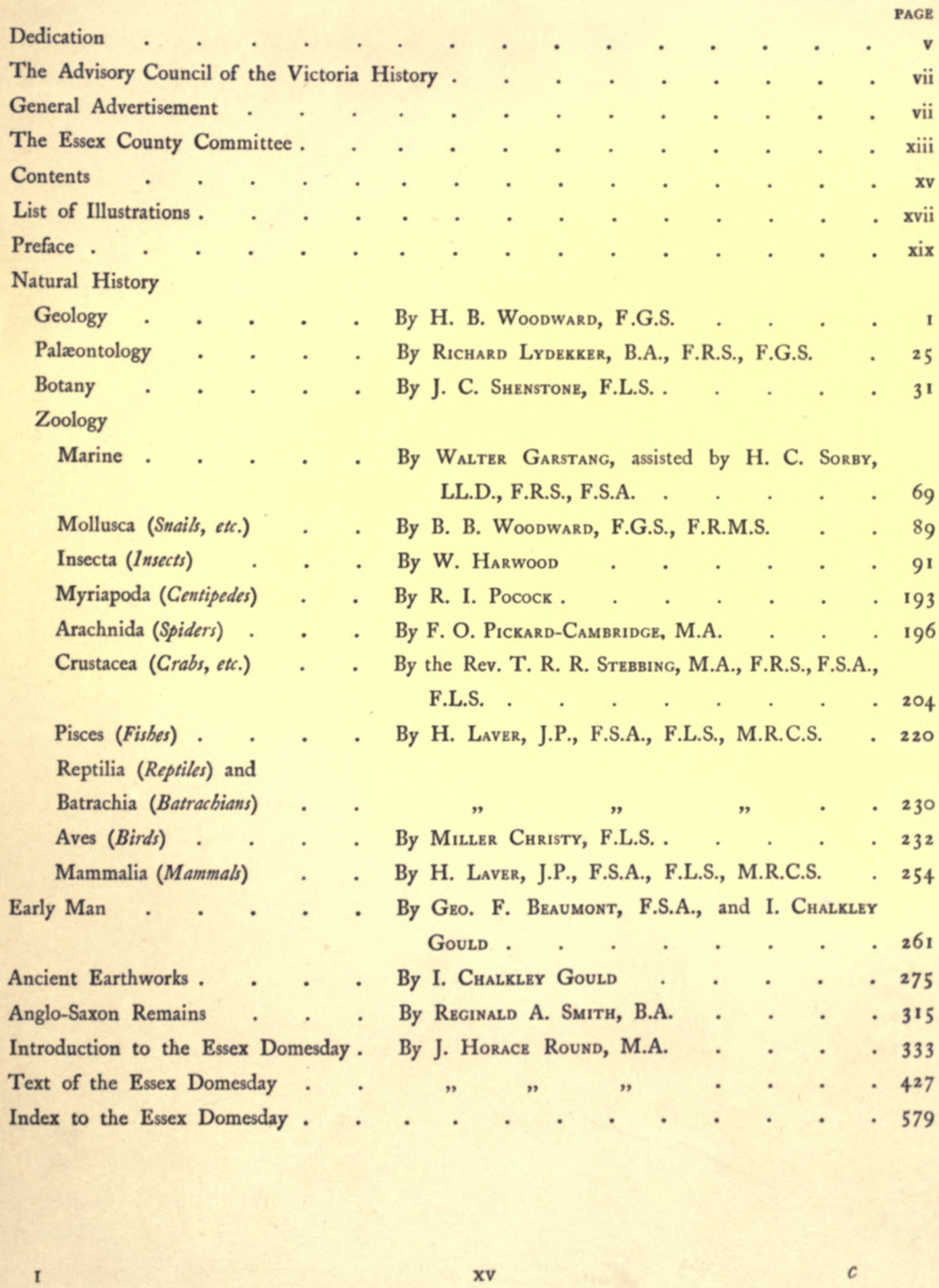




\section{LIST OF ILLUSTRATIONS}

Canvey Island. By WilLiam Hyde

PAGE

Palæolithic Weapons from the Lea Valley

Neolithic Celts from Inworth and Stisted $\}$

frontispiece

Weapons from Walton, Shoebury, Dovercourt, near Stansgate and

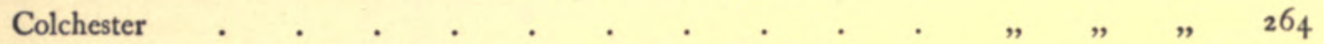

Pottery from Chesterford, Great Clacton, Great Oakley and Colchester " " " $\quad 265$

Penannular Armlet and Palstave from Shoebury . . . . . . . . 266

Palstaves from Shoebury and Pleshey..$\dot{ } \cdot\}$. . . . full-page plate, facing 266

Bronze Spearheads from Plaistow Marshes, Walthamstow, and

Hatfield Broad Oak . . . . . . . . ” ” ” 267

Handles of a Bronze Cauldron from Hatfield Broad Oak . . )

Part of the Box of a Chariot Wheel, with Nails, found at Shoebury $\} \quad$ " , $\quad 268$

Parts of the Rim of a large Vessel from Hatfield Broad Oak . )

Late Celtic Vessels, etc. . . . . . . . . . . . N $\quad$. $\quad 269$

Implements from Site of Fascine Dwellings . $\}$. . . , , , 270

Loughton Camp . . . . . . . . . . . . . . . 277

Ambresbury Banks . . . . . . . . . . . . . 278

Ring Hill Camp, Littlebury . . . . . . . . . . . 280

Uphall Entrenchments, near Barking . . . . . . . . . . $28 \mathbf{1}$

Wallbury Camp . . . . . . . . . . . . . . 282

Pitchbury Ramparts, Great Horkesley . . . . . . . . . . 285

Shoeburyness . . . . . . . . . . . 287

Witham Bury . . . . . . . . . . . . 288

Berden Mound . . . . . . . . . . . . . 289

Great Canfield . . . . . . . . . . . . . 290

Clavering . . . . . . . . . . . . . . 292

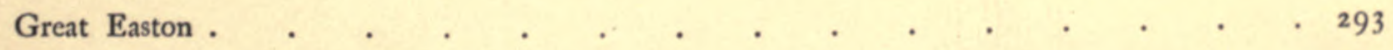

Mound in Castle Grove, Elmdon . . . . . . . . . . . 294

Hedingham Castle . $. \quad . \quad . \quad . \quad . \quad . \quad . \quad . \quad . \quad . \quad . \quad .294$

Ongar Castle . . . . . . . . . . . . . . . . 297

Pleshey . . . . . . . . . . . 298

Rayleigh Mount . . . . . . . . . . . . 300

Rickling. . . . . . . . . . . . . 301

Stansted . 


\section{LIST OF ILLUSTRATIONS}

Stebbing Mount . . . . . . . . . . . . . 302

Sections of a Denehole and Ground Plan of Chambers . . . . . . 309

Anglo-Saxon Objects . . . . . . . . . . . coloured plate facing 322

Bronze Pan from Broomfield . . . . . . . . . . . . 322

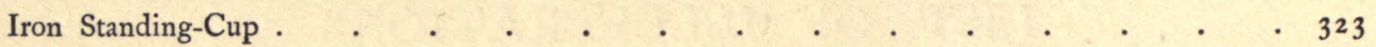

Pottery Vase . . . . . . . . . . . . . . . . . 324

Turold . . . . . . . . . . . . full-page plate facing 342

Milking Ewes )

$\left.\begin{array}{l}\text { Wallasea Island } \\ \text { Canvey Island }\end{array}\right\} \cdot+\cdot \cdot \cdot \cdots \quad \cdot \quad \cdot \quad \cdot \quad \cdot \quad \cdot 369$

\section{LIST OF MAPS}

Geological Map

Botanical Map

Pre-Historical Map

Earthworks Map

Anglo-Saxon Map

Domesday Map 


\section{PREFACE}

$7 \mathrm{HE}$ only complete history of Essex hitherto issued is that of Philip Morant, published in 1768 and reprinted in $1816 .^{1}$ It

1 may perhaps be reasonably claimed that the county is entitled to a newer history and one more complete than could be compiled in the eighteenth century.

The aims of the series of which the Victoria History of Essex forms a part are to be found in the General Advertisement printed in this volume.

It has been found impossible in the present instance to adhere to chronological order in the sequence of the articles included in this volume. It is hoped to print the section on the Romano-British Period in the second volume.

Whilst the editors cannot as a rule make special reference to the services of contributors, they feel in the present instance it is only right to acknowledge their great indebtedness to Mr. J. Horace Round, not only for the infinite pains he has expended under adverse circumstances of health on the Domesday section, which in the case of Essex is one of peculiar difficulty, but also for the valuable help he has given to others in the preparation and revision of their articles.

1 It would appear that Morant did little more than edit materials collected by previous students of Essex history (see 'Historians of Essex,' Essex Review, iii. 27-41, 238-53). 


\section{A HISTORY OF ESSEX}





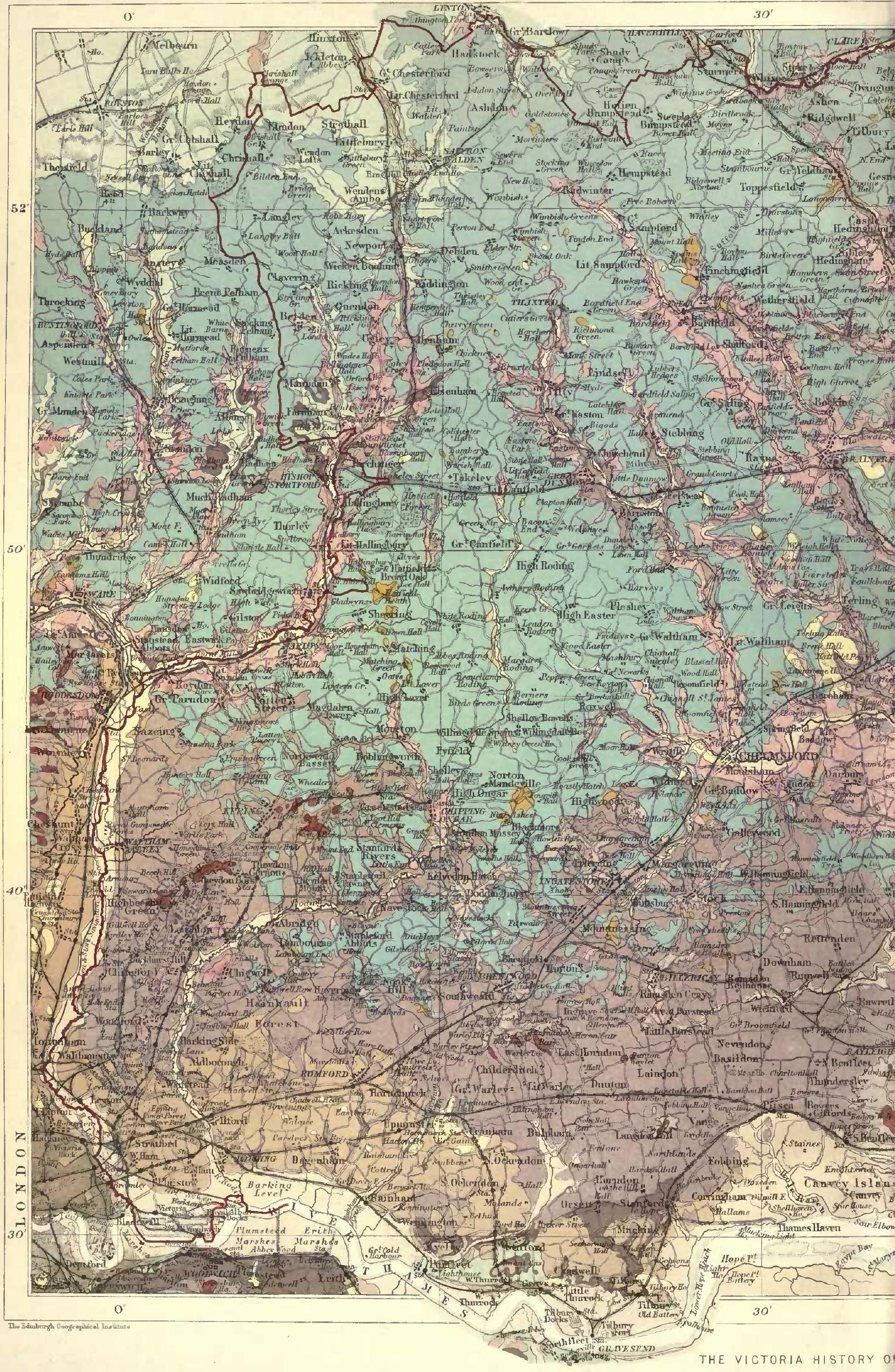




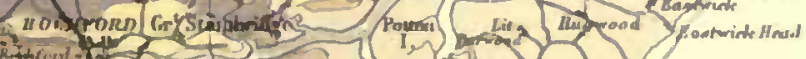

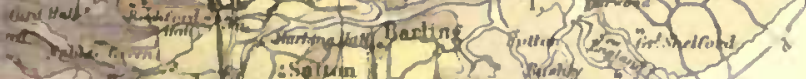

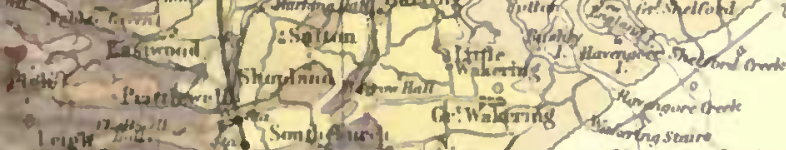

briph siatlls

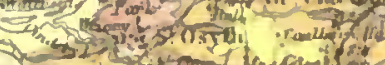

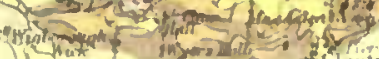

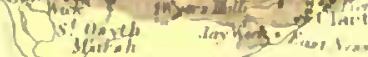

iostret

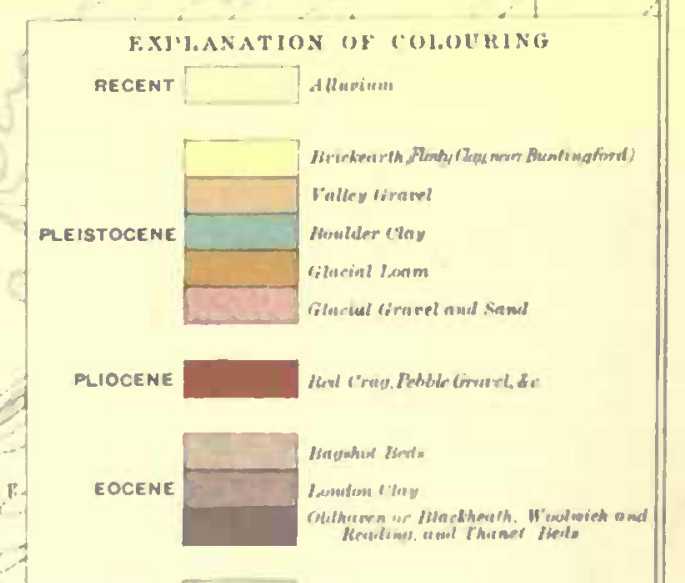

CRETACEOUS In:HA 



\section{GEOLOGY}

$\mathrm{E}$

SSEX occupies a large part of the irregular tract which is known to geologists as the London Basin, and which has for its framework the great Chalk formation. The southern rim of this Basin rises in the North Downs of Kent, whence the Chalk slopes gradually to the borders of the Thames at Erith and Gravesend, comes to the surface in south Essex at Purfleet and Grays, and then sinks below ground over the greater part of the county. The northern rim of the Basin appears in the downs of Dunstable, Luton and Royston, and in the uplands of Heydon and Saffron Walden in Essex.

The contour of the Chalk Basin is to some extent modified by slight undulations and fractures along the Kentish side of the Thames between Greenwich and Erith, so that while the curvature is for the most part gentle, the inclination becomes somewhat steeper on the southern side of Essex. Hence at Dagenham, Rettenden and Southend the Chalk is about 400 feet below ground, at Chelmsford it is about 360 feet, and thence northward it more gradually approaches the surface. Near Heydon however there are some striking evidences of local disturbance, to which further reference will be made.

Resting in the hollow of the Basin, and conforming generally with its curvature, is a series of Eocene strata, the most important of which is the London Clay. The succeeding deposits include small outlying tracts of Crag, but they consist chiefly of the irregular and variable accumulations grouped as 'drift.' These lie scattered over the uplands in the form of gravel and Boulder Clay, and are spread along the river valleys in the form of gravel, brickearth and alluvium.

The structure of the ground is thus comparatively simple, but there are difficulties in the determination of the relative ages of some of the scattered superficial deposits. There are grave difficulties also when it is sought to decipher the underground rocky structure beneath the Chalk and other Cretaceous strata. The problem is of the highest interest and practical importance, but it raises questions which deep borings alone can solve.

Although the county is essentially a flat one, and especially along the river and sea coasts which are bordered by marshes, yet inland there is an abundant variety of soil, and these regions are very pleasantly diversified with arable land and pasture, with woodlands, commons and welltimbered hedgerows. Indeed to quote an old agricultural work, 'Every species of soil, from the most stubborn to the mildest loam, is to be found.' ${ }^{1}$

1 General View of Agric. of Essex, by Messrs. Griggs, 4to (Lond. 1794), p. 7. 


\section{A HISTORY OF ESSEX}

To the geologist the richly fossiliferous strata of the Red Crag at Walton-on-the-Naze, and the Pleistocene valley-deposits with their many notable remains of mammalia and mollusca, have attracted a large share of attention.

Our knowledge of Essex geology, due chiefly to the labours of Prestwich, Searles V. Wood, jun., Prof. W. Boyd Dawkins, and Mr. W. Whitaker, has been augmented by the workers of the Essex Field Club and of the Geologists' Association, and notably by Mr. T. V. Holmes. ${ }^{1}$

The following is a Table of the Formations met with in Essex, the names in italics referring to those not exposed at the surface :-

\begin{tabular}{|c|c|c|c|}
\hline Period & Formation & Character of the strata & $\begin{array}{l}\text { Approximate } \\
\text { thickness } \\
\text { in feet }\end{array}$ \\
\hline $\begin{array}{l}\text { Rece } \\
\text { Neo }\end{array}$ & 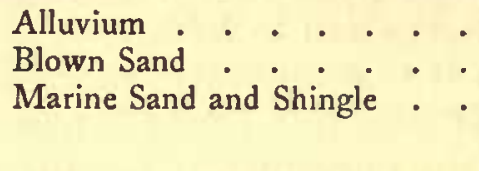 & $\begin{array}{l}\text { Silt, peat, clay . } \\
\text { Fine sand } \\
\text { Sand with shells and pebbles of } \\
\text { flint, quartz, etc. . }\end{array}$ & $\begin{array}{l}20 \text { to } 50 \\
\text { about } 15 \\
\text { about } 10\end{array}$ \\
\hline $\begin{array}{c}\text { Pleistocene, } \\
\text { Palæolithic } \\
\text { and } \\
\text { Glacial }\end{array}$ & 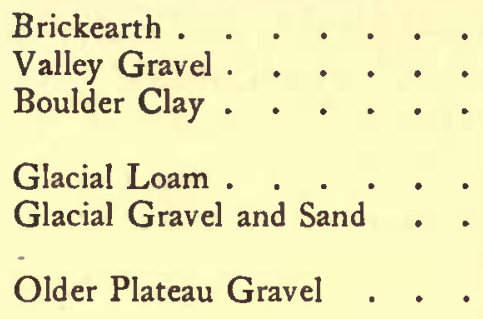 & $\begin{array}{l}\text { Loam . } \\
\text { Sub-angular flint gravel } \\
\text { Chalky clay, with flints and } \\
\quad \text { erratics. } . . \\
\text { Loam . } \\
\text { Sub-angular gravel with flints, } \\
\text { quartzite, etc.. } \\
\text { Pebbles of flint and quartz. }\end{array}$ & $\begin{array}{l}10 \text { to } 30 \\
10 \text { to } 50 \\
20 \text { to } 70 \\
10 \text { to } 15 \\
20 \text { to } 75 \\
5 \text { to } 12\end{array}$ \\
\hline Pliocene & $\mathrm{ag} \cdot$. . . . . & $\begin{array}{l}\text { Red shelly sand and gravel, } \\
\text { laminated clay, phosphatic } \\
\text { nodules and ironstone } .\end{array}$ & 5 to 21 \\
\hline Eocene & 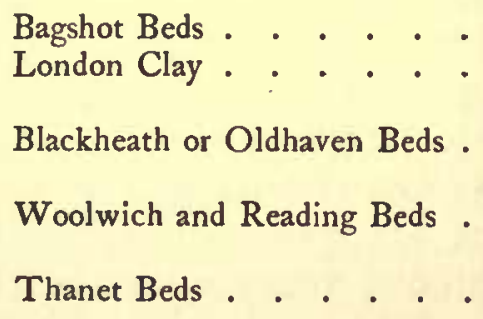 & $\begin{array}{l}\text { Sand and pebble beds . } \\
\text { Brown and blue clay with } \\
\text { septaria. } \\
\text { Sand with shells and flint } \\
\text { pebbles } \\
\text { Mottled clay, sand, and flint } \\
\text { pebbles. } \\
\text { Grey sand and sandy clay. }\end{array}$ & $\begin{array}{l}20 \text { to } 40 \\
400 \\
10 \text { to } 50 \\
25 \text { to } 80 \\
10 \text { to } 85\end{array}$ \\
\hline $\begin{array}{c}\text { Upper } \\
\text { Cretaceous }\end{array}$ & 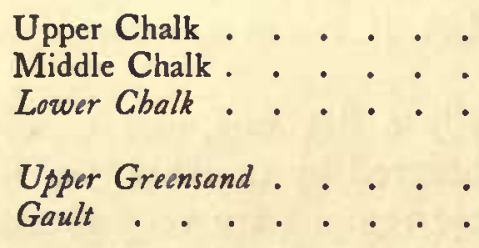 & $\begin{array}{l}\text { Chalk with flints } \\
\text { Bedded chalk with few flints. } \\
\text { Blocky chalk with curved } \\
\text { jointing, and marl } \\
\text { Green sand and brown loam } \\
\text { Clay and marl. }\end{array}$ & $\begin{array}{l}400 \text { to } 450 \\
200 \\
120 \\
30 \\
50 \text { to } 170\end{array}$ \\
\hline Palceozoic & Silurian? (or older) . . . . & Slaty rock. . . . . . & unknown \\
\hline
\end{tabular}

1 See Bibliography in Whitaker's 'Geology of the London Basin,' Mem. Geol. Survey, vol. i. (1872) p. 393 ; and Geology of London, vol. i. (1889) p. 87 ; also 'List of Works on the Geology, etc., of Essex,' by W. Whitaker and W. H. Dalton, Essex Nat., vol. iii. (1889) Pp. 61-84. 


\section{GEOLOGY}

\section{PALÆOZOIC ROCKS}

The question whether productive Coal Measures are likely to occur at a workable depth beneath Essex is one which has aroused keen interest of late years. So long ago as $185^{8}$ a boring at Harwich proved the occurrence of a dark slaty rock beneath the Gault, at a depth of 1,029 feet from the surface. ${ }^{1}$ It was then thought that this rock, which was penetrated to a depth of 69 feet, was of Lower Carboniferous age owing to the supposed occurrence in it of the fossil mollusc Posidonomya. The specimen was however re-examined in 1896 by Prof. W. W. Watts, and he came to the conclusion that, while the rock itself was not at all like that of any known British Carboniferous rock, the supposed fossil was an inorganic structure. ${ }^{3}$

A somewhat similar dark slaty rock was touched at a depth of 994 feet in a trial boring in Suffolk, at Stutton on the northern side of the Stour estuary ; and again in a further trial in Essex, at Weeley between Colchester and Walton-on-the-Naze, where the old rock was reached at a depth of 1,094 feet. $^{3}$

These two trials in search of Coal Measures were made after due deliberation with the highest geological authorities. That they were unsuccessful is an indication, not that the chances of obtaining coal beneath Essex are hopeless, but that scientific knowledge is insufficient to tell precisely where concealed coal-basins occur. Nevertheless enterprise need not be damped. There is always a possibility of finding coal where the strata at the surface are newer than the Coal Measures; but as the older rocks were bent and fractured and largely eroded before the Secondary and Tertiary strata were spread over them, it is evident how speculative must be the search for Coal Measures under these circumstances. Were the exposed coalfields to be covered up with a mantle of Chalk, we should have no certain guide from one successfut boring as to the nature of the deep-seated rocks at a distance of a few miles, because there is no regularity in the preservation of coal-basins. Again if rocks much older are proved in a boring, it is quite possible that Coal Measures may exist near by, because in south Staffordshire, Leicestershire and Warwickshire the older Palæozoic rocks occur in juxtaposition with productive Coal Measures.

It has lately been suggested by Prof. W. J. Sollas that Enfield Lock, just across the Lea on the Hertfordshire side, is a likely place for a successful trial. It may be so, but there is no information that would prove that it is a more promising site than any other unproved locality in Essex or Hertfordshire."

In Essex several deep borings have been made in search of water. Thus at Wickham Bishop a boring was carried to a depth of 1,180 feet,

1 Prestwich, Quart. Jourm. Geol. Sec., vol. xiv. p. 252.

Ann. Report of Geol. Survey for 1896, p. 5. 18 Whitaker, Rep. Brit. Assoc. for 1895.

4 For further information on the underground rocks sce Whitaker, Geology of London, vol. i. p. 10. (In this work full references are made to the suggestions of Godwin-Austen, Prestwich and others on the older deep-seated rocks.) 


\section{A HISTORY OF ESSEX}

including 703 feet of Chalk (base not reached). It is probable that the thickness of the Eocene strata was here to a certain extent duplicated by a reversed fault or fold. ${ }^{I}$ At Loughton a boring was made to a depth of I, 100 feet into Gault; and at South Shoebury another was carried I, 048 feet, probably into Lower Chalk. An old boring at Saffron Walden was carried to a depth of a little over 1,000 feet, but the details of the strata cannot now be interpreted with certainty. In all of these borings, if we except the Palæozoic rock, the oldest formation whose age has been proved is the Gault.

\section{GAULT AND UPPER GREENSAND}

The Gault consists of stiff blue and grey clay and marl, which was proved to have a thickness of 172 feet in the deep boring at Loughton. It was found below Harwich and Weeley, and is probably everywhere present beneath the Chalk under Essex; but it evidently becomes thinner towards the north-east, as it was only 50 or 60 feet thick at Harwich.

There is evidence of the presence of Upper Greensand beneath a portion of Essex along the Lea valley. Mr. Whitaker has remarked that this formation was found beneath the Chalk at Cheshunt, and was met with in the deep well at Loughton, the thickness being about 30 feet. Below the Gault at Loughton there was sand, which may possibly represent Lower Greensand. ${ }^{2}$

\section{CHALK}

The Chalk appears at the surface over a comparatively small portion of Essex, but where it does occur its presence is usually indicated by pits and lime-kilns.

The Lower Chalk in Cambridgeshire includes at its base the wellknown bed of phosphatic nodules and phosphatized fossils termed the ' Cambridge Greensand,' but whether or not this bed occurs underground in the northern part of Essex is unknown. Above is the Chalk Marl, a mass of grey marl 50 or 60 feet thick, which yields Ammonites varians, Inoceramus latus and other fossils. Still higher we come to the Totternhoe Stone, a hard band of somewhat sandy rock, which north of Heydon is a noted water-bearing stratum, strong springs being thrown out at its junction with the Chalk Marl. The Totternhoe Stone is characterized by Rbyncbonella mantelliana, Kingena lima, Pecten orbicularis and $P$. fissicostata. The uppermost portion of the Lower Chalk comprises a mass of grey chalk or clunch which yields Belemnitella (Actinocamax) plena and Holaster subglobosus. ${ }^{3}$ These portions of the Chalk do not appear at the surface in Essex, but they no doubt occur everywhere below ground.

The Middle Chalk, which is exposed north of Heydon, at Great

1 See Whitaker, Trans. Essex Field Club, vol. iv. pp. 149, 168.

2 Ibid. vol. iv. pp. 158, I59; and Quart. Journ. Geol. Soc., vol. lvi. p. lxxv.; and Jukes-Browne, Cretaceous' Rocks of Britain, vol. i. p. 370.

3 See W. Hill and A. J. Jukes-Browne, Quart. Fourn. Geol. Soc., vol. xlii. p. 2 I6. 


\section{GEOLOGY}

Chesterford, Hadstock, and Sturmer near Haverhill, includes at its base the Melbourn Rock, named from the Cambridgeshire village of Melbourn. This is a hard rocky chalk with marly and nodular layers, about ten feet in thickness. The mass of the Middle Chalk above is well bedded in layers that appear to be lenticular or wedge-shaped, and it has but few flints. Among the fossils are Rbyncbonella cuvieri, Terebratulina, and Holaster subglobosus. The last-named fossil is found also in a band of hard cream-coloured limestone with green coated nodules and grains of glauconite, known as the Chalk Rock, which separates the Middle from the Upper Chalk. The Chalk Rock has been observed in several places in the northern portions of the county.

Between Heydon and Chishall the Chalk is locally disturbed, and instead of the normal southerly or south-easterly dip at a gentle angle, the strata are inclined at an angle of $25^{\circ}$ N.N.W., and the flints are fractured. This high dip increases to the south-west in Hertfordshire. Whether the disturbance is due to faulting or to the surface derangements produced by glacial agents has not been satisfactorily determined. That glacial action has been potent is manifest from the deeply excavated trough near Newport, to which reference will be made.

The Upper Chalk, which lies about 43 feet below the surface near the Thames at Beckton, appears above ground at Grays and Purfleet in south Essex; and in the north it may be seen at Farnham and Clavering in the Stort valley, at Quendon, Newport, Audley End and Saffron Walden in the Cam valley, and eastwards at Great Yeldham and Middleton, near Sudbury. It consists of soft chalk with layers of flints, and yields remains of the saurian Leiodon (allied to Mosasaurus), of fishes such as Ptycbodus polygyrus, molluscs including Inoceramus and Lima, brachiopods such as Terebratula carnea, the echinoderms Cidaris and Goniaster, as well as crinoids and corals.

At Purfleet, Grays and West Thurrock the Chalk has been largely used in the manufacture of whiting, lime and cement.

At Hangman's Wood a remarkable series of excavations known as Deneholes occur. These are shafts carried through about 50 or 60 feet of gravel and Thanet Sand, and 20 feet or more into the Chalk, but as their interest is mainly archæological they will be described elsewhere.

There is no doubt that the Chalk has been used 'from time immemorial' for chalking the land, and more extensively in old days. Arthur Young in 1768 , after remarking on the badness of the road between Billericay and Tilbury, observed that "to add to all the infamous circumstances, which concur to plague a traveller, I must not forget the eternally meeting with chalk-waggons.' $\mathrm{He}$ mentioned also that Chalk was brought from Kent by sea to Maldon. ${ }^{\mathrm{I}}$

At Stifford the Chalk has not only been worked in open pits, but also by means of shafts or 'chalk-wells,' evidence of which was brought

'A Six Wecks Tour shrough the Soustern Countics, p. 72 ; see also his General Vievo of the Agriculture of Essex, vol. ii. (1807) p. 206. 


\section{A HISTORY OF ESSEX}

to the notice of $\mathrm{Mr}$. T. V. Holmes through subsidences having occurred on account of the old workings. In these cases the Chalk was reached at a depth of about 12 feet, ${ }^{1}$ and was probably dug for agricultural purposes.

The Chalk itself has little direct influence on the agriculture, but open down-like tracts occur near Saffron Walden, and the soil generally on the uplands bordering the Cam valley and extending to Heydon is dry and more or less 'hurrocky,' that is mixed chalky and gravelly." Along the Cam valley below Newport many springs issue and there are good watercress beds. In very wet weather the valley is liable to be flooded from the drainage off the clay uplands.

During excavations at Grays a former proprietor, Richard Meeson, opened up some copious springs which were afterwards utilized for the water supply of a considerable district. ${ }^{3}$

The Chalk indeed is of the greatest importance as a water-bearing formation, and from it supplies are obtained in many a well in Essex. The rain falling on the North Downs and on the downs in Hertfordshire and Cambridgeshire descends into the trough of Chalk which underlies Essex. Here the water is pent up beneath the mass of Tertiary strata, chiefly London Clay, and borings carried into the Chalk yield a varying supply. There is no doubt that the Chalk below sea-level is saturated, and this plane of saturation rises inland to some extent with the rise of the land and the amount of rainfall; but when covered by a great thickness of Tertiary strata the Chalk itself is firmer and closer than it is near the surface. There are fewer fissures, and therefore a free supply at a great depth is not to be depended upon. Water may be pumped faster than it can be replaced. Saturated Chalk of course acts like an impervious stratum, and the additions flow away in springs. Thus overflows from this Basin escape at the surface on the margin of the Tertiary strata, as at Benfield Springs near Bishops Stortford on the north, and at Grays and Purfleet on the south. On the far northern side of the Chalk Basin there is a copious outflow beyond Heydon along the outcrop of the Totternhoe Stone, and numerous springs issue at and below Newport in the Cam valley. Pumping from deep wells takes so much from the body of the Chalk, and the amount is naturally lost to the springs.

\section{THANET BEDS}

Overlying the Chalk there is generally to be found a mass of pale and greenish-grey sand and sandy clay. This formation known as the Thanet Beds contains at its base a layer of green-coated flints, which appear to have originated from the dissolution of the upper layers of Chalk in which the flints were formerly embedded.

The strata are exposed between Purfleet and Aveley, at Stifford,

1 Essex Nat., vol. iii. p. 183.

2 C. Vancouver, General View of the Agriculture of Essex (1795) pp. 104, 105.

3 Prestwich, Quort. Fourn. Geol. Soc., vol. xxviii. p. xliii.; see also Minutes of Evidence, Roy. Comm. on Metrop. Water Supply, 1893. 


\section{GEOLOGY}

Chadwell and West Tilbury. They have been opened up in pits north of Grays Thurrock station, and have been seen to a thickness of 53 feet by Mr. T. V. Holmes in one of the Deneholes in Hangman's Wood, north of Little Thurrock. Being in this area largely covered by valley gravel they have but little direct influence on the soil. Eastwards and westwards they are concealed beneath the alluvial deposits bordering the Thames, but over a great part of Essex they have been proved in borings and sinkings as at Stratford, Loughton and elsewhere.

Along the northern margin of the county their presence has not everywhere been determined, and they have not been separated from the Woolwich and Reading Beds on the Geological Survey map, because in that area the strata are largely concealed by Glacial Drift, and it is known that although they occur at Sudbury, the Thanet Beds are not present to the north-west of the London Basin.

\section{WOOLWICH AND READING BEDS}

The Woolwich and Reading Beds comprise mottled clay, laminated clay and sand, also shelly clays and lignite, and usually at the base greenish-grey sand with flint pebbles. In composition and thickness this formation is as usual variable, and it is known better in Essex from the records of well-sections than from the surface exposures. The thickness varies from 25 to 60 feet or more.

The beds occur beneath the valley gravels at West Ham and also at Beckton, and they come to the surface from near Wennington to Aveley, Stifford, Orsett and Stanford-le-Hope, where they may be seen here and there in temporary excavations.

Along the northern outcrop they appear at Roydon, and near Farnham and Stanstead Montfitchet. Near Elsenham and Debden they probably occur further north than the map indicates. They are seen again north of Thaxted and at Castle Hedingham.

Among the fossils Melania inquinata, Ceritbium funatum, Cyrena cuneiformis and Ostrea bellovacina indicate estuarine conditions.

\section{BLACKHEATH OR OLDHAVEN BEDS}

The Blackheath (or Oldhaven) Beds consist locally of grey sands with flint pebbles, and contain marine shells like those of the London Clay, but they have been somewhat doubtfully recognized by $\mathrm{Mr}$. Whitaker in borings in south Essex. Thicknesses of I I feet at Barking Side, 50 feet at Stanford-le-Hope and 37 feet at Shoeburyness are thus assigned to this formation, ${ }^{1}$ which is well represented south of the Thames in the pebble-beds of Blackheath, and in the sands of Oldhaven or Bishopstone Gap.

The occurrence of flint pebbles in the Blackheath Beds shows that in some areas the Chalk must have been upraised to form cliffs. This may have been in the area of the Weald from which the Chalk has since been removed.

$$
1 \text { See Whitzker, Grology of London, vol. i. p. } 233 .
$$




\section{A HISTORY OF ESSEX}

The soils furnished by these Lower Eocene strata between the Chalk and London Clay are on the whole loamy, being mixed soils of sand and clay. The formations themselves exercise no marked influence on the scenery.

\section{LONDON CLAY}

The London Clay occupies a large part of the surface of Essex, more especially in the south, and where well developed it is upwards of 400 feet thick.

It is naturally exposed in the cliffs at Southend, Shoeburyness and Clacton-on-Sea, where it is capped by valley gravels, and it is seen again in the cliffs at Frinton, Walton-on-the-Naze, and also at Harwich. It occurs at the surface over considerable areas along the valley of the Crouch, around Langdon Hill, over Hainault and Epping Forests and near Waltham Abbey.

In north Essex the London Clay is exposed along the Stour valley below Middleton; along the Colne valley from Castle Hedingham and Gosfield; along the Pant and Blackwater valleys from Wethersfield ; and along the Pods Brook, Ter and Chelmer valleys at Braintree, Terling, Thaxted and Dunmow. In the Stort valley it occurs in a few places along the Essex borders.

The formation where it appears at the surface is a stiff brown clay, which soaks up a good deal of water in wet weather, and shrinks and cracks in very dry weather. Where dug from a depth it is bluish-grey in colour, and in this unweathered portion of the deposit, or in the cement-stones, the fossils which characterize the London Clay are more usually found. These include mammals allied to the hyrax and tapir, some remarkable birds, turtles, a large serpent, sharks and other fishes, crabs and lobsters, as well as mollusca such as the Nautilus, Voluta, Cypraa, and a boring-shell or 'ship-worm' called Teredina. Among plant-remains there are fruits and seeds of palms, euphorbias, mimosæ and acaciæ.

Towards the base of the London Clay there are occasional flint pebbles and also hard and impersistent bands of calcareous sandstone, yielding Aporrbais sowerbyi, Natica, Cytherea orbicularis, Panopcea and Pectunculus. ${ }^{1}$ Blocks of this rock were obtained during an excavation at the gasworks at Beckton.

As a rule however the London Clay rarely yields any fossils, and one may examine many a brick-pit or railway-cutting without finding a single specimen. The presence of selenite (or of moulds of its crystals) may have arisen from the decomposition of iron-pyrites and of calcareous organisms : hence in this and other formations the mineral may indicate the former occurrence of fossils. ${ }^{2}$

The London Clay is characterized by nodules of argillaceous limestone known as cement-stones or septaria. These may be seen in the

\footnotetext{
1 See also Prestwich, Quart. Fourn. Geol. Soc., vol. vi. p. 262.

2 See P. M. Duncan, ibid. vol. xxii. p. I2.
} 


\section{GEOLOGY}

cliffs at Clacton, and many were formerly dredged to the south of Harwich for the manufacture of Roman cement. The cracks or septa are filled with calc-spar, and sometimes contain pyrites or 'copperas." The septaria no doubt originated from the segregation of the more calcareous portions of the clayey mud after the deposition of the London Clay. Morant says these nodules were used in the walls of Colchester.

The London Clay has been extensively dug for brick-making and especially for tile-making, as at Buckhurst Hill, Loughton and elsewhere. The loamy beds which occur at the junction with the Bagshot Beds, as at Brentwood, near Theydon Bois and on Epping Plain, are very suitable for brick-making.

The soil is naturally thin and tenacious, and has been described as a cold, heavy and wet clay on tile-earth; but it is ameliorated on the slopes where the higher grounds are covered by Bagshot Sands or drift gravels. On the stiffer grounds of Epping Forest the oak and hornbeam find a congenial soil.

\section{BAGSHOT BEDS}

Overlying the London Clay, and connected with it by alternations of sand, loam and clay, are the Bagshot Beds. These consist in mass of fine buff-coloured sand with thin layers of pipeclay, overlaid in places by pebble-beds which are mainly composed of flint pebbles. The occurrence of zircon among the minute materials of the Bagshot Sands at High Beech was detected by Mr. A. B. Dick. ${ }^{2}$ The formation occurs in outliers, which are but remnants of a wide-spread deposit. These outliers constitute some of the higher and more picturesque tracts, as at Epping and High Beech (362 feet), Brentwood, Warley ( 360 feet), Billericay, Stock, Langdon Hill ( 385 feet), Rayleigh and a few other localities. The land is less cultivated than on other formations, and commons, village greens and much woodland help to diversify the scenes.

From the fact of this gradual passage from the London Clay into the Bagshot Beds there has arisen considerable difference of opinion with regard to the boundary line that should be drawn on geological maps to separate the two formations. Those who, like S. V. Wood, jun., take the first prominent bed of sand in the ascending series to indicate the Bagshot Beds, would mark much larger areas of that formation, notably along the high grounds from High Beech to Epping, and between Theydon Mount and Northweald Basset. On the other hand those who in the downward succession take the first mass of clay to belong to the London Clay indicate much smaller areas of Bagshot Beds. In the one case we have to map clay in the Bagshot Sand, and in the other sand in the London Clay. Absolute consistency is not however to be obtained, and the difficulties met with in deciding about a boundary near Epping are encountered also near Brentwood and Rayleigh.

Some casts of shells, apparently Turritella, Natica and Voluta were

' Hence perhaps the name Copperas Bay, west of Harwich. Copperas (sulphate of iron) is manufactured from pyrites. See also P. Morant, Hist. and Ansig. of Essex (1768), vol. i. p. 500.

Whitaker, Grology of London, vol. i. p. 523. 


\section{A HISTORY OF ESSEX}

found at Mill Green, north of Frierning, by Messrs. H. W. Monckton and R. S. Herries.

Overlying the Bagshot Sands in some of the outliers there are pebblebeds composed almost wholly of flint, and these belong to the Bagshot Beds. The best section, to which attention was first drawn by S. V. Wood, jun., was at Langtons in South Weald Park near Brentwood. The pebble-bed was fifteen feet thick, and overlaid by about six feet of rearranged pebbly gravel, largely derived from the beds below. Other sections of the pebble-beds have been noted at Warley, Billericay and Stock, where also there are reconstructed pebbly gravels above the Bagshot Beds. ${ }^{1}$

While the Chalk indicates marine conditions of considerable depth and at a distance from any land, the succeeding Thanet Sands were formed in a shallow sea probably within the influence of the great Eocene river which directly brought succeeding sediments. There is a great break between the Chalk and Thanet Sand, as indicated in some areas by the destruction of the Chalk and its layers of flints, and everywhere by the change in the life of the periods: though locally the break is unaccompanied by any discordance in the stratification of the two series.

During the period of the Thanet Sand there is no evidence, as Mr. J. Starkie Gardner points out, that any elevated Chalk coast-line came locally into contact with the waves. ${ }^{2}$ After the deposition of the Thanet Beds the region underwent some elevation and came under the influence of freshwater and estuarine conditions.

The Woolwich and Reading Beds indicate a temperate climate, which however was gradually changing towards the sub-tropical conditions which subsequently prevailed. The period was one dominated by the great Eocene river, and it was followed by subsidence which, as Mr. Gardner remarks, ushered in the Blackheath and London Clay deposits.

The fossils of the London Clay indicate that the climate during its formation was almost tropical, while the deposit itself must have been laid down slowly and quietly in the wide estuary of the Eocene river. The succeeding Bagshot Sands were deposited in shallower water, probably estuarine in the Essex area, but passing westwards into freshwater beds with many plant-remains of sub-tropical character.

The various Eocene strata up to the Bagshot Beds were spread over the entire area of Essex, and while as before mentioned some tracts of Chalk in the south of England were suffering denudation in Eocene times, yet later on in Oligocene and Miocene times the region was generally raised above water for an extended period. It was then that the curvature of the London Basin was produced, a disturbance accompanied by elevation and followed by immense destruction of the land. Surface agents in the shape of rain and rivers began to erode channels and to wear away

1 See H. B. Woodward, in Whitaker's Geology of London, vol. i. pp. 270-279; Prestwich, Quart. Joum. Geol. Soc., vol. xlvi. p. 165 ; H. W. Monckton and R. S. Herries, Proc. Geol. Assoc, vol. xi. pp. 18 and lxv.; vol. xii. p. 108 ; and Monckton, Nature, June 26, 1890.

a Quart. Fourm. Geol. Soc., vol. xxxix. p. 202. 


\section{GEOLOGY}

the strata-a process which continued into the Pliocene period, when the north-eastern portions of the area were submerged and received banks of the shelly sand known as Red Crag. How far this Pliocene submergence extended it is difficult to say, for although there are some high-level or plateau deposits of pebble-gravel which may date back to Pliocene times, there is no evidence from fossils to prove the point ${ }^{1}$ (see p. 12).

Prior to the Glacial period the more prominent physical features of the country had been formed, as the Bagshot Beds must have been largely removed, only scattered outliers remaining on an irregular foundation of London Clay; and Mr. T. V. Holmes has pointed out that as a thickness of 400 feet of London Clay (nearly the full thickness) has been proved at Dagenham, it is probable that some outliers of Bagshot Beds may have diversified the surface in that neighbourhood just prior to the formation of the Thames valley. ${ }^{2}$

\section{RED CRAG}

The Red Crag is one of the more attractive of geological formations, mainly because fossils are readily to be obtained and partly because the exposures occur for the most part in pleasant places. In Essex the most famous locality is Walton-on-the-Naze.

As early as 1703 the fossils of Harwich cliff were noticed by S. Dale, and they were more prominently brought before the public in the descriptions and figures published in his appendix to Silas Taylor's History and Antiquities of Harwich and Dovercourt." From this account we learn of an outlier of the shelly Crag that has since been destroyed by the ravages of the sea.

Attention was drawn to another outlier at Beaumont, by John Brown of Stanway, while small tracts occur between Harwich and Little Oakley, at Mistley, and again in the country from Langham to near Boxted. Some of these remnants of the Crag have been noticed at the surface, others have been detected from the material brought up in occasional borings or well-sinkings. A phosphatic nodule-bed at the base of the Crag was at one time worked at Wrabness and also at Walton-on-the-Naze.

The Red Crag in Essex is regarded as the oldest portion of the formation, and from its development at Walton-on-the-Naze, it has been termed the Waltonian stage by Mr. F. W. Harmer. He observes that the majority of the characteristic shells found in it are either extinct or south-European forms: they include Cypraa avellana, Voluta lamberti, Purpura tetragona, Tropbon (Neptunea) contrarius, and many others. A band of clay above the shelly Crag at Walton has been regarded as a representative of the Chillesford Clay of Suffolk, but this correlation is questioned by Mr. Harmer.

1 Sec Whitaker, Geology of London, vol. i. pp. $290,494$.

- Phil. Trans., vol. xxiv. (1704) p. 1568, in a letter to Edward Lhwyd, 1703.

1730 , ed. 2, 1732.

'Quart. Fourn. Geol. Soc., vol. Ivi. p. 709 ; see also C. Reid, 'Pliocene Deposits of Britain,' Mem. Geol. Survey, 1890. 


\section{A HISTORY OF ESSEX}

Most of the shells appear to have belonged to animals which lived on the spot : they do not bear evidence of having been shifted and rolled as in later stages of the Red Crag. The Crag at Little Oakley is regarded by Mr. Harmer as a slightly newer stage than that at Walton. He has lately reopened the pit at Beaumont and obtained a fine series of fossils.

Occupying such small areas the Crag has no particular influence on the scenery and very little on the soils. As a rule the land is fertile, and the deposit itself when very shelly has been dug for marling ground deficient in lime.

The Pliocene period affords evidence of temperate conditions which were slowly changing towards the more rigorous climate of the Pleistocene. At the close of the period England was still united across the Straits of Dover with the continent. ${ }^{1}$

There are several tracts of pebbly gravel in Essex, some mainly derived from the old Bagshot pebble-beds as at High Beech, near Brentwood, Langdon Hill and Hadleigh, some derived probably from earlier Eocene pebble-beds.

These are most largely formed of pebbles of flint and quartz, and in this respect they differ from the more mixed gravels of the other high grounds, which contain quartzites, various igneous rocks, and likewise fossils derived from many older formations, and which are definitely connected with the Glacial period.

Some patches of pebbly gravel seen in the cliff at Walton-on-theNaze, also near Marks Tey, Witham, Braintree and Thaxted, and near Epping, have been regarded as Westleton Beds by Prestwich, ${ }^{2}$ who took the name from the village of Westleton in Suffolk, and regarded the beds as the base of the Glacial series. The age of the Westleton Beds of Westleton is not undisputed : they may belong to the Glacial period." Hence it will be best not to attempt any full discussion of this vexed question, but to be content here to remark that as Prof. T. M`K. Hughes, S. V. Wood, jun., Prestwich, Mr. Whitaker and others have pointed out there may be gravels of Pliocene (or Pre-Glacial) age which were spread over the country and partially denuded prior to the great glaciation which came about in later times. To S. V. Wood, jun., we are particularly indebted for a knowledge of the Drift deposits of East Anglia. He was the first to commence their detailed and systematic study in Essex, and in 1867 he presented to the Geological Society copies of the Ordnance Sheets I and 2 (Old Series) on which he had surveyed the geology including the various superficial deposits. The maps were accompanied by a MS. Memoir on the Structure of the Glacial and PostGlacial Beds in southern Essex.

1 See Reid, Origin of the British Flora, pp. 34, etc.

2 Quart. Fourn. Geol. Soc., vol. xlvi. pp. I 28 , 162 , etc., and Geol. Mag., 1898, p. 404 ; Monckton and Herries, Proc. Geol. Assoc., vol. xi. p. 18 and p. lxv. and vol. xii. p. 108 (where further references are given).

3 H. B. Woodward, Geol. Mag., 1882, p. 452 ; and Geol. England and Wales, ed. 2, p. 505. 


\section{GEOLOGY}

\section{GLACIAL DRIFT}

Glacial Drifts and especially Boulder Clay occupy a large portion of the surface of Essex and form some of the more fertile agricultural areas. The Boulder Clay is a tough unstratified clayey deposit of irregular thickness, containing numerous rounded fragments of Chalk of all sizes from that of a pea to large blocks; hence it is known as the Chalky Boulder Clay. It contains also numerous unworn and angular fragments of flints, and pebbles of various rocks, fossils and rocks derived from different formations, together with schists, granites and greenstones.' Essentially however it is a chalky clay, the soil being a 'strong loam' which forms good land for wheat, barley and beans. This loam is a decalcified portion of the Boulder Clay which in places resembles the soil on the London Clay, but is usually stony and very much thicker. Among the more abundant fossils are Gryphaa dilatata derived from the Oxford Clay, Belemnites abbreviatus from the Corallian, and Lucina minuscula from the Kimeridge Clay.

The Boulder Clay lies somewhat irregularly on the strata beneath, chiefly London Clay and Chalk; and there are remarkable instances of glacial erosion which took place prior to or during the Glacial epoch. Thus a deep gorge filled with Drift occurs along the Cam valley, partly in Essex and partly in Cambridgeshire. The evidence derived from well-borings has been published by $\mathrm{Mr}$. Whitaker, ${ }^{2}$ who notes the extraordinary thickness of Glacial Drift at Newport ( 340 feet), Wenden (272 feet), Littlebury (2 I 4 feet), and Great Chesterford (I 56 feet). It appears probable that this great trench was excavated and subsequently filled up during the time of most intense glaciation, and that possibly the disturbed Chalk near Chishall (previously noticed) may then have been tilted like the Chalk in several localities in Norfolk. Boulder Clay occurs on the Chalk uplands in the north-western part of the county in the neighbourhood of Heydon, Chrishall, and also around Debden and Broxted. Further south it forms a more or less continuous sheet at Hatfield Forest, Hatfield Broad Oak, High Easter and the Rodings. Eastwards it is broken up by valleys which divide the high grounds near Thaxted, Dunmow, Braintree, Halstead and Coggeshall.

To the south the Boulder Clay extends to Chelmsford and Chipping Ongar and in patches to the heights, as at Havering-atte-Bower, overlooking the Thames valley. Its presence in this valley was unsuspected until in the making of the railway near Hornchurch a mass of tough Chalky Boulder Clay fifteen feet thick was found by Mr. T. V. Holmes to underlie one of the higher tracts of Thames valley gravel. ${ }^{8}$ This discovery is of the greatest interest as it was the first instance where Boulder Clay had been seen in connection with the Thames valley gravel. As Mr. Holmes points out it does not prove that the Thames valley was

\footnotetext{
1 See Rev. A. W. Rowe, 'On the Rocks of the Essex Drift,' Quart. Journ. Gcol. Soc, vol. xliii. p. 351.

2 Quart. Journ. Geol. Sac, vol. xlvi. p. 333.

Ibid. vol. xlviii. p. 365 ; and Essex Nat, vol, vii. p. 1.
} 


\section{A HISTORY OF ESSEX}

pre-glacial, but that an old hollow or valley was subsequently cut into during the excavation of the Thames valley. River gravel also overlies Boulder Clay in the Blackwater valley near Kelvedon.

Underlying the valley gravel at Romford, Mr. Holmes has observed a deposit of silt and sand with pebbles of Chalk and flint, evidently of subsequent date to the Boulder Clay from which it was largely derived. ${ }^{\text {I }}$ He looked upon it as evidence of an ancient silted-up stream whose course he would trace between Warley, Billericay and Maldon on the north and west, and Laindon, Rayleigh and Althorne on the south and east, and into the valley of the Blackwater below Maldon. In any case this silted-up channel, like that in the Cam valley, belongs to a more ancient period than the present Thames valley; but whether these old valleys which are occupied by Boulder Clay were pre-glacial valleys, or were scooped out by ice-action during the Glacial period may fairly be questioned. There is however no doubt that the main features of the country were formed prior to the glaciation, and therefore we should expect here and there to find traces of old valleys.

When the Ice age was brought about the surface of the land had long been subject to subaërial waste, the Chalk-tracts were covered with clay-with-flints, and there was generally much weathered material or soil over the land. Before any great movement of ice took place, the accumulation of snow led to the formation of much ice, and to the base of this the soil and weathered sub-strata were frozen.

Eventually, when movement set in and there was coalescing of great sheets of ice which traversed regions of Jurassic rock and Chalk, the base of the ice tore off the frozen soil and débris, and in some cases great strips of the strata ; in other cases impinging against higher ground the formations were locally disturbed, as may have been the case near Heydon.

The débris thus removed would rise by overthrusts into higher horizons in the ice, and be then carried forward and widely distributed and commingled with local detritus during alternate recessions and readvances of the ice-margin; the Boulder Clay being deposited, to a large extent, by the melting of the ice, as indicated many years ago by Mr. J. G. Goodchild in his account of ice-work in Edenside.

The abundant chalky detritus was no doubt carried along minor planes of movement in the ice, the chalk lumps being scored by fractured flint, and the material being transported far and wide at higher levels in the ice than the bulk of the more local material. In certain instances the soil frozen to the base of the ice-sheet was little if at all moved, being overridden by subsequent ice-movements; and much Boulder Clay must also have been overridden after deposition, owing to its exceedingly tough character. ${ }^{2}$

1 Quart. Fourn. Geol. Soc., vol. 1. p. 443 ; and 'Notes on the Ancient Physiography of South Essex,' Essex Nat., vol. ix. p. I93.

2 See H. B. Woodward, Geol. Mag., 1897, p. 485 ; J. E. Marr, ibid. 1887, p. 262 ; and J. Geikie, The Great lce Age. 


\section{GEOLOGY}

The intercalation of sand and gravel with the Chalky Boulder Clay is best explained as a marginal phenomenon produced at different stages in the advance and retreat of the ice-sheet.

In the ancient hollow along the Cam valley the Boulder Clay was seen to be much mixed with sand and gravel in alternate irregular masses. This is also the case at Elsenham and elsewhere. Gravel overlies Boulder Clay in some places on the higher ground, although not to any considerable extent, as at Mountnessing and near Chipping Ongar.

Loam also associated with the Boulder Clay occurs over a large area in north-eastern Essex; it rests mostly on gravel and sand, and from its mode of occurrence it might be taken to replace the Boulder Clay. It thus extends over the heaths of Boxted, Ardleigh, Crockleford and Elmstead, and around Wicks and Great Bentley, where the soil-a 'fertile loam' -is regarded as good turnip-land.

Minor patches of loam occur on the Boulder Clay between Pebmarsh and Twinstead, at Finchingfield, south of Terling, and on Hatfield Heath : in such situations the loam is usually a decalcified portion of the Chalky Boulder Clay.

In former days the Boulder Clay was much used for claying or marling the ground for agricultural purposes; hence numerous old pits, now for the most part ponds, may be noticed in the fields.

Sands and gravels occur beneath the main mass of Boulder Clay, but their occurrence though widespread is uncertain. They were distributed during the earlier stages of the period of great glaciation, and occasionally, as in Hertfordshire, seams of Boulder Clay occur in the gravel. They may outcrop between Boulder Clay and London Clay on one side of a valley and be absent from the other side. Hence in sinking a well through Boulder Clay supplies of water cannot always be depended upon, although in many localities a good supply is obtained.

These sands and gravels occur along the Cam valley at Quendon, along the Stort Valley at Clavering, Harlow and Roydon, below Sudbury in the Stour valley, along the Colne from Great Yeldham to Halstead and Gosfield, along the Pant from Radwinter, the Pods Brook from its source near Great Bardfield, and the Chelmer in places from Thaxted.

In some of these valleys, as along the Chelmer, it is not easy to separate the Glacial gravels from the newer valley gravels which are principally derived from them. Occasionally, as near Roxwell, the gravel is cemented into a conglomerate.

Gravel extends over the high grounds of Danbury, being perhaps in part the wreck of an outlier of older pebbly gravel. Towards the south and west Boulder Clay is intercalated with the gravel, while on the east, at Maldon and on Hazeleigh Common, Boulder Clay overlies it.

Glacial gravel occurs around Colchester, at Brightlingsea and St. Osyth; and there are patches on Mersea Island, at Tolleshunt and on Tiptree Heath. Some of these tracts of gravel are not clearly to be separated from the range of old valley gravels which in east Essex 


\section{A HISTORY OF ESSEX}

fringe the marshes near Burnham. Again, in the western portion of the county, near Loughton, on Buckhurst Hill and north of Chigwell, there are gravels which it is exceedingly difficult to distinguish from neighbouring gravels on a slightly lower level which seem to form part of the true valley gravels. Some of these deposits may indeed represent stages in the denudation of the country which followed the recession of the ice-sheet.

While the action of land-ice was partly to efface the old scenery by thick accumulations of Drift, it tended also to degrade and soften the bolder features; but these to some extent have reappeared through the influence of subsequent denudation.

The passing away of icy conditions, the melting away of the landice which enveloped so much of the ground, must have been attended by the formation of torrential streams which initiated the present lines of drainage. Along the Stour, Colne and Blackwater, and along the Lea and Thames, we find evidence of later Pleistocene gravels and brickearths, to which attention must now be directed. Along the Crouch however we find no such ancient deposits. Rising in the hills of Langdon and Billericay, it drains an area of London Clay comparatively free from the Glacial gravels, which in other valleys afforded material readymade for the accumulations of valley gravel. The Crouch may indeed have existed in Pleistocene times, and have simply eroded without depositing much material along its course : but there is no evidence to show that this was the case.

\section{VALLEY GRAVEL AND BRICKEARTH}

The deposits of valley gravel and brickearth are old accumulations of the rivers and their tributaries, and they occupy grounds higher than the Alluvium, but often extend beneath it.

The more important tracts of valley gravel and brickearth are those which occupy the Thames valley. They occur from Leyton and Stratford to Barking, Romford and South Ockendon, in a belt which in places is four or five miles broad, and rises 100 feet above the river. These deposits belong to the earliest system of drainage along the present valleys, and to a period when palæolithic man co-existed with a fauna many of the members of which are either extinct or no longer inhabitants of this country.

The mammalian remains have been met with in notable abundance at Ilford and Grays, not because these were exceptionally favoured places of entombment, but because the brickearth at Ilford and the Chalk below the brickearth at Grays have been very extensively worked, and for many years the remains were carefully looked after by the late Sir Antonio Brady at Ilford and by Richard Meeson at Grays.

Sir A. Brady observed that the bones near Ilford were mostly found in the sands and gravels and in a very decayed condition, but they were better preserved in the brickearth. The chief locality was the Uphall 


\section{GEOLOGY}

brickfield, on the right hand side of the lane leading from Ilford to Barking, a spot about twenty-eight feet above the river Thames. ${ }^{1}$

The mammals include fine examples of the mammoth or Elephas primigenius, also $E$. antiquus, the hippopotamus, three species of rhinoceros, the Irish elk, bison, urus, red deer, brown bear, grisly bear, wolf and many others. A few flint implements have likewise been found. Occasional remains of birds and fishes, and numerous land and freshwater mollusca also occur in the brickearth, a deposit laid down under more tranquil conditions than the gravel, and due largely to the destruction of Eocene beds and Drift sands and loams.

The gravel has been derived mainly from pre-existing gravels formed of flint, with less abundant quartz and quartzite. The flint pebbles were derived from Eocene pebble-beds, and the sub-angular flints, quartz and quartzite mainly from the Boulder Clay or from old plateau or Glacial gravels which border the Thames valley from near Great Marlow to Rickmansworth, Hendon and Finchley. Occasional greywethers occur, as at Grays. ${ }^{2}$

The sheets of gravel and brickearth which extend from Southend and Shoeburyness northwards to Great Wakering, Burnham, Southminster and Bradwell, and occur also on Osea Island, may originally have been connected with the tracts around Clacton and Little Holland. Indeed, it is considered that in old times the Thames turned northwards along the eastern margin of Essex, receiving the Blackwater as a tributary. In this region its right bank has been wholly lost by the subsequent waste of the land on that side. Thus the Thames was a much mightier river than it is now, but when we contemplate the broad expanse occupied by the old valley gravels and brickearths, we need not conclude that the river ever occupied, unless in seasons of flood, the entire area. Its tendency has been to alter its course, and, as pointed out by Mr. Whitaker, for the most part to diverge towards the south, so as to cut against the Kentish shores, while leaving broad tracts of loam and gravel to the north. ${ }^{3}$ It is difficult to say whether the land was higher or lower during the earlier stages of the formation of these valley deposits, if we accept the view that the lower terraces are of later age where the river cut deeper into the valley. On this subject opinions differ. The land originally may have been much higher, and the river, more or less torrential, cut deeper and deeper into its valley before reaching a base-level of erosion.

In other valleys there are deposits of river gravel, as along the Colne at Dedham village, and the Cam at Wenden and Great Chester-

1 See Catalogue of the Pleistocene Vertebrate from the neigbbourbood of Ilford, Essex, in the Collection of Sir Antenio Brady, by William Davies, 8vo, London, 1874 ; also Henry Woodward, Geol. Mag., 1864 , p. 241, 1868, p. 540 ; and M. A. C. Hinton, Proc. Geol. Assoc., vol. xvi. P. 277.

- For details relating to Grays see B. B. Woodward, Proc. Geol. Assoc, vol. xi. pp. 363, 364 (herein are references to the labours of all previous workers); see also Prestwich, Geol. Mag., 1898 , p. 409 .

For a review of the literature of the Thames Valley Drift and of the origin of the Thames, see Whitaker, Geology of London, vol. i. pp. 353,496; Ramary, Qwart. Journ. Geol. Sor., vol. xxviii. p. 148 ; Prestwich, ibid. vol. xlvi. p. 155 ; J. W. Gregory, Natural Science, vol. v. p. 97. 


\section{A HISTORY OF ESSEX}

ford. Elsewhere in Essex there are sheets of valley gravel and brickearth that have yielded interesting fossil remains, to which attention has been directed by the late John Brown of Stanway, by the Rev. Osmond Fisher, and others. Such deposits occur at Great Clacton, at Lexden, Copford and Marks Tey to the west of Colchester, at Kelvedon, Witham and Chelmsford, and again at Great Yeldham. They comprise brickearth, peaty clay, and shell marl, with remains of mammalia, land and freshwater mollusca, and occasionally of beetles and plants. Among the mollusca the more noteworthy are Corbicula fluminalis which has been found at Clacton, Grays and Ilford, Unio littoralis found at Clacton and Grays, and Paludestrina marginata found at Copford, Clacton and Grays.' These are extinct in Britain; the majority however belong to species still existing in the district. A few plant-remains have been obtained at Grays : these include the ivy, and as remarked by $\mathrm{Mr}$. C. Reid, they indicate a temperate climate with mild winters. ${ }^{2}$

In places the brickearth, as at Grays, exhibits a disturbed not to say contorted surface, recalling features that are seen in glaciated districts where the Chalky Boulder Clay rests on beds which have been disturbed during the process of its formation.

The discovery at Hornchurch (previously mentioned) where Boulder Clay underlies the Thames Valley Drift, proves that these superficial disturbances are of later date than the main glaciation. They may have arisen in part from the effects of river-ice, in part from the later influences of freezing and thawing and slipping of the soil."

At Wanstead Mr. Martin Hinton has observed in the 'High-Terrace Drift' much contorted gravel overlain by undisturbed gravel, affording ' evidence of the rivers having been frozen in winter; and, on the breaking up of the ice, of huge ice-rafts floating down, contorting the deposits in process of formation wherever they grounded.' In the 'Low-Terrace Deposits' at Ilford the brickearth and overlying gravel and sand are also in places remarkably contorted, evidently by 'the crushing action of ice.'

\section{RECENT DEPOSITS}

The Alluvium is the tract of marshland bordering the rivers, and is in some cases six or seven feet below the level of high-water at springtides. It comprises some of the most recent deposits, and is a variable series of muds or silts, clays, shell-marls and peaty deposits with sand and gravel, attaining a thickness of fifty feet at Thames Haven and more

1 See B. B. Woodward, 'On the Pleistocene (Non-Marine) Mollusca of the London District,' Proc. Geol. Assoc., vol. xi. p. 335 ; and A. S. Kennard and B. B. Woodward, 'The Post-Pliocene NonMarine Mollusca of Essex,' Essex Nat., vol. x. p. 87, and Proc. Geol. Assac., vol. xvi. p. 282 . In these articles references are given to other papers. See also J. P. Johnson and G. White, Essex Nat., vol. xi. p. 157.

2 Quart. Fourn. Geol. Soc., vol. liii. p. 464.

3 See O. Fisher, 'On the Warp (of Mr. Trimmer),' Quart. Fourn. Geol. Soc., vol. xxii. p. 553 ; and 'On the Ages of the "Trail" and "Warp," Geol. Mag. 1867, p. 193; see also F. C. J. Spurrell, 'History of Rivers and Denudation,' Proc. West Kent Nat. Hist. Soc., 1886.

1 M. A. C. Hinton, Proc. Geol. Assoc., vol. xvi. p. 271. 


\section{GEOLOGY}

elsewhere. As might be expected the deposits are of an estuarine character where they border the Thames, the wide mouths of the Crouch, Blackwater and Colne, and the inlets between Walton-on-the-Naze and Harwich. Scrobicularia plana and Tellina baltbica occur in the tidal clays. $^{+}$

Along the left bank of the Lea there is a variable breadth of Alluvium forming a succession of marshes. At Walthamstow during excavations for the filter-beds and reservoirs of the East London Waterworks Company in $1868-69$, many interesting remains were found and described by Dr. Henry Woodward. Besides numerous land and freshwater shells of existing species, many bones of mammalia and a few of birds and fishes were obtained. There were skulls and portions of skeletons of man, of prehistoric and later age, as well as implements of stone, bone, bronze and iron. There were remains of $\mathrm{dog}$, fox, horse, wild boar, red deer, reindeer, roebuck, elk, urus and short-horned ox, also remains of beaver in considerable abundance. As remarked by Dr. Woodward, the work and enjoyment of the beaver is to construct dams, forming large deep and clear pools of water, with a series of small waterfalls at intervals. $^{2}$

From Felstead, Chignal St. James, Roxwell and other localities in Essex many land and freshwater mollusca have been obtained from shellmarl and other alluvial deposits. ${ }^{3}$

Along the borders of the Thames valley many interesting sections have been recorded. Thus an excavation made in 1890 for a new gasholder at Beckton, North Woolwich, showed the following strata :-

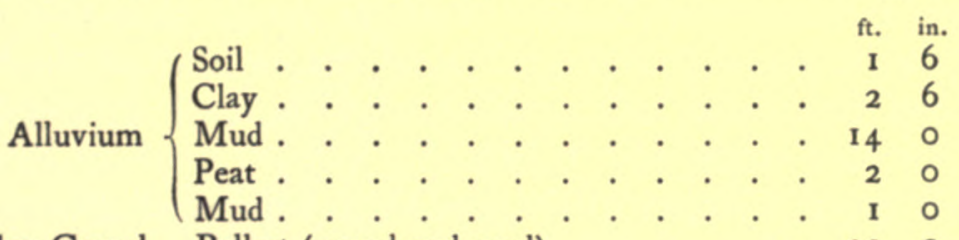

Valley Gravel. Ballast (gravel and sand) . . . . . . 200

Basement-bed of London Clay and Woolwich and Reading Beds.

The peat yielded much wood, including bog-oak, while in the Alluvium down to a depth of twenty feet there were found human remains and bones of ox [Bos taurus, var. primigenius and var. longifrons], red deer, wild boar, dolphin and whale."

In other localities remains of birch, alder, hazel and yew have been recognized.

From the mouth of the Lea eastwards there is indeed a succession of

1 See F. C. J. Spurrell, ‘On the Estuary of the Thames and its Alluvium,' Proc. Geol. Assoc., vol. xi. p. 210 ; H. Robinson, Proc. Inst. C. E., vol. xv. p. 196.

2 Geol. Mag., 1869, p. 385 ; and 'The Ancient Fauna of Essex,' Trans. Essex Field Club, vol. iii. p. 1. See also Holmes, Essex Nat., vol. xii. p. I.

3 M. Christy, Essex Nat., vol. iii. p. 1 ; J. French, ibid. p. 11 ; A. S. Kennard and B. B. Woodward, ibid. vol. x. p. 87. For other fossils from alluvial deposits, see Whitaker, Geology of London, vol. i. p. 476 .

${ }_{17}^{47}$ The section was examined by Mr. T. V. Holmes and the writer, and the bones were identified by Mr. E. T. Newton. 


\section{A HISTORY OF ESSEX}

broad levels, and on those of Plaistow and East Ham, where the land is comparatively cheap, the population has greatly increased despite the naturally undesirable character of the situation. The Gas-Light and Coke Company have created the village of Beckton, and other manufactories have attracted many workers.

The marshland disappears for a space at Purfleet and again at Grays, where the Thames in its windings almost touches the higher grounds of valley gravel. At Tilbury Fort there is again a wide spread of Alluvium, to which attention has been specially directed because at the base of the clays and peaty beds at a depth of a little over thirty feet there was found a human skeleton of prehistoric, but not, as was originally supposed, of palæolithic age. The beds above included peat and tidal clay, and the peat contained roots of birch and hazel, and remains of reeds, ferns and mosses. Above the uppermost layer of peat were evidences of Roman occupation. ${ }^{1}$

At Thames Haven and Canvey Island there is a broad tract of marshland, consisting of fifty feet of clay, silt, sand and peat.

Marshlands border east Essex at Wakering, including Foulness and other islands, and northwards they extend along the Crouch valley below Rettenden, and from Burnham to Bradwell on the borders of the river Blackwater. On the opposite side Tollesbury Marsh is continued to the spit known as Shingle Head Point.

At the mouth of the Colne St. Osyth marsh extends towards Clactonon-Sea, where the peaty portion of the Alluvium, clay with plantremains, and stools and prostrate trunks of trees, exposed at low-tide, has given rise to a submerged forest. On the south side the marshes are bordered by a ridge of shingle and sand, "which rises above the level of the highest tides, and still continues to increase in width although freely used for road-metal and ballast.' ${ }^{2}$

South-west of Clacton there are thin fringes of Blown Sand, and there is a tiny patch at Stour Point between Walton-on-the-Naze and Harwich. Harwich itself appears to be built partly on marine sand.

These alluvial tracts comprise not only the old embanked areas below high-water mark, including islands and other tracts of excellent loamy soil adapted for grazing as well as arable ground, but they include also salt marshes or saltings which rise ten feet and more above Ordnance Datum. The spring tides cover these salt marshes, and by leaving thin films of sediment, tend gradually to raise their level, until in the end the sea may be excluded. As the saltings continually widen seaward, fresh strips have been from time to time enclosed. ${ }^{3} \quad$ The trouble with all these marshlands has been the want of fresh water in dry seasons, but deep wells carried through the London Clay have provided a remedy.

1 Holmes, Trans. Essex Field Club, vol. iv. (1885); Owen, Proc. Roy. Soc., vol. xxxvi. p. 136 ; and Antiquity of Man as deduced from the Discovery of a Human Skeleton, etc., at Tilbury, 1884; see also Spurrell, Proc. Geol. Assoc., vol. xi. p. 224.

2 W. H. Dalton, 'Geology of Colchester,' Geol. Survey, 1880 , p. 11.

3 W. H. Dalton, Geol. Mag., 1876, p. 492. 


\section{GEOLOGY}

The age of the older embankments is unknown, but Mr. Spurrell says there are none below Purfleet so old as the Roman period ; ${ }^{1}$ and the fact that the marshes so protected are now in many places below the level of high-tide is attributed by $\mathrm{Mr}$. Whitaker to the drying and contraction of the alluvial deposits since they were preserved from inundation. ${ }^{2}$

The drainage off the alluvial tracts before they were embanked led to the formation of irregular islands, which have retained their outlines since they were protected. Some like Canvey and Foulness are wholly alluvial and recent. Others like Osea and Northey in the Blackwater valley, are formed partly of London Clay and partly of Gravel or Alluvium. In the Crouch valley there are ancient islets of London Clay no longer surrounded by water, but enclosed by marshland. Bricks are made from the alluvial clay on Bridgemarsh Island south of Latchingdon.

Although the tidal waters of the Thames ascend as far as Richmond and Teddington, nevertheless its estuary is sometimes taken to mean that portion east of a line drawn between Southend and Sheerness, onwards to the bank known as the Kentish Knock. The area off Essex is composed of broad banks and shoals of sand and mud with shells, trending northeast and divided by channels known as 'deeps' which are connected with the Thames, Crouch and Blackwater. Some of the isolated banks as well as the broad foreshore known as the Maplin Sands are dry at lowwater. The Maplin Sands, though shifting sands, are mostly firm when uncovered, although there are muddy tracts near the shore. The condition of the estuary is regarded by Capt. T. H. Tizard as due to the action of the sea in casting up banks, and of the tidal flow in cutting channels through the banks thus formed. ${ }^{3}$ Changes in the depths of channels and banks are continually in progress, and their forms are liable to more abrupt alterations during gales.

The presence of peaty beds in the Alluvium indicates that the land has subsided some twenty feet or more, and consequently that the tidal waters are enabled to extend higher up than was formerly the case. As the Rev. O. Fisher has remarked, "The tidal rivers are evidently nothing more than a continuation of the valleys beneath the sea-level.' The estuarine character of the waters is favourable to the cultivation of oysters, and the Colne, Crouch and Blackwater form famous grounds for the Colchester and Burnham 'natives.' Nevertheless there has been much silting up of the tidal creeks, and Maldon in old times was a more important port than it is now.

Much waste is going on along the coast between Harwich and Southend, waste which has in places been greatly accelerated by landslips. The greater losses have taken place between the mouth of the

1 See C. Vancouver, General Viero of the Agriculture of Essex (1795); and Spurrell, 'Early Sites and Embankments on the Margins of the Thames Estuary,' Arch. Jourm., vol. xliii. p. 269.

Guide to Geol. London, ed. 5. (1889), p. 78.

S Nature, April 10, 1890, p. 539 ; see also J. B. Redman, 'The River Thames,' Proc. Inss. C. E., vol. xlix. p. 67.

1 Quart. Journ. Geol. Sec., vol. xvii. p. 1. 


\section{A HISTORY OF ESSEX}

Colne and Harwich. Mr. Redman observed in 1864 , that 'At Holland the mere basements of the east buttresses of the church are left, indicating the site of the ruins. Here, on a mile of frontage, three acres of land have been lost in eight years, equal to a recession of one yard per annum.' I In January, 1901, an extensive landslip took place at Frinton, when hundreds of tons of the cliff fell away on to the foreshore and into the sea.

That land is elsewhere growing by the process of reclamation has been indicated, but in this respect it is only a partial recovery of lost ground. That the sea has in comparatively recent times burst over the present artificial bounds is indicated by the marine beach-deposits of shelly sand and shingle which are found on Shoebury Common. Similar patches occur in Foulness Island, and in the marshes east of Burnham and Southminster, Tillingham and Bradwell. ${ }^{2}$ Among the shells the periwinkle, mussel, and more especially the common cockle are to be found. Formerly the shelly deposit at Tillingham was dug for manuring the land.

In early times the settlers being dependent on ready local supplies of drinking-water from wells and springs fixed their habitations on the Thames valley gravels or on the Bagshot Sands or Glacial gravels, or on the Chalk. Settlements on the areas of London Clay were rare, until with the finding of artesian water abundant supplies could be obtained below ground and transmitted from a short distance.

It is noteworthy that along the western side of the Lea valley in Hertfordshire and Middlesex a number of important villages grew up on the broad tracts of valley gravel, while on the eastern and more clayey side in Essex the villages are few and far between, Waltham Abbey being the only place of particular note, and this is situated on gravel. The same remarks apply to large areas of London Clay between Brentwood and Rayleigh. Over great part of Essex however gravelly and sandy beds occur here and there in the Boulder Clay, and these throw out springs, some of which, however, are far from permanent, failing in dry summer weather. The larger independent masses of Glacial sand and gravel afford more enduring supplies.

Among the noteworthy permanent springs is one known as Cromwell's Well, at Maldon, which issues from the Glacial gravels ; but there are numerous others, not the least important being those which issue from the Chalk (see p. 6).

An old writer mentions a chalybeate spring at Witham, and another spring that issues from a hill (probably Chadwell) two miles from the river at Tilbury, remarking that 'It makes excellent Punch, and is extremely good for Tea.' ${ }^{3}$ Other mineral springs have been noted at Woodford, Chigwell, Brentwood and North Upminster.

\footnotetext{
1 J. B. Redman, 'The East Coast between the Thames and the Wash Estuaries,' Proc. Inst. C.E., vol. xxiii. p. 186 ; see also W. H. Dalton, Geol. Mag. 1876, p. 492.

2 See Whitaker, Geology of London, vol. i. p. 478.

3 R. Russel, Dissertation on Sea Water, etc., ed. 5 (1769), p. 293 ; see also Morant, Hist. and Antig. of Essex (1768), vol. i. pp. 39, 110,164 .
} 


\section{GEOLOGY}

Essex possesses one mineral water which attained a temporary reputation. This was at Hockley Spa, where a permanent spring issues from the base of the Bagshot Sand. Here about sixty years ago an endeavour was made 'to establish a Spa with pump-rooms, and a woman was employed to dispense them, whose strong healthy appearance visitors were led to believe was the result of the medicinal effects of the water,' but 'the speculation proved a failure.' 1 Dr. A. B. Granville, writing in $184 \mathrm{I}$, gives an account of the discovery of the mineral water, and states that it contained sulphates of magnesia and lime, carbonate of lime, and chloride of sodium. ${ }^{2}$

With the growth of population the supplies of water from shallow sources have in many cases become not only inadequate, but also contaminated; and even when the supply remains sufficient for a small country village the danger from pollution is great, especially if any serious illness arises.

The whole aspect of Essex appears geologically to be one of somewhat sluggish repose despite the constant waste of the ground by rain and rivers and sea. The force of the breakers is however broken by the shallow ground which borders a great part of Essex.

Nevertheless geological action occasionally makes itself manifest in a more startling manner. In 1884 a remarkable earthquake was felt especially in the country between Colchester and the mouth of the Blackwater; and according to the detailed investigations made by Prof. R. Meldola and Mr. W. White it was 'the most serious that has happened in the British Islands for about four centuries.' They state that the number of buildings damaged by the shock was between I,200 and I, 300, including 20 churches and I I chapels, and that the main axis of damage had a general direction from north-east to southwest, extending from Wivenhoe to Peldon. The effects produced may, in their opinion, have resulted from the rupture of deep-seated rocks under strain or pressure, such as the sudden production or extension of a line of faulting; and the localization of the damage was probably due to the disturbance having originated under a clay area. ${ }^{3}$

1 H. W. Bristow in Whitaker's Geology of London, vol. i. p. 261.

2 The Spas of England, vol. iii. p. 606.

3 'Report on the East-Anglian Earthquake of April 22 nd, 1884,' Essex Field Club Special Memoirs, vol. i. (London, 1885). 



\section{PALAONTOLOGY}

A

$\mathrm{S}$ regards the past history of vertebrated animals (with which alone we are concerned on the present occasion) interest in Essex is chiefly concentrated on the wonderful series of mammalian remains which have been obtained from the Pleistocene gravels and brickearths of various localities in the Thames valley, and more especially at Ilford and Grays, as well as those from approximately contemporaneous deposits in other parts of the county, notably Clacton. From the brickearth at Grays has been obtained the sole evidence of the former occurrence of monkeys in the British Isles; the so-called Macacus eocanus from the Eocene of Suffolk being described on the evidence of a tooth which was subsequently ascertained to belong to the undermentioned Hyracotberium leporinum. A considerable amount of interest likewise attaches to the remains of mammals from the valley of the Lea at Walthamstow; but as these, on account of their later age, belong to existing species, their importance is far less than the remains from the brickearths. In this connection it may avoid confusion to mention that, in addition to this particular series of remains, certain other mammalian fossils, notably teeth of the mammoth, have been obtained at Walthamstow which appear to belong to an older deposit, approximately equivalent to the valley gravels and brickearths of other parts of the county.

Another important element in the palæontological history of the county is represented by the vertebrate remains from the London Clay of Harwich, the majority of these belonging to extinct types of turtles, although at least one species of mammal has been recorded from this locality, while a second is represented by a specimen dredged off the coast between Harwich and St. Osyth. Although the Red Crag occurs in the county, it has very few vertebrate fossils in comparison with those found in the same formation in Suffolk.

Since the nature of these various Tertiary formations, as well as the localities where they occur, are mentioned in the chapter on geology, no further reference is required in this place.

The mammalian remains from the alluvium of the marshes at Walthamstow were first described by Dr. H. Woodward, ${ }^{1}$ but some emendations on the list of species then given have been made subsequently. The species include the dog (Canis familiaris), horse (Equus 


\section{A HISTORY OF ESSEX}

caballus), wild boar (Sus scrofa), red deer (Cervus elapbus), roebuck (Capreolus capreolus), reindeer (Rangifer tarandus), elk (Alces macblis), Celtic shorthorn (Bos taurus), wild ox (Bos taurus primigenius), goat (Capra bircus) and beaver (Castor fiber). The Celtic shorthorn, it may be observed, is frequently alluded to as Bos longifrons or Bos taurus longifrons; but since it is believed to be only a domesticated breed it has no more claim to a distinct name (other than Bos taurus) than has the modern shorthorn or any other existing breed. The alluvial marshes extend some way along the Lea valley, the British Museum possessing a fine pair of red deer antlers dug up at Edmundsea near Waltham Abbey. Remains of the Celtic shorthorn have also been recorded from Audley End, Clacton and Walton.

The Walthamstow deposits have also yielded a wing-bone of a species of sea-eagle. This specimen, now in the British Museum, was at one time regarded by the present writer ${ }^{1}$ as probably belonging to the Pacific Haliaẽtus pelagicus. The recent skeleton in the British Museum on which the determination was made has however been found to have been wrongly named, and the Walthamstow specimen probably belongs to the European $H$. albicilla.

Remains of existing species of mammals have been found in the prehistoric deposits of other places in the county, but there would be no advantage in alluding to them in detail. Reference is made in the chapter on geology to the occurrence in the alluvium of Beckton, Woolwich, of remains of the wild boar, red deer, Celtic shorthorn, wild ox, dolphin (Delpbinus delphis) and a whale. It may be added that from the marshes of East Ham have been disinterred remains of the bottlenosed whale (Hyperoödon rostratus), a species which is one of the most common cetacean visitors to the British shores. A skull and vertebræ (now in the British Museum) of the blackfish (Globicepbalus melas) have been dug up in the marshes at Barking Creek. Teeth of the sperm-whale (Physeter macrocephalus) have also been recorded from the estuarine turbary of the county.

Passing on to the consideration of the vertebrate remains from the brickearths, valley gravels and other deposits which, from containing a percentage of extinct mammals, may be regarded as of Pleistocene rather than prehistoric age, it may be mentioned in the first place that many of these are not strictly contemporaneous with one another. Evidence of this is afforded by a difference in the mammalian fauna. At Chelmsford ${ }^{2}$ for instance we have the mammoth, the woolly rhinoceros and the hippopotamus, whereas at Great Yeldham ${ }^{3}$ the hippopotamus is wanting and the woolly rhinoceros replaced by the slender-nosed species, the mammoth being common to both deposits.

The most interesting of all these animals is the Essex monkey, the sole evidence of whose former existence is a single upper molar tooth in a fragment of the jaw which was obtained from Grays, and is now in the

1 Cat. Fossil Birds Brit. Mus. p. 23 (1891). 2 See E. T. Newton, Essex Naturalist, ix. 16 (1895).

3 See Holmes, ibid. 115 (1896). 


\section{PALÆONTOLOGY}

British Museum. It was described by Sir Richard Owen in 1846 under the name of Macacus pliocenus.

Of Carnivora, the first on the list is the cave-lion (Felis leo spelaca), of which remains have been obtained both at Ilford and Clacton, the specimens obtained by Sir A. Brady from the former locality including part of the lower jaw and one of the bones of the foot. The wild cat (F. catus) is known by a lower jaw from Grays preserved in the museum at Oxford. The extinct European race (Hyana crocuta spelaa) of the spotted hyæna, a species now restricted to Africa, has been met with in the Pleistocene deposits of Grays and Walton; and remains of the wolf (Canis lupus) occur at Grays, and those of the fox (C. [Vulpes] vulpes) both at Grays and Ilford. Bones of the otter (Lutra lutra) have likewise been discovered at Grays. Remains of bears are recorded from Grays, Great Yeldham, Ilford and Walton; some of these certainly belong to the common European brown bear (Ursus arctus), but others have been assigned to the American grizzly bear. In view however of the numerous forms more or less closely allied to the typical brown bear which have recently been recognized in northern Asia and North America this determination is extremely doubtful. In his British Fossil Mammals and Birds Sir R. Owen expressed the opinion that certain ursine remains from Clacton and Grays might pertain to the great.cavebear (U. spelaus), but this also requires confirmation.

A jaw of some species of shrew (Sorex) from Grays seems to be the only known representative of the Insectivora in the Essex Pleistocene. Allusion has already been made to the occurrence of remains of the beaver at Walthamstow, and evidence of the presence of the same animal at Ilford and Grays has likewise been obtained. The beds at the former locality have yielded remains of two other rodents, namely the water-vole (Microtus ampbibius) and the common field-vole (M. agrestis). ${ }^{1}$ The common mouse (Mus musculus) is recorded from Copford, where have likewise been obtained molar teeth of a large undetermined beaverlike rodent.

The list of Ungulate, or hoofed, mammals from these deposits is very large indeed. From Clacton have been obtained antlers of a fallow deer which has been regarded as distinct from the ordinary European species and named Cervus browni, in honour of the late Mr. John Brown of Stanway, who did so much to advance our knowledge of the fossil mammals of the Essex coast. Remains of the giant fallow deer (C. giganteus), so constantly miscalled 'Irish elk,' have been obtained from Audley End, Grays, Ilford and Walton-on-the-Naze. Of the red deer remains have been recorded from Clacton, Colchester, Grays, Great Yeldham and Walton, and those of the roe from Grays and Great Yeldham. The bison (Bos [Bison] priscus) is known from the coast, Ilford, Walton and possibly Chelmsford. Magnificent skulls of the wild ox were obtained by Sir Antonio Brady from Ilford, so large indeed that they were regarded as belonging to a peculiar species, for which the 


\section{A HISTORY OF ESSEX}

name Bos giganteus was suggested by Sir $\mathrm{R}$. Owen. Its remains have likewise been found at Clacton, Grays, Great Yeldham and Walton. In addition to its occurrence at Walthamstow, the wild boar has been recorded from Clacton, Colchester and Grays, although, curiously enough, none of its remains were obtained by Sir A. Brady from Ilford. Of the extinct European race of the hippopotamus (Hippopotamus ampbibius major) teeth and bones have been found in considerable numbers at Chelmsford, Grays, Ilford and Walton.

The wild horse (Equus caballus fossilis) appears to have been widely distributed over the county, its remains being recorded from Audley End, Clacton, Grays, Ilford, Saffron Walden and Walton. Of much greater interest are the remains of rhinoceroses from the Essex deposits, these being more varied and occurring in greater perfection than perhaps in any other English county. They have been assigned to three species. Of the woolly rhinoceros (Rbinoceros antiquitatis), which was a twohorned species closely allied to the so-called white rhinoceros of Africa, remains have been recorded from Chelmsford, Clacton, Ilford and Walton. The second species, $R$. leptorbinus, which differs by the form of its cheek-teeth but has a similar bony partition dividing the two nostrils, occurs at Clacton, Grays, Great Yeldham, Ilford and Walton. It is represented in the British Museum by no less than four Essex skulls, two of which are from Walton and the others respectively from Grays and Clacton. The Clacton skull, which is figured in Sir R. Owen's British Fossil Mammals and Birds, has been the subject of much controversy. The third form, $R$. mercki or $R$. megarbinus, has teeth very similar to the last, with which indeed some have thought it to be identical; but, according to a recent publication by Professor H. F. Osborn, it is perfectly distinct. It appears to have no partition between the nostrils. Its remains occur at Grays, Ilford and Walton, many of the molar teeth from the two former localities having been described by Professor W. B. Dawkins.

Teeth and bones of the mammoth (Elephas primigenius), a near relative of the Indian elephant, have been obtained in great numbers from the Ilford pits, which have likewise yielded a nearly entire skull, with the tusks, of the same species, which is now preserved in the British Museum. Mammoth remains have likewise been recorded from Chelmsford, Clacton, Grays, Great Yeldham, Harwich, Hedingham, Ilford, Isle of Dogs, Walthamstow and Walton. Neither is evidence wanting of the former presence in the county of the straight-tusked elephant (E. antiguus), its remains, although less abundant than those of the mammoth, occurring at Clacton, Grays, Harwich, Ilford, Saffron Walden and Walton. Of the older southern elephant ( $E$. meridionalis) no remains appear to have been obtained on land within the confines of the county, although its molar teeth have been dredged up off the coast.

Vertebræ provisionally assigned to the bottle-nosed dolphin (Tursiops tursio) are known from the brickearth at Grays.

One bird alone appears to have been identified as occurring in the 


\section{PALÆONTOLOGY}

Essex Pleistocene, this being the wild swan (Cygnus musicus), of which the British Museum possesses a leg-bone from Grays.

A few fish remains have been obtained from the brickearths of Essex, mainly from Grays, and have been provisionally assigned to the following species," viz. the pike (Esox lucius), ruff (Acerina vulgaris), roach (Leuciscus rutilus), dace ( $L$. dobula), rudd ( $L$. erytbopbthalmus), and eel (Anguilla vulgaris). With the exception of the first, which also occurs at Copford and Ilford, all these forms are known from the deposits at Grays.

Mammalian remains from the Red Crag at Walton and other localities where the same formation occurs in the county appear to be exceedingly rare. Fragments of the tusks of the Crag walrus (Odobanus buxleyi) are however recorded from Essex.

At the time when the 'cement stones,' or septaria, of the London Clay were collected in the neighbourhood of Harwich, these when broken were occasionally found to be formed round part of a mammalian skeleton or the shell or skull of a turtle. In the winter of $1856-7$ a portion of such a nodule containing bones, which had been obtained near Harwich, was brought to Sir R. Owen, who described the skull and other remains found therein as those of a new genus of mammal, under the name of Pliolophus vulpiceps. Subsequently however they were identified by Sir W. H. Flower with a mammal previously described by Owen from the London Clay of Kent as Hyracotberium leporinum. The animal in question, which was about the size of a fox; was one of the ancestral types of the horse. The Essex specimen is in the British Museum.

Of even greater interest is a fragment of the lower jaw of a much larger mammal in the same collection containing two teeth, which was dredged off the Essex coast between St. Osyth and Harwich some time previous to the year 1846 , and appears to have been derived from the London Clay. This specimen is described and figured in Owen's British Fossil Mammals and Birds under the name of Corypbodon eocanus, and forms the type of both the genus and the species. For many years the affinities of the Coryphodon were unknown, but from the evidence of complete skeletons abtained in North America it is now ascertained to have been a large hoofed mammal of very primitive type allied to the wonderful horned Uintatberium of the North American Eocene.

Skulls and shells of large marine turtles belonging to the extinct genus Lytoloma are not uncommon in these Harwich cement stones, and there is a considerable series of such specimens in the British Museum. Some of these remains belong to $L$. crassicostatum, of which the type specimen is from Harwich, and was originally described by Sir R. Owen as Chelone crassicostata. The second species, originally described by the same palæontologist on the evidence of a skull from Harwich, is $L$. planimentum.

From the Chalk of Essex remains belonging to those gigantic 1 See E. T. Newton, Geol. Mag. Dec. 4, viii. 51 (1901). 


\section{A HISTORY OF ESSEX}

extinct marine lizards known as Mosasauria are occasionally met with, some of these belonging to Liodon anceps, while others indicate a species more nearly allied to, if not identical with, the typical genus Mosasaurus, whose remains are so abundant in the Upper Cretaceous formation of Belgium.

Very few species of fishes appear to have been hitherto recorded from the Chalk of Essex. These include Ptychodus polygyrus, a common species of a well known Cretaceous genus of pavement-toothed rays, teeth of which have been found both at Grays and Purfleet. Three species of sharks are known, all from Grays, namely Scapanorbynchus subulatus, Corax falcatus and Oxyrbina mantelli, the latter being represented in the British Museum collection by an associated series of fiftyseven teeth and some vertebræ from Grays. All are common Cretaceous forms. The same locality has also yielded teeth of Enchodus lewesiensis, an extinct barracuda-like fish with large teeth, originally named on the evidence of remains from the Sussex Chalk. 


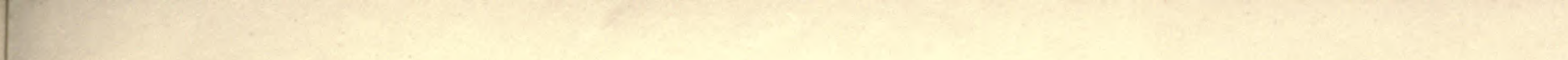




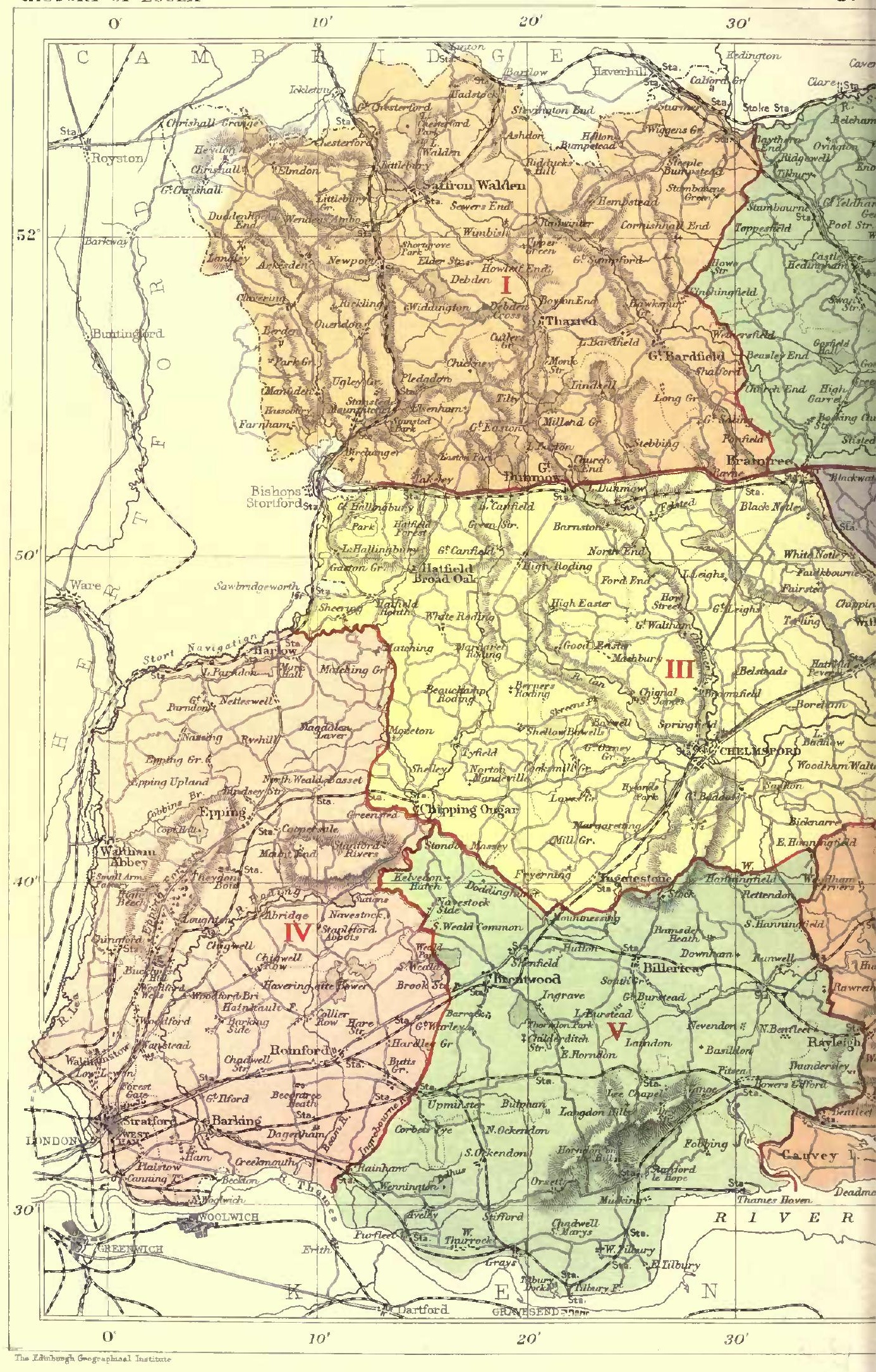


ISTRICTS.

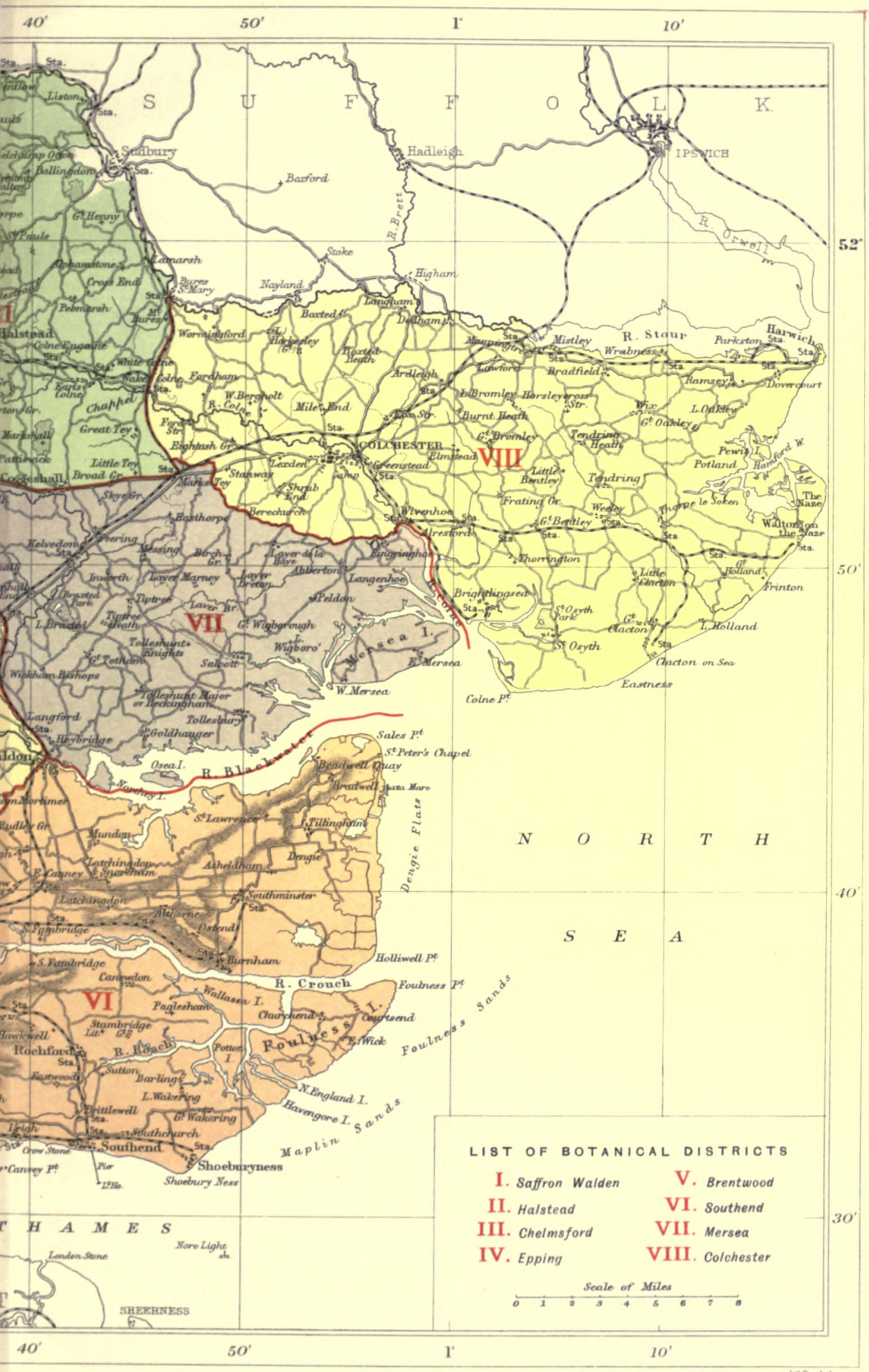

E COUNTIES OF ENGLAND 



\section{BOT ANY}

$\mathrm{P}$

LANTS first became of interest to man on account of their value as food, their medicinal virtues or the poisonous properties possessed by so many of them. Hence the first steps in the building up of our science consisted in attempts to describe plants with a degree of accuracy which would enable students to recognize those which could be utilized for food or medicine, or which should be avoided because of their poisonous character. Attempts of this kind slowly developed into the vast subject now known as vegetable biology.

Owing no doubt to the fact that the metropolis, the home of many of the earlier English writers, is only a few miles from the borders of Essex, the history of the botany of our county is practically coterminous with that of the science in Britain. Hence we must seek the early records of the Essex flora in the works of William Turner, the father of English botany, and in those of Gerard, Johnson, Parkinson, How, Robert Turner, Merrett, Ray, Morison and Dale.

Since a brief outline of the botany of Essex is all that space permits of in this article, and an account of the 'History of the Botany of Essex,' by Professor G. S. Boulger is now appearing in the Essex Naturalist, I wish to refer my readers to that publication for details of this interesting subject.

William Turner was born in Northumberland between $\mathrm{I} 5 \mathrm{IO}$ and 1515. He was educated at Pembroke College, Cambridge. Like many who adopted the principles of the Reformation of that period, Turner spent a portion of his time in prison and in foreign travel. His herbal, which was written just three centuries before the publication of Gibson's flora, contains the first records of Essex plants, viz. Ruscus aculeatus, a Tilia, a hellebore and mistletoe.

'Butcher's broom (Ruscus aculeatus),' he says, 'groweth verye plenteously in Essex.' The 'Lind tre,' he tells us, 'groweth very plenteously in Essekes in a parke within two miles of Colichester, in the possession of one maister Bogges,' but whether he alludes to the

1 I desire here to express my indebtedness to the following correspondents: Professor G. S. Boulger, F.L.S. ; Dr. M. C. Cooke, M.A., LL.D.; Mr. Philip Lake, M.A. ; Mr. E. E. Turner. I am under special obligations to Mr. E. M. Holmes, F.L.S., for looking over MS. and proofs, and for revising and rearranging portions of the cryptogamic flora of Essex. 


\section{A HISTORY OF ESSEX}

indigenous or to the planted species is uncertain. Of hellebore he says," I dare not saye that ever I found the righte black hellebor, but thys I dare holde, that a man for defaut of it, may use verye well that kinde of bear foot that goeth every yeare into the grounde, whereof groweth greate plentye in a parke besyde Colchester.' Of the mistletoe he tells us that it grows more plentifully than elsewhere.

Essex perhaps owes more to John Gerard than to any other early botanist.

Gerard was born at Nantwich in Cheshire in I 545. He was educated in a neighbouring school, but at an early age he studied medicine and travelled in Denmark, Poland, Sweden and Russia. In I 577 he had charge of the gardens of Lord Burleigh in the Strand and at Theobalds in Hertfordshire, and at one time he had a house and garden of his own in Holborn. In I 597 he became a warden of the BarberSurgeons Company, and issued his celebrated herbal, which was illustrated by I,800 woodcuts, mostly reproduced from the Eicones Stirpium of Tabernamontanus. This herbal records about seventy-five Essex plants.

I must not pass from these pioneers in botanical science without referring to Ray, who filled an important place among the great founders of botany and zoology. To his works Linnæus, Buffon, Jessieu, Brown, De Candolle and others were largely indebted. Ray was born at Black Notley near Braintree. The son of a blacksmith he studied at Cambridge, entering at St. Catharine College and subsequently at Trinity College. He was elected a fellow of Trinity in I649. He was appointed Greek lecturer of his college, and at the age of twenty-five he was made mathematical tutor. He finally settled in our county, and the house he lived in was destroyed by fire quite recently. The county may well be proud to have given birth to this great man.

More recent records of Essex botany are to be found in a catalogue of plants in Gough's edition of Camden's Britannia, in Warner's Plante Woodfordiensis (pub. 1771), Watson's Botanical Guides, in the Pbytologist, in Smith's English Flora, Withering's works and several herbaria which are preserved in the British Museum, and finally in Gibson, who, assisted by a band of workers, published the first complete Essex Flora in 1862 , a work which will compare favourably with any county flora since published.

During the last twenty years many lists of plants found in the county have been published in the journal of the Essex Field Club (Essex Naturalist, edited by W. Cole). The plants thus added to the records of the Essex flora are chiefly those belonging to the so-called critical genera, which were not recognized as species in Gibson's day, and casuals, some of which may establish themselves as permanent residents. The cryptogamic plants included in this article are almost entirely derived from the above journal, and afford an example of the value of such publications. That the contributors include the names of Mr. E. A. L. Batters, Dr. M. C. Cooke, the Rev. James Crombie, Messrs. English, E. M. Holmes, G. P. Hope, Worthington Smith 


\section{BOTANY}

and E. G. Varenne is sufficient guarantee of the trustworthiness of those records.

There is no reason to suppose that the flora of the county has changed since the publication of Gibson's Flora. I have botanized through that portion of the county which forms Gibson's district 8, Mr. E. E. Turner of Witham has done much work in district 7 , and the Rev. J. T. Powell has contributed a paper to the Essex Naturalist (vi. I) on the existing flora of Epping Forest. I do not know of any species of flowering plants which have been certainly lost to us. Filago gallica has not been found for some years, owing to the field from which it was formerly collected having been left uncultivated.

In some districts of the county, more especially near the metropolis, the rapid growth of town threatens the early destruction of the flora. Such abundant plants as the primrose and the wild hyacinth are said to have been almost exterminated in some neighbourhoods, and the advent of the bicycle has unfortunately extended the range through which this destruction may take place.

\section{DISTRIBUTION}

The chief forces which influence the distribution of plants may be generalized as follows. When we travel north and south we observe considerable change in the flora, and though such changes are not very marked in a small country like England, the distinction between the flora of the tropical, subtropical, temperate and arctic latitudes has always greatly impressed travellers. Again, as we travel east and west a less marked change may be noted. In the latter case the difference in the climatic conditions is not great. In so small an area as that of Essex these changes may be neglected.

When we climb a mountain, plants which were abundant at the lower levels gradually disappear and new ones take their place. The highest ground in Essex does not greatly exceed 400 feet above the sea ; we should therefore not expect to meet with representatives of the mountain flora, but strange though it may seem our coast produces several plants which are also found high up on mountains, though they do not grow at intervening altitudes.

The most potent agent in regulating the distribution of plants is undoubtedly climate. The difference between tropical, subtropical, temperate and arctic vegetation is so marked that geologists do not hesitate to tell us that England was once a tropical and later an arctic country, because they find remains of tropical and arctic flora in different strata underlying our eastern counties.

England was once part of the continent of Europe, and during at least a portion of that time was clothed by arctic plants; these however gave place to our modern flora, which is similar in character to the flora of Europe, and is therefore no doubt derived from the adjacent continent. 


\section{A HISTORY OF ESSEX}

The meteorological conditions of a district have a most important influence upon the flora, plants being peculiarly sensitive to drought or excessive moisture in the atmosphere, and also to winds and other atmospheric conditions.

Perhaps next to climate the geological formations on the surface of the earth have the most potent influence upon the distribution of plants, and botanists can frequently identify a geological formation by plants which occur on its surface. In the county of Essex the distribution of plants is mainly determined by geological conditions.

All plants are more or less adapted to their environment. Hence in those districts where the field boundaries are constructed of stone certain plants become more or less rare which elsewhere are comparatively common; and in counties from which stone is absent those plants which delight in stone walls are rare or absent. Again, if a wood is converted into arable land or pasturage, plants which need the shade and other forms of vegetable life peculiar to woodland country soon disappear. Pasturage, heath land, cultivated land and river barks have each their peculiar inhabitants.

In order to show clearly the distribution of plants over any area it is necessary to divide it into districts. When possible it is better that these districts should coincide with the geological formation, or when this is impossible with the natural features of the country. Reference to the geological map of Essex will show that the surface geological formations are so scattered that any division of the county coinciding with the geological structure is practically impossible.

Watson in his Cybele Britannica has subdivided Great Britain into its river beds, and although the distribution of plants does not in all cases coincide with river beds this system has many practical advantages. Professor G. S. Boulger has suggested the adoption of this system for the county of Essex, ${ }^{1}$ and has worked out the districts of Essex on that basis; but I do not think that for practical purposes this arrangement is as convenient in this county as the purely artificial divisions adopted by Gibson. Therefore in the list of Essex flowering plants here given Gibson's divisions have been adhered to.

As the geology of Essex is fully dealt with elsewhere it is only necessary here to summarize those features of the surface geology of our county which influence the flora.

Essex occupies a large part of an irregular tract known as the London basin, which has for its foundation the great chalk formation, and the chalk comes to the surface at Purfleet and Grays in south Essex; at Quendon, Newport, Audley End and Saffron Walden in north Essex; and at Great Yeldham and Middleton eastwards.

London clay, which lies upon the chalk, is a very stiff bluish-grey clay, brown on its surface ; it shrinks and cracks in dry weather, but absorbs much water in wet weather. It occupies a large part of the county, and is exposed over considerable areas.

1 Transactions of the Essex Field Club, ii. 69. 


\section{BOTANY}

Overlying the London clay we have various formations consisting of sands and gravels. Amongst these are: (I) Bagshot beds, which constitute some of the higher and more picturesque tracts, as at High Beech, Brentwood, Warley, Billericay, Stock, Langdon Hill and Rayleigh; (2) the glacial gravels occurring at Quendon, at Clavering, at Harlow and at Roydon, along the Colne from Great Yeldham, Halstead, Gosfield, Great Bardfield, Thaxted, over the high grounds of Danbury, around Colchester, Brightlingsea and St. Osyth, in patches at Mersea Island and Tolleshunt, and at Tiptree Heath ; (3) valley gravel in the Thames valley.

Boulder clay, another glacial drift formation, occupies a large portion of the surface of Essex.

Bordering on our rivers we have large tracts of alluvium recently deposited, forming extensive marshlands. These marshlands near the sea and riverine estuaries are either covered at high tides, when they are known as saltings, or the sea water permeates them, when they may be described as brackish marshes. We have also on the edges of the sea coast considerable stretches of shingle and sand. The long stretches of sea wall protecting the coast have a characteristic though limited flora.

It will therefore be evident that Essex has an abundant variety of soil, and is very pleasantly diversified with arable land and pasture, with woodlands, commons and well timbered hedgerows. It includes every species of soil from the most stubborn to the mildest loam.

For our present purposes we may group the geological formations as follows :-

I. Chalk and Boulder Clay, which contains much chalk.

2. London Clay.

3. Gravels and Sands.

4. Alluvium.

5. Marine.

Though chalk only comes to the surface over a small area in the county the chalk flora extends over a considerable portion of its surface, for the Essex boulder clay usually contains so much chalk that the chalk loving plants may always be met with upon this formation. It is upon this strata that the traveller's joy (Clematis Vitalba) flourishes more particularly. Both the green hellebore and the fortid hellebore also occur as natives upon the boulder clay. Berberis vulgaris is found at Saffron Walden on the chalk, also the common rockrose (Heliantbemum vulgare), which plant also occurs at other stations. The hairy violet (Viola birta) is common both upon the chalk and upon the boulder clay. The following chalk plants are included in our flora : the buckthorn (Rbamnus catbarticus), ladies' fingers (Antbyllis Vulneraria), the wild liquorice (Astragalus glycyphyllos), the purple milk-vetch ( $A$. bypoglottis), the dropwort (Spiraa Filipendula), the salad burnet (Poterium Sanguisorba), common hare's ear (Bupleurum rotundifolium), dwarf thistle (Carduus acaulis), yellow-wort (Cblora perfoliata), autumnal gentian 


\section{A HISTORY OF ESSEX}

(Gentiana amarella), deadly nightshade (Atropa Belladonna), the dwarf orchis (Orchis ustulata), the pyramidal orchis (O. pyramidalis), the green man orchis (Aceras antbropopbora), bee orchis (Opbrys apifera), spider orchis (O. aranifera), the fly orchis (O. muscifera), large white helleborine (Cepbalantbera pallens), and other chalk plants.

London clay is perhaps remarkable for the limited character of its flora. In the summer the surface dries and becomes so hard that a pick can scarcely penetrate it, whilst below it retains much moisture. It favours those plants which send their roots deep into the soil, e.g. coltsfoot (Tussilago Farfara), which is common on undrained London clay. Thymus Chamadrys also favours this formation, whilst wild oat (Avena fatua) is peculiarly abundant on it.

The gravels and sands possibly stand next to chalk for the variety of characteristic plants which these soils produce in the county. The following may be mentioned as characteristic of these formations : the interesting mouse's-tail (Myosurus minimus), the small-flowered ranunculus (Ranunculus parviflorus), flixweed (Sisymbrium Sopbia), swine's cress (Senebiera Coronopus), lesser swine's cress (S. didyma), dog violet (Viola canina), Deptford pink (Diantbus Armeria), English catchfly (Silene anglica), purple sandwort (Spergula rubra), trailing St. John's wort (Hypericum bumifusum), upright St. John's wort ( $H$. pulcbrum), allseed (Radiola millegrana), needle whin (Genista anglica), hare's foot trefoil (Trifolium arvense), lesser trefoil (T. minus), slender trefoil (T. fliforme), annual knawel (Sclerantbus annuus), purple-tipped cudweed (Filago apiculata), field cudweed ( $F$. minima), narrow-leaved cudweed ( $F$. Gallica), slender-flowered thistle (Carduus tenuiforus), common sheep's scabious (fasione montana), downy hemp nettle (Galeopsis ocbroleuca), and the pretty little orchid 'lady's tresses' (Spiranthes autumnalis).

The riverside and alluvium flora is well represented; amongst these plants we have the common meadow-rue (Thalictrum flavum), greater spearwort (Ranunculus Lingua), white water lily (Nymphaa alba), yellow water lily (Nuphar luteum), bitter ladies' smock (Cardamine amara), purple loosetrife (Lytbrum Salicaria, L.), the willow herbs (Epilobium), common hare's-tail (Hippuris vulgaris), whorled water-milfoil (Myriophyllum verticillatum), spiked water-milfoil (M. spicatum), meadow-sweet (Spirca Ulmaria), common marshwort (Helosciadium nodiflorum), the very poisonous water dropworts (Enantbe), common valerian (Valeriana officinalis), small teasel (Dipsacus pilosus), hemp agrimony (Eupatorium cannabinum), bur marigold (Bidens tripartita and B. cernua), yellow rattle (Rbinantbus Crista-galli), most species of the mints (Mentha rotundifolia, $M$. aquatica, $M$. sylvatica, $M$. viridis, $M$. piperita, $M$. pratensis, $M$. sativa), scullcap (Scutellaria galericulata), water violet (Hottonia palustris), yellow loosestrife (Lysimacbia vulgaris), great water dock (Rumex Hydrolapatbum), yellow flag (Iris pseudacorus), great flowering rush (Butomus umbellatus), sweet flag (Acorus Calamus), all the duckweeds (Lemna), and bullrush (Scirpus lacustris).

Essex possesses a very representative marine flora. There are 36 


\section{BOTANY}

stretches of sand and shingle, upon which the following plants occur: horned poppy (Glaucium luteum), sea rocket (Cakile maritima), sea kale (Crambe maritima), saltwort (Salsola Kali), various species of orache (Atriplex) and sea spurge (Euphorbia Paralias).

Our saltings are very extensive and their flora includes scurvy grass (Cocblearia anglica, C. officinalis, C. Danica), golden samphire (Inula critbmoides), thrift (Armeria maritima), sea lavenders (Statice Limonium, S. rariflora and S. occidentalis), marsh samphires (Salicornia berbacea, S. radicans), sea aster (Aster Tripolium), sea blite (Suceda maritima).

Upon our sea walls and waste ground near the sea we find whitlow pepperwort (Lepidium Draba), broad-leaved pepperwort or cress (L. latifolium), smooth sea heath (Frankenia lavis), sea campion (Silene maritima), marsh-mallow (Althea officinalis), Alexanders (Smyrnium Olusatrum), sea wormwood (Artemisia maritima), sea lettuce (Lactuca saligna), shrubby sea blite (Suceda fruticosa), shrubby sea purslane (Obione portulacoides), sea dock (Rumex maritimus), asparagus (Asparagus officinalis), round fruited rush (Funcus Gerardi), wild celery (Apium graveolens). Common mustard (Brassica sinapioides) is said to be a native of our coast, and upon sandy ground near our coast Medicago minima, M. maculata and $M$. denticulata occur.

The very extensive brackish marshes, covering thousands of acres, do not produce a great variety of plants; but the rare Vicia lutea has been found upon them, and the uncommon Trifolium maritimum also occurs.

The very interesting grass vetch, Lathyrus Nissolia, grows in considerable quantities on some of these marshes. In the dikes, or at the edges of the dikes bounding the marshes, the following plants are abundant : Slender hare's ear (Bupleurum tenuissimum), salt marsh club rush (Scirpus maritimus) and tassel pondweed (Ruppia maritima).

Drainage and enclosure have been carried out in Essex so extensively that the bog flora has been almost exterminated, but boggy places remain at Danbury, at Warley and in Epping Forest, hence we have the following representatives of the bog flora : Drosera rotundifolia, Parnassia palustris, Hypericum elodes, Eriophorum angustifolium and E. latifolium.

The old walls of Essex afford us the wallfower (Cbeirantbus Cbeiri), the Spanish catchfly (Silene Otites), which latter was planted on the walls in Colchester by a lepidopterist as a food plant for larvæ, and has been well established for twenty years. The rue-leaved saxifrage (Saxifraga tridactylites), viper's bugloss (Ecbium vulgare), mother of thousands (Linaria Cymbalaria), wall pellitory (Parietaria officinalis) and wall veronica (Veronica arvensis). There is an abundant wood flora, waste ground flora, hedge flora and cornfield flora, but space will not permit the enumeration of the species which favour these situations.

It will thus be evident that if Essex is not so rich in rarities, nor in the actual number of species as some of the southern counties of England, it nevertheless ranks high as a field for botanical research, and affords an abundant variety of species for the lover of wild plants. 


\section{A HISTORY OF ESSEX}

\section{RARE AND INTERESTING PLANTS}

Among the rare plants of Essex may be mentioned Bupleurum falcatum, an interesting plant which appears to be truly indigenous, and is confined in Britain to one situation in Essex, where it is very plentiful and extends over an area of several square miles. It was discovered by Corder in I 83 $\mathrm{I}$. Another is Latbyrus tuberosus; this beautiful plant is still plentiful in the Essex locality. It was first noticed by O. Corder in I 859 , but is figured in Gerard's herbal of I 597, and specimens occur in some old herbaria, but previous to Mr. Corder's rediscovery it was confused with $L$. macrorbizus. It occurs nowhere else in England. $L$. birsutus occurs in only a few other counties in Britain. It has been known in Essex since I861. Galium Vaillantii was discovered in Britain by Gibson in 1844 in a field in Essex. It is spread over a large district, where it is abundant in fields, more particularly in those planted with potatoes.

Besides the above we have the following plants which are only found in two or three of Watson's subprovinces: Filago gallica (this plant has not been collected for some five years, but probably still occurs), Primula elatior, Chenopodium botryoides, Peucedanum officinale, Crepis feetida, Medicago falcata, Barbarea stricta, Diotis maritima (probably now lost).

The following plants should also be mentioned as amongst the rarer plants of Essex : Enanthe pimpinelloides, Galium Anglicum, Hypocharis maculata, Lactuca Scariola, L. saligna, Cynoglossum montanum, Scropbularia vernalis, Melampyrum arvense, Galeopsis ocbroleuca, Suada fruticosa, Aceras Antbropopbora, Ceratopbyllum submersum, Fritillaria Meleagris, Lepidium latifolium, Vicia gracilis, Actinocarpus Damasonium, Carex elongata, Pbleum Boebmeri, Polypogon Monspeliensis, Trifolium ocbroleucum, Spartina stricta, Salicornia radicans, Limnantbemum peltatum.

One of the most interesting plants of Essex, and indeed of England, is Primula elatior, the true oxlip. This must not be confounded with the hybrids between the cowslip and the primrose so often mistaken for the oxlip. The true oxlip is a very beautiful primula. It is very difficult to give any specific characters by which it can be distinguished from its relations. The peduncle is more slender, the calyx fits more tigbtly to the corolla tube, the form of the umbel is peculiarly graceful, the pedicels varying in length so that the flowers are arranged one over the other, all facing in one direction, the petals of a pale buff colour quite distinct from that of other primulas. The free portions of the petals are peculiarly regular in outline and never overlap one another, whilst the folds or boxes in the neck of the corolla, present in all other species of primrose, are absent from the true oxlip.

This plant is confined to an area of our county where it borders upon Suffolk, Cambridgeshire and Hertfordshire, extending into those counties. It covers a stretch of country some 475 square miles in extent, having an irregular outline. There are some outlying patches, one in Cambridgeshire, one in Suffolk and one in Norfolk. Within the 


\section{BOTANY}

district where it grows it entirely replaces the primrose and is even more abundant. On the borders of the district, which in some parts divides woods into two portions, there is usually a narrow belt of country which is occupied by hybrids between the primrose and the true oxlip. Mr. Miller Christy suggests that the primrose, which is the more hardy plant, is gradually destroying the oxlip by hybridization and replacing it. I have visited the oxlip country upon several occasions with Mr. Miller Christy, and think that there is much to support his view. It will be interesting if botanists of a later period note the boundary line between the oxlip and the primrose country, and observe whether the habitat of the former has been reduced. Mr. Miller Christy gives a carefully prepared map of the oxlip country in his paper. ${ }^{1}$ The oxlip is confined to the boulder clay.

Another interesting plant of Essex is the sea holly (Eryngium maritimum). A candy was prepared from the roots of this plant for which the town of Colchester was formerly celebrated, and in the chamberlain's accounts for the borough items frequently appear for purchasing the roots to present to royal and other distinguished persons. It was first prepared by one Robert Buxton, an alderman of the borough, during the Civil War, and its manufacture was continued down to some forty years ago. ${ }^{2}$

The coast flora of Essex presents points of interest and should afford opportunities for scientific work to our county naturalists. The climatic conditions and the nature of the soil is rendered quite different from the climate and the soil of the inland portions of the county by the presence of salt, and consequently the character of the flora is quite distinctive. A thorough investigation of the variation of the coast plants and of their nearest allies growing inland would, I am sure, be profitable.

The action of the salt water and atmosphere favours those plants known to botanists as xerophytes, as it reduces the amount of transpiration. Hence there is a similarity between the coast flora and that of rocky or dry situations; but in the one case we have an abundance of water under conditions which reduce the amount of transpiration, in the other we have at times a dearth of water, and consequently those plants thrive which retain the water in their tissues. We find therefore that whilst the plants which favour our coast line are similar in character to those which we find in dry and rocky inland situations, yet they show distinct variations from the latter and are known as halophytes.

On our sandy shores Silene maritima frequently occurs; it is considered by some a mere variety of $S$. Cucubalus, the latter growing in sandy and chalky situations; thus we have two very near relations both having the characters of xerophytes, but one confined to the coast and the other to the inland districts of the county; but strange as it may

1. 'The Primula elatior in Great Britain,' Journal of the Linnean Sacien, 1897.

A full account of this manufacture will be found in the Essex Naturalist, "Report on the Flowering Plants of Essex,' J. C. Shenstone, February, 1897. 


\section{A HISTORY OF ESSEX}

appear the marine species occurs also high up on mountains. Common thrift (Armeria maritima), which grows abundantly on our saltings, covered at every tide by salt water, also flourishes high up on mountains, where the conditions of soil and climate must be very different; in fact it is difficult to imagine localities affording wider differences. In the sea plantain (Plantago maritima) and scurvy grass (Cocblearia officinalis) we have also two plants which flourish on our saltings and high up on mountains.

The species of Atriplex on our coast should also provide material for investigation. On our sandy shores there is a wide range of variations, and inland another series of variations. The sandworts (Spergularia) give four forms: S. rubra, growing in hot, sandy, inland situations; $S$. saligna, found in muddy or rocky situations by the sea; S. media, occurring on muddy sea marshes; and lastly a species found only in rocky places by the sea, $S$. rupestris. It is scarcely necessary to say that this latter does not occur in Essex. These plants are so closely related that botanists do not agree in dividing them into species and varieties, but the inland forms are quite distinct from the marine forms. It will thus be seen that the coast flora of Essex offers problems of great scientific interest.

Insectivorous plants mostly occurring in bogs are represented in the county, though rare. We have the sundew (Drosera rotundifolia), the great bladderwort (Utricularia vulgaris), rue-leaved saxifrage (Saxifraga tridactylites), and that remarkable plant the toothwort (Latbraa squamaria), which obtains its vegetable diet from the roots of plants to which it attaches itself, and its animal nourishment by catching small insects in its scale-like leaves, folded back at the edges to form traps for unwary insects. The plant only needs to come above the ground in the spring to form flowers and seeds, not requiring green leaves like other plants.

Orchids remarkable for the mechanism of their flowers by which their fertilization is accomplished are well represented in the county, though not so abundant as in some of the southern counties of England.

The poisonous plants growing in the county are both of scientific and also of practical interest to the farmer and country resident. They may be summarized as follows: The poppy, which is unwholesome, though not so deadly as those species favouring hot climates; the common celandine, which is an acrid and violent irritant; the soapwort; the Deptford pink; the white campion, the red campion, and most plants of the natural order Caryophylleæ, which contain the active principle saponine and are therefore either poisonous or unwholesome. Fortunately saponine is destroyed by heating, hence flour made from corn containing seeds of these plants is rendered harmless by cooking. Holly berries cause violent irritation of the bowels. The leafless vetchling (Latbyrus apbaca), the rough-podded vetchling ( $L$. birsutus), and the broom (Cytisus Scoparius) are the only British plants of the pea-flower tribe which have been known to possess deleterious qualities, causing violent headache 


\section{BOTANY}

and vomiting. Many species of the rose family contain emulsin and amygdalin, and when the seeds are bruised these substances react and the deadly prussic acid is formed. The kernel of the sloe also contains these principles. Cattle have been poisoned by browsing on the leaves of the bird cherry, and the berries of the mountain ash have been known to cause symptoms of poisoning to children who have eaten them.

Common bryony is a powerful and highly irritant purgative. The natural order Umbelliferæ affords perhaps some of the most virulent of British poisonous plants. There are found in Essex the hemlock (Conium maculatum), the water hemlock (Cicuta virosa), the water dropwort (Enantbe fistulosa), the parsley dropwort ( $E$. pimpinelloides), the hemlock dropwort $(E$. crocata), the fineleaved dropwort (EE. Phellandrium), and the fool's parsley (Etbusa Cynapium), all of which have caused fatal poisoning; and to these may be added the wild parsnip (Pastinaca sativa), though the cultivated plant is such a useful vegetable. Ivy has purgative and emetic properties, and common elder and honeysuckle are both unwholesome.

The composite plants only afford us wormwood, containing an oil which is a narcotic poison, but the plant can scarcely be considered dangerous.

Privet berries have certainly caused fatal poisoning, and in the root and herbage of great bindweed we have a strong emetic and purgative.

The nightshade family is perhaps the most poisonous of all our orders of plants. Most if not all the plants of this order contain some one of the alkaloids known as the mydriatic alkaloids, though curiously the potatoes and tomatoes, both belonging to this order, are valuable vegetables. Potatoes are said to be poisonous when uncooked. We have in the county the following plants of this order: Bitter-sweet (Solanum Dulcamara), common nightshade (S. nigrum), deadly nightshade (Atropa Belladonna), thorn-apple (Datura Stramomium), the henbane (Hyoscyamus niger), most of which are still used in medicine. The foxglove is both very poisonous and much valued in medicine. The bark of the mezereon (Daphne Mezereum) and of the spurge laurel (D. Laureola) both afford us strong blistering agents. The spurges and perennial mercury are powerful irritant poisons. The poisonous properties of the yew are too well known: the branches in a halffaded condition are even more deadly than when fresh. It is stated that yew berries are not poisonous; it is however wisest to leave them untasted. The wild hyacinth and herb Paris are very acrid. The meadow saffron is a narcotic irritant poison and is still used in medicine. The wild arum is very acrid, but the poison is destroyed by heat and the roots formerly provided a wholesome farina called Portland arrowroot, the manufacture of which was discontinued in 1853 . Black bryony (Tamus communis) was formerly a favourite internal medicine, but was discontinued as it was found to be dangerous in its action. It is still used when grated as an application to blackened eyes.

Common rye grass is apt to be attacked by a fungus known as ergot, 


\section{A HISTORY OF ESSEX}

which is poisonous but useful in medicine. The darnel grass is the only British grass which is said to be poisonous.

\section{A LIST OF BRITISH FLOWERING PLANTS FOUND IN ESSEX}

Showing the districts in which they are found. ${ }^{1}$

Clematis Vitalba, L. ${ }^{2} \quad$ I-8

Thalictrum saxatile, Bab. I

- flavum, L. 1-8

Anemone Pulsatilla, L.

- nemorosa, L. I-8

[Adonis autumnalis, L.] $\quad \mathbf{1}-5$

Myosurus minimus, L. 2-8

Ranunculus heterophyllus, Fries. I, 6, 7

- peltatus, Fries. 4, 7,8 var. floribundus, Bab. " " Hiern. Mon. 8

" truncatus, Dumort. 8 , penicillatus, Dumort. 8

- confusus, Godr. 6,8

- Baudotii, F. Godr. 8

- trichophyllus, Chaix. I, 4, 7,8

- Drouetii, F. Schultz. 1, 4, 8

- fluitans, Lam. 1, 4

- circinatus, Sibth. $\quad$ I-8

- hederaceus, L. I-8

- Lingua, L. I

- Flammula, L. 1-8

- auricomus, L. $\quad$ I-8

- sceleratus, L. I-8

- acris, L. $1-8$

- repens, L. I-8

- bulbosus, L. I-8

- hirsutus, L. 2, 4-8

- arvensis, L. I-8

- parviflorus, L. I-4, 6-8

- Ficaria, L. I-8

Caltha palustris, L. I -8

Helleborus viridis, L. 1, 3, 4

- foridus, L. I, 3-5, 7

Aquilegia vulgaris, L. I-3

Delphinium Ajacis, Reichb. I, 4, 6, 8

[Aconitum Napellus, L.] I, 3

Berberis vulgaris, L. I, 3, 4, 7

Nuphar luteum, Sm. I-8

Nymphxa alba, L. I-8

Papaver Argemone, L. 1-4, 6-8

- hybridum, L. $\quad 1,6,8$

- Rhœas, L. I-8

- dubium, L. 1-8

- Lecoqii, Lamotte. 2, 5

[- somniferum, L.] 1,5

Glaucium luteum, Scop. 6-8

Chelidonium majus, L. I-8

1 The numbers refer to corresponding numbers marked upon the map, and indicate the districts in which the species occur. Those species enclosed in brackets are probably casuals. A hyphen between two numbers indicates that the intermediate numbers are to be included.

2 The arrangement and nomenclature followed in this list is that of the Students' Flora of the British Islands, ed. 3 (1 884), by Sir J. D. Hooker.
Fumaria capreolata, L. 4, 5, 8

- officinalis, L. 1-8

- densiflora, DC. 1

- parviflora, Lamk. I var. Vaillantii, Loisel. I

Corydalis claviculata, DC. $3,4,8$

[- lutea, DC. ] 1, 3, 4, 7,8

[- solida, Hook.] I

Cheiranthus Cheiri, L. I, 3, 4, 6, 8

Nasturtium officinale, Br. I-8

- sylvestre, Br. 3, 4, 6

- palustre, DC. I-8

- amphibium, Br. 3, 4, 6, 7

Barbarea vulgaris, $\mathrm{Br}$. $\quad 1-8$

[- precox, Br.] I-4, 7,8

Arabis stricta, Huds. 5

- perfoliata, Lamk. $3,4,8$

Cardamine hirsuta, L. $\quad 1-8$ var. sylvatica, Link. $3,5,7$

- pratensis, L. I-8

- amara, L. 2-5, 7

Sisymbrium Thaliana, Hook. I-8

- Irio, L. 3

- Sophia, L. 1-8

- officinale, Scop. I-8

- Alliaria, Scop. I-8

Erysimum Cheiranthoides, L. I-8

Brassica oleracea, L. 6

- campestris, L. 4, 6, 8

- sinapioides, Roth. I, 2, 4-8

- sinapistrum, Boiss. I-8

- alba, Boiss. I-7

Diplotaxis muralis, DC. $5-8$

- tenuifolia, DC. $4,5,8$

Erophila vulgaris, DC. $\quad$ I-8

Alyssum calycinum, L. I, 4, 7

- maritimum, L. 4, 5,8

Cochlearia officinalis, L. 6-8

- Danica, L. 8

- Anglica, L. 4-8

- Armoracia, L. 1-8

Camelina sativa, Crantz. I , 4-6

Capsella Bursa-Pastoris, Mœnch. I-8

Senebiera didyma, Persoon. 1, 3, 4

- Coronopus, Poiret. 1-8

Lepidium latifolium, L. 4-8

- ruderale, L. $3,5-8$

- campestre, $\mathrm{Br}$. 2-8

[- Draba, L.] 1, 3, 6, 7

Thlaspi arvense, L. I-4, 6-8

Iberis amara, L. I, 2

Teesdalia nudicaulis, Br. 4,8

Isatis tinctoria, L. I , 4

Crambe maritima, L. 8

Cakile maritima, Scop. 6-8

Raphanus Raphanistrum, L. I-8

Reseda lutea, L. I-6, 8

- Luteola, L. I-8 


\section{BOTANY}

Helianthemum vulgare, Gærtn. 1-4, 6

Viola palustris, L. 5

- odorata, L. $\quad 1-8$

- hirta, L. $\quad 1-4,6,7$

- canina, L. 7,8

- sylvatica, Fries. I-8

- tricolor, L. I-8

Polygala vulgaris, L. I-8 var. depressa, Wend. 5

Frankenia lævis, L. 6-8

Dianthus Armeria, L. $\quad \mathrm{I}-4,6,7$

[- deltoides, L.] 3

[- plumarius, L.] 4

Saponaria Officinalis, L. $\quad 1-5,8$

Silene Cucubalus, Wibel. I-8

- maritima, With. 6-8

[- conica, L.] 8

- Gallica, L. 8 var. Anglica, L. 2, 8

[- Otites, L.] 8

- noctiflora, L. I, 3, 4

Lychnis Flos-cuculi, L. 1-8

- diurna, L. I-8

- vespertina, Sibth. I-8

Githago segetum, Desf. $\quad$ I-8

Cerastium quaternellum, Fenzl. 3-8

- tetrandrum, Curtis. 5, 6, 8

- semidecandrum, L. 1, 4, 6-8

- glomeratum, Thuillier. I-8

- triviale, Link. $\quad$ I-8

- arvense, L. 1, 3, 4, 6

Stellaria aquatica, Scopoli. $\quad$ I-8

- media, Vill. 1-8

- Holostea, L. 1-8

- palustris, Ehrh. 3, 4

- graminea, L. I-8

- uliginosa, Murr. I-8

Arenaria tenuifolia, L. I

- trinerva, L. $\quad$ I-8

- serpyllifolia, L. I-8 var. leptoclados, Guss. I, 5, 6

- peploides, L. 6-8

Sagina apetala, L. 1-8

- ciliata, Fries. 5, 7

-- procumbens, L. I-8

- nodosa, Frenzl. 3

- maritima, Don. 6, 7

Spergula arvensis, L. I-8

Spergularia rubra, Pers. I, 3-8

- salina, Pers. 4-8 var. medium, Fries. $\quad 5-8$

Montia fontana, L. 2-8

Claytonia perfoliata, Don. 3, 8

Tamarix Gallica, L. 6,8

Hypericum Androsæmum, L. 1-8

- quadrangulum, L. I-8

- perforatum, L. 1-8

- humifusum, L. I-8

- pulchrum, L. I-8

- hirsutum, L. 1-8

- Elodes, Huds. 4, 5

Althra officinalis, L. 5-8

Malva sylvestris, L. I-8

- rotundifolia, L. I-8

- moschata, L. 1-8
[Lavatera arborea, L.] 6

[Tilia europæa, L.] 1-8.

- parvifolia, Ehrh. I-5, 7, 8

[- platyphyllos, Scop.] $\quad$ 1-8

Linum catharticum, L. I-8

- perenne, L. $\quad 1$

- angustifolium, Huds. 2, 5, 6, 8

[- usitatissimum, L.] $1-4,6,7$

Radiola linoides, Gmel. 3, 4, 7, 8

Geranium sanguineum, L. I

- pratense, L. $\quad 1-3,6$

[- pyrenaicum Burm. f.] $\quad 1-4,7$

- molle, L. I, 3-8

- rotundifolium, L. 4

- pusillum, L. $\quad$ I-8

- columbinum, L. $\quad 1-3,5-8$

- dissectum, L. I-8

- Robertianum, L. 1-8

- lucidum, L. $\quad \mathrm{I}-4,6-8$

Erodium cicutarium, L'Herit. I-8

[- moschatum, L'Herit.] 1, 4, 8

Oxalis Acetosella, L. 1-8

Impatiens parviflora, DC. I, 4, 8

Ilex Aquifolium, L. I-8

Euonymus europæus, L. $\quad$ I-8

Rhamnus catharticus, L. $\quad 1-7$

- Frangula, L. 2-8

Acer campestre, L. I-8

- pseudoplatanus, L. I-8

Genista tinctoria, L. I, 3-8

- Anglica, L. 3-5, 7, 8

Ulex europæus, L. I-8

- nanus, Forster. 4, 5

Cytisus Scoparius, Link. $\quad$ I-8

Ononis spinosa, L. I-8

Trigonella ornithopodioides, DC. 3, 4, 7

Medicago falcata, L. 1-8

- sativa, L. I, 3

- lupulina, L. I-8

- denticulata, Willd. I, 6-8

- maculata, L. 2-8

- minima, Desr. $4,6,8$

Melilotus altissima, Thuill. $\quad 1-7$

- alba, Desr. I, 4, 7,8

- officinalis, Desr. 1, 7, 8

Trifolium subterraneum, L. 3-8

- arvense, L. 1-8

- ochroleucum, L. I-3, 5-7

- pratense, L. I-8

- medium, Huds. I-7

- maritimum, Huds. 4-8

- striatum, L. 1-8

- scabrum, L. I, 5-7

- glomeratum, L. 6

- hybridum, L. I, 3

- repens, L. 1-8

- fragiferum, L. $\quad$ I-8

- procumbens, L. $\quad$ 1, 2, 4-8

- dubium, Sibth. 1-8

- filiforme, L. 1-8

Anthyllis Vulneraria, L. I

Lotus corniculatus, L. I-8

- tenuis, Waldst. and Kit. I, 3-8

- uliginosa, Schk. 1-8

Astragalus glycyphyllos, L. I-3, 5 


\section{A HISTORY OF ESSEX}

Astragalus hypoglottis, L. I

Ornithopus perpusillus, L. 3-8

Hippocrepis comosa, L. I

Onobrychis sativa, Lamk. I, 3-5

Vicia tetrasperma, Mœnch. I-8

- gracilis, Loisel. I, 6

- hirsuta, Koch. I-8

- Cracca, L. I-8

- sepium, L. I-8

- lutea, L. 8

- sativa, L. I-8

- angustifolia, Roth. I-4, 6-8

- bithynica, L. 2, 3, 6

Lathyrus Aphaca, L. I-4, 6

- Nissolia, L. I-8

- hirsutus, L. 4-6

- pratensis, L. I-8

- sylvestris, L. I, 3, 4, 6

- tuberosus, L. 3

- macrorrhizus, Wimm. 3-7

Prunus communis, Huds. $1-8$

- insititia, L. I, 2, 4-8

- cerasus, L. I, 2, $4,7,8$

- Avium, L. I-3, 6-8

Spirza Ulmaria, L. I-8

- Filipendula, L. I, 4

Rubus Idæus, L. 1-8

- suberectus, Anders. var. plicatus, W. \& N. 5,8 , affinis, W. \& N. I, 4, 7

- rhamnifolius, W. \& N. I, 2, 4, 5, 7, 8

- Lindleianus, Lees. 2, 4, 5, 7, 8

- corylifolius, $\mathrm{Sm} . \quad \mathrm{I}-7$ var. Balfourianus, Blox. 7 " althæifolius, Bab. 7

- crsius, L. 1-8

- discolor, W. \& N. I-8 var. thyrsoideus, Wimm. 7

- leucostachys, Sm. I, 2, 4, 7

- villicaulis, Weihe. I, 7

- umbrosus, Arrh. var. carpinifolius. 2, 4

- macrophyllus, Weihe. $5,7,8$

- Sprengelii, Weihe. 4

- dumetorum, Weihe. var. nemorosus, Hayne. I, 7 "diversifolius, Lind. 4

- radula, Weihe. 7 var. rudis. $2,7,8$

- Bloxamii, Lees. var. scaber, Weihe. "fusco-ater. Weihe. 2, 7

- Kœhleri, Weihe. 1, 2, 4, 7

- hystrix, Weihe. 4 var. rosaceus, Weihe. 4

- pallidus, Weihe. 2, 4, 5, 7 var. hirtus, Weihe. 5,7

- glandulosa, Bell. I, 4, 5, 7,8

- saltum, Focke. var. Guntheri, Weihe. 5, 7

- pyramidalis, Kaltenb. 4

Geum urbanum, L. I-8

- rivale, L. I, 2 var. intermedium, Ehrh. I

Fragaria vesca, L. 1-8
Fragaria elatior, Ehrh. 2, 3

Potentilla Comarum, Nestl. 7,8

- Tormentilla, Scop. I-8

- reptans, L. 1-8

- Fragariastrum, Ehrh. 1-8

- argentea, L. 2-8

Alchemilla arvensis, Lamk. 1-8

- vulgaris, L. 1-3

Agrimonia Eupatoria, L. I-8

- odorata, Mill. 6

Poterium Sanguisorba, L. 1, 4-6

- muricatum, Spach. I, 2

Rosa spinossima, L. 5, 6,8

- tomentosa, Sm. I-8

- rubiginosa, L. I-8

- micrantha, Sm. I, 3-8

- inodora, Freis. I, 4, 7

-- canina, L. I-8

- lutetiana, Leman. 8

- surculosa, Woods. I, 4

- sphærica, Gren. 8

- sarmentacea, Woods. 1, 4, 5

- urbica, Leman. 4, 5

- frondosa, Steven. 4

- Andevagensis, Bast. 8

- verticillacantha, Merat. 8

- collina, Jacq. 8

- decipiens, Dumort. 8

- arvensis, Huds. I-8

- systyla, Woods. I-4, 7

Pyrus communis, L. I $\quad$-7

- Malus, L. I-8

- torminalis, Ehrh. 1-4, 6-8

[- Aria, Sm.] 7

- Aucuparia, Gærtn. 1, 3-8

Cratzgus Oxyacantha, L. I-8

Saxifraga tridactylites, L. I-8

- granulata, L. I, 3-8

Chrysosplenium alternifolium, L. 2-4, 8

- oppositifolium, L. 1-6,8

Parnassia palustris, L. I, 3, 4

[Ribes Grossularia, L.] I-4, 6, 7

- rubrum, L. 1, 2, 4, 5, 7,8

- nigrum, L. $\quad 1-5,7,8$

Sedum Telephium, L. I-3, 7, 8 var. Fabaria, Koch. 7

- album, L. I, 3, 7

- dasyphyllum, L. 1, 2

- acre, L. I-8

- reflexum, L. I, 3-8

Sempervivum tectorum, L. I, 2, 4-8

Drosera rotundifolia, L. $3-5,7,8$

Hippuris vulgaris, L. I, 2

Myriophyllum verticillatum, L. I-5, 7

- alterniflorum, L. 3, 4,7

- spicatum, L. I-8

Callitriche verna, $L$. I-8

- platycarpa, Kuetz. J, 2, 4-7

- pedunculata, DC. I, 4,8

Lythrum Salicaria, L. I-8

Peplis Portula, L. I-8

Epilobium angustifolium, L. I-5, 7, 8

- hirsutum, L. I-8

- parviflorum, Schreb. I-8

- montanum, L. I-8 


\section{BOTANY}

Epilobium roseum, Schreb. I-8

- tetragonum, L. I-8

- obscurum, Schreb, 2, 3, 5, 8

- palustre, L. $\quad$ I, 3-8

[Genothera biennis, L.] 8

Circra lutetiana, L. I-8

Bryonia dioica, L. 1-8

Hydrocotyle vulgaris, L. $3-8$

Eryngium maritimum, L. 6-8

Sanicula europrea, L. I-8

Conium maculatum, L. $\quad 1-8$

Smyrnium Olusatrum, L. I, 3-8

Bupleurum rotundifolium, L. I, 3-5

- falcatum, L. 3

- tenuissimum, L. $\quad 4^{-8}$

Apium graveolens, L. I, 3-8

- nodiflorum, Reichb. $\quad$ I-8 yar. repens, Koch. 3-7

- inundatum, Reichb. $1,3-8$

[Carum Carui, L.] 2, 6, 7

- segetum, Benth. I, 3-8

- Petroselinum, Benth. I, 3, 4, 7, 8

Sison Amomum, L. I-8

Sium latifolium, L. 4,8

- angustifolium, L. I-8

Ægopodium Podagraria, L. 1-5, 7, 8

Pimpinella Saxifraga, L. $\quad 1-8$

- major, Huds. I, 3, 5

Conopodium denudatum, Koch. 1-8

Scandix Pecten-Veneris, L. I-8

Chærophyllum temulum, L. I-8

Anthriscus vulgaris, Pers. I-4, 6-8

- sylvestris, Hoffm. 1-8

- Cerefolium, Hoffm. 4, 7

[Crithmum maritimum, L.] 8

Enanthe fistulosa, L. I-4, 6-8

- pimpinelloides, L. 7

- Lachenalii, Gmel. 5-8

- crocata, L. 4-6

- phellandrium, Lamk. 2-8

- fluviatilis, Colem. I $-5,7,8$

Æthusa Cynapium, L. I-8

Silaus pratensis, Besser. I -8

Angelica sylvestris, L. 1-8

Peucedanum officinale, L. 8

- palustre, Mœnch. 4

Pastinaca sativa, L. I, 2, 4-8

Heracleum Sphondylium, L. I-8

Daucus Carota, L. I-8

Caucalis daucoides, L. I, 5

- latifolia, L. 3

- Anthriscus, Huds. 1-8

- nodosa, Scopoli. I-8

Hedera Helix, L. I-8

Cornus sanguinea, L. 1-8

Viburnum Lantana, L. I, 3-6

- Opulus, L. 1-8

Sambucus Ebulus, L. I-8

- nigra, L. $\quad$ I-8

Adoxa Moschatellina, L. I-8

Lonicera Periclymenum, L. I-8

- Caprifolium, L. 1, 2, 7

- Xylosteum, L. I, 3, 4

Galium verum, L. I-8

- Cruciata, Scopoli. I, 3, 4, 6, 8
Galium palustre, L. 1-8

- uliginosum, L. I-5, 7

- saxatile, L. 3-8

- Mollugo, L. 1-8 var. erectum, Huds. 1

- Aparine, L. I-8 var. Vaillantii, DC. I

- tricorne, With. I-7.

- Anglicum, Huds. I

Asperula odorata, L. $\quad 1-4,6-8$

- cynanchica, L. I, 3, 5

Sherardia arvensis, L. $\quad$ I-8

Valeriana dioica, L. $1-5,7,8$

- officinalis, L. I-6, 8 var. sambucifolia, Mikan. I, 2, 4, 5, 7

Valerianella olitoria, Mœnch. 1-8

- carinata, Loisel. 3, 4, 7, 8

- Auricula, DC. 7,8.

- dentata, Poll. I, 3-8

Dipsacus sylvestris, L. I-8

- pilosus, L. I-8

Scabiosa succisa, L. I-8

- Columbaria, L. I, 4, 5, 8

- arvensis, L. I-8

Eupatorium cannabinum, L. 1-4, 6-8

Aster Tripolium, L. 4-8

Erigeron acre, L. I, 5, 6, 8

- Canadense, L. $\quad 4,5,8$

Bellis perennis, L. I-8

Solidago Virgaurea, L. 2-7

Inula Conyza, DC. $\quad \mathrm{I}-3,5-8$

- crithmoides, L. 6-8

[- Helenium, L.] I, 3, 4, 6

Pulicaria dysenterica, Gærtn. I, 2, 4-8

- vulgaris, Gærtn. 3, 4, 6-8

Gnaphalium sylvaticum, L. I-8

- uliginosum, L. I-8

[Antennaria margaritacea, Br.] 2

Filago Germanica, L. $\quad$ I-8 var. spathulata, Presl. I, 6-8 , apiculata, G. E. Sm. 5, 7, 8

- minima, Fries. 3-5, 7, 8

- Gallica, L. 2, 8

Bidens cernua, L. I-8

- tripartita, L. I-8

Anthemis arvensis, L. 2-5, 7,

- Cotula, L. 1-8

- nobilis, L. I, 3-8

Achillea Ptarmica, L. I-8

- Millefolium, L. I-8

Diotis maritima, Cass. 7

Matricaria Chamomilla, L. 2, 4-8

- inodora, L. I-8

Chrysanthemum segetum, L. 1-8

- Leucanthemum, L. I-8

- Parthenium, Pers, I-8

Tanacetum vulgare, $L . \quad I-8$

Artemisia vulgaris, L. I-8

- Absinthium, L. I-8

- maritima, L. 5-8 var. Gallica, Willd. 6-8

Petasites vulgaris, Desf. $\quad I-4,6-8$

Tussilago Farfara, L. 1-8

[Doronicum Pardalianches, L.] I

- plantagineum, L. I, 3 


\section{A HISTORY OF ESSEX}

Senecio vulgaris, L. I-8

- sylvaticus, L. 2-8

- viscosus, L. 4

- Jacobæa, L. I-8

- erucifolius, L. 1-8

- aquaticus, L. I-8

- campestris, DC. I

Arctium Lappa, L.

var. majus, Schkuhr. 1, 2, 4-8

" tomentosum, Bab. 4, 5

" minus, Schkuhr. I-8

", intermedium, Lange. 1, 3-7

Carlina vulgaris, L. I, 3-8

Centaurea nigra, L. I-8

- Scabiosa, L. I-8

- Cyanus, L. I-8

- Calcitrapa, L. 2, 4-6

- solstitialis, L. 1-6,8

Serratula tinctoria, I. I, 4

Carduus nutans, L. I, 3-6, 8

- crispus, L. I-8

var. acanthoides, L. I, 4, 7,8

- pycnocephalus, L. 3-8

Cnicus lanceolatus, Hoffm. I-8

- eriophorus, Hoffm. 1-3

- acaulis, Hoffm. I $-5,7$

- dubius, Willd. I

- arvensis, Hoffm. I-8

- palustris, Hoffm. I-8

- pratensis, Willd. 4

Onopordium Acanthium, L. I-8

Silybum Marianum, Gærtn. I -8

Cichorium Intybus, L. I-8

Arnoseris pusilla, Gærtn. 2-4, 8

Lapsana communis, L. I-8

Picris hieracioides, L. I-7

- echioides, L. I-8

Crepis virens, L. I-8

- biennis, L. I-7

- fotida, L. 1, 3,5

- taraxacifolia, Thuill. 5, 6

[- setosa, Haller fil.] I, 8

Hieracium Pilosella, L. I-8

- umbellatum, L. 3-5, 7

- boreale, Fries. 2-5, 7,8

- tridentatum, Fries. 3, 7,8

- vulgatum, Fries. 1, 3-5, 7,8

Hypochœris radicata, L. I-8

- maculata, L. I

Leontodon hirtus, L. I -8

- hispidus, L. 1-8

- autumnalis, L. I-8

Taraxacum officinale, Web. 1-8

Lactuca virosa, L. I, 3-8

- Scariola, L. 5, 6

- saligna, L. 5, 6

- muralis, Fresen. 4,8

Sonchus arvensis, L. I-8

- palustris, L. 4

- oleraceus, L. I-8 sub-sp. asper, Hoffm. I-8

Tragopogon pratensis, L. 1, 3-7 var. minor, Fries. I -8

- porrifolius, L. 2, 4-8

Jasione montana, L. 2-8
Wahlenbergia hederacea, Reichb.

Campanula rotundifolia, L. I-8

[- Rapunculus, L.] 3,4

[- patula, L.] 2, 3

[- rapunculoides, L.] I

- Trachelium, L. 1-5

- glomerata, L. I-4

Specularia hybrida, DC. I-8

Vaccinum Myrtillus, L. 3,4

- Vitis-Idæa, L. 4

- Oxycoccos, L. 4

Erica Tetralix, L. 3-8

- cinerea, L. $4,5,7,8$

Calluna vulgaris, Salisb. $2-8$

Hypopitys multiflora, Scop. I, 3, 4

Armeria maritima, Willd. 5-8

Statice Limonium, L. $\quad 5-8$ sub-spec. rariflora, Drejer. 5-8

- auriculæfolia, Vahl. 8

Primula vulgaris, Huds. I-8

- elatior, Jacq. I-3

- veris, L. I-8

Lysimachia vulgaris, L. $3,4,7,8$

- nemorum, L. I-8

- Nummularia, L. I-8

Glaux maritima, L. $\quad 4-8$

Centunculus minimus, L. 4, 6, 7

Anagallis arvensis, L. I -8 var. cœrulea, Schreb. 2-4, 6-8

- tenella, L. I, 3-5, 7

Hottonia palustris, L. $\quad 2-8$

Samolus Valerandi, L. I, 3-8

Ligustrum vulgare, L. $\quad 1-8$

Fraxinus excelsior, L. I- 8

Vinca minor, L. 1-8

- major, L. 1-8

Chlora perfoliata, L. I-8

Erythræa Centaurium, Pers. $\quad 1-4,7$

- pulchella, Fries. 5,6

Gentiana Amarella, L. I-3

Menyanthes trifoliata, L. I-8

Limnanthemum peltatum, Gmel. 4

[Polemonium cœruleum, L.] 1, 4

Echium vulgare, L. I-8

Borago officinalis, L. I, 3, 4, 6-8

Symphytum officinale, L. I-8

- tuberosum, L. 5,8

Anchusa arvensis, Bieb. 1-8

- sempervirens, L. $\quad 2,4,7,8$

Lithospermum officinale, L. I, 3-8

- arvense, L. I-8

Myosotis palustris, With. I-8

- cæspitosa, Schultz. I-8

- sylvatica, Hoffin. I, 2, 4, 6, 8

- arvensis, Hoffm. I-8

- collina, Hoffm. I-4, 6-8

- versicolor, Reichb. 2-8

[Asperugo procumbens, L.] 5

Cynoglossum officinale, L. I, 3-8

- montanum, Lamk. 4, 5, 7

Convolvulus arvensis, L. I-8

— sepium, L. 1-8

- Soldanella, L. 6-8

Cuscuta europæa, L. I, 2, 4

- Epithymum, Murr. 4-6,8 


\section{BOTANY}

Cuscuta Epilinum, Weihe. 1

- Trifolii, Bab. $\quad$ I-3, 6-8

Hyoscyamus niger, L. I, 3-8

Solanum Dulcamara, L. 1-8

- nigrum, L. I-8

Atropa Belladonna, L. I, 4, 7, 8

Plantago major, L. I-8

- media, L. I-8

- lanceolata, L. I-8

- maritima, L. 4-8

- Coronopus, L. 1, 3-8

Littorella lacustris, L. 4

Verbascum Thapsus, L. 1-8

- nigrum, L. I, 3-6, 8

[- Blattaria, L.] 4,7

Linaria Cymbalaria, Mill. $\quad 1-6,8$

- spuria, Mill. 1-8

- Elatine, Mill. I-8

- vulgaris, Mill. 1-7

- minor, Desf. 1-8

Antirrhinum Orontium, L. 1, 4, 7, 8

- majus, L. 1, 4-6

Scrophularia nodosa, L. I-8

- aquatica, L. I-8

- vernalis, L. I, 3, 8

Limosella aquatica, L. 4

Digitalis purpurea, L. I, 3-8

Veronica agrestis, L. $\quad$ I-8 sub-sp. polita, Fries. 1-8

- Buxbaumii, Ten. I-8

- hederæfolia, L. I-8

- arvensis, L. 1-8

- serpyllifolia, L. I-8

- officinalis, L. 1, 2, 4-8

- Chamrdrys, L. 1-8

- montana, L. I-8

- scutellata, L. $\quad \mathrm{I}-5,7,8$

- Beccabunga, L. I-8

- Anagallis, L. I-8

Bartsia Odontites, Huds. I-8

Euphrasia officinalis, L. I-8

Rhinanthus crista-Galli, L. I-8

Pedicularis palustris, L. $\quad \mathrm{I}-5,8$

- sylvatica, L. 2-8

Melampyrum pratense, L. 2-8

- arvense, L. I, 3

- cristatum, L. I, 2

Lathrea Squamaria, L. 2

Orobanche major, L. $\quad$ 2-5, 7, 8

- elatior, Sutt. I-3, 7

- minor, Sutt. I, 2, 6-8

Utricularia vulgaris, L. $\quad 2-5,7$ sub-sp. neglecta, Lehm.

Verbena officinalis, L. I-8

Mentha sylvestris, L. I-8

- rotundifolia, L. I-5, 7

- viridis, L. $\quad 1-5,7$

- piperita, Huds. I-8

- aquatica, L. I-8

- sativa, L. I-8

- rubra, Sm. 8

- pratensis, Sole. 1, 2, 4, 5, 7

- arvensis, L. 1-8

- Pulegium, L. $\quad 1,4,5,7,8$

Lycopus europæus, L. $\quad$ I-8
Origanum vulgare, L. $1,2,4^{-6}$

Thymus Serpyllum, L. $\quad$ I-8

- Chamædrys, Fries. I, 5-8

Calamintha officinalis, Mœnch. $\quad 1-6,8$

- Nepeta, Clairv. I, 3-8

- Clinopodium, L. I-7

- Acinos, Clairv. I, 8

Melissa officinalis, L. I-4, 6-8

Salvia Verbenaca, L. I-8

Nepeta Cataria, L. I-8

- Glechoma, Benth. I-8

Prunella vulgaris, L. I-8

Scutellaria galericulata, L. 1-8

- minor, L. 3

Marrubium vulgare, L. $\quad$, , 3-8

Stachys sylvatica, L. $\quad$ I-8

- palustris, L. I-8

- ambigua, Sm. I-4, 7

- arvensis, L. I, 3-8

- Betonica, Benth. I-8

Galeopsis Ladanum, L. $\quad 1-8$

- dubia, Leers. 8

- Tetrahit, L. I-8 sub-sp. speciosa, Miller, I, 4, 7

Lamium purpureum, L. I-8 sub-sp. hybridum, Vill. I-3, 6-8

- amplexicaule, L. I-5, 7, 8

- album, L. I-8

- Galeobdolon, Crantz. I-8

Ballota nigra, L. I-8

Teucrium Scorodonia, L. 1, 3-8

Ajuga reptans, L. I-8

- Chamæpitys, Schreber. 5

Scleranthus annuus, L. I-8

Chenopodium Vulvaria, L. $4^{-8}$

- polyspermum, L. 1-8

- album, L. I-8

- ficifolium, Sm. I, 2, 4-7

- urbicum, L. 3-7

- hybridum, L. $\quad \mathbf{2 ,} 4,7$

- murale, L. I-7

- rubrum, L. I, 3-8 var. botryoides, $\mathrm{Sm} . \quad 6,7$

- glaucum, L. 4, 7, 8

- Bonus-Henricus, L. I-4, 6-8

Beta maritima, L. $4^{-8}$

Atriplex erecta, Huds. I-8

- angustifolia, $\mathrm{Sm}$. I-8

- triangularis, Willd. $\quad \mathrm{I}-6,8$

- hastata, L. I-8

- Babingtonii, Woods. 6,8

- marina, L. 5, 6,8

- laciniata, L. 6-8

- portulacoides, L. 5-8

Salicornia herbacea, L. $4^{-8}$

- radicans, Sm. 6-8

Suæda maritima, Dumort. 5-8

- fruticosa, Forsk. 6-8

Salsola Kali, L. 6-8

Amaranthus Blitum. 1, 3-6, 8

Polygonum Bistorta, L. $\mathrm{I}-4,6,8$

- amphibium, L. 1-8

- lapathifolium, L. 1-8

- maculatum, Dyer \& Trimen. $\quad 2-5,7,8$

- Persicaria, L. I-8 


\section{A HISTORY OF ESSEX}

Polygonum mite, Schrank. 4, 5

- Hydropiper, L. I-8

- minus, Huds. 3-5

- aviculare, L. $\quad \mathrm{x}-8$

- Convolvulus, L. I-8

Rumex obtusifolius, L. I-8

- acutus, L. 1, 2, 4, 5, 7,8

- pulcher, L. I-8

- maritimus, L. 5, 8

- palustris, Sm. 4, 5

- crispus, L. I-8

- sanguineus, L. I-8

- conglomeratus, Murray. I-8

- Hydrolapathum, Huds. I-8

- Acetosa, L. I-8

- Acetosella, L. I-8

[Aristolochia Clematitis, L.] 5

Daphne Laureola, L. I-7

[- Mezereum, L.] I, 7

[Hippophae rhamnoides, L.] 6

Viscum album, L. I-4, 6, 7

Thesium linophyllum, L. I

Euphorbia Helioscopia, L. I-8

- platyphyllos, L. I-7

- amygdaloides, L. I-8

[— dulcis, L.] 8

- peplus, L. I-8

- exigua, L. I-8

- Paralias, L. 6, 8

- Cyparissias, L. I, 4

[- Lathyris, L.] I-3, 5

Mercurialis perennis, L. I-8

- annua, L. I, 4, 6, 8

Ulmus montana, Sm. I-8

- campestris, $\mathrm{Sm}$. I-8

- suberosa, Ehrh. 1, 3-6, 8

- glabra, Mill. I-7

Urtica urens, L. $\quad 1-8$

- dioica, L. I-8

- pilulifera, L. 4, 6-8

Parietaria officinalis, L. I-8

Humulus Lupulus, L. I-8

Betula alba, L. I, 3-5, 7, 8 sub-sp. glutinosa, Fries. I-3, 5, 6

Alnus glutinosa, Gærtn. I-8

Quercus Robur, L. I-8

- sessiliflora, Salisb. 1, 3, 4, 7

Fagus sylvatica, L. 1, 2, 4-7

Corylus Avellana, L. 1-8

Carpinus Betulus, L. I-7

Populus alba, L. I-7 sub-sp. canescens, Sm. I, 3-5

- tremula, L. I-8

- nigra, L. 1, 3-5, 7

Salix triandra, L. $\quad I-4,8$ var. Hoffmanniana, Sm. I, 3-5, 7 "undulata, Ehrh. I, 4

- fragilis, L. I, 2, 4-6, 8 var. decipiens, Hoffm. I, 3, 5

- Russelliana, Sm. I, 2, 4, 5

- alba, L. I, 2, 4-8 var, vitellina, L. I, 4-7

- Caprea, L. I-8 sub-sp. cinerea, L. I $\quad$-7 sub-var. aquatica, Sm. I, 4-6
Salix Caprea, sub-var. oleifolia, Sm. I, 3-5

- aurita, L. I, 3-5, 7,8

- repens, L. $3-5,7,8$

- incubacea, Sy. 3,4

- viminalis, L. $1,4,5,7,8$

- Smithiana, Willd. 1, 4, 5,7

- stipularis, Sm. 4, 7

- ferruginea, G. And. I

- acuminata, Sm. I, 2, 7

- purpurea, L. 4, 7 sub-sp. rubra, Huds. I, 4 var. Helix, L. $1,4,7,8$

Ceratophyllum demersum, L. I-4, 6-8 sub-sp. submersum, L. 4, 6, 7

[Pinus sylvestris, L.] 1-8

Juniperus communis, L. I, 4, 8

[Taxus baccata, L.] I, 4, 5

Hydrocharis Morsus-Ranx, L. 2, 4-6, 8

Stratiotes aloides, L. 2

Elodea Canadensis, Michx. 3, 8

Neottia Nidus-avis, L. I-8

Listera ovata, Br. $\quad$ I-8

Spiranthes autumnalis, Rich. I-8

Epipactis latifolia, Sw. I, 3-8 var. media, Fries. I, 2, 4, 5, 7

- palustris, Sw. I-4

Cephalanthera pallens, Rich. I, 4

Orchis mascula, L. I-4, 6-8

- latifolia, L. I-3, 7 sub-sp. incarnata, L. I, 3, 4

- maculata, L. I-8

- Morio, L. I-4, 6-8

- ustulata, L. I, 2

- pyramidalis, L. I, 3-6

Aceras anthropophora, Huds. 2, 3, 6

Ophrys apifera, Huds. $\mathrm{I}-5,7,8$

- aranifera, Huds. I, 2

- muscifera, Huds. I, 3, 7

Herminium Monorchis, Br. I, 3

Habenaria viridis, $\mathrm{Br}$. I, 3

- conopsea, Benth. I, 3, 4

- bifolia, Br. I, 4, 7 sub-sp. chlorantha, Bab. I-3, 5-8

Iris pseudacorus, L. I-8

- føtidissima, L. I, 3-6

Narcissus pseudo-narcissus, L. I, 3, 4, 6-8

[- biflorus, Curt.] I, 4

[Galanthus nivalis, L.] I, 3

[Leucojum rstivum, L.] 4

Tamus communis, L. I-8

Ruscus aculeatus, L. 3-8

Asparagus officinalis, L. 6,8

Polygonatum multiflorum, All. 4

Convallaria majalis, L. 2-8

Allium vineale, $L . \quad 1-4,6-8$

- oleraceum, L. 1, 3

Muscari racemosum, Miller. 3, 4

Scilla nutans, Sm. I-8

Ornithogalum umbellatum, L. I, 3,8

[Lilium Martagon, L.] I

Fritillaria Meleagris, L. I, 3, 4

[Tulipa sylvestris, L.] 3

Colchicum autumnale, L. I

Paris quadrifolia, L. $\quad 1-4,7$

Juncus effusus, L. I-8 


\section{BOTANY}

Juncus effusus, var. conglomeratus, L. $\quad 1-8$

- glaucus, Ehrh. I-8

- diffusus, L. 2, 4, 7

- maritimus, Sm. 2, 5-8

- squarrosus, L. 3-8

- compressus, Jacq. I, 4-8 sub-sp. Gerardi, Loisel. 5-8

- obtusiflorus, Ehrh. 1, 3-5, 7

- articulatus, L. I-8 sub-sp. supinus, Mœnch. 3-5, 7,8

- lamprocarpus, Ehrh. I-8

- bufonius, L. I-8

Luzula maxima, DC. 2-5, 7, 8

- vernalis, DC. $\quad$ I-8

- Forsteri, DC. 4,6

- campestris, Willd. 1-8 var. erecta, Desv. I-8

Sparganum ramosum, Huds. I-8

- simplex, Huds. 1-7

- minimum, Fries. 1, 3

Typha latifolia, L. 1-8

- angustifolia, L. 2-8

Arum maculatum, L. $\quad$ 1-8

Acorus Calamus, L. 3, 4

Lemna minor, L. $\quad$ 1-8

- trisulca, L. $\quad$ I-8

-- gibba, L. 2-8

- polyrhiza, L. I-8

Alisma Plantago, L. I-8

- ranunculoides, L. I, 4, 5, 7

Damasonium stellatum, Pers. 4, 5

Sagittaria sagittifolia, L. $\quad$ I-8

Butomus umbellatus, L. 1-8

Triglochin palustre, L. $\quad \mathrm{I}-4,6-8$

Potamogeton natans, L. I-8

- polygonifolius, Pourr. $4,5,7,8$

- rufescens, Schrad. 2, 3, 7

- heterophyllus, Schreb. 4

- lucens, L. I-4, 6-8

- prælongus, Wulfen. 3, 6, 7

- perfoliatus, L. $3,4,7,8$

- crispus, L. I-8

- densus, L. 1-4

- zosteræfolius, Schum. 3

- obtusifolius, Mert. \& Kock. 3, 4

- pusillus, L. I-4, 7, 8

- pectinatus, L. 2-4, 6-8 sub-sp. flabellatus, Bab. 7

Ruppia maritima, L. 6-8 sub-sp. rostellata, Kock. $\quad 5-8$

Zannichellia palustris, L. 1, 4-8

Zostera marina, L. 6-8 var. angustifolia, Syme. 6,8

Heleocharis palustris, $\mathrm{Br}$. $\quad \mathrm{I}-8$

- multicaulis, Sm. 3, 4, 7, 8

- acicularis, Sm. 4

Scirpus lacustris, L. 1-8

- Tabernæmontani, Gmel. 2, 6-8

- maritimus, L. 2, 4-8

- sylvaticus, L. $\quad 1-5,7,8$

- setaceus, L. $\quad$ I-8

- fluitans, L. $3-5,7,8$

- cæspitosus, L. 5, 7

- pauciflorus, Lightf. 3,4
Scirpus Caricis, Retz. I-8

Eriophorum polystachion, L. I, 3-5, 8 sub-sp. latifolium, Hoppe. $1-3$

Schœnus nigricans, L. 5

Carex pulicaris, L. I, 3, 4

[- dioica, L.] 3

- divisa, Huds. $4^{-8}$

- disticha, Huds. I, 3, 4, 6-8

- arenaria, L. 6-8

- paniculata, L. I-8

- teretiuscula, Good. 4

- muricata, L. I-8 sub-sp. divulsa, Good. I-8

- vulpina, L. I-8

- echinata, Murr. I, 3-8

- remota, L. 1-8

- axillaris, Good. I-8

- leporina, L. $\quad$ I-5, 7, 8

- elongata, L. 2

- acuta, L. I, 3, 4, 6-8

- stricta, Good. 1, 3-5

- Goodenovii, Gay. 1, 3-5

- glauca, Murr. 1-8

- pallescens, L. I-8

- panicea, L. I, 3-5, 7

- pendula, Huds. I-8

- precox, Jacq. I-8

- pilulifera, L. I, 3-8

- hirta, L. I-8

- extensa, Good. 8

- flava, L. 1, 3-7 sub-sp. Ederi, Ehrh. 1, 3-7

- distans, L. I, 3, 5-8

- fulva, Good. I

- binervis, Sm. I, 3-8

- lævigata, Sm. 3, 5-7

- sylvatica, Huds. I-8

- strigosa, Huds. 1-5, 7

- vesicaria, L. 2-5

- ampullacea, Good. 1, 3, 4

- Pseudocyperus, L. I-7

- paludosa, Good. I-8

- riparia, Curtis. I-8

Setaria viridis, Beauv. 8

Spartina stricta, Roth. 6-8

[Phalaris Canariensis, L.] I, 3, 4, 6-8

- arundinacea, L. I-8

Anthoxanthum odoratum, L. I-8

Alopecurus agrestis, L. I-8

- pratensis, L. I-8

- geniculatus, L. 1-8 sub-sp. fulvus, $\mathrm{Sm}$. 1-4, 6, 7 , bulbosus, Gouan. 5, 8

Milium effusum, L. I-8

Phleum pratense, L. I-8

- arenarium, L. 6-8

- phalaroides, Koel.

Agrostis canina, L. I-8

- vulgaris, With. 1-8 var. pumila, L. $\quad$ I, 2, 4, 5, 7, 8

- alba, L. 1-8

Polypogon Monspeliensis, Desf. 4-6

- littoralis, Sm. 5

Calamagrostis Epigejos, Roth. I, 3-8

- lanceolata, Roth. 6-8 


\section{A HISTORY OF ESSEX}

Gastridium lendigerum, Gaud. 2, 3, 5-8

Apera Spica-venti, Beauv. 4

- interrupta, Beauv. 7

Ammophila arundinacea, Host. $\quad$ 6-8

Aira caryophyllea, L. I-8

- precox, L. I, 3-8

Deschampsia flexuosa, Trin. 3-6

- crspitosa, Beauv. 1-8

Holcus lanatus, L. I-8

- mollis, L. I-8

Trisetum flavescens, Beauv. I-8

Avena fatua, L. I-8

[- strigosa, Schreb.] I, 5

- pratensis, L. I

- pubescens, Huds. I, 4

Arrhenatherum avenaceum, Beauv. I-8

Triodia decumbens, Beauv. I, 3-8

Phragmites communis, Trin. I-8

Cynosurus cristatus, L. 1-8

Koeleria cristata, Pers. I, 5, 6

Molinia cærulea, Mœnch. I, 3-8 var. depauperata, Lind. 7,8

Catabrosa aquatica, Beauv. $1-8$

Melica uniflora, Retz. I-8

Dactylis glomerata, L. $\quad$ 1-8

Briza media, L. I-8

Poa annua, L. I-8

- pratensis, L. I-8

- compressa, L. I-6

- trivialis, L. I-8

- nemoralis, L. I-8

Glyceria aquatica, $\mathrm{Sm}$. I-8

- fluitans, Br. 1-8

- plicata, Fr. I-3, 5, 7,8

- maritima, Wahlb. 4-8

- Borreri, Bab. 4-8

- distans, Wahlb. 4-8

- procumbens, Dumort. 4-8

Festuca elatior, L. 1-6, 8

- pratensis, Huds. I-8

- gigantea, Vill. I-8

- ovina, L. I-8 sub-sp. duriuscula, L. 1-8 " rubra, L. I, 3-8

- Myuros, L. I, 3-8 sub-sp. sciuroides, Roth. 1-8

- uniglumis, Sol. 6,7

- rigida, Kth. I-8

- loliacea, Huds. I-8

Bromus asper, Murr. I -8

- erectus, Huds. 1, 6

- sterilis, L. 1-8

- mollis, L. $\quad 1-8$

- racemosus, $L$. I, 4, 6,8

- commutatus, Schrad. 1-8

- secalinus, L. I-4, 7,8

- arvensis, L. I, 6
Brachypodium sylvaticum, R \& S. I-8

- pinnatum, Beauv. I, 3

Lolium perenne, L. I-8

- temulentum, L. I-4, 6,8

Agropyrum caninum, Beauv. I-8

- repens, Beauv. I-8 sub-sp. pungens, R. \& S. 5

- acutum, R. \& S. 8

- junceum, Beauv. 5-8

Lepturus filiformis, Trin. 8 var. incurvatus, Trin. $\quad 5-8$

Nardus stricta, L. $\quad$ I, 3-8

Hordeum sylvaticum, Huds. I, 2

- pratense, Huds. 1-8

- murinum, L. 1-8

- maritimum, With. 5-8

Elymus arenarius, L. 6,7

Pteris aquilina, L. I -8

Lomaria Spicant, Desv. 3-8

Asplenium Ruta-muraria, L. 1, 3-7

- Trichomanes, L. I-8

- Adiantum-nigrum, L. I-8

- Filix-formina, Bernh. 2-8

- Ceterach, L. I, 4, 5

Scolopendrium vulgare, $\mathrm{Sm}$. I-8

Cystopteris fragilis, Bernh. [var. alpina, Desv.] 4

Aspidium aculeatum, Sw. $\quad 1-5,7,8$

- lobatum, Sw. 1-7

- angulare, Willd. 3-8

Nephrodium Filix-mas, Rich. 1-8

- spinulosum, Desv. $\quad \mathrm{I}-5,7,8$ sub-sp. dilatatum, Desv. 2-8

- Thelypteris, Desv. 3, 4

- Oreopteris, Desv. 3-5,

Polypodium vulgare, L. I-8

Osmunda regalis, L. $\quad 3-6,8$

Ophioglossum vulgatum, L. 1-5, 7,8

[Botrychium Lunaria, Sw.] 8

Equisetum arvense, L. I-8

- maximum, Lamk. $\quad 1 \div 8$

- sylvaticum, L. $3-5,7,8$

- palustre, L. I-6, 8

- limosum, L. 1-8

Lycopodium clavatum, L. 3-5

- inundatum, L. 4, 7

Pilularia globulifera, L. 4

Nitella flexilis, C. Ag. I, 5

- syncarpa, Kuetz. 7

- translucens, C. Ag. 7

- gracilis, C. Ag. 2

Chara polyacantha ?, Braun. I

- vulgaris, L. 1, 5, 7

- hispida, L. 1, 3, 6, 7

- aspera, Willd. I

— fragilis, Desv. 7

\section{MOSSES (Musci)}

The mosses of Essex have by no means been thoroughly investigated. The only records available are the list prepared from the collections of the late Mr. E. G. Varenne of Kelvedon (Essex Naturalist, v. I) and other notes issued at intervals in the same publication, and 


\section{BO'TANY}

specimens collected by myself near Colchester. There is a herbarium of mosses collected by the late Mr. J. English in Epping Forest and its vicinity in the possession of the museum of the Essex Field Club at Stratford, but unfortunately it will not be available in time for use for this publication.

The county, as far as explored, is comparatively rich in species occurring in bogs, and such as are found at ordinary elevations in woods, heaths, clayey and sandy soils, and in maritime situations; but it is chiefly deficient, as might be expected, in species which occur on subalpine and alpine districts, and on limestone or granitic rocks.

The occurrence of several species characteristic of calcareous soil, such as Weissia crispa, Pottia lanceolata, Anomodon viticulosus, Camptothecium lutescens, Eurbyncbium tenellum and Hypnum molluscum, render it probable that the calcareous districts in the north of the county would, on further exploration, yield many more species.

One moss found in Essex has a special interest, since it is only found, so far as is known, in two other counties in England, viz. Somersetshire and Sussex, and is rare and local on the continent. This is Zygodon Forsteri, which was first found in this country on a felled tree in a timber yard in Walthamstow early in the last century, and was not again seen in Essex until detected in Epping Forest by Mr. E. M. Holmes a few years ago and shortly afterwards in another locality in the Forest by Mr. H. N. Dixon. The exact Sussex locality is unknown, so that Essex can boast of possessing one of the rarest of British mosses.

Other rare species found in the county are Pottia Wilsoni and Zygodon conoideus, Ortbotricbum pallens and Hypnum giganteum.

Comparatively few species of Sphagna are recorded, but the list of species of this genus will probably be largely increased by further investigation.

Sphagnum cymbifolium, Ehrh.

- squarrosulum, Nees \& Hornsch.

- rigidum, Schimp.

- subsecundum, Nees var. contortum, Schimp.

- acutifolium, Ehrh. var. purpureum, Schimp.

- intermedium, Hoffm.

Tetraphis pellucida, Hedw.

Catharinea undulata, Web. \& Mohr.

Polytrichum nanum, Neck.

- aloides, Hedw.

- piliferum, Schreb.

- juniperinum, Willd.

- formosum, Hedw.

- commune, Linn.

Pleuridium axillare, Lindb.

- subulatum, Rabenh.

- alternifolium, Rabenh.

Ditrichum homomallum, Hampe.

Ceratodon purpureus, Brid.

Dicranella heteromalla, Schimp.
Dicranella cerviculata, Schimp.

- varia, Schimp.

Dicranoweisia cirrhata, Lindb.

Campylopus pyriformis, Brid.

- fragilis, Bruch. \& Schimp.

Dicranum Bonjeani, De Not.

- scoparium, Hedw.

Leucobryum glaucum, Schimp.

Fissidens exilis, Hedw.

- viridulus, Wahl.

- incurvus, Starke

- bryoides, Hedw.

- taxifolius, Hedw.

Grimmia apocarpa, Hedw.

- pulvinata, Smith

Rhacomitrium canescens, Brid.

Acaulom muticum, C. Muell.

Phascum cuspidatum, Schreb.

Pottia Heimii, C. Muell.

- truncatula, Lindb.

- intermedia, Fuernr.

- Wilsoni, Bruch. \& Schimp. 


\section{A HISTORY OF ESSEX}

Pottia minutula, Fuernr.

- Starkeana, C. Muell.

- lanceolata, C. Muell.

Tortula pusilla, Mitt.

— ambigua, Æingstr.

- aloides, De Not.

- atrovirens, Lindb.

- cuneifolia, Roth.

- marginata, Spruce

- muralis, Hedw.

- mutica, Lindb.

- lævipila, Schwægr.

- intermedia, Beck.

- ruralis, Ehrh.

- papillosa, Wils.

Barbula rubella, Mitt.

- fallax, Hedw.

- rigidula, Mitt.

- Hornschuchiana, Schultz.

- revoluta, Hedw.

- unguiculata, Hedw.

Weisia crispa, Mitt.

- microstoma, C. Muell.

— viridula, Hedw.

- mucronata, Bruch. \& Schimp.

Cinclidotus Brebissoni, Husnot.

Zygodon viridissimus, Brown

- conoideus, Hook. \& Tayl.

- Forsteri, Wils.

Ulota Bruchii, Hornsch.

- crispa, Brid.

Orthotrichum anomalum, Hedw.

- leiocarpum, Bruch. \& Schimp.

- Lyellii, Hook. \& Tayl.

- affine, Schrad.

- Sprucei, Mont.

- stramineum, Hornsch.

- tenellum, Bruch.

- pallens, Bruch.

- pumilum, Dicks.

- diaphanum, Schrad.

Ephemerum serratum, Hampe.

Physcomitrella patens, Bruch. \& Schimp.

- pyriforme, Brid.

Funaria fascicularis, Schimp.

- hygrometrica, Sibth.

Aulacomnion palustre, Schwægr.

- androgynum, Schwagr.

Bartramia pomiformis, Hedw.

Philonotis fontana, Brid.

Leptobryum pyriforme, Wils.

Webera nutans, Hedw.

- carnea, Schimp.

Bryum pendulum, Hornsch.

- inclinatum, Bland.

- pallens, Swartz.

- bimum, Schreb.

- intermedium, Brid.

- cæspiticum, Linn.

- capillare, Linn.
Bryum erythrocarpum, Schwægr.

- atropurpureum, Web. \& Mohr.

- argenteum, Linn.

Mnium affine, Bland.

- undulatum, Linn.

- hornum, Linn.

- punctatum, Linn.

- subglobosum, Bruch. \& Schimp.

Fontinalis antipyretica, Linn.

Cryphæa heteromalla, Mohr.

Neckera complanata, Huebn.

Homalia trichomanoides, Brid.

Leucodon sciuroides, Schwægr.

Porotrichum alopecurum, Mitt.

Leskea polycarpa, Ehrh.

Anomodon viticulosus, Hook. \& Tayl.

Thuidium tamariscinum, Bruch. \& Schimp.

Pylaisia polyantha, Bruch. \& Schimp.

Isothecium myurum, Brid.

Pleuropus sericeus, Dixon

Camptothecium lutescens, Bruch. \& Schimp.

Brachythecium albicans, Bruch. \& Schimp.

- rutabulum, Bruch. \& Schimp.

- velutinum, Bruch. \& Schimp.

- purum, Dixon

Eurhynchium piliferum, Bruch. \& Schimp.

- prælongum, Bruch. \& Schimp.

- Swartzii, Hobkirk

- pumilum, Schimp.

— tenellum, Milde

- myosuroides, Schimp.

- striatum, Bruch. \& Schimp.

- rusciforme, Milde

- murale, Milde

- confertum, Milde

- megapolitanum, Milde

Plagiothecium denticulatum, Bruch. \& Schimp.

- sylvaticum, Bruch. \& Schimp.

Amblystegium serpens, Bruch. \& Schimp.

- irriguum, Bruch. \& Schimp.

- filicinum, De Not.

Hypnum riparium, Bruch. \& Schimp.

- stellatum, Schreb.

- aduncum, Hedw.

- fluitans, Linn.

- uncinatum, Hedw.

- intermedium, Hedw.

- commutatum, Hedw.

- cupressiforme, Linn.

- resupinatum, Schimp.

- molluscum, Hedw.

- stramineum, Dicks.

- cordifolium, Hedw.

- giganteum, Schimp

- cuspidatum, Linn.

- Schreberi, Willd.

Hylocomnium splendens, Bruch. \& Schimp.

- squarrosum, Bruch. \& Schimp.

- triquetrum, Bruch. \& Schimp. 


\section{BOTANY}

\section{SCALE-MOSSES, LIVERWORTS AND CRYSTALWORTS}

The list of Essex Hepaticx includes only the commonest species, with the exception of Trichocolea tomentella and Ptilidium ciliare, which are characteristic of subalpine boggy woods and moorlands, and where they occur there must almost certainly be other unrecorded species. The genera Kantia, Cephalozia, Lejeunia, Jungermannia, Reboulia and Zegatella are almost certain to occur in the county. The list must therefore be considered an imperfect one.

Frullania dilatata, Dumort
Radula complanata, Dumort
Porella platyphylla, Carr \& Pears
Ptilidium ciliare, Nees
Trichocolea tomentella, Ehrh.
Lepidozia reptans, Dumort
Scapania undulata, Dumort
- nemorosa, Dumort
Diplophyllum albicans, Dumort
Lophocolea bidentata, Dumort
- heterophylla, Dumort

Frullania dilatata, Dumort

Radula complanata, Dumort

Ptilidium ciliare, Nees

Trichocolea tomentella, Ehrh.

Lepidozia reptans, Dumort

Scapania undulata, Dumort

Diplophyllum albicans, Dumort

- heterophylla, Dumort

\author{
Plagiochila asplenioides, Dumort \\ Aplozia crenulata, Dumort \\ - inflata, Huds. \\ Nardia scalaris, Carr \\ Pellia epiphylla, Corda \\ Metzgeria furcata, Dumort \\ Aneura multifida, Dumort \\ Marchantia polymorpha, Nees \\ Lunularia vulgaris, Mich. \\ Riccia glauca, Linn. \\ Ricciella fuitans, Braun.
}

\section{LICHENS (Lichenes)}

The Epping Forest district of Essex and the neighbourhood of Kelvedon are the only portions of the county from which the lichen flora has been at all fully recorded. It is therefore difficult to estimate what wealth of lichens the county possesses, for there are other districts, such as Hatfield Forest and some well wooded portions of the county, worth investigating.

Lichens occur more particularly upon trees and upon rocks. The majority of lichens are of extremely slow development, remaining latent except when the moisture and other conditions of the atmosphere are favourable. It is therefore upon comparatively old trees and in situations suitable to their requirements that one would expect to find interesting species. Owing to the former bad management of the Epping Forest, the Rev. J. M. Crombie tells us in 1883 that its lichen flora was not so good as it would be under better conditions, and that the species had diminished in numbers since the time when he first visited it, but I am informed that under the new management of the forest the lichen flora is improving.

Granitic sandstone and calcareous rocks which some lichens love so well do not occur in the county; it is therefore only upon the stonework and upon the brickwork of old buildings that these species are represented.

The first records of lichens are in Turner and Dillwyn's Botanist's Guide, published in 1805 , where fifteen species are enumerated. The next list was by Mr. Edward Forster, to whom the county owes so much. More recently the Rev. James M. Crombie has brought our knowledge up to date.

1 - On the Lichen Flora of Epping Forest and the causes of its recent diminution,' Transactions Essex Field Club, iv. 54, 1886. 


\section{A HISTORY OF ESSEX}

The late Mr. E. G. Varenne ${ }^{1}$ has also left us many records of lichens. It is from these records that the following list is compiled :-

Collema furvum, Ach.

- pulposum, Ach.

- crispum, Ach.

- cheileum, Ach.

Collemodium biatorinum, Nyl.

- microphyllum, $\mathrm{Nyl}$.

Leptogium tenuissimum, Kœrb.

- pusillum, Nyl.

- palmatum, Mont.

- lacerum, Gray sub-sp. pulvinatum, Nyl.

Sphinctrina turbinata, Fr.

Calicium chrysocephalum, Ach.

- aciculare, Fr.

- trichiale, Ach.

- melanophæum, Ach. var. ferrugineum, Schærb.

- hyperellum, Ach.

- trachelinum, Ach.

- quercinum, Pers.

- curtum, Turn. \& Bott.

- subtile, Pers.

Coniocybe furfuracea, Ach.

Trachylia tigillaris, Fr.

- tympanella, Fr.

- stigonella, Fr.

Bæomyces rufus, DC.

- roseus, Pers.

Cladonia alcicornis, Flœrke

- pyxidata, Fr.

f. epiphylla, Nyl. var. chlorophæa, Flœrke

- fimbriata, Fr.

var. tubæformis, Fr.

f. exigua, Cromb. var. carneopallida, Nyl. sub-sp. fibula, $\mathrm{Nyl}$. var. subcornuta, Nyl. f. nemoxyna, Nyl.

- gracilis, Hoffm.

- furcata, Hoffm. var. spinosa, Hook. sub-sp. racemosa, Nyl.

- pungens, Florke

- squamosa, Hoffm. sub-sp. adspersa, Nyl.

- coccifera, Schær. f. cornucopioides, $\mathrm{Fr}$.

-- digitata, Hoffm.

- cæspiticia, Flœrke

- macilenta, Hoffm.

var. scolecina, Nyl.

" maidenta, Hoffm.

" scabrosa, Nyl.

" coronata, Nyl.
Cladonia macilenta, var. ostreata, Nyl.

- flerkeana, Fr.; f. trachypoda, Nyl.

- bacillaris, Nyl.

Cladina sylvatica, Nyl. f. tenuis, Lamq.

- rangiferina, Nyl.

- uncialis, Nyl.

Usnea hirta, Hoffm.

- ceratina, Ach.; var. scabrosa, Ach. ; f. ferruginascens, Cromb.

Alectoria jubata, Nyl.

Evernia furfuracea, $F$ r.

- prunastri, Ach.

Ramalina calicaris, Hoffm.

- farinacea, Ach.

- fraxinea, Ach. f. ampliata, Ach.

- fastigiata, Ach.

- pollinaria, Ach.

- evernioides, Nyl.

Cetraria aculeata, Fr. ; f. hispida, Cromb.

Platysma glaucum, $\mathrm{N}_{\mathrm{H}}$.

Sticta pulmonaria, Hook.

Peltigera canina, Hoffm.

- spuria, Leight.

- polydactyla, Hoffm.

Parmelia caperata, Ach.

- subaurifera, Nyl.

- exasperata, Nyl.

- physodes, Ach. f. labrosa, Ach.

- reddenda, Stirt.

- perlata, Ach.

- Borreri, Turn.

- fuliginosa, Nyl. var. lætevirens

- acetabulum, Dub.

- saxatilis, Ach.

- sulcata, Tayl.

Physcia parietina, De Not var. aureola, Nyl.

" lychnea, Ach.

"polycarpa, Ehrh. ". cinerascens, Leight.

- ciliaris, DC.

- pulverulenta, Nyl. sub-sp. pityrea, Ach. var. angustata, $\mathrm{Nyl}$.

— stellaris, Nyl. var. leptalea, Nyl. sub-sp. tenella, Nyl.

- aipolia, Nyl.

- cæsia, Nyl.

- erosa, Leight.

1 'Cryptogamic Flora of Kelvedon and its neighbourhood,' Essex Naturalist, v. I, I 89 I. 


\section{BOTANY}

Physcia astroidea, Nyl.

- obscura, Nyl.

- ulothrix, Nyl. var. virella, Cromb.

- adglutinata, Nyl.

Pannaria nebulosa, Nyl.

Squamaria saxicola, Sm.

Placodium murorum, Leight.

- decipiens, Leight.

- callopismum, Mudd.

- miniatum, Hoffm.

- chalybæum, Mudd.

- citrinum, Ach. f. granulosa, Cromb.

Lecanora vitellina, Ach. var. coruscans, Cromb.

- epixantha, Nyl.

- laciniosa, Nyl.

- glaucocarpa, Ach.

- pruinosa, Nyl.

- squamulosa, Nyl.

- fuscata, Nyl.

- cinerea, Somm.

- sarcopis, Ach.

- varia, Ach.

- atra, Ach.

- circinata, Ach.

- sulphurea, Ach.

- symmicta, Ach.

- oresthea, Ach.; var. sublivescens, Nyl.

- expallens, Ach.

- subfusca, Nyl. var. campestris, Nyl.

- allophana, Ach.

- parisiensis, Nyl.

- rugosa, Nyl. sub-sp. chlarona, Nyl.

- intumescens, Kœrb.

- atrynea, Nyl.

- epibryon, Ach.

- galactina, Ach. sub-sp. dispersa, Nyl.

- Hageni, Ach. var. pallidior, Larb.

- calcarea, Somm. f. concreta, Schær.

- gibbosa, Nyl. f. vulgaris, Th. Fr.

- parella, Ach.

- turneri, Sm.

- pallescens, Nyl.

- irrubata, Nyl. sub-sp. calva, Nyl.

- angulosa, Ach.

- albella, Ach.

- aurantiaca, Nyl. sub-sp. erythella, Nyl. var. inalpina, Nyl.

- ferruginea, Nyl. f. corticola, Leight.
Lecanora cerina, Ach.

f. cyanolepra, Nyl.

var. stillicidiorum, Nyl.

sub-sp. chlorina, Nyl.

- angulosa, Ach.

var. sordidescens, Flœrke

- pyracea, Nyl. sub-sp. holocarpa, Nyl.

- lutea-alba, Nyl.

- teicholyta, Ach.

- phlogina, Nyl.

- sophodes, Ach.

f. roboris, Duf.

f. exigua, Ach.

f. metabolica, Ach.

f. lecideoides, Nyl.

- erysibe, Nyl.

f. cinereo-fusca, Cromb.

- syringea, Ach.

- coccinea, Cromb.

- conizaea, Nyl.

- conizaeoides, Nyl.

Pertusaria dealbata, Nyl.

- communis, DC.

- melaleuca, Dub.

- Wulfenii, DC.

- lutescens, Lamy.

- velata, Nyl.

f. aspergilla, Cromb.

- amara, Nyl.

- globulifera, Nyl.

- pustulata, Nyl.

- leioplaca, Schær.

- coccodes, Nyl. ; f. bacillosa, Nyl.

Phlyctis agelæa, Koerb.

- argena, Koerb.

Thelotrema lepadinum, Ach.

Urceolaria scruposa, Ach.

Lecidea Friesii, Ach.

- ostreata, Hoffm.

- fuliginosa, Tayl.

- dispansa, Nyl.

-- crustulata, Ach.

- flexuosa f. æruginosa, Borr.

- sphæroides, Dicks.

- decolorans, Flœrke

- quernea, Dicks.

- enteroleuca, Ach.

- minuta, Schær.

- tenebricosa, Ach.

- parasema, Ach.

var. tabescens, Koerb.

„ flavens, Nyl.

", elæochroma, Ach.

- uliginosa, Schrad.

f. fuliginosa, Fr.

- coarctata, Sm.

f. elacista, Ach.

f. involuta, Tayl.

f. globulosa, Sm. 


\section{A HISTORY OF ESSEX}

Lecidea coarctata, f. ornata, Smrf.

- fuscoatra, Ach.

f. fumosa, Ach.

f. meiosporiza, Nyl.

- sub-Kochiana, Nyl.

- Taylori, Salw.

- contigua, Fr.

- confluens, Leight.

- canescens, Dicks.

- disciformis, Fr.

- myriocarpa, DC.

f. chloropolia, DC.

f. pinicola, Ach.

f. leprosa, DC.

f. quercicola, Rabh.

f. saprophila, Ach.

- nigritula, Nyl.

- chalybeia, Borr.

- grossa, Pers.

- Lightfootii, Sm.

- anomala, Fr.

- tricolor, With.

- Ehrhartiana, Ach.

- Caradocensis, Leight.

- incompta, Borr.

- alboatra, Hoffm.

f. populorum, Mass.

f. epipolia, Ach.

- Dilleniana, Ach.

- aromatica, Sm.

- umbrina, Ach.

- milliaria, Fr. ; f. terrestris, Fr.

- endoleuca, Nyl.

- premnea, Ach.

- phacodes, Kœrb.

- sabuletorum, Florke

- rubella, Ehr.

- effusa, Sm.

- contigua, Ach.

- petræa, Wulf.

f. fuscescens, Leight.

- tantilla, Nyl.

- parmeliarum, Smrft.

- parasitica, Floerke

Opegrapha herpetica, Ach.

f. vera, Leight.

f. rubella, Pers.

f. rufescens, Pers.

- atra, Pers.

f. denigrata, Ach.

f. nigrita, Leight.

f. parallela, Leight.

f. hapalea, Ach.

f. arthonoidea, Leight.

- Turneri, Leight.

- saxicola, Ach.

var. Chevallieri, Leight.

- varia, Pers.
f. pulicaris, Leight.

f. notha, Ach.

Opegrapha varia, f. diaphora, Ach. f. tigrina, Ach.

f. tridens, Ach.

- vulgata, Ach.

f. vulgata, Ach.

f. stenocarpa, Ach.

f. subsiderella, Nyl.

- lyncea, Sm.

Stigmatidium crassum, Dub.

Arthonia lurida, Ach.

- vinosa, Leight.

- punctiformis, Ach.

- astroidea, Ach.

- epipasta, Ach.

- Swartziana, Ach.

- cinnabarina, Wallr.

var. kermesina, Nyl.

f. rosacea, Turn. \& Borr.

f. marginata, Turn. \& Borr. var. pruinata, Del.

f. dubia, Turn. \& Borr.

var. anerythræa, Nyl.

f. detrita, Turn. \& Borr.

- pruinosa, Ach.

- anastomosans, Ach.

Graphis elegans, Sm.

- scripta, Ach.

f. minuta, Leight.

f. varia, Leight.

f. horizontalis, Leight.

var. pulverulenta, Ach.

f. betuligna, Ach.

var. serpentina, Ach.

- dendritica, Ach.

f. Smithii, Leight.

f. obtusa, Leight.

- inusta, Ach.

f. vera, Leight.

f. simpliuscula, Leight.

f. macularis, Leight.

- sophistica, Nyl.

f. Alexuosa, Leight.

f. radiata, Leight.

f. divaricata, Leight.

var. pulverulenta, Sm.

" dendriticoides, Leight.

Endocarpum hepaticum, Ach.

f. trapeziformis, Zoega.

Mycoporum miserrimum, Nyl.

Verrucaria papillosa, Ach.

- mutabilis, Borr.

- mauroides, Schær.

- nigrescens, Pets.

- plumbea, Ach.

- fucella, Turn.

- glaucina, Ach.

- macrostoma, Duf.

- viridula, Schrad.

- rupestris, Schrad. var. muralis, Ach. 


\section{BOTANY}

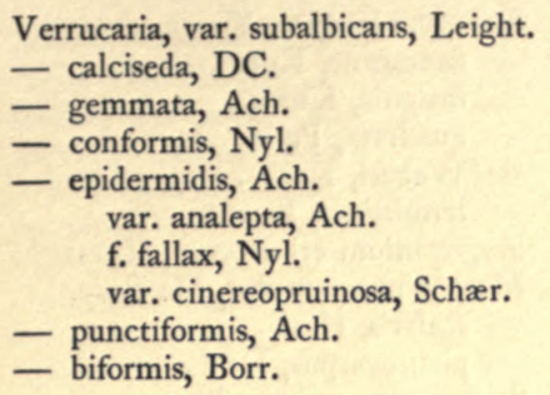

Verrucaria Salweii, Leight.

- rugulosa, Borr.

- chlorotica, Ach.

- nitida, Weig.

- glabrata, Ach.

- albissima, Ach.

- epipolytropa, Mudd.

- hymenogonia, Nyl.

Melanotheca gelatinosa, Chev.

\section{FRESHWATER ALGÆ}

Probably Essex is one of the best counties in England for freshwater algæ. It has plenty of small ponds, pools, streams, fresh and brackish ditches, and other conditions so favourable to their growth. Dr. M. C. Cooke writes to me that the Epping Forest district is the best anywhere around London. Of course such species as are to be found only on rocks and in mountainous districts are absent from Essex.

The Conjugate and Conferva are well represented, also the Zygnemacea, Desmidiacee and EEdogoniacea. Dr. Cooke has never found EEdogonium crassiusculum anywhere else, nor does he recollect receiving E. pluviale from any other locality.

He says: 'As to species of interest, I fancy that the constant and perennial excursions of the Quekett Club will show that there is always the prospect of something worth going after if it is only Volvox and Gonium, and Eudorina, the latter especially. For myself, I have never been disappointed in a trip to the Forest district when in search of algæ, having always managed to secure something new, or comparatively interesting.'

The following list is by Dr. M. C. Cooke ${ }^{1}$ and includes records by himself, Dr. Hassall, E. G. Varenne, Mr. C. E. Mainland, and the excursion lists of the Quekett Microscopic Club. They are from the Epping Forest district and from Kelvedon. No doubt this list would be very considerably extended if the whole county had been explored.

Pleurococcus vulgaris, Menegh

Palmella hyalina, Rabenh.

- Mooreana, Harv.

Porphyridium cruentum, Næg.

Tetraspora bullosa, $\mathrm{Ag}$.

- lubrica, C. Ag.

- gelatinosa, Desv.

Apiocystis Brauniana, Næg.

Raphidium falcatum, Cooke

Protococcus viridis, C. Ag.

Chlorococcum gigas, Grun.

Scenedesmus obtusus, Meyen

- acutus, Meyen

- quadricauda, Bréb.

Hydrodictyon utriculatum, Roth.
Pediastrum Boryanum, Menegh

- rotula, A. Br.

Hydrianum heteromorphum, Reinsch.

Chlamydococcus nivalis, A. Br.

Volvox globator, Ehr.

- minor, Stein.

Gonium pectorale, Muell.

Eudorina elegans, Ehrenb.

Sphærozosma secedens, De Bary

Hyalotheca dissiliens, Bréb.

- mucosa, Ehrenb.

Desmidium Swartzii, Ag.

Docidium Ehrenbergii, Ralfs.

- nodulosum, Bréb.

- baculum, Bréb.

1 Essex Naturalist, vii. 170. 


\section{A HISTORY OF ESSEX}

Closterium Lunula, Ehrenb.

- acerosum, Ehrenb.

- gracile, Bréb.

- Ehrenbergii, Menegh

- moniliferum, Ehrenb.

- Jenneri, Ralfs

- Leibleinii, Kuetz.

- Dianæ, Ehrenb.

- striolatum, Ehrenb.

- intermedium, Ralfs

- lineatum, Ehrenb.

- rostratum, Ehrenb.

- setaceum, Ehrenb.

- linea, Perty.

Penium margaritaceum, Bréb.

- digitus, Bréb.

- closteroides, Ralfs

- Brebissonii, Ralfs

Mesotænium Braunii, De Bary

Tetmemorus Brebissonii, Ralfs

- granulatus, Ralfs

Spirotzenia condensata, Breb.

Micrasterias denticulata, Bréb.

- rotata, Ralfs

Euastrum oblongum, Ralfs

- crassum, Kuetz.

- affine, Ralfs

- ansatum, Ehrenb.

- circulare, Hass.

- elegans, Kuetz.

- inerme, Lund.

Cosmarium cucumis, Corda

- Meneghinii, Bréb.

- Brebissonii, Menegh

- margaritiferum, Menegh

- botrytis, Menegh

Xanthidium armatum, Bréb.

Arthodesmus octocornis, Ehrenb.

- incus, Hass.

- convergens, Ehrenb.

Staurastrum dejectum, Bréb.

- cuspidatum, Bréb.

- orbiculare, Ralfs

- muricatum, Bréb.

- punctulatum, Bréb.

- alternans, Bréb.

- polymorphum, Bréb.

- Arachne, Ralfs

Zygnema cruciatum, C. Ag.

- Vaucherii, C. Ag. var. stagnale, Kirchn.

- anomalum, Cooke

Spirogyra crassa, Kuetz.

- nitida, Link.

- orthospira, Naeg. .

- setiformis, Kuetz.

- orbicularis, Hass.

- bellis, Crouan

- porticalis, Cleve

- condensata, Kuetz.
Spirogyra longata, Kuetz.

- Alavescens, Kuetz.

- insignis, Kuetz.

- quadrata, Petit

- Weberi, Kuetz.

- tenuissima, Kuetz.

Zygogonium ericetorum, Kuetz.

Mesocarpus parvulus, De Bary.

- scalaris, Hass.

- pleurocarpus, De Bary

Staurospermum gracillimum, Kuetz.

- capucinum, Kuetz.

- viride, Kuetz.

Botrydium granulatum, Grev.

Vaucheria aversa, Hass.

- sericea, Lyngb.

- Dillwynii, C. Ag.

- sessilis, DC.

- geminata, DC. var. racemosa, Walz.

- hamata, Lyngb.

- terrestris, Lyngb.

Prasiola crispa, C. Ag.

Enteromorpha intestinalis, Link.

Microspora floccosa, Thur.

- vulgaris, Rabenh.

- fugacissima, Rabenh.

Chætomorpha Linum, Kuetz.

Conferva bombycina, C. Ag.

Cladophora crispata, Kuetz.

- glomerata, Kuetz.

- Havescens, Kuetz.

- fracta, Kuetz.

Edogonium vernale, Wittr.

- paludosum, Kuetz.

- Rothii, Pringsh.

- pluviale, Nordst

- flavescens, Kuetz.

- crassiusculum, Wittr.

- capillare, Kuetz.

- Boscii, Bréb.

- hexagonum, Kuetz.

- fasciatum, Kuetz.

- longatum, Kuetz.

- sphæricum, Kuetz.

- Muelleri, Kuetz.

Bulbochæte setigera, C. Ag.

Hormiscia zonata, Aresch.

Ulothrix tenuis, Kuetz.

- tenerrima, Kuetz.

- radicans, Kuetz.

Chroolepus aureum, Kuetz.

Stigeoclonium thermale, A. Br.

- nanum, Kuetz.

Draparnaldia glomerata, C. Ag.

- plumosa, C. Ag.

Chætophora pisiformis, C. Ag.

- tuberculosa, Hook.

- elegans, C. Ag.

- endivcæfolia, C. Ag. 


\section{BOTANY}

Coleochxte scutata, Bréb.

A phanothece prasina, A. Br.

Nostoc commune, Vauch.

Anabrna Hassalii, Wittr.

Cylindrospermum macrospermum, Kuetz.

Spirulina Jenneri, Kuetz.

- oscillarioides, Kuetz.

Oscillatoria amphibia, C. Ag.

- tenuis, C. Ag.

Symploea muscorum, Gom.
Symploea limosa, C. Ag.

- nigra, Vauch.

Phormidium autumnale, Gom.

Microcoleus terrestris, Desmaz.

Gloiotrichia natans, Rabenh.

- Pisum, Thur.

Batrachospermum moniliforme, Roth.

- vagum, C. Ag.

- ectocarpum, Sirod.

- Dillenii, Bory.

\section{MARINE ALGÆ}

The flat muddy coast of the county, without any natural rocks capable of affording a stable anchorage, is not a favourable locality for seaweeds, hence the list of Essex seaweeds is not large.

A list of the marine algæ of Essex has been compiled by $\mathrm{Mr}$. E. A. L. Batters, chiefly from the herbarium of Mr. G. P. Hope, ${ }^{1}$ and it is from this source that $\mathrm{I}$ have obtained the following list. A few species are added from a list of seaweeds quite recently collected by Dr. H. C. Sorby and named by Mr. E. M. Holmes.

So far as is at present known the marine flora of Essex consists of 158 species included in 95 genera, and is marked as much by the absence of many species common and abundant elsewhere as for the presence of a few which are very rarely met with on the shores of our islands. As examples of the latter class, Ectocarpus erectus, Pbyllitis filiformis, Scinaia furcellata and Grateloupia filicina may be mentioned; while as examples of the former, Calotbrix confervicola, Desmarestia aculeata, Dictyosiphon feeniculaceus, Asperococcus ecbinatus, Spbacelaria cirrbosa, Cbordaria Aagelliformis, Leatbesia difformis, Laminaria digitata, Saccorbiza bulbosa, Pelvetia canaliculata, Cbantransia secundata, Gelidium crinale, Gigartina mammillosa, Callopbyllis laciniata, Lomentaria clavellosa, Nitophyllum punctatum, Ceramium ecbionotum, C. acanthonotum, C. ciliatum, Polysiphonia fastigiata, all of them common species, are 'conspicuous by their absence' from the flora of Essex.

The marine flora of Essex is southern in its character. The following have been recorded:-

Gloeocapsa crepidinum, Thur.

Aphanocapsa marina, Hansg.

Dermocarpa prasina, Born.

Hyella cxspitosa, Born. \& Flah.

Spirulina subsalsa, Ersted

Oscillatoria corallina, Gom.

Lyngbya semiplena, J. Ag.

- xstuarii, Liebman.

Symploca hydnoides, Kuetz.

Microcoleus chthonoplastes, Thur.

Calothrix scopulorum, C. Ag.

- pulvinata, C. Ag.

- confervicola, C. Ag.

Isactis plana, Thur.
Rivularia atra, Roth.

Mastigocoleus testarum, Lagerh.

Anabæna variabilis, Kuetz.

Chlorochytrium inclusum, Kjellm.

Monostroma laceratum, Thur.

Enteromorpha ramulosa, Hook.

- erecta, J. Ag.

- clathrata, C. Ag.

- canaliculata, Batt.

- percursa, Harv.

- compressa, L.

- intestinalis, L.

- Linza, J. Ag.

- tubulosa, Kuetz.

1 Essex Naturalist, viii. 1, and species recorded by E. M. Holmes in the same publication. 


\section{A HISTORY OF ESSEX}

Enteromorpha minima, Naeg.

Ulva latissima, J. Ag.

Epicladia Flustræ, Reinke

Urospora penicilliformis, Aresch.

- flacca, Holm. \& Batt.

Chætomorpha ærea, Kuetz.

- Melagonium, Kuetz.

- Linum, Kuetz.

- litorea, Holm. \& Batt.

- tortuosa, Kuetz.

Rhizoclonium riparium, Harv.

Cladophora rupestris, Kuetz.

- Hutchinsiæ, Kuetz.

- utriculosa, Kuetz.

- glaucescens, Harv.

- fracta, Kuetz.

- albida, Kuetz.

- uncialis, Harv.

Bryopsis plumosa, C. Ag.

Vaucheria sphærospora, Nordst.

Punctaria plantaginea, Grev.

Ectocarpus erectus, Kuetz.

- Crouani, Thur.

- confervoides, Le Jol.

- siliculosus, Lyngb.

- granulosus, C. Ag.

- tomentosus, Lyngb.

Pylaiella litoralis, Kjellm.

Elachista fucicola, Aresch.

Sphacelaria plumigera, Holmes

Stypocaulon scoparium, Kuetz.

Cladostephus verticillatus, C. Ag.

- spongiosus, C. Ag.

Myrionema strangulans, Grev.

Hecatonema reptans, Saur.

Ralfsia verrucosa, Aresch.

- clavata, Crouan

Phyllitis filiformis, Batt.

Scytosiphon lomentarius, Endl.

Chorda Filum, Stackh.

Laminaria saccharina, Lamour.

Cutleria multifida, Grev.

Fucus ceranoides, L.

- vesiculosus, L. ; f. spiralis, L. f. Baltica, J. Ag.

- platycarpus, Thur.

- serratus, L.

Ascophyllum nodosum, Le Jol. f. scorpoides, Hauck.

Himanthalia lorea, Lyngb.

Halidrys siliquosa, Lyngb.

Dictyota dichotoma, Lamour.

Taonia atomaria, J. Ag.

Padina pavonia, Gaillon.

Porphyra laciniata, C. Ag.

- f. typica, Holm. and Batt.

- linearis, Grev.

- leucosticta, Thur.

Bangia fusco-purpurea, Lyngb.

Scinaia furcellata, Bivona.
Harveyella mirabilis, Reinke

Chondrus crispus, Stackh.

Phyllophora rubens, Grev.

- membranifolia, J. Ag.

Gymnogongrus Griffithsiæ, Mart.

- Norvegicus, J. Ag.

Ahnfeltia plicata, Fr.

Actinococcus aggregatus, Schmitz.

- peltæformis, Schmitz.

Colacolepis incrustans, Schmitz.

Sterrocolax decipiens, Schmitz.

Cystoclonium purpurascens, Kuetz.

Catenella Opuntia, Grev.

Gracilaria confervoides, Grev.

Calliblepharis ciliata, Kuetz.

Rhodymenia palmata, Grev.

Lementaria clavellosa, Gaill.

Chylocladia kaliformis, Grev. f. squarrosa, Harv.

Plocamium coccineum, Lyngb.

Nitophyllum laceratum, Grev.

Delesseria alata, Lamour.

- Hypoglossum, Lamour.

- sinuosa, Lamour.

- sanguinea, Lamx.

Bostrychia scorpioides, Montg.

Rhodomela subfusca, C. Ag.

Laurencia hybrida, Lam.

- pinnatifida, Lamx.

Chondria dasyphylla, C. Ag.

Polysiphonia urceolata, Grev.

- elongata, Harv.

- atro-rubescens, Grev.

- nigrescens, Grev.

- affinis, Moore

Brongniartella byssoides, Bory

Dasya coccinea, C. Ag.

Spermothamnion Turneri, Aresch.

Griffithsia setacea, C. Ag.

- corallina, C. Ag.

Halurus equisetifolius, Kuetz.

Pleonosporium Borreri, Naeg.

Rhodochorton Rothii, Naeg.

- foridulum, Näg.

Callithamnion polyspermum, C. Ag.

- roseum, C. Ag.

- corymbosum, C. Ag.

- pseudobyssoides, Crouan

Plumaria elegans, Schmitz.

Antithamnion Plumula, Thur.

Ceramium tenuissimum, J. Ag.

- Deslongchampsii, Chauv.

- strictum, Harv.

- diaphanum, Roth.

- rubrum, C. Ag.

- flabelligerum, J. Ag.

Grateloupia filicina, C. Ag.

Dumontia filiformis, Grev.

Dilsea edulis, Schmitz.

Fastigiaria furcellata, Stackh. 


\section{BOTANY}

Polyides rotundus, Grev.

Cruoriella Dubyi, Schmitz.

Hildenbrandtia prototypus, Nardo.

Melobesia membranacea, Lamour.

- corticiformis, Kuetz.
Melo besia Corallinæ, Crouan

Lithophyllum Lenormandi, Rosan

Corallina officinalis, L.

- rubens, L.

- corniculata, L.

\section{FUNGI $^{1}$}

It is difficult to compare the cryptogamic flora of one county with that of another, because cryptogamic botanists are few and the record of cryptogamic plants for all counties is very incomplete.

Probably the Epping Forest district is one of the most thoroughly investigated of England. For many years a large party of members of the Essex Field Club have explored the Forest each autumn in search of fungi. Messrs. English and Worthington Smith have also collected fungi in this county. In spite of these many workers, Dr. M. C. Cooke says that it may be taken for granted that the mycology of the Forest has been by no means exhausted.

Altogether 406 species of Hymenomycetous fungi have been recorded in Epping Forest. ${ }^{2}$ This is a good record, as only I, 338 species are recorded as occurring in Great Britain. It is evident that Essex is not an unfavourable county for the development of fungi. Several species new to Britain have been first detected in Epping Forest.

E. G. Varenne contributed a list of the cryptogamic plants in the neighbourhood of Kelvedon, ${ }^{3}$ a part of Essex which is possibly more in character with the county generally than the Epping Forest.

A short list of Ustilaginei and Æcidiomycetes was also contributed by M. C. Cooke." Of these Delitscbia insignis, Mont., and Sporodesmium pyriforme, Corda, are new to Britain.

The following is a list of the Essex fungi, found mostly in the Epping Forest and in the neighbourhood of Kelvedon. A few were observed by myself in the neighbourhood of Colchester.

Agaricus (Amanita) phalloides, Fr.

- vernus, Bull.

- " " mappa, Fr.

- $\quad$ muscarius, Fr.

- " pantherinus, Fr.

- " strobiliformis, Fr.

- $\quad$ excelsus, Fr.

- $\quad$ rubescens, Fr.

- $\quad$ spissus, Fr.

- " " nitidus, Fr.

- " $\quad$ vaginatus, Fr.

$-$
Agaricus (Lepiota) procerus, Scop.

- " rachodes, Vitt.

- " " excoriatus, Schaeff.

- " acutesquamosus, Weinm.

- $\quad$ " cristatus, A. \& S.

- " carcharias, Pers.

- " granulosus, Batsch.

- (Armillaria) constrictus, Fr.

$$
\text { - " melleus, Vahl. }
$$

- " mucidus, Schrad.

- (Tricholoma) sejunctus, Sow. var. nivalis, Grev. $\quad$ - $\quad$ portentosus, Fr. strangulatus, Fr. $\quad$ - $\quad$ " resplendens, Fr.

1 The arrangement and nomenclature followed in this list is that of the Handbook of British Fungi, by M. C. Cooke (1871), and of the British Uredinea and Ustilaginee by Chas. B. Plowright (1889). iii. $24^{8}$.

2 'Hymenomycetal Fungi of Epping Forest,' by M. C. Cooke, M.A., LL.D., Essex Naturalist,

3 Essex Naturalist, v. 21. xi. 313 .

4 Ibid. i. 184, and 'Recent Additions to the Fungi of Epping Forest,' by Geo. Massee, F.L.S., in 


\section{A HISTORY OF ESSEX}

Agaricus (Tricholoma) acerbus, Bull.

\begin{tabular}{|c|c|c|}
\hline - & $"$ & fulvellus, Fr. \\
\hline & $"$ & flavo-brunneus, Fr. \\
\hline & $"$ & albo-brunneus, Pers. \\
\hline & $"$ & ustalis, $F_{r}$. \\
\hline & $"$ & $\begin{array}{l}\text { rutilans, Schaeff. } \\
\text { variegatum. Schaeff. }\end{array}$ \\
\hline & $"$ & $\begin{array}{l}\text { variegatum, Schaett. } \\
\text { columbetta, Fr. }\end{array}$ \\
\hline & $"$ & scalpturatus, Fr. \\
\hline & $"$ & imbricatus, Fr. \\
\hline & $"$ & vaccinus, Pers. \\
\hline & $"$ & terreus, Schaeff. \\
\hline & $"$ & saponaceus, Fr. \\
\hline & $"$ & $\begin{array}{l}\text { cunelfolius, Fr. } \\
\text { carneus, Bull. }\end{array}$ \\
\hline & $"$ & gambosus, Fr. \\
\hline & $"$ & civilis, $\mathbf{F r}$. \\
\hline & $"$ & personatus, $\mathbf{F r}$. \\
\hline & $"$ & nudus, Bull. \\
\hline & $"$ & $\begin{array}{l}\text { grammopodius, Bull. } \\
\text { subpulverulentus. Pers. }\end{array}$ \\
\hline & & $\begin{array}{l}\text { subpulverulentus, Pers. } \\
\text { sordidus, Fr. }\end{array}$ \\
\hline & (Clitocybe) & nebularis, Fr. \\
\hline & $"$ & clavipes, Pers. \\
\hline - & $"$ & odorus, Bull. \\
\hline & $"$ & cerussatus, $\mathrm{Fr}$. \\
\hline & $"$ & $\begin{array}{l}\text { phyllophilus, Fr. } \\
\text { dealbatus, Sw. }\end{array}$ \\
\hline & $"$ & elixus, Sow. \\
\hline & $"$ & gallinaceus, Fr. \\
\hline & $"$ & fumosus, Pers. \\
\hline & $"$ & maximus, Fr. \\
\hline & $"$ & infundibuliformis, Schaeff. \\
\hline & $"$ & $\begin{array}{l}\text { flaccidus, Fr. } \\
\text { geotrupus, Bull. }\end{array}$ \\
\hline & $"$ & $\begin{array}{l}\text { geotrupus, Bull. } \\
\text { inversus, Fr. }\end{array}$ \\
\hline & $"$ & catinus, Fr. \\
\hline & $"$ & ericetorum, Bull. \\
\hline & $"$ & cyathiformis, Fr. \\
\hline & $"$ & brumalis, Fr. \\
\hline & $"$ & $\begin{array}{l}\text { metachrous, Fr. } \\
\text { ditopus, Fr. }\end{array}$ \\
\hline & $"$ & fragrans, Sow. \\
\hline & $"$ & obsoletus, Batsch. \\
\hline & " & bellus, Fr. \\
\hline & (Collybia) & laccatus, $F_{r}$. \\
\hline & $"$ & $\begin{array}{l}\text { radicatus, Bull. } \\
\text { platyphyllus, Fr. }\end{array}$ \\
\hline & $"$ & $\begin{array}{l}\text { platyphyllus, Fr. } \\
\text { fusipes, Bull. }\end{array}$ \\
\hline- & $"$ & maculatus, A. \& S. \\
\hline 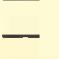 & $"$ & distortus, $F r$. \\
\hline & $"$ & $\begin{array}{l}\text { butyraceus, Bull. } \\
\text { velutipes, Curt. }\end{array}$ \\
\hline & $"$ & $\begin{array}{l}\text { confluens, P. } \\
\text { Pest. }\end{array}$ \\
\hline & $"$ & cirrhatus, Schum. \\
\hline & $"$ & tuberosus, Bull. \\
\hline & $"$ & psathyroldes, Cke. \\
\hline & " & ocellatus, Fr. \\
\hline
\end{tabular}

Agaricus (Collybia) muscigenus, Schum.

\begin{tabular}{|c|c|c|}
\hline & $"$ & laceratus, Lasch. \\
\hline & (Mycena) & elegans, Pers. \\
\hline - & $"$ & purus, Pers. \\
\hline - & $"$ & adonis, Bull. \\
\hline & $"$ & $\begin{array}{l}\text { lacteus, Pers. } \\
\text { pynseus. Fr. }\end{array}$ \\
\hline & $"$ & rugosus, Fr. \\
\hline - & $"$ & $\begin{array}{l}\text { galericulatus, Scop. } \\
\text { var. calopus, Fr. }\end{array}$ \\
\hline - & $"$ & polygrammus, Bull. \\
\hline & " & parabolicus, $\mathrm{Fr}_{0}$ \\
\hline & $"$ & $\begin{array}{l}\text { tintinnabulum, Fr. } \\
\text { pullatus, Berk. \& Cke }\end{array}$ \\
\hline & $"$ & leptocephalus, Pers. \\
\hline & " & alcalinus, Fr. \\
\hline & $"$ & ammoniacus, Fr. \\
\hline & " & metatus, Fr. \\
\hline & $"$ & tenuis, Bolt. \\
\hline & $"$ & amictus, $F_{r}$ \\
\hline & ", & vitilis, Fr. \\
\hline & $"$ & hæmatopus, Fr. \\
\hline & $"$ & sanguinolentus, Fr. \\
\hline & $"$ & galopus, Fr. \\
\hline & $"$ & leucogalus, Cke. \\
\hline & $"$ & epipterygius, Fr. \\
\hline & $"$ & clavicularis, Fr. \\
\hline & $"$ & Torrtich \\
\hline & " & capillaris, Schum. \\
\hline & $"$ & griseus, Fr. \\
\hline & " & fibula, Bull. \\
\hline
\end{tabular}

(Omphalia) hydrogrammus, Fr.
pyxidatus, Bull.
oniscus, Fr.
demissus, Fr.
pseudoandrosaceus, BulL

(Pleurotus) corticatus, Fr.

dryinus, Pers.

spongiosus, $\mathrm{Fr}$.

petaloides, Bull.

Leightonii, Berk.

ulmarius, Bull.

ostreatus, Jacq.

var. euosmus, Berk.

acerosus, $\mathbf{F r}$.

septicus, Fr.

mastrucatus, Fr.

Leightoni, Berk.

chioneus, Berk.

acerinus, Fr.

mitis, Pers.

limpidus, Fr.

(Volvaria) medius, Schum.

(Pluteus) cervinus, Schaeff.

umbrosus, Pers.

" nanus, Pers. 


\section{BOTANY}

Agaricus (Entoloma) sinuatus, Fr. lividus, Bull. prunuloides, Fr. Saundersii, Fr. jubatus, Fr. sericellus, Fr. sericeus, Bull.

"nidorosus, Fr.

» orcella, Bull.

" carneo-albus, With.

(Nolanea) pascuus, Pers.

" pisciodorus, Ces.

" subglobosus, A. \& S.

(Claudopus) euosmus, Berk. variabilis, Pers.

(Pholiota) terrigenus, Fr. præcox, Fr. radicosus, Bull. comosus, Fr. squarrosus, Muell. var. Muelleri, Fr.

var. verruculosus, Lasch. durus, Bolt. spectabilis, Fr. adiposus, $\mathrm{Fr}$. mutabilis, Schaeff. marginatus, Batsch.

Inocybe) pyriodorus, $\mathrm{P}$. maritimus, Fr. lacerus, $\mathrm{Fr}$. perlatus, Cke. fastigiatus, Schaeff. rimosus, Bull. asterosporus, Q. eutheles, B. \& Br. destrictus, Fr. geophyllus, Sow.

(Hebeloma) fastibilis, Fr. mesopheus, Fr. sinapizans, $\mathrm{Fr}$. crustuliniformis, Bull.

" crustuliniform

(Flammula) gummosus, Lasch. spumosus, $\mathrm{Fr}$. carbonarius, $\mathrm{Fr}$. alnicola, Fr. flavidus, Schaeff. inopus, Fr. hybridus, Fr.

(Naucoria) centunculus, Fr. melinoides, Fr. pediades, Fr. semiorbicularis, Bull. carpophilus, Fr.

(Galera) tener, Schaeff. ovalis, Fr. rubiginosus, $P$. hypnorum, Batsch. var. sphagnorum, Fr.
Agaricus (Galera) mniophilus, Fr.

(Tubaria) furfuraceus, $P$.

var. trigonophyllus, $\mathrm{Fr}$. stagninus, Fr.

(Crepidotus) mollis, Schaeff.

(Psalliota) arvensis, Schaeff.

$" \quad$ cretaceus, Fr. campestris, Fr. sylvaticus, Schaeff.

(Stropharia) æruginosus, Curt. albocyaneus, Desmaz. inunctus, Fr. coronillus, Bull. squamosus, Fr. thraustus, Kalchbr. Worthingtonii, Fr. merdarius, Fr. stercorarius, $\mathrm{Fr}$. semi-globatus, Batsch. spintriger, Fr.

(Hypholoma) sublateritius, Schøeff. epixanthus, Fr. fascicularis, Huds. dispersus, Fr. storea var. cœespitosus,

\section{Cooke}

lachrymabundus, Fr. velutinus, Pers. pyrotrichus, Holmsk. Candolleanus, Fr.

" appendiculatus, Bull.

(Psilocybe) hydrophilus, B
ericæus, Pers. udus, Pers. semilanceatus, Fr. spadiceus, Fr.

(Psathyra) fœenisecii, Pers.
conopileus, Fr.

" corrugis, Pers.

" fibrillosus, Pers.

" pennatus, Fr.

") semivestitus, Berk.

(Panæolus) separatus, Fr.

" fimiputris, Bull. phalenarum, Fr. retirugis, $\mathrm{Fr}$. sphinctrinus, Fr. campanulatus, L. papilionaceus, Bull. ” caliginosus, Jungh.

(Psathyrella) trepidus, Pers. disseminatus, Pers. " pronus, Fr.

Coprinus comatus, Fr.

- ovatus, Schaeff.

- atramentarius, Fr.

- picaceus, Bull.

- niveus, Pers.

- micaceus, Bull.

- aratus, Berk. \& Br. 


\section{A HISTORY OF ESSEX}

Coprinus radians, Desmaz.

- deliquescens, Bull.

- congregatus, Bull.

- radiatus, Bolt.

- plicatilis, Curt.

Bolbitius Boltoni, Pers.

— fragilis, Fr.

Cortinarius (Phlegmacium) varius, Fr.

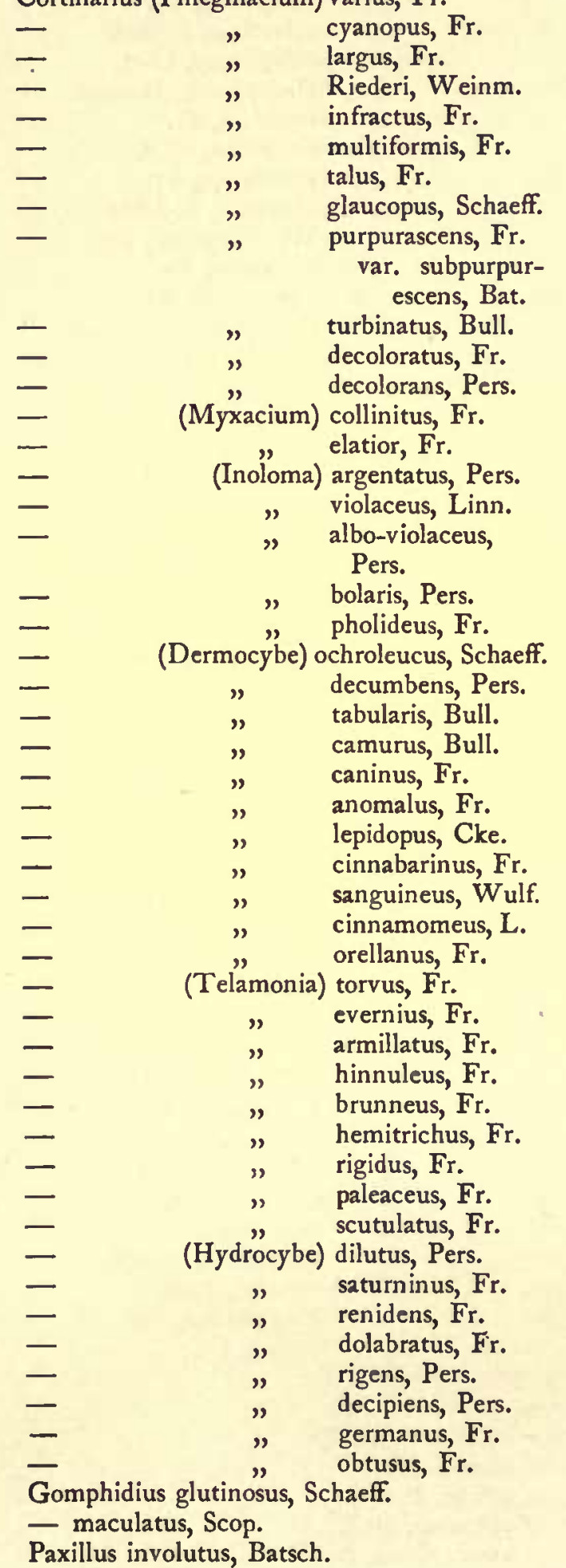

Paxillus atrotomentosus, Batsch.

- Alexandri, Gill.

Hygrophorus chrysodon, Batsch.

- eburneus, Bull.

- cossus, Sow.

- penarius, Fr.

- pratensis, Pers.

- virgineus, Wulr.

- russo-coriaceus, Berk. \& Br.

- Colemannianus, Blox.

- latus, Fr.

- ceraceus, Wulf.

- coccineus, Schaeff.

- miniatus, Fr.

- turundus, Fr.

- conicus, Scop.

- calyptræ formis, Berk.

- chlorophanus, Fr.

- psittacinus, Schaeff.

Lactarius torminosus, Fr.

— turpis, Fr.

- controversus, Fr.

- insulsus, Fr.

- blennius, Fr.

- trivialis, Fr.

- pyrogalus, Fr.

- chrysorrhœus, Fr.

- pergamenus, Fr.

- piperatus, Fr.

- vellereus, Fr.

- deliciosus, Fr.

- pallidus, Fr.

- quietus, Fr.

- aurantiacus, Fr.

- rufus, Fr.

- glyciosmus, Fr.

- fuliginosus, Fr.

- lilacinus, Lasch.

- volemum, Fr.

- serifluus, Fr.

- mitissimus, Fr.

- subdulcis, Fr.

- cimicarius, Batsch.

- camphoratus, Fr.

- subumbonatus, Lindgr.

Russula nigricans, Fr.

— adusta, Fr.

- delica, Fr.

- furcata, Fr.

- rosacea, Fr.

- maculata, Quel.

- granulosa, Cke.

- depallens, Fr.

- lactea, Fr. var. incarnata, Quel.

- virescens, Fr.

- cutefracta, Cke.

- lepida, Fr.

- rubra, Fr. 


\section{BOTANY}

Russula xerampelina, Fr.

- Linnæi, Fr.

- vesca, Fr.

- cyanoxantha, Fr.

- heterophylla, Fr.

- consobrina, Fr. var. sororia, Fr.

- fœetens, Fr.

- fellea, Fr.

- subfœtens, Sm.

- emetica, Fr.

- fallax, Schaeff.

- pectinata, Fr.

- ochroleuca, Fr.

- citrina, Gillet

- fragilis, Fr. var. violacea, Pers.

- integra, Fr.

- Armeniaca, Cke.

- alutacea, $\mathrm{Fr}$.

- lutea, Fr.

- Chameleontina, Fr.

Cantharellus cibarius, Fr.

- aurantiacus, Fr.

- tubæformis, Fr.

- infundibuliformis, $\mathrm{Fr}$.

Nyctalis asterophora, Fr.

- parasitica, Fr.

Marasmius urens, Fr.

- peronatus, Fr.

- oreades, Fr.

- fuscopurpureus, Fr.

- terginus, Fr.

- erythropus, Fr.

- cohærens, Fr.

- ramealis, $\mathrm{Fr}$.

- rotula, Fr.

- androsaceus, Fr.

- Hudsoni, Fr.

- epiphyllus, Fr.

Lentinus lepideus, Fr.

- cochleatus, Fr.

Panus torulosus, Fr.

- stypticus, Fr.

- farinaceus, Fr.

Lenzites betulina, $\mathrm{Fr}$.

Boletus elegans, Schum.

- flavus, With.

- bovinus, Fr.

- tenuipes, Cke.

- badius, Fr.

- piperatus, Bull.

- chrysenteron, Fr.

- subtomentosus, Linn. var. radicatus, Quel.

- rubinus, Sm.

- versicolor, Rostk.

- parasiticus, Fr.

- calopus, Fr.

- pachypus, Fr.
Boletus candicans, Fr.

- edulis, Bull.

- impolitus, Fr.

- æstivalis, Fr.

- satanas, Fr.

- luridus, Fr.

- purpureus, Fr.

- eyrthropus, $\mathrm{Fr}$.

- laricinus, Fr.

- versipellis, Fr.

- duriusculus, Schulz.

- scaber, Fr.

- felleus, Bull.

Fistulina hepatica, Fr.

Polyporus Schweinitzii, Fr.

- rufescens, Fr.

- squamosus, Huds.

- picipes, Fr.

- varius, Fr.

- elegans, Fr.

- umbellatus, $\mathrm{Fr}$.

- intybaceus, $\mathrm{Fr}$.

- giganteus, Fr.

- sulphureus, $\mathrm{Fr}$.

- imbricatus, Fr.

- cæsius, Fr.

- chioneus, $\mathrm{Fr}$.

- adustus, Fr.

- adiposus, B.

- cuticularis, Fr.

- hispidus, Fr.

- dryadeus, Fr.

- betulinus, Fr.

- fulvus, $\mathrm{Fr}$.

- salignus, Fr.

Fomes lucidus, $\mathrm{Fr}$.

- applanatus, $\mathrm{Fr}$.

- fomentarius, Fr.

- igniarius, Fr.

- roseus, Fr.

- annosus, Fr.

- fraxineus, Fr.

Polystictus perennes, Linn.

- radiatus, $\mathrm{Fr}$.

- fibula, Fries

- versicolor, $\mathrm{Fr}$.

Poria vaporaria, $\mathrm{Fr}$.

- medula-panis, Fr.

- vulgaris, Fr.

Trametes gibbosa, $\mathrm{Fr}$.

- mollis, Somm.

Dædalea quercina, $P$.

- confragosa, Fr.

- unicolor, Fr.

Merulius tremellosus, $\mathrm{Fr}$.

- corium, Fr.

Hydnum repandum, $\mathrm{Fr}$.

- zonatum, Fr.

- erinaceum, Fr.

- cirrhatum, Fr. 


\section{A HISTORY OF ESSEX}

Hydnum diversidens, Fr.

- ferruginosum, Fr.

Sistotrema confluens, Fr.

Radulum quercinum, $\mathrm{Fr}$.

- fagineum, Fr.

Grandinia granulosa, Fr.

Craterellus cornucopioides, Fr.

- crispus, Fr.

Thelephora multizonata, Berk. \& Br.

- caryophyllea, Fr.

- anthocephala, Fr.

- clavularis, Fr.

- palmata, Fr.

- laciniata, P.

- cristata, Fr.

- crustacea, Fr.

Stereum purpureum, Fr.

- hirsutum, Fr.

- spadiceum, Fr.

- sanguinolentum, Fr.

- rugosum, Fr.

Hymenochoete rubiginosa, Fr.

- tabacina, Fr.

Peniophora quercina, Cke.

- incarnata, Fr.

Corticium laeve, Fr.

- serum, Fr.

- comedens, Fr.

- sebaceum, Fr.

Coniophora puteana, Fr.

- olivacea, Fr.

- cellare, Pers.

Phlebia radiata, Fr.

- merismoides, Fr.

Auricularia mesenterica, Fr.

Cyphella Curreyi, Berk. \& Br.

- villosa, Pers.

Clavaria amethystina, Fr.

- fastigiata, Fr.

- coralloides, Fr.

- cinerea, Fr.

- cristata, Fr.

- rugosa, Fr.

- aurea, Schaeff.

- grisea, Pers.

- fusiformis, Sow.

- inæqualis, Fr.

- fragilis, Holms.

- vermicularis, Scop.

- pistillaris, Linn.

- contorta, Holms.

Calocera viscosa, Fr.

- cornea, Fr.

Typhula phacorhiza, Fr.

Pistillaria quisquiliaris, Fr.

Tremella foliacea, Pers.

- mesenterica, Retz.

- albida, Huds.

Exidia glandulosa, Fr.

Dacryomyces deliquescens, Duby.
Dacryomyces stillatus, Nees

- chrysocoma, Bull.

Lycoperdon giganteum, Batsch.

- saccatum, Vahl.

Didymium physarioides, Fr.

Arcyria punicea, Pers.

Cyathus striatus, Hoffm.

- vernicosus, DC.

Phoma radula, Berk. \& Br.

- depressum, Berk. \& Br.

Leptothyrium Ribis, Lib.

- Juglandis, Lib.

Dothiora sphæroides, Fr.

Piggottia astroidea, Berk. \& Br.

Discella carbonacea, Berk. \& Br.

Torula ovalispora, Berk.

— pulvillus, Berk. \& Br.

- pulveracea, Corda

Sporidesmium pyriforme, Corda

Sterigmatocystis dubia, Sacc.

Phragmidium mucronatum, Link.

- bulbosum, Sch.

- gracile, Grev.

- Fragariastri, DC.

- Potentillæ, Schrot.

Triphragmium Ulmariæ, Link.

Puccinia Graminis, Pers.

- arundinacea, Hedw.

- striola, Link.

- coronata, Corda

- Polygonorum, Link.

- bupleuri, DC.

- Menthæ, Pers.

- Vincæ, Berk.

- sparsa, Cooke

- Compositarum, Sch.

- syngenesiarum, Link.

- Malvacearum, Corda

- discoidearum, Link.

- glomerata, Grev.

- albescens, Plowr.

- Tragopogi, Wint.

- umbelliferarum, DC.

- Apii, Corda

- Anemones, Pers.

- Violarum, Link.

- Lychnidearum, Link.

- Epilobii, DC.

- Prunorum, Link.

- Circææ, Pers.

- pulverulenta, Grev.

- Hydrocotyles, Cke.

- acuminata, Fckl.

- Centaurex, DC.

- Lapsanx, Fckl.

- obtegens, Tul.

- amphibii, Fckl.

- Trailii, Plow.

- Primula, Wint. 


\section{BOTANY}

Puccinia Caricis, Schum.

Tilletia caries, Tul.

- striæformis, Schroet.

Ustilago carbo, Tul.

— longissima, Tul.

- hypodytes, Fr.

- Salveii, B. \& Br.

- utriculosa, Tul.

- receptaculorum, Fr.

- antherarum, Fr.

Uromyces Fabæ, Pers.

- Betæ, Wint.

- apiculosa, Lev.

- Ficariæ, Wint.

- Geranii, Wint.

- Trifolii, DC.

- Valerianæ, Schum.

- avicularæ, DC.

- Rumicum, Lev.

- Scillarum, Grev.

- Pox, Raben.

Coleosporium Tussilaginis, Lev.

- Campanulæ, Lev.

- Senecionis, Lev.

- Rhinanthacearum, Lev.

Schinzia Alni, Woron.

Gymnosporangium Sabinæ, Wint.

- clavariæforme, Wint.

Melampsora Populina, Lev.

- Salicina, Lev.

- Euphorbiæ, Cast.

- Tremulæ, Tul.

Cystopus candidus, Lev.

- cubicus, Str.

Edocephalum fimetarium, Sacc.

Tubercularia granulata, Pers.

Fusidium griseum, Link.

Helminthosporium Tiliæ, Fr.

Macrosporium Sarcinula, Berk.

- Cheiranthi, Fr.

- Brassicæ, Berk.

- concinnum, Berk.

Cladosporium dendriticum, Wallr.

- epiphyllum, Nees

Peronospora infestans, Mont.

- gangliformis, Berk.

- Urticæ, Casp.

- Schliedeniana, De Bany.

Polyactis vulgaris, Link.

- fascicularis, Corda

Oidium concentricum, Berk. \& Br.

- Erysiphoides, Berk.
Pilobolus crystallinus, Pers.

Sphærotheca Castagnei, Lev.

Uncinula adunca, Lev.

- bicornis, Lev.

Phyllactinia guttata, Lev.

Podosphæria Kunzei, Lev.

- clandestina, Lev.

Microsphæria Grossulariæ, Lev.

- Mougeotii, Lev.

- penicillata, Lev.

- Martii, Link.

- Montagnei, Lev.

- Tortilis, Link.

- communis, Schl.

Erysiphe lamprocarpa, Lev.

- Martii, Link.

- Montagnei, Lev.

- tortilis, Link.

- communis, Schl.

Peziza salmonicolor, $\mathrm{Br}$.

- aurantia, Fr.

- coccinea, Jacq.

- domestica, Sow.

Lachnea crucipila, Cooke

Mollisia cinerea, Karst.

Helotiun virgultorum, Fr.

Orbilia xanthostigma, Pers.

Ascobolus furfuraceus, Pers.

- venosus, Berk.

- glaber, Fr.

Rhyparobius sexdecemsporus, Crouan

Ascophanus granuliformis, Bornet

Patellaria lignyota, Fr.

Claviceps purpurea, Tul.

Rhytisma acerinum, Pers.

Hysterium angustatum, A. \& S.

Epichloe typhina, Berk.

Polystigma rubrum, Pers.

Dothidea Ulmi, Fr.

- trifolii, Fr.

Diatrype quercina, Tul.

- verrucæformis, Fr.

Massaria Curreyi, Tul.

Sphæria apotheciorum, Mass.

Sordaria decipiens, Wint.

- coprophila, De Not

- curvula, Fr.

Sporormia intermedia, De Not

- minima, Anersw.

Delitschia insignis, Mouton

Gymnoascus Reesii, Baran. 



\section{ZOOLOGY}

\section{MARINE ZOOLOGY}

$\mathrm{D}$

URING the summer months for the last twenty years I have lived on board my yacht the Glimpse more or less in Essex waters, and have devoted much of my time to the study of the marine animals, either by dredging or collecting on shore. I have also done much from the deck of the yacht, which has enabled me to obtain various specimens floating in the tide.

Having thus had a somewhat unusual experience, I venture to do the best I can for my subject, although I feel that it is very incomplete, and that a great deal remains to be learned both as to specific identity and local distribution.

If in years gone by I had known that it would have been my lot to write an essay on the marine invertebrata of the coast of Essex I should have collected the necessary material and studied several groups of animals which I have almost entirely neglected. My aim has chiefly been to find out how to kill certain animals in a fully expanded condition, and permanently to preserve them with their natural colours, either as transparent lantern slides, mounted in Canada balsam, or kept in glass vessels in undiluted glycerine. Animals not suited for these purposes have been almost entirely neglected, and I have directed far more attention to experiments with species easily procured than to making a complete and accurately named collection of those living on the coast. Though I have a large amount of the above-named preparations, showing the general character of the animals extremely well, they are sometimes not suitable for specific identification, since they cannot be turned about or dissected, and the characteristic structure may be lost or hidden.

In connection with the distribution of the animals along the coast it must be borne in mind that living on the yacht has led to the special study of places where the anchorage was secure and where we could obtain what is necessary, and to the neglect of other localities open to objection from a yachtsman's point of view. Since my collecting has thus been done from the side of the water the rarity or abundance of particular species may probably appear different to what it would be to any one collecting from the shore. There are also great changes from 69 


\section{A HISTORY OF ESSEX}

year to year, so that what was common at one time may be rare at another, and particular species may have ceased to occur in one locality and have established themselves in another.

In addition to the animals I have collected myself I give the Hydroids, Polyzoa, etc., collected near Harwich by Mr. S. P. Hope, lent to me by Mr. William Cole, and identified by Mr. Walter Garstang; and those of various groups collected near Brightlingsea by $\mathrm{Mr}$. H. W. Unthank, as described in his paper, 'Natural History Work at Brightlingsea,' published in the Fournal of the Essex Tecbnical Laboratories, No. I9, April, 1896, pp. 206-10. These additions are more especially valuable because they give a number of species in groups of animals to which I have paid little attention. I also give a very complete and wellarranged list of the Mollusca drawn up by Mr. William Cole.

In concluding this introduction I must express my best thanks to a number of friends who have assisted me in identifying the various species. These belong to so many groups, and my time has been so much taken up with other matters, that I did not feel confident in my own determination. My thanks are especially due to Mr. Walter Garstang, who has examined and named many of the sponges, Cœlenterata, Nemertians, Chætopoda and Polyzoa. Professor Herdman has assisted me in naming the Ascidians and Nudibranchs. The Rev. T. R. R. Stebbing has examined some of my crustaceans; and my Sheffield friends, Professor Denny, Mr. Arnold T. Watson and Mr. E. Howarth, have assisted me over sundry animals. I hope therefore that on the whole the names are correct, but fear that some may not be, owing to the want of suitable specimens collected and preserved for this special purpose. The difficulties are also apparently increased by the probable existence of varieties differing from the recognized types, owing to local conditions and other causes. In several cases species which at one time were extremely common and in some respects have been well preserved could not lately be procured for exact specific identification. I may also here say that in the Essex district some of the animals are abnormally small, as if dwarfed by unfavourable conditions. In some cases also only single specimens have been found, and it is uncertain whether they are full-grown animals. On the whole there are ten or a dozen doubtful identifications.

\section{CHARACTERISTIC FEATURES OF THE COAST}

Before describing the various animals it seems to me desirable to give a short account of the chief characters of the coast, along the whole of which I have passed more or less frequently, since they must have such a great influence on the kind of animals found along it.

My knowledge of the Thames is chiefly confined to the vicinity of Erith and Greenhithe, at both which places I lived on the yacht for some weeks in 1882 . Though the free-swimming animals and plants are of much interest, the district cannot be looked upon as marine ; and I do not know exactly how far the influence of fresh water extends, 


\section{MARINE ZOOLOGY}

which must vary much with the season. Passing down the river to beyond Shoeburyness there is the large flat tract of the Maplin Sands, in some parts $3 \frac{I}{2}$ miles wide at low water. I have examined this imperfectly off Havengore and at the east end of Foulness. In the Swin, off the Maplin Sands, the water is deeper than anywhere else along the coast of Essex, but yet its maximum depth is only 13 fathoms, maintained by the strong tidal currents. Passing westwards along the northern side of Foulness we have the estuaries of the Crouch and Roche, as well as sundry channels and creeks, all having muddy shores, but no extensive flat tracts left dry at low water. In these estuaries and creeks oyster culture is of such importance that hundreds of men are employed, and some of the river beds are worth one hundred times as much as the adjoining meadow land. I am best acquainted with the Crouch, having remained in it off Burnham many times for weeks. When there in summer I have found the low water more salt than the high water, which is an unusual thing in an estuary; and the water at Battle Bridge, 12 miles from the mouth, more salt than the North Sea, no doubt owing to small rainfall and great evaporation. North of Foulness to the estuary of the Blackwater is a sandy tract left dry at low water for a width of a mile, which I have never examined for marine animals. In the estuary of the Blackwater, often called 'Pont,' I have examined the shores near Bradwell, and have dredged off an island called Osea. Between the Blackwater and the Colne are sundry creeks near West Mersea, and a tract of more or less sandy mud, left dry at low water for a width of $\frac{3}{4}$ mile, the east end of which I have examined to some extent. I have lived in the estuary of the Colne for weeks at a time almost every year for more than twenty years, and have examined the shores and creeks in every direction, and dredged and trawled in the open water off Mersea. On the east side of the Colne, both above and below Brightlingsea, there is good ground for collecting at low water from a boat or in long waterproof boots. Between the Colne and Walton-onNaze is a long extent of coast with narrow sands, which I have never examined. The open water off this, in the Wallet, is seldom more than 6 fathoms deep, which is no more than in some of the estuaries. On one occasion I dredged in this near the Gunfleet Bank, but in many places the ground is too full of large stones for dredging purposes. The creeks on the east side of Walton-on-Naze are very good collecting ground. In 1889 I remained some time in what is marked on the charts as 'Walton Channel,' but I know nothing of its present condition, since the sewage discharge from Walton was so objectionable that I have not gone there again. But for this it would be the best place on the coast for collecting, since there is no oyster culture and no disturbance by steamboats. East of the Naze is a tract of coast which I have never examined, except near Harwich. Both outside and inside the harbour is or was excellent collecting ground in fine calm weather, but when it is windy little or nothing can be done. Passing up the Stour are vast tracts of mud, covered with Zostera marina, which are left dry at low 


\section{A HISTORY OF ESSEX}

water in some places for a mile in width; but my more intimate knowledge of the upper part is confined to near Mistley, where I have often collected and dredged, though it is too far up to be satisfactory.

It will thus be seen that though I have fairly well studied some districts there are large tracts which I have never examined, on account of being too far from any convenient anchorage. It must also be borne in mind that my account of the marine invertebrata of Essex has been made much less complete than it would have been owing to difficulties connected with the oyster fisheries. One cannot dredge in some most suitable and convenient places, and in some cannot even use a small light trawl. In some no one is, or was, allowed to collect on the shore at low water, or to dredge even where there are no oysters. If special facilities had not been conceded to me this article could not have been written.

The total length of the coast, including the chief estuaries and creeks, is considerably over 200 miles, and it would take a long time to examine properly the whole. Some of the animals found are so rare and so local that possibly many more species occur than I have been able to collect, though there may not be so much variation along the exposed coasts as in the estuaries. These play a most important part, since the total length of their shores is fully three times that of the more open coast. In summer the water is not much less salt than in the sea, and in some special cases even more salt. The extremes of temperature are also great, since there is relatively such a large extent of very shallow water and of mud banks left dry when the tide is low. In summer in the Orwell I have known it as high as $74^{\circ}$, and in winter some of the estuaries are occasionally filled with masses of ice. The conditions are therefore very unsuitable for certain kinds of animals, and they probably explain why some common species are of smaller size than elsewhere. At the same time there is a tendency for the colder water to sink and pass out to sea, and for the warmer to remain in the estuaries and creeks, and therefore in the long run for these to have a higher temperature than the more open water. This is probably one great reason why some parts of the Essex district are so admirably fitted for oyster culture, since the proper development of spat depends so much on a sufficiently high temperature.

Along the coast of Essex there are thus no quiet deep water, and no rocks, and no clear rock-pools, but strong currents and great stretches of gravel, sand and mud; so that the animals found are necessarily of a restricted character. At the same time these circumstances seem favourable for certain kinds, and some are common which may be very rare in other districts.

The coast of Essex is thus peculiar, and estuarine conditions must have great influence as compared with the coast of Norfolk. The following table shows the number of species of such groups of animals as seem to have attracted a fair amount of attention in both counties. Those of Norfolk are taken from a proof of a portion of the Victoria History lent to me by Mr. Walter Garstang. This did not include the 


\section{MARINE ZOOLOGY}

Crustacea or the Mollusca. Those of Essex are from my own list, including those collected by Mr. Hope and Mr. Unthank :-

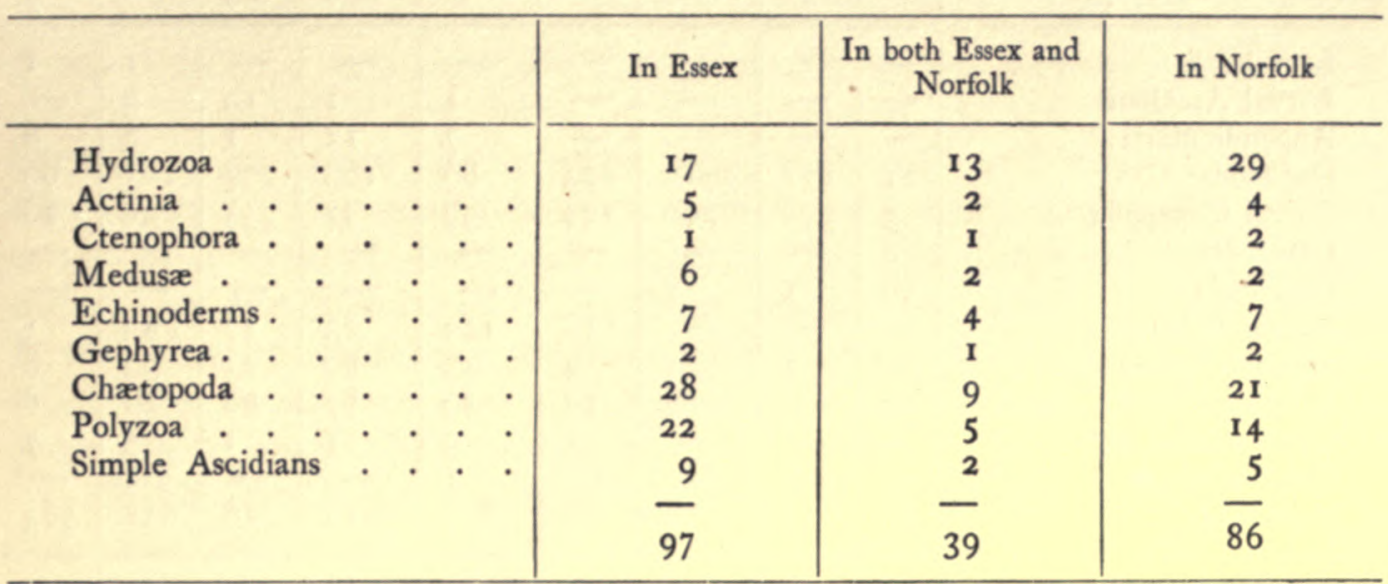

It will thus be seen that there is a remarkable difference, and that whilst fifty-eight species found in Essex are not found in Norfolk, and forty-seven in Norfolk not in Essex, there are only thirty-nine common to both. These results are no doubt in part due to imperfect collecting, but yet, I think, still more to the materially different characters of the coasts.

\section{MARINE AND FRESHWATER PLANKTON}

During the years 1882 to $I 889$, from the early part of May to the middle of September, I carried out continuous observations of the number of small free-swimming animals per gallon of water. The method adopted was to collect the water near the surface, half way down and near the bottom, in a bottle sunk empty, and filled by pulling out the cork. Usually $2 \frac{1}{2}$ gallons were collected, and passed through a fine sieve, not allowing any animal larger than $\frac{1}{100}$ of an inch in diameter to pass. The material so separated was then washed out by pouring a few ounces of sea water on the back of the sieve, care being taken that none of the animals should be killed by drying. I had a glass trough 3 inches deep, $I$ inch broad, and $\frac{I}{2}$ inch from front to back, into which the water containing the animals was poured, and the number of the various kinds counted, the process being repeated until the whole had been examined. The different sorts could in general be easily distinguished by their different form or manner of swimming. It would be out of place to go into detail, but it seems desirable to give some of the general results which, though never printed, were repeatedly described by me in public lectures at a time when this subject had attracted little or no attention.

In the following tables I give the number of the animals per Io gallons of water, but omit those which on an average do not amount to one in that quantity. These were determined from my first three years' observations, and might be somewhat modified by the later, which have not yet been adequately discussed. As might be expected larval forms play a very important part. 


\section{A HISTORY OF ESSEX}

TABLE I

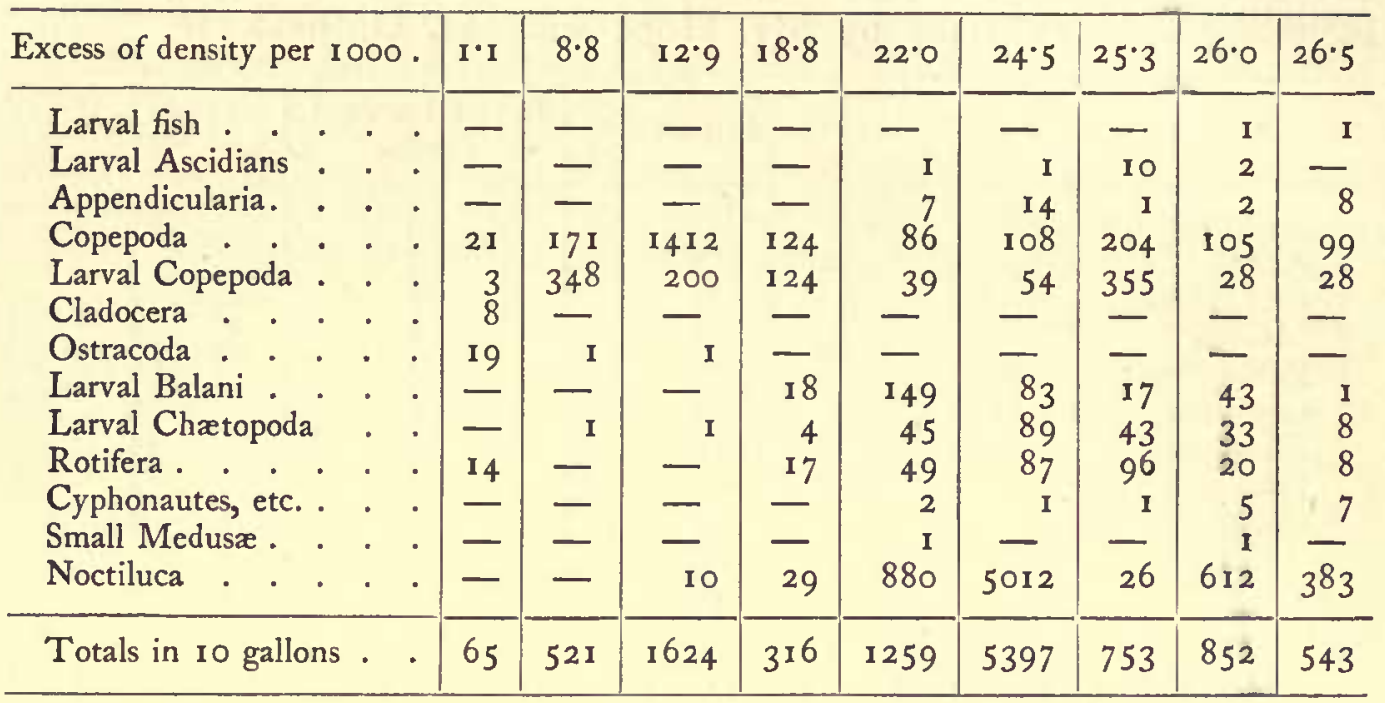

TABLE II

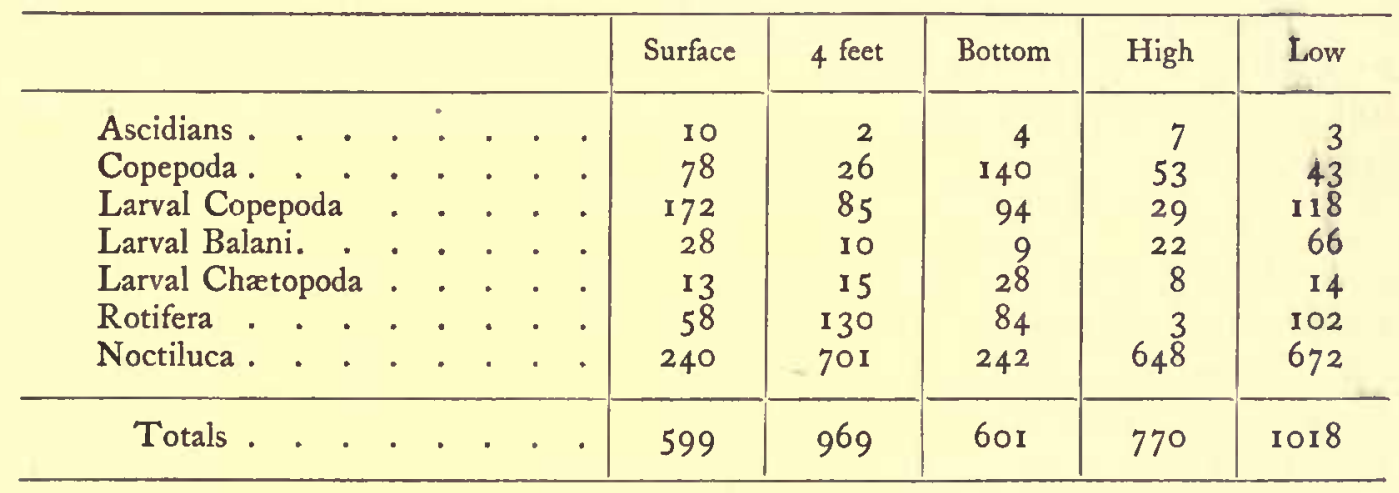

TABLE III

Totals in 10 gallons

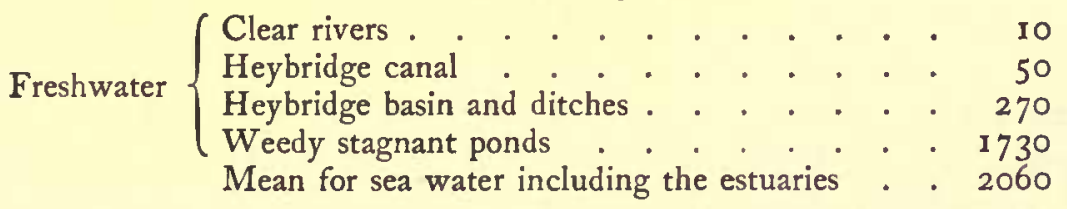

One great object I had in view was to trace the changes in passing from freshwater conditions down to the sea. The density of the water was therefore determined by observing the excess in weight of the measure of I,000 grains of fresh water, which is given in the upper line of Table I. In preparing this table I made no distinction between Essex, Suffolk or Kent; and the results are derived from observations made in the Crouch, Roche, Blackwater, Colne, Stour, Orwell, Alde, Bentley and Medway.

As will be seen from Table I. there is a most striking difference in the character and number of the different animals as we proceed from freshwater conditions to the open sea, but there are very few kinds more numerous in this than where the water is less salt. On the whole there are most in the somewhat sheltered estuaries, where the 


\section{MARINE ZOOLOGY}

excess of density is about 23 or 24 . This fact is of much interest in connection with the culture of oysters, which is such an important industry in Essex, since it is in such localities that they are laid down to fatten; and although they probably do not feed on some of the animals included in the table, it seems almost certain that there is a corresponding excess of the more minute animals and plants on which they do feed. The relatively great number of larval Balani and Ascidians is also to be noticed, and agrees with the fact that the bottoms of vessels become so much covered with them when lying long in such water. It will also be seen that there is a well marked secondary maximum where the excess of density is about $12 \frac{I}{2}$, due almost entirely to the great development of Copepoda.

Table II. shows the distribution of some of the minute animals from the top to the bottom, and also according to the state of the tide.

Table III. shows what a remarkable increase occurs in the number of free-swimming animals as we proceed from clear running rivers to more stagnant water, in which they have time to multiply. This fact was confirmed in a striking manner by my observations in the rivers and broads of Norfolk. As will be seen, the mean number in the sheltered estuaries and the more open water just outside them is comparable to that in the stagnant freshwater ponds, probably because it also is not so changed, by the introduction of plankton-free water, as to prevent the accumulation of the animals.

\section{THAMES}

In August and September of 1882 I lived at anchor for about six weeks at Greenhithe and Erith, carrying out researches for the Board of Works in connection with the main drainage of London. For this purpose it seemed important to study the Entomostraca and the freeswimming organisms, since the combination of various facts indicated that minute animals and plants played a very. important part in removing sewage from the river. Though the Thames in the district studied cannot be looked upon as sea water, yet it forms such a long stretch of coast in Essex that it seems desirable to describe some of the observed facts, it being of course understood that they relate only to a particular season of the year. The extraordinary strength of the tidal currents, and the great amount of mud held in suspension, make this river very unlike any other in Essex.

Table IV. shows the mean number of Entomostraca and larval shrimps in Io gallons of water, combining half flood with high water and half ebb with low water, and shows well the variation in the numbers of these animals which are more especially characteristic of fresh water and salt water, the extreme variations being at Erith combined half ebb and low, and at Greenhithe combined half flood and high. One effect of this great and constant change in the character of the water 


\section{A HISTORY OF ESSEX}

is that few kinds of animals can establish themselves permanently, which is very unlike what occurs in other tidal estuaries in the county.

TABLE IV

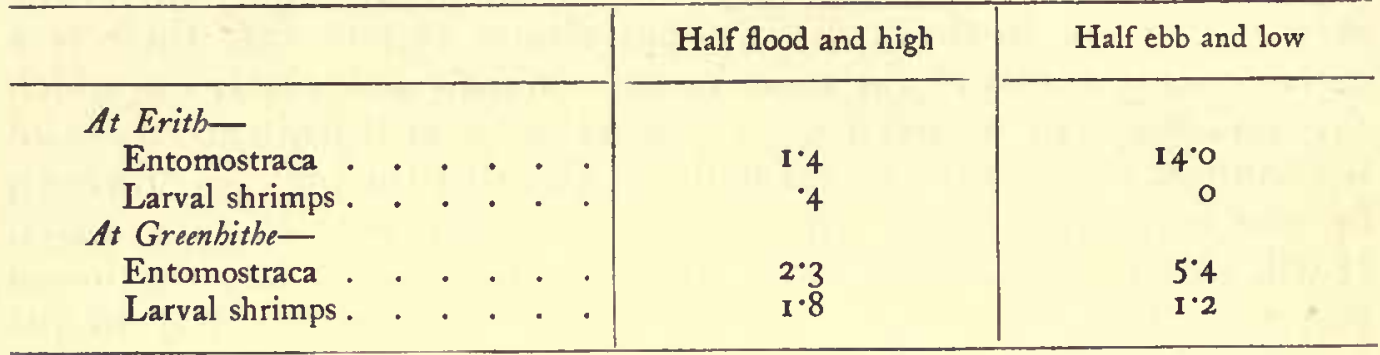

Mean of all per to gallons . $\quad 6.6$

\section{PROTOZOA}

\section{Noctiluca miliaris.}

This varies greatly in numbers at different places and in different seasons. Sometimes there are few, but on one occasion I found that the average number in the water of Harwich harbour, from the surface to the bottom, was about 4,000 per gallon.

\section{PORIFERA (Sponges)}

The best locality in the county seems to be the creeks east of Walton-on-Naze. The following species have been identified, but probably others occur, which have been obtained in the Orwell.

\section{CALCAREA}

I. Leucosolenia lacunosa, Johnston.

Dredged in the Wallet by Mr. H. W. Unthank.

2. Leucosolenia botryoides, Ellis \& Sol.

Pin Mill on the Orwell; also dredged in the Wallet by Mr. Unthank.

3. Sycon coronatum, Ellis \& Sol.

In the creek east of Walton-on-Naze and in the Colne. Mr. Unthank records it from the Wallet.

4. Sycon compressum, Auctt.

The only place in the county where I have found this species is in the creek east of Walton-on-Naze.

\section{SILICEA}

\section{Cbalina oculata, Pallas.}

Possibly all my preserved specimens have been collected just outside Essex, but it is almost certain that it occurs at Harwich and Walton.

\section{Halichondria panicea, Pallas.}

This occurs in the Colne, but not abundantly, and I think I have seen it near Harwich and at Walton.

3. Isodictya fucorum (Bowerbank).

Dredged in the Wallet by Mr. Unthank.

4. Isodictya palmata? (Bowerbank).

Dredged in the Wallet by Mr. Unthank.

5. Cliona celata (Grant).

This sponge does some injury to the oysters. My friend, the late Mr. Fred. Wiseman, told me he had found that by keeping the shells dry for a time the sponges could be killed, and the oysters restored to a healthy state.

I have found several other species not yet identified, and probably many more occur, since some seem to be very local, and not to be met with every year.

\section{COELENTERATA}

(Fellyfish, Sea Anemones, etc.)

\section{HYDROZOA}

\section{HydroId ZoOphytes}

I have never made any effort to collect the more minute species, and the list would have been much more incomplete than it is if $\mathrm{Mr}$. W $\mathrm{m}$. Cole had not lent me a collection made by $\mathrm{Mr}$. Hope near Harwich, the species of which are distinguished by his name. They have been identified by Mr. Walter Garstang.

I. Coryne vaginata, Hincks.

Taken by Mr. S. P. Hope in Essex waters near Harwich in June and July.

2. Syncoryne eximia.

Off Brightlingsea (H. W. Unthank). 


\section{MARINE ZOOLOGY}

3. Tubularia larynx, Ellis \& Sol.

My specimens have usually been obtained from the bottom of my yacht, and dead ones are so often seen in such situations that the species must be common all along the coast. Small groups are also occasionally dredged off Mersea.

It is interesting to note that the original description of this species (1755) was probably based on Essex specimens, since Ellis refers to the abundance of the 'windpipe coralline' 'near the mouth of the Thames, adhering to other marine bodies, and often to the bottoms of ships.'

4. Tubularia indivisa.

Mr. Unthank gives this as found off Brightlingsea. Unfortunately in 1901 I was unable to obtain any specimens in order to be sure that I had found this species as well as T. larynx.

\section{Eudendrium ramosum.}

Off Brightlingsea (H. W. Unthank).

6. Obelia gelatinosa (Pallas).

Several fine specimens in my collection from the Orwell, and there can be little doubt as to its occurrence in Essex waters.

7. Clytia johnstoni (Alder).

Off Brightlingsea (H. W. Unthank).

8. Halecium halecinum, Linn.

The specimens collected were probably dredged off Mersea.

9. Sertularella polyzonias (Linn.).

Found by Mr. Hope near Harwich.

10. Sertularia pumila, Linn.

Found by Mr. Hope near Harwich at all seasons. The specimens show considerable variation in the thickness of the stems and attenuation of the internodes, some having all the characters of Hassall's species gracilis, which Mr. Hope thinks should probably be regarded as a variety of pumila.

11. Sertularia operculata, Linn.

Found by Mr. Hope near Harwich.

12. Sertularia abietina, Linn.

Found by Mr. Hope near Harwich.

13. Sertularia argentea, Ellis \& Sol.

Near Harwich (S. P. Hope).

14. Hydrallmania falcata (Linn.).

Near Harwich (S. P. Hope), and often dredged off Mersea and in other localitics of Essex.
15. Antennularia antennina (Linn.).

Near Harwich (S. P. Hope), and dredged in various other localities.

\section{Plumularia setacea (Ellis).}

Specimens bearing gonophores from the Orwell, and probably occurs also in the neighbouring estuaries of Essex.

\section{Plumularia echinulata, Lamarck.}

This appears to be a common species in Essex waters. Specimens taken near Harwich by $\mathrm{Mr}$. Hope in June and October bear gonophores, and are attached to pieces of filamentous weeds and Zostera.

\section{Meduse}

The smaller medus $x$ (Hydromedus $x$ ) are produced by lateral budding from various Hydroid stocks, e.g. Syncoryne, Obelia.

The larger medusx (Discomedusx) do not always exhibit a similar alternation of stages in their life history, but Aurelia and Cbrysaora are known to be produced by a remarkable process of successive fission from minute Hydra-like polyps which form extensive colonies on old oyster shells and similar objects.

\section{A. Hydromedusce}

1. Phialidium, sp. var.

Caught in a tow-net in the Wallet, but not well preserved. Probably many other species could be obtained if carefully looked for.

\section{B. Discomeduse}

2. Chrysaora isosceles (Linn.).

I have collected this in the Crouch at Burnham and in the Stour at Mistley, but more off Harwich than elsewhere, though I have never seen many. The colour seems to vary a good deal in different years, the upper surface being sometimes beautifully striped with brown, and sometimes scarcely marked at all. In 1899 I saw off Felixstowe one estimated to have a disk a foot in diameter and the appendages five or six feet long, but such are extremely rare.

\section{Cyanea capillata (Linn.).}

This species occurs in nearly all localities, but is seldom or never very abundant. It grows to be more than a foot in diameter, and the tentacles are some few yards in length when fully extended. The usual colour is a creamy white, varying to a sort of orange colour. In I 90 I I caught a specimen which seemed to differ from the above in having much shorter tentacles, but it was accidently destroyed before having been 


\section{A HISTORY OF ESSEX}

sufficiently examined to decide whether it was a different species or only a variety.

\section{Cyanea lamarckii.}

In July, I 888 , this was very abundant in the Alde at Shingle Street, and I think I have seen it, or an unusually blue $C$. capillata, in the Stour or Colne, but so many years ago that I am not certain, and the specimens were not caught and examined carefully. In any case it seems to occur only now and then.

\section{Cyanea imporcata, A. M. Norman.}

On July 26, I 884 , I caught in the Colne off Mersea a medusa of a beautiful purpleblue colour. At that time I was studying the spectra of the colouring matters of marine animals, and after making a careful drawing I destroyed the specimen in studying the pigment, not knowing that it was such a rare species. In the seventeen subsequent years I have looked in vain for another specimen. On sending my drawing to Mr. Garstang, he recognised it as a Cyaneid medusa, on account of the sixteen radial gastric pouches indicated in my figure, the deep and much folded oral membranes, the absence of marginal tentacles and the presence of eight crescentic groups of tentacles attached to the under side of the disk at some distance from the edge. The tentacles are seen to be of various lengths, but many exceed twice the length of the oral appendages. The medusa, on the other hand, differs from the common Cyanece of our coasts in the cup-shaped disk, the diameter of which is less than twice the height. In this respect the medusa closely resembles the $C_{y}$ anea imporcata of Norman (Nat. Hist. Trans. Nortbumberland and Durbam, I 865, i. 5860 , pl. xi.), of which only a single specimen has hitherto been recorded, and that also in the North Sea, between the Dogger Bank and Newcastle. Mr. Garstang believes the two to belong to the same species, although my specimen was probably devoid of the superficial markings on the disk which Norman figured, and which he tentatively but erroneously described as radiating and secondary canals. Possibly the species inhabits the deeper waters to the north of our islands, from which region stray specimens have drifted from time to time down our east coast. Further information is much to be desired to clear up several doubts connected with this species, which is evidently very rare in the English seas.

\section{Aurelia aurita (Linn.)}

Though there seems to be a great variation in number in different years, yet on the whole this is by far the most common medusa on the coast. Occasionally it is extremely abundant. By far the larger number are under 6 inches in diameter, but those of at least double that size are sometimes numerous in the latter part of the season. I have collected and preserved a considerable number of abnormal varieties, differing much in the number of the different organs.

\section{Rbizostoma octopus, Linn.}

I have occasionally seen very fine specimens in the $W$ allet and in the Swin. I have collected many small ones in the Crouch at Burnham and one in the Colne, but none in any other of the Essex estuaries.

\section{CTENOPHORA}

Jellyfish devoid of a muscular umbrella and provided with eight vertical (meridional) rows of iridescent paddles.

\section{Pleurobrachia pileus, Modeer.}

Formerly common at most places, but during the last few years has become less and less abundant, and in I900-I comparatively scarce. The best way to preserve it is to take it out of the water by means of a sieve, and put it at once into diluted formalin. Trawled or dredged specimens are almost worthless. I have a mounted specimen which had been swallowed by another only a little larger.

\section{ANTHOZOA}

(Sea Anemones and Corals)

Nomenclature: Gosse, British Sea Anemones and Corals (I 860).

I. Alcyonium digitatum, Linn.

The only locality in which I have found this is in the open water off Harwich, never having dredged it in the estuaries. Mr. Unthank has met with it in the Wallet.

\section{Actinoloba diantbus, Ellis.}

The white, the flesh-coloured and the brown varieties all occur abundantly in the Crouch at Burnham, attached to large stones on the south shore, and can be easily obtained when the tide is very low. Some years ago I found some on the oyster beacons in Pyefleet, but I have not seen any for several seasons. The white and the fleshcoloured varieties are abundant on the timber of the pier at Harwich, but are exposed only when the tide is very low. By using menthol it may be killed and preserved in a fully expanded condition. 


\section{MARINE ZOOLOGY}

3. Sagartia viduata (O. F. Maller).

This is common in the Crouch at Burnham on the south shore, but seen only when the tide is low. It can be killed in an expanded state by using menthol.

\section{Sagartia troglodytes.}

What are probably young or somewhat small individuals of this species are common in the Orwell, a short distance outside Essex.

\section{Tealia crassicornis (O. F. Muller).}

I have occasionally caught this in the Crouch when trawling, and it is often dredged in the more open sea. I have collected a fair number of specimens at low water on both the east and west shores of the Colne near Brightlingsea. In 1901 it was very abundant on the shore off Harwich, near the level of extreme low water.

\section{Halcampa chrysanthellum (Gosse).}

Found in sandy gravel near the mouth of the Colne, but the colour of the disk differs somewhat from the Cornish specimens described by Gosse.

Though Actinia mesembryanthemum is so common on the coast of Kent, I have never seen one in Essex.

\section{NEMERTINEA}

\section{Lineus obscurus, Desor.}

The only place where I have found this is in the mud at Mistley.

\section{Amphiporus lactiforeus, Johnston.}

I have found only one specimen, which was obtained in the Orwell a short distance outside Essex.

\section{NEMATODA (?)}

\section{Nectonema (?)}

I have never seen more than one specimen, which was caught wriggling about at the surface in the Stour off Harwich. It is $1 \times \frac{1}{2}$ inches long and tr inch thick and full of eggs, and is almost certainly a fish parasite which had escaped from its host when mature.

\section{ANNELIDA}

\section{POLYCHÆTA}

\section{Apbrodita aculeata (Linn.).}

This used to be fairly common in the Stour off Harwich, but lately I have not obtained it there. It is much more common in the Wallet near the Gunfleet bank.

\section{Lepidonotus squamatus, Linn.}

This occurs commonly in most parts of the district. It is often found in the tubes of Amphitrite jobnstoni.

\section{Nereis diversicolor, Mall.}

Very abundant in the mud banks of St. Osyth's creek and found in most other Essex estuaries, though comparatively rare in the Crouch. In some places it is much coloured by a fugitive green pigment, and in others coloured red by the great amount of hæmoglobin which is comparatively absent in others. In some places almost at high water mark and up the estuaries far from the sea it is abundant to the exclusion of other similar animals.

\section{Nereis cultrifera (Grube).}

Common in particular places in sandy mud near low water mark at the mouth of the Colne and off Harwich.

\section{Nereis pelagica, Linn.}

All the specimens I have procured were dredged outside Harwich harbour, where it occurred amongst the sandy tubes built by Sabellaria spinulosa.

\section{Nereis dumerilii, Aud. \& M. Edw.}

Readily distinguished from the three other species by having very long tentacular cirri. I have always found it in tubes built amongst algre. When kept in a small aquarium it built a semi-transparent tube open at both ends and came out and ate Ulva and returned to its tube. It laid very many eggs without passing into the Heteronereis condition. What I believe was the same species passed into that condition in my larger aquarium, but they may have been males. Though I have lived in the Orwell and Stour for a total period of between one and two years I seldom if ever saw Heteronereis except in the early morning of July 16,1898 , when males of about 2 inches long were swimming on the surface in Harwich harbour in such numbers that I estimated them at something like a million. When dried and mounted in Canada balsam this species differs from all the others in turning deep brown, but this does not happen in the case of the male Heteronereis.

\section{Nephthys hombergii (Cuvier).}

Cominon in the more or less sandy mud exposed at low water in the Colne and near Harwich but much rarer near Burnham. It varies considerably in colour owing to the greater or less amount of hxmoglobin and of a brown pigment. 


\section{A HISTORY OF ESSEX}

8. Nephtbys caca (Fabr.).

Much larger than the above and not so common, but occurs in sandy mud at the mouth of the Colne and off Harwich.

\section{Pbyllodoce maculata (?) (Johnston).}

Only one specimen has been found, which occurred in the sandy mud at low water off Harwich.

I0. Glycera capitata (?) (Oerst.).

Apparently rare in the Essex district since I have found only two specimens which occurred in the mud of the Crouch at Burnham and corresponded with the figures given at plate xvb of the Brit. Mus. Catalogue (1865).

\section{I. Syllis armillaris (Mull.).}

Possibly not uncommon but easily overlooked from being so small. It is interesting from the manner in which it divides into two or more individuals.

\section{Goniada maculata (?) (Grube).}

Only one specimen was found in the sandy mud near the mouth of the Colne. It seems to agree with the description in the Brit. Mus. Catalogue (1865).

\section{Nerine foliosa (Aud. \& M. Edw.).}

Occurs in the sandy mud near the mouth of the Colne near low water, but it is almost impossible to obtain perfect specimens.

14. Nerine cirratulus (Delle Chiaje).

Common in sandy gravel near Mersea stones much above low water mark.

\section{Scoloplos armiger (O. F. Muller).}

Occurs in considerable numbers in gravelly sand at the mouth of the Colne.

\section{Cirratulus cirratus (Malmgren).}

Found in sandy mud near low water mark at the mouth of the Colne, but not common, and the specimens small.

\section{Flabelligera affinis (Sars).}

Though all my specimens have been obtained in the Orwell, yet when floating as it often does in the tide it must have sometimes passed into Essex.

\section{Notomastus latericeus (Sars).}

Occurs in sandy mud near the mouth of the Colne and off Harwich.

\section{Arenicola marina, Linn.}

This is very abundant in sandy gravel near the mouth of the Colne and off Harwich, and dug extensively for bait.
20. Lanice conchilega, Pall.

I have found this over nearly the whole district. It occurs in large numbers on the east side of the Colne below Brightlingsea near low water mark.

\section{Amphitrite johnstoni (Holmgren).}

Common in particular places in sandy mud near the mouth of the Colne.

\section{Nicolea zostericola, Örst.}

This used to be very common in the Orwell just outside Essex, but was not found in 1901 .

\section{Polycirrus aurantiacus, Grube.}

This is common at the mouth of the Colne in sandy gravel at about half-tide level, but only in restricted areas, where it occurs along with Phascolosoma. It seems surprising that such a long tender animal can move about in such coarse rough material.

\section{Melinna cristata, Sars.}

Occurs in the sandy mud near the mouth of the Colne, but all the specimens found were of small size.

25. Pectinaria belgica, Pallas.

I have never found this alive, but empty tubes are common off Mersea.

\section{Terebellides strcemii.}

This interesting species, of which only one specimen had been found in British waters, over a hundred years ago, in Scotland, used to be fairly common in the Orwell near Pin Mill, a few miles outside Essex, but was rare in I 901 .

\section{Sabellaria spinulosa, Leuck.}

I have dredged this off Harwich and off the Colne, and it must be common in many other places in the more open water but not in the estuaries. It builds the sandy tubes locally called ross.

\section{Sabella pavonina, Sav.}

This is more or less common over the whole district and occurs in enormous numbers along the east side of the Colne above Brightlingsea Creek at the level of low water. Some years ago I found in that district a considerable number of what was either a dwarfed variety or a somewhat different species not met with lately.

\section{GEPHYREA}

\section{Phascolosoma, sp.}

I have never found this except in one small tract of sandy gravel at about half-tide level 


\section{MARINE ZOOLOGY}

on the east shore of the Colne just below the mouth of Blakestone Hole. This tract is kept constantly wet and soft by water oozing out, and the animals are so abundant that several are often found in each spadeful of material. A number of these have been examined by Mr. A. E. Shipley, and though he cannot identify them with any named species he does not like to give them a new specific name.

\section{Priapulus caudatus.}

This occurs in small numbers at most stations along the coast in mud banks left dry at low water. I have specimens with tails one and a half times as long as the body. Occasionally there are two tails.

\section{ARTHROPODA}

\section{COPEPODA}

A considerable amount of material was collected but had deteriorated too much by long keeping before being properly examined. When the material was fresh I identified the following species with more or less certainty, but probably many others occur in the district :-

I. Dactylopus tisboides.

2. Dias longiremis.

3. Harpacticus chelifer.

4. Laophonte curticauda.

5. - longicaudata.

6. - similis.

7. Pseudocalanus elongatus.

8. Temora longicornis.

\section{PANTOPODA (Sea Spiders)}

I. Pycnogonum littorale (Ström.).

An occasional specimen collected at most stations, but it was very abundant in the Crouch at Burnham, living amongst the tentacles and on the bodies of the Actiniæ, and I think even inside them without apparent injury.

\section{Nymphon rubrum (Hoda.).}

A few specimens found in most places, but not so fine or abundant as in the Deben in Suffolk.

\section{MOLLUSCA}

On the whole I have paid but little attention to the shells, one reason being that they are not of much interest in connection with my special studies, and another being that it seems to me to be a poor district except for a limited number of species, the individuals of which are extremely abundant. I have often been surprised to find so very few species in dredging, and at the great number of dead shells in many places where the living animals are rare or altogether absent. In some cases this may be due to the extra amount of fresh water at flood time now that the land is better drained, and in others to sewage discharge or to the operations connected with oyster culture. The following list is given mainly to show what are the commonest species, not including those of small size. It might have been made much longer by including dead shells of species which must have lived in the district not many years ago. I mention only those found near the coast alive or very recently dead. The names adopted are those recommended by the Conchological Society.

\section{AMPHINEURA}

\section{Craspedocbilus onyx (Spengl.).}

2. Acanthochites fascicularis (Linn.).

In the Colne district and probably elsewhere.

\section{LAMELLIBRANCHIA}

1. Nucula nucleus (Linn.).

Dredged off Essex.

2. Mytilus edulis, Linn.

Common along the coast and largely dredged for manure.

3. Ostrea edulis, Linn.

Naturally common, and its culture is the chief industry in some localities. Enormous numbers of dead shells occur where the living animals are seldom, if ever, found, which may have been exposed at the bottom for a very long period; since, unlike some shells, they decompose very slowly. I often think that many of these dead shells are of more elongated shape than the modern living varieties. These also vary, and those who have paid much attention to the subject can recognize them as coming from particular localities, and how they have been moved from one to another. The large oysters dredged in the North Sea differ greatly from those of the Essex estuaries. The contrast between the comparatively young and wellfed Colchester and Burnham natives, and some of the very old oysters I have occasionally dredged from places little, if ever, disturbed is very remarkable. Instead of having large fat animals and thin shells, the animals may be relatively small, and the shell a solid, heavy mass, something like $I_{\frac{1}{2}}$ inch in thickness. 


\section{A HISTORY OF ESSEX}

The question of the food of the oysters in different localities is one of great importance, and may vary so much as to account for the difference in flavour, and why they become green in some localities and not in others, and lose that colour when moved elsewhere. This question of the food can be properly studied only on the spot, by examining the contents of the stomachs immediately after the animals have been taken out of the water in which they have lived, before the food has been digested.

Large numbers of the French oysters and of the specifically distinct Portuguese and American have been laid down in particular localities. Mr. T. Newman, the manager of the Colne fishery, informs me that the Portuguese have reproduced, though not in such a manner as to be of commercial value; but the general temperature of the water is too low for the successful reproduction of the American or for that of the somewhat delicate French variety of our native species, which unfortunately for the same reason often fails to arrive at maturity, to the great loss of those interested in the fishery.

\section{Scrobicularia plana (Da Costa).}

Occurs in great numbers in Pye Fleet and in some other estuaries. It is interesting to keep it alive in an aquarium at the bottom of which is a depth of 2 or 3 inches of mud, and to see how it projects its longer syphon to an extent of 5 inches and scoops up the mud, which it swallows and afterwards ejects. It may be killed with the syphons elongated by keeping it in a vessel from which all air is carefully excluded.

\section{Macoma baltbica (Linn.).}

Common in the mud of the estuaries. I have kept it alive in an aquarium with a mud bottom and bred hundreds of small ones, so that the surface of the mud seemed alive with the protruded syphons. Some grew to be $\frac{8}{5}$ inch in diameter in three or four months.

\section{Tellina tenuis ( $\mathrm{Da}$ Costa) and}

\section{Tellina fabula, Gronovius.}

These also occur, but are not so common as Macoma baltbica.

\section{Mactra stultorum, Linn.}

Not common but has been seen.

\section{Tapes aureus (Gmelin).}

This may be obtained alive from the mud off Mersea when left dry at low water, being fairly abundant.
I0. Cardium edule, Linn.

Common in many localities. Some years ago it was very abundant in the sandy mud off Foulness, but living individuals were comparatively rare in 1894 , after the previous very severe winters.

\section{1. Mya arenaria, Linn.}

This is very common in most of the estuaries, and judging from the great number of dead shells in the living position it seems to have been still more common in some localities than it now is.

\section{Mya truncata, Linn.}

Probably lives off Mersea since the shells of recently dead individuals are not uncommon.

13. Barnea candida (Linn.).

Abundant in Blakestone Hole near Brightlingsea and in the mud above Harwich.

\section{GASTROPODA PROSOBRANCHIA}

\section{Gibbula cineraria (Linn.).}

Common in various places.

\section{Littorina littorea (Linn.).}

This is so extremely abundant on the mud flats left dry at low water that it must outnumber all other associated mollusca combined. Many men and boys are employed in collecting it for food.

\section{Littorina abtusata (Linn.).}

Found in sundry places, but not abundantly.

\section{Rissoa and Zippora.}

These small shells are common in the estuaries, and dead ones sometimes collect in vast numbers on the shores. My specimens seem to be chiefly-

4. Rissoa inconspicua, Alder.

5. Zippora membranacea, J. Adams.

Probably others could be found by careful searching.

\section{Buccinum undatum, Linn.}

This is more or less common all along the coast and dredged at almost every station.

\section{Purpura lapillus (Linn.).}

This is commonly known as the 'dog whelk, and is collected and destroyed on account of the damage it does in the oyster grounds, by killing the animals. 


\section{MARINE ZOOLOGY}

\section{Nassa reticulata (Linn.).}

I have found this in the Colne and I think elsewhere, but it is not abundant.

\section{GASTROPODA OPISTHO- BRANCHIA}

1. Acera bullata, Müller.

This must be common in the upper part of the Stour, and I think I have collected it in the Colne.

2. Pbiline aperta (Linn.).

Common off Mersea and met with in most other places.

\section{Nudibranchiata}

1. Galvina cingulata, var. vittata (?)

Specimens dredged off the Gunfleet bank in 1895 , but not preserved or identified, were as far as I can remember more like $E$. vittata than any other figured by Alder and Hancock.

2. Facelina coronata, Forbes and Goodsir.

Some years ago this was not uncommon at a depth of a few fathoms off Mersea but always of small size, and lately has been rare. In 1889 good specimens were common in the creek east of Walton-on-Naze. Specimens carefully dried on glass, and well soaked with gum arabic to protect them from the solvent action of the Canada balsam in which they were afterwards mounted, have kept their colour well for ten years, and are in every way satisfactory.

3. Fiona marina (Forskál).

Many years ago I dredged in Harwich harbour a Nudibranch which I did not again find until 190I, when I obtained two in the Orwell, a short distance outside Essex. They seem to differ from the figures in Alder and Hancock's Ray Society's monograph only in being smaller, which is not surprising, since the two which they had found were obtained off Falmouth.

4. Acanthodoris pilosa (Muller).

This is common amongst the Fuci on the banks of the Crouch at Burnham, and is also dredged off Mersea. By proper management both the form and colour may be well preserved in undiluted glycerine.

\section{Goniodoris castanea, Ald. \& Han.}

I obtained in the Orwell a specimen of this which corresponds with the figure of the only specimen which Alder and Hancock had found, and is quite unlike any other.

\section{Cephalopoda}

I. Sepia officinalis, Linn.

In 1899 I caught a number of small specimens off Mersea, but had never seen one before. They are rather too young for accurate determination, but probably belong to this species.

2. Sepiola atlantica, D'Orb.

Eleven years ago this was very abundant in the creek east of Walton-on-Naze, and not uncommon at all other stations, but latterly has become more and more rare.

3. Loligo media (Linn.).

Some years ago this was fairly common in the Stour near Harwich, but latterly it has become more and more rare. This has been kindly identified for me by Mr. W. E. Hoyle.

At my request $\mathrm{Mr}$. Wm. Cole has very kindly supplied me with the following list of the marine testaceous mollusca of the Essex coast, which have come under his notice in connection with the Essex Field Club and the museum at West Ham. It will show the species which occur outside the district which I have more especially studied. 


\section{A HISTORY OF ESSEX}

\section{LIST OF THE MARINE MOLLUSCA}

\begin{tabular}{|c|c|c|c|c|c|c|}
\hline No. & Name & $\begin{array}{l}\text { Estuaries } \\
\text { of Orwell } \\
\text { and Stour }\end{array}$ & $\begin{array}{l}\text { River } \\
\text { Colne }\end{array}$ & $\begin{array}{l}\text { River } \\
\text { Black- } \\
\text { water }\end{array}$ & $\begin{array}{l}\text { River } \\
\text { Crouch }\end{array}$ & Other localities \\
\hline & AMPHINEURA & & & & & \\
\hline 12 & $\begin{array}{c}\text { Crasped ochilus onyx (Spengl.) } \\
\text { (= Chiton cinereus) }\end{array}$ & 2,4 & 10 & 1 & - & \\
\hline 15 & $\begin{array}{l}\text { Acanthochites }(=\text { Chiton) fasci- } \\
\text { cularis (L.). }\end{array}$ & - & - & I & - & \\
\hline & Pelecypoda & & & & & \\
\hline 18 & Nucula nucleus (L.) & 2,4 & - & I & 3 & \\
\hline 19 & -- nitida, G. B. Sowerby. & 4 & - & I & - & \\
\hline 46 & Anomia ephippium, L. . . & - & 6 & 1 & 5 & \\
\hline 60 & Mytilus edulis, L. . . & 2,4 & 10 & I & 5 & Clacton (8) \\
\hline ז6 & Volsella (= Modiolus) modiolus, L. & - & - & - & 5 & \\
\hline 62 & - barbatus (L.) : . . . & - & - & I & - & \\
\hline 66 & Modiolaria marmorata (Forbes) & 4 & - & I & 5 & \\
\hline 69 & - discrepans (Leach) (= nigra) & - & - & - & 5 & \\
\hline 77 & Ostrea edulis, $\dot{L}$. & 2,4 & 10 & I & IO & \\
\hline 79 & kimus (L.) & - & - & - & 5 & \\
\hline $8 I$ & Chlamys (= Pecten) varius (L.) & 2,4 & IO & 1 & - & \\
\hline II 3 & Lucina borealis (L.). & 4 & - & - & 一 & \\
\hline 142 & Syndosmya (= Scrobicularia) alba & & & & & \\
\hline 145 & Scrobicularia plana (Da Costa) & 4 & - & - & 5 & \\
\hline & (=piperita). . . . & 4 & 7,10 & I & 一 & Foulness (8) \\
\hline 154 & Tellina tenuis ( $\mathrm{Da}$ Costa) & - & - & I & - & \\
\hline 156 & Macoma (Tellina) balthica (L.) & 4 & - & I & 5 & Foulness (8) \\
\hline 160 & Mactra stultorum, L. & - & - & - & - & Foulness (8) \\
\hline 162 & Spisula (= Mactra) solida (L.) & 4 & 一 & 1 & - & \\
\hline 164 & - subtruncata (Da Costa) & - & - & I & - & \\
\hline 178 & Tapes aureus (Gmelin). & - & 8,9 & I & 5 & \\
\hline I 79 & - virgineus (L.) & - & - & 1 & - & \\
\hline 180 & — pullastra (Montagu) $\cdot$ & 2,4 & 8,9 & I & 5 & (Mc \\
\hline I 8 I & 一 decussatus (L.) . . . & 4 & 7 & - & - & $\left\{\begin{array}{c}\text { Burnham Mar } \\
(8)\end{array}\right.$ \\
\hline I 86 & Cardium & - & 10 & 1 & 5 & \\
\hline 189 & - exiguum, Gmelin . & 4 & 9 & I & 5 & Walton N. (8) \\
\hline 192 & - edule, L.. . . & 2,4 & 10 & I & 10 & Foulness (8) \\
\hline I 99 & Mya arenaria, $\mathrm{L}$. & 2,4 & I0 & I & 5 & Foulness (8) \\
\hline 200 & - truncata, L. . & 4 & 8, Iо & I & 5,10 & \\
\hline 207 & Ensis (= Solen) ensis (L.). . & - & $8,9,10$ & - & - & \\
\hline 209 & Solen vagina, L. . . . . & - & - & - & 3 & \\
\hline 212 & Saxicava rugosa (L.). . . . & 2 & - & - & - & Foulness $(8,9)$ \\
\hline
\end{tabular}

Norz.-The numbers in the first column correspond with those in the 'List of British Marine Mollusca and Brachiopoda' given in the Fournal of Concbology (1901), x. 9. The numbers in columns three to seven refer to the following :

I. W. Crouch, Essex Naturalist, ii. 248.

2. W. Crouch " " iv. 169 .

3. E. A. Fitch " " " v. 145-52.

4. W. Crouch " " $"$ v. 244 .

5. W. Crouch " " $"$ vi. $81-92$

6. Dr. Sorby " " $\quad$ v. 259 .

7. Dr. Sorby, Essex Naturalist, x. 166.

8. W. Dalton, MS. Catalogue.

9. Dalton Collection, Essex Museum Nat. Hist.

Io. Cole

11. Colchester

I2. W. Crouch. 
MARINE ZOOLOGY

\begin{tabular}{|c|c|c|c|c|c|c|}
\hline No. & Name & $\begin{array}{l}\text { Estuaries } \\
\text { of Orwell } \\
\text { and Stour }\end{array}$ & $\begin{array}{l}\text { River } \\
\text { Colne }\end{array}$ & $\begin{array}{l}\text { River } \\
\text { Black- } \\
\text { water }\end{array}$ & $\begin{array}{c}\text { River } \\
\text { Crouch }\end{array}$ & Other localities \\
\hline 215 & Pholas dactylus, L. . . . • & 4 & 7,10 & - & 3 & Foulness $(8,9)$ \\
\hline 216 & Barnea (= Pholas) candida (L.) . & 4 & 10 & $\mathbf{I}$ & 3 & \\
\hline 221 & Teredo norvegica, Spengler . . & - & 9 & - & - & \\
\hline 222 & - navalis, L. . . . . . & - & - & - & 5 & \\
\hline 227 & - fimbriata, Jeff. . . . . . & - & - & - & - & Clacton (8) \\
\hline 239 & $\begin{array}{c}\text { Thracia fragilis, } \text { Penn. (= papyracea) } \\
\text { SCAPHOPODA }\end{array}$ & - & - & $\mathbf{I}$ & 3 & \\
\hline 265 & $\begin{array}{c}\text { Dentalium entalis, L. . } \cdot \cdot \cdot \cdot \\
\text { GASTROPODA }\end{array}$ & - & - & - & 3 & \\
\hline 274 & Patella vulgata, L. . · · & - & - & $\mathbf{I}$ & - & \\
\hline $\begin{array}{l}295 \\
296\end{array}$ & $\begin{array}{l}\text { Gibbula (= Trochus) majus (L.). } \\
- \text { tumida (Montagu). }\end{array}$ & 二 & $\overline{8,9}$ & $\stackrel{I}{-}$ & - & \\
\hline 297 & - cineraria (L.) & 2,4 & - & I & 3 & $\left\{\begin{array}{l}\text { T. cinereus, } \\
\text { Foulness }(8)\end{array}\right.$ \\
\hline $\begin{array}{l}298 \\
305\end{array}$ & $\begin{array}{l}-(=\text { Trochus }) \text { umbilicata (Mont. }) \\
\text { Calliostoma (= Trochus) zizyphi- }\end{array}$ & - & - & I & - & \\
\hline & nus (L.). & - & 10 & - & - & Walton $(8,1 \mathrm{I})$ \\
\hline 324 & Lacuna crassior (Montagu) . & 4 & 6 & 6 & 5 & \\
\hline $\begin{array}{l}326 \\
227\end{array}$ & - parva (Da Costa) (= puteolus) & 二 & 8 & 二 & 二 & \\
\hline $\begin{array}{l}327 \\
328\end{array}$ & $\begin{array}{llll}\text { pallidula }(\mathrm{Da} \text { Costa }) & \cdot & \cdot & \cdot \\
\text { Littorina obtusata (L.) } & . & \cdot & .\end{array}$ & - & $\underline{6}$ & $\overline{1}$ & - & \\
\hline $33^{\circ}$ & 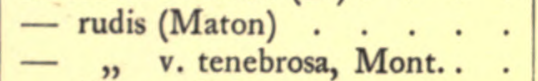 & 2,4 & 10 & $\underline{I}$ & - & Foulness (8) \\
\hline 331 & $\begin{array}{l}\text { - littorea (L.) . . . . . . . . } \\
\text { - littoralis }\end{array}$ & 2,4 & 10 & $\underline{I}$ & 二 & Foulness (8) \\
\hline 346 & $\begin{array}{l}\text { Zippora ( }=\text { Rissoa) membranacea, } \\
\text { v. labiosa, Mont. (= membra- } \\
\text { nacea) }\end{array}$ & 4 & $6,8,9$ & I & - & Foulness (8) \\
\hline 359 & $\begin{array}{l}\text { Paludestrina }(=\text { Hydrobia) stagna- } \\
\text { lis (Baster), }(=\text { ulvæ) }\end{array}$ & 4 & 6,8 & I & - & Foulness (8) \\
\hline 371 & $\begin{array}{l}\text { Truncatella truncata (Mont.). } \\
\text { - subcylindrica }\end{array}$ & - & $\begin{array}{c}6 \\
8,9\end{array}$ & - & - & \\
\hline $\begin{array}{l}374 \\
3^{8} \mathrm{I}\end{array}$ & Crepidula (fornicata, L.) · · & - & 6,10 & - & 10 & \\
\hline $\begin{array}{l}381 \\
3^{89}\end{array}$ & $\begin{array}{l}\text { Natica catena (Da Costa) } \\
\text { Velutina lævigata (Penn.) }\end{array}$ & - & - & - & 3 & Foulness (8) \\
\hline 454 & Turbonilla (=Odostomia) lactea & - & - & 1 & 5 & \\
\hline 489 & Buccinum undatum, L. & $\overline{2,4}$ & $8 \overline{8}, 10$ & $\begin{array}{l}\mathbf{I} \\
\mathbf{I}\end{array}$ & $\overline{3}$ & \\
\hline $\begin{array}{l}495 \\
508\end{array}$ & $\begin{array}{l}\text { Neptunea (= Fusus) antiqua (L.). } \\
\text { Ocinebra (= Murex) erinacea (L.) }\end{array}$ & - & - & - & 二 & $\begin{array}{l}\text { Walton (8) } \\
\text { Walton (8) }\end{array}$ \\
\hline 515 & Purpura lapillus (L.) . . . . & 4 & 10 & 1 & 3 & \\
\hline 518 & Nassa reticulata (L.) & 2,4 & 10 & I & 3 & Foulness (8) \\
\hline 519 & - incrassata (Strom.). & - & - & I & - & \\
\hline $\begin{array}{l}531 \\
552\end{array}$ & Bela (= Pleurotoma) rufa (Mont.) & - & - & I & 3 & \\
\hline 553 & $\begin{array}{l}\text { Tornatina }(=\text { Utriculus and Cyli- } \\
\text { chna truncatula (Bruguiere). }\end{array}$ & - & - & - & - & $\left\{\begin{array}{l}\text { C. truncata, } \\
\text { Foulness (8) }\end{array}\right.$ \\
\hline 554 & $\begin{array}{c}\text { - obtusata (Mont.) } \\
\text { OPISTHOBRANCHIA }\end{array}$ & - & 6 & I & - & Foulness (8) \\
\hline $\begin{array}{l}572 \\
580\end{array}$ & $\begin{array}{l}\text { Acera bullata, Muller . . . } \\
\text { Philine aperta (L.) }\end{array}$ & - & - & $\mathbf{I}$ & - & \\
\hline & Philine aperta (L.) . . . . . & 2,4 & 10 & - & 3 & \\
\hline
\end{tabular}


MARINE ZOOLOGY

\begin{tabular}{|c|c|c|c|c|c|c|}
\hline No. & Name & $\begin{array}{l}\text { Estuaries } \\
\text { of Orwell } \\
\text { and Stour }\end{array}$ & $\begin{array}{l}\text { River } \\
\text { Colne }\end{array}$ & $\begin{array}{l}\text { River } \\
\text { Black- } \\
\text { water }\end{array}$ & $\begin{array}{l}\text { River } \\
\text { Crouch }\end{array}$ & Other localities \\
\hline & Nudibranchiata & & & & & \\
\hline 603 & Eolis papillosa (L.) . . . & - & - & - & 5 & \\
\hline 614 & Cratena (= Eolis) concinna (Alder & & & & & \\
\hline 635 & Facelina (=Eolis) coronata, Forbes & - & - & - & 5 & \\
\hline & and Goodsir . . . . . . & 2 & - & - & 5 & \\
\hline $\begin{array}{l}636 \\
648\end{array}$ & - drummondi, Thomson. . & - & - & - & 5 & \\
\hline $\begin{array}{l}648 \\
658\end{array}$ & Doto coronata (Gmelin) $\cdot \cdot \cdot$ & - & - & - & 5 & \\
\hline & $\begin{array}{l}\text { Archidoris }(=\text { Doris) tuberculata } \\
\text { (Cuvier) . . . . . . }\end{array}$ & 一 & - - & - & 5 & \\
\hline 674 & $\begin{array}{c}\text { Acanthodoris (= Doris) pilosa } \\
\text { (Mull.). }\end{array}$ & 4 & - & - & 5 & \\
\hline 700 & $\begin{array}{l}\text { Alexia (= Melampus) denticulata } \\
\text { var. myosotis (Drap.). }\end{array}$ & - & - & I & - & \\
\hline & Cephalopoda & & & & & \\
\hline 707 & Loligo forbesi (Steenstrup). . & - & 10 & - & 5 & \\
\hline \multirow[t]{2}{*}{710} & Sepia officinalis, L. • • • • & - & IO & - & & Foulness (8) \\
\hline & $\begin{array}{l}\text { Petricola pholadiformis. } \\
\text { [A North American species; has } \\
\text { been introduced recently, and is } \\
\text { spreading both here and on the } \\
\text { North Kent coast] }\end{array}$ & - & - & - & 12 & \\
\hline
\end{tabular}

IX. POLYZOA

r. Gemellaria loricata, Linn.

Brightlingsea (H.W.U.), Harwich (G.P.H.).

2. Scrupocellaria reptans, Linn.

Harwich (G.P.H.).

3. Bicellaria ciliata, Linn.

Brightlingsea, Orwell.

4. Bugula plumosa, Pallas.

Brightlingsea.

5. Notamia bursaria, Linn. Brightlingsea.

6. Flustra foliacea, Linn.

Met with in the open water, but not common.

7. Flustra papyracea, Ell. \& Sol.

Harwich (G.P.H.).

8. Membranipora lacroixii, Audouin.

Common on old mussel shells, etc. Orwell,

Brightlingsea. The larva Cyphonantes is abundant.

9. Membranipora pilosa, Linn. Brightlingsea (H.W.U.), Harwich (G.P.H.). ro. Membraniporella melolontha, Busk.

Dredged in the Orwell (Harmer).

II. Schizoporella linearis, Hassall.

Brightlingsea.

12. Crisia eburnea, Linn.

Often growing on other forms, especially Hydrallmania falcata and Flustra foliacea, Brightlingsea (H. W. Unthank).

13. Alcyonidium gelatinosum, Linn.

So extremely abundant in some of the estuaries that the bottom must to a large extent be covered by it. By the local fishermen it is called 'pipe-weed.'

I4. Alcyonidium mytili, Dalzell.

A whitish or yellowish incrustation on stones and shells. Brightlingsea (H.W.U.).

15. Alcyonidium birsutum, Fleming.

16. Flustrella bispida, Fabr.

I7. Vesicularia spinosa, Linn.

Common; Brightlingsea, Orwell.

18. Amathia lendigera, Linn.

Brightlingsea (H.W.U.), Harwich (G.P.H.). 


\section{A HISTORY OF ESSEX}

20. Anguinella pasmata, V. Ben.

Common; Dovercourt, Orwell (Harmer).

21. Valkeria uva (var. cuscuta).

Harwich (G. P. Hope).

22. Pedicellina cernua, Pallas.

Brightlingsea.

\section{ECHINODERMATA}

1. Echinus miliaris, Linn.

This is extremely abundant in Harwich harbour, and less so in the open water off Mersea.

\section{Solaster papposus (Fabr.).}

Fairly common at all the places I have examined. Though some specimens are of a fine red colour, there is considerable variation, due to the varying amount of several different pigments.

\section{Asterias rubens, Linn.}

This is common all along the coast, and dredged in large quantities for manure.

\section{Opbiura ciliaris, Linn.}

Extremely abundant in the open water near the mouth of the Colne, and common in many other localities.

\section{Opbiothrix fragilis (O. F. Maller).}

This is fairly common in Harwich harbour, though it cannot be said to be abundant.

\section{Synapta inberens, O. F. Maller.}

$I$ do not remember ever finding this in Essex, but at one time it was common in a restricted area in the Orwell, a few miles outside the county.

\section{Cucumaria, sp. (?)}

At one time a Holothurian, something like a Cucumaria, was fairly common in the Stour off Parkeston, but lately I have dredged for it in vain. Unfortunately all my early specimens seem to have been destroyed, and only the tentacles and digestive organs preserved, mounted as a lantern slide. This may be an abnormal specimen, since it shows only eight tentacles, which are of dark brown colour, and until other specimens have been found identification is impossible.

\section{Thyone fusus, O. F. Muller.}

Many years ago I dredged this in Harwich harbour, and lately in the Orwell, but in each case only one specimen.

\section{TUNICATA (Sea-squirts)}

\section{Styelopsis grossularia, Van Beneden.}

This flesh-coloured ascidian is very common all along the coast and in the estuaries, attached to stones, shells and alga.

2. Polycarpa comata, Alder.

Small specimens occur in the Stour, and larger in the creek east of Walton-on-Naze, often so covered with attached sand as to look like a ball of hardened sand.

3. Polycarpa pomaria, Savigny.

Much less common than the other species.

4. Ascidiella aspersa, O. F. Maller.

5. Ascidiella virginea, O. F. Maller.

These two species occur in greater or less abundance all along the coast, and in the estuaries; in some cases fixed objects being covered by them.

6. Ascidia plebeia, Alder.

Found in the Stour near Harwich, but not common.

7. Ascidia producta, Hancock.

Fairly common in some parts of the Colne, often much attached along its side to algx.

8. Ciona intestinalis, Linn.

Though less abundant than the above named Ascidia, this is also common all along the coast.

9. Clavelina lepadiformis, O. F. Muller.

This occurs in bunches of many individuals on the east bank of the Colne below Brightlingsea and at Walton-on-Naze.

Compound ascidians. - These are sometimes difficult to preserve for future identification. Much remains to be learned about their colouring matters.

10. Botryllus, spp.

Specimens of this genus are common along the coast. The exact species cannot be properly identified from preserved specimens, but amongst them appear to be probably $B$. scblosseri and polycyclus. The colours are various and due to a mixture of two or three different pigments. The blue one is changed into a deep red one by formalin. The yellow and flesh-coloured specimens turn to a dirty dark brown in alcohol, owing to the formation of a new pigment by oxidization ; but by careful management they may be fairly well preserved in undiluted glycerine.

11. Botrylloides rubrum, M. Edw.

This is found below Brightlingsea and on 


\section{A HISTORY OF ESSEX}

the pier at Harwich. Mounted in Canada balsam specimens show the structure well, and have retained the natural colour for a good many years.

12. Botrylloides leachii, Sav.

Common in the Orwell just outside Essex, and I think I have also found it in the Stour. By proper management both the form and natural colour may be well preserved in undiluted glycerine.

13. Polyclinum aurantium.

In I 889 fine specimens were common in the creek east of Walton-on-Naze. Sections mounted in Canada balsam show the structure very well, and have retained the natural orange colour for many years without any apparent change.

14. Didemnum,

15. Leptoclinum, and

16. Diplosoma.

Some species of these genera occur in the Orwell, just outside Essex, and probably could be found in the Stour and in the creeks near Walton-on-Naze.

17. Oikopleura, sp.

Appendicularians are common in sievings of the sea water all along the coast. 


\section{MOLLUSCS}

A coastal county with numerous estuaries, marshes, streams, and many woodlands and heaths, Essex is an ideal spot from the molluscan point of view.

Accordingly we find that out of a possible $\mathrm{r} 39$ species for the whole of the British Islands 110 are now living in the area while 10 more have been met with in the numerous Post-pliocene deposits, viz. Vitrea excavata, Helicella cartusiana, Acantbinula lamellata, Pupa anglica, Vertigo minutissima, $V$. alpestris, $V$. angustior, Clausilia rolpbii, Succinea oblonga and Acicula lineata.

Some of these, and one or two more slugs, may yet be discovered in the county. In addition the Post-pliocene deposits have yielded the following which no longer live in this country, viz. Pyramidula ruderata, Eulota fruticum, Paludestrina marginata, Unio littoralis and Corbicula fluminalis, with two entirely extinct forms Vivipara clacktonensis and Pisidium astartoides.

The notable absentees from the list are consequently the species peculiar to the south-western portions of England.

The principal sources of information are papers by Mr. W. M. Webb, A. S. Kennard and B. B. Woodward in the Essex Naturalist, vol. x. I 897.

\section{A. GASTROPODA}

\section{PULMONATA \\ a. STYLOMmatophorA}

Testacella baliotidea, Drap. Sisted, Widford - scutulum, Sby. Buckhurst Hill; Wanstead Limax maximus, Linn.

- flavus, Linn.

- arborum, Bouch.-Chant. Saling; Chignal; Weald Hall Park, Brentwood ; Ingrave Agriolimax agrestis (Linn.)

- levis, Mall. Wanstead ; Warley ; Halstead; Chelmsford

Amalia sowerbii (Fér). Barking Side ; Chelmsford; Brentwood

Vitrina pellucida (Mull.)

Vitrea crystallina (Mull.)

- alliaria (Miller)

- glabra (Brit. Auct.)

- cellaria (Mull.)

- nitidula (Drap.)

- pura (Ald.)

- radiatula (Ald.)

- nitida (Mull.)

- fulva (Mull.)
Arion ater (Linn.)

- bortensis, Fèr.

- circumscriptus, John.

- subfuscus (Drap.). Warley

Punctum pygmeum (Drap.)

Pryamidula rupestris (Drap.). Barking Side

- rotundata (Mull.)

Helicella virgata (Da C.)

- itala (Linn.)

- caperata (Mont.)

- cantiana (Mont.)

Hygromia fusca (Mont.). Saffron Walden

- granulata (Ald.)

- bispida (Linn.)

- rufescens (Penn.)

Acantbinula aculeata (Mull.)

Vallonia pulchella (Mull.)

Helicigona lapicida (Linn.)

- arbustorum (Linn.)

Helix aspersa, Müll.

- pomatia, Linn. Great Bardfield; Chappel; Chalkney Wood; Witham; Chignal Smealey

- nemoralis, Linn.
I2 


\section{A HISTORY OF ESSEX}

Helix bortensis, Mull.

Buliminus montanus (Drap.). 'Essex' (Brit. Mus.)

- obscurus (Mull.)

Cocblicopa lubrica (Mull.)

Azeca tridens (Pult.)

Cacilianella acicula (Mull.)

Pupa cylindracea (Da C.)

- muscorum (Linn.)

Spbyradium edentulum (Drap.)

Vertigo antivertigo (Drap.)

- substriata (Jeff.)

- pygmea (Drap.)

- moulinsiana (Dup.). Roydon

- pusilla, Müll. Bardfield (?)

Balea perversa (Linn.)

Clausilia laminata (Mont.)

- bidentata (Ström.)

Succinea putris (Linn.)

- elegans, Risso.

\section{b. Basommatophora}

Carychium minimum, Mall.

Melampus denticulatus (Mont.). River Colne, Wyvenhoe

Alexia myosotis (Drap.). Grays; Purfleet; Dovercourt

Leuconia bidentata (Mont.). Brightlingsea ; Dovercourt

Ancylus fuviatilis, Mull.

Velletia lacustris (Linn.)

Limnea auricularia (Linn.)

- pereger (Mull.)

- palustris (Mull.)

- truncatula (Mull.)

- stagnalis (Linn.)

- glabra (Mull.). Woodford; Barking Side ; Colchester
Planorbis corneus (Linn.)

- albus, Mull.

- glaber, Jeff. Carswell Pond; Dagenham

- nautileus (Linn.)

- carinatus, Mull.

- marginatus, Drap.

- vortex (Linn.)

- spirorbis, Mall.

- contortus (Linn.)

- fontanus (Lightf.)

- lineatus (Walker)

Pbysa fontinalis (Linn.)

- bypnorum (Linn.)

\section{PROSOBRANCHIATA}

Paludestrina confusa (Frau.). Becton (probably now extinct)

- jenkinsi (Smith). Becton; Rainham; Tilbury

- ventrosa (Mont.). Coldharbour Point to Tilbury; Thurrock Marsh; between Walton and Thorpe-le-Soken

- stagnalis (Bast.). Grays; Tilbury; Wyvenhoe; Colchester

Bitbynia tentaculata (Linn.)

- leachii (Shepp.)

Vivipara vivipara (Linn.)

- contecta (Millett). Old River Lea; Colchester ; River Stour

Valvata piscinalis (Mull.).

- cristata, Mull.

Assiminea grayana, Leach. Grays and other spots along the Thames; River Colne, Colchester. (Becoming extinct)

Pomatias elegans (Müll.). Felstead ; Coggleshall; Saffron Walden; Wicken Bonhunt ; Belchamp

Neritina fuviatilis (Linn.).

\section{B. PELECYPODA}

Dreissensia polymorpha (Pall.). River Lea

Unio pictorum (Linn.)

- tumidus, Retz.

Anodonta cygncea (Linn.)

Spharium rivicola (Leach). River Stort

- corneum (Linn.)

- ovale (Fér.). Woodford
Spharium lacustre (Mull.)

Pisidium amnicum (Mall.)

- pusillum (Gmel.)

- nitidum, Jenyns. Colchester

- fontinale (Drap.)

- milium (Held.). Lea Marshes 


\section{INSECTS}

Entomology, though the most extensive of all the domains of natural history, would not at one time have occupied the space which is accorded to it here; but knowledge has been making rapid strides in recent years, and it is hoped that the information now given will be of value as well to the student of economic entomology as to the collector.

In compiling the lists that follow, the entomologist has been at a great disadvantage as compared with some of his fellow contributors, for in several other branches of natural history admirable and exhaustive monographs have already been published, whereas as far as can be ascertained the only complete list of any of the Essex insects is Mr. Fitch's list of the butterflies, which appeared in the Essex Naturalist for March, $189 \mathrm{r}$, et seq. In the same publication (iii. 123) there is a long annotated list of 'The Lepidoptera of Leigh and its Neighbourhood' by the late Mr. Howard Vaughan, and Mr. F. G. Whittle published a similar list of the 'Lepidoptera of South-east Essex' in Science Gossip for 1899 , vol. v. n.s.

Besides these sources of information there are innumerable short lists and records of individual captures scattered through the entomological literature of the past century, and for many years Mr. Fitch has been making notes of these; but as pressure of other work has prevented him from completing his contemplated list of the insect fauna of the county, he has very kindly placed the whole of his material at the disposal of the writer, and from this many interesting particulars have been obtained; but as a general rule it has been thought preferable to rely upon the more recent observations of competent living authorities whose accuracy need not be questioned. ${ }^{1}$

If it be noticed that a very large proportion of the records are from certain limited localities, it is because these have been more assiduously and thoroughly worked than other parts of the county, and not because the species mentioned are confined to them, for nearly all would probably be found if well looked for in other places where sufficient food supplies and other favourable conditions exist.

1 For local lists and assistance in other ways the writer wishes to acknowledge the courtesy and kindness of Mr. F. C. Adams, F.E.S.; Mr. Percy Adams; Rev. E. N. Bloomfield, M.A., F.E.S. ; Mr. Malcolm Burr, F.Z.S., F.L.S., F.E.S. ; Mr. G. C. Champion, F.E.S. ; Mr. F. B. Jennings, F.E.S. ; Mr. W. J. Lucas, B.A., F.E.S. ; Mr. R. McLachlan, F.R.S., etc.; Rev. F. D. Morice, M.A. ; Mr. L. B. Prout, F.E.S. ; Mr. Percy Reid, F.E.S.; Mr. C. R. V. Perkins, B.A.; Mr. A. Thurnall ; Mr. G. H. Verrall, F.E.S. ; Mr. W. West. 


\section{A HISTORY OF ESSEX}

Owing to the unsatisfactory condition of natural history nomenclature and the frequent mistakes made by early writers and observers many ancient records are of more than doubtful value, and where any such have been used the authorities for them have been given, but as a rule they have been ignored.

All reasonable efforts have been made to ensure accuracy and completeness, and insufficient and unsatisfactory as some of the lists are, it is yet hoped that on the whole they will compare not unfavourably with those of other counties, and that they very fairly represent the extent of our knowledge at the present day.

\section{ORTHOPTERA}

Our list of British Orthoptera is a very short one, and of the few recorded as having been met with a large proportion must be regarded as casual immigrants or naturalized foreigners. In Essex little attention seems hitherto to have been paid to these insects, but those named below have been identified in the Colchester district, and doubtless several more will be found there and elsewhere in the county when they are sytematically sought for.

\section{FORFICULARIA}

\section{Earwigs}

The Lesser Earwig (Labia minor) may occasionally be found in some numbers in manure heaps, but does not generally obtrude itself upon our notice after the manner of its larger relative.

The Common Earwig (Forficula auricularia) is much too common, and is one of the most troublesome insect pests we have, as scarcely anything comes amiss to it in the way of food, and no place seems to be secure from its invasion. It varies considerably, especially in the length of the forceps, and formerly some of its varieties were described as distinct species.

Forficula lesnei, Finot, has only recently been identified as British, though it probably existed previously as an old inhabitant under another name. It is far from common, but seems to be well distributed and may be beaten from trees and bushes and shaken out of rubbish in damp places.

\section{BLATTODEA}

\section{Cockroaches}

Ectobiida. Ectobia panzeri, Steph., is not uncommon in several places on our coast sands. The variety nigripes, Steph., is of much less frequent occurrence.

Pbyllodromiida. Pbyllodromia germanica, L., was formerly excessively abundant in one of the principal hotels in Colchester, where it was said to have been introduced in officers' luggage. Mr. G. F. Mathew reports it as common at Dovercourt. 


\section{INSECTS}

Periplanetida. The Common Cockroach (Blatta orientalis) is such a well-known and widely distributed household pest that few can have failed to make its acquaintance.

\section{ACRIDIODEA}

\section{Grassboppers}

Truxalida. Stenobotbrus rufipes, Zett., seems to be fairly well distributed, but has not hitherto been noticed in any great numbers.

S. bicolor, Charp., is very abundant in all directions and appears to be the commonest member of the family.

S. elegans, Charp., is considered scarce and local, but may sometimes be met with rather freely on our coast sands in August.

S. parallelus, Zett., has been found and is probably common, but as it has only partially developed wings and elytra, it is likely to be passed over by the inexperienced collector as an immature form.

Gompbocerus maculatus, Thunb. A pretty little species with clubbed antennæ, much smaller than any of the above, is common in dry places.

Edipodide. Pacbytylus danicus, L. This conspicuous locust is not a native of Britain but only a casual straggler to our shores. 'Locusts' have been reported from Colchester, Epping and Southend, under the names of Gryllus or Pacbytylus migratorius and $P$. cinerascens, but apparently they were all referable to one species, which in accordance with the law of priority is now known as $P$. danicus.

Tettigida. Tettix bipunctatus, L., frequently turns up unexpectedly, especially in open spaces in woods, and would probably prove a common insect if systematically sought for.

\section{LOCUSTODEA}

\section{Locusts}

Pbaneropterida. Leptopbyes punctatissima, Bosc., has been found near Colchester, and is probably as generally common throughout the county as it is in other parts of England.

Meconemida. Meconema varium, Fabr. This pretty green insect is generally common, especially about oak trees, from the boughs of which it may be freely beaten in the autumn. It is also frequently found in a semi-torpid state on the boles of the trees as soon as the nights become colder.

Conocepbalida. Xipbidium dorsale, Latr., is considered rare in this country, but may frequently be found in grassy places, especially on certain of our sea walls. As a rule it is a micropterous insect, that is, its elytra and wings are only partially developed, and it is therefore quite incapable of flight; but in August, 1899 , two examples of a form with fully developed wings and elytra were met with near Clacton-on-Sea, and one of them was disporting itself in the air somewhat after the manner of a dragonfly. No previous record of such a form is known, and these may have been examples of a rare local variety or of a new 


\section{A HISTORY OF ESSEX}

species. Others were searched for in 1900 but only ordinary specimens were found.

Locustida. Locusta viridissima, L., is the largest of our indigenous Orthoptera, and it may appear strange to some that the creatures we have so long known as locusts should be placed with the grasshoppers, while this giant grasshopper is classed with the locusts; but it must be remembered that those who are responsible for the present classification of the Orthoptera are not responsible for their popular English names. This conspicuous insect is sometimes brought to the entomologist as a great curiosity, but to him it is generally a very familiar object, for it is often common in his hunting grounds, though the ordinary passer-by may fail to see it.

Decticida. Thamnotrizon cinereum, L. This large brown species is frequently found in nettles and other herbage in the autumn and in the larva stage earlier in the year; it is very plentiful in some of the lanes about Colchester.

Platycleis grisea, Fabr., is very much more local and has so far only been found on the sea coast among rest harrow.

\section{GRYLLODEA}

\section{Crickets}

Gryllide. The House Cricket (Gryllus domesticus) is very common in bakehouses, where it excavates extensive burrows between the brickwork near the oven and increases and multiplies prodigiously. Its shrill chirp is also a familiar sound in many an English house that has been a home for several generations, though it appears to be incompatible with new houses and the methods of the modern builder.

Gryllotalpida. The Mole Cricket (Gryllotalpa gryllotalpa) is very rare in the county. Two specimens have been found near Colchester, Mr. Fitch has secured two or three near Maldon, and it has also been reported from Dovercourt by Mr. G. F. Mathew, and from the Southend district. As it makes an effective illustration it is often figured in books on injurious insects, whereby an erroneous impression is apt to be conveyed, for though on the continent it really seems harmful sometimes, the British collector always considers it a good find.

\section{NEUROPTERA}

\section{ODONATA}

\section{Dragonfics}

There are some who affect to despise popular science, and who especially object to the employment of trivial names for our native animals and plants. But happily for our literature-and especially for our poetry - the popular names of many of our wild flowers, birds and insects, were definitely fixed long before the scientific pedant appeared upon the scene. And any one who has watched the larger Odonata hawking for their prey and has marked their rapid evolutions among 


\section{INSECTS}

their helpless victims, must admit that the term 'dragonflies' came as a happy inspiration to the person who first employed it; since in their relation to their fellow insects these powerful and voracious creatures are well calculated to produce a vivid conception of 'the dragons of the prime.' They are so well known that no description of them and their methods can be needed here. We have some forty British species, of which about three-fourths have been found in the county.

Leucorrbinia dubia, Lind., is generally accounted a northern species, but has been reported by the late Mr. Henry Doubleday as occurring, though rarely, on Coopersale Common near Epping.

Sympetrum striolatum, Charp., is abundant in many places about Colchester. It has also been reported from Wanstead and Epping and probably occurs freely throughout the county.

S. flaveolum, L., is as a rule rare, but has occurred recently at Colchester and St. Osyth, and according to Mr. Doubleday was formerly periodically common about Epping.

S. sanguineum, Müll., seems to have a much more restricted range than its commoner relative $S$. striolatum, with which it may frequently be found on the coast at St. Osyth and elsewhere. It has also occurred at Epping.

S. scotium, Don. 'Epping, about old gravel pits '(H. Doubleday).

Libellula depressa, L. This handsome insect is one of the earliest to appear, and is generally distributed and usually common, but also very wary and more frequently seen than captured. The variety bageni is much scarcer.

L. quadrimaculata, L., appears to occur pretty regularly in many places in Britain, but is a migratory species of which large swarms are occasionally reported. Such a swarm was observed off the Essex coast in June, 1888 . In June, 1900 , for one day only, many specimens were seen at Wivenhoe, but most contrived to elude capture. Colchester and Epping are other localities for it, and the var. pranubila has been met with near Clacton-on-Sea.

L. fulva, Müll. Very rare, but Doubleday reports it from Ongar Park woods and a single specimen has occurred at Colchester.

Cordulia anea, L., is extremely local, the only records being Coopersale Common (Doubleday) and Woodford (Harcourt Bath).

Gompbus vulgatissimus, L., is also very local and is only reported by Mr. Doubleday from High Beech and elsewhere near Epping.

Anax imperator, Leach, the largest European dragonfly, is now a rarity in the county, though like several others it seems to have been less uncommon in the Epping district formerly. A single specimen was captured in the High Woods at Colchester several years ago, but no others have since been seen.

Bracbytron pratense, Müll., is widely distributed but seldom met with ; it has occurred at Colchester, Epping and St. Osyth.

Escbna mixta, Latr., is considered a rare and local insect, but during the past two years has extended its range and appeared in larger 


\section{A HISTORY OF ESSEX}

numbers; owing however to its cautious habits, lofty flight and extreme rapidity of movement, its capture is attended with some difficulty. It is now well distributed in the Colchester district, and as all the inland examples seem to be mature, while the majority of those found on the coast are immature, this may afford a clue to a fuller knowledge of its earlier stages than we at present possess.

E. cyanea, Müll., is by far the commonest as well as one of the handsomest and most widely distributed of its family.

A. grandis, L., though recorded only from Colchester, Epping, Wanstead, and St. Osyth, is so powerful on the wing that he would be rash who ventured to set bounds to its local distribution, and probably it is acquainted with every parish in the county.

The Demoiselle Dragonflies (Calopteryx virgo and C. splendens) both occur; the former appears in the Epping list and is not uncommon near Birch Park. The latter abounds beside ditches and streams in all directions.

Lestes dryas, Kirby, is one of our rarest species. A single specimen was taken by $\mathrm{Mr}$. C. R. Briggs near Leigh in $189 \mathrm{I}$.

L. sponsa, Hansem, occurs at Epping (Doubleday) and Wanstead (F. A. Walker), and has recently been found at St. Osyth.

[L. virens, Charp.] is doubtfully British, and its only claim to appear in our list is that Mr. Doubleday believed several specimens had been taken by himself at Epping.

Platycnemis pennipes, Pall., is also recorded from Epping by Doubleday, and there is a later record by Mr. C. R. Briggs.

Erytbromma naias, Hansem. Epping (H. Doubleday), Wanstead (F. A. Walker).

Pyrrbosoma nympbula, Sulz. (minium, Charp.), is common at Colchester, Birch, Epping, and in many other localities.

$P$. tenellum, Vill., formerly occurred at Epping, but there is no evidence of any recent captures.

Iscbnura pumilio, Charp., was stated by Doubleday in 187 I to be ' rare about the red gravel pits in the Epping district.'

I. elegans, Lind., is very common in the county, especially beside marsh ditches near the coast.

Agrion pulcbellum, Lind. 'Epping, not common' (Doubleday).

$A$. puella, L., is very common everywhere.

Enallagma cyatbigerum, Charp., has probably been generally overlooked by Essex naturalists, as it is widely distributed elsewhere, and should occur in many places besides Epping.

The other sections of the Neuroptera occurring in this country include the diminutive $P$ socida, which are among the smallest British insects, the Perlidae or Stoneflies, and the Epbemerida or Mayflies. These are known as Pseudo-Neuroptera. The curiously constructed Snake and Scorpion flies and the beautiful golden-eyed Lacewings are classed as Neuroptera Planipennia, and the Caddisflies as Trichoptera.

All the species included in the following list have been found in the 


\section{INSECTS}

Colchester district, except a few recorded by Mr. J. J. King from Epping Forest. Hitherto these insects have received little attention from Essex entomologists, or many others would have been identified.

PSEUDO-NEUROPTERA

\section{PsocID}

Psocus, Latr.

- longicornis, Fabr. Colchester, Epping

- nebulosus, Steph. Colchester

- variegatus, Fabr. Epping

- fasciatus, Fabr. Colchester

Stenopsocus, Hag.

- immaculutus, Steph. Epping

- cruciatus, L. Colchester, Epping

Cæcilius, Curt.

- vittatus, Dalm. Epping

Peripsocus, Hag.

- phæopterus, Steph. Epping

Elipsocus, Hag.

- unipunctatus, Mull. Colchester, Epping

\section{PERLIDF}

Leuctra, Steph.

- geniculata, Steph. Colchester

Nemoura, Latr.

- variegata, Oliv. Colchester

\section{EPHEMERIDF}

Ephemera, L.

— vulgata, L. danica, Müll. $\}$ Colchester

Leptophlebia, Westw.

- submarginata, Steph. Colchester

Cloeon, Leach

- dipterum, L. Colchester, Epping

NEUROPTERA-PLANIPENNIA

\section{SIALIDF}

Sialis, Latr.

- lutaria, L. Colchester

RAPHIDIIDF

Raphidia, L.

$\left.\begin{array}{l}\text { - notata, Fabr. } \\ \text { - xanthostigma, Schum. }\end{array}\right\}$ Colchester

\section{OsMYLIDE}

Osmylus, Latr.

- chrysops, L.

Sisyra, Burm.

- fuscata, Fabr. Colchester, Loughton

\section{HEMEROBIID $\pi$}

Micromus, Ram.

- variegatus, Fabr. )

- paganus, L.

Hemerobius, L.

- elegans, Steph. Epping

- micans, Oliv. $\}$ Epping, Colchester

- subnebulosus, Steph.

- stigma, Steph.

- concinnus, Steph.

\section{CHRYSOPIDF}

Chrysopa, Leach

- flava, Scop.

- vittata, Wesm. $\}$ Colchester

- alba, L. Colchester, Epping

- tenella, Schn.

- vulgaris, Schn.

- septempunctata, Wesm.

, Wesm.

- aspersa, Wesm. ?

- ventralis, Curt. Colchester, Epping

- phyllochroma, Wesm. )

- perla, L. Colchester

Nothochrysa, McLach.

- capitata, Fabr. Colchester

ConIOPTERYGIDE

Coniopteryx, Curt.

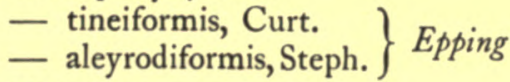

PANORPIDE

Panorpa, L.

- communis, L. - germanica, L. $\}$ Colchester, Epping

\section{TRICHOPTERA}

Phryganeide

Phryganea, L.

- grandis, L.

- striata, L.

- minor, Curt.

LiMNOPHILIDE

Colpotaulius, Kol.

- incisus, Curt. Colchester

Grammotaulius, Kol.

- atomarius, Fabr. Colchester, Epping

Glyphotælius, Steph.

- pellucidus, Retz. Colchester
LIMNOPHILIDE (continued)

Limnophilus, Leach

- rhombicus, L.

- marmoratus, Curt.

- lunatus, Curt.

— politus, McLach.

- affinis, Curt. Colchester, Epping

- auricula, Curt. $\}$ colchester

- centralis, Curt. $\}$ Colchester, Epping 


\section{A HISTORY OF ESSEX}

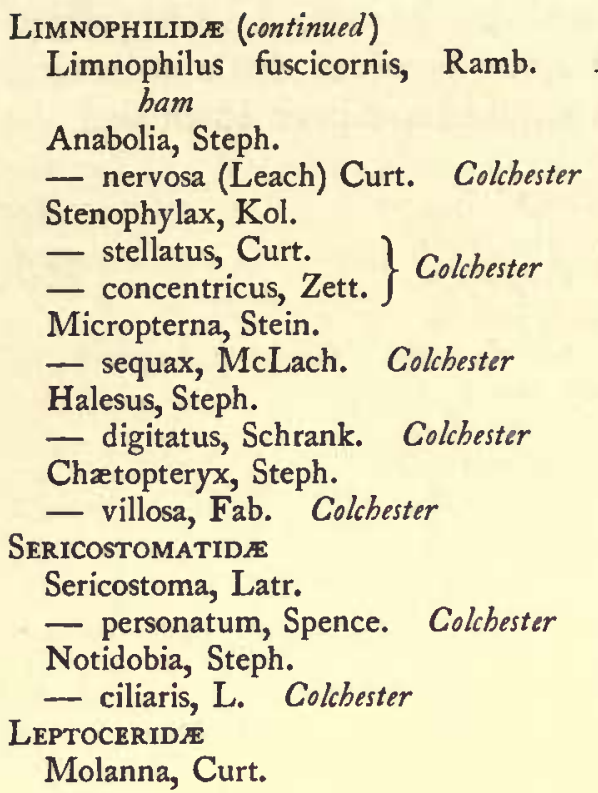

LEPTOCERIDA (continued)

Ded- Molanna angustata, Curt. Colchester

Leptocerus, Leach

— - cinereus, Curt. $\}$ Colcbester

Mystacides, Latr.

- longicornis, L. $\}$ Colchester

HYDROPSYCHIDE

Hydropsyche, Pict.

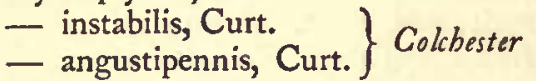

Polycentropus, Curt.

- favo-maculatus, Pict. Colchester

Cyrnus, Steph.

- trimaculatus, Curt.

Tinodes, Leach.

- wæneri, L.

RHYACOPHILIDE

Agapetus, Curt.

- fuscipes, Curt.

\section{HYMENOPTERA}

\section{ACULEATA}

The order Hymenoptera is an extensive one, consisting of insects which as a rule have four membranous wings, though certain among them are wingless. In the Aculeate section, which comprises ants, sand wasps, wasps and bees, the female is provided with a sting, which, being connected with a poison bag, constitutes a formidable weapon of offence or defence. The solitary species consist of fully developed males and females only, but in the social species-ants, hive bees and humble bees - there are also undeveloped females, known, and very fittingly known, as workers, on whose labour depends the welfare of the community.

In recent years, owing principally to the admirable work which has been done in them by Mr. Edward Saunders, these insects have received more attention than was accorded to them formerly, and as a consequence their local distribution is much more fully understood and additional species are being frequently added to our list.

The late Mr. Frederick Smith, author of $A$ Catalogue of British Bees in the British Museum, occasionally collected at Southend, and more recently the Colchester district has been pretty well worked, though it is probable that additional species will for a long time result from further investigation, for while some are excessively local or very erratic in their appearances, others more given to wandering are constantly on the look out for suitable places in which to found fresh colonies; and seeing that their habitations are constantly liable to adverse influences either by the dense growth of vegetation, the ravages of mankind, or other causes, the Aculeate fauna of a particular district may be materially modified in the course of a few years.

Where no locality is given in the list that follows the Colchester district is to be understood, and this includes not only the neighbourhood 


\section{INSECTS}

of the town but also the sea coast between the mouth of the Colne and Walton-on-the-Naze. Among the more interesting species the Great Wood Ant (Formica rufa) may be mentioned, for though excessively abundant in some of our larger woods, it is worthy of notice for the important part it plays in the destruction of other insects. Sometimes about the end of May the caterpillars of certain moths occur in such prodigious numbers that they completely strip the oaks and other large trees, and then descending upon the underwood speedily effect a similar clearance there. Not long ago the High Woods at Colchester were for a time so denuded of their leaves at the beginning of June that they appeared almost as bare as they had been during the previous winter, but there was one corner, which at a distance seemed to be marked off from the rest by a sharp boundary line, within which the foliage had not suffered. Closer investigation revealed the fact that the ground under the trees was covered with ants, multitudes of which were busily engaged descending the boles with caterpillars in their mouths or ascending them for fresh burdens.

The House Ant (Monomorium pharaonis), a very minute species, is exceedingly troublesome in those houses in which it effects a settlement, as some Colchester householders can testify. Mr. Gervase F. Mathew also reports it as a pest in houses at Dovercourt. The rare Ponera punctatissima has been found in a bakehouse at Colchester; and another ant worthy of mention is Solenopsis fugax, which lives in galleries in the walls of other ants' nests. Mr. F. Smith took this at Southend. Mutilla europae is a very handsome insect, which is parasitic in the nests of humble bees; it is always scarce, but the apterous female may sometimes be found on our coast sands, while the winged male is occasionally captured on umbelliferous flowers. Metboca icbneumonides and the scarce Pompilus unicolor are also reported from Southend by Mr. F. Smith, while $P$. bicolor, $P$. consobrinus, $P$. minutulus and $P$. wesmaeli, which, according to Mr. Saunders, 'are among the desiderata of most of us,' are found in the Colchester district, where also Pseudagenia carbonaria (punctum) and Agenia bircana may be occasionally met with. Tachytes unicolor has only been found on the coast, where hitherto it has apparently been confined to a patch of sand a few yards square. Ceratophorus morio is extremely rare, only three specimens having so far been met with; and Mimesa equestris and $M$. dablbomi have hitherto proved as scarce here as in other parts of the country. Gorytes campestris is an uncertain insect, and some years may be sought for to little purpose, but in 1900 it was found in larger numbers than usual on umbelliferous flowers. Hoplisus bicinctus, a very beautiful and elegant species, is apparently also local and rare, few collectors having ever met with it, but it may sometimes be found running over leaves in August; while Nysson trimaculatus, another scarce species with a similar habit, may occasionally turn up if Hoplisus is looked for in vain. Didineis lunicornis has twice been captured at Colchester, and the very rare Pbilanthus triangulum is recorded from Snaresbrook by Mr. F. Smith. Cerceris ornata in recent years seems to have 


\section{A HISTORY OF ESSEX}

been having a very good time, for while its old settlements have been considerably extended many new ones have been formed; it provisions its nest with bees of the genus Halictus, and may often be seen dragging its victims down its burrows in trodden paths in the late summer. It is a handsome insect with bright yellow markings, but in I 899 an example was captured near Donyland Heath in which the yellow was replaced by white. This is apparently a very rare if not an altogether unique form. Cerceris quadricincta has only been reported from Kent and Essex. At Colchester it seems to be mainly an urban insect, for it forms its burrows in the public streets, where, owing to alterations, two colonies have been destroyed recently; it is very partial to mignonette flowers. Oxybelus mucronatus has occurred at Alresford, where a single specimen was found in 1900 .

In the extensive genus Crabro, C. tibialis, C. clavipes and $C$. capitosus are occasionally noticed; and the very rare $C$. signatus has been taken at Colchester and St. Osyth, where C. lituratus is also to be found in favourable seasons, for it does not occur regularly. This seems to be a very local species, as it has rarely been recorded from other parts of the country.

The Hornet (Vespa crabro) cannot be called a rarity, but is neither common or generally distributed. Probably it was much commoner formerly than it is now, as the violent antipathy which exists against it in the rustic mind leads to its speedy extirpation when it can be attacked with impunity. It may not be generally known that this powerful insect sometimes carries on its operations by night as well as by day, and occasionally comes freely to 'sugar' placed on the trees to attract moths. $V$. norvegica is a much scarcer insect in this part of the country, but has been found at St. Osyth, and in 1893 a nest was discovered in a thick hedge at Lexden.

In the genus Odynerus several good species occur, including $O$. crassicornis, of which only two recent British examples are known, and $O$. reniformis, which has only been reported from two other localities in Surrey. O. pictus, O. melanocepbalus and $O$. gracilis are also far from common species.

Among the bees Colletes succincta is worthy of notice. In other parts of the country it seems to frequent heath flowers, but with us it is exclusively a coast species, and confines itself to the flowers of maritime plants, the sea holly and starwort being especial favourites. Extensive colonies exist at several places between the Colne and Stour, and the males have a curious habit of congregating together late in the afternoon on flower heads of the marram grass, ragwort and other plants, where they form dense masses that are often conspicuous at a distance. Occasionally a female may be found among them, but this is exceptional.

Prosopis pictipes, though usually regarded as scarce and local, has been found rather freely on several occasions in a garden at Colchester in flowers of geranium and campanula. The red bodied genus Sphecodes is well represented, $S$. rubicundus, $S$. spinulosus, $S$. puncticeps and the rare 


\section{INSECTS}

S. ferruginatus being the most noteworthy species. At sallow flowers in the spring Andrena bimaculata, $A$. rose var. spinigera, $A$. dorsata and many others are found. The scarce and local $A$. fasciata has occurred at Dovercourt, but only one example was seen. 'Its near relative, $A$. fulvicrus, was for many years scarce near Colchester, but recently extensive colonies have been found, and it is now quite a common insect. $A$. pilipes also, which was for long represented by a single specimen, has during the past two years been turning up in all directions.

The beautiful $A$. cineraria, one of the early spring bees, is found near Walthamstow. A. battorfiana, the finest species of the genus, has been met with at Alresford, Donyland and Lexden. As a rule only the black form is found, but one year nearly all the specimens seen were highly coloured red ones. $A$. cetii is another very local and extremely variable insect, though in this the red forms predominate. It is occasionally found at Aldham and Alresford, but more frequently at Colchester. It seems to be somewhat uncertain in its appearances, and may often be looked for to little purpose. $A$. rosa is also generally scarce in its summer form, but during the past year or two has occurred pretty freely at bramble flowers, while $A$. nigriceps has been far from scarce on ragwort. Of the rare $A$. tridentata only a single specimen has so far been found, but $A$. fucata and $A$. fulvago seem to occur regularly. $A$. labialis was seen in prodigious numbers in 1898 , especially on the sea walls at St. Osyth, where its males were observed congregating together after the manner of Colletes succincta, their bright yellow faces rendering the masses they formed very noticeable and curious objects. The genus Nomada, which is largely parasitic on Andrena, is naturally also well represented, $N$. armata and $N$. obtusifrons being its most noteworthy species as regards rarity; but $N$. sexfasciata seems also to be strangely rare in north Essex, seeing that the Long-horned Bee (Eucera longicornis) to which it is attached is abundant. Only a single specimen of the parasite has been discovered, at Walton-on-the-Naze. Mr. Smith however formerly found it in some numbers near Southend. The little Blue Bee (Ceratina cyanea) seems to be seldom met with in other parts of the country ; it is not infrequent on daisies in the spring and on composite flowers later in the year. The Rose-cutter Bees are well in evidence throughout the summer. Megacbile maritima is principally a coast species, while $M$. circumcincta and $M$. ligniseca are found inland. The scarcer $M$. versicolor, which has only recently been reinstated in our list, was also met with in August, 1900.

Osmia pilicornis is a rare species; two females were captured in $188_{3}$, but others have since been sought for in vain. O. bicolor, which forms its cells in empty snail-shells, is occasionally met with at Lexden but more frequently at Aldham, where there is a fairly strong colony. The genus Stelis, which is parasitic on Osmia, is represented by S. aterrima and $S$. pbooptera, the latter being much the rarer. Melecta luctuosa, which is the 'cuckoo' of Antbopbora retusa, is very rarely met with, though its 'host' from being a rarity has recently become quite 


\section{A HISTORY OF ESSEX}

common. A. furcata, which forms its cells in decaying posts, though far from common, may often be heard even before it is seen busily engaged among the flowers of Stacbys sylvatica and other labiates. The velvet coated humble bees and their parasites of the genus Psitbyrus, which so closely resemble them, may be met with in all parts of the county during the warmer portion of the year; but two species are very rare. Of Bombus lapponicus only a single specimen, which was captured on a sea holly flower at St. Osyth, has been found ; it is a mountain species, and as far as can be ascertained no other specimen has been recorded from the south of England. B. cullumanus has only been found at Southend, where the late Mr. Frederick Smith took six examples many years ago.

\section{A LIST OF THE ACULEATE HYMENOPTERA OCCURRING IN THE COUNTY}

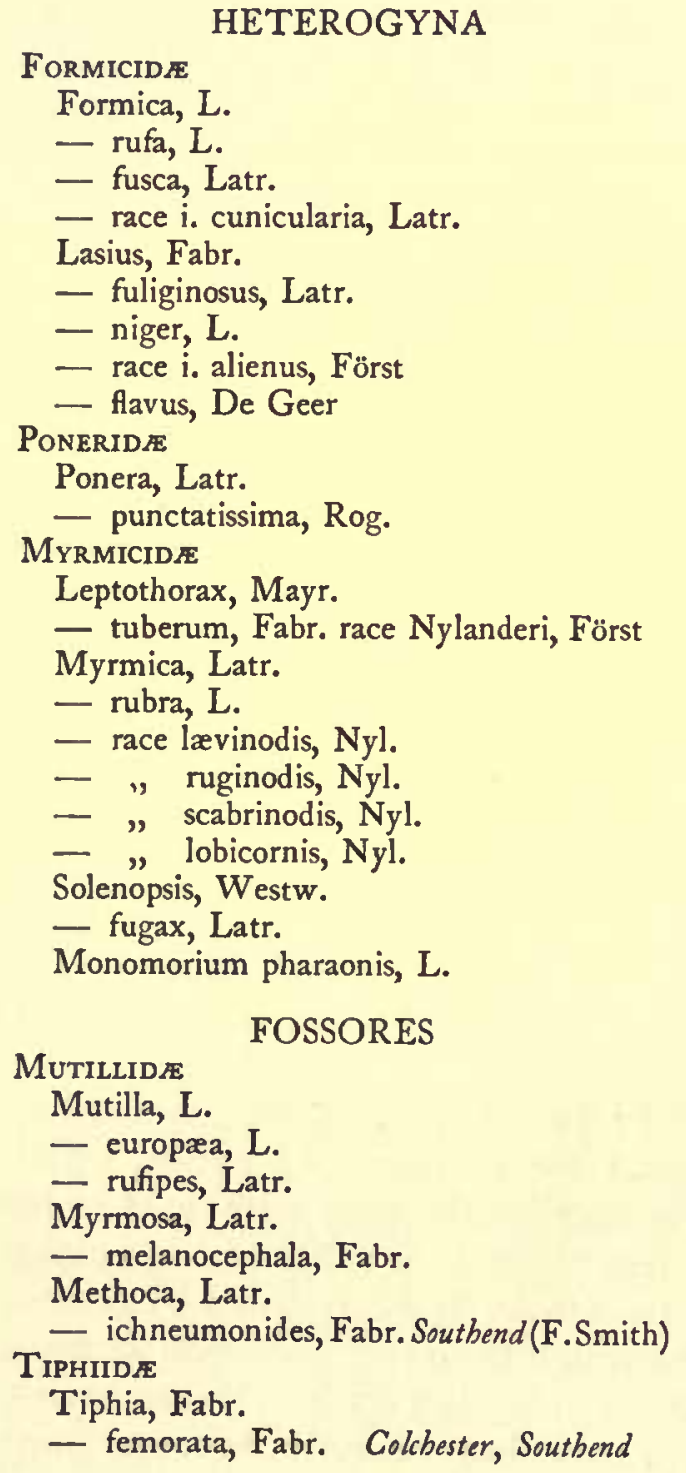

SAPYGIDE

Sapyga, Latr.

- quinque punctata, Fabr.

Pompilide

Pompilus, Fabr.

— unicolor, Spin.

- bicolor, Lep.

- rufipes, L.

- cinctellus, Spin.

- plumbeus, Fabr.

- consobrinus, Dahlb.

- minutulus, Dahlb.

- spissus, Schiödte

- chalybeatus, Schiödte

- gibbus, Fabr.

- unguicularis, Thoms.

- wesmaeli, Thoms.

- pectinipes, V. de Lind.

Salius, Fabr.

- fuscus, L.

- affinis, V. de Lind. Southend (F. Smith)

- exaltatus, Fabr.

- pusillus, Schiödte.

- parvulus, Dahlb.

Calicurgus, Lep.

- hyalinatus, Fabr.

Pseudagenia, Kohl.

- carbonaria, Scop.

Agenia, Schiödte.

- hircana, Fabr.

Ceropales, Latr.

- maculata, Fabr.

SPHEGIDE

Astatus, Latr.

- boops, Schr.

Tachytes, Pz.

- unicolor, $\mathrm{Pz}$.

- pectinipes, $\mathrm{L}$. 


\section{INSECTS}

SPHEGIDF (continued)

Trypoxylon, Latr.

- figulus, $\mathrm{L}$.

- clavicerum, Lep.

- attenuatum, Smith

Ammophila, Kirb.

- sabulosa, L.

- lutaria, Fabr. St. Osyth and Southend

Stigmus, Jur.

- solskyi, Moraw.

Pemphredon, Latr.

- lugubris, Latr.

- shuckardi, Moraw.

- wesmaeli, Moraw.

- lethifer, Shuck.

- morio, V. de Lind.

Diodontus, Curt.

- minutus, Fabr.

- tristis, V. de Lind.

Passaløecus, Shuck.

- corniger, Shuck.

- insignis, V. de Lind.

- monilicornis, Dhlb.

Mimesa, Shuck.

- equestris, Fabr.

- bicolor, Fabr.

- dahlbomi, Wesm.

Psen, Latr.

- pallipes, Pz.

Gorytes, Latr.

- tumidus, Pz.

- mystaceus, L.

- campestris, L.

Hoplisus, Lep.

- quadrifasciatus, Fabr.

- bicinctus, Rossi

Nysson, Latr.

- spinosus, Fabr.

- trimaculatus, Rossi

- dimidiatus, Jur.

Didineis, Wesm.

- lunicornis, Fabr.

Mellinus, Fabr.

- arvensis, L.

Philanthus, Fabr.

- triangulum, Fabr. Smith)

Cerceris, Latr.

- ornata, Schæff.

- quadricincta, Pz.

- arenaria, L.

- interrupta, Pz.

- labiata, Fabr.

Oxybelus, Latr.

- uniglumis, L.

- mucronatus, Fabr.

Crabro, Fabr.

- tibialis, Fab.

- clavipes, L.

- leucostomus, L.
SPHEgIDF (continued)

Crabro pubescens, Shuck.

- capitosus, Shuck.

- podagricus, V. de Lind.

- palmarius, Schreb. Southend

- palmipes, L.

- varius, Lep.

- wesmaeli, V. de Lind.

- elongatulus, V. de Lina.

- quadrimaculatus, Dhlb.

- signatus, Pz.

- vagabundus, $\mathrm{Pz}$.

- cephalotes, Pz.

- chrysostomus, Lep.

- vagus, L.

- cribrarius, L.

- interruptus, De G.

- lituratus, Pz.

- albilabris, Fabr.

Entomognathus, Dahlb.

- brevis, V. de Lind.

VESPIDF

\section{DIPLOPTERA}

Vespa, L.

- crabro, L.

- vulgaris, L.

- germanica, Fabr.

- rufa, L.

- sylvestris, Scop.

- norvegica, Fabr.

EUMENIDF

Odynerus, Latr.

- spinipes, L.

- melanocephalus, Gmel.

- reniformis, Gmel.

- callosus, Thoms.

- parietum, L.

- pictus, Curt.

- trimarginatus, Zett.

- trifasciatus, Oliv.

- parietinus, L.

- antilope, Pz.

- crassicornis, Pz.

- gracilis, Brullé

Snaresbrook (F. - sinuatus, Fabr.

\section{ANTHOPHILA}

\section{OBtusilingues}

Colletide

Colletes, Latr.

- succincta, L.

- fodiens, Kirb.

- picistigma, Thoms.

- marginata, Smith

- daviesana, Smith

Prosopis, Fab.

- communis, Nyl.

- signata, Pz.

- hyalinata, Smith 


\section{A HISTORY OF ESSEX}

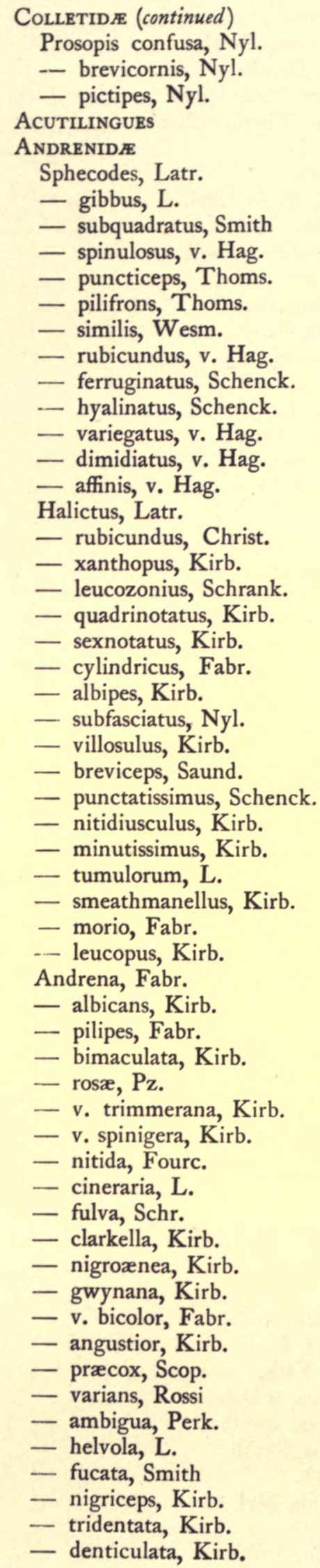

ANDRENIDE (continued)

Andrena fulvicrus, Kirb.

- fasciata, Nyl.

- hattorfiana, Fabr.

- cetii, Schr.

- cingulata, Fabr.

— albicrus, Kirb.

- chrysoceles, Kirb.

- coitana, Kirb.

- fulvago, Christ.

- humilis, Imhoff.

- labialis, Kirb.

- minutula, Kirb.

- nana, Kirb.

- dorsata, Kirb.

- similis, Smith

- wilkella, Kirb.

- afzeliella, Kirb.

Cilissa, Leach

- hæmorrhoidalis, Fabr.

- leporina, Pz.

Dasypoda, Latr.

- hirtipes, Latr.

Nomada, Fabr.

- obtusifrons, Nyl.

- solidaginis, Pz.

- sexfasciata, Pz.

- succincta, Pz.

- lineola, Pz.

- alternata, Kirb.

- jacobææ, Pz.

- ruficornis, L.

- bifida, Thoms.

- borealis, Zett.

- ochrostoma, Kirb.

- armata, H. Schff.

- ferruginata, Kirb.

- fabriciana, L.

- flavoguttata, Kirb.

- furva, Pz.

APIDF

Epeolus, Latr.

- productus, Thoms.

- rufipes, Thoms.

Ceratina, Latr.

- cyanea, Kirb.

Chelostoma, Latr.

- florisomne, L.

- campanularum, Kirb.

Coelioxys, Latr.

- rufescens, Lep.

- elongata, Lep.

- acuminata, Nyl.

Megachile, Latr.

- maritima, Kirb. St. Osyth, Southend

- willoughbiella, Kirb.

- circumcincta, Lep.

- ligniseca, Kirb.

- centuncularis, L.

- versicolor, Smith 


\section{INSECTS}
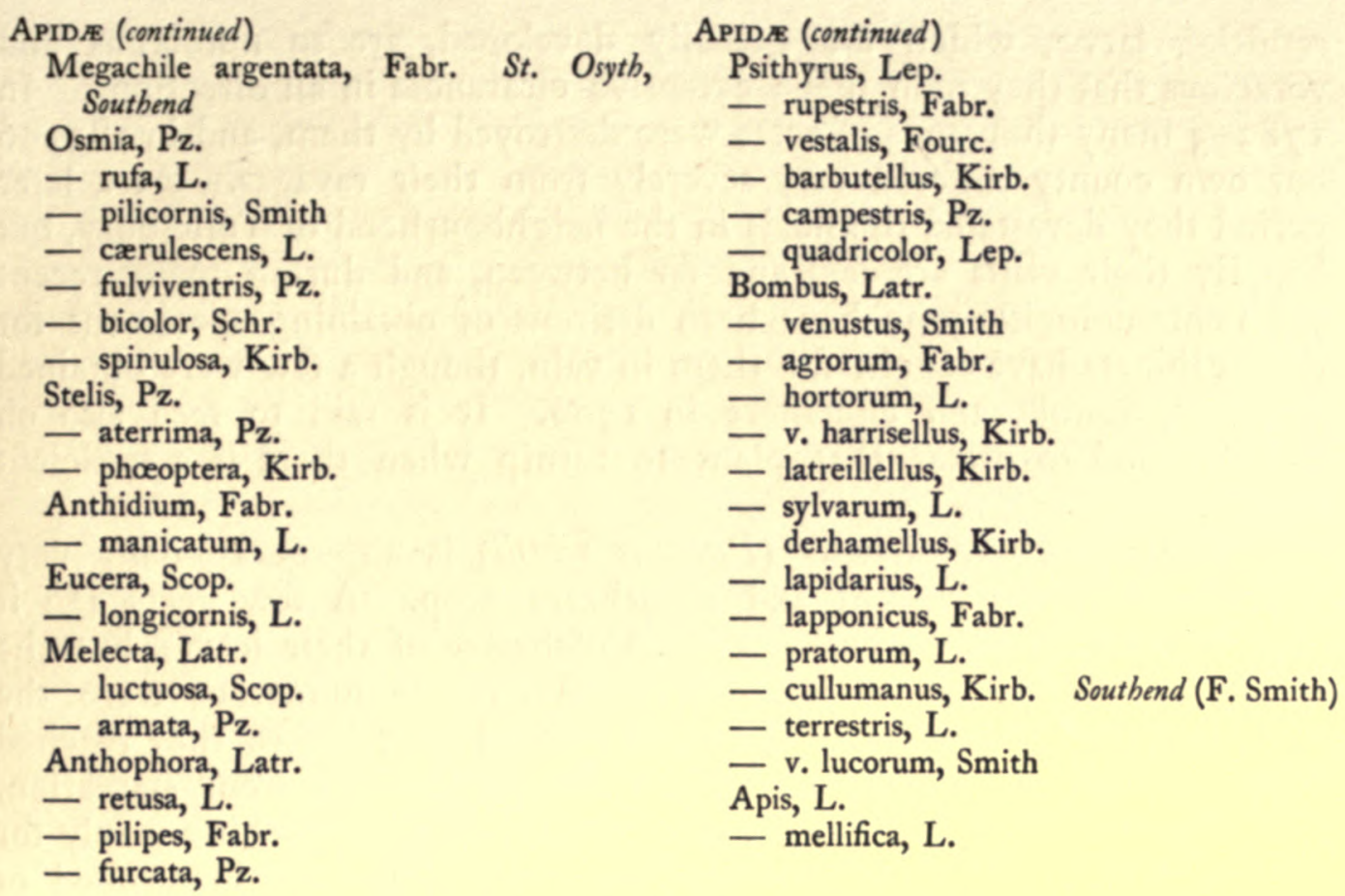

\section{PHYTOPHAGA}

The Phytophagous Hymenoptera comprise the Sawflies (Tentbredinida) and their allies, and the great majority of the Gallflies (Cynipida). The females of these insects have the ovipositor modified into a saw or borer, and in some cases into an instrument which combines the properties of saw, lance and file all in one ; for they vary considerably in their structure according to the work which they have to do, such species as deposit their ova in hard woody substances requiring stronger implements than those which simply make incisions between upper and lower leaf surfaces. As the name implies they are as a rule plant feeders in the larval state, and the majority feed up during the summer and autumn and appear in the perfect state during the following spring, but some are to be met with much later in the season, and Emphytus serotinus is often abundant on herbage under oak trees during fine weather in October. The early species may be found on leaves and at the flowers of various plants, the Umbellifer a being especially attractive to them. Angelica sylvestris is also a great favourite with those which appear in the late summer and autumn. So far as our present knowledge goes, we have about 400 Sawflies in Britain, but many of them are extremely local or excessively rare, and as the great majority of the individuals are females they are not nearly so much in evidence as many other insects, and consequently they rarely do much damage to vegetation in ordinary seasons. Occasionally however certain among them appear in immense numbers and prove harmful to particular crops. Prominent among these is the Turnip Sawfly, Atbalia spinarum, of which vast migratory swarms sometimes invade our shores, and dispersing themselves over considerable tracts of country proceed to lay their eggs on the turnip leaves, and the 


\section{A HISTORY OF ESSEX}

resulting larvæ, which are speedily developed, are so numerous and voracious that they soon make extensive clearances in all directions. In 1 782-3 many thousands of acres were destroyed by them, and in I 835-6 our own county suffered very severely from their ravages. At a later period they devastated the fields in the neighbourhood of Tollesbury, but happily their visits are few and far between, and during many recent years entomologists who have been desirous of obtaining specimens for their cabinets have sought for them in vain, though a few were obtained in Essex, Suffolk and elsewhere in I900. It is said to feed also on charlock and to prefer that plant to turnip when there is a sufficient supply.

The Gooseberry Sawfly (Pteronus ribesii) is also occasionally very destructive to the currant and gooseberry crop. A few years ago it entirely denuded all the bushes about Colchester of their leaves, but the disease speedily produced its own remedy, for so numerous were the larvæ that they consumed all the available food long before they reached maturity, and apparently the whole brood perished from starvation. After leaving the naked bushes they wandered about seeking vainly for food elsewhere, and at this time the pathways in the neighbourhood of market gardens were black with their dead bodies, which for several days emitted a sickly odour that compelled attention.

Another species (Hoplocampa testudinea) deposits its eggs in the apple blossom, and the larvæ feed in the young fruit, causing it to fall when about half-grown. Probably the damage thus done is generally set down to the Codling Moth (Carpocapsa pomonella) for both feed after a similar fashion; the Sawfly however does not seem to be very abundant, at least in north Essex, and has only been found there in the early summer fruit. As soon as the fruit falls to the ground the larvæ proceed to make themselves scarce, so that many apples may be opened and few larvæ found, and as these are by no means easy to rear, the insect is very scarce in collections and probably few entomologists have ever seen it.

The Corn Sawfly (Cepbus pygmaus) is another insect with an evil reputation on the continent, its larvæ feed in the interior of corn stems, but any damage they may do in this country is seldom if ever brought home to them, though seeing how very abundant the perfect insect is in our own fields in the early summer, one would think it must be to some extent injurious. The two species of Sirex (S. gigas and $S$. juvencus) are large handsome insects with powerful ovipositors adapted for boring into the solid wood of fir trees, to which they are accused of being very destructive. In this country they are far from common, and though they are sometimes met with about Colchester they never there attack healthy standing trees, but only such as are dying or have been felled. No doubt they do attack larch and spruce posts and take possession of any trees that have been left unduly long on the ground after they have been felled, and speedily render these good for nothing but firewood. Many of the Sawflies are very beautiful, and the problems connected 


\section{INSECTS}

with their life history are so intensely interesting that they are well worthy of far greater attention than they have hitherto received. It has been already stated that the females greatly outnumber the males, but in many cases the males are quite unknown and in some species only females are believed to be produced. Parthenogenesis is extremely common among them, and though in some instances ova deposited by virgin females have produced males, as a rule such ova produce only females, and it has been abundantly proved that these possess the faculty of reproducing their like without any male assistance for an indefinite number of generations.

Among the more noteworthy species found in the county, attention may be drawn to those of the very handsome genera Lyda, Abia and Arge, which are well represented. Three species of Dolerus (D. rugulosus, $D$. fumosus and $D$. gibbosus) are as yet only known as British from examples captured near Colchester, where Loderus palmatus is occasionally found. The rare Macropbya rufipes is also worthy of mention, and Allantus flavipes is from a collector's point of view a good insect, as it is not often obtained in Britain and is scarce elsewhere. Several specimens were found on charlock flowers near Langham Lodge Wood many years ago, but none have occurred recently. The male of Strongylogaster cingulatus is accounted a rarity though the female is abundant, but one day in the spring of 1899 , in Donyland Wood, several males were captured before any females had been seen, which is contrary to Mr. Cameron's experience, as he states that though he has bred hundreds of females he only succeeded in getting one male, which curiously enough appeared some days after all the females of the same batch had emerged. As two of his virgin females produced fertile eggs he concludes that parthenogenesis plays a constant rôle with this species. Allantus zona is another scarce species which has occurred at St. Osyth.

The Gallfies (Cynipida) form those abnormal growths upon trees and plants of which the oakapple, the marble and woody galls of the oak, and the moss-like Bedeguar gall of the rose are familiar and conspicuous examples, but all gall-producing insects are not Hymenopterous, as many of them belong to other orders, such as the Gall-gnats (Cecidomyida) among the Diptera and certain of the Aphides and beetles.

The facts and problems connected with the reproduction of the Cynipida are even more interesting and complicated than in the case of the Tentbredinida, and though it is impossible to go fully into them here, it may be briefly stated that some insects which were formerly believed to be distinct are now known to be different forms of the same species, which inhabit totally dissimilar galls and appear at different times of the year, the earlier brood consisting of both males and females and the later brood of females only, which lay fertile eggs and produce the bisexual brood of the following season.

But besides this alternation of generations, there are other species which are well known to be single brooded and which consist of females only, for though they have been bred by hundreds of thousands by different investigators, all endeavours to discover the males have been 


\section{A HISTORY OF ESSEX}

unavailing, and among other theories it has been suggested that in their case males formerly existed, but owing to the increase in the faculty of virgin reproduction they have ceased to be produced, being no longer necessary.

There is a very able and valuable paper on the ' Galls of Essex' by Mr. Fitch in the Transactions of the Essex Field Club (ii. 98-156), which deals with all the gall-feeding insects, and to which the reader who desires further information can be confidently referred.

In the following list of Tentbredinida some names will be found which do not appear in Cameron's Phytophagous Hymenoptera. Certain of these belong to species which were not known as British when that work was written, and in other cases it has been deemed advisable to follow the more recent classification and nomenclature of Konow, which is partially adopted in Cameron's fourth volume. Some of the Sawflies are extremely difficult to determine correctly, and all such have been submitted either to the Rev. F. D. Morice or Pastor Konow, to whom we are indebted for much of the most recent work done in the group here and on the continent. All the Tentbredinida named below have been found in the Colchester district with one exception, for which the locality is given. The list of Cynipide is taken from Mr. Fitch's 'Galls of Essex.'

\section{A LIST OF THE PHYTOPHAGOUS HYMENOPTERA OCCURRING IN} THE COUNTY

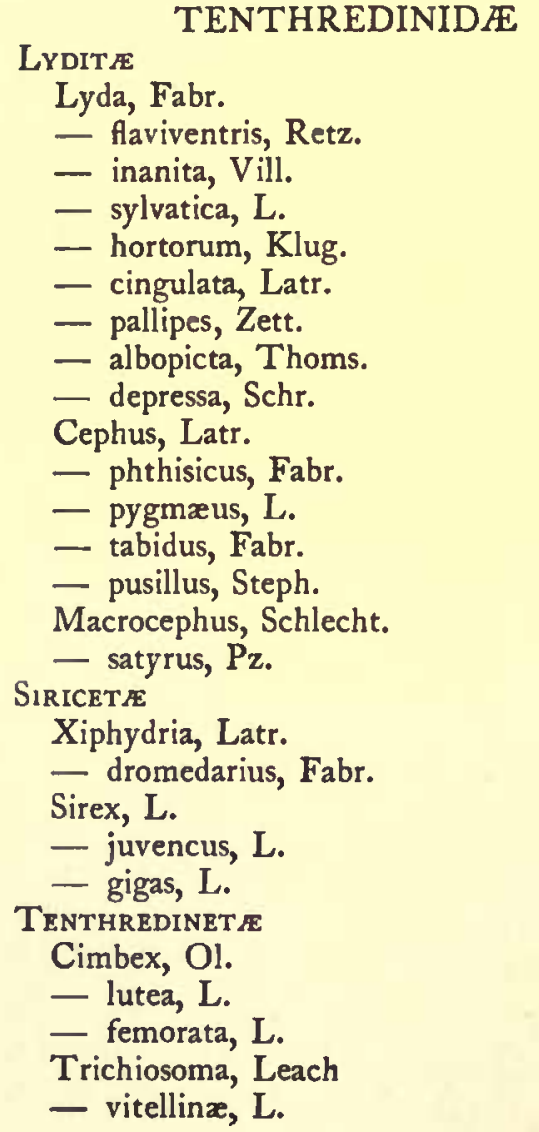

Tenthredineta (continued)

Trichiosoma betuleti, Klug.

Abia, Leach

- fasciata, $L$.

- sericea, L.

Arge, Schr.

— enodis, L.

- gracilicornis, Klug.

- fuscipes, Fall.

- ustulata, $\mathrm{L}$.

- pagana, $\mathrm{Pz}$.

- cyanocrocea, Först.

- rosæ, De Geer

Lophyrus, Latr.

- sertiferus, Fourc.

Cladius, Ill.

- pectinicornis, Fourc.

Trichiocampus, Htg.

- viminalis, Fall.

- rufipes, Lep.

- eradiatus, Htg.

Priophorus, Latr.

- padi, L.

Leptopus, Htg.

- luridiventris, Fall.

Hemichroa, Steph.

- alni, L.

- rufa, Pz.

Dineura, Dhlb.

- stilata, Klug. 
INSECTS

Tenthredineta (continued)

Cryptocampus, Htg.

- amerinæ, L.

Pontania, Costa

- leucosticta, $\mathrm{Htg}$.

- vallisnierii, Htg.

- xanthogastra, Först.

Pteronus, Jur.

- pavidus, Lep.

- miliaris, Pz.

- salicivorus, Cam.

- curtispinus, Thoms.

- virescens, Htg.

- melanaspis, Htg.

- nigricornis, Lep.

- hortensis, Htg.

- myosotidis, Fabr.

- leucotrochus, Htg.

- ribesii, Scop.

- melanocephalus, $\mathrm{Htg}$.

- salicis, L.

Amauronematus, Knw.

- histrio, Lep.

- leucolenus, Zadd.

- viduatus, Zett.

Crœesus, Leach

- septentrionalis, L.

- latipes, Vill.

- varus, Vill.

Holcocneme, Knw.

- crassa, Fall.

- cœruleocarpa, Htg.

- lucida, Pz.

Nematus, Jur.

- abdominalis, Pz. luteus, $\mathrm{Pz}$.

- acuminatus, Thoms.

Pachynematus, Knw.

- capreæ, Pz.

- einersbergensis, Htg.

- xanthocarpus, Htg.

Pristiphora, Latr.

- betulæ, Retz.

- quercus, Htg.

- appendiculata, Htg.

- ruficornis, Ol.

Eriocampoides, Knw.

- cinxius, Klug.

- varipes, Klug.

- annulipes, Klug.

- limacinus, Retz.

Hoplocampa, Htg.

- cratægi, Klug.

- pectoralis, Thoms.

- testudinea, Klug.

Mesoneura, Htg.

- verna, Klug.

Periclista, Knw.

- melanocephala, Fabr.

Pareophora, Knw.
Tenthredinete (continued)

Pareophora nigripes, Klug.

Tomostethus, Knw.

- nigritus, Fabr.

- fuliginosus, Schr.

- dubius, Gmel.

- luteiventris, Klug.

Blennocampa, Htg.

- assimilis, Fall.

- pusilla, Klug.

- subcana, Zadd.

- tenuicornis, Klug.

Monophadnus, $\mathrm{Htg}$.

- geniculatus, Htg.

- ruficruris, Brullé

- albipes, Gmel.

Kaliosysphinga, Tischb.

- ulmi, Sundev. Stratford (Healy)

Athalia, Leach

- ancilla, Cam.

- spinarum, Fabr.

- rosæ, L.

- lugens, Klug.

-- annulata, Fabr.

Selandria, Klug.

- serva, Fabr.

— sixii, Voll.

- stramineipes, Klug.

- aperta, Htg.

Thrinax, Knw.

- macula, Klug.

Strongylogaster, Dhlb.

- cingulatus, Fabr.

Eriocampa, Htg.

- ovata, L.

Pocilosoma, Thoms.

- pulverata, Retz.

- carbonaria, Knw.

- immersa, Klug.

- submutica, Thoms.

- excisa, Thoms.

- tridens, Knw.

Emphytus, Klug.

- succinctus, Klug.

- cinctus, L.

- togatus, Fabr.

- rufocinctus, Retz.

- calceatus, Klug.

- tibialis, Pz.

- serotinus, Klug.

- grossulariæ, Klug.

Taxonus, Htg.

- glabratus, Fall.

- equiseti, Fall.

- agrorum, Fall.

Dolerus, Jur.

- fulviventris, Klug.

- madidus, Klug.

- puncticollis, Thoms.

- gonager, Fabr. 


\section{A HISTORY OF ESSEX}

Tenthredinete (continued)

Dolerus picipes, Klug.

- nigritus, Müll.

- fumosus, Zadd.

- coruscans, Knw.

- gibbosus, Htg.

- niger, Klug.

- hæmatodes, Schr.

- rugulosus, v. D. Torre.

- æneus, Htg.

Loderus, Knw.

- palmatus, Klug.

- vestigialis, Klug.

Rhogogastera, Knw.

- picta, Klug.

- viridis, L.

- punctulata, Klug.

- lateralis, Fabr.

- aucupariæ, Klug.

Tenthredopsis, Costa

- coqueberti, Klug. var. cordata, Fourc. var. microcephala, Lep. var. femoralis, Steph. var. caliginosa, Steph. var. nigricollis, Cam.

- nassata, L.

- raddatzi, Knw.

- dorsalis, Lep.

- excisa, Thoms.

- litterata, Geoff.

- campestris, L.

- dorsivittata, Cam.

Pachyprotasis, Htg.

- variegata, Klug.

- antennata, Klug.

- rapæ, L.

Macrophya, Dhlb.

- rustica, L.

- rufipes, L.

- punctum-album, L.

- ribis, Schr.

- albicincta, Schr.

- 12-punctata, L.

- blanda, Fabr.

- neglecta, Klug.

Allantus, Jur.

- maculatus, Fourc.

- bicinctus, L.

- vespa, Retz.

- scrophulariæ, L.

- zona, Klug.

- cingulum, Klug.

- arcuatus, Först

- flavipes, Fourc.

Tenthredo, L.

- rufiventris, $\mathrm{Pz}$.

- atra, L.

- livida, L.
Tenthredinet F (continued)

Tenthredo solitaria, Scop.

- mesomela, L.

\section{CYNIPIDÆ}

Rhodites, Htg.

- eglanteriæ, Htg.

- rosæ, L.

- nervosa, Curt.

rosarum, Gir.

Aulax, Htg.

- glechomæ, Htg.

_ rhøeādis, Htg.

papaveris, Perris.

- hieracii, Bouché.

Xestophanes, Först

- potentillæ, Vill.

Diastrophus, Htg.

- rubi, Htg.

Andricus, Htg.

- ostreus, Gir.

$-\{$ fecundatrix, Htg.

- gemmæ, L.

$-\{$ globuli, Htg.

- inflator, Htg.

- radicis, Fabr.

- nnoduli, Htg.

- sieboldi, Htg.

- corticis, L.

- collaris, Htg.

- curvator, Htg.

- ramuli, L.

- autumnalis, L.

- quadrilineatus, $\mathrm{Htg}$.

cirratus, Adler.

\{callidoma, Gir.

- solitarius, Fonsc.

- albopunctatus, Schlecht.

Cynips, Htg.

- kollari, Htg.

Trigonaspis, Htg.

$-\left\{\begin{array}{l}\text { megaptera, } \mathrm{Pz} . \\ \text { renum, Gir. }\end{array}\right.$

Biorhiza, Westw.

- terminalis, Fabr. aptera, Fabr.

Dryophanta, Först

- folii, L.

- divisa, Htg.

- agama, Htg.

Neuroterus, Htg.

Slenticularis, Oliv. baccarum, L. fumipennis, Htg. tricolor, Htg. læaviusculus, Schr. $\{$ albipes, Schr. numismatis, Oliv. $\{$ vesicatrix, Schlecht. 


\section{INSECTS}

\section{ENTOMOPHAGA}

\section{Icbneumons and their Allies}

This group comprises several thousands of species, of which, though some are of moderate size, the great majority are very small and obscure, and in the present imperfect state of our knowledge the study of most of them is attended with considerable difficulty ; for while many are excessively variable, others though abundantly distinct are superficially so much alike, and their specific distinctions are so minute and so easily overlooked, that only a very few experts are able to determine them with certainty.

They are divided into several sections, which include the Cbrysidida, the Icbneumonida, the Braconida, the Evaniida, the Cbalcidida and the Proctotrupida. As a rule they are parasitic upon other insects, a large proportion of them passing their earlier stages in the larvæ of the Lepidoptera. The Cbrysidida or Ruby-tailed flies are not very numerous in Britain, and their proper place is perhaps rather with the Aculeata than the Entomophaga. They prey upon certain of the bees and wasps, laying their eggs in the burrows of their victims after the manner of the cuckoo bees. They are extremely beautiful insects, being resplendent with brilliant blue, green, crimson, burnished copper and other gorgeous colours. The Icbneumonida, Braconida and Evaniida deposit their eggs principally upon or in the larvæ and ova of the Lepidoptera, but they attack other insects and also spiders; and upon the efficient discharge of their important functions the welfare of the world depends to a far greater extent than the world generally is at present aware of. For if all insects were allowed to increase without let or hindrance, they would multiply at such a prodigious rate that every green leaf would speedily be devoured by them. It is quite true that other agencies, such as insectivorous birds, are also at work in keeping them in check, but it is probably not going too far to say that the birds are but the Sauls who slay their thousands while the ichneumons are the Davids who slay their tens of thousands. Nay, it is highly probable that by far the larger portion of those larvæ which are consumed by birds would perish in any case from the attacks of ichneumons, and more than possible that in many instances the attacks of birds, though immediately fatal to multitudes of individual larvæ, may be ultimately beneficial to the species to which they belong by the wholesale destruction of its far more inveterate and insidious foes.

But while of the innumerable larva that emerge from the egg very few escape from the attacks of the ichneumon, Nature is also careful of her children in more ways than one; for when a parasite becomes so numerous as to threaten the extinction of a race, it is very frequently itself preyed upon by a hyper-parasite, which attacks it after a similar fashion.

The Cbalcidida are for the most part extremely minute brilliantly coloured insects, with habits similar to those of the Icbneumonida. The 


\section{A HISTORY OF ESSEX}

Proctotrupide are still smaller and of soberer hues. They also appear to be largely parasitic, but with regard to the transformations of many of them more seems to be at present conjectured than is actually known.

Of course it is quite impossible to deal adequately with this important class of insects in a few brief paragraphs, and unfortunately we have at present no reliable monograph on any of its component sections. Much was done among the Cbalcidida, etc., by the late Mr. Francis Walker at Wanstead, who left behind him voluminous notes, which are now in Mr. Fitch's possession; but they require very careful revision before publication. Many pages could have been filled with Walker's names, but a mere list of names where no intelligible and reliable published accounts and descriptions exist would be worse than useless. Mr. Fitch, in conjunction with the late Mr. Bridgman, commenced a series of valuable outline descriptions of the Icbneumonida in the Entomologist for February, I 880, and continued them at intervals for several years, but unfortunately circumstances for a time prevented their completion. It is to be hoped that Mr. Fitch, who is still our leading British authority on the Entomophaga, and who is abundantly supplied with material and well equipped for the task in every way, will at no distant date be able to resume his labours, and obtain for this branch of British Entomology the high position which a few years ago it seemed so likely to take, and which of late it has appeared in such imminent danger of losing.

In the following list of Icbneumonide the species marked M. have only been identified from the Maldon district by Mr. Fitch. The others have all been obtained near Colchester, many being common to both districts. For the incompleted list of Braconida Mr. Fitch is solely responsible.

\section{A LIST OF THE ENTOMOPHAGOUS HYMENOPTERA OCCURRING IN} THE COUNTY

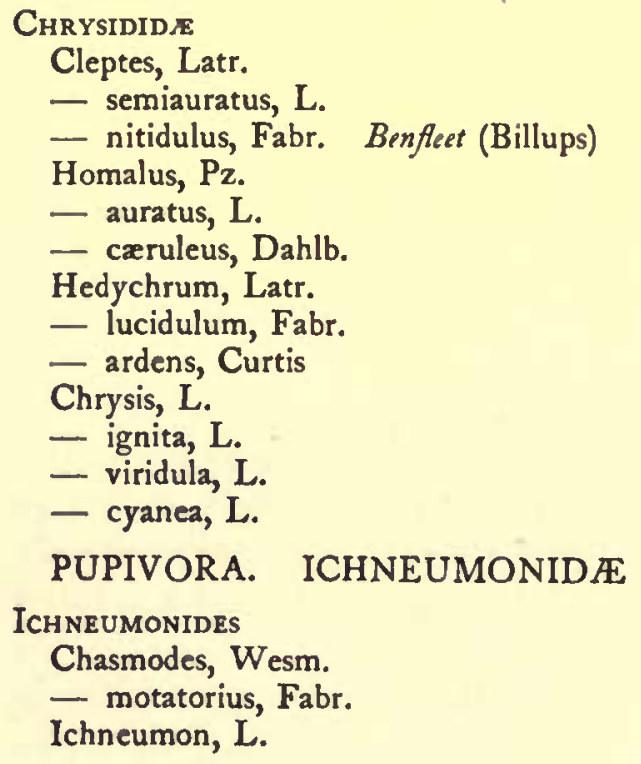

ICHNEUMONIDES (continued)

Ichneumon bilineatus, Gmel.

- sinister, Wesm.

- leucocerus, Gr.

- lineator, Fabr.

- impressor, Zett.

- derasus, Wesm.

- castaneiventris, Gr.

- fuscipes, Gmel. M.

- periscelis, Wesm.

- pistorius, Gr.

- trilineatus, Gmel.

- multiannulatus, Gr.

- molitorius, L.

- tempestivus, Holmgr. M.

- vaginatorius, $\mathrm{L}$.

- xanthorius, Forst

- confusorius, Gr.

- suspiciosus, Holmgr.

- gracilentus, Wesm. M. 


\section{INSECTS}

ICHNEUMONIDES (continued)

Ichneumon luctatorius, $\mathrm{L}$.

- latrator, Fabr.

- multipictus, Gr.

- primatorius, Först. M.

- gracilicornis, Gr.

- caloscelus, Wesm.

- variegatorius, $\mathrm{Pz}$.

- quæsitorius, L. M.

- analis, $\mathrm{Gr}$.

- saturatorius, L. M.

- faunus, Gr.

- nigritarius, Gr.

- fabricator, Fabr.

- curvinervis, Holmgr.

- pallidifrons, Gr.

- varipes, Gr.

- lanius, Gr.

- leucomelas, Gmel. M.

- vestigator, Wesm.

- lepidus, Gr.

- octoguttatus, Gr.

- anator, Fabr. M.

- ruficeps, Gr.

- albifrons, Ste.

- obator, Desv.

Hoplismenus, Gr.

- perniciosus, Gr.

Limerodes, Wesm.

- arctiventris, Boie.

Amblyteles, Wesm.

- palliatorius, Gr. M.

- armatorius, Först

- oratorius, Fabr.

- flavocinctus, Desv.

- notatorius, Fabr.

- subsericans, Gr.

- crispatorius, L.

- glaucatorius, Fabr.

- occisorius, Fabr.

- negatorius, Fabr.

- uniguttatus, Gr.

- castanopygus, Ste.

- castigator, Fabr.

- fossorius, $\mathrm{Gr}$.

- divisorius, Gr.

- messorius, Gr.

- funereus, Fourc.

- proteus, Christ. M.

- fusorius, L.

- alticola, Gr.

Trogus, Pz.

- lutorius, Fabr. M.

- exaltatorius, Pz. M.

Eurylabus, Wesm.

- torvus, Wesm.

- dirus, Wesm. M.

- tristis, Gr.

Platylabus, Wesm.

- rufus, Wesm.
ICHNEUMONIDES (continued)

Platylabus orbitalis, Gr.

- tricingulatus, Gr.

- dimidiatus, Gr.

- nigricollis, Wesm. M.

Herpestomus, Wesm.

- brunnicornis, $\mathrm{Gr}$.

Colpognathus, Wesm.

- celerator, Gr.

Dicœlotus, Wesm.

- pumilus, Gr.

Phæogenes, Wesm.

- melanogonus, Gmel. M.

- scutellaris, Wesm.

- calopus, Wesm. M.

- fulvitarsis, Wesm. M.

- ischiomelinus, Gr.

Alomyia, Pz.

- debellator, Fabr.

CRYPTIDES

Stilpnus, Gr.

- gagates, Gr. M.

- pavoniæ, Scop. M.

Phygadeuon, Gr.

- variabilis, Gr. M.

- fumator, Gr. M.

- troglodytes, Gr. M.

- jejunator, Gr. M.

- vagans, Gr. M.

- erythrogaster, Gr. M.

- hopei, Marshall

- vagabundus, Gr.

- cinctorius, Fabr.

- quadrispinus, $\mathrm{Gr}$.

- abdominator, Gr. M.

- jucundus, Gr. M.

- procerus, Gr.

Cryptus, Fabr.

- viduatorius, Fabr.

- tarsoleucus, Schr.

- moschator, Fabr.

- cyanator, Gr.

- parvulus, Gr.

- anatorius, Gr. M.

- attentorius, Schæf.

- titillator, Gr.

- albatorius, Vill.

- dianæ, Gr.

- obscurus, Gr.

- analis, Gr. M.

- leucotarsus, Gr.

- peregrinator, L. M.

- migrator, Fabr.

- cimbicis, Tschck.

- pygoleucus, Gr. M.

- signatorius, Fabr. M.

Mesostenus, Gr.

- obnoxius, Gr. M.

- ligator, Gr.

Hemiteles, Gr. 


\section{A HISTORY OF ESSEX}

Cryptides (continued)

Hemiteles furcatus, Tasch. M.

- tenebricosus, Gr. M.

- micator, Gr. M.

- oxyphimus, Gr. M.

- crassicornis, Gr. M.

- similis, Gr. M.

- fulvipes, Gr. M.

- formosus, Desv.

- bicolorinus, Gr. M.

- æstivalis, Gr. M.

- areator, $\mathrm{Pz}$.

- inimicus, Gr. M.

- floricolator, Gr. M.

- fragilis, Gr.

- cingulator, Gr. M.

Cecidonomus, Bridg.

- westoni, Bridg. M.

- gallicola, Bridg. M.

Orthopelma, Tasch.

- luteolator, Gr. M.

Agrothereutes, Först

- hopei, Gr.

Aptesis, Först

- nigrocincta, $\mathrm{Gr}$.

Hemimachus, Ratz.

- rufocinctus, Gr. M.

- fasciatus, Fabr.

Pezomachus, Gr.

- tener, Först. M.

- ochraceus, Först. M.

- corruptor, Först. M.

— viduus, Först

- transfuga, Först

- insolens, Först. $M$.

- xylocophilus, Först

- analis, Först. M.

- nigricornis, Först

- intermedius, Först

OPHIONIDES

Henicospilus, Ste.

- merdarius, Gr. M.

- ramidulus, L.

- combustus, Gr.

- repentinus, Holmgr.

Ophion, Fabr.

- obscurum, Fabr.

- luteum, L.

- minutum, Kriechb. M.

- ventricosum, Gr.

Schizoloma, Wesm.

- amicta, Fabr.

Heteropelma, Wesm.

- calcator, Wesm.

Anomalon, Jurine

- xanthopus, Schr. M.

- mirabile, Desv.

- bellicosum, Wesm. M.

- cerinops, Gr.

- fibulator, Gr.
OpHIONIDEs (continued)

Anomalon tenuitarsum, $\mathrm{Gr}$.

- clandestinum, Gr. $M$.

- anomelas, Grav.

- cylindricum, Bridg. M.

- melanobatum, Gr. M.

Agrypon, Först

- flaveolatum, $\mathrm{Gr}$.

- tenuicorne, Gr.

- canaliculatum, Ratz.

Trichomma, Wesm.

- enecator, Rossi

Paniscus, Schr.

- cephalotes, Holmgr. M.

- virgatus, Fourc.

- testaceus, Gr.

- tarsatus, Brischke.

- fuscicornis, Holmgr. M.

Absyrtus, Holmgr.

- luteus, Holmgr.

Campoplex, Gr.

- mixtus, Gr.

- bucculentus, Holmgr. M.

- erythrogaster, Först. M.

- carinifrons, Holmgr.

- falcator, Thunb. M.

- ebeninus, Gr.

- oxyacanthæ, Boie. M.

- tenuis, Först. M.

- eurynotus, Först. M.

- punctatus, Bridg. $M$.

- costulatus, Bridg. $M$.

Sagaritis, Holmgr.

- zonata, $\mathrm{Gr}$.

- postica, Bridg. M.

Casinaria, Holmgr.

- orbitalis, Gr. M.

- vidua, Gr. $M$.

Limneria, Holmgr.

- crassicornis, Gr.

— elishæ, Bridg. M.

- ensator, Gr.

- erucator, Zett. $\quad M$.

- exareolata, Ratz. M.

- faunus, Gr. M.

- geniculata, Gr.

- interrupta, Holmgr. M.

- longipes, Mull.

- majalis, Gr.

- mutabilis, Holmgr.

- rapax, Gr.

- rufipes, Gr. M.

- ruficincta, $\mathrm{Gr}$.

- tibialis, Gr. M.

- vestigialis, Ratz. M.

- vulgaris, Tschck. M.

- virginalis, Gr. M.

Atractodes, Gr.

- bicolor, Gr.

Exolytus, Holmgr. 


\section{INSECTS}

OPHIONIDES (continued)

Exolytus lævigatus, Gr.

Mesochorus, Gr.

- sylvarum, Hal.

- (?) pictilis, Holmgr.

Collyria, Schiödte

- calcitrator, Gr.

Exetastes, Gr.

- osculatorius, Fabr.

- guttatorius, $\mathrm{Gr}$.

- albitarsus, Gr.

Banchus, Fabr.

- variegator, Fabr.

- falcator, Fabr.

- moniliatus, $\mathrm{Gr}$.

\section{TRYPHONIDES}

Mesoleptus, Gr.

- insolens, Gr.

- sternoleucus, Gr.

Catoglyptus, Holmgr.

- fuscicornis, Gmel.

Euryproctus, Holmgr.

- atomator, Gr.

Perilissus, Holmgr.

- prærogator, Gr.

Mesoleius, Holmgr.

- aulicus, Gr.

- caligatus, Gr.

- alacer, Gr.

- niger, Gr.

- insolens, Gr.

Trematopygus, Holmgr.

- procurator, Gr.

Tryphon, Fallén.

- elongator, Fabr.

- rutilator, L.

- trochanteratus, Holmgr.

Eumesius, Westw.

- albitarsus, Cur.

Polyblastus, Hart.

- varitarsus, Gr.

Acrotomus, Holmgr.

- lucidulus, $\mathrm{Gr}$.

Cteniscus, Hal.

- mesoleptoides, Ste.

- apiarius, Gr.

Colpotrochia, Holmgr.

- elegantula, Schr.

Exochus, Gr.

- alpinus, Zett.

Bassus, Fabr.

- lætatorius, Fabr.

- nigritarsus, Gr.

Metopius, Pz.

- dissectorius, Pz.

\section{Prmplides}

Rhyssa, Gr.

- persuasoria, $\mathrm{L}$.

Ephialtes, Gr.

- imperator, Kriechb.
Pimplides (continued)

Ephialtes rex, Kriechb.

Perithous, Holmgr.

- mediator, Fabr.

- varius, Gr.

Pimpla, Fabr.

- instigator, Fabr.

- examinator, Fabr.

- turionellæ, L.

- rufata, Gmel.

- flavonotata, Holmgr.

- roborator, Fabr.

- scanica, Vill.

- oculatoria, Fabr.

- arctica, Zett.

- graminellæ, Schr.

- stercorator, Fabr.

- brevicornis, Gr.

Glypta, Gr.

- monoceros, Gr.

- ceratites, Gr.

- lugubrina, Holmgr.

- incisa, Gr.

- bifoveolata, $\mathrm{Gr}$.

- rubicunda, Bridg.

Lampronota, Hal.

- caligata, Gr.

Lissonota, Gr.

- parallela, Gr.

- decimator, Gr.

- bellator, Gr.

- cylindrator, Vill.

- sulphurifera, Gr.

- semirufa, Desv.

Meniscus, Schiödte

- setosus, Fourc.

- impressor, Gr.

- bilineatus, Gr.

- murinus, Gr.

Phytodiaetus, Gr.

- plantarius, Gr.

- segmentator, Gr.

\section{BRACONID压}

Bracon, Fabr.

- pectoralis, Wesm.

- erythrostictus, Marshall

- minutator, Fabr.

- fulvipes, Nees

- longicollis, Wesm.

- variegator, Nees

- stabilis, Wesm.

- brevicornis, Wesm.

- erraticus, Wesm.

- lævigatus, Ratz.

- mediator, Nees

- fuscicoxis, Wesm.

- tornator, Marshall

- satanas, Wesm.

- epitriptus, Marshall 


\section{A HISTORY OF ESSEX}

BRACONIDE (continued)

Bracon prætermissus, Marshall

- colpophorus, Wesm.

- discoideus, Wesm.

- regularis, Wesm.

- terebella, Wesm.

- otiosus, Marshall

- variator, Nees

- obscurator, Nees

- anthracinus, Nees

- bisignatus, Wesm.

Phanomeris, Först

- fragilis, Hal.

Bathystomus, Först

- funestus, Hal.

Rhysipolis, Först

- mediator, Hal.

Rhyssalus, Hal.

- indagator, Hal.

Colastes, Hal.

- braconius, Hal.

Oncophanes, Först

- lanceolator, Nees

Spathius, Nees

- exarator, L.

Hecabolus, Curt.

- sulcatus, Curt.

Coloides, Wesm.

- melanotus, Wesm.

Chremylus, Hal.

- rubiginosus, Nees

Hormius, Nees

- moniliatus, Nees

Clinocentrus, Hal.

- exsertor, Nees

Pelecystoma, Wesm.

- lutea, Nees

Rhogas, Nees

- irregularis, Wesm.

- tristis, Wesm.

- bicolor, Spin.

- nigricornis, Wesm.

- circumscriptus, Nees

- armatus, Wesm.

- testaceus, Spin.

Sigalphus, Latr.

- floricola, Wesm.

- obscurellus, Nees

- luteipes, Thoms.

Chelonus, Jurine

- inanitus, L.

- submuticus, Wesm.

- wesmaelii, Curt.

- carbonator, Marshall

- oculator, Fabr.

- canescens, Wesm.

- parcicornis, Schaff.

- sulcatus, Nees

- latrunculus, Marshall

Ascogaster, Wesm.
BRACONIDE (continued)

Ascogaster instabilis, Wesm.

- annularis, Nees

- rufipes, Latr.

- rufideus, Wesm.

- varipes, Wesm.

- armatus, Wesm.

- quadridentatus, Wesm.

Mirax, Hal.

- spartii, Hal.

Accelius, Hal.

- subfasciatus, Hal.

Apanteles, Först

- ruficrus, Hal.

- ordinarius, Ratz.

- congestus, Nees

- analis, Nees

- rubripes, Hal.

- glomeratus, L.

- sericeus, Nees

- spurius, Wesm.

- jucundus, Marshall

- caiæ, Bouché

— juniperatæ, Bouché

- difficilis, Nees

- lætus, Marshall

- falcatus, Nees

- cultrator, Marshall

- ultor, Reinh.

- xanthostigmus, Hal.

- emarginatus, Nees

- albipennis, Nees

- impurus, Nees

- coniferæ, Hal. ?

- longicaudis, Wesm.

- abjectus, Marshall

- pallidipes, Reinh.

- bicolor, Nees

- lateralis, Hal.

- fulvipes, Hal.

Microplitis, Först

- spinola, Nees

- ocellatæ, Bouché

- tristis, Nees

- dolens, Marshall

- spectabilis, Hal.

- mediator, Hal.

- tuberculifera, Wesm.

Microgaster, Latr.

- alvearius, Fabr.

- connexus, Nees

- tiro, Reinh.

- russatus, Hal.

- rugulosus, Nees

- subcompletus, Nees

- globatus, Nees

- tibialis, Nees

Earinus, Wesm.

- gloriatorius, $\mathrm{Pz}$.

Microdus, Nees 


\section{INSECTS}

BRACONIDE (continued)

Microdus cingulipes, Nees

- mediator, Nees

Orgilus, Hal.

- obscurator, Nees

Euphorus, Nees

- pallidipes, Curt.

- similis, Curt.

- intactus, Hal.

- apicalis, Curt.

Microctonus, Wesm.

- cultus, Marshall

Meteorus, Hal.

- albiditarsus, Curt.

- chrysophthalmus, Nees

- caligatus, Hal.

- ictericus, Nees

- obfuscatus, Nees

- jaculator, Hal.
BRACONIDE (contimued)

Meteorus atrator, Curt.

- albicornis, Ruthe

- abdominator, Nees

- micropterus, Hal.

- pulchricornis, Wesm.

- scutellator, Nees

- unicolor, Wesm.

- consors, Ruthe

- ictericus, Nees

Proterops, Wesm. - nigripennis, Wesm.

Zele, Curt.

- testaceator, Curt.

Macrocentrus, Curt.

- thoracicus, Nees

EvanIDE

Fœnus, Fabr.

- assectator, $\mathrm{L}$.

\section{COLEOPTERA}

\section{Beetles}

Though the Coleoptera of Essex have not received anything like so large a share of attention from entomologists as the Lepidoptera, owing to its proximity to London, the county, and especially its southern portion, has at various times attracted many of our best workers, who have found within it a considerable number of the rarer and more interesting British species; and more recently the north-eastern portion has been extensively investigated with some notable results.

As the order is such a very large one, and as very many of the species included in it are exceedingly minute, it is impossible at present to supply a complete county list ; but from that which follows anybody competent to form an opinion will see that much good work has been done, and that the workers have not been without their substantial reward.

Unfortunately, owing to the curtailment of the ancient forests of Epping and Hainault, the total disappearance of extensive woods and heaths elsewhere, and the sweeping changes that have been going on in all directions, many good insects which probably occurred in the county formerly have not been found in recent years; and seeing that the accounts which have come down to us concerning them are now considered to belong rather to the domain of tradition than of history, they cannot be suitably dealt with here. But among the more noteworthy species which ought to be mentioned are Dyscbirius extensus, which has recently been found on the coast near Clacton-on-Sea. The two handsome species of Panagaus, crux-major and quadripustulatus, are also occasionally met with, the former at Colchester and the latter on coast sands. The rare Stenolopbus elegans, Harpalus melancholicus and $H$. servus have occurred at Southend, and the last has also several times been taken at 


\section{A HISTORY OF ESSEX}

St. Osyth. The scarce Sphodrus leucopbtbalmus is occasionally found in cellars and outhouses at Colchester, and the extremely local Aëtophorus imperialis frequents marshy places near the mouth of the Colne, and has also been obtained at Ilford and Dagenham. Bracbinus sclopeta has now been relegated to the list of doubtful British species, as it has not been captured for many years; but it is stated on the authority of Mr. Hope to have been taken at Southend, and there seems to be no reason why it should not turn up again. Hydropbilus piceus, one of the very largest of our British beetles, is found in the Epping district. Spercbeus emarginatus was taken in some numbers by Mr. Billups near West $\mathrm{Ham}$ in I 878, only two or three British examples being previously known. Unfortunately the locality has since been destroyed. Aleochara ruficornis and Microglossa gentilis have been taken in and near nests of Lasius fuliginosus at Colchester, and the extremely rare Myrmedonia baworthi has once been obtained in the same locality and also at Southend. In the extensive family Homalota a reference to the list will show that many of the better species are found in various parts of the county. Stichoglossa semirufa is at present unique as British, a single specimen having been beaten from oak at Colchester in 1898 . Tacbinus elongatus and Megacronus inclinans are also found at Colchester. Velleius dilatatus, one of the rarest of our native Stapbylinida, was captured at Wanstead by Mr. Willoughby, and exhibited at a meeting of the Entomological Society on February 5, I 849 .

A single specimen of Emus birtus, captured at Southend, was shown at the Entomological Society's meeting on October 3, 1859. The extremely rare and handsome Ocypus cyaneus has several times been captured at Colchester, and $O$. pedator has been obtained at Southend. Pbilontbus addendus and P. ebeninus, var. corruscus, are occasionally found near Colchester. Mr. Waterhouse captured $P$. fuscus at Southend in September, $185^{8}$, and $P$. punctus has been taken in ditch rubbish at St. Osyth and Southend.

The scarce Hister marginatus has occurred in ants' nests at Colchester. Anisotoma cinnamomea was recorded by Curtis from Saffron Walden, and $A$. grandis has been taken at Colchester. Trichopteryx brevicornis has only been found in Essex, Mr. Billups having taken several specimens in the West Ham marshes on November 29, I883. T. guerinii has also been found in the same locality, and $\mathcal{T}$. ambigua at Loughton. Single specimens of Gnorimus nobilis were obtained at Colchester in 1899 and r 900, and Mr. West has also taken this fine insect in south Essex. Agriotes sordidus was first discovered as British by Mr. T. V. Wollaston, who took it at Southend.

Prionus coriarius is frequently met with on the wing or at rest on trees near Colchester. Hylotrupes bajulus is stated in Fowler's British Coleoptera to have occurred at Epping. Clytus arcuatus was obtained at Loughton by Dr. Power, and has also been reported from Epping and Hainault. Callidium sanguineum, which is now considered doubtfully British, was recorded by Mr. S. Stevens as having been captured in an 


\section{INSECTS}

outhouse at Plaistow by Mr. Hindley. Obrium cantharinum was bred in some numbers by Dr. Power from aspen bark obtained at Wanstead; it has also been taken at Epping and Leytonstone. Molorchus minor is occasionally found in the Colchester district, but is decidedly rare; and Strangalia quadrifasciata is frequently met with in certain woods in the Tendring Hundred. S. revestita has been beaten from oak in Hainault Forest (Zoologist, ii. 414). Mesosa nubila has severalt imes been taken in the woods at St. Osyth. Saperda carcbarias occurs very sparingly at Colchester, and Pbytacia cylindrica at Aldham.

Orsodacna lineola and $O$. cerasi occur pretty regularly in one restricted locality at Colchester, where the very rare Zeugophora flavicollis was obtained in 1896-7. The handsome Cryptocepbalus sex-punctatus and Crepidodera nitidula have also been found on two or three occasions in fair numbers in the Colchester and St. Osyth woods, but are always very local and generally extremely scarce. Helops caruleus is not often met with, but a single decaying tree occasionally yields a large number of specimens, as was the case with a mulberry tree in a Colchester garden, and an elm tree embedded in the sand on the Clacton coast. Cistela ceramboides was obtained at Colchester in 1900 . Tetratoma desmaresti was found by Mr. E. W. Janson in Hainault Forest in 1 845-7. Meloe rugosus was taken in some numbers by Mr. Frederick Smith and the Rev. H. S. Gorham at Southend, and also by Dr. Power at Prittlewell.

Lytta vesicatoria, familiarly known as the Spanish Fly or Blister Beetle, is very rarely met with, but in 1837 appeared in immense numbers in the Colchester district, when it is said that every ash tree was swarming with specimens. In much more recent years the species was again taken rather freely by Mr. J. G. Grapes at Donyland, but other entomologists have assiduously searched for it to no purpose. ${ }^{1}$ Platyrrbinus latirostris was captured in Hainault Forest in 1843 , and Cboragus sheppardi has been taken at Southend. Three or four specimens of the very rare Cleonus albidus have been captured on the coast sands, but none have been seen recently. The family Bagous contains a number of rare species, and of these $B$. petro, $B$. cylindrus, $B$. argillaceus, $B$. limosus and $B$. subcarinatus are all found in the county. Balaninus cerasorum may occasionally be obtained on birch and alder in the Colchester district. And lastly Larinus scolymi, a large and conspicuous south European insect, was captured at Colchester in I 900 , and is recorded here as in case of its re-occurrence in Britain the date of its first appearance will be interesting.

It would be possible to extend these notes indefinitely, but the subject is much too extensive to be treated exhaustively in what purposes to be simply a local list.

1 This fine insect again occurred in considerable numbers near Colchester in 1901. 


\section{A HISTORY OF ESSEX}

\section{A LIST OF THE COLEOPTERA OCCURRING IN THE COUNTY}

\section{Cicindelide}

Cicindela campestris, L. Colchester

\section{CARABIDFE}

Cychrus rostratus, I.

Carabus catenulatus, Scop.

- nemoralis, Mull.

- violaceus, L.

- granulatus, L.

- monilis, Fabr.

Colchester

Calosoma inquisitor, L. Loughton (W. West)

Notiophilus biguttatus, Fabr.

- substriatus, Wat.

- 4-punctatus, Dej.

- aquaticus, L.

- palustris, Duft.

- rufipes, Curt.

Leistus spinibarbis, Fabr.

- fulvibarbis, Dej.

- ferrugineus, L.

- rufescens, Fabr.

Nebria brevicollis, Fabr.

Blethisa multipunctata, L. Essex (Fowler, Brit. Col.)

Elaphrus cupreus, Duft.

Loricera pilicornis, Fabr.

Colchester

Clivina fossor, $\mathrm{L}$

Dyschirius thoracicus, Rossi. Y Clacton-

- nitidus, Dej.

- extensus, Putz. $\}$ St. Osyth

- globosus, Herbst. Colchester

Broscus cephalotes, L. Essex coast

Panagæus crux-major, L. Colchester

- quadripustulatus, Stm. Essex coast

Badister bipustulatus, Fabr. Colchester

- sodalis, Duft. Boxted

Chlænius vestitus, Payk.

- nigricornis, Fabr.

Colchester

Oodes helopioides, Fabr.

Stenolophus skrimshiranus, Steph. Essex coast

- elegans, Dej. Tilbury (Janson)

- vespertinus, Pz. Essex coast

Acupalpus exiguus, Dej. var. luridus, Dej. $\}$ Colchester

- meridianus, L.

- consputus, Duft. Essex coast

Bradycellus distinctus, Dej. West Bergholt

- verbasci, Duft. $\}$ harpalinus, Dej. $\}$ Colchester

- similis, Dej. Great Horkesley

Harpalus sabulicola, $\mathrm{Pz}$. Colchester

- rotundicollis, Fairm. Essex coast

- punctatulus, Duft. Colchester

- rupicola, Sturm. Walton (Champion)

- puncticollis, Payk. Essex coast
CARABIDEe (continued)

Harpalus rufibarbis, Fabr.

- ruficornis, Fabr.

- æneus, Fabr.

- consentaneus, Dej. Essex coast

- rubripes, Duft. Colchester and Essex coast

- latus, L. Colchester

- melancholicus, Dej. Banks of the Thames (W. West)

- tardus, Pz. Colchester

- servus, Duft. St. Osyth and Soutbend

- anxius, Duft. Essex coast

- ignavus, Duft. $\}$ Colchester

- picipennis, Duft. Essex (Dawson, Geod. Brit.)

Dichirotrichus obsoletus, Dej.
- pubescens, Payk.

Anisodactylus poeciloides, Steph. Waltonon-Naze (Fowler, Brit. Col.)

Zabrus gibbus, Fabr. Colchester and Boxted Stomis pumicatus, $\mathrm{Pz}$.

Platyderus ruficollis, Marsh.

Pterostichus cupreus, L.

- versicolor, Sturm

- madidus, Fabr.

- vulgaris, L.

- nigrita, Fabr.

- minor, Gyll.

- strenuus, $\mathrm{Pz}$.

- picimanus, Duft.

- inæqualis, Marsh.

- vernalis, Gyll.

- striola, Fabr.

Amara apricaria, Sturm

- spinipes, Auct.

- convexiuscula, Marsh. Essex coast

- bifrons, Gyll.

- ovata, Fabr. Colchester

- similata, Gyll.

- tibialis, Payk. Essex coast

- lunicollis, Schiod.

- familiaris, Duft.

- lucida, Duft.

- trivialis, Gyll.

- communis, Pz.

- continua, Thoms.

— plebeia, Gyll.

Calathus cisteloides, $\mathrm{Pz}$.

- fuscus, Fabr.

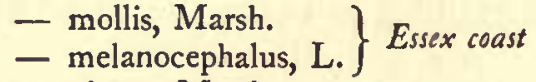

- piceus, Marsh.

Taphria nivalis, $\mathrm{Pz}$.

Pristonychus terricola, Herbst

Colchester

Sphodrus leucophthalmus, $L$.

Colchester

Anchomenus angusticollis, $\mathrm{Fabr}$. 


\section{INSECTS}

Carabide (continued)

Anchomenus dorsalis, Mull.

- albipes, Fabr.

- oblongus, Sturm

- marginatus, $\mathrm{L}$.

- sexpunctatus, L. Epping (E. Doubleday)

- parumpunctatus, Fabr.

- atratus, Duft.

- viduus, Pz. var. mœestus, Duft.

- micans, Nic.

- fuliginosus, $\mathrm{Pz}$.

- gracilis, Gyll.

- thoreyi, Dej.

- puellus, Dej.

Olisthopus rotundatus, Payk.

Lymnæum nigropiceum, Marsh. Southend (Janson)

Bembidium rufescens, Guér.

- obtusum, Sturm

- guttula, Fabr.

- mannerheimi, Sahl.

- biguttatum, Fabr.

- riparium, $\mathrm{Ol}$.

— æneum, Germ.

- fumigatum, Duft. Dagenbam (HudsonBeare)

- clarki, Daws. Essex coast

- articulatum, Pz. Loughton (Lewcock)

- minimum, Fabr. Essex coast

- normannum, Dej.

- gilvipes, Sturm

- lampros, Herbst.

- nitidulum, Marsh

Colchester

- quadriguttatum, Fabr.

- quadrimaculatum, Gyll.

- lunatum, Duft. Rainham (Lewcock)

- concinnum, Steph.

- femoratum, Sturm

- littorale, Ol.

Colchester

- pallidipenne, Ill. Essex coast (Dawson, Geod. Brit.)

- ephippium, Marsh. St. Osyth

- flammulatum, Clairv. Colchester

- varium, Ol. Essex coast

- paludosum, Pz. North Woolwich (West)

Tachypus flavipes, L. Colchester

Trechus discus, Fabr. Boxted

- lapidosus, Daws. Southend (Fowler, Brit. Col.)

Patrobus excavatus, Payk. $\}$

Pogonus littoralis, Duft.

$\overline{\text { Masoreus wetterhalii, Gyll. }}\}$

Odacantha melanura, Payk. Ilford (Champion)

Lebia chlorocephala, Hoff. Colchester

Aetophorus imperialis, Germ. I Colne

Demetrias unipunctatus, Germ. marshes

I

Colchester

Essex coast 


\section{A HISTORY OF ESSEX}

Dytiscides (continued)

Hydroporous discretus, Fairm. Birdbrook (Power)

- pubescens, Gyll.

- planus, Fabr.

- lituratus, Fabr.

Agabus biguttatus, Ol. Colchester

- paludosus, Fabr.

- nebulosus, Forst.

- conspersus, Marsh.

- femoralis, Payk. Walthamstow (Fowler, Brit. Col.)

- abbreviatus, Fabr. Hainault (J. S. Norman)

- sturmii, Gyll.

- chalconotus, $\mathrm{Pz}$.

- bipustulatus, L.

Colchester

Ilybius fuliginosus, Fabr.

- fenestratus, Fabr. Epping (E. Doubleday)

- ater, De G.

- obscurus, Marsh. $\}$ Colchester

Copelatus agilis, Fabr.

Rhantus exoletus, Forst. Epping

- pulverosus, Steph.

- notatus, Berg. North Woolwich (West)

- adspersus, Fabr. Epping (E. Doubleday)

Colymbetes fuscus, L. Colchester

Dytiscus punctulatus, Fabr. Epping (Lewcock)

- marginalis, L.

- circumflexus, Fabr. Colchester

Acilius sulcatus, $\mathrm{L}$.

\section{Gyrinidex}

Gyrinus elongatus, Aubé. Harwich (Fowler, Brit. Col.)

- marinus, Gyll. Colchester

HYDROPHILIDE

Hydrophilus piceus, L. ) North Woolwich

Hydrous caraboides, L. $\}$ (West)

Hydrobius fuscipes, L. Colchester

Paracymus nigroæneus, Sahl. $\}$ Essex coast

Anacæna limbata, Fabr.

- globulus, Payk.

Colchester

Philhydrus testaceus, Fabr.

- maritimus, Thoms. Essex coast

- nigricans, Zett.

- melanocephalus, OI.

- coarctatus, Gredl.

Colcbester

Cymbiodyta ovalis, Thoms.

Helochares lividus, Forst. Donyland

Laccobius sinuatus, Mots.

- alutaceus, Thoms.

Colchester

- bipunctatus, Fabr.

Berosus luridus, L. Epping (E. Doubleday)

- affinis, Brullé. Rainbam (Fowler, Brit. Col.)

- spinosus, Stev. Essex coast
HYDROPHILIDE (continued)

Limnebius truncatellus, Thoms.

- papposus, Muls.

- nitidus, Marsh.

Spercheus emarginatus, Schall. West Ham (Billups)

Helophorus rugosus, $\mathrm{Ol}$.

- nubilus, Fabr. $\}$ Colchester

- intermedius, Muls. Walton-on-Naze (Fowler, Brit. Col.)

- aquaticus, L. Colchester

- dorsalis, Marsh. North Woolwich (West)

- æneipennis, Thoms. Colchester.

- affinis, Marsh. Northey Isle (Janson)

- brevipalpis, Bedel.

Hydrochus angustatus, Germ.

Octhebius marinus, Payk.

- pygmæus, Fabr.

- bicolon, Germ.

- rufimarginatus, Steph. Birdbrook (Ent. xvii. 160 )

- exaratus, Muls. Essex coast

- æneus, Steph. Birdbrook (Power)

- æratus, Steph. Soutbend (Ent. xvii. 160)

- punctatus, Steph. Essex coast

Hydræna testacea, Curt. Epping (Fowler, Brit. Col.)

- riparia, Kug. Colchester

- nigrita, Germ. Epping

Cyclonotum orbiculare, Fabr.

Sphæridium scarabæoides, Fabr. Colchester

- bipustulatum, Fabr.

Cercyon littoralis, Gyll. Essex coast

- depressus, Steph. North Woolwich (West)

- hæmorrhous, Gyll.

- hæmorrhoidalis, Herbst

- obsoletus, Gyll.

- Havipes, Fabr.

- lateralis, Marsh.

- melanocephalus, L.

- unipunctatus, $\mathrm{L}$.

- quisquilius, L.

- nigriceps, Marsh.

- pygmæus, Ill.

- terminatus, Marsh.

- analis, Payk.

- lugubris, Payk.

Megasternum boletophagum, Marsh.

Cryptopleurum atomarium, Fabr.

StaphyLinider

Ateochara ruficornis, Grav.

- fuscipes, Fabr.

- lata, Grav.

- brevipennis, Grav. Southend (Fowler, Brit. Col.) 


\section{INSECTS}

\section{STAPHYLINIDE (continued)}

Aleochara bipunctata,

- cuniculorum, $\mathrm{Kr}$.

- lanuginosa, Grav.

- succicola, Thoms.

- nitida, Grav.

- grisea, Kr.

- algarum, Faur.

- obscurella, Er.

Microglossa suturalis, Sahl.

— nidicola, Fairm.

- gentilis, Märk. Colchester, Birdbrook (Power)

Oxypoda spectabilis, Märk.

- vittata, Märk.

- opaca, Grav.

- alternans, Grav.

- exoleta, Er.

- lentula, Er.

- umbrata, Grav.

- nigrina, Wat.

- longiuscula, Er.

- recondita, Kr. Loughton (Fowler, Brit. Col.)

- hæmorrhoa, Mann. Colchester

- waterhousei, Rye. West Ham (Fowler, Brit. Col.)

- annularis, Sahl. Colchester

- brachyptera, Steph. Southend (Fowler, Brit. Col.)

Thiasophila angulata, Er. Southend (Gorham)

- inquilina, Märk. Birdbrook (Power)

Ischnoglossa corticina, Er.)

Stichoglossa semirufa, Er. Colchester

Ocyusa maura, Er.

- picina, Aubé. Dagenbam (HudsonBeare)

Phloeopora reptans, Grav.

- corticalis, Grav.

Ocalea badia, Er.

Ilyobates nigricollis, Payk.

Calodera nigrita, Mann.

- riparia, Er.

- xthiops, Grav.

Chilopora longitarsis, Steph.

Atemeles emarginatus, Payk.

Myrmedonia haworthi, Steph. Colchester, Southend (Gorham)

- collaris, Payk.

- limbata, Payk.

- funesta, Grav.

- humeralis, Grav.

- lugens, Grav.

- laticollis, Märk.

Colchester

Astilbus canaliculatus, Fabr.

Callicerus obscurus, Grav.

- rigidicornis, Er.

Notothecta confusa, Märk. Birdbrook (Power)
STAPHYLINIDE (continued)

Alianta incana, Er.

Homalota gregaria, Er. $\}$ Colchester

- luteipes, Er. Dagenbam (Fowler, Brit. Col.)

- fallax, Kr.

- luridipennis, Mann.

- gyllenhali, Thoms.

- hygrotopora, $\mathrm{Kr}$.

- elongatula, Grav.

- volans, Scrib.

- vestita, Grav.

- silvicola, Fuss. Loughton (Fowler, Brit. Col.)

- vicina, Steph. Colchester

- pagana, Er. Birdbrook (Fowler, Brit. Col.)

- graminicola, Gyll. Colchester

- halobrectha, Sharp. Northey Isle (O. E. Jansen)

$\left.\begin{array}{l}\text { - puncticeps, Thoms. } \\ \text { - occulta, Er. }\end{array}\right\}$ Colchester

- fungivora, Thoms. Loughton (Champion)

- nigella, Er.

- angustula, Gyll.

- linearis, Grav.

— pilicornis, Thoms.

- circellaris, Grav.

- ægra, Heer

- immersa, Heer

- cuspidata, Er.

- gemina, Er.

- analis, Grav.

- decipiens, Sharp. Southend (Fowler, Brit. Col.)

- soror, Kr. Loughton (Champion), Colchester

- depressa, Gyll.

- hepatica, Er.

- æneicollis, Sharp Colchester

- euryptera, Steph.

- trinotata, $\mathrm{Kr}$.

- xanthopus, Thoms. Southend (Fowler, Brit. Col.)

- triangulum, Kr. $\}$ Colchester

- fungicola, Thoms. $\}$ Colchester

- ignobilis, Sharp. Loughton (Champion)

- coriaria, Kr. Colchester

- sodalis, Er. Loughton (Champion)

- palustris, Kies. Nortbey Isle (Janson)

- corvina, Thoms. Loughton (Champion)

- atomaria, Kr. Birdbrook (Fowler, Brit. Col.)

- autumnalis, Er. $\}$ Colchester

- sericea, Muls. $\}$ Colchester

- indubia, Sharp. Birdbrook (Fowler, Brit. Col.)

- atricolor, Sharp. Colchester 


\section{A HISTORY OF ESSEX}

STAPHyLINIDE (continued)

Homalota inquinula, Grav. (Fowler, Brit. Col.)

- nigra, Kr. Colchester

- sordidula, Er. Dagenbam (Fowler, Brit. Col.)

- canescens, Sharp. Loughton (Fowler, Brit. Col.)

- villosula, Kr. Loughton (Fowler, Brit. Col.)

- cinnamoptera, Thoms.) Loughton

- cadaverina, Bris. (Champion)

- marcida, Er. Colchester

- intermedia, Thoms. Epping (Fowler, Brit. Col.)

- longicornis, Grav.

- sordida, Marsh. Colchester

- testudinea, Er.

- muscorum, Bris. Loughton (Champion)

- laticollis, Steph. Colchester

- montivagans, Woll. Birdbrook (Fowler, Brit. Col.)

- fungi, Grav. $\}$ Colchester

Xenusa uvida, Er. $\}$ Essex coast

- sulcata, Kies. $\}$ Essex coast

Falagria sulcata, Payk. Colchester

- sulcatula, Grav. Soutbend (Fowler, Brit. Col.)

- thoracica, Curt. Southend (Gorham)

- obscura, Grav.

Autalia impressa, Ol.

- rivularis, Grav.

Encephalus complicans, Westw.

Gyrophæna affinis, Mann.

- minima, Er.

- lævipennis, Kr.

- lucidula, Er.

- strictula, Er.

Agaricochara lævicollis, Kr.

Euryusa laticollis, Heer. Loughton (Fowler, Brit. Col.)

Leptusa fumida, Er.

Sipalia ruficollis, $E_{r}$.

Bolitochara bella, Märk.

Phytosus spinifer, Curt.

Diglossa mersa, Hal. Southend (Fowler, Brit. Col.)

Hygronoma dimidiata, Grav.)

Oligota pusillima, Grav.

- punctulata, Heer.

- flavicornis, Lac. Wanstead (Fowler, Brit. Col.)

Myllæna dubia, Grav. Colchester

- intermedia, Er. Essex coast

- brevicornis, Matth. Colcbester

Gymnusa brevicollis, Payk. Loughton (Fowler, Brit. Col.)

Hypocyptus discoideus, Er. Dagenham (Fowler, Brit. Col.)
STAPHYLINIDF (continued)

Conosoma littoreum, $\mathrm{L}$.

- pubescens, Grav.

- immaculatum, Steph.

- pedicularium, Grav.

- lividum, Er.

Tachyporus obtusus, L.

- pallidus, Sharp.

- chrysomelinus, L.

- hypnorum, Fabr.

- pusillus, Grav.

- brunneus, Fabr.

Cilea silphoides, $\mathrm{L}$.

Tachinus humeralis, Grav.

- rufipes, $L$.

- subterraneus, $\mathrm{L}$.

- marginellus, Fabr.

- elongatus, Gyll.

Megacronus analis, Fabr.

- inclinans, Grav.

Bolitobius lunulatus, L.

- trinotatus, Er.

- pygmæus, Fabr.

Mycetoporus splendens, Marsh.

- lepidus, Grav.

- longulus, Mann.

- angularis, Rey.

- clavicornis, Steph.

- splendidus, Grav.

Habrocerus capillaricornis, Grav.

Heterothops binotata, Er. Essex coast

- dissimilis, Grav.

- quadripunctula, Gyll. $\}$ Colchester

Velleius dilatatus, Fabr. Wanstead (Whittingham)

Quedius microps, Grav. Loughton (Fowler, Brit. Col.)

- lateralis, Grav. var. fageti, Thoms.

- brevicornis, Thoms. Birdbrook (Fowler, Brit. Col.)

- cruentus, Ol. Colchester

- scitus, Grav. Birdbrook and Loughton (Power)

- cinctus, Payk.

- brevis, Er.

- fuliginosus, Grav.

- tristis, Grav.

- molochinus, Grav.

- picipes, Mann.
- nigriceps, $\mathrm{Kr}$.

- fumatus, Steph.

- maurorufus, Grav.

- umbrinus, Er.

- suturalis, Kies.

- scintillans, Grav.

- rufipes, Grav.

Colchester 


\section{INSECTS}

STAPHYLINIDA (continued)

Quedius attenuatus, Gyll.)

- semiæneus, Steph.

- boops, Grav.

Creophilus maxillosus, $\mathrm{L}$.

Colchester

Emus hirtus, L. Southend (Haward)

Leistotrophus nebulosus, Fabr. )

- murinus, L.

Colchester

Staphylinus pubescens, DeG. North Woolwich (West)

- stercorarius, Ol.

- cæsareus, Ceder.

Ocypus olens, Mull.

- similis, Fabr.

- cyaneus, Payk.

- brunnipes, Fabr.

- fuscatus, Grav.

- cupreus, Rossi

- pedator, Grav. Southend (Fowler, Brit. Col.)

- ater, Grav. Essex coast

- morio, Grav.

- compressus, Marsh.

Philonthus splendens, Fabr.

- laminatus, Creutz.

- æneus, Rossi

- proximus, $\mathrm{Kr}$.

- addendus, Sharp.

- carbonarius, Gyll.

- decorus, Grav.

- politus, Fabr.

- varius, Gyll. var. bimaculatus, Grav.

- marginatus, Fabr.

- albipes, Grav.

- umbratilis, Grav.

- cephalotes, Grav.

- fimetarius, Grav.

- sordidus, Grav.

- fuscus, Grav. Southend, $185^{8}$ (Waterhouse)

- ebeninus, Grav. var. corruscus, Grav.

- debilis, Grav.

- sanguinolentus, Grav.

- cruentatus, Gmel.

- longicornis, Steph.

- varians, Payk.

- agilis, Grav.

- ventralis, Grav.

- discoideus, Grav.

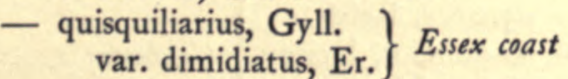

- splendidulus, Grav.)

— thermarum, Aubé $\}$ Epping

- micans, Grav.

- nigritulus, Grav. Colchester

- trossulus, Nord.

- punctus, Grav. North Essex coast, Southend district (West)
STAPHYLINIDE (continued)

$\left.\begin{array}{l}\text { Cafius xantholoma, Grav. } \\ \text { - sericeus, Holme. }\end{array}\right\}$ Essex coast

Xantholinus fulgidus, Fabr. Birdbrook (Fowler, Brit. Col.)

- glabratus, Grav.

- punctulatus, Payk. Colchester

- tricolor, Fabr. Essex coast

- linearis, Ol. Colchester

Leptacinus parumpunctatus, Gyll. Birdbrook (Fowler, Brit. Col.)

- batychrus, Gyll.

- linearis, Grav.

- formicetorum, Märk.

Baptolinus alternans, Grav.

Othius fulvipennis, Fabr.

- melanocephalus, Grav.

- myrmecophilus, Kies.

Colchester

Lathrobium elongatum, L.

- boreale, Hoch.

- fulvipenne, Grav.

- brunnipes, Fabr.

- longulum, Grav.

- punctatum, Zett. Ilford (Champion)

- terminatum, Grav.

- multipunctum, Grav.

Achenium depressum, Grav. Colchester

- humile, Nic.

Cryptobium glaberrimum, Herbst. Essex coast

Stilicus rufipes, Germ.

— orbiculatus, Er.

- affinis, Er.

Colchester

Scopæus sulcicollis, Steph. Southend (Fowler, Brit. Col.)

Medon fusculus, Mann. Essex coast

- propinquus, Bris.

- obsoletus, Nord.

Lithocharis ochracea, Grav.

Sunius filiformis, Latr. Southend (Gorham)

- intermedius, Er.

- angustatus, Payk.

Pæderus littoralis, Grav.

- riparius, L. Dagenbam (Fowler, Brit. Col.)

Evæsthetus scaber, Thoms.

- ruficapillus, Lac.

Dianous cœerulescens, Gyll.

Stenus bipunctatus, Er.

- bimaculatus, Gyll.

- juno, Fabr.

- speculator, Er.

- providus, Er.

- buphthalmus, Grav.

- incrassatus, Er.

- melanarius, Steph.

- circularis, Grav.

- declaratus, Er.

- carbonarius, Gyll. Ilford (Champion) 


\section{A HISTORY OF ESSEX}

Staphylinide (continued)

Stenus argus, Grav.

- brunnipes, Steph.

- subæneus, Er.

- ossium, Steph.

- fuscicornis, Er.

- impressus, Germ.

- ærosus, Er.

- erichsoni, Rye. Dagenham (HudsonBeare)

- pallipes, Grav.

- flavipes, Steph.

- pubescens, Steph.

- binotatus, Ljun.

- canescens, Ros.

- bifoveolatus, Gyll.

- nitidiusculus, Steph.

- picipennis, Er.

- picipes, Steph.

- cicindeloides, Grav.

- similis, Herbst

- solutus, Er.

- tarsalis, Ljun.

- paganus, Er.

- latifrons, Er.

- fornicatus, Steph. Loughton (Fowler, Brit. Col.)

Oxyporus rufus, L. Colchester

Bledius spectabilis, $\mathrm{Kr}$. Essex coast

- longulus, Er. Soutbend (Fowler, Brit. Col.)

- opacus, Block. Essex coast

- atricapillus, Germ. Southend (Fowler, Brit. Col.)

Platystethus arenarius, Fourc.

- cornutus, Gyll.

- capito, Heer

Oxytelus rugosus, Grav.

- insecatus, Grav.

- sculptus, Grav.

- laqueatus, Marsh.

- inustus, Grav.

- sculpturatus, Grav.

- maritimus, Thoms. Essex coast

- nitidulus, Grav.

- complanatus, Er.

- tetracarinatus, Block.

Haploderus cœlatus, Grav.

Trogophlœus bilineatus, Steph.

- rivularis, Mots.

- elongatulus, Er.

- fuliginosus, Grav.

- foveolatus, Sahl. Essex coast

- corticinus, Grav. Colchester

Syntomium æneum, Mull. Southend (Gorham)

Coprophilus striatulus, Fabr. Colchester

Acrognathus mandibularis, Gyll. Epping (Fowler, Brit. Col.)
Staphylinide (continued)

Deleaster dichrous, Grav.

Lesteva longelytrata, Goeze

- pubescens, Mann.

- sicula, Er.

Acidota cruentata, Mann.

Olophrum piceum, Gyll.

Lathrimæum atrocephalum, Gyll.

- unicolor, Steph.

Micralymma brevipenne, Gyll. Essex coast

Philorhinum sordidum, Steph.

Coryphium angusticolle, Steph.

Omalium rivulare, Payk.

- riparium, Thoms.

- exiguum, Gyll.

- oxyacanthæ, Grav.

- excavatum, Steph.

- cæsum, Grav.

- nigriceps, Kies.

- rufipes, Fourc.

- iopterum, Steph.

- concinnum, Marsh.

Hapalaræa pygmæa, Gyll.

Anthobium torquatum, Marsh.

Proteinus ovalis, Steph.

Megarthrus affinis, Mill.

- sinuatocollis, Lac.

Phlœobium clypeatum, Müll.

Colchester

\section{PSElaPhide}

Pselaphus heisei, Herbst

Tychus niger, Payk.

Bythinus puncticollis, Denny Colchester

- bulbifer, Reich.

- curtisi, Denny

Batrisus venustus, Reich. Loughton (Champion)

Bryaxis sanguinea, L. Colchester

- waterhousei, Rye. Soutbend (Fowler, Brit. Col.)

- fossulata, Reich. Colchester

- helferi, Schmidt. Essex coast

— humatica, Reich. $\}$ Colchester

- impressa, Pz. Dagenham (Fowler, Brit. Col.)

Bibloporus bicolor, Denny. Loughton (Champion)

Euplectus karsteni, Reich. Lougbton (Fowler, Brit. Col.)

- signatus, Reich.

- sanguineus, Denny Colchester

- piceus, Mots.

SCYDMANIDFE

Neuraphes elongatulus, Müll.)

— angulatus, Mull.

- sparshalli, Denny

Colchester

Scydmænus godarti, Latr. Loughton (Champion) 


\section{INSECTS}

SCYDMANID E (continued)

Scydmænus scutellaris, Müll.
— collaris, Mull.

- poweri, Fowler. Birdbrook (Fowler, Brit. Col.)

- exilis, Er. Loughton (Fowler, Brit. Col.)

Eumicrus tarsatus, Mull.

Eutheia schaumi, Kies.

- plicata, Gyll.

Cephennium thoracicum, Müll.

\section{SILPHIDF}

Calyptomerus dubius, Marsh.

Agathidium nigripenne, Kug.

- atrum, Payk.

- seminulum, L.

- lævigatum, Er.

- marginatum, Sturm.

- varians, Beck.

- convexum, Sharp.

- nigrinum, Sturm. (Fowler, Brit. Col.)

Amphicyllis globus, Fabr.

Liodes humeralis, Kug.

- orbicularis, Herbst

Anisotoma cinnamomea, Er. Saffron Walden (Curtis)

- oblonga, Er. (grandis, Fairm).

- dubia, Kug.

- punctulata, Gyll.

- calcarata, Er.

- curvipes, Schmidt. Northey Isle (O. Janson)

Colenis dentipes, Gyll. Colchester

Hydnobius strigosus, Schmidt. Birdbrook (Fowler, Brit. Col.)

Necrophorus humator, Fabr.

- mortuorum, Fabr.

— vestigator, Heer

- ruspator, Er.

- vespillo, L.

Silpha tristis, Ill. Southend (Fowler, Brit. Col.)

- obscura, L.

- quadripunctata, L.

- opaca, L.

- thoracica, L.

- rugosa, L.

- sinuata, Fabr.

- dispar, Herbst

- atrata, L. var. brunnea, Herbst

Choleva cisteloides, Fröhl.

— agilis, Ill.

- velox, Spence

- wilkini, Spence

- anisotomoides, Spence

- fusca, Pz.

- nigricans, Spence

- morio, Fabr.
SILPHIDF (continued)

Choleva grandicollis, Er.

- nigrita, Er.

- tristis, Pz.

- kirbyi, Spence

— chrysomeloides, Pz.

- fumata, Spence

- watsoni, Spence

Ptomaphagus sericeus, Fabr.

Colon serripes, Sahl.

- brunneum, Latr. Wrabness (Fowler, Brit. Col.)

\section{HISTERIDA}

Hister quadrimaculatus, L. Essex coast

- merdarius, Hoff. Epping Forest (F. B. Jennings)

- cadaverinus, Hoff.

- \{ purpurascens, Herbst

- $\left.\begin{array}{c}\text { var. niger, Er. } \\ \text { marginatus, Er. }\end{array}\right\}$ Colchester

- neglectus, Germ. Harwich (Fowler, Brit. Col.)

- bissexstriatus, Fabr. Southend (Fowler, Brit. Col.)

$\left.\begin{array}{l}\text { - I 2-striatus, Schr. } \\ \text { - bimaculatus, L. } \\ \text { Carcinops minima Aubé }\end{array}\right\}$ Colchester

Carcinops minima, Aubé

Paromalus flavicornis, Herbst. Southend (Gorham)

Dendrophilus punctatus, Herbst. Hainault (Norman)

- pygmæus, L.

Saprinus nitidulus, Payk. Colchester

- æneus, Fabr.

- immundus, Gyll. Loughton (West)

- virescens, Payk. Colchester

- rugifrons, Payk. Southend, Harwich (Fowler, Brit. Col.)

- maritimus, Steph. Essex coast

Abræus globosus, Hoff. Near Maldon

- granulum, Er. Walthamstow (Janson)

SCAPHIDIIDE

Scaphidium quadrimaculatum, $\left.\begin{array}{l}\text { Ol. } \\ \text { iosoma agaricinum, L. }\end{array}\right\}$ Colchester

Scaphiosoma agaricir
RICHOPTERYGID

Trichopteryx brevicornis,
TrichOPTERYGIDF Mots.

- guerinii, All. $\quad$ (Billups)

- ambigua, Matth. Lougbton (West)

Actidium coarctatum, Hal. Walton-onNaze (Champion)

$\left.\begin{array}{c}\text { Ptenidium fuscicorne, Er. } \\ \text { - evanescens, Marsh. }\end{array}\right\}$ Colchester

\section{CoRYLOPHIDE}

Orthoperus kluki, Wank. Lougbton (Fowler, Brit. Col.)

Sericoderus lateralis, Gyll. Colchester 


\section{A HISTORY OF ESSEX}

\section{Coccinellide}

Subcoccinella 24-punctata, L. Colchester, Southend

Hippodamia variegata, Goeze. Colchester

Anisosticta 19-punctata, L. Essex coast

Adalia obliterata, L. Birch

- bipunctata, L. Colchester

Anatis ocellata, L. Essex coast

Coccinella decempunctata, L.)

- I I-punctata, L.

- 7-punctata, L.

Halyzia 1 4-guttata, L.

- conglobata, $\mathrm{L}$.

- 22-punctata, L.

Micraspis I6-punctata, L.

Hyperaspis reppensis, Herbst

Scymnus nigrinus, Kug.

- pygmæus, Fourc.

- frontalis, Fabr.

- suturalis, Thunb.

- testaceus, Mots.

- hæmorrhoidalis, Herbst

- capitatus, Fabr.

- minimus, Rossi. Birdbrook (Fowler, Brit. Col.)

Chilocorus similis, Rossi

Exochomus quadripustulatus, $\mathrm{L}$.

Rhizobius litura, Fabr.

Coccidula rufa, Herbst

- scutellata, Herbst

Colchester

ENDOMYCHID F

Symbiotes latus, Redt. Southend (Gorham)

Mycetæa hirta, Marsh.

Alexia pilifera, Mull.
Lycoperdina bovistæ, Fabr.

Colchester

Endomychus coccineus, L.

EROTYLIDE

Dacne humeralis, Fabr.

- rufifrons, Fabr.

Triplax russica, $L$.

Cyrtotriplax bipustulata, Fabr.

Colchester

Phalacride

Phalacrus corruscus, Payk. Colchester

- brisouti, Rye. Rainbam (Fowler, Brit. Col.)

- caricis, Sturm. Boxted

Olibrus corticalis, $\mathrm{Pz}$.

- xneus, Fabr.

- bicolor, Fabr. Harwich (Fowler, Brit. Col.)

- millefolii, Payk. Southend (Fowler, Brit. Col.)

Eustilbus testaceus, $\mathrm{Pz}$. Colchester

- oblongus, Er. Essex coast

MicROPEPLIDFE

Micropeplus staphylinoides,

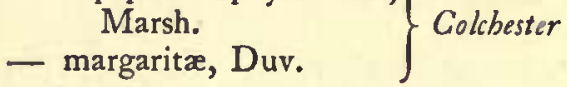

NitidULIDE

Brachypterus urticæ, Fabr. Colehester
Nitidulide (continued)

Cercus pedicularius, $\mathrm{L}$.

- bipustulatus, Payk. Colchester

- rufilabris, Latr.

Epuræa decemguttata, Fabr. Birdbrook (Fowler, Brit. Col.)

- xstiva, L.

- melina, Er.

- florea, Er.

- deleta, Er.

- obsoleta, Fabr.

- pusilla, Er.

Micrurula melanocephala, Marsh. Loughton (Fowler, Brit. Col.)

Nitidula bipustulata, $L$.

- rufipes, $L$.

- quadripustulata, Fabr.

Soronia punctatissima, Ill.

- grisea, L.

Amphotis marginata, Er.

Omosita colon, $\mathrm{L}$.

- discoidea, Fabr.

Thalycra sericea, Sturm.

Pocadius ferrugineus, Fabr.

Pria dulcamaræ, Scop.

Meligethes rufipes, Gyll.

- lumbaris, Sturm. Loughton (Fowler, Brit. Col.)

- fulvipes, Bris. Southend (Fowler, Brit. Col.)

- æneus, Fabr.

- viridescens, Fabr.

- ovatus, Sturm.

- picipes, Sturm.

- erythropus, Gyll.

Colchester

Cychramus luteus, Fabr.

Cryptarcha strigata, Fabr.

- imperialis, Fabr.

Ips quadriguttata, Fabr.) Hainault

- quadripustulata, L. $\}$ (Norman)

\section{Trogositide}

Tenebrioides mauritanicus, L. Colchester

\section{Colydidde}

Aglenus brunneus, Gyll. Birdbrook (Fowler, Brit. Col.)

Orthocerus muticus, L. Essex coast

Ditoma crenata, Fabr. Hainault (Norman)

Cicones variegatus, Hellw. Loughton (Champion)

Cerylon histeroides, Fabr.
- ferrugineum, Steph. Colchester

CuCUjIDE

Rhizophagus perforatus, Er.

- ferrugineus, Payk.

- bipustulatus, Fabr.

Colchester

Pediacus dermestoides, Fabr. Loughton (Power)

Læmophlœus bimaculatus, Payk. Loughton (Fowler, Brit. Col.)

- pusillus, Schön. Maldon (Fitch) 


\section{INSECTS}

CucuJIDF (continued)

Psammøechus bipunctatus,

Fabr.
Silvanus surinamensis, L.

Colchester

- unidentatus, Fabr. Hainault (Norman)

Monotomida

Monotoma formicetorum, Thoms.

— spinicollis, Aubé

- picipes, Herbst

- sub-4-foveolata, Wat. Hainault Forest

\section{LATHRIDIDE} (E. W. Janson)

Anommatus 12-striatus, Mull.)

Lathridius lardarius, DeG. Colchester

Coninomus nodifer, Westw.

- carinatus, Gyll. Birdbrook (Fowler, Brit. Col.)

$\left.\begin{array}{c}\text { Enicmus minutus, L. } \\ \text { - transversus, Ol. }\end{array}\right\}$ Colchester

- rugosus, Herbst. Loughton (Fowler, Brit. Col.)

- testaceus, Steph.

Cartodere ruficollis, Marsh.

- elongata, Curt.

Corticaria pubescens, Gyll.

- crenulata, Gyll.

- denticulata, Gyll.

- serrata, Payk. Lougbton (Fowler, Brit. Col.)

- elongata, Humm. Colchester

Melanophthalma transversalis, Gyll. Southend (Fowler, Brit. Col.)

- fuscula, Humm.

- fulvipes, Com. Colchester

CRYPTOPHAGIDA

Telmatophilus caricis, Ol. St. Osyth

- typhæ, Fall. Antherophagus nigricornis,
Fabr.

- pallens, Gyll. Birdbrook (Fowler, Brit. Col.)

Cryptophagus lycoperdi, Herbst

- setulosus, Sturm

- pilosus, Gyll.

- saginatus, Sturm

- umbratus, Er.

- scanicus, L.

- badius, Sturm

- dentatus, Herbst

- distinguendus, Sturm

- bicolor, Sturm

Micrambe vini, Pz.

Cænoscelis ferruginea, Sahl. Birdbrook (Fowler, Brit. Col.)

Atomaria fimetarii, Herbst

- barani, Bris.

- nigriventris, Steph.

- umbrina, Er.

Colchester
CRYPTOPHAGIDF (continued)

Atomaria linearis, Steph. Colchester and Maldon

- fuscipes, Gyll.

- peltata, $\mathrm{Kr}$.

- fuscata, Schön.

- atra, Herbst

- atricapilla, Steph.

- berolinensis, $\mathrm{Kr}$.

- mesomelas, Herbst

- gutta, Steph.

- apicalis, Er. Essex coast

- analis, Er.

- ruficornis, Marsh. $\}$ Colchester

- versicolor, Er. Birdbrook (Fowler, Brit. Col.)

Ephistemus gyrinoides, Marsh. Colchester

\section{MYCETOPHAGID F}

Typhæa fumata, L. Colchester

Triphyllus suturalis, Fabr. West Bergholt

- punctatus, Fabr. Boxted

Litargus bifasciatus, Fabr. Loughton (West)

Mycetophagus quadripustulatus, L. St. Osyth

- piceus, Fabr. Donyland

- atomarius, Fabr. Epping (F. B. Jennings)

- populi, Fabr. Epping (G. Stockley)

- quadriguttatus, Mull. Colchester

- multipunctatus, Hellw. Donyland

\section{BYTURID瓜}

Byturus tomentosus, Fabr. Colchester

\section{DERMESTIDF}

Dermestes vulpinus, Fabr. $\}$ Colchester
- murinus, L.

- undulatus, Brahm. Southend (Fowler, Brit. Col.)

- lardarius, L. West Bergholt

Attagenus pellio, $\mathrm{L}$.

Megatoma undata, Er.

Tiresias serra, Fabr.

Colchester

Anthrenus claviger, Er.

BYRRHIDE

Byrrhus pilula, L.

- fasciatus, Fabr.

Cytilus varius, Fabr.

Colchester

Simplocaria semistriata, Fabr.

Limnichus pygmæus, Sturm. Harwich (Fowler, Brit. Col.)

Aspidiphorus orbiculatus, Gyll. Colchester

PARNIDF

Elmis æneus, Müll.)

— volkmari, Pz. $\}$ Donyland

- cupreus, Mull. West Bergholt

Parnus prolifericornis, Fabr. Essex coast

- auriculatus, Pz. Colchester

\section{HETEROCERIDF}

Heterocerus flexuosus, Steph. Essex coast

- lævigatus, Pz. Colchester

— sericans, Kies. $\}$ Essoletus, Curt. $\}$ Esex coast 


\section{A HISTORY OF ESSEX}

\section{LUCANIDE}

$\left.\begin{array}{l}\text { Lucanus cervus, L. } \\ \text { Dorcus parallelopipedus, L. }\end{array}\right\}$ Colchester

\section{SCARABAIDIE}

Onthophagus nutans, Fabr. Lougbton (West)

- conobita, Herbst. Essex coast

- vacca, L. Epping (F. B. Jennings)

- nuchicornis, L. Donyland

Aphodius erraticus, $L$.

- subterraneus, L.

- fossor, L.

- hæmorrhoidalis, L. Colchester

- fotens, Fabr.

- fimetarius, L.

- ater, DeG.

- constans, Duft. Epping Forest (F. B. Jennings)

- granarius, L.

- sordidus, Fabr. Loughton (Fowler, Brit. Col.)

- rufescens, Fabr.

- lividus, Ol.

- porcus, Fabr.

- pusillus, Herbst

Colchester

- merdarius, Fabr.

- inquinatus, Fabr.

- tessulatus, Payk. Hainault Forest (Fowler, Brit. Col.)

$\left.\begin{array}{l}\text { - conspurcatus, L.) } \\ \text { - sticticus, Pz. }\end{array}\right\}$ Loughton (West)

- punctato-sulcatus, Stm. Colchester

- contaminatus, Herbst. Essex coast

- zenkeri, Germ. Epping (F. B. Jennings)

- luridus, Fabr.

- rufipes, L. $\}$ Colchester

Heptaulacus testudinarius, Fabr. Loughton (West)

Egialia arenaria, Fabr. Essex coast

Geotrupes typhoeus, L.

- spiniger, Marsh.

- stercorarius, L.

Trox sabulosus, $\mathrm{L}$.

- scaber, L.

Hoplia philanthus, Füss. Donyland

Serica brunnea, $L$.

Rhizotrogus solstitialis, L. Colchester

Melolontha vulgaris, Fabr.

Phyllopertha horticola, L. Donyland

Cetonia aurata, L. Colchester

Gnorimus nobilis, L. Colchester, Blackwall (West)

\section{BUPRESTID}

Agrilus angustulus, Ill. Colchester

Aphanisticus pusillus, Ol. Soutbend (Fowler, Brit. Col.)

Trachys troglodytes, Gyll. Loughton (West)
THROSCIDE

Throscus carinifrons, Bonv. Colchester

- obtusus, Curt. Ilford (Champion)

EUCNEMIDAE

Melasis buprestoides, L. Colchester

Elateride

Lacon murinus, L. Essex coast

Cryptohypnus riparius, Fabr. Colchester

Elater præustus, Fabr. Hainault (Norman)

- sanguinolentus, Schr. Epping (Fowler, Brit. Col.)

- miniatus, Gorham. Hainault (Norman)

- balteatus, L. Donyland

Ischnodes sanguinicollis, $\mathrm{Pz}$. Hainault (Norman)

Melanotus rufipes, Herbst

Athous niger, $\mathrm{L}$.

- longicollis, $\mathrm{Ol}$.

- hxmorrhoidalis, Fabr.

Colchester

- vittatus, Fabr. St. Osyth

Limonius minutus, $\mathrm{L}$.

Agriotes sputator, $\mathrm{L}$.

- obscurus, L.

- lineatus, L.

- sordidus, Ill. Southend (Wollaston)

- sobrinus, Kies.

- pallidulus, Ill.

Dolopius marginatus, L.

Corymbites pectinicornis, $\mathrm{L}$.

- tessellatus, Fabr.

- quercus, Gyll. var. ochropterus, Steph.

- holosericeus, Fabr.

- metallicus, Payk.

- bipustulatus, L. Wrabness (Fowler, Brit. Col.)

Campylus linearis, L. Donyland

DASCILlide

Helodes minuta, L. West Bergholt

Microcara livida, Fabr.

Cyphon coarctatus, Payk.

- variabilis, Thunb.

Colchester

— padi, L.

Scirtes hemisphæricus, L.)

- orbicularis, Pz. Dagenham (Fowler, Brit. Col.)

MALACODERMIDAE

Lampyris noctiluca, L. Colchester

Silis ruficollis, Fabr. Dagenbam and Epping (Fowler, Brit. Col.)

Podabrus alpinus, Payk.

Telephorus fuscus, $L$.

- rusticus, Fall.

- lividus, $L$.

Colchester

- pellucidus, Fabr.

-- nigricans, Mull.

- lituratus, Fabr. Essex coast

_- bicolor, Fabr.

- hæmorrhoidalis, Fabr. $\}$ Colchester

- oralis, Germ. Essex coast 


\section{INSECTS}

MALACODERMIDE (continued)

Telephorus flavilabris, Fall. Colchester

- thoracicus, Ol. Northey Island (O. E. Janson)

Rhagonycha fuscicornis, $\mathrm{Ol}$.

- fulva, Scop.

- limbata, Thoms.

- pallida, Fabr.

Malthinus punctatus, Fourc.

- fasciatus, $\mathrm{Ol}$.

- frontalis, Marsh.

Malthodes marginatus, Latr.

- minimus, L.

Malachius æneus, L.

- bipustulatus, L.

- viridis, Fabr.

- marginellus, Ol. $\}$ Essex coast

Axinotarsus pulicarius, Fabr. Colchester

- ruficollis, Ol. Loughton (Fowler, Brit. Col.)

Anthocomus rufus, Herbst. Colne marshes

- fasciatus, L.

Dasytes flavipes, Fabr. Colchester

- ærosus, Kies.

Psilothrix nobilis, III.

Dolichosoma lineare, Rossi $\}$ Essex coast

Haplocnemus nigricornis, Fabr. St. Osyth, Birch

\section{Cleride}

Tillus elongatus, L. Colchester

Opilo mollis, L. Loughton (West)

Thanasimus formicarius, L. Hainault (Norman)

Necrobia ruficollis, Fabr.

- violacea, L.

- rufipes, De G.

Colchester

Corynetes cœruleus, De G.

PTINIDF

Ptinus germanus, Fabr. Colchester

- lichenum, Marsh. Hainault (Norman)

Niptus hololeucus, Fald. $\}$ Colchester

Hedobia imperialis, L.

Dryophilus pusillus, Gyll. Birch

Priobium castaneum, Fabr.

Anobium domesticum, Fourc.

Xestobium tessellatum, Fabr. Colchester

Ernobius mollis, L.

Ochina hederæ, Mull.

Dorcatoma chrysomelina, Sturm.

- flavicornis, Fabr.

Anitys rubens, Hoff.

Southend

LYCTIDE

Lyctus canaliculatus, Fabr. Colchester

Cisside

Cis boleti, Scop.

- villosulus, Marsh. $\}$ Colchester

- micans, Fabr. Loughton (Fowler, Brit. Col.)
Cisside (continued)

Cis hispidus, Payk. Essex (Fowler, Brit. Col.)

- bidentatus, $\mathrm{Ol}$. )

- $\left.\begin{array}{c}\text { alni, Gyll. } \\ \text { nitidus, Herbst }\end{array}\right\}$ Colchester

- festivus, Pz. Ulting near Maldon (Fowler, Brit. Col.)

- fuscatus, Mell. Colchester

Ennearthron affine, Gyll. Loughton (Fowler, Brit. Col.)

- cornutum, Gyll.

Octotemnus glabriculus, Gyll. $\}$ Colchester

\section{Cerambycida}

Prionus coriarius, L. Colchester

Aromia moschata, L. Near Chelmsford

Hylotrupes bajulus, L. Epping (Fowler, Brit. Col.)

Callidium violaceum, L. Hainault (Norman)

- variabile, L. Colchester

- alni, L. Hainault (Norman)

- sanguineum, L. Plaistow (Hindley, recorded by S. Stevens)

Clytus arcuatus, L. Loughton (Power)

- arietis, L. Colchester

- mysticus, L. Loughton and Cbingford (West)

Gracilia minuta, Fabr. Essex coast

Obrium cantharinum, L. Wanstead (Power), Epping and Leytonstone (Stephens)

Molorchus minor, L.

Rhagium inquisitor, Fabr. $\}$ Colchester

- bifasciatum, Fabr. Great Horkesley

Toxotus meridianus, Pz. West Bergholt

Leptura scutellata, Fabr. Epping and Hainault (Fowler, Brit. Col.)

- livida, Fabr. Colchester

Strangalia quadrifasciata, L. Colchester district

- revestita, L. Hainault (Norman)

- armata, Herbst. Colchester

- attenuata, L. Southend (Stephens, Fowler, Brit. Col.)

- nigra, L. Hainault (Norman)

- melanura, L.

Grammoptera tabacicolor, De G.

Colchester

- ruficornis, Fabr.

Leiopus nebulosus, L.

Pogonochærus bidentatus, Thoms.

- dentatus, Fourc. Colchester

Mesosa nubila, Ol. Colchester district

Saperda carcharias, L.) Colchester

Tetrops præusta, L. Colchester

Phytæecia cylindrica, L. Aldham

BRUCHIDIE

Bruchus rufimanus, Roh. Colchester

- luteicornis, Ill. Soutbend and Maldon (Fowler, Brit. Col.) 


\section{A HISTORY OF ESSEX}

BRUCHIDF (continued)

Bruchus loti, Payk. )

— villosulus, Fabr. $\}$ Colchester

Chrysomelide

Orsodacna cerasi, L.

- lineola, $\mathrm{Pz}$. var. humeralis, Latr.

Donacia dentata, Hoppe. Epping (Keeley)

- versicolorea, Brahm. Loughton (West)

- dentipes, Fabr. Epping (Keeley)

- limbata, Pz. Nortbey Isle (O. E. Janson)

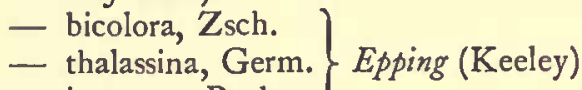

- impressa, Payk.

- simplex, Fabr. Colchester

- vulgaris, Zsch. Epping (Keeley)

- clavipes, Fabr. $\left.{ }_{\text {- semicuprea, Pz. }}\right\}$ Colcbester

- cinerea, Herbst. Epping (Keeley)

- sericea, L. Colchester

- braccata, Scop. Essex coast

- affinis, Kunze. Epping (F. B. Jennings)

Hæmonia curtisi, Lac. Essex coast

Zeugophora subspinosa, Fabr.

- flavicollis, Marsh.

Lema cyanella, L.

- lichenis, Vœt.

- melanopa, L.

Crioceris asparagi, L.

Clythra quadripunctata, L.

Cryptocephalus sexpunctatus, L.

- bipunctatus, L. var. lineola, Fabr.

- aureolus, Suffr. $\}$ Loughton (West)

- moræi, L. Colchester

- bilineatus, L. Essex coast

- fulvus, Goeze

- pusillus, Fabr.

- Iabiatus, L.

Timarcha tenebricosa, Fabr.

- violaceonigra, De G.

Chrysomela marginalis, Duft.

- marginata, L. Southend (Champion)

- banksi, Fabr.

- staphylea, L.

- polita, L.

- orichalcia, Mull.

- hæmoptera, L.

Colchester

- varians, Schall.

- menthastri, Suffr.

- hyperici, Forst.

Melasoma longicolle, Suffr. ?

Phytodecta rufipes, De G. $\}$

- olivacea, Forst. Colchester

Gastroidea viridula, De G. Dedham.
Chrysomelid (continued)

Gastroidea polygoni, L.

Plagiodera versicolora, Laich.

Phædon tumidulus, Germ.

- armoracia, L.

- cochleariz, Fabr.

Phyllodecta cavifrons, Thoms.

— vitellinæ, L.

Hydrothassa aucta, Fabr.

- marginella, L.

Prasocuris junci, Brahm.

- phellandrii, L.

Luperus nigrofasciatus, Goeze

- rufipes, Scop. Dedham

Lochmæa caprex, L.

- suturalis, Thoms.

- cratægi, Forst.

Gallerucella viburni, Payk.

- sagittariæ, Gyll.

- calmariensis, L. Boxted

- tenella, L. Epping (Lewcock)

Adimonia tanaceti, L. Epping (Fowler, Brit. Col.)

Sermyla halensis, L. Colchester

Longitarsus absinthii, Kuts. Essex coast

- dorsalis, Fabr. Soutbend (Power)

- castaneus, Duft.

- Iuridus, Scop.

- suturellus, Duft, var. fuscicollis, Steph.

- atricillus, $\mathrm{L}$.

- melanocephalus, All.

- suturalis, Marsh. Birdbrook (Fowler, Brit. Col.)

- nasturtii, Fabr. Colchester

- ballotx, Marsh. Walton-on-Naze (Fowler, Brit. Col.)

- femoralis, Marsh. $\}$ Colchester

- jacobææ, Wat. Essex coast

- gracilis, Kuts. Colchester

- lavis, Duft. Essex coast

- pellucidus, Foudr. Birdbrook (Fowler, Brit. Col.)

Haltica lythri, Aubé. Soutbend (Fowler, Brit. Col.)

- coryli, Brit. Col. $)$ Colchester

Hermæophaga mercurialis, Fabr. West Bergholt

Phyllotreta consobrina, Curt.)

— punctulata, Marsh.

- atra, Payk.

- cruciferæ, Goeze
- undulata, Kuts.

- nemorum, L.

- ochripes, Curt.

- exclamationis, Thunb.

Aphthona nonstriata, Goeze. Wivenboe

- venustula, Kuts. Colchester

Colchester 


\section{INSECTS}

Chrysomelide (continued)

Aphthona atrocœerulea, Steph. Colchester

- virescens, Foudr. Birdbrook (Fowler, Brit. Col.)

Batophila rubi, Payk. West Bergbolt

Sphæroderma testaceum, Fabr.

- cardui, Gyll.

Apteropeda orbiculata, Marsh.

Podagrica fuscicornis, $\mathrm{L}$.

Mantura rustica, L.

- obtusata, Gyll.

Crepidodera transversa, Marsh.

- ferruginea, Scop.

- rufipes, L.

- ventralis, Ill. Birdbrook (Fowler, Brit. Col.)

- nitidula, L.

- helxines, L.

- chloris, Foudr.

- aurata, Marsh.

Colchester

- smaragdina, Foudr.

Hippuriphila modeeri, L.

Chætocnema aridula, Gyll. Lougbton (Champion)

-- hortensis, Fourc.

Plectroscelis concinna, Marsh. $\}$ Colchester

Psylliodes chrysocephala, L. Essex coast

- napi, Koch. Colchester

- cuprea, Koch. West Bergholt

- affinis, Payk. Colchester

- marcida, Ill. Harwich, Southend (Fowler, Brit. Col.)

- picina, Marsh. Colchester

Cassida murræa, L. Plaistow marshes (Fowler, Brit. Col.)

- nebulosa, L. Colchester

- vibex, Fabr. Essex coast

- sanguinolenta, Fabr. Southend, Epping (Fowler, Brit. Col.)

- vittata, Vill.

- nobilis, L.

- flaveola, Thunb. Colchester

- viridis, Fabr.

- hemisphærica, Herbst. (West)

TENEBRIONIDF

Blaps mucronata, Latr. Colchester

Crypticus quisquilius, $\mathrm{L}$.

Heliopathes gibbus, Fabr.

Opatrum sabulosum, Gyll. Essex coast

Microzoum tibiale, Fabr.

Phaleria cadaverina, Fabr.

$\left.\begin{array}{l}\text { Heledona agaricola, Fabr. } \\ \text { Scaphidema metallicum, Fabr. }\end{array}\right\}$ Colchester

Alphitophagus quadripustulatus, Steph. Maldon (Fowler, Brit. Col.)

Tenebrio molitor, $\mathrm{L}$.

- obscurus, Fabr.

Gnathocerus cornutus, Fabr.

Tribolium confusum, Duv.
TENEBRIONIDAs (continued)

Palorus melinus, Herbst. Birdbrook (Fowler, Brit. Col.)

Hypophlœus bicolor, Ol. West Bergholt

Helops coeruleus, L. Colchester

- pallidus, Curt. Essex coast

- striatus, Fourc. Colchester

\section{Cistelide}

Cistela luperus, Herbst. Wrabness (Fowler, Brit. Col.)

- ceramboides, L. $\}$ Colchester

Eryx ater, Fabr. Wivenhoe

Mycetochares bipustulata, Ill. Epping (F. B. Jennings)

\section{LAGRIIDF}

Lagria hirta, L. Colchester

MELANDRYIDE

Tetratoma fungorum, Fabr. Boxted

- desmaresti, Latr. Hainault (Edward Janson)

- ancora, Fabr. Loughton (West)

Orchesia micans, Pz. Colchester

Clinocara tetratoma, Thoms. Birdbrook (Power)

Hallomenus humeralis, $\mathrm{Pz}$.

Conopalpus testaceus, $\mathrm{Ol}$. Colchester

Melandrya caraboides, L.

Abdera quadrifasciata, Steph. Hainault

Pythide

Salpingus castaneus, $\mathrm{Pz}$. Colchester

Lissodema quadripustulata, Marsh. Southend (Gorham)

Rhinosimus ruficollis, $\mathrm{L}$.

- viridipennis, Steph. Colchester

- planirostris, Fabr.

OEDEMERIDAF

Oedemera nobilis, Scop. West Bergholt

Nascerdes melanura, Schmidt $\}$ Colchester

Ischnomera

Pyrochroa coccinea, L. Epping (Fowler, Brit. Col.)

- serraticornis, Scop. Colchester

MoRDELlide

Mordellistena abdominalis, Fabr. Wrabness (Fowler, Brit. Col.)

- humeralis, L.

- brunnea, Fabr. Colchester

- pumila, Gyll.

- brevicauda, Boh. Essex coast

Anaspis frontalis, L.

- pulicaria, Costa.

- geoffroyi, Mall.

- ruficollis, Fabr.

Colchester

- flava, L.

- subtestacea, Steph.

- maculata, Fourc.

RHIPIDOPHORIDF

Metœecus paradoxus, L. Colchester 


\section{A HISTORY OF ESSEX}

AnTHicide

$\left.\begin{array}{l}\text { Notoxus monoceros, L. } \\ \text { Anthicus humilis, Germ. }\end{array}\right\}$ Essex coast

- floralis, L. Colcbester

- instabilis, Schmidt. Essex coast

- angustatus, Curt. Wrabness, Soutbend (Fowler, Brit. Col.)

- antherinus, L. Colchester

XYLOPHILIDE

Xylophilus populneus, Fabr. Colchester

\section{MELOID}

Meloe proscarabæus, L. var. cyaneus, Muls. Colchester

- cicatricosus, Leach. Southend (Fowler, Brit. Col.)

- rugosus, Marsh. Southend (Smith and Gorham), Prittlewell (Power)

Lytta vesicatoria, L. Colcbester

ANTHRIBIDEE

Brachytarsus varius, Fabr. Colchester

Platyrrhinus latirostris, Fabr. Hainault (Norman)

Choragus sheppardi, Kirby. Southend

\section{Curculionidet}

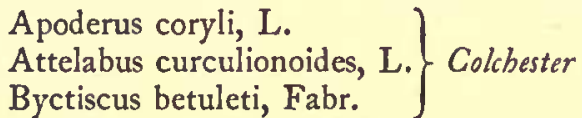

Byctiscus betuleti, Fabr.

Rhynchites cupreus, $\mathbf{L}$.

— æquatus, L.

Colchester

- cœruleus, De G. West Bergholt

- minutus, Herbst. Colchester

- interpunctatus, Steph. ) Lougbton

- pauxillus, Germ. $\quad$ (Lewcock)

- nanus, Payk.

- sericeus, Herbst Colcbester

- pubescens, Fabr.

Deporalis megacephalus, Germ. Wrabness (Fowler, Brit. Col.)

Apion pomonæ, Fabr. $\}$ Colchester

- craccæ, L. Dagenbam (Fowler, Brit.Col.)

- subulatum, Kirby. Birdbrook (Fowler, Brit. Col.)

- ulicis, Forst. Colchester

- genistæ, Kirby. Epping (Lewcock)

- fuscirostre, Fabr.

- malvæ, Fabr.

- urticarium, Herbst

- miniatum, Germ.

Colchester

- hæmatodes, Kirby

- rubens, Steph.

- pallipes, Kirby. Birdbrook (Fowler, Brit. Col.)

- rufirostre, Fabr.

- difforme, Germ. Colchester

- varipes, Germ.

- lævicolle, Kirby. Southend (Fowler, Brit. Col.)
Curculionide (continued)

Apion schönherri, Boh. Southend (Rye and Gorham)

- apricans, Herbst. Colchester

- bohemani, Thoms. Essex coast

- trifolii, L.

- dichroum, Bedel

- nigritarse, Kirby

- stolidum, Germ.

- hookeri, Kirby

- æneum, Fabr.

- radiolus, Kirby

— onopordi, Kirby

- carduorum, Kirby

- virens, Herbst

— pisi, Fabr.

- æthiops, Herbst

- ebeninum, Kirby

- striatum, Kirby

— immune, Kirby

- ervi, Kirby

— vorax, Herbst

— unicolor, Kirby

- livescerum, Gyll. Southend (Fowler, Brit. Col.)

- loti, Kirby

- seniculum, Kirby

- simile, Kirby

- pubescens, Kirby

- curtisi, Walt.

- limonii, Kirby. Essex coast

- sedi, Germ. Soutbend, Harwich (Fowler, Brit. Col.)

- marchicum, Herbst

- affine, Kirby

- violaceum, Kirby

- hydrolapathi, Kirby

- humile, Germ.

Otiorrhynchus raucus, Fabr.

- scabrosus, Marsh.

- ligneus, Ol. Essex coast

- picipes, Fabr.

- sulcatus, Fabr.

- ovatus, $L$.

Trachyphlœus aristatus, Gyll.
— scaber, L.

- scabriculus, L. \}Southend

- spinimanus, Germ. (Gorham)

- alternans, Gyll. Southend (Fowler, Brit. Col.)

Cænopsis waltoni, Schön. Great Horkesley Strophosomus coryli, Fabr.

- capitatus, De G.

- retusus, Marsh.

Colibester

- faber, Herbst

Exomias araneiformis, Schr.

Omias mollinus, Boh. Southend (Gorham)

Sciaphilus muricatus, Fabr. Colchester

Tropiphorus carinatus, Müll.) West

- tomentosus, Marsh. $\}$ Bergholt 


\section{INSECTS}

CURCUlionida (continued)

Liophlœus nubilus, Fabr.

Polydrusus micans, Fabr.

- tereticollis, De G.

- pterygomalis, Boh.

- flavipes, De G. Loughton (Fowler, Brit. Col.)

- cervinus, L. Colchester

- chrysomela, Ol. $\}$ Essex coast

Phyllobius oblongus, $\mathrm{L}$.

- calcaratus, Fabr.

- urticæ, De G.

- pyri, L.

- argentatus, L.

Colchester

- maculicornis, Germ.

- pomonæ, Ol.

- viridiæris, Laich.

Tanymecus palliatus, Fabr. $T_{e y}$

Philopedon geminatus, Fabr. Essex coast

Barynotus obscurus, Fabr. Colchester

- elevatus, Marsh.

Alophus triguttatus, Fabr.

West Bergholt

Sitones cambricus, Steph.

- regensteinensis, Herbst

— tibialis, Herbst

- hispidulus, Fabr.

- humeralis, Steph.

- flavescens, Marsh.

- puncticollis, Steph.

- lineatus, L.

Hypera punctata, Fabr.

- rumicis, $\mathrm{L}$.

- pollux, Fabr.

- polygoni, L.

- variabilis, Herbst

- murina, Fabr.

- plantaginis, De G.

- trilineata, Marsh.

- nigrirostris, Fabr.

Cleonus sulcirostris, L.
- albidus, Fabr.

Liosoma ovatulum, Clairv. $W_{\text {est }}$ var. collaris, Rye. $\}$ Bergbolt

- oblongulum, Boh. Wrabness (J. J. Walker)

Liparus coronatus, Goeze

Orchestes quercus, $\mathrm{L}$.

— alni, L.

- ilicis, Fabr.

- avellanæ, Don.

- fagi, L.

- rusci, Herbst

- stigma, Germ.

- salicis, L.

Rhamphus flavicornis, Clairv. Colchester

Orthocætes setiger, Beck.

Grypidius equiseti, Fabr.

Erirrhinus scirpi, Fabr.
Curculionide (continued)

Erirrhinus bimaculatus, Fabr. Dagenham (Fowler, Brit. Col.)

- acridulus, L.

Thryogenes festucæ, Herbst

- nereis, Payk.

Dorytomus vorax, Fabr.

- tortrix, L.

- hirtipennis, Bedel. Birdbrook (Power)

- validirostris, Gyll.

- maculatus, Marsh.

- pectoralis, Gyll.

Tanysphyrus lemnæ, Fabr.

Bagous alismatis, Marsh.

- petro, Herbst. Harwich (J. J. Walker)

- cylindrus, Payk. Essex coast

- argillaceus, Gyll. Southend (Fowler, Brit. Col.)

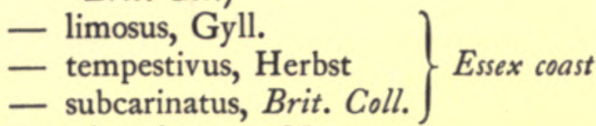

Anoplus plantaris, Naez.

- roboris, Suffr.

$\left.\begin{array}{l}\text { Tychius venustus, Fabr. } \\ \text { - meliloti, Steph. }\end{array}\right\}$ Colchester

- tibialis, Boh. Soutbend (Fowler, Brit. Col.)

Miccotrogus picirostris, Fabr. Colchester

Sibinia arenariæ, Steph. Harwich (Fowler, Brit. Col.)

Miarus companulæ, L. Colchester

- plantarum, Germ. Birdbrook (Fowler, Brit. Col.)

Gymnetron beccabungæ, L. Colchester

- rostellum, Herbst

- pascuorum, Gyll.

- antirrhini, Payk.

Mecinus pyraster, Herbst

- collaris, Germ. Essex coast

Anthonomus ulmi, De G. West Bergbolt

- pedicularius, L. Colchester

- rubi, Herbst. West Bergholt

Cionus scrophulariæ, L.

- hortulanus, Marsh.

- blattariæ, Fabr.

- pulchellus, Herbst

Orobitis cyaneus, L.

Cryptorrhynchus lapathi, L.

Acalles ptinoides, Marsh.

- turbatus, Boh.

Coliodes rubicundus, Herbst

- quercus, Fabr.

- ruber, Marsh.

- erythroleucus, Gmel.

- cardui, Herbst

- quadrimaculatus, L.

- exiguus, Ol. Walton-on-Naze, Southend (Gorham) 


\section{A HISTORY OF ESSEX}

Curculionide (continued)

Poophagus sisymbrii, Fabr.

- nasturtii, Germ.

Ceuthorrhynchus assimilis, Payk.

- cochleariæ, Gyll.

- erysimi, Fabr.

- contractus, Marsh.

- cyanipennis, Germ. Southend

- chalybæus, Germ. (Gorham)

- quadridens, Pz. Colchester

- geographicus, Goeze. Purfleet (Fowler, Brit. Col.)

- pollinarius, Forst. Colchester

- viduatus, Gyll. Ilford (Champion)

- pleurostigma, Marsh. Colchester

- verrucatus, Gyll. Southend (Fowler, Brit. Col.)

- rugulosus, Herbst

- melanostictus, Marsh.

- asperifoliarum, Gyll.

- chrysanthemi, Germ.

- triangulum, Boh. Wrabness (J. J. Walker)

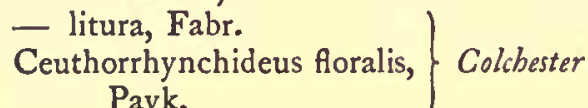
Payk.

- pyrrorhynchus, Marsh. Southend (Gorham)

- melanarius, Steph.

- troglodytes, Fabr.

Amalus hæmorrhous, Herbst

Rhinoncus pericarpius, $\mathrm{L}$.

Colchester

- gramineus, Herbst

- perpendicularis, Reich.

- castor, Fabr.

- bruchoides, Herbst. Northey Isle (O. E. Janson)

Litodactylus leucogaster, Marsh. Colchester

Phytobius comari, Herbst. Dagenbam (Fowler, Brit. Col.)

- waltoni, Boh. Loughton (Lewcock)

- quadrituberculatus, Fabr. Colchester

- canaliculatus, Fabr. Loughton (Fowler, Brit. Col.)

$\left.\begin{array}{l}\text { Limnobaris t-album, L. } \\ \text { Baris picicornis, Marsh. }\end{array}\right\}$ Colchester
Curculionide (continued)

Baris lepidii, Germ. Southend (Gorham)

Balaninus venosus, Grav.

- nucum, L.

- turbatus, Gyll.

- betulæ, Steph.

- villosus, Fabr.

- salicivorus, Payk.

- pyrrhoceras, Marsh.

Magdalis armigera, Fourc.

- cerasi, L.

- pruni, L.

Calandra granaria, $\mathrm{L}$.

- oryzæ, L.

Rhyncolus lignarius, Marsh.)

- ater, L. Walton-on-Naze (W. G. Blatch)

Stereocorynes truncorum, Germ. Epping (W.G. Blatch), Leytonstone (Gorham), Wanstead (Power)

Caulotrypis æneopiceus, Boh. Loughton (West)

Codiosoma spadix, Herbst. Essex coast

\section{SCOLYTIDE}

Scolytus destructor, Ol.

- pruni, Ratz.

- rugulosus, Ratz. Colchester

Hylastes cunicularius, Er. Birdbrook (Fowler, Brit. Col.), Southend (Gorham)

- angustatus, Herbst. Epping (G. Stockley)

- palliatus, Gyll. Birdbrook (Fowler, Brit. Col.)

Hylastinus obscurus, Marsh.

Hylesinus crenatus, Fabr.

- fraxini, $\mathrm{Pz}$. - fraxini, $\mathrm{Pz}$.
Phloeophthorus rhododactylus,
Marsh.

Xylocleptes bispinus, Duft. West Bergbolt Dryocæates villosus, Fabr. Colchester

Tomicus nigritus, Gyll. Colbster

Xyleborus saxeseni, Ratz. Loughton (Fowler, Brit. Col.)

\section{STYLOPIDE}

Stylops melittæ, Kirby. Colchester

\section{LEPIDOPTERA}

\section{RHOPALOCERA}

\section{Butterfies}

The Swallow-tail (Papilio macbaon) is met with occasionally, especially on the coast-Southend, Shoebury, Tillingham, Walton-on-theNaze and Maldon are recorded localities; but whatever may have been the case formerly it cannot now be considered a native of the county, 


\section{INSECTS}

the few examples noticed being doubtless immigrants from the continent, stragglers from the fens, or released captives.

The Large, Small and Green-veined Whites (Pieris brassica, $P$. rapa and $P$. napi) abound in every direction. About twelve years ago more than a dozen larvæ of the Large White were seen busily engaged feeding on savoys near Colchester on Christmas Day.

The Chequered or Bath White $(P$. daplidice) is a very rare immigrant, but has been taken at.Berechurch by the late Dr. Maclean, at Colchester by Mr. Norman Halls, at Epping by Mr. Walter Nash and at Southend by Mr. V. E. L. Young.

The Orange Tip (Eucbloe cardamines) occurs freely throughout the county, and occasionally very beautiful and striking varieties are bred or captured. In 1899 a form with lemon instead of orange tips was bred at Colchester, where during the previous summer many larvæ were found in company with those of the Large and Small Whites, feeding on the seed vessels of the charlock in cornfields.

The Wood White (Leucopbasia sinapis), according to Dr. Maclean, was common in several woods near Colchester in the early years of the past century; it also occurred freely near Epping in 1839 (J. English), but has rarely been seen in recent years, one at Donyland, one at Coggeshall and one in Ongar Park Woods being the only trustworthy records.

The Clouded Yellow (Colias edusa) is generally scarce, but occasionally occurs in the greatest profusion. In 1877 it appeared to be the commonest butterfly throughout the county, and was fairly common in 1892 and 1900 . The pale variety of the female (belice) and intermediate forms occur sparingly with the type in favourable seasons.

The Pale Clouded Yellow ( $C$. byale) is usually much scarcer than its deeper coloured relative, but in 1900 the reverse was the case. Both are very uncertain in their appearances, but as a rule byale is absent for much longer periods than edusa. It was plentiful in 1857,1868 and I 875 , and was then scarcely seen till 1892 , after which it quite disappeared as an Essex species till 1900, when it probably occurred in larger or smaller numbers in every clover and lucerne field in the county. In IgoI it again appeared sparingly in the northern and more commonly in the southern districts.

The Brimstone (Gonopteryx rbamni) is common and generally distributed. Hibernated specimens sometimes appear very early in the year if the weather be mild, and one was once observed on the wing in the High Woods at Colchester on Christmas Day.

The Small Pearl-bordered Fritillary (Argynnis selene) is fairly common and sometimes abundant in flowery places in woods. The first brood appears at the end of May, but is more numerous in June; and in some localities there is frequently a second brood in August, the examples of which are far fewer in number and smaller in size.

The Pearl-bordered Fritillary ( $A$. eupbrosyne) frequents similar places, but is more often found, and as a rule in larger numbers; but 


\section{A HISTORY OF ESSEX}

both species have their good and bad seasons, and a year of unusual abundance is frequently followed by a period of comparative scarcity.

The Queen of Spain Fritillary ( $A$. latona) is a migratory species which is seldom met with: According to Haworth only six British specimens were known previous to 1818 , when it occurred in some numbers and was taken in many places, including Colchester (probably by the late Dr. Maclean and Mr. L. Brock, who obtained specimens at Berechurch). Several others were taken at Colchester from I857 to I 868. It has also been reported from Braintree by Mr. B. Holland; from Southend, where three were captured, by Mr. J. Russell; and from Rainham by Mr. F. Venables. A single specimen which occurred at St. Osyth on September I 4, I $88 \mathrm{I}$, appears to have been the last found in the county.

The Dark Green Fritillary (A. aglaia) is recorded by old authors as occurring near Colchester, at Lexden Heath, Dedham Birch Wood, Bromley Thicks, and woods at West Bergholt; but all these localities have undergone extensive changes, and if aglaia ever was a north Essex species it must have long ago disappeared; and there are no trustworthy records from any other quarter, for though examples are occasionally reported they always prove to be the next species.

The High-brown Fritillary $(A$. adippe) is common at Colchester and in several of the larger woods in the north-east of the county, but seems scarce in the south, though the Rev. G. H. Raynor says it is not uncommon at Brentwood and occurs sparingly at Hazeleigh and Woodham Mortimer. It is also reported from the Southend district, and appears formerly to have been frequently taken at Epping and Hainault.

The Silver-washed Fritillary $(A$. papbia $)$ is much more restricted in its range about Colchester than adippe, but is common in several woods, including those at Donyland and St. Osyth. Mr. G. F. Mathew reports it from the Harwich district, Mr. Raynor from Hazeleigh and Warley, and Professor Meldola from Leyton. It has practically disappeared from Epping Forest, where it formerly abounded.

The Greasy Fritillary (Melitea aurinia) was formerly found in several localities near Epping, but since June, I 872, ' when three specimens were taken near the Robin Hood,' no others have been seen. In Newman's Britisb Butterflies Colchester is quite erroneously given as a locality for the species, and in the same work Mr. W. R. Jeffrey is made responsible for its occurrence at Saffron Walden.

The Heath Fritillary ( $M$. athalia) according to tradition was formerly found in several woods in north Essex, but in the latter half of the past century it was practically confined to those 'woods bordering the road from Colchester to Ipswich,' where Mr. Edward Doubleday found it many years previously. In his day they were 700 acres in extent and constituted one of the very best localities for insects in the country, but now they are reduced to about 120 acres, which are strictly preserved. In one of the woods atbalia abounded till about i 890 , when, as more cover was required for game, the underwood was allowed 


\section{INSECTS}

to grow over its whole extent, and no fresh clearance was made for several years. The glades were also kept closely clipped and mown, which resulted in the total disappearance of all the sun-loving plants, including the Melampyrum and Digitalis on which the larvæ of atbalia feed, nor were any bramble or other flowers left for the perfect insects. Consequently the species was literally starved out and completely exterminated; for though at the commencement of its evil days stragglers might be met with miles away from their native home, it is to be feared that none of them succeeded in establishing a new colony elsewhere, which is greatly to be regretted, as the Essex form of this beautiful insect was larger and more richly coloured than any occurring elsewhere.

The Comma (Vanessa $C$-album) seems to have abounded at Epping in the early part of the nineteenth century, but only occasional stragglers have been met with in the county in more recent times. About $185^{\circ}$ several specimens were captured near Colchester by the late W. Tillaney. Mr. Jeffrey records it from Saffron Walden, and Mr. R. E. Stuart captured an example at Mundon, near Maldon, in $187 \mathrm{I}$.

The Large Tortoiseshell ( $V$. polycbloros) is very widely distributed and frequently common, though it seems to have its adverse periods. The larvæ most frequently feed on elm, but may also be found on sallow, osier, cherry, pear, etc., and Mr. J. A. Tawell once found a brood at Earles Colne feeding on nettle.

The Small Tortoiseshell ( $V$. urtica) abounds everywhere from early spring till late autumn, and has been seen flying briskly along the streets in Colchester on an exceptionally warm day in January.

The Peacock $(V . i 0)$ is very common in some seasons. In I900 the nettles about Colchester were black with the larva in the early part of July, and in August the perfect insects visited the clover fields in enormous numbers.

The Camberwell Beauty ( $V$. antiopa) is usually very rare and cannot be considered a native of Britain, but from the numerous records it seems to have been at some time noticed in all parts of the county. In 1872 it was comparatively common, but has been extremely rare since. A single specimen was taken at Middlewick, Colchester, in 1880. Single specimens were also taken at Hornchurch, near Dunmow, and at Chelmsford in 1900, and one was seen near Chelmsford on September 7, 1901 .

The Red Admiral ( $V$. atalanta) is common and generally distributed, and has been exceptionally abundant in recent years.

The Painted Lady ( $V$. cardui) is an erratic insect, as uncertain in its appearances as are the 'Clouded Yellows.' After being extremely rare or entirely absent for long periods it will suddenly turn up in great abundance everywhere. Whether it often hibernates in the perfect state in this country is doubtful, but there can be no doubt that most of the specimens found here in the autumn are the progeny of immigrants which reach our shores earlier in the year. 


\section{A HISTORY OF ESSEX}

The White Admiral (Limenitis sibylla) is found in most of the larger woods in north Essex, and in the closing year of the past century was very abundant in some of them. It seems however to be scarce in the other districts. Mr. Fitch reports a single specimen from Hazeleigh in $1899, \mathrm{Mr}$. Jeffrey gives Saffron Walden as a locality, and formerly it occurred in Epping Forest. As the larvæ feed on the honeysuckle that grows among the tallest underwood, it follows that large numbers of them must perish every winter when the annual clearances are made, and where these are unusually extensive and continued for three or four years the species may be reduced to the verge of extinction; and this is probably the main cause of the fluctuation in its numbers in restricted localities.

The Purple Emperor (Apatura iris) doubtless suffers from the same cause. The larvæ hibernate upon the sallow, and in some of its most favoured haunts there are only a few scattered bushes, and when these are cut the larvæ necessarily perish. In many woods sallows abound, and there the struggle for existence is carried on under more favourable conditions; but in these days the species must always be much scarcer than it was formerly when thousands of acres of grand old trees stood where only a few miserable sticks stand to-day. For the green woods of England have disappeared in all directions, and their beautiful wild flowers, birds and insects have to a very considerable extent gone with them. But even under the most favourable circumstances this butterfly was always more or less sporadic. In $1855-6$ it was common in the Colchester district, and again for two or three years in the early eighties was comparatively common; but since then it has become exceedingly rare, not only in Essex but also in Kent, where it occurred freely about the same time. There its disappearance has been attributed to the rapacity of collectors, but here it cannot have been due to this cause, for certainly not more than five per cent. of the specimens seen were captured, as far as can be ascertained. It seems to have occurred in all the larger Essex woods in past years, and doubtless still exists in some of them, and may again recover its lost ground for a time in the near future.

The Marbled White (Melanargia galatea) was formerly abundant near the wood on Mersea Island, but disappeared with the wood many years ago. Hartley Wood, St. Osyth, also produced it in great plenty ; but only a small remnant of that wood is still standing, and to the few entomologists of this generation who have visited it galated is only a tradition not a memory. It still occurs pretty freely in south Essex, where it is found at Laindon, on Canvey Island, on the slopes near Hadleigh Castle and elsewhere, but has disappeared from several other districts. In $185^{8-9}$ specimens were found on the railway embankment at Lexden, and much more recently a single example was captured on the railway near Wivenhoe; but whether these were stragglers from the south or from an undiscovered colony which may possibly still exist in the north is a moot point. 


\section{INSECTS}

The Speckled Wood (Pararge egeria) was common in the eastern counties in the middle of the past century, but ere its close had vanished completely from nearly all its former haunts, though Mr. B. G. Cole found it still common in Epping Forest about 1890 . Why it disappeared is a mystery, for it was common in nearly every copse and shady place, and abounded in some woods where it was quite unmolested by collectors.

The Wall ( $P$. megara) is common everywhere in grassy places, though the spring brood is usually much less numerous than that which appears at the close of the summer.

The Grayling (Satyrus semele) is with us very rare and local. Stragglers turn up occasionally, and have occurred at Dedham and Colchester, where after an interval of many years a single specimen was found on September 9, rgoo. Probably it abounded on some of the extensive heaths and moors that surrounded Colchester in past times.

The Large and Small Meadow Browns (Epinepbele janira and $E$. titbonus), the Wood Ringlet (E. byperanthus) and the Small Heath (Caenonympba pampbilus) are all abundant and widely distributed.

The Brown Hair-streak (Tbecla betula) is common some seasons in Epping Forest, but scarce elsewhere. It is recorded from Hazeleigh by Mr. Raynor and from Mundon Furze by Messrs. Raynor, Fitch and others. Previous to 1860 it was found sparingly on blackthorn hedges to the north of Colchester and at Langham, but has not been seen there in recent years.

The White Hair-streak ( $\mathcal{T}$. w-album) appears to be found wherever the wych-elm grows, and is so very generally distributed that it is needless to mention any special localities. In favourable seasons it is fairly common, and sometimes abounds.

The Purple Hair-streak and the Green Hair-streak $(\mathcal{T}$. quercus and T. rubi) are common and generally distributed, the former in oak woods and the latter in rough places where broom and furze grow freely.

The Small Copper (Polyommatus pblacas) is generally common during the summer, especially on the coast. Silvery white, pale golden, nearly black, black-banded and other varieties have at various times been found.

The Silver Studded Blue (Lycana agon) occurs freely in one or two places in the Epping district, to which it seems to be entirely restricted.

The Brown Argus (L. astrarche) has recently become one of our commonest butterflies. Previous to 1896 it was quite a rarity in the neighbourhood of Colchester, but in that year many thousands of specimens might have been taken; for they abounded in all directions, and the species has continued to hold its ground since, though in lesser numbers. Mr. Fitch had previously taken it commonly at Purleigh and on Osey Island, and Mr. Raynor at Warley, and it is probably at the present time generally common in the county.

The Common Blue (L. icarus) is abundant everywhere, especially on the coast, where vast numbers may be seen at rest on grass stems towards the close of the day. 


\section{A HISTORY OF ESSEX}

The Clifden or Dartford Blue (L. bellargus) is stated by $\mathrm{Mr}$. Joseph Clarke to have certainly been taken once or twice near Saffron Walden, where there are old specimens in the museum presumably of local origin.

The Chalk-hill Blue (L. corydon) is rare in Essex though common elsewhere. Previous to 1860 it occasionally occurred on the railway embankments near Colchester, while several specimens were once met with in the High Woods, though none had been found there previously or have been seen since. It seems to have been common near Epping about 1859 , and single specimens were taken in 1885 and 1892 . The latest records are one example at Havering-atte-Bower by Miss Gertrude Pemberton-Barnes in 1899 , and one at Great Horkesley in 1901.

The Azure Blue ( $L$. argiolus) is widely distributed, but often scarce in some districts; but in $1900-1$ it appeared in far greater numbers than had ever been observed before, and seems to have abounded everywhere.

The Mazarine Blue ( $L$. semiargus) appears to be almost extinct in England, but is reported by Mr. Joseph Clarke to have been formerly taken near Saffron Walden.

The Small Blue (L. minima) is reported from the Epping district by Messrs. J. A. Clarke and W. Machin, and Mr. Joseph Clarke records a single specimen captured by himself ' a mile south of Walden.'

The Duke of Burgundy (Nemeobius lucina) is uncommon and local. It is however sometimes met with in several woods in the Tendring Hundred. Mr. Raynor finds it sparingly at Woodham Ferris, and Mr. Howard Vaughan found it at Eastwood near Southend.

The Grizzled Skipper (Syricbtbus malva) is widely distributed and common in many places.

The Dingy Skipper (Nisoniades tages) seems to have always been considered a common insect in Epping Forest, where Professor Meldola and Mr. W. Cole found it in abundance in $1889-90$; but previous to 1893 only a single example had occurred in the Colchester district. In that year several were found in the High Woods, and since then it has been quite common. Mr. G. F. Mathew states that it also occurs near Harwich.

The Small Skipper (Hesperia thaumas) is abundant everywhere in rough grassy places.

The Essex Skipper $(H$. lineola) is common all along the coast, but does not seem to be found far inland. Before 1890 it was mixed up in our collections with the previous species, of which it was considered to be a variety, till Mr. Hawes when looking over the plates of Lang's Rbopalocera Europa found it to be distinct.

The Large Skipper (H. sylvanus) is the most generally distributed species of the family, and is common everywhere from the end of May till August.

The Silver-spotted Skipper ( $H$. comma) is reported from Danbury by Mr. Fitch, who states that three examples were taken there on 


\section{INSECTS}

August 2, 1884, and there are specimens in the Saffron Walden Museum which Mr. Joseph Clarke says were caught in that neighbourhood. It does not seem to have occurred elsewhere in the county.

\section{HETEROCERA}

\section{Moths}

\section{SPHINGES AND BOMBYCES}

The Death's Head Hawk Moth (Acberontia atropos) is usually scarce, but occasionally the larvæ and pupæ are found in some numbers. In 1900 it was exceptionally common throughout the county. The Convolvulus Hawk (Spbinx convolvuli) seems to be found in larger or smaller numbers every season; from its powerful flight no limit can be set to its range, and if looked for at dusk on a warm September evening it would probably be found everywhere. The Privet Hawk (S. ligustri) is also of general occurrence, and in the larva state frequently common on privet, lilac, ash and other trees. The Bedstraw Hawk (Deilepbila galii) is nearly always rare, but occasionally occurs in some numbers. In 1888 its larvæ abounded on various species of Galium all along the coast in August and September, and many were found dead on the sands when the nights became cold. In previous seasons it has been found on Clarkia and CEnotbra at Colchester, and has been recorded from several other localities. The last occurred in 1895 when five larvæ were found between Brightlingsea and Clacton-on-Sea. The Striped Hawk (D. livornica) is an occasional migrant like the last, but is always very rare. Colchester, Mistley, Upton Park, Walton-on-theNaze and Walthamstow are recorded localities. The Silver Striped Hawk (Cbarocampa celerio), another rare migrant, has repeatedly occurred, larvæ having been found feeding on vine at Colchester, Coggeshall and Chelmsford, and perfect insects at Great Baddow, Chelmsford, Harwich, Walton-on-the-Naze and other places. The Small Elephant Hawk (C. porcellus) is very widely distributed, especially near the coast. The Large Elephant Hawk (C. elpenor) is occasionally found rather freely in the larva state on willow-herb and bedstraw in damp meadows at Colchester and sometimes in gardens on Clarkia and fuchsia, and doubtless occurs under similar conditions throughout the county. The Eyed, Poplar and Lime Hawk Moths (Smerintbus ocellatus, S. populi and $S$. tilia) are generally common among the trees and shrubs upon which their larvæ respectively feed. The Humming Bird Hawk (Macroglossa stellatarum) occurs everywhere, and though usually scarce and sometimes absent from some districts for long periods is occasionally quite common, as was the case in 1899 and 1900. The Broad-bordered Bee Hawk ( $M$. fuciformis) seems to be found in all woods where bugle and campion flowers abound; its larva feeds on the honeysuckle and may sometimes be found in hedges. The Narrowbordered Bee Hawk ( $M$. bombyliformis), the larva of which feeds on Scabiosa succisa, is extremely rare and local. A single specimen was 


\section{A HISTORY OF ESSEX}

captured at Colchester in June, 1896. Mr. H. C. Cole has found it at High Beech, and Mr. Doubleday formerly took it at Epping. Little dependence can be placed in other records, as the specific name of each of these two species is often erroneously applied to the other.

The Poplar Hornet Clearwing (Trocbilium apiformis) was commoner some years ago than it is now. Its larva feeds on the solid wood of the black and balsam poplar and aspen, preferring trees that are in the full vigour of their growth; but so many poplars have been felled and so few planted in recent years that it is no longer an easy species to obtain. The Sallow Hornet Clearwing ( $\mathcal{T}$. crabroniformis) occurs everywhere where sallows and osiers abound, but though the holes in the stems from which it has emerged are very much in evidence, the perfect insect is generally much more difficult to discover. The Dusky Clearwing (Sesia tabaniformis) can scarcely be considered a British insect in these days, and its only claim to a place in our list rests on its capture at Epping by Mr. H. Doubleday in I 839. The White-barred Clearwing (S. sphegiformis) is also extremely rare and local, but has been taken in south Essex by Mr. J. A. Cooper in 1890 and by Mr. Thurnall in 1888 . The Currant Clearwing ( $S$. tipuliformis) is common in gardens, where its larvæ are said to be very injurious; but however this may be elsewhere, certain old currant bushes at Colchester which have been affected for more than forty years were producing their usual prolific crop of fruit quite recently. The Yellow-belted Clearwing (S. asilifor$m i s$ ) is found in the larva state nearly everywhere in oak stumps where the trees have been felled the previous year. The Red-belted Clearwing (S. myopiformis) is often common in gardens and orchards, and is probably the greatest enemy of the apple grower that exists; for though the Codling Moth takes heavy toll of the fruit this insect often slowly but surely destroys the trees themselves. The Large Redbelted Clearwing (S. culiciformis) affects freshly cut birch stumps, and would be very common but for the woodpeckers; it seems to occur in all woods where birch grows freely. A white-belted variety has been captured at Colchester. The Red-tipped Clearwing (S. formiciformis) is local and less frequently found now than when osiers-on the pith of which the larvæ feed-were more extensively cultivated. It occurs at Colchester, Mark's Tey and Coggeshall, and probably elsewhere where old osier grounds still exist. The Six-belted Clearwing (S. icbneumoniformis) occurs sparingly at Southend, where Mr. Whittle met with it in I goo. The Rev. C. R. N. Burrows also finds it at Benfleet, and it has been seen on Northey Island. The Fiery Clearwing (S. cbrysidiformis) formerly occurred near Southend, but does not seem to have been found since 1860 , which was probably the most disastrous year experienced by Lepidoptera in recent times. The Green Forester (Ino statices) is found in the Epping district, and has been taken at Warley by Mr. Willament.

The Broad-bordered Five-spotted Burnet (Zygana trifolii) is reported from Epping and Hainault by Mr. Machin and from Warley Gap by 


\section{INSECTS}

Mr. Willament. The Narrow-bordered Five-spotted Burnet (Z. lonicer $a$ ) is also recorded from Hainault by Mr. Machin. The Six-spotted Burnet (Z. filipendula) occurs in many places, including Southend, Warley Gap, Maldon, Clacton and Walton-on-the-Naze. The pale yellow form has been captured at Leigh, and quite recently there was a large colony near Colchester which produced very beautiful pink, orange and terra cotta forms. Owing to changes effected since 1896 it is to be feared that this colony is now practically extinct.

Sarotbripus undulanus is scarce and local. A few were taken at Mucking by Mr. Burrows in 1900 , and examples have been captured at Colchester and St. Osyth.

Earias cblorana is sometimes common among osiers.

The Green Silver-lines (Hylopbila prasinana) is of general occurrence among oak, birch and beech, and the Scarce Silver-lines (H. bicolorana) though far from common is widely distributed in parks and oak woods.

The Short-cloaked (Nola cucullatella) is common among whitethorn and blackthorn and also about fruit trees.

The Small Black Arches (N. strigula) is scarce and local, but has been found at Brentwood and Hazeleigh by Mr. Raynor, at Southend by Mr. Howard Vaughan, near Harwich by Mr. Mathew, and also at Colchester and St. Osyth. The Least Black Arches ( $N$. confusalis) is found sparingly in the same localities and seems to be more generally distributed.

Nudaria senex is found at Dovercourt by Mr. Mathew, at Mucking by Mr. Burrows, and at Halstead by Mr. Percy Adams, and is also recorded from Epping and Leigh. N. mundana has occurred sparingly at Colchester, Mucking and St. Osyth.

The Dew Moth (Setina irrorella) was reported by Mr. Edward Doubleday to have been found commonly in the larva state on Licben caninus at Mersea and St. Osyth many years ago. There are no other records for the county, and this may have been a mistake; for though the larva of an allied species (Litbosia complana) has been frequently obtained since on Lichen caninus at St. Osyth no irrorella have been found.

The Rosy Footman (Calligenia miniata) is fairly common in woods. A yellow form has been twice met with at Colchester. The Four-dotted Footman (Litbosia mesomella) is widely distributed, but not generally common. The Orange Footman ( $L$. sororcula) was common for a period some twenty-five years ago, but afterwards became very scarce ; it has again occurred rather more frequently during the past three or four years, and in $1899 \mathrm{Mr}$. Raynor met with it in some numbers at Hazeleigh. The Dingy Footman (L. griseola) is of frequent occurrence in many places, and its variety, L. flava (stramineola, Dbl.), is recorded from the Epping and Harwich districts. The Common Footman ( $L$. lurideola) is of general distribution, but is seldom so common as to be abundant. The Scarce Footman (L. complana) is more local, but not really scarcer where it occurs than the last species; it seems to be more 


\section{A HISTORY OF ESSEX}

frequently met with on or near the coast than inland. The Large Footman ( $L$. quadra) has been taken among other places at Colchester, Harwich and Hazeleigh, but was always rare, and has not been found recently. The Red-necked Footman (L. rubricollis), like most members of its family, is a somewhat uncertain species. It was at one time very abundant at Langham and Little Bentley, but is not of frequent occurrence now, though it may still be occasionally found in some woods in the Tendring Hundred. The Crimson-speckled Footman (Deiopeia pulcbella) is a rare migrant which was captured at Epping in 1846 , at Southend in 1882 , and at St. Osyth, where Mr. Fitch found two specimens on June 6,1892 .

The Cinnabar (Euchelia jacobace) occurs sparingly in many places, but seems only to be well established and common in two or three localities in the Epping and Southend districts.

The Clouded Buff (Nemeopbila russula) is scarce and local, but has been taken in Epping Forest by Professor Meldola, at Eastwood by Mr. Whittle, and near Brentwood by Messrs. Burrows and Raynor. It formerly occurred sparingly near Colchester, but has not been seen since 1867.

The Wood Tiger ( $N$. plantaginis) was not uncommon twenty years ago in one of the St. Osyth woods, but has died out or gone elsewhere.

The Common Tiger (Arctia caja) was until recently extremely common everywhere, but for several years has been very uncommon in the northern part of the county. The last time the larvæ abounded they were largely infested with ichneumons, and it may very probably be to this cause that their present scarcity is due. The Cream-spot Tiger $(A$. villica) is now much commoner than it was formerly, especially on the coast, where the larvæ in some seasons abound. Several specimens of a very beautiful and striking variety have been obtained by $\mathrm{Mr}$. Mathew at Dovercourt, and other fine forms have been bred from larvæ found elsewhere. The Ruby Tiger (Spilosoma fuliginosa) appears to be scarce and local, for it is only reported for the Colchester district in recent years, though there are old records of its occurrence at Epping and Witham. The Muslin Moth (S. mendica) is found sparingly all over the county. The Buff Ermine ( $S$. lubricipeda) and the White Ermine ( $S$. mentbastri) are generally common, but the Water Ermine ( $S$. urtice) is scarce and local. It has occurred at Colchester and Frinton. The Ghost (Hepialus bumuli) is common in grassy places everywhere. The Wood Swift $(H$. sylvanus) may sometimes be found on the coast, but more frequently among bracken in woods. The Common Swift ( $H$. lupulinus) abounds in all directions, and the Golden Swift ( $H$. bectus) is common for a few minutes about sunset in damp places in woods. The Goat Moth (Cossus ligniperda), though still common, is less abundant than formerly, as large numbers of infested trees have been removed and the woodpeckers have been unremitting in their attentions to those that still remain. The Wood Leopard (Zeuzera pyrina) is far from common generally, but occurs sparingly in many places, including Colchester, Ilford, Maldon 


\section{INSECTS}

and St. Osyth. Heterogenea limacodes (testudo) is fairly common in many oak woods, but does not seem to frequent those near Harwich and St. Osyth. $H$. asella is very local, but is widely distributed in the Epping Forest district, and single examples have occurred at Colchester and Little Bentley. The Brown-tail (Portbesia cbrysorrbcea) is a very uncertain insect. It suddenly became extremely abundant for a short period about twentyfive years ago, after which it entirely disappeared and was supposed to be extinct ; but during the past three years it has again been found commonly near Colchester, and Mr. Mathew has also found it plentifully near Harwich. The Yellow-tail ( $P$. similis) abounds everywhere. The White Satin (Leucoma salicis) is widely distributed and frequently common about poplars and willows, but of somewhat irregular occurrence. It is probably to a large extent a migratory species, as $\mathrm{Mr}$. Kerry reports it coming in from the sea in thousands at Harwich on June 27,1878 . The Black Arches (Psilura monacba) occurs freely in oak woods. The Dark Tussock (Dasycbira fascelina) was formerly common on the railway embankments between Colchester and Mark's 'Tey, where the larvæ fed on broom and sallow, but since the system of firing the herbage has been regularly practised it has disappeared with many other species, though possibly stragglers may still linger somewhere in the district. It has also occurred sparingly at Great Bentley and Southend. The Light Tussock (D. pudibunda) is common throughout the county. The Scarce Vapourer (Orgyia gonostigma) is found in the neighbourhood of Brentwood, where Mr. Raynor says it is very local. It has also occurred at Danbury. The Common Vapourer ( $O$. antiqua) abounds everywhere, and may sometimes be seen flying even in the main streets of the more populous towns. The Pale Eggar (Tricbiura cratagi) is very generally distributed, but seems to be nowhere common. The December Moth (Pacilocampa populi) must have received its English name from a belated specimen, as it usually appears in November, when the male comes rather freely to light. It is of general occurrence, but both this and the last species have been scarce of late. The Small Eggar (Eriogaster lanestris) sometimes occurs in extreme abundance, and the webs of its gregarious larvæ may be seen in all directions. A few may be found almost any year, but occasionally they are scarce for indefinite periods. The Lackey (Bombyx neustria) is of similar habits to the last, and the same account will serve equally well for it. The Coast Lackey (B. castrensis) inhabits the salt marshes, from which its ova are frequently borne by the tides to the higher levels of the sea walls and coast sands. Though sometimes difficult to find, they are extremely abundant in favourable seasons- such as 1899 and 1900 - and occur in suitable places all along the coast from Southend to Harwich. The Fox Moth (B. rubi) is often abundant on the coast and elsewhere in the larva state in the late autumn, and the perfect insect may sometimes be seen flying over rough uncultivated places in June. The Oak Eggar (B. quercus) is generally common, but there are often periods of scarcity during which its larvæ may be looked for to very little purpose. The Drinker (Odonestis potatoria) was ex- 


\section{A HISTORY OF ESSEX}

tremely common before the great drought of 1893 , but since then has been very scarce, at least in the Colchester district. As it has been found in immense numbers in the Fens of late, it may perhaps have forsaken its former sunburnt haunts for a time for more congenial surroundings. The Lappet (Lasiocampa quercifolia), though far from common, is widely distributed, and may be sought for with a good chance of success in any district where sloe abounds. The Emperor Moth (Saturnia pavonia) is frequently met with in the larva state, and being gregarious and polyphagous it is easy to obtain a good supply of the perfect insect. The Scalloped Hook Tip (Drepana lacertinaria) has of late been absent from Dedham and St. Osyth, where it was at one time not uncommon. It has also been found at Warley and Epping, and probably occurs periodically in most birch districts. The Pebble Hook Tip (D. falcataria) is common, and speedily avails itself of fresh opportunities for extending its boundaries. The Oak Hook Tip (D. binaria) is generally distributed among oaks, and seems to have been commoner recently than it was formerly. The Beech Hook Tip (D. cultraria) is found in some numbers in Epping Forest and also more sparingly at Brentwood, but has been assiduously sought for in vain in north Essex. The Chinese Character (Gilix glaucata) abounds everywhere. The Sallow Kitten (Dicranura furcula) and the Poplar Kitten (D. bifida) are of general occurrence but cannot be called common, the latter being much the scarcer of the two. The Puss (D. vinula) is common everywhere. The Lobster (Stauropus fagi) is scarce, but seems to be found in all parts of the county, especially where beech grows freely, as at Epping and Brentwood, but it also occurs in most of the larger woods. The Dusky Marbled Brown (Glypbisia crenata) is extremely rare in Britain, but two specimens were captured by Mr. H. Doubleday in Ongar Park Woods in 1839 and $184 \mathrm{I}$. The Pale Prominent (Pterostoma palpina) is found sparingly among poplars and willows. The Coxcomb Prominent (Lopbopteryx camelina) is common everywhere. The Maple Prominent (L. cuculla) is scarce and local, but occurs pretty regularly on the boulder clay to the north-west of Colchester. The Birch Prominent (L. carmelita) has only been recorded from the Epping district, where $\mathrm{Mr}$. Doubleday occasionally met with it many years ago. The Swallow Prominent (Notodonta dictea) is fairly common among poplars, and the Lesser Swallow Prominent ( $N$. dictcoides), though scarce, is sometimes found at Epping, Colchester, St. Osyth and elsewhere. The Iron Prominent ( $N$. dromedarius) will frequently be found if well looked for on birch and alder, from which its larva may be beaten in the autumn. The Three Humped Prominent ( $N$. trilopbus) is one of our greatest rarities. The only known Essex specimen was bred by $\mathrm{Mr}$. J. W. Douglas on August 10, I 842, from a larva found on aspen at St. Osyth. The Pebble Prominent ( $N$. ziczac) is common in the larva state on aspen, poplar and sallow. The Great Prominent ( $N$. trepida), the Lunar Marbled Brown ( $N$. cbaonia) and the Marbled Brown ( $N$. trimacula) are found in parks and oak woods; they are widely distributed but always 


\section{INSECTS}

scarce. The Buff Tip (Pbaleria bucepbala) is found everywhere and often in superabundance. The Chocolate Tip (Pygara curtula) occurs freely in the larva state on aspen, and the Small Chocolate Tip $(P$. pigra) abounds on aspen and sallow. The Buff Arches (Thyatira derasa) and the Peach Blossom $(\mathcal{T}$. batis) occur generally among brambles, but are not usually found in large numbers. The Figure of Eighty (Cymatophora octogesima) is scarce but cannot be considered local, as nobody acquainted with its habits need despair of finding it in any part of the county where poplars abound. The Poplar Lutestring (C. or) is of general occurrence among aspens, especially in woods. The Lesser Satin Lutestring ( $C$. duplaris) may be found flying among birches at dusk in June. The Lesser Lutestring (Asphalia diluta) comes freely to 'sugar' in the autumn. The Yellow Horned ( $A$. flavicornis) is to be looked for on birch twigs and stems on mild days in March, but though very widely distributed, it seems to be less common in Essex than in some other counties. The Frosted Green ( $A$. ridens), being attached to the oak, occurs in all the well wooded districts, but is not nearly so common in our county as in the New Forest.

\section{NOCTUE \\ BRYOPHILIDÆ}

Bryopbila perla is generally common on old walls.

\section{BOMBYCOID压}

Moma orion is widely distributed in oak woods, especially near Colchester and in the Tendring Hundred. Demas coryli is fairly common among birch and beech. Acronycta tridens and $A$. psi are generally distributed, the former being the scarcer, but both have been much less common since 1893 than they were previously. A. leporina is far from common. It was formerly found occasionally near Colchester, and has more recently occurred at Brentwood and Epping. $A$. aceris was a common Colchester insect some years ago, but gradually decreased in numbers and at last entirely disappeared. Larva were always to be found on two old sycamores that formerly stood in the Abbey Field, and it was after their removal that the period of scarcity set in. It still occurs in several localities in south Essex. A. megacepbala is generally common about poplars. $A$. alni is very rare, but has occurred at Colchester and Wormingford. A. ligustri is scarce at Alresford and Colchester, but doubtless has a wide distribution among ash and privet. A. rumicis and Diloba caruleocepbala abound everywhere.

\section{LEUCANIIDÆ}

Leucania conigera during the recent period of extreme agricultural depression swarmed at thistle flowers, which then abounded in some of the forsaken fields, but since these have again come under the plough the insect has been much less numerous. L. vitellina is unique for the county, and has only recently obtained a place in our list, a single specimen having been taken by the Rev. W. Claxton at Navestock in 


\section{A HISTORY OF ESSEX}

September, 1900. L. turca does not seem to occur in north Essex, but is found in the Epping district, and Mr. Raynor says it is periodically common at Brentwood. L. litbargyria occurs freely everywhere. $L$. obsoleta is scarce and local, but has been taken in the Southend district by Mr. Whittle and others, and at Rainham and Mucking by Mr. Burrows. L. littoralis is found by $\mathrm{Mr}$. Mathew at Dovercourt, and occurs sparingly at Clacton-on-Sea. L. impudens (pudorina, Hb.) has been taken by $\mathrm{Mr}$. Whittle near Southend. L. comma sometimes comes pretty freely to 'sugar.' L. straminea is not common, but occurs generally on the coast and probably elsewhere among reeds. Mr. Cansdale used to find it at Witham. L. impura and L. pallens are generally common. L. favicolor, a comparatively recent addition to the British list, was discovered by Mr. Mathew at Dovercourt, and a single specimen has been taken by Mr. Whittle at Great Wakering. These are the only captures at present recorded. Calamia pbragmitidis is of general occurrence among reeds, in the stems of which its larvæ feed. Senta maritima (ulva, Hb.) is scarce and local, but is included in Mr. Howard Vaughan's Leigh list, has been taken near Alresford, and Mr. Burrows reports it from Mucking, where it seems to occur more freely than elsewhere in the county. Cenobia rufa (despecta, Tr.) occurs in the Harwich district, and is also found at Epping and Hainault. Tapinostola fulva occurs in swampy meadows among rushes in the Colchester and Southend districts, and probably has an extensive range. Nonagria arundinis (typba, $\mathrm{Hb}$.) is of

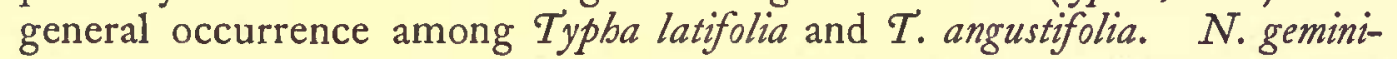
puncta is found among reeds at Alresford, Harwich, Mucking and Witham, and doubtless at many other places. $N$. neurica is generally scarce and local, but has been found at Benfleet by Mr. Whittle, near Harwich by Mr. Mathew, and at Rainham and Mucking by Mr. Burrows. Calamia lutosa has a wide distribution among reeds and is not uncommon in some coast localities.

\section{APAMEID压}

Gortyna ocbracea (flavago, Esp.) is found in all directions, its larvæ feeding in the stems of thistles and many other plants. A very fine form, differing materially from all other British specimens, has been found on the coast between Harwich and Walton-on-the-Naze. Hydrecia nictitans is of general occurrence and is extremely variable, especially the coast forms, which are generally larger and paler than those found inland. $H$. micacea may often be seen at suburban gas lamps, and its larvæ and pupæ may sometimes be found by 'raking' at the roots of maritime plants. Axylia putris, Xylopbasia rurea, $X$. litboxylea and $X$. monoglypba (polyodon, L.) are of general occurrence and as a rule common. $X$. bepatica is somewhat scarcer and more local. $X$. scolopacina has been found in the Harwich district and occasionally occurs at Colchester, but is decidedly scarce. Dipterygia scabriuscula (pinastri, L.) is generally distributed and comes rather freely to 'sugar.' Aporopbyla australis was once bred from a larva found on the St. Osyth coast. Neuria reticulata (saponaria, Esp.) 


\section{INSECTS}

occurs sparingly in many places, and has been met with in some numbers by Mr. Burrows at Mucking. Neuronia popularis comes freely to 'light,' and often knocks for admittance at the windows of country houses late in the evening. Charaas graminis has the reputation of being extremely injurious in the larva state to pastures, but though common in many parts of the county, the Essex farmers do not appear so far to have traced any extensive ravages home to it. Cerigo matura (cytherea, $\mathrm{Fb}$.) is also a grass feeder, which occasionally comes to 'sugar' in some numbers, but seems to be commoner in the Maldon and Stanford-le-Hope districts than further north. Luperina testacea and $L$. cespitis are attracted by 'light,' and both may be found at rest on grass culms after dark, the latter being very much scarcer than the former. Mamestra abjecta is a coast species which is found in suitable localities along all the coast line from Southend to the mouth of the Stour, where Mr. Mathew has met with it in some numbers and in great variety. Mr. Burrows has also taken it freely at Mucking and Rainham and Mr. Laver at Tollesbury. $M$. sordida (anceps, Hb.) is occasionally common at 'sugar.' M. albicolon is sometimes found at Dovercourt and elsewhere on coast sands. One year the larvæ were by no means uncommon at St. Osyth, but none have occurred there recently. (M. furva was recorded by the late Mr. Edward Doubleday to have been exceedingly common at Epping in 1832 , frequenting the flowers of the raspberry, but probably this was an error of determination, as the northern species we now know as furva would not be likely to occur so far south.) $M$. brassica and $M$. persicarice are common garden insects, the former-the well known Cabbage Mothbeing really an 'injurious insect,' which is more than can be said for some other species that are frequently so designated. Apamea basilinea is also common, and is said to be very destructive in corn fields. $A$. gemina is sometimes plentiful at 'sugar' and flowers, especially those of the common rush. A. unanimis is frequently found in the larva state beside rivers and ditches. A. ophiogramma seems to occur rather freely some seasons in south Essex, but not north of the Maldon district; it has been found at Brentwood, Rainham, Mucking and Woodford. $A$. leucostigma (var. fibrosa, $\mathrm{Hb}$.) has been taken in some numbers and in great variety at rush flowers at Colchester. $A$. didyma occurs everywhere, often in very great abundance. Miana strigilis, $M$. fasciuncula and $M$. bicoloria (furuncula, $\mathrm{Tr}$.) are common generally. $M$. literosa is scarcer and more local; especially in the north, but has been found in greater numbers on the south coast. $M$. arcuosa is common at Colchester, and probably occurs in most places among Aira caspitosa.

\section{CARADRINID死}

Grammesia trigrammica (trilinea, Bork.) frequently swarms at 'sugar,' and fine varieties may be met with. Caradrina morpbeus, $C$. alsines, G. taraxici (blanda, Tr.), C. quadripunctata (cubicularis, Bork.) and Rusina tenebrosa are all more or less common generally, but like other common species they sometimes have their adverse periods. 


\section{A HISTORY OF ESSEX}

\section{NOCTUID $Æ$}

Agrotis vestigialis (valligera, $\mathrm{Hb}$.) is found on the coast sands, but not commonly. A.puta and A. suffusa sometimes occur freely at 'sugar.' $A$. saucia is usually scarce but occasionally somewhat common. $A$. segetum and $A$. exclamationis are too abundant in fields and gardens, where they are among our most destructive insects. A. corticea is often found at lime blossom at Colchester and Maldon, and Mr. Burrows has taken it freely at Mucking. A. ripa occurs at Harwich, Walton, Clacton and St. Osyth, where $A$. cursoria is also to be met with occasionally. $A$. nigricans is more of a field and garden insect, and is frequently found on flowers at dusk. $A$. tritici is somewhat common on the coast sands. $A$. aquilina, which is held by many authors to be a form of tritici, is found sparingly at Colchester at 'sugar' and lime blossom. A. strigula (porpbyrea, $\mathrm{Hb}$.) was formerly common at Dedham, and is found at Brentwood, Epping, and probably in most places where any extent of heather still exists. $A$. pracox has once been found at rest on a house at Colchester, and once in the larva state near Clacton-on-Sea. A. obscura (ravida, $\mathrm{Hb}$.) occurs sparingly at Colchester, Maldon, Brentwood, Stanford-le-Hope and Southend. It has been reported 'abundant in Essex,' but such is not the experience of resident entomologists. Noctua glareosa is far from common, but has been found at Epping and Brentwood. Professor Meldola has met with it at Woodford, and it is occasionally taken at Colchester. $N$. augur, $N$. plecta and $N$. c-nigrum are generally distributed. $N$. ditrapezium is very local and is only recorded from Brentwood, where Mr. Raynor formerly obtained it occasionally. $N$. triangulum is common and of general occurrence. $N$. stigmatica (rbomboidea, Tr.) has a wide distribution but is decidedly scarce. $N$. brunnea and $N$. festiva are common in woods. $N$. dablii has been recorded as occurring in the county by Mr. J. W. Tutt. N. rubi comes freely to 'sugar.' N. umbrosa and $N$. baja are widely distributed but not very common. $N$. castanea (neglecta, Hb.) has been taken at Wanstead by Mr. Machin. N. xantbographa is extremely abundant everywhere. Triphana iantbina is moderately common and generally distributed. $\mathcal{T}$. fimbria is found rather freely in the larva state in most woods in the spring, and the perfect insect comes to 'sugar' later in the year. $\widetilde{T}$. interjecta is widely distributed, and may sometimes be seen flying wildly about hedges after 4 p.m., but has been scarcer of late, and is now more poorly represented in collections than the other species. $\mathcal{T}$. comes (orbona, $\mathrm{Fb}$.) and $\mathcal{T}$. pronuba are common everywhere.

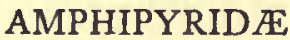

Ampbipyra pyramidea, A. tragopogonis, Mania typica and M. maura are all so generally common that it is unnecessary to give localities for them.

\section{ORTHOSIID压}

Panolis piniperda is somewhat scarce, but occurs at Birch, Colchester and Brentwood, and is probably well distributed among Scotch fir. 


\section{INSECTS}

Pacbnobia rubricosa is sometimes found at sallow and sloe blossoms, but is far from common. Taniocampa gotbica and $\mathcal{T}$. incerta (instabilis, Esp.) are abundant. $\mathcal{T}$. opima is rare, but has been found at Wanstead by Mr. Machin and at Southend by Mr. Whittle, and was bred from a Colchester larva in April, r 901 . T. populeti is widely distributed among aspen. $\mathcal{T}$. stabilis is abundant. $\mathcal{T}$. gracilis is of general occurrence. $\mathcal{T}$. miniosa is usually scarce but is found in many oak woods, where its gregarious larvæ are occasionally common. $\mathcal{T}$. munda is more frequent among elm; it is widely distributed but scarce. T. pulverulenta (cruda, Tr.) abounds everywhere. Ortbosia suspecta is very local. It is reported from Brentwood by Mr. Raynor and from Rainham by Mr. Burrows. O. upsilon, O. lota, O. macilenta, Ancbocelis rufina and $A$. pistacina are all generally common. A. lunosa is found pretty freely at ivy blossom and suburban gas lamps. A. litura and Gerastis vaccinii are found everywhere. C. ligula (spadicea $\mathrm{Hb}$.) is much scarcer, at least in the Colchester and Southend districts. Scopelosoma satellitia is common throughout the county. Oporina croceago is scarce and local, but has occurred at Danbury, and has been taken at Epping by Mr. Oldham, at Brentwood by Mr. Raynor, and at Wormingford by Mrs. Bull. Xantbia citrago is well distributed among lime trees. $X$. fulvago (cerago, Fb.) and $X$. flavago (silago, $\mathrm{Hb}$.) are common, especially the former; the larvæ may be beaten from sallow catkins in the spring and the perfect insects from yellow leaves in the autumn. $X$. aurago is very scarce in the northern part of the county, but is more frequently met with in the south. It has occurred at Colchester and also in the Epping, Brentwood, Maldon and Stanford-le-Hope districts. $X$. gilvago may be beaten freely some seasons from the seeds of the wych elm. $X$. ocellaris is extremely rare, single specimens only having been captured by Mr. Percy Reid at Feering Bury near Kelvedon, and by Mr. Whittle at Southend. $X$. circellaris (ferruginea, Esp.) is common everywhere. Cirrbedia xerampelina is apparently local and scarce, but has been taken at Colchester, Epping, Maldon and Southend.

\section{COSMIID $Æ$}

Tetbea subtusa is frequently found among black poplar and aspen, but has been less common recently than it was formerly. $\mathcal{T}$. retusa is much scarcer and more local, but has been taken at Epping, Harwich, Layer Marney and Rainham. Cosmia paleacea (fulvago, Hb.) was once captured at Hazeleigh by the Rev. G. H. Raynor, which seems to be the only record. Dicycla oo has sometimes been found freely in many places in south Essex, but is of very rare occurrence in the northern districts. Epping, Hainault, Brentwood, and Rainham seem to have been the most favoured localities, but it has been taken at Coggeshall, and by Mr. Percy Adams at Halstead. Calymnia trapezina is very common throughout the county. C. pyralina is rare and local. Mr. Raynor has met with it at Brentwood and Hazeleigh, Mr. Garrow at Leytonstone, and it has also been found by Mr. Burrows and Mr. Whittle. C. diffinis and $C$. affinis have a wide distribution and are not uncommon in some elm districts. 


\section{A HISTORY OF ESSEX}

\section{HADENIDÆ}

Eremobia ocbroleuca was common and generally distributed in the county some twenty years ago, and after remaining more or less common for several seasons completely disappeared. During the past two years it has reappeared in the Southend and Maldon districts, and will very possibly soon be common again for a period. It is probably a migratory species which has so far failed in its endeavours to become a permanent resident. Diantbecia nana (conspera, Esp.) was taken at Epping by $\mathrm{Mr}$. H. Doubleday. D. capsincola is common everywhere among Lychnis. $D$. cucubali and D. carpopbaga are not uncommon. The larvæ may sometimes be found on Silene inflata and S. maritima, but the former has not been seen for several years. Hecatera cbrysozona (dysodea, $\mathrm{Hb}$.) was formerly very common about Coggeshall, where its larvæ fed on lettuce flowers and seed, but the particular species of lettuce it mostly favoured is little cultivated there now and the moth is proportionately scarce. It has also occurred at Colchester, and larvæ have been found on wild lettuce (Lactuca virosa) at Walton-on-the-Naze. H. serena is generally common, especially in the larva state on flowers of Crepis virens. Polia flavicincta is often found at rest on walls and palings in the autumn. Epunda lutulenta is scarce and local, but in 1898 was taken in some numbers by Mr. Burrows at Mucking. Cleoceris viminalis may often be taken freely in the larva state on sallow. Miselia oxyacantha, Agriopis aprilina, Euplexia lucipara and Pblogophora meticulosa are common and occur throughout the county. Aplecta prasina (berbida, $\mathrm{Hb}$.) seems to be scarce. Mr. Raynor took it at Warley, and it has several times been found at Colchester. A specimen bred there in a warm room on January Io, I 90 I, was perhaps the first British Noctua to appear in the new century. $A$. occulta is a very uncertain and local species, but has been taken by Professor Meldola near Woodford, by Mr. Doubleday at Epping, and also at Colchester and Hazeleigh. A. nebulosa is frequently found on the boles of trees in woods and comes freely to 'sugar.' $A$. tincta is rare. $\mathrm{Mr}$. Doubleday records it for Epping, and it has also been taken at Hazeleigh and Woodford. A. advena, though not common, is often taken at 'sugar,' and is very partial to dogwood flowers. Hadena adusta, $H$. protea, $H$. dentina and $H$. trifolii occur generally. (H. atriplicis is given as an Essex species in Newman's British Motbs.) H. dissimilis (suasa, Bork.) is found in many places on the coast, including Benfleet, Dovercourt, Northey Island and St. Osyth. $H$. oleracea, $H$. pisi and $H$. thalassina are generally distributed and common. Some of the Essex forms of $H$. pisi are very beautiful. $H$. contigua is extremely local; it was frequently found at Dedham up to I 890 . H. genista is generally distributed though far from common.

\section{XYLINID压}

Xylocampa areola (litboriza, Bork.) is generally to be found on posts and tree trunks in April. Xylomiges conspicillaris is a rarity in Britain, and only two specimens have been met with in Essex, one at Danbury and the other at Brentwood, both by Mr. Raynor. Calocampa vetusta is not 


\section{INSECTS}

of frequent occurrence, but has been found at Colchester, Epping and Southend. $C$. exoleta is commoner and more widely distributed, and comes to 'sugar' late in the autumn. Xylina ornitbopus (rbizolitba, Fb.) is occasionally found near Colchester and probably throughout the county. $X$. semibrunnea and $X$. socia (petrificata, $\mathrm{Fb}$.) are scarce and local. Both were taken at Temple Mills by Mr. Machin, and Mr. Raynor has met with the former at Hazeleigh. Asteroscopus spbinx (cassinea, $\mathrm{Hb}$.) is very generally distributed but not common ; it comes to 'light' in November. Cucullia verbasci is common in the larva state on mullein and figwort, but the perfect insect is seldom found. The larvæ of $C$. asteris have been taken in some numbers by Mr. F. J. Hanbury at Benfleet, by Mr. Whittle at Southend, and by Mr. Mathew at Dovercourt. C. chamomilla is common some seasons in the larva state in many parts of the county, but is very irregular in its appearances. C. umbratica may often be found at rest on posts, rails and park palings, and hovering over honeysuckle flowers at dusk.

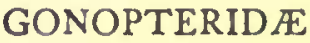

Gonoptera libatrix occurs everywhere among willows and poplars.

\section{PLUSIIDÆ}

Habrostola tripartita (urtica, Hb.) is generally distributed but not common among nettles. $H$. triplasia is recorded from Brentwood, Epping, Harwich, and Maldon, but has not so far been found at Colchester. Plusia moneta, which has in recent years invaded England and established itself in several counties, has only once been found in Essex, a single specimen having been captured by Mr. C. Oldham at Woodford. $P$. chrysitis is found everywhere among nettles. $P$. festuce is scarce, but has occurred at Benfleet, Colchester, Maldon and St. Osyth. P. iota, though widely distributed, is generally scarce. It was however common at honeysuckle flowers at Chingford in 1892 . $P$. pulcbrina is found sparingly at West Bergholt and St. Osyth, and Mr. R. Miller Christy has taken it at Chignal St. James. Probably it has a wide range elsewhere in the county. $P$. gamma is ubiquitous and often occurs in myriads. On August I I, I 900, the coast near Clacton-on-Sea swarmed with specimens, which rose in clouds at nearly every step for several miles. They were especially abundant on sea lavender flowers. A very fine melanic example much larger than the type was met with.

\section{HELIOTHID压}

Anarta myrtilli probably occurred on most of the extensive heaths and moors in the county previous to their enclosure. It was still to be found sparingly on Tiptree Heath a few years ago. Heliaca tenebrata (arbuti, Fb.) may frequently be seen in flowery places in May, especially among buttercups. Heliotbis dipsacea was not uncommon on the northern part of the coast sands up to the great drought of 1893 , since which it has been very rare. A single specimen has been taken in the High Woods at Colchester. $H$. peltigera is rare, but was formerly found 


\section{A HISTORY OF ESSEX}

occasionally with dipsacea. $H$. armigera is a scarce migrant, worn specimens of which once appeared in some numbers in a clover field at Colchester. Cbariclea umbra (marginata, Fb.) is found on the coast, and also in inland woods, where its larvæ feed on the young shoots of hazel and birch.

\section{ACONTIID $Æ$}

Agropbila trabealis (sulpburalis, Lin.) cannot be considered a native of the county, but was once found at Temple Mills by Mr. Machin. Acontia luctuosa has been taken at Grays and Benfleet, and occurred somewhat freely in 1900 at Maldon and Mucking. It has not been met with in north Essex.

\section{ERASTRIID压}

Erastria venustula is a very local species, but has occurred rather freely in several parts of Epping Forest and also at Warley. E. fasciana (fuscula, Bork.) is a widely distributed woodland species, sometimes occurring in fair numbers, but often scarce for long periods.

\section{POAPHILID}

Pbytometra viridaria (enea, $\mathrm{Hb}$.) is found commonly at Epping. It frequents open spaces in woods and was plentiful at Dedham previous to 1890 .

\section{EUCLIDIIDÆ}

Euclidia $m i$ is common on the coast, but had not been seen in the neighbourhood of Colchester till much of the land for a time became derelict, during which period it established itself in several fresh localities where it still continues common. E. glypbica is of frequent occurrence at Epping and Southend, but is not found in the northern part of the county.

\section{CATEPHIID压}

Catepbia alcbymista is one of the rarest of the British Lepidoptera, and is unique as regards the county. A single example was found at rest on an oak tree near Colchester by W. Tillaney on June 9, 1875 .

\section{CATOCALID}

Catocala fraxini is also a rarity. Two specimens were captured at Southend by $\mathrm{Mr}$. Hope in 1846 , and one was taken at Colchester in September, 1869. C. nupta is common and generally distributed. An example of the rare variety carulescens was once taken by Mr. Laver at Colchester. C. promissa and $C$. sponsa are both rare. A larva of the former was once beaten from oak in Langham Lodge Wood, and the latter was taken at Hainault by Mr. Machin.

\section{AVENTIIDÆ}

Aventia flexula is scarce, but has been found at Colchester, Halstead, Hazeleigh and Langham. 


\section{INSECTS}

\section{TOXOCAMPID E $^{-}$}

Toxocampa pastinum is local, and is only recorded from Leigh, where a few specimens were taken by Mr. Howard Vaughan.

\section{BOLETOBIID压}

Boletobia fuliginaria, the latest addition to our list, was captured at Hale End, Walthamstow, by Mr. R. W. Robbins on July 29, I 901 .

\section{HERMINIID Æ}

Rivula sericealis is found in the Colchester, Maldon, Rainham and Southend districts. Zanclognatba grisealis and $Z$. tarsipennalis are of general occurrence. $Z$. emortualis is excessively rare, and has only been found at High Beech and Loughton. Herminia cribralis has been taken at Leigh and also in some numbers at Mucking, and a single specimen has occurred at Walton-on-the-Naze. $H$. derivalis is sometimes found in fair numbers, but is extremely local in the Colchester district; and two specimens were captured by Mr. Pryor at Leigh in 1870 . Pechypogon barbalis is generally distributed and common in woods.

\section{HYPENID压}

Hypena rostralis abounds among hops, and $H$. proboscidalis is common everywhere among nettles. Hypenodes albistrigalis and $H$. costastrigalis are found at Epping, and Mr. Raynor has met with the former at Brentwood and the latter at Hazeleigh.

\section{BREPHIDES}

Brephos parthenias is found at Colchester, Epping, St. Osyth, Messing, Wrabness and probably in most large woods among birch. In 1846 it was captured at Epping as early as February 28. B. notba is usually scarcer and more local, but occurs in many woods, including those at Epping, Ongar, Messing, Wrabness and St. Osyth.

\section{GEOMETRE}

UROPTERYGIDÆ

Uropteryx sambucaria is of general occurrence.

\section{ENNOMID压}

Epione apiciaria is widely distributed but not common. E. advenaria was recorded as rare at Eastwood near Southend by Mr. Howard Vaughan. Rumia luteolata (cratagata, L.) and Venilia maculata are generally common. Angerona prunaria is found frequently in many woods, but has not recently been seen in the Colchester district, where it was formerly common, for several years. Metrocampa margaritaria is found in woods and lanes everywhere. Ellopia prosapiaria (fasciaria, Schiff) occurs sparingly at Birch, Colchester and near Harwich, and probably among Scotch fir generally. Eurymene dolabraria and Pericallia syringaria are widely distributed but are not common. Selenia bilunaria (illunaria, Hb.) abounds everywhere. S. lunaria though found in many places is nowhere common. S. tetralunaria (illustraria, $\mathrm{Hb}$.) is extremely local. It occurs 


\section{A HISTORY OF ESSEX}

at Epping and Hainault, and Mr. Mathew reports it for the Harwich district, but it does not seem to have occurred elsewhere in north Essex. Odontopera bidentata and Crocallis elinguaria occur in all parts of the county, the latter being much the commoner. Eugonia autumnaria has once been taken at Shoeburyness by Mr. Whittle. Another example was captured by Mr. Mathew at Dovercourt on Oct. 4, I 90 I. E.alniaria (tiliaria, Bork.) comes freely to 'light.' E. fuscantaria is scarce, but is found at Colchester, Harwich, and probably generally in the ash districts. E. erosaria and $E$. quercinaria (angularia, Bork.) are found in many oak woods, the former being much the scarcer. Himera pennaria may be found everywhere, and comes freely to suburban gas lamps in the late autumn.

\section{AMPHIDASYDÆ}

Pbigalia pedaria (pilosaria, $\mathrm{Hb}$.) is frequently found on the trunks of trees in January if the weather be mild, and is of general occurrence. Nyssia bispidaria occurs similarly in February and March, but is much scarcer and more local. Biston birtaria is generally common, especially about elms and at gas lamps. Ampbidasys strataria (prodromaria, Schiff.) is frequently found on the boles of oak during mild weather in the spring. $A$. betularia is generally distributed and common; the black variety doubledayaria and intermediate forms are occasionally captured or bred.

\section{BOARMIID压}

Hemeropbila abruptaria is of frequent occurrence at rest on walls and palings. Cleora licbenaria was formerly common in the Colchester district-especially at Birch and Layer-de-la-Haye-but has disappeared in recent years. Boarmia repandata and $B$. gemmaria (rbomboidaria, $\mathrm{Hb}$.) are found everywhere. $B$. abietaria and $B$. cinctaria occur about Epping and Ongar. $B$. roboraria was formerly frequently obtained on the oak trees at Langham Lodge Wood, but has since been vainly sought for in the few acres that remain of that once grand hunting ground. A single specimen was obtained at Colchester in 1897 , and it also occurs at Hainault, St. Osyth and Warley. B. consortaria is also recorded from Hainault by Mr. Machin, and was at one time common at St. Osyth. Tepbrosia consonaria, $\mathcal{T}$. crepuscularia and $\mathcal{T}$. biundularia are Epping insects -crepuscularia being also recorded from the Harwich district by Mr. Mathew, and a single specimen of $\mathcal{T}$. biundularia was found at Colchester in May, IgoI. T. Iuridata (extersaria, Hb.) though very far from common has an extensive range, and probably occurs in all large woods. $\tau$. punctulata is moderately common among alder and birch at Colchester and doubtless elsewhere.

\section{GEOMETRID压}

Pseudoterpna pruinata (cytisaria, Schiff.) is of general occurrence among broom and furze. Geometra papilionaria is scarce, but is found in many places among alder, birch and hazel. G. vernaria is somewhat local but not uncommon among Clematis vitalba. Pborodesma pustulata (bajularia, Schiff.) is to be found in nearly all oak woods, and in recent 


\section{INSECTS}

seasons has occurred in larger numbers than usual. $P$. smaragdaria-the Essex Emerald-was for many years a great rarity, Southend, Southminster and St. Osyth being its only recorded British localities; but since the discovery of its food plant it has been found freely all along the coast from Southend to St. Osyth, which is the present known limit of its northern range. It is to be feared that this beautiful insect has been much too keenly 'worked for' of late by the London and other collectors, wha should remember that though common at present its range in Britain is very restricted, and that altogether apart from direct human agency its struggle for existence must sometimes be severe. During a recent dry season at St. Osyth nearly all the food plants had been bitten or trodden down by cattle, and most of the larvæ must necessarily have perished. Iodis lactearia and Hemitbea strigata (tbymiaria, Gn.) are common in woods and lanes everywhere.

\section{EPHYRIDÆ}

Zonosoma porata and $Z$. punctaria occur freely among scrub oak and are widely distributed. After a long period of scarcity they are again common at Colchester. Z. linearia (trilinearia, Bork.) is plentiful among beech at Epping. $Z$. annulata (omicronaria, $\mathrm{Hb}$.) occurs freely in many places-especially on the boulder clay-among maple. $Z$. pendularia is local and not common now, though it was formerly plentiful at Dedham and St. Osyth.

\section{ACIDALIID压}

Astbena luteata is common among maple and is frequently found among alder. $A$. candidata abounds everywhere. $A$. blomeri was once captured by the Rev. C. R. N. Burrows at Wanstead-this must have been a straggler from some other county. Eupisteria obliterata (beparata, Haw.) is rather common in the Colchester district and doubtless occurs generally among alder. Acidalia ocbrata is extremely local, being only found at Southend and St. Osyth. A. dimidiata (scutulata, Bork.) and $A$. bisetata are common. A. trigeminata is scarcer, but may be disturbed from underwood and hedges, and captured on the wing at dusk in many localities. A. rusticata is a recent addition to the county list, and has only been found by Mr. Burrows and Mr. Whittle, who took it in the Southend district. A. dilutaria (interjectaria, Bdv.) and $A$. virgularia (incanaria, $\mathrm{Hb}$.) are generally common. A. ornata was once captured at Leigh by Mr. Walker, who took a single specimen in 1893 . A. marginepunctata (promutata, Gn.) is widely distributed and often common. $A$. subsericeata is somewhat scarce, but has been found more freely in the southern than in the northern portion of the county. A. immutata occurs at Southend and Leigh. A. remutaria and $A$. imitaria are generally common. A. emutaria occurs sparingly in many coast localities. A. aversata abounds everywhere. A. inornata is found frequently in woods. A. emarginata is very common, and Timandra amataria may be met with everywhere, especially in damp places in woods. 


\section{A HISTORY OF ESSEX}

\section{CABERID瓜}

Cabera pusaria is found commonly in all parts of the county; its variety rotundaria is extremely scarce. $C$. exantbemata abounds among sallows. Bapta temerata is far from common, though it is very widely distributed. B. bimaculata (taminata, Hb.) has been taken in Epping Forest by Messrs. Clark, Machin and Prout. Aleucis pictaria was originally discovered at Colchester in 1842 , and was for many years supposed to be a great rarity, but is now known to occur freely among blackthorn in several English counties.

\section{MACARIIDAE}

Macaria notata is scarce and local, but has occurred at Dedham, Langham, St. Osyth, Brentwood and Southend. M. liturata was somewhat common at Langham and Colchester before the larches on which it fed were cut down. Halia vauaria is moderately common in gardens among currant.

\section{FIDONIID死}

Strenia clatbrata and Panagra petraria are generally common. Numeria pulveraria is frequently found among hazel in woods. Fidonia limbaria (conspicuata, Schiff.) was formerly fairly common among broom on the railway embankments and in the cuttings at Lexden and Stanway, but owing to the practice which has prevailed in recent years of firing the herbage this excessively local insect has been exterminated there and now seems in imminent danger of disappearing from Britain. Dr. Battershall Gill records it from Grays in I 869. Ematurga atomaria may probably still occur where any extent of heather is left. It was found in some numbers at Layer-de-la-Haye a few years ago, and Mr. Burrows reports it as occurring in the Stanford-le-Hope district. Bupalus piniaria is found among Scotch fir at Alresford, Birch and Brentwood, and is probably of general occurrence. Minoa murinata (eupborbiata, Fb.) is scarce and local, but has been found in the Southend and St. Osyth woods. Scoria lineata (dealbata, Lin.) was found freely on the slopes at Leigh by Mr. Bouchard and Drs. Boswell Syme and Battershall Gill previous to I860, but is now extinct there. A single specimen was captured by Captain B. Blaydes Thompson at Burnham-on-Crouch on July 25, I900. Sterrba sacraria is a rare migrant which was once captured near Reed Hall, Colchester. Aspilates ocbrearia (citraria, Hb.) is common on the sea walls and coast sands in the northern part of the county. A. gilvaria occurs at Southend.

\section{ZERENIDA}

Abraxas grossulariata sometimes abounds among currant and gooseberry bushes in gardens and also on blackthorn hedges. Very beautiful yellow and other forms are sometimes met with. A. sylvata (ulmata, Fb.) is found rather freely at Laindon, and Messrs. B. G. Cole and C. Oldham have taken it in Epping Forest. Ligdia adustata and Lomaspilis marginata are common everywhere. 


\section{INSECTS}

\section{LIGIIDE}

269).

Pacbycnemia bippocastanaria, 'Rochford, Essex' (Stephens, Ills. iii

\section{HYBERNIIDE}

Hybernia rupicapraria, $H$. leucophearia and $H$. marginaria (progemmaria, $\mathrm{Hb}$.) are common in the early months of the year, and H.aurantiaria and $H$. defoliaria come freely to 'light' in mild November weather, especially when it is somewhat foggy. Anisopteryx cescularia is fairly numerous, especially among elm.

\section{LARENTIID压}

Cheimatobia brumata abounds everywhere. C. boreata is much scarcer and more local, but is found at Epping, Harwich and St. Osyth. Oporabia dilutata and Larentia didymata are generally common. L. multistrigaria is recorded for Epping, Wanstead and Hazeleigh. L. viridaria (pectinitaria, Fues.), Emmelesia affinitata and $E$. alchemillata are of frequent occurrence in woods and lanes. E. albulata has been taken at Brentwood and Doddinghurst by Mr. Raynor and at Maldon by Mr. Fitch ; it also occurs at Epping. E. decolorata is generally distributed among Lycbnis vespertina. E. unifasciata is sometimes common in the larva state in north Essex on Bartsia odontites. Eupithecia venosata occurs near Braintree, Colchester, Danbury, and probably in most places where Silene inflata grows. E. consignata is very rare, but $\mathrm{Mr}$. Machin has found it at Epping and Loughton. E. linariata is common some seasons among Linaria vulgaris, but in other years may be looked for in vain. $E$. pulchellata occurs freely in the Colchester district, and probably everywhere where Digitalis grows. E. oblongata (centaureata, Fb.) is to be met with everywhere. E. succenturiata is found in the Colchester, Maldon and Harwich districts. E. subfulvata is sometimes common among yarrow, but has been scarce during the dry seasons we have experienced recently. E. scabiosata (subumbrata, Gn.) is found on the coast at Southend, Shoeburyness and St. Osyth. E. plumbeolata occurs in many woods in June among Melampyrum. E. isogranmaria is abundant among Clentatis. E. egenaria, a very rare insect about which little seems to be known, has been taken at Loughton. E. satyrata is reported from the Harwich district by Mr. Mathew. E. castigata is generally common. E. trisignaria seems only to have been noticed at Colchester, where it is a great rarity. E. virgaureata has been recorded from Epping by Messrs. Doubleday, Machin and A. H. Waters. E. fraxinata occurs sparingly at Colchester. E. pimpinellata is sometimes common, especially on the boulder clay among Pimpinella saxifraga. E. irriguata was formerly found at Epping by Mr. Doubleday. E. innotata has been bred by Mr. W. Warren from larvæ found at Shoeburyness. E. nanata was common among heather at 'Crockleford Hangings' near Colchester a few years ago. This locality is now strictly preserved and is inaccessible to naturalists, but the species is probably widely distributed in the county. E. subnotata is common among Chenopodium. E. vulgata is generally common. E. albipunctata was common a few years ago on the flowers and 


\section{A HISTORY OF ESSEX}

seeds of Angelica, but has been scarce recently. E. absintbiata is common. E. minutata has occurred at Epping and Dedham, and probably is generally distributed on heath. E. assimilata is sometimes common among currant and hop. E. tenuiata has occurred at Epping, Harwich, Southend and St. Osyth. E. subciliata is recorded from Leigh as ' rare' by Mr. Howard Vaughan. E. lariciata is not uncommon among larch in the Colchester district. E. abbreviata is found generally on oak boles and boughs and also at sallow flowers. $E$. dodoneata has been taken at Epping by Dr. Gill, at Loughton by Mr. Machin, and near Harwich by Mr. Mathew, but is a scarce insect in the county and far from common elsewhere. $E$. exiguata is generally distributed. E. sobrinata is not uncommon at Donyland, and has been captured at Woodford by Mr. E. B. Bishop. E. togata is rare; Mr. Mathew records it from Harwich, and Mr. Prout captured a specimen at Higham Park in 1892 . E. pumilata is common. $E$. coronata sometimes occurs freely about Colchester, especially on the boulder clay. E. rectangulata is common in gardens and orchards. Lobophora sexalisata (sexalata, Vill.) occurs among sallow at Colchester, Hazeleigh and St. Osyth. L. balterata (bexapterata, Schiff.) may frequently be found at rest on boles of aspens and poplars, and is widely distributed. $L$. viretata is rare, but has been taken at Epping and Walthamstow, and Mr. Laver once found a specimen at Colchester. L. carpinata (lobulata, Hb.) has been found several times at Donyland and St. Osyth. L. polycommata is in a list of Epping insects by Mr. Edward Doubleday, published in the Entomological Magazine, vol. iii. (1836). Thera juniperata is to be found at Donyland, where it does not appear to be very common. $\mathcal{T}$. variata and $\mathcal{T}$. firmata both occur among larch and Scotch fir. The former is common and generally distributed, the latter scarcer and more local; but Mr. Burrows has taken it rather freely, and it has also been found at Birch and Berechurch. Hypsipetes ruberata seems to be scarce in the county judging by the paucity of records. It occurs sparingly at Colchester, where the specimens are more richly coloured and of a larger size than most of those from other parts of Britain. H. trifasciata (impluviata, Hb.) is not very common, but may be usually found among alder. $H$. sordidata (elutata, Hb.) abounds among sallow everywhere. Melantbia bicolorata (rubiginata, Fb.) was common among alder at Colchester and Langham a few years ago, but is now extremely scarce. $M$. ocellata is common everywhere among Galium molluga and G. verum. $M$. albicillata, though far from common, appears to have a wide range. Melanippe bastata is local, but has been taken at Southend, Brentwood, Messing and St. Osyth. $M$. procellata is not scarce on the boulder clay near Colchester; Professor Meldola has found it at Southend, and Mr. Mathew has taken it at Harwich. M. unangulata and $M$. rivata are somewhat common locally. $M$. sociata, M. montanata and $M$. fluctuata abound everywhere. Anticlea cucullata (sinuata, Hb.) is extremely rare, and the only recorded capture was made in Epping Forest by $\mathrm{Mr}$. A. H. Waters in May, 1896 . A. rubidata has a wide distribution, and has for three or four years been comparatively common after a long period of scarcity. 


\section{INSECTS}

A. badiata and $A$. nigrofasciaria (derivata, Bork.) occur among wild rose in many parts of the county ; the former is abundant and the latter, as a rule, decidedly scarce. A. berberata is extremely local ; it was formerly found at Epping, and is still plentiful in the Saffron Walden district. Coremia designata (propugnata, Fb.) has been found at West Bergholt, Great Tey, Langham and near Harwich, but does not seem to be common generally. C. ferrugata and C. unidentaria are to be found everywhere and often in abundance. C. quadrifasciaria is scarce but is well distributed, the known localities being too numerous to mention. Camptogramma bilineata is very common, but $C$. fluviata is rare, single specimens only having been recorded from Colchester, Pitsea, Leigh, Woodford, Hainault and Rainham. Pbibalapteryx tersata and $P$. vitalbata are generally to be found among Clematis. $P$. vittata (lignata, $\mathrm{Hb}$.) is scarce, but was once taken at West Bergholt by Mr. J. G. Grapes, and others have been captured by Mr. Burrows at Rainham. Tripbosa dubitata and Eucosmia certata are found in Epping Forest and at Saffron Walden. The latter also occurs occasionally at Colchester. E. undulata inhabits most woods, but is not common. Scotosia vetulata and S. rbamnata are also Epping and Saffron Walden insects. Cidaria miata is of general occurrence, especially at gas lamps. C. picata has a wide distribution, and was no rarity previous to the great drought of 1893 , but has been very difficult to find since. C. corylata and C. truncata (russata, Bork.) are common everywhere. C. immanata, which is by some authors considered a form of truncata, is much less common. C. suffumata seems to occur freely at Epping and Maldon, and Mr. Mathew finds it in the Harwich district, but it is rarely taken at Colchester. C. silaceata is rare, but has been found at Colchester and Epping. C.prunata was formerly common at Epping, where Mr. Doubleday says ' it sometimes strips the currant bushes of their leaves'; Mr. Fitch says it is also found at Maldon. C. testata is of frequent occurrence among sallow and birch. C. fulvata is common among wild rose. C. dotata (pyraliata, Fb.) is widely distributed, but by no means abundant. C. associata (dotata, Gn.) occurs freely in gardens among currant. Pelurga comitata is sometimes plentiful among Chenopodium.

\section{EUBOLIIDE}

Eubolia cervinata is common among mallow and hollyhock. E. limitata (mensuraria, Schiff.) abounds among vetches. E. plumbaria (palumbaria, Bork.) is sometimes common in heathy places among furze. $E$. bipunctaria is local, but occurs at Epping, Southend and Harwich. It was once seen in some numbers at Walton-on-the-Naze, but the encroachments of the sea seem to have been fatal to it. Anaitis plagiata is of general occurrence among Hypericum. Chesias spartiata abounds among broom. C. rufata (obliquaria, Bork.), though very much scarcer, is probably also found in most places where broom grows freely.

\section{SIONIDE}

Tanagra atrata (cbaropbyllata, L.) is recorded from Epping and Hainault. 


\section{A HISTORY OF ESSEX}

\section{PYRALIDES}

PYRALIDID Æ

Cledeobia angustalis is found in many coast localities. Aglossa pinguinalis occurs in houses, and though reputed generally common seems to be scarce in many places. A. cuprealis occurs sparingly at Colchester, Harwich, Hazeleigh and Southend. Pyralis costalis and $P$.glaucinalis are somewhat plentiful at Colchester, and the former is common in the Maldon district. $P$. farinalis is generally common. Scoparia ambigualis abounds on tree trunks in woods. S. basistrigalis occurs at Dovercourt and Hazeleigh. S. cembre is scarce, but has a wide range. S. dubitalis is common everywhere. S. conspicualis is reported for the Harwich district by $\mathrm{Mr}$. Mathew. S. mercurella is generally abundant. S. ulmella has been found at Woodham Ferris by Mr. Raynor. S. cratagella has been captured at Colchester and Epping. S. truncicolella occurs at Epping and Hazeleigh. S. angustea is found on several old walls at Colchester. S. pallida is a marsh insect that has been occasionally taken at Leigh and St. Osyth. Nomopbila noctuella (bybridalis, Schiff.) is a frequent migrant; it is generally distributed, and is sometimes very abundant, especially on the coast. Pyrausta aurata (punicealis, Schiff.) was very common in the Colchester district a few years ago, but has quite disappeared. $P$. purpuralis, which was formerly scarce there, has become very common. $P$. ostrinalis has been found at Brentwood by Mr. Raynor. Herbula cespitalis is generally distributed, and is occasionally very common at Donyland and St. Osyth. Ennychia nigrata (anguinalis, $\mathrm{Hb}$.) was taken at Epping by Mr. Doubleday. E. octomaculata is reported by Mr. Whittle to be rare near Southend. Endotricba flammealis is common at Colchester, and probably far from rare generally.

\section{BOTYDÆ}

Eurrbypara urticata abounds among nettle. Scopula lutealis is rare, but has been found at Epping by Mr. Doubleday and at Pitsea by Mr. Whittle. S. olivalis and S. prunalis are common. S. ferrugalis has a wide distribution, but is far from common; it has been found at Colchester, Maldon, and in the Southend and St. Osyth districts. Botys pandalis has also been taken at Southend. B. ruralis (verticalis, Schiff.) abounds among nettles. B. fuscalis is common among Melampyrum. Ebulea crocealis occurs freely among Inula. E. verbascalis is sometimes common among Teucrium. S. sambucalis abounds among elder. E. stachydalis is not rare on the boulder clay near Colchester. Spilodes sticticalis can scarcely be considered a native, and only two specimens are recorded: one at Colchester in 1868 and one at Hazeleigh in 1900. S. palealis became generally common in north Essex-where it had not previously been seen-about I $875-6$, but totally disappeared after a brief period. In $1898 \mathrm{Mr}$. Laver noticed some larvæ on the southern coast of the county, and the following year Mr. Whittle obtained some near Southend. In 1900 the species again made its appearance in the north, a single moth and a number of larvæ being found near Clacton-on-Sea, and in $1901 \mathrm{Mr}$. Fitch took it at Burnham. S. verticalis (cinctalis, $\mathrm{Tr}$.), though not very common, is widely 


\section{INSECTS}

distributed in corn and clover fields. Pionea forficalis is a common garden insect. Orobena straminalis (stramentalis, $\mathrm{Hb}$.) is extremely local, but is found in small numbers at West Bergholt. Perinepbele lancealis was formerly far from scarce at Langham Lodge Wood, and has occurred at Southend and St. Osyth.

\section{HYDROCAMPIDE}

Cataclysta lemnata abounds everywhere on duckweed. Paraponyx stratiotata is local and seems scarce; Mr. Howard Vaughan records it from Leigh, and it is occasionally found at Colchester. Hydrocampa nympbaata and $H$. stagnata are widely distributed and frequently common.

\section{ACENTROPODIDE}

Acentropus niveus has occurred at Colchester, but is not often seen.

\section{PTEROPHORI (Plume Moshs) \\ CHRYSOCORIDID $Æ$}

Chrysocoris festaliella is recorded from the slopes near Hadleigh Castle by Mr. Howard Vaughan, and from Brentwood by Mr. Raynor.

\section{PTEROPHORIDÆ}

Agdistis bennetii is found on all the salt marshes of the county among sea lavender. Cnamidopborus rbododactylus was formerly taken at Loughton by Mr. Machin. Platyptilia ocbrodactyla is found at Colchester among tansy, and $\mathrm{Mr}$. Burrows has taken it rather freely at Mucking. $P$. bertrami also occurs among yarrow in the same localities. $P$. gonodactyla (trigonodactyla, Haw. ?) is generally common among coltsfoot. Amblyptilia acantbodactyla is recorded from Leigh by Mr. Howard Vaughan, and is occasionally found at Colchester among Ononis, Stacbys, Galeopsis and other plants. Mimaseoptilus pbeodactylus has been found at Witham by Mr. Cansdale. M. bipunctidactyla is generally common. M. zopbodactylus (loweii, Zell.) has been found at Leigh and Shoeburyness by Messrs. Howard Vaughan and Whittle. M. pterodactylus (fuscus, Retz.) is common in many places. Edematophorus litbodactylus was formerly found freely in the north of the county among Inula, but has been absent in recent years. Pteropborus monodactylus (pterodactyla, Hb.) is very common. Leioptilus lienigianus is found at Colchester and in south Essex. L. tepbradactylus has been taken near Southend. Aciptilia galactodactyla is frequently found among burdock. A. pentadactyla - often called by the Colchester children 'the angel' - is common everywhere.

\section{ALUCITID在}

Alucita bexadactyla (polydactyla, Hb.) is common, and is frequently found on windows in the spring.

\section{$C R A M B I$}

\section{H I L I D A}

Cbilo pbragmitellus is common at Southend and Pitsea. Scbcenobius forficellus is common at Wanstead, and has been captured near Braintree 


\section{A HISTORY OF ESSEX}

and Colchester. S. gigantellus is included in Mr. Vaughan's lișt of the Lepidoptera of Leigh.

\section{CRAMBIDE}

Platytes cerussellus is very abundant on the coast. Crambus falsellus is scarce at Colchester, and has been found at Hazeleigh and Leigh. $G$. pratellus and $C$. pascuellus are generally common. $G$. pinellus is usually scarce, but was common for a couple of years on a derelict farm at Colchester; it is also found at Danbury and Hazeleigh. C. latistrius was once taken by Dr. Wallace at St. Osyth. C. perlellus is common generally ; its variety warringtonellus occurs near Brightlingsea. C. selasellus is found sparingly in several coast localities. C. tristellus is abundant. C. fascelinellus was once taken at Dovercourt (W. H. H.). C. inquinatellus is common. C. contaminellus (salinellus, Tutt.) has been found in marshes near Southend by Dr. Chapman, Mr. Whittle and others. C. geniculeus and $C$. culmellus are common. C. cbrysonucbellus occurs at Epping and Loughton. $C$. bortuellus abounds everywhere.

\section{PHYCID压}

Anerastia lotella is plentiful on the coast sands. Ilitbyia semirubella (carnella, Lin.) was once taken at Nightingale Hall near Halstead by the late Mr. S. R. Bentall in 1872. Myelopbila cribrum is common on the coast, and while much of the land remained out of cultivation, extended its range many miles inland. Nyctegretes achatinella is scarce, but was once bred in some numbers from larvæ found at St. Osyth. Homceosoma sinuella is widely distributed and by no means scarce. $H$. nimbella is recorded by $\mathrm{Mr}$. Vaughan from Leigh. $H$. nebulella is scarce, but is sometimes found at Southend and St. Osyth. $H$. binevella occurs in many coast localities. $H$. senecionis is an erratic species, but when found is occasionally common. Epbestia elutella is local, but sometimes common about old clover stacks; it was very abundant at Stanway in I9oo. $E$. semirufa has been taken at Hazeleigh and Leigh. E. kubniella, a comparatively recent introduction from abroad, was found in great numbers in a bakery at Leytonstone by Mr. Cooper. Euzophera pinguis is found sparingly at Colchester about old ash trees. Cryptoblabes bistriga is reported from Southend, and is frequently taken at Colchester and St. Osyth. Gymnancyla canella is very local and uncertain, but has been occasionally found near Clacton-on-Sea. Pbycis betula is sparingly distributed among birch at Leigh and in several woods about Colchester. P. fusce (carbonariella, Fisch.) has been found at Brentwood by Mr. Raynor and at Southend by Mr. Thurnall. $P$. adornatella was taken at Loughton by Mr. Machin. Nepbopteryx spissicella (roborella, Zinck.) is frequently found in oak woods. N. rbenella (adelphella, Stainton) is rare and local, and has only been found in the Colchester district and at Hazeleigh. Pempelia palumbella occurs at Epping and Loughton. Rbodopbea formosa is fairly common among elm near Colchester and probably elsewhere. $R$. consociella occurs freely among oak. $R$. advenella is frequently found among hawthorn. $R$. marmorea is found sparingly at Leigh. $R$. suavella 


\section{INSECTS}

has a wide range in north Essex, and Mr. Vaughan records it as 'uncommon' at Leigh. $R$. tumidella is found among oak, occasionally in some numbers. R. rubrotibiella (tumidana, Schiff.) is rare, and has only been taken by Mr. Raynor at Hazeleigh.

\section{GALLERID压}

Galleria mellonella (cereana, Lin.) is found in the Colchester and Maldon districts; it feeds on the comb in beehives. Apbomia sociella is generally common. Acbreea grisella (alveariella, Gn.) occurs at Colchester and Hazeleigh, and is probably only too well known to beekeepers throughout the county.

\section{TORTRICES \\ TORTRICIDÆ}

Tortrix podana is common. $\mathcal{T}$. piceana is scarce, and has only been found at Brentwood by Mr. Raynor. $\mathcal{T}$. cratagana is far from common at Colchester and St. Osyth. $\mathcal{T}$. xylosteana is abundant everywhere. $\mathcal{T}$. sorbiana is of general occurrence, but is not very common. $\mathcal{T}$. rosana is extremely common. $\mathcal{T}$. diversana is found among elm at Colchester. $\mathcal{T}$. cinnamomeana was taken at Loughton by Mr. Machin, and does not seem to be found in other districts. $\mathcal{T}$. beparana and $\mathcal{T}$. ribeana are common. $\mathcal{T}$. corylana occurs at Southend, Colchester and St. Osyth, but is not an abundant species. $T$. unifasciana is common everywhere. $T$. semialbana is local and scarce. $\mathcal{T}$. costana and its variety latiorana and $\mathcal{T}$. viburnana are found on the salt marshes at Southend and St. Osyth. $\mathcal{T}$. viridana and $\mathcal{T}$. ministrana are common everywhere. $\mathcal{T}$. forsterana is somewhat scarce and local, but is found at Colchester, Hazeleigh and Leigh. Dicbelia grotiana is found in the same localities as the last, and also at Brentwood. Leptogramma literana and L. scabrana occur sparingly at Colchester, and the latter was taken at Stratford by Mr. Machin. Peronea sponsana is widely distributed but not very common. P. rufana has been captured at Leigh by Mr. Whittle. P. mixtana was found at Hainault by $\mathrm{Mr}$. Machin. $P$. schalleriana and $P$. comparana have occurred sparingly at Colchester. $P$. variegana is very common. $P$. cristana seems to be confined to Epping and Hainault. $P$. bastiana is found everywhere among sallow and osier. P. umbrana is also recorded from Epping and Hainault. $P$. ferrugana is not scarce among birch. $P$. aspersana is frequently common in strawberry beds at Colchester. Rbacodia caudana, Teras contaminana, Dictyopteryx loffingiana, D. bolmiana, D. bergmanniana, D. forskaleana, Argyrotoxa conwayana and Ptycholoma lecheana are generally common.

\section{PENTHINID压}

Ditula bartmanniana is rare at Colchester and is recorded by $\mathrm{Mr}$. Machin from Temple Mills. D. semifasciana has been found at Hazeleigh, Saffron Walden and St. Osyth. Pentbina corticana (picana, Fröl.) and $P$. betulatana are widely distributed among birch. $P$. capraana occurs at Colchester and St. Osyth. P. sororculana (pralongana, Gn.) is 


\section{A HISTORY OF ESSEX}

found at rest on birch trunks, but is not common. $P$. pruniana is extremely abundant. $P$.ocbroleucana is said to be common at Leigh, but is not often taken at Colchester. $P$. variegana (cynosbatella, Wilk.) is plentiful in hedges. $P$. dimidiana is an Epping species. $P$. gentiana is of general occurrence among teazle. $P$. sellana occurs in the Leigh district. $P$. marginana is found at Saffron Walden and Southend. $P$. fuligana has been captured by Mr. Raynor at Brentwood. Antitbesia salicella has been taken at Colchester, where it is very rare.

\section{SPILONOTIDA}

Hedya ocellana abounds everywhere. $H$. pauperana has only been taken by Mr. W. R. Jeffrey and Mr. W. Warren at Saffron Walden. $H$. aceriana and $H$. dealbana are common. $H$. neglectana has been taken at Wanstead Flats, Temple Mills and near Southend. H. servillana is found at Colchester, Loughton and St. Osyth among sallow. H. simplana is rare among aspen, but has been found at Colchester. Spilonota incarnatana occurs at Epping. S. trimaculana (suffusana, Zell.), S. rosacolana, S. roborana and Pardia tripunctana are generally, common.

\section{SERICORID死}

Aspis udmanniana occurs everywhere among bramble. Sideria achatana is found sparingly among whitethorn at Colchester. S. littoralis is common in the salt marshes among thrift. $S$. cespitana is found at Loughton, S. rivulana (concbana, Hb.) at Wanstead. S. urticana and $S$. lacunana are common everywhere. Roxana arcuana is local but abounds in some woods, and is now common in the High Woods at Colchester, where a few years ago it was never seen. Eucbromia purpurana has been taken at Hazeleigh, Leigh, Walton-on-the-Naze and St. Osyth, but is always scarce. Ortbotenia striana is found sparingly at Colchester and Brightlingsea, and more commonly at Leigh. O. branderiana occurs in many woods among aspen. O. ericetana is scarce and local, but has been captured at Colchester, Brentwood and Hazeleigh.

\section{SCIAPHILID压}

Pbtbeocbroa rugosana is frequently found in the larva state in briony berries, but is difficult to rear and the perfect insect is not common. Cnepbasia politana (lepidana, Curt.) is rare in the county. Mr. Whittle once took it at Benfleet. C. musculana and Sciapbila nubilana are common. $S$. conspersana (perterana, Gn.) is recorded from Leigh by Mr. Vaughan. $S$. subjectana and $S$. virgaureana are common. S. pascuana has been taken at Brentwood by Mr. Raynor. S. cbrysantbeana occurs sparingly at Colchester. S. bybridana is not uncommon near Colchester and at Southend. Spbaleroptera ictericana abounds on the coast and Capua favillaceana is common in woods.

\section{GRAPHOLITHID压}

Bactra lanceolana is often abundant in damp places among rushes. B. furfurana was taken at Temple Mills by Mr. Machin. Pboxopteryx 168 


\section{INSECTS}

siculana is found in woods in the Colchester district. $P$. uncana has been taken at Brentwood by Mr. Raynor and at Epping and Loughton by $\mathrm{Mr}$. Machin. P. biarcuana has also been found at Loughton by Mr. Thurnall. $P$. lundana is found everywhere. $P$. diminutana is very local and uncommon at St. Osyth. $P$. mitterpacberiana is widely distributed and fairly common among birch. P. upupana is scarce and local ; it is found at Colchester and St. Osyth. $P$. lactana occurs rather freely among aspen. Grapbolitba ramella is generally distributed among birch. $G$. nisella has been found at St. Osyth, Wanstead Flats and Pitsea among sallow, but does not seem to be as common in the county as elsewhere. $G$. cinerana is very common on the boles of large aspens in the Tendring Hundred. G. nigromaculana occurs sparingly at Leigh and St. Osyth. $G$. subocellana is very common among sallow. $G$. minutana is found among poplars at Colchester. G. trimaculana and $G$. penkleriana are common. G. obtusana is found in small numbers at Colchester, Southend and St. Osyth. G. navana is abundant among holly everywhere. Pblcodes tetraquetrana is very common. $P$. immundana and $P$. demarniana are found sparingly at Brentwood and St. Osyth, and the latter has also been taken at Leigh. Hypermecia cruciana and Batodes angustiorana are generally common. Padisca bilunana is frequently met with among birch. $P$. oppressana is found on black poplar at Colchester and Hazeleigh. $P$. rufimitrana has once been taken at Dovercourt (W. H. H.). P. corticana abounds on tree trunks in woods. $P$. profundana is widely distributed and has been reported common at Leigh, but seems to be scarce elsewhere. $P$. opbtbalmicana may be found at rest on aspens at St. Osyth, but is not common. $P$. solandriana, $P$. semifuscana and $P$. sordidana have all been taken somewhat freely at Colchester. Epbippipbora similana (bimaculana, Don.) is found sparingly at Colchester, Brentwood and Wanstead. E. cirsiana and E. pflugiana occur among thistles, the former being by far the commoner and more widely distributed. E. brunnicbiana is very common among coltsfoot. E. inopiana occurs at Colchester, and is reported from the neighbourhood of Southend by Mr. Vaughan and Mr. Machin. E. feenella seems always to be found among mugwort. $E$. nigricostana has occurred at Colchester, Brentwood and Epping. $E$. signatana has been recorded for Epping. E. trigeminana, though rather local, is frequently found among ragwort. E. tetragonana is scarce, but has been taken at Epping, Leigh and St. Osyth. E. populana occurs sparingly at Colchester and Hazeleigh. E. obscurana was reported as scarce at Leigh by Mr. Vaughan, and has also been captured at Epping. Semasia spiniana and S. iantbinana are found at Epping, and the latter has also occurred at Southend. S. rufillana is common among wild carrot everywhere. S. waberiana is too frequently met with among fruit trees, to which its larva, which feed on the inner bark, do a great deal of damage. Coccyx splendidulana is found sparingly at Colchester and Southend. C. argyrana is very common everywhere on oak trees, and C. tadella (byrciniana, Uslar) on spruce. Heusimene fimbriana is occasionally taken at Colchester, where it is scarce. Retinia buoliana, $R$. 


\section{A HISTORY OF ESSEX}

pinicolana and $R$. pinivorana are found in the Colchester district and probably throughout the county on Scotch fir. Carpocapsa splendidana occurs among oak everywhere. C. grossana is found among beech at Brentwood. C. pomonella, the well known 'Codling Moth', is much too common in the larva state in 'maggot-eaten' apples and pears. Opadia funebrana takes a heavy toll of the plum crop most seasons. Endopisa nigricana is another injurious species which in the larva state is found in the pods of peas. Stigmonota leguminana, which is extremely rare, $S$. perlepidana and $S$. internana are found at Epping and the last named at Stanway. $S$. compositella is frequently very common in clover fields. $S$. nitidana and $S$. flexana (weirana, Doug.) occur sparingly at Colchester and also at Epping. S. regiana is of general occurrence among sycamore, and $S$. roseticolana among wild rose. S. germarana has been taken at Epping. Dicrorampha politana and D. alpinana are found at Colchester, Brentwood and Loughton. D. sequana is common at Colchester and Leigh. D. petiverella abounds everywhere. D. plumbana occurs at Brentwood and Southend. D. saturnana is also taken at Southend. $D$. plumbagana is very common among vetches. D. acuminatana has been captured at Leigh and Colchester. D. simpliciana is found somewhat freely about Artemesia vulgaris. $D$. tanaceti is common at Colchester among tansy. D. consortana was obtained on the 'Essex salt marshes' by Mr. Machin. Pyrodes rbeediella is generally common. Catoptria albersana is found at Dedham, Danbury and Southend. C. ulicetana abounds everywhere among furze. $G$. juliana is scarce at Dedham and Southend. C. nimbana has occurred in Epping Forest, where Mr. Thurnall has taken it sparingly. C. microgrammana is rare, and has only been recorded from Leigh by $\mathrm{Mr}$. Vaughan. C. bypericana is found commonly among Hypericum and $C$. cana on thistles. C. candidulana (wimmerana, Wilk.) occurs among Artemesia maritima on the coast at Southend and St. Osyth. C. scopoliana (bobenwartbiana, Gn.) is abundant among Centaurea nigra. C. cacimaculana has been taken at Leigh and St. Osyth. C. conterminana is occasionally found among lettuce at Colchester and Leigh. C. amulana was captured at Eastwood near Southend among golden rod by Mr. Whittle. C. tripoliana (Bar.) is periodically common among Aster tripolium, but has not been found in north Essex recently. C. expallidana has been captured at Leigh by Mr. Vaughan and at Benfleet by $\mathrm{Mr}$. Whittle. C. citrana occurs at Southend and on Canvey Island. C. pupillana is recorded from Essex in Stanton's Manual. Trycheris aurana is frequently found on Angelica flowers.

\section{PYRALOIDID压}

Choreutes myllerana has been taken at Temple Mills by Mr. Machin, who has also taken Symatbis pariana at Loughton. S. oxyacantbella (fabriciana, St.) abounds everywhere among nettle.

\section{CONCHYLIDE}

Eupcecilia nana has a wide range among birch. $E$. dubitana occurs near Southend and at Temple Mills. E. atricapitana is also found at 


\section{INSECTS}

Southend. E. maculosana abounds among wild hyacinth. E. bybridella has been captured at Colchester, Leigh and Witham. E. ambiguella finds a place here on the authority of Meyrick's Handbook. E. angustana is not uncommon in many districts. E. affinitana and $E$. vectisana are generally distributed in the salt marshes. $E$. udana has been taken at Temple Mills and St. Osyth. E. notulana was once met with at Leigh, where E. roseana is common. The latter species is also found at Hazeleigh. E. ciliella is plentiful among cowslip at Aldham. Xantbosetia zoegana occurs sparingly in many places. X. bamana abounds everywhere among thistles. Cbrosis alcella (tesserana, $\mathrm{Tr}$.) is of common occurrence on the coast, and has been taken freely at Colchester and Witham. C. bifasciana (audouinana, Dup.) is rare and local, and has only been recorded from Epping and Wanstead. Lobesia reliquana is probably in all wooded districts. Argyrolepia bartmanniana (baumanniana, Schiff.), a very local species, has occurred at Eastwood, Epping and Layer-de-la-Haye. $A$. zepbyrana is rather common among wild carrot. A. maritimana is scarce and local on the coast sands, where much of its food plant - the beautiful sea holly-has disappeared with the growth of the seaside watering places. A. badiana is found among burdock and $A$. cnicana among thistles at Colchester and St. Osyth. $A$. aneana occurs sparingly in the Southend district, where also Conchylis dipoltella and C. francillana are found. $C$. smeatbmaniana and $C$. straminea occur at Colchester. $C$. alternana is said to be an Essex species in Meyrick's Handbook.

\section{APHELIID瓜}

Tortricodes byemana is very abundant in all oak woods in the early months of the year.

\section{TINEÆ}

The insects belonging to this group have so far received considerably less attention than those already dealt with, and doubtless many additions will be made to the following list when the entire county has been thoroughly and systematically explored.

\section{EPIGRAPHIIDÆ}

Lemnatopbila phryganella is somewhat common in oak woods in November, and is widely distributed. Dasystoma salicella is very local, but is found at Brentwood and Dedham. Exapate congelatella occurs at Loughton. Diurnea fagella is abundant everywhere. Semioscopus avellanella is scarce at Hazeleigh, Southend and St. Osyth. Epigraphia steinkellneriana is generally distributed but is not very common.

\section{PSYCHID压}

Talaporia pseudo-bombycella is fairly common in woods. Epichnopteryx pulla is often plentiful on the coast, and is found in many inland localities. E. reticella is very local, but is obtained by Mr. Whittle in the Southend marshes. Fumea crassiorella has been taken by $\mathrm{Mr}$. Burrows at Rainham. F. betulina is stated in Meyrick's Handbook to occur in the county. $F$. intermediella is common everywhere, and Solenobia inconspicuella is reported from Brentwood by Mr. Raynor. 


\section{A HISTORY OF ESSEX}

\section{TINEID压}

Diplodoma marginepunctella, Xysmatodoma melanella and Ocbsenbeimeria birdella have been taken at Colchester, and the last has also occurred at Shoeburyness. O. bisontella, O. vaculella, Scardia boleti and $S$. corticella have been found at Epping, and the two latter at Colchester. $S$. parasitella was common in Donyland Wood in $1898 . S$. granella, $S$. cloacella, S. arcella, Blabopbanes ferruginella, $B$. rusticella and Tinea tapetzella are all more or less common. $\mathcal{T}$. albipunctella and $\mathcal{T}$. caprimulgella are local but have occurred at Colchester. $\mathcal{T}$. misella has been taken at Shenfield by Mr. Raynor. $\mathcal{T}$. pellionella and $\mathcal{T}$. fuscipunctella are of general occurrence. $\mathcal{T}$. argentimaculella has been found at Epping and Colchester, $\mathcal{T}$. pallescentella at Colchester. $\mathcal{T}$. lapella is generally common, and $\mathcal{T}$. semifulvella is found sparingly at Colchester and Hazeleigh. Tineola biselliella, Lampronia quadripunctella and $L$. luzella have been captured at Southend. L. pralatella is found at Brentwood, $L$. rubiella at Colchester, and Incurvaria muscalella abounds everywhere. I. pectinea and $I$. oeblmanniella are by no means uncommon. I. capitella is occasionally taken at Colchester among currant. Micropteryx caltbella, $M$. aruncella, $M$. sepella, $M$. thunbergella and $M$. purpurella are common. M. kaltenbacbii (Stt.) is given as an Essex species in Meyrick's Handbook. $M$. semipurpurella and $M$. sparmannella occur at Colchester, $M$. subpurpurella is found everywhere among oak. Nemophora swammerdammella and $N$. scbwarziella abound in woods.

\section{ADELID $Æ$}

Adela fibulella and $A$. rufimitrella have a wide range in the Colchester district, where $A$. cresella is scarce and local. $A$. degeerella and A. viridella abound everywhere. Nematois cupriacellus is found at Colchester, Epping and St. Osyth. $N$. fasciellus is by no means scarce among Ballota nigra at Colchester.

\section{HYPONOMEUTIDE}

Swammerdammia combinella, S. casiella, S. lutarea, S. oxyacantbella and $S$. pyrella are all more or less common and have a wide distribution. S. spiniella was taken at Brentwood by Mr. Raynor. Scytbropia cratcegella is found sparingly at Benfleet and Leigh, and more commonly at Stanway and Colchester. Hyponomeuta vigintipunctatus was formerly taken in some numbers at Colchester and Witham, but has been looked for vainly in recent years. ${ }^{I} H$. plumbellus is frequently found among spindle at Colchester, and has also occurred at Prittlewell. $H$. padellus and $H$. cagnagellus are very common. H. evonymellus was once obtained on the seashore at St. Osyth. Prays curtisellus is generally distributed among ash.

\section{PLUTELLIDÆ}

Eidophasia messingiella was captured by Mr. W. R. Jeffrey at Saffron Walden. Plutella cruciferarum abounds throughout the county. $P$. porrectella is common among Hesperis matronalis at Colchester, and $\mathrm{Mr}$.

1 This species again occurred at Colchester in 1901 . 


\section{INSECTS}

Whittle sometimes finds it at Southend. Cerostoma vittella, C. radiatella, $C$. costella and $C$. sylvella are very generally distributed. The scarce and local $C$. alpella has been captured by Mr. Warren at Wanstead and by Mr. Whittle at Southend. C. lucella and C. borridella are also scarce. Both have been taken at Brentwood by Mr. Raynor, and the latter has also been found at Colchester, Loughton and Woodham Ferris. Harpipteryx scabrella occurs in Epping Forest, $H$. nemorella is found sparingly at Colchester and Southend, and $H$. xylostella commonly among honeysuckle in many places. Theristis mucronella, though far from common, is frequently found at Colchester, Hazeleigh and Saffron Walden among spindle.

\section{GELECHIIDÆ}

Orthotelia sparganella is not uncommon at Wanstead, and Henicostoma lobella in the Colchester and Maldon districts. Pbibalocera quercana abounds among oak, Depressaria costosa and $D$. flavella are generally distributed, $D$. umbellana has been taken somewhat freely at West Bergholt and St. Osyth. D. assimilella and $D$. scopariella are locally common among broom. D. atomella has been found at Epping by Mr. Machin. $D$. arenella, $D$. propinquella and $D$. subpropinquella are generally common. D. rbodocbrella has been reported from Brentwood by Mr. Raynor. $D$. alstremeriana is plentiful among hemlock at Colchester. D. purpurea has occurred at Hazeleigh and Southend. D. liturella is found freely among Hypericum, D. conterminella among osiers, and $D$. angelicella has frequently been noticed in the larva state at St. Osyth. D. cnicella occurs only on the coast sands. D. ocellana is frequently taken among sallow. D. yeatiana is recorded from Southend and Hazeleigh. $D$. applana is abundant. $D$. depressella has occurred at Southchurch and Southend, D. albipunctella at Hazeleigh, $D$. douglasella at Pitsea. These last three are scarce. D. cbaropbylli abounds at Colchester. D. ultimella has been taken at Witham. D. badiella is found sparingly at Colchester, and $D$. beracleana abundantly in all the districts. Psoricoptera gibbosella is recorded from Epping and Hainault. Gelecbia vilella has been taken by Mr. Warren at Shoeburyness. $G$. pinguinella is found on poplars at Colchester and Hazeleigh, G. nigra on aspens at Wanstead, and was once taken at St. Osyth. G. lentiginosella is an Epping species (Stainton's Manual). G. ericetella, G. mulinella, $G$. sororculella and $G$. diffinis are generally common. G. rbombella occurs at Colchester; $G$. scalella is not scarce on oak trees in June. Bracbmia mouffetella is to be found among honeysuckle at Colchester. Bryotropba terrella, B. affinis and $B$. domestica are very common and widely distributed. Lita maculea and L. tricolorella are somewhat common. L. leucomelanella has only once been bred-from a larva found at St. Osyth. L. junctella occurs at Epping and Hainault (Stainton's Manual). L. obsoletella was obtained in the south Essex marshes by Mr. Machin. L. atriplicella and $L$. suadella have been taken at St. Osyth. L. ocellatella, $L$. instabilella and $L$. salicornice are also salt-marsh insects. Teleia proximella is generally common among birch, $\mathcal{T}$. notatella has been taken at Hockley by $\mathrm{Mr}$. Whittle, $\mathcal{T}$. 


\section{A HISTORY OF ESSEX}

bumeralis at Epping by Mr. Machin, $\mathcal{T}$. vulgella is plentiful among hawthorn, $\mathcal{T}$. luculella and $\mathcal{T}$. scriptella occur at Colchester and Southend. $\mathcal{T}$. fugitivella is somewhat common on elm in various localities, $\mathcal{T}$. sequax has been found at Benfleet, $\mathcal{T}$. dodecella at Colchester and $\mathcal{T}$. triparella at Hazeleigh. Recurvaria leucatella is somewhat common on apple stems and boughs, $R$. nanella has occurred at Southend and Woodham Mortimer, Pecilia nivea at Colchester, $P$. albiceps and Argyritis pictella have been taken near Southend. Nannodia bermannella is often found among Chenopodium at Colchester. Apodia bifractella, Ptocbeuusa inopella, $P$. subocellea and Ergatis brizella have all occurred in the Leigh district; E. ericinella was obtained at Loughton by Mr. Machin, Doryphora lutulentella at Witham by Mr. Cansdale, Monochroa tenebrella is an Epping species. Lamprotes atrella is found at Saffron Walden and St. Osyth, Anacampsis albipalpella at Loughton, $A$. ligulella at St. Osyth, $A$. vorticella at Colchester, Brentwood and Hazeleigh, $A$. taniolella at Southend and A. anthyllidella in the Maldon district. Tacbyptilia populella abounds everywhere among poplar and birch. T. temerella was taken at Epping by Mr. Machin. Brachycrossata cinerella and Ceratophora rufescens are widely distributed. C. inornatella has occurred among reeds at Benfleet, and Cladodes gerronella at Colchester and Epping. Parasia lappella is found at Benfleet, Cleodora cytisella at Epping, Colchester and Witham. Chelaria buibnerella is sometimes common at St. Osyth. Anarsia spartiella is frequently found among broom at Stanway, Haplota palpella is recorded from Hainault, Sopbronia parentbesella from Brentwood and Southend, and Pleurota bicostella from Epping. Harpella geoffrella and Dasycera sulphurella are common everywhere. $D$. olivierella is widely distributed and not scarce in the Colchester district, where also Ecophora minutella, $\mathscr{E}$. fulviguttella, $\mathscr{E}$. tripuncta and $\mathscr{E}$. angustella are to be met with. The rare and local $Q E$. formosella has occurred at Wanstead. $E$. lunaris is reported from many districts, the scarce $\mathscr{E}$. lambdella from Epping and Colchester, $Q E$. tinctella from Hazeleigh; while $Q E$. panzerella, $Q E$. unitella and $\alpha E$. flavifrontella have an extensive range in the county. E. fuscescens has been taken at Epping and Hazeleigh. $\mathscr{E}$. pseudospretella is a pest everywhere. Ecogenia quadripunctata and Endrosis fenestrella are generally common. Butalis grandipennis is extremely local, but has been taken in some plenty at Wanstead. The rare $B$. cicadella was obtained at Southend by Mr. S. Stevens. B. chenopodiella is found among Chenopodium at Colchester and Wanstead, and the local Pancalia latreillella occasionally occurs at St. Osyth.

\section{GLYPHIPTERYGID压}

Röslerstammia erxlebenella is not uncommon among lime at Colchester, Glypbipteryx fuscoviridella abounds everywhere, G. thrasonella, G. equitella and G. fischeriella are found at Colchester, and Perittia obscurepunctella and Heliozele sericiella at Epping and Brentwood.

\section{ARGYRESTHIID压}

Argyrestbia epbippella and $A$. nitidella are generally common.

$A$. 


\section{INSECTS}

semitestacella occurs at Epping, $A$. spiniella at Southend, $A$. albistria, $A$. conjugella, $A$. semifusca, $A$. mendica, $A$. glaucinella and $A$. retinella are all found in the county more or less commonly. $A$. andereggiella was taken at Epping by Mr. P. C. Wormald. A. curvella is plentiful among apple, $A$. pygmalla is far from scarce among sallow, $A$. gadartella abounds on alder and $A$. brocbella on birch.

\section{GRACILARIID压}

Gracilaria alcbimiella occurs everywhere, G. stigmatella and G. elongella are found sparingly at Colchester, $G$. tringipennella is recorded as somewhat scarce at Benfleet, $G$. syringella is very abundant among privet and lilac, G. auroguttella has been captured at Brentwood and Shoeburyness, and Coriscium brongniartellum at Danbury by Mr. Raynor. Ornix avellanella and $O$. anglicella are common, $O$. betula was obtained at Snaresbrook by Mr. Machin. O. torquillella and $O$. guttea are well distributed and somewhat common.

\section{COLEOPHORIDE}

Goniodoma auroguttella was captured by Mr. G. Coverdale at Shoeburyness. Coleopbora fabriciella has occurred at Colchester and Epping, $C$. deauratella at Colchester, Southend and Witham. $C$. alcyonipennella is not scarce among Centaurea nigra; $C$. wockeella is rare, and has only been found at St. Osyth. C. potentilla has been taken near Walthamstow, $C$. conspicuella at Benfleet, $C$. vibicigerella at Fobbing, $C$. albicosta at Colchester and $C$. vulneraria at Brentwood. $C$. anatipennella is common and generally distributed, $C$. palliatella has been captured at Colchester, Epping and Southend, $C$. ibipennella at Southend, $C$. currucipennella and $C$. discordella at Epping. $C$. geniste is recorded from Wanstead, C. saturatella is somewhat common among broom at Colchester, $C$. therinella has been taken at Southend and Canvey, and $C$. maritimella at Vange. C. lineolea is common everywhere among Ballota nigra, $C$. caspititiella abounds among rushes, $C$. laripennella has occurred at Colchester, $C$. salinella at Benfleet, Shoeburyness and Great Wakering and $C$. artemisicolella at Vange, Canvey and Leigh. $C$. argentula is common among yarrow, $C$. tripoliella has been taken at Southend, $C$. virgaurea at Colchester, $C$. bemerobiella is included on the authority of Meyrick's Handbook. C. laricella abounds among larch, $C$. albitarsella, $C$. nigricella and $C$. fuscedinella are common and widely distributed. $C$. orbitella has been taken at Brentwood by Mr. Raynor and at Snaresbrook by Mr. Machin, C. gryphipennella at Benfleet by Mr. Whittle and $C$. siccifolia in Epping Forest by Mr. J. Scott. $C$. viminetella, $C$. solitariella, $C$. lutipennella and $C$. badiipennella have an extensive range in the county, and are not uncommon. $C$. adjunctella was captured at Shoeburyness by $\mathrm{Mr}$. Coverdale, and $C$. limosipennella at Leyton by $\mathrm{Mr}$. Machin.

\section{ELACHISTIDÆ}

Bedellia somnulentella has been found at Witham. Stathmopoda pedella is scarce among alder, and Cosmopteryx eximia not uncommon 


\section{A HISTORY OF ESSEX}

among hop at Colchester, where Batracbedra praangusta abounds on poplar. B. pinicolella and Cbauliodus cbaropbyllellus have been taken at Brentwood. Laverna lacteela and $L$. stepbensi are both found in the Epping district. L. epilobiella is abundant everywhere on Epilobium birsutum, L. ocbraceella has been obtained at Eastwood near Southend. $L$. decorella, according to $\mathrm{Mr}$. Fitch, is generally distributed but not common. L. subbistrigella has been captured at Hazeleigh, L. atra and Cbrysoclysta aurifrontella are common everywhere among hawthorn. Antispila pfeifferella has been found at Brentwood, Elacbista magnificella at Colchester, $E$. albifrontella is common, $E$. stabilella is reported from Brentwood, $E$. nigrella and $E$. obscurella are very common. $E$. gangabella occurs at Epping, E. cerussella at Colchester, E. triatomea at Benfleet ; E. pollinariella was taken at Fairmead Bottom by Mr. Machin, $E$. rufocinerea and $E$. argentella are generally abundant. Tischeria complanella is very common among oak. The local $\mathcal{T}$. dodonea has been obtained by Mr. Whittle at Eastwood near Southend, $\mathcal{T}$. marginea is plentiful among brambles, $\mathcal{T}$. gaunacella has occurred at Colchester and Witham.

\section{LITHOCOLLETID压}

Litbocolletis bortella occurs at Colchester, L. lantanella at Southend. $L$. irradiella and $L$. lautella are found at Brentwood; the latter has also been obtained by Mr. Fincham-who has given much attention to this genus and Nepticula-at Colchester. L. cavella is recorded for the county in Meyrick's Handbook. L. pomifoliella, L. coryli, L. spinicolella, $L$. faginella, $L$. salicicolella and $L$. viminetorum are common at Colchester. $L$. carpinicolella has been taken at Loughton, Wanstead and Southend. L. ulmifoliella, L. spinolella, L. quercifoliella, L. messaniella, L. corylifoliella, $L$. viminiella, L. alnifoliella, $L$. beegeriella, L. cramerella, $L$. tenella and $L$. sylvella have all been found at Colchester, and with the exception of tenella are common there; this has also occurred at Wanstead. $L$. emberizapennella has been obtained at Southend. L. nicellii, L. scbreberella, L. tristrigella and L. trifasciella are Colchester species, and like most of this family have probably a wide range in the county, though few definite localities are at present known for them.

\section{LYONETIID里}

Pbyllocnistis suffusella, Cemiostoma spartifoliella and C. laburnella are common at Colchester. Opostega salaciella has been taken at Brentwood by Mr. Raynor, $O$ spatulella at Witham by $\mathrm{Mr}$. Cansdale, and at Southend by Mr. Whittle. Bucculatrix ulmella occurs at Hazeleigh and Southend, $B$. vetustella is recorded from Epping, where $B$. cratagi is common. B. maritima is plentiful in the marshes at Benfleet and Southend, and $B$. cristatella is reported from Benfleet and Witham.

\section{NEPTICULID瓜}

Nepticula atricapitella is found at Epping, $N$. anomalella and $N$. pygmaella are common at Colchester, $N$. pomella has been taken at I 76 


\section{INSECTS}

Wanstead, $N$. viscerella at Colchester and Wickham Bishops, $N$. catharticella at Danbury, $N$. septembrella is plentiful at Colchester, and $N$. intimella has occurred at Witham. $N$. subbimaculella, $N$. trimaculella, $N$. quinquella and $N$. foslactella occur frequently at Colchester. $N$. salicis, $N$. microtberiella, $N$. plagicolella and $N$. tityrella are common. $N$. malella has been found at Walthamstow, $N$. angulifasciella at Colchester, and $N$. rubivora has been taken in the county by Mr. Warren. $N$. marginicolella, $N$. alnetella and $N$. aurella are common. $N$. regiella has been obtained at Brentwood and Colchester, $N$. pulverosella has been bred from Epping Forest larvæ by Mr. E. R. Bowles. Trifurcula immundella has been captured at Wanstead by Mr. Warren.

\section{DIPTERA}

\section{Flies}

The Diptera are for the most part small or moderate sized insects with two fully developed membranous wings and two inconspicuous haltares or balancers situated where other insects are provided with hind wings.

The order is extremely numerous in species, many of which are so excessively prolific and so ubiquitous that everybody is of necessity more or less acquainted with some of them, though they have been hitherto so little studied in this country that few British entomologists know much about them.

In recent years a small number of earnest workers have been endeavouring to bring about a more satisfactory condition of things, and with the commencement of the new century Mr. Verrall, who is our chief authority, has brought out the first volume of what promises to be a fine work on the order; so that it is to be hoped that before long we may be able to give a better account of it than we are at present.

The Diptera have been painted in anything but alluring colours hitherto, and even Professor Westwood, from whom they might have expected better treatment, condemns them root and branch; for in his famous Introduction to the Modern Classification of Insects he says that ' while their size entitles them to small consideration, they have slender claims to our notice on the score of beauty, their forms are inelegant and their manners and customs atrocious and disgusting.'

While some species of Diptera are undoubtedly harmful to us or to our belongings there is another side to the question, since among them are many which render us essential service as scavengers in the removal of putrefying substances, as checks upon the undue increase of other insects, as fertilizers of flowers and in a variety of other ways.

Nor is the statement that they are devoid of elegance of form or beauty of colouring to be allowed to pass without challenge, seeing that many among them are brilliantly coloured and extremely beautiful. On the continent, and to a limited extent in this country, it has been the 


\section{A HISTORY OF ESSEX}

custom hitherto to impale these insects on long pins without making any attempt to arrange and display their wings, bodies and legs, and treated in this fashion they are certainly melancholy and pitiable objects; but a collection in which the specimens are all properly set and arranged is far more useful for all purely scientific purposes, and is calculated to form a source of considerable pleasure to those who are not wholly wanting in all æsthetic sensibility.

Some of the families into which this order is divided require much attention and revision before even the most competent British entomologists can speak with authority about them; and seeing how small a portion of our own county has been even superficially investigated, it behoves us to be modest in displaying our knowledge even of the better understood families, but a little should be said about some of them.

The Gall Gnats (Cecidomyidee and their allies) have been fully dealt with by Mr. Fitch, and to his article on the 'Galls of Essex' (Trans. Essex Field Club, ii. 98-156) reference should be made by any one desiring the best available information concerning them.

The Bibionida are represented by about a dozen of the typical genus Bibio. B. venosus, the scarcest of these, is occasionally found at Colchester; $B$. marci (St. Mark's fly) is a conspicuous black insect which suddenly appears in vast swarms early in the spring, and is one of several insects for the 'bringing over' of which the rural population make the east wind responsible.

The Gnats (Culicida, etc.) are well in evidence in mild weather throughout the year. Several of them are only too well known from their blood sucking propensities, and in certain parts of the county species are found which if met with elsewhere would be called mosquitoes, and would have as good a right to the name as other members of the same family to which it appears to be somewhat indiscriminately applied.

The Crane-flies (Tipulida), more familiarly known as 'Daddy-longlegs,' are numerous, and some of them, such as Tipula gigantea, T. lutescens, etc., are large and handsome insects; but their legs are so loosely joined to their bodies that it is extremely difficult to prepare them for the cabinet in perfect condition, and therefore they do not receive the attention from collectors which they otherwise deserve. Among the better species Dictenidia bimaculata occurs at Colchester, and the handsome Citenopbora flaveolata has been captured by Mr. G. F. Mathew at Dovercourt.

The Stratiomyidae include some fine insects, notably Stratiomys potamida, S. longicornis and Odontomyia ornata, which are occasionally found at Colchester, and $S$. furcata and $O$. tigrina, which occur on the coast. The species of Sargus and Chloromyia are elegant insects with brilliant green and purple metallic bodies; they are well distributed and not uncommon.

The Tabanida or Breeze-flies, also known as Gadflies, which are so troublesome to horses and cattle and occasionally to mankind, are natur- 


\section{INSECTS}

ally strongly represented in a county which contains so much grazing land as ours. The larger and more robust species seem to be found more freely in the woods and marshes towards the coast than further inland, but the pertinacious ' clegg,' Hamatopota pluvialis, and the brilliant eyed Cbrysops cacutiens have a wider distribution.

Among the Asilida the rare Dioctria reinbardi has occurred at Colchester, and the large and voracious Asilus crabroniformis, which preys upon grasshoppers and other insects, is sometimes far from scarce in the autumn, especially in pastures where horses are feeding. Pbilonicus albiceps is a local coast species which is not uncommon on the St. Osyth sands.

The Bombylidae are represented by Antbrax paniscus and Bombylius discolor and B. major. The Antbrax is a coast species not often seen and still less frequently captured, as it is an extremely wary insect. The two species of Bombylius called ' Unicorn-flies,' because of the extreme length of the proboscis, may frequently be noticed hovering before primrose and other flowers, or poised in the air making a loud humming noise with their wings, which vibrate so rapidly that their motion is hardly perceptible. In the larva state they are parasitic on the larvæ of bees of the genus Antbopbora.

The extensive family Syrpbida comprises many of our largest and most brilliantly coloured native Diptera. Some of them are robust insects bearing a strong superficial resemblance to Humble-bees. The typical genus Syrphus contains many common species; in the larva state they prey upon aphides, vast numbers of which are devoured by them. S. umbellatarum and S. tricinctus are scarce, and S. eucbromus and S. triangulifer very rare.

Among the more notable members of other genera deserving of special mention are the fine Xanthandrus comtus, the rare Didea alneti and D. fasciata-D. alneti was added to the British list from a specimen taken at Colchester in 1893 . Volucella inflata and $V$. inanis, two fine and very local species, are occasionally met with in some of our woods.

The extremely variable Merodon equestris, at one time considered a great rarity, is rapidly becoming much too common, as many local bulb growers are discovering to their cost, large numbers of their finest narcissus and other bulbs being devoured by its larvæ.

The handsome genus Criorrbina is generally well represented at May blossom and raspberry and bramble flowers in certain favoured spots.

The curiously constructed Conopide or Wasp-flies are generally well in evidence in the late summer among composite flowers, and several of the species seem to be commoner in the Colchester district than in other parts of England.

The Muscida- which in the list that follows are placed in accordance with Mr. Austen's arrangement of the new collection in the National Museum-include a number of species parasitic on the larvæ of the Lepidoptera, and as some of them are excessively numerous in 


\section{A HISTORY OF ESSEX}

individuals and prey upon many different kinds of larvæ they destroy prodigious numbers, in some cases only leaving a few survivors out of large broods. The common House-flies (Musca corvina and M. domestica), the Flesh-fly (Sarcophaga carnaria), the blue and green Bottle-flies (Calliphora and Lucilia) also belong to this group, which includes many less familiar and more handsome species, such as the brilliant blue Cynomyia mortuorum, occasionally found in some numbers on the coast and less frequently inland; the large glossy black Mesembrina meridiana, the wings of which have the basal portion conspicuously yellow, and Micropalpus pudicus. This, though by no means rare in the Colchester district, does not seem to have been identified from any other locality at present.

The Horse Bot-fly (Gastropbilus equi), the Ox Warble-fly (Hypoderma bovis) and the Sheep Nostril-fly (Estrus ovis) are also now classed with the Muscide, but the literature devoted to them is already so voluminous and so easily accessible that it need not be added to here.

The Antbomyide and the families which follow them include many insects which perform an important part in the economy of nature by the removal of putrefying animal and vegetable substances; also some that are very destructive to our crops, such as Pegomyia beta, which probably generally feeds on the wild beet (Beta maritima) on the sea coast, but is occasionally very destructive to mangel-wurzel; the Celery-fly (Acidia beraclei), the Carrot-fly (Psila rosa), and a number of beautiful little insects with spotted wings, among which the rare Gonyglossum wiedemanni and Icterica westermanni are especially noteworthy.

When no other locality is mentioned in the list the Colchester district is to be understood.

\section{A LIST OF THE DIPTERA OCCURRING IN THE COUNTY}

Pulicide

\section{NEMATOCERA}

Pulex, L.

- irritans, $\mathbf{L}$.

Cecidomyide

Lasioptera, Mg.

- rubi, Schrk.

Asphondylia, Lw.

- pimpinellæ, F. Lw. Maldon (Fitch)

- sarothamni, Lw. Epping (Fitch)

Cecidomyia, Mg.

- bursaria, Bremi. Birdbrook (Fitch)

- ? clausilia, Meade. Maldon (Fitch)

- cratægi, Winn. Essex (Fitch)

- galii, Lw. Birdbrook, Maldon (Fitch)

- persicariz, L. Burnbam (Fitch)

- plicatrix, Lw.

- ? pruni, Kltb.

- ranunculi, Bremi.

- rosaria, Lw. Essex (Fitch)

- rosarum, Hardy. Maldon (Fitch)

- salicis, Schrk. Essex (Fitch)

- sisymbrii, Schrk. Romford (Fitch)

- taxi, Inch. Greenstead (Fitch)
Cecidomyide (continued)

Cecidomyia trifolii, F. Lw. Maldon (Fitch)

- ulmariz, Bremi. Maldon, Rayleigh (Fitch)

- urticæ, Perris. Essex (Fitch)

- veronicx, Vallot. Loughton (Fitch)

Diplosis, Lw.

- botularia, Winn. Birdbrook, Maldon (Fitch)

- buxi, Laboulb. Birdbrook (Fitch)

- loti, Deg. Epping, Maldon (Fitch)

Hormomyia, Lw.

- caprex, Winn. Maldon (Fitch)

- corni, Gir. Helions Bumpstead (Fitch)

- fagi, Hartig. South Benfleet (Fitch)

- millefolii, Lw. Maldon (Fitch)

- piligera, Lw. Danbury, Epping (Fitch)

MYCETOPHILIDE

Sciara, Mg.

- thomæ, L.

- tilicola, Lw. Maldon (Fitch)

Platyura, Mg.

- marginata, $\mathrm{Mg}$. 


\section{INSECTS}

\section{BIBIONIDFE}

Dilophus, Mg.

- febrilis, L.

Bibio, Geoff.

- pomonæ, Fabr.

- marci, L.

- hortulanus, L.

- anglicus, Ver.

- venosus, Mg.

- reticulatus, Lw.

- nigriventris, Hal,

- varipes, $\mathrm{Mg}$.

- laniger, Mg.

- johannis, L.

- lepidus, Lw.

Chironomide

Chironomus, $\mathrm{Mg}$.

- plumosus, L.

Culicidere

Culex, L.

- ciliaris, L.

- cantans, Mg.

- annulatus, Schrk.

PTYCHOPTERIDF

Ptychoptera, Mg.

- contaminata, L.

- albimana, Fabr.

LiMNOBIDF

Limnobia, Mg.

- nitida, Ver.

Pœcilostola, Schin.

- punctata, Schrk.

Trichocera, $\mathrm{Mg}$.

- hiemalis, Deg.

TIPULIDE

Pachyrrhina, Mcq.

- maculosa, $\mathrm{Mg}$.

- quadrifaria, Mg.

Tipula, L.

- marmorata, $\mathrm{Mg}$.

- varipennis, $\mathrm{Mg}$.

- lateralis, Mg.

- gigantea, Schrk.

- lutescens, Fabr.

- oleracea, L.

Dictenidia, Brul.

- bimaculata, $\mathrm{L}$.

Ctenophora, Mg.

- flaveolata, Fabr. Dovercourt

\section{RHYPHIDF}

Rhyphus, Ltr.

- fenestralis, Scop.

\section{BRACHYCERA}

\section{STRATIOMYIDE}

Nemotelus, Geoff.

- notatus, Ztt.

Oxycera, Mg.

- pulchella, $\mathrm{Mg}$.
STRATIOMYide (continued)

Oxycera trilineata, Fabr.

Stratiomys, Geoff.

- potamida, Mg.

- furcata, Fabr.

- longicornis, Scop.

Odontomyia, Mg.

- ornata, Mg.

- tigrina, Fabr.

- viridula, Fabr.

Sargus, Fabr.

- flavipes, $\mathrm{Mg}$.

- cuprarius, L.

- infuscatus, $\mathrm{Mg}$.

Chloromyia, Dunc.

- formosa, Scop.

Microchrysa, Lw.

- polita, L.

Beris, Ltr.

- clavipes, L.

- vallata, Forst.

- chalybeata, Forst.

TABANIDEE

Hæmatopota, Mg.

- pluvialis, L.

- crassicornis, Whlbg.

Therioplectes, Zlr.

- tropicus, Mg. var. bisignatus, Jaen.

- solstitialis, Mg.

Atylotus, O-Sack.

- fulvus, Mg.

Tabanus, L.

- bromius, L.

- autumnalis, $\mathrm{L}$.

Chrysops, Mg.

- cæcutiens, L.

- relictus, Mg.

Leptis, Fabr.

- scolopacea, L.

- tringaria, L.

- lineola, Fabr.

Chrysopilus, Mcq.

Leptogaster, Mg.

- cylindrica, Deg.

Dioctria, $\mathrm{Mg}$.

- œlandica, L.

- reinhardi, W.

- atricapilla, Mg.

- rufipes, Deg.

- baumhaueri, Mg.

Laphria, L.

- marginata, $\mathrm{L}$.

Asilus, L.

- crabroniformis, L.

Philonicus, Lw.

- albiceps, $\mathrm{Mg}$.

Neoitamus, O-Sack. 


\section{A HISTORY OF ESSEX}

AsILIDE (continued)

Neoitamus cyanurus, Lw.

Machimus, Lw.

- atricapillus, Fln.

Dysmachus, Lw.

- trigonus, $\mathrm{Mg}$.

BOMBYLIDE

Anthrax, Scop.

- paniscus, Rossi

Bombylius, L.

- discolor, Mik.

- major, L.

ThereVID $x$

Thereva, Ltr.

- nobilitata, Fabr.

- bipunctata, Mg.

- annulata, Fabr.

\section{EMPIDE}

Hybos, Mg.

- grossipes, L. Epping (Brunetti)

Rhamphomyia, $\mathrm{Mg}$.

- sulcata, Fln.

Empis, L.

- tessellata, Fabr.

- livida, L.

- trigramma, $\mathrm{Mg}$.

- nigritarsis, $\mathrm{Mg}$.

Hilara, Mg.

- litorea, Fln. Epping (Brunetti)

Trichina, $\mathrm{Mg}$.

- clavipes, Mg. Epping (Brunetti)

DoLICHOPODIDE

Dolichopus, Ltr.

- trivialis, Hal. Epping (Brunetti)

Pocilobothrus, Mik.

- nobilitatus, $L$.

Argyra, Mcq.

- diaphana, Fabr.

- leucocephala, Mg.

Scellus, Lw.

- notatus, Fabr.

Campsicnemus, Wlk.

- curvipes, Fln. Epping (Brunetti)

LONCHOPTERIDE

Lonchoptera, Mg.

- lutea, Pz. Epping (Brunetti)

\section{PROBOSCIDEA}

\section{SYRPHIDEE}

Pipizella, Rnd.

- virens, Fabr.

- maculipennis, Mg.

Pipiza, Fln.

- noctiluca, $L$.

- lugubris, Fabr.

Cnemodon, Egg.

- vitripennis, $\mathrm{Mg}$.

Chrysogaster, $\mathrm{Mg}$.

- metallina, Fabr.

- hirtella, Lw.
Syrphidex (continued)

Chrysogaster virescens, Lw.

— splendens, $\mathrm{Mg}$.

- solstitialis, Fall.

Chilosia, Mg.

- sparsa, Lw.

- soror, $\mathrm{Ztt}$.

- scutellata, Fln.

- vernalis, Fln.

- proxima, $Z_{\mathrm{tt}}$.

- fraterna, Mg. (chloris, Mg.)

- bergenstammi, Becker.

- grossa, Fln.

- albipila, Mg. (flavicornis, Fabr.)

- albitarsis, Mg. (flavimana, Mg.)

- variabilis, $\mathrm{Pz}$.

- honesta, Rond.

- barbata, Lw.

- vulpina, Mg.

- intonsa, Lw.

- illustrata, Harris (œestracea, L.)

Leucozona, Schin.

- lucorum, L.

Melanostoma, Schin.

- scalare, Fabr.

- mellinum, $L$.

Melangyna, Ver. (Melanostoma pars Schin.)

- quadrimaculata, Ver.

Xanthandrus,Ver. (Melanostoma pars Schin.)

- comtus, Harris (hyalinatum, Fln.)

Pyrophæna, Schin.

- ocymi, Fabr.

Platychirus, St. Farg.

- manicatus, $\mathrm{Mg}$.

- albimanus, Fabr.

- peltatus, Mg.

- scutatus, Mg.

- fulviventris, Mcq. Epping (Brunetti)

- immarginatus, $\mathrm{Ztt}$.

- scambus, Stæg.

- clypeatus, Mg.

- angustatus, Ztt.

Didea, Mcq.

- alneti, Fln.

- fasciata, Mcq.

Syrphus, Fabr.

- barbifrons, Fln.

- umbellatarum, Fabr.

- labiatarum, Ver.

- euchromus, Kow.

- triangulifer, Zett.

- auricollis, Mg.

- cinctellus, $Z$ tt.

- balteatus, Deg.

- bifasciatus, Fabr.

- luniger, Mg.

- corollx, Fabr.

- nitidicollis, $\mathrm{Mg}$.

- vitripennis, $\mathrm{Mg}$.

- ribesii, L. 
INSECTS

SYRPHIDE (continued)

Syrphus grossulariæ, Mg.

- tricinctus, Fln.

- venustus, $\mathrm{Mg}$.

- quadrilunulatus, Schaum.

- albostriatus, Fln.

- laternarius, Mull.

Catabomba, O-Sack.

- pyrastri, L.

Sphærophoria, St. Farg.

- scripta, L. var. dispar, Lw.

- menthastri, L.

Xanthogramma, Schin.

- citrofasciatum, Deg.

- ornatum, $\mathrm{Mg}$.

Baccha, Fabr.

- elongata, Fabr.

Ascia, Mg.

- floralis, $\mathrm{Mg}$.

Rhingia, Scop.

- campestris, $\mathrm{Mg}$.

Brachyopa, Mg.

- bicolor, Fln.

Volucella, Geoff.

- bombylans, $\mathrm{L}$.

- pellucens, L.

- inflata, Fabr.

- inanis, L.

Sericomyia, Mg.

- borealis, Fln.

Eristalis, Latr.

- sepulchralis, I.

- æneus, Scop.

- tenax, L.

- intricarius, L.

- arbustorum, L.

- pertinax, Scop.

- nemorum, L.

- horticola, Deg.

Myiatropa, Rnd.

- florea, L.

Helophilus, Mg.

- trivittatus, Fabr.

- pendulus, L.

- versicolor, Fabr.

- transfugus, L.

- lineatus, Fabr.

- vittatus, $\mathrm{Mg}$.

Merodon, $\mathrm{Mg}$.

- equestris, Fabr.

Tropidia, Mg.

- scita, Harris (milesiformis, Fln.)

Criorrhina, Mcq.

- berberina, Fabr.

- asilica, Fln.

- oxyacanthæ, Mg.

- floccosa, $\mathrm{Mg}$.

Xylota, $\mathrm{Mg}$.

- segnis, L.
SYRPHIDE (continued)

Xylota lenta, $\mathrm{Mg}$.

- nemorum, Fabr.

- sylvarum, L.

Syritta, St. Farg.

- pipiens, L.

Eumerus, $\mathrm{Mg}$.

- ornatus, Mg.

- strigatus, Fall.

Chrysochlamys, Rnd.

- cuprea, Scop.

Chrysotoxum, Mg.

- cautum, Harris (sylvarum, Mg.)

- octomaculatum, Curt.

- festivum, L.

- bicinctum, L.

\section{Conopide}

Conops, L.

- quadrifasciatus, Deg.

- ceriiformis, Mg.

- flavipes, L.

Physocephala, Schin.

- rufipes, Fabr.

Sicus, Scop.

- ferrugineus, L.

Myopa, Fabr.

- buccata, L.

- testacea, L.

- polystigma, Rond.

Muscider

Ceromasia, Rond.

- stabulans, $\mathrm{Mg}$.

- senilis, Mg.

Exorista, $\mathrm{Mg}$.

- vetula, Mg.

Epicampocera, $\mathrm{Mg}$.

- ambulans, $\mathrm{Mg}$.

Blepharidea, Br. and Berg.

- vulgaris, Fln.

Myxexorista, Br. and Berg.

- libatrix, Br. and Berg.

Phorocera, Dsv.

- cilipeda, Rond.

- concinnata, $\mathrm{Mg}$.

Chætolyga, Rond.

- quadripustulata, Fln.

Eutachina, Br. and Berg.

- larvarum, L.

- præpotens, $\mathrm{Mg}$.

Gonia, Mg.

- ornata, Mg.

Aporomyia, Rond.

- dubia, Fln.

Mintho, Dsv.

- præceps, Scop.

Melanota, Rond.

- volvulus, Fabr.

Macquartia, Dsv.

- dispar, Fln.

Thelaira, Dsv. 


\section{A HISTORY OF ESSEX}

Muscide (continued)

Thelaira leucozona, Pz.

Myobia, Dsv.

- inanis, Fln.

Oliviera, Dsv.

- lateralis, Fabr.

Micropalpus, Mcq.

— vulpinus, Fln.

- pudicus, Rond.

Erigone, Dsv.

- radicum, Fabr.

- strenua, Mg.

Tachina, Mg.

- fera, L.

Phorichæta, Rond.

- carbonaria, $\mathrm{Pz}$.

Thryptocera, Mcq.

- latifrons, Mg.

Alophora, Dsv.

- hemiptera, Fabr.

Trixa, Mg.

— œestroidea, Rob.

Sarcophaga, Mg.

- carnaria, L.

- vulnerata, Sch.

Cynomyia, Dsv.

- mortuorum, L.

Nyctia, Dsv.

- halterata, Pz.

Miltogramma, $\mathbf{M g}$.

- punctata, Mg.

Dexiosoma, Rond.

- caninum, Fabr.

Dexia, Mg.

- rustica, Fabr.

Pollenia, Dsv.

- rudis, Fabr.

Musca, L.

- domestica, L.

- corvina, Fabr.

Graphomyia, Dsv.

- maculata, Scop.

Cyrtoneura, Mcq.

- stabulans, Fln.

Mesembrina, $\mathrm{Mg}$.

- meridiana, L.

Calliphora, Dsv.

- groenlandica, Zett.

- azurea, Fln.

- erythrocephala, Mg.

- vomitoria, $\mathrm{L}$.

Lucilia, Dsv.

- cæsar, L.

- sericata, Mg.

Gastrophilus, Leach

- equi, Fabr.

Hypoderma, Latr.

- bovis, Deg.

Oestrus, L.

- ovis, L.
ANTHOMYIDF

Polietes, Rond.

- lardaria, Fabr.

- albolineata, Fln. Epping (Brunetti)

Hyetodesia, Rond.

- lucorum, Fln.

- perdita, Mg.

- erratica, FIn.

- basalis, Ztt.

- scutellaris, Fln.

- populi, Mg.

- pallida, Fabr.

- faveola, Fln.

Mydæa, Dsv.

- impuncta, Fln.

- affinis, Meade

Spilogaster, Mcq.

- communis, Dsv.

Hydrotæa, Dsv.

- ciliata, Fabr.

- dentipes, Fabr.

Ophyra, Dsv.

- leucostoma, W.

Hylemyia, Dsv.

- strigosa, Fabr. Epping (Brunetti)

- prepotens, W.

Anthomyia, Mg.

- radicum, L. Epping (Brunetti)

Phorbia, Dsv.

- histrio, Ztt.

Pegomyia, Dsv.

- betæ, Curt.

- versicolor, $\mathrm{Mg}$.

Homalomyia, Bouche

- aprica, Hal.

- canicularis, L.

- incisurata, $Z$ tt. Epping (Brunetti)

- triangulifera, Rond.

\section{Cordyluride}

Cordylura, Fln.

- pubera, L.

- pudica, Mg.

- ciliata, Mg.

Scatophaga, $\mathrm{Mg}$.

- spurca, $\mathrm{Mg}$.

- lutaria, Fabr.

- inquinata, $\mathrm{Mg}$.

- stercoraria, L.

- squalida, Mg.

HELOMYZIDE

Tephrochlamys, Lw.

- rufiventris, $\mathrm{Mg}$.

SCIOMYZIDE

Dryomyza, Fln.

— anilis, Fln.

- flaveola, Fabr.

Neottiophilum, Frfd.

- præustum, Mg.

Tetanocera, Fln.

- elata, Fabr. 


\section{INSECTS}

ScromYziD e (continued)

Tetanocera ferruginea, Fln.

- reticulata, L.

- punctulata, Scop.

Limnia, Dsv.

- marginata, Fabr.

Elgiva, Mg.

- dorsalis, Fabr.

- rufa, Pz.

Sepedon, Latr.

- sphegeus, Fabr.

- spinipes, Scop.

PsILIDE

Psila, Mg.

- fimetaria, L.

- rosæ, Fabr.

Loxocera, Mg.

- aristata, Pz.

MicRoPEZIDE

Micropeza, $\mathrm{Mg}$.

- corrigiolata, L.

\section{ORTALIDE}

Dorycera, $\mathrm{Mg}$.

- graminum, Fabr.

Ptilonota, Lw.

- guttata, Mg.

Ceroxys, Mcq.

- pictus, Mg.

- crassipennis, Fabr.

Anacampta, Lw.

- urticæ, L.

Platystoma, Mg.

- seminationis, Fabr.

Seoptera, Kirby

- vibrans, L.

TRYPETIDE

Acidia, Dsv.

- cognata, W.

- heraclei, L.

Gonyglossum, Rond.

- wiedemanni, Mg.

Spilographa, Lw.

- zoë, Mg.

Trypeta, Mg.

- falcata, Scop.

- onotrophes, Lw.

Urophora, Dsv.
TRYPETID (continued)

Urophora solstitialis, L.

- stylata, Fabr.

- cardui, L.

Icterica, Lw.

- westermanni, Mg.

Tephritis, Latr.

- miliaria, Schrk.

- vespertina, Lw.

SAPROMYZIDE

Sapromyza, Fln.

- præusta, Fln. Epping (Brunetti)

Lauxania, Latr.

- ænea, Fln. Epping (Brunetti)

OPOMYZID

Opomyza, Fln.

SEPSIDF

- germinationis, L. Epping (Brunetti)

Sepsis, Fln.

- cynipsea, L. Epping (Brunetti)

Nemopoda, Dsv.

- cylindrica, Fabr. Epping (Brunetti)

EPHYDRIDF

Hydrellia, Dsv.

- griseola, Fln. Epping (Brunetti)

Parhydra, Stnb.

- coarctata, Fln. Epping (Brunetti)

Ephydra, Fln.

- micans, Hal.

Chloropide

Chlorops, $\mathrm{Mg}$.

- tæniopus, Mg.

BORBORIDE

Borborus, $\mathrm{Mg}$.

- nitidus, $\mathrm{Mg}$.

- equinus, Fln.

- vitripennis, Mg. Epping (Brunetti)

- geniculatus, Mcq.

PHORIDE

Phora, Latr.

- rufipes, $\mathrm{Mg}$.

\section{EPROBOSCIDEA}

HiPPOBOSCIDF

Ornithomyia, Latr.

- avicularia, $\mathrm{L}$.

\section{HEMIPTERA}

\section{HETEROPTERA}

Bugs

This order has thus far received but scant attention from British entomologists, though some of the species comprised in it are conspicuous for their beauty and many are extremely interesting from their great diversity of structure. They feed principally upon plants, from 


\section{A HISTORY OF ESSEX}

which they suck the juices; but some of them prey upon other insects, and one has conferred an evil reputation upon the rest from its too assiduous attentions to mankind. Some are winged, but are not so frequently found flying as other insects; others have only rudimentary wings and elytra, and a few are altogether wingless. Although they are mainly attached to land plants, a good many are found in or on the surface of the water.

Among the more notable Essex species are Eurygaster maura, which has been swept from mint at St. Osyth ; Alia acuminata, which occurs on the coast, and has also been beaten from birch at Colchester. A single specimen of Pentatoma fuscispina was taken at St. Osyth on August 19, 1901. Of this fine insect only six British specimens were previously recorded, all from Devonshire. The rare Stracbia oleracea has been found near Clacton-on-Sea, where Beosus luscus may not unfrequently be met with. The very beautiful Zicrona carulea has been captured at Dedham. Henestaris laticeps and Ceraleptus lividus are coast insects, and the curious Chorosoma scbillingi may be met with freely on the flower heads of the marram and other seaside grasses. Dictyonota fuliginosa, for which Weybridge is the only recorded locality, has several times been found, and the rare Monantbia ciliata once only. A macropterous example of Nabis brevipennis, which is usually micropterous in this country, and concerning which Saunders says, 'I have never seen a fully developed British specimen,' has occurred, and a similar fully developed specimen of $N$. lativentris. Probably the high temperature of some recent summers may have produced these unusual forms. $N$. lineatus is occasionally to be found on the coast sands, while Lopus flavomarginatus, which is usually considered local and scarce, seems to be widely distributed in the northern part of the county.

\section{HOMOPTERA}

The Homopterous section of the Hemiptera includes the froghoppers and cuckoo-spits. They are mostly of small size, the strange looking Ledra aurita being our largest Essex species. This is by no means common, but may sometimes be found in oak woods in the autumn. Issus coleoptratus is another curiously formed insect, which occurs somewhat freely near Colchester. Triecphora vulnerata, our most beautiful native species, is common throughout the summer. The universally distributed Pbilanus spumarius, commonly known as the 'spittle-bug,' is also worthy of notice. The larva of this species, which advertises its presence by surrounding itself with a frothy secretion, is said by all the gamekeepers about Colchester to be fatal to young pheasants if they eat it, and according to them large numbers actually do perish every year from this cause. All species included in the list which follows have occurred in the Colchester district except where other localities are given :- 


\section{INSECTS}

\section{A LIST OF THE HEMIPTERA OCCURRING IN THE COUNTY}

\section{HETEROPTERA}

GYMNOCERATA

PENTATOMINA

\section{SCUTELLERIDA}

Corimelæna, White

- scarabæoides, L.

Eurygaster, Lap.

- maura, L.

Podops, Lap.

- inuncta, Fabr.

CydnID瓜

Sehirus, Am. S.

- bicolor, L.

- biguttatus, L.

Gnathoconus, Fieb.

- albomarginatus, Fabr.

Pentatomida

Ælia, Fabr.

- acuminata, L.

Neottiglossa, Curt.

- inflexa, Wolff

Pentatoma, Oliv.

- fuscispina, Boh.

- baccarum, L.

- prasina, L.

Piezodorus, Fieb.

- lituratus, Fabr.

Tropicoris, Hahn

- rufipes, L.

Strachia, Hahn

- oleracea, L.

\section{Asopids}

Picromerus, Am. S.

- bidens, L.

Asopus, Burm.

- punctatus, L. Loughton (Billups)

Podisus, H.S.

- luridus, Fabr.

Zicrona, Am. S.

- cœerulea, L.

Acanthosomide

Acanthosoma, Curt.

- hæmorrhoidale, L.

- dentatum, DeG.

- interstinctum, L.

\section{COREINA}

\section{Coreide}

Syromastes, Latr.

- marginatus, L.

Verlusia, Spin.

- rhombea, L.

Ceraleptus, Cost.

- lividus, Stein.

Coreus, Fabr.

- denticulatus, Scop.
Alydide

Alydus, Fabr.

- calcaratus, L.

STENOCEPHALID $F$

Stenocephalus, Latr.

agilis, Scop.

CorizIDE

Myrmus, Hahn

- myriformis, Fall.

Chorosoma, Curt.

- schillingi, Schml.

\section{BERYTID盾}

Neides, Latr.

- tipularius, L.

Berytus, Fabr.

- minor, H.S.

Metacanthide

Metacanthus, Cost.

- punctipes, Germ.

\section{LYGEINA}

LYGEIDA

Nysius, Dall.

- thymi, Wolff

Cymide

Cymus, Hahn

- glandicolor, Hahn

- claviculus, Fall.

Ischnorhynchus, Fieb.

- resedæ, Panz.

HenestaRIDF

Henestaris, Spin.

- laticeps, Curt.

Artheneid 压

Chilacis, Fieb.

- typhæ, Perr.

HETEROGASTRID

Heterogaster, Schill.

- urticæ, Fabr.

PACHYMERIDF

Rhyparochromus, Curt.

- prætextatus, H.S. St. Osyth

- dilatatus, H.S.

- chiragra, Fab.

Plinthisus, Fieb.

- brevipennis, Latr.

Acompus, Fieb.

- rufipes, Wolff

Stygnus, Fieb.

- rusticus, Fall. Purfeet (R. M. Leake)

- pedestris, Fall.

- arenarius, Hahn

Peritrechus, Fieb.

- geniculatus, Hahn

- nubilus, Fall.

- luniger, Schill. 


\section{A HISTORY OF ESSEX}

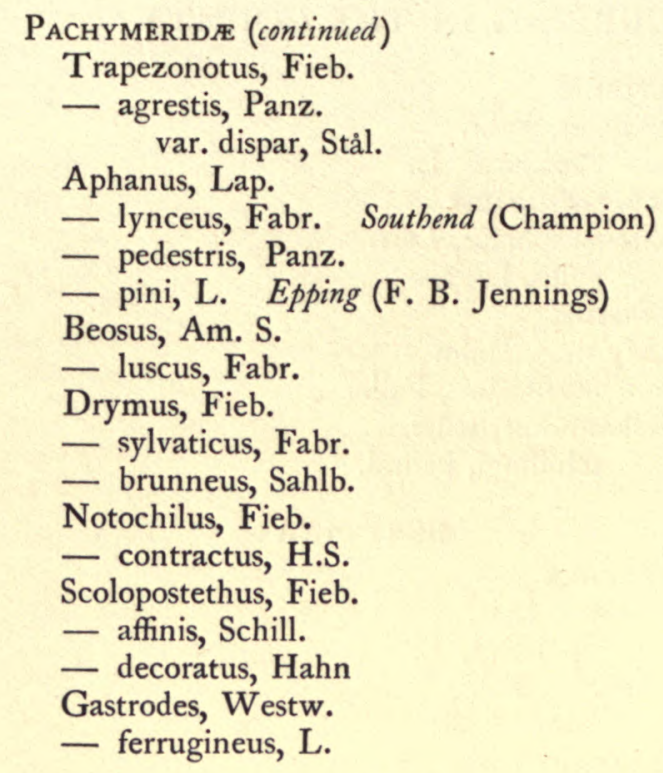

\section{TINGIDINA}

Piesmide

Piesma, Lap.

- quadrata, Fieb.

- capitata, Wolff

- maculata, Lap.

TingIDIDE

Serenthia, Spin.

- læta, Fall.

Orthostira, Fieb.

- parvula, Fall.

Dictyonota, Curt.

- crassicornis, Fall.

- strichnocera, Fieb.

- fuliginosa, Costa

Derephysia, Spin.

- foliacea, Fall. Marks Tey

Monanthia, Lep.

- ampliata, Fieb.

- cardui, L.

- ciliata, Fieb.

- humuli, Fabr.

\section{ARADINA}

Aradus, Fabr.

- depressus, Fabr.

Aneurus, Curt.

- lævis, Fabr.

\section{HEBRINA}

Hebrus, Curt.

- pusillus, Fall. Rainbam (Billups)

- ruficeps, Thoms. Loughton (Billups)

\section{HYDROMETRINA}

\section{HYDROMETRIDF}

Hydrometra, Latr.

- stagnorum, L.
VELIIDF

Velia, Latr.

- currens, Fabr.

GerRID

Gerris, Fabr.

- najas, DeG.

- costæ, H.S.

- thoracica, Schum

- gibbifera, Schum

- lacustris, L.

- odontogaster, Zett.

- argentata, Schum

\section{REDUVIINA}

\section{Emesid}

Ploiaria, Scop.

- vagabunda, L.

ReDUVIIDE

Reduvius, Fabr.

- personatus, L.

Coranus, Curt.

$\mathrm{N}_{\text {ABIDE }}$

Nabis, Latr.

- brevipennis, Hahn

- lativentris, Boh.

- major, Cost.

- flavomarginatus, Scholtz

- limbatus, Dahlb.

- lineatus, Dahlb.

- ferus, L.

- rugosus, $\mathrm{L}$.

\section{SALDINA}

Salda, Fabr.

- pallipes, Fabr.

- littoralis, L.

- lateralis, Fall.

- cincta, H.S.

- cocksii, Curt. West Ham (Billups)

\section{CIMICINA}

\section{Cimicid五}

Cimex, L.

- lectularius, L.

ANTHOCORIDE

Lyctocoris, Hahn

- campestris, Fall.

Piezostethus, Fieb.

- galactinus, Fieb.

- cursitans, Fall. Loughton (Champion)

Anthocoris, Fall.

- confusus, Reut.

- nemoralis, Fabr.

- sylvestris, L.

Acompocoris, Reut.

- pygmæus, Fall. Purfleet (R. M. Leake)

Triphleps, Fieb.

- minuta, L. 


\section{INSECTS}

\section{CAPSINA}

\section{CaPSID}

Pithanus, Fieb.

- maerkeli, H.S.

Miris, Fabr.

- calcaratus, Fall.

- lævigatus, L.

Megaloceræa, Fieb.

- erratica, L.

- longicornis, Fall.

- ruficornis, Fourc.

Teratocoris, Fieb.

- antennatus, Boh.

- saundersi, D. and S. Purfleet (R. M. Leake)

Leptopterna, Fieb.

- ferrugata, Fall.

- dolobrata, L.

Monalocoris, Dahlb.

- filicis, L.

Pantilius, Curt.

- tunicatus, Fabr.

Lopus, Hahn

- flavomarginatus, Don.

Phytocoris, Fall.

- populi, L.

— tiliæ, Fabr.

- longipennis, Flor. Purfleet (R. M. Leake)

- reuteri, Saund.

- varipes, Boh.

- ulmi, L.

Calocoris, Fieb.

- striatellus, Fabr.

- bipunctatus, Fabr.

- chenopodii, Fall.

- roseomaculatus, DeG.

- infusus, H.S.

- striatus, L.

Oncognathus, Fieb.

- binotatus, Fabr.

Dichrooscytus, Fieb.

- rufipennis, Fall.

Plesiocoris, Fieb.

- rugicollis, Fall. Purfeet (R. M. Leake)

Lygus, Hahn

- pratensis, Fabr.

- contaminatus, Fall.

- viridis, Fall.

- pabulinus, L.

- pastinacæ, Fall.

- cervinus, H.S.

- kalmii, L.

Zygimus, Fieb.

- pinastri, Fall.

Pœciloscytus, Fieb.

-. nigritus, Fall. Purfleet (R. M. Leake)

Camptobrochis, Fieb.

- lutescens, Schill.

Liocoris, Fieb.
CAPSIDE (continued)

Liocoris tripustulatus, Fabr.

Capsus, Fabr.

- laniarius, L.

Rhopalotomus, Fieb.

- ater, L.

Pilophorus, Hahn

- perplexus, Scott

- clavatus, L.

Halticus, Burm.

- luteicollis, Pz.

- apterus, L. Purfleet (R. M. Leake)

Labops, Burm.

- saltator, Hahn

Dicyphus, Fieb.

- constrictus, Boh. Purfleet (R. M. Leake)

- epilobii, Reut.

- errans, Wolff

- pallidicornis, Fieb.

- globulifer, Fall.

Campyloneura, Fieb.

- virgula, H.S.

Cyllocoris, Hahn

- histrionicus, L.

- flavonotatus, Boh.

Ætorhinus, Fieb.

- angulatus, Fabr.

Mecomma, Fieb.

- ambulans, Fall.

Cyrtorrhinus, Fieb.

- caricis, Fall.

Orthotylus, Fieb.

- bilineatus, Fall. Purfeet (R. M. Leake)

- marginalis, Reut.

- tenellus, Fall.

- nassatus, Fabr. Purfleet (R. M. Leake)

- prasinus, Fall.

- flavosparsus, Sahlb. Harwich (Champion)

- chloropterus, $\mathrm{Kb}$.

- adenocarpi, Perr.

Loxops, Fieb.

- coccinea, Mey.

Heterotoma, Latr.

- merioptera, Scop.

Heterocordylus, Fieb.

- tibialis, Hahn

Malacocoris, Fieb.

- chlorizans, Fall.

Onychumenus, Reut.

- decolor, Fall. Purfleet (R. M. Leake)

Oncotylus, Fieb.

- viridiflavus, Goeze

Macrotylus, Fieb.

- paykulli, Fall.

Conostethus, Fieb.

- roseus, Fall. Epping (Marshall)

Macrocoleus, Fieb.

- hortulanus, Mey. y Purfleet (R. M.

- molliculus, Fall. $\}$ Leake) 


\section{A HISTORY OF ESSEX}

CAPSIDE (continued)

Harpocera, Curt.

- thoracica, Fall.

Byrsoptera, Spin.

- rufifrons, Fall. Purfleet (R. M. Leake)

Phylus, Hahn

- palliceps, Fieb.

- melanocephalus, L.

- coryli, L.

Psallus, Fieb.

- ambiguus, Fall. Purfleet (R. M. Leake)

- betuleti, Fall.

- variabilis, Fall.

- quercus, $\mathrm{Kb}$.

- fallenii, Reut.

— varians, H.S.

- diminutus, $\mathrm{Kb}$.

- sanguineus, Fabr.

- salicellus, Mey. Purfleet (R. M. Leake)

Plagiognathus, Fieb.

- albipennis, Fall.

- viridulus, Fall.

— arbustorum, Fabr.

\section{CR PPTOCERATA}

\section{NAUCORIDINA}

Naucoris, Geoffr.

- cimicoides, L.

\section{NEPINA}

Nepa, L.

- cinerea, L.

Ranatra, Fabr.

- linearis, L. Epping (Enoch)

\section{NOTONECTINA}

Notonecta, L.

- glauca, L.

Plea, Leach

- minutissima, Fabr.

\section{CORIXINA}

Corixa, Geoffr.

- geoffroyi, Leach

- lugubris, Fieb.

- hieroglyphica, Duf.

- sahlbergi, Fieb.

- limitata, Fieb.

- semistriata, Fieb.

- striata, L.

- fallenii, Fieb.

- distincta, Fieb.

- mœsta, Fieb.

- fabricii, Fieb.

- concinna, Fieb.

Sigara, Fabr.

- minutissima, L.

\section{HOMOPTERA}

CICADINA

\section{Membracide}

Centrotus, Fabr.

- cornutus, L.

Gargara, Am. et Serv.

IsSIDE genistæ, Fabr.

Issus, Fabr.

- coleoptratus, Geoff.

Delphacide

Liburnia, Stål.

- lineola, Germ.

- vittipennis, J. Sahl.

- pellucida, Fabr.

Stiroma, Fieb.

- albomarginata, Curt.

- pteridis, Boh.

\section{CERCopid}

Triecphora, Am. et Serv.

- vulnerata, Illig.

Aphrophora, Germ.

- alni, Fall.

- salicis, DeG.

Philænus, Stål.

- spumarius, L.

- campestris, Fall.

- lineatus, L.

\section{LEDRIDF}

Ledra, Fabr.

- aurita, L.

\section{ULOPIDF}

Ulopa, Fall.

- reticulata, Fabr.

- trivia, Germ.

PAROPIIDE

Megophthalmus, Curt.

- scanicus, Fall.

BYTHOSCOPIDE

Macropsis, Lewis

- lanio, L.

Bythoscopus, Germ.

- alni, Schr.

- flavicollis, L.

Pediopsis, Burm.

- scutellatus, Boh.

- tibialis, Scott

- ulmi, Scott

Idiocerus, Lewis

— adustus, H.S.

- fulgidus, Fabr.

- populi, L.

- confusus, Flor.

Agallia, Curt.

- puncticeps, Germ.

- venosa, Fall.

Tettigonid

Evacanthus, Lep. et Serv. 


\section{INSECTS}

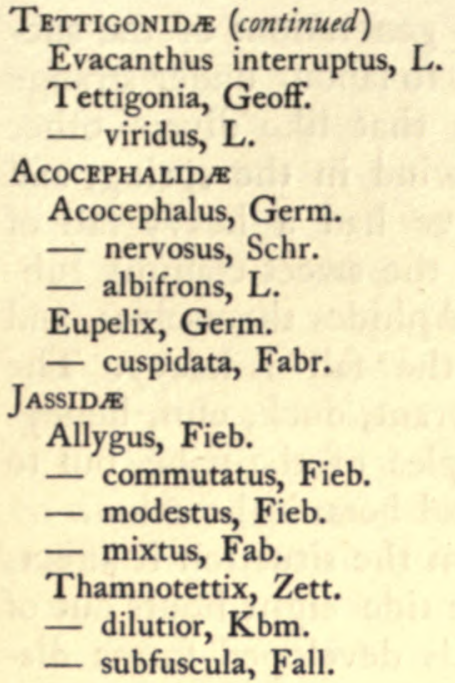

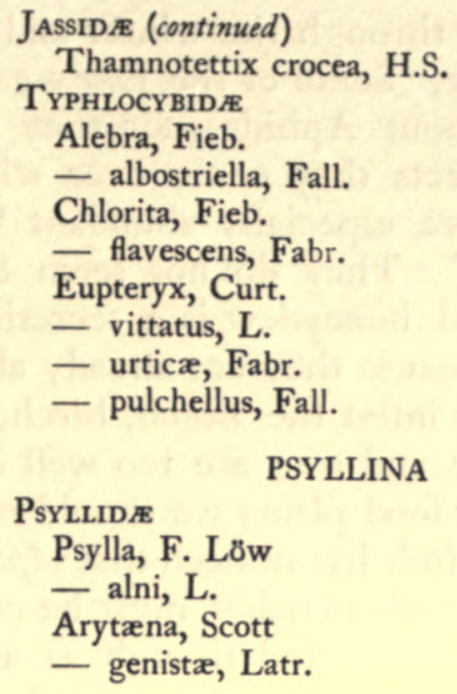

\section{A P H I D ES}

\section{Plant Lice}

Although dwellers in the country are necessarily much too familiar with the insects included in this section, nobody seems to have systematically studied and differentiated the Essex species.

Of all insects they are the most numerous, the most ubiquitous and the most harmful, and the loss they sometimes occasion is incalculable. They infest alike the lowliest herbage and the loftiest trees; some live underground upon roots, out of which they suck the sap, and others submerged in water upon aquatic plants. In former times it was imagined that every plant had its own peculiar Aphis, and as the various species were named after the plants upon which they were found some of them received a large number of names, which are sunk as synonyms now that we know that the same Aphis in some cases affects a great many different plants, and that some of these afford sustenance to several different Aphides.

When they first appear in the spring they are not very numerous, but they arrive at maturity so rapidly, and increase at such a prodigious rate, that before the summer is far advanced it is said a single individual may number its descendants by hundreds of millions, and the term 'Smother-flies,' which is sometimes applied to them, is then amply justified. Their life history is very interesting and peculiar, for the ordinary processes of nature have been so materially modified to meet their special case that the actual facts would appear almost incredible if they had not been abundantly proved. The first brood of the year emerges from eggs which have been laid by the fertilized females of the previous autumn, and consists of females exclusively, which without any male intervention bring forth other females, and the process is continued as long as a suitable food supply lasts and the climatic conditions remain favourable; but when these change a bisexual brood is produced, the males of which fertilize the females, and eggs are deposited which 


\section{A HISTORY OF ESSEX}

lie dormant through the winter and produce the generations of the succeeding year. Some of the Essex gardeners seem to labour under strange delusions about Aphides, for they will tell you that like divers other noxious insects they come over with the east wind in the spring, and that they are especially abundant 'after we have had a heavy fall of honey-dew.' They do not seem to know that the sweet clammy substance called honeydew is a secretion from the Aphides themselves, and that it is because they are already abundant that the 'fall' is heavy. The species that infest the beech, birch, cabbage, currant, dock, elm, honeysuckle, lime and rose are too well known examples of the tribe, but to name all its food plants we should require a second botanical section.

Mr. Fitch has noticed that Apbis asteris, from the situation it affects in the Essex salt marshes, must be covered by the tide eight hours out of the twenty-four; and though as a rule the fully developed forms disappear in the autumn, some of them may in mild seasons be met with much later in the year. Sipbonophora lactuca for instance was abundant among the inner folded leaves of lettuce at Colchester during December, I 900, and continued to flourish till its food was destroyed by the severe frosts that followed. Some authors say that all the individuals of the early broods are wingless, but this is certainly not the case invariably, for winged specimens of some species have been common at Colchester during the present spring (r $90 \mathrm{I})$. Existing in such enormous numbers, and carrying on their operations on such an extensive scale, Aphides are generally formidable enemies to contend against ; small greenhouse plants can be easily freed from them, but large trees and crops that cover extensive areas do not so readily lend themselves to successful treatment, and most of the remedies recommended are costly and useless, and in applying them we are in danger of interfering with nature's remedies, which are as a rule much more efficacious than ours.

No tribe of insects has so many formidable enemies among other orders as the plant lice. They are preyed upon by certain of the fossorial Hymenoptera, which carry them off to their burrows as food for their larvæ, and as they sting and paralyze but do not kill them the larvæ are provided with a sufficient supply of fresh meat as long as they require it. Large numbers of species of Braconida, Cbalcidide and other parasitic Hymenoptera deposit eggs in their bodies, and in this way destroy myriads of them. The larva of the Lacewing flies among the Neuroptera, the Syrpbida among the Diptera, and the Coccinellides among the Coleoptera also devour enormous multitudes, and when a systematic attack is made upon them by the horticulturist he is far more likely to destroy his friends than his foes, as they are much more easy for him to get at, and thus he too often stops their beneficent operations in blissful ignorance of their very existence. 


\section{MYRIAPODA}

With the exception of a few specimens collected by Mr. B. B. Woodward at Walton-on-the-Naze, the Myriapoda recorded in the subjoined list were obtained by Mr. W. M. Webb, who at one time not only paid special attention to collecting representatives of this neglected group, but in addition stimulated to that end the interest of naturalists in various parts of the county of Essex. As a result we have perhaps as complete a knowledge of the Myriapoda of this county as of any other county in Great Britain.

Most of the specimens belong to species which have a wide distribution in the south of England and in the adjacent countries of the continent. None are peculiar to the county. On the other hand, there are one or two noteworthy deficiencies in the fauna. Of these the most noteworthy is the apparent absence of Litbobius variegatus, a relatively large and striking form and one not likely to be overlooked by collectors, a species too which is the most prevalent element in the myriapod fauna of all the other counties of Great Britain where collecting has been carried on to any extent. The absence of the species from Essex gains in interest when it is remembered that the animal is, so far as we know, restricted in its range to Great Britain and the Channel Islands. The apparent absence too of Stigmatogaster subterraneus is to be noted. Elsewhere in England this species is perhaps the commonest, as it is the largest, representative of the Geophilidæ. It also occurs in Denmark, Belgium, etc. Hence, as is probably the case with other elsewhere common species, it may have been overlooked in Essex.

Finally, it may be mentioned that a single specimen of Scutigera coleoptrata, a species of Chilopod which is common in the south of Europe and has already been recorded as an importation in Scotland by Mr. Gibson Carmichael, was captured in a house in Colchester. Presumably, since no other specimens have come to hand from Essex, the one discovered by $\mathrm{Mr}$. Webb was artificially introduced.

\section{CHILOPODA \\ Centipedes \\ LITHOBIIDE}

Short-bodied, swift-running centipedes, furnished with eyes and only fifteen pairs of legs.

1. Lithobius forficatus, Linn. Syst. Nat. ed. 10 , p. 638 (1758).

Brentwood, Stock, Maldon, Finchingfield, Warley, Colchester, West Horndon, Dagenham, Ingrave, Rivenhall, Shoeburyness.

Common throughout the whole of north and central Europe, and abundant everywhere in England in the neighbourhood of houses as well as in fields and woods.

2. Lithobius calcaratus, Koch. Die Myr.-Gatt. Lithobius, p. 86 (1862).

Brentwood, Warley. 1.

One of the smaller species, with long antennze and peculiarly modified anal legs in the male. Common in central Europe and abundant throughout the south of England.

3. Lithobius crassipes, Koch. Die Myr.-Gatt. Lithobius, p. 71 (1862).

Brentwood.

Common in England and central Europe. A small species with short antennz. Generally mistaken by collectors for the young of L. forficatus.
25 


\section{A HISTORY OF ESSEX}

\section{CRYPTOPIDE}

Eyeless centipedes of medium length and thickness, with twenty-one pairs of short legs, and though somewhat intermediate in form between the preceding and the succeeding families, resembling the latter rather than the former in their slow movements.

4. Cryptops bortensis, Leach. Tr. Linn. Soc. A widely distributed species, but never ocLond. xi. 384 (1815). curring in any very great numbers. AbunMaldon, Warley. dant all over central and southern Europe.

\section{GEOPHILIDÆ}

Long-bodied vermiform centipedes without eyes, and furnished with a large but variable number of legs.

5. Geopbilus flavus, De Geer. Mim. Ins. vii. 561 (1778) (= longicornis, Leach).

Brentwood, Maldon, Stock, West Mersea (under Zostera on the beach), Finchingfield, Warley, West Horndon, Dagenham, Ingrave, Colchester.

Common throughout Europe. Distinguishable from all the other British species by its long antennal segments.

6. Geophilus proximus, Koch. Syst. d. Myr. p. 186 (1847).

Brentwood, Finchingfield, Colchester, Rivenhall.

Although widely distributed on the continent, this species, so far as our knowledge at present extends, appears to be restricted in its range to the eastern counties of Great Britain. It may be distinguished by the presence of a pair of short oval impressions on the sterna of anterior segments of body.

7. Geophilus carpophagus, Leach. Zool. Misc. iii. 43 (1817).

Brentwood, Warley.

Common everywhere in England and on the continent. Distinguishable by the ball and socket method of articulation of the anterior sternal plates.

8. Geophilus truncorum, Meinert. Nat. Tidskr. iv. 94 (I 866).

Warley, Ingrave.

A small species, often overlooked, but ranging throughout the south of England and Wales. Distinguishable by the presence of three strong grooves on the anterior sternal plates.

9. Linotania acuminata, Leach. $\mathcal{T} r$. Linn. Soc. Lond. xi. $3^{86}$ (1814).

Warley.

Widely distributed in the south of England and on the continent.

10. Linotania crassipes, Koch. Deutschl. Crust. etc. 3, pl. iii. (1835).

Brentwood, Warley, Ingrave, Colchester.

This species has the same distribution as the last, to which it is nearly allied. The two are the common British luminous centipedes which frequently attract attention on damp evenings in the autumn by the emission of a phosphorescent secretion from their sternal glands.

I I. Linotania maritima, Leach. Zool. Misc. iii. 44 (18 17 ).

West Mersea (under Zostera on the beach).

Fairly common in suitable localities round the coasts of Great Britain and on those of western Europe, living beneath stones between tide marks or under accumulated seaweed left by the tide.

12. Schendyla nemorensis, Koch. Deutschl. Crust. etc. 9, pl. 4 (1 837).

Warley.

A small and delicate centipede of about the same size and general appearance as $G$. truncorum. Found under tree trunks and stones in woods, etc., throughout England and central Europe.

\section{DIPLOPODA Millipedes \\ POLYDESMID压}

Millipedes with from nineteen to twenty body segments, most of which are furnished with paired scent-glands supported on a larger or smaller lateral crest or keel.

13. Polydesmus complanatus, Linn. Faun. 14. Polydesmus subinteger, Latzel. Bull. Soc. Suecic. ed. 2, p. 502 (1761).

Stock, Warley, Epping Forest, Widford, Walton-on-the-Naze.

The commonest and largest British species. Found all over Europe.

$$
\text { Rouen (2), xix. } 269 \text { (1883). }
$$

Walton-on-the-Naze.

A smaller and much scarcer species than the foregoing, and known from a few of the 


\section{MYRIAPODA}

southern counties. Occurs also in the western 15. Brachydesmus superus, Latzel. Die Myriap. countries of central Europe.

Ester. Ungar. Mon. ii. 130 (1884).

Finchingfield, Walton-on-the-Naze.

\section{CHORDEUMID压}

Millipedes with typically thirty segments furnished dorsally with six symmetrically disposed bristles, without scent-glands and usually keeled like those of the Polydesmidæ.

16. Atractosoma polydesmoides, Leach. Zool. This species, with its large keels, closely Misc. iii. $36(1817)$.

Brentwood, Finchingfield, Warley. resembles an elongate Polydesmus.

\section{IULIDÆ}

Millipedes in which the body consists of a large but variable number of segments, each of which, excepting the most anterior, is furnished with scent glands, but without the keels characteristic of the Polydesmidx.

17. Iulus sabulosus, Linn. Syst. Nat. ed. I0, p. 639 (1758).

Walton-on-the-Naze, Chelmsford, Widford.

A large species with acute caudal prolongation and a pair of yellow longitudinal dorsal stripes.

18. Iulus niger, Leach. Zool. Misc. iii. 34 ( 1817$)$.

Warley.

Common in England and in the western countries of the continent. As large as the preceding but slenderer, without dorsal bands, and with the anterior portion of the segments transversely grooved.

19. Iulus ligulifer, Latzel. Berl. Ent. Zeits. xxxvi. I52 (189I).

Stock, Warley.

A small black-tailed species, without stripes and without transverse grooves on the segments. Fairly common in central Europe and no doubt also in England, though not previously recorded as British.

20. Iulus pilosus, Newport. Ann. Mag. Nat. Hist. xi. 316 (1842).

Warley.

Very nearly allied to I. ligulifer, and probably often confounded with that species so far as the females are concerned. The males of the two are easily distinguishable by the form of the first pair of legs.
21. Iulus punctatus, Leach. Zool. Misc. iii. 34 (1 817).

Warley.

A yellowish-brown species, with a blunt expanded caudal process and a row of dark spots on each side of the body. Found in rotten wood. Common throughout England and on the continent.

22. Iulus teutonicus, Pocock. Ann. Mag. Nat. Hist. (7), vi. 206 (1900).

Stock, Warley, Colchester, Great Baddow, Dagenham.

This species, which is common at least in the south-eastern counties of England and in the western countries of Europe, has erroneously passed until recently under the name Iulus londinensis. With exception of the latter, which has never been discovered since Leach's time, I. teutonicus is the largest tailless form of this genus met with in Britain.

Iulus londinensis, Leach $(\mathcal{T} r$. Linn. Soc. xi. $378[1815])$, described from the environs of London, may prove to belong to the fauna of Essex.

23. Blaniulus guttulatus, Bosc. Bull. Soc. Philom. p. 12 (1792).

Finchingfield.

A long and slender eyeless species, with the head and anterior segments pale, and a line of blood-red spots on each side of the body.

\section{POLYXENID压}

24. Polyxenus lagurus, Linn. Syst. Nat. ed. 10, p. 637 (1758).

Brightlingsea.

This species is commonly found beneath the loose bark of old fences or tree trunks.
The examples above recorded however were collected beneath weeds upon the beach. In spite, however, of the peculiarity of the habitat, they seem to belong to $P$. lagurus, the common European species of the genus. 


\title{
A HISTORY OF ESSEX
}

\section{ARACHNIDA}

\author{
Spiders, etc.
}

There have been already published two contributions towards a knowledge of the Aracbnida of Essex. The first appeared in the Trans. Essex Field Club in $\mathrm{I}_{88}$ (iv. 4I-9), by the Rev. O. PickardCambridge; the second in 1901 in the Essex Naturalist (xi. 31 5-8). These two publications had brought the number of records for the county, up to that date, to ninety-five, including 'harvestmen' and ' false-scorpions.' Many more however have been added from time to time by the present author and others, so that the list has considerably increased and includes at the present time 153 spiders, 3 false-scorpions and 6 harvestmen.

The county as physically constituted offers some magnificent situations where Arachnida ought to be found in abundance, though generally speaking a predominance of heavy clay soil is not favourable to the members of this family.

None the less however there are several special localities which would always repay a thorough investigation; Epping Forest and district, Chelmsford, and all the estuaries on the coast, including the salt marshes, such as Benfleet, Burnham-on-Crouch, the Blackwater, and in the neighbourhood of Walton-on-the-Naze.

So very little collecting however has been hitherto done that the present list must only be regarded as a small contribution which can easily be very largely increased with but little trouble.

The initials of those who collected the specimens or recorded their occurrence have been added to names in the list except in cases where the present author is himself responsible for them. Many species were recorded by Rev. O. Pickard-Cambridge (O. P.-C.) and others by Messrs. William Cole and F. P. Smith (F. P. S.).

In cases where the generic or specific name quoted is not that under which the spider has usually been recognized in the works of English authors, a note has been added calling attention to the fact. With these few preliminary remarks, we may proceed at once with the list of the spiders of Essex.

\section{ARANEÆ \\ ARACHNOMORPHE \\ DYSDERID压}

Spiders with six eyes and two pairs of stigmatic openings, situated close together on the genital rima; the anterior pair communicating with lung books, the posterior with tracheal tubes. Tarsal claws, two in Dysdera, three in Harpactes and Segestria.

I. Dysdera cambridgii, Thorell.

Broxted.

Not uncommon under stones and bark of trees, where it lurks within a tubular retreat. The spider is easily recognizable by its elongate form, orange legs, dark mahogany carapace and pale clay-yellow abdomen. The palpal bulb of the male has no cross-piece at the apex. The spider is also known as $D$. erythryna, Blackwall. 


\section{SPIDERS}

2. Harpactes hombergii (Scopoli).

Broxted; Epping Forest (F. P. S.).

Rare under bark of trees, and recognizable by its linear ant-like form, black carapace, and pale clay-yellow abdomen and three tarsal claws.
3. Segestria senoculata (Linnæus).

Epping Forest (F. P. S.).

Not common ; under bark of trees, in the crevices of loose stone walls and amongst detached rocks. Recognizable by its linear form and the black diamond-shaped blotches on the dorsal surface of the abdomen.

\section{DRASSID $Æ$}

Spiders with eight eyes, situated in two transverse rows. The tracheal openings lie just in front of the spinners. The tarsal claws are two in number, the anterior pair of spinners are set wide apart at the base, and the maxillæ are more or less impressed across the middle.

4. Drassodes lapidosus (Walckenaer).

Broxted ; Epping Forest (O. P.-C.).

Very common under stones. Also known as Drassus lapidicolens.

5. Drassodes sylvestris (Blackwall).

Epping Forest (O. P.-C.).
6. Scotophaus blackwallii (Thorell).

\section{Broxted.}

A dark elongate mouse-grey spider, often found wandering about the walls of dwelling and outhouses at night. Known also as Drassus sericeus, Blackwall.

\section{CLUBIONIDÆ}

Spiders with eight eyes, situated in two transverse rows. The tracheal openings lie immediately in front of the spinners. The tarsal claws are two in number, but the anterior pair of spinners are set close together at the base; the maxillæ are convex and not impressed across the middle.

\section{Micaria pulicaria (Sundevall).}

Broxted ; Epping Forest (O. P.-C.).

A small dark spider, iridescent and shining, with a white cincture round the middle of the anterior half of the abdomen. Known also as Drassus nitens, Blackwall.

8. Phrurolithus festivus, C. L. Koch.

Chelmsford ; Epping Forest (O. P.-C.).

Also known as Drassus propinquus, Blackwall.

9. Zora spinimana (Sundevall).

Broxted.

Iо. Clubiona stagnatilis, Kulczynski.

Broxted.

Known also as $C$. bolosericea, Blackwall.

1 1. Clubiona terrestris, Westring. Broxted; Epping Forest (O. P.-C.).

12. Clubiona reclusa, O. P.-Cambridge. Chelmsford.
13. Clubiona lutescens, Westring. Broxted.

14. Clubiona brevipes, Blackwall. Epping Forest (O. P.-C.).

15. Clubiona pallidula (Clerck). Broxted ; Epping Forest (F. P. S.).

16. Clubiona corticalis (Walckenaer). Danby Park.

1 7. Clubiona phragmitis, C. L. Koch. Dunmow.

18. Clubiona compta, C. L. Koch. Broxted ; Epping Forest (O. P.-C.).

19. Chiracanthium erraticum (Walckenaer). Broxted.

Known also under the name of $C$. carnifex.

20. Agraeca proxima, O. P.-Cambridge. Epping Forest.

21. Agraca brunnea (Blackwall). Epping Forest (F. P. S.).

\section{ANYPH正ID正}

The spiders of this family resemble those of the Clubionida in most respects, except that the tracheal stigmatic openings beneath the abdomen are situated about midway between the genital rima and the spinners, and not, as in the last family, immediately in front of the spinners. One species only is indigenous to Great Britain and is very common amongst the foliage of trees in May and June.

22. Anyphana accentuata (Walckenaer).

Broxted; Epping Forest (F. P. S.). 


\section{A HISTORY OF ESSEX}

\section{THOMISIDÆ}

Spiders with eight eyes, situated in two transverse rows, two tarsal claws and anterior spinners close together at their base. Maxillæ not impressed. The crab-like shape and sidelong movements of these spiders are their chief characteristics, enabling them to be easily distinguished from the more elongate Drasside and Clubionida.

23. Philodromus dispar, Walckenaer. Broxted.

24. Pbilodromus aureolus (Clerck). Broxted ; Epping Forest (F. P. S.).

25. Pbilodromus caspiticolens, Walckenaer. Dunmow.

26. Tibellus oblongus (Walckenaer). Broxted.

27. Xysticus cristatus (Clerck). Broxted.
28. Oxyptila praticola (C. L. Koch). Chelmsford.

29. Oxyptila trux (Blackwall). Chelmsford.

30. Misumena vatia (Clerck). Earl's Colne.

31. Dicea dorsata (Fabricius). Broxted.

\section{ATTID $\approx$}

The spiders of this family may be recognized in a general way by their mode of progression, consisting of a series of leaps. More particularly they may be known by the square shape of the cephalic region and the fact that the eyes are arranged in three rows of $4,2,2$, the centrals of the anterior row being much the largest. Otherwise the spiders are simply specialized Clubionids with two tarsal claws and other minor characters possessed in common with other members of this family.

32. Salticus scenicus (Clerck). Dunmow.

33. Salticus cingulatus (Panzer). Danby Park.

This species is not nearly so common as the last.

34. Euophrys frontalis (Walckenaer). Broxted ; Epping Forest (O. P.-C.).

35. Neon reticulatus (Blackwall). Broxted ; Epping Forest (O. P.-C.).

36. Attus pubescens (Fabricius). Epping Forest (O. P.-C.).

Known also as Salticus sparsus, Blackwall.
37. Ergane falcata (Clerck). Broxted.

Known also as Salticus coronatus, Blackwall.

38. Heliophanus favipes, C. L. Koch. Chelmsford.

Rare; found on the Roman road.

39. Marptusa muscosa (Clerck). Epping Forest (O. P.-C.).

Common. Known also as Salticus tardigradus, Blackwall.

40. Ballus depressus (Walckenaer). Epping Forest (F. P. S.).

Known also as Salticus obscurus, Blackwall.

\section{PISAURIDÆ}

Spiders with eight eyes in three rows of $4,2,2$; the small anterior eyes being sometimes in a straight line, sometimes recurved and sometimes procurved. Those of the other two rows are situated in the form of a rectangle of various proportions and are much larger than the eyes of the anterior row. The tarsal claws are three in number. Pisaura runs freely over the herbage, carrying its egg-sac beneath the sternum; while Dolomedes is a dweller in marshes and swamps.

41. Pisaura mirabilis (Clerck).

Broxted ; Epping Forest (O. P.-C.).

Known also as Dolomedes, or Ocyale, mirabilis. 


\section{SPIDERS}

\section{LYCOSID年}

The members of this family are to be found running freely over the ground, and carrying the egg-sac attached to the spinners. Many of the larger species make a short burrow in the soil and there keep guard over the egg-sac. Eyes and tarsal claws as in the Pisaurida, with slight differences.

42. Lycosa ruricola (De Geer). Broxted; Epping Forest (F. P. S.).

Known also as $L$. campestris, Blackwall.

43. Lycosa terricola, Thorell.

Broxted ; Epping Forest (O. P.-C.).

Known also as $L$. agretica, Blackwall.

44. Lycosa accentuata, Latreille. King's Oak.

Known also as Tarentula andrenivora.

45. Lycosa pulverulenta (Clerck). Broxted.

Known also as L. rapax, Blackwall, and Tarentula pulverulenta.

46. Pardosa lugubris (Walckenaer). Broxted; Epping Forest (O. P.-C.).
47. Pardosa pullata (Clerck). Broxted; Epping Forest (O. P.-C.).

Known also as Lycosa obscura, Blackwall.

48. Pardosa nigriceps, Chorell. Epping Forest (O. P.-C.).

49. Pardosa palustris (Linnæus). Chelmsford.

Known also as Lycosa exigua, Blackwall.

50. Pardosa amentata (Clerck). Epping Forest (O. P.-C.).; Broxted.

51. Pardosa annulata, Chorell. Epping Forest (O. P.-C.).

52. Pirata piraticus (Clerck). Loughton (F. P. S.).

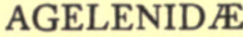

Spiders with eight eyes, situated in two straight or more or less curved transverse rows. Tarsal claws, three. The species of this family spin a large sheet-like web, and construct a tubular retreat at the back of it, which leads to some crevice amongst the rocks or in the herbage, or in the chinks in the walls of outhouses and barns, wherever the various species may happen to be found. The habits of Argyroneta, the water spider, are however quite different. The posterior pair of spinners is much longer than the others in the more typical genera of this family.

53. Tegenaria atrica, C. L. Koch.

Epping Forest.

54. Tegenaria parietina (Fourcroy). Epping Forest.

Abundant in parts of this county and the London district generally. Known also as $\mathcal{T}$. guyonii and $\mathcal{T}$. domestica.

55. Tegenaria derhami (Scopoli).

Epping Forest ; Broxted.

A very common species everywhere.

56. Tegenaria silvestris, L. Koch. Broxted; Chelmsford.

Known also as $\mathcal{T}$. campestris.

57. Cicurina cinerea (Panzer).

Broxted; Epping Forest, under bark (F. P. S.).

Common in a cellar at the vicarage.
58. Agelena labyrinthica (Clerck). Epping Forest.

Abundant, forming large sheet-like webs on the herbage, with a funnel-shaped tubular retreat.

59. Hahnia elegans (Blackwall).

Chelmsford.

Not uncommon amongst the roots of aquatic plants and riverside herbage. Known also as Agelena elegans, Blackwall.

6o. Habnia montana (Blackwall).

Epping Forest (O. P.-C.).

Not uncommon. Known also as Agelena montana, Blackwall.

6r. Argyroneta aquatica (Clerck).

Whipps Cross, Walthamstow (F. P. S.).

\section{ARGIOPID平}

The spiders included in this family have eight eyes, situated in two rows, the lateral eyes of both rows being usually adjacent if not in actual contact, while the central eyes form a quadrangle. The tarsal claws are three, often with other supernumerary claws. The web is 


\section{A HISTORY OF ESSEX}

either an orbicular snare, as in the case of the 'common garden spider,' or consists of a sheet of webbing, beneath which the spider hangs and captures the prey as it falls upon the sheet. This immense family includes those usually separated under the names Epeirida and Linyphiida.

62. Meta segmentata (Clerck).

Epping Forest (O. P.-C.) ; Broxted.

Very abundant. Known also as Epeira inclinata, Blackwall.

63. Meta meriana (Scopoli).

Epping Forest (O. P.-C.) ; Broxted.

Not uncommon. Known also as Epeira antriada, Blackwall, and a striking variety as E. celata, Blackwall.

64. Tetragnatha extensa (Linnæus).

Epping Forest (O. P.-C.) ; Broxted.

Most abundant and generally distributed.

65. Tetragnatha solandri (Scopoli). Broxted.

66. Pachygnatha clerkii, Sundevall. Broxted; Epping Forest (F. P. S.).

67. Pachygnatha degeerii, Sundevall. Broxted ; Epping Forest (F. P. S.).

Common and generally distributed.

68. Cyclosa conica (Pallas). Snaresbrook.

A few specimens only have been taken. Known also as Epeira conica, Blackwall.

69. Zilla $\times$-notata (Clerck).

Epping Forest (F. P. S.).

Very common. Known also as Epeira similis, Blackwall.

70. Zilla atrica, C. L. Koch.

Snaresbrook; Epping Forest (F. P. S.).

Almost as common as the above. Known also as Epeira callophylla, Blackwall.

71. Araneus cucurbitinus, Clerck. Epping Forest (O. P.-C.).

Common and generally distributed.

72. Araneus diadematus, Clerck.

Epping Forest (O. P.-C.).

Abundant and generally distributed.

73. Araneus cornutus, Clerck. Broxted.

Common. Known also as Epeira apoclisa, Blackwall.

74. Araneus patagıatus, Clerck. Epping Forest (F. P. S.).

75. Araneus umbraticus, Clerck. Broxted; Earl's Colne (F. P. S.).

Common and generally distributed.
76. Araneus triguttatus, Fabricius.

Epping Forest.

Not common. Known also as Epeira agalena, Blackwall.

77. Linyphia impigra, O. P. Cambridge. Chelmsford.

78. Linyphia triangularis (Clerck). Broxted; Epping Forest (O. P.-C.).

Common. Known also as $L$. montana, Blackwall.

79. Linyphia hortensis, Sundevall. Broxted.

Known also as L. pratensis, Blackwall.

8o. Linyphia pusilla, Sundevall. Epping Forest.

Known also as $L$. fuliginea, Blackwall.

81. Linyphia montana (Clerck). Broxted.

Common. Known also as $L$. marginata, Blackwall.

82. Linyphia clatbrata, Sundevall.

Broxted; Epping Forest (O. P.-C.).

Abundant. Known also as Neriene marginata, Blackwall.

83. Linyphia insignis, Blackwall. Epping Forest.

84. Linyphia peltata, Wider. Epping Forest (O. P.-C.).

85. Labulla thoracica (Wider). High Beach (F. P. S.) ; Broxted.

Common. Known also as Linyphia cauta, Blackwall.

86. Floronia bucculenta (Clerck).

Chelmsford.

Rare. Known also as Linyphia frenata (Wider).

87. Stemonyphantes lineatus (Linnæus).

Epping Forest.

Known also as Linyphia bucculenta, O.P.-C., and Neriene trilineata, Blackwall.

88. Lepthyphantes leprosus (Ohlert).

Broxted.

Common. 


\section{SPIDERS}

89. Lepthyphantes blackwallii, Kulczynski. Epping Forest; Broxted.

Common.

90. Lepthyphantes minutus (Blackwall). Broxted; Snaresbrook.

91. Lepthyphantes tenuis (Blackwall). Epping Forest.

92. Lepthyphantes obscurus (Blackwall). Epping Forest (O. P.-C.).

Rare.

93. Lepthyphantes nebulosus (Sundevall). Broxted; Snaresbrook.

Rare and very local. Known also as Linyphia vivax, Blackwall.

94. Lepthyphantes ericeus (Blackwall). Epping Forest (O. P.-C.).

Not common.

95. Lepthyphantes pallidus (O. P.-Cambridge). Broxted.

Rare.

96. Bathyphantes pullatus (O. P.-Cambridge). Epping Forest.

Common.

97. Bathyphantes nigrinus (Westring). Tilty, near Dunmow.

Common. Known also as Linyphia pulla, Blackwall.

98. Bathyphantes meadii (O. P.-Cambridge). Chelmsford.

Abundant. Known also as Linyphia approximata (O. P.-Cambridge).

99. Bathyphantes dorsalis (Wider).

Chelmsford.

Not uncommon. Known also as Linyphia claytonia, Blackwall.

100. Bathyphantes circumspectus (Blackwall). Broxted.

101. Bathyphantes gracilis (Blackwall). Epping Forest (F. P. S.).

102. Bathyphantes concolor (Wider). Broxted; Epping Forest (O. P.-C.).

Not uncommon. Known also as Theridion slipes, Blackwall.

103. Hilaira uncata (O. P.-Cambridge). Epping Forest (F. P. S.).

A few taken in marshy places.

104. Centromerus bicolor (Blackwall). Epping Forest (O. P.-C.).
105. Macrargus abnormis (Blackwall). Broxted.

106. Microneta subtilis (O. P.-Cambridge). Broxted.

Known also as Neriene anomala, O. P.Cambridge.

107. Microneta viaria (Blackwall).

Epping Forest (F. P. S.).

108. Micryphantes innotabilis (O. P.-Cambridge).

Epping Forest (O. P.-C.).

109. Micryphantes rurestris, C. L. Koch.

Broxted.

Known also as Neriene fuscipalpis, O. P.Cambridge, ad partem; and probably $N$. gracilis and flavipes, Blackwall.

I 10. Erigone atra (Blackwall).

Epping Forest.

Very abundant on railings.

II I. Erigone dentipalpis (Wider).

Loughton (F. P. S.).

Equally abundant as the last species and in the same situations.

I $12 . T$ iso vagans (Blackwall).

Epping Forest (F. P. S.).

Rare; two specimens only have been recorded.

I 3. Neriene rubens (Blackwall).

Broxted.

Known also as Gonatium rubens.

I 4 . Neriene isabellina (C. L. Koch).

Broxted.

Known also as Neriene rubella, Blackwall.

I I5. Dicyphus cornutus, Blackwall.

Hoddesdon and Lea Valley (F. M. C.).

I 16. Hypomma bituberculatum (Wider).

Chelmsford.

Known also under the name Neriene.

I 17. Trachygnatha dentata (Wider).

Wanstead Park (F. P. S.).

Known also under the name Neriene.

118. Kulczynskiellum fuscum (Blackwall). Epping Forest (O. P.-C.).

Known also under the name Neriene.

I I 9. Kulczynskiellum retusum (Westring). Chelmsford.

Known also under the name Neriene.

I 20. Lophomma herbigradum (Blackwall).

Epping Forest (O. P.-C.).

Known also under the name Neriene. 


\section{A HISTORY OF ESSEX}

121. Dicymbium nigrum (Blackwall). Broxted.

Known also under the name Neriene.

122. Prosoponcus cristatus (Blackwall). Broxted.

123. Plasiocrarus fuscipes (Blackwall). Chelmsford.

Known also under the name $W$ alckenaera. 124. Plasiocrarus latifrons (O. P.-Cambridge). Chelmsford.

Known also under the name Walckenaera.

125. Plasiocrarus picinus (Blackwall).

Epping Forest (O. P.-C.).

126. Savignia frontata, Blackwall.

Broxted.

Known also under the name $W$ alckenaera.
127. Gongylidiellum vivum (O. P.-Cambridge). Epping Forest (O. P.-C.).

Rare and local. Known under the name Neriene.

128. Dismodicus bifrons (Blackwall).

Epping Forest (O. P.-C.).

129. Walckenaria acuminata (Blackwall).

Epping Forest (O. P.-C.).

Not uncommon, but females only. Known also under the name $W$ alckenaera.

130. Viderius cucullatus (C. L. Koch). Epping Forest (O. P. C.).

131. Lophocarenum parallelum (Wider). Broxted.

Rare. Known also under Walckenaera.

\section{THERIDIID压}

The members of this family have eight eyes, situated very much like those of the Argiopide; but the mandibles are usually weak, the maxillæ are inclined over the labium, and the posterior legs have a comb of stiff curved spines beneath the tarsi. The web consists of a tangle of crossings lines, and the spider often constructs a tent-like retreat wherein the egg-sac is hung up. The tarsal claws are three in number.

132. Theridion formosum (Clerck).

Broxted; Wanstead (O. P.-C.).

Known also as $\mathcal{T}$. sisyphium, Blackwall.

133. Theridion tepidariorum, C. L. Koch. High Beach (F. P. S.) ; Broxted.

134. Theridion sisyphium (Clerck).

Epping Forest (O. P.-C.).

Known also as $\mathcal{T}$. nervosum, Blackwall.

135. Theridion denticulatum (Walckenaer). Epping Forest.

136. Theridion varians, Hahn.

Epping Forest (O. P.-C.) ; Broxted.

137. Theridion vittatum, C. L. Koch.

Hoddesdon (F. M. C.) ; Broxted.

Known also as $\mathcal{T}$. pulchellum (Walckenaer).

138. Theridion pallens, Blackwall.

Broxted.

139. Theridion simile, C. L. Koch.

Epping Forest (O. P. C.).
140. Theridion ovatum (Clerck).

Broxted.

Known also under the name Pbyllonethis lineata.

141. Theridion familiare, O. P.-Cambridge. Broxted.

In an old barn.

142. Episinus lugubris, Simon.

Broxted.

Known also as Theridion angulatum, Blackwall.

143. Pholcomma gibbum, Westring.

Broxted; Epping Forest (O. P.-C.).

144. Steatoda bipunctata (Linnæus).

Broxted; Epping Forest (O. P.-C.).

Known also as Theridion quadripunctatum, Blackwall.

145. Steatoda guttata (Wider).

Epping Forest (O. P.-C.).

Known also as Theridion guttatum, Blackwall. A single specimen only.

146. Pedanostethus lividus (Blackwall).

Epping Forest (O. P.-C.). 


\section{SPIDERS}

\section{MIMETID居}

Spiders of this family are similar in general respects to the Theridiida, having eight eyes and three tarsal claws. The species of Ero construct a small brown pear-shaped or cylindrical egg-cocoon suspended on a fine silken stalk.

147. Ero furcata (Villers).

Broxted.

This spider is known also as $E$. thoracica and Theridion variegatum, Blackwall.

\section{DICTYNID蚱}

The spiders belonging to this family possess three tarsal claws, and the eyes, eight in number, situated in two transverse rows, the laterals being in contact. The cribellum (or extra pair of spinning organs) and the calamistrum (a row of curving bristles on the protarsi of the fourth pair of legs) are present in all members of the family. They construct a tubular retreat with an outer sheet of webbing, which is covered with a flocculent silk made with the calamistrum from threads furnished by the cribellum.

148. Amaurobius fenestralis (Stroem).

Not so common as similis. Known also as Ciniflo atrox, Blackwall.

149. Amaurobius similis (Blackwall).

Epping Forest; Broxted.

Common. Known also under the name Cinifio.

150. Amaurobius ferox (Walckenaer).

Snaresbrook; Broxted.

Common. Known also under the name Ciniflo.
151. Dictyna arundinacea (Linnæus).

Epping Forest (O. P.-C.).

Abundant. Known also as Ergatis benigna, Blackwall.

152. Dictyna uncinata, Thorell.

Epping Forest (F. P. S.).

153. Dictyna latens (Fabricius).

Epping Forest (O. P.-C.).

Not common. Known also under the name Ergatis.

\section{CHER NETES \\ CHELIFERIDÆ}

Out of the twenty species of false scorpions hitherto recorded as indigenous to Great Britain only two have been taken in this county.

154. Cheiridium muscorum, Leach.

'Forest School,' Wanstead (O. P.-C.).

155. Cthonius rayi, L. Koch.

Epping Forest (O. P.-C.).
156. Obisium simile, L. Koch.

Epping Forest (O. P.-C.).

\section{OPILIONES}

The harvestmen are spider-like creatures with eight long legs, the tarsi very long and flexible. Eyes simple, two in number, situated on each side of an eye eminence. Body not divided into two distinct regions by a narrow pedicle as in spiders; abdomen segmentate.

157. Phalangium opilio, Linn.

Epping Forest (O. P.-C.).

158. Phalangium parietinum, De Geer.

Epping Forest (O. P.-C.).

159. Phalangium saxatile (C. L. Koch.).

Epping Forest.
160. Oligolophus ephippiatus, C. L. Koch. Epping Forest (O. P.-C.).

161. Nemastoma lugubre (O. F. Muller). Epping Forest.

162. Liobunum rotundum (Latreille).

Epping Forest. 


\section{CRUSTACEANS}

So lately as ten or twelve years ago the crustacea of this county were still suffering from a kind of conspiracy of silence. A few Entomostraca, noted as occurring in pools and ditches round London, might be presumed to inhabit this part as well as others of that great circumference. One important species is recorded by Baird, on the authority of E. Doubleday, Esq., as having been taken 'near Epping.' On the not improbable assumption that this was found within the borders of the county, Essex may include in its fauna the beautiful non-crustaceous crustacean, Cbirocephalus diaphanus, Prevost. This is a creature that collectors may accuse of caprice. Its appearances are fitful. The secret lies in its adaptation to shallow patches of water, liable to complete desiccation. Though it cannot itself survive the vanishing of its native pool, its eggs will rest contentedly in an expanse of dried mud or meadow, till some miniature deluge, instead of destroying them, restores them to a watery world. In this they speedily hatch, pass through their larval stages, and in the adult form are distinguished by their glassy length, the constant movement of their leaf-like limbs, and by the negative character of having no carapace. The graceful slenderness of this species is in strange contrast to the clumsy, sullen-looking figure of the hard and hairy-coated Dromia, a rare crab, and the only one that Adam White in his Popular History of British Crustacea, assigns to Essex. Unfortunately White seems to have been less trustworthy as a geographer than as a carcinologist, for he says that the Dromia vulgaris was 'first recorded as British by Dr. Gray, who obtained a specimen in Billingsgate market, amongst oysters from Whitstable in Essex, in $1825^{\prime}$ ' It is possible that, using a very small map, he found the name of Whitstable stretching all across the mouth of the Thames, and so fell into the confusion of transferring the place from the southern bank of the river to the northern.

For vagueness and inadequacy in the past science has lately been making ample amends, and when a thorough investigation of its Malacostraca and salt water Entomostraca has been completed, the county may find that its marine crustacea are as diversified and interesting as those of its inland waters have been already proved to be.

Of the Brachyura or short-tailed crabs, Mr. Edward Lovett has recently published the following records. After mentioning that 'the spider crabs of the genera Stenorbyncbus and Inacbus are very delicate in structure, and occur in deep water in the western parts of the Channel,' he continues, 'Stenorbynchus rostratus is common in the Thames estuary. A more robust form $H$ yas araneus (and its near relative $H$. coarctatus) are

1 British Entomostraca, Ray Soc. P. 54 (1850).

2 Popular Hist. Brit. Crust. p. 68 (1857). 


\section{CRUSTACEANS}

the typical Essex "spiders," as the members of the genus are always found on a sandy or muddy bottom, to which the colour of the crabs almost invariably corresponds.' After discussing some points in the biology of Pisa gibbsii, without definitely stating that it is found in Essex, he notes that 'Pisa tetraodon occurs at the Nore and may be considered an Essex species.' Further on he says that 'the common shore-crab (Carcinus manas) is very widely distributed and is a well-known Essex form, where its colour is invariably identical with the sandy or muddy bottom on which the creature lives. When however we find it in rockpools on the granite or serpentine of Cornwall, or on the syenite or basaltic shores of the Channel Islands, this interesting species assumes the most beautiful markings, tinted with really gorgeous colour, and mottled in the most delicate manner. It is often almost impossible to detect the crab in these localities, so perfectly does it resemble its surroundings."

Mr. Lovett's remarks on the colouring of the shore-crab are novel. As a rule it is only young specimens that display any striking pattern, the adults being in general of a sombre green or, as Leach says, "sometimes of a pale green more or less mottled with a darker teint [tint].' Bell gives the colour as blackish green, with the qualification that ' they vary, however, considerably both in the hue and in the intensity of the colour,' but this is very different from saying that they ever assume the tints of sand and mud.

The spider crabs no doubt owe their popular name to the long spindly legs by which many of them show a kind of resemblance to some spiders or to spider-like terrestrial animals. Science groups them in the Oxyrrhyncha, the sharp-beaks, because they have the carapace acutely produced in front. The readiness with which they utilize the resources of the sea, its mud and sand, its weeds, its sponges, its zoophytes, and other objects, for their own purposes of disguise, has long attracted attention. Of late years the wonder has turned to admiration, from the discovery that these crabs are not impassive sluggards, helplessly encumbered and overgrown against their will, but active participants in all that bappens, each the predominant partner in a diversified yet strictly limited company. On a territory consisting of their own crustaceous covering they plant the garden, arrange the menagery, spread the soil, permit the presence of fixed or moving tenants. By their arts of concealment, though they are pleasing to the palate of numerous and powerful foes, they hold their place successfully in the battle of life. Their movements are in general lethargic, but the long claws can be darted out with lightning rapidity to seize the passing prey.

To Mr. Lovett's notice of Stenorbynchus rostratus, Mr. William Cole, F.L.S., the editor of the Essex Naturalist, adds the remark that it is also found in the estuary of the Colne. On this same species Dr. H. C. Sorby, LL.D., F.R.S., in manuscript notes on the Crustacea of this

1 The Essex Noturalist, vol. xi. pp. 252, 253 (1900).

- Malacostraca Podophthalmata Britannia, text to pl. 5 (1816).

- Britisb Stalk-cyed Crustacea, p. 77 (1853). 


\section{A HISTORY OF ESSEX}

county, makes the following observations: 'Common at all my stations. Though sometimes free from such things, it is very commonly much covered by small sponges, ascidians, and polyzoa, which seem to be growing on the shell ; but, in some cases, many portions of the broken leaves of Zostera marina are so attached as to make it almost certain that they were intentionally so fixed by the animal.' According to the generally accepted rules of zoological nomenclature this species is more correctly called Macropodia rostrata (Linn.), the name of Linnæus being added in parenthesis to indicate that he is responsible for the specific name rostrata, but that the generic name Macropodia was assigned by a later hand. The true names of some of our crabs are by no means easy to determine. But those who scoff at zoologists on this account will perhaps find themselves at a loss to tell the surnames of the kings and queens of Europe or even those of the last and present sovereigns of their own country. The two crabs which Mr. Lovett follows Bell in calling Pisa tetraodon and $P$. gibbsii are called by Adam White respectively Arctopsis tetraodon (Pennant) and A. lanata, Lamarck, while Mr. E. J. Miers calls the latter P. (Arctopsis) tribulus (Linn.). The American writer, Miss M. J. Rathbun, a high authority on the subject, thinks that Lamarck's genus Arctopsis was too vaguely defined for identification. In that case the two species will become Blastus tetraodon (Pennant) and $B$. tribulus (Linn.), the generic name Blastus having been established by Leach for tetraodon in precedence of the name Pisa which at the same date he published for the other species. ${ }^{1}$ Hyas araneus (Linn.) has an extensive range, being not only a typical Essex 'spider,' but being found large and fine and plentifully in arctic waters. Dr. Sorby says: "This is common all along the coast. It is often so much covered by ascidians, sponges and other objects either growing or dead that when creeping on the bottom of an aquarium it can scarcely be recognized as a crab.' $H$. coarctatus, Leach, is usually smaller and descends into deeper waters, but otherwise so resembles its frequent companion as to lie under some suspicion of being a variety of it rather than an independent species.

According to Dr. Sorby's notes Cancer pagurus, Linn., the common eatable crab, may be included in the Essex fauna, for 'though seldom if ever dredged in the estuaries or near the shore it is caught by fishermen outside.' The aloofness of the great crab is compensated by the familiarity of the smaller eatable crab, Carcinus manas, for 'this is extremely abundant everywhere along the coast and in the estuaries.' Of Portunus bolsatus, Fabricius, Dr. Sorby says : "This is fairly common in the Crouch but less abundant elsewhere.'

Of the Macrura anomala two very generally distributed British species are reported by Dr. Sorby. Of the common hermit crab, Eupagurus bernbardus (Linn.), he says: "This is very abundant off Mersea and also found at most stations. The colour of the animal and of the bunch of eggs is well preserved when mounted as a lantern slide

\footnotetext{
1 Edinburgh Encyclopadia, vol. vii. p. 431 (1814). 2 Ann. Nat. Hist, ser. 7. vol. v. p. 2 (1900). 


\section{CRUSTACEANS}

in Canada balsam or when kept in strong glycerine, such preparations being extremely satisfactory.' Of Porcellana longicornis (Linn.) he says : ' I have obtained most of my specimens in dredging just outside Harwich harbour where it lives amongst the sandy tubes built up by Sabellaria alveolata. A few have been collected off Mersea of somewhat larger size and having one claw much longer than the other.'

In regard to the Macrura, Mr. Lovett states that 'the shrimps (Crangonidæ) and prawns (Palæmonidæ) . . . are well represented on the Essex coast.' Of the former group however he only specifies Crangon vulgaris, dignifying it by the title of 'the true shrimp,' and explaining why it is called ' the brown shrimp,' 'because it does not turn red on being boiled like the prawn under like treatment.' $\mathrm{He}$ comments on the nice adaptation of its colouring to the sand or mud on which it is found by the lighter or darker speckling of its grey or brownish-grey coat, so that in shallow clear water, where shrimps almost cover the floor, they will remain unperceived till some sudden alarm startles them into motion, and then 'hundreds of little flashes' show their passage from one station of invisibility to another. Mr. Cole speaks of having verified this observation in the sea-rivulets of the Essex coast, as many other seeing eyes will have done both there and elsewhere. That C. vulgaris, Fabricius, is the true shrimp may well be admitted as a patriotic opinion among Englishmen, though, if shrimps could express their views, the idea would no doubt be laughed to scorn by the far more magnificent Crangonidæ of the arctic regions. On the companion group Mr. Lovett remarks :

"Pandalus annulicornis is really a "prawn" and is a typical Essex form. It is in fact the "red shrimp" of the Thames excursion steamers. It works the tide up and down for its food, and is a most useful scavenger. The term "red shrimp" is applied to several diverse species round the coast. At Southampton I saw Palamon squilla (the small prawn) hawked about under this commercial name, and $P$. varians, where it occurs commonly, is also so called.

' The true prawn $(P$. serratus) is also an Essex species and well known. $P$. squilla is a small form from the western part of the Channel, where it is " the prawn."

' $P$. varians is another and decidedly Essex form, occurring in vast numbers in the creeks and inlets of this part of our coast.'

On these records one or two comments may be offered. It is no more easy to determine what is 'really a prawn' than what is 'the true shrimp,' for both appellations are essentially vague and defy definition. When narrowly applied, each of them still includes several genera and species. Size is no criterion, for while some shrimps are much larger than our common prawn, there are some prawns as large as good-sized lobsters, and others no larger than our common shrimp. If prawns be limited to the Palæmonidæ, then Pandalus annulicornis is not really a prawn, 


\section{A HISTORY OF ESSEX}

for it belongs to the family Pandalidæ. Its proper name is $P$. montagui, Leach. That which Mr. Lovett speaks of as the true prawn, evidently meaning thereby the prawn most familiar to his own countrymen, is Leander serratus (Pennant). Its companion species is L. squilla (Linn.), and the third Palamon above mentioned is now known as Palamonetes varians (Leach). All these shrimps and prawns are included in a great tribe Caridea, in which the third pair of trunk-legs are simple, that is, they do not end in an opposable thumb and finger forming what is called a chela. This helps to distinguish them, not indeed from all the rest of the Macrura, but from a goodly number, including lobsters and crayfishes and also a large assortment of otherwise prawn-like animals. The tribe is divided into four sections, distinguished by characters of the first and second trunk-legs. Crangon vulgaris and the rest of the first section have the peculiarity that the front limbs are subchelate. They have a finger which is prehensile by closing down upon the extremity of the hand, but that hand is not itself so produced into a thumb as to form a nipper like a pair of tongs. In the next section, which includes Pandalus montagui, the distinguishing feature is in that part of the second pair of limbs which supports the hand. This part, often called the wrist, instead of being as usual a single piece, is here subdivided into several small articulations, giving it a snake-like flexibility. The three remaining species all belong to the third section, in which the front limbs may be either simple or chelate, and the second have an undivided wrist. Palamonetes. varians has the advantage of being able to live either in salt water or fresh.

Of Crangon vulgaris Dr. Sorby notes that it is 'common at all stations especially in the estuaries,' and of Leander serratus that it is 'very abundant in the open water off the coast but much rarer in the estuaries. The common size is not over three inches but occasionally as much as four.' Of Palinurus vulgaris, the crawfish or rock lobster, he says: 'I have never obtained any in trawling or dredging, but it is caught in traps off Walton-on-Naze.' He further records the little schizopod, Praunus flexuosus (Müller) as ' fairly common in most of the estuaries.'

Potamobius pallipes (Lereboullet) is not specially assigned to Essex by Mr. Lovett, but in a note to Mr. Lovett's paper Mr. Cole says: 'The crayfish used to be common, and probably is so still, in the Lea and Chelmer, and is found in some of the streams of the New River Company in prodigious abundance.' On the other hand, Mr. Fred Field, writing from St. Leonard's Road, Ealing, in March of this year, on the subject of these same freshwater crayfishes, says 'the Colne which used to be full of them no longer contains any.'

The sessile-eyed crustacea of Essex have not yet received much attention. Of one among the marine Isopoda however I can speak from personal opportunity. In September, 1895, the British Association met at Ipswich, and at the close of the meeting an excursion was made to the oyster-beds of the Colne. On this occasion not only were thousands of costly and delicious oysters sacrificed to science, but later in the day great quantities of freshly caught Pandalus montagui were consumed in the 


\section{CRUSTACEANS}

same interest. Many specimens of the latter were infested, or for some of us invested with an added charm, by the isopod Hemiartbrus abdominalis (Kröyer), one of their appropriate parasites. The resounding name of this creature is exposed to some cavillings, but until it is displaced it very well suits the facts of the situation, and at least the generic part of it is valid. It means that the animal is half-limbed, in the same way that we call a man half-witted without being too precise as to the halving. The specific title alludes to the fact that this purple-tinged parasite nestles under the pleon or abdomen of the prawn. In Leander serratus there is a very similar and much more familiar species commonly known as Bopyrus squillarum, which lodges in the branchial cavity of the carapace, thereby acquiring for itself a lopsided shape, and giving its host the look of having a swollen cheek. It is rather strange that the Hemiartbrus, though not cramped for room, is nevertheless lopsided even more extravagantly than the Bopyrus. The fact is that the female, while still young and slender, catches hold of a front swimming foot of the prawn either with her seven feet on the left or her seven feet on the right, and then allows her opposite side to bulge as it pleases. While all the feet of that side except the first disappear, the marsupial plates develop, some of them, especially the second on the outer side, being greatly extended. Eventually the vast pouch is filled with thousands of eggs. The father of this numerous progeny remains insignificant in bulk. To judge by his dwindled mouth-organs he is no glutton. To judge by his consolidated pleon or abdomen devoid as it is of pleopods, he has no inclination to wander from home. He retains his symmetry. His seven pairs of walking legs are undiminished in number. He can therefore, when prompted by a desire for exercise, at least traverse his wife and family, a small domain but his own.

Of non-parasitic marine Isopoda, Dr. Sorby reports that Idotea linearis (Linn.) 'occurs at nearly all stations and is usually caught when swimming on the surface,' and that a few specimens of I. baltica (Pallas) have been taken under similar circumstances. As to Ligia oceanica (Linn.) he notices that "in some years this was extremely common on the quays at Row Ledge on the Colne, but in I 900 none were seen.'

Of terrestrial Isopoda or woodlice there is no doubt that Essex possesses all the commonest species that are generally distributed in England, but rather singularly the only record is a very recent one, referring to a species hitherto not included in the British fauna. This is Porcellio ratzeburgii, Brandt, reported by Mr. W. M. Webb, F.L.S., from Warley, and identified by the Rev. Dr. Norman, F.R.S. ${ }^{1}$ Budde-Lund includes this species in the division of the genus distinguished by the presence of trachex in the upper branch of all the pleopods, whereas other members of the genus have such spiracles only in the pleopods of the first two pairs. Seeing that crustaceans taken as a whole are essentially waterbreathing animals, there is a rather special interest in any modification

1 The Essex Naturalist, vol. xi. p. 127 (1899). 


\section{A HISTORY OF ESSEX}

of structure which assists them in breathing air. The colour of $P$. ratzeburgii is described as grey, with a row of six white spots along each side of the back.

For the Amphipoda which, like the Isopoda, are fourteen-footed sessile-eyed malacostracans, there are no available printed records, but I can scarcely omit to mention the occurrence of Fassa pulcbella, Leach, Coropbium crassicorne, Bruzelius and Caprella linearis (Linn.), since specimens kindly given me by Dr. Sorby indicate that these well-known species are as abundant in Essex waters as in many other localities. Also on the oyster-testing excursion above mentioned, I was myself able to obtain specimens of Hyperia galba (Montagu) from its accustomed habitat in the common jelly-fish Aurelia aurita.

The results thus brought together, however scanty in themselves, are at least suggestive that Essex, as might be expected from the position and character of its coast-line, will be found to provide very abundant and attractive resources for students of marine carcinology. For those interested in the crustacean fauna of inland waters, there is no need to rely on conjecture or presumption. In regard to freshwater Entomostraca the labours of Mr. D. J. Scourfield have placed this county in the front rank. Twelve years ago there was not a record traceable for any single species of this group with definite locality assured to it. At present, although the subtle manœuvres, the diminutive size, or the absolute rarity of some species may have left them to be gleaned by future researches, already $\mathrm{Mr}$. Scourfield has been able to enumerate more species from this county than have yet been recorded from any other, having found in Essex more than a hundred species out of a total of less than two hundred known from the British Isles at large.

To make any account intelligible of this great number of species, an outline.must be given of their classification. There are three principal companies, called Branchiópoda, Ostracóda, Copépoda. The Ostracoda, or shelly group, have their unsegmented bodies boxed up in a pair of valves, as if they were little molluscs. The Copepoda, by name and nature oar-footed, have the body segmented and not enclosed in a bivalved shell. These however, when parasitic, often become subject to strange vagaries of structure, which set definition at defiance. The Branchiopoda are so called from the branchial or respiratory character proper to their limbs. They include three subdivisions, Phyllópoda, Cladócera, Branchiúra, among which difference of appearance is often quite as prominent as likeness. The Phyllopoda are again divided into sets far from closely resembling one another, since one set has a carapace and another set has none, while the third has the body almost enclosed in a pair of valves. Cbirocepbalus diapbanus, already noticed, belongs to those that have no valves nor carapace, yet being of all our freshwater Entomostraca though unadorned adorned the most.

The Branchiura are a very small and rather perplexing group, represented in our islands chiefly by the long-known Argulus foliaceus (Linn.), a disk-like parasite on various fishes and tadpoles, with its 


\section{CRUSTACEANS}

second maxillæ converted into suckers. Scourfield records it as taken in May, July and August at various stations in Epping Forest.'

The Cladocera, called branching horns, in allusion to their twobranched second antennæ, are a very large group of very little animals. They have from four to six pairs of feet, most or all of them leaf-like, a character which allies them to the phyllopods, and they have the body encased in a sort of bivalved covering, somewhat after the fashion of the Ostracoda, only that here the head is more or less distinct. There are two sets, one having the bivalved carapace well developed and almost entirely covering the feet, the other with the carapace small so that the feet are not covered by it. It is only with the former that we are here concerned. This is subdivided into the Ctenópoda, or comb-feet, in which the six pairs of foliaceous feet are all similar, branchial, nonprehensile, with a comb-like arrangement of setæ; and the Anomópoda, variety-feet, in which the pairs are not uniform, the front ones being more or less prehensile, without branchial laminæ, while the hinder pairs are as in the Ctenopoda.

In the family Sididx, of the comb-footed division, there are two Essex species, Sida crystallina (O. F. Müller), of which Mr. Scourfield says: "This beautiful species has only been taken in the "Shoulder of Mutton Pond" and the adjoining pool in Wanstead Park'; and Diaphanosoma brandtianum, Fischer, I 85 I, which has occurred more frequently. For this latter species the synonymy is rather intricate. In 1850 Baird described his Dapbnella wingii from a "pond on the edge of the Colne, between Twickenham and Whitton, Middlesex." The generic name had to be given up. It was preoccupied. The specific name was also given up, on the ground that Baird's species had been already named Sida bracbyura by Liévin in 1848 , with which some authors further identify Fischer's brandtianum. Others uphold this as distinct, and Mr. Scourfield affirms that the Epping Forest forms evidently belong to it. At the same time he places in the synonymy 'Dapbnella wingii (in part), Baird.' This however is inconsistent, for if Fischer's species be distinct from Liévin's but identical with Baird's, the earlier name must stand, and the species will be Diapbanosoma wingii (Baird).

The Anomopoda are divided into four families, over which the majority of the Cladocera are distributed. Of these families the most familiar is that of the Daphniidx, and in this the typical genus Daphnia, after frequent restrictions, still retains numerous species. From Epping Forest Mr. Scourfield reports Dapbnia magna, Straus, D. pulex, de Geer, D. obtusa, Kurz, D. lacustris, Sars, D. longispina, O. F. Müller, D. byalina, Leydig, D.(?) galeata, Sars, and D.(?) cucullata, Sars. It would be pleasing

1 It may be sufficient to refer here once for all to Mr. Scourfield's Papers on 'The Entomostraca of Epping Forest, with some General Remarks on the Group,' in The Essex Nasuralist, vol. x. pp. 193210 (1897); vol. x. pp. 259-74 (1898); vol. x. pp. 313-34 (1898), the last part containing a valuable bibliography of the subject, in addition to a detailed list of the Epping Forest species, to which my quotations refer when not otherwise noted.

Britisb Ensomoseraco, Ray Soc. p. 110. 


\section{A HISTORY OF ESSEX}

to discriminate all these by a few luminous strokes of the pen, but no more can be attempted here than to indicate the difficulties of such an undertaking. Always, everywhere, and by all men, the common water flea has been known as $D$. pulex, de Geer. Why then does M. Jules Richard in his important Révision des Cladocères write it down as $D$. pulex, Leydig? His reason is simple: that Leydig in 1860 was the first to give a really satisfactory description of a species under that name, earlier writers having left it uncertain what particular species or what jumble of species may have been intended by what they chose or chanced to call $D$. pulex. Only Zenker, he says, in $185 \mathrm{I}$ had already noted 'the long ciliated abdominal prolongation of the male,' which is highly characteristic for that sex, the females being recognizable by the very small first antennæ, the concave ventral border of the head, and the general shape. ${ }^{1}$ Dr. G. S. Brady, citing both de Geer and Leydig, describes and figures both sexes of this species, the male from a pond at Whipscross Road, Essex, whence Mr. Scourfield had supplied him with specimens. ${ }^{2}$ For $D$. magna a characteristic feature is found, not in the abdomen, but in the post-abdomen. This in the female has the dentate parts of its dorsal margin separated by a deep sinus. In the male it 'bears in front of the terminal unguis a finger-like lobe,' in allusion to which Dr. Brady calls the new genus in which he places it Dactylúra, finger-tail.' Of his 'Daphnia(?) galeata, Sars,' Mr. Scourfield says: 'By comparison with specimens of $D$. galeata kindly sent to me by Prof. Sars, I have been able to see that our Epping Forest form is not only not a typical representative of the species, but that it may even be quite distinct. As I cannot decide, however, to which of the other hyaline species it belongs, I have preferred to continue to refer it doubtfully to $D$. galeata. The typical $D$. galeata has been recorded as British by Prof. Brady.' According to Brady's figures this 'helmeted' form is very variable and sometimes of rather comical aspect. Upon his other doubtful species, Mr. Scourfield remarks: 'This form, which I have recorded in the paper on the Entomostraca of Wanstead Park [Fourn. Quekett Micro. Club, I 893] as D. cucullata, is almost exactly similar to the foregoing species, but is without the eye-spot. It is certainly not a characteristic representative of $D$. cucullata, but, on the other hand, it cannot with greater certainty be referred to any other species.' He suggests its possible identity with ' $D$. kablbergensis, Brady' ( 1898 ), but this reference is a little inexact, since Brady writes 'Hyalodapbnia kablbergensis (Schœdler),' though in regard to Schödler's Hyalodapbnia he agrees with Richard that it scarcely differs from Dapbnia except by the absence of an eye-spot. In both of these genera the first antennæ of the female are immovable; in Ceriodapbnia, Dana, they are movable, and of this genus Mr. Scourfield finds five species in Essex, C. megalops, Sars, C. rotunda (Straus), C. reticulata (Jurine), C. quadrangula (O. F. Müller)

1 Annales des Sciences Naturelles, ser. 8, vol. ii. p. 235 (1896).

2 Nat. Hist. Trans. Nortbumberland, etc., vol. xiii. pt. 2, p. 223 (1898).

3 Loc. cit. p. 240. 


\section{CRUSTACEANS}

and $C$. scitula, Herrick. The first four are noted by Baird under the genus Dapbnia, but he regards quadrangula as only a variety of reticulata. Herrick's species, being new to the British fauna, is described and figured by Mr. Scourfield. After noting its rather large size and the comparatively small hexagons in the reticulation of its valves, he continues: "The fornices ${ }^{1}$ are prominent, but not angulated, though in the males there may be an indication of a tooth at the point of greatest extension. The antennules in the female are small, but those of the male are large, being, in fact, probably larger than in any other known species, with the exception of $C$. megalops. The post-abdomen is tapered towards the end, and is furnished with about ten anal teeth. The terminal claws are without combs. The females carry about eight eggs in the brood chamber, and these are retained in position by a very large spur, which quite overshadows the little projection occupying the place of the second spur.'

In Scapboleberis the ventral margin of the valves is almost straight, with no convergence between it and the dorsal margin as in Dapbnia. In Simocéphalus the reticulation of the valves is formed by long transverse lines instead of small meshes. Both these genera were separated from Daphnia by Schödler. They yield to Essex Scapboleberis mucronata (O. F. Muiller), with its variety cornuta, and the very common Simocepbalus vetulus (O. F. Müller), together with S. exspinosus (de Geer), a species so near to its neighbour that Mr. Scourfield apologizes for the smallness of the distinctions between them. Of the Scapboleberis, he says: "The evidence from the whole of Epping Forest is the same as that already recorded from Wanstead Park, namely, that during the earlier part of the annual period of activity only the cornuta form is to be found, the typical form not making its appearance until August at the earliest.' Of Moina rectirostris (O. F. Müller), from the margin of the Warren Pond, Chingford, he notes that the ephippium contained only one egg. Generally in the Daphniidæ this 'saddle' contains two eggs. The eggs laid in this strange casket are called 'resting-eggs' or winter eggs, and will not hatch without fertilization. When this has occurred, at the next change of the mother's skin, the ephippium or case formed for sheltering them is thrown off along with it, and they can rest in patient security till a favourable season for their development comes round. The ordinary eggs develop parthenogenetically within the matrix, and without need of a father.

From the small family Bosminidæ Essex is credited with Bosmina longirostris (O. F. Müller) and its near ally B. cornuta (Jurine).

For the next family Mr. Scourfield adopts the name Lyncodaphnidæ, but this from its earliest genus should rather be called Macrotrichidx. It is illustrated in this county by Ilyocryptus sordidus (Liévin), a nonswimming species, with an unflattering name that means "the mud-hidden dirty one,' and by two species of the typical genus, Macrotbrix laticornis thorax.

1 These so-called arches are chitinous projections at the sides of the head, uniting it with the 


\section{A HISTORY OF ESSEX}

(Jurine), and $M$. birsuticornis, Norman and Brady, of which Mr. Scourfield writes: "Without doubt this is one of the best records in the whole list of Epping Forest Entomostraca. Since the species was first described in 1867 , it appears to have been only once again recorded in the British Isles, ${ }^{1}$ and on the continent it has only been found by a few observers. It is a fine species, being in fact the largest of the genus. Numerous specimens were taken in Connaught Water on March Io, I 894 , but curiously enough none could be found about a month later, nor has the species been seen again.'

The fourth family of this section has been called by several writers Lynceidx, a name which properly belongs to the phyllopod family Limnetidx, and which cannot in any case be used for a group in which there is now no such genus as Lynceus. The present family must be called Chydoridx, from its earliest genus Cbydorus, instituted in 18 i 6 by W. E. Leach, who may be regarded as the founder of English carcinology. To Essex are assigned Chydorus spbaricus (O. F. Müller), one of the excessively common species ; $C$. calatus, Schödler ; $C$. latus, Sars; C. globosus, Baird. From the numerous other genera Mr. Scourfield records Eurycercus lamellatus (O. F. Müller); Acroperus barpa, Baird, with a large variety perhaps equivalent to Koch's Lynceus leucocepbalus; Camptocercus rectirostris, Schödler, which is perhaps Baird's $C$. macrourus; Leydigia quadrangularis (Leydig), with a name of rather doubtful validity; Graptoleberis testudinaria (Fischer) ; Alona guttata, Sars; A. tenuicaudis, Sars; A. quadrangularis (O. F. Müller); $A$. affnis, Leydig ; A. costata, Sars; $A$. rectangula, Sars, to take the place of $A$. intermedia, Sars, an earlier record now cancelled; $A$. rustica, T. Scott, 'only obtained by washing pieces of wet moss'; Alonella excisa (Fischer) ; $A$. nana (Baird), smallest of known arthropods; $A$. rostrata (Koch); Pleuroxus trigonellus (O. F. Müller) ; P. uncinatus, Baird ; Peracantba truncata (O. F. Müller); and Monospilus tenuirostris (Fischer). Of the last Mr. Scourfield says: "The presence of this very peculiar species in the forest district was first ascertained by its being found in the stomach of a roach from the Eagle Pond. It has since been taken with the net from the same piece of water.' The genus Monospilus, Sars, has more than one character that may well claim to arrest the student's attention. Thus M. Jules Richard observes, "Exuviation is the rule among Cladocera, but in some cases the old carapace is not shed; it remains on the new one, so that we have the appearance of lines of growth fringed with setæ as in Ilyocryptus and Monospilus.' ${ }^{2}$ This, it will be remembered, is a regular and prominent feature in the bivalved phyllopods. Another character is enjoyed by Monospilus uniquely among the Cladocera, and to this it is indebted for its rather singular name, meaning 'with only a spot.' The rest of the Cladocera have each a single median eye, composed of more or less numerous elements, and in addition to this they sometimes have, and sometimes have not, on the ventral face of the head a small mass of

1 Scott and Duthie, Fishery Board for Scotland, 14th Ann. Rep. p. 229 (1896).

2 Annales des Science Naturelles, ser. 7, vol. xviii. p. 309 (1895). 


\section{CRUSTACEANS}

pigment, called the eye-spot. What may be its precise function is not perhaps precisely known, but if that function be not visual the species of Monospilus must be blind, for they have the eye-spot, but apart from that they have no eye.

In Mr. Scourfield's various papers many interesting observations are given on the species above enumerated. It would take up too much space to give adequately even a summary of all this valuable information, but attention may be called to one branch of his researches which may be regarded as exceptionally important. In a paper on Leydigia acantbocercoides (Fischer), a species closely related to L. quadrangularis (Leydig), he says: "There seems no room for doubt at the present day that the production of winter or resting eggs is of universal occurrence among the little animals belonging to the Crustacean sub-order Cladocera, notwithstanding the fact that in many species such eggs have not yet been observed. In the most representative family, the Daphnidx, these special eggs are always enclosed in a very remarkable and complex modification of the shell of the mother, commonly known as the 'ephippium,' because of its resemblance to a saddle both as regards shape and position. In the other Cladoceran families the production of an ephippium, similar in all respects to that found among the Daphnidx, is extremely rare, the only certain instance, so far as I know, being Macrotbrix spinosa, King, recorded by Professor G. O. Sars in Additional Notes on Australian Cladocera raised from Dried Mud. Nevertheless structures clearly homologous to true ephippia, though usually very much simpler, are found in the families Bosminidæ, Lyncodaphnidæ and Lynceidx. The species belonging to the remaining families of the Cladocera appear to allow their resting eggs to escape freely into the water without providing them with any auxiliary coverings."

Mr. Scourfield then proceeds to point out that already in 1820 Jurine 'distinctly refers to the saddle or ephippium in the case of Chydorus spharicus,' that Schödler in 1846 records of Eurycercus lamellatus, 'that a number of winter eggs were deposited at one time in the almost unmodified cast shell of the mother, a fact which has since been confirmed by Weismann,' that by Kurz in 1874 protective coverings for the winter eggs were reported ' in some sixteen species belonging to the genera Camptocercus, Alona, Plearoxus, Chydorus, etc.,' and that slightly later, in 1877 , "Weismann independently discovered the resting eggs of several species of the same family' [Chydoridx], while since that time 'the resting eggs of many other species have been alluded to, in more or less detail, by various writers.' In an earlier paper Mr. Scourfield says: "Compared with the highly evolved "ephippium" which is formed by the Daphnidæ for the protection of their resting eggs, the arrangement in Chydorus spharicus (and other species of the Lynceidx) is manifestly very primitive, and although both are fundamentally the same I would suggest that the simpler structure be distinguished as a proto- 


\section{A HISTORY OF ESSEX}

ephippium.'1 Subsequently however he found that although this structure in the Cbydorus might be regarded as the most highly evolved of the proto-ephippia hitherto recorded, an advance upon it was made in no less than three respects by the homologous structure in Leydigia acantbocercoides, of which he says: 'First, it is formed, as in the Daphnidx, from a much more limited portion of the shell, bounded approximately by a semicircle described upon the dorsal margin; secondly, it possesses a thick inner coat of specially formed spongy tissue ; and thirdly, it is provided with large hook-like appendages. In spite of these advances in complexity however it does not quite reach the level of the Daphnidan ephippium, because its outer coat is not specially altered beyond the mere deposit of pigment and some extra chitin perhaps, whereas in typical ephippia there is always a more or less abundant development of closely-set hexagonal prismatic cells which are quite independent of the original cell structure, and which, becoming readily filled with air, render the ephippium lighter than water.'

Of the Ostracoda all but one in Mr. Scourfield's list belong to the family Cyprididæ, in which the valves are usually smooth and the hinge not toothed. They are Cypria exsculpta (Fischer); C. opbtbalmica (Jurine) ; Cyclocypris serena (Koch) ; C. lavis (O. F. Müller) ; Cypris fuscata, Jurine; $C$. incongruens (Ramdohr); C. virens, Jurine, a large species which ' is essentially an inhabitant of very small pieces of water, especially such as are well stocked with aquatic vegetation'; $C$. (?) reticulata, Zaddach ; ' $C$. tessellata (in part), Brady [I 868] : only the immature "tessellata" forms from Wanstead Park have hitherto been seen, so that it is still a little uncertain whether they should be referred to C. reticulata or not'; C. obliqua, Brady ; Erpetocypris reptans (Baird) ; E. strigata (O. F. Müller) ; E. tumefacta (Brady and Robertson), this and the two preceding species belonging properly to Erpetocypris as instituted in 1889 , not to Herpetocypris as proposed in 1896 , the name in either form alluding to the creeping habit, as to which Norman and Brady write: "The power of swimming is lost, and the habits of the animals, which creep along the bottom, are thus very different from those of Cypris'; ${ }^{2}$ Prionocypris serrata, Norman ; Cypridopsis villosa (Jurine) ; Pionocypris vidua (O. F. Müller); Notodromas monacba (O. F. Müller) ; Ilyocypris gibba (Ramdohr) ; Candona candiaa (O. F. Müller) ; C. lactea, Baird ; C. compressa (Koch); C. pubescens (Koch); C. fabaformis (Fischer). In regard to $C$. pubescens the remark is made that 'within the Epping Forest area it has only been found at Wanstead Park, and this is in fact its only known British locality, as the reference to Pavenham [Bedfordshire] in Brady and Norman's Monograpb [part 2] p. 729 was made under a misunderstanding.' The name of the genus Notodromas, Lilljeborg, signifies a dorsal runner. Of animals that can move easily with the back downwards house-flies on our ceilings are familiar examples. Many kinds of Entomostraca swim by preference on their backs. In

1 The Annual of Microscopy, p. 64 (Oct. 1898).

2 Trans. Royal Dublin Soc. ser. 2, vol. iv. p. 84 (1889). 


\section{CRUSTACEANS}

respect to a limited number of these, among which Notodromas monacba is included, Mr. Scourfield has pointed out an interesting special adaptation. To several of the minute crustacea the surface-film of water proves a dangerous trap. When accidentally placed upon it they are disabled from effecting a return by their own exertions to its underside. But by help of a flattened ventral area, water-repellent surfaces and filmpiercing ridges, Notodromas monacha turns the risky situation to its own advantage. 'Close attention to the movements of an isolated specimen will show that although it swims nearly vertically, the moment it touches the surface it assumes a horizontal position, back downwards, thus bringing its straight ventral margin into close contact with the surface-film. ... In this position the animal may continue to move about for an indefinite period, usually rather briskly, but sometimes so leisurely that no doubt is left in the observer's mind that the weight of its body is actually supported by the surface-film.' For further details and the philosophy of the matter whether as a question of physics or as affecting the safety of the animal and its chances of food supply, the Fournal of the Linnean Society should be consulted.'

The ostracode that remains to be mentioned is Limnicytbere inopinata (Baird). This belongs to the family Cytheridæ, which is almost exclusively marine, among the few exceptions being the species of Limnicythere. Of $L$. inopinata Brady and Norman say that it is 'generally distributed in ditches, lakes and slowly running streams throughout the British Islands; found also not uncommonly in estuarine localities, and sometimes dredged at sea, though in these cases it has probably been washed down out of fresh water."

The Copepoda of Essex are distributed among three families. One of these is called Calanidæ by Dr. G. S. Brady in 1891 , but more recent classification allots that name to a different set of species. Accordingly Mr. Scourfield follows the high authority of Giesbrecht and Schmeil in using the name Centropagidæ, but it is clear that the family ought to take its name from the earliest genus within it, and therefore it will properly be called the Diaptomidx from Diaptomus, Westwood, 1836. This genus gives to Essex D. castor (Jurine), a large species ' practically confined to small weedy pools, such as occur plentifully on Leyton Flats'; $D$. gracilis, Sars; $D$. vulgaris, Schmeil, 'one of the commonest of the genus on the continent, or at any rate in Germany,' not hitherto known as British except from 'The Lake,' Wanstead Park, though probably not really uncommon, 'as it is more than likely that this form has been mistaken for $D$. gracilis, to which it is very closely allied'; Eurytemora lacinulata (Fischer), of which the usual habitat 'is in brackish pools near the coast : as a freshwater animal it is decidedly rare,' Mr. Scourfield only knowing of four British freshwater localities for it. The question of its range appears to be rather complicated by an intricate synonymy.

\footnotetext{
1 Joum. Linn. Sac. London, vol. xxv. p. 10 (1896).

Trans. Royal Dub. Soc. ser. 2, vol. iv. p. 170 (1889).
} 


\section{A HISTORY OF ESSEX}

The next family, the Cyclopidæ, derives its name from the old, much restricted, but still very extensive genus Cyclops, O. F. Müller. In this the county possesses $G$. strenuus, Fischer; $C$. leuckarti, Claus; C. oitbonoides, Sars; G. dyboweskiz, Lande, an addition to the British fauna; G. bicuspidatus, Claus ; C. languidus, Sars ; G. vernalis, Fischer ; C. bisetosus, Rehberg ; C. viridis (Jurine), of which Lubbock's C. brevicornis and the C. gigas of Claus are now usually regarded as synonyms, but Scourfield urges that in Epping Forest gigas (the typical viridis) is not connected by any intermediate links with brevicornis; that the former is an exceedingly widely distributed form, but rarely occurs in the open waters of ponds of moderate size, whilst the latter, on the contrary, is practically only found in such situations'; in addition to which he notices that gigas can always be distinguished from brevicornis by the presence of a line of hairs on the inner margin of each caudal ramus and by its longer ovisacs ; C. bicolor, Sars; C. fuscus (Jurine); C. albidus (Jurine); C. bistriatus, Koch, a peculiar and rare form, of which it has been suggested that it ' is really a hybrid between C. fuscus and C. albidus,' but with some peculiarities of its own; 'as stated by Koch the anterior portion of the carapace [in the Essex specimens] was finely spotted with brown whilst the posterior thoracic segments and the feet were blue or rather blue-green : to the naked eye the whole animal appeared of a blue-green colour, and attracted attention at once as something out of the common'; the specimens were found in ponds at Rectory Lane, Loughton, Ambresbury Banks and Lodge Road leading to Copped Hall ; G. serrulatus, Fischer ; C. (?) macrurus, Sars, 'a very doubtful Epping Forest species,' perhaps a variety of $G$. serrulatus with exceptionally long caudal rami; $C$. prasinus (Jurine) ; C. affinis, Sars; C. pbaleratus, Koch ; C. fimbriatus, Fischer.

The third family is named Harpacticidæ, after the genus which Milne-Edwards in 1840 named Arpacticus. But this family should be called the Canthocampidx, if we include in it the earlier genus Cantbocampus, Westwood, 1836 . Of this genus Essex is credited with seven species, C. staphylinus (Jurine) ; C. minutus, Claus ; C. trispinosus, Brady; C. nortbumbricus, Brady ; C. crassus, Sars ; C. pygmaus, Sars, of which it is remarked that 'next to $C$. stapbylinus this is the commonest species of the genus: the records would not have been nearly so numerous however if the practice of washing wet mosses had not been adopted'; G. zscbokkei, Schmeil. To these must be added Nitocra bibernica (Brady) and Moraria anderson-smitbi, T. and A. Scott, of which it is observed that 'on each of the three occasions when this species has been taken it has been associated with sphagnum moss.'

For the sake of completeness in the history of the county one may regret that its marine Entomostraca have not been investigated with the assiduity, the trustworthy skill and ample learning which Mr. Scourfield has brought to bear upon those of its inland waters. But, on the other hand, had all sections of the Crustacean class been made the objects of equally thorough research, to have drawn up an adequate account of them within any reasonable compass might have proved an almost 


\section{CRUSTACEANS}

impracticable task. Dr. Sorby reports the curious parasitic copepod, Lerneonema spratta (Sowerby), 'found on the eyes of sprats caught in the open water off Essex,' and the sessile cirripede 'Balanus punctatus' as 'common all along the coast, and especially in the estuaries, where the number of larvæ is sometimes so great that in a few days the bottom of a yacht is completely covered with the young shells.' In regard to ' $B$. punctatus' a reference to Darwin's celebrated work shows that the name is rather deeply afflicted by chronic vagueness. Under his account of B. balanoides (Linn.) Darwin explains that this species, 'in its corroded and therefore punctured state, is certainly the $B$. punctatus of most British collections; but,' he adds, 'I do not believe it is the $B$. punctatus of Montagu, which I have scarcely any doubt is the Chtbamalus stellatus so often found in the southern shores of England, and even in some of the best arranged collections, mingled with our present species.' ${ }^{\prime}$ Under C. stellatus (Poli) he says, 'On the coast-rocks of the southern shores of England it is, in parts, even more numerous than the Balanus balanoides, with which it often grows mingled. As already stated, it is often confounded in British collections with this species of Balanus under the name of $B$. punctatus ; that Montagu had this Chthamalus in view when describing his Lepas punctatus is certain, from his original specimen in the British Museum, but whether this was the case with his predecessor Pulteney in the Dorset Catalogue I do not feel so sure.' ${ }^{1}$ As Dr. Sorby has kindly furnished me with some of his specimens, I can testify that they include Cbthamalus stellatus, and, as I believe, also Balanus crenatus, Bruguière, which has a calcareous basis, whereas that of $B$. balanoides is membranous. On the whole it may be concluded that there are at least three species of Thyrostraca or Cirripedes on the Essex coast. Apart however from Dr. Sorby's interesting manuscript notes, the crustacean parasites of fishes and of many other aquatic animals, the barnacles, stalked or sessile, fixed or floating, and several important groups of the Malacostraca have hitherto had few records or none by which their relative prominence in this locality can be determined. Some future faunistic description of Essex will show, certainly that they are not absent, probably that they are present in abundance.

\footnotetext{
1 Balanida, Ray Soc. pp. 208, 456 (1854).
} 


\section{F ISHES}

The Essex coast is a very favourable one for those species of fish whose habitat is mainly confined to a shallow sea with a bottom of sand or mud, but to those requiring deeper waters and rocks these conditions are not the most suitable, as there is no hard rock in the county or in the adjoining seas, and these rock loving species are therefore to a great extent absent from our fauna, and when found are usually stragglers from the rocky districts of the more northern counties. Nevertheless the list of Essex fish, incomplete as it must be from causes to be referred to further on, is a comparatively large one in consequence of the shallow estuaries, creeks and channels forming such excellent feeding grounds and nurseries. Considerable difficulties occur to any one endeavouring to compile a list of the fish of a county unless there are some records to refer to, for it is impossible for any single observer to be thoroughly acquainted with all the captures which have occurred in every part of such an extensive coast line as that of Essex. Many species will certainly be omitted, and but little help can be obtained in increasing the list from those fishermen who pursue this calling for a living, as they pay attention only to those species which are marketable, and even amongst these they lump together several under some local name, probably used elsewhere to designate an entirely different species or genus. This difficulty is however not confined to Essex, it is common to the whole coast of the kingdom and is a great drawback to the value of lists in which the captures are described and recorded under their local designations. It might have been expected that in at least one of our numerous fishing villages there would have been found some educated and intelligent observer who would interest himself to discover and record the different species of fish caught and to ascertain the nature of the food on which the marketable fish thrive. Unfortunately however this branch of natural history appears to have been entirely neglected in all our districts, with the result that records of captures in the natural history journals are very scanty. Residents in the county who have been interested in natural history have given their attention to other branches to the utter neglect of this one, which is perhaps the most important of all in so far as the well being of the population is concerned. Cause for complaint may possibly soon be removed, for a competent naturalist has lately interested himself in the fisheries of the Thames estuary, so that it may be hoped that our list will be considerably added to in the future. It has unfortunately not been possible to get any list from him up to the present. The writer of this article has therefore laboured 


\section{FISHES}

under a great disadvantage, since there are but few Essex records to consult and there are unfortunately no early lists for the county, the only exception being that in Dale's History of Harwicb and Dovercourt, published in 1732, which has been used by later writers who have copied from it without making any additions of value.

The few records in Yarrell, Day and Donovan, and the occasional notes in the Zoologist, The Field and Land and Water, comprise all, or nearly all, the material that the compiler has been able to procure to assist him in making the following list. He has therefore had but little to add to the notes and records which he had put together from his own knowledge and observation. Free use has been made of the information contained in the list which he had previously compiled and which appeared in one of the special volumes issued by the Essex Field Club, but he has added, so far as his information enables him to do so, all those species which are known to have been captured since the publication of this volume.

In the following list an asterisk (*) is placed opposite the names of those species which are found only in freshwater, and two asterisks (**) against those that may be found in both fresh water and salt.

\section{TELEOSTEANS}

\section{ACANTHOPTERYGII}

*I. Perch. Perca Auviatilis, Linn.

Occurs commonly in all the rivers of the county. One weighing $4 \mathrm{lb}$. is reported from Dagenham Lakc (Field, October, 29, 1881).

2. Ruff or Pope. Acerina cernua, Linn.

Lieutenant Croft in a paper (Trans. Herts Nat. Hist. Soc. 1881) says this species is an inhabitant of the river Lea, but it appears to be absent from all the other Essex rivers, unless there may be some in that portion of the Cam which is within the Essex boundary.

**3. Sea Bass. Morone labrax, Linn.

Taken occasionally in all the Essex estuarics.

4. Ballan Wrasse. Labrus maculatus, Bloch.

Very rare; three specimens only recorded; muddy and sandy shores do not suit the habits of this family.

5. Baillon's Wrasse. Crenilabrus melops, Linn.

Specimens from the Thames estuary have been presented to the British Museum by Dr. J. Murie, as I am informed by Mr. Boulenger.

*6. Miller's Thumb. Cottus gobio, Linn.

Occurs plentifully in all our streams, especially those with a gravelly bottom.
7. Greenland Bullhead. Cottus grenlandicus, Cuv. \& Val.

Dr. Day confirmed Mr. J. T. Carrington's identification of several specimens of this fish which had been captured in the whitebait nets in the Thames (Zool. 1880, p. 147). They have never been seen to approach the size they are said to attain in Greenland.

8. Father-lasher, Bullhead. Cottus scorpius, Linn.

Very frequent all round the coast. $C$. greenlandicus is considered by many to be a varicty of this species.

9. Bubalis. Cottus bubalis, Euphr.

Another very common species. The local name for all these three species is Bullhead.

10. Four-horned Cottus. Cottusquadricornis, Linn.

This is very rare, but Leonard Jenyns says (British Vertebrate Animals, 1835, p. 346) some specimens in the British Muscum were found among sprats taken at the mouth of the Thames.

11. Grey Gurnard. Trigla gurnardus, Linn.

Caught sometimes during September in some numbers. In Dale's History of Harwich, p. 431, under grey gurnard, is the following statement: "This I have seen caught in the sea before this (i.e. Harwich) harbour.' 


\section{A HISTORY OF ESSEX}

12. Red Gurnard. Trigla cuculus, Linn.

Sometimes frequent on the coasts, at others it is rare or entirely absent for several seasons in succession.

\section{Tubfish or Sapphirine Gurnard. Trigla birundo, Linn.}

This gaily coloured fish is occasionally taken in all the Essex estuaries.

14. Piper. Trigla lyra, Linn.

Dale (loc. cit.) says, "This was caught near Harwich.'

\section{5. Pogge. Agonus cataphractus, Linn.}

This curious fish is very frequently taken in the shrimp nets, and small ones may be often seen amongst the boiled shrimps. Yarrell says (Britisb Fishes, i. 71), 'on the eastern coast it is very plentiful.'

16. Lump-sucker. Cyclopterus lumpus, Linn.

Is frequently caught on the coast and in the mouths of the rivers.

\section{Sea Snail. Liparis vulgaris, Flem.}

This is very common, and frequently taken in shrimp and eel trawls. It is a very variable fish, some specimens being beautifully coloured and others almost without markings. Couch says (Hist. of Fishes of Brit. Islands, I860, ii. I9I), "it is found even at the mouth of the Thames.'

\section{Network or Montagu's Sucker. Liparis montagui, Donov.}

Not infrequently taken in shrimp trawls. Day says (Fishes of Great Britain, i. 187) 'it is common off the mouth of the Thames.'

I9. Doubly-spotted Sucker. Lepadogaster bimaculatus, Penn.

Has been rarely recognized, but there is one specimen in Brightlingsea marine station caught in the mouth of the Colne.

20. Spotted Goby. Gobius minutus, Gmel.

Common. Yarrell says (British Fishes, i. 260), 'It is apparently a new species from Colchester.' Day (Fishes of Great Britain, i. 166) calls it numerous at the mouth of the Thames, and says it 'is commonly found amongst whitebait brought to the London market.'

\section{Two-spotted Goby. Gobius ruthensparri,} Euphr.

This little fish is common on the shores of the Wallet opposite Clacton, where it flourishes on the hard, almost rock-like London clay. It is frequently caught and boiled with the shrimps.
22. Transparent Goby. Aphia pellucida, Nardo.

Possibly this may be common on the Essex coasts, but as the shrimpers throw away all the unsaleable fish they catch the opportunities for seeing it are few. I have seen examples that were captured in the Wallet by the fishermen employed at the Biological Station at Brightlingsea.

23. John Dory. Zeus faber, Linn.

Occasionally taken in the shrimp trawls, but the specimens are usually small.

\section{Boar-fish. Capros aper, Linn.}

According to Day (Fishes of Great Britain, i. 137) numbers were caught at Harwich and Southend about May, 1879. Mr. Carrington further records (Zoologist, 1879, p. 342) the fact of the capture of these specimens in a shrimp trawl.

\section{Mackerel. Scomber scombrus, Linn.}

Dale says (Hist. of Harwich, I 732, p. 429), ' These in their season are here to be caught.' As they are so plentiful both on the Kentish coasts and on those of Suffolk they are no doubt equally frequent on the Essex coast, although there is no regular fishery for them.

\section{Common Tunny. Orcynus tbynnus, Linn.}

Jenyns (British Vertebrate Animals, p. 363) calls it rare, and quoting Donovan he states that three were captured in the mouth of the Thames in 1801 and brought to Billingsgate market. In Essex County Cbronicle of October 26, I 897, Mr. H. L. Matthams records the finding of a specimen of this fish on the shore at Foulness on the 20th of that month. It measured 9 feet in length and weighed about 5 or 6 cwt. (see also Zoologist, I 897, p. 579).

27. Blackfish. Centrolophus pompilus, Linn.

One was captured in the Colne and forwarded to Dr. Gunther at the British Museum, and was described by him in Ann. and Mag. Nat. Hist. 1882, pp. 204, 338 ; also in Zoologist, 1882, pp. 75, 152 .

\section{Swordfish. Xipbias gladius, Linn.}

Mr. Montford records (Zoologist, 1847, p. I 9 II) the finding of a dead one off the coast of Essex in 1834. C. Parsons also mentions (Zoologist, 1862, p. $828 \mathrm{~g}$ ) the capture of a living one in Potton creek, the sword of which was 3 feet long. An Essex specimen mentioned by Day (Fishes of Great Britain, i. 148) was probably the same fish. Buckland (Familiar Hist. of Brit. Fishes, p. 37) says a 


\section{FISHES}

fine specimen 8 feet $8 \frac{1}{3}$ inches long, of which he made a cast, was caught at Leigh near Southend in November, 1866 (see also Field, November 3, 1896, p. 362).

29. Greater Weever. Trachinus draco, Linn.

A fish which is caught occasionally in eel trawls on the muddy Zostera covered shores. Mr. E. A. Fitch records (Essex Nat, iii. 188) the capture of one in the Blackwater by hook.

30. Common Weever, Viper Weever. Trachinus vipera, Cuv.

This is also taken in the eel trawls in the same situations as the last, but much more commonly.

\section{Dragonet or Dusky Skulpin. Callionymus lyra, Linn.}

The shrimp trawlers very often capture this species in their shrimp nets on our sandy shores, a locality just suited to its habits. Day's figure (Fishes of Great Britain, pl. liv.) was taken from a fish captured at Southend, where the reddish specimens are called 'foxes.'

\section{Angler. Lophius piscatorius, Linn.} Locally, Toad-fish.

This ungainly fish has been frequently captured on the Essex coast, but it is not often brought on shore by the fishermen.

33. Wolf-fish. Anarrbichas lupus, Linn.

This fish has been captured at Walton-onNaze (Essex Standard, August 29, 1885). Common as it is on many parts of the English seaboard it appears only as a straggler off Essex; the sandy shallow shores do not suit its habits.

34. Gattorugine. Blennius gattorugine, Bloch.

Mr. E. A. Fitch records in Zoologist, iii. 326 , ser. 4 the capture of one at Stansgate in the Blackwater on August 19, 1898 .

35. Butterfish. Centronotus gunnellus, Linn.

This is another fish frequently caught in eel trawls. I find it very commonly on the Zostera covered ooze at Mersea. Yarrell (Brit. Fishes, i. 240) says it is found in the mouth of the Thames.

36. Viviparous Blenny. Zoarces viviparus, Linn.

Not a rare fish. It is taken occasionally among sprats by the stow-boat fishermen, also by eel trawlers.

\section{ANACANTHINI}

37. Cod. Gadus morrhua, Linn.

The value of this fish as food is well known, but most of those of large size captured ir the Essex estuaries are not in a fit condition for the table, being more or less diseased. Many young ones called 'codling' are however captured in the finest condition all round the coasts by hooks or nets.

\section{Large-headed Cod. Gadus macrocephalus,} Tiles.

Dr. Day (Fourn. Linn. Soc. vol. xiv. No. 8o, p. 689 ) describes a specimen caught in the mouth of the Thames at Southend. (This is also recorded in Zoologist, 1880, p. 26.) Yarrell saw a large one from the mouth of the Thames, but he considered the abnormal size to be due to disease.

The local fishermen call this variety 'Lordfish' (see Day's Fishes of Great Britain, i. 278).

39. Haddock. Gadus aglefinus, Linn.

I have occasionally taken this species in some numbers in the Crouch, but I do not think it is a very common fish on the Essex coast.

A large number were observed and taken off Purflect by the officers of the training ship Cornwall in 1879 (Land and Water, March 1, 1879, p. 179). They have also been noted in Dagenham Breach (ibid. March 22, 1879, p. 236) by Mr. P. Hood, who communicated his surprise at finding them in freshwater to F. Buckland.

The latter's explanation that the water of Dagenham Breach was brackish probably accounted for their presence.

40. Bib, Whiting Pout. Gadus luscus, Linn. Locally, Wule or Whiting Wule.

This is extremely common during the early winter months, large numbers being caught by all those who fish either from piers or from boats with hooks.

\section{Power or Poor Cod. Gadus minutus, Linn.}

Mr. E. A. Fitch informs me it is not altogether rare at times in the Thames estuary.

\section{Whiting. Gadus merlangus, Linn.}

In some seasons very abundant; it arrives in our estuaries about the middle or end of September, and is a great favourite with those who practise the form of fishing which is locally called 'spruling.'

43. Pollack, or Whiting Pollack. Gadus pollachius, Linn.

Dale says (Hist. of Harwich, 1732, p. 428) that in his time the whiting pollack was sometimes caught and brought to Braintree market with the other varieties of whiting. 


\section{A HISTORY OF ESSEX}

44. Hake. Merluccius vulgaris, Linn.

Although this fish is so common on the south and west coasts of this island I never remember seeing more than one specimen which had been captured on the Essex coast. The fish was sent me by a dealer to name. Dale says (Hist. of Harwich, p. 429), 'Hake is sometimes caught here, and when salted and dried is called "Poor Jack.",

\section{Ling. Molva vulgaris, Flem.}

Mr. E. A. Fitch writes me that his informant, G. Gibson, has seen several Thames examples 9 to 12 inches long during the winter and spring months, and one was obtained in the trawl below Southend pier on April 1, 1897. It measured I foot in length and contained in its stomach a rockling half as big as itself.

\section{Five-bearded Rockling. Motella mustela, Linn.}

This is not common, our muddy shores not suiting its habits, but I possess a specimen taken in the Colne. Day (Fishes of Great Britain, i. 316) gives the mouth of the Thames among its haunts.

\section{Three-bearded Rockling. Matella tri- cirrata, Linn.}

Mr. E. A. Fitch has taken this in the Blackwater.

\section{Lesser Fork-beard. Raniceps raninus, Linn.}

Day records (Fishes of Great Britain, i. 32I) the capture of one by Mr. S. W. Wand in May, 1858 , in the river Crouch.

\section{Holibut. Hippoglossus vulgaris, Flem.}

Mr. H. L. Matthams informs me this is sometimes taken in the 'keddles' on the sands at Foulness, but it may be considered a rare visitor to the Thames estuary. One was captured in 1856 by hook and line. It was $3 \mathrm{ft}$. long. Another $5 \mathrm{ft}$. long is reported to have been captured about thirty years ago.

50. Long Rough Dab. Hippoglossus limandoides, Bloch.

Mr. E. A. Fitch informs me that specimens of this fish have been taken in the Blackwater in the spring.

\section{Turbot. Rhombus maximus, Linn.}

This well known fish is taken on all parts of our coast where suitable ground occurs. It is most frequently captured by trawling, but many are caught on the sandy shores or Foulness in ' keddles,' that is, in V-shaped nets the apex of which points seawards.

52. Brill. Rhombus levis, Linn.

This fish is captured in the same manner and is not rare.

\section{Eckström's Topknot. Zeugopterus uni- maculatus, Risso.}

Occasionally taken, but very rare.

54. Muller's Topknot, Common Topknot. Zeugopterus punctatus, Bloch.

As an Essex fish is very rare. Mr. E. A. Fitch informs me one was caught in the Blackwater, September 6, 1900. Another in the Crouch, November 6, 1900. And as both of these were considered by the fishermen to be young brill, it is probable that they may be more common than they are generally considered to be.

55. Scaldfish or Megrim. Arnoglossus laterna, Walb.

Mr. Fitch informs me that one of these fish was caught in a trawl near the Chapman on April 21, 1900. It measured 5 in. long.

\section{Plaice. Pleuronectes platessa, Linn.}

Small sized plaice are very common on all parts of the coast, and if light tackle and small hooks are used they afford good sport.

57. Smear Dab, Lemon Dab or Mary Sole. Pleuronectes microcephalus, Donovan.

This is taken frequently on the coast and in the estuaries only by trawling or other forms of netting. Is one of the best flavoured of the family.

58. Pole, Craig Fluke or Long Flounder. Pleuronectes cynoglossus, Linn.

Very rare. Mr. E. A. Fitch writes me that he has a specimen from the Blackwater.

59. Dab, Sand Dab. Pleuronectes limanda, Linn.

Very common on all our coasts.

**6o. Flounder. Pleuronectes fesus, Linn.

A fish common everywhere on all parts of the coast, ascending rivers much beyond the tideway and frequently seen in the slightly brackish water of the marsh ditches.

\section{I. Sole. Solea vulgaris, Quensel.}

This very common and delicious fish occurs on all our sandy coasts in great but largely diminishing numbers. 


\section{FISHES}

62. Lemon Sole. Solea lascaris, Risso.

Very rare as an Essex fish. There is one Essex specimen at the biological station at Brightlingsea.

63. Little Sole. Solea lutca, Risso.

This also is rare. An Essex specimen is preserved at Brightlingsea station.

\section{PLECTOGNATHI}

64. Short Sun-fish. Orthagoriscus mola, Linn. Lindsey says (A Season at Harwich, p. 102) this 'occurs but occasionally on the Essex coast.' Mr. E. A. Fitch informs me he saw a very large one which had been taken in the river Crouch, at Battles Bridge, on October 21,1874 . It was a female, measuring $4 \mathrm{ft} .6$ in. in length, and was carried about and exhibited (see Land and Water, October 31,1874, p. 340). Mr. Fitch also saw another in the same river at Burnham.

65. Oblong Sun-fish. Orthagoriscus truncatus, Retz.

Lindsey says (A Season at Harwich, pt. 2, p. 101) the oblong sun-fish is rare.

\section{PERCESOCES}

**66. Grey Mullet. Mugil capito, Cuv.

Yarrell says (British Fishes, i. 202) it occurs constantly on the Essex coast. It still is found commonly in the season.

**67. Lesser Grey Mullet. Mugil chelo, Cuv.

Is not so common as the last-mentioned species.

68. Atherine, Sand Smelt. Atherina presbyter, Jenyns.

Occasionally captured by the smelt fishermen at the mouth of the Colne. This year, 1901, they were very common about Walton and Clacton piers.

69. Larger Launce or Sand-Eel. Ammodytes lanceolatus, Le Sauvage.

This is found, but not so commonly as the next species.

70. Lesser Launce or Sand-Eel. Ammodytes tobianus, Linn.

This is common, but I do not think it is ever especially fished for, as is the case in the west of England, where large numbers are caught for bait.

71. Gar-fish. Belone vulgaris, Flem.

Large numbers of this are taken at certain seasons round the coast. They meet with a ready sale in London.

\section{HEMIBRANCHII}

** 72. Three-spined Stickleback. Gastrosteus aculeatus, Linn.

Common everywhere in streams, ponds and ditches. Doing very well in the brackish waters of the marsh ditches.

**73. Ten-spined Stickleback or Tinker. Gastrosteus pungitius, Linn.

This is not nearly so common as the last species, being found more frequently in small streams rather than ponds, although it occurs in the latter situations. I have never found it in brackish water. Many of our specimens have only nine spines.

74. Fifteen-spined Stickleback. Gastrosteus
spinachia, Linn.

I have found this species very commonly in trawling for eels amongst the Zostera marina, on the muddy shores of the Blackwater at Mersea. Unlike the rest of the family this species is entirely confined to the sea.

\section{LOPHOBRANCHII}

75. Broad-nosed Pipe-fish. Siphonostoma typhle, Linn.

Very common amongst the Zostera.

76. Greater Pipe-fish. Syngnathus acus, Linn.

This, the commonest species of the family, is found on all parts of the coast, especially in the beds of Zostera.

\section{Ocean or Snake Pipe-fish. Nerophis} aquoreus, Linn.

Although not so common as the last two, this is found in some quantity in the eel trawls, in the same situation amongst the Zostera. Day (Fishes of Great Britain, ii. 262) gives the estuary of the Thames as their habitat.

78. Straight-nosed or Snake Pipe-fish. Nerophis ophidion, Linn.

Buckland says (Fam. Hist. of Brit. Fishes, p. 197) this is often taken with whitebait in the mouth of the Thames.

79. Sea - horse. Hippocampus antiquorum, Leach.

Dr. Bree records (Field, Dec. 1, 1866, p. 420) the capture of two specimens of this rare fish at Brightlingsea. 


\section{A HISTORY OF ESSEX}

\section{HAPLOMI}

*80. Pike. Esox lucius, Linn.

This fish is found in all parts of the county, both in rivers and ponds, but never appears to attain the size sometimes found in those counties where more extensive tracts of water are found.

The largest one of which we have any record was taken at Dagenham on November 22, 1896 . It weighed $30 \mathrm{lb}$. (Badminton Mag. 1897, p. 628).

\section{OSTARIOPHYSI}

* 81. Carp. Cyprinus carpio, Linn.

Occurs in many of the sluggish streams and also in numerous ponds.

* 82. Crucian or Prussian Carp. Cyprinus carassius, Linn.

Has been introduced into many of our ponds, but it does not appear to occur in any of our rivers excepting the Lea, where one was caught by Mr. Williams near Tottenham (Land and Water, November, 1887, p. 4I2). Day says (Fishes of Great Britain, ii. I66) it is very common about London.

* 83. Goldfish. Cyprinus auratus, Linn.

Does not occur in any of our rivers. It is however naturalized in ponds throughout the county.

* 84. Barbel. Barbus vulgaris, Flem.

This is probably another introduced species as far as Essex is concerned. According to Day (Fishes of Great Britain, ii. I 7 I) and Yarrell (British Fishes, i. 322) it occurs in the Lea.

*85. Gudgeon. Gobio fuviatilis, Flem.

A fish that occurs in numbers in all our rivers, but is mostly local. It abounds in the Lea and Stort.

*86. Roach. Leuciscus rutilus, Linn.

Found everywhere in streams and ponds.

* 87. Rudd. Leuciscus erythrophthalmus, Linn.

Considerable numbers of this fish occur in the Suffolk Stour. It is rare in the Colne and common in the Lea. Mr. Pennell found (Day's Fishes of Great Britain, ii. 184) a lemon or yellow-coloured variety in some ponds near Romford.

Another variety called a blue roach occurs in the small stream entering the sea near Clacton. It is described in Land and Water, 1876, p. 153 .
* 88. Dace. Leuciscus dobula, Linn.

A fish found in the Chelmer, the Stour, and according to Lieutenant Croft (Trans. Herts Nat. Hist. Soc. ii. I3) in the Lea. It occurs probably in other streams also.

* 89. Chubb. Leuciscus cephalus, Linn.

Until quite recently this was another inhabitant of the Lea only among Essex rivers. Now it must be added to the list of Blackwater fish, as the Witham Angling Society has turned into that river 350 specimens (Field, Feb. 29, 1896, p. 320).

*9o. Minnow. Leuciscus phoxinus, Linn.

Frequent in most of the rivers of Essex.

*91. Tench. Tinca vulgaris, Cuv.

Is an inhabitant of many ponds in all parts of the county, and occurs also in the Stour, Colne, Lea and probably in all the other rivers.

* 92. Lake Bream. Abramis brama, Linn.

This is found in considerable numbers in the Essex and Suffolk Stour and in some other Essex rivers. The variety called Pomeranian bream is found, according to Day (Fishes of Great Britain, ii. 195), on the authority of Yarrell, in Dagenham Breach, where it is still plentiful (Land and Water, Aug. 4, 1888, p. I 34).

* 93. White Bream. Abramis blicca, Bloch.

It occurs in the Essex and Suffolk Stour, also in the Lea (Trans. Herts Nat. Hist. Soc. ii. I2), but not so commonly as the last species.

*94. Bleak. Alburnus lucidus, Heckel.

Day says (Fishes of Great Britain, ii. 200) this is found in the Lea, but does not appear to be known in any other Essex river.

* 95. Loach. Nemachilus barbatulus, Linn.

Found in all our smaller streams where there is a gravelly bottom.

A specimen of the continental sheat-fish (Silurus glanis, Linn.) was captured in the Stour and recorded (Field, Sept. 8, 1894, p. 4I I ) and a full account was therein given of the attempts made to acclimatize this species in English waters, fortunately I think without success. But as it has been taken in Essex waters many years after the attempts referred to, allusion to it may be made in this list. 


\section{FISHES}

\section{MALACOPTERYGII}

* 96. Salmon. Salmo salar, Linn.

Although salmon have disappeared from all our Essex rivers, they are still taken in nets on various portions of the coast and in the mouths of most of the rivers. And few years pass without several being taken in the 'keddles' on the sands of Foulness. Common as they were in years gone by in the Thames it seems hopeless to expect them ever again to ascend that river to their old 'redds.'

* 97. Sea Trout. Salmo trutta, Linn.

The same statements may be made with reference to this fish as the last. They are occasionally caught in the mouths of the rivers and in the Foulness 'keddles,' and would no doubt pass on to the fresh waters of several of our streams were it not for obstacles or impurities rendering such a proceeding impossible.

\section{* 98. Brown Trout. Salmo fario, Linn.}

Common as this fish is all over Britain it is rare in Essex, and excepting in the Lea it only occurs in our streams as the result of artificial stocking. And generally speaking it may be said that wherever introduced it has done well.

In the Roding it was introduced about I88 1 by Mr. Rodwell, and in the Roman river, a feeder of the Colne, by the Rev. Mr. Marsh about 1860 . Since this time it has been introduced into the Chelmer, Blackwater and Stour.

*99. Grayling. Thymallus vexillifer, Linn.

This is said to occur in the Cam, and therefore is possibly an inhabitant of that part of this river which rises in and flows through Essex. Day says (Fishes of Great Britain, ii. 135) a large batch of fry were placed in the Lea in 1863.

* roo. Smelt. Osmerus eperlanus, Linn.

Considerable numbers of this delicious fish are caught in all our rivers when they come up to spawn. They appear to be generally abundant up to the tide limit, and where it is possible for them to get still higher they are also frequent, but are only fished for in the mouths of the rivers.

wo1. Houting. Coregonus exyrbynchus, Linn.

Of this apparently rare British fish I saw in 1886 several examples which had been captured in the smelt nets in the Colne. And as it is frequently seen in boxes of
Dutch smelts it is probably much more common in Holland than in this country. This is rather strange when we consider the nearness of the Dutch coast.

102. Anchovy. Engraulis encrasicholus, Linn.

Day (Fishes of Great Britain, ii. 207) gives instances of the capture of this fish on the Essex coast, and Yarrell (i. 1 53) says : 'It is reported to be at this time an inhabitant of the piece of water below Blackwall called Dagenham Breach.

\section{Herring. Clupea harengus, Linn.}

This occurs commonly all round the coast, but there is no special fishery for it, although a few are still taken in drift nets in the estuary of the Blackwater.

104. Pilchard. Clupea pilchardus, Linn.

Is occasionally taken on the coast. Dale gives it in his list of Harwich fish, and says (Hist. of Harwich, p. 432): 'It is rare, but is occasionally brought among herrings to market.' Day says (Fishes of Great Britain, ii. 230) Yarrell obtained one in May, 1838 , from the mouth of the Thames.

\section{I05. Sprat. Clupea sprattus, Linn.}

Enormous numbers of this fish are taken off our coast by the stow-boat fishermen, and used for manure, besides those sent to market in London and the northern towns for food.

Unfortunately for our fishermen they have been comparatively scarce for the last two or three seasons, apparently having changed their habitat, and are now found in all parts of the English Channel as far west as Cornwall.

\section{* 106. Allis Shad. Clupea alosa, Linn.}

Rare. Day (Fishes of Great Britain, ii. 236), quoting Yarrell, mentions one being taken in the Thames above Putney in 1831 . Jenyns describes it (Brit.Vert. Animals, p. 438) as 'occasionally, though rarely, taken in the Thames.'

\section{* 107. Twait Shad. Clupea finta, Cuv.}

This is occasionally common in the Colne. Many were taken by the smelt fishermen in August, 1886, and one was caught on November 29, 1886, at East Bridge, Colchester, which point is the tide limit. Jenyns says (Brit. Vert. Animals, p. $43^{8}$ ) it is very abundant in the Thames.

\section{APODES}

* 108. Eel. Anguilla vulgaris, Turton.

Very common in streams and ponds everywhere. 


\section{A HISTORY OF ESSEX}

109. Conger. Conger vulgaris, Cuv.

Taken occasionally. One of $40 \mathrm{lb}$. weight is recorded (Essex Standard, Jan. 3r, I885) as having been picked up on the beach at Clactonon-Sea. Day, quoting Donovan, says (Fishes of Great Britain, ii. 253) one of 130 lb. weight was captured at the Nore.

In the Zoologist (1869, p. 1520) a record is given of several which were caught in the Thames as high as Woolwich.

\section{GANOIDS}

x 10 . Sturgeon. Acipenser sturio, Linn.

Is occasionally taken in all our rivers, but it is rare. When captured in the Thames, within the jurisdiction of the City of London, it is usually judged a proper present for the Lord Mayor's table.

The capture of a sturgeon, weighing I3 I lb., in the Blackwater river near Beeleigh Mills, Maldon, is noted as a re- markable circumstance (Donovan, British Fishes, vol. iii. pl. lxv.).

Mr. E. A. Fitch records the capture of two very large sturgeons in the Blackwater on May 9, 1886, and May 15, 1890. The latter, which weighed $212 \mathrm{Ib}$. and measured 7 feet $\mathbf{I}$ inches in length, went eventually to Sweetings in Cheapside (Essex Naturalist, iv. 120). Others are mentioned (Zoologist, I 879, p. $3^{8} 3 ; 1883$, p. 34 I).

\section{CHONDROPTERYGIANS}

I I I. Toper or Sweet William. Galeus vulgaris, Flem.

This shark is but rarely taken on our coast. One caught by trawling in the Wallet on October 23, 1886, was thought by its captor of sufficient rarity to make it worth exhibiting in the town of Colchester. The capture of one below Brightlingsea, $4 \mathrm{ft} .9$ in. long, in a shrimp trawl, and another, $5 \mathrm{ft} .6$ in. long, at Clacton are noted in the Essex Naturalist, ii. 137, 236. These were both females.

\section{I12. Porbeagle. Lamna cornubica, Gmel.}

A specimen of this shark was captured near the coast in 1874 . It measured $8 \mathrm{ft} .2$ in. long (Land and Water, $\mathrm{r} 874, \mathrm{p} .285$ ). Another captured off Harwich measured nearly $10 \mathrm{ft}$. in length (Essex Naturalist, vi. I 54). Several others have been taken since.

I 3. Picked Dogfish. Acanthias vulgaris, Risso.

This voracious fish is always much too common, and in some years especially so, on all our coasts.
11 4. Angel or Monk-fish. Rbina squatina, Linn.

Frequent on all the coasts of Essex.

115. Skate. Raia batis, Linn.

Very common on all our sandy shores. The small ones are called maids.

16. Thornback. Raia clavata, Linn.

This is also very common.

I 7 . Sharp-nosed Skate. Raia alba, Lacép.

Lindsey says ( $A$ Season at Harwich, pt. 2, p. 98) the French, who are great consumers of skate, this species being their favourite, would come to Harwich for this fish if greater encouragement were given to the fishery. As it is they go to Plymouth and purchase large quantities during the season of Lent.

Ix 8. Sting Ray. Trygon pastinaca, Linn.

It is frequently taken in the channels between the sands if one may judge from the number of needles made from the spines upon its tail that are to be seen in the possession of fishermen, who use them for stringing flat fish together through the gills for the convenience of carriage.

\section{CYCLOSTOMES}

\section{** I 9. Sea Lamprey. Petromyzon marinus, Linn.}

This is captured occasionally in the mouths of all our rivers. In Essex Naturalist, v.
134 is recorded the capture of two in the Colne. Day (Fishes of Great Britain, ii. $35^{8}$ ) gives for their habitat the mouth of the Thames. 


\section{FISHES}

* 1 20. Lampern or Silver Lampern. Petromyzon fuviatilis, Linn.

Day (Fishes of Great Britain, ii. 360, $\left.{ }^{36} \mathrm{I}\right)$ says they are captured in the Thames, where they abound in quantities. Jenyns says (British Vert. Animals, p. 521) they are common in many of our rivers, especially in the Thames. Yarrell makes the same re- mark. They are stated to be very common in the Stour.

*121. Planer's Lamprey, Mud Lamprey. Petromyzon branchialis, Linn.

According to my experience this is rare in Essex. I have however observed it in the Colne in two localities. 


\section{REPTILES \\ AND BATRACHIANS}

The greater portion of the land of the county of Essex is arable, mostly in a condition of high cultivation, and there is no large sandy waste, open common, or bog, and with the exception of Epping Forest, no extensive woodland.

Any large area of this character does not present the most favourable condition for the habitat of some of the members of these classes, and therefore it may be readily understood that those species, to which an open sandy district is almost a necessity of their existence, will not be found; but these are few in number, and do not prevent the total species of the Essex list from comparing favourably with, in this respect, more richly endowed counties.

The number of species of reptiles recognized as inhabiting Great Britain is seven, and including the edible frog (Rana esculenta) six batrachians. Of this number, Essex possesses four reptiles and six batrachians, but the evidence is hardly sufficient to enable it to be said that the edible frog has succeeded in becoming established in those localities, in Epping Forest and elsewhere, where various attempts have been made to naturalize it. Those introduced by the late $\mathrm{Mr}$. Doubleday in Epping Forest did well for a time, but every colony would seem to have disappeared. This frog is claimed for several counties as a member of their fauna, but wherever found there can be no doubt of its having been introduced from the continent.

The absence of sandy wastes from all parts of Essex accounts for the sand lizard never having been found in this county, and probably also the same cause is responsible for the fact of the smooth snake having never been seen, its favourite food, the sand lizard, not occurring.

The slow worm is not found so frequently as it was some years ago, and one of the causes of the diminution in numbers of this species, and of the snakes generally, for they also are less abundant, is the great alterations that have been made in the hedgerows within the last half or three-quarters of a century.

Before that time hedges were higher and broader, and often the hedge and bank occupied perhaps three times the space they do at the present time, and this diminution of their place of refuge and hunting ground has not only affected reptiles unfavourably, but mammals and birds as well. 


\section{REPTILES AND BATRACHIANS}

The grass or ring snake and the adder or viper are both frequent in some districts, more so perhaps on the marshes and the localities bordering on the marshes than elsewhere, but even where most common they do not occur in anything like the numbers they did fifty years ago. In some parts of the county both species would appear to be almost approaching extinction, so rarely are they found.

The common frog is abundant everywhere in suitable localities, and the toad is here, as everywhere else, common alike in dry and wet situations.

The absence of the natterjack in Essex is difficult to account for, as it is to be found in both Norfolk and Suffolk.

The other batrachians, the newts, are well represented, all the species being common.

\section{LACERTILIA}

I. Common or Viviparous Lizard. Lacerta vivipara, Jacq. Locally, 'Swift.'

Is common in most parts of the county wherever the district is dry enough to suit its habits, but like many of the other reptiles, inclosure and cultivation are telling on its numbers.

2. Slow-worm. Anguis fragilis, Linn.

Occurs commonly still in most parts of Essex. It is much feared by many people who dread to touch it, in consequence of its supposed venomous powers.

\section{OPHIDIA}

3. Common or Ringed Snake. Tropidonotus natrix, Linn.

Fairly numerous, especially near water.

4. Adder or Viper. Vipera berus, Linn.

Still found in some numbers in wooded districts, but not confined to them. It is generally stated to be most common in dry districts, but in this country it is found quite as frequently on the marshes inside the sea walls. The red variety has there been found, as also has more commonly the black viper. This last is considered by the country people to be especially venomous.

\section{BATRACHIANS}

\section{ECAUDATA}

I. Common Frog. Rana temporaria, Linn.

Extremely common, and generally distributed, especially in the neighbourhood of water.

2. Common Toad. Bufo vulgaris, Laur. Common, and generally distributed.

\section{CAUDATA}

3. Great Crested Newt. Molge cristata, Laur. Locally, Water Swift.

Common, and found throughout the county.
4. Common Newt or Eft. Molge vulgaris, Linn.

Locally, Water Swift.

Very common in almost every stagnant pool in summer; in winter often found in cellars and other damp places.

5. Palmated Newt. Molge palmata, Schneid.

This is not rare. Mr. G. A. Boulenger, who first discovered this species in Epping Forest (Essex Naturalist, i. 8), gives the distribution of this species in Scotland and England, and the distinguishing marks of the two allied species in their winter attire. 


\section{B I R D S}

The avi-fauna of the county of Essex is rich in respect both of number of species and abundance of individuals. From the ornithologist's point of view indeed the county has been favoured in many ways, both by Nature and by circumstance.

Essex is, in the first place, a maritime county, and as such it possesses naturally a far richer avi-fauna than any inland county, however large. It is also exceptionally well placed, ornithologically speaking, even for a maritime county. Situated on the east coast of England, in close proximity to continental shores, it lies upon the main highway followed by the majority of our migrant species as they pass and repass across the North Sea. Furthermore the county is of great extent, covering some I, 542 square miles and standing, in respect of area, tenth among the English counties. Its surface is considerably diversified, and therefore offers attractions to many different species.

The regions or districts into which the county may be divided, according to its natural and physical features, require brief notice.

First come what may be called the lowlands, covering probably at least two-thirds of the county and occupying the whole of its central portion. This is, for the greater part, a region of stiff clay-mainly the London Clay, though this is overlaid in places by the Chalky Boulder Clay. It presents everywhere the same features, with very little variation. It is, and long has been, generally under cultivation, a small proportion of pasture mingling with a much larger proportion of arable land. In all parts old hedgerows, wide overgrown ditches and quiet lanes abound, while there is a large number of small copses. These afford homes for innumerable warblers, finches, and other small birds.

Interspersed throughout this region, and forming strictly speaking a part of it, are several fairly extensive stretches of forest and woodland. The aggregate area covered by them is not however very large. They occupy for the most part the high ground and hill-tops, where the prevalence of Bagshot Sands and gravels renders the soil of little value for agricultural purposes. Such are Epping Forest (about 6,000 acres), in the south-western portion of the county; Takeley or Hatfield Forest (about I,500 acres), near the western border ; the Writtle High Woods and the woods around Danbury and Little Baddow, near the centre; the Bull Wood at Hockley, in the south-east; the woods around Thorndon Park ; and others of less extent elsewhere. These still form a home for many woodland species, but the hand of the game preserver has greatly reduced, even exterminated, many others, especially the larger birds of 


\section{BIRDS}

prey, such as the kite and the buzzard, which were still fairly common a century ago. The hobby is on the verge of extinction, if not quite extinct, as a breeding species; but sparrow-hawks and kestrels are still pretty numerous. In the central parts of the county the magpie, once common, is all but extinct, though the jay remains abundant, probably because it is a more retiring bird and builds a less conspicuous nest. Epping Forest is and long has been a stronghold for the hawfinch, which is possibly more abundant there and at Danbury than elsewhere in England.

Our uplands-if one may call them by that name-are of small extent, being confined to the extreme north-west corner of the county, where the elevated undulating chalk downs which occupy so large an area in the adjacent counties of Cambridgeshire and Hertfordshire extend into Essex. This down country, though generally open, is wooded in places. On it the stone-curlew, which nests nowhere else in the county, still breeds occasionally.

Turning from the most inland portion of the county to that nearest the sea, we find another region which, like the last-named, is of comparatively small extent, though possessed of marked individual featuresnamely the marshes, saltings, and mudflats of the coast. This kind of country is probably of greater extent in Essex than in any other English county. It lies chiefly round the estuaries of our rivers, especially the Crouch, the Blackwater, the Colne, and the Stour. 'Marshes' in Essex are tracts of land which have been reclaimed from the sea and are now protected from its inroads by strong sea-walls of mud. They are grasscovered and valuable for grazing purposes. They form favourable breeding haunts for the redshank, the peewit, and the sky-lark; while the wide ditches known as 'fleets,' by which they are intersected, and the quiet reedy pools which are scattered here and there, are the homes of the black-headed gull, the coot, the dabchick, the pochard, and not a few other water birds. 'Saltings' (sometimes called 'bentlings') lie on the outer side of the sea-wall, yet are not strictly speaking sea-shore, for they are covered only by the highest tides and support a rich flora of coast plants. The saltings are intersected by innumerable muddy dykes which slowly fill and empty with the rise and fall of every tide. Outside the saltings again-and occupying, in fact, the very beds of the river estuaries - are very extensive mudflats, which are left uncovered regularly at low water. Taking the whole of our coast, the area of our mudflats at low tide must approach a hundred square miles. Here during the periods of spring and autumn migration, and to a lesser extent during winter, one may meet with myriads of wading birds, of which the dunlin (called locally the 'oxb'd') is the most numerous; while curlews, whimbrels, godwits, knots, sanderlings, ring-plovers and many others are more or less abundant, and not a few scarce and interesting species have been met with from time to time. So numerous, indeed, are the dunlins that over 300 are reported credibly to have been killed on more than one occasion by a single discharge of the gun. From 


\section{A HISTORY OF ESSEX}

the ornithologist's point of view, no part of Essex equals our coast in interest.

Among the more interesting of the birds breeding round our coast is the black-headed gull, called formerly in Essex the 'pewit 'or 'puit.' Though now much reduced in number and having only one or two breeding-stations, its former abundance may be inferred from the fact that no fewer than three islands round our coast bear the name "Pewit Island,' because each had formerly upon it a large nesting-colony of this species: (I) a large island in Hamford Water; (2) a smaller one near Mersea; and (3) another near Bradwell. As long ago as 1662 , Fuller made the following quaint reference to the breeding of this gull on the the first-named island (Wortbies, p. 3 r 8 ) :-

There is an island of some two hundred acres, near Harwich, in the parish of Little Okeley, in the manour of Matthew Gilly, Esquire, called the Puit Island, from Puits [which are] in effect the sole inhabitants thereof. . . . On Saint George his day [April 23rd] precisely (so I am informed by Captain Farmer, of Newgate Market, copyholder of the Island), they pitch on the Island, seldom laying fewer than four or more than six eggs. Great [is] their love to their young ones; for though against foul weather they make to the mainland (a certain Prognostick of Tempests), yet they always weather it out on the Island when hatching their young ones, seldom sleeping whilst they sit on their eggs (afraid, it seems, of Spring-tides), which signifieth nothing as to securing their eggs from the inundation, but is an argument of their great Affection. Being [i.e. when] young, they consist onely of bones, feathers, and lean flesh, which hath a raw gust [i.e. taste] of the sea. But Poulterers take them and feed them with Gravel and Curds (that is Physick and Food), the one to scour, the other to fat them in a fortnight, and their flesh thus recruited is most delicious.

Fuller's statements as to the habits of the bird must not, however, be taken too literally.

The seas adjacent to our coast require notice in connection with the county. During summer they are singularly devoid of bird life, for our coast is totally unprovided with those rocky cliffs and eminences which most sea-birds require as breeding places. From the end of summer however right on to the beginning of the following breeding season the sea off our coast and the estuaries of our rivers swarm with gulls, divers, grebes, shearwaters, petrels, guillemots, razorbills, ducks, and geese.

The brent goose (called locally 'black goose'), which formerly appeared off our coast in almost fabulous numbers, is still numerous whenever the weather becomes severe. Old sportsmen tell of these birds having appeared formerly 'by the acre' on the Main and in our larger estuaries, making huge areas of the sea appear black from a distance; while the numbers reported as having been killed by a single discharge of a punt gun, or by several such guns fired simultaneously into a flock, seem almost incredible. Thus a Maldon gunner, shooting by himself, is said to have killed on one occasion fifty geese by a single discharge of his gun; while, as to organized shoots, it is said that, on various occasions, the following numbers have been obtained: I 45 birds by two gunners; I 60 birds by several gunners; 300 birds by twelve gunners; 360 birds by seventeen gunners; and 704 birds by thirty-two gunners. Nowadays, however, the geese are so much disturbed, owing 


\section{BIRDS}

to the increase of the number of gunners and the use of steam-yachts, that their numbers are reduced greatly and such 'shoots' as those mentioned above occur only in the severest weather, as in January, I891, when a number of gunners (how many not stated) secured nearly 300 birds by a single joint discharge of their guns in the Blackwater estuary, which was then filled with ice. Further information on this subject must be sought in the chapter on wildfowling.

Thus the surface of the county is considerably diversified, though it lacks entirely those tracts of mountain and wide open moorland which add so much to the richness of the avi-fauna of some more northerly counties. Large inland sheets of fresh water are also entirely lacking; but there are not a few smaller sheets of ornamental water, chiefly artificial, in parks and pleasure grounds. The largest are those in Wanstead, Gosfield, and Debden Parks.

Allusion must be made here to the existence of wildfowl decoys. The large number of which traces may yet be found proves that decoying was once an important industry in the county, and old records tell of the immense numbers of wildfowl formerly taken. A large amount of information on this subject is given in the present writer's work, the Birds of Essex (1890), pp. 47-71. In all there are, or have been, in the county some thirty-five decoys, of which only two are now worked regularly. Of these thirty-five, all but two are situated close to the coast-in most cases actually on the marshes. The two southernmost lie in the parishes of Paglesham and Southminster. Around the shores of the large Blackwater Estuary there are no fewer than twenty (ten on each side), lying chiefly in the parishes of Tillingham (twoboth still used), Bradwell (two), Steeple, Mayland, Latchingdon, Goldhanger (four), Tolleshunt D'Arcy (several—one still used occasionally), and West Mersea. At Kirby-le-Soken there is one. Around the shores of the Colne Estuary are two decoys; around those of Hamford Water four; and on the southern (or Essex) side of the estuary of the Stour four. The remaining two Essex decoys are those already mentioned as being situated inland-one (nine acres in extent) beside the river Stour at Wormingford: the other still further inland, between Pond Park Farm and the site of Leighs Priory at Little Leighs, almost in the centre of the county. ${ }^{2}$ The only decoys now worked regularly are the Grange and Marsh House decoys, which lie within a mile or so of one another in Tillingham parish. Their annual 'catches' of fowl have of course fallen off enormously of late, but are still large enough to pay the expenses of working. Fuller information on this subject must be sought, however, in the chapter on wildfowling.

Essex has been in the past the home of a considerable number of good working ornithologists, who have left us, either in the pages of the natural history journals or among their private papers, many records of

1 Since the foregoing was written, I have heard of, but not definitely established, the existence of another decoy (the thirty-sixth) at Fobbing. This is the only decoy I ever heard of in Essex anywhere on the banks of the Thames. 


\section{A HISTORY OF ESSEX}

rare occurrences or interesting observations, which have been made use of in the following list. Among the chief of these may be noticed the Rev. Canon J. C. Atkinson (I 8 I 4-I 900), of Danby, Yorkshire, who spent the earlier portion of his life in Essex; Charles R. Bree, M.D. (18I I-86), of Colchester; Mr. Joseph Clarke, F.S.A. (1802-95), of Saffron Walden ; Henry Doubleday ( $1808-75$ ), of Epping ; Christopher Parsons ( $1807-82$ ), of Southchurch; and Colonel Champion Russell (1820-82), of Stubbers, Romford.

Among living ornithologists who are resident in the county and have assisted the writer with information during the compilation of the following list are Mr. G. H. Baxter, F.Z.S., of Hutton Park ; Mr. E. A. Fitch, F.L.S., of Maldon; Mr. G. P. Hope, of Havering Grange ; Mr. F. Kerry, of Harwich; Dr. Henry Laver, F.L.S., and Mr. F. Spalding, both of Colchester; Mr. Walter B. Nichols, of Bradfield; Mr. Champion B. Russell, of Stubbers; Dr. J. H. Salter, of Tolleshunt Darcy; Mr. Charles Smoothy, of Danbury; and various others. The number of practical working ornithologists now resident in the county is small and, it is to be feared, decreasing.

The Essex County Council is to be congratulated on the intelligent and practical interest it has long taken in the legal protection of the wild birds frequenting the area under its control. Upon several occasions the Home Secretary, upon the application of the Council, has made Orders varying, as occasion required, the close time mentioned in the Wild Birds Protection Acts, 1880 to 1896 , thus extending the protection afforded to certain species in certain areas. The most recent order bears date May 3, I goI. These variations have been made, as a rule, on the initiative of Messrs. E. N. Buxton, E. A. Fitch, and Champion B. Russell, working in co-operation with the Essex Field Club. At present, the close time is from March I 5 to August I 5, both inclusive. The kingfisher is protected all the year round. The barn-owl and kestrel-most useful of birds-might well be similarly protected. A number of other species are also protected all the year round, but only in that portion of the county lying within the Metropolitan Police District and in certain parishes adjacent thereto. All birds are protected on Sundays in six Poor Law Unions. In that portion of the county lying within the Metropolitan Police District, the taking of eggs of a considerable number of species (some of which are, however, hardly likely to be found breeding there) is prohibited ; while along practically the whole of the foreshore of the county, from Harwich to Shoeburyness, the taking of the eggs of all breeding species is similarly prohibited for a period of five years from May 3, I901. The latter provision is of especial value. It will lead probably to a substantial increase in the number of certain species, such as the lesser tern, the ringed plover, the sheld duck, and others, whose nests are especially liable to destruction. The lesser tern was, when the order first came into force, hovering on the very verge of extinction as a breeding species in Essex. Conceivably, too, the protection thus afforded might lead to 


\section{BIRDS}

a return of certain species which have ceased to breed with us, as the common and Sandwich terns. These provisions, though somewhat complicated, are judicious and are working satisfactorily.

The present writer's work, the Birds of Essex (1890), may be consulted with advantage for fuller information as to occurrences, etc., of earlier date than the year of its publication. A supplement to this work is now in preparation, and will appear hereafter in the Essex Naturalist.

NotE.-I have used, throughout the following list, the nomenclature employed in Mr. Howard Saunders' admirable List of British Birds (1899). This I have done, by the Editor's wish, in order to secure uniformity with other lists in this series; but $\mathrm{I}$ am permitted to state that $\mathrm{I}$ am unable to approve the treatment, in that list, of certain forms which show regional divergence from recognized types.M. C.

1. Missel-Thrush. Turdus viscivorus, Linn. A fairly common resident in all districts.

2. Song-Thrush. Turdus musicus, Linn. A very abundant resident.

3. Redwing. Turdus iliacus, Linn.

A common winter visitor, especially abundant during severe weather.

4. Fieldfare. Turdus pilaris, Linn.

As the last species. It usually arrives late in September, and remains till the beginning or middle of May, but has been recorded as early as September 6 and as late as the end of May (Birds of Essex, p. 73).

5. White's Thrush. Turdus varius, Pallas.

A rare and occasional straggler. The only example known to have been obtained in the county was shot, in January 1894 , in Langley High Wood. It now belongs to Mr. W. H. Rolfe of Clavering, who has been good enough to submit it to me for identification.

6. Blackbird. Turdus merula, Linn.

A very abundant resident, but varies greatly in numbers from time to time.

7. Ring-Ouzel. Turdus torquatus, Linn.

An uncommon spring and autumn migrant, seen usually in April and October. A pair bred at Wickham Bishops in 1879 (Zoologist, I879, p. 267).

8. Wheatear. Saxicola cenanthe (Linn.).

A summer visitor, though local, breeding only round the coast and among the chalky uplands in the north-western corner of the county. Known elsewhere as a fairly common passing migrant in spring and autumn.
9. Whinchat. Pratincola rubetra (Linn.).

A regular summer visitor, fairly common on furze-covered commons and similar open spaces.

10. Stonechat. Pratincola rubicola (Linn.).

An uncommon resident, though partially migratory. It breeds on open commons where furze abounds, but varies unaccountably in number from time to time.

11. Redstart. Ruticilla phrenicurus (Linn.).

A. regular summer visitor, rather uncommon, though locally abundant.

12. Black Redstart. Ruticilla titys (Scopoli).

A rare autumn and winter visitor, chiefly to the coast.

13. Red-spotted Bluethroat. Cyanecula suecica (Linn.).

A rare straggler. Reported to have occurred once near Harwich (Birds of Essex, p. 80).

14. Robin or Redbreast. Erithacus rubecula (Linn.).

A very abundant and familiar resident.

15. Nightingale. Daulias luscinia (Linn.).

A common summer visitor.

16. Whitethroat. Sylvia cinerea (Bechstein).

An abundant summer visitor. It has occurred once in winter.

17. Lesser Whitethroat. Sylvia curruca (Linn.).

A fairly common summer visitor. One was shot near Colchester on December 6, 1892 .

18. Blackcap. Sylvia atricapilla (Linn.).

As the last-named. A few occasionally winter with us. 


\section{A HISTORY OF ESSEX}

1 9. Garden-Warbler. Sylvia bortensis (Bechstein).

As the last named.

20. Dartford Warbler. Sylvia undata (Boddaert).

$A$ resident, but very rare and local.

21. Goldcrest. Regulus cristatus, K. L. Koch.

A resident, but nowhere very common. In winter its numbers are increased by immigration.

22. Firecrest. Regulus ignicapillus (Brehm).

A rare visitor, though perhaps often mistaken for the foregoing.

23. Chiffchaff. Pbylloscopus rufus (Bechstein).

A regular summer visitor, but decidedly local and nowhere abundant. It is most numerous when on migration in spring and autumn. It is our earliest migrant to arrive, being often heard in March and occasionally early in that month.

24. Willow-Warbler. Pbylloscopus trochilus (Linn.).

A common summer visitor.

25. Wood-Warbler. Phylloscopus sibilatrix (Bechstein).

A summer visitor, though very local and nowhere common.

26. Reed-Warbler. Acrocephalus streperus (Vieillot).

A regular summer visitor, but decidedly local and apparently confined to the coast, or nearly so.

[Marsh Warbler. Acrocephalus palustris (Bechstein).

Occurs in all probability, but not as yet actually identified, so far as I know.]

27. Sedge-Warbler. Acrocephalus phragmitis (Bechstein).

An abundant summer visitor.

28. Grasshopper-Warbler. Locustella navia (Boddaert).

A summer visitor, but decidedly uncommon and seldom heard, except round Danbury and Maldon, where it is fairly common (Fitch).

29. Savi's Warbler. Locustella luscinioides (Savi).

A rare summer visitor. The only record (Zoologist, 1850, p. 2849) of its occurrence in the county (a nest said to have been taken at Dagenham on May 24, 1850) is somewhat unsatisfactory.
30. Hedge - Sparrow.

Accentor

modularis (Linn.)

Locally, Hedge-Betty.

An abundant resident.

31. Alpine Accentor. Accentor collaris (Scopoli).

$A$ rare and accidental visitor. The first British and only recorded Essex example was shot at Walthamstow in August I8I 7 (Birds of Essex, p. 89).

32. Dipper. Cinclus aquaticus, Bechstein.

$A$ rare and accidental visitor. There are about a dozen records of its occurrence in the county.

33. Black-bellied Dipper. Cinclus melanogaster, Brehm.

Most of the occurrences noted under the foregoing species relate, in all probability, to this form, which is probably only sub-specifically distinct; but only one is known to do so (see Birds of Essex, p. 90).

34. Bearded Tit. Panurus biarmicus (Linn.).

Formerly a resident, common in suitable localities, such as the reed-beds round the coast : now extinct, or nearly so, in the county. Probably however it still breeds with us occasionally, as specimens have been seen within recent years (see Birds of Essex, p. 92). One was found dead near Harwich on March 30, I 895 (Essex Nat. ix. 52), and Dr. Salter watched one for some time at Goldhanger, on April 21, 1896, when it was probably breeding.

35. British Long-tailed Tit. Acredula rosea (Blyth).

Locally, Bottle-Tit, Oven-builder, etc.

A fairly common resident, but apparently decreasing, probably because it builds so large and conspicuous a nest so early in the spring.

36. Great Tit. Parus major, Linn.

Locally, Saw-sharpener, etc.

A common resident, more abundant or more apparent in winter than in summer.

37. British Coal-Tit. Parus britannicus, Sharpe and Dresser.

A resident, but local and nowhere common.

38. British Marsh-Tit. Parus dresseri, Stejneger.

A common resident.

39. Blue Tit. Parus coruleus, Linn. Locally, Pick-cheese and Bluecap.

A very abundant resident. 


\section{BIRDS}

40. Crested Tit. Parus cristatus, Linn.

$A$ rare and occasional straggler. One or two examples are said (Birds of Essex, p. 94) to have been obtained near Saffron Walden early in last century, but none have been seen since.

41. Nuthatch. Sitta cresia, Wolf.

A fairly common resident, especially in parks and wooded districts where fine old timber exists.

42. Wren. Troglodytes parvulus, Koch. Locally, Tiddy-Wren, Jenny-Wren, etc.

A common resident.

43. Tree-Creeper. Certhia familiaris, Linn.

Resident and fairly common everywhere, but too retiring to be seen very often.

44. Pied Wagtail. Motacilla lugubris, Temm.

A common resident, though comparatively few remain through severe winters.

45. White Wagtail. Motacilla alba, Linn.

An uncommon visitor, chicfly in spring: often mistaken, no doubt, for the last-named species.

46. Grey Wagtail. Motacilla melanope, Pallas.

A regular but uncommon visitor in autumn and winter. It is not known to have nested in the county.

47. Bluc-headed Yellow Wagtail. Motacilla Alava, Linn.

An occasional spring visitor: often mistaken, doubtless, for the next species. The first example detected in Britain was shot by Henry Doubleday on the cliffs at Waltonon-the-Naze on October 3, 1834 (Birds of Essex, p. 98). Probably it has bred in the county, as it has been observed in pairs in May.

48. Yellow Wagtail. Motacilla raii (Bonaparte).

A summer visitor, breeding commonly beside the marsh ditches near the coast, though never inland, so far as my experience goes.

49. Trec-Pipit. Anthus trivialis (Linn.).

A fairly common summer visitor.

50. Meadow-Pipit. Anthus pratensis (Linn.). Locally, Tit-lark.

A resident, abundant in the meadows and on the marshes and saltings round the coast : much less numerous inland.
51. Rock-Pipit. Anthus obscurus (Latham).

Common during winter among the saltings and mudflats in the estuaries of our rivers, where it is generally found running about, singly or in small parties, upon the mud under the 'brew' of the ditches inside the sea-walls. It is said to have bred formerly on our coast, and has been known to do so on one recent occasion-at East Mersea, in 1892 (Fitch).

52. Golden Oriole. Oriolus galbula, Linn.

A summer visitor, but uncommon. The appearance of individuals, singly and in pairs, in the county of late years during early summer seems to leave little doubt that it has bred recently with us, and that it would have done so oftener had it not been molested ; but there is no actual record of its having done so which is wholly satisfactory.

\section{Great Grey Shrike. Lanius excubitor,} Linn.

A regular though uncommon winter visitor, some occurring every year. A few individuals have been seen in the county during summer, but it is not known to have bred in Britain. The Eastern form of the bird ( $L$. major) has occasionally occurred in Essex, while at least one other sub-specific form is likely to occur, and these should be carefully discriminated.

54. Red-backed Shrike. Lanius collurio, Linn.

A fairly common summer visitor, but steadily decreasing, I believe, in numbers, probably because the large thorn-hedges in which it used to nest are now largely cut down.

55. Woodchat Shrike. Lanius pomeranus, Sparrman.

A rare and occasional summer visitor. A pair were shot at Arkesden late in August 1880 , and one or two other individuals have been reported as seen from time to time (see Birds of Essex, p. 106).

\section{Waxwing. Ampelis garrulus, Linn.}

An irregular winter visitor. In some years (for instance, $1835,1850,1866$ and 1893) it has occurred in considerable numbers : in others, none have been seen.

\section{Pied Flycatcher. Muscicapa atricapilla,} Linn.

A passing migrant, occasionally seen in spring and autumn when going to or from its breeding haunts further north. It is said (Harting's Summer Migrants, p. 163) to have bred in the county on one occasion. 


\section{A HISTORY OF ESSEX}

58. Spotted Flycatcher. Muscicapa grisola, Linn.

A fairly common summer visitor.

59. Swallow. Hirundo rustica, Linn.

An abundant summer visitor.

6o. House-Martin. Chelidon urbica (Linn.). As the last-named.

61. Sand-Martin. Cotile riparia (Linn.).

A very common summer visitor wherever sandy banks suited to its nesting requirements exist.

62. Greenfinch. Ligurinus chloris (Linn.).

Everywhere an abundant resident.

63. Hawfinch. Coccothraustes vulgaris, Pallas.

A resident and fairly common, though not very often seen, owing to its shyness. It breeds occasionally, I believe, in nearly all parts of the county, and is certainly increasing in numbers. Epping Forest has long been known as a stronghold of the species.

64. Goldfinch. Carduelis elegans, Stephens.

A resident, but local, uncommon, and certainly decreasing in numbers, owing to the efforts of bird-catchers.

65. Siskin. Carduelis spinus (Linn.).

A regular winter visitor, occasionally in some numbers, but generally uncommon.

[Serin Finch. Serinus bortulanus, Koch.

There is reason to believe (see Zoologist, I 889 , p. 29) that this rare visitor to Britain has been taken in the county, but no individual has been, as yet, identified satisfactorily.]

66. House-Sparrow. Passer domesticus (Linn.). Everywhere too abundant.

67. Tree-Sparrow. Passer montanus (Linn.).

A resident, breeding sparingly in some parts of the county, especially the southwestern portion. In winter it is often common, owing to arrivals from elsewhere.

\section{Chaffinch. Fringilla coelebs, Linn.}

An abundant resident.

69. Brambling. Fringilla montifringilla, Linn.

A winter visitor, generally uncommon, but often fairly numerous during severe weather.
70. Linnet. Linota cannabina (Linn.).

An abundant resident, especially near the coast.

71. Mealy Redpoll. Linota linaria (Linn.).

An irregular and uncommon winter visitor.

72. Lesser Redpoll. Linota rufescens (Vieillot).

A common winter visitor, especially numerous round the coast : less common, apparently, than formerly. It breeds in the county occasionally, though not, I believe, with any regularity.

\section{Twite. Linota flavirostris (Linn.).}

A common winter visitor to our coast, where it is often to be seen in company with redpolls and linnets.

74. Bullfinch. Pyrrbula europaea, Vieillot.

A fairly common resident, most often seen in winter: certainly becoming more numerous, especially among the uncultivated lands in Dengie Hundred.

\section{Crossbill. Loxia curvirostra, Linn.}

An irregular and uncertain visitor, appearing usually in late summer or winter: sometimes common. It has bred in the county not very infrequently.

\section{Parrot Crossbill. Loxia pityopsittacus,} Bechstein.

A rare visitor, though no fewer than nine examples are recorded from our county-a pair at Saffron Walden about 1823 ; one in Epping Forest in 1835 ; three at Lamborne on September $2 \mathrm{x}, \mathrm{x} 86 \mathrm{I}$; and three at Colchester in 1862 (see Birds of Essex, p. 1 26). In my opinion this is merely a sub-specific form.

\section{Two-barred Crossbill. Loxia bifasciata (Brehm).}

A very rare straggler which has twice occurred in the county-at Epping in or about 1846, and at Dedham in 1866 (see Birds of Essex, p. 1 26).

78. Corn-Bunting. Emberiza miliaria, Linn.

A resident, but local, uncommon, and certainly decreasing in numbers.

79. Yellow Hammer. Emberiza citrinella, Linn.

Everywhere an abundant resident. 


\section{BIRDS}

80. Cirl Bunting. Emberiza cirlus, Linn.

Possibly a resident, but so rare that it seems best to regard it as an occasional visitor merely.

81. Little Bunting. Emberiza pusilla, Pallas.

A very rare straggler to Britain. A female bird of the year was taken with some linnets and yellow hammers by some bird-catchers at Southchurch in September 1892 . It was kept alive for some days, but soon died and was thrown away, though not till it had been seen and identified by Mr. J. G. Keulemans.

82. Reed-Bunting. Emberiza schoeniclus, Linn.

A fairly common resident in suitable localities throughout the county.

83. Snow-Bunting. Plectrophenax nivalis (Linn.).

A winter visitor. In mild seasons it is uncommon, but during severe weather it is abundant on our coast and sometimes appears inland.

\section{Lapland Bunting. Calcarius lapponicus (Linn.).}

An occasional visitor. One was shot near Waltham Abbey in 1872 (Essex Naturalist, iv. 118). The bird has probably occurred and been overlooked on other occasions.

\section{Starling. Sturnus vulgaris, Linn.}

A very abundant resident which is rapidly becoming increasingly numerous. Enormous flocks are sometimes seen. Cream-coloured, white, and pied varieties are by no means uncornmon.

\section{Rose-coloured Starling. Pastor roseus} (Linn.).

A rare and occasional visitor. Some halfdozen individuals only are known to have been met with in Essex during the last halfcentury.

87. Chough. Pyrrhocorax graculus (Linn.).

$A$ rare and occasional visitor. Two individuals were observed off Harwich on April 2, 1888 (Zoologist, I888, p. 185). Formerly, when it was a more abundant species, it visited us doubtless more often; but it is now everywhere decreasing in numbers.

\section{Nutcracker. Nucifraga caryocatactes (Linn.).}

A rare and irregular straggler. In or about 1859 , in the month of September, one was shot at Horkesley, another at Ardleigh, and another at Boxted, all adjoining parishes.
Another was killed at Tollesbury in September 1872 (see Birds of Essex, p. 131). Two examples were obtained in the county in the autumn of 1900-one (which had been seen about for a fortnight) at Bradwellon-Sea on October 27, and one in Epping Forest on November 5.

\section{Jay. Garrulus glandarius (Linn.).}

A common resident in well wooded districts, in spite of incessant persecution.

\section{Magpic. Pica rustica (Scopoli).}

Formerly a common resident in all parts of the county, but now almost exterminated in most districts through persecution. It is now more numerous round our coast than elsewhere, especially, I think, in the Dengie Hundred, where it is, possibly, increasing in number.

\section{Jackdaw. Corvus monedula, Linn.}

An abundant resident, breeding commonly in places where an abundance of ancient timber affords suitable nesting sites.

\section{Raven. Corvus corax, Linn.}

Now only, it is to be feared, a rare autumn or winter visitor, though until quite recently a resident in small numbers. Early in last century it was fairly common in the county, and not a few 'raven trees,' in which it bred regularly, are still pointed out. It continued to breed occasionally in the inland parts of the county up to about the year 1865 . In the vicinity of the coast it lingered somewhat longer. There were nests annually near Thundersley up to the year 1880 , and a pair bred every year from 1871 to about 1878 in a clump of firs in the park of Lawford Hall. Up to at least the year 1890 the raven continued to breed regularly though in very small numbers among the islands and lowlands on the coast, in Dengie Hundred and the vicinity of the Blackwater Estuary - within forty miles of the Metropolis-making its nest in the tall elms which stand in the hedgerows and form a striking feature of the landscape in the district indicated. On April 15, 1889, I visited a 'raven trec'-a tall elm-on Osey Island, in whicls a pair had been known to breed for many years, but found it unoccupied. The nest used the year before lay rotting in a ditch below the tree, having been poked down by a lad with a stick the previous summer because a pair of hawks had laid eggs in it after the ravens had left it. The old birds had been seen about the island however a few weeks before, and had commenced a 


\section{A HISTORY OF ESSEX}

nest in another tree, but had afterwards departed and had probably nested, or attempted to nest, somewhere on the adjacent mainland. This survival of the raven as a breeding species until so recent a period is of much interest, for at the date in question it had long ceased to breed in any other county in the east of England. Mr. Fitch saw, on the shore at Fambridge, as lately as September I901, a bird which may possibly have bred in the vicinity.

\section{Carrion-Crow. Corvus corone, Linn.}

A resident, though uncommon, local, and decreasing in numbers through persecution, except in the south-western portion of the county, where it seems to be increasing, probably because of the large amount of refuse it finds among the London manure now used so largely in that district. It is now most abundant among the poorly-cultivated lands in Dengie Hundred and elsewhere round our coast.

94. Grey or Hooded Crow. Corvus cornix, Linn.

A winter visitor, common enough as a rule on and near the coast: much scarcer inland. It is reported (see Birds of Essex, p. I35) to have bred formerly on the coast in Dengie Hundred,

\section{Rook. Corvus frugilegus, Linn.}

An abundant resident. In its nesting babits it appears to be very erratic. Often a few pairs will nest in the late autumn or winter if the weather be mild: at other times old and well established rookeries are suddenly deserted in the middle of the breeding season without apparent reason: sometimes too a single pair or several will establish a new rookery which is often quickly deserted. Dun-coloured, creamy, or white varieties are not uncommon.

\section{Sky-Lark. Alauda arvensis, Linn.}

An abundant resident. In winter, especially if the weather be severe, large flocks arrive from elsewhere.

\section{Wood-Lark. Alauda arborea, Linn.}

Formerly, a resident, though scarce and local. Now it seems to have almost entirely disappeared from the county through some unknown cause.

\section{Shore-Lark. Otocorys alpestris (Linn.).}

A scarce and irregular winter visitor to our coast.
99. Swift. Cypselus apus (Linn.).

Locally, Shriek-Owl and Tommy-Devil.

A common summer visitor, breeding wherever there are buildings which afford it suitable nesting sites. It leaves early, about August 15 as a rule, but one was shot at Chesterford on October 27, 1877-an extremely late occurrence.

100. Alpine Swift. Cypselus melba (Linn.).

A rare straggler which has been reported, though on somewhat weak authority (see Birds of Essex, p. 145), as occurring in Essex on one or two occasions.

\section{ror. Needle-Tailed Swift. Acanthyllis cauda- cuta (Latham).}

The first recorded example of this very rare straggler to Britain was shot at Great Horkesley on July 8, 1846 (Zoologist, I 846, p. 1 492).

102. Nightjar. Caprimulgus europaus, Linn.

A regular summer visitor, common in districts where woods and bracken-covered commons abound, but elsewhere scarce and seen only when on migration.

103. Wryneck. Ij̈nx torquilla, Linn.

A fairly common summer visitor. It appears to vary considerably in its numbers from year to year.

104. Green Woodpecker. Gecinus viridis (Linn.).

Locally, Whetile, Yaffle, etc.

A fairly common resident in parks and wooded districts, but scarce in the more open parts : rapidly decreasing, it is to be feared, in the county, owing to frequent eviction from its breeding holes by the starling.

105. Great Spotted Woodpecker. Dendrocopus major (Linn.).

$A$ resident and widely distributed, but decidedly uncommon and seldom seen.

106. Lesser Spotted Woodpecker. Dendrocopus minor (Linn.).

As the last-named.

107. Kingfisher. Alcedo ispida, Linn.

A resident in all parts of the county but everywhere rather scarce and, I think, decreasing in numbers. A correspondent knew, however, of six nests during IgOI within five miles of Maldon. With the additional legal protection now afforded, the bird may hold its own and even increase. 


\section{BIRDS}

108. Roller. Coracias garrulus, Linn.

A very rare straggler. One shot at Great Chesterford in 1865 is now in the Saffron Walden Museum.

109. Bee-Eater. Merops apiaster, Linn.

A very rare straggler. One was shot at Feering about June 21, 1854, and another has been seen near Wanstead (see Birds of Essex, p. 150).

110. Hoopoe. Upupa epops, Linn.

A not uncommon though somewhat irregular passing migrant, at least one example being met with almost every year. It is most often seen during the latter half of April or early in May ; but it sometimes occurs in autumn, usually during September. It has bred in some other of the southern counties, but no instance of its having done so in Essex has been recorded. Its frequent appearance in pairs in spring leaves no doubt, however, that it would do so occasionally if not so mercilessly shot.

111. Cuckoo. Cuculus canorus, Linn.

A common summer visitor.

112. White or Barn-Owl. Strix fammea, Linn.

A fairly common resident in most parts of the county. No British bird more richly deserves the protection of landowners, farmers, and game preservers. All such should strictly enjoin their gamekeepers and other servants on no account to molest it. Its food consists almost exclusively of rats, mice, voles and shrews, though occasionally small birds are eaten. The damage it does to game is inconsiderable: its services to the farmer are immense.

113. Long-eared Owl. Asio otus (Linn.).

$A$ resident, though in very small numbers, except at Alresford, where it breeds frecly (Laver). Better known as an uncommon winter visitor.

114. Short-eased Owl. Asio accipitrinus (Pallas).

Locally, Woodcock Owl, Cabbage Owl, etc.

A winter visitor, common in some years, especially those in which the short-tailed field vole (Microtus agrestis) is abnormally abundant, but usually uncommon. Of late years however it has been known to breed on the Essex marshes on several occasions-as at Little Oakley from 1884 to 1897 (Kerry), on Northey Island in 1896 (Fitch, Zoologist, 1896, p. 233), and at Bradwell-on-Sea.
115. Tawny Owl. Syrnium aluco (Linn.).

A resident, but local and not common, though fairly numerous in some of our more extensive woods, where, however, it is much persecuted by game-preservers.

116. Tengmalm's Owl. Nyctala tengmalmi (Gmelin).

$A$ rare and accidental straggler to Britain. One was killed at Poplar at the end of January, 1877 (Zoologist, 1877 , p. 176).

117. Little Owl. Athene noctua (Scopoli).

A rare and occasional visitor which has occurred several times in the county. All now met with must be regarded with suspicion, as many have been turned out of late years.

118. Snowy Owl. Nyctea scandiaca (Linn.).

$A$ rare and occasional winter visitor which is said to have been seen in the county several times (see Birds of Essex, p. I 59).

119. Scops-Owl. Scops giu (Scopoli).

$A$ rare and occasional visitor. Some five or six examples are recorded as having occurred in the county. There is also some reason to think a pair may have bred more than once between the years 1886 and 1889 in the vicinity of Heydon, but the evidence is far from conclusive (see Essex Naturalist, iii. 17).

120. Eagle-Owl. Bubo ignavus, T. Forster.

Said to have been seen in the county (sec Birds of Essex, p. 161). The individuals observed had perhaps escaped from confincment.

121. Egyptian Vulture. Neophron percnopterus (Linn.).

An occasional straggler to Britain. On September 28, 1868, an immature individual was shot at Peldon (Zoologist, 1868, p. 1456).

\section{Marsh-Harrier. Circus aruginosus} (Linn.).

Formerly a common resident, breeding in numbers, especially in the marshy districts near the coast : now only an occasional visitor though not very rare.

123. Hen-Harrier. Circus cyaneus (Linn.).

As the preceding.

124. Montagu's Harrier. Circus cineraceus (Montagu).

Also as above, but less often met with. 


\section{A HISTORY OF ESSEX}

125. Buzzard. Buteo vulgaris, Leach. Locally, Puttock.

Formerly a common resident, breeding in all parts of the county. In the Epping district it was practically exterminated by the year 1830 , but at that time it still bred in the extensive woodlands in Rochford Hundred and elsewhere. Fields in many parts of the county still known as 'Puttock's Lees' attest its former prevalence. Now it is no more than a casual visitor, usually seen when passing on migration.

126. Rough-legged Buzzard. Buteo lagopus (Gmelin).

An uncommon and irregular visitor, chiefly during autumn and winter.

127. Spotted Eagle. Aquila maculata (Gmeliii).

A very rare straggler to Britain. One was captured alive in a very exhausted state at Elmstead on October 29, I 89 I (see Zool. I 89 I, p. 470 and Essex Nat. v. 2 I 8), and another, also much exhausted, was shot five days later, on November 3, at Leigh (see Essex Nat. v. 2 I 8, and Zool. I 892, p. 76). An eagle which was seen about Bardfield, Lindsell and Thaxted throughout the month of December following was probably of the same species. At least one other individual was shot and another seen about the same time in Suffolk, showing that the eastern counties must have been visited by something like a small flock of thesc birds-blown out of their way probably by a scvere gale which occurred just before they were seen.

128. Golden Eagle. Aquila chrysaëtus (Linn.).

An occasional winter visitor.

129. White-tailed Eagle. Haliaëtus albicilla (Linn.).

A winter visitor, seen not very uncommonly on the coast, especially during severe weather.

130. Goshawk. Astur palumbarius (Linn.).

A rare straggler which has been reported once or twice as occurring in the county, but under somewhat doubtful circumstances (see Birds of Essex, p. I68).

131. Sparrow-Hawk. Accipiter nisus (Linn.).

A resident and still fairly common, though steadily decreasing through constant persecution.

132. Kite. Milvus ictinus, Savigny.

Locally, Crotch-tailed Puttock.

Formerly a common resident. It bred in the county in some numbers up to about the year 1830 , and has done so occasionally since then. A pair is said to have nested at Mersea about 1845 , and $I$ have seen a fine male said to have been shot at Sampford about 1870 in the middle of summer (see Birds of Essex, p. I70). As no Essex specimen has been reported for many ycars it may be regarded as extinct in the county, though its occurrence as a casual visitor would not be surprising.

133. Honey-Buzzard, Pernis apivorus(Linn.).

Formerly a not uncommon summer visitor. There is no record of its having bred in the county for many years, but it has not improbably done so, as individuals have occurred from time to time in the height of summer. Now however it is with us not more than a passing migrant, usually seen during September when passing southward.

134. Gyr-Falcon. Falco gyrfalco (Linn.).

A rare winter visitor. A falcon shot beside the lake in Hatfield Forest about nine years ago by the late forest ranger is, I believe, a male of this species (or race), and leading authorities who have examined it have held the same view, though others have pronounced it a large female peregrine. It is exceedingly dark in colour, the back being almost black and the breast darkly striped. Another gyrfalcon, shot near Coggeshall in 1855 , but no longer in existence, may have belonged also to this or the nearly allied species (or race) known as the Greenland gyr-falcon (Falco candicans).

\section{I35. Peregrine Falcon. Falco peregrinus, Tunstall.}

Formerly no doubt resident in small numbers, and a pair is said to have nested in a tree at Sampford in the summer of 1843 (see Birds of Essex, p. 173). Now however it is only a winter visitor, though undoubtedly commoner than is usually supposed.

136. Hobby. Falco subbuteo, Linn.

Once a fairly common summer visitor, breeding regularly in the county. It nested at Felstead in 1877 , near Belhus Park in 1879 , at Great Waltham about 1885 , and near Bishops Stortford in 1887. Doubtless it has done so since, but no instance has come under my notice. Individuals still occur however from time to time.

137. Merlin. Falco asalon, Tunstall.

Now no more than an uncommon autumnal or winter visitor; but it is said to have bred formerly on the marshes near the coast in Rochford Hundred (see Birds of Essex, p. I 76). 


\section{BIRDS}

138. Red-footed Falcon. Falco vespertinus, Linn.

A rare straggler. One was shot at Alresford on May 31, 1873 (Zoologist, 1873, pp. 3615 and 3688): another at Suttons, Stapleford Tawney, on May 21, 1897 (Hope); another at Bradwell-on-Sea on October 17, 1901 (J. H. Gurney in litt.).

139. Kestrel. Falco tinnunculus, Linn.

Perhaps our commonest hawk, but nowhere abundant and certainly decreasing. Though harmless, or nearly so, scldom touching game of any kind, it is a 'hawk,' and as such comes in for a share of the relentless persecution dirceted against all 'hawks,' good and bad alike.

140. Osprey. Pandion haliątus (Linn.).

A scarce and irregular spring and autumn or winter visitor, met with chicfly in the estuarics of our rivers, but occasionally further inland.

14. Cormorant. Phalacrocorax carbo (Linn.).

A common visitor to our coast from autumn to spring: occasionally met with inland after severe storms.

142. Shag. Phalacrocorax graculus (Linn.).

As the foregoing, but less common.

143. Gannet. Sula bassana (I,iun.).

Not very uncommon off our coast from autumn to spring: sometimes found inland after very rough weather.

144. Heron. Ardea cinerea, Linn.

Locally, Frank, Frank-hern, and Hernshaw.

A common resident, seen frequently at ncarly all seasons of the year on the marshes near the coast. There are however only four regular heronries in the county. By far the most important is that at Birch Hall (the Rt. Hon. James Round, M.P.), numbering some two hundred nests. It is believed to have been started by a pair which came from Brightlingsea some thirty-five years ago, when the Magens estate there was sold and the purchasers persecuted the herons which had long nested there. The first pair nested on a large oak tree in Chess Wood. By the year 1877 , there were about one hundred nests. In 1878 , owing to the cutting down of some trees, the herons removed to Calves Pasture Wood, where they again increased largely. Later they returned, for a similar cause, to Chess Wood, where thcy now remain, carefully protected by Mr. Round. Our next largest heronry is that in Wanstead Park, the property of the Corporation of the City of
London. It has been established for a century or more and is most carefully preserved by the Conservators, the nearest public footpaths being closed during the nesting season. It has been increasing steadily for some years, and now numbers about fifty nests, which are placed in some tall elms growing on an island in the largest sheet of water in the park. Next in importance stands the heronry at St. Osyth Priory (Sir John H. Johnson, $\mathrm{Kt}_{\mathrm{t}}$ ). It was established by a single pair which came from Brightlingsca in 1872 , when the heronry there was destroyed; and, being protected, they increased steadily. There are now from thirty to forty nests, built for the most part in trees growing on two small islands in one of the ponds in the Nun's Wood. The smallest Essex heronry is that at Borcham House (Lieut.-Col. TufnellTyrrel). It has been established thirty or forty years, but has been removed more than once during that time from one site in the park to another, and has been several times almost destroyed by shooting the young birds. Recently, however, it has been protected, and in the spring of $190 \mathrm{I}$ there were about twenty-five nests.

There can be no doubt that there were formerly many other heronries in Essex. Thus Norden speaks (1594) of one at Tolleshunt D'Arcy, and Holman (about I7IO) of another at Belhus, Aveley. The names Heron Hall and Herongate at East Horndon imply the former existence of a heronry therc. A heroury existed for many years, as stated above, in Heronry Wood, near the church, at Brightlingsea; but, when the estate was sold, about 1870 , the heronry was destroyed by the purchasers, and the present proprietor $(\mathrm{Mr}$. John Bateman) has failed in his efforts to re-establish it. Formerly, too, there was a heronry on Walton's Hall Farm at Mucking. Isolated nests occur not infrequently.

145. Purple Heron. Ardea purpurea, Linn.

An accidental straggler, which has occurred in the county at least once-namely in a wood near Maldon in April 1839 (Essex Literary Journal, 1839, p. 126).

146. Great White Heron. Ardea alba, Linn.

A very rare straggler. One was observed on several occasions in and around the estuary of the Stour on October 3, 1823 (Trans. Linn. Soc, xv, 40). Another (which scems to have becn identified correctly) was seen on many occasions in June and July 1901, beside a small lake close to the house in Lexden Park, near Colchester (Sir M. E. Grant Duff). 


\section{A HISTORY OF ESSEX}

147. Night-Heron. Nycticorax griseus (Linn.).

A rare straggler. An immature female was shot at Dovercourt on November 29, I 880 (Zoologist, 1881 , p. 68), and a young male at Brightlingsea on December 5, I89 I (see Essex Standard, Dec. 17, 1891).

148. Little Bittern. Ardetta minuta (Linn.).

A rare and irregular visitor. Six or eight individuals are known to have occurred in the county, most of them in the autumn, but two were obtained in the middle of June, 1867 , when it is just possible they were breeding.

149. Bittern. Botaurus stellaris (Linn.).

Formerly, without doubt, a common resident, but now an uncommon and irregular winter visitor only, though a good many specimens have been met with. Probably some of these would prove, if examined critically, to be the American Bittern ( $B$. lentiginosus), which has occurred not unfrequently in Britain.

150. White Stork. Ciconia alba, Bechstein.

An occasional visitor. Two were taken at Tillingham in January I 879 (Chelmsford Chronicle, January 31, 1879).

I51. Black Stork. Ciconia nigra (Linn.).

Another accidental straggler. A fine female was shot beside the Stour at Stokeby-Nayland on or about April 12, I88I (see Birds of Essex, p. I 88).

152. Glossy Ibis. Plegadis falcinellus (Linn.).

Another accidental straggler. An immature individual was shot as it rose from the old decoy pond on the South Hall Marshes, Paglesham, on October I5, I872 (see Birds of Essex, p. 189).

153. Spoonbill. Platalea leucorodia, Linn.

Once without doubt a resident, breeding in the county, though there is, I believe, no actual record of its having done so. Now it is only an occasional visitor, chiefly during spring and autumn.

[Flamingo. Pboenicopterus roseus, Pallas.

An exceedingly rare straggler to Britain. One seen on our coast was afterwards shot in the isle of Sheppey on August 16, 1873. It was probably one which had escaped shortly before from the Zoological Society's Gardens.]

154. Grey-lag Goose. Anser cinereus, Meyer.

A winter visitor to our coast during severe weather. Occasionally seen inland.
155. White-fronted Goose. Anser albifrons (Scopoli).

A not uncommon winter visitor.

I 56. Bean Goose. Anser segetum (Gmelin).

An uncommon winter visitor.

157. Pink-footed Goose. Anser brachyrbynchus, Baillon.

An occasional winter visitor.

158. Red-breasted Goose. Bernicla ruficollis (Pallas).

An exceedingly rare straggler to Britain. One was shot out of a flock of brent geese on the Main, off Tillingham, near the Ray Sands, on January 6, 187 I (Essex Naturalist, iii. 35).

I59. Barnacle Goose. Bernicla leucopsis (Bechstein).

A rather uncommon winter visitor.

160. Brent Goose. Bernicla brenta (Pallas).

An abundant winter visitor to the seas around our coast, especially during severe winters, arriving usually early in October : seldom seen inland except when wounded. The vast numbers formerly seen now come however no longer. The numbers killed by the discharge of a single punt gun or by the discharge of a number of such guns fired simultaneously into a flock are often astonishingly large - as many as fifty in the former case and seven hundred in the latter (see Birds of Essex, p. 193). The light-bellied North American race (the $B$. brenta-glaucogaster of some writers) occurs not infrequently in small numbers.

I6I. Whooper Swan. Cygnus musicus, Bechstein.

A winter visitor to our coast, and occasionally seen inland. Its numbers with us depend largely upon the severity of the weather.

162. Bewick's Swan. Cygnus bewicki, Yarrell. Locally, Little Swan.

As the foregoing.

163. Mute Swan. Cygnus olor (Gmelin).

Common in a more or less domesticated condition: probably met with occasionally during winter in a genuinely wild state.

164. Sheld-Duck. Tadorna cornuta (S. G. Gmelin).

Locally, Bar-goose.

A resident on our coast, though very much less common than formerly and decreasing as a breeding species : more often seen in winter. 


\section{BIRDS}

165. Ruddy Sheld-Duck. Tadorna casarca (Linn.).

$A$ rare and occasional visitor. One is said to have been shot about twenty-five years ago on the Main, outside the estuary of the Blackwater (Birds of Essex, p. 200).

166. Mallard or Wild Duck. Anas boscas, Linn.

A fairly common resident, breeding in increasing numbers on the marshes round the coast and in private parks containing sheets of ornamental water. In winter the resident birds are however greatly recruited by arrivals from elsewhere. At this season considerable numbers are taken in our decoys.

167. Gadwall. Anas strepera, Linn.

Locally, Sand Wigeon.

A scarce winter visitor.

168. Shoveler. Spatula clypeata (Linn.).

A scarce resident breeding in small but increasing numbers at several spots on the marshes round our coast. Fairly common, especially near the coast, during the winter.

169. Pintail. Dafila acuta (Linn.).

A scarce winter visitor.

170. Teal. Nettion crecea (Linn.).

A resident, breeding in small numbers on the marshes round our coast and occasionally inland. Better known however as a fairly common winter visitor.

171. Garganey. Querquedula circia (Linn.). Locally, Summer Tcal.

A scarce visitor, chiefly when on migration. Not improbably it has bred in the county, but I know of no instance of a nest having been found, though a bird shot at St. Osyth on May 24, 1890, belonged probably to a breeding pair, and on July 17,1896 , nine (probably a family party) were seen together on a fleet at Paglesham (Hope).

172. Wigeon. Mareca penelope (Linn.).

A very common winter visitor on our coast : less often seen inland. Adults have been seen occasionally in the county during summer and young birds carly in autumn. Probably therefore it has bred with us, but there is no conclusive record of its having done so. Prodigious numbers were taken formerly in our decoys, and fair catches are still made.

[American Wigeon. Mareca americana (Gmelin).

A female is said to have been shot on the Essex coast in January 1862 , but the record requires further substantiation (see Birds of Essex, p. 201).]

\section{Red-crested Pochard. Netta rufina (Pallas).}

$A$ rare and casual visitor. One was killed near Colchester about January 1844 .

174. Pochard. Fuligula ferina (Linn.).

A common winter visitor to our coast. Vast numbers were taken formerly in the decoys. Early in last century a few bred occasionally on the marshes, but for a long period none were known to do so until within the last seventeen years. It is now resident in small but steadily increasing numbers at several spots round our coast, chiefly on the Old Hall Marshes, Tollesbury, where it first bred (so far as is known) in 1886.

\section{Ferruginous Duck. Fuligula nyroce (Guldenstădt).}

An occasional straggler during winter. One was obtained at the Marsh House Decoy, Tillingham, about the year 1880 (see Birds of Essex, p. 209).

176. Tufted Duck. Fuligula cristata (Leach).

A somewhat uncommon winter visitor to our const : occasionally met with inland. Not improbably it has bred in the county (for instance, at the Wade, in Steeple parish, in 1888 : see Birds of Essex, p. 206), but there is no authentic recorded instance.

177. Scaup-Duck. Fuligula marila (Linn.).

A fairly common winter visitor, principally to the coast.

178. Goldeneye. Clangula glaucion (Linn.).

As the foregoing.

179. Long-tailed Duck. Harelda glacialis (Linn.).

A rare winter visitor.

180. Eider Duck. Somateria mollissima (Linn.).

An uncommon winter visitor to our coast during severe weather.

181. Common Scoter. Edemia nigra (Linn.). Locally, Black Duck.

$A$ very abundant winter visitor to the seas round our coast : very rarely seen inland. A few non-breeding birds remain through the summer.

182. Velvet-Scoter. Odemia fusca (Linn.).

A scarce winter visitor to our coast. 


\section{A HISTORY OF ESSEX}

183. Goosander. Mergus merganser, Linn. Locally, Saw-bill.

An uncommon winter visitor.

184. Red-breasted Merganser. Mergus serrator, Linn.

A not uncommon winter visitor to our coast. A pair frequented the shores of Northey Island during the summer of 1888 , but apparently did not breed (Fitch).

185. Smew. Mergus albellus, Linn.

A scarce winter visitor.

186. Ring-Dove or Wood-Pigeon. Columba palumbus, Linn.

A very abundant resident, especially in wooded districts.

I87. Stock-Dove. Columba aenas, Linn.

A fairly common resident throughout the county and apparently increasing in numbers.

[Rock-Dove. Columba livia, Gmelin.

Occurs in all probability from time to time as a straggler; but it is practically impossible to discriminate between genuinely wild birds and those which have escaped from domestication.]

188. Turtle-Dove. Turtur communis, Selby.

A common summer visitor, apparently increasing in numbers.

189. Passenger-Pigeon. Ectopistes migratorius (Linn.).

A very rare straggler to Britain from America. An adult male, apparently wild, was killed on the very border of the county, between Chrishall and Royston, in July 1844 (see Birds of Essex, pp. 215 and 281). It is now in the museum at Saffron Walden.

I90. Pallas's Sand-Grouse. Syrrhaptes paradoxus (Pallas).

A resident on the steppes of Asia, whence it occasionally migrates westward across Europe in a most erratic and unaccountable manner. A few have reached Britain on several occasions, while in 1863 and 1888 large numbers arrived. On both occasions small flocks spread themselves over the county, and not a few individuals were shot, especially in I888. A few are reported to have remained at Barkingside through the summer of 1889 (Crouch : see Birds of Essex, p. 2 ( 7).

[Red Grouse. Lagopus scoticus (Latham).

It is difficult to regard two specimens shot respectively at Little $\mathrm{Tey}$, in the spring of I 864, and at Ulting, one autumn about 1885 , otherwise than as individuals which had been turned out.]

191. Pheasant. Phasianus colcbicus, Linn.

An abundant resident wherever sufficiently preserved.

192. Partridge. Perdix cinerea, Latham.

An abundant resident.

193. Red-legged Partridge. Caccabis rufa (Linn.).

Locally, French Partridge or Red-leg.

As the foregoing, though originally introduced. In some of the upland parts of the county it appears to be as abundant as the common partridge. The idea that its prevalence is inimical to the other species seems to have no foundation in fact, at least in Essex.

194. Quail. Coturnix communis, Bonnaterre:

Formerly fairly common, but now scarce and becoming, apparently, more so. It still breeds however occasionally in the county.

195. Land-Rail. Crex pratensis, Bechstein.

An uncommon summer visitor, breeding occasionally in most parts of the county, but far less often than formerly. It is however best known as a passing migrant in spring and autumn, and is killed not infrequently by partridge-shooters in September. Occasionally it occurs in winter.

196. Spotted Crake. Porzana maruetta (Leach).

A rare and local summer visitor, though probably commoner than is usually supposed. It stays occasionally well into the winter. Undoubtedly it breeds, or has bred, in Essex, but I know of no authentic instance of its eggs having been taken. Mr. Fitch has, however, an egg taken from the body of a female shot, many years ago, on Northey Island.

197. Little Crake. Porzana parva (Scopoli).

Rare. One was shot during October about the year 1885 at Paglesham (Birds of Essex, p. 224).

198. Baillon's Crake. Porzana bailloxi (Vieillot).

Rare. One was shot on October 3, 1874 , in a reedy ditch adjoining 'Dagenham Gulf,' and another on December 1, 1891, beside the river Lee, near Waltham Abbey.

199. Water-Rail. Rallus aquaticus, Linn.

A resident, but scarce and seldom seen on account of its skulking habits. During hard 


\section{BIRDS}

frosts it sometimes becomes fairly abundant. It breeds sparingly in suitable spots, such as the marshes round the coast and the lake near Holfield Grange, Coggeshall.

200. Moor-Hen. Gallinula chloropus (Linn.).

A very abundant resident. During winter large numbers arrive from elsewhere.

201. Coot. Fulica atra, Lims.

An abundant resident on and near the coast. Inland it is not often met with, but it appears occasionally on sheets of ornamental water in private parks and sometimes breeds in such situations. It is with us a decreasing species, and the vast flocks which used to appear on our coast during winter have now largely disappeared.

202. Crane. Grus communis, Bechstein.

Once probably common on the marshes, but now a rare and occasional straggler only. On November 9, 1888, one was shot out of a flock of eight which settled in a field at Elmstead near Colchester. In the following year one frequented Hamford $W$ ater and the adjacent mudflats for several weeks-from the end of September till towards the end of October.

203. Great Bustard. Ofis tarda, Linn.

Now only a very rare and occasional straggler, but formerly a resident, though probably never common in Essex, unless on the extensive open downs around Heydon and Chrishall. A female was shot at Woodham Ferris on December 5, 1879, during a severe frost. On the 6th of the following February another was killed on the border of the county near West Wickham, while a third is said to have been killed about the same time near Manningtree. A female was shot at Tillingham about the middle of December 1890 , and an individual has been reported to me as having been seen at Hatfield Broad Oak on October 31 , 1899 , during frosty weather.

204. Little Bustard. Otis tetrax, Linn.

$A$ rare and occasional straggler. It has occurred at least nine times in Essex-always during winter.

205. Stone-Curlew. OEdicnemus scolopax (S. G. Gmelin).

A scarce summer visitor, usually met with when on migration; but a few pairs breed still (or endeavour to do so) on the elevated downland in the extreme north-west corner of the county.

206. Pratincole. Glareola pratincola, Limn.

A rare straggler. A female was shot about the middle of August 1861, on the Old Hall Marshes, Tollesbury (see Birds of Essex, p. 233).

207. Cream-coloured Courser. Cursorius gallicus (Gmelin).

A rare straggler to Britain. An example was shot on October 19,1858 , when in a very exhausted condition on the Temple Mills Marshes beside the river Lea near Stratford.

208. Dotterel. Eudromias morinellus (Linn.).

A rare passing migrant in spring and autumn. The open chalk downs in the extreme northwest corner of the county were formerly a favourite halting-place.

209. Ringed Plover. Egialitis hiaticola (Linn.).

A resident on the coast, breeding sparingly in suitable localities. Large arrivals take place in the autumn.

210. Kentish Plover. Egialitis cantiann (Latham).

A rare passing migrant in spring and autumn.

211. Golden Plover. Charadrius pluvialis, Linn.

A common winter visitor, appearing in small flocks in all parts of the county after strong easterly gales and hard weather, and sometimes remaining till the beginning of April, by which time many have assumed their full breeding plumage.

212. Grey Plover. Squatarola helvetica (Linn.).

A fairly common visitor to our coast from autumn to spring.

213. Peewit or Lapwing. Vanellus vulgaris, Bechstein.

Locally, Green Plover, Black Plover, etc.

A common but by no means abundant resident, breeding on the marshes and in fields near the coast and at a few spots inland. Its numbers have been much reduced however by systematic 'egging.' From the inland parts of the county, where it bred formerly not uncommonly, it has been almost banished, probably by high farming. During winter, especially after rough weather, large flocks frequent the large open fields inland.

214. Turnstone. Strepsilas interpres (Linn.).

A fairly common passing migrant in spring and autumn, but individuals have been met with occasionally on our coast at almost all seasons of the year. 


\section{A HISTORY OF ESSEX}

2 15 . Oyster-Catcher. Hamatopus ostralegus, Linn.

Locally, Olive, Olaf, and Sea-pie.

A scarce resident on our coast, where it used to breed commonly, but now does so only occasionally. Fairly common as a winter visitor.

216. Avocet. Recurvirostra avocetta, Linn.

Now only a rare and accidental straggler, but formerly a not uncommon summer visitor. An old record leaves no doubt that in 1700 it bred on Northey Island (Dale : History of Harwich and Dovercourt, 1730, p. 402).

217. Black-winged Stilt. Himantopus candi$d u s$, Bonnaterre.

A very rare straggler. One was seen near Saffron Walden about the year 1820 (see Birds of Essex, p. 240).

218. Grey Phalarope. Phalaropus fulicarius (Linn.).

An uncommon and irregular visitor, generally when on its autumn migration. In some years it appears in numbers.

219. Red - necked Phalarope. Phalaropus byperboreus (Linn).

An uncommon passing migrant in spring and autumn.

220. Woodcock. Scolopax rusticula, Linn.

A resident, breeding occasionally in suitable localities throughout the county. It is better known however as a fairly common winter visitor, much more abundant in some years than others.

221. Great Snipe. Gallinago major (Gmelin).

A scarce visitor, generally when on migration in autumn, though one was shot near Waltham Abbey on February 27, 1897.

222. Common Snipe. Gallinago colestis (Frenzel).

A resident, but in very small numbers, breeding on the marshes at various spots round our coast and perhaps in Epping Forest. Much better known however as a common winter visitor, appearing singly or in small parties, usually before or during hard weather.

223. Jack Snipe. Gallinago gallinula (Linn.).

A not uncommon winter visitor.

224. Dunlin. Tringa alpina, Linn. Locally, Oxbird.

A very abundant visitor to our coast from early autumn to late spring: rarely seen inland. Non-breeding birds remain occasionally through the summer.

225. Little Stint. Tringa minuta, Leisler.

Not uncommon on the coast when migrating in spring and autumn.

226. Temminck's Stint. Tringa temmincki, Leisler.

A scarce straggler, seen occasionally when on migration.

227. Curlew-Sandpiper. Tringa subarquata (Güldenstädt).

Not rare, especially in some years, on the coast during autumn migration.

228. Purple Sandpiper. Tringa striata, Linn.

A regular though scarce winter visitor.

229. Knot. Tringa canutus, Linn.

Locally, Male or Marle.

A very common visitor to our coast from autumn to spring.

230. Sanderling. Calidris arenaria (Linn.).

A not uncommon visitor to our coast from autumn to spring.

231. Ruff. Machetes pugnax (Linn.).

Formerly a resident breeding on our coast : now known only as a scarce passing migrant in spring and autumn.

232. Common Sandpiper. Totanus bypoleucus (Linn.).

Not rare as a passing migrant in spring and autumn, but not recorded as having bred in the county.

233. Wood Sandpiper. Totanus glareola (Gmelin).

A scarce visitor, seen occasionally when on migration. 234. Green Sandpiper. Totanus ochropus
(Linn.).

An occasional visitor, met with singly or in small parties irregularly at almost all seasons of the year, most frequently on the coast but occasionally inland.

235. Redshank. Totanus calidris (Linn.).

An abundant resident on our coast, breeding in all suitable localities among the marshes and saltings, but rapidly decreasing, owing to persistent 'egging.' Its numbers are largely increased in winter by arrivals from elsewhere. 236. Spotted Redshank. Totanus fuscus (Linn.).

A rare visitor, seen occasionally when on migration. 


\section{BIRDS}

237. Greenshank. Totanus canescens (Gmelin).

Not uncommon as a passing migrant in spring and autumn.

238. Red - breasted Snipe. Macrorbamphus griseus (Gmelin).

A rare straggler. One is said to have been seen near Harwich in April 1882 (Birds of Essex, p. 254).

239. Bar-tailed Godwit. Limosa lapponica (Linn.).

Locally, Prine or Preen.

Fairly common on the coast when on migration.

240. Black-tailed Godwit. Limosa belgica (Gmelin).

As the foregoing, but less common.

241. Curlew. Numenius arquata (Linn.).

Very common on the coast from early autumn to late spring. A few non-breeding birds remain throughout the summer. Occasionally seen inland when migrating.

242. Whimbrel. Numenius phacopus (Linn.). Locally, Titterell.

Common on our coast during autumn, winter and spring.

243. Black Tern. Hydrochelidon nigra (Linn.).

Now only an uncommon visitor when on migration, but formerly a regular summer visitor, breeding in the county. Individuals still occur occasionally however in the county during spring and summer. For instance, a pair was shot at Paglesham in the middle of May 1890 , and another pair seen at Colne Point about the same time.

244. Sandwich Tern. Sterna cantiaca, Gmelin.

Now only a scarce passing migrant, but formerly a regular summer visitor, breeding on our coast. A few pairs continued to nest within the last twenty years, but they do so no longer.

245. Roseate Tern. Sterna dougalli, Montagu.

A rare summer visitor.

246. Common Tern. Sterna fuviatilis, Naumann.

Locally, Sea-Swallow.

Formerly a fairly common summer visitor, nesting regularly in the county. Now it is scarce and nests with us no longer.

247. Arctic Tern. Sterna macrura, Naumann.

An uncommon passing migrant in spring and autumn.
248. Little Tern. Sterna minuta, Linn.

Locally, Little Sea-Swallow.

Formerly a fairly common summer migrant, brceding at various suitable spots round our coast. A couplc of small colonies at most now exist.

249. Sooty Tern. Sterna fuliginosa, Gmelin.

A very rare straggler. One is recorded to have been killed near Colchester in the winter of 1880-1 (Field, April 23, 1881).

250. Lesser Sooty Tern. Sterna anrestheta (Scopoli).

Another very rare straggler. The only specimen known to have occurred in Britain was obtained on one of the lightships at the Nore in September 1875 (Zoologist, 1877, p. 213).

251. Sabine's Gull. Xema sabinii (J. Sabinc).

A very rare straggler. One was shot on the Thames in September 1862 (Harting: Birds of Middlesex, p. 252).

252. Little Gull. Larus minutus, Pallas.

An uncommon winter visitor. Most of the individuals which occur are immature.

253. Black-headed Gull. Larus ridibundus, Linn.

Locally, Peewit Gull (formerly) or Cob.

A resident, though in much smaller numbers than formerly. There are on our coast (as already stated) at least three islands which have derived the name of 'Pewit Island,' and several which have derived the name of ' $\mathrm{Cob}$ Island,' from the former breeding of this gull upon them. It is now the only species of gull which breeds in the county. It has at present only one or two comparatively small breeding colonies among the marshes and saltings on our coast in place of the many large colonies it had formerly. There appears to be no record of it having ever bred inland in Essex.

254. Mediterrancan Black-headed Gull. Larus melanocephalus, Natterer.

A very rare straggler. One was shot near Barking Creek in January 1866 (Seebohm: British Birds, iii. 315).

255. Common Gull. Larus canus, Linn.

A common winter visitor. A record that it formerly bred on our coast scems questionable (sec Birds of Essex, p. 263).

256. Herring-Gull. Larus argentatus, Gmelin. Locally, Great Cob.

A common winter visitor, especially on or near the coast. 


\section{A HISTORY OF ESSEX}

257. Lesser Black-backed Gull. Larus fuscus, Linn.

Locally, Great Cob or Saddleback.

As the foregoing. Some remain during the summer but do not breed.

258. Great Black - backed Gull. Larus marinus, Linn.

As the foregoing. A record that it formerly bred in the county seems doubtful (see Birds of Essex, p. 264).

259. Glaucous Gull. Larus glaucus, Fabricius.

$A$ rare and occasional winter visitor.

260. Iceland Gull. Larus leucopterus, Faber.

A scarce winter visitor. One was shot near Brightlingsea on January I, I 887 , and another in Harwich Harbour on December 3 , 1892 (Kerry).

261. Kittiwake. Rissa tridactyla (Linn.).

A winter visitor. Common on the coast and often driven inland by storms.

262. Great Skua. Megalestris catarrbactes (Linn.).

Locally, Turd-bird or Dung-eater.

A rare winter visitor to our coast.

263. Pomatorhine Skua. Stercorarius pomatorbinus (Temminck).

An occasional winter visitor to our coast.

264. Richardson's Skua. Stercorarius crepidatus (Gmelin).

An uncommon winter visitor to our coast.

265. Buffon's Skua. Stercorarius parasiticus (Linn.).

An occasional winter visitor to our coast.

266. Razorbill. Alca torda, Linn.

Fairly common at sea round our coast from autumn to spring. There are in the county no breeding sites suited to its needs.

267. Guillemot. Uria troile (Linn.).

As the foregoing. The 'ringed' variety is met with occasionally.

268. Black Guillemot. Uria grylle (Linn.).

A rare winter visitor. One was shot at Mersea in December 1869.

269. Little Auk. Mergulus alle (Linn.).

An irregular winter visitor: sometimes not uncommon, especially after severe storms, by which it is occasionally driven far inland.
270. Puffin. Fratercula arctica (Linn.)

An uncommon winter visitor to the sea round our coast from autumn to spring. Occasionally found far inland after rough weather.

271. Great Northern Diver. Colymbus glacialis, Linn.

Locally, Loon or Sprat-loon.

Fairly common at sea off our coast during winter.

272. Black-throated Diver. Colymbus arcticus, Linn.

As the foregoing, but less common. After severe storms individuals are sometimes found far inland.

273. Red-throated Diver. Colymbus septentrionalis, Linn.

Locally, Sprat-loon.

As the foregoing, but very much more abundant.

274. Great Crested Grebe. Podicipes cristatus (Linn.).

An uncommon winter visitor to our coast. It has bred in the county, so far as is known, on one occasion only-near Walton-on-theNaze in 1888 (see Birds of Essex, p. 275).

275. Red-necked Grebe. Podicipes griseigena (Boddaert).

An uncommon visitor to our coast from autumn to spring.

276. Slavonian Grebe. Podicipes auritus (Linı.).

As the foregoing.

277. Eared Grebe. Podicipes nigricollis (Brehm).

As the foregoing.

278. Little Grebe or Dabchick. Podicipes fuviatilis (Tunstall).

A resident, I believe, in all or nearly all parts of the county, but scarce everywhere except on and near the coast, where it breeds in decreasing numbers in the marsh ditches.

279. Storm-Petrel. Procellaria pelagica, Linn.

A winter visitor, generally seen when blown in towards the coast by severe storms, by which it is often driven far inland.

280. L.each's Fork-tailed Petrel. Oceanodroma leucorrboa (Vieillot).

A rare straggler, occasionally blown inland by severe storms during winter. 


\section{BIRDS}

281. Wilson's Petrel. Oceanites oceanicus (Kuhl).

A petrel, bought at Doubleday's sale, which Mr. Hope has (see Birds of Essex, p. 27I), is of this species : not Leach's. There is nothing to prove that it is the example, found dead in a field near Epping after a storm, about the middle of November 1840 , which Doubleday seems to speak of as a Leach's petrel ; but this is probable, as the bird is believed to be an Essex specimen.

282. Great Shearwater. Puffinus gravis (O'Reilly).

An occasional autumn and winter visitor.

283. Manx Shearwater. Puffinus anglorum (Temminck).

As the foregoing. Sometimes driven by storms far inland.

284. Fulmar. Fulmarus glacialis (Linn.).

An occasional winter visitor, seldom seen except when driven ashore by severe storms.

\section{ADDENDA}

285 (47a). Grey-headed Yellow Wagtail Motacilla borealis, Sundevall.

A very rare straggler to Britain. An example was taken by some bird catchers in a nightingale trap, set in the fields between Southend and Shoeburyness, early in May, some six or eight years ago (Keulemans).

286 (21 1 a). Lesser Golden Plover. Charadrius dominicus, P. L. S: Muller.

A very rare straggler to Britain, which has occurred once only in Essex. An example, believed to be an adult male, was shot on August 6, 1896, at Shellhaven Point, in the Fobbing marshes, by Mr. H. Nunn (Zool. 1897, p. 330).

287 (243a). Gull-billed Tern. Sterna anglica, Montagu.

A rare straggler to Britain. An example, one of five which flew over Ashdon on May 21, 1901, was shot by Mr. Howe, a gamekeeper, who still has it. I have not yet been able to examine it. It has been submitted to Mr. G. N. Maynard, curator of the museum at Saffron Walden, who believes that its identification is correct.

\section{SUMMARY}

The 287 species of birds admitted into the foregoing list as belonging to the county of Essex may be classified roughly as follows :-

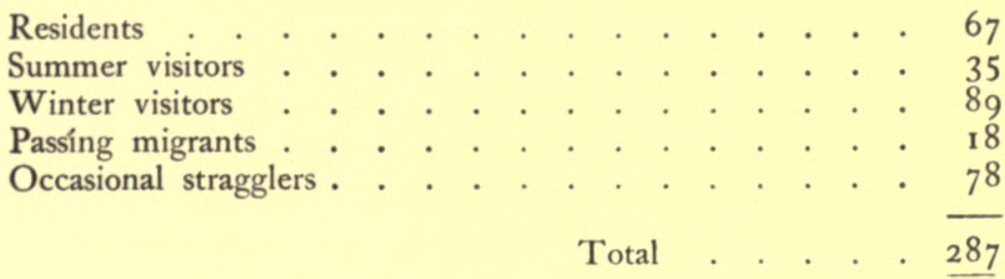




\section{MAMMALS}

The highly cultivated condition of the county of Essex has-been unfavourable to the continued existence of several of the larger mammals, though Epping Forest has been a haven of refuge for some species that would otherwise have been extinct. The list of Essex mammals (forty-eight in number) compares, however, very favourably with the total number of recognized British mammals, viz. seventy-two-fortyfive terrestrial and twenty-seven marine.

Of bats the list is larger than those of most counties, for we have eight out of the sixteen described by Bell, who credits Essex with one species, the greater horse-shoe bat, apparently in mistake. This bat does not exist anywhere in the county, certainly not in the locality Bell mentions. If it did exist some later record would be found, for it could hardly escape observation either on the wing or when in the hand, its characters being so very distinct and unlike any other of the family.

The badger, marten and polecat are now rare, especially the last two, yet up to the present time individuals have continuously existed. Evidence satisfactorily shows that in the earlier part of the nineteenth century all of them were fairly abundant.

Deer, in a wild condition, exist to-day in very few English counties. Yet in consequence of the survival in Essex of the virgin woods of Epping Forest, we are enabled to claim these interesting animals as members of our fauna, as they have undoubtedly been from time immemorial. Fallow deer remain until the present time; red deer were known until the early years of the nineteenth century, when the surviving members of the wild herd were removed to Windsor, but stags lingered in the Forest at least as late as 1827 (Proc. Essex Field Club, i. p. xlviii.). A few red deer have since been re-transferred to the forest in the hope of restoring the original stock, but they proved so destructive to the crops of the neighbouring farmers that they had to be destroyed. A herd was also introduced into Weald Park between twenty-five and thirty years ago. Roe deer, which appear to have been by no means rare in late mediæval times, became extinct for many years; but this species has also been re-introduced from Dorsetshire and is doing well.

Wild swine (Sus scrofa) appear to have existed in Essex until the sixteenth century, if not later. Amongst the muniments of Colne Priory is this passage :-

'The surveye of the Lordshipps and Manors of Earls Colne and Colne Priory, parcels of the possession of Richard Harlackenden, made in anno domini 1598 by Israel Amyse, Esq.,-Chalkney Wood-this wood in tymes past was impaled and the Erles of Oxcnforde in former times (for their pleasur bredd and maintayned wilde 


\section{MAMMALS}

swyne in the same untill the reigne of King Henry the Eight. About which time they were destroied by John then Erle of Oxenford, for that he understode that the inhabitants thereabout sustained by them very great loss and damage.' (Essex Note Book and Suffolk Gleaner, Nov. 1885, p. 136.)

The large estuaries which form so considerable a part of the shores of Essex, and the numerous sand-banks and creeks, are traps for the capture of a considerable number of marine mammals which from time to time are stranded on their shores or become entangled amongst these banks. The list of these accidental visitors is much above the average of most of the maritime counties of England where such facilities for their capture do not exist. Ten marine mammals, out of a total list of twenty-seven recognized as British species, have been recorded for Essex. These include the porpoise and the bottle-nose dolphin, both of which may be seen frequently off this coast and may therefore count as regular, not accidental, visitors.

\section{CHEIROPTERA}

1. Long-eared Bat. Plecotus auritus, Linn.

One of the commonest bats in Essex, and the one which is most frequently found entering open windows. Its haunts are usually under the roofs of buildings; sometimes, but not so commonly, in hollow trees.

2. Barbastelle. Barbastella barbastellus. Schreber.

Bell-Barbostellus daubentonii.

This bat is not nearly so rare as it is generally considered to be. Its habits and its haunts in woods and hollow trees prevent its coming so frequently under observation. When seen it is usually flitting up and down under the lee of a hedge or plantation, and its size at this time causes it to be passed over as a pipistrelle.

3. Serotine. Vespertilio serorinus, Schreber.

Bell-Scosophilus serotinus.

Twice only has this bat been captured in Essex, on one occasion near Chelmsford by Mr. Miller Christy. It must therefore be very rare in Essex, a rather extraordinary circumstance considering the number that have been taken in the immediate vicinity of the metropolis.

4. Great Bat or Noctule. Pipistrellus noctula. Schreber.

Bell-Scotopbilus nactula; White, Vespertilio alivivolans.

This is a common bat throughout Essex, but by its high-flying habits frequently eludes observation. It has its home very frequently in buildings but more commonly in hollow trees, and is frequent in those within the town of Colchester. White, in his account of this bat, allowed it a very short period of activity, but in this district it has a similar period to other bats and is very frequently to be seen as late as the middle of November flying through the streets of Colchester hardly above the houses. It is also commonly to be seen any autumn evening hunting for its prey low down in the valley of the Colne.

5. Pipistrelle. Pipistrellus pipistrellus, Schreber. Bell-Scosophilus pipistrellus.

A common bat everywhere, resting in houses or buildings as well as in hollow trees.

6. Natterer's Bat. Myotis nattereri. Kuhl. Bell-Vespersilio nossereri.

One of the commonest bats in the Colchester district, and found frequently throughout Essex. Cellars, caverns (as those under Colchester Castle) and similar places, are generally chosen as hibernacula. Crevices in the brickwork of the deep wells in Colchester district would also appear to be frequently selected for the same purpose, as in the late autumn these bats are frequently drawn up in buckets with the water.

7. Daubenton's Bat. Myoris daubentoni. Leisler.

Bell-Vespersilio daubensonii.

Is not rare throughout the county in suitable localities. It may often be found fying, or rather fitting, over water, generally only a short distance, sometimes a few inches, above it. A small pond nicely sheltered appears to be a sufficient hunting ground for a whole evening. It is rarely seen except in the neighbourhood of water. It chooses similar positions for the winter to those selected by Natterer's bat. 


\section{A HISTORY OF ESSEX}

8. Whiskered Bat. Myotis mystacinus, Leisler. Essex, its habits in every way resembling Bell-Vespertilio mystacinus.

Found, like Daubenton's bat, throughout those of that species. Both these bats are constantly mistaken for the pipistrelle, but they are neither of them so plentiful.

\section{INSECTIVORA}

I. Hedgehog. Erinaceus curopacus, Linn.

Everywhere common, in spite of the constant persecution of all game preservers. Frequently killed and eaten by foxes.

2. Mole. Talpa europrea, Linn.

Common everywhere.

3. Common Shrew. Sorex araneus, Linn.

Generally distributed and common everywhere.

4. Pigmy Shrew. Sorex minutus, Linn. Bell-Sorex pygmaus.

\section{CARNIVORA}

1. Fox. Vulpes vulpes, Linn.

Bell-Vulpes vulgaris.

Common throughout the county.

2. Marten. Mustela martes, Linn.

Bell-Martes abietum.

The Rev. R. Lubbock in his Fauna of Norfolk (1845) says this animal is still occasionally found in Essex. It was formerly very common, and I have heard old sportsmen speak of shooting it from the deserted nests of magpies.

Mr. H. M. Wallis says (Zoologist, 1879 , p. 264): 'In 1822 one was killed at Waltham Woods near Chelmsford.

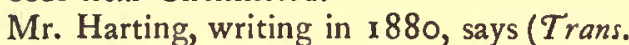
Essex Field Club, i. 95), the last killed in Essex, so far as could then be ascertained, was trapped in April, 1853 , by Mr. Luffman, head keeper to Mr. Maitland, in one of that gentleman's covers at Loughton.

From all accounts it appears, however, that the marten still exists in Essex. Mr. E. A. Fitch of Maldon, records (Essex Nat. iv. 1 53) the existence of undoubted martens in Hazeleigh Hall Wood, although he had failed to capture an individual.

The late Mr. English of Epping recorded (Fournal of Proc. Essex Field Club, iv. 64) having seen one near Ambresbury Banks, in the Forest, on July 30, 1883 . And there are accounts from other observers corroborating his statements.

3. Polecat. Putorius putorius, Linn. Bell-Mustela putorius.

Another member of the mammalian fauna
Nearly, if not quite, as common as the preceding species.

\section{Water Shrew. Neomys fodiens, Pallas.}

Bell-Crossopus fodiens.

Very common in the ditches and pools of the marshes, but it is not confined to these, as it may be found not uncommonly in all streams and ponds throughout the county. It is also found at some distance from water. A most interesting animal to watch when hunting in a shallow pool.

England which is rapidly disappearing in consequence of the great attention which is being paid to the preservation of game. In the earlier half of the century just passed it was not at all uncommon in many parts of Essex, and was well known to most of the country lads before 1830 . In the writer's boyhood it was a very common occurrence to disturb a polecat in a day's rabbiting in Paglesham and district, and there were very few of the country lads who had not experienced the truth of the saying 'stinks like a polecat.' It is probably not yet extinct.

Mr. Reginald Christy reports (Essex Nat. ii. 37): "The last specimen known to have been killed in the neighbourhood of Roxwell was trapped on the Boyton Hall farm in or about the year 1855.'

\section{Stoat. Putorius ermineus, Linn. \\ Bell-Mustela erminea.}

Still abundant.

5. Weasel. Putorius nivalis, Linn.

Bell-Mustela vulgaris.

Very common.

6. Badger. Meles meles, Linn.

Bell-Meles taxus.

The badger is by no means extinct in Essex. Some were liberated in Epping Forest by Mr. E. N. Buxton in 1886 and are doing well. In all probability they were not extinct there even before these were introduced. They certainly have never been extinct in the neighbourhood of Stanway. In the Essex Naturalist (i. 183) are records of captures in woods adjoining Epping Forest in 1850 and 1874 , and this appears to support the idea 


\section{MAMMALS}

that the badger was not extinct in the Epping district when Mr. Buxton liberated some in 1886.

In 1842 there were some badgers' earths or burrows on the sides of the hill near the woods at South Bemfleet.

In Benton's History of Rochford Hundred (i. 197), is a record of one being captured in 1841 on Foulness Island, and another on New England. Another was unearthed at Asheldham Hall in May, 1891 (Essex County Chronicle, May 29). In 1894 , eleven were captured near Braintree (London Standard, May 17). One was shot in Brooke's Wood, Stisted, carly in May, 1897 (Essex County Chronicle, May 14, 1897).

7. Otter. Lutra lutra, Linn.

Bell-Lutra vulgaris.

Some years ago this was a very rare animal and seemed approaching extinction, but lately it has become much more common in all parts of the county. Most Essex rivers are now haunted by otters, and they are also to be found in the reed beds and fleets of the marshes.

8. Common Scal. Pboca vitulina, Linn.

Occurs sparingly on all parts of the Essex coast, but is not seen every year. Properly speaking all the seals taken on the shores of this county can only be considered as stragglers.

9. Hooded Seal. Cystophora cristata, Erxl.

Mr. W. B. Clark records (Zoologist, I 847 , p. 1870) the capture of a specimen of this seal in the Orwell. It is now in the Ipswich Museum. As the Orwell empties itself into Harwich Harbour we are entitled to place this seal in our catalogue of the Essex fauna, although its normal habitation is within the Arctic Circle.

10. Grey Seal. Halicharus gryphus, Fabr.

In the Annals and Magazine of Natural History for 1841 is a record of the capture of an example of this seal in the Colne. The specimen is now in the Cambridge Anatomical Muscum.

\section{RODENTIA}

1. Squirrel. Sciurus leucourus, Kerr. Bell-Sciurus vulgaris.

Common throughout the county.

2. Dormouse. Muscardinus avellanarius, Linn. Bell-Myoxus avellanarius.

The distribution of this animal in Essex, as throughout England, is very unaccountable. In some parts of the county apparently suitable to its habits it is not found. In others of exactly similar character it is common. Generally it may be said to be found in Essex where oak and hazel abound, or where there is sufficient woodland or overgrows hedgerow to protect it.

\section{Brown Rat. Mus decumanus, Pallas.}

Much too abundant.

4. Black Rat. Mus rattus, Linn.

Not uncommon in those parts of the county bordering on the docks. It is a question whether all these are not importations. Probably extinct in the inland parts of Essex.

5. House Mouse. Mus musculus, Linn.

Abundant everywhere.

6. Long-tailed Field Mouse or Wood Mouse. Mus sylvaticus, Linn.

Abundant everywhere.
7. Harvest Mouse. Mus minutus, Pallas.

Until the last three years this mouse had been frequent throughout Essex. The close cutting of the stubble has been assigned as a cause of the present infrequency of it, but this can scarcely be the case as the closely cut stubble has been the rule here for years.

8. Water Vole or Water Rat. Mucrotus amphibius, Linn.

Bell-Arvicola amphibius.

Common wherever there are streams or pools. Black varieties occasionally are found.

9. Field Vole. Microtus agrestis, Linn. Bell-Arvicolo agrestis.

Abundant in all grass lands.

10. Bank Vole. Evotomys glareolus, Schreber. Bell-Arvicola glareolus.

Does not appear to be very frequent in Essex, although it was from this county that Yarrell obtained the first British specimen recorded. Probably it may be much more common than supposed if all voles captured were examined more carefully.

11. Common Hare. Lepus europecus, Pallas. Bell-Lepus timidus.

Formerly very frequent, but now in some districts approaching extinction in consequence
33 


\section{A HISTORY OF ESSEX}

of persecution and want of protection, the results of the Ground Game Act.
1 2. Rabbit. Lepus cuniculus, Linn.

Much too abundant everywhere.

\section{UNGULATA}

I. Red Deer. Cervus elaphus, Linn.

Mr. J. E. Harting quotes (Essex Nat, i. 55) from a manuscript note by Cary himself in a copy of Cary's Survey of the Country fifteen miles round London, 1786 (owned by Mr. B. S. Cole), the statement that the Crown had an unlimited right to keep deer in Epping Forest, of which, during Cary's time, and also when Norden wrote his Description of Essex, I 594 (ed. I 840, p. 9), there was a goodly stock both of red and fallow deer.

About 1827, according to Mr. J. E. Harting (Trans. Essex Field Club, i. 79), the last red deer were removed from Epping Forest to Windsor. Until that date this species had continuously from the earliest times been a resident in a wild condition in this county, as the various mention of red deer in the Forest records attest. It is stated (Fisher's Forest of Essex, 1887, p. 220) that an effort had been made a few years previously to restore red deer to the Forest by bringing back some from Windsor. The experiment, however, was not very successful, and so many complaints were made of the damage they caused that it was considered desirable to remove them, and orders were given for them to be destroyed. It is said (Zoologist, I 888, p. 74) that some still exist in the Forest, but whether there are any remaining or not the species may with justice be added to the list, for, with the exception of perhaps fifty years of the last century, the Forest has never been without wild red deer. Professor Flower records (Zoologist, 1887, p. 344) the existence of a small herd in Takeley Forest near Hatfield Broad Oak, the progeny of a single hind lost by the hounds during a chase.

\section{Fallow Deer. Cervus dama, Linn.}

This animal is probably an introduction into Britain, but as it has been many centuries truly feral in Epping Forest, we may fairly claim it as an Essex animal. Although fossil or semi-fossil remains of the red and roe deer are not infrequently discovered, none of the fallow deer have yet come to light.

The judicial decision which fortunately placed Epping Forest under the charge of the Corporation of London came just in time to save the remnant of the Epping fallow deer, as in 1870 the stock of the Forest had dwindled down to only five or six brace of deer and one buck (Fisher's Forest of Essex, p. 221 ; the Field, August 5, I 876, p. 156 ; and Zoologist, I888, p. 74).

Mr. J. E. Harting says (Essex Nat. i. 46) : 'The fallow deer have held their own in spite of all difficulties until the present time, and have strangely preserved their ancient character in regard to size and colour. They are comparatively small in size, of a uniform dark brown, almost black colour, in which respect they vary from herds in other parts of the country, and with very attenuated antlers '-characters which he considers show by their persistency the probable antiquity of the stock.

There are now at least 200 fallow deer in Epping Forest, all apparently with the same characteristics as above described.

\section{Roe Deer. Capreolus capreolus, Linn. \\ Bell-Capreolus caprea.}

Mr. Harting shows (Essex Nat. i. 58) conclusively from charters, court rolls, and other satisfactory proofs, some of them geological, that the roe was formerly an inhabitant of Essex. It disappeared from the forest of Essex apparently before Norden wrote his Description of Essex in 1594.

Mr. Harting also details the active part he took, in company with Mr. E. N. Buxton, one of the verderers of Epping Forest, in successfully reintroducing to the Forest in 1884 this interesting and beautiful creature, and we are thereby enabled to add this species to the Essex list (see also Field, April 5, 1884 , pp. $487-8$ ). In 1897 the Field further reported that the roes were doing well, and are supposed to number over twenty.

In excavating the remains of a Roman building at West Mersea, in 1897 , bones and antlers of the roe deer, were found, with those of the sheep and the small Celtic ox.

\section{CETACEA}

I. Common Rorqual. Balenoptera musculus, Linn. (Balanoptera physalis).'
There are numerous records of the capture or of the stranding of this whale on various

1 The names in brackets are those advocated by Dr. F. W. True, of the United States National Museum, in his revision of the names of the European whalebone whales (Proc. U.S. Nat. Mus. xxi. 617-35). 


\section{MAMMALS}

parts of our coasts. If there may be room for doubt concerning the identification of many of the specimens, there can be none with reference to that captured at Burnham on February 12, 1901, as this was examined and fully described by Mr. Walter Crouch (Essex Nat. v. 124).

\section{Rudolphi's Rorqual. Balenoptera borealis,} Lesson.

Bell-Balanoptera laticeps.

This whale, said to be rare on the British coasts, has been four times captured in Essex water within the last few years. The first record of this whale as an Essex species is by Dr. J. E. Gray (Proc. Zool. Soc. 1864, p. 2 I 8), who mentions one being found in Hope Reach, in the Thames near Gravesend, in the year 1 859. The second was stranded and killed near Cricksea, in the river Crouch, on November 8,1883 . It was identified by Professor Flower and described by him (Proc. Zool. Soc. 1883 , p. 514). The third was found dead at Tilbury, and was identified, drawn and described by Mr. Walter Crouch (Essex Nat. ii. 41). The fourth was captured in the Medway, and having passed through the Thames estuary must have been in Essex waters. This also was identified and described by Mr. Walter Crouch in the Rochester Naturalist for 1888 , where a figure and measurements are given.

3. Lesser Rorqual. Balenoptera rostrata, Fabricius (Balcenoptera acuto-rostra, Lacép.).

This is one of the best marked and most easily distinguished species of the family, and at the same time one of the most common on our coasts. It has occurred in the Thames several times. One is recorded and figured (Zoologist, 1843, p. 33), and is now preserved in the British Muscum. Mr. E. A. Fitch records (Zoologist, Nov. I 5, 1900) the capture of a small female in Mayland Creek.

4. Sperm Whale. Physeter macrocephalus, Linn.

This tropical whale has occasionally wandered to the shores of our island. A live one ran ashore in the Thames in 1788 (Bell's Brit. Quad. ed. 2, p. 417). Dale (Hist. of Harwich, ed. 2, 1732, p. 413) mentions one caught in the Thames.

An original manuscript letter from Walberswick, Suffolk, dated March 7, 1788 , preserved in the British Museum copy of the volume of the Philosophical Transactions for 1787 , records the appearance of twelve sperm whales after a hard gale of northerly winds in February, 1763. Two of these were driven ashore dead on the coast of Essex-the writer does not say at what point. He cut up however more than one of the twelve, and gives the dimensions of some of the animals.

\section{Bottle-Nose or Common Beaked Whale.} Hyperoodon rostratus, Chemnitz.

A well-known and easily distinguished species. There are several records of its capture on the Essex coasts. Hunter records one captured in the Thames in 1783 , above London Bridge (Bell's Brit. Quad. ed. 2, p. 423). Dale (Hist. of Harwich, ed. 2, p. 412) mentions one captured in the Blackwater, and in July, $189^{\circ}$, two males occurred in the Thames (Essex Nat. v. 170).

\section{Grampus. Orca gladiator, Lacépéde.}

Hunter records the capture of three specimens in the Thames towards the end of the eighteenth century (see Bell's Brit. Quad. ed. 2, p. 446). There is in the British Museum the skull of one taken on the Essex coast (Zoologist, 1873, p. 3429), and Dale (Hist. of Harwich, p. 412) mentions another specimen.

\section{Risso's Grampus. Grampus griseus, Cuvier.}

One of this species was found stranded in the Crouch about September 5, 1885, just above the spot where Rudolphi's rorqual, previously mentioned, was stranded. The remains of the skull and lower jaw were deposited in the British Museum, and Professor Flower, after examining them, confirmed the identification (see Zoologist, 1888 , p. 260).

8. Porpoise. Phocena communil, Cuvier.

Very common on the coasts and often seen in the rivers.

\section{Bottle-Nosed Dolphin. Tursiops tursio,} Fabricius.

\section{Bell-Delphinus tursio.}

Generally considered rare, but it is not so on the Essex coasts, where it may often be seen. There are records of many captures (Zoologist, 1882, pp. 147-351).

10. White-beaked Dolphin. Delphinus albirostris, J. E. Gray.

On September I I, I $88 \mathrm{~g}$, a school of nine specimens of this rare cetacean visited the Colne; five of them were captured (sec Zoologist, 1889, p. $3^{82}$ ). 



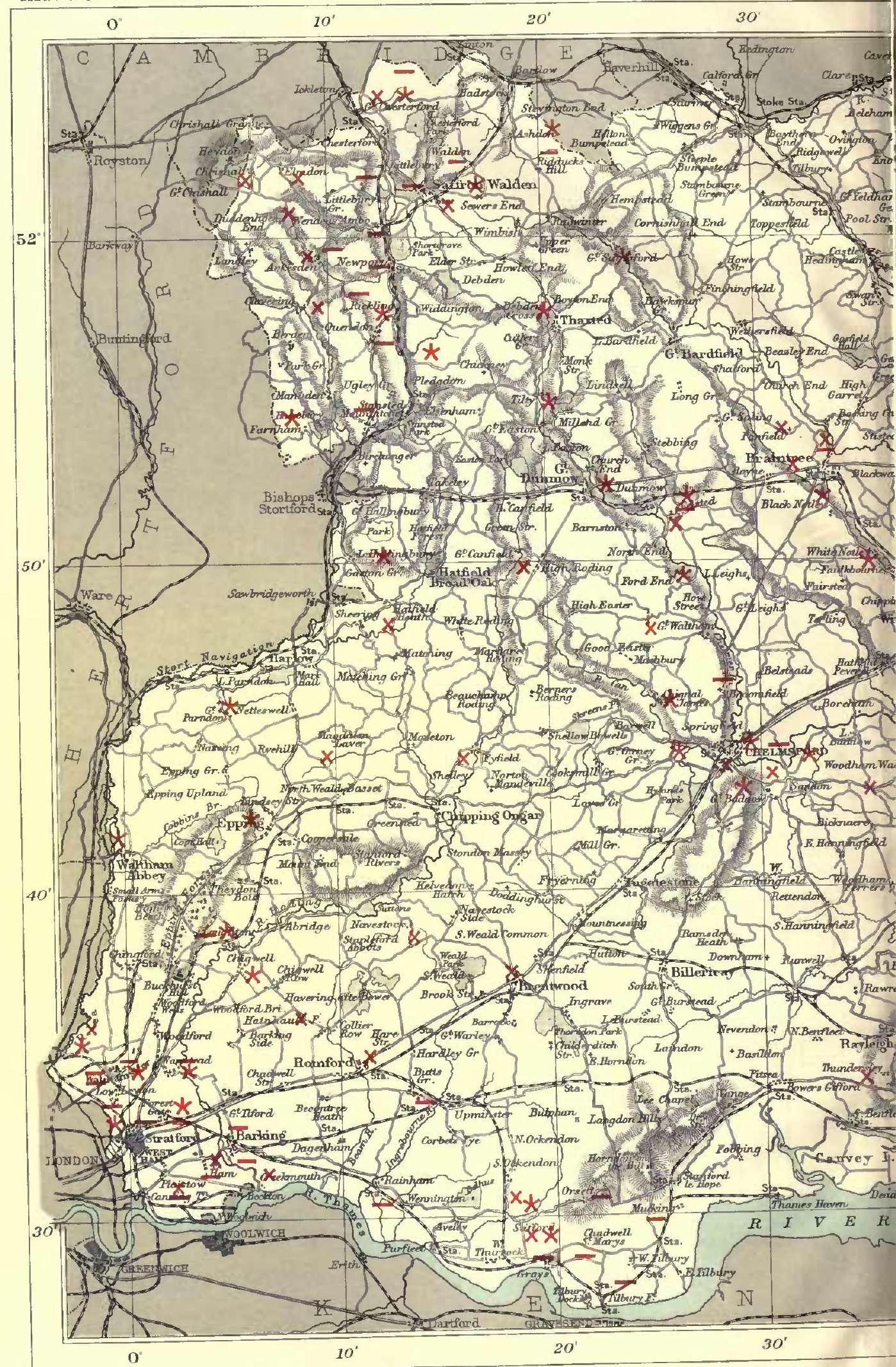





\section{EARLY MAN}

$\mathrm{R}$

EGARD being had to the necessarily uncertain date of the various archæological remains of early man, the period covered by this section of the local history cannot be arbitrarily limited, but may broadly be said to include the vast succession of ages between the appearance of man, as evidenced by his earliest handiwork, and the dawn of British history faintly traced in the writings of Roman historians. Nor can a terminal limit be fixed at the advent of the imperial power, for many stone, bronze and iron implements and much rude pottery must necessarily be classed as prehistoric, some of which may, for ought we know, have been fabricated in Romano-British days, while British coins were struck long after the Romans first attempted the conquest of the island.

\section{THE PALÆOLITHIC PERIOD}

In Essex few finds have been unearthed which raise the question of the existence of human beings in preglacial days ${ }^{1}$; nevertheless, to ages so remote that no approximation of date is possible must be assigned the first traces of man's presence.

Our land was then separated from the north-west of Europe only by the waters of a great river flowing northward, occupying a minute part of the space now covered by the North Sea, and no channel separated the chalk hills of Dover from Cape Gris Nez.

The waters which flowed through ancient valleys have left deposits of loam, sand and gravel, forming the strata yielding the major part of the implements of palæolithic man.

Some of these valleys remain, ${ }^{2}$ but so altered by geological changes since that period that the gravel terraces, once below water, now form the building ground of (for example) parts of Leyton, Walthamstow, Clapton and Stoke Newington.

It was from these terraces that Mr. Worthington G. Smith obtained many specimens which now enrich the British Museum, and from that source came numerous finds presented by the Rev. J. W. Kenworthy to the Essex Field Club collections. The Thames valley has yielded evidence of the presence of man at many points on its old terraces.

1 Mr. J. E. Greenhill expressed the opinion that there was proof of the presence of man in both interglacial and preglacial ages, and referred specially to an implement found below chalky boulder drift at Newport in Essex (Essex Field Club Fournal, iv. 95).

2 The broad rivers which eroded the valleys are now represented by narrower streams flowing at lower levels.

I 


\section{A HISTORY OF ESSEX}

Other Essex examples have been found in the Roding and smaller river valleys, while some finds have been made in the gravel on higher ground.

Coeval with the mammoth and Rbinoceros tichorbinus, now long extinct, and with the reindeer, hippopotamus, bison, hyæna and other animals no longer habitant in England, man waged war against beasts of forest and fen, his weapons being of wood or stone.

The paucity in variety of weapons indicates a savage condition in which man's wants were few ; while the chipped, but never ground or polished, tools show the narrow limit of his ideas of fabrication; but within those lines his works were excellent for their purpose, and display judgment in the selection of material and skill in shaping it.

Flint was in most cases the material used for the palæolithic weapons which have survived, and the varieties consist mainly of flakes, oval cutters and tongue or pear-shaped pointed implements; no relics which can with certainty be described as arrowheads have been discovered, but the sharply-pointed little triangular flints may have been used for arrowheads or served as javelin points.

The flakes, which probably were used as scraping and cutting instruments, are of much the same character as those of the neolithic period to be presently mentioned, but generally speaking they may be described as larger, coarser, thicker and broader. ${ }^{1}$

The tools referred to as oval cutters partake sometimes of more circular shape; they are flat in form and usually carefully chipped round the edge. It has been suggested that they were frequently used as missiles, but probably their use was multiplex (fig. I).

The implements which are best described as tongue-shaped or pearshaped are the most characteristic weapons of palæolithic man, serving probably as his constant companions in war, the chase and everyday life. They vary considerably in size, as in gradations of form, though all may be regarded as pointed implements. Most of our examples have a rounded butt, from which the sides taper. Some were probably hafted to handles, others possibly fixed to the end of wooden spears, but most would be suitable for use in the hand alone. Though not exactly of the celt or chisel form, these weapons may have been the embryo of the neolithic celt, which in its turn was the parent of bronze and iron axes, hatchets and adzes (fig. 2).

A 'palæolithic floor' at Little or East Thurrock provided $\mathrm{Mr}$. Worthington G. Smith with a fossilized antler, showing an artificial fracture produced by the straight edge of a palæolithic weapon, but it is rare to find relics of man of this period in any material other than stone. ${ }^{2}$

Cave dwellings of later palæolithic men have in some parts of the kingdom yielded a great variety of weapons of stone and of bone, and examples of rudimentary art in incised pictures, but we have discovered

1 Evans' Ancient Stone Implements (1897), p. 642.

2 Wood has been found on the palæolithic ground of the Lea gravels, and may have been used for stakes, clubs, hut roof timbers or other purposes. 


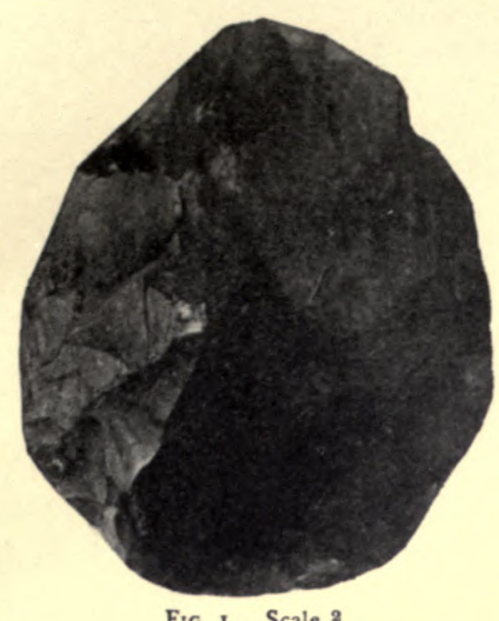

Fig. I. Scale ?

PaLelolithic Weapon of OVAL Form FRom the Lea $V_{\text {ALley. }}$

(Forest Museum, Chingford)

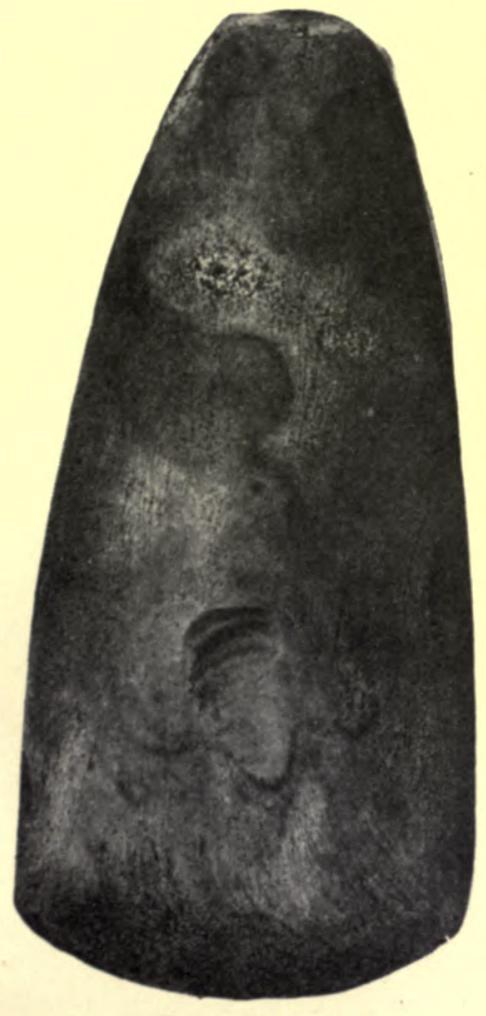

Fio. 3. Scale $\frac{2}{8}$

Neolithic Celt from Inworth. (Mr. Beaumont's Collection)

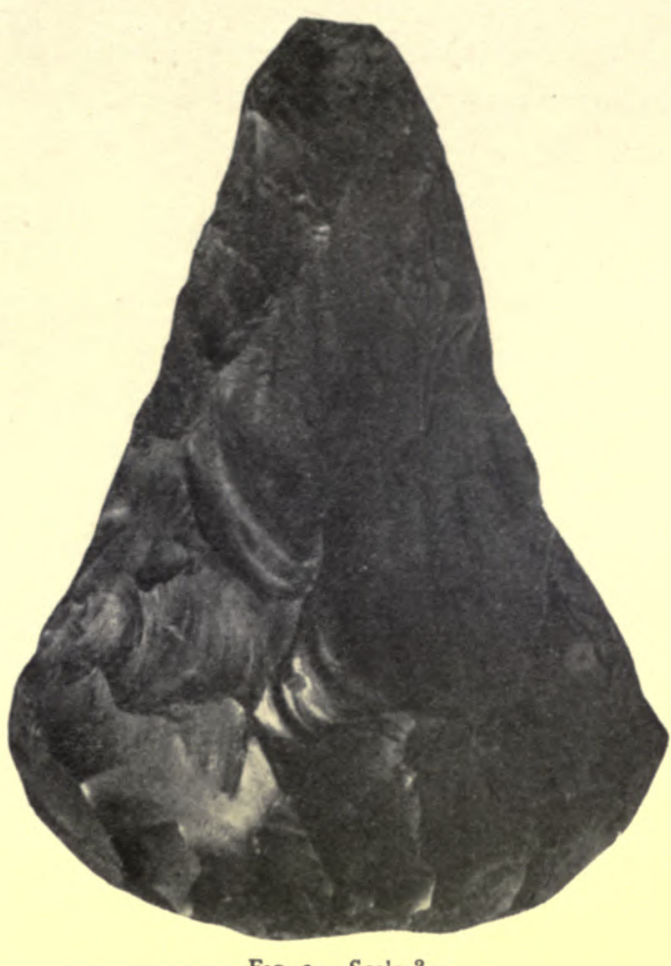

Fig. 2. Scale $\frac{2}{3}$

Palfolithic Weapon from the Lea V ALLEY.

(Forest Museum, Chingford)

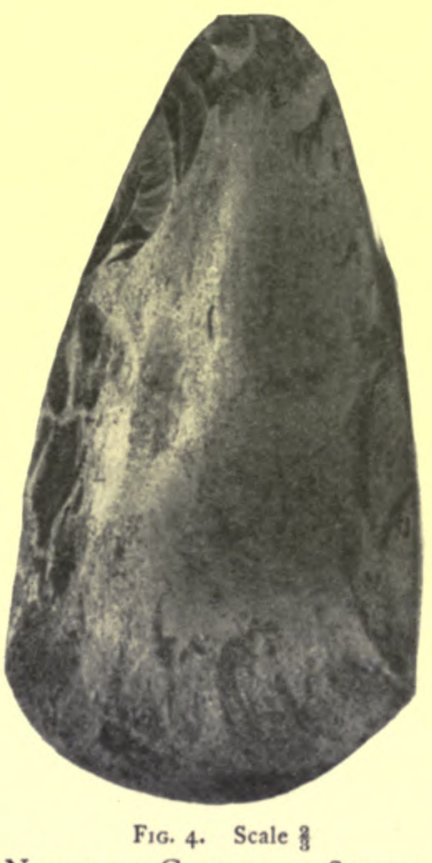

Neolithic Celt from Stisted. (Mr. Beaumont's Collection)

To face page 262 . 



\section{EARLY MAN}

no traces of cave-dwellers in Essex, though it is possible that the chalk range of the north-west or the outcrop on the south afforded opportunity for excavating such homes.

\section{THE NEOLITHIC PERIOD}

Ere neolithic man appeared great geological changes occurred, separating our lands from the continent by a channel. How long a time elapsed before the new race occupied the land we know not, nor where the continuity of the human species was maintained. We do know that man survived in more favoured regions of the earth, if not here, and migrated thence, bringing with him a higher civilization than had existed in the older times.

That he was far in advance of his palæolithic predecessors is amply evidenced by the greater variety of implements, the higher finish of many, and the introduction of pottery. The most prolific sources of relics have been burial barrows (generally long in shape and with skeleton remains, showing that the practice of inhumation prevailed), the sites of lake or mere-dwellings, and those of neolithic manufactories.

That the characteristic long barrows of neolithic man have existed in Essex is likely, but probably in the days of prosperous agricultural operations every example was destroyed, and we can only surmise the possibility of their existence at places where many relics have been found together. Nor have we yet discovered any example of a pile or fascine dwelling of undoubted neolithic date, though it seems possible that the recently-discovered traces of early habitation in the hollow of the Brain or Pod river near Braintree are of very early origin (see p. 270).

It is tolerably certain that a 'factory' existed near Walton-on-theNaze, where so many neolithic weapons have been unearthed, as chips and waste are also found.

The wide range of articles of the neolithic period makes it necessary to refer to the principal forms only.

Typical neolithic celts are of well-polished flint or other hard stone, but some which we know to be of the same period, from the circumstances of the discoveries, are rough-hewn or chipped, as were the palæolithic weapons.

The celts were used as hatchets, adzes or axes, the cutting end of the weapon being sharpened to an efficient edge by grinding." Stone implements of similar form are still used by the North American Indians as skinners for removing the hides of animals from the flesh (figs. 3, 4).

Wheresoever neolithic man's traces are observable, we find flakes of flint-some mere wasters thrown aside when the parent block was struck

1 The Hon. R. C. Neville (afterwards Lord Braybrooke) in 1848 opened a chamber at Heydon on the extreme north-west of Essex, which contained Roman remains. The chamber may possibly have been excavated long before Romano-British days, though used in that period.

A remarkable example from Walton, of greenstone, with grooves worked vertically to its cutting edge, is in Dr. Laver's collection. 


\section{A HISTORY OF ESSEX}

in manufacturing knives, scrapers, etc. ${ }^{1}$-others carefully chipped at the edge, suggesting their use as cutting or rasping instruments.

Small circular or oval implements chipped to a sharp edge are frequently found. It is generally thought that these were used as scrapers in preparing the skins of animals for clothing, for shaping wood for implements, etc. (fig. 5).

In arrowheads our Essex collections are poor, though some have been found (figs. 6, 7). To the legends and folklore gathered round these 'fairy weapons' space will not allow us to refer; suffice it to say that even to this day a certain or uncertain power of preservation from evil is in some quarters attributed to them. The use of arrowheads of flint and obsidian continued long after the neolithic period, and has hardly yet died out in certain remote parts of the world.

Longer pieces of flint, pointed and chipped to a cutting edge, served as spearheads, or maybe were hafted to handles for use as daggers and knives (figs. 8, 9, 10).

Pestles for pounding or grinding corn and food are occasionally found, but as their use extended to later days it is impossible to say with certainty that all appertain to the neolithic age. From the surroundings there can be no doubt that an example in Mr. Spalding's collection belongs to the period, but a remarkable implement from Epping Forest (Loughton parish) may have been fashioned by those Late Celtic men who built the earthwork fort near.

It is composed of hornblendic granite, or hornblendic gneiss, I $2 \frac{5}{8}$ inches long, tapering from a diameter of 2 inches to $1 \frac{3}{8}$ inches, and has been pecked and partially ground into shape. It is fully described by Mr. Worthington G. Smith in the Essex Naturalist (I888, vol. ii.), and may be seen in the Forest Museum at Chingford.

Occasionally, holed hammerheads, axes, or maces of hard stone are found ${ }^{2}$ (figs. I 1, I 2). A fine hammerhead, discovered at Epping, is illustrated in the Essex Naturalist, viii. I 64.

The discovery of spindle-whorls indicates a knowledge of that primitive method of spinning, while finds of weavers' weights show that weaving was practised, at all events, in the later part of the period.

Of neolithic pottery Essex has few or no recorded examples, though doubtless in the recent dark ages of archæology many an urn may have been smashed by the plough or the spade. ${ }^{3}$

Though the advent of a people who understood the art of smelting metals stopped the exclusive use of stone and bone for weapons, it must be remembered that stone implements were used for a long period after

1 In the shed of one of the present-day workers of gun flints at Brandon a bushel of such wasters was heaped.

\& Sir John Evans considers that perforated implements belong to the very late neolithic or early bronze ages. An example in Saffron Walden Museum of basaltic stone has a clean-cut hole, apparently bored with a metal tool.

3 Near Birdbrook two tumuli were levelled to the ground, when, according to the testimony of an agricultural labourer, 'some rubbishy pots were found instead of gold.' The tumuli may have been Romano-British, but their shape was suggestive of the neolithic period. 


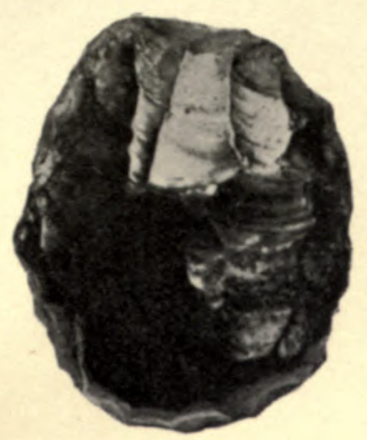

Fig. 5. Scale

Scraper from WaLton.

(Dr. Laver's Collection)

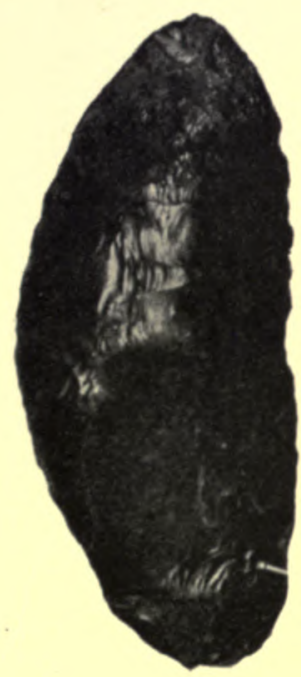

Fig. 8. Scale $\frac{2}{3}$

WEAPON From Shoebury. (Dr. Laver's Collection)

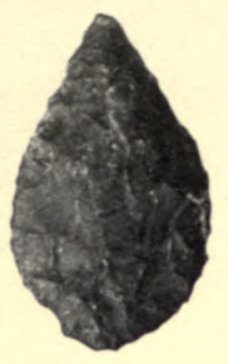

Fig. 6. Scale 1 Leaf-shaped Arrowhead FROM WALTON.

(Dr. Laver's Collection)

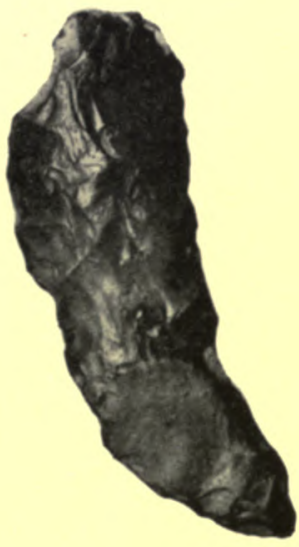

F1G. 9. Scale $\frac{?}{3}$

KNife from Dovercourt.

(Dr. Laver's Collection)

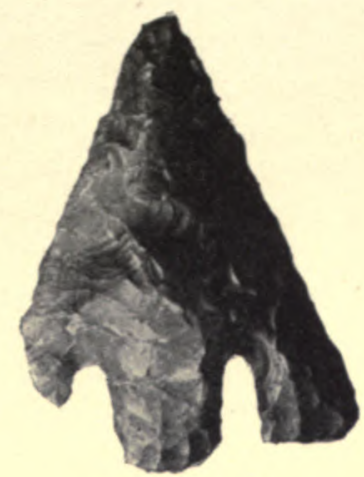

Fig. 7. Scale $\frac{1}{1}$

Barbed Arrowhead from W ALTON.

(Dr. Laver's Collection)

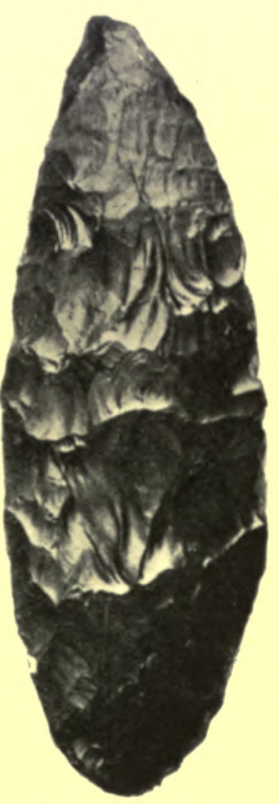

Fig. 10. Scale ?

Spearhead from $W_{\text {alton. }}$. (Mr. Spalding's Collection)

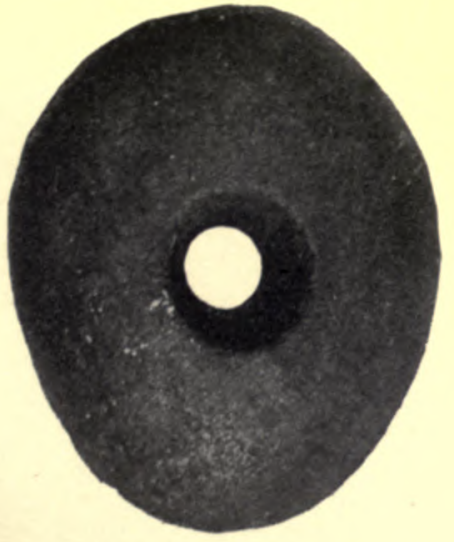

Fig. 11. Scale 웡

From the Blackwater near Stansgate. (Dr. Laver's Collection)

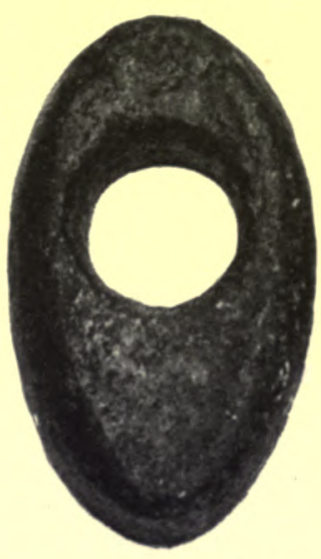

Fig. 12. Scale ?

From Colchester. (Dr. Laver's Collection)

To face page $25_{4}$. 




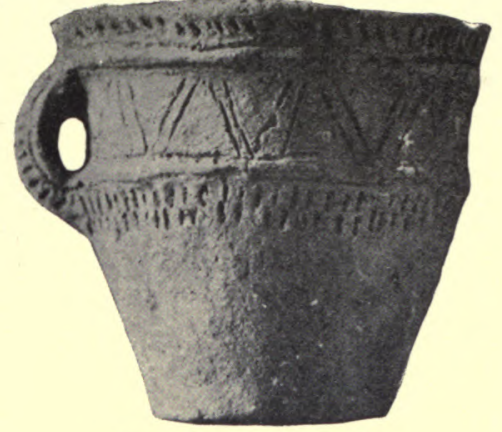

Fig. 13. 5 inches high.

From Chesterford.

(Saffron Walden Museum)

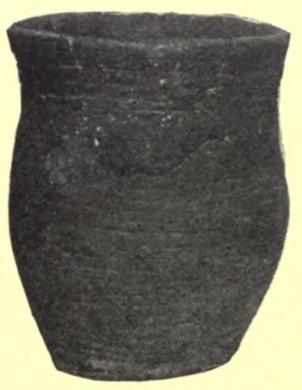

FiG. 15. 5 inches high.

From Great Clacton.

(Colchester Museum)

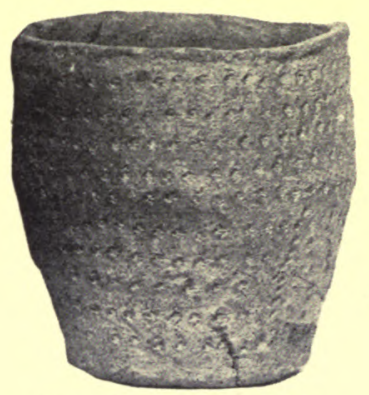

FIG. I6. 48 inches high.

From Great OAKLEY.

(Colchester Museum)

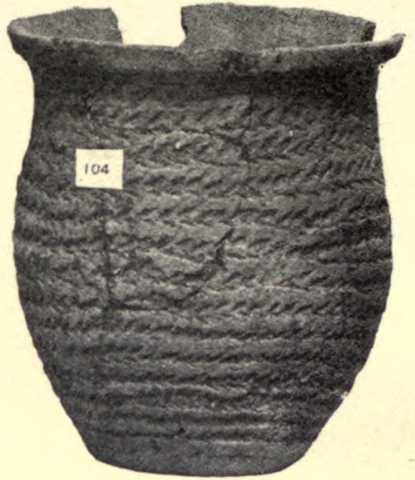

Fig. I4. $5 \frac{1}{2}$ inches high.

From Great Clacton.

(Colchester Museum)

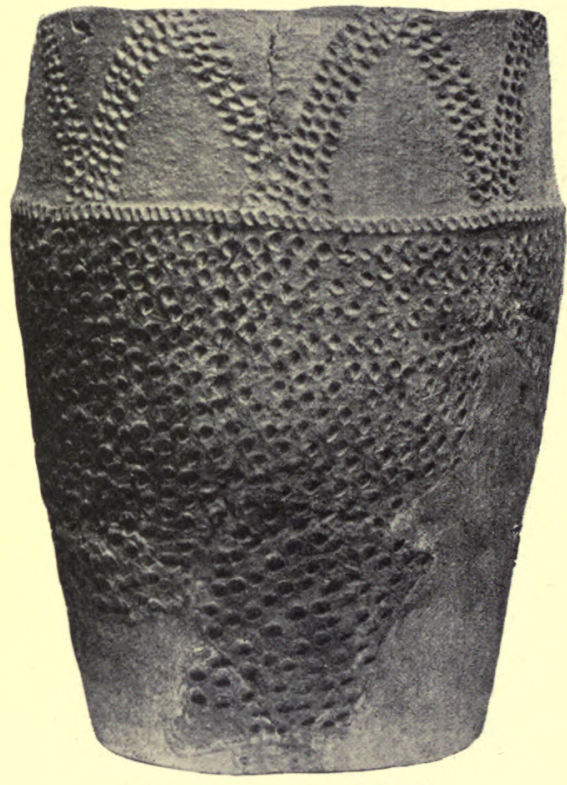

FIG. 17. $22 \frac{1}{2}$ inches high. From Colchester.

(Colchester Museum) 


\section{EARLY MAN}

the passing away of the neolithic age, and indeed have been fashioned and used to the present day by uncivilized races. ${ }^{1}$

\section{THE BRONZE PERIOD}

It is tolerably certain that the introduction of the use of metals here was accomplished by the advent of an alien race.

They practised a different mode of sepulture, generally burning the body instead of burying it, as was usually the neolithic habit. They reared round instead of long barrows over the dead, and their osseous remains indicate a broader-headed people than is shown by the skulls of neolithic men.

Though the two races continued to a large extent co-existent, the strangers (who are generally recognized as the first of 'Celtic' race to touch our shores) drove neolithic men from the more temperate and fruitful parts of the land.

Sir John Evans thinks that the bronze period may have commenced here c. I 200 to I 400 years B.c. and endured for not less than eight or ten centuries, which would bring it down to about 500 B.c.; but weapons to some extent, and ornaments more largely, were made of bronze long after the introduction of iron. ${ }^{2}$ Swords and beautiful ornaments of this material are found in many collections of Romano-British relics, and it has been said that even at the battle of Hastings (I 066 A.D.) some use was made of bronze weapons. This however is open to grave doubt, the notion being based upon an expression in Wace's poem, written in the twelfth century.

It is to the bronze age we must assign the dawn of decorative art. It gave vast variety of weapons, implements, ornaments and pottery, while some of the hill fortresses of our land owe their creation to that period.

The antiquities are too numerous to admit of more than the briefest reference; they include pottery, celts or hatchets and adzes, spearheads, gouges, sickles, knives and other implements of bronze, and personal ornaments and domestic articles of metal, stone, bone and horn.

Pottery was made and decorated with an art in advance of neolithic efforts. We give illustrations of four vessels probably of the earliest part of the bronze period (figs. I 3, I 4, I 5, I6).

Among the various vessels of this age in the Colchester Museum is the large example which we illustrate. It was found in the town in 1889 , is $22 \frac{1}{2}$ inches high and 15 inches wide at the top, and is of a pale red colour roughly decorated in the manner shown. The chevron pattern on the upper band is formed of three rows of distinct impressions; below this is a raised cordon ornamented, while the body is covered with simple indentations (fig. I7).

Workers in bronze (a mixture of copper and tin) seem to have

1 In Borneo timber is still felled with adzes of stone, though the natives possess beautifully finished and decorated steel weapons (Ironwork, by J. Starkie Gardner, 1893).

2 Some scholars are inclined to an earlier date and estimate it at about 2000 B.c. Dr. Schrader considers that it is to Babylonia we owe the discovery of the art of making bronze (Atheneum, June 8, 1901).

I 265 


\section{A HISTORY OF ESSEX}

travelled the land, carrying their material and casting it into weapons as required. Though isolated celts have occasionally been found, it is mainly to the hoards of the workers that we are indebted for the finds of bronze weapons in Essex, a county devoid of traces of such burial mounds of that age as have in other counties yielded a harvest of antiquities.

Some of the hoards may have been the property of dealers or merchants rather than founders, but when we discover lumps of raw metal and broken weapons (with or without the finished articles), there can be little doubt that they were the stock-in-trade of a bronze founder.

The founder's hoard discovered on Lord Rookwood's estate in Hatfield Broad Oak parish in 1893 included not only the metal for fusing

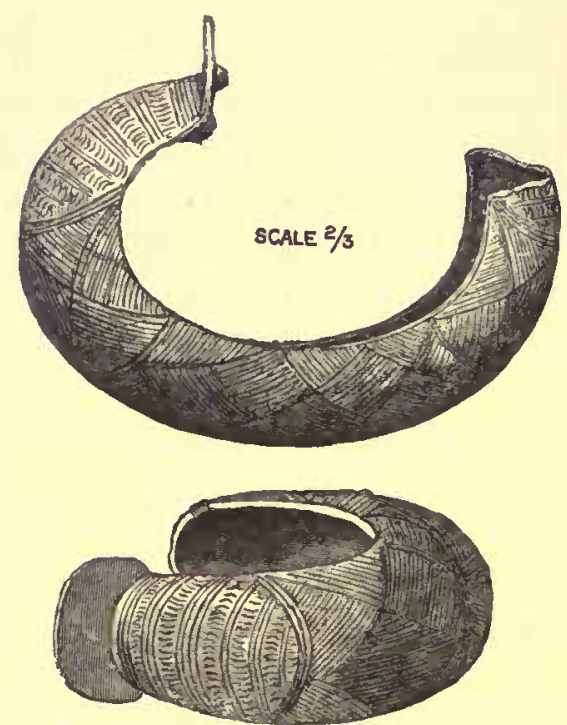

FIG. I 8.

Penannular Armlet from Shoebury. ${ }^{1}$

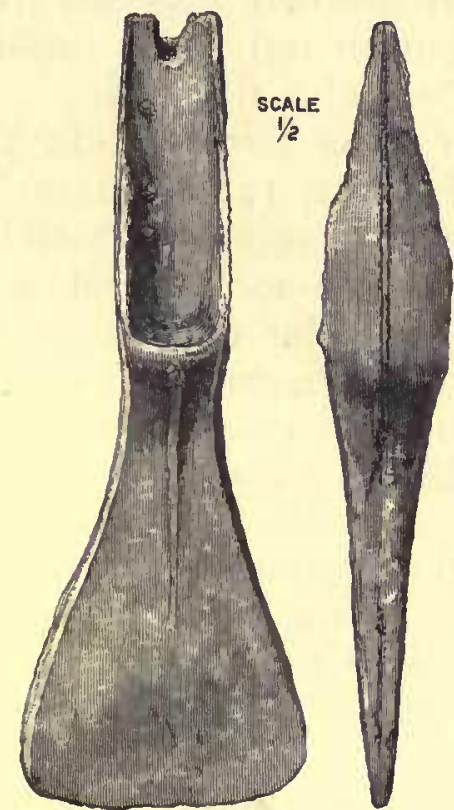

F1G. 19.

Palstave from Shozbury. ${ }^{1}$

but the remains of the earthen pot in which the hoard was contained. In addition to perfect socketed celts, broken weapons, cauldron handles, etc., a noticeable socketed hammer and the rim of a vessel decorated with line-ornament were discovered (figs. 22, 23, 26, 27, 28, 29, 32, 33). This valuable hoard was presented by Lord Rookwood to the Essex Archæological Society, and is exhibited in the museum at Colchester, where may also be seen a smaller hoard found at Southchurch, including a handle with rivet-holes (possibly of a sickle).

Shoebury was the source of discovery in 189 I of a hoard which is now exhibited in the British Museum, consisting of socketed celts, palstaves, part of a sword blade, etc. A penannular armlet decorated with diagonal hatching is of exceptional interest from the rarity of such discoveries, and is illustrated, together with a palstave showing details not usual on British examples (figs. I 8, I 9).

\footnotetext{
1 Cast from blocks kindly lent by the Society of Antiquaries.
} 


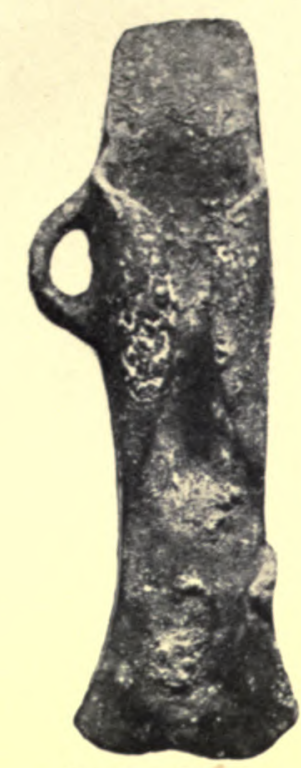

Fig. 20. Scale ?

Palstave from Shoebury.

(British Museum)

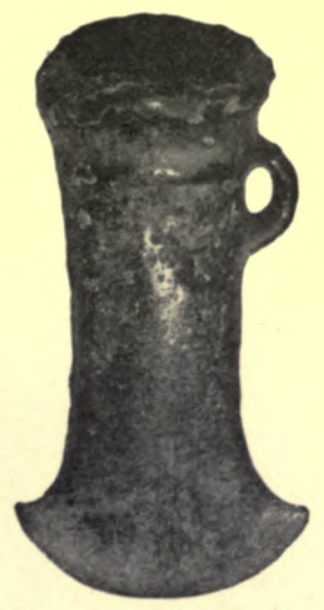

F1G. 22. $3 \frac{1}{2}$ inches high.

Bronze Socketed Celt from Hatfield Broad OAK.

(Colchester Museum)

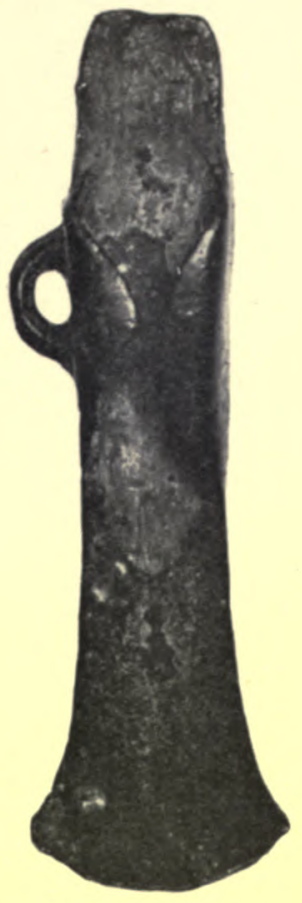

Fig. 21. Scale $\frac{2}{3}$ Palstave from Pleshey. (Dr. Laver's Collection)

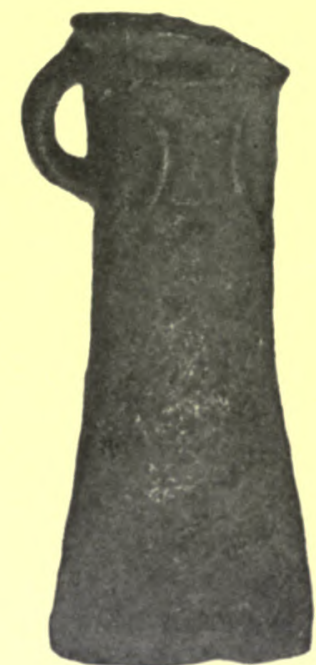

FiG. 23. $4 \frac{1}{8}$ inches high.

Bronze Socketed Celt from Hatfield Broad Oak. (Colchester Museum) 




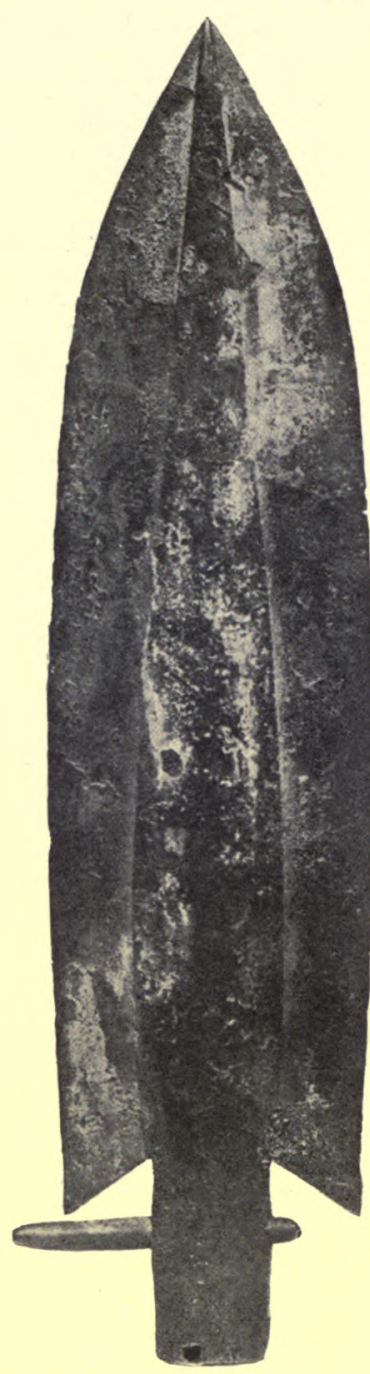

FIG. 24. Scale $\frac{1}{2}$

Bronze Spearhead from Plaistow Marshes. (British Museum)

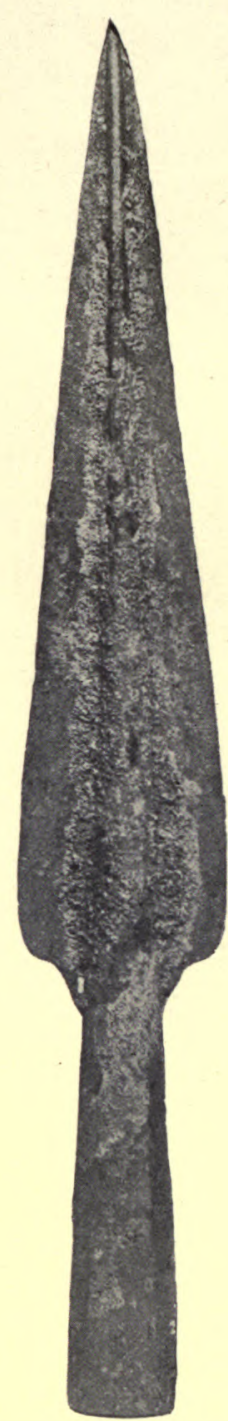

FIG. 25. Scale $\frac{1}{2}$

Bronze Spearhead from Walthamstow. (British Museum)
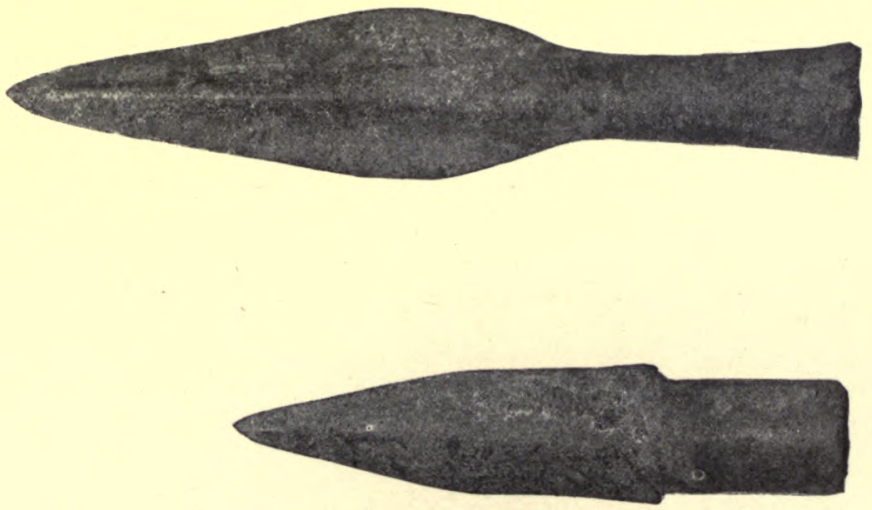

Figs. 26, 27. Scale $\frac{1}{2}$

Bronze Spearheads from Hatfield Broad Oak.

(Colchester Museum)

To face page 267. 


\section{EARLY MAN}

A hoard found at High Roding, exhibited at the British Museum, consists of twelve socketed celts and eight lumps of metal for fusing. In the same collection is part of a hoard from Chrishall containing some socketed celts, a broken sword blade, a spearhead, etc.

At Arkesden many weapons were found, also masses of metal and a mould used in casting a socketed celt. ${ }^{1}$

A small hoard from Romford is in the Saffron Walden Museum. Hoards of bronze have also been found at Baddow, Elmdon, Danbury, Grays, Fyfield, Thundersley and Wendon. Fifty or more celts were discovered together in a cleared portion of Hainault Forest near Hog Hill.

Thanks mainly to the works of Sir John Evans, the evolution of the bronze celt is generally known. The earliest type is that of the flat celt, a copy in metal of the most advanced axe of the stone age.

The second or palstave type has wings at the side, and is usually provided with a stop-ridge to regulate the position of the weapon in its handle, while some are also provided with a loop at the side for attachment (figs. 19, 20, 21). Occasionally, though rarely, a loop is on each side.

The third and latest development has a hollow socket for insertion of the haft and a loop for attachment (figs. 22, 23).

In decoration of their celts the workers in bronze occasionally displayed considerable art, but for illustrations of this fact and for minor developments and variations of form we must refer our readers to S:r John Evans' Ancient Bronze Implements, wherein the subject is so fully and lucidly treated.

In addition to those already mentioned, celts are recorded from Barking, Brentwood, Chelmsford (3), Felstead (3), Navestock, Panfield (5), Rayne (with spearheads) and Shoebury.

A sword about 2 feet in length discovered in the river Lea has rivet-holes for attachment to the haft, and is in the British Museum collection, together with a dagger from Bow Bridge and a knife from Walthamstow.

Barking yielded a leaf-shaped sword 18 inches long with four rivet-holes, and at Grays Thurrock there was found a bayonet-shaped blade $15 \frac{1}{4}$ inches long and $\mathrm{I}$ inch broad

In the British Museum is a bronze spearhead from Plaistow Marshes curiously barbed and riveted (fig. 24). At Walthamstow, in addition to the specimen shown (fig. 25), a leaf-shaped spearhead was discovered having a broad socket extending only an inch below the blade. A spearhead is also recorded from Hull bridge in the parish of Hockley.

In the Cambridge Museum of Archæology is a spear or daggerhead of uncommon form, found at Saffron Walden. It is perfectly flat,

1 The late Joseph Clarke, F.S.A., added an illustrated account of the Arkesden finds to his paper, entitled, 'Notes on Objects in the Mayer Collection (Liverpool) relating to Essex' (1891). 'This hoard unfortunately got scattered; a portion is in the Saffron Walden Museum and three of its celts are in Mr. Edward Taylor's collection, but we are unable to discover the whereabouts of the mould and many other articles. 


\section{A HISTORY OF ESSEX}

of lozenge shape, and provided with a flat tang; the blade is $3 \frac{\mathrm{I}}{2}$ inches in length by $\mathrm{I} \frac{5}{8}$ inches in width at the widest point, the tang being $1 \frac{1}{2}$ inches long by $\frac{1}{2}$ inch in width.

A very fine sword or dagger of bronze was found on Cains farm in North Weald. It is $5 \frac{3}{4}$ inches in total length and is illustrated in the Essex Naturalist (viii. I 63).

Space will not allow mention of the numerous other weapons and implements of the bronze age, but we may note in conclusion the remains of a fine bronze bowl from Walthamstow in the British Museum. It is of about 16 inches diameter, and retains the heads of the rivets by which the plates were attached.

\section{THE LATE CELTIC PERIOD OR IRON AGE}

At a date which may be approximated at about 400 B.c. a fresh swarm of invaders came, bringing knowledge of the preparation of iron, and the habit of using the metal, which caused this period to be known as the 'early iron age.'

Iron did not entirely supplant bronze, indeed the latter continued long in use, sometimes in conjunction with iron, as in knives or swords, of which the blades were of iron and the handles of bronze, sometimes alone, as in body armour of Roman soldiers-the first armour known to British archæologists.

Finds of early iron are comparatively rare notwithstanding the enormous use to which the metal was doubtless put, for unfortunately iron is as perishable as it is useful.

In Neville's Sepulcbra Exposita (p. ro) is an account of the discovery at Wendon ${ }^{1}$ of iron spearheads and the iron boss of a buckler, together with a vase of unbaked clay, apparently of early iron age. Belonging probably to the same period were the finds on Fambridge farm, ${ }^{2}$ where in $185 \mathrm{I}$ a hand-made urn was found on a crescent of burnt flints, together with other vessels in fragmentary condition. ${ }^{3}$

In the marshes of the Lea by Walthamstow relics have been found which indicate the existence of settlements in the iron age; notable among these is the iron celt with loop, now in the British Museum.

Its form is peculiar, while its interest is increased by the fact that fragments of its wooden handle remain in the socket (fig. 34).

Celts of iron are rare, but Sir John Evans records one $5 \frac{1}{4}$ inches long, with a rounded socket and no loop, found at Grays Thurrock in Essex."

Two coarse cylindrical urns thought to belong to this age and found at Great Bentley are in the Colchester collection. They stand about $9 \frac{\mathrm{I}}{2}$ inches high with a diameter of 7 inches.

Associated with fragments of early pottery, coarse, heavy rings of

1 It is not clear whether Wendon Lofts is intended or Wendens Ambo.

2 This farm is partly in Cressing and partly in White Notley parish.

3 Essex Arch. Soc. Trans. ii. 240.

4 Ancient Bronze Implements, p. 144. 


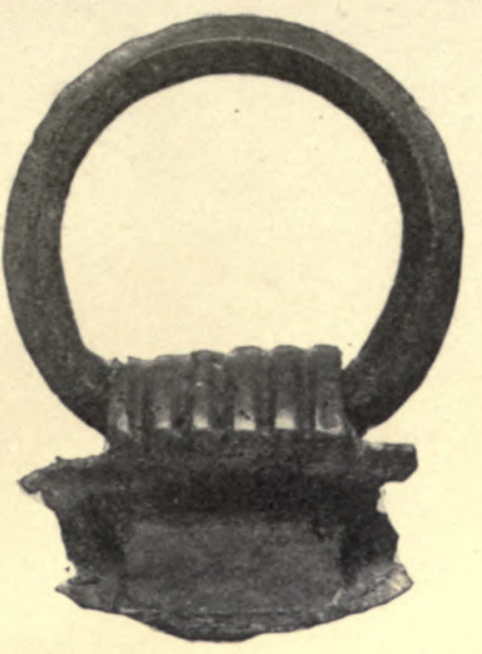

Figs. 28, 29. Scale $\frac{1}{2}$

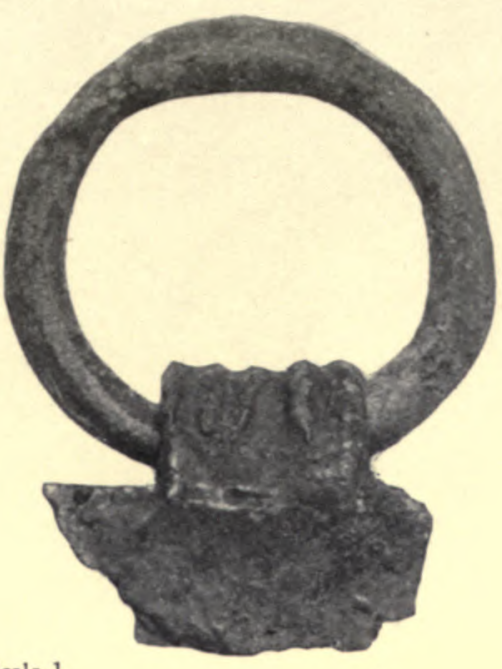

Two Handles of a Bronze Cauldron or large Vessel. (Part of the Hatfield Broad Oak hoard in Colchester Museum)
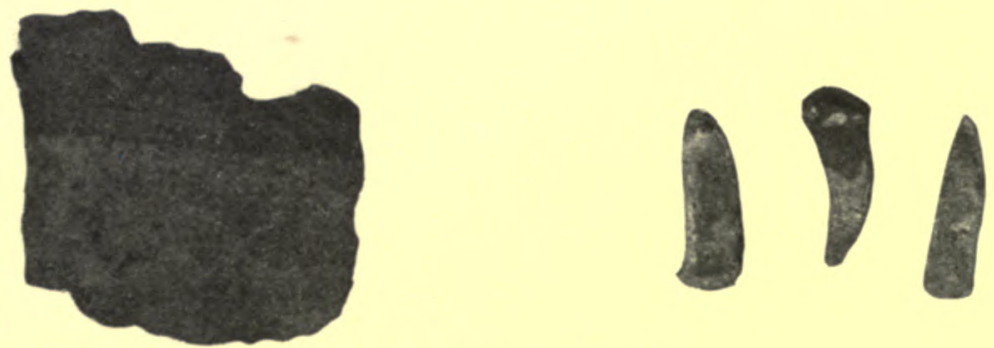

Fics. 30, 31. Scale $\frac{1}{2}$

Part of the Box of a Chariot Wheel found at Shoebury, together with Three Bronze Nails probably used for holding the Tire.

(Dr. Laver's Collection)

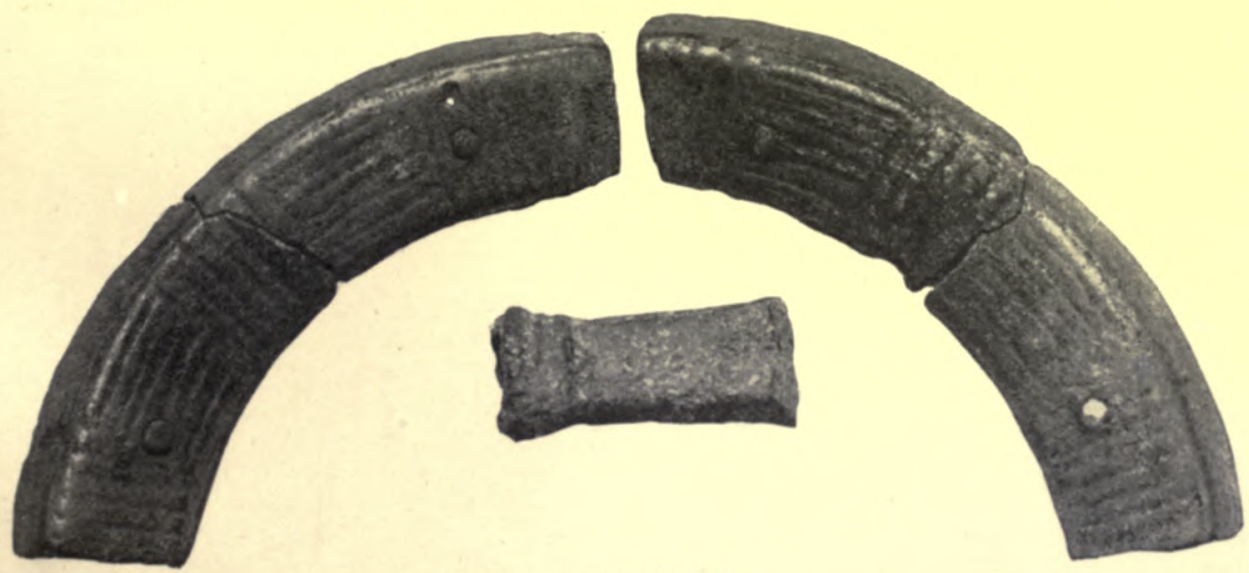

Figs. 32, 33. Scale $\frac{1}{2}$

Parts of the Rim of a Large Vessel, Decorated with Punched Lines, and Socketed Bronze Hammer.

(From the Hatfield Broad Oak hoard)

To face page 268 . 




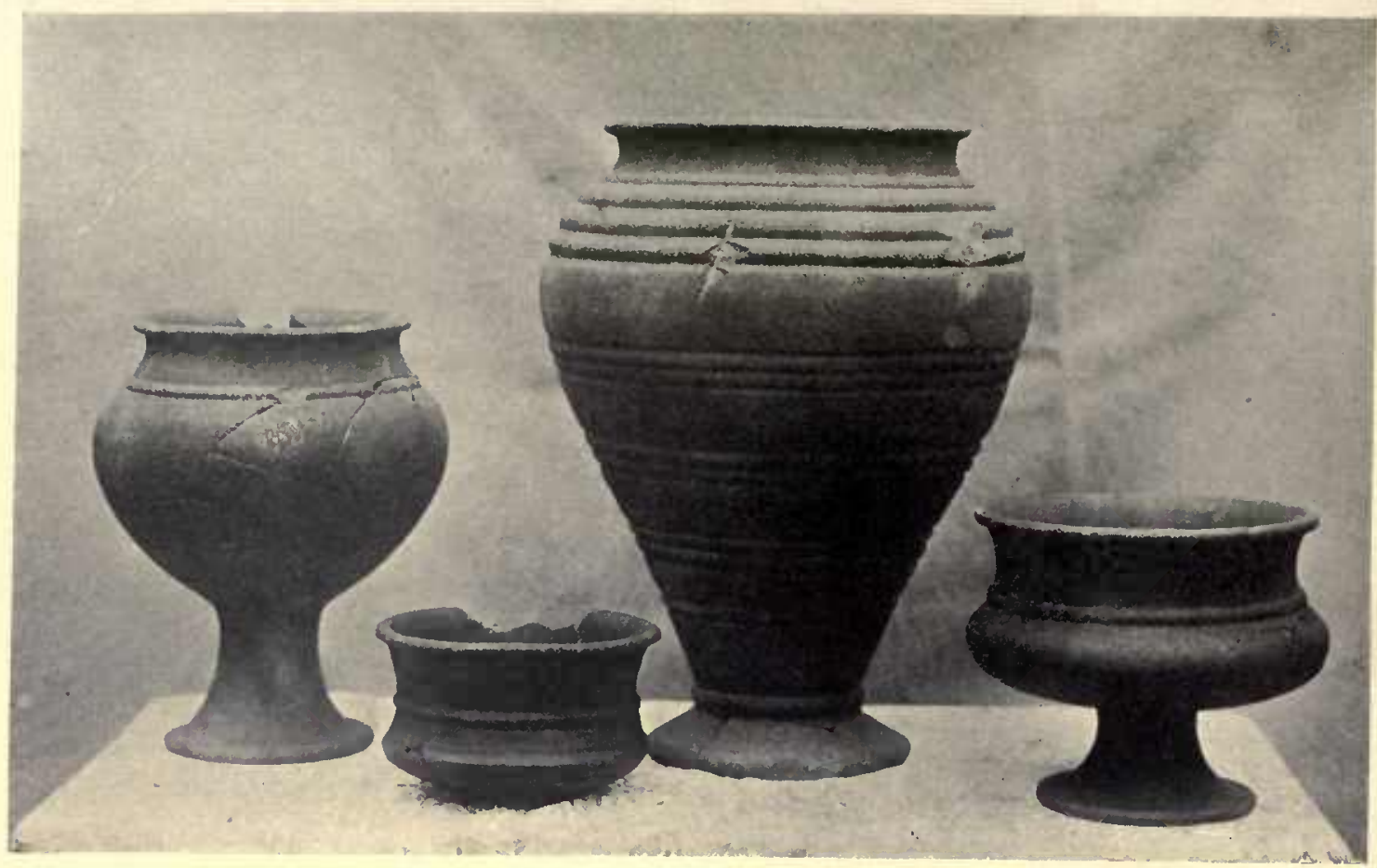

Figs. 35, 36, 37, 38. Scale $\frac{1}{5}$

Late Celtic Vesshis found at Shohbury,

(Colchester Museum). From negative kindly lent by Mr. J. C. Shenstone.

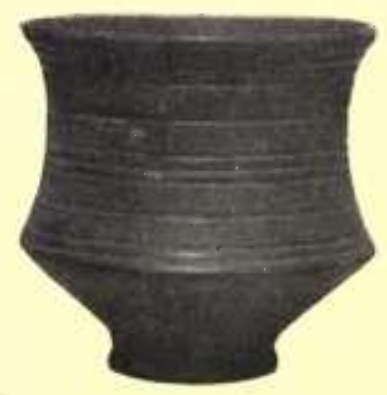

F1G. 40. $4 \frac{7}{8}$ inches high. Late Celtic Vessel.

(Colchester Museum)

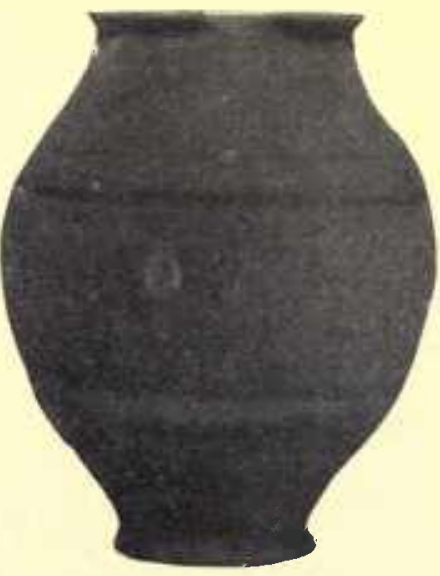

FIG. 39. 8 inches high.

Iate Celtic Vessel found at Colchester.

(Colchester Museum)

To face page 269 .

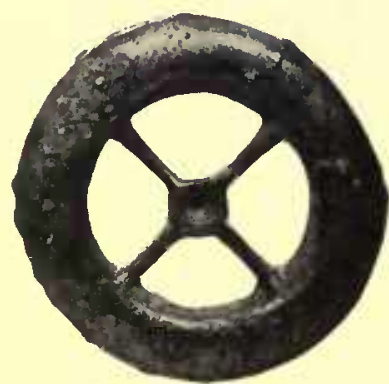

FIG. 42. Full size.

Found at Colchester.

(British Museum)
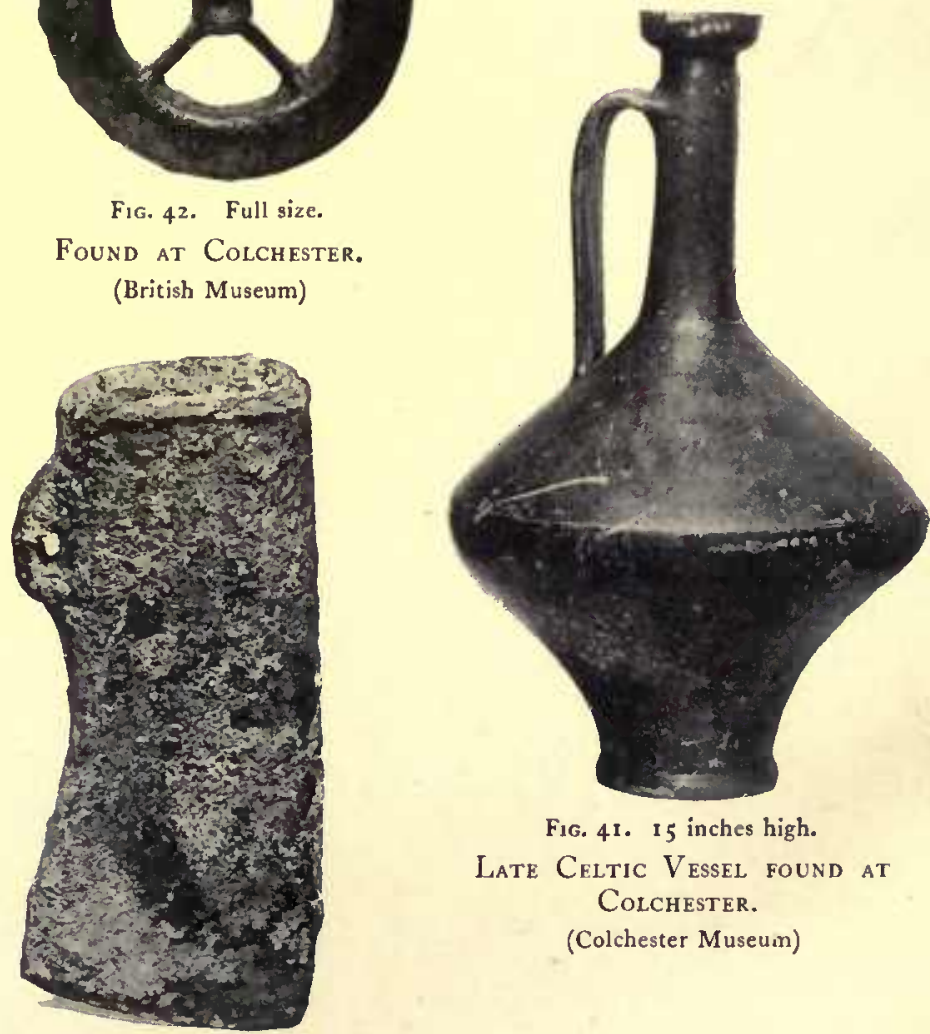

Fig. 4I. 15 inches high.

Late Celtic Vessel found at Colchester.

(Colchester Museuin)
Fug. 34. Scale $\frac{1}{2}$

Iron Celt from Walthamstow. (British Museum) 


\section{EARLY MAN}

burnt clay have been found at Southminster and other places. These are usually styled ' net sinkers,' but it is open to question whether they were not used to support pots in burning in the kiln. ${ }^{1}$

Other collections contain articles found in Essex appertaining to the early iron age, but the exigences of space compel us to pass to the later portion of the period under consideration, the time that produced those vessels upon which so much light has been shed by Dr. Arthur Evans in his paper on a late celtic urn field at Aylesford, Kent. ${ }^{2}$ Dr. Evans lucidly shows how this late (probably Belgic-Celtic) pottery was developed from bronze models, both in decoration and, in some instances, in shape also, and the course of the migration from northern Italy is indicated. We may not dwell on this, but use for illustration the vessels now in Colchester Museum which came from the rich ground of Shoebury in $1896^{3}$ (figs. $35,36,37,3^{8}$ ).

In the same museum we see an urn of this period $8 \frac{3}{8}$ inches in height which was found in Colchester; this we illustrate (fig. 39), as well as a beautifully turned vessel $4 \frac{7}{8}$ inches high discovered in the neighbourhood (fig. 40). These are of dark grey colour.

In the Joslin collection at Colchester may be seen examples of this late Celtic workmanship, showing sometimes by their juxtaposition that the earlier tradition of this form had survived in Romano-British days. Fragile bronze fibulæ of remarkable beauty accompanied an earthenware vase of polished red surface with a handle and the 'carinated' form suggestive of a bronze model (fig. 41).

Lord Braybrooke has some late Celtic pottery at Audley End, and it is not difficult to find examples in other Romano-British collections. Chigwell has provided some fragments, and one vessel found at Southend is preserved in the Technical Schools in that town.

To the late Celtic period is assigned work in gold and some enamel decorations found in various counties, but in Essex we have no definite record of such finds, though possibly the beautifully enamelled vase, discovered in one of the Bartlow Hills in 1835 , and attributed to the Romans, was the work of Celtic enamellers to a Roman design. ${ }^{6}$

In the British Museum is a small wheel-like article of unknown purpose, which (judging from somewhat similar forms found in Gaulish contemporary cemeteries) is of the late Celtic period. It is $\mathrm{I} \frac{1}{2}$ inches in diameter, has four spokes, and is not pierced in the centre of the hub, as would be the case were it part of a toy. This was found at Colchester some years since (fig. 42).

Here it may be well to refer to the recent discovery of a British dug-out boat or canoe, near Walthamstow, in the course of excavations

1 See similar articles from continental lake dwellings in British Museum.

- Arebalogia (1890), lii.

- Essex Arch. Soc. Trans. n.s. vi. 222.

- Group 30, No. 178 , Joslin collection, Colchester Museum.

6 This vase was greatly injured in the fire which destroyed Easton Lodge in 1847 . A portion of it is in the British Museum, and a facsimile of the whole vessel stands by its side. It was illustrated in colours in Archaologio (t836), xxvi. A facsimile is also in Saffron Walden Museum. 


\section{A HISTORY OF ESSEX}

carried on in forming new reservoirs for the East London Water Company. ${ }^{1}$ Though not, strictly speaking, found within the county of Essex, as now understood, its discovery in the border river bed may excuse reference here.

It is hollowed out of a piece of oak, is nearly I 5 feet long by 2 feet 4 inches in extreme breadth, and is I foot 4 inches in its extreme depth. A rib is left across (6 inches wide and 7 inches deep) at 8 feet from the stern, while nearer the bow a smaller rib has been left.

These measurements are quoted from a note in the Reliquary (vol. vii.). In the Essex Naturalist (vol. xii.), is a full page illustration of the boat in situ at the excavations, with some particulars as to the geological conditions of the valley of the Lea.

Our sketch of antiquities would not be complete without a chronicle of the British coins found in Essex, or relating to the county, were not that subject dealt with by another writer. In a separate chapter will be found our notes on the Ancient Earthworks.

So far as those relics of antiquity are concerned which can be classed as palæolithic, neolithic, bronze or late Celtic our task is accomplished, but it remains to notice the antiquities from the fascine dwellings at Braintree, which it is impossible at present to assign to a definite period, the question of its date awaiting the result of further examination.

Our thanks are due to C. H. Read, Esq., F.S.A.; W. Cole, Esq., F.L.S.; to the curators of Colchester, Saffron Walden and Chingford Museums and others for permission to photograph objects; and especially to H. Laver, Esq., F.S.A., for ever-ready access to his valuable collection.

\section{Fascine Dwellings at Braintree}

Near to the town of Braintree a mere or lake was in early times formed by the silting up of the stream now known as the Pod or Brain, and there below the accumulated alluvial soil traces of 'fascine' dwelling places have been found. To the Rev. J. W. Kenworthy, vicar of Braintree, we are indebted for much information published in the Essex Naturalist (vol. xi.) as the result of some years watching of the excavations carried on for obtaining brickearth from the site. ${ }^{2}$ It appears that an artificial floor was raised in the manner usual with fascine dwellings. "To support and secure this artificial concretion, wooden stakes were driven into the ballast of the lake or river. Outside the raised platform there was still water, in which the peaty mud has accumulated until it has levelled all up; and it was no doubt into this water which surrounded the floor on which the huts were built that numerous relics fell or were swept by the dwellers. So large was the

1 This valuable relic has been secured for the British Museum.

2 In addition to Mr. Kenworthy's paper the journal contains valuable supplements-archaological by Mr. F. W. Reader and geological by Mr. T. V. Holmes, F.G.S. 

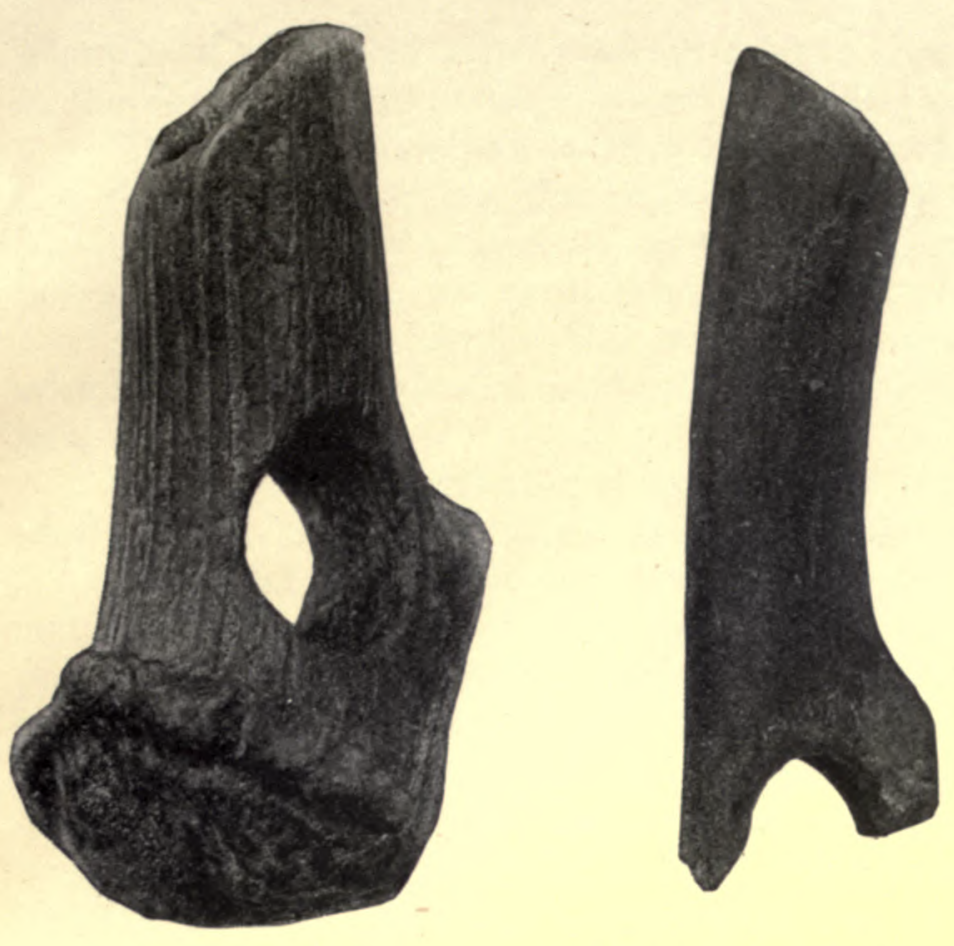

Fics. 43, 44, 45. Scale ?

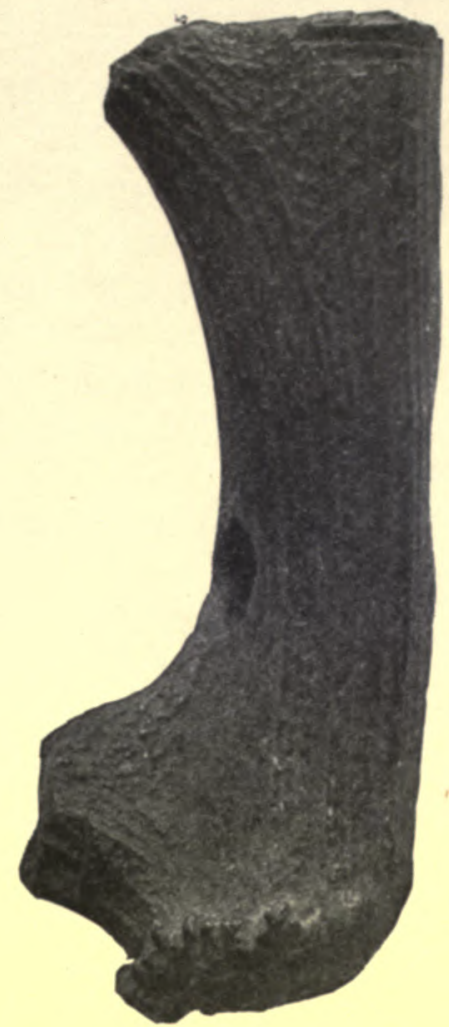

Three Implements made from Red Deer Antlers, from site

of Fascine Dwellings.

(From blocks kindly lent by the Essex Field Club)

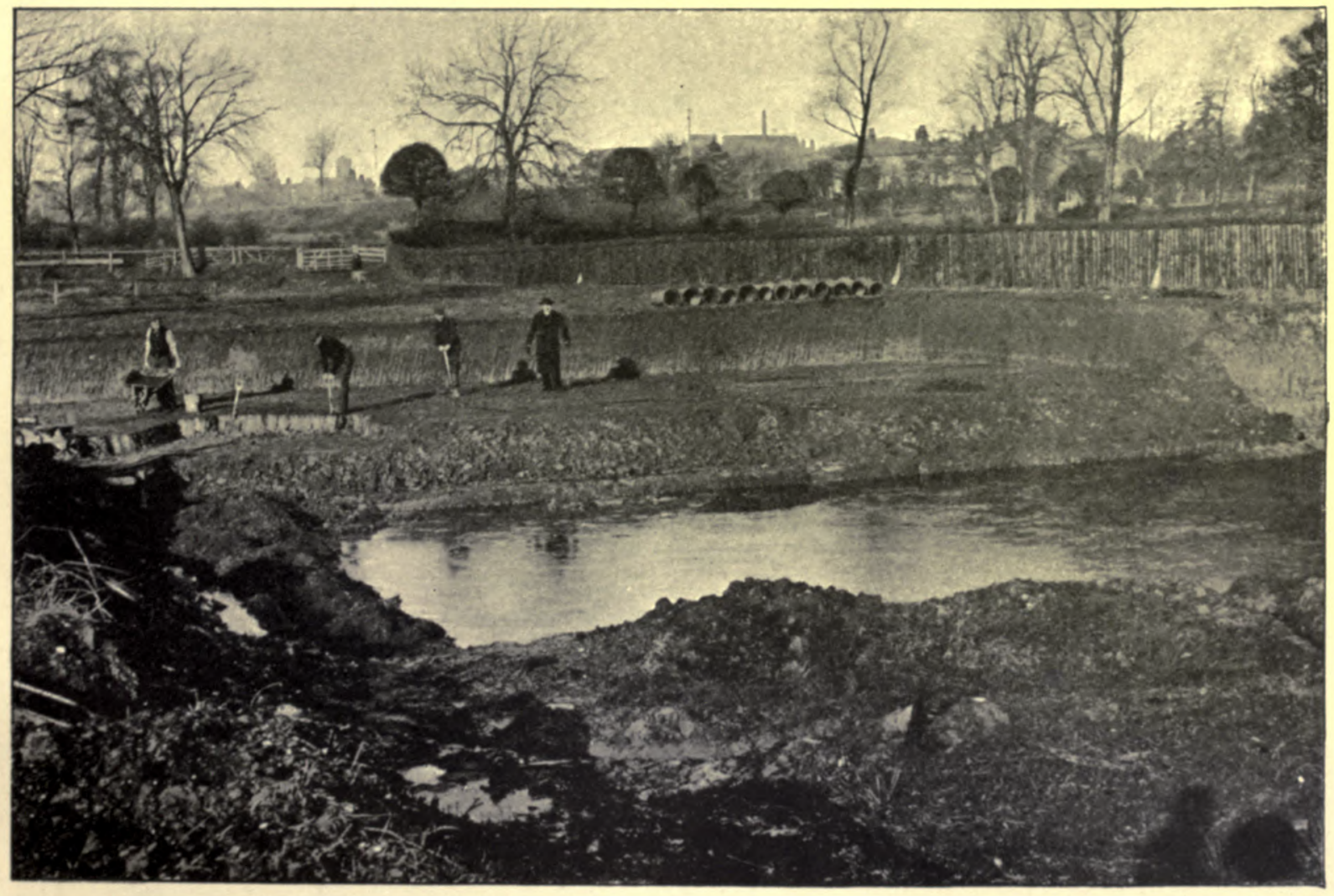

FIG. 46.

View of the Site of the Fascine Dwellings at Braintree. (From block kindly lent by the Essex Field Club) 


\section{EARLY MAN}

quantity of wood and other material used to construct this platform that in the course of years some tons have been dug out.' ${ }^{1}$

The relics discovered include the bones of the ox (Bos longifrons) and those of a larger ox, the bones and antlers of the red deer (Cervus elapbus), the roe deer (Capreolus caprea) and other animal remains, burnt bones and charcoal, an arrowhead of finely chipped flint, numerous worked flakes, a sandstone sharpener, bone and horn implements, of which some are perforated artificially, three picks made from deer's antlers, etc.

Of pottery it is difficult to say that the relics came from the fascine strata, as the site has been occupied in after ages.

The great question of the date of this settlement is still sub judice, and must so remain till further explorations throw more light on the point ; the absence of metal weapons (even of the almost imperishable bronze) suggests neolithic origin, but on the other hand there has not been discovered a single relic which is incompatible with a Late Celtic origin, while some of the sawn antlers and wood indicate the use of metal tools unknown to neolithic man. Whatever the date may be, it must be acknowledged that archæologists owe a deep debt to the indefatigable exertions of the vicar of Braintree.

\section{INDEX AND SUMMARY}

The following abbreviations are used to indicate the principal publications referred to in this index :-

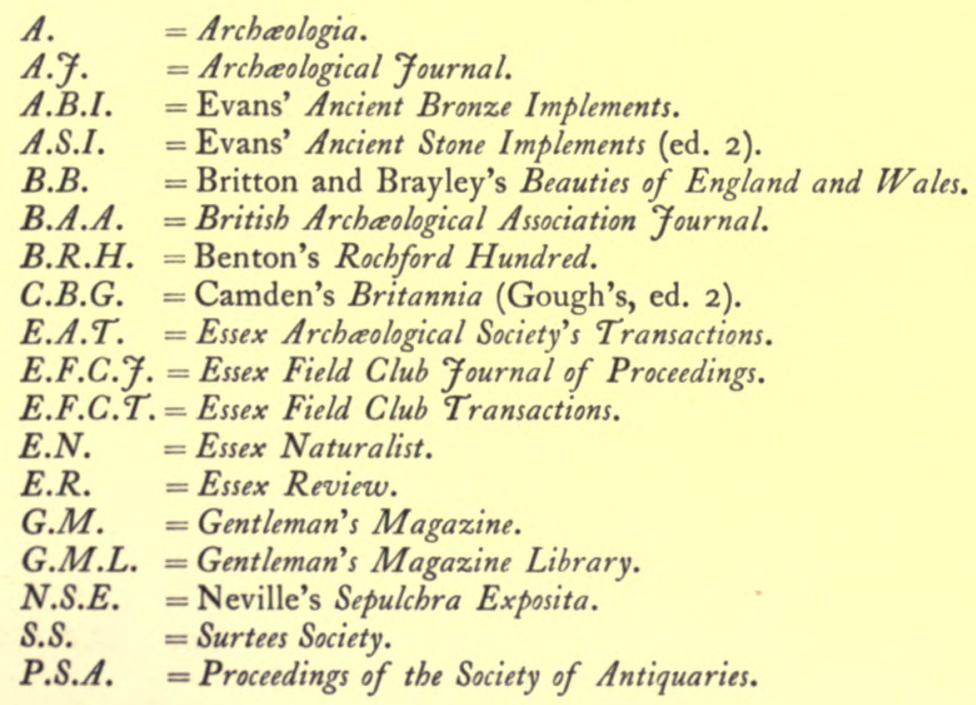

AbBerton.-Palæolithic implement : Colchester Museum.

Arderigh.-Palæolithic implements : Colchester Museum.

ArKesDen.-Palæolithic implements: Saffron Walden Museum. Bronze hoard : p. 267 ante. Ashdon.-Palæolithic implements: Saffron Walden Museum. Neolithic weapons: Saffron Walden Museum [A. $\mathcal{~ . ~ x x i . ~ 1 7 8 ] . ~}$

Baddow (Great and LrtTle).-Neolithic implement [E.N. x. 306]. Bronze finds: p. 267 ante [A. ix. 378 ; A.B.I. 43 ; E.A.T. i. I99; E.F.C.T. ii. 31].

1 Essex Naturalist, xi. 100. 


\section{A HISTORY OF ESSEX}

BARKING.-Palæolithic implements [E.F.C.T. iii. I I I ; E.N. ii. 262]. Neolithic implements [A.S.I. 603]. Bronze celt [A.B.I. 1 Io]. Bronze sword: p. 267 ante [A.B.I. 284; P.S.A. ser. 2, i. 144].

Barling.-Late Celtic pottery : Colchester Museum.

Bentley (Great).-Early iron age vessels : Colchester Museum.

BERECHURCH.-Bronze socketed celt : Dr. Laver's collection.

Bergholt (West).-Palæolithic implements : Dr. Laver's collection.

BOXTED.-Neolithic celt : Colchester Museum.

Bradwell-on-Sea.-Celtic 'ring money' of gold : British Museum (Franks Bequest).

Braintree.-Palæolithic implements [E.F.G.F. iv. I 77]. Fascine dwelling relics: p. 270 ante $[E . N$. xi. 94-126]. Bronze celts, etc. : Saffron Walden Muscum.

BRENTWOOD.-Bronze palstave : British Museum.

BroomFreld.-Palæolithic implements : Mr. Mothersole's collection [E.N.x. 305].

Burnham.-Palæolithic implement : Mr. Mothersole's collection.

Burstead (Great).--In Norsey Wood, near Billericay, have been found stone implements of palæolithic and later times, as well as British pottery, probably of pre-Roman date. A bronze ring or rim was discovered; which was decided to be of the late Celtic age, and much material of the Roman period. [Information supplied by General B. R. Branfill.]

Chelmsford.-Palæolithic flakes: Mr. Mothersole's collection. Neolithic spearhead [E.F.C.T. ii. 30]. Bronze celts [A.B.I. $90 ;$ E.N. x. 306].

Chesterford.-Palæolithic and neolithic implements: Saffron Walden Museum. Holed stone hammerhead: Saffron Walden Museum [B.A.A. xxv. 272]. Bronze age pottery : Saffron Walden Museum. Bronze palstave [B.A.A. xxii. 45I].

Chignal.-Neolithic implement [E.F.C.T. ii. 30].

Chigwell.-Neolithic flakes [E.F.C.F. iv. I $]$ ].

Chrishall.-Bronze hoard : p. 267 ante [A.B.I. I I 7, 283 ; N.S.E. 2].

Clacton (Great).-Bronze age pottery : p. 265 ante; Colchester Museum.

Clavering.-Bronze celts, etc. : Saffron Walden Museum.

Coggeshall.-Neolithic celts: Mr. Beaumont's collection and Stratford Museum.

Colchester.-Palæolithic implement [E.N. ii. I 87]. Neolithic implement: Dr. Laver's collection [A.S.I. 578]. Bronze age pottery: p. 265 ante; Colchester Museum. Bronze article (wheel): p. 269 ante; British Museum. Late Celtic pottery: p. 269 ante; Colchester Museum.

Colne Engarne.-Neolithic whetstone: Colchester Museum.

DanbURY.-Bronze hoard : p. 267 ante [A.v. 116 ; E.A.T. i. 199].

Dovercourt.-Palæolithic implements: Dr. Laver's collection. Neolithic implement : p. 264 ante.

Dunmow (Great).-Neolithic implements [A.S.I. 351] : Saffron Walden Museum.

EASTON (GREAT).-Neolithic pick [A.S.I. I 73].

ELMSTEAD.-Neolithic implements : Dr. Laver's collection.

EPPING.-Holed stone implement: p. 264 ante [A.S.I. 229 ; E.N. vi. 17 ; viii. 164].

Farnham.-Neolithic implement: Saffron Walden Museum.

Felstead,-Palæolithic implements [E.F.C.F. iv, 97]. Neolithic celt [E.N. i. 62]. Bronze celts [P.S.A. ser. 2, v. 428$]$.

Fingringhoe.-Bronze age pottery : Colchester Museum.

Forest Gate.-Neolithic implements [E.N. iv. I 7].

Fyfield.-Bronze hoard: p. 267 ante [A.v. I 16 ; A.B.I. $424 ; B . A . A$. iii. 322 ; B.B. v. 423 ; C.B.G. ii. I30; S.S. lxxvi. I 57$]$.

Grays Thurrock.-Palzolithic implements [E.N. xii. 52]. Bronze hoard: p. 267 ante [P.S.A. ser. 2, xvi. 327]. Bronze blade: p. 267 ante $[A . B . I .254 ; A . \mathcal{F}$. xxvi. 191 ; P.S.A. ser. 2, iii. 406]. Iron celt [A.B.I. 144$]$.

HaInault FoRest (Dagenham Parish).-Hoard of bronze celts discovered about I 883 . [Information supplied by Mr. G. P. Hope of Havering Grange.]

Hallingbury (LitTtle).-British urns [E.N. iii. 226].

Halstead.-Bronze mass : Colchester Museum.

Ham (EAST).-Palæolithic implements [E.F.C.T. iii. 11 I]. Bronze celt : British Museum.

HAM (WEST).-Palæolithic implements [E.F.C.T. iii. III].

Hatfield Broad OAK.-Bronze hoard: p. 266 ante [E.A.T. n.s. iv. 301 , vi. 172; E.R. iii. 273 ; P.S.A. ser. 2, xvi. 96]. 


\section{EARLY MAN}

Henham.-Neolithic implement: Saffron Walden Museum.

HorkEsLeY (Great).-Palreolithic implements : Colchester Museum.

HocKLEY.-Bronze spearhead : p. 267 ante [B.A.A. iv. 74].

HORNCHURCH.-Palæolithic implement of ovate form about $6 \frac{1}{\frac{1}{3}}$ inches long by $3 \frac{1}{2}$ inches at widest part. [Information supplied by Mr. G. P. Hope.]

ILFORD.-Palæolithic implements [E.N. xii. 52].

InworrH.-Neolithic celt : Mr. Beaumont's collection.

Kelvedon,-Neolithic celts and leaf-shape javelin head : Stratford Museum.

LEXDEN.-Palæolithic implement : Dr. Laver's collection.

LEYTON.-Palæolithic implements [E.F.C.T. iii. 1111$]$; British Museum. Neolithic celts : Capt. J. M. Knight's collection.

LitTLEBURY.-Palæolithic implements [A.S.I. 538].

Loughton.-Stone pestle: p. 264 ante $[E . N$. ii. 4$]$. Neolithic implement $[E . A . T$. n.s. viii. 229].

MALDON.-Palæolithic and neolithic finds [Fitch's Maldon, p. 3].

Mistley.-Neolithic implements : Mr. Brook's collection.

Mucking.-Palæolithic implements [A.S.I. $603 ;$ E.F.C.T. iii. I1 1 ].

Navestock.-Bronze celt [S.S. Ixxvi. I64].

NEWPORT.-Palæolithic implements [E.F.C.F. iv. 95].

NotLeY (W HITE). - Neolithic flakes [E.A.T. n.s. vii. 340$]$.

OAKLEY (Great).-Neolithic implements: Dr. Laver's collection. Bronze age pottery : p. 265 ante.

Orsett.-Palæolithic implements [E.F.C.T. iii. I I 1 ]

Panfield.-Bronze celts (5) [A.B.I. $468 ;$ P.S.A. ser. 2, v. 428].

Parndon (Great).-Neolithic implement [E.F.C.F. ii. 58].

PlaIstow.-Palzolithic implements [E.F.C.T. iii. III]. Bronze spearhead: p. 267 ante [A.B.I. 338].

Pleshey.-Bronze celts : Dr. Laver's collection.

Prittlewell.-Neolithic implements : late Mr. Benton's collection.

Quendon.-Palæolithic implements: Saffron Walden Museun [A.S.I. 538]. Neolithic celt : Saffron Walden Museum.

Rainham.-Palæolithic implement [A.S.I. 603].

Rayne.-Bronze celt, etc. [G.M. (1844) i. 299 ; G.M.L. Arch. i. 74 ; G.M.L. Top. 164].

Rivenhall.-Bronze socketed celts : Mr. Mothersole's collection.

ROCHFORD.-Palæolithic implement lent to Stratford Museum by the Rev. J. W. Kenworthy.

Roding (High).-Bronze hoard: p. 267 ante [A.B.I. I09, I16, 424 ; P.S.A. ser. 2, xvi. 328].

ROMFORD.-Bronze hoard: p. 267 ante [A.B.I. 86, 172, 424 ; A.F. ix. 303].

RoYDon.-Neolithic weapon : Stratford Museum.

Saffron Walden.-Palæolithic implements: Saffron Walden Museum. Neolithic implements: [A.S.I. 254, 336] ; Saffron Walden Museum. Bronze spear or daggerhead : Archæological Museum, Cambridge.

St. OsYтн.-Palæolithic implements : Dr. Laver's collection.

SAMPFORD.-Neolithic implement: Saffron Walden Museum.

Shoebury.-Neolithic implements : p. 264 ante. Bronze hoard: p. 266 ante [E.R. ii. 101 ; P.S.A. ser. 2, xiv. 174]. Bronze implements, etc. p. 266 ante [E.A.T. iv. 120] Early Celtic pottery : Colchester Museum. Late Celtic pottery: p. 269 ante [E.A.T. n.s. vi. 222]. Weaver's weight : Colchester Museum.

Southchurch.-Celtic pottery : Colchester Museum. Bronze hoard : p. 266 ante [E.A.T. n.s. vi. 173].

SouTHEND,-Palæo lithic implements [E.F.C.T. iii. 111 ] . Celtic pottery : p. 269 ante.

Southminster.-Net sinkers (?): p. 269 ante. Celtic pottery : Colchester Museum.

Stansted.-Palæolithic implements : Saffron Walden Museum.

Stanwar.-Palzolithic implements: Dr. Laver's collection. Neolithic implements: Dr. Laver's collection.

Steeple (Stangate).-Holed stone implement: p. 264 ante.

STIFFord.-Neolithic celt [A.S.I. 93]. Circular hammerhead [A.S.I. 229]. Bronze sword [E.A.T. iv. 120$]$.

STISTED.- Neolithic celt : Mr. Beaumont's collection.

TeY (Great).-Bronze socketed celt : Dr. Laver's collection.

ThAxTED. - Celtic penannular ring ornament of gold: British Museum [A.F. vi. 56]. 


\section{A HISTORY OF ESSEX}

ThUndersley.-Bronze hoard : p. 267 ante [B.R.H. 77 I]

ThURRock (EAST).-Palæolithic relic: p. 262 ante [E.N. i. 129].

TILBURY.-Palæolithic implements [E.F.C.T. iii. III].

Tiptree Heath.-Neolithic implements: Dr. Laver's collection and Stratford Museum.

W AKERING.-Celtic pottery : Colchester Museum.

Waltham ABbeY.-Neolithic flakes [E.F.C.F. iv. 19].

Waltham (GReat).-Neolithic implement: Stratford Museum.

W althamstow.-Palæolithic implements [E.F.C.T. iii. III]. Bronze implements: p. 267 ante $[$ A.B.I. 3I 7$]$. Bone implements [E.F.C.T. iii. 147]. Iron celt : p. 268 ante.

W ALTON-ON-THE-NAzE.-Palæolithic implements : Dr. Laver's collection. Neolithic implements : pp. 263,264 ante.

Wanstead.-Palæolithic implement [E.F.G.T. iii. III]. Neolithic axe [E.F.G.F. iv. 95].

Weald (NoRTh).-Bronze weapon : p. 268 ante [E.N. viii. 163].

Wendens Амво.-Palæolithic implements : Saffron Walden Museum.

Wendon LofTs.-Bronze hoard: p. 267 ante; Clarke's Mayer collection, p. 9. Iron age finds: p. 268 ante.

Wicken Bonant.-Palæolithic implements: Saffron Walden Museum.

Witham.-Neolithic celt [A.S.I. 75]. Celtic vessels [B.A.A. ix. 60].

WORMINGFORD.-Curious implement of a stag's antler, about $\mathrm{I}_{3}$ inches long and $\mathrm{I}_{\frac{3}{4}}$ inches broad. A hole is perforated at one end, the other end is cut and rubbed to a chisel shape. Now in Stratford Museum [E.N. x. 310].

WRITTLE.-Neolithic hammerhead [E.F.C.T. ii. 30]. 



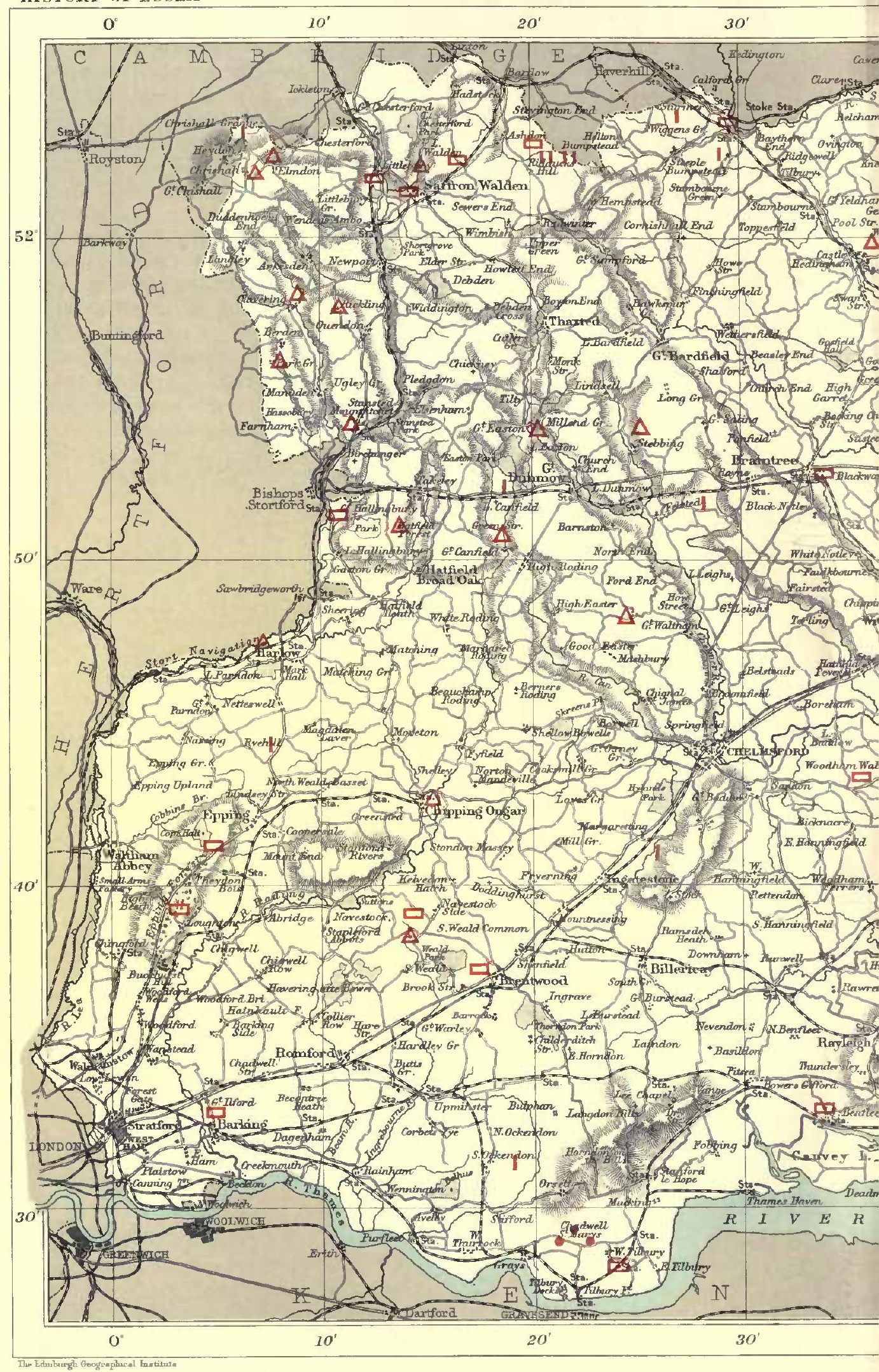





\section{ANGIENT \\ EARTHWORKS}

U

NDER this heading we include both defensive earthworks, and those constructed for other purposes, but as interest largely centres upon the former, we confine our notes mainly thereto, mentioning tumuli, etc., in brief, among miscellaneous works.

Throughout the large county of Essex, we find no examples of the earliest defensive works such as can be attributed to the stone age or bronze period; perhaps the marshy nature of the low-lying districts and the thickly-wooded character of the other parts were not favourable to the settlements of early man, or it may be that long years of cultivation have swept away all traces of the earliest defences.

In the succeeding periods of time, from the earliest part of the iron age, our land has been cultivated, and homes have been established, but of purely defensive works we have no example which can with certainty claim earlier date than the Celtic iron age.

Of that time, or about the period of the Roman invasions, we have important fortified positions, but of demonstrably Roman 'camps,' perhaps none.

Passing to later days, Essex can boast of some of the most characteristic examples of the 'mount and court' type of castles; the earthworks of these we may describe, but the castles of masonry which in some instances afterwards occupied the same sites, will be referred to by other writers.

In the following notes the aim has been to group defensive works of each class or character together, with but little attempt at chronological order ; for it must be remembered that some of the earliest types of works were repeated in after days, and that it is therefore, in the absence of the invaluable aid of spade-labour, impossible to judge the age by the form of earthwork.

On account of the simplicity of its plan, rather than of evidence of early construction, we mention Gryme's Dyke first among the defensive earthworks of Essex, passing next to enclosures defended by rampart and fosse. Such defensive works are usually known as 'camps,' but the word is not to be regarded as signifying temporary occupation only, as in many instances these fortified positions may have been intended for permanent use. 


\section{A HISTORY OF ESSEX}

\section{GRYME'S DYKE AND OTHER RAMPARTS NEAR COLCHESTER}

Gryme's Dyke, which forms the subject of an interesting paper by Dr. H. Laver, F.S.A., ${ }^{1}$ is to be traced through the greater portion of its original length, still retaining in parts the rampart with deep fosse on its western side.

It was about $3 \frac{\mathrm{I}}{2}$ miles long, extending from the Colne on the north to the Roman river on the south, forming a defence to the west of the British oppidum, the side which was unprotected by water. ${ }^{2}$ Though there is no positive proof, we are probably safe in assigning a Celtic origin to this work, for as Dr. Laver says :-

There is no recorded instance of anything later than the British period ever having been found under any portion of this dyke, although Roman remains abound on the eastern side, and quite up to it.

A very large part of what has been destroyed has been levelled during the last forty years; and, as several observers have during this period sought carefully for relics of the Roman period and never found anything that could be identified with that people, it may fairly be concluded, that this work was raised before they came, especially if it is borne in mind that fragments of pottery of a distinctly British character have been unearthed at various points.

Though the remains vary in section, Gryme's Dyke consists mainly of a fosse on the west, about 12 feet deep, with a rampart on the east, raised some 20 feet above the bottom of the fosse. The work, which otherwise runs north and south, has, at Butcher's Green, a rectangular break $\sim$ throwing the southern portion of the defence more westward; this curious break may represent the site of a fort on the long line of rampart, but the traces of further work are very indistinct.

Another line of entrenchment, about a mile in length, extends nearly parallel with Gryme's Dyke on the eastern side of the latter, but is so much destroyed that it is impossible to speculate upon its age or purpose.

Lexden Park Ramparts which lie still more to the east, extend far beyond the limits of the park on the north and south, being traceable for about two miles from the Bergholt road on the north, passing the ancient moated enclosure (now occupied by Lexden Lodge), across the river Colne, up the slope to Lexden Park, where the rampart is carried along the brow of a steep slope, forming a picture of great beauty in this well-timbered domain, then southward to the old London road.

For the greater part of its length, this un-named work (which we have called Lexden Park Ramparts) is similar in construction to Gryme's Dyke, but there is no evidence of its age. Dr. H. Laver has admirably summed up all that has been said of it, but commits himself to no theory on the subject. ${ }^{3}$

1 Essex Arch. Soc. Trans. n.s. vi. 17.

2 It should be noted that entrenchments are partly traceable on the south side of the Roman river, suggesting an extension of Gryme's Dyke in that direction.

3 Essex Arch. Soc. Trans. n.s. viii. 108. 


\section{ANCIENT EARTHWORKS}

\section{CAMPS, ETC.}

Loughton CAmp.-Among those which retain sufficiently definite form to be classed as early defensive earthworks we place Loughton first, as, like Ambresbury, it has the advantage of having been scientifically examined by means of excavation. It is in the heart of the old Forest of Waltham, now known as Epping Forest, and is situated about a mile and a half from Loughton railway station.

The position of the camp is remarkable ; and, considered from a military point of view, it is perhaps the most advantageous in the whole Forest district. It occupies the southern headland of an elevated plateau, many parts of which are densely wooded. From the southern side of the camp an extensive view may be had looking towards the south-east, bounded by the Kentish hills beyond the Thames . . .

At the northern angle of the camp, the elevation is about 3 ro feet above the Ordnance datum. The ground gradually trends away towards the southern rampart, and then suddenly dips down to Debden Slade, a low marshy valley distant about $\mathrm{I}, 000$ feet to the south, and the level of which is only 160 feet above datum, showing a fall of about 120 feet from the southern aspect of the camp, or 150 feet from the higher plateau ground at the northern end. From the western side the ground descends even more abruptly to form a smaller valley, the levels showing a fall of about 70 feet. $^{1}$

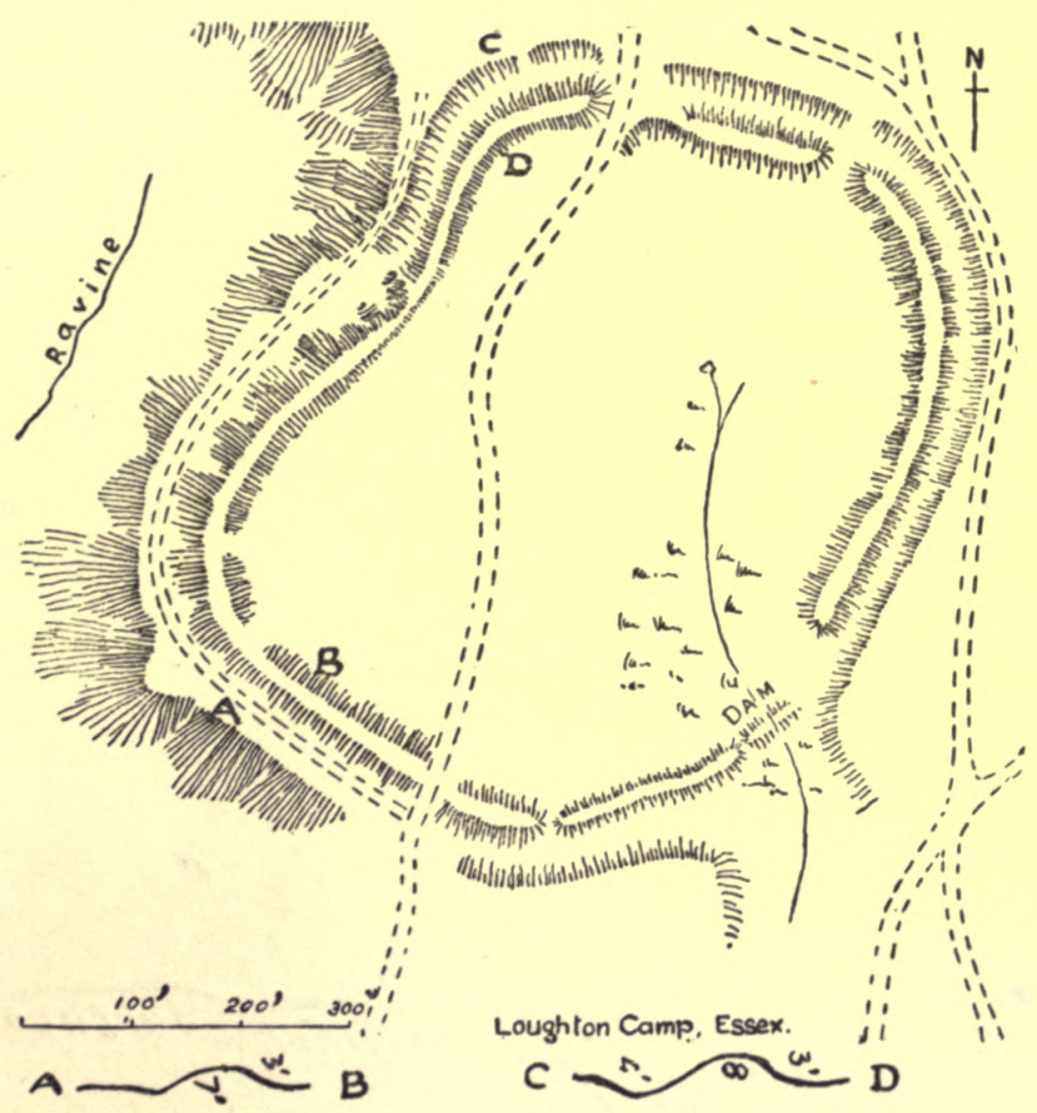

The investigations of the Essex Field Club proved that a fosse between 6 and 7 feet deep existed at $A$, but has been entirely silted up. The fosse on the north side, now 4 feet below the counter-scarp, was originally nearly 5 feet deeper. The sections show the present condition. Our plan is based upon one issued in the Trans. of the Essex Field Club.

1 Essex Field Club Trans. iii. 212. 


\section{A HISTORY OF ESSEX}

In 1882 four cuttings were made by the Essex Field Club through or into the bank, and one of them was carried to the bottom of the ditch. The ditch, like that of Ambresbury, was found to be pointed. Many flint flakes, a flint chisel or celt, and fragments of pottery were found in the excavations. From the evidence obtained in these explorations, General Pitt-Rivers was of opinion that the camp was pre-Roman.

Pits of various shapes and size exist on the enclosed area, and more numerously on the plateau adjoining on the northern side. These may have been the result of digging for sandy material, or, as some think, the regular circular form of many may indicate habitations of early men.

Personally we incline to think their material was excavated as an ingredient of the plaster so commonly and long used in wattle-and-daub houses

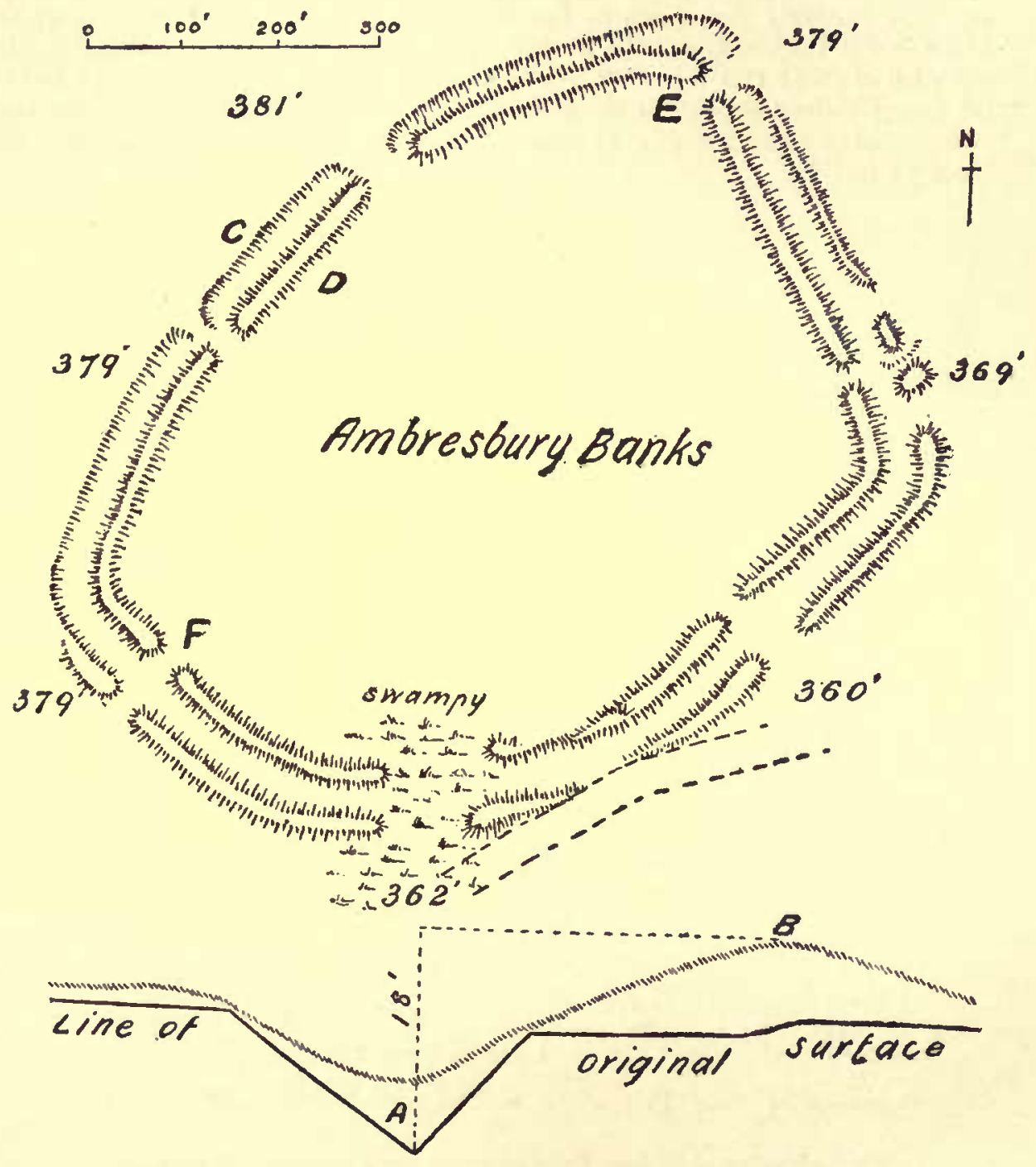

A, 7 feet of silt had accumulated here sioce fosse was cut.

B, Present summit of rampart, originally higher. The shaded line indicates present surface.

c, D, Position at which the trench was cut for examination by the Essex Field Club.

I, r, Banks cut in the sixteenth century to form a roadway. The figures indicate feet above sea level. The section is copied from Essex Field Club Transactions, 1881 . 


\section{ANCIENT EARTHWORKS}

Ambresbury Banks.-This fortified position, lying about 2 miles from Loughton Camp, we may next describe, although its relics show it to be somewhat later in date.

Variously known as Amesbury, Ambersbury and Ambresbury, ${ }^{1}$ it is situated in the forest, but close to the modern high road at the fourteenth milestone on the way from London to Epping, partly in the latter parish and partly in that of Waltham Holy Cross.

Although at one time this earthwork, from its somewhat angular form was supposed to have been constructed by the Romans, the excavation which was carried out by the Essex Field Club in $188 \mathrm{I}$ under the direction of the late General Pitt-Rivers led that eminent authority to conclude that the camp was of British origin, but whether it was erected before or after the Roman conquest he considered could only be decided by further exploration. The excavation which was made consisted of a section near the centre of the north-western side of the camp. The objects found comprised several fragments of imperfectly-baked pottery without ornamentation and a few flint flakes. ${ }^{2}$ The original ditch was found, like that of Loughton Camp, to be triangular and pointed at the bottom, a feature somewhat unusual in ditches of British camps. The escarp rises at an angle of $45^{\circ}$ and the counter-scarp probably at the same angle; the fosse was 22 feet wide at the top and ro feet deep, and as the annexed plan shows has become silted up 7 feet from the bottom.

Navestock : Fortification Wood.-About 4 acres are enclosed by a low bank, with shallow moat traceable on three sides and part of the fourth. At the southern end of the enclosure is a deep excavation forming a pond nearly across from east to west, possibly more recent work than the banks.

During some period long past, the bank was more exposed to weather and it is consequently reduced in height, while its moat or fosse has been partially filled up by the deposit of leaves of many summers. The dense growth of tangled wood has of late prevented further destruction of the bank, but at the same time it renders detailed examination of the work very difficult.

The late Rev. S. Coode Hore, in a paper read before the Essex Field Club in 1894 , said he was 'strongly inclined to think this earthwork and wood may be identified with a certain wood known in the year 1222 as The Defence of Navestock. . . . We find in an ecclesiastical visitation of that date known as the Domesday of St. Paul's the following entry : "Stephen son of Robert holds .. . half an acre, juxta defensum de Nastok. ..'

The expression might suggest the existence of some military work

1 Some local guides add to the attraction of the camps by styling this the Roman Camp, and the Loughton earthwork Boadicea's Camp, but there is no authority for either statement.

The flakes may have belonged to the soil when the rampart was constructed.

S See Essex Field Club Transactions, ii. 55-68.

- Domesday of St. Paul's, Camden Soc. 1858. 


\section{A HISTORY OF ESSEX}

in Navestock, but that the word defensum was applied to any enclosure or fenced ground (see Bailey's Dictionary, 1733).

We may fairly conclude that so long ago as 1222 the area was producing timber, but whether the earthwork had previously an independent existence or was simply formed to protect the wood is not apparent.

Saffron Walden: The Repell or Paille Ditches.-The Paille, Repell, Peddle or Paigle Ditches which are the remains of a Roman camp or of a British oppidum are situated on ground gently rising from the course of the Slade, a stream once of sufficient volume to give added security to the north of the earthworks. On all sides was probably a rampart of earth with its ditch or moat outside and a slighter ditch within. Of this defensive work only part remains, about 480 feet on the west and 500 feet on the south sides. Buildings, gardens, etc., have largely destroyed the inner ditch and altered the levels of the interior space ; the eastern side of the oppidum is completely covered with buildings. Within the area was found a large number of skeletons and many objects which had been buried or subsequently thrown aside on the site. ${ }^{1}$

The antiquities discovered when the skeletons were unearthed do not fall within our province to describe, as the cemetery is generally thought to belong to the Saxon period, although we consider some of the pottery indicates 'late Celtic' days, or at all events the influence of the art of that period, in its decoration. However that may be, there is

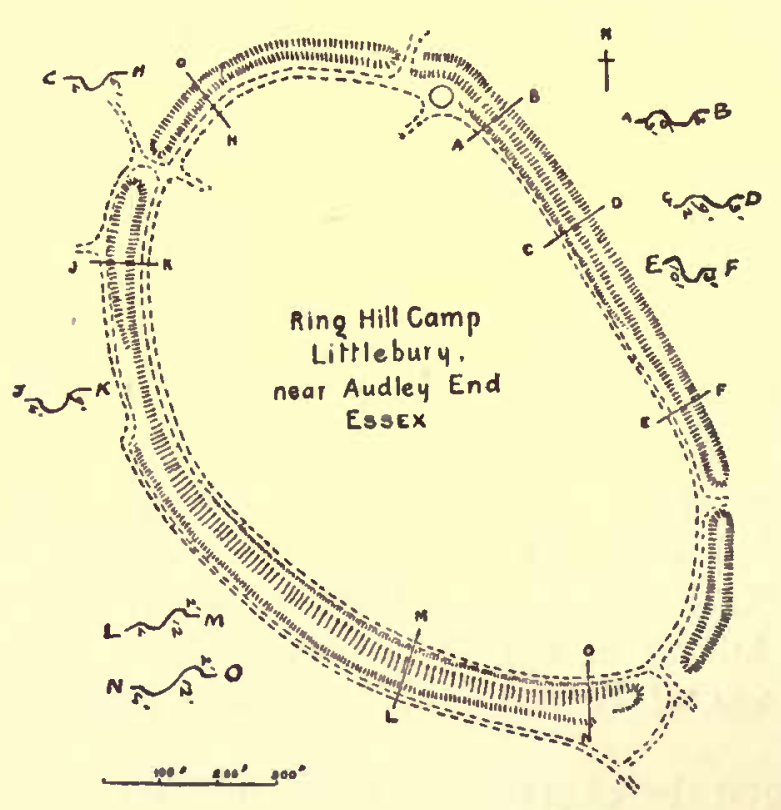

no doubt of the important fact that beneatb the burials referred to were found traces of earlier occupants of the site, probably the men who made the early defensive rampart and moat.

Littlebury : Ring Hill Camp. - The earthwork is about 1,100 yards in circumference, occupies the eastern end of a chalk range on the western side of Lord Braybrooke's park at Audley End, and covers about i 8 acres of ground. It is an oval fortification originally provided with rampart and exterior fosse, but the construction of a drive above the fosse has largely obliterated the inner bank. Though known to

1 H. Ecroyd Smith in Essex Arch. Soc. Trans. n.s. vol. ii. gives a full account of the discoveries, a plan of the cemetery and numerous illustrations of the finds. 


\section{ANCIENT EARTHWORKS}

antiquaries of the early eighteenth century, ${ }^{1}$ and apparently referred to long before in Holinshed's Chronicles (1 577), ${ }^{2}$ no careful survey has been published and no record of explorations exists.

We need not enter into the views and opinions expressed by Stukeley, Salmon and others as to its date and origin, but it is well to note the fact that Roman coins have been recorded as found on the spot, although this of course shows only that the place was occupied in the time of the imperial domination of Britain.

UPHALL ENTRENCHMENTS NEAR Barking.-These entrenchments were described by Smart Lethieullier, about $1750,{ }^{3}$ as ' not regular but

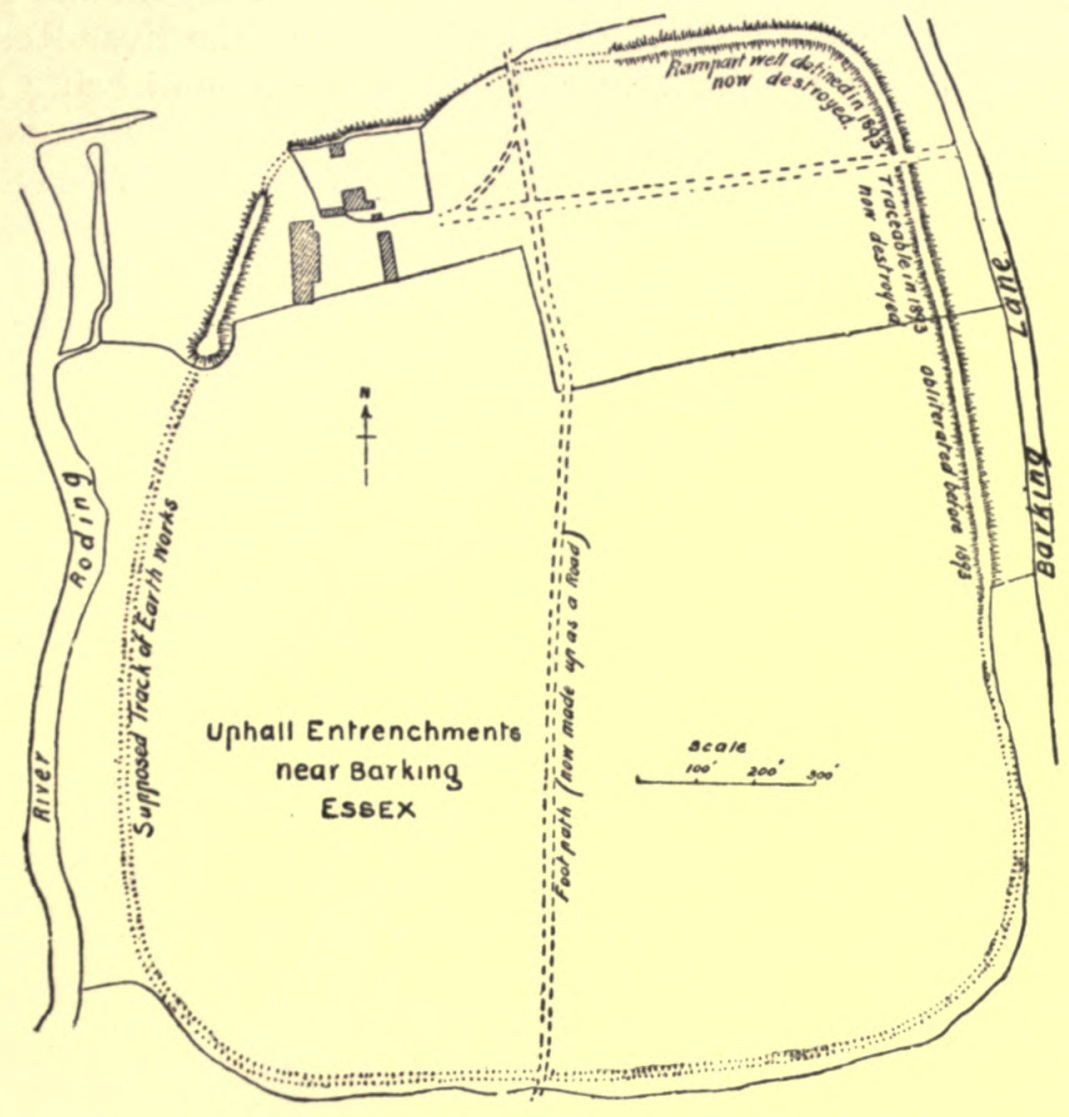

From plan by Mr. Walter Crouch, F.Z.S.

tending to a square; the circumference is 1792 yards . . . enclosing an area of forty-eight acres, one rood, and thirty-four perches. On the north, east and south sides it is single-trenched; on the north and east sides the ground is dry and level (being arable land), and the trench from frequent ploughing almost filled up ; on the south side is a deep morass ; on the west side, which runs parallel with the river Roding, and at a short distance from it, is a double trench and bank; at the north-west corner was an outlet to a very fine spring of water, which was guarded by an inner work and a high keep or mound of earth.' By far the best

1 See reference to Dr. Stukeley's and Roger Gale's opinions in Gough's Additions to Camden.

2 The reference in Holinshed is to 'Starbirie hils.' Ring Hill was locally known as Starberry Hill long after Holinshed's time.

3 Lyson's Environs of London (1796), vol. iv. 


\section{A HISTORY OF ESSEX}

modern account of this camp is that by Mr. Walter Crouch, F.Z.S., ${ }^{1}$ who, from its form and position and by comparison with other early works, was of opinion that it was probably a British settlement subsequently occupied during the Roman period, ${ }^{2}$ though others regard it as of Danish origin, the view eloquently maintained by Mr. F. J. Norris. ${ }^{3}$

The peculiar position of the mound on the rampart is suggestive of the much smaller work at Tempsford, Bedfordshire, which the Saxon Chronicle leads us to believe was Danish and it is quite possible the Danes altered an existing work at Uphall and added the mound.

It is with sadness we have to record that little is left of the ancient defences except the fragment of the rampart with the mound as shown at the north-west end on plan. On the side facing the river Roding, the rampart rises about 15 feet from the marsh, the mound being some 14 feet higher.

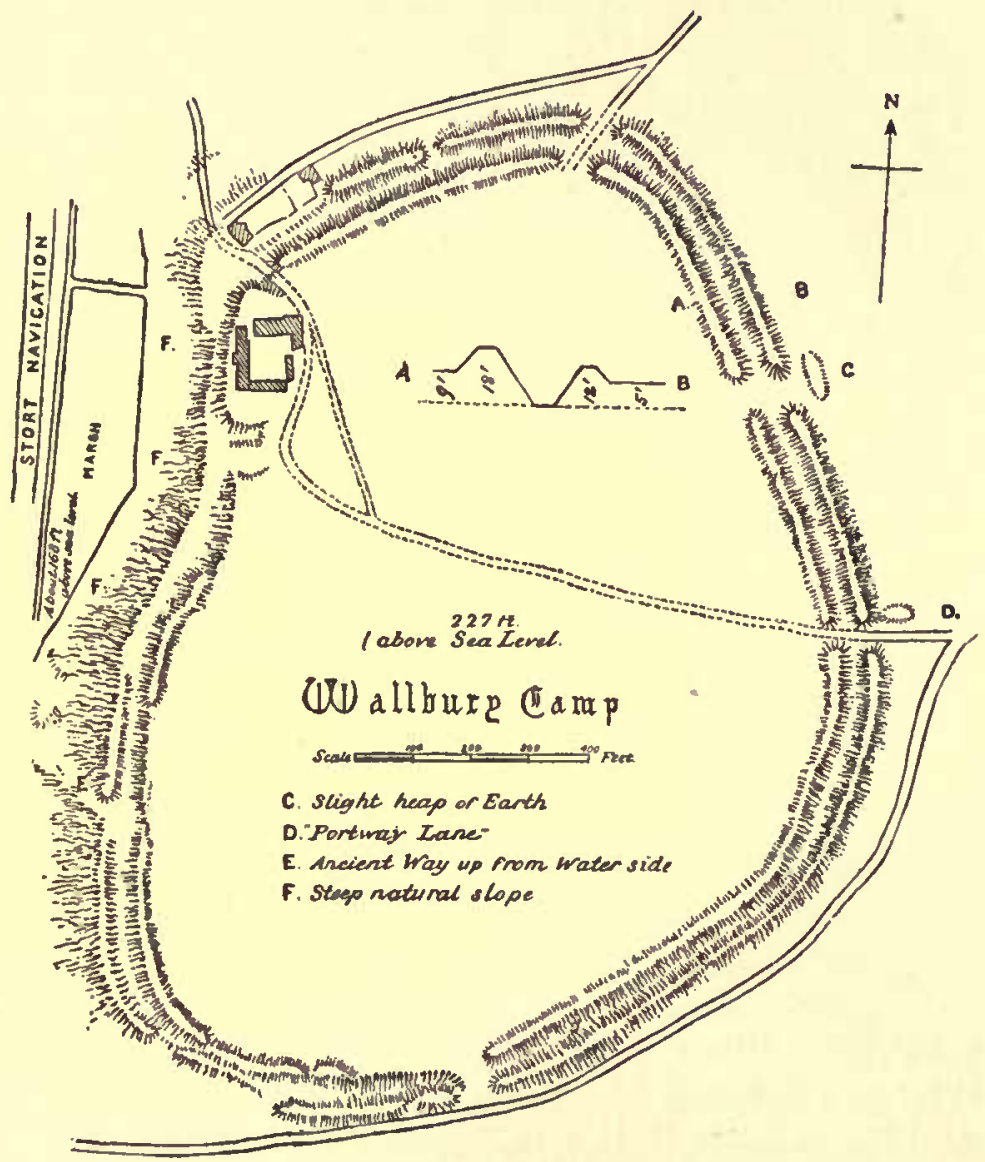

Wallbury, Great Haling bury.-Wallbury is of somewhat similar form to Loughton Camp in Epping Forest, but is of much larger extent, containing about 35 acres, and instead of depending upon a single bank and ditch, is mainly protected by a double rampart and two ditches.

1 Essex Naturalist, vol. vii. I 3 r.

2 This view is strengthened by the recent discovery of Roman remains within the camp.

3 Gentleman's Magazine, 1888 , p. 370. 


\section{ANCIENT EARTHWORKS}

On part of the west side, a steep natural slope to the valley of the Stort rendered much ramparting unnecessary, though even here we find traces of the outer rampart in places.

The camp seems to have been made in the later period of preRoman days, when men had learned to dispense with tortuous entrances, and required forts not for defence alone but rather as places in which a body of flghting men could be protected and rapidly issue thence to attack an opposing force in strength. Cultivation has destroyed all trace of huts or houses, but probably this and other of these late levelsurfaced enclosures had many such.

It is not improbable that this great earthwork, which stands on the high ground overlooking the valley of the Stort, was an oppidum of the Trinobantes, as a defence against the Catuvellauni, their neighbours on the west. Though likely, if already in existence, to have been occupied by the imperial soldiers, no Roman antiquities are recorded as having been found within the camp, but this may be due to the fact that very little excavation has been made within its area. ${ }^{1}$

It should be noted that Sir James H. Ramsay ${ }^{2}$ suggests the identification of Wallbury with the position 'established' by Hasten the Dane in A.D. 894 (? 895). This shows the need for keeping an open mind upon the question of the date of the creation of such earthworks. ${ }^{3}$ Of one thing we may be sure: whensoever made, this was one of the largest and most important fortresses of these eastern lands.

South Weald Camp. - The camp occupies an elevated position partly within the bounds of Weald Hall Park, and partly on cultivated land to the east. The area enclosed was about 7 acres.

It is difficult to trace the lines of the work-excepting the bank within the confines of the park, all have been mutilated or destroyed; but it is still possible by careful examination of the ground east of the road which adjoins the park to ascertain where the rampart and fosse were carried. There is nothing in its form inconsistent with Celtic work, but Salmon thought this of Roman origin 'too small to contain an army and fit only for castra exploratorum.'

Of the majority of the following 'camps' but faint traces exist, while some have disappeared since their mention by our old historians. In form they approximate to the class of works under consideration.

Ashdon.-An ancient entrenchment is to be seen parallel with the Bourne stream near the Bartlow Hills, consisting of bank and ditch over 300 feet long measuring about 30 feet across. The bank is now about 4 or 5 feet in height and the ditch which is V-shaped is of corresponding depth, but was originally 5 feet deeper. There is a rectangular

1 Mr. G. E. Pritchett, F.S.A., about the year 1876 reported the discovery of at least seven ossuary urns and ampulla in a gravel-pit near the encampment.

2 Foundations of England (1898).

3 It may be that the Danish work was on the south bank of the Lea at Hertford. Vallans wrote in the sixteenth century : "There remayneth yet the ruines of an old castel or fort betweene Hartford Castel and the Mill, which I doe undoubtedly beleeve was the verie selfe same fort that the Danes builded ' (see Leland, Hearne's ed. 1744, v. 22).

1 History of Essex, p. 263. 


\section{A HISTORY OF ESSEX}

enclosure at one end. Mr. A. R. Goddard in an account of this earthwork ${ }^{1}$ calls attention to the fact that the fosse is on the interior side of the enclosed space and the agger beyond it. ${ }^{2}$

Asheldham.-Entrenchments for the most part levelled but apparently originally of somewhat oval form, enclosing about 16 acres near Asheldham church at the corner of the road to Southminster. From the remains there is not sufficient to justify more than a conjecture that the works may have been British.

Billericay : Blunt's Walls.-Salmon speaks of the earthworks here as consisting of a ditch and rampart surrounding about 4 acres, one part of which was once separated by ditches within which enclosure there were several artificial mounds, then for the most part levelled. Since Salmon's time, the ditch, ramparts and mounds have disappeared.

Billericay (Norsey Wood).-General B. R. Branfill has drawn attention to entrenchments surrounding this wood, and to a number of excavations which may have been ancient habitations.

The protecting bank is reported to be about 5 to 6 feet high, with a ditch outside, completely surrounding the wood of about I95 acres area. Towards the southern end are remains of ancient dams where, by the fall in the level, water naturally accumulates.

It is suggested that the extensive banks surrounding the wood may be due to the great rising of the peasants in the time of Richard II. when, according to John Stow the historian, 'a new multitude at Byllerica' seem to have 'fortified themselves with ditches and carriages.'

BIRCH.—- Birch Castle,' as it is called, is a small much-destroyed enclosure, partly protected by a rampart and trench. Morant said it was connected with the earthworks on Lexden Heath, but there is no trace of the connection to be found at the present day. ${ }^{3}$

BirdBRook.-At Watsoe Bridge the ancient road from Colchester to Cambridge crosses a stream which flows into the Stour from the south; here was situated an earthwork, probably of Roman origin.

Few traces remain, there are deep depressions here and there which may indicate the line of the fosse, and there is a rectangular corner, but the plough has left little to mark the spot. Thomas Walford, in a communication published by the Society of Antiquaries in I $80 \mathrm{o}$, shows the camp or station, but even in his day all that remained to be recorded was a part of the west vallum, that 'at the north-west end was taken down in January, 1793.'

Many Roman coins were discovered near by, and the site of a cemetery was found. Morant refers to the spot (under Bumpsted Steple) and thinks a tower of some sort stood here.

Wright suggests that there had been a camp on the summit of Bailey Hill, Birdbrook parish, but his evidence is not satisfactory.

BRAINTREE. - An embankment with fosse stands on the south side

1 Trans. Essex Arch. Soc. vii. 349. $\quad$ A A plan of the work appeared in Archacologia, xxv. 3.

3 It should be recorded that a field adjoining the enclosure is locally known by the suggestive name 'the bailey.' 


\section{ANCIENT EARTHWORKS}

of Stane Street. Cottages occupy part of the fosse, the rampart is in the grounds of Mount House, and there is no doubt that we have here part of one side of a large, otherwise destroyed camp.

CANEwDON.-There is said to have been a camp here of oblong form, which enclosed about 6 acres. At the beginning of last century the vallum had been levelled, but the fosse was still visible. Mr. Benton considered that 'Duckett's Mead,' which adjoins the fosse before mentioned, and had a ditch a rod wide on its northern side, probably occupied the site of the camp.

HARwich.-No remains of a camp are now to be seen, but from Morant we learn that in his day traces existed at least half a mile long, one side of the work running southerly from without the Town-gate to the Beacon Hill field, in the midst of which was a tumulus. The rampart was in many places $\mathrm{I} 2$ feet high, and the ditch, though chiefly filled up, at least 6 feet deep and 40 feet wide. The sea had devoured the rest. On the top of the hill another work ran across from the former in an easterly direction. The Essex historian considered the camp a work of the Romans.

HoRKESLEY (GREAT).-Here are some remains of an earthwork known as 'Pitchbury' or 'Pitsbury Ramparts.' When the late Rev. Henry Jenkins described the camp in 1841 , he stated that it was of oval shape, and contained about 6 acres. Most of it was levelled for agricultural operations about fifty years ago, but there are still some remains, consisting of two banks with their accompanying ditches. The lines moreover of that part which was destroyed can be partially traced in the adjoining fields.

Layer Marney. - The Rev. H. Jenkins writing in $186_{3}$ said that until lately there were at Haynes Green, between Layer Marney Wood and Podswood, the remains of a double-trenched

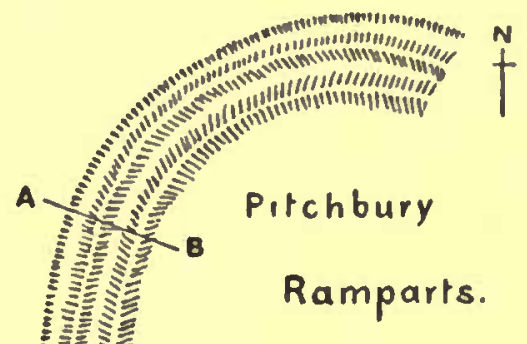

Creat Horkesley

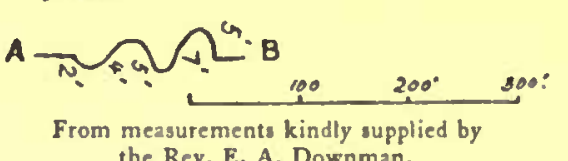
the Rev. E. A. Downman.

Roman camp, which was then gradually disappearing beneath the encroachments of the plough.' Its condition is now so fragmentary that it is impossible to guess its purpose. It has not the slightest appearance of ever having formed part of the entrenchments of a Roman camp.

LEYTon.-In the grounds of Rukholt Manor there were, in the early part of last century, the remains of an ancient entrenchment on a small eminence rising from the river Lea, which appeared to consist of a square embankment enclosing a circular one. The latter was about 33 feet in diameter, surrounded by a moat about 6 yards in width; the

1 The remains are doubtless the same as those a plan of which was published in the Transactions of the Essex Archeological Society in 1895 . 


\section{A HISTORY OF ESSEX}

former had traces of a double rampart divided by a ditch. Nothing now remains of this work.

ORSETT.-According to Morant there were in his time some ancient entrenchments enclosing 4 or 5 acres, but it is possible he was misled by the appearance of the remains of moats, banks and fishponds appertaining to the site of a mansion of Bishop Bonner.

PritTLEWELl.-There are remains of an entrenchment on Fossett's farm. The enclosure is situate upon rising ground, and is of somewhat oval shape, having on two sides the bank well defined, with outer fosse in part. It embraced about 8 acres, and can still be traced in several fields. At one point of the work was possibly a circular mound, but it has been lowered, now rising only about 8 feet above the surrounding land.

Saffron Walden.-Grimsditch Wood has a fosse along what was probably one side of a camp or station, a purpose for which the commanding site would render it suitable. Of other sides of the fortress there are traces, but nearly all the banks have been partially destroyed and the ditches correspondingly lessened in importance.

Though the features of the following five earthworks are, or were, in the main similar to those of camps such as we have been considering, it seems well to separate them therefrom and to group them together as, happily, the period of their construction may be assumed with confidence.

BenfleEt.-In the Saxon Chronicle, under the date of A. 894, we hear of Beamfleote having been already constructed by Hasten, the Danish leader (Hafde Hasten er geworbt bat geweorc at Beamfleote). The Chronicle tells of his treachery, and of the conquest of his fort by part of King Alfred's army, aided by the townsmen of London-an interesting story with a noble sequel, but one upon which we may not dwell.

We seek in vain for satisfactory traces of Hasten's fort at Benfleet. It has been thought that it occupied the high ground above the railway, but as Dr. H. Laver, F.S.A., says in an admirable summary': 'There is quite enough remaining around the churchyard to mark out one corner of the fortress.'

Assuming this to be correct, the fort occupied a position by the side of the creek. It is worthy of note that when the railway was being constructed remains of burnt vessels were found in the waterway; valuable evidence when we remember that the Saxon Chronicle thus tells us the deeds of King Alfred's men: 'And all the ships they either broke in pieces or burned or brought to London or to Rochester.'

ShoEBury.-The Danish work here is historically linked with that of Benfleet, for we learn from the Saxon Chronicle that in 894, the year in which Alfred's forces drove Hasten's army out of that fort, the Danes constructed a fortress at Shoebury (ba bergas weron ba gegaderode begen to Sceobyrig on Eastseaxum E bar geweorc worbtun). As there are no traces of other earthworks, it may be assumed that those fragments 


\section{ANCIENT EARTHWORKS}

which remain on the coast are of Hasten's construction. Though originally an inland fortress, as is proved in Mr. F. C. J. Spurrell's papers, ${ }^{1}$ the sea has washed away about half of it, and the banks of the remaining portion have been sadly mutilated by the War Office authorities, who now occupy the site.

Rampart and ditch remain on the south side while Rampart Street marksthe north line. A fraction exists, or did till recently, on

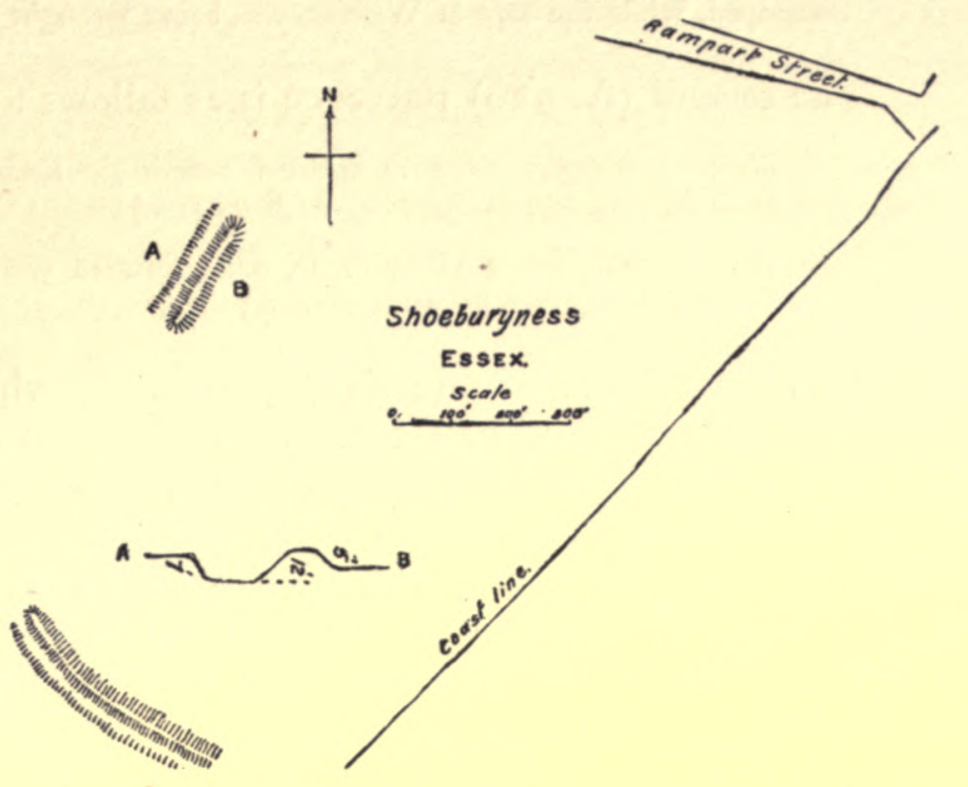
the west side, showing a ditch 40 feet wide outside a bank of about 12 feet in height.

In the words of Dr. H. Laver ${ }^{2}$ :-

It is probable that the few remains of this historical camp will soon disappear, unless an effort is made to enlist the help of the War Office authorities in its preservation, a matter which should not be difficult, seeing its value as an historical monument, and that the cost of preservation would be next to nothing.

MaLDon.-If any reliance can be placed upon the plan shown by Strutt, ${ }^{3}$ the earthwork at Maldon must have been of the most simple form-a rampart with a wide moat, surrounding an open space; but it is practically certain that in Strutt's days it was by no means so complete as indicated, for Salmon, who wrote earlier ( 1740 ), speaks of part being built upon and defaced. In his day three sides of the fortification remained; but now, alas! Mr. E. A. Fitch in his description of Maldon $(1898)$ can only say: "The site of this Saxon camp can still be faintly traced.'

Salmon ${ }^{4}$ says :-

There are the remains of a camp on the west side of the town, through the middle of which the Road to Chelmsford goes; three sides of the Fortification are visible. The ground within the Vallum seems to be of about twenty-two Acres . . . We see three sides of a Square or Oblong, the rest being built upon and defaced.

This has a fair Pretence to be Roman ; but as Edward the elder encamped here, it is not certain whether he fortified it, or found it ready done to his hands.

There are two references in the Saxon Chronicle. The first (A. 913) simply states that King Edward went to Maldon with some of his force and encamped while his burb at Witham was being constructed.

1 Essex Naturalist, iv. and Archaological Fournal, xlii.

3 Manners, Customs, etc. (1774).

2 Essex Arch. Trans. n.s. vi. 97.

4 History of Essex (1740), p. 419. 


\section{A HISTORY OF ESSEX}

(pa for Eadweard cyning mid sumum bis fultume on Eastseaxe to Maldune E wicode par ba bwile be man ba burb worbte $\xi^{\circ}$ getimbrede at Witham.)

(Then went King Edward with some of his force to Maldon in Essex, and there encamped, while the burh at Witham was being wrought and built.)

The second (A. 920) reference is as follows :-

(Her on bys gere foran to middum sumera for Eadweard cyning to Maldune छ॰ getimbrede pa burg छे gestađolode ar be ponon fore.)

(In this year, before Midsummer, King Edward went to Maldon, and built and established the burg, ere he went thence.)

Witham Bury.-Some sixty years ago, when little interest was taken in such relics of past history, the Eastern Counties railway was cut through the heart of this fortress, which is second to none to those who are interested in England's story unfolded in the pages of the Saxon Chronicle; for there we read of King Edward staying in Maldon in A. 9 I 3 while this burb was being constructed.

Road-makers and gravel-diggers have for long aided in the work

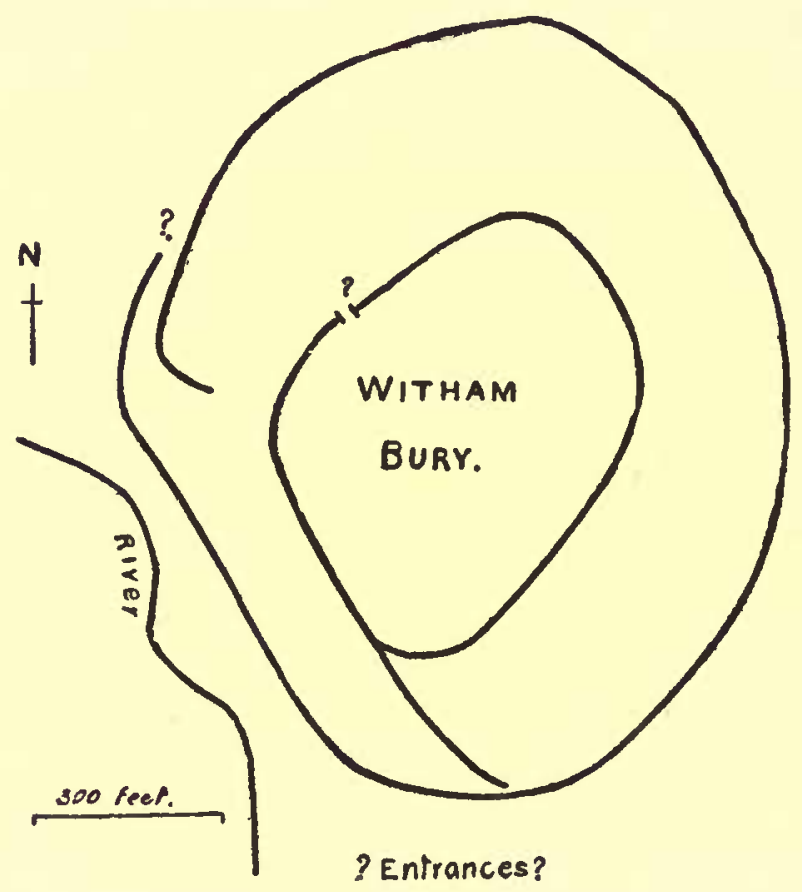
of its destruction, till only fragments remain of the burb that Edward worbte $\&$ getimbrede at Witham.

The best modern account of this earthwork was written by Mr. F. C. J. Spurrell. ${ }^{1}$ His paper gives a plan showing, in addition to the ramparts which are plain to the eye of the passer-by, the course of the destroyed works, traced by Mr. Spurrell when in winter visits he was able to follow their line.

The original fort seems to have consisted of a large enclosure of about 400 by $35^{\circ}$ yards, with an inner ward or keep 200 by 175 yards.

If this could be regarded as the typical form for a royal military burb of the period, much importance would be added to traces thereof.

Mr. Spurrell (to whose courtesy we are indebted for the basis of our plan, in which the black lines signify banks) says :-

On the south-west side, or that on which the River Panta runs, the hillside is very steep; on the other sides the land slopes gently from the middle of the camp. ... The ditches were dry; about thirty feet wide, and of slight depth.... I should think that, measured from the inside, the average height [of the banks] was seven feet.

1 Essex Naturalist, 1887 , i. 19. 


\section{ANCIENT EARTHWORKS}

It must however be noted that the sketch given by Strutt ${ }^{1}$ differs materially from Mr. Spurrell's plan, showing a low circular mound with bank, fosse and rampart.

All that a cursory examination now shows of this royal fortress are the ramparts on the south-west, standing high above the river, and these mutilated by the intersection of the Great Eastern railway.

DANBURY.-Here we have not the advantage of any Chronicle references nor of early plans of the defences before they were mutilated or destroyed by buildings, roads and cultivation.

There seems ground to believe it was occupied, if not constructed, by the Danes, who, it may be, simply adapted an older work. - The situation, upon the top of a hill rising high above the valleys, suggests British rather than either Roman, Saxon, or Danish origin.

The Danes seem to have added considerably to the interior arrangements, so far as can be judged by the plan in Mr. F. C. J. Spurrell's paper. $^{2}$ The attempt is made to compare the detail of this, with its (?) three wards, with the Saxon burb at Witham, but no very marked similarity is apparent.

The southern part of the outer earthwork is shown in Morant's Essex and in Gough's edition of Camden's Britannia, with a note in Morant that the 'glacis is 30 feet or more.'

$\mathrm{Mr}$. Spurrell found the banks in this part clearly defined, and in some other portions traceable upon careful examination.

\section{MOATED MOUNDS AND COURTS}

Under this head we include the simple moated mounds and mounds with base-courts. This is not the place in which to discuss the vexed question of period of origin of 'mound and court' castles; here we must generally be content to record their existence and present appearance.

BERDEN.-Three quarters of a mile south of Berden church, at Stock's farm, is a small moated mound unmentioned in our county histories.

The depth of the moat suggests serious defensive purpose, but the mound does not

\section{Berden Mound}

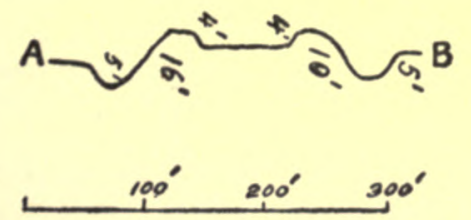

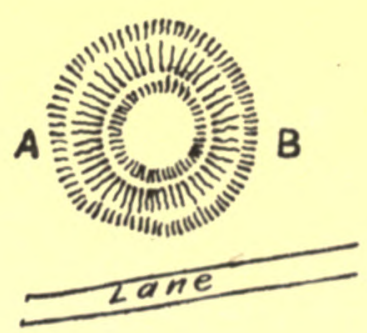
attain any considerable height ; it is however furnished with a bank on the inner side of the moat-an important feature of early defences. On the south and east sides the moat, now dry, has been partially filled in, being but 10 feet below the interior bank, while on the west and north sides the moat still contains water and is about 6 feet deeper.

1 Manners, Customs, etc. (1774).

I
${ }^{2}$ Essex Naturalist, 1890 , iv. 138. 


\section{A HISTORY OF ESSEX}

Bures Mount. - The parish has from early date been distinguished as Mount Bures, in contradistinction from the adjoining Bures St. Mary in Suffolk.

The mount with its surrounding moat covers about an acre and a half, there are no distinct remains of outer works, and the fort seems to have consisted mainly of the defenced mount, which Gough considered the keep of a castle of the Sackvilles.

The land to the west slopes rapidly to a brook, and on that side the moat has been partially destroyed by excavation for sand. On other sides the moat remains about Io feet deep, the great mound rising 48 feet on the west and $3^{8}$ feet on the east above the present level of the moat.

CANFIEld (GREAT).-All antiquaries may be thankful for the state of preservation in which the earthworks of Canfield Castle remain.

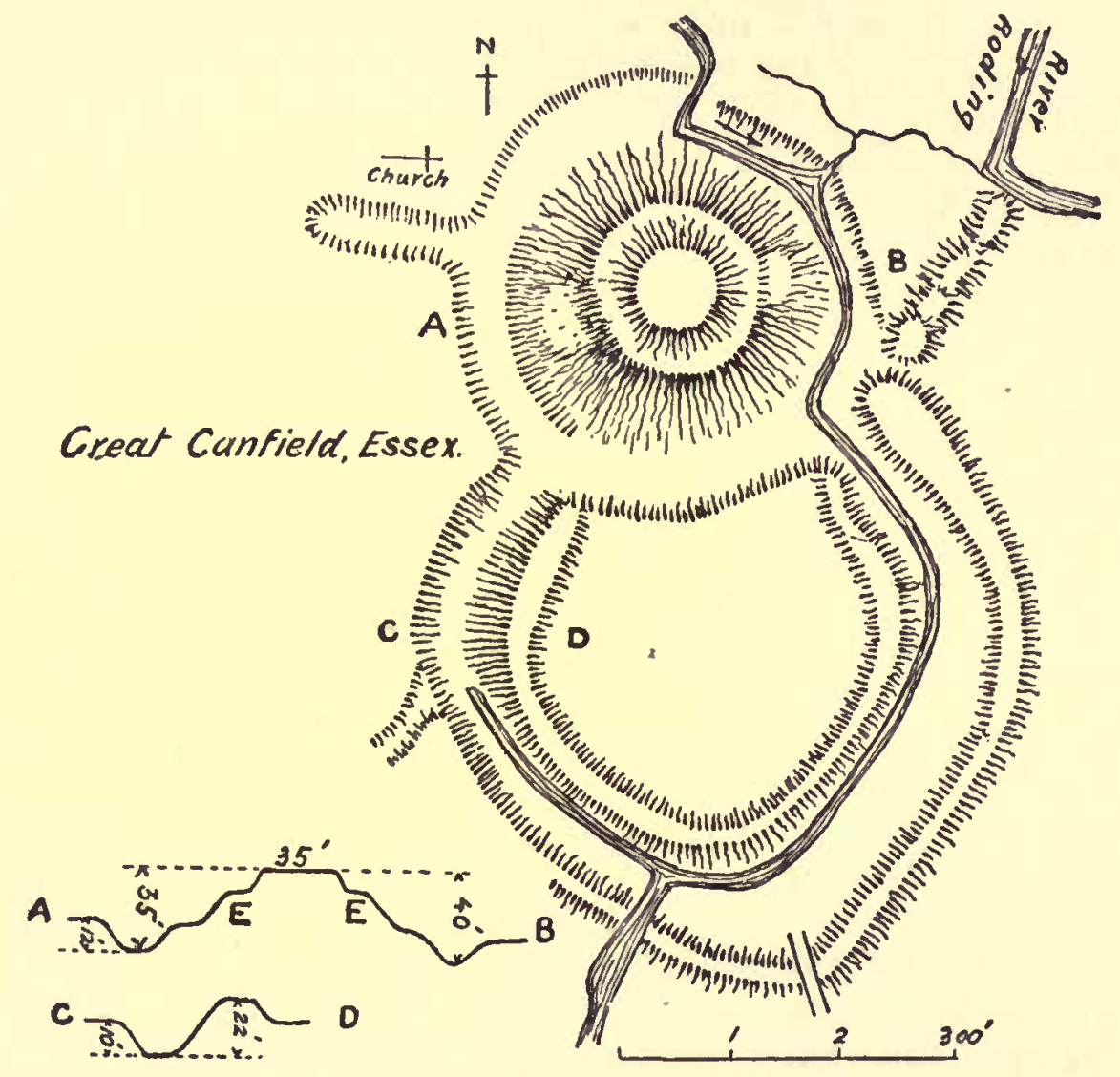

The work is second to none as an example of the methods of defence adopted in its construction - a great mound of earth, no doubt originally furnished with rings of wooden barrier defences, surrounded by a deep moat fed with water by the diversion of a little stream from its natural course, the mound still showing where one or more courses of palisading surrounded it, and showing too breaks in its ring, where probably approach and exit were effected by drawbridges; 


\section{ANCIENT EARTHWORKS}

while appended to the mound, but separated from it by the moat, is the horseshoe-shaped bailey, defended by its own deep moat, still retaining the greater part of a rampart on its outer side.

The plan shows a dam on the east, by means of which the waters of the Roding could be added to those of the little diverted stream, forming a never-failing body of water as an added defence to the mound on its eastern face.

Faithful to our promise not to discuss dates, we will not express our own views, but will show with how open a mind our old historian, Salmon, treated the question :-

When this was erected nothing shows [he states that some had implied it to be of Roman times]. There is room for other Guesses, which may be indulged, since we can arrive at no Certainty.

Fair Eddeva might fortify here before the Conquest ... or de $V$ er might do it during the war between Maud and Stephen . . . or de Ver might fortify here upon King John's destroying the Bishop's Castle of Weytemore.

Moating is projected forward at two points on the west ; this may indicate extension to form a second court or bailey, but it seems hardly likely, as the land rises considerably and shows no traces of continuation of the fosse.

CHRISHALL.-On the southern edge of a wood north-east of Chrishall church is a circular work with moat, a low broad bank or rampart surrounding the outer edge of the moat, save on the south-west, where it has been destroyed, or where possibly a natural declivity rendered additional protection unnecessary.

Owing to the density of the undergrowth we were unable to make a reliable plan, nor does the work appear in the 25 -inch ordnance survey map, but it is approximately of 150 feet diameter, with moat of about Io feet depth, excepting on the south-west, where it is 5 or 6 feet deeper. The outer bank above mentioned, being intersected by ditches from the surrounding wood, assumes somewhat the form of a succession of mounds, hence Salmon's statement-copied by Morant and subsequent writers-that mounds 'are raised at four places near the verge."

Clavering.- The principal part of the remains here consists of an oblong mound with a summit area of about 300 by 185 feet, elevated some 16 or 17 feet above its surrounding moat. On the north is a long rampart outside the moat, and further earthworks, to which we presently refer.

There is nothing in the character of the castle earthworks inconsistent with a pre-Norman origin, but Suene of Essex held the lordship at the time of the Domesday survey, and possibly by him, or by those holding under him, the mound was erected, or we may owe it to Robert Fitz Wimarc, who was lord in Edward the Confessor's time.

1 There is another work in the wood, but we think it was probably merely an ornamental adjunct to the gardens of 2 mansion built in the seventeenth century by Sir John James when this great wood was the park of Chrishall Hall.

\& Mr. J. H. Round is inclined to identify Clavering with 'Robert's castle,' to which the Saxon Chronicle tells us that certain Normans fled in A.D. 1052 (see p. 345 below). 


\section{A HISTORY OF ESSEX}

Morant speaks ( $\mathrm{r} 768$ ) of castle walls ' not long since in being.' No masonry remains above ground to tell the story, nor, so far as we know, have excavations brought anything to light.

Mention must be made of the great banks adjoining on the north. The plan shows the Stort, here but a small stream, flowing between deep precipitous banks, and forming a bend on the north-east, with a high and wide embankment on its southern side; below this bank is a low hollow area, about 70 feet wide, ending southward against the bifurcated rampart immediately north of the castle moat. ${ }^{1}$

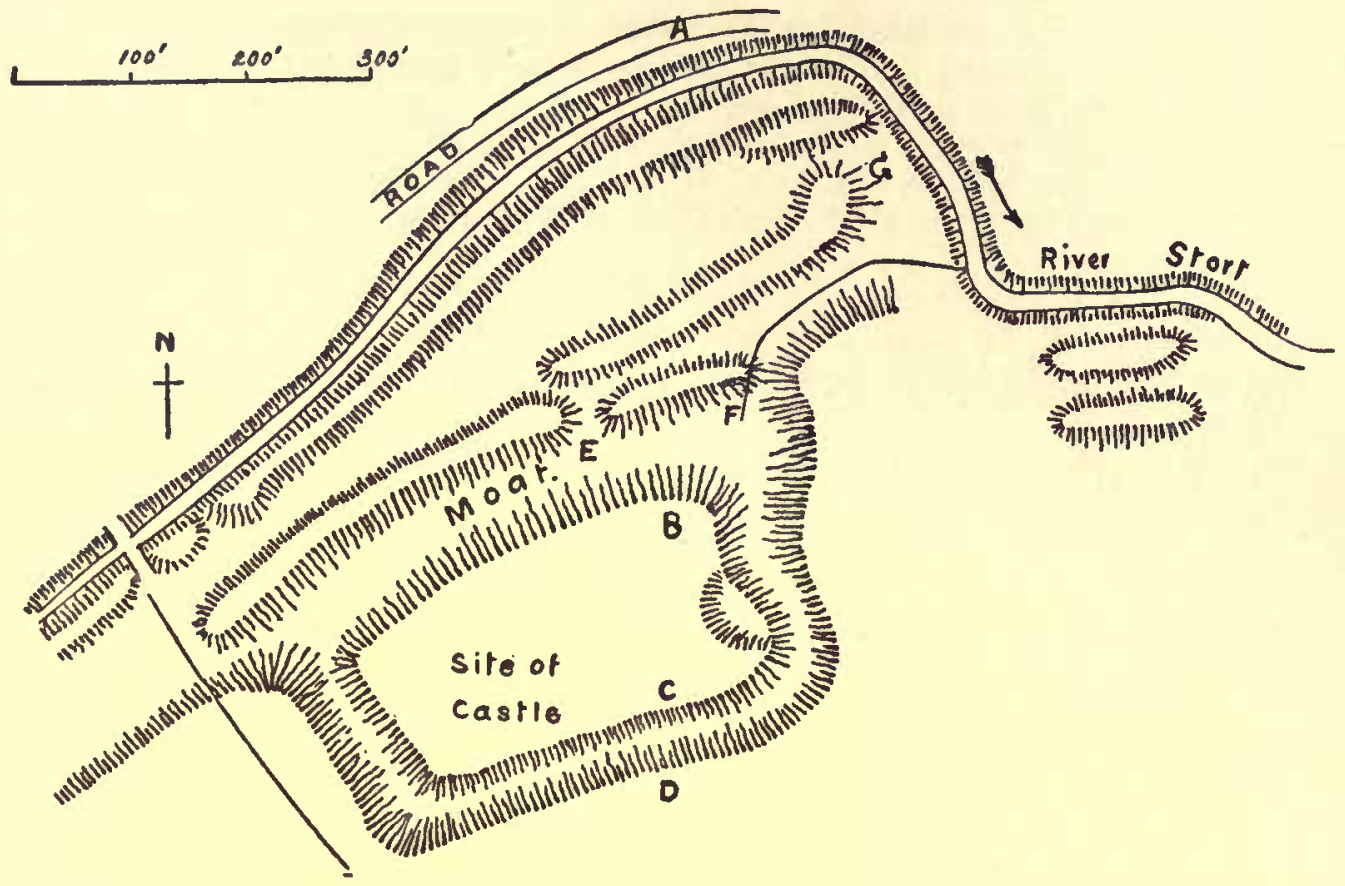

CLAVERINC. ESSEX.

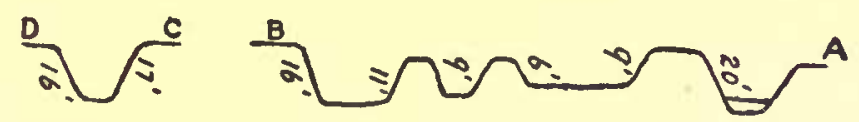

A careful examination of the extension of the banks up the valley westward enables us to understand their purpose. It is evident that the waters of the Stort flowed in part through the hollow area; the great banks keeping the water back formed a reservoir, probably for use in part to work a mill which may have stood at $\mathrm{G}$ where the banks divide.

But evidence is visible of further use for this reserve of water-at $E$ on plan there is an inlet through the banks, high enough to flood the whole moat surrounding the castle.

The bifurcation of the rampart close by the inlet $\mathrm{E}$ was no doubt furnished with sluices, which allowed the water to be carried away out-

1 The Rev. E. A. Downman is of opinion that these works have no connection with the castle enclosure, but whenever made they involved an immense amount of labour, and we incline to consider them part and parcel of the whole. 


\section{ANCIENT EARTHWORKS}

side the works or to be retained when needed. The castle moat proper could be relieved of its surplus water by a sluice at $F$, a point much lower than the inlet $\mathrm{E}$.

Close to and on the east of the present footbridge over the Stort will be noticed a break in the embankment, now partially filled up, through which the river water could be led into the reservoir; but examination of the ground further west shows that at some time a stream flowed along the bottom, indeed it is most probable that the Stort itself flowed here and was artificially diverted. Banking is evident to the west of the ground shown on the plan, and there are two mysterious little banks on the east which we indicate.

We have devoted much space to these outer earthworks, because they appear to form an interesting example of hydraulic engineering of an early date.

EAston (Great).-The moated mound here though insignificant when compared with the large work at Mount Bures is like thereto in giving a distinctive name to its parish, for there can be little doubt that the Norman place-name Easton ad Montem was derived from this artificial mount as Bures ad Montem from that.

Some would assign the mound to Roman or pre-Roman days, but it may well have been a lonely little fortified work in a clearing of the great woodland in Saxon times, or it may represent part of the defensive work of the grantee in Norman

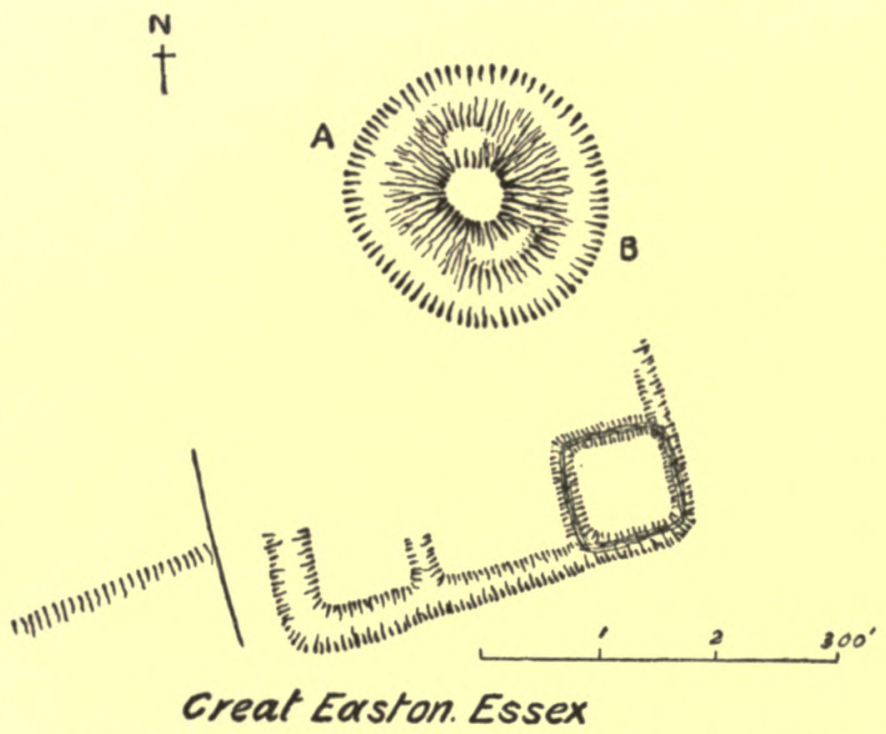

A line from $\mathrm{A}$ to $\mathrm{B}$ shows a moat about 8 feet in depth, the mound of about 20 feet altitude and the moat again.

William's reign. This view is perhaps strengthened if we can regard the scanty traces of outer work on the south as part and parcel of the whole.

Elmdon.-Close to Elmdonbury, now the chief manor-place of this parish, is a wood for generations past known as Castle Grove ; within it is a circular moated mound, to which no reference is made in our county histories. It may have been, probably was, the first site of the castle or manor-house of the manor mentioned in Domesday, then held of Count Eustace of Boulogne by Roger de Sumeri. ${ }^{1}$

1 It may be well to note that the present house of Elmdonbury, though of some antiquity, is not on the site of the late-mediæval manor house, it occupied the square moated enclosure about 400 yards to the west. 


\section{A HISTORY OF ESSEX}

The mound with its surrounding moat is only about 150 feet in diameter, and the moat has been lessened in depth by centuries of accumulation of leaves and decayed vegetation. Along the inner edge
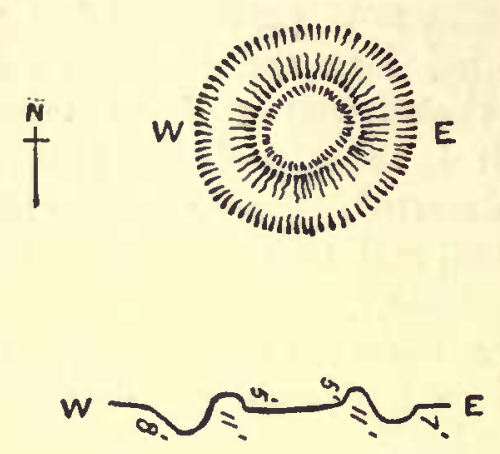

Mound in Castle Grove

ELMION ESSEX.

\begin{tabular}{ll}
$100^{\circ} \quad 200^{\circ} \quad 000^{\circ}$ \\
\hline
\end{tabular} of the moat runs a bank, as at Berden, giving a saucer-like form to the top of the mound.

FeLsTead.-There is a small mound at Bannister Green known as the Quakers' Mount. Mr. J. French writes ${ }^{1}$ : 'It is from I 5 to 20 feet high and somewhat oval, with a flat top, being about 20 paces long at the top and 18 broad. Its sides incline at an angle of $45^{\circ}$, and it was formerly surrounded by a moat about 8 or 10 feet broad. Not quite half of this moat still exists, the rest having been filled in in great part by earth removed from one end of the mound. The original symmetry can be well made out in spite of this mutilation.'

Hedingham (CAstie). - The noble twelfth century tower of Hedingham Castle has been the subject of artists' pencils and antiquaries'

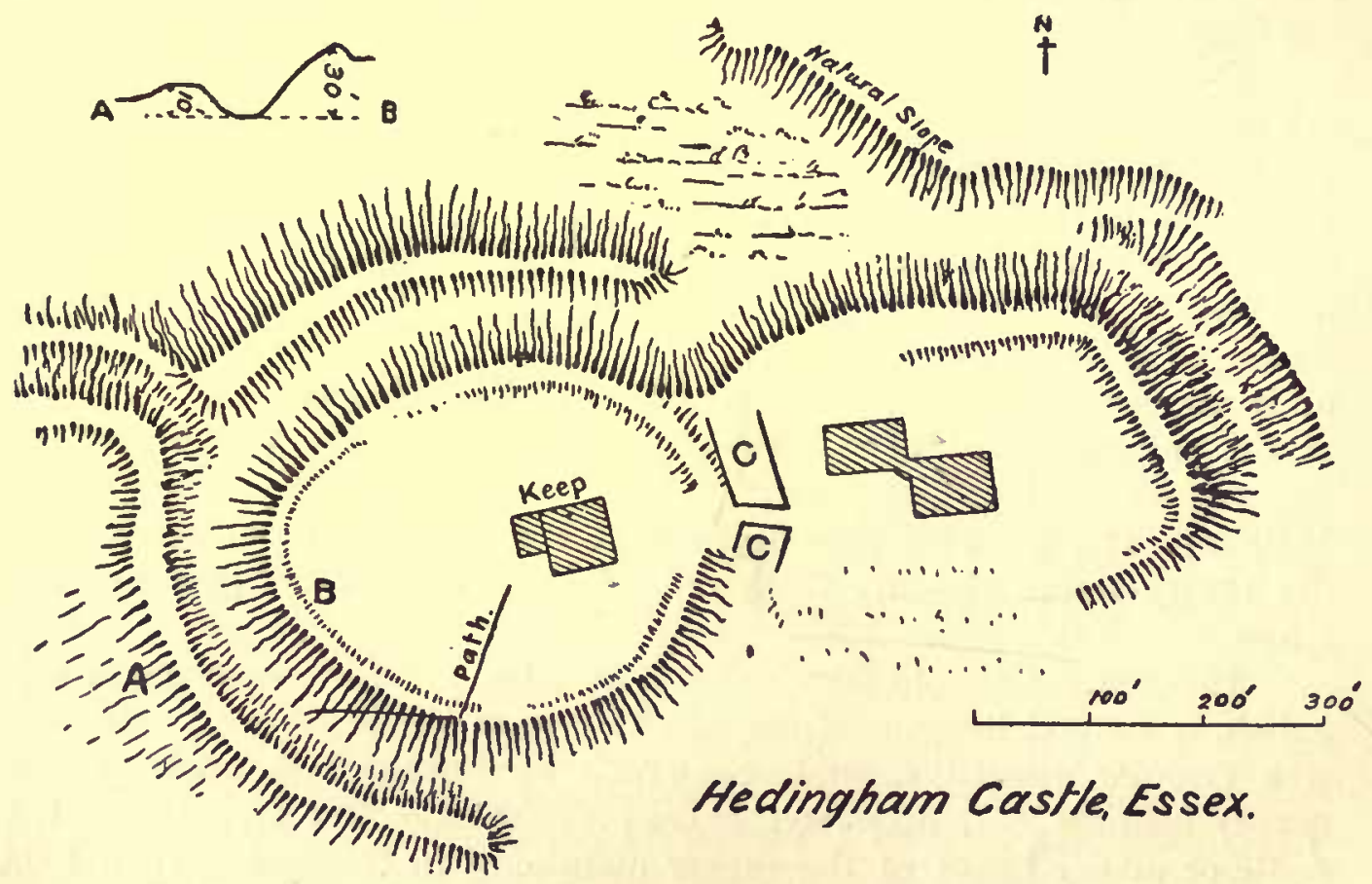

pens, but the great fosse and ramparts have seldom, if ever, been depicted or described. That they were here long before the stone keep is probable, but how long before we may not assert. 


\section{ANCIENT EARTHWORKS}

A natural hill projecting towards the west, near the junction of two roads of ancient importance, was seized upon as a suitable site for defence.

Across the promontory was cut a fosse (c), separating the high west end from the rest; this fosse remains, but partially filled up and spanned by a Tudor bridge.

Then a great dyke was scored around the steep sides of the high ground, and the material largely thrown outwards, forming a protecting rampart. Either at the same time or probably later, a base-court or bailey was formed on the east of the mound, protected by its own high rampart and deep fosse.

The fosse of the bailey is discontinued on its north-west at a point where a sheet of water appears to have existed.

It is noteworthy that in exactly the same relative position at the castle of Canfield, water was provided in abundance if needful.

At the west end of the earthworks a narrow pass is cut through the outer rampart, the banks being continued outwards for its defence. Down this pass water trickles, probably the overflow of that which supplies the castle well on the height above, and the path here is the only existing original entrance to the works. The terracing of the gardens in front of the mansion long ago destroyed traces of the bailey rampart and fosse on the south, but probably it was there that the main entrance to the castle was placed.

LatTon.-Within the parish of Latton, but close to Harlow station, is a low hill rising about 23 feet above the general level of meadows. It is an open question whether man's handiwork is traceable on this hill, which has been long associated by local tradition with a fort of some sort.

So long ago as $182 \mathrm{I}$ tradition found voice in the Gentleman's Magazine, and in Arcbaologia, where very strong walls are said to have been found a few feet below the surface.

The hill or mound was practically an island in early days, as the waters of the Stort gave a morass-like character to the surrounding valley.

The opinion that some modifications have been made of the natural form of the hill, that relics of Roman occupation have been found, and that the deep trackway to the hill, coupled with local tradition, points to some defensive work having existed, will be found in the Transactions of the Essex Arcbaological Society. ${ }^{1}$

The view that the whole hill is of unmodified natural creation is expressed by Mr. T. V. Holmes, F.G.S.

The riddle must remain unsolved, unless perchance the pick and shovel some day throw light on the matter.

NAvEsTock.-Early in the eighteenth century Dr. Stukeley, the celebrated antiquary, discovered somewhere on Navestock Common ${ }^{3}$

\footnotetext{
1 Essex Arcb. Trans. n.s. v. 95 ; viii. 239.

2 Essex Nasuralist, ix. 59.

Then waste land, but enclosed and cultivated since 1768 .
} 


\section{A HISTORY OF ESSEX}

an earthwork which he imagined to be an 'Alate Temple of the Druids.'

Extracts from Stukeley's diary ${ }^{1}$ show that he was at his Alate Temple at least four times (from 1725 to $176 \mathrm{I}$ ).

The entry of August 5, I761, says: "Tis much overgrown with fern, and but lately, so that 'tis difficult fully to discern it. They have dug gravel there lately.'

Fortunately Stukeley not only specifically described the position of the earthwork but also made a sketch of its form, ${ }^{2}$ and we may recognize in the main the lines of a 'mound and court' fortress such as we have some, splendid examples of in Essex, though here the mound by Stukeley's time had lost some of its altitude or he could not have found it 'difficult fully to discern.'

The late Rev. S. Coode Hore of Navestock and Professor Meldola, F.R.S. (of course without any faith in Stukeley's Druid theory), determined to discover the site, and after a prolonged search they arrived at the conclusion that the excavation by the roadside near Princes' Gate is part of the work.

The solitary remnant of an excavation fails to convey any definite impression, but its position tallies with Stukeley's description of the site.

ONGAR.-The altitude and bulk of the great mound of Ongar Castle, the depth and width of the moat, the solid rampart round the bailey, and its height above its moat, tell us that we have here the remains of a once important fortress.

Part of the rampart and fosse of a second bailey extends for about 400 feet on the west, the rest having been mainly destroyed in the growth of the town of Ongar, though here and there further traces of the sweep of the defences may be found.

There are indications also of a court to the east of the mound, and perhaps of a second beyond, or possibly of an outwork cutting off the site of the fortress on that side.

Careful examination is necessary to realize the physical conditions of the site in the days when it was first fortified-a promontory projecting southward from the tableland above, with the then marshy valley of the Roding on the east, a narrower stretch to the south, and the little valley on the west, through which the Cripsey flowed to meet the Roding. Only on the north was natural protection entirely lacking, and across that side the earliest occupiers seem to have constructed some slight protective work.

It was probably long subsequent to the first occupation of the site that the great earthworks of Ongar Castle were constructed.

Without going into detail as to their date, we may say that our view is that though there may have been works here in pre-Norman days which had fallen into disuse when Count Eustace of Boulogne

1 Essex Naturalist, viii. $221,222$.

2 Reproduced in facsimile in Essex Naturalist, ix, 214. 


\section{ANCIENT EARTHWORKS}

obtained the grant and probably made Ongar the 'caput' of his great Essex fief, ${ }^{1}$ he materially altered the defences, and that it was not till Richard de Luci's lordship in the twelfth century that the final development took place, a development which made Ongar Castle a huge fortress.

The plan shows all that is left of the ramparts, but it is necessary to add that solidly built rubble and tile masonry occurs at $e$, probably the only gateway from the outer to the inner bailey.

The earthen ramparts were mainly crowned with stockades or palisading of timber, but here and there towers of masonry may have been erected, as rubble is found at one or two points on the bank. The

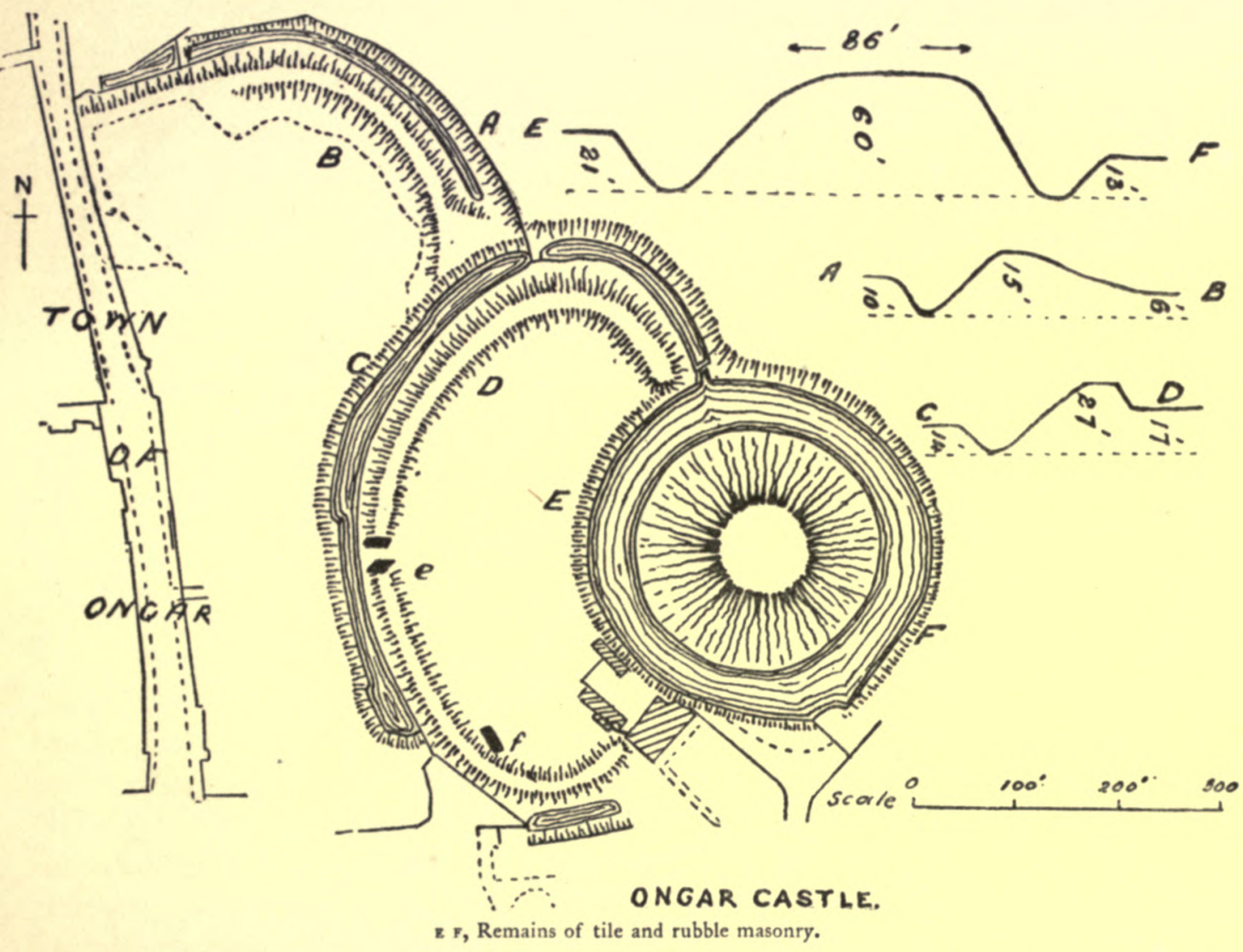

old local idea was that the masonry which is exposed at $e$ ran round, forming a core to the bailey rampart, but excavations have proved that chalky boulder-clay, gravel and sand rammed together are the main constituents of the wall.

Pleshey.- It has usually been considered that the construction of the outer entrenchment at Pleshey took place long anterior to the time when the great mound and court castle was thrown up, perhaps destroying a portion of the older work on the southern side. The outer work consisted of a rampart of earth with a fosse or moat without, both are well defined in a portion of the circuit but much reduced in the height

1 See Mr. J. H. Round in Essex Arch. Trans. n.s. vii. 143, and Chisenhale-Marsh's Domesday, lx. 


\section{A HISTORY OF ESSEX}

of the bank, and correspondingly lessened in the depth of the fosse, while in some parts the rampart has been levelled.

Its complete circuit was doubtlessly much longer, but about $\mathrm{I}, \mathrm{I}$, yards remain. Though numerous finds of early pottery and some bronze implements have been made within the area enclosed by the outer

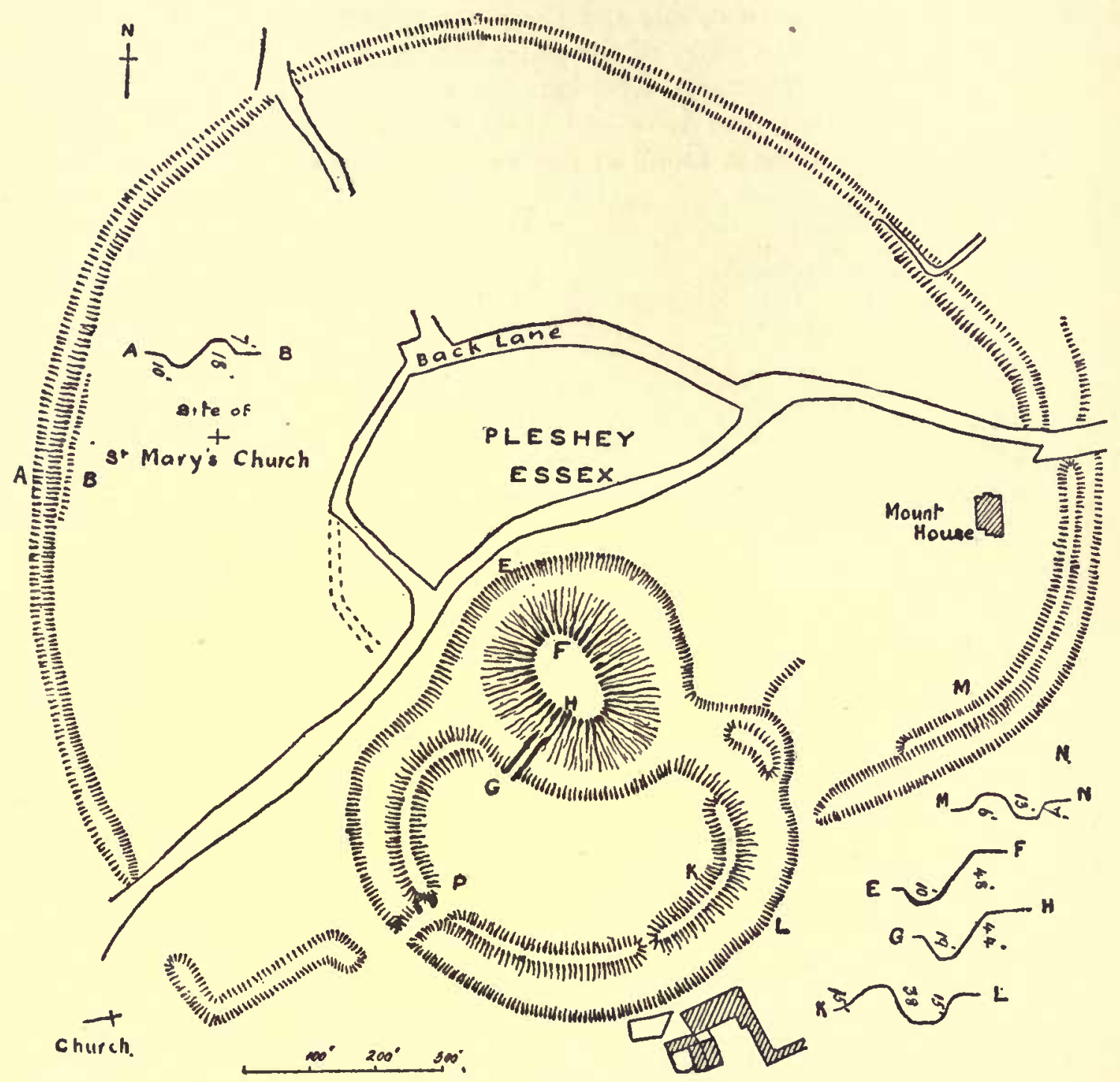

entrenchment there is no positive evidence as to its date. Mr. J. Horace Round has shown that the parish takes its name from the old French word Plaisseis or Plaisseiz, signifying an enclosure. ${ }^{1}$ This it would seem cannot but refer to the rampart and ditch surrounding the village. From its general appearance it seems probable that the work was one of British origin. ${ }^{2}$

The great castle mound, with its appendant court on the south, is

1 Essex Arch. Trans. n.s. v. 83-6.

2 The Rev. E. A. Downman, who possesses probably an unequalled acquaintance with the earthworks of England, is inclined to think the outer works of the same date as the castle mound and court. 


\section{ANCIENT EARTHWORKS}

far better known than the outer entrenchment to which we have referred, and has the advantage of having played a part in Shakespeare's magic pages. Other hands will take up the story of Pleshey Castle in historic times, for us it is left to record the remains - the bare earthen skeleton, parent of the towers and walls and halls of masonry which subsequently formed the castle home of the high constables of England.

We find now a great keep-mound, somewhat oval in form, rising nearly 50 feet above its surrounding moat, a brick bridge connecting it with the base-court or bailey, which is protected by a high rampart with its own proper moat 30 to 40 feet below, and some indication of a second bailey on the north of the mound. Back Lane seems to follow the course of the moat to this second or outer bailey.

Some say masonry runs through the length of the southern bailey rampart, but we think that, as at Ongar, masonry was used only at the gateways, timber being a sufficient protection for the summit of the ramparts standing high above the water-filled moat.

The masonry indicated at $P$ on plan consists of two rubble walls, the space between being filled with clay and sand. The outer wall is $3 \frac{\mathrm{I}}{2}$ feet thick, the inner 2 feet. The latter has red tiles with the rubble.

PuRleigh.-There is an entrenched mound here slightly raised above the surrounding surface level. It apparently gives name to a manor at Purleigh known as 'Le Howe,' formerly a member of the manor of 'Lalling,' or, as it is now known, 'Lawling.' It was possibly a moot hill or law hill.

Mr. E. A. Fitch ${ }^{1}$ describes it as probably Saxon or Danish, circular, about 55 yards in diameter, and surrounded by a ditch about 12 feet wide.

Rayleigh CASTle.-The commanding position it occupies renders Rayleigh Castle in some respects the most striking of Essex earthworks.

A short spur projects from the range of hills running high above the wide lowlands to the west, overlooking a great extent of country, a point of strategic importance in early days. ${ }^{2}$

This spur has been boldly modified into a typical mound and court fortress; the keep mound occupies the westward end, and is nearly surrounded by a deep dry fosse, which on its east divides it from the bailey, an enclosure furnished with its own proper fosse. Of the second or outer bailey some effort is necessary to enable us now to trace the lines, owing to alterations for houses and gardens of the little town of Rayleigh, and to some levelling of the pastures which has taken place within the last hundred years or so.

Pre-Roman or British origin has been claimed for all or part of the earthworks by some of our eminent antiquaries, while Weever, writing

1 Maldon and the River Blackwater.

2 With sorrow we have to advise those who wish to see Rayleigh Castle to do so speedily, for the destroyer is at hand; already roads are marked out on the western slope, and soon the grand view will (thanks to modern vandalism) be changed to a prospect of back premises of villas and cottages.

3 A plan of about 1789 in Kerrich's collection (British Muscum Add. MS. 6735) shows a second bailey. There are traces of further works around, for which see plan (opposite p. 172, Essex Arch. Soc. Trans. iv. n.s.). 


\section{A HISTORY OF ESSEX}

in 1631 , says, "Swein de Essex .. built the ruined castle in this towne, in the raigne of Edward the Confessor.'

Mr. J. H. Round has expressed the view that the Domesday words ' in boc manerio Suenus fecit suum castellum,' imply, though they may not prove, that Suene raised the mound in William's reign. ${ }^{2}$

We think however that the words would equally apply though Suene had simply utilized the site of already existing but ruined works for his castellum. No sign of the use of stone is apparent on any part

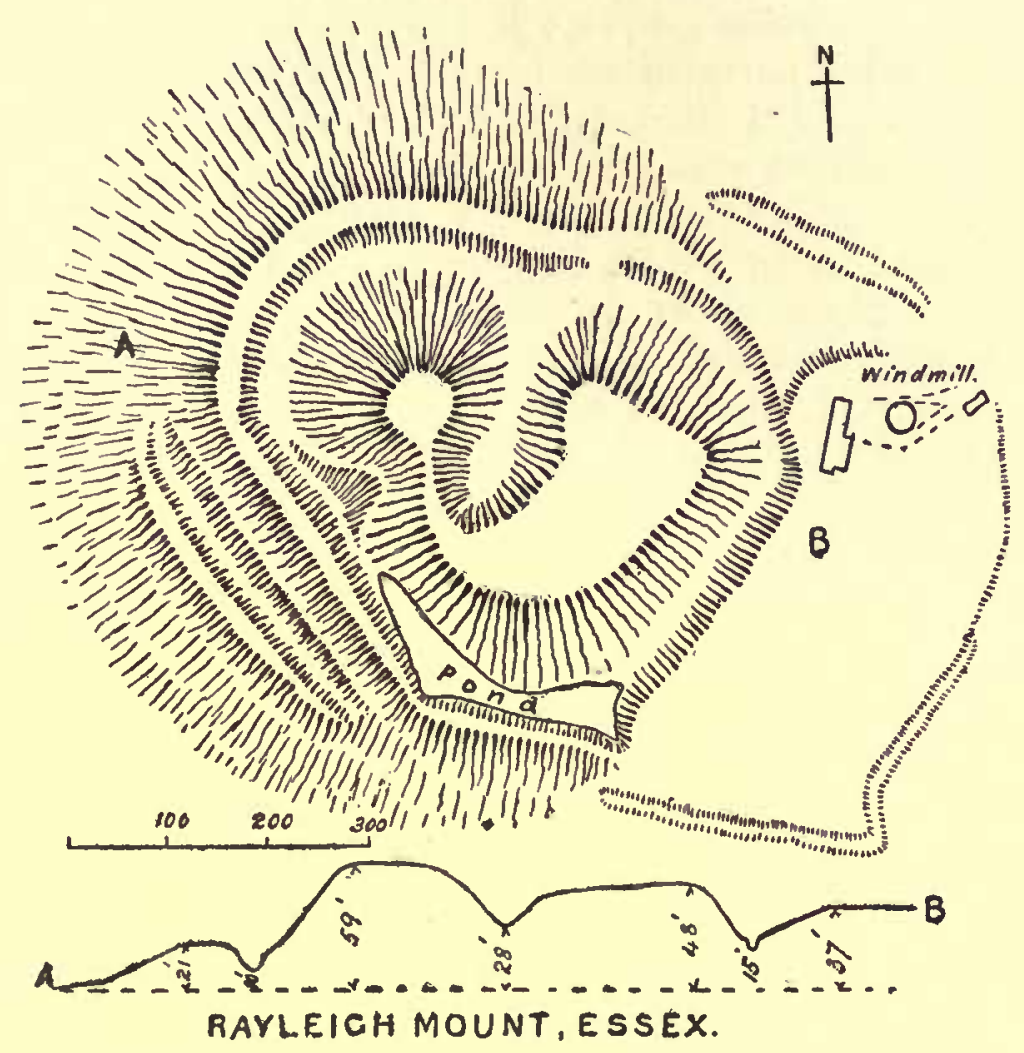

of the site, though one may speculate that Weever's reference to the ruined castle implies an existence of masonry at his time.

Rickling Mound.- In the pages of Morant's History is a short pleasing description of Rickling Hall, which we would quote, but that our section of the Victoria History deals with earlier work than the remnants of this once important mansion, which, by the way, is well described and illustrated by Mr. C. R. B. Barrett. ${ }^{3}$

Traces of extensive moating remain around the hall, suggesting the existence here of some earlier well-defended abode.

Our concern however is with the mound adjoining the hall enclosure on the south, for though the moats of the hall may have existed contemporaneously with the mound, we are inclined to think the latter

\footnotetext{
1 Weever, Ancient Funerall Monuments, p. 603.

2 See pp. 345-6 below.

9 Barrett, Essex: Highways, Byways, and Waterways, ser. 2, p. 21. 


\section{ANCIENT EARTHWORKS}

earlier, mainly because the fosse or moat proper to it has been at some period obliterated by the southern moat of the hall, which, though now filled up, is easily detected. The mound-keep, never large, has been mutilated, but the plan and section show its present condition.

The size of the banking outside the keep-fosse, on the south-west side, indicate considerable protective work, and for the greater part of the circumference the moat or fosse is still in evidence.

SAFFron WALDEN.-Traces of earthwork defences are around the castle of Geoffrey de Mandeville on
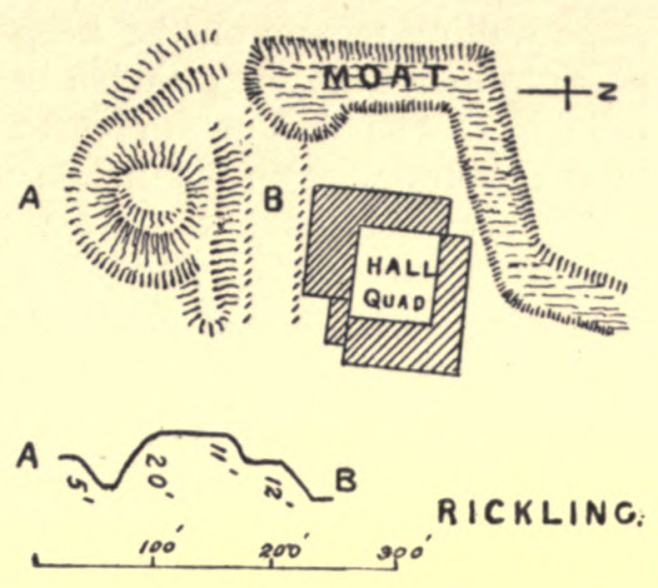
Bury Hill, the highest point in the town; they are however too slight to warrant detailed mention here. The interest of the place centres in the ruined castle of the Norman lords rather than in the possibly earlier earthworks.

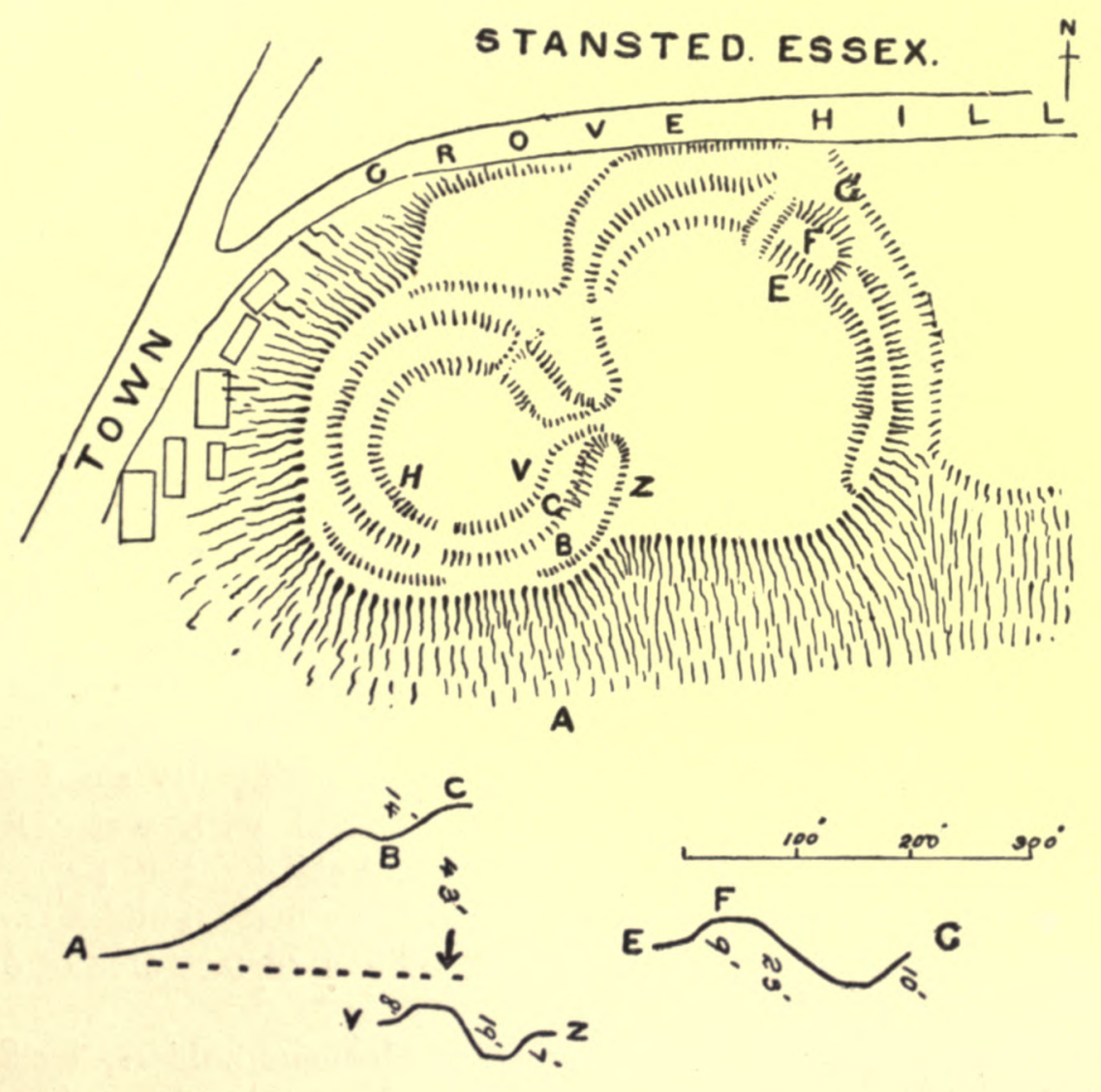

Stansted Montfitchet.-To tell the story of the Norman Gernons or of the Montfitchets would be trespassing on ground to be covered by other writers, but we may mention that it is thought that the castle 


\section{A HISTORY OF ESSEX}

was destroyed during its possession by Richard de Montfitchet in I 2 I 5 , and that it never was rebuilt ; its walls of masonry proving a quarry for building operations throughout the neighbourhood. Just a few feet of stone walling remain on the keep at $\mathrm{H}$ on plan, but foundations of other portions may exist, long hidden beneath the turf. Some antiquaries have thought that an older mound fort existed previously, but from some points in the castrametation we incline to think this one of the latest mound and court forts in Essex. Here, as at Rayleigh, advantage was taken of a naturally strong position, though here the spur of hill is in a little valley in place of being a bold promontory overlooking an open country.

The existing earthworks show a strongly situated keep, defended in part by the steepness of the slope and in part by a deep fosse (the eastern side of this fosse separating the keep from the slightly higher bailey) and the bailey or base court with high rampart and remains of

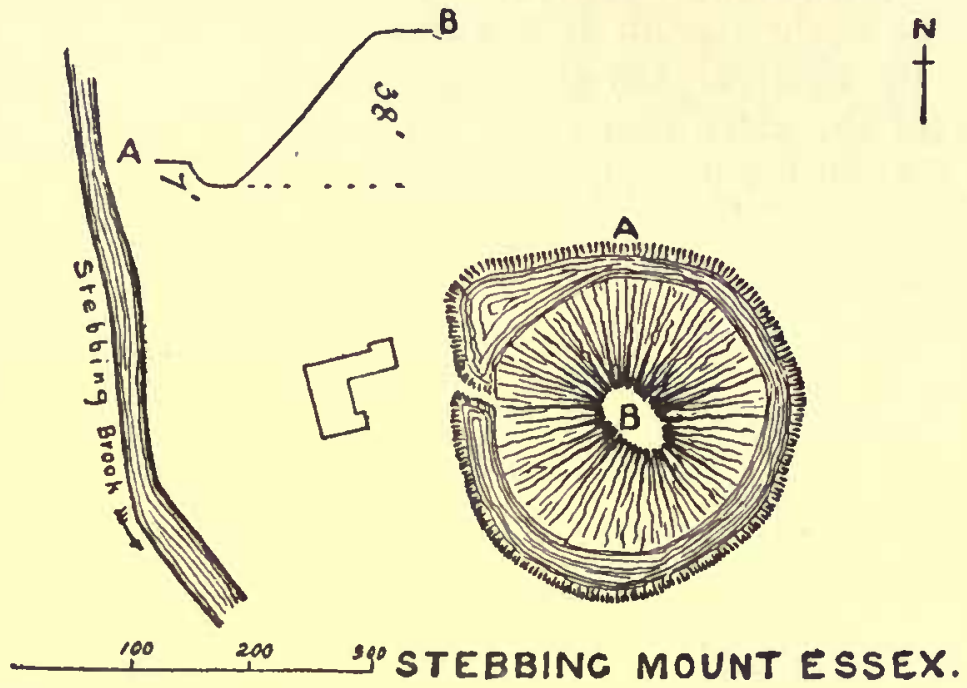

fosse. Unfortunately the bailey rampart and fosse has been destroyed all along its southern side, where no doubt gravel has been excavated. Ancient houses occupy part of the fosse on the west of the keep, and a road has destroyed its extension on the north of the bailey.

It is hoped that no further mutilation of this interesting little castle will be allowed.

Stebbing Mound.-The mound is raised artificially some 38 feet above its surrounding moat, which is well filled with water from a spring. The manor of Stebbing Hall was held by the Ferrers and Peverells at the great survey, when probably the main building was on the summit of the mound, which is flat, with a surface area of 60 feet by 25 feet.

Whether thrown up by one of these Norman holders, by Siward who owned the land in Edward the Confessor's time or by earlier occupants, we cannot say.

The History of Essex, by a Gentleman ( 1769 ), says: 'Here are two 


\section{ANCIENT EARTHWORKS}

hills or mounts, on the highest of which, as tradition goes, a castle formerly stood.' If ever there was a second mound it has disappeared.

\section{HOMESTEAD MOATS}

We thus denominate the level-surfaced, small, watermoated enclosures which abound in the eastern and some other counties of England. Though usually the site of an ancient manor house or hall, grange or farmhouse, in some cases church, hall and hamlet were included in the protecting sweep of the moat, as at Mundon, Hazeleigh and Canewdon.

As Essex possesses between 300 and 400 examples of homestead moats, needless to say we do not propose to enumerate them, but may briefly mention some peculiarities of construction.

As a rule the works are rectangular, the only defence a deep moat, varying in Essex from 12 or 15 feet to 60 feet in width (Botelers in Basildon has one over 60 feet wide), the earth dug from the moat being thrown inwards and spread, the surface of the island thus created is made higher than the surrounding ground.

Occasionally we find circular moated enclosures; these almost always exhibit evidence of early and more defensive work, for example at North Weald, where the little unoccupied circular site has remnants of a low rampart on the inner verge of the water.

Here and there we have moats with the island intersected by a channel, dividing it into two defensible parts, as at Warish Hall (Takeley), Shellow Bowells, etc.

There are some with secondary moated enclosures added irregularly to the main island, as at Berwick Berners, Fingreth Hall (Blackmore), Stock Hall (Matching) and others.

Sometimes the extension of the waterworks created three such islands, for example, Essex Hall (Stambourne), and Colchester Hall (Takeley).

At Helions Bumpstead and Pierce Williams (Hatfield Broad Oak) are curious stirrup-shaped works, one side straight, the remainder curved. ${ }^{1}$ A nearly similar one is at Bolding Hatch (Roxwell).

It is interesting to find examples of double moating one within the other, the outer generally slight and at some considerable distance, allowing space for pasture, as at Edwin's Hall (Woodham Ferrers), Mardens Tye (High Easter), Warish Hall (Takeley) and elsewhere.

At Good Easter, by the church, is a batch of four moated enclosures close together, but not conjoined, apparently independent one of another, and each the site of an ancient home.

The exigencies of space will not permit of much discussion of the question; when was this simple form of defensive earthwork first adopted?

We point to examples at the head or on the sides of creeks and

1 Curiously enough on the inner verge of the moat of exch of these are (or were) one or two small mounds or tumuli. 


\section{A HISTORY OF ESSEX}

rivers, up which Danish raiders doubtless passed, and ask ourselves whether it was not for defence against those marauders that these homestead moats were made, or in some instances by landing parties of the Scandinavians themselves ?

At no subsequent period could it have been necessary to defend a whole village, as in the case of Mundon and others already mentioned.

Great moats guard the site of the eleventh-century homestead of the priory of St. Valery, where Warish Hall stands with its double island, water-girded, and its traces of the outer moat. Tiptofts, in Wimbish, has thirteenth-century oaken columns, door and stud work, within its modern casing.

We find moats surrounding fifteenth century halls, such as Cammas in the Roothing country (a district abounding with homestead moats) and others, while of sixteenth century homes thus water-guarded we have far too many to name here.

The moated enclosures may, of course, have been ready to hand when the houses were reared, but we incline to think that such moats were made from an early time down to the late period when barns and stacks needed protection from beasts of the forests rather than from human foes.

\section{MISCELLANEOUS EARTHWORKS}

[Under this heading are included tumuli, barrows, boundary banks, and such early works as cannot be definitely classified.]

Ashdon: The Bartlow Hills.-Although named after the parish in Cambridgeshire to which they are contiguous, these fine tumuli are situate in the parish of Ashdon in Essex. There were originally seven of these mounds, the height of the largest being 45 feet and its diameter I 47 feet. The remainder were of somewhat smaller dimensions. There are now only four of the hills remaining. Those which were situate near the road were removed in 1832 for the purpose of clearing the ground for agricultural use, but their contents were duly recorded and their sites are still indicated by slight elevations of the surface. Between the years 1835 and 1840 three tumuli were opened up and examined. Drawings and plans with full reports of the excavations are given in Arcbaologia. As these works were erected during the Roman occupation, reference to them will be found in the chapter devoted to that period and it is therefore unnecessary to add more here.

Chrishall.- In 1847 the Hon. R. C. Neville (afterwards Lord Braybrooke) opened a barrow, apparently in this parish, though there is some difficulty in identification of the neighbourhood from the writer's description.

Of relics the tomb was 'rich only in poverty,' but it was of exceptional interest insomuch as the one barrow contained 'two different modes of interment . . . one Roman the other British.'

Colchester.- The earthworks (still in part surrounding the castle bailey) cover much Roman masonry. It is only necessary here to men- 


\section{ANCIENT EARTHWORKS}

tion the fact of the banks having been thrown up at some period subsequent to the construction of the Roman building ${ }^{1}$ now hidden beneath, and the existence of a deep and wide fosse or moat on the north side and partly on the east.

Dunmow (LiTTLE).-Wright refers to 'a square area, surrounded by earthworks which are very high on the southern side' to the south of the church. We judge these to be simply remains of the Dunmow Priory fishponds.

In a field sloping towards the Stane Street were found some pits containing numerous fragments of pottery and much charred matter.

EPPING.-Remains of mounds exist in the neighbourhood of the town, but in the absence of proper exploration it is impossible to say that they are other than hillocks thrown up in modern times, though the opinion has been expressed that they are ancient tumuli.

Fesstead.-Here is an ancient dam across a valley about a mile north of the village. It is intersected by the Dunmow and Braintree branch of the Great Eastern railway and is about I 50 yards long, about 35 feet broad at its base, Io feet at its top and 20 high at its highest part. It has been suggested that it forms the dam of a lake constructed in prehistoric times.

Hatfield Broad OAK.-Within the forest, at or near Portingbury Hill, there are the remains of a defensive enclosure (now little more than ditches and a slightly raised platform with shallow moat) so indistinct in parts that it is difficult to classify the work. Salmon, writing in 1740, says of it: "In Beggars-Hall Coppice on the Forest, in the Way to StaneStreet, is a small Spot of Ground called Porting-Hills, and PortingburyHills. At a little Distance from that, the traces of a larger circular Entrenchment, with what Intention made does not appear.'

Hockley.-Plumborough Mount has been claimed to be of Danish origin, owing its existence to Canute's great victory over Edmund Ironside in 1016. The memorable fight took place at Assandûn, now Ashingdon, the neighbouring parish.

In Benton's Rocbford Hundred an alternative suggestion is made that the mound ' may have been thrown up for the purpose of signals in connection with the comes littoris Saxonici' in Roman days.

A careful examination might tell whether to either of these or to earlier days this barrow belongs.

It appears wholly artificial, its base being about 90 feet in circumference and its summit though lowered, I 6 feet above the round hill upon which it stands, forming a conspicuous landmark.

Partly in this parish but on the northern side of the Crouch are groups of small barrows; for description of these see Woodham Ferrers. Maldon.-A tumulus situated in Mountfield is described by Mr. E. A. Fitch," who says it is 'doubtless Saxon or Danish, and stands

1 Possibly it is to these banks the following entry in the Pipe Roll refers: " $\_50$ ad faciendam Balliom circa Cossellum de Colecestria' (19 Hen. II. 1172-3); but it may relate to an outer bailey being then constructed.

Maldon and the River Blackwaser, P. 37, ed. 3 (1898). 


\section{A HISTORY OF ESSEX}

in a commanding position between the Saxon camp at Maldon, and within sight of the Danish camp and settlement at Danbury (Danes' town); it is probably contemporaneous with these and with Purleigh Mount.'

Other tumuli which existed in this part of the county have been ruthlessly destroyed, though traces of some are indicated on the 25 -inch Ordnance Survey map ${ }^{1}$ while one on Northey Island in the parish of St. Mary, Maldon, remains intact.

Stow Maries: Barrows.-See Woodham Ferrers.

Tilbury (West).- - South of the hall garden is a fosse or ditch with a broad bank on its outer side formed by the ridge of a steep hillside rising abruptly above the Thames valley.

This fosse, about 250 feet long, and a return piece of 72 feet on the west, are the only vestiges of antiquity that we see here.

Some assert that a Roman 'camp' was here, while others have claimed that the work was constructed as a defence to the camp of Elizabeth, when that queen rested at West Tilbury the night before her celebrated review of her troops on August 9, I 588. As Mr. Thorne indicates $^{2}$ a contemporary chart exists, which shows the camping ground to have been adjacent to the church and hall.

Mr. F. C. J. Spurrell, writing in $188_{5}$, referred to outer earthworks and a slight ridge bordering the hilltop "which may have been of a very early date,' but these evidences seem to have disappeared, owing perhaps to the gravel-digging which is in progress.

Totham (GREat).-On the southern tongue of this parish and in Heybridge (on the northern side of the Blackwater) were tumuli known as the Barrow or Borough Hills; few or no traces remain, though the mounds were formerly considerable in number.

Salmon thought them the graves of Saxons or Danes slain in warfare, but nothing was found, or at all events, recorded, to enable us to fix an approximate date.

Wigborough (Great).- Salmon and all his copyists mention the small tumulus near the church as possibly thrown up to cover those who were slain in some battle which may have taken place here, and he surmised that the wasting of their bodies caused the mound to sink to its low level!

Woodham Ferrers, Stow Maries and Hockley.-A large group of barrows or mounds remains on the northern side of the river Crouch, within the parishes named. Gough mentions ' 24 barrows grouped in pairs and most of them surrounded by a ditch,' erroneously assigning them to Woodham Mortimer parish. Upon examination in about I 868, Mr. (now Sir John) Evans inclined to think them comparatively modern, and the late Mr. H. W. King wrote: 'If the earthworks were really what $\mathrm{Mr}$. Evans regards them, they were probably hastily thrown

1 Mr. E. A. Fitch expresses the opinion that two tumuli shown on the Ordnance Survey are of quite recent construction.

2 Environs of London, p. 6 I 4. 


\section{ANCIENT EARTHWORKS}

up during the middle of the $17^{\text {th }}$ century, when the Dutch attempted more than once a landing on the neighbouring coast.'

Mr. E. A. Fitch thinks that they date back at least to Saxon or Danish times.

WormingFord.-The Rev. Henry Jenkins, writing in 1842 , speaks of a high artificial mound on which the farm house at Garnons was built and which he conjectured formerly protected the passage or ford of the river Stour, and that from it the parish of Wormingford, anciently Withermundford, took its name. ${ }^{1}$ In a footnote in Arcboologia he mentions that a large mound in this parish, close to the Decoy and to the banks of the river Stour, was moved about $183_{3} 6$ in order that the earth might be spread over the lower part of the field, and many hundreds of urns were then discovered, placed in parallel rows like streets.

Other tumuli, barrows, etc., than those above-mentioned remain, but not generally of sufficient size or importance to need detailed reference-among these are examples at Birdbrook, Little Canfield, East Donyland, Latton, Lawford, Margaretting, Messing (in Coneyfield Wood), Mersea Island (about a mile from the ancient causeway "The Strood,' which connects the island with the mainland), Ockenden, Prittlewell, Sturmer, Tendring and Tolleshunt Major.

Two low tumuli, which proved to have been used as burial places in Romano-British time, formerly existed in Norsey Wood near Billericay, and are fully described in the Transactions of the Essex Archaological Society.

Boundary banks and dykes of ancient date are occasionally found, as the Devil's Ditch at Wethersfield, or recorded by place-names, but these we cannot here enumerate.

It remains only to record two most interesting groups of works, viz. the Red Hills and the Deneholes-with these our task is concluded.

\section{THE ' RED HILLS'}

Under this cognomen are known the mysterious low mounds which abound on the borders of creeks and rivers of the Essex coast.

They rise to the height of from 2 to $5 \mathrm{feet}$, have an area varying from rather less than half an acre to about 30 acres, and are clearly artificial, as the material is largely of burnt earth, while mingled therein we find pieces of coarse pottery and some broken brick.

That they were of early date is manifest, as one is intersected by a creek formed since, while another has yielded Samian ware and other remains of the Roman period, ${ }^{2}$ and a Roman coin was found on one on Wallasea Island. Another evidence of great age may be the fact that the artificial material extends through the accumulated surrounding

$1 \mathrm{Mr}$. J. H. Round (Commune of London and other Studies) says that the 'Domesday name is Widemondefort, obviously derived from Widemond, the name of an individual.'

See framents, found in 2 Red hill at Burnham, now in stratford Museum. 


\section{A HISTORY OF ESSEX}

alluvium down to the London Clay ${ }^{\mathrm{I}}$; it may possibly be that this shows only that the makers cleared away the soil, but considering the enormous size of some sites, this would have been an herculean task for which it is difficult to suggest a motive. Is it not more conceivable that the mounds were formed before the deposition of the alluvium ?

The use of these mounds is as uncertain as their age, though their position in relation to the tide ought perhaps to throw some light on the subjects; Mr. H. Stopes ${ }^{2}$ to whom we are mainly indebted for our information, states that "they lie, as a rule, just above the average highwater mark, or its level, where the saltings ${ }^{3}$ have been inclosed, as after conversion into marshes, the saltings always shrink, chiefly from loss of water, to much below their original level.' It must however be noted that some of these mounds are above the level referred to, near streams containing no other than fresh water.

Mr. W. H. Dalton, F.G.S., suggests that they were camp sites or places of refuge ' when the surrounding country was densely covered with forest, except the belt between normal high water and the storm range of spring tides.'

The late Rev. J. C. Atkinson regarded them as relics of salt works* for the evaporation of salt from sea water.

The burning of kelp or seaweed for the sake of the ashes in the manufacture of glass is also suggested, but indications point to an age prior to the knowledge or great use of glass.

The more popular and possibly correct notion is that of $\mathrm{Mr}$. W. Cole, F.L.S., who believes them the sites of potters' works.

This belief is strengthened by the discovery of wedge-shaped pieces of hard burnt pottery about 4 inches high, similar to those now used in Staffordshire for supporting articles in the course of firing. ${ }^{5}$ Occasionally these supports (if such was their purpose) are found of a cylindrical form with a flat base or top somewhat of $T$ shape and about $7 \frac{1}{2}$ inches high.

The hills are scattered through various parishes, including Burnham, Clacton (G.), Fambridge (S.), Fingrinhoe, Foulness, ${ }^{6}$ Goldhanger, Langenhoe, Mersea (E. and W.), Mundon, Pagglesham, Peldon, St. Osyth, Salcott, Southminster, Steeple, Tilbury (E.), Tillingham, Tollesbury, Virley, Walton-on-Naze and Wigborough (L.). No accurate computation has been made of the number of those remaining; many have been removed for the sake of their material, which is found useful as a dressing upon clay-lands, others have been so lowered as to be scarce noticed, but it is believed that from I 50 to 200 yet exist, affording a fine

1 Mr. H. Stopes in Essex Naturalist, 1887 , i. 99.

'The Salting Mounds of Essex,' Essex Naturalist, 1887, i. 96. tively.

3 'Saltings' are areas of land between the range of high water at spring and neap tides respec-

Arch. Foum. 1880, vol. xxxvii.

5 In the Museum at Stratford Mr. Cole shows such modern wedges side by side with those from the Red hills.

- Mr. W. H. Dalton does not consider this to have been a true 'Red hill.' 


\section{ANCIENT EARTHWORKS}

field for archæological exploration which may set at rest the long-debated question as to their age and purpose.

\section{THE 'DENEHOLES'}

Hangman's Wood near Grays ${ }^{1}$ contains the curious pits known as 'deneholes,' which have been a mystery to enquirers from the days of Camden ${ }^{2}$ to the present time.

Many writers have in modern days issued papers on the subject, but the gist of the information will be found in the Essex Naturalist, edited by Mr. W. Cole, who, with Mr. T. V. Holmes, has devoted much time and attention to the examination of the pits in the course of explorations undertaken by the Essex Field Club with a view to the elucidation of the mystery surrounding their age and purpose. ${ }^{3}$

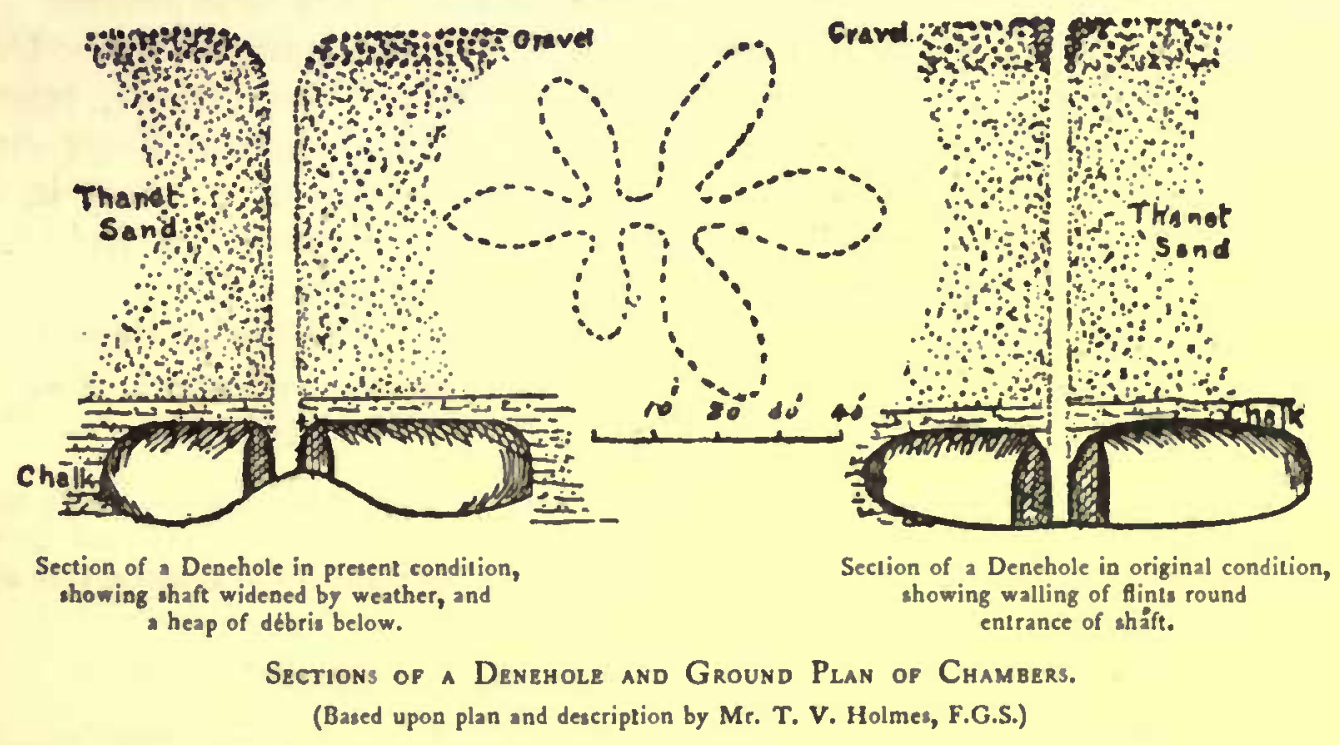

Seventy-two deneholes have been counted within 4 acres of Hangman's Wood-mostly near together and consisting each of a vertical shaft carried down from 50 to 100 feet through Thanet Sand into the Chalk. The shafts are from 3 to 4 feet in diameter and end in caves or excavations branching into chambers of about 20 feet in length.

The shafts have become more or less closed up by soil and débris from above, those pits which were cleared by the Essex Field Club in their explorations showing each a great heap of sand and soil at the base.

1 The wood is partly in the parish of East Thurrock and partly in Orsett. Deneholes appear also to have been found in the adjoining parish of Chadwell St. Mary.

Britannia (1586).

3 In the index will be found references to various papers and notices which have appeared from time to time. We may here mention some notable essays which have been published: 'Report of Explorations,' by T. V. Holmes and W. Cole, Essex Nat. 1887 ; 'Deneholes and Bell Pits,' by T. V. Holmes, Geol. Mag. 1898 ; 'Deneholes and Artificial Caves,' by F. C. J. Spurrell, Arth. Jourm. 1881 ; 'On Deneholes,' by Miller Christy, Reliquary, I895 ; 'Deneholes,' by J. G. Waller, Reliquary, 1896 ; - The Origin of Deneholes,' by A. R. Goddard, Essex Arcb. Trans. 1899 ; Note by J. H. Round on the same, Essex Arb. Trans. 1899. 


\section{A HISTORY OF ESSEX}

The chambers (which show bands of flints in the chalk walls) are of varying height, the floor of one referred to by Mr. Miller Christy being about 25 feet from the base of the shaft. In some shafts are still traceable 'foot-holes' formed in the hard sand, by which it may have been easy to descend and ascend with the aid of guide-ropes.

Darkness and doubt surround the age and purpose of the deneholes; those who desire to form an opinion upon these points cannot do better than study the papers above named, but we may briefly say that the Essex Field Club exploration 'has made the post-Neolithic age of the Hangman's Wood pits almost certain.' $\quad$ Pick-marks, evidently made by metal tools, show construction at later date than the stone age, while a somewhat indefinite reference by $\mathrm{Mr}$. R. Meeson ${ }^{3}$ suggests the use of one pit for a Roman burial, though this of course would not prove construction in Roman times. Of the immense age of the pits there can be no doubt, but to what period they can be assigned is ' not proven.'

Space will not allow us to say much as to their possible use. Dr. Plot, writing upon the natural history of Oxfordshire (1705), refers incidentally to these pits as 'the gold mine of Cunobeline in Essex discovered again temp. Henry IV.' Absurd as the gold-mine theory is, it was not too absurd for a wild attempt during the 'South Sea Bubble' (c. 1720) to float a company to rework the pits for gold.

Mr. J. G. Waller, ${ }^{3}$ Mr. Charles Dawson " and many others consider the pits to have been made simply for the excavation of chalk, a view which is energetically opposed by Messrs. Cole and Holmes. ${ }^{5}$

If the primary wish of the excavators was to obtain chalk they knowingly and wilfully concentrated their efforts of every kind so as to ensure the least and worst possible return for their labour - a thing which no people, ancient or modern, ever did or will do.

Mr. Miller Christy is equally forcible in his remarks ${ }^{8}$ :-

It can hardly be conceived that any community, if wanting chalk, would have dug down through nearly 60 feet of superimposed strata to obtain it, when an unlimited supply could have been obtained actually at the surface within a mile. To suppose any race of people capable of such absurdity is to discredit their sanity.

Moreover, if merely chalk pits, why should all the Deneholes have been excavated upon the same symmetrical plan? And why, above all things, should care have been exercised (as it most clearly had been) to avoid any underground communication between the different pits.

Mr. A. R. Goddard" suggests the use of the pits as lairs for ambushment or refuge in very early days.

Others suggest mining for flints, search for iron pyrites, wells for water, etc., but all of these suggestions are combated in the papers mentioned, and we feel that the amount of our present information is summed up in the words, 'the hypothesis that the Hangman's Wood Deneholes were mainly used as secret storehouses for grain, furnishes perhaps the

1 Essex Naturalist, i. 245.

3 Reliquary, 1896, p. 36.

5 Essex Naturalist, i. 251.

7 Essex Arch. Soc. Trans. n.s. vii. 252, 400.

2 Arch. Foum. xxvi. 191.

4 Geological Mag. I 898, pp. 293, 447.

6 Reliquary, 1895, p. 80. 


\section{ANCIENT EARTHWORKS}

most probable explanation of their existence,' though it must be admitted that 'the mystery surrounding the origin of the Deneholes and the purposes of their makers still constitutes one of the most interesting and perplexing problems.'

\section{INDEX AND SUMMARY}

The following abbreviations are used to indicate the principal publications referred to in this index :-

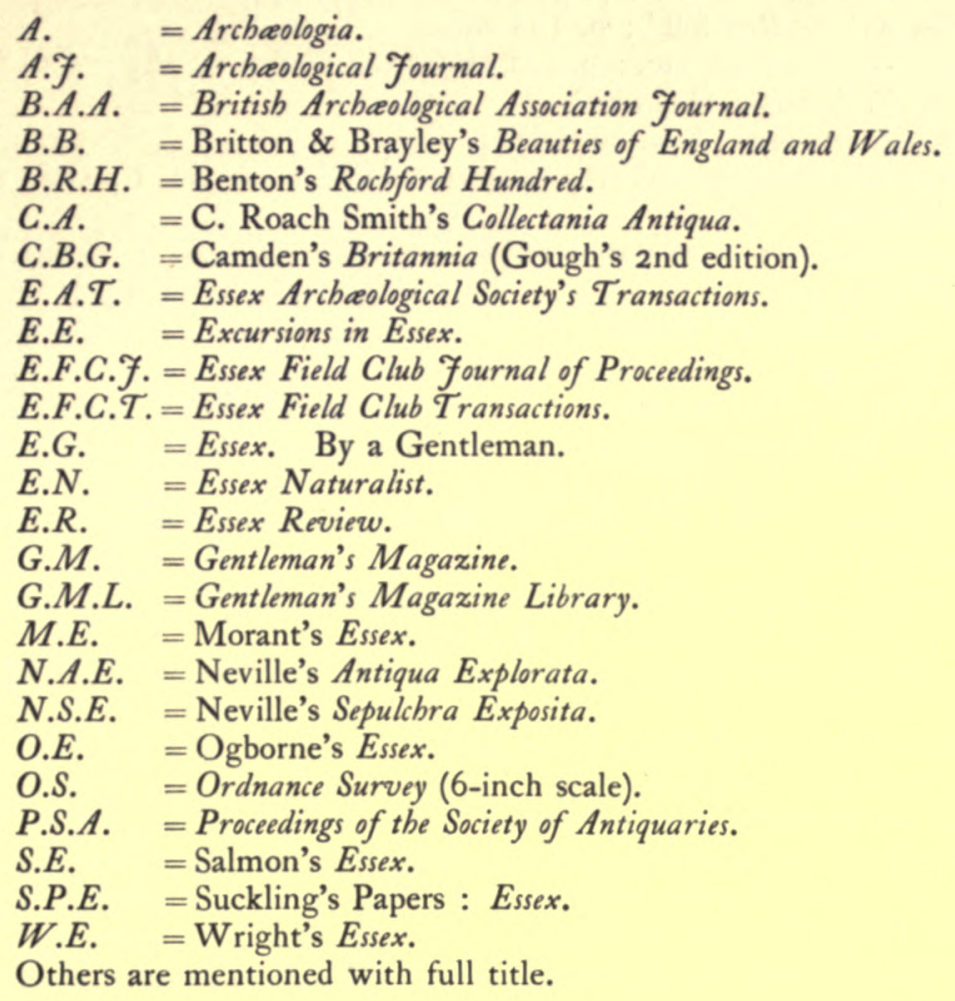

Ambresbury Banks (near Epping).-p. 279 ante [E.F.C.T.ii. 55 ; E.F.C.F. ii. 28 ; A.F. xxxiii. 89 , 244 ; O.E. 217 ; E.E. ii. 25 ; W.E. ii. 467 ; B.B. v. 431 ; C.B.G. ii. 127 ; Brit. Assoc. Rep. (1881) 697 ; O.S. lviii.].

Ashdon.-Entrenchment near the Bartlow Hills: p. 283 ante [A.xxv. 3; E.A.T. n.s. vii. 353]. Asheldham.-Entrenchment : p. 284 ante [E.A.T. n.s. vi. 350 ].

BARKING.-See Uphall.

Bartlow Hills, Ashdon.-p. 304 ante [E.A.T.n.s. vii. 349; Wright's Celt, Roman Eo Saxon, 377 ; E.N. iii. 288 ; A. xxv. I-23, xxvi. $300-17,462$, xxviii. I, xxix. I, xxxiii. 343 ; N.A.E. 30 ; M.E. ii. 539 ; W.E. ii. 98 ; S.E. 167 ; E.G. ii. 309 ; G.M. (1822) ii. 305 ; G.M.L. Top. 79 ; B.B. v. 380 ; O.S. iii.; G.M. (1832) i. 162 ; G.M.L. Rom. i. 66 ; C.B.G. ii. 140$]$.

BeNfLEET.-Site of earthwork: p. 286 ante [E.A.T. ii. 75 ; viii. n.s. 233 ; E.N. iv. 150; B.R.H. 54 ; A.F. xlii. 294].

BERDEN.-Moated mound : p. 289 ante [E.A.T. n.s. iv. 289 ; O.S. xiii.].

BillericaY.-Blunt's Walls : p. 284 ante [E.E. i. 129 ; W.E. ii. 544 ; S.E. 335 ; E.G.v. 31 ; B.B. v. 489 ; S.P.E. 145 ; M.E. i. 196; E.A.T. ii. 70 ; P.S.A. ser. 2 , vii. 370$]$. Norsey Wood, Tumuli, etc. : p. 307 ante [E.A.T. v. 212 ; n.s. v. 226].

Birch 'CAstLe.'-p. 284 ante [B.A.A. xix. 277 ; E.G. vi. 151 ; E.N. viii. 204 ; M.E. ii. 182 ; W.E. i. $391 ;$ O.S. xxxvi.].

BirdBrooK.-Camp : see Watsoe. Tumuli ; [O.S. iv.].

BrainTREE.-Camp; p. 284 ante [E.N. x. $405 ;$ O.S. xxv.]. 


\section{A HISTORY OF ESSEX}

Bures.-Moated mound : p. 290 ante $[A$. xxix. $250 ; M . E$. ii. 224;E.E. ii. 159; W.E. i. 435 ; E.G. vi. 2 I 4 ; B.B.v. 359 ; C.A. ii. 25 ; E.N.x. I 55 ; C.B.G. ii. I 39 ;O.S. xvii.].

Burnham.- ' Red hill.' Relics in Stratford Museum.

Canewdon.-Site of camp; p. 285 ante [A. ix. $379 ;$ B.B.v. 496 ; B.R.H. 90 ; O.S. lxx.]. Canfield (Great).-Castle mound; p. 290 ante [M.E. ii. $460 ;$ W.E. ii. 264 ; S.E. 217 ; $B . B$. v. $415 ; E . A . T$. n.s. vi. $225 ; E . N . x .151 ; O . S . x x x i i$.$] .$

Canfield (Littrle).-Tumulus; [O.S. xxiii.].

Chadwell St. Mary._- 'Deneholes': see Thurrock (East).

Chrishald.-Circular moated enclosure : p. 291 ante ; [E.E. ii. I33; E.G. iii. 91 ; M.E. ii. $603 ;$ S.E. I22]. Barrow: p. 304 ante [N.S.E. 27].

Clacton (GReat).-'Red hill': p. 308 ante.

Clavering.-Castle mound, etc. : p. 291 ante [E.A.T.n.s. iv. $289 ;$ E.G. iii. 104 ; M.E. ii. 6 I I ; W.E. ii. I 95 ; O.S. xiii.].

Coggeshall.-Interments [E.N. vii. 68].

Colchester.-Castle bailey banks: p. 304 ante [E.A.T. n.s. iii. I ; O.S. xxvii.]. See also Gryme's Dyke.

Danbury,-Earthwork : p. 289 ante [E.N. iv. I 38 ; O.S. liii.; E.F.C.F. ii. 54 ; A. ix. 379 ; W.E. i. $126 ; B . B$. v. $270 ; M . E$. ii. $30 ;$ C.B.G. ii. 134$]$.

Deneholes. - See Thurrock (East).

Donyland (East).-Tumulus [O.S. xxxvii.].

Dunmow (LITTLE).-Embankments, etc. : p. 305 ante [E.N. vii. I 30 ; W.E. ii. 222$].$

Easton (Great).-Moated mound: p. 293 ante [E.A.T. n.s. viii. 324 ; M.E. ii. 433 ; O.S. xxiii.; W.E. ii. 229].

Elmdon.-Moated mound : p. 293 ante [O.S. ii.; Elmdonbury, S.E. 129 ; M.E. ii. 598 ; E.A.T. vii. 198].

EPPing.-Tumuli : p. 305 ante. See also Ambresbury Banks.

Fambridge (South)._-'Red hill' : p. 308 ante.

FELSTEAD.-Moated mound : p. 294 ante $[E . N$. vi. IO0]. Ancient dam : p. 305 ante $[E . N$. vi. 34].

Fingringhoe.-' Red hills' [E.N. i. 181 I].

Foulness.-' Red hills' [B.R.H. I 75].

Goldhanger.—' Red hills': p. 308 ante.

Gryme's DyKe, ETC. (near Colchester).-p. 276 ante [A. xxix. $244 ;$ E.A.T. n.s. iii. 133 ; vi. 17,87 ; E.N. ii. 120 ; $W . E$. i. 353 ; B.B. v. 295 ; C.B.G. ii. 138; O.S. xxvii.].

Hallingbury (Great).-See Wallbury.

HARWICH.-Site of camp : p. 285 ante [M.E. i. $499 ; E . E$. i. 106 ; W.E. ii. 8 I 4 ; C.B.G. ii. $139 ; B . B$. v. 330 ].

Hatfield Broad OAK.-Entrenchment : p. 305 ante [E.A.T.n.s.viii. 241 ; E.N. ii. 226 ; O.S. xxxii. ; S.E. $9 \mathrm{I}]$.

Hedingham.-Castle earthworks : p. 294 ante [Clark's Med. Mil. Arch. i. I7 ; O.S. xi.].

HeYBridge.-Barrows : see Totham (Great).

Hockley.-Barrows north of the Crouch : see Woodham Ferrers. Plumborough Mount : p. 305 ante $[B . R . H .280 ; E . A . T$. ii. $80 ;$ O.S. lxx.].

Horkesley (GREAT).-Pitchbury : p. 285 ante [A. xxix. $250 ; E . A . T$. n.s. vii. IO9; E.N. i. 82 ; M.E. ii. 238 ; W.E. i. 449 ; E.G. vi. 237 ; O.S. xviii.].

Langenhoe._- 'Red hills' : [E.N. i. I03].

Latron (near Harlow Station).-p. 295 ante [A. xix. $410 ;$ G.M. (1821) i. 66; E.A.T. n.s. v. 95 ; viii. $239 ; E . N$. ix. 59]. Tumulus : [O.S. 1.].

LAWFORD.-Tumulus [O.S. xix.].

Layer Marney.-Fosse near Haynes Green : p. 285 ante [A.xxix. $252 ; B . A . A . x i x .277$; E.A.T. n.s. v. $100 ;$ O.S. $\mathrm{xxxv}^{\mathrm{s}}$.].

LEXDEN.-Park ramparts [E.A.T. n.s. viii. I08; O.S. xxvii ; and see Gryme's Dyke].

LEYTON.-Site of earthwork : p. 285 ante [E.E. ii. 62 ; W.E. ii. 500].

Lit thebury.-Ring Hill near Audley End : p. 280 ante $[E . F . C . \mathcal{F}$. iv. $85 ;$ S.E. 132; E.E. ii. 132 ; B.B.v. 396 ; O.S. viii. ; C.B.G. ii. I 40 ; Stukeley (Itin. Cur.) i..79, pl. 45 ; Braybrooke's Audley End, I 36 ; M.E. ii. 594].

Loughton Camp.-p. 277 ante [E.F.C.T. iii. 212 ;E.F.C.F. iii. 51 ; A.F. xxxiii. 88, 244.]. MALDON.-Earthwork: p. 287 ante [E.N. ii. 234 ; S.E. $419 ;$ M.E. i. 328 ; E.E. i. 27 ; W.E. ii. 639 ; Strutt's Manners and Customs, i. 24 ; C.B.G. ii. I 35 ; Fitch's Maldon, ed. 3, 5]. Tumuli : p. 306 ante [Fitch's Maldon, ed. 3, 37 ; O.S. liv.]. 


\section{ANCIENT EARTHWORKS}

Margaretting.-Tumulus [Christy's Handbook for Essex, 152; S.P.E. 10].

Mersea (EAST).- 'Red hills' [E.N.i. 103; A.7. xxxvi. 369].

(WEST).-Tumulus: p. 307 ante [O.S. xlvii.]. 'Red hills' [E.N. i. 103; 1.F. xxxvi. 369].

Messing.-Tumulus [O.S. xxxv.].

Mundon.-'Red hill': p. 308 ante.

NAvesrocK.-Fortification wood: p. 279 ante [E.N. viii. 217-22; Hale's St. Paul's Domesday, 78 (Camden Soc.); O.S. lix.]. Stukeley's Temple of the Druids: p. 295 ante [E.A.T. n.s. viii. 327 ; E.N. viii. 213,220 ; S.S. Ixxvi. 157, 164; W.E. ii. 419].

OCKENDEN (South). - Tumuli [O.S. Ixxv.].

OngAR.-Castle earthworks: p. 297 ante [M.E. i. 128 ; C.B.G. ii. 129 ; E.E. ii. 3; W.E. ii. $330 ; B . B$. v. 423 ; O.S. li.; E.N. x. $155 ;$ E.A.T. n.s. vii. 137 ; G.M. Uune, I 890).]

OrsEtT.- 'Deneholes': see Thurrock (East). Entrenchments: p. 286 ante [M.E. i. 222].

Pagglesham.-' Red hills': p. 308 ante.

Peldon.-'Red hills' [A.F. xxxvi. 369 , xxxvii. 196 ; E.N. i. 103].

Pleshey.-Earthworks: p. 298 ante [M.E. ii. 451 ; E.E. ii. 79 ;W.E. ii. 255; S.E. 226 ; C.B.G. ii. 133 ; E.N. x. 152 ; E.A.T. n.s. v. 83 ; Strutt's Chron. of Eng. i. 299 ; Gough's Hist. of Pleshey ; O.S. xliii. xxxiii.].

Prittlewell.-Tumulus (destroyed) [B.R.H. 476]. Earthwork: p. 286 ante [B.R.H. ii. $498 ;$; E.A.T. n.s. v. 7 1].

Purleigh.-Moated mound : p. 299 ante [E.A.T.n.s. vii. 409 ; O.S. Ixii.].

RAYLEIGH.-Castle works : p. 299 ante [A. ix. 380 ; S.E. 353 ; C.B.G. ii. 120 ; E.A.T. n.s. iv. 172 ; v. 41 ; E.N. x. $152 ; M . E$. i. 277 ; W.E. ii. 595 ; Strutt's Manners and Customs, i. 93 ; O.S. Ixix.]

RickLING.-Keep mound : p. 300 ante [S.E. I1 3 ; M.E. ii. 582 ; E.G. iii. 37 ; E.E. ii. 104 ; O.S. xiii.].

Saffron W WLDEN.-The Repell Ditches: p. 280 ante [E.A.T. n.s. ii. 284,311 ; E.F.C.F. iv. $85,89,201$; E.E. ii. 128 ; W.E. ii. $122 ;$ B.B. v. 389 ; C.B.G. ii. 140 ; O.S. ix.]. Grimsditch : p. 286 ante. Bury Hill : p. 301 ante.

St. OsYth._-'Red hill' : p. 308 ante.

Salcott.- 'Red hills' [E.N. i. 103].

Shorbury.-Camp : p. 286 ante [E.A.T. ii. 76 ; vi. n.s. $97 ;$ E.N. iv. $150 ;$ W.E. ii. 6r 2 ; E.G.v. $216 ;$ B.B. v. 493 ; A.F. xlii. 294 , xlvii. 78 ; C.B.G. ii. 130; O.S. Ixxix.]

SOUTHMINSTER._- 'Red hills': p. 308 ante.

Stansted Monfitchet.-Earthworks: p. 301 ante [A. xix. lii.; S.E. 95; M.E. ii. 576 ; C.B.G. ii. 142 ; W.E. ii. 157 ; E.N. x. $152 ; E . A . T$. n.s. viii. 141 ; O.S. xxii.].

Stanway.-See Gryme's Dyke.

StrbBing.-Moated mound: p. 302 ante [E.G.i. $460 ; W . E$.ii. 49 ; E.N.x. $155 ;$ O.S. xxiv.].

STEEPLE.-'Red hill': p. 308 ante.

Stow Maries.-Barrows: see Woodham Ferrers.

Sturmer. - Tumulus $[A$. xiv. $72 ;$ O.S. iv.].

Tendring.-Tumulus [O.S. xxix.].

Thurrock (EAST).- 'Deneholes': or 'Daneholes,' p. 309 ante [A.F. xxvi. 191, xxxviii. 391-409, xxxix. 1-22;C.A. vi. 243 ; C.B.G. ii. 130; E.A.T. n.s. vii. 252, 400 ; E.F.C.F. iii. $28-41,56-60$, iv. 20 ; E.F.C.T. iii. 48 , iv. 87 ; E.G. v. 84 ; E.R. viii. 45 ; E.N. i. 225 ; M.E. i. 229 ; S.E. 297 ; W.E. ij. 561 ; Geol. Mag. (1898), 293, 447; Idler (1898) 163; Leisure Hour (Nov. 1882); Palin's Stifford, 41; Palin's More about Stifford, $3^{8}$; Reliquary (1895) 65, (1896) 36].

Tilbury (EAst).- 'Red hill': p. 308 ante.

(West)-Fosse : p. 306 ante [A.F. xlii. 296; C.B.G. ii. 130].

Tillingham.- 'Red hills'? p. 308 ante.

TOllesBury.-'Red hills' [E.N. i. 97].

Tolleshunt Major.-Tumulus [O.S. xlv.].

Totham (Great).-Tumuli : p. 306 ante [W.E. ii. 709 ; S.E. $460 ;$ E.G. v. $379 ;$ G.M. (1840) ii. 114 ; G.M.L. Arch. i. 129 ; Fitch's Maldon, ed. 3, 51 ].

UphalL ENTRENCHMENTs (near Barking).-p. $28 \mathrm{I}$ ante [B.B. v. 453 ; M.E. i. 1; W.E. ii. $474 ;$ O.E. $41 ; E . N$. vii. $131 ; E . G$. iv. $271 ; E . N$. x. $374 ; E . R$. viii. $51 ; B . A . A$. n.s. iv. 291 ; C.B.G. ii. 129 ; A.F. xlii. 297 ; G.M. (Oct. 1888); Lysons' Environs of London, iv. 57 ; O.S. Ixxiii.]. 


\section{A HISTORY OF ESSEX}

VIRLEY.-'Red hills' [E.F.G.F. iv. I13; E.N. i. 103].

Wallbury (Great Hallingbury).-p. 282 ante [S.E. 91 ; M.E. ii. $514 ;$ E.F.C.F. iii. $5 ; A$. xix. $4 \mathrm{II}$; W.E. ii. 323 ; E.G. iv. I35; E.A.T. i. 198, n.s. viii. 139; G.M.L. Arc. i. 274 ; G.M. (1865) ii. 760 ; E.N. ii. 225 ; N.S.E. 47 ; B.B. v. 413 ; C.B.G. ii. 142 ; C.A. vii. 76 ; O.S. xxxi. ; Strutt's Manners and Customs, i. 14].

Walton-on-the-Naze.- ' Red hill': Relics in Colchester Museum.

Watsoe (BIRDBRooK).-Camp : p. 284 ante [A. xiv. $70 ; M . E$. ii. 348 ; W.E. i. 607].

WeAld (South).-Camp : p. 283 ante [M.E. i. 117 ; E.G. v. 7 ; B.A.A. iii. 318, xvi. 142 ; W.E. ii. $53^{8}$; S.E. 263,303 ; E.N. iii. 211 ; O.S. lxvii.].

WeTHERSFIELD.-Devil's Ditch [O.S. xvi.].

WigBorough (Great).-Tumulus: p. 306 ante [S.E. $43^{8} ;$ M.E. i. 419 ; E.G. v. $43^{8}$; E.E. i. 89 ; W.E. ii. $\left.73^{8}\right]$.

Wigborough (LitTle).—'Red hills': p. 308 ante [E.N. i. I03].

Witham.-Earthwork: p. 288 ante [E.A.T. n.s. ii. 208 ; M.E. ii. 105; E.N. i. 19; W.E. i. 216 ; B.B. v. 281 ; O.S. xlv.; C.B.G. ii. 134; Strutt's Manners and Customs, i. 24].

Woodham Ferrers.-Barrows : p. 306 ante [B.A.A. iii. 323 ; B.R.H. 289 ; G.B.G. ii. I 31 ; E.A.T. iv. 276 , n.s. vii. $406 ; W$.E. ii. 628$]$.

WORMINGFORD.-Earthworks: p. 307 ante $[A$. xxix. 250 ; E.N. i. 82].

[The majority of the references are kindly supplied by Mr. G. F. Beaumont, F.S.A.] 


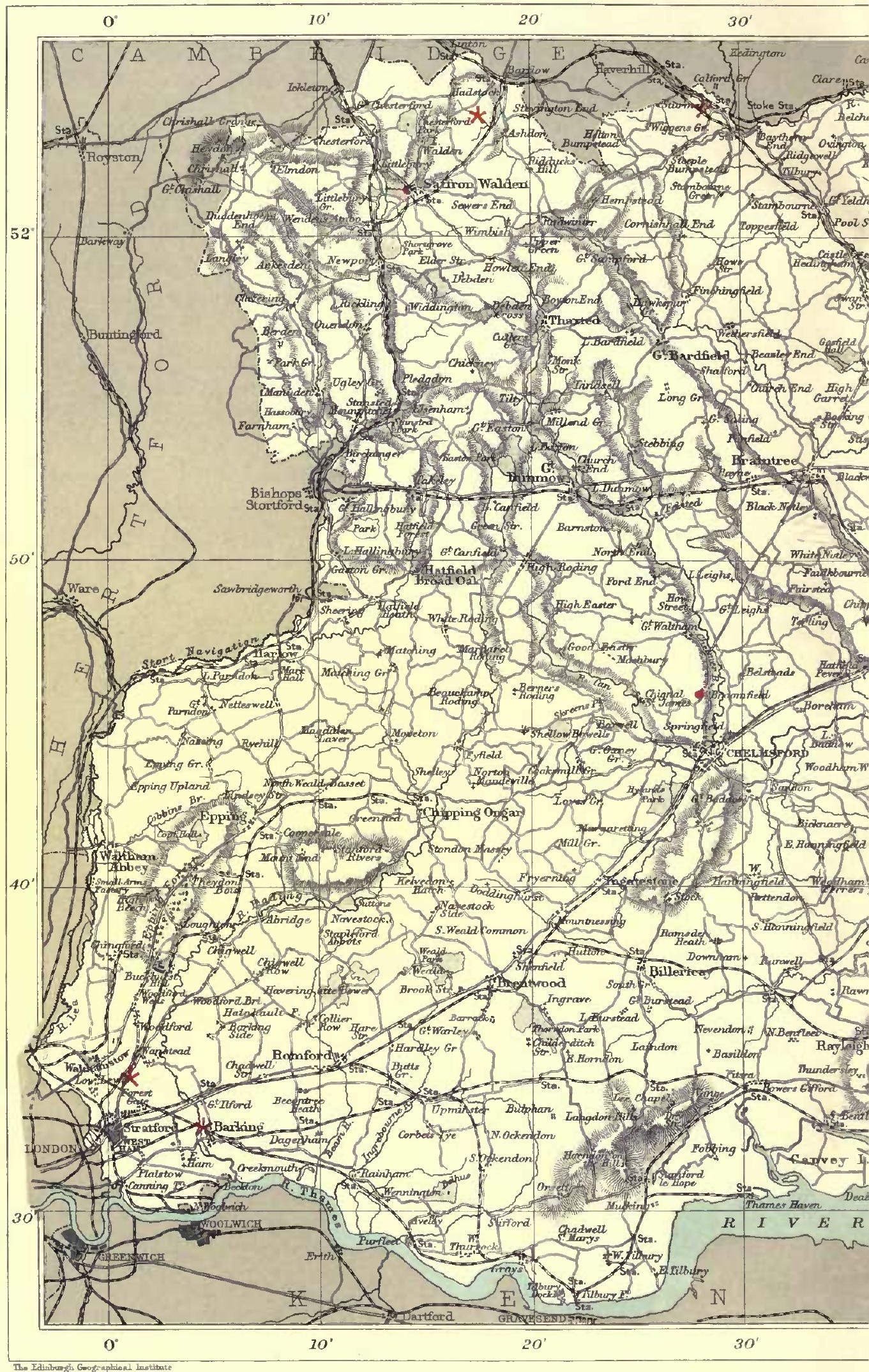




\section{REMAINS.}

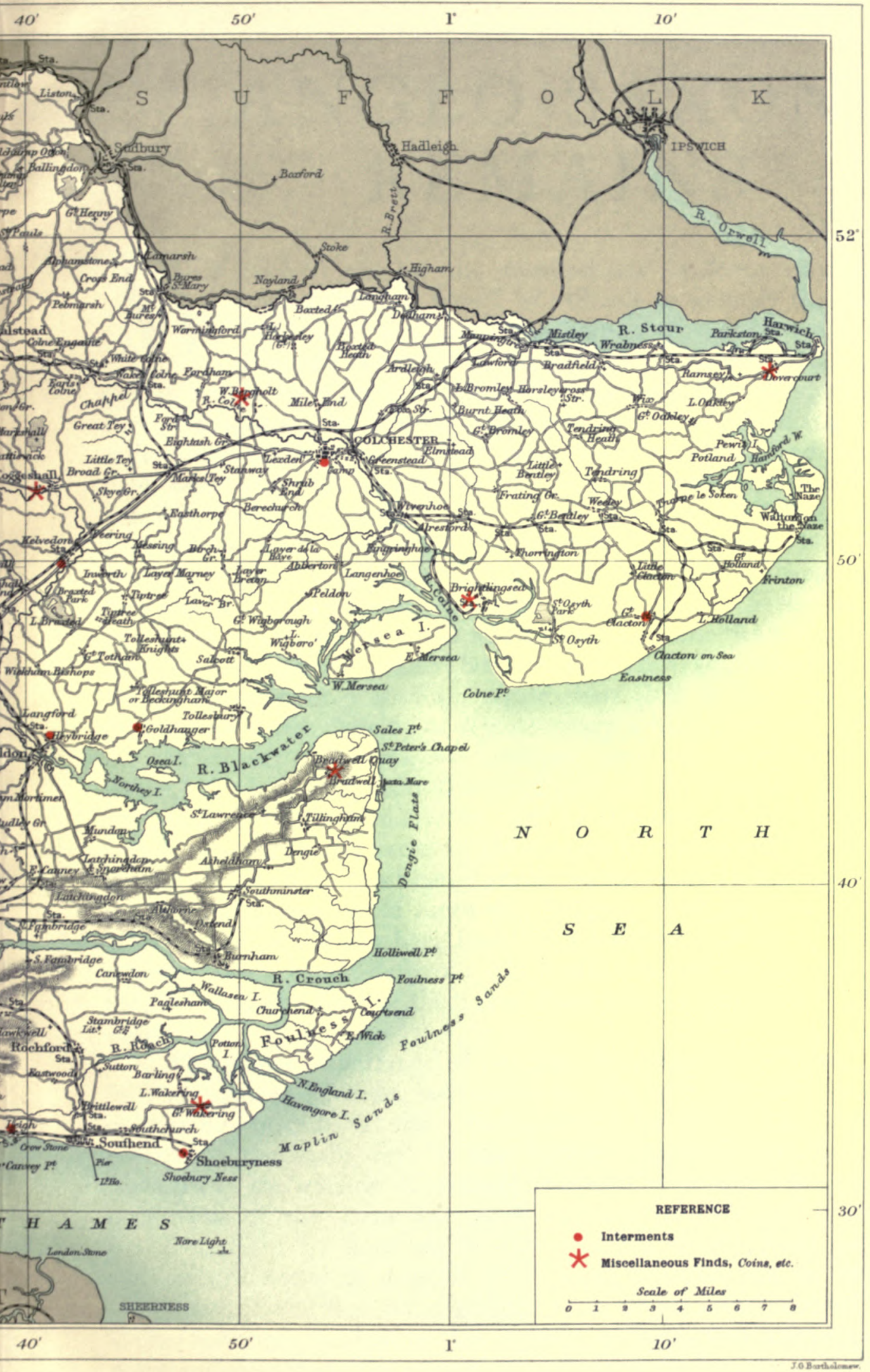

COUNTIES OF ENGLAND 



\section{ANGLO-SAXON REMAINS}

W ERE it not for the unmistakable evidence afforded by the county name, it would be difficult to identify the founders of Essex with any particular branch of the Teutonic race that migrated westward as the Roman power declined. A natural course would have been to assign the conquest and occupation of this part of Britain to the Anglian tribesmen who spread themselves over the region between the central east coast and the Fens; and there would have been little or nothing in the physical features of the country to preclude such a possibility. The river Stour, which forms the greater part of the county border on the north would not have been a serious obstacle to intercourse between the dwellers on either bank, much less to a hostile advance in one direction or the other. Fourteen centuries ago there was no doubt much more marsh and woodland along its course than at the present time; but practised seamen ascending the river would easily effect a landing, while their skill as boat builders would render such forest clearing as was necessary a matter of little difficulty.

What actually happened however may well have been quite different. So long as Britain remained part of the Empire, the police of our narrow seas was doubtless one of the first duties of the Roman authorities; while the career of the usurper Carausius and the fortification of the Saxon shore combine to show the necessity then felt of guarding the natural approaches to south-east Britain. Such an inlet as the mouth of the Stour would not have been left unsecured so long as the province retained means of self-defence ; but it will perhaps always remain doubtful how long the forts of the Saxon shore were maintained in an efficient state.

The prime importance of London, the Augusta of Britain, had been fully recognized by those responsible for the safety of the province; but it must be remembered that Colchester was another of the chief military centres in the early days of the Roman dominion, and was doubtless included in the scheme of defence evolved some centuries later for the protection of the coast-line most exposed to piratical attacks. The havoc wrought by Boadicea in the year 62, so far from permanently ruining Colchester as a point of vantage, probably led to the erection of its walls; and here an organized force could stand sentinel over the Colne waterway as well as the system of roads that converged at this point and connected the eastern stronghold with London and the north. 


\section{A HISTORY OF ESSEX}

Facing the mouth of the Colne and guarding the estuary of the Blackwater was the fortress of Othona or Ithanceaster, now located with general approval at Bradwell-on-Sea. So long as the Count of the Saxon shore had garrisons and ships at his disposal, this approach to the interior would not have been available; and it was not till the central government had collapsed, that the Teutonic immigrants who were pouring inland all along the eastern coast from Kent to the Firth of Forth would be able to penetrate the swampy belt that formed the Essex shore, and, ascending the rivers, plant their settlements inland.

Implicit confidence cannot be placed in the tradition professing to date the arrival of the East Saxons, and practically nothing is known of the course of affairs in this part of Britain during the fifth and sixth centuries. No territory, says Lappenberg, ${ }^{1}$ ever passed so obscurely into the hands of an enemy as the north bank of the Thames where the kingdom of the East Saxons comprised the counties of Essex and Middlesex. The year $527^{2}$ is mentioned, he continues, as that of the first landing of the Saxons there under Æscwine, whose name reminds us of Æsc, the prince of the Teutons on the south shore of the Thames. His father's name, Offa, points however to a connection with the royal house of Mercia.

Another account makes Sleda the first king of the East Saxons in $587,{ }^{3}$ and this is a much more likely date for the settlement of the people whose relics are described in the following pages, though it is just possible that there were Teutonic colonists on the coast before the departure of the Romans and that the Saxon shore was so called on this account. If they differed to any extent from the Romanized Briton, their remains have yet to be discovered.

An interesting piece of evidence is however afforded by the coinage of the post-Roman period. It was not until about 600 that the English replaced their feeble copies of Roman and Merovingian coins by a creation of their own called the sceatta, and this denomination was current till the close of the eighth century, when the penny was introduced. Yet of all the sceattas those with the name Lundonia are alone in being of silver so base that it becomes a question whether they should not be described as copper coins. Gold pieces also occur, and it is significant that the two classes of Roman coins current in this country were of these two metals, whereas the preference for silver coins was in some sort a badge of the Teutonic nations." It would seem therefore that London retained some degree of autonomy while the various AngloSaxon kingdoms were growing up in other parts of the country; and it is fairly certain that the East Saxons were supplied with coined money from London till the days of $\mathbb{E}$ thelred II., who set up local mints ${ }^{6}$ at Maldon and Colchester.

\footnotetext{
1 History of England under Anglo-Saxon Kings (Thorpe's translation), i. I I 2.

2 Henry of Huntingdon. $\quad 3$ William of Malmesbury.

4 Catalogue of Anglo-Saxon Coins (British Museum), i. p. xx.

b Others were established later at Horndon, Harwich (?) and Witham.
} 


\section{ANGLO-SAXON REMAINS}

The general priority of the Saxon invasion is suggested by the early entries of the Chronicle, and is to some extent borne out by archæological research; but in the absence of direct testimony there are reasons for supposing the Anglian conquest north of the Stour to have preceded the Saxon occupation of the district between that river and the Thames. The finds in Norfolk and Suffolk are not entirely homogeneous, but cremation is throughout a preponderating element which may safely be considered Anglian, and has so far been conspicuously absent in Essex. Should future discoveries confirm this distinction, archæology will have provided a touchstone whereby the mythical alloy of the historical records may be impartially estimated.

For our present purpose the test may be provisionally accepted, and it will be seen that independent testimony from more than one quarter justifies the view that the Stour represents the great gulf fixed between Angle and Saxon in these parts.

First, it may be gathered from the continuous record of the Church that the early kingdom of Essex formed in Christian times a diocese. As the king's chaplain, the bishop would have ecclesiastical jurisdiction throughout the realm of his sovereign; and there can be little difficulty therefore in determining the extent of the East Saxon rule, at least in the seventh century. How long before that date the East Saxons had been recognized as a political unit and their frontiers respected by their neighbours there is little to show; but Mr. Green was confident that the conquest of this district was not secured long before 500; and the first king that can be regarded as historical was contemporary with Æthelberht of Kent.

It is clear from their charters that the Anglo-Saxons, like other early communities, availed themselves of the more striking and permanent natural features of the country as boundary marks of public or private property; and it may be taken for granted that the Stour has always bounded Essex to the north. Of this there are other possible indications. Apart from its utility as a natural barrier the river seems to have served also as a linguistic frontier. The Essex speech has retained to this day peculiarities enough to stamp it as distinct from the Anglian dialect of Suffolk; and even if the test of language be regarded as fallacious or at best inadequate, the physical traits of the inhabitants, till recent times a trustworthy indication of origin, confirm the distinction already drawn from other observations.

Dr. Beddoe, ${ }^{1}$ whose investigations in this field have extended over many years, is of opinion that there was a considerable survival of the Romano-British population in Essex; and that though the invading Saxons preponderated near the coast, the case was otherwise in the forest tracts of the interior, traces of which survive to-day in Epping and Hainault. To our own day the inhabitants of inland Essex are more usually dark-haired than those of Kent and East Anglia ; and it seems probable that here more than elsewhere there was a mixed native and 


\section{A HISTORY OF ESSEX}

Saxon population. While there are indications that the East Saxon settlement was comparatively late, actual remains discovered in the graves of their kinsmen to the west show that the upper valley of the Thames was reached and occupied by a Teutonic people before the barbarian craftsman had quite forgotten the artistic methods and designs of Roman civilization. Continental archæologists agree in referring a somewhat realistic treatment of the favourite animal forms to the fifth century, and undoubted specimens of the kind have occurred in the Berkshire cemeteries as well as in the more Romanized district of the Cantware.

The loose employment by the early historians of the term Saxon to denote any or all of the roving Teutonic bands that for centuries infested the northern seas, does not affect the supposed connection between the peoples east and west of London; and there still remains a distinction between Saxon and Angle that is certainly not accidental, but amply confirmed by dialect and archæology. On the imperfect data as yet available is therefore based a belief that Essex was founded by a branch of the Saxon race that passed over from the continent some time after the Gewissae had found a new home in this country, but probably not while the Angles were founding Norfolk and Suffolk.

A study of the map, with some consideration of the early condition of the county, must give the impression that Essex as a kingdom was compact and powerful out of all proportion to its size. Its ability to maintain the northern frontier against a population more numerous and probably hostile, may be in part explained by the inclusion of Colchester and London with their Romanized inhabitants under the rule of Uffa's line; and partly perhaps by an understanding with their powerful and progressive neighbours to the south. Whether there is any justification for Dr. Beddoe's identification of the East Saxons with the Jutes ${ }^{1}$ may indeed be open to question, but in any case Essex first appears in history as a sub-kingdom forming part of the Kentish dominions which, however, at that time stretched from the English Channel to the Humber, and included East Anglia.

A natural frontier better than the Stour was afforded by the forest of Middlesex that stretched in a continuous belt from the Chilterns through south Hertfordshire into the western half of the present county of Essex. This tract was indeed crossed by the Watling Street that connected St. Albans with the Thames, but the Roman township was beyond the forest and probably retained its independence till in course of time a growing Teutonic population spread north and west, even through woodlands that had prevented the Roman engineers from continuing the Ermine Street to London. Ethnological observations seem to show that the Saxons settled in considerable numbers in the neighbourhood of London, at least in Middlesex, but it is open to question whether they ever destroyed the city. ${ }^{2}$ The Chronicles are significantly silent on this point, and it may be that no Teutons gained a footing

$$
1 \text { Beddoe, Races of Britain, p. } 42 .
$$




\section{ANGLO-SAXON REMAINS}

there till the rapine and slaughter of the pagan period had given place to peaceful settlement.

Seeing that for cogent geographical reasons Essex cannot be regarded as the starting point of the Saxon settlements in Britain, it is not surprising to find very few relics of the pagan period in this part of the country. It is perhaps to the Romano-Britons rather than to their Saxon conquerors that we must attribute a deposit of bronze vessels discovered nearly a century ago 3 feet below the surface in the village of Sturmere on the Suffolk border and not far from a Roman station. These nine bowls ${ }^{2}$ had been packed one inside the other, with a large flat pan on the top; and all are now preserved in the museum at Saffron Walden. Their forms as well as the circumstances of their discovery recall a series of eight discovered at Irchester, comprising both Roman and Anglo-Saxon forms, and pointing to the transition period of the fifth century. Some have the rim turned abruptly inwards, and slightly thickened, while others have a projecting top which is quite horizontal. Their use is quite uncertain; but as some of them are of very thin metal, they were probably intended for ceremonial use. In neither case was there any sign of an interment in the vicinity; in fact, cemeteries of the early Anglo-Saxon period are very rare in Essex, and what there are have not been thoroughly explored. Experience warns us against expecting complete uniformity in the grave furniture and funeral rites met with in any particular district, however strong the tradition of its occupation by a single race; and Essex is no exception to the rule though there remains but little material for purposes of comparison. It has been already remarked that the distinctive Anglian rite stops short at the Suffolk border; and with possibly one or two exceptions unburnt burials are the rule among the East Saxons.

Among the sepulchral pottery found in the county there does not appear to be any undoubted example of a cinerary urn such as are commonly met with in the neighbouring Anglian district. In the Colchester Museum there is indeed one such urn, but it formed part of a collection made in Suffolk and was probably discovered in that county. One vase from Feering, also preserved at the Castle, is barely 3 inches high and is certainly not of the size usual for the reception of calcined remains; while another originally twice that height is not of the proper shape and was moreover found with two skulls on the same site. Mr. G. F. Beaumont, who excavated the Feering site, states his belief that several fragments of urns were found in the same field on other occasions, but cannot remember that any calcined bones were found there; and his opinion that burial on that site was principally by inhumation, rather confirms the suspicion that the pottery fragments belonged not to cinerary urns but to ceremonial vases such as are often found with unburnt burials. A more crucial instance is perhaps the Heybridge urn, 6 inches high, now preserved at Colchester ; but in spite of its close resemblance to the Anglian type no record can be found at

\footnotetext{
1 Four are figured in Archaologia, vol. xvi. pl. lxix. Victoria Hissory of Northants, i. 239.
} 


\section{A HISTORY OF ESSEX}

the museum or elsewhere that it ever contained the products of cremation. Nor is the find at Witham a case in point. There was exhibited to the Archæological Institute ${ }^{1}$ in 1844 a collection of objects from the site of an ancient camp there, called Temple Field, at the east end of the town; but they are evidently not of the same date, and indeed were found in two different spots, three skeletons being taken from a railway cutting, and parts of six urns being turned up by the plough. Bones and ashes were found inside, but the dimensions show these cremation urns to be of prehistoric date; while the skeletons follow what appears to have been the rule in Essex, though the objects found with them are of an indeterminate character. In the Chelmsford museum are preserved three pieces of iron from this site, which may be described as spearheads, but of themselves are unsatisfactory evidence of date.

There is but slender evidence therefore that the rite of burning the dead was ever practised by the East Saxons; but there is an interesting case in which fire was certainly employed at the funeral, though not in the manner usual with the Anglians.

This somewhat puzzling discovery was made at Broomfield near Chelmsford, and the following account is based on a paper read to the Society of Antiquaries ${ }^{2}$ by Mr. C. H. Read, who was invited by Mr. David Christy, the owner of the property, to undertake the exploration. In digging gravel about I 888 in a pit behind Clobb's Row the men came upon portions of a sword, a spear, knife and other remains about 6 or 7 feet below the present surface; but no particular attention was paid to them or to the site till six years later, when digging was resumed, and it was then found that the northern part of a grave lying east-southeast and west-north-west had been cut away. It was there that the objects already mentioned had been noticed, and these may be described before proceeding to the principal discoveries.

"The sword, though much broken, is nearly complete, and in one respect is of uncommon make. The decomposition of the iron has preserved a good deal of the wooden sheath, so that the blade itself can only be seen in section, where sword and sheath have been broken across. It is of the usual broad two-edged type, nearly 3 feet in length, the grip being represented, as is generally the case, by the tang only. The peculiar feature is that the upper part of the sheath, for nearly 4 inches from the mouth, is covered with strips of a finely-woven material like tape, bound upon itself from the mouth downwards.' 'Two other objects of special interest were found, probably in close proximity to the sword. One is of gold (fig. I3, A, B) in the form of a four-sided truncated pyramid, the base being about three-quarters of an inch square. The top and sloping sides are set with slices of garnet or ruby glass backed with chequered gold foil to add to the brilliancy, and enclosed within gold filagree work of a plaited pattern.

Comparison with a few other specimens of this kind suggests the manner in which these objects may have been used. It is not often 


\section{ANGLO-SAXON REMAINS}

they are found so richly ornamented, but there are a few notable examples in this country: one from Tuddenham, Suffolk, now in the Cambridge Archæological Museum; and another from Sarre, Kent, a full-size drawing of which is published in Archaologia Cantiana, vii. 3 II. These buttons or caps would be naturally more common in bronze, and one has been found in position on the pommel of a sword at Longbridge, Warwick, ${ }^{1}$ while specimens have also been found in the Burgundian graves of Charnay and figured in M. Baudot's sumptuous volume. ${ }^{2}$ One found at Oberolm in Rhenish Hesse has been described ${ }^{3}$ as a stud for leather. Yet another, of silvered bronze inlaid with stones, was found at Beckum, some miles south-east of Münster, Westphalia; and though it is described as the bezel of a finger-ring, the presence of a single and double-edged sword in the grave supports the above view. In either case it would be natural to find it near the hand.

The most complete parallel is however afforded by a discovery in Wiltshire. On the Salisbury race-course, about three miles south-west of the city, a small grave-mound adjoining the Roman road to Dorchester was opened by Sir Richard Colt Hoare, who published a description of the find in 1821.5 Previous to the construction of the mound, an oblong pit had been cut in the soil to the depth of $3 \frac{1}{2}$ feet, and on its level floor were found an iron sword 29 inches long of the usual description, three iron spearheads, two knife-blades, a shield-boss and discs probably attached to the shield, a buckle with traces of leather, and other small buckles of iron. The chief interest however lics in the further discovery of two glass tumblers, and a thin bronze vessel with marks of gilding, $6 \frac{1}{2}$ inches in diameter and about $1 \frac{1}{4}$ inches deep. This object resembles a modern frying-pan, but was found fastened to a bowl of oak, and so cannot have been used for culinary purposes. Close to this and the shield-boss already mentioned were four or five rings of silver wire (rather large for the finger), one of gold, and two bronze ornaments of pyramidal form, almost identical with the Broomfield and other specimens found in this country, ornamented with garnets set in white enamel; but though their use is as yet doubtful, there is little warrant for classing them as parts of bracelets. A detail that renders the similarity between the two discoveries still more striking is that at Salisbury as in Essex, not the slightest marks of any human interment could be traced, though the earth was thoroughly examined.

The second object (fig. I 4) was also of gold, the front being entirely covered with slices of garnet and blue glass set in gold cells very delicately and skilfully made. It seems to have been found in company with the pommel already noticed, and in all probability formed part of the decoration of the sword-handle. In the absence of anything

1 Joumal of British Archacological Assaciation, xxxii. 108.

2 Sepultures merovingiennes de Chamay, pl. x. fig. 21 , and pl. xi. fig. 32.

- Lindenschmit, Handbucb der deutschen Alterthumskunde, p. 380.

- Zeitschrift far vaterlandische Gescbichie und Alterthumskunde (Munster, 1865), ser. 3, vol. v. pl. v. 55t. p. 358 .

Ancient Wiltsbire (Roman KEra), pp. 26, 27 ; all but the iron objects are figured on pls. xxxvi., xxxvii. 


\section{A HISTORY OF ESSEX}

exactly comparable, it may be suggested that the grip was enriched with this and perhaps other jewelled plates somewhat in the manner observed on a remarkable sword-handle of wood from Cumberland, now preserved in the British Museum.

After an interval of six years, further excavation revealed the grave, the two ends of which were clearly defined in the gravel by a black line starting from the bottom and curving irregularly inwards through a vertical space of about 3 feet. At the extremities of the grave were rows of large flint nodules, and throughout the filling were numbers of flints, partly calcined, as well as fragments of Roman tiles. Somewhat

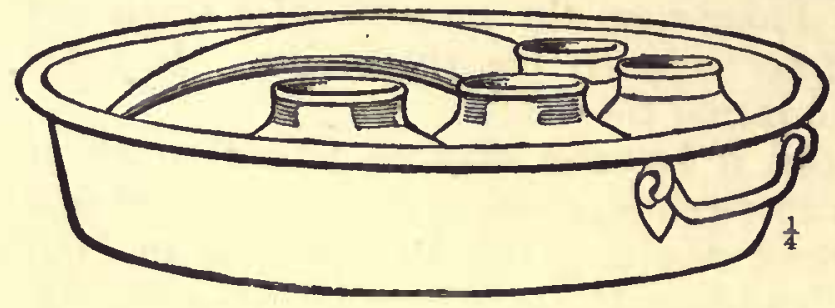

Bronze Pan from Anglo-Saton Grave at Broompiezd. east of the centre lay the fragments of a circular bronze pan about I 3 inches in diameter, with a flat projecting rim and two swing-handles of iron working in loops of bronze. Beneath was a mass of folded woollen fabric of two distinct qualities, resting on logs of birchwood; and it was evident that the pan had originally contained part of a cow's horn and four vessels that claim particular attention. Two (fig. I 9) are of deep sapphire glass, forming a pair that in shape, size and decoration are nearly identical with one found at Cuddesdon, Oxfordshire, with a remarkable

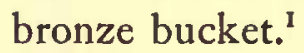

In the pan with the glass vases were two wooden cups turned on the lathe and furnished with thin rims of gilt bronze at the lips. Their exact form is uncertain, as the wood which was about one-eighth of an inch in thickness had not retained its shape; but as the mouth was about 2 inches wide, and the body appeared to have been little larger, it is not unreasonable to suppose that these cups resembled one ${ }^{2}$ found at Farthingdown, Surrey, which originally measured $2 \frac{1}{4}$ inches at the mouth and was somewhat barrel-shaped, with broad gilt bands at the top and bottom embossed with a serpentine pattern. A very similar mount ${ }^{3}$ was also found at Faversham in the King's Field, and is now in the Gibbs collection at the British Museum. As cups of this description are of rare occurrence, it should be observed that the examples given are from the south-east of England, in Kent and districts that must have been in communication with that kingdom from the first; and another feature that points to contact with a higher civilization south of the Thames estuary is that the Broomfield wooden cups were turned on the lathe, a process that was hardly known outside Kent in the pagan period when Anglian potters were making urns to contain the ashes of their dead.

1 These are figured in colours by Akerman, Pagan Saxondom, pls. vi. xiii.

2 Figured in Surrey Archocological Collections, vi. I 13.

3 Figured in Roach Smith's Collectanea Antiqua, vol. vi. pl. xxvi. fig. I.

4 It is pointed out by Dr. Sophus Muller that during the Migration period in Denmark the lathe was used for wood but not for metal or pottery (Nordische Altertumskunde, ii. 1 I I). 


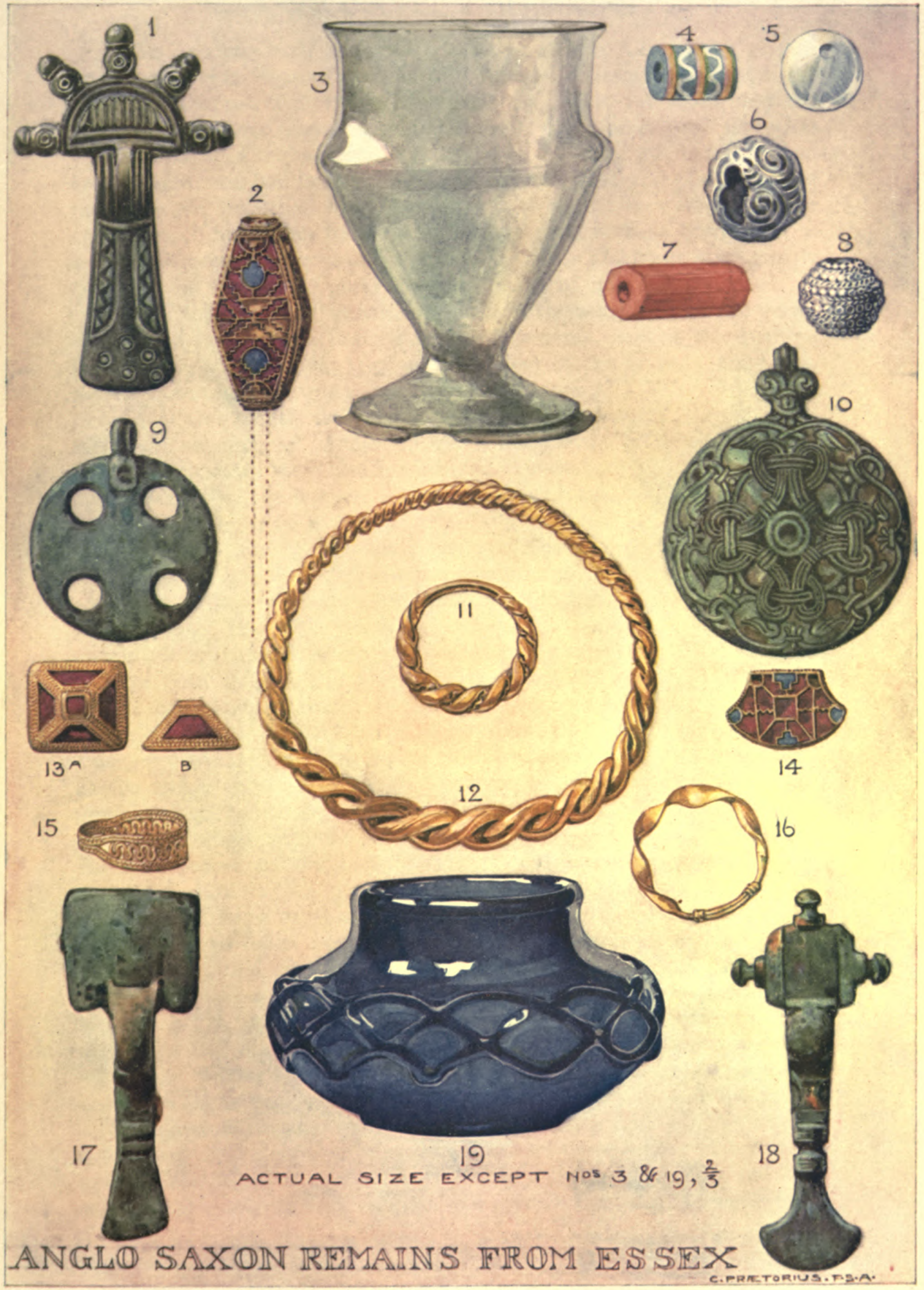





\section{ANGLO-SAXON REMAINS}

The iron pan itself also finds a close parallel in Kent, and a passage from Rev. Bryan Faussett's record may here be of interest. In I 760 he excavated a woman's grave at Gilton near Sandwich, and found near the feet a round bronze trivet on which stood a flat bronze $\operatorname{pan}^{1}{ }_{1} 8$ inches wide and about 4 inches deep. It had two handles, was much broken and decayed, and had been patched and mended in several places. It was plain that the body had been buried in a large and very thick chest or coffin, which had either been excavated by fire or perhaps been burnt to a certain degree in order to make it more durable. The bones were greatly decayed, and there were many shapeless pieces of iron near the head.

Near this group of vessels, but towards the south side of the grave, were found two wooden buckets with iron mounts, sunk in the earth so that the upper edges were level with the floor of the grave. They contained nothing of interest, but iron bands were noticed at the mouth, the middle and bottom, and both had overarching handles of the same metal. The wooden staves were clearly visible in the earth, and showed that the buckets had a diameter of 12 inches and a depth of 10 inches.

At the middle of the south side was found a hemispherical iron cup containing a compact mass of sand, and supported on a tall stem terminating in four feet. The total height was originally just over I I inches, but nothing quite similar appears to have been met with in graves or elsewhere, and that it was a lamp or brazier is merely a conjecture. In the south-west corner the excavators came upon a deep cylindrical cauldron of iron with a stout flat handle and a capacity of about 2 gallons. It was much broken, and though of unusual size no doubt served the same purpose as other large vessels found in graves of the same period in different

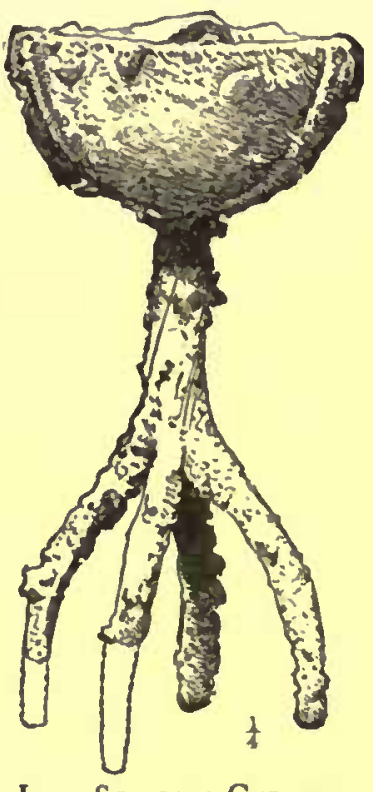

Iron Standing-Cup from Grave at Broomfield. parts of England.

A much more usual article of sepulchral furniture is the iron shieldboss which was taken from the east end of the grave where the sword and certain other objects had been previously found. A circle of a darker colour than the earth showed where the wooden shield had been, but was not definite enough to prove the dimensions. Scattered about in this part of the grave were fragments of a vase of dense grey ware, well baked and made on the wheel, the ornament consisting of impressed chevrons. It is quite unlike the ware usually found with such interments in Kent, and is perhaps more nearly related to the Merovingian than to the Roman civilization, which is not indicated by any other object in the grave. The Merovingian pottery is fairly uniform in quality and size, and is quite distinct both in form and texture from Roman and Anglo-

1 Both are figured in Inventorium Sepulchrale, pl. xv. figs. 1, 2 ; for description of the grave, see p. 16 and reference there. 


\section{A HISTORY QF ESSEX}

Saxon specimens; it is all the more remarkable therefore that almost an exact duplicate ${ }^{1}$ of this vase was found at Faversham, Kent, in the rich and extensive cemetery known as the King's Field ; and another, ${ }^{2}$ of red

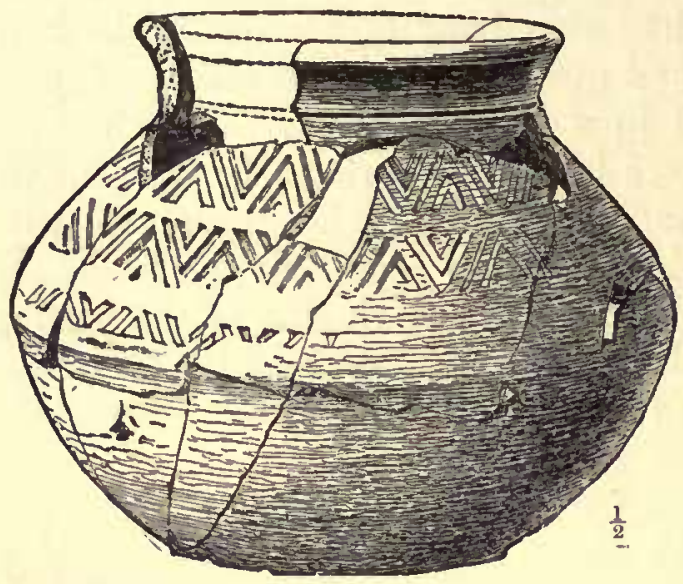

Pottery Vase from Grave at Broomfield. earth, with the famous Kingston brooch near Canterbury.

Nothing further was noticed except a good deal of very dark matter, charcoal, fragments of wood and parts of flat iron bars and angleirons with rivets, all in the western half of the grave. Though no traces of bones were met with, it seemed evident that the body had been placed in a stout coffin and burnt as it lay in the ground. The appearance of the sides point to this conclusion, though combustion under such circumstances must have been slow and imperfect, and if any bones were left unconsumed they must have decayed completely in the interval.

According to the plan given in the original account of the discovery, the grave was 8 feet in length with rounded projections at each corner; and though the form and section are peculiar, the contents are sufficient to show that this, like the majority of graves with relics, belonged to the pagan period.

Discoveries in Essex have not been plentiful enough to decide whether this or any other kind of burial was characteristic of the East Saxons. It will be observed that the discovery at Broomfield presents several novel features in the way of funeral accessories that cannot be classified as Anglian. Whether they are indeed Saxon in the strict sense of the term is another question; but further discoveries may one day point to a connection with Kent or disclose a continental trait that may justify a more exact attribution of these important relics of the past. The remarkable size and variety of the objects discovered in the Broomfield grave may indeed find a parallel in two well-known interments, but the treatment of the body differed in each of the three cases. At Bourne Park near Canterbury was found a grave, nearly i 4 feet long and half as wide, cut carefully in the solid chalk and filled with fine mould brought from a distance. In one corner had stood a bucket with bronze hoops, and nearer the centre a shield, with horse's bit, buckle and several nails; while at the head was a bronze bowl, thickly gilt, with two handles of iron. So far the analogy is fairly complete, but the appearance of the grave as well as the absence of the sword and knife showed that the

1 In the Gibbs Collection, British Museum; figured in de Baye's Industrial Arts of the Anglo-Saxons, pl. xvi. fig. 6 .

Inventorium Sepulchrale, p. 78 and pl. xx. fig. 6. 


\section{ANGLO-SAXON REMAINS}

interment of the body had never taken place, and that this was in fact a Saxon cenotaph.'

The other instance was at Taplow, Bucks, and the resemblance here is certainly too close to be accidental. To judge from the contents, both were the graves of leaders among men; and in spite of their distance apart and the difference in race that such distance would otherwise suggest, it is hard to believe that the two warriors were not of the same race and period. Of the two the Taplow grave is the richer, and is an excellent example of the type that is somewhat imperfectly represented at Broomfield. Though commonly known as a Viking's grave, the Taplow barrow is really earlier than the first appearance of the Northmen towards the middle of the ninth century; and a comparison of the relics with others in the same room at the British Museum will serve to fix the dates within fairly narrow limits. Of the characteristic Viking ornaments there is not a trace, and the gold buckle that formed the chief treasure of the discovery finds the closest of parallels in the wonderful jewellery of the Kentish graves.

It is apparent at once from the respective ground-plans that the two graves were cut in exactly the same direction, namely east-south-east and west-north-west; and both were of ample dimensions, though the richer was also the longer by about 4 feet. For the sake of convenience either grave may be considered to be in a line running east and west; and in the north-west corner, where a shield-boss was found at Broomfield, two shields had evidently been deposited at Taplow. Very near these must have been the handle of the sword in either grave; and while the iron blade alone was found at Taplow, the pommel and perhaps another part were found in addition at Broomfield. About the centre in each case was a large bronze pan or bucket containing two glass drinking vessels and two horns. The glasses are of different forms, but both pairs excellent of their kind; but the cow's horns of the Essex grave are but poor substitutes for the Taplow drinking-horns with their silver-gilt mountings and bountiful capacity.

Near these groups, but more to the south, were a pair of iron buckets at Broomfield, and one of bronze at Taplow; and a little to the west was found in the latter case a remarkable bronze vase standing 1 i inches high, with vandyked rim and drop-handles. Nothing of quite the same kind has hitherto been found in the country; but its rarity may suggest an explanation of the equally rare object found in the corresponding place at Broomfield. Though of iron and roughly made, there can be little doubt that this was intended to serve the same purpose as the magnificent bronze vessel that it equals in height and roughly corresponds to in form.

At the south-west end the Taplow grave contained fragments of wood and iron that tally well with the iron cauldron, capable of holding

\footnotetext{
1 Faussett, Invenforium Sepulchrale, p. 96.

2 It is thus described in the Illustrated London News, Nov. 17,1883; the Picrorial W'orld, Dec. 27, 1883 , and elsewhere.
} 


\section{A HISTORY OF ESSEX}

two gallons, in the other interment. As the northern portion of the Essex site was cut away without proper supervision, it is now impossible to say whether the other vessels found at Taplow were also represented; but it may be pointed out that the draughtsmen found at the foot of the latter grave remind us of the specimens found near the head of the skeleton at Bourne Park.

The remarkable coincidences here enumerated may justify some further conclusions. An examination of the Broomfield site indicated that the body had been enclosed in a wooden coffin and burnt inside the grave; but the difficulty of combustion in these circumstances was fully realized, and it may be added that the glass and especially the wooden vessels that must have been in close proximity to the fire, show no trace of contact with it. There can be little doubt that in both cases the body was protected by a wooden covering; and the fact that very few bones remained at Taplow is not to be accounted for by supposing all but these to have been consumed by fire. It has been constantly noticed, as in the Salisbury interment above described, that a grave which must have had an occupant, preserved not a trace of the body; and that this is due rather to decay than to cremation is evident from the extreme durability of calcined bones.

Enough was however left of the skeleton at Taplow to show that the head lay at the east end, contrary to the Christian orientation. It is therefore probable that the same conditions obtained at Broomfield; and in the absence of later and Scandinavian forms of ornament, we are entitled to fix upon the seventh century as the latest date for this interment in East Saxon soil. That it was before 600 is indeed possible, but as there are indications of a somewhat late settlement of Essex, it is more prudent to refer this interment to the years immediately preceding the introduction of Christianity into these parts.

In the absence of very precise details it is difficult to assign any more definite date to the Feering (Inworth) cemetery, which appears to have been as large as any of the period in Essex. A small series of antiquities was exhibited to the Essex Field Club ${ }^{1}$ in 1888 ; with them were found, besides the vases already mentioned as not being cinerary urns, several skulls, which are good evidence against cremation. There were a number of glass and amber beads, an iron sword and spearhead, and a peculiar crescent of bronze. Even the bronze brooches, which generally have a tale to tell, are here unimportant. Six of these were of a common circular form, four having simple punched designs, and two ornamented with gilded plates applied to the face, but now in a very poor condition. Another type (figs. 17, 18) is common enough, and a ring-brooch with chevron ornament is equally uninstructive. There was however a buckle set with a garnet that has a very Kentish appearance.

The discovery was made in a field near the river bridge, not far from Kelvedon station, an old survey dated $175^{8}$ preserving the name

\footnotetext{
1 Essex Naturalist, ii. 124.
} 


\section{ANGLO-SAXON REMAINS}

of 'Barrow Field,' while in the adjoining parish of Feering the 'Barrow Hills' may also point to some tradition of ancient burials there. These remains were presented to the Colchester Museum by the excavator, and a further exploration of the site led to similar results, which however have not been fully published. This is particularly unfortunate, as the Feering cemetery included several Roman or Romano-British burials, which might have thrown some light on the transition period of the fifth century. One of them was of special interest, as showing the sequence of events in Essex. ${ }^{1}$ Above a stone coffin now in the Castle museum a Saxon had been buried unburnt; but it would be idle to speculate on the interval that separated the two interments, as there were no characteristic ornaments in the upper burial, and there is little to indicate the latest possible date for the sarcophagus.

Isolated discoveries have been made from time to time elsewhere in the county, and may be included here to show in what localities traces of the pagan Saxon inhabitants may be looked for. In all the Roman cemeteries in and around Colchester Saxon burials have been discovered, ${ }^{2}$ and from one of them came a pale green glass cup (fig. 3 ) of peculiar form now preserved in the national collection; but most have been found at St. Botolph's Gate, the southern entrance to the Roman town, where most of the shield bosses in the Joslin collection, now preserved at the Castle museum, were discovered. At West Bergholt near Colchester was found a gold ring (fig. 12) now preserved in the British Museum. It was exhibited to the Society of Antiquaries by Rev. J. H. Pollexfen in 1863 , and consists of two tapering strands, intertwined with which is a slender twisted ribbon of the same metal in a manner characteristic of the Viking period. Another gold ring (fig. I6), consisting of a simple twisted ribbon, has been found at Colchester itself, and is now in the museum there. To these may be added a bracelet (fig. I I) of the same metal, now in the collection of Sir John Evans, K.C.B. ; it was found at Brightlingsea, and consists of two strands, of which the tapering ends are rather clumsily joined together.

A finger-ring of a different character is described " from Coggeshall (fig. I 5); it is of pale gold, the hoop consisting of two bands of finely plaited wire, like that on the Broomfield jewel (fig. I3), expanding on one side to enclose a length of thicker wire arranged in a series of scrolls. It was found in $185 \mathrm{I}$, and in default of evidence to the contrary may be referred on technical grounds to some time before the eighth century, while the other gold rings here enumerated more probably date from the ninth to eleventh century.

Certain graves at Shoeburyness have been described as Saxon; and

\footnotetext{
1 References to other examples at Colchester are to be found in Roach Smith's Introduction to Inventorium Sepukbrale, p. 50 ; T. Wright, Celt, Roman and Saxon, ed. 4, P. 470.

2 These and other particulars hitherto unpublished have been kindly communicated by Dr. Henry Laver, F.S.A.

Proceedings, ser. 2, ii. 247 (fig.).

- Joumal of British Archaological Association, xiii. 31 , pl. 39, fig. 1.
} 


\section{A HISTORY OF ESSEX}

though nothing of importance was found in them, the arrangement in two cases was remarkable. The bodies were disposed in a ring, and radiated from the centre, as was recently found to be the case at Newport Pagnell, Bucks. ${ }^{1}$ 'The feet were in both cases turned towards the centre, and parallels are thus furnished in this country to a discovery made some years ago at Vendhuile, a Merovingian site in the Department of Aisne, France. ${ }^{2}$

Saxon or Danish relics are said to have been discovered some years since at Goldhanger when several small grave mounds were opened on the marshes; and several burials at Leigh near Southend were dated approximately by numerous silver pennies of Alfred $(87 \mathrm{I}-900)$ and Plegmund, Archbishop of Canterbury (890-914). Specimens of these are in the museum at Colchester.

By that date the practice of burying ornaments and weapons with the dead had been abandoned under the influence of the Church, and finds in graves of the later Anglo-Saxon period are very exceptional.

Coins of the ninth and tenth centuries have seldom any other than a numismatic importance, and there are only a few recorded discoveries in Essex. A penny of Beornwulf, King of Mercia, found at Ashdon (Hadstock), ${ }^{3}$ throws no light on a number of burials placed north and south and accompanied by weapons of some kind ${ }^{4}$; nor is the postRoman history of Ithanceaster (Bradwell-on-Sea) any clearer for the discovery of a silver penny and sceatta there. ${ }^{5}$ To these may be added various coins found at Leyton ${ }^{6}$ and Barking, ${ }^{7}$ but no further details of any importance survive.

As a comprehensive survey of the archæological remains in the county may one day throw some light on the extent to which in the post-Roman period Christianity influenced the native or his conqueror, the few details recorded of missionary effort in this region will not be out of place. According to Bede, who wrote early in the eighth century, London was the metropolis of the East Saxons; and the story of Mellitus, its first bishop, is too well known to be repeated here. From the archæological point of view it is more important to notice that at the opening of Anglo-Saxon history, as soon as the records became credible, Essex is a sub-kingdom with its ruler Sigeberht bound by ties of marriage to his Kentish overlord. The foundation of the see of London was no doubt one of many ways in which Kentish influencé was exercised north of the river; and it is hard to imagine that along their opposite coasts there was not easy communication between Jute and Saxon, or whatever races owned a common allegiance to the throne of Ethelberht at the opening of the seventh century.

Traces of such influence may be noticed in the Essex finds, but

\footnotetext{
1 Antiquary, I900, xxxvi. 97.

- É. Fleury, Antiquités et monuments du Dépt. de l'Aisne, pt. 2, p. I 31 .

3 Fournal of British Archaological Association, v. 80.

- Essex Archaological Transactions, new ser. iv. 7. $\quad$ Gentleman's Magazine, 1865, pt. ii. 403.

6 'T. Wright, History of Essex, ii. 500 ; Gough's edition of Camden's Britannia, ii. 50.

7 Lyson's Environs of London, iv. 58.
} 


\section{ANGLO-SAXON REMAINS}

it must be confessed that they are few and unimportant and are perhaps no more conspicuous here than in other counties not so favourably situated for trading in continental productions, for which Kent appears to have been the principal depôt in this country.

In addition to the Broomfield jewels, of which enough has already been said, there belongs to this category a handsome jewelled ornament (fig. 2) that was probably worn by some wealthy lady as the head of a pin for the hair and points unmistakably to Kent as the place of manufacture. This remarkable relic ${ }^{1}$ was found at Forest Gate, and is of massive gold with four sides broadest in the middle, the truncated ends pierced for the reception of the pin, probably of silver. The four faces are inlaid with garnets and blue glass arranged in step-pattern, the design being the same on opposite pairs. This cell-work is characteristic of Kentish jewellery, and is easily distinguishable from foreign examples of the art. ${ }^{2}$ At the other end of the county, at Dovercourt near Harwich, was found a bronze radiated brooch (fig. I) which may also have been manufactured south of the Thames. It is of the usual type, rare in this country outside Kent but common in Switzerland, Western Germany, and Normandy, and its discovery so close to the sea can throw little light on the nationality or origin of the dwellers inland at the time of its deposit, some time in the seventh century. Another interesting find near the coast was made at Great Clacton during the demolition of a mound within an entrenchment. A glass cup was discovered with broken tiles and charred wood, but further details are not available, and without dwelling on the apparent similarity to graves in Kent it will suffice to notice the close resemblance of the cup to several found in that county as well as certain other localities, such as Wheathampstead, Herts, and Desborough, Northants. Tumblers of this mammiform type were perhaps not of native manufacture; and the present specimen $^{3}$ is evidently contemporary and intimately connected in origin with continental specimens from the Rhine district. Of three bone combs found at Great Wakering and now in the national collection, two are of a type fairly common in Kentish graves, having two rows of teeth running the entire length; while the third has a very thick cylindrical handle, of which there are two examples in the same collection from the Thames and one from the county of Durham. A diminutive axe-head of iron" found at Colchester was probably intended for the use of a boy, as the 'francisca' was one of the commonest weapons among the Frankish peoples across the Channel, though rarely met with in Anglo-Saxon graves.

Of quite another character is an important discovery at Saffron

1 Now in the possession of Sir John Evans, who has kindly lent it for illustration, together with the radiated brooch (fig. 1) and gold bracelet (fig. ti).

- Pin-heads of similar form but different ornamentation are figured in Lindenschmit's Alterthumer unserer heidmischen Vorzeit, vol. ii. pt. x. pl. vi. figs. 13 (Andernach) and 14 (Palatinate).

- Figured in Journal of British Archacological Association, ii. 99 ; its Kentish character is noticed 2t p. 54 of the same volume.

- Figured in Akerman's Pagan Saxondom, pl. xxiii. fig. 2 ; Hore Ferales, pl. xxvii. fig. 18. 


\section{A HISTORY OF ESSEX}

Walden, which probably belongs, at least in part, to a comparatively late period, as was indeed pointed out at the time of its first publication. In the north-west angle of the British 'camp' fifty or sixty human skeletons were dug up within a few yards of the western bank in the year 1830 , and traces of other burials noticed in other parts of the enclosure ; but it was not till 1876 that a systematic excavation of the site was undertaken by the owner, the late Mr. G. S. Gibson, with the assistance of Mr. Ecroyd Smith who wrote a report for the Essex Archæological Society. ${ }^{1}$ About 150 skeletons were met with on this occasion at various depths owing to a surface alteration in later times; but it was evident that the usual practice had been to remove the upper soil to a depth of 2 to 3 feet, and then to excavate the solid chalk another foot for the reception of the body, which was usually placed on its back at full length, with the head pointing to the west. In most cases the interments had been made with reverential care, but no remains of coffins were found and only a few traces on pottery or bronze ornaments of the cerecloth in which the more wealthy seem to have been buried. A reference to the plan published with the report shows that the graves had been cut for the most part in rows from north-east to south-west, and in some cases the intervals are so regular as to suggest that each burial was distinguished by a mound or some other mark to avoid overlapping.

It may here be mentioned that the discovery of pits in the chalk dug prior to the Anglo-Saxon interments shows that the site had been occupied in the remote past ; and a very systematic and laborious superintendence would have been necessary to keep the relics of the different periods apart. There seems no doubt however that Anglo-Saxon pottery, made without the wheel and ornamented with impressed devices, was plentiful, but whether in the form of cinerary or domestic vessels is uncertain. Closer observation of such particulars would in this case have been specially welcome as bearing on the question whether the Anglian rite of cremation prevailed here to any extent. The East Saxons must have guarded their borders jealously indeed if such an unimportant river as the Stour, I 2 miles from Walden and there only a stream, remained throughout a barrier between the Angle and Saxon whose nationality is declared not only by the territorial divisions of to-day, but by the difference in their funeral customs established by archæological inquiry.

In what is called the best part of the cemetery the graves were close together and arranged with some system, but elsewhere, especially to the south, instances occurred that imply some difference of race, condition or period. Skeletons were here found sometimes without a grave and sometimes lying confusedly in pits; while others had been deliberately buried with the head to the south, the contrast to the majority being very noticeable on the plan.

Whether the orientated graves may be referred to Christians and the others to their pagan contemporaries, or whether these features 


\section{ANGLO-SAXON REMAINS}

belong to different periods cannot at present be determined; but there are grounds for attributing the best part of the cemetery to a converted population of about the tenth century. The paucity of ornaments and weapons is itself a strong argument in favour of such a view, and the peculiar character of the principal relics marks these interments off from the generality discovered in this country. Of the large number of skeletons ${ }^{1}$ discovered, only one was found with personal ornaments of any kind. A woman had been buried with bronze anklets and beads of crystal (fig. 5), carnelian (fig. 7), glass-paste (fig. 4) and silver (figs. 6, 8) apparently strung on a necklace the principal ornaments of which were a pair of floriated bronze discs (fig. I0) and a plain one (fig. 9) with four circular holes in it perhaps once filled with imitation gems, but now retaining but few traces of a tinned surface. The pair are of more especial interest as the design is one that puts at least one limit to the date of the burial. Neither Saxon nor Anglian elements are to be distinguished in this instance, but there are on the other hand close affinities to objects of the Carlovingian period which have been found in Scandinavia, where the heathen practice of burying the dead in full dress lasted two or three centuries longer than elsewhere in north-west Europe. Though it is to Viking ornaments that one turns for the closest parallels, the design of the two discs may also be seen not only on the coinage of that time both in England and France, but on the seal of $Æ l f r i c^{2}$ now preserved in the form of a brooch in the national collection and ascribed to about the year rooo. A pendant of the same character is published, ${ }^{3}$ with hollow silver beads that forcibly recall the Walden specimens.

Further, it is as certain as any deduction from the evidence available can be, that no relic ornamented in this particular style would ever be found in an interment of the pagan period in England. The Carlovingian Renaissance of Roman art began about the year 800 , and after reaching its zenith about 850 , declined during the next century and a half; and the conventional foliage of the Walden pendants has only to be placed side by side with the grotesque animals and geometrical designs of the post-Roman period to render the difference of date and origin apparent to the most casual observer.

1 Specimens are exhibited in Saffron Walden Museum.

2 Figured in Victoria History of Hampsbire, i. 398.

3 Mémoires de la Société des antiquaires du Nord (1890), p. 217. 
1 


\section{DOMESDAY SURVEY}

Assessment of the county, p. 333-The Crown manors, p. 336-The Church lands, p. 338The barons' fiefs, p. 342 - Their English predecessors, p. 35I-The stamp of the Conquest, p. 356-The peasantry, p. 359-Rents and values, p. 363-The ploughs and live stock, p. 365-The sheep in the marshes, p. 369-The swine in the woodlands, p. 374Pasture, mills and fisheries, p. 378 -Saltpans, vineyards and beehives, p. 380 -The clergy and their glebes, p. 383-Towns and their houses, p. 385-Identification of manors, p. 387 -Corruption of place names, p. 398-The vill and the parish, p. 400'Ness' and 'Thorpe,' p. 405-The Hundreds and their boundaries, p. 406-Duplicate entries, p. 410-Domesday pleas, p. 411-The Domesday volume, p. 4 I3.

The Survey of Colchester, p. 414-Holders of houses, p. 417-The king's ferm, p. 419-The mint, p. 421-Miscellanca, p. 422.

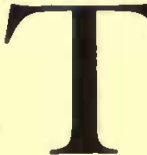

1HE position occupied in Domesday Book by the county of Essex is unique. As is, no doubt, generally known, it is one of the three counties surveyed in 'Little Domesday,' that is, in the smaller of the two volumes which enshrine 'the Survey of England.' The record therefore of its lands displays those peculiar features by which this smaller volume is so sharply distinguished from the other, its contracted forms, its inferior workmanship, and its marvellous wealth of detail. On the other hand, although the survey of Essex appears at first sight, for this reason, to resemble those of Norfolk and Suffolk, which are the two other counties comprised in this volume, careful examination soon reveals a system entirely distinct. Essex, as its name implies, was not an Anglian but a Saxon land; this is a fact which lies at the very root of its history. And it is because it was a Saxon land that we find it in Domesday assessed in 'hides,' like Middlesex, like Sussex, like the westward counties which formed part of Wessex, and thus proclaiming its affinity with the rest of Saxon England, just as Norfolk and Suffolk, in their own peculiar assessment, preserved, even on the pages of Domesday, the traces of their alien existence as the kingdom of East Anglia.

It is needful at the very outset to insist on this distinction, for it appears from the words of Professor Cunningham to be occasionally overlooked. Grouping together the three counties, he observes that -

A vast mass of interesting detail has been preserved to us in the parts of Domesday which deal with Norfolk, Suffolk and Essex. These Eastern Counties were assessed on an intricate system which was quite different from that prevailing in the rest of England; its difficulties have been successfully unravelled by Mr. Corbett's careful investigation. Instead of assessing each vill according to the number of bides, every 


\section{A HISTORY OF ESSEX}

hundred was regarded as responsible for the payment of $£_{\mathrm{I}}$; and the share of each village is given by stating the number of pence it would contribute to make up $\ell_{\text {I }}$ for the whole hundred, etc., etc. ${ }^{1}$

The East Anglian system of assessment, which is here somewhat inaccurately stated, has been explained by me in another place. ${ }^{2}$ It is radically distinct, as $I$ have said, from that of Essex, although the three counties are surveyed in the same volume. The great underlying principle of 'the five-hide unit,' on which was constructed the system of assessment in all hidated counties, is peculiarly prominent in Cambridgeshire and Beds; is recognizable, though less distinct, in Hertfordshire; but has been so obscured in Essex that it might even at first sight be imagined to be non-existent. There are however sufficient traces of its original existence in Essex to warrant the assertion that here also it lay at the root of the system. And this, as might be expected, is best seen in those old intact lordships which were held by the Crown and by the Church. Of those manors which head the Survey, and which, as I shall argue, had been Crown demesne for the most part, Hatfield (Regis) was assessed at 20 hides, Havering, (Great) Chesterford, Lawford and Brightlingsea at Io hides each, while Waltham (Holy Cross), which Harold had also held, was reckoned as 40. Of the Church's manors Barking appears with an old assessment of 30 hides, as does the Bishop of London's manor of Southminster. Littlebury stood at 25, Rettendon and Clacton at 20, Belchamp St. Paul's, Wrabness, Strethall and Woodford at 5 each. Of manors in the hands of lay barons, Clavering was assessed at i 5 hides, Mundon and Great Oakley at Io, Woodham Mortimer, Shopland, Fobbing, Langdon, Amberden, Thunderley, Wix, Ugley and Little Chesterford at 5 hides each. But the great system of assessing vills in multiples of the five-hide unit is in Essex, as a rule, unrecognizable, and even 'Fifhida' itself (now corruptly Fyfield) is not entered in Domesday as a vill of 5 hides.

I have here dealt first of all with the local assessment for (Dane)geld, because, as Professor Maitland has rightly said of Domesday, "one great purpose seems to mould both its form and its substance; it is a geld-book,' ' that is, a book recording the assessments on which the land tax of the period was levied. But although this was the chief intention with which the Survey was compiled, the modern student is more concerned with the other information it contains, especially where, as in the case of Essex, the 'hides,' 'virgates' and 'acres' in which the holdings were assessed cannot apparently be combined, as in the neighbouring county of Cambridgeshire, to illustrate the artificial system of assessing the Hundred and its 'vills.' "

1 The Growth of English Industry and Commerce in the Early and Middle Ages (3rd ed. 1896), pp. $162-3$.

2 See my section on 'The East Anglian Leet' in Feudal Engtand (1895), pp. 98-103. The 'Hundred' was of course responsible for much more than $\oint_{0} 1$, even when the 'geld' was normal.

3 Domesday Book and Beyond, p. 3.

4 There is sufficient evidence that the unit of assessment known as the 'hide' was divided, as elsewhere, into 4 quarters termed 'virgates,' each of which was reckoned as containing 30 'geld' acres. This evidence is found under Waltham (Holy Cross), where 7 hides and $\frac{1}{2}$ virgate $=7$ hides and 15 


\section{THE DOMESDAY SURVEY}

The subjects on which Domesday Book contains, in Essex, information of most interest and value are the distribution of estates before and after the Conquest; the various classes represented among the small holders and peasantry, with the indications that these classes were passing through a period of change; the rise and fall in value of land; the relation of the Hundred to the 'vill' or to the parish of to-day; the extent and distribution of the woodland and of the live stock kept upon the demesne, that is, roughly speaking, on the home farm of the manor. Of the industries and sources of wealth Domesday can tell us little, for these at the date of the great Survey were primitive and few. Here as elsewhere the place of honour is assigned by Domesday to the plough, with its all-important team of oxen, reckoned as eight in number. The streams watered the meadows which provided hay for the oxen, and turned the wheels of the ancient mills where the men of the manor, to the lord's profit, brought their corn to be ground. The woodland provided the kings with sport, and supplied timber and fuel for the local lords and their men, but was valued mostly for the feed it afforded for vast herds of swine. The rural economy of Essex in all these respects differed nowise from that which the Survey shows us in other counties; but one great feature appears to be peculiar to itself. For I hope to show that the frequent entries of manors containing 'pasture for sheep' possess a special meaning, and refer, although the fact has been hitherto unsuspected, to the famous marshes of Essex. They reveal, it will be found, the existence of an old-world industry, of which the tradition lingers in the 'wicks' of the Essex coast, and they help to explain the strange detached fragments of parishes which form a very mosaic down among the sludgy creeks.

Down by the sea also were the saltpans, especially in the north-east of the county, providing by primitive methods a then precious commodity. In a few places, chiefly near the seats of Norman barons, vineyards had been lately planted, while the beehives, of which the Survey so carefully records the number, produced not only honey, and wax for the candles of the time, but also what our forefathers quaintly termed 'that salutary and delicious species of wine called metheglin or mead. ${ }^{1}$ Of trade there was then little or none; not a single market appears in Essex, although they are found on its northern border at Haverhill, Sudbury and Clare. Colchester, already a town of importance, described apart and at some length at the close of the county survey, was peopled of course by 'burgesses,' and there is mention of 'burgesses' at Maldon; but there are few traces of trade at either, even at a later date. In addition to the points I have now enumerated there are as usual incidental statements rich in unexpected information, and affording glimpses of lawless aggression, of questions referred to the sworn men of the Hundred or the county

acres ; Felsted, where a hide is found to consist of 3 virgates plus I virgate; Rettendon, where $16 !$ hides plus 1 hide and 30 acres plus 2 hides and 30 acres $=20$ hides. Nor do these entries stand alone.

i See Young's Agriculture of Essex (1807), citing (ii. 363) Howlett, who found the labourer still regaling 'himself with the pleasant cooling beverage obtajned from the last droppings of the combs.' 


\section{A HISTORY OF ESSEX}

court, and even of the Domesday commissioners themselves at work on the king's behalf.

Dealing first with the evidence of Domesday on the changes wrought by the Conquest in the distribution of land, we turn to the manors held by King William himself, and are struck at once by the salient fact that in Essex not a single manor had been held by Edward the Confessor. The surveys of Cambridgeshire and Suffolk begin, as was usually the case, with the valuable manors in which King William had succeeded his predecessor on the throne. Why did Essex in this respect differ from other counties? Could it have contained no manors that were 'ancient demesne' of the Crown? In seeking an answer to this question we may find assistance perhaps in the adjoining county of Hertford. There also, of the manors held by the king himself, not one is entered as having been held by Edward. I have elsewhere suggested that this may be explained, at least in the case of Hitchin, by far the greatest of them all, by the fact that Harold had obtained possession of the Crown's 'ancient demesne.' There is strong reason, I think, to believe that in Essex also this had happened. Another solution indeed is suggested by Professor Maitland, although he seems not to have observed, or at least not have addressed himself to the special case of Essex. Writing on the king's manors in Domesday Book and Beyond (pp. I 66-8), he speaks of 'comital manors':-

King William is much richer than King Edward was. The Conqueror has been chary in appointing earls, and consequently he has in his hand, not only the royal manors, but also a great many comital manors. . . . One of the best marked features of Domesday Book, a feature displayed on page after page, the enormous wealth of the house of Godwin, seems only applicable by the supposition that the earlships and the older ealdormanships had carried with them a title to the enjoyment of wide lands. - . A great deal of simple rapacity is laid to the charge of Harold by jurors whose testimony is not to be lightly rejected; but the greater part of the land ascribed to Godwin, his widow and his sons, seems to consist of comitales ville.

That the vast estates of Harold in Essex were partly, at least, Crown lands we have incidental hints. Domesday itself, surveying the great lordship of Writtle, tells us first that Harold had held it, and then mentions that a hide ' in Writtle' held by the Bishop of Hereford had belonged to 'the king's fee' (in feudo regis). This entry is repeated later under the name of the Bishop of Hereford, with the difference only that the hide in question is said to have belonged to 'Harold's fee' (feudo Haroldi)." 'This surely suggests that Harold's fee had been the king's. But I base my conclusion rather on the peculiar character of the manors found in Harold's hands. Writtle itself had rendered ' $x$ noctes de firma,' and Brightlingsea, Lawford and Newport ' 2 nights' each. 'This archaic system of providing ' feorm' for the household was normally characteristic of 'ancient demesne' of the Crown, ${ }^{3}$ and the only other Essex manor on which it was found was that which Earl Elfgar had held at Baddow.

With these introductory remarks we turn to Harold's lands, and

1 Victoria History of Hertfordsbire, i. 278 2. 2 See pp. $434,460$.

8 Compare, for instance, Eyton's Key to Domesday: Dorset Survey, p. 80. 


\section{THE DOMESDAY SURVEY}

find his chief manors were Writtle, Hatfield (Broadoak), Havering, Stanway, Lawford, Brightlingsea, Newport, Waltham (Holy Cross), Feering, (West) Thurrock, Witham and Benfleet. But to these must be added those which he bestowed on his great foundation at Waltham, none of which however was exceptionally valuable or large except Waltham itself, which, according to his charter of foundation, was included among them, but which was bestowed by William on the Norman Bishop of Durham. Feering and Ockendon, which had been held by Harold, are found at the time of Domesday in the hands of Westminster Abbey, but in the case of the latter the Survey tells us that the abbey had acquired it by exchange 'since the king crossed the sea.' This refers to a transaction by which King William regained the manor of Old Windsor, which his predecessor had bestowed on the abbey. A charter of the Conqueror in English addressed to the Bishop of London, to 'Swein' the sheriff of Essex, and to all his thegns in the county, announces that he has given to the abbey 'Feringe and Wokindone' in exchange for that manor. ${ }^{1}$ This charter cannot be later than 1075 and, being in English, probably belongs to the early days of the reign. Except for these manors and for that of (West) Thurrock, which William bestowed on the Count of Eu, he kept almost the whole of Harold's lands for himself, including the great lordships I have named above. These formed thenceforth the bulk of his Essex demesne. ${ }^{2}$

Next in importance to these were the lands of Earl Ælfgar, of which he similarly kept the bulk in his own hands. Ellfgar, who had died in or about 1062, had. added to his own earldom of Mercia that of East Anglia; but it is not easy to account for his possessions so far to the south as Essex, for it has not been supposed that this county was at any time under his sway. In any case the earl had held the manors of (Great) Chesterford, Shalford, Wethersfield, Felsted, Great Baddow and Gestingthorpe with a smaller one in Finchingfield. Improbable though it may seem, the Earl 'Edgar' of Domesday, who is entered as the former lord of (Great) Chesterford, was a magnate who had no existence. The entries found under Cambridgeshire which refer to this manor enable us to say positively that Earl Ælfgar was its lord. ${ }^{3}$ It is worth noting that in Essex as in Bucks " lands which had belonged to Earl Ælfgar were bestowed, in the first instance, by William on his queen. This was certainly the case at Shalford and at Finchingfield, and probably also at Felsted, for Queen Matilda is recorded as joining with him in the gift of that manor, in the year 1082, to that noble Abbaye aux Dames so familiar in the present day to visitors to Caen. ${ }^{5}$ It is probable therefore that Baddow also owed to the same circumstance its bestowal on that

1 Cotton MS. Faust, A. III. fo. 113.

2 In estimating the whole extent of Harold's estates in the county it is necessary to remember also those which were bestowed on Count Eustace, John son of Waleram, Robert son of Corbutio, and Ralf de Limesi.

See p. 338, note I below. i.e. the manors of Hambleden and Marlow.

- See my Calendar of Documenes Preserved in France, p. 141. One may note also that Gilbert the priest claimed to hold his land at Middleton (near Gestingthorpe), which had belonged to " 9 sokemen of Earl Elfgar,' 2s 'of the Queen's gift' (p. 564 below).

1 


\section{A HISTORY OF ESSEX}

abbey, a fact which is made known to us by Domesday, but of which, it would seem, no trace is found either in the charters of the house or in the later history of the manor. In this connexion one may mention that when, on the queen's death, Bury St. Edmund's received from the king a Northamptonshire manor 'for her soul,' it was again one which had been Earl Ælfgar's. Wethersfield and Great Chesterford appear to have been reserved, from the first, by the Conqueror for himself.

Great Chesterford illustrates well a peculiar feature of the Essex manors which had fallen to the king's share. Lying as it does on the Cambridgeshire border, it possessed in that county an outlying 'hide and a half,' the locality of which is not given, but which can be clearly shown to have lain in Histon just north of Cambridge. It also possessed in that county an unnamed half hide, which can be recognized as 'half a hide and half a virgate' in Babraham, a few miles to its north, which, like itself, was 'farmed' by Picot the Cambridgeshire sheriff.' There had further been appendant to this manor, in the time of Edward the Confessor, a hide and a half, which, says Domesday, Hardwin 'de scalariis' held in I086, though the Hundred knew not how. I think that these lands also can be recognized in entries relating to Babraham and to Histon. ${ }^{2}$ To Newport there had been similarly appendant a Cambridgeshire estate at Shelford, a little to the south of Cambridge. Brightlingsea possessed a Suffolk dependency in Harkstead on the northern side of the Stour, while to Hatfield (Broadoak) there had been appendant three 'berewites' in Hertfordshire, which are entered as held by Ralf de Limesi in I086. These are described as Hertford, Amwell and Hoddesdon, but they appear to have been all comprised in that great manor of Amwell (lying just between Hertford and Hoddesdon) which Domesday enters as held by Ralf and as having been held by Harold (fo. 138 ). With these dependencies of Essex manors in Suffolk, Cambridgeshire and Herts it was not easy for Domesday to deal; but its primary purpose, that of a rate-book, involved their survey in the county and the Hundred in which they assessed, although their rental might be comprised in that of the Essex manor. In the case of Shelford details are given under Newport as well as in Cambridgeshire, with the strange result of proving that the surveys differ. ${ }^{3}$ If Essex manors possessed these outlying dependencies, there was an instance of the opposite kind in the Kent manor of Chalk, of which Domesday records that there rightly belonged to it one hide in Essex. ${ }^{4}$

Next, in Domesday to the king's lands are entered those belonging to bishops and religious houses. Of these, as will be seen on the Domesday map, the great bulk was in the hands of the Bishop of London or his canons. The head of his fief was Bishop Stortford (which thence derived its name) on the border of Hertfordshire and

1 See p. $43 \mathrm{I}$, note I below. It is the mention of Earl Ælfgar as the former holder in both these Cambridgeshire entries that enables us to identify the 'Earl Edgar' who held Great Chesterford.

2 See p. 430 below.

3 See p. 410, note I below.

4 'In Exesse est una hida quæ juste ad hoc manerium pertinet' (i. 9). Compare pp. 35 I, 352. 


\section{THE DOMESDAY SURVEY}

Essex, and in both counties manors are found, down to a far later time, owing the service of castle-ward or the money commutation for it to his castle there upon the Stort. That this 'castel' was standing at the time of the Domesday Survey is proved by a charter of the Conqueror, addressed to Peter de Valognes and others, which gives to Bishop Maurice the 'castel of Estorteford,' as held by Bishop William his predecessor.' The bishop's castle reminds us of his position as a tenantin-chief holding his great fief by military service. One of the difficult questions raised by Domesday in Essex is its application of the phrase 'fief of the Bishop of London' to a portion only of his manors 'the earlier portion being headed 'land of the Bishop of London' a distinction emphasized by its repetition at the head of fo. 9. ${ }^{2}$ One might naturally suppose that the bishop's 'fief' was that portion of his lands which was held by knight-service; but even in Domesday it is clear enough that both portions were so held, and the valuable lists of the hishop's knights in the twelftls and the thirteenth centuries $^{3}$ make it certain that this was so. We must therefore seek elsewhere the meaning of this distinction. It is found, I think, in certain entries in the Domesday Survey of Hertfordshire." We there read of Bishop Stortford that 'it belongs to the fief (est de feudo) that Bishop William bought'; of part of Wickham, that 'this land is of Bishop William's fief' (feudo); of an estate in Throcking, that 'this land is (part of) the purchase of Bishop William'; and of Thorley, that "William Bishop of London bought this manor of King William, ... and now the Bishop of London claims it.' With these clues we return to Essex and observe at once that what is there styled the "fief of the Bishop of London' is entirely composed of lands which had been held by sundry lay owners under Edward the Confessor. And this was not the case with the 'land of the Bishop of London,' all of which had been held, at some period, by his see, except the first manor entered, of which the previous owner, a free woman, may have bestowed it on the church. It may therefore be inferred with much probability that the 'fief of the Bishop of London' had been acquired by Bishop William for his church during his long and eventful tenure of the see ( $1051-75)$.

Bishop William had enjoyed the favour of the Conqueror as of the Confessor, which the former showed by giving him the manor of Warley as an old possession of his see, by restoring the vast estate of Southminster, which Cnut, says Domesday, had taken away, and by enabling him to prove the right of his church to two manors in the Layers. His most valuable manors, taking them in order, were Clacton, Orsett, Southminster and St. Osyth ('Cice'). Turning from the bishop to his canons we find Domesday, as usual, ${ }^{6}$ inconsistent with itself. In Middlesex it

\footnotetext{
1 Dugdale's History of St. Paul's, pp. 304-5.

8 Red Book of the Exchequer, pp. 186-7, 54 1-2.

- See the Victoria History of Hertfordsbire, i. 279.

- See the Victoria History of Worcestersbire, i. 245.
} 


\section{A HISTORY OF ESSEX}

groups under one heading ('the land of the Bishop of London') the manors held by the bishop and by the canons, though those of the bishop precede the others. In Hertfordshire they are ranged under separate headings, and even separated by intervening fiefs. In Essex the headings are again separate, but the canons' lands follow immediately on those of the bishop. ${ }^{1}$ Their most important possession was the great soke' of Eadwulfsness, now represented by 'the Sokens,' as they are familiarly called, Kirby, Thorpe, and Walton-on-the-Naze. Tillingham was another of their ancient manors, the total of which had been augmented since the death of the Confessor by the gift of an estate at Norton (Mandeville), the acquisition of others at Navestock and West Lee - the former, they alleged, by the king's gift-and the annexation or seizure of others at Navestock and Barling. On the other hand their own lands had been encroached on at Chingford and Heybridge by Norman magnates. The value of the canons' estates had either increased or was stationary, while that of the bishop's manors had on the whole decreased. These Domesday values, I may observe, cannot be connected with the firma rendered to the canons by their manors at or soon after this period. ${ }^{2}$

The other old English foundations holding lands in the county were the monastery of Christchurch, Canterbury, the local nunnery of Barking, the Suffolk abbey of St. Edmund's, and the Cambridgeshire one of Ely. The lands of Christchurch ('Holy Trinity') precede even those of the Bishop of London in the Survey. This was doubtless due to its close connexion with the primate. They are chiefly remarkable as representing what were afterwards known as his 'peculiars' in this county, subject to the commissary still known as the Dean of Bocking, Bocking (with Bocking Hall in Mersea) being one of the Christchurch manors. Barking had lost a manor at Benfleet, which the Conqueror, we know not how, had bestowed on Westminster Abbey, and an estate at (Abbess) Roding, which Geoffrey de Mandeville had obtained but seems to have subsequently disgorged; and it had also suffered the usual petty encroachments at the hands of the newcomers. St. Edmund's had not only lost nothing, but had actually gained, as elsewhere, at the hands of the Conqueror, who had given it a manor at Little Waltham, and possibly the addition to its estate which it had obtained at Harlow. Ely, which had lost his favour by its share in Hereward's rising, became the special prey of the Norman spoiler. Its chief possessions in Essex were Littlebury, said to have been given by King Æthelred in 1004, and Rettendon, assigned to the gift, not long before, of Brihtnoth, the famous alderman, and his wife. But it retained, in ro86, some three or four other manors of lesser importance. Domesday however records its

'Domesday speaks of the canons' manors as having been held by 'St. Paul,' and applies the same formula to the bishop's manor of Wanstead; but Archdeacon Hale has observed that 'the bishops of London appear to have possessed their manors in the time of the Anglo-Saxon kings in their own right, for there are no traces of any of the episcopal lands having at any time belonged to the cathedral' (Domesday of St. Paul's, p. iv.).

2 See for these firme Hale's Domesday of St. Paul's, p. xxxix. 


\section{THE DOMESDAY SURVEY}

claims to many estates which are found in the hands of Norman barons. Chief among these was the great manor of High Easter, which had passed into the hands of Geoffrey de Mandeville and became, if it was not already, the site of the Mandeville castle of Pleshey. The Domesday entry on the title to the manor' is explained by the abbey's chronicle, which tells us that Geoffrey's predecessor, the potent Ansgar, had forcibly obtained from the monks a life estate therein." The abbey had also suffered heavily, at the hands of Eudo Dapifer and William de Warenne, in the Rodings, and had further been despoiled, to a more or less serious extent, at (South) Fambridge, Witham, (West) Hanningfield, Broxted, Sandon (?), Amberden and Shellow (Bowells). In all, the lands it had retained in Essex were substantially less in value than those which were held by its spoilers in $1086 .^{3}$

The more recent English foundations holding lands in Essex were those of the Confessor at Westminster, of Harold at Waltham (Holy Cross), of Ingelric at St. Martin-le-Grand, and of William himself at Battle. Westminster had greatly extended its lands in the county since its founder's death. Besides the manors obtained by exchange and that of which Barking was despoiled," it had received two interesting gifts. A thegn, going with Harold to the battle of Stamford Bridge, gave it, as he left, a manor at Paglesham; and Æthelric, who appears to have taken part in a mysterious naval fight (navale prolium) against King William, fell ill on his return home and gave the abbey his estate at Kelvedon Hatch. But the latter gift was imperfectly attested, and had never received the king's sanction. It was also claimed on behalf of the king that the abbey had obtained some land at Fanton by a forged writ (per falsum breve), a kind of document for which the abbey became somewhat notorious. Of Waltham Abbey I have spoken already ; ${ }^{3}$ and as for Battle, it obtained only manors at Hutton and at Hersham (Hall). The canons of St. Martin-le-Grand held Good Easter of the king, and lands at Maldon and Tolleshunt of Count Eustace, Ingelric's successor, between whom and themselves there was naturally some friction."

The foreign religious houses endowed with land were four in number. The most interesting of the gifts made to them is that of 'Mersea' to St. Ouen. We can hardly hesitate to class this endowment by Edward the Confessor of the great Rouen abbey with his similar grants on the coast of Sussex. ${ }^{7}$ Domesday, indeed, only tells us that St. Ouen had held the manor in Edward's time; but the fact that it was given by him appears to be unquestioned. ${ }^{8}$ It comprised not only West Mersea, with the manor of Peete on the mainland adjoining, but also Fingringhoe

1 See p. 509 below.

2 Liber Eliensis (Anglia Christiana Society), i. 2 16-8.

3 See Inquisitio comilatus Cantabrigiensis, pp. 122,127-30, 193. It will be seen in the Domesday text that the sworn men of the Hundreds generally testified to the justice of the abbey's claims.

- See pp. 337, 340 above.

See p. 337 above.

- See The Commune of London, and orher Studies, pp. 28-30; Studies in Peerage and Family Hissory, p. 155 .

7 See Feudal England, pp. 319-20.

8 His charter of donation was printed by Morant (i. 426) from a copy at Colchester, but its form appears to be most suspicious. Its datc purports to be 1046 . 


\section{A HISTORY OF ESSEX}

on the Colne, a few miles distant. The fact that Fingringhoe had already been given, towards the close of the tenth century, to 'St. Peter

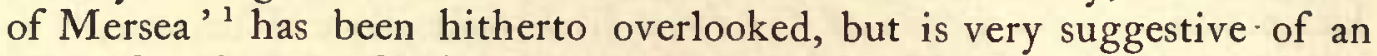
early foundation of which Edward availed himself. St. Ouen held, according to Domesday, two-thirds of the profits arising from the Hundred court of Winstree, and the Hundred is subsequently spoken of as the abbey's. Of the other religious houses two were the abbeys at Caen. I have already dealt with the endowment of the Abbaye aux Dames. The Abbaye aux Hommes (St. Stephen of Caen) received the manor of Panfield as its share, not indeed, as Domesday might lead us to expect, from William, but from a local baron, Waleram, whose son John had succeeded him in 1086, and who also gave the tithe of his lands at Aveley and at Bures. ${ }^{2}$ The Abbey of St. Walery, ${ }^{3}$ which received lands in Essex alone, its chief estate being Takeley, was provided for mainly from the forfeited possessions of Turchil, an Englishman, in the Hundreds of Uttlesford and of Dengie.

Although classed by Domesday among ecclesiastical holders, Odo the warrior Bishop of Bayeux filled an anomalous position. It was in his personal capacity that he shared in the spoils of the Conquest; and his fief, instead of passing to his see, was broken up after his fall. In Essex, as in other counties, the Survey teems with proofs of this grasping prelate's encroachments on the lands of others. His example in this respect was followed by one of his great under-tenants, the extent of whose holdings in Essex is somewhat obscured in Domesday. Ralf ' the son of Turold' held of him at Vange, Barstable, Ingrave, Wickford, Hassingbroke (in Stanford-le-Hope), Chadwell, Samanton (near Mersea), Thorrington, and in the Hanningfields, where was his largest estate. He was the son of Turold 'of Rochester,' by whose lawless aggression much of this land had been acquired. At Thorrington Turold had seized upon the manor together with the land of a freeman at Alresford near by ; in the Hanningfields he had ousted no fewer than twenty-two freemen, wronging thereby the abbey of Ely; at Mucking he had encroached on the lands of Barking Abbey, and at Fobbing on those of Count Eustace. In Kent also, where his estates were large, we find his name (as 'Turoldus de Hrovecestria') among those tenants of Bishop Odo who had encroached on lands of the church and were forced by Lanfranc to restore them in 1072." The part played in Essex by this great landgrabber tempts one to present his portrait as given by the Bayeux Tapestry. Against it 'Turold' is written. Turold's acts lived after him; for Essex manors held by him are subsequently found paying for castleguard at Rochester, the place from which he took his surname. ${ }^{5}$ The

1 Harl. Cart. 43 C. 4 .

2 Calendar of Documents Preserved in France, pp. 156, 162 .

3 See p. 356 below.

4 Anglia Sacra, i. 335-6. Mr. Freeman spoke of him as "Turold of Rochester, whose dwarfish form still lives in the Tapestry of Bayeux' (iv. 366, compare Archecologia, xix. 191, 204), but it is not likely that a man of Turold's importance would be represented as a mere retainer and as of dwarfish proportions. The legend 'Turold' must refer to the standing warrior.

5 See Arch. Journ. lix. 152. 


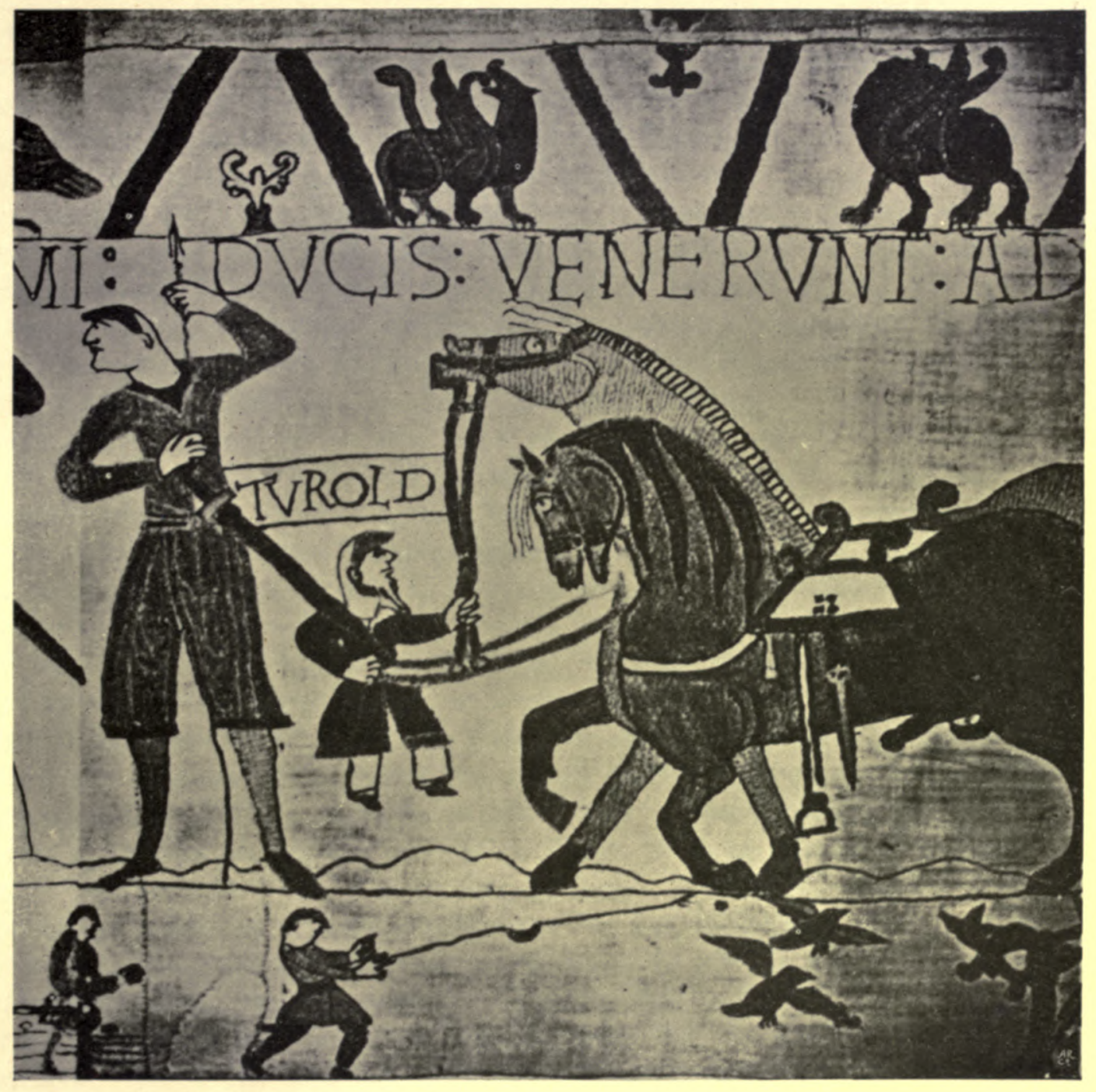

Turold.

(From the Bayeux Tapestry) 



\section{THE DOMESDAY SURVEY}

distinctive feature of Odo's fief was the number of small estates that it contained, representing, as it did, not the possessions of any great English landowner, but those of a multitude of small ones.

Of the lay barons, the names perhaps most familiar to our ears are those of Geoffrey de Mandeville and Aubrey de Vere. Their namesakes and heirs, connected by marriage, obtained earldoms in the days of Stephen, and the Vere Earls of Oxford were continuously connected with the county down to the extinction of the title only two centuries ago. The house of Mandeville became extinct in 1189 , but its earldom of Essex continued as the style of its descendants in the female line, who also retained down to the year 1372 Pleshey, the stronghold of the early Mandevilles, together with the bulk of the Domesday fief, the largest, after that of Count Eustace, of any lay baron in the county. As these two families and their fiefs played so large a part in the history of the county, we may deal with their Domesday possessions in some detail and together. Geoffrey was the recognized grantee of the vast but scattered estates of Ansgar (or Esgar) the "staller,' to which he had succeeded in Berkshire, Middlesex, Herts, Oxon, Northants, Warwickshire, Essex and Suffolk. ${ }^{2}$ In Essex the bulk of Ansgar's, and therefore of Geoffrey's, estate lay in the heart of the county, where High Easter (with Pleshey) and Great Waltham formed around his stronghold a compact block of some 12,000 acres, and were in turn surrounded by his lands in Leighs, Terling, Broomfield, the Chignals, Mashbury, the Rodings, and Barnston. It is exceptional in Domesday to find the manors of a tenant-in-chief so compactly grouped as this. But Geoffrey had also succeeded Ansgar at (Saffron) Walden, where, as at Pleshey, existing earthworks bear witness to a stronghold of his house. Another English predecessor of Geoffrey, Friebern, whom he had succeeded in two Essex manors, was clearly the thegn of that name whom he had succeeded in a Suffolk one (fo. $411 b$ ). Vast as were Geoffrey's estates in Essex, he did not scruple to add to them, in some places, by aggression. ${ }^{8}$ Aubrey de Vere, whose fief in Essex was much smaller than Geoffrey's, owed it almost exclusively to his succession to a certain Wulfwine, who had also been his predecessor in all his Cambridgeshire estates and in four Suffolk manors. (Castle) Hedingham appears to have been the chief seat of his house from the first, but his estates were much scattered. Both he and his wife are charged with a little wrongful increase of their extent."

Of the four great escheated 'Honours' named in Magna Carta, the Honour of Boulogne was one. For the origin of this 'Honour' we must turn to Domesday Book, where we find Count Eustace of

1 See for this notable man, a grandson of Tofig the proud (founder, in the first instance, of Waltham Holy Cross), Freeman's Norman Conquest, vol. iii. passim.

2 Ellis (Introduction to Domesday, ii. 43) omits Suffolk, but Geoffrey had succeeded Ansgar at Holton and Reydon in that county. Ellis was also gravely in error in stating that in the other counties Geoffrey's lands 'are marked uniformly as having been, in former times, the property of Asgar or his homagers.' This was by no means the case in Essex.

See pp. 568-9 below.

- See pp. 569-70 below. 


\section{A HISTORY OF ESSEX}

Boulogne the greatest lay baron in Hertfordshire as well as in Essex. But Essex was the chief seat of his power, and at Witham in this county was held the court of the 'Honour.' This fief, of which the wide extent is shown on the Domesday map, was composed partly of the lands of a number of English predecessors and partly of those which had been acquired, both under Edward the Confessor and in the earlier days of William, by Ingelric the priest, a favourite of both sovereigns and the founder of St. Martin-le-Grand. ${ }^{1}$ The existence of this element in the fief accounts for the traces of another court held in connexion with the fief at that religious house. In the Essex Domesday there are found two mysterious allusions to the Count's ' 100 manors' (mansiones) which have as yet defied explanation. But for the history of the county the feature of greatest interest on his fief is the relation it established between the barons and religious houses of the Boulonnais and this East-Saxon land. I may perhaps be allowed to quote what I have elsewhere said of 'Adelolf de Merc,' who is found holding of the Count in ro86 no fewer than eleven estates in Essex.

Deeper than the counts themselves or than any other of their vassals, have Adelolf and his heirs stamped their name on the East-Saxon land. This younger branch of the vicomtes of Marck, near Calais, which was at that time in the Boulonnais, is commemorated in the parish of Marks Tey, as in the manor of Merks or Marks in Dunmow, which was held by Adelolf himself in 1086, by his heir Enguerrand de Merc in $125^{8}$, and by the same family in 1340. Mark Hall, in Latton, is another of the manors which take their names from this family, and was held by Adelolf, its founder, in 1086. His descendants increased and multiplied in the land: Fulc de Merc and M. de Merc attended the count's feudal court in Essex before I120; Geoffrey and Enguerrand de Merc of Essex are found on the Pipe Roll of 1130; Henry and Simon de Merc are recorded as holding lands on the Boulogne fief in the days of John. ${ }^{2}$.

The seigneurs of Austruy, constables of the Boulonnais, held under their counts at Shopland and Chich (St. Osyth), and their tenants at Parndon derived their name from Wissant, the port of the Comté. Of its religious houses Rumilly-le-Comte obtained rent-charges on Fobbing and Shenfield, together with the churches of High Ongar, Stanford Rivers, Langenhoe, Little Laver, and apparently of Coggeshall ; and St. Wulmer de Samer received a rent-charge on Fobbing and tithes at Rivenhall. To anticipate a little further, the importance in Essex history of the great Boulogne fief was shown when, forty years after the Domesday Survey, the heiress of the counts brought it in marriage to Stephen, afterwards king.

When a great fief escheated to the king, it retained its corporate existence under the name of an 'Honour.' Essex affords other instances besides that of the Honour of Boulogne, and two of these may be dealt with together, because under Stephen they both came, by descent, to Henry of Essex, and in the early years of the next reign escheated, on his fall, to the Crown. These were known as the Honour of Rayleigh, which was held in 1086 by Suain of Essex, Henry's paternal ancestor,

1 See p. 341 above.
2 Studies in Peerage and Family History, pp. $156-7$. 


\section{THE DOMESDAY SURVEY}

and the Honour of Haughley, or of the constableship, of which the lord was Hugh de Montfort at the time of the Domesday. The head of each was its lord's castle-of which, in both cases, the moated mound remains-but as that of Haughley is in Suffolk it concerns us less immediately here.

Suain 1 'of Essex' was a personage of quite exceptional interest among the local barons. I am strongly of opinion that the use by himself, his son, and his grandson of the name of the county as a surname arose from the tenure of its shrievalty by him and by his father before him." Mr. Freeman, who gave his attention to both of them, ${ }^{3}$ had observed that Suain's father, Robert, had been sheriff of Essex under Edward as well as under William, and that Domesday alludes to the tenure of the office by him and by his son, and to acts of theirs while holding it. Robert himself is always spoken of as 'the son of Wimarc,' and we only learn, Mr. Freeman wrote, from William of Poitiers that Wimarc was a woman. The Essex Domesday however always mentions her as such ('Robertus filius Wimarce'). Her name, I may add, was Breton. Robert is found, under Edward, holding the post of staller, and he further received from that king, to hold 'sicut canonicus,' a prebend at St. Mary's, Shrewsbury, which he made over to his son-in-law." When, in 1052 , on Godwine's triumphant return, Norman favourites of Edward had fled for their lives, some, we read, escaped 'north to Rodbertes castele.' Mr. Freeman held that 'Robert's castle must be some castle belonging to Robert the son of Wymarc, as distinctly the most notable man of his name in the country after Robert the Archbishop,' but he sought in vain to identify it. It appears to me that, with much probability, we might assign it to Clavering, where the earthworks of a castle of the time are still to be seen, and which was the greatest manor held by him in Essex. Domesday shows us his son in possession of the Hundred itself ${ }^{5}$ - that is, of the Hundred court-and there can be little doubt that Robert had held it before him.

It was observed by Mr. Freeman that Robert's fief was subjected to much change before the Domesday Survey. He appears to have obtained fresh manors from the Conqueror, if not from Harold; but, on the other hand, lands which he had held, especially in counties other than Essex and Suffolk, are not found in his son's hands in ro86. I cannot find however that in Essex itself any of his land failed to pass, as alleged by Mr. Freeman, to Suain. A great change in the balance of the fief was effected by the large additions it received in the southeast of the county after the death of Edward. To this I attribute Suain's choice of Rayleigh as the site of his castle. The Domesday entry

1 Mr. Freeman rendered his name as 'Swegen,' but the Domesday forms, Suain, Suanus, Suenus, represent it phonetically better.

2 Sec Feudal England, p. 168, for the adoption by sheriffs of the name of their county town as a surname. In the case of Essex there was then no such county town, and the sheriff would therefore adopt the name of the county itself.

3 See Appendix on 'Robert and Swegen of Essex' in Norman Conquest (1871), iv. 736-8.

4 Domesday, i. 2526. Compare Eyton's Shropshire, v. 207-9, where the hazardous suggestion is made that Robert Fitz. Wimarc was identical with Robert the Deacon. See p. 489 below.

I 


\section{A HISTORY OF ESSEX}

relating to it is of very great importance as bearing on the actual construction by the Normans of moated mounds for their castles. ${ }^{1}$ Both Suain and his father appear to have made additions to their estates by seizing on small holdings in their private capacity or as sheriffs. Owing to the number of his manors in the south-east of the county, Suain, lord of the marshland, was the greatest sheepmaster in Essex. It was reckoned that his marshes would carry over four thousand sheep.

The fief of Hugh de Montfort is chiefly of interest for his succession to 'Gudmund,' who had been his predecessor at Kelvedon, Purleigh, Latchingdon, Rayne, Markshall and Sandon (?). Gudmund was a brother of Wulfric, who had been abbot of Ely and had taken advantage of that position to lease to him certain manors in order to enable him to marry well. The only Essex manor of the abbey so parted with was 'Bedenestede' (Sandon ?), ${ }^{2}$ and in the Domesday entry relating to it the claims of the monks are mentioned.

Another 'Honour' formed from an Essex Domesday fief was that of 'Peverel of London,' which is also, in at least one instance, styled the Honour of Hatfield Peverel. ${ }^{3}$ These honours are identical, not distinct, ${ }^{4}$ but must be carefully distinguished from the Honour of 'Peverel of Nottingham,' which was only represented in Essex by the two manors of William Peverel. Morant confused the latter with the above great fief of Ranulf Peverel, of which the descent was entirely distinct, for it escheated to the Crown under Henry I., and placed at the disposal of Stephen the means of rewarding his followers handsomely in this county." Rannulf's fief was virtually restricted to the eastern counties, and his English predecessors can be traced in more than one of them. 'Ketel,' for instance, who had held Frating was probably the 'Ketel' who had preceded him in a Suffolk manor and at Walsingham, Melton (Constable) and Ketteringham in Norfolk. We may observe, perhaps, in the Essex survey that Ranulf had frequently succeeded a man named Siward', but it is only when we turn to that of Suffolk that we find him identified as 'Seward of Maldon ('de Meldona') a thegn,' who had held the great manors of Acton and Assington with another at Icklingham. In Essex, besides his estate at Maldon itself, he had possessed very valuable manors at Debden, Amberden and Stebbing, and others at Hazeleigh, Woodham Mortimer, Willingale Doe, Bradwell-by-Sea, Stangate-inSteeple, Rettendon, Tolleshunt Darcy and St. Osyth.

Rannulf's fief is immediately preceded, in Domesday, by that of Ralf Bainard, which, like his own, was associated with London through Ralf's tenure of 'Castle Baynard,' to which we subsequently find some of his Essex manors rendering castle-ward. Ralf, who had acted as sheriff of the county, appears to have fixed on Little Dunmow as his

\footnotetext{
1 'In hoc manerio fecit Suenus suum castellum' (compare p. 300 above). So late as I 69 Rayleigh (with its port) appears to have been still alternatively known as 'castellum Suein' (Pipe Roll, i 5 Hen. II. p. I 34).

2 Liber Eliensis (Anglia Christiana Society), i. $218-9$. See, for its identity, p. 390 below.

3 Red Book of the Exchequer, p. 74 o.

4 They are indexed as if they were distinct in Red Book of the Exchequer, pp. $1194,1234$.

- See my Geoffrey de Mandeville.
} 


\section{THE DOMESDAY SURVEY}

seat therein, for his family priory was there founded. His fief, like that of Ranulf Peverel, escheated to the Crown under Henry I., but was promptly granted out anew, together with Castle Baynard, to the founder of the house of Fitz Walter, a cadet of the house of Clare. One of the points of difference in the distribution of land before and after the Conquest is the wide extent of the estates held by women on the eve of that event as compared with those which they are entered as holding at the time of the Domesday Survey. This is a feature of the great record which has somewhat escaped attention. An instance in point is afforded, in the case of Essex, by the broad lands of Ailid', 'a certain free woman,' from which the fief of Ralf Bainard was largely formed. In this county she had been his predecessor at Wimbish and at Little Dunmow, as at Henham, at Ashdon, and probably at Pentlow, all of them valuable manors. In Norfolk, at Fincham, Barton, the Shouldhams, Tottenhill, Boughton, Bradenham, Merton and Wilby, Ailid' had been his predecessor. In Suffolk she had held 'under the glorious King Edward' the great manors of Shimpling and Kedington. Her name is so uncommon in Domesday that I believe her also to have been the Ailid' who had been the possessor of Chipping Ongar, although in that manor her successor was Count Eustace. ${ }^{2}$

Another fief of which the caput lay from the first in Essex was that of Robert Gernon ('Greno'), whose name is surrounded by errors. Morant wrote that a document printed in the Monasticon had 'led Sir William Dugdale into some mistakes' (ii. 576) ; but he himself was wrong in stating that Robert was ' descended from the House of Bologne,' that "his son and heir dropt the surname of Gernon, and took that of Montfichet,' and that he and his manor of Stansted took that name 'from an artificial fixt, or firm, Mount of earth, erected by William Gernon, on which his castle was built.' Ellis, in his Introduction to Domesday (i. 423), repeated Morant's errors, but it is now known that the house of Montfiquet, from which Stansted derives its name, was quite distinct from that of Gernon, whose estates however it obtained in the days of Henry I., together with that forestership of Essex which one of Domesday's incidental hints (under the forest manor of Writtle) leads us to believe was already held, in 1086, by Robert.

A familiar name among the Domesday tenants-in-chief in Essex is that of 'Eudo dapifer,' a statue of whom was recently set up at Colchester, where he founded the great abbey of St. John and appears to have occupied an important position at a somewhat later date. But the story of his life is so embellished in the chronicle of the house he founded that it is difficult to disentangle facts from fiction. It is certain however that Eudes ('Eudo') was a son of Hubert de Ryes, that he enjoyed the favour alike of the Conqueror and of both his sons, and that he lived on till I I 20, when he died in Normandy at his castle of Préaux rich in worldly possessions, but, contrary to what has always been believed, childless. His fief, which had increased since the Survey, then reverted 


\section{A HISTORY OF ESSEX}

to the Crown, which proceeded to dispose of it anew. Eudes, it will be seen, cannot have been more than middle-aged at the date of Domesday, and indeed he had been preceded in possession of some at least of his manors by another Norman, Lisois de Moustiers.

Eudes had married a daughter of Richard Fitz Gilbert de Clare, the head of whose fief was on the Essex border, where the moated mound of his castle is still to be seen at Clare. The 'Honour of Clare' continues to exist among the possessions of the Crown and includes manors in Essex; but it must be treated as a Suffolk fief, its caput lying in that county. It should however be observed that in Essex as in Suffolk the bulk of Richard's lands had belonged to Wisgar (son of Ælfric), whose vast estates he had obtained. His predecessor's father Ælfric was the son of an older Wisgar (alias Withgar), and occurs as such not only among those 'thegns of Essex' who attest a grant of Wimbish to the church of Canterbury under Edward the Confessor," but also as the lord of Clare itself, ${ }^{2}$ which he gave in the same reign to 'St. John,' placing in charge of the religious house there founded ' a certain priest, Ledmar,' " who held estates at Bendish (Hall) and Gestingthorpe in Essex. ${ }^{3}$ The extent of Wisgar's estates will be evident from the Domesday text, where it will be seen that in Essex his most valuable possession was Thaxted. Wisgar's 'sphere of influence,' as it may be termed, should be observed. It is naturally found in the Hundred of Hinckford, where small properties are entered as held by sokemen ' under Wisgar' in many places; but in Tendring Hundred also he had a few sokemen, and a man who held 'freely' at Bromley was 'commended' to him. At Bendish, we read, Wisgar had annexed 30 acres since the coming of King William, but his successor took far more advantage of the temptation offered by the number of 'small holders' in the north of the county. At the end of a list of such holders in the Hundred of Hinckford, whose lands Richard had annexed, we read that Wisgar had only possessed their 'commendation.' "

A certain interest attaches to another predecessor of Richard, Phin styled ' the Dane.' In Essex he is entered as having held Langham and Barrow (Hall) in Wakering, manors lying widely apart, which had both passed to the lord of Clare. It is only when we turn to Suffolk that we learn something about him. The solitary reference given by Ellis conveys no idea of his importance in that county ; for Richard de Clare held in Ipswich fourteen burgesses, who had been held by Phin (fo. 393), and allusion is made to the 'land,' the 'fief' and even the 'honour' of Phin (fos. 393-5b). He had also men 'commended' to him. As he is charged with adding some free men to a manor ' in the time of King William,' he must, like Wisgar, have weathered the actual Conquest; and even in 1086 his widow was holding in Essex two manors, of which one at least had previously been held by her husband (see p. 565). There is fortunately preserved in the cartulary of St. John's Abbey,

1 Madox's Formulare, p. 238 , and Morant's Essex, ii. 558.

2 Domesday, ii. 3896 . \$ See pp. 471,477 below. 348

4 See p. 572 below. 


\section{THE DOMESDAY SURVEY}

Colchester, a writ of.William Rufus directing the sheriff of Essex to give Eudo Dapifer seisin of those manors ('mansiones') which the wife of Phyn the Dane ('Dani') had held of his father on the day of the latter's death. ${ }^{1}$ It should be added that the manor of Langham was held of Richard by Walter Tirel, whose name is so familiar, and who, like 'Eudo Dapifer,' had married one of his daughters."

The bulk of the fief of Peter de Valognes, lay in the south-west of the county, near the border of Hertfordshire, in which county, at Bennington, was the caput of his barony. ${ }^{3} \quad$ His importance, for Essex, lies in the fact that he was sheriff at the time of the Survey." He was also then sheriff of Hertfordshire, ${ }^{b}$ so that the arrangement of placing these two counties under one sheriff is at least as old as Domesday. Later evidence enables us to say that they were similarly combined under Geoffrey de Mandeville as sheriff, though that great Domesday Baron cannot have acted in that capacity until after the Survey. He appears to have 'farmed' the county of Essex for $\oint_{3} 300$, and that of Hertford for $f_{0} 60$ a year. Peter, whose fief extended into Norfolk and Suffolk, Cambridgeshire and Lincolnshire, married a sister of 'Eudo Dapifer.' Domesday mentions as his predecessors in the shrievalty of Essex, since the Conquest, Robert Fitz Wimarc, Suain 'of Essex,' and Ralf Bainard, all of them Essex tenants-in-chief.

Two other fiefs deserve some mention because they both reappear in I 66 among those of which the caput was in Essex. The first is that of Roger de 'Rames,' which lay in the three eastern counties and in Middlesex. Morant confidently asserted that Roger 'took the surname of Raines or Ramis' from Rayne in this county, where the manor of Old Hall was the head of his descendants' barony. But this view is clearly erroneous, and indeed he himself was confused on the subject. ${ }^{7}$ As several Essex manors were held by this family, its history is of some importance. I have elsewhere shown in a paper on the subject ${ }^{8}$ that the fief was originally one of twenty knights, but that we find it under Henry II. divided between two members of the family, each of whom owed the service of ten knights. The other fief is that of Walter the Deacon, of which Little Easton was the head, and which was of ten knight's fees; it is subsequently found in the hands, successively, of the Windsor and the Hastings families."

The Bretons and Flemings, who in some counties are conspicuous

1 Ed. Roxburghe Club, p. 18. The attestation of 'the bishop of Durham' suggests 1099-1100 for the date. Peter de Valognes was sheriff at the time of the writ.

See Feudal England, pp. 468 et seq.

See the Victoria History of Hertfordshire, i. $276,282$.

See, for instance, the entry under Havering (p. 430).

- Domesday, i. 132, 133.

- This important information is derived from the charters granted by King Stephen in 1141, and by the Empress Maud in 1142, to his grandson and namesake (see my Geoffey de Mandeville, pp. 142, 166-7).

7 He went on to say that the name of Raines, or Rennes as it is sometimes written, might arise from this Roger coming from the 'city of Rennes' (ii. 403).

8 See my Geoffrey de Mandeville, pp. 399-404.

- See my paper in The Ancestor, ii. 91-2, and pp. 393, 547, note 8 below. 


\section{A HISTORY OF ESSEX}

among the tenants-in-chief, are hardly represented at all in Essex. Count Alan, the head of the Bretons in England, had large interests in Suffolk, but a single page of Domesday suffices for his Essex manors. His chief tenant in the county was Hervey 'de Ispania,' who held of him at Willingale ('Spain'), Finchingfield, Bentley, Manhall (in Saffron Walden), etc. The name of Hervey is distinctively Breton. It is worthy of notice that at Canfield, and at one of the Rodings, Aubrey de Vere was tenant of the count, for there seems to have been some connexion between Aubrey and the Counts of Brittany ; ${ }^{1}$ and when the priory was founded at Hatfield Broad-Oak, half a century after Domesday, by his namesake and successor, it was given as a cell to St. Melaine of Rennes, the count's capital. One is glad to be able to establish the fact that 'Edeva,' whom the count had succeeded in several Essex estates, was no other than Edith 'the beautiful' (pulchra), Edith 'the fair' (faira), Edith 'the rich' (dives), whose vast estates in the adjoining counties of Hertfordshire, Cambridgeshire and Suffolk had been largely bestowed on Count Alan. ${ }^{2}$ The one Breton fief of which the head was in Essex was that of 'Tihel the Breton.' He is so entered in Domesday under Essex, except in a stray passage (fo. 24), where he occurs, as in Suffolk, as Tihel 'de Herion.' This name is but a variant of the 'Helion' in Helion Bumpstead, and the house which bore it derived it from what is now Helléan, a canton of Josselin near Plöermel (Morbihan). Their barony, which was afterwards held by the service of ten knights, lay in the three eastern counties and largely in the Haverhill neighbourhood.' As Tihel de 'Heriun' or 'Heliun' its Domesday lord was one of the 'barons' or commissioners (legati) appointed by the Conqueror to determine the rights of Ely Abbey in 1080." "Gilbert the son of Salomon' also must, from his name, have been a Breton. In Essex he had but a tiny holding, and his only other estates were at Meppershall and Felmersham. No distinctively Flemish name is found among the Essex tenants-in-chief, but Walter de Douai ('doai'), a great baron in the south-west of England, held three manors.

Of the remaining fiefs that of Hamo the 'dapifer' or the sheriff (of Kent) is chiefly remarkable for his succession to Thurbern at Faulkbourne, Totham, etc., and especially at Colchester, and to a woman called 'Gotild' in several manors. The widespread succession of Henry de Ferrers to the lands of Bondig the 'staller' enables us to identify the latter with the former holder of Steeple, Butsbury and Woodham (Ferrers). Otto 'the goldsmith' (aurifaber, aurifex) deserves mention,

1 See my Calendar of Documents Preserved in France, p. 423.

2 See, for this mysterious person, Freeman's Norman Conquest (1875), iii. 792 . It is clear from the Suffolk entries of Earl Ralf's manors which Godric dapifer was 'farmıng' for the king (fos. $284 b$ et seq.) that some of Edith's manors had been secured by Earl Ralf (of Norfolk), and had passed on his fall to the king. Among these, we thus learn, was Great Sampford in Essex, which 'tenuit Edeva; post Radulfus comes; modo Godricus dapifer in manu regis' (see p. 436 below). The identity of the Essex 'Edeva' has never, I believe, been noted.

'See for all this my paper on 'Helion of Helion's Bumpstead' in Essex Archaological Transactions, [n.s.] viii. $187-91$.

4 See Inquisitio comitatus Cantabsigiensis, pp. xvii., xviii. 


\section{THE DOMESDAY SURVEY}

not only because his name is preserved in that of an Essex parish, but also on account of the interesting position held by himself and his descendants as hereditary masters of the mint. His only manor was that of Gestingthorpe, which had been held by Earl Ælfgar, with whose former estates he was associated as farming them for the Crown. In Essex he so farmed them at Shalford and Finchingfield, and in Suffolk he was associated with Godric the 'dapifer' in farming them at Sudbury and Cornard. These estates, as an entry under Colchester reminds us, had been held by Ælfgar's widow, Ælfgifu, and afterwards by William's queen. It is an interesting fact that the lord of Gestingthorpe was entrusted by William Rufus with the monument of gold and silver, encrusted with gems, erected over the Conqueror's tomb at Caen.'

In studying the holders of land before and after the Conquest we have to keep our eyes on more counties than one. We can often thus trace the identity of those Englishmen to whose estates the newcomers had succeeded, although at first sight their names may suggest nothing. One of the most interesting cases of such succession in Essex is that of Walter the Deacon. Wix, where his son and namesake founded a priory for nuns, had been given him by Queen Edith since the coming of King William, and she had also been his predecessor at (Little) Bromley and (Little) Chesterford; but his predecessor at 'Colne' was named Leofwine, and his two manors in Purleigh had been held by Leofwine and Leofwine 'Cilt.' Now his 'Colne' manor is ignored by Morant, but on working through the manors in the Colnes we learn from his own account that the manor of Overhall in Colne Engaine ' is ancient and an entire lordship, not holding of any of the adjoining manors of Colne-Engaine, Wakes, or Earls; but of the manor of Witnesham ... in Suffolk' (ii. 219). Following up the clue thus obtained we find Witnesham in Domesday held by Walter the Deacon, who had there succeeded 'Leofwine, a free man.' We thus at once locate Walter's manor in the Colnes, and identify its English holder with the lord of Witnesham, Suffolk. But we do more than this. In Suffolk as in Essex we find that Walter has succeeded a Leofwine in some of his manors and Queen Edith in others (fos. 426-7). But while at Bacton his predecessor is styled 'Leofwine a free man of Harold, at another he is 'Leofwine of Bacton (de Bagatona), a thegn of King Edward,' so these were certainly the same man. We can see him also in 'Leofwine, a free man,' holder, as above, of Witnesham, and even, I think, in 'Leofwine cilt a free man' (fo. 376 b), who occurs at Ulvestone in Debenham. Therefore, to return to Essex, we can doubtless see him also in the 'Leofwine' and 'Leofwine cilt' whom Walter the Deacon had succeeded in two manors at Purleigh. This conclusion is of more than personal or local interest; for it illustrates the looseness of the Domesday scribe, especially in dealing with the names of English-

1 - auri et argenti gemmarumque copiam Othoni aurifabro erogavit, et super patris sui mausoleum feri mirificum memoriale pracepit. Ille vero, regiis jussis parens, insigne opus condidit, quod ex auro et argento et gemmis usque hodie competenter splendescit' (Ordericus Vitalis). 


\section{A HISTORY OF ESSEX}

men, and the rashness of concluding that the liber bomo was a smaller man than the thegn.

Another such illustration is afforded by the facts which follow. The historic name of Ingwar was borne by an Essex thegn whom it doubtless proclaims to be of Danish blood.' His lands at Roydon, Southchurch, Birdbrook, St. Lawrence, and one of the 'Ings,' though widely scattered, passed to Ranulf brother of Ilger, which enables us to identify him also with that 'Ingewar,' otherwise 'Inguare a thegn of King Edward,' of whose lands in Huntingdonshire and at Gamlingay in Cambridgeshire Ranulf became the possessor. ${ }^{2}$ This identification is chiefly of importance because Ingwar is in Essex styled a free man (liber bomo) and in Cambridgeshire a 'thegn of King Edward,' which is one of several instances of these terms being used indifferently, and enables us further to detect him in that 'Ingar a thegn' whose great manor at Burstead had passed to the Bishop of Bayeux.

So famous are the 'house-carls' in the tale of the Norman Conquest that the mention of one of them in Domesday is always worth noting. The 'Sexi' who, at one of the Lavers, had been succeeded by Ralf de Todeni was clearly the 'Sexi housecarl of King Edward,' whom Ralf had also'succeeded at Westmill, Herts. Of more interest however is the case of 'Scalpinus,' of whom we read under Great Lees that Harold, receiving that manor from Ansgar, had given it to ' a certain housecarl of his, Scalpinus by name,' who had settled it on his wife in dower, ${ }^{3}$ etc. I have no hesitation in identifying this 'Scalpinus' as the 'Scalpius' or 'Scapius' who had held, as ' a thegn of Harold,' the manors of Charsford and Stutton in Suffolk, in which he had been succeeded by Robert Gernon. Returning to Essex, we find on Robert Gernon's fief a manor in Ardleigh, of which we read that it had been held by Scapius, and was attached to (jacet) a certain manor in Suffolk. William, its undertenant, was doubtless the William d'Aunay who held the above Suffolk manors of Robert. Here then we have a 'house-carl' holding a landed estate, nor was his case exceptional.

Here is another illustration of the need for studying adjoining counties together. A curious story in the Suffolk Domesday throws light on the devolution of an Essex thegn's estates. In the southeastern extremity of the former county we read under Falkenham (fos. 423b, 424) that 'Brictmar,' who held land there, had several estates (plures terras), of which a part was given by the king to Ingelric, another to Ranulf brother of Ilger, and a third to Ralf Pinel. This is followed by several entries, in which Ranulf had obtained the lands of men commended to Brihtmar or his mother 'Quengeuet.' Of the two small estates in Suffolk that Ralf Pinel

1 An Ingwar was one of the three leaders who had landed in East Anglia, at the head of a Danish host, in 866 .

2 He must also however have been the 'Ingwar' whose manor at Creshall, with that at Duxford, Cambs, not far off (the 'Ingara' of the latter entry is omitted by Ellis), were obtained by Count Eustace.

s See p. 507 below. 


\section{THE DOMESDAY SURVEY}

held in chief (fo. 437) one had been held by 'Bricthmar,' as had been the whole of his Essex one (p. $5^{6} 3$ below). When we turn to the Essex lands of Count Eustace, the successor of Ingelric, we find them headed by Fobbing (fo. 26), which had been held by 'Brictmar, a thegn of King Edward,' and after him by Ingelric. At Laver also and Fifield we find the Count succeeding to lands which had been held by 'Brictmar'; and we can say therefore that in these estates we have that portion of his lands which had fallen to Ingelric's share. We thus identify a thegn as a landowner in Essex and Suffolk, and obtain a good instance of an Englishman having not one but several aliens as his successors. A similar instance of the breaking up of an English thegn's estates is afforded by the case of Ælfric (Aluricus) Camp, ${ }^{1}$ who had held land in Essex, Cambridgeshire and Suffolk, and had been of sufficient importance to have sokemen and commended men of his own. Restricting ourselves to those instances in which his identity is proved, we find that in Essex his manors lay in the north-east of the county, and that while Great Oakley was secured by Robert Gernon, Ramsey passed to Ralf Bainard, and Bradfield and Dedham to Roger 'de Ramis.' In Suffolk, Ælfric is spoken of as the predecessor of 'Eudo Dapifer,' who succeeded him, we find, at Layham, as he also did in Cambridgeshire, at Babraham, Papworth and Sawston, though Robert Gernon was in that county, his successor at Duxford and Foulmire."

On the whole it would seem that in Essex both types of succession are very well represented. If we have cases in which Norman lords obtained virtually the whole possessions of great English landowners, such as Ansgar the staller, Wulfwine, or Withgar of Clare, we have also abundant instances of fiefs formed from numerous small estates, and a certain number in which the lands of an English holder were broken up and divided between two or more of those who shared in the spoils of England. It is probable that these last would be much more numerous if it were not for the great difficulty of identifying with exactitude the bearers of English names which were more or less common.

No general conclusion can be stated as to the proportion or local distribution of large and small estates in Essex before the Conquest. The Domesday scribe, when recording only the Christian name of an English predecessor, gave us, in doing so, no indication whether he was but a small yeoman (to adopt, for convenience, a later term) or a magnate holding wide estates in more than one county. In Essex again the scribe was fond of entering land as having been held by 'one free man' or more. And this vague term, as I have already indicated, might denote a considerable landowner as well as a very small one. Again, although we have cases in which the assessment figures suggest

1 This name is found as Camp, Campe, Campa, Capin, Capus and Cemp, which further illustrates the loose practice of the Domesday scribe in the matter of Anglo-Saxon names.

2 The Inquisitio Comitatus Cantabrigiensis enables us to trace more accurately his possessions in that county by adding the distinctive surname, which was often omitted by the Domesday scribe.

1 


\section{A HISTORY OF ESSEX}

extreme subdivision, the geld ' hides' and 'acres' are a most misleading guide. The valuable manor of Gestingthorpe, for instance (p. ${ }_{5} 64$ below), in which Otto the goldsmith had succeeded Earl Ælfgar, was assessed at only half a hide. ${ }^{\mathrm{I}}$ The recorded values afford a surer guide to follow. Speaking guardedly and very generally, we form the impression from the Essex survey that the larger holders were steadily acquiring, even before the Conquest, rights over the smaller ones, even if 'only such as commendation gave.' In the tumult and confusion of the Conquest period some of the smaller holders, we find, suffered downright aggression at the hands of their own countrymen; but it was naturally by the newcomers that their lands were chiefly absorbed. This absorption was effected partly by actual grant from the Crown, a grant which had to be completed by formal livery of seisin. There are several allusions in the Essex survey to the absence of such livery in the case of contested titles. The other way in which it was effected was simple lawless encroachment, the usual form of such encroachment being the extension of a Norman's lordship at the cost of an English free man whose lands adjoined it. It is very difficult to estimate the extent of such encroachment in the county, because the invasio or occupatio is sometimes recorded under a fief and is sometimes found among the long list of invasiones super regem at the close of the county survey. This lawless aggression was at times the subject of complaint from one Norman against another, at times effected at the cost of Englishmen, and often at that of the king. His own manors, with which the Survey opens, teem with notices of such encroachment; but it must be remembered that the seizure, without authority from him, of the land of a 'free man' would be treated as a wrong done to himself, insomuch as it diminished the total spoils available for distribution.

We are apt to forget that twenty years had elapsed between the date of William's victory and that of the great Survey. The disputes as to title recorded in Domesday Book must have been greatly increased by this lapse of time ; for, besides the 'aggressions' of English predecessors, there were those also of aliens who had gained and lost their lands between the two dates. The lands of Count Eustace had been swollen by the acts of his predecessor Ingelric, and the fief of 'Eudo dapifer' by those of Lisois de Moustiers;" Walter the deacon had succeeded to the lands of his brother Thierri, and John the son of Waleram to those of his father; and at Wormingford and Stanway Roger of Poitou had benefited by the aggressions of a predecessor with the strange Provençal name of Reimund Girald."

It has always appeared to me that Mr. Freeman, in avowed reaction from Thierry, was disposed to underestimate the wholesale

1 'There were, at Gestingthorpe, two manors, each apparently of six ploughlands and each assessed at half a hide (fos. 39,98 ). The parish now contains 2,700 acres, and the assessment of the whole at one hide is worth noting for its lowness. It is evidently not accounted for by Earl Flfgar's tenure of one of the two manors. The low assessments of High Easter, of Tiltey, and of Stambourne and Toppesfield may be compared. 2 See pp. 463-8 below.

3 Compare Ing. Com. Cant. pp. 192-3. - See my notes on him in The Ancestor, i. 122. 


\section{THE DOMESDAY SURVEY}

transfer of lands that followed the Norman Conquest. ${ }^{1}$ The eastern counties, he held, 'were precisely the parts of England which had come into William's hands without effort or resistance,' and to which therefore he showed himself 'mild and debonair ' ${ }^{3}$ and yet in Essex the transfer of land was for all purposes complete. Every Englishman, small or great, who held his land 'freely' seems to have forfeited its possession. ${ }^{3}$ One does not see how this could have been, as Mr. Freeman seems to have held, the result of individual forfeitures incurred by definite acts. The loss may not have followed immediately on William's triumph; indeed there are cases in which the Survey shows that it did not; but undoubtedly the impression conveyed by Domesday in this county is that all Englishmen were held to have forfeited, as such, their lands. It affords us at least one very suggestive case of an Englishman, whose lands had been taken from him, being actually employed by the Crown in a position of trust. Ælffric 'Wand' or 'Wants,' whose estate at Arkesden and Radwinter had been secured by 'Eudo dapifer,' is found in Suffolk placed in charge of a number of Crown manors as reeve (prepositus). English reeves or foresters were useful, on account of their experience and knowledge, to the Normans; and in Essex we find Richard Fitz Gilbert employing two English reeves who are charged with aggression on his behalf, and whom he seems to have left to their fate. ${ }^{4}$ Grim, another English reeve, had taken advantage of his official position to obtain possession of forfeited estates at Bowers (Gifford) and Chadwell ${ }^{6}$; and one fortunate officer of the king, with the typically English name of Godric, was 'farming' royal manors on a great scale in Norfolk and Suffolk (fos. I 196,2846 ), besides holding lands as a tenant-in-chief in both those counties. His 'farming' operations extended to Essex, where we find him, as Godric dapifer, in charge of Great Sampford. Mr. Freeman observed that in some cases the widows of English landowners were allowed, as a favour, to hold some portion of their husbands' estates. With the widow of 'Phin the Dane' we have already dealt; her two manors are immediately followed by the small holding of 'Edeva the widow of Edward son of Suan' in the Hundred of Chafford. The interest of this entry is that it bears directly on the Middlesex manor of 'Lilestone, ${ }^{6}$ which Domesday speaks of as held 'in almoin' by 'Eideva,' and as having been held by Edward son of Suan. The Essex entry proves that 'Eideva' must have been his widow. The case of Modwine, who had lost his land at (East) Donyland, but who was holding in 1086 a smaller property in the same vill and several other estates of moderate size in addition, may illustrate the practice (as I think it) of making even the Englishman who was still a landowner hold, from the Conquest,

1 See Norman Conquest (1871), iv. 14-15, 22-27. Ibid. Pp. 26, 29.

3 Amall holding in 'Totham was retained by 'Gunner,' but only as an under-tenant of that great baron, Suain. There are 2 few other cases of the same kind.

See p. 573 below. One of these cases is the subject of a duplicate entry. $\quad$ See p. 564 below.

- Domesday i. 130b. The name is still preserved in Lisson Grove. The manor was held in the time of John by the heirs of Otho the goldsmith. 


\section{A HISTORY OF ESSEX}

a new estate under a new title. Before approaching the difficult subject of the changes under the new order in the status of what we may term the peasantry, we may glance at the witness to the Conquest borne by the map of Essex.

There is no county perhaps that bears more clearly than Essex the imprint of the Norman Conquest. Two of its parishes indeed have actual French place-names, ${ }^{1}$ and one the name of a Frenchman. ${ }^{2}$ The suffixes which serve to distinguish.its villages of the same name are rich in memories of Domesday lords, both barons and under-tenants. Helion('s) Bumpstead, Hatfield Peverel, Norton Mandeville, Woodham Ferrers, Theydon Gernon and Belchamp Otton preserve the names of Domesday barons, whether derived directly or through cadets of the house. The name of Warish Hall in Takeley disguises that of St. Walery, the saint whose relics the Norman host had adored at the mouth of the Somme, and whose sending the longed-for southern wind was rewarded after the Conquest by the gift of Essex manors. And what shall we say of the under-tenants whose names will meet us in the text ? With Adelulf de Merc I have dealt already $;^{3}$ Cardon's Hall in Chishall was the home of William Cardon; Hervey de Ispania is commemorated not only in Spain's Hall in Willingale Spain, but in Spain's Hall in Finchingfield; and in Stondon Massey is disguised the name of Ralf de Marci. By a similar disguise the Tolleshunt of Mauger has become Tolleshunt Major, and the Shellow of Lambert (de Buelle) the modern Shellow Bowells. The Roding of Hugh de Berneres is Berners Roding to this day.

It was again the Norman Conquest that brought to England such houses as those of Grai, Mortemer, and Giffard, of Beauchamp, Munteni, and Montfiquet. Their association indeed with Essex may be later than the date of the great Survey, but in Grays (Thurrock), Woodham Mortimer, Bowers Gifford, Beauchamp Roding, Mountnessing and Stansted Mountfichet the memory of Norman lordship is vividly preserved. To lords of the alien race are also due the names of Layer Marney, Layer Breton, and Layer de la Hay, of North Weald Basset, Theydon Bois, Stapleford Tawney and Colne Engaine. The change from the English 'Alferestune' to the present 'Bigods' in Dunmowa name which Lady Warwick's enterprise has made widely knowntypifies the great transfer. Within two miles of it $\mathrm{B}(\mathrm{l})$ amsters Hall preserves the name of the Blancmoustier family, tenants of the house of Warenne, whose own Norman stronghold of Bellencombre is the origin of the name of Belcumber $\mathrm{Hall}$ in Finchingfield. In Sible Hedingham the manor of 'Grassals' had once been the holding of Geoffrey Grosvassal, a knightly tenant of the house of De Vere, while Hosden's farm in Great Maplestead, not far away, preserves the name of a family descended from Hugh de Hosdenc, a Domesday under-tenant in the three eastern counties. The Counts of Guînes have bequeathed

1 Beaumont and Pleshey (see pp. 396, 509, note 4 and p. 298 above).

2 Virley. For Robert de Verli see p. 389. 


\section{THE DOMESDAY SURVEY}

their name to Guines Court in Tollesbury, where, as at other places in Essex, they held of the Honour of Boulogne." Woodham Walter, again, reminds us of its lords the house of Fitz Walter, descended in the male line from the Domesday lord of Clare.

That those whom the Norman lords replaced as holders of wide estates were the chief sufferers by the Conquest is no doubt the case; but if the peasantry, and even what may be termed the yeomanry, remained as before upon the land, it does not follow that their condition had in no way changed for the worse. Obscure as is still the gradation of classes in England before the Conquest, it appears to be now generally held that the coming of the Normans tended to simplify the classification. If the learned researches of Professor Maitland? failed to enable him to arrive at any clear or definite conclusion on the liberi bomines, the socemanni and the villani of Domesday, it is not likely that others will be more successful in the task. Indeed, the more one studies the Survey, the more one shrinks from attaching to its terms a denotation so precise as that of modern times. I have already drawn attention to the evidence in the Essex survey of such terms as 'thegn' or 'free man' being indifferently used.' It is this recklessness of the scribe-as the modern mind would deem it-which makes it rash to argue from such an entry as we find, for instance, under Goldhanger, where we read of an estate annexed, apparently, to the main manor that ' 9 free men dwelt on (in) half a hide, and one man (who was) a thegn held 30 acres, and two others (who were) free men held ro acres.' Here we might infer that a 'thegn' was distinct from a 'free man,' had we not evidence to the contrary in the Survey itself. Again, in this same entry we read lower down of 15 acres which had belonged to one 'free thegn' (francus teignus), a formula which is probably unique in Domesday, although in its other volume we have once teini liberi (fo. 254). So, in Essex, when the scribe was tired of writing liberi bomines, he wrote, for a change, franci bomines." One ought, perhaps, to say something of the Essex entries bearing on the difficult subject of status, but for the general reader it will be sufficient to know that

the English peasants did suffer by the substitution of English for French lords. ... We cannot treat either the legal or the economic history of our peasantry as a continuous whole; it is divided into two parts by the red thread of the Norman Conquest. That is a catastrophe. . . As a result of the Conquest, the peasants, at all events some of the peasants, had fallen from their free estate; free men, holding freely, they had been compelled to do unfree services. . . . Domesday Book is full of evidence that the tillers of the soil are being depressed. Here we may read of a free man with half a hide who has now been made one of the villeins, etc., etc. ${ }^{6}$

I break off the quotation here with an instance taken from the first entry in the Essex survey. The fate of this Benfleet 'free man' is one of the most eloquent incidents recorded in the great Survey.

1 Sec Feudal England, p. 463.

- Domesday Book and Beyond, pp. 25, 39-46,67 et seq. S Sec p. 352 above.

- Illustrations of the scribe's vagaries will be afforded in the instances of duplicate entries below.

- Domesday Book and Beyond, pp. 51, 60, 61.

${ }^{6}$ See p. 428 below. 


\section{A HISTORY OF ESSEX}

In the entry relating to Fobbing there is a passage of considerable importance for the status of ' free men' and 'sokemen.' Count Eustace's estate there was composed of a five-hide 'manor,' which had been held by a thegn, to which Ingelric, the count's predecessor, had added (the holdings of) no fewer than 22 'free men' assessed at more than three times that amount. Domesday states that the 'manor' had been worth $\oint_{2} 20$ and the sokemen's land (terra sochemanorum) $\oint_{1} \mathrm{I}$, and that in 1086 the value of the whole estate was $£_{3} 36$. Here, the unwary might conclude, we have definite evidence that Domesday treated liberi bomines and socbemani as convertible terms. ${ }^{1}$ Yet at Finchingfield we read of a small estate that it had been held by ' 2 sokemen and I free man' (fo. $35^{b}$ ), a phrase which obviously implies that the two classes were distinct. The references to 'sac and soc' in the Essex survey are many; but it cannot be said that they enlighten us on this difficult subject. At Chignal Sawin the priest and 'Erfin' were 'so. free (liberi ita) that they could sell their land with the sac and soc where they would' (fo. 59). Wulfwine held his land at Waltham 'freely with (the) soc' (fo. 58), which probably comes to the same thing. But at Radwinter, though Ælfric the sokeman ' had power to sell the land,' which he held ' as a manor,' yet 'the soc and sac remained' to the lord (fo. 78 ); and so at Theydon (fo. 50b) and at one of the Rodings (fo. $5 \mathrm{I}$ ), though a sokeman in each ' had power to sell his land,' yet 'the soc remained in the manor' (an equivalent formula). At another Roding a free man had held $1 \frac{3}{4}$ hides, of which 'half used to render soc to Ansgar, and the rest was free' (fo. $61 b$ ). Where we read, as at Newnham, of sokemen ' remaining with (the) soc' (fo. 34), it probably implies that the sokeman could part neither with the land nor with its soc. At Stapleford (Abbots) there is a curious entry of ' 2 free men in the soke of the manor' (fo. 20), and at Shopland it is noted of two sokemen that 'their lord had (the) soc and sac' (fo. $34 b$ ). When we come to personal 'commendation,' the light is a little clearer. At Prested (in Feering) Brihtmar, who held this manor, was 'commended' to Siward (of Maldon), 'but could betake himself (ire) with his land where he would' (fo. 75). At (Abbess) Roding a manor was held of Barking Abbey by a tenant who 'was only the man of Geoffrey's predecessor' ('Ansgar the staller') and had no power to dispose of (mittere) this land ' away from the abbey' (fo. 57b). At Vange a free man 'became, in King William's time, the man of Ranulf's predecessor (Siward of Maldon), but did not give him his land' (fo. $7 \mathrm{I} b$ ), though Ranulf was in possession in 1086. At Manhall (in Saffron Walden) a free man similarly 'became, in King William's time, the man of Geoffrey (de Mandeville) of his own accord,' but this was held to be insufficient to account for the possession of his land by Geoffrey in 1086 (fo. 62b). At Hanningfield the abbot of Ely claimed the land of two 'free men,' but the jurors found that 'they used

1 At Pitsea (fo. $45^{b}$ ) there were two manors, of which one had been held by a sokeman of Robert (Fitz Wimarc), and the other by 'I free man,' the soke belonging to Robert. Here the difference between the two is not obvious. 


\section{THE DOMESDAY SURVEY}

to hold their land freely, and were only commended to the abbot of Ely' (fo. 25). In all these cases the line is clearly drawn between a man's personal 'commendation' of himself, for security, to a lord and the giving to that lord of rights over his land.

In Essex, as in other counties, we find great importance attached to the power of the former holder to 'give,' 'assign,' or 'sell' his land, or to betake himself elsewhere ${ }^{1}$ without having to obtain leave. At Hanningfield (fo. 25) I 4 hides were held by 22 free men, "who could withdraw themselves (recedere) without the leave of the lord of that manor' (ipsius mansionis); at Sutton (fo. 96) there belonged to the manor a free man, holding half a hide, "who could withdraw himself (abire) without the leave of the lord of that manor.' It is probable that the complication of tenures which had grown up under the English system was almost as obscure to the newcomers as it is to ourselves; but if they set themselves to cut the knot, if their rough and ready methods led to the infliction of much hardship upon those small holders whose tenure was affected for the worse, or who even lost their lands, yet the classes below them, it might be thought, would remain much as they were; the organization of the peasantry would not be affected by the change. This assumption, however, would be wrong. Professor Maitland has selected Essex as a county in which the Conquest had a marked effect on the figures of the peasant classes.

Let us look, for example, at the changes that take place in some Essex villages during the twenty years that precede the Domesday Inquest. The following table shows them :-

\begin{tabular}{|c|c|c|c|c|c|}
\hline & Villeins & Bordars & Serfis & $\begin{array}{l}\text { Lord's } \\
\text { teams }\end{array}$ & $\begin{array}{l}\text { Men's } \\
\text { teams }\end{array}$ \\
\hline $\begin{array}{l}\text { heydon (Mount) T.R.E. [1066] } \\
\text { T.R.W.[1086] }\end{array}$ & $\begin{array}{l}5 \\
. \quad 1\end{array}$ & $\begin{array}{r}3 \\
17\end{array}$ & $\begin{array}{l}4 \\
0\end{array}$ & $\begin{array}{l}2 \\
3\end{array}$ & $\begin{array}{l}4 \\
3\end{array}$ \\
\hline
\end{tabular}

These are but specimens of the obscure little revolutions that are being accomplished in the Essex villages. In general there has been a marked increase in the number of bordarii at the expense of the villeins on the one part and the serfs on the other, and this, whatever else it may represent, must tell us of a redistribution. of tenements, perhaps of a process that substitutes the half-virgate for the virgate as the average holding of an Essex peasant. The jar of conquest has made such revolutions easy. ${ }^{3}$

The notable increase of the 'bordars' at the cost of the classes above and below them is a constantly recurring feature throughout the Essex survey, and one to which, as the Professor observes, I was the first to call attention. At the same time it has to be observed that this process was by no means uniform; there are cases not only of the three classes remaining unchanged in their numbers, but even of the serfs exhibiting, not a decrease, but an increase. The learned Professor writes thus :-

On manor after manor the number of villeins and bordiers, if of them we make one class, has increased, while the number of servi has fallen. We take 100 entries

1 On the equivalence of these phrases see Feudal England, pp. 24-6.

2 I only give the first out of five in Professor Maitland's table.

- Domesday Book and Beyond, p. 363. 


\section{A HISTORY OF ESSEX}

(four batches of 25 apiece) and see that the number of villani and bordarii has risen from 1,486 to 1,894 , while the number of servi has fallen from 423 to 303 . We make another experiment with a hundred entries. This gives the following result :-

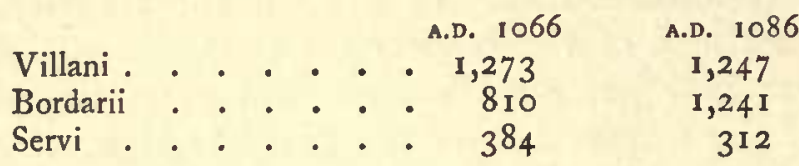

This decrease in the number of servi seems to be pretty evenly distributed throughout the county. ${ }^{1}$

As this feature of the county survey has attracted so much attention, I give here some selected types, inviting attention to the fact that, apart from the proportion of the classes, the total number of the peasantry shows an almost steady increase.

\begin{tabular}{|c|c|c|c|c|c|c|c|c|c|c|c|}
\hline \multicolumn{6}{|c|}{ LANGHAM } & \multicolumn{6}{|c|}{ Panfield } \\
\hline \multirow{3}{*}{$\begin{array}{l}(1066) \\
(1086)\end{array}$} & V. & B. & S. & & Total & & V. & B. & S. & & Total \\
\hline & 22 & 9 & 4 & $=$ & 35 & $(1066)$ & 10 & 8 & 8 & $=$ & 26 \\
\hline & 17 & 27 & 0 & $=$ & 44 & $(1086)$ & 8 & 15 & 7 & $=$ & 30 \\
\hline \multicolumn{6}{|c|}{ GREAT BARDFIELD } & \multicolumn{6}{|c|}{ FoBbING } \\
\hline \multirow{3}{*}{$\begin{array}{l}(1066) \\
(1086)\end{array}$} & V. & B. & S. & & Total & & V. & B. & s. & & Total \\
\hline & 24 & 7 & 8 & $=$ & 39 & (1066) & 8 & 8 & 12 & $=$ & 28 \\
\hline & 20 & 22 & 8 & $=$ & 50 & (1086) & 3 & 22 & 6 & $=$ & $3^{I}$ \\
\hline \multicolumn{6}{|c|}{ SAMPFORD } & \multicolumn{6}{|c|}{ Elmstead } \\
\hline \multirow{5}{*}{$\begin{array}{l}(1066) \\
(1086)\end{array}$} & V. & B. & S. & & Total & & V. & B. & S. & & Total \\
\hline & 23 & 2 & 6 & $=$ & 3 I & $(1066)$ & 14 & 3 I & 6 & $=$ & $5 \mathrm{I}$ \\
\hline & I 4 & 18 & 4 & $=$ & 36 & $(1086)$ & 13 & 36 & I & $=$ & 50 \\
\hline & \multicolumn{5}{|c|}{ RAYLEIGH } & \multicolumn{6}{|c|}{ NotLEY } \\
\hline & V. & B. & S. & & Total & & V. & B. & S. & & Total \\
\hline \multirow{2}{*}{$\begin{array}{l}(1066) \\
(1086)\end{array}$} & $2 I$ & 6 & 2 & $=$ & 29 & $(1066)$ & 10 & 3 & 9 & $=$ & 22 \\
\hline & 6 & 15 & 2 & $=$ & 23 & $(1086)$ & 6 & 16 & 4 & $=$ & 6 \\
\hline
\end{tabular}

The only unvarying feature here is the marked increase in 'bordars,' even when the total decreases and even when the serfs are stationary. The two cases which follow are examples of an increase, instead of a decrease, in the number of villeins, significantly concurrent with an increase in the 'men's plough-teams' and a decrease in those on the lord's demesne.

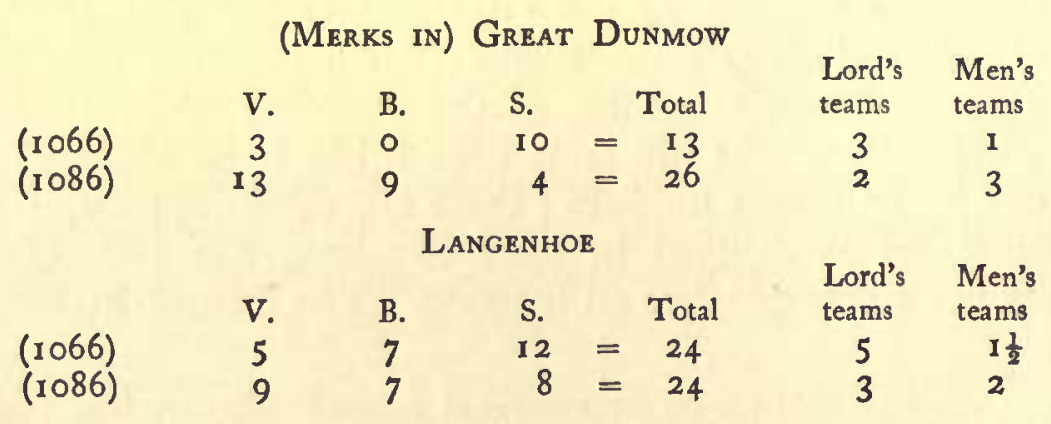

It is a safe generalization to say that the typical Essex manor exhibits a marked increase of bordars, at the cost of the classes above and below 


\section{THE DOMESDAY SURVEY}

them, between 1066 and 1086 , together with an increase in the total number of the three peasant classes. We occasionally meet with an increase either in the villeins or the serfs, or again with a decrease in the total number of the peasantry, but the one persistent feature is that the bordars either show a marked increase or appear in 1086 in places where there had been none twenty years before. Four more types may here, perhaps, be in point.

\begin{tabular}{|c|c|c|c|c|c|}
\hline \multicolumn{6}{|c|}{ Claret (Halx) } \\
\hline & v. & B. & s. & & Total \\
\hline$(1066)$ & 7 & o & 10 & $=$ & 17 \\
\hline (10 & 4 & 12 & 4 & $=$ & 20 \\
\hline \multicolumn{6}{|c|}{ LeEbury (IN Elmdon) } \\
\hline & V. & B. & S. & & Total \\
\hline$(1066)$ & 5 & 1 & 4 & $=$ & 10 \\
\hline$(1086)$ & 5 & 8 & 0 & $=$ & 13 \\
\hline
\end{tabular}

\begin{tabular}{|c|c|c|c|c|c|}
\hline \multicolumn{2}{|c|}{ Little } & \multicolumn{2}{|c|}{ YELDHAM } & & \\
\hline $\begin{array}{l}(1066) \\
(1086)\end{array}$ & $\begin{array}{l}\text { V. } \\
8 \\
6\end{array}$ & $\begin{array}{r}\text { B. } \\
\circ \\
8\end{array}$ & $\begin{array}{l}\text { S. } \\
8 \\
6\end{array}$ & $=$ & $\begin{array}{c}\text { Total } \\
16 \\
20\end{array}$ \\
\hline \multicolumn{6}{|c|}{ Quickbury (in SheEring) } \\
\hline & V. & B. & S. & & Total \\
\hline$(1066)$ & 7 & $\circ$ & 5 & $=$ & 12 \\
\hline$(1086)$ & 6 & 6 & 2 & $=$ & I 4 \\
\hline
\end{tabular}

Without dwelling at greater length on this remarkable change one may note the form it took at Hassingbrooke, where i 4 bordars make their appearance, though none had been there before (fo. 23); for this was an estate which had been held by 'I 6 free men.' typical holding of the bordar was perhaps half that of the villein, that is to say, half a virgate, ${ }^{2}$ though it was often less; and it is noteworthy that when we emerge into daylight with the Domesday of St. Paul's (1 222) we find half a virgate the normal holding of the peasant who owed service to the lord's demesne.

The 'cottar' class, intermediate between the bordar and the serf, is found in Cambridgeshire, Hertfordshire and Middlesex, but is not mentioned in Essex. The serfs, of whose remarkable diminution evidence has already been given, require some notice, for I am able to throw fresh light on their special work and position. The 'bovarii' of the west of England, as I have elsewhere shown, ${ }^{8}$ were the men in charge of the oxen attached to the lord's plough; and to each ploughteam there were two. Now these men belonged essentially to a servile class," and it is my contention that the "servi' of Essex and other counties correspond to the 'bovarii' of the west. Dealing with the 'servi' of Domesday Professor Maitland takes a Surrey and a Hertfordshire manor, on the former of which there were 5 plough-teams in the lord's demesne and Io 'servi,' and on the latter 6 such teams and 12 'servi ' $;$ ' but these suggestive figures do not seem to have struck him. Yet they are the clue to follow. In Essex, it is true, the proportion is by no means constant, but a careful investigation of the survey of the whole county proves that it is general enough to point to its existence bordarius.

1 Equally significant is the entry, under Abberton (fo. $46 b$ ): "Tune I liber homo. Modo I

3 The evidence is almost confined to the survey of Middlesex.

3 Victoria History of Worcestershire, i. 274-6.

- Compare Mr. Seebohm on the yrthling of a century before Domesday (English Village Community, pp. $165-6)$. 


\section{A HISTORY OF ESSEX}

as a rule; and the fact that it was more general in 1066 than twenty years later is significant of its former prevalence. The most striking cases no doubt are those in which the change in the number of serfs corresponds with that in the number of teams on the lord's demesne. At Writtle the ploughs in demesne had diminished from 12 to 9 , and the serfs from 24 to 18 ; at (Saffron) Walden the ploughs in demesne had, on the contrary, increased from 8 to ro and the serfs from 16 to 20. At Stanstead Mountfichet and at Moreton we read of a decrease in these ploughs from 3 to 2 and in the serfs from 6 to 4 ; at Latton, Bobbingworth and Newport alike these ploughs have decreased from 2 to $I$ and the serfs from 4 to 2. Of manors where the number of the serfs as well as of demesne ploughs was the same in 1086 as in 1066 , we find 12 serfs and 6 ploughs at Debden with 6 serfs and 3 ploughs at Amberden in Debden; on two of the Bumpstead manors we have respectively 4 demesne ploughs and 8 serfs and 3 demesne ploughs and 6 serfs. At Bendish (Hall), Great Bardfield and Castle Hedingham there are in each case 8 serfs and 4 demesne ploughs, while each of two manors at Gestingthorpe has 6 serfs and 3 such ploughs, a proportion which is found also at Strethall, Chreshall, Chishall, Newham, Stanway, Great Braxted, Ramsey, Dovercourt, Great Baddow and Tilbury-byClare. At Greenstead the proportion on the two manors is 6 to 3 and 4 to 2. At Hockley, where the lord is credited with $2 \frac{1}{2}$ plough teams, we find 5 serfs. There are twenty-eight cases in which the proportion, in 1086 and in 1066 , is 2 demesne ploughs and 4 serfs, so that one need hardly dwell on the numerous examples of a proportion of $I$ to 2 . Yet more striking is the great number of cases in which the ratio existed at the death of Edward the Confessor, although it had changed since then. At Thaxted there then had been i 6 serfs to 8 demesne ploughs, at Elmdon 12 to 6, at Great Easton and at Hatfield Peverel 10 to 5 ; at one of the Layers, at Panfield, at Hempstead, at Henham and at Clavering 8 to 4 . At fifteen other places it had been 6 to 3 , and at thirty-five 4 to 2. Here again the number might be swollen by adding examples of 2 to I ; but, after the scores of examples given, this can hardly be needful. It has been sufficiently demonstrated that the 'serfs' before the Conquest were normally men of whom two had charge of each plough-team on the lord's demesne.

Although at the time of the great Survey we find these 'serfs' disappearing, or at least diminishing in number, their work had still to be done, and one can hardly doubt that in many cases they had become, or had been replaced, in I 886 , by 'bordars.' At Little Thurrock, for instance, we read: 'Then I bordar; now 6. Then 6 serfs; now I' (fo. I I $b$ ). - And in the next entry but one we find at Little Burstead: 'Then I bordar; now 6. Then 4 serfs; now I.' So also at Good Easter (fo. $20 b$ ), where the villeins were stationary in number, there were 5 more bordars and 5 fewer serfs. At Stambridge (fo. $23^{b}$ ) we have an extreme case, in which all the 7 villeins and 3 serfs have disappeared, the bordars increasing at the same time from 5 to 10 . This, 


\section{THE DOMESDAY SURVEY}

it will be seen, involved a total decrease of 5 in the number of the peasantry; and yet the lord's plough-teams were 2 as before, while those of the men had increased from 3 to 4 . An abnormal case such as this is a further warning surely against the vain attempt to obtain definite conclusions from the bewildering morass of figures contained in Domesday Book. All that we can hope for is, here and there, to discover a patch of firm ground, as in the relation of 'servi' or 'bovarii' to the ploughs on the lord's demesne.

Professor Maitland has well observed that we should hardly expect the Norman lords to mark their advent by improving the condition of any class of the peasantry, and that 'it speaks ill' for the fate of the villeins and bordars ' that under the sway of foreigners, who may fairly be suspected of some harshness and greed, their inferiors, the true servi, are somewhat rapidly disappearing.' 1 It must however be remembered that in name at least the classes are unchanged, and that the labour services due from the classes above the 'serfs' were already, so far as we can learn, fixed in amount. Where the oppression of the new system seems to be most manifest is in the exorbitant rents occasionally exacted for manors : how the reeves who 'farmed' them contrived to pay these rents remains somewhat of a mystery. The county survey opens with the king's manor of Benfleet, of which one of the Essex tenants-inchief had charge. $\mathrm{He}$ is shown paying for that manor $\mathcal{E}_{12}$ a year, though its annual value was appraised at only 68 . Hatfield (Broadoak) was reckoned to be worth $\oint_{60}$ a year, but Peter de Valognes, the sheriff, was drawing from it for the king $\oint_{80}$ a year, and $\oint_{0} 5$, it would seem, in addition from its sub-tenant. Worse still, from Havering, worth $f_{4}{ }^{\circ}$ a year, he was drawing $f_{0} 80$, together with another $f_{0} 10$, which some one must have paid for the privilege of leasing it from him."

The example of King William was followed by Count Eustace, whose demesne manors of Coggeshall and Rivenhall are entered in succession. The former was reckoned to have risen in value from fio to $f_{1} 14$, but was made to pay $\oint_{2} 20$; from the latter, which has risen only from $f_{0} 9$ to $f_{12}, f_{0} 20$ was similarly exacted. ${ }^{3}$ The value of Amberden had remained unchanged at $\oint_{1} 12$, but Ranulf Peverel had for three years been drawing from it $f_{0} 8$ annually. Kelvedon, we read, had risen in value from $\AA_{5} 5$ to $\AA_{0} 8$, but the Abbot of Westminster contrived to draw from it $\AA_{0} 12$ a year. The most instructive case perhaps is at Thaxted, which important lordship was reckoned to have risen from $£_{3} 30$ to $f_{0} 5^{\circ}$ in value since it had passed into the hands of Richard Fitz Gilbert, but which had been leased by him for for to 'a certain Englishman,' who appears to have lost at least $\oint_{1} 10$ a year by the bargain." In this case,

1 Domesday Book and Beyond, pp. 35-6.

From Hatfield he received 'c. solidos de gersuma' and from Havering ' $x$. libras de gersuma' in addition to the rent. These entries are valuable for their bearing on those under Colchester, from which the sheriff similiarly received 'c. solidos de gersuma.' They should also be compared with the Colchester entries for the greatly increased amounts exacted by the Crown (see p. 421 below).

3 See pp. 46i-2 below.

- On this employment of Englishmen by Normans see the remarks on p. 355 above.

- Tunc valuit xox. libras, et quando recepit similiter; modo valet 1. libras, ut dicunt franci et 363 


\section{A HISTORY OF ESSEX}

Domesday tells us, 'the French and English' were agreed on the true annual value, but in some cases they differed. Barking, for instance, was worth, said the English, no more than in King Edward's time, that is $f_{0} 80$; 'but the French appraise (it at) $f_{0} \mathrm{r} 00$.' This mention of the two nationalities refers to the fact that, as I have shown, "there were practically for each Hundred exactly eight juratores, half of them "French" and half "English." I Another conflict of opinion as to value is seen at Waltham (Holy Cross), where Harold's estate had been worth to him only $£ 36$ a year. The 'men' of its Norman grantee, the Bishop of Durham, valued it at $\delta_{0} 6_{3} 5^{s} .4 d$., but 'the other men of the Hundred' boldly appraised it as worth fioo."

The question of Domesday valuation-the meaning of the word valet-has always been recognized as difficult. In the Essex survey there are two entries which have a bearing on the question. Geoffrey de Mandeville's manor of South Ockendon had risen in value, we read, from $f_{7}$ to $f_{\mathrm{I}} 6$, and Domesday proceeds to tell us that 'in this land are I 3 sokemen who hold freely $8 \frac{\mathrm{I}}{2}$ hides and 20 acres and have 12 bordars,' and that the proceeds of them are included in 'this rent of $f_{0}$ r6.' So again of (West) Thurrock we read that: 'It was then worth $f_{0}$ I 2 ; now $f_{0} 3 \circ$; and there are 7 houses in London which belong to this manor, and (of which the proceeds are included) in "this rent", It is absolutely clear that in these instances the value (valet) represents the actual rent (firma) received. ${ }^{5}$ On the other hand, we have seen above that the actual rent received was in some cases much in excess of the estimated value (valet). It is difficult, if not impossible, to extract from this conflicting evidence a definite conclusion as to the meaning of the word 'valet' in Domesday. One may however suggest that, as a rule, it represented the rent received, but that in those cases where the rent was notoriously in excess of the value the return made a pointed distinction between the two sums. This may seem but a lame conclusion, and yet no other suggests itself.

A strong reason for believing that 'valet' meant the actual sum received is found in the incomprehensible advances in the values of Essex manors frequently recorded in the text. It will be found that attention is drawn in notes to the text to some of the striking cases of such advance in value where the stock remains unchanged, if indeed it has not decreased. Stanford (Rivers) had been worth, we read, $£_{24}$ in 1066 and afterwards when Count Eustace received it, but was worth $f_{4} 40$ 'blanch' in 1086, although the ploughs on the demesne had dwindled from Io to 5. At Thaxted, with which we have just dealt, the demesne

anglici ; sed Ricardus dedit cuidam anglico ad censum pro lx. libris; sed unoquoque anno deficiunt illi ad minus x. libre' (fo. $38 \mathrm{~b}$ ). The meaning seems to be that it was the Englishman who lost.

1 Feudal England, p. 121. 8 See p. 446 below.

3t 'Et jacent ad hanc firmam de xvi. libris' (fo. 58 ).

4 "Que jacent huic manerio et in hac firma" (fo. 63 ).

6 The same conclusion may be drawn in the case of a holding at Halstead, of which we read 'valet xxx. denarios. Istos denarios recepit Aluret prepositus' (fo. 103). So also on the king's manor of Lawford : 'valebat xiii. solidos et hucusque habuit R. istum censum' . . . 'val' x. solidos et istum censum usque huc habuit Waleram' (fo. 66). For 'census' see the next note. 


\section{THE DOMESDAY SURVEY}

ploughs and teams had diminished from 8 to 7 , and those of the peasants from 34 to 18 , Domesday adding that the stock consequently could be increased by 16 ploughs. Except for an increase in the number of sheep, and the gain of an additional mill, there is nothing to explain the rise in 'value' from $\oint_{0} 30$ to $£_{250}$; indeed the peasantry had slightly decreased in number. Here again one has to point out that, owing to its solitary grandeur, the great record cannot be interpreted by the help of others of its age, and that we know very little of the actual form in which the Norman lords received their revenues from the land. A baron might follow the example of the Crown and the great ecclesiastical landowners and lease a manor such as Thaxted for a fixed sum of money, ${ }^{1}$ or he might keep it, as it were, 'in hand ' and work it through his own bailiff. In the latter case of course there would be no fixed rent, and the value apparently would have to be appraised by 'the men of the Hundred.' One does not see how such appraisal could result in a greatly increased valuation where all the conditions remained virtually unchanged. On the whole therefore it must be admitted that in this matter of 'value' we have still to feel our way.

The most important source of wealth at the time, the essential item in rural economy, was the plough. And without its team of plough-oxen, in Domesday always reckoned as 8 in number, ${ }^{2}$ the plough was useless. On the opening page of the county survey we read that the 'men's ploughs' at Witham had diminished from 18 to 7 ; ' and this loss was in the time when Suean and Baignard were sheriffs, and (was caused) by the death of the beasts.' At Hatfield Broadoak, where the men's ploughs had similarly diminished from 40 to $3 \mathrm{I}$, 'this loss was in the time of all the sheriffs, and (was caused) by the death of the beasts." It was the duty of the sheriff or other 'farmer' of a manor to keep up the number of the live stock, especially of the plough-oxen. Illustrations of this practice are found in the early leases of Essex manors belonging to the church of St. Paul's. It is difficult to say how nearly the plough-team in actual use corresponded with that of 8 oxen, which alone was recognized in Domesday. A century after the great Survey the Rotulus de Dominabus (1185) shows us at Wigborough, where the land is heavy, 6 oxen and 4 horses in a team. At Wickham St. Paul's there were on the demesne, in ro86, two plough teams, and in 1222 we find it reckoned that its cultivation required 'two teams of 16 head' of stock, that is, 8 in each. But at Walton-on-the-Naze and Thorpe-le-Soken there were 10 head to the team in 1222 , as there were in an early lease of the entire

1 'The normal term for this word was 'firma,' as at Mundon, where we read, 'Tunc val' x. lib. ; modo xvii. ; fuit ad frmam pro xxx. lib' sub ipso Eudone'; but at 'Thaxted 'census' is employed, $2 s$ it also is at Havering and Shalford. It has been supposed that 'census' was specially applied to woodlands on the ground of the chapter 'De censu nemorum' in the 'Dialogus de scaccario' (ii. II); but it was not thus specialized in Domesday. One may here note the solitary appearance of censarii (rent-paying tenants) in Essex, viz. at Waltham (Holy Cross), where they had increased in number from 20 to 36.

See Feudal England, pp. 35-6.

At the present moment farming operations are greatly hampered in the Transvaal 'by the loss of the plough-oxen" during the war. 


\section{A HISTORY OF ESSEX}

manor of 'Eadwulfsness,' in which they were included.' At Belchamp St. Paul's 10 head went to the team in 1222 , and at Heybridge, but at the latter an equal number of oxen and horses were employed. At Tillingham the two teams were composed of 12 oxen and 8 horses in all, while at Barling there were only 8 in the team, 'half horses and half oxen.' ' But of the use of the horse for this purpose Domesday apparently knows nothing. A quarter of a ploughland it describes as 'land for 2 oxen." The plough-oxen, "small, with short horns and high fore-feet,' "reign among its live stock supreme.

Yet so complete, if gradual, was the disappearance of the ox in favour of the horse at the plough that, seven centuries after the Conquest, the use of oxen for ploughing was deemed a bold innovation, a novelty full of promise. It was only, in his eagerness said Arthur Young, the stupidity of Essex farmers that stood in the way of its adoption. Lord Clare's Gosfield estate he mentioned (1767)-

chiefly on account of a stroke in agriculture most unusual in Essex, which is the using of oxen instead of horses for all the purposes of draught. . . This scheme you may be very sure was highly ridiculed by all the neighbouring farmers, who would as soon believe that an ox could speak as draw. . . His lordship used them for the culture of his farm as long as he kept it in his hands and had once near 30 in constant work. . . But notwithstanding the clear superiority none of the farmers have followed the example. ...

You will excuse my being thus particular in my account of this introduction of oxen into Essex; but the novelty of the thing in that county (his lordship's being the only team in it), the ridicule cast on it by the farmers, and the uninterrupted success it met with, has induced me to be more minute than otherwise I should have been. 5

But this eager if unconscious reversion to 'the wisdom of our forefathers' was doomed to share the fate of other agricultural 'reforms' in the county of Tusser and of Mechi. Mr. Montague Burgoyne abandoned the experiment in $1786,{ }^{\circ}$ and the famous parson, Bate Dudley, who was an advocate for oxen, seems to have only worked them for five years at Tillingham." Yet some landowners and farmers continued to use them, and one at least was absolutely confident of their superiority to horses in every respect at the plough. ${ }^{8}$

One of the great pecularities of the Domesday of the eastern counties is that, like the 'Exon Domesday' in the south-west of England,

1 Hale's Domesday of St. Paul's.

2 Ibid. Compare Seebohm's English Village Community, pp. 64-5, 74. The horses, doubtless, as in later times, were more powerful for ploughing than oxen, if more expensive to keep.

3 See examples in the text below. $\quad 4$ Andrews' The Old English Manor, p. 254.

5 A Six Weeks' Tour through the Southern Counties (1 772), pp. 73-5.

6 Young's Agriculture of the County of Essex (1 807), ii. 449.

7 Ibid. ii. 358. In his letter to Vancouver ( 1794 ?) he had insisted on the need for using them at Bradwell : 'Independently of the ordinary savings, the introduction of oxen on farms where grazing and tillage are so generally blended, would prove extremely productive, but the difficulty of weaning the prejudices of a country from an old system, however erroneous, and the risk of throwing an extensive business out of its regular course, deter those who experience the loss from attempting a reformation. Having full-aged oxen from the yoke to graze on the spot, without the loss attendant on over-driven beasts, would give a saving of full twenty-five per cent in addition to the advantages derived from their draught' (Vancouver's General View of the Agriculture of the County of Essex, p. 19I).

8 Young's Agriculture of the County of Essex, ii. pp. 357-60. 


\section{THE DOMESDAY SURVEY}

it records, as a rule, the live stock. This rule is by no means invariable, and, even where the numbers are recorded, we are not always told whether they had increased or diminished in the interval between the death of the Confessor and the date of the Domesday Survey. But where this latter information is given, it is of considerable interest. We may take as an exceptionally good instance Aubrey de Vere's manor of (Earls) Colne :

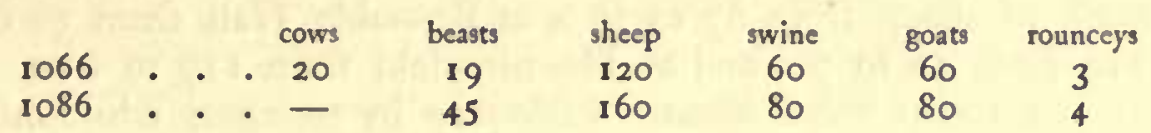

There were also in 1086 ' 6 asses and 20 mares,' so that we have such variety of stock as is not recorded, perhaps, anywhere else in the county. The first point to strike us here is the vague use of the term 'beasts' (animalia), which is generally recognized as equivalent to animalia otiosa, that is, cattle kept for other purposes than that of draught. The (Earls) Colne entry is but one of several which suggest, as I have pointed out in notes to the text, that cows, though sometimes separately named, must often be included in the term 'beasts' (animalia). We have here another illustration of that looseness of terminology that is so distinctive of the Domesday scribe and so alien from our own usage. Its position on the banks of the river from which it derived its name made the manor, as Domesday shows, rich in the meadow land required for its head of stock, besides providing it with the two watermills it possessed then as now, Domesday naming them, as usual, immediately after the meadow.

The live stock entered in Domesday was that of the lord on his demesne. Of this we are reminded by the occasional addition of the words ' in dominio.' There are several records by which light is thrown on the system of stocking manors in the century after Domesday. The early leases of St. Paul's record, for certain manors, the live as well as the dead stock which the 'farmer,' at the close of his lease, had to restore to the canons ; $^{1}$ the Pipe Rolls record the expense incurred in stocking or re-stocking manors which had come by escheat into the king's hands ${ }^{2}$ and the Rotulus de Dominabus ( I 85 ), a century after Domesday, which contains estimates of the amount of stock required on manors belonging to wards in the king's hands to make them fully productive. Both these latter records assume that a manor must increase in annual value when fully stocked.' But this, though it seems obvious, does not follow in

1 At Wickham St. Paul's, for instance (Domesday of St. Paul's, p. 122 ), he had to produce I 6 (plough) oxen (worth 28 pence each), 4 horses (worth 10 shillings), eight score sheep (at 4 pence each), 24 swine (at 5 pence each), a sow with 9 porkers (worth 19 pence), and 36 goats (at 4 pence each). These figures contrast with Domesday's two plough-teams in demesne, 2 rounceys (i.e. horses), 4 beasts, 23 swine, 50 sheep, and 24 goats (see p. 442 below).

In 1167 two of the escheated manors of Henry of Essex, Stoke(-by-Nayland) and Prittlewell, had to be re-stocked. For the former there were bought 5 oxen, 6 cows, 80 sheep, 5 sows, and 11 porkers, at a cost of $\mathrm{f}_{3} 6 \mathrm{6s}$. $4 d$.; for the latter, 1 ox, 2 boars, and 82 sheep, at a cost of $f_{0} 1$ I6s. $4 d$. (Pipe Roll, 13 Hen. II. p. 153).

8 It valued the manor of Rickling 23 worth 615 without stock and 620 if properly stocked (p. 40). At Rochford, where there was no stock on the manor, its value was reckoned at $\ell_{12}$ if properly stocked, that is, if supplied with 6 cows, I bull, 10 sows, I boar, 2 plough-teams, 250 sheep and 25 rams (p. 39). The proportion of 1 to 10 was then observed with rams and boars. At about the same time (1181) it $3^{67}$ 


\section{A HISTORY OF ESSEX}

Domesday. At one of the Layers the plough-teams had increased from $I \frac{I}{2}$ to 2 , the rounceys from $I$ to 2 , the beasts from 3 to 5 , and the sheep from $3^{8}$ to 146 , and there was a mill where there had been none. Yet the value had gone down from $£_{4} 4$ to $£_{3}$. If the Norman lords laid hands on more than belonged to them, they had often the merit of stocking their manors well. Even on those of Ralf son of Turold of Rochester ${ }^{1}$ we find cases in point. At Vange he had increased the flock of sheep from 67 to 270 , at Barstable Hall from 36 to 80 , at Ingrave from 40 to 76 , and at Hanningfield from I I 7 to 810 . As his horses and beasts were almost stationary in number, while his swine increased only from 84 to I 8 , we are led to believe that sheep-farming must have offered special inducements. On four other of his manors, it is true, the increase is more general, the beasts increasing from 20 to 59 , the swine from 35 to 101 , and the sheep from 163 to 399 . As the earlier figures refer to the eve of the Conquest, we cannot account for their smallness by the devastation that may have followed.

Thorold Rogers, in his Agriculture and Prices, speaks of cheese and butter as 'these exceedingly important articles of agricultural economy.' For these and for milk, at the time of Domesday, reliance was placed not only on the cow, but also on the sheep and the goat. All three are mentioned throughout the Essex survey, and I have already given reasons for believing that cows were more plentiful than might at first sight be supposed. But the quantity of cheese consumed was great; its value as food was fully realized, especially by the lower orders, and the Pipe Rolls of the twelfth century show us how large a part it played in the provisioning of castles. In the middle ages-

The manufacture of cheese generally commenced at Christmas and was continued till Michaelmas. Two cows, according to Walter of Henley's calculations, would produce a wey of cheese within this time besides half a gallon of butter each week.

Ewe milk, though less rarely taken and manipulated, was, however, occasionally employed for the same purpose. The writer quoted above seems to reckon ten ewes as equal in productiveness to one cow. It is possible, when ewe milk was used, that it was mixed with that of the cow. Goats' milk was very rarely, if ever, employed, goats having been very seldom kept in England or even in South Wales.

We are now dealing with a period earlier than that described by Thorold Rogers, and the goats, we shall find-the she-goats-were still a recognized part of the live stock, though by no means, like the swine and the sheep, an essential part. The goat-herd, in days before the Conquest, 'was allowed the herd's milk after Martinmas, ... and during the summer his share of the whey,' with one kid from the flock's increase yearly." It is possible that the absence of the goat on many Essex

was reckoned that the proper stock for Chingford was 100 sheep, 100 she-goats, 15 cows, I bull, 10 sows and 1 boar, apart from the horses and the plough-oxen (Domesday of St. Paul's, p. 1 44).

I See p. 342 above.

3 Ibid. p. 404. The period described is $1259^{-1} 400$.

4 Andrews, The Old English Manor, p. 221 , citing the Rectitudines. It must be remembered that the young kids were then and for centuries afterwards killed for food. Their skins also were made use of, for Domesday records that ten goat skins (pelles caprinas) formed part of the annual render due from Ipswich under the Confessor (fo. 119). For goats as live stock in the twelfth century, at Wickham St. Paul's and at Chingford, see p. 367 above. 


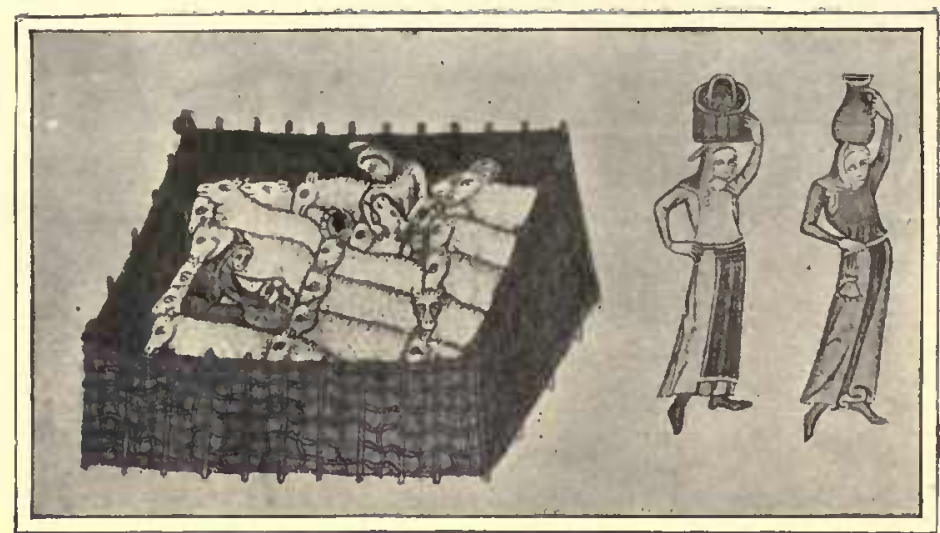

Milking Ewes.

(From Social England, by permission of Messrs. Cassell \& Co., Ltd.)

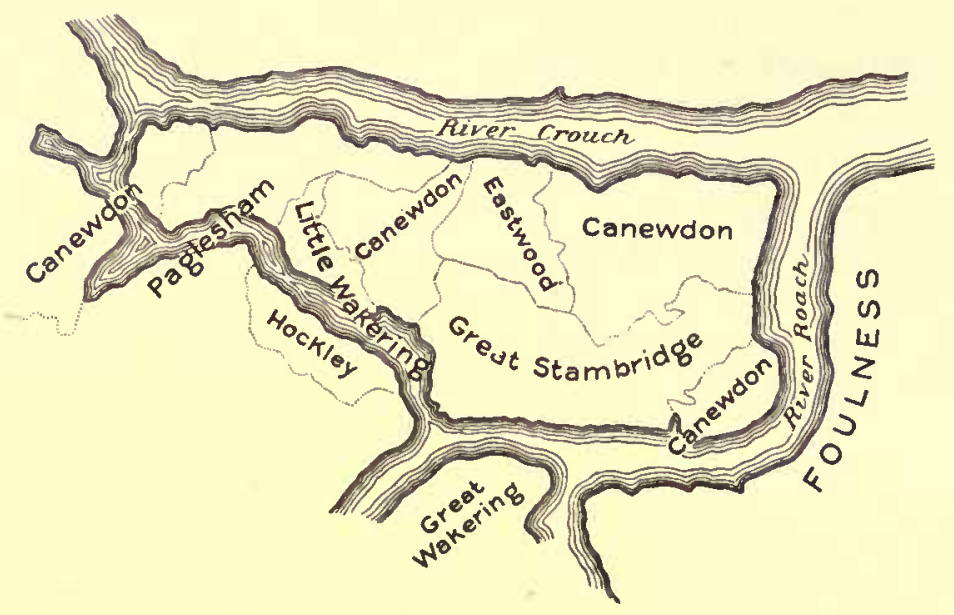

Wallasea Island and Neighbourhood.

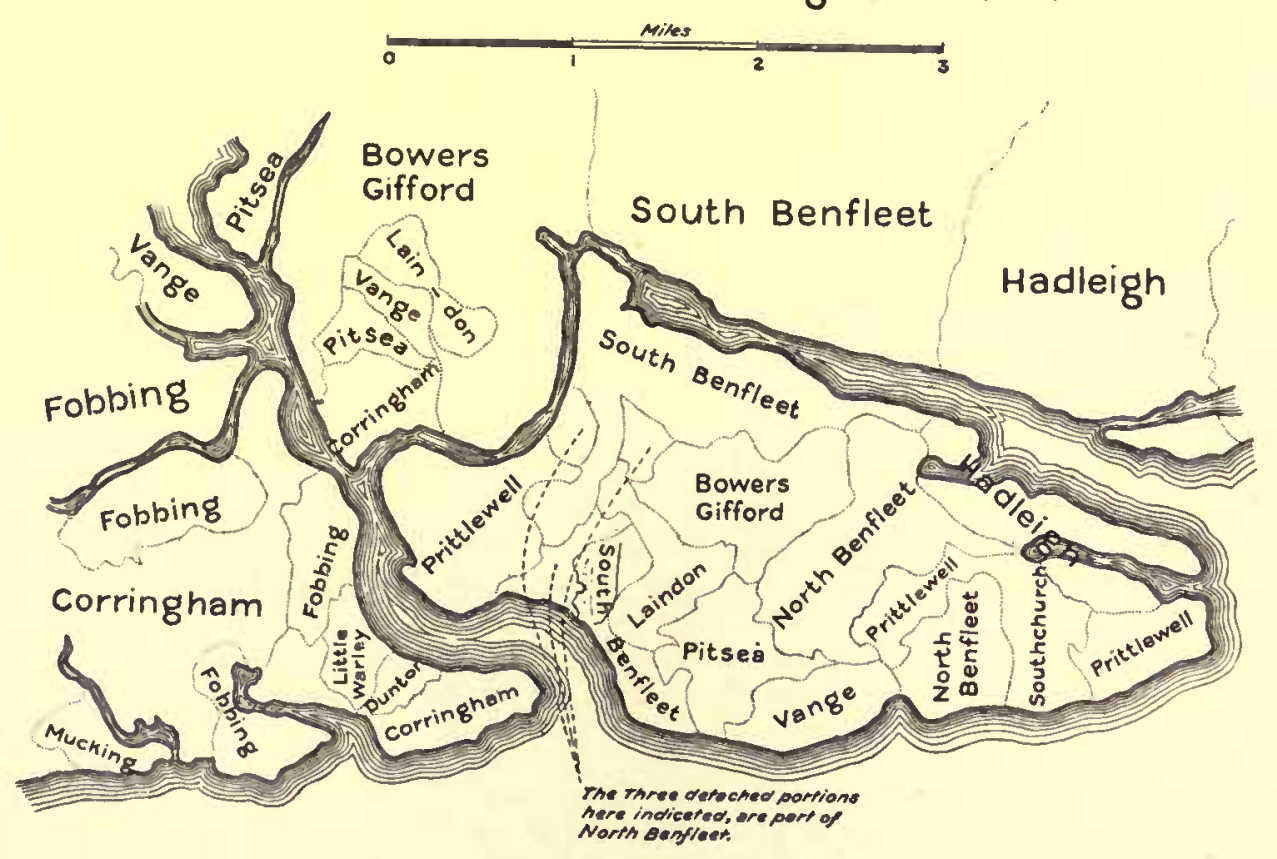

Canvey Island and Neighbourhood.

To face page 369 .

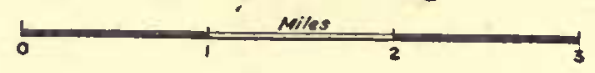




\section{THE DOMESDAY SURVEY}

manors is accounted for by its coming disappearance from the live stock of the farm. Where, as in parts of Australia, in Malta, and elsewhere, it is the only substitute for the cow, it is still indispensable.

The reason for dwelling at some length on the consumption and making of cheese is that it bears on a great feature of the Domesday survey of Essex, a feature which has hitherto, I believe, entirely escaped notice. It will be found that the formula 'pasture for $x$ sheep' occurs on a number of manors, and a brief examination will show that these manors are on the coast. Closer investigation reveals the fact that this 'pasture' corresponds with the famous Essex marshes, and that where these are most extensive, the number of sheep for which the Survey records ' pasture' is largest. The carrying capacity of the coast marshes appears to amount in all, in Domesday, to over 18,000 sheep, a total which must of necessity be a rough one, not only because the figures are usually round numbers, but also because the 'hundred,' for sheep, was doubtless the 'long hundred' of six score. East and west of Mersea Island the marshes of Langenhoe at the mouth of the Colne could feed 600 sheep, and those of Tollesbury, at the mouth of the Blackwater, at least 700. In Dengie Hundred, to the south, where the marshes widen towards the Crouch, those of Bradwell, with its long coast line, could feed 650 , of Tillingham 400, of Dengey 360, of Southminster 1,300, and of Burnham 9oo. But most interesting of all perhaps, as we shall see, were those in the Hundreds of Chafford, Barstable and Rochford, along the northern bank of the Thames. ${ }^{2}$

For the study of these Hundreds and their marshes reveals a system which is not found in other parts of the county. The inland manors recorded as possessing 'pasture for sheep,' outside these Hundreds, are virtually restricted to Terling, Butsbury, one of the Notleys, Margaretting(?), and one of the Hanningfields, each of which is credited with 'pasture for 100 sheep,' to which we may possibly add Weeley and Bocking. But within those Hundreds Childerditch, Great Warley, Little Warley, an Ockendon, Burstead, Ramsden, Thorndon, Horndonon-the-Hill, West Lee, Laindon, Langdon, Basildon, North Benfleet, Thundersley and Wheatley-in-Rayleigh all had 'pasture for sheep,' and the bulk of these were in Barstable. A glance at the ordnance map will suggest the explanation of the curious fact that these manors enjoyed feed in the marshes, though themselves inland. Canvey Island affords the clue. Opposite is a map of the island and the marshes to its north and west, drawn to show the parish boundaries as they formerly stood." It is over this mosaic that we look in the frontispiece to this volume.

'The 'pasture for sheep' in the rich marshes fringing the northern bank is traced westward to the block formed by the Tilburys, Chadwell, and the Thurrocks, which are credited respectively with pasture for 650, 200, and 780 sheep. Moreover, Higham, on the Kentish bank, opposite East Tilbury, had 'pasture in Essex for 200 sheep' (Domesday i. 9).

The most important point to observe is that these fragments of parishes belong to three Hundreds, and that, consequently, the marshes in and about Canrey Island were never the common pasture of any one Hundred. The detached portion of Prittlewell at the west end of the island should be specially observed, for it lies some eight miles to the west of Prittlewell, which is in Rochford Hundred. On the opposite side of Holehaven Creek, facing it, are portions, it will be seen, of Little Warley and Dunton, 


\section{A HISTORY OF ESSEX}

We have here only the relics of a system under which a number of 'vills' had rights in a common pasture, but these marshes can now be added to similar vestiges in other parts. Professor Maitland has drawn attention to two parallel districts in the west and in the east of Norfolk :-

In the Marshland Fen there is a considerable tract of ground which consists 'of 'detached portions' of these and other villages.' Each has been given a block there, a fairly rectangular block. At one point the partition is minute. A space of less than 36 acres has been cut up so that six villages shall have a piece, a rectangular piece of it. It seems very possible that this fen has at some time been common ground for all these villages, and, as already said, it is in this quarter that we may perhaps find traces of something that resembled the 'marks' of Germany.

So important, from the standpoint of institutional history, are these standing witnesses to the practice of a remote past that allusion may be made to the fenland on the border of Cambridgeshire and Hunts. In her learned monograph on Economic conditions on the manors of Ramsey Abbey, Miss Neilson has observed that-

the boundaries in the fens were very uncertain, and hence the pasture rights were the cause of many disputes. The many difficulties arising from the frequent intercommoning of Ramsey and neighbouring monasteries seem to point back to a time when the fen was held as common land, and the cattle of all the men of the region fed there 'horn under horn.' In the eleventh, twelfth and thirteenth centuries rights of common were being differentiated and boundaries established, and innumerable disputes resulted (pp. 62-3).

Professor Maitland tells us that 'traces of what might have become " the mark system" may perhaps be found in England; but not where they have been usually sought.' ${ }^{3}$ He finds them in that Domesday ' tract in Suffolk,' just across the Stour, 'which is common pasture for the whole hundred of Coleness,' in Tilney Smeeth in Norfolk, and in 'the intercommoning of vills' in Epping Forest." But he knew not of that most interesting example, Tiptree Heath in Essex, on which some sixteen parishes, lying in four different hundreds, enjoyed 'common of pasture.' Nor did he know of the traces found in the marshes in the south-east of the county, to the discussion of which I now return.

which are inland to the north-west, Little Warley (in Chafford Hundred) lying some ten miles away. Barstable Hundred, it should be remembered, lies between that of Chafford to the west and Rochford to the east.

The boundaries of these detached portions of parishes in the marshes are usually formed by the partition ditches which separate the marshes from one another. Thus these portions represent normally separate marshes, as in Wallasea Island, which must be presumed to represent a commutation for rights in the common pasture. On Tiptree Heath and in Epping Forest the rights remained unapportioned.

Canvey Island was made a civil and ecclesiastical parish in 1881 .

1 In the extreme west of Norfolk.

2 Domesday Book and Beyond, pp. 367-8. The example in the east of Norfolk given by Prof. Maitland is 'near Yarmouth along the banks of the Waveney,' where we find a mosaic of 'detached portions' as at Canvey Island. Lincolnshire, I may add, affords examples along the banks of the river Witham to the north-west of Boston and in Deeping Fen near the Cambridgeshire border.

3 Ibid. p. 355.

4 Ibid. p. 356, note. This intercommoning is well and fully described in Fisher's Forest of Essex, pp. $265,274-6,289$.

s See Morant's Essex, ii. I 4 I-3, where most valuable information is given on this subject. 


\section{THE DOMESDAY SURVEY}

At the extreme east of Rochford Hundred lies Foulness (Island), which although now a separate parish, " was originally no distinct parish, but the tithes of it belonged to the neighbouring parishes of Rochford, Sutton, Little Wakering, Shopland, Little Stambridge, and Eastwood,' in Rochford Hundred. ${ }^{1}$ If Foulness was once in six parishes, Wallasea, to its west, was in five. When Morant wrote, six of its marshes belonged to Canewdon parish, two to Great Stambridge, two to Paglesham, one to Little Wakering, and one to Eastwood. ${ }^{3}$ This division still prevails, and the island contains no fewer than three detached portions of the parish of Canewdon. On the opposite bank of the fleet which divides it from the mainland is a detached portion of Hockley seven miles away. The same distance separates a detached portion of Eastwood, in the north of Wallasea (Island), from its parish church. In 1618 this was held with a manor in Eastwood as 'Alford-nashe-marsh' (now Alfleet's farm), and as early as 1246 it belonged to the Countess of Kent, then lady of Eastwood. We have now seen why these marshy flats had no recognized existence in 1086, and are consequently left without a name on the Domesday map.

But they were the home of the sheep. And even as the cow was then valued not only for its milk, but for its flesh, ${ }^{3}$ so was the sheep expected to supply not only mutton and wool, but, above all, milk. The production of cheese from sheep's milk was a recognized Essex industry, even though William Harrison, that quaint Elizabethan chronicler, seems to have been somewhat strangely ignorant of the fact. But then his parsonage of Radwinter was at the other end of the county." We are fortunate in obtaining contemporary glimpses of this curious and ancient practice in the days of Queen Elizabeth. Of Canvey Island, over which we look in the frontispiece to this volume, Camden wrote that-

It is so low as to be frequently under water, except a few eminences to which sheep retreat. It feeds near 4,000 sheep of a delicate favour, which I have seen milked by boys instead of women, on little stools, who also make cheeses of the milk in the cheese-sheds, called there Wiches. ${ }^{5}$

\section{Norden's Description of Essex (1 577) contains a similar picture :-}

Near the Thames mouth, below Beamflete, are certaine ilandes, called Canvey Ilandes, low merishe grounds; and for that the passage over the creeks is unfitt for cattle, it is onlie converted to the feeding of ews, which men milke, and therof make

1 Morant's Essex, i. 324.

1 Ibid. pp. 325-6 (see map facing p. 369).

3 Fifty salted cows were bought for Warwick Castle and forty for that of Kenilworth in 1173 at the high price of two shillings each (Pipe Roll).

1 He writes that some farmers, he believed, added the milk of five sheep to that of ten kine, adding: 'I am sure hereof that some housewives can and do add daily a less portion of ewe's milk unto the cheese of so many kine, whereby their cheese doth the longer abide moist, and eatech more brickle and mellow than otherwise it would. . . . Only this I know, that ewe's milk is fulsome, sweet, and such in taste as (except such as are used unto it) no man will gladly yield to live and feed withal' ( $A$ Description of England [ed. Withington], p. 157).

- Brisannia, ed. 1586. Compare the illustration facing P. 369. 


\section{A HISTORY OF ESSEX}

cheese (suche as it is), and of the curdes of the whey they make butter once in the yeare, which serveth the clothier. ${ }^{1}$

Of the rich marshes in Dengie Hundred, which about a century ago were deemed 'better than any,' ' and which at the time of Domesday seem to have swarmed with sheep, Camden wrote as follows :-

The hundred of Dengy, formerly Dauncing $;^{3}$ abounding in pasturage and cattle, but both the soil and air unhealthy, whence the chief manufacture is cheese, and the men, instead of the women, milk the sheep. They make cheeses of an uncommon size, which are sent not only over England but abroad, for the use of the peasants and labourers.

It is to this that Drayton alludes when writing of the Colne in his Poly-olbion :-

Or Cheese, which our fat soyle to every quarter sends ;

Whose tacke the hungry. Clowne and Plow-man so commends.

Norden also alluded to these enormous cheeses, produced along the Essex coast :-

The hundreds of Rocheforde, Denge, Dansye, or Dansing, ${ }^{3}$ which lye on the south-easte part of the shire, yelde milke, butter and cheese in admirable aboundance : and in these parts are the great and huge cheeses made, wondred at for their massiveness and thicknes. They are made also in Tendring hundred, where are many wickes or dayries. ${ }^{\circ}$

A welcome phrase in a document at St. Paul's carries back this industry at a bound more than half way to the date of Domesday Book. It occurs in a lease of the Heybridge estate belonging to the Dean and Chapter, where the inventory (I $30 \mathrm{I}$ ) includes 'a building for making cheese from sheep.' ${ }^{8}$ Here we have one of these ' cheese-sheds' spoken of by Camden as used for the purpose on Canvey Island. Domesday enters this Heybridge estate as affording 'pasture for I 60 sheep,' which the Survey of 1222 identifies as a marsh of sixty acres. ${ }^{7}$

Lastly, we are enabled by another record to trace the cheese of the marshes to within a century of Domesday. In a plea of I 201 Thomas de Camville (lord of Fobbing) claimed against Robert de Sutton the marsh of 'Richeresnes'-that is, 'Richernesse' in Bowers Gifford, seen, I believe, in the frontispiece to this volume ${ }^{8}$-alleging that, in the time of Henry II., his grandfather had taken 'issues thereof, as in cheeses, and wool, and rushes.' ${ }^{9}$ Here, precisely, as in Domesday

1 Ed. Camden Society, p. 10. 2 Young's Agriculture of Essex, ii. 1 22. 3 This is an error.

1 The peninsula at the north-east of the county. In this hundred Morant speaks of 'the Marsh farm, or Dairy-house, standing among the marshes' (now Great Marsh farm) in Thorrington, and 'Old Dairy-house' is still the name of a farm in Foulton marsh, where Domesday records 'pasture for 160 sheep,' and in which 'feed for 50 sheep' was part of the endowment of Foulton chapel.

5 Entries of December 10, I46I, November 3, 1466, and of May 1, 1480 on the Patent Rolls speak of 'a dairy alias " a wyk" called Dangeybrigge in Dengey' (Calendar of Patent Rolls).

6 'Domus ad caseum faciendum de bidentibus' (9th Report on Historical MSS. part i. p. 37).

7 Domesday of St. Paul's, p. 52 : 'In marisco sunt lx. acre et possunt sustinere duodecies $\mathbf{x x}$. [240] oves.'

$8 \mathrm{It}$ is mentioned in a fine of 12 Hen. III $(1227-8)$, No. 59.

9 Select Civil Pleas (Selden Society), i. 36. The making, at this date, of cheese from ewes' milk is confirmed by a charter of Adam de Poynings (at the foot of the South Downs) giving to Lewes Priory 'decimam totam caseorum meorum de Bercbariis meis de Puninges et de Pingedena' (Cott. MS. F. xv. 


\section{THE DOMESDAY SURVEY}

Book, we find the marshes of Essex treated as feed for sheep; and their chief product was the cheese. We may even believe that the 'huge cheeses' which excited the wonder of a later age were already known in the twelfth century, for 'great cheeses' are entered as fetching sixpence each under Henry II., while the price of others was as low as twopence. ${ }^{1}$

We are now justified in tracing back to an even earlier period this venerable practice. For in the Rectitudines, a document believed to date from the tenth century, the duties of the shepherd are described as including the milking of the ewes twice a day, and the making of cheese and butter. Among his perquisites were "the milk of the herd for seven nights after the equinox and a bowl of whey or butter-milk each night during the summer.' ${ }^{2}$ It will be observed that the milking of the ewes was then in the hands of men as it was in the days of Elizabeth; and this confirms the belief that the whole practice was continuous.

Of these primitive dairies down in the Essex marshes the memory is still preserved in the 'wicks' which dot its coast. The 'wickes or dayries' of the Tendring Hundred are represented in St. Osyth alone by Well Wick, Lee Wick, Wigborough Wick, and Cocket Wick; and so are those of Canvey Island by Monks Wick, West Wick, North Wick, Farther Wick, and Knights Wick. When Benfleet and Canvey were 'disafforested ' in 1563 , eight 'marshes' in the island had names ending in 'wick.' The statements of Camden and of Norden are thus fully confirmed. The evidence moreover is clinched by a passage of great importance in the survey of St. Paul's manors in 1222 . Of Tillingham we read that "in the marsh are four sheepwalks (bercarie), of which one is called Howich and can carry (sustinere) I 80 head; another is called Middelwich and can carry I 30 head; a third is called Doddeswich and can carry 132 head ; a fourth is called Pirimers and can carry I Io head.' The total number of sheep, it will be seen, was 552 , as against the 400 for which, according to Domesday, the Tillingham marshes had afforded feed in 1086.

Now that the meaning of 'pasture for sheep' has been thus made clear, its mention becomes sometimes of assistance in identifying doubtful manors. Essex possesses a Tilbury-by-Clare in addition to the better known East and West Tilbury(-on-the-Thames). Which of these was the 'Tiliberia' held by Thierri Pointel in 1086? Mr. Chisenhale-Marsh

fo. 310). These cheeses must have been made from ewes' milk alone, and the witnesses' names date the charter as of $1164-89$.

1 Fifty 'magni casei' were bought for Berkhampstead Castle in 1173 at a cost of $25 \mathrm{~s}$., while 200 which were sent to Gloucester, cost only $6113 \mathrm{~s} .4$., that is twopence each (Pipe Roll, 19 Henry II. pp. 22, 23). But 100 'magni casei' sent to Arundel cost less than the others, namely $[2$ os. $7 d$. (ibid. p. 26). The wey of cheese was then selling at about $4.6 d$.

2 Andrews' The Old English Manor, p. 220.

- Domesday of St. Paul's (Camden Society), p. 59. For the "dairy alias a "wyk" ' in the adjoining parish of Dengie, see p. 372 note 5 above. Domesday records (i. $5^{8}$ ) that at Buckland, Berks, on the banks of the Thames, there was a 'wick' producing yearly 10 weys of cheese ("Wica de $x$. pensis caseorum ') worth (I 1 2s. 4d.

- See p. 442 below. At another of St. Paul's manors, Walton-on-the-Naze, now well known for its flock of Suffolk sheep, there was, in 1222 , 'pastura in marisco et in terra susenna ad quadringentas oves cum suis fetibus,' and this marsh is named later 'Ewenemersh,' carrying 400 ewes 'ad majus centum.' 


\section{A HISTORY OF ESSEX}

left it in doubt, pointing out that 'Morant, without explanation, refers it to East Tilbury and then to Tilbury-by-Clare.' But its 'pasture for fifty sheep' decides the question in favour of Tilbury-on-the-Thames. And we can go further than this. Domesday assigns to Geoffrey de Mandeville a large and valuable, but nameless estate in the Hundred of Barstable The entry suggests that it probably adjoined Suain's manor of West Tilbury and states that it contained ' pasture for 300 sheep.' Now East Tilbury has extensive marshes; it contained, says Morant, five manors which we cannot account for in Domesday; and its manors were held of the Honour of Mandeville, Geoffrey's heir, Humfrey de Bohun, Earl of Hereford and Essex, holding there 3 knights' fees in I 372. And, as if to clinch the proof, we even find its five manors represented by the ' 5 knights' who held this nameless estate of Geoffrey de Mandeville in Domesday.

It is time that we should turn from the sheep to the swine, from the rich marshes on the coast to the forest and the woodland tracts. As the marshland was valued in Domesday for the feed it afforded for sheep, so was the woodland, not for its use for hunting, for firing, for building and fencing, but-as its most important purpose-for the mast it yielded for the swine who then fed within it. The 'pork and beans,' which now forms the staple diet of the Canadian lumberman, were all-important among ourselves in that of the twelfth century. ${ }^{1}$ In Essex, a forest county, the swine, as might be expected, meet us at every turn. 'Forest' however is a term which needs to be defined at the outset.

In spite of the 'deer forests' of Scotland existing still to remind us of the true historical meaning of the word, it is difficult to overcome the conviction that a forest is all woodland. 'Antiently,' wrote the historian of Essex, 'the whole county was in a manner one continued forest.' It is probable that Morant here used the word in its legal sense, but others, after him, seem to have imagined that, because the whole county was at one time 'within the forest,' it was much in the same condition as Epping Forest to-day. 'The history of 'the forest of Essex' will be given in another section, but it is to Domesday that we owe our earliest historic information on the distribution of the actual woodland, as shown by the number of swine for which it could supply feed.

There are three points which call for notice in the Domesday entries of Essex woodland. The first, as I have said, is the light they throw on its distribution at the time. The second is their reckoning, occasionally, its extent, not by the swine it could feed, but in 'hides' and 'acres.' The third is the evidence they contain on a matter somewhat overlooked - the destruction of woodland here and there between I 066 and 1086.

1 'Et pro quater xx. Baconibus ... Et pro xx. summis fabarum' (Pipe Roll, 19 Henry II. p. 23 ). 'Et pro lx. baconibus viii. libras. Et pro xx. summis fabarum et pisarum xxxiii. sol et iiij. den' (ibid. p. 81), etc., etc. In the next century Bowers Gifford (north of Canvey Island) was held by the serjeanty of 'scalding the king's hogs' (Red Book of the Exchequer, pp. 457, 507) or as the jurors found

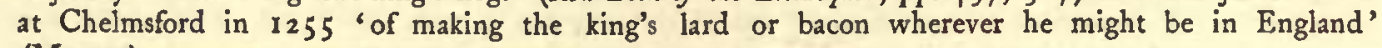
(Morant). 


\section{THE DOMESDAY SURVEY}

The only way in which to gauge the distribution of woodland at the time of King Edward's death is to mark down on a map of the county the amount, reckoned in swine, as given for each parish. The results of this tedious process are of interest if treated with that caution which is always so essential in dealing with Domesday figures. When one finds such estimates as $100,500,1,000$ frequently made, it is obvious that the estimate can only be accepted as a very rude one. Moreover the number of swine has to be compared with the acreage, a most laborious task. Certain general conclusions are therefore the most that one can hope for. And the first of these to be attained is that the actual woodland was distributed very unevenly, and that we can trace it as most abundant, even at that remote date, in places where its remnants linger down to the present day. Mr. Miller Christy enumerates among the 'stretches of forest and woodland' still existing in the county Epping Forest, Takeley or Hatfield Forest, and 'the woods around Thorndon.' When we apply to the Domesday figures the test of ascertaining the number of swine to every hundred acres (according to the modern acreage), we find the south-west of the county a heavily wooded district. Waltham (Abbey), which gave its name to the ancient forest of Waltham (now, corruptly, of Epping), owed its origin to a hunting lodge, established there before the Conquest on account of the multitude of its deer. The number of swine it was reckoned to feed in 1086 was 2,382 , actually the largest in the county; but the great area of the parish reduces the proportion to $2 \mathrm{I} \frac{3}{4}$ per 100 acres. In Loughton, adjoining Waltham, it was $23 \frac{\mathrm{I}}{2}$, and in the three Theydons, next to Loughton, it was $22 \frac{1}{3}$ taking them as a whole. ${ }^{2}$ At Woodford it was $23 \frac{1}{4}$, at Leyton $22 \frac{\mathrm{I}}{2}$, and at Navestock $25 \frac{3}{4}$. South of Waltham Abbey the proportion drops to 18 at Chingford and $13 \frac{1}{2}$ at Walthamstow; at Wanstead it is 15. On the other hand, if we pass north-eastward to the Ongars, there is a marked increase. On the two Ongars together it is 38 , at Norton Mandeville $32 \frac{\mathrm{I}}{2}$, while at Greensted it leaps to the high figure of 75 . A remarkable belt of woodland appears to have connected that of the Ongars with the Thorndon woods, although it has long vanished. At Blackmore the proportion works out at $38 \frac{1}{2}$, which is as high as in the Ongars; and although it falls to 17 in Mountnessing, it jumps suddenly

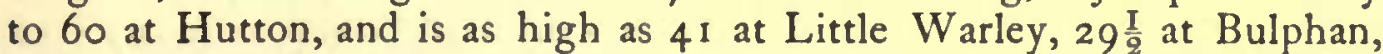
and $23 \frac{3}{4}$ at Orsett. At Cranham, due south of Brentwood, it is $26 \frac{1}{3}$.

Leaving now the district round Brentwood, we may turn to what appears to have been the most densely wooded district in Essex. Takeley and Elsenham could feed between them 3,500 swine, Stansted to the west of them I,200, Little Easton to the east 800, and Hatfield Broadoak to the south 820 . At Elsenham the proportion is as high as $72 \frac{2}{5}$, at Takeley it is 65 , at Little Easton 50, and at Stansted $28 \frac{\mathrm{I}}{2}$. Hatfield (or Takeley) Forest and Little Easton Park are now the representatives of this tract of forest, which shaded off in the Dunmows to a ratio of

1 See p. 232 above.

- All these figures may be taken as correct within a unit, which is sufficient for practical purposes. 


\section{A HISTORY OF ESSEX}

22. Broadly speaking, if we draw a line north and south through the county from Haverhill to Tilbury-on-Thames we shall find that the great bulk of the woodland lies to the west of it. In what are locally termed 'the Hundreds,' that is those of Dengey and Rochford, between the Blackwater and the Thames, the scarcity of woodland is very marked. In the north of the county, or, more exactly, in the great Hundred of Hinckford, it was by no means abundant, but on the uplands between the Blackwater and the Colne the proportion attains at Stisted $26 \frac{2}{3}$. At times we find some thick woodland represented by an ancient park. There was one for instance at Langham, on the Stour, where the Domesday ratio is 34, and another at Leighs, where it is nearly 30. Attention may also be directed to a distinct belt of woodland running almost north and south from Hatfield Peverel to Woodham Ferrers. On the former manor the proportion was as high as $35 \frac{3}{4}$, and on the latter 20; at Woodham Walter it was 19 , and at Woodham Mortimer and at Hazeleigh just over I4. From this belt a spur appears to have extended through Purleigh into Latchingdon, to the east of which the Hundred of Dengie was almost devoid of woodland. The Hundred of Rochford however seems to have been as a whole more destitute of woods than any other in the county. That proximity to the sea was not the cause either here or in Dengie Hundred is seen from the fact that those of Thurstable, Winstree, and Tendring to the north had a fair amount of woodland throughout. St. Osyth, indeed, could feed, it was reckoned, over I,200 swine, but its great area reduces the ratio to 14 to the acre.

One must not analyse further the distribution of the woodland, for other points have to be discussed. In a few places, which are almost all situate in Barstable Hundred, we find the curious reckoning of woodland by hides and acres. At Vange there was 'half a hide' of woodland (fo. 226 ), and at Pitsea the same, to which another ' 30 acres' had been added since the Conquest (fo. 98). At Bowers Gifford (fo. 86) there were ' 30 acres of woodland laid waste' (silve vastate), ${ }^{1}$ and at Fanton Hall the same (fo. I 4). At Great Burstead there was half a hide, to which as much as ' 5 hides of woodland' had been similarly added (fo. 22b), at Ingrave to the north $\mathrm{I} \frac{\mathrm{I}}{2}$ hides, and at Whatley with Wickford I hide (fo. 23). At Thorndon we read of 2 hides (fo. 42), at Langdon of I hide (fo. 42), on two manors in Wickford of 30 acres and 20 acres (fo. $42 b$ ), while on a third we have the strange entry: "Then I 2 hides of woodland ; now 6 acres' (fo. 43). In this last case the whole manor was assessed at only ro hides, which makes the entry of importance. Outside the Hundred of Barstable such entries as these are rare. At Cold Norton, a manor assessed at 8 hides, we read that 'of these hides two are of woodland' (fo. 69), and at Wigborough that it was assessed at ' 7 hides of land and I of woodland,' and that Bernard had abstracted 'the abovesaid hide of woodland' (fo. $55^{b}$ ). These phrases, it must frankly be confessed, are at present extremely obscure to us. Before leaving the subject we may note that the woodland at Wickford is

1 For the proximity of these three places see the map of Canvey Island opposite p. 369 above. 


\section{THE DOMESDAY SURVEY}

reckoned in four or five entries in hides, and in two others by the number of swine for which it afforded feed. This would seem to point to the two methods of reckoning being used indifferently. Indeed, at Shalford, where Domesday records 'woodland for roo swine,' it adds that the manor is short of ' 30 acres of woodland,' which the queen had given out of it.

The destruction of woodland between the years 1066 and 1086 is a matter of more direct interest, and one on which it is possible to speak with more confidence. It is in what we have found to be the most densely wooded district in the county that this destruction is most evident. At Elsenham it had been steadily progressive, for the entry carefully informs us that the woodland had 'then' (1066) sufficed for I, 300 swine, but, when the manor was bestowed, for only 1,100 , and lastly, at the date of the Survey, for 1,000. St. Walery's manor at Takeley, where the woodland had sufficed for 1,000 swine, had only enough for 600 in 1086, while at Little Easton there was a decrease of no less than half, the estimate dropping from 800 to 400 ! At Clavering, to the north-west, the figures had fallen from 800 to 600 , at Ugley from 200 to 160 , at Farnham, ${ }^{1}$ to the west, from 200 to 150 , at Bigods in Dunmow, to the east, from 400 to 350 , and at Thaxted, to the north-east, from 1,000 to 800 . In the north-west of the county there is a decrease from 1,050 to 830 at Saffron Walden, 500 to 400 at Wimbish, 100 to 80 at Thunderley, ${ }^{1}$ and 250 to 200 at Amberden ${ }^{1}$ (in Debden). The diminution at Stanstead (in Halstead) from 500 to 400 , at Sible Hedingham from 600 to 500 , and at Coggeshall also from 600 to 500 , may possibly point to forest clearings to the south-west of the Colne. Other manors where the decrease is noted are Notley ( $33^{\circ}$ to 200), Great Saling ${ }^{1}$ (250 to 200), Little Maplestead (60 to 16 ), and Henny ( 60 to 30 ), four manors of John son of Waleram which follow one another on fo. 84. We have also a decrease at White Notley from 200 to 100 , at Great Easton from 200 to 150 , and at Little Hallingbury from 150 to 100 . Of manors which only possessed woodland for 100 swine or less, Wickham (Bonhunt) shows a decrease from 100 to 60 , as does one of the Layers (fo. 926 ) ; East Tilbury 100 to 50 ; another of the Layers, a manor in the Notleys, Hersham Hall in Bumpstead, Birchanger, and Yardley in Thaxted all show decreases from 40 to 30. At Polhey in Pebmarsh there was a diminution from 60 to 40 , at 'Wickham' from 40 to 20 (fo. 39), at Brandon from 20 to 6, at a manor in Finchingfield from 20 to 5. With the cases of 'devastated woodland' at Fanton and Bowers Gifford we have dealt above.

No one district and no one fief can be associated in a definite manner with this destruction of timber, which only, one imagines, the convulsions of the Conquest could have made possible in twenty years. What can have been its cause? A local demand for timber cannot account for it, and there were obviously no facilities for selling it at a distance. The only suggestion one can make is that times of war or

1 This decrease is specially recorded to have taken place under King William. 


\section{A HISTORY OF ESSEX}

disturbance were accompanied by such destruction. I have elsewhere dwelt on the importance attached by Geoffrey, Earl of Essex, under Stephen to immunity for his 'assarts' and 'waste of the forest,' ' and drawn attention to mention of such an 'assart' at Ugley in a charter of the same reign. ${ }^{2}$ Other references to assarts are found in early charters relating to Essex, and we know from three entries, under Herefordshire, in Domesday that clearings in the woodlands for the purpose of cultivation were already known as assarts (or essarts) in $1086 .^{3}$ Judging from such evidence as we have both before and after the Conquest, we must assume that this loss of woodland represents that extension of the cultivated area (terra lucrabilis) that was always in progress.

In addition to the coast marshes and the woodlands, 'pasture' and 'marsh' are occasionally mentioned inland. At Fairsted, for instance, in the heart of the county, we have mention of pasture worth fourpence (a year), and at Notley, adjoining it, of pasture worth sixpence (a year), while at Walthamstow eight shillings a year were received from the ' pasture,' at Waltham (Holy Cross) eighteen shillings, at Roydon two shillings, at Hallingbury 28 pence, and at Epping with Nasing 32 pence. At Witham the annual value of the pasture had risen from sixpence to fourteenpence. The 'pasture' at Hatfield Broadoak is of interest for the curious payment received from it; it rendered to the manor 9 wethers and the service of ploughing $4^{\mathrm{I}}$ acres. An entry, apparently unique, records that at Great Wigborough there was 'pasture for roo sheep, rendering r 6 pence (a year).' At Tiltey we have 20 acres of marsh ('maresc'), and at Greenstead on the Colne (adjoining Colchester), 24 acres 'of meadow and marsh.' At Little Parndon there were 45 'what with meadow and marsh,' and at Great Canfield 48 'of meadow what with meadow and marsh.'" A remarkable entry under Peldon speaks of ' 80 acres of arable land and 200 acres of marsh' having been taken from its 5 hides. This must be a solitary mention of coast marsh as such, and appears to correspond with the few cases in which woodland, as we saw, was reckoned by hides and acres, and not by the number of swine for which it afforded feed.

We have still to deal with the mills, the fisheries and the saltpans among the sources of profit to the holders of land. The multure or right of the lords to the grinding of all the wheat at their mill made its possession of some value, and it is interesting to find how often the watermills entered in Domesday can be identified at the present day. The most remarkable group of mills in Essex was at West Ham, on the Lea, where we read there were 8 mills and had been 9. At Leyton to its north, a mill, we are told, had been 'taken away' (ablatus est), a phrase which needs explanation. At some places we find a mill where there had been none; at others there was none, though there had

1 Geoffrey de Mandeville, pp. 376-8.

2 Essex Arch. Trans. [n.s.] viii. 328.

3 Domesday, i. $179 b$, I $84 b$ ('essarz'), 180 ('exsarta silva'). In the first of these the word 'essarz' is written over 'terræ projectæ de silva,' which implies the identity of the two.

4 'Inter pratum et maresc' is the formula used in both cases. 


\section{THE DOMESDAY SURVEY}

been one ; at some there was ' half a mill.' A single case will explain the matter.

Under Rivenhall we read (fo. 27) that there was 'then one mill, (but) now a half'; and that 'Richard de Sachevilla has taken away a moiety of the mill.' What was Richard doing at Rivenhall ? We know him only, in Domesday, as holding Aspenden, Herts, under Eudo Dapifer. ${ }^{1}$ If we follow the clue thus given us and look for a manor in this neighbourhood held by Eudo, we find that he held Great Braxted, divided only by the stream from Rivenhall, and that his tenant there was 'Richard' (fo. 49). We find, moreover, that on this manor there was 'now half a mill'; and a charter of donation to Eudo's abbey enables us to clinch the matter. For by this charter William 'de Sakevilla' gave a rent of five shillings in Braxted from 'Rivenhall mill.' We thus learn that Eudo's tenant, in 1086, at Braxted, was Richard de Sachevilla, and that he had annexed a moiety of the mill which still stands on the stream between Rivenhall and Braxted. The whole of the mill had belonged to Rivenhall; but thenceforth each of the manors possessed ' half a mill.' A common but obscure Domesday phrase is thus at once explained.

The above gift was confirmed by a charter of Richard de Anesti as nephew and heir to William; and this enables us, for the first time, to trace the origin in England of the noble house of Sackville. It has long been known that Richard de 'Anesti,' whose seat was at Anstey, Herts, succeeded an uncle, William de Sackville, but the parentage of this William has remained in doubt. Mr. Chester Waters, who claimed to have 'corrected,' with the aid of the charters of St. John's, Colchester, the pedigree of the Essex Sackvilles, made him the son of another William, of whom he wrote :-

William de Sackville and his younger brother Robert were the sons of Herbrand, a noble Norman knight, and came to England in the reign of Henry I. in the train of Stephen de Blois, who rewarded their services by lands in Essex and Suffolk held of his honour of Eye.

But the evidence I have now given enables us to trace the settlement of the Sackvilles back to the time of Domesday. As Great Braxted descended by marriage from Sackville to Anesti and thence to Montchensy, there can be no question that these houses were the heirs of Richard de Sackville. It is of much interest to find that Richard held under Eudo, for Secqueville-en-Bessin, from which he must have come, was only some seven miles, as the crow flies, from Eudo's home at Ryes.

1 This is one of the entries omitted in Ellis' Index (Introduction to Domesday, ii. 385).

2 Cartulary of St. Fobn's Abbey, Cokbester (Roxburghe Club), pp. 163-5.

3 Chesters of Cbicheley, p. I9I. See also the 'corrected pedigree' of the Essex Sackvilles on p. 200 , in which Richard of Braxted finds no place.

- The settlement of the Sackvilles at Mount Bures (see p. 290 above) and West Bergholt ("Bergholt Sackville') was no doubt somewhat later and was quite distinct. These manors were held by Roger of Poitou in Domesday, and the fact that Roger's fief, as well as the Honour of Eye, was eventually granted to Count Stephen seems to have led to the two being confused (see preceding note). 


\section{A HISTORY OF ESSEX}

But we must now pass to the fisheries, which are styled in Essex ' piscinæ.' We find that these were not restricted to river or eel fisheries, as was usually the case, but included coast fisheries. They occur at the following places on or close to the coast: Mistley (I), Little Oakley (I), Clacton (I), East Mersea (4), West Mersea (I), ${ }^{1}$ Tollesbury (I), Osea Island (I), Bradwell-by-the-Sea (I), Lawling in Latchendon (I), 'Hacflet' (I), Tillingham (I), Southchurch (2), Benfleet (I), Vange (I), Fobbing ( $\frac{1}{3}$ and $\left.\frac{I}{2}\right)$, Horndon-on-the-Hill ( $\left.\frac{1}{4}\right)$, Mucking (I), East Tilbury (I), Chadwell (2), ', Grays Thurrock (I),' West Thurrock (I, but 2 in I086), Barking (I), Ilford ( $\mathrm{I}$ ). The last twelve places lay along the Thames. Of these salt water fisheries the nature, at that time, is obscure, and they must be dealt with in a special note appended to this Introduction, in which it will be suggested that they were akin to the weir. The fisheries on the river Lea form a distinct group. These would clearly be weir fisheries such as bridled, we know, the Thames and the Medway, ${ }^{3}$ the Exe ${ }^{4}$ and the Severn. ${ }^{5}$ We trace them up from Leyton, where there had been $9 \frac{I}{2}$, through Walthamstow, where there had been 6 with $3 \frac{1}{2}$ more at Higham, and Chingford, where there were 6, to Waltham Abbey, where were 5, and Nasing where there was 'half a fishery.' ${ }^{6}$ At Leyton all had disappeared; at Walthamstow and Higham all but one. Of 'fisheries' inland we have mention only of one each at Wormingford, Hutton and Springfield, and two-thirds of one at Marshalls in Hatfield Peverel, of one at Bardfield, added since the Conquest, and one at Wheatley in Rayleigh, to which a second had similarly been added. Mention may here be made of the 'fisherman' who occurs on the Bishop of London's manor at Little Totham, and of the ' 5 bordars by (super) the water, who hold no land,' at Leigh, on the Thames, for they suggest the infancy of that little port which, in the days of Queen Elizabeth, was 'stocked with lusty seamen.'

It is needless to dwell on the importance, at that period, of salt, especially in a county so far distant from the brinepits of Worcestershire or Cheshire. A good supply must have been needed for the marsh-made cheese alone. The distribution of the saltpans was in Essex extremely local, being virtually restricted to the Hundreds of Tendring, Winstree and Thurstable in the north-east of the county. Lawford, Bradfield, Wrabness and Ramsey had one each, to which another had been added

1 Before the Conquest.

2 Since the Conquest.

3 It was granted by 'Magna Carta' that 'Omnes kydelli de cetero deponantur penitus de Thamisia, et de Medewaye, et per totam Angliam, nisi per costeram maris.' This last clause may throw some light on the nature of the coast fisheries of Essex (see p. 424 below).

4 'The city had to defend her commercial being against successive earls. In Henry the Third's reign the first hindrance to navigation was caused by the Countess Isabel, who made a weir which is still called after her Countess Weir. She did however leave a narrow passage for ships, but afterwards the passage was closed' (Freeman's Exeter, p. 84).

5 See Seebohm's English Village Community, pp. 1 50-4.

6 An interesting fine of 1228 ( 12 Hen. III.) relates to the right to 'fix a weir and make a fishery' within certain limits at Nasing. It speaks of a 'fishery' being 'cast down' (prostrata), which implies a weir. A fishery could be halved either by dividing the profits or by the holder of each moiety having the right to it for three days out of each week. 


\section{THE DOMESDAY SURVEY}

since the Conquest at Bradfield Manston. We then come to an important group lying round Hamford Water, Great Oakley having two, Moze three, Beaumont ('Fulepet') two, and the three 'sokens' three, ten in all. In this Hundred of Tendring, Great Bentley, Thorrington, and Elmstead, though they barely touched the water, had each of them one saltpan.

The Hundreds of Thurstable and of Winstree may be dealt with together as the chief seat, in Essex, of the salt industry. Salcot (once 'Saltcot'), which derived its name from that industry, lies at the head of the creek dividing the two Hundreds, although it was actually in Winstree. Adjoining it, in that Hundred, was Great Wigborough with six saltpans, ${ }^{2}$ and, beyond it, Peldon with one, and Langenhoe with one. To the south of Salcot, Tollesbury had three, and Tolleshunt Guisnes, within it, which had possessed twelve, still had five. Adjoining Tollesbury and Salcot the other Tolleshunts had eight, and Layer (Morney) one ; Goldhanger, to their west, had one and a half as against half a one before, the Tothams seven as against five, and Heybridge one. In addition to all these the king, we find, had four somewhere in Thurstable Hundred. Thus the entire group comprised nearly forty. The only other saltpan mentioned in Essex belonged to the unlikely manor of Wanstead.

As late as Morant's day ( 1768 ) there was at Goldhanger still 'a considerable saltwork, in which is used rock salt brought from Cheshire, mixed with the seawater.' ${ }^{3}$ But the old process of obtaining salt from the sea alone has so long been obsolete that we are indebted for our knowledge of it to a distinguished Scottish antiquary, Mr. George Neilson of Glasgow. At the other end of England,-

In its saltworks the Solway possessed an industry of great importance and high antiquity. At intervals all along both its Scottish and English shores there were salina or saltworks. These were all situated at places where a loose and porous clayey sand, called 'sleech,' formed natural salt beds presenting a surface capable of retaining a very heavy solution of salt after being covered by the tide. The heat of the summer sun disclosed the salty particles glittering on the sleech like hoar frost. From time to time in due season the 'salters,' as the makers of salt were called, first collected the surface sleech on the salt bed by a kind of sledge-drag or scraper, called a 'hap,' drawn by a horse, carted it to the merse or grassy beach, and laid it in heaps beside the place where, after some time, it was to be filtered. Neither the apparatus nor process of filtration was complex. A hole dug in the merse formed a ' kinch' or pit : its bottom and sides were puddled with clay to make it watertight: on the bottom, above the clay, peats were laid : the peats in turn were covered with a layer of sods : sleech was put on the sods till the kinch was nearly filled to the brim, and finally as much salt water was added as the kinch would hold. Filtering through the sleech and the sods the brine at length, when strong enough to float an egg, was allowed to escape by a tube or spout into a wooden reservoir, out of which it was lifted and carricd in pails to the saltpans. These were broad, shallow metal pans, beneath which great fires of peat were lit. After about six hours' boiling the process was complete; the liquid of the brine was wholly evaporated, and the pans full of the finished article. The name of Saltcotes was given to the little cluster of buildings which contained the pans, the 'girnels' or stores in which the salt was kept, and the dwellings of the salters. Such was the system pursued on the Solway in the end of last [the eighteenth] century, and there is small reason to

I See p. 396 below.

2 Down by what are now 'Abbot's Hall saltings,' which belonged to Barking Abbey in 1086.

Morant, i. $3^{89}$. Dr. Laver examined the saltpans there in 1889 . 


\section{A HISTORY OF ESSEX}

doubt that substantially the same primitive and laborious mode of manufacture prevailed from early times. ${ }^{1}$

Mr. Neilson cites a work published in 1612 , in which we read that on the banks of Solway-

the country people gather up the sand within the flood marke, bringing it to land, and laying it in great heapes, etc,, etc. . . there is made thereof good white salt after the temperance of the weather. This place is called the Salt coats.

He also tells us that he saw 'at Saltcoats in Ayrshire, in the summer of I 887 , an old deserted saltpan surviving its usefulness by half a century,' that 'reminiscences of these saltworks occur in the place-names of the sea-board parishes' about the Solway, as in a 'Saltcots' on the shore of Carlaverock parish, 'Lady Saltcots' in Ruthwell, and a 'Saltcots' on the southern or English shore. ${ }^{2}$

No apology is needed for dealing in some detail with an industry which, though long defunct, gave its name to an Essex parish-the only one of that name in England-and of which the memory is preserved by lesser place-names in the county far to the south of the district where alone it flourished at the Survey. ${ }^{3}$

The Domesday vineyards of Essex can hardly be included among its industries, as they were only intended to provide wine for the use of the lord himself; and they are of sufficient interest to deserve separate treatment. In a paper on the subject I have argued that, contrary to general belief, the Normans reintroduced into England the culture of the vine to provide themselves with the drink to which they had been accustomed on the other side of the Channel. ${ }^{4}$ The evidence for this proposition is largely drawn from Essex. Domesday proves that the vineyards existing at the time of the great Survey had been often planted since the days of the Confessor; that they had not, in some cases, yet begun to bear; that they were almost universally reckoned by 'arpents,' a foreign measure ; and that they are normally found on manors held in the lord's hand and probably containing a lord's residence. By 'lord' I here mean a 'baron' or tenant-in-chief. The last of the above four points is well illustrated in Suffolk, where Ixworth, the most northerly point reached by the vine in the east of England, and Clare, on the Essex border, were both the capita of baronies. Of the vineyards at these two places, that of Clare at least had been planted since the Conquest.

In Essex, if not in all England, the most interesting vineyard is

1 Annals of the Solway (1899), pp. 44-51.

2 Mr. Neilson has observed 'holes in the grassy foreshore, from two to three feet deep, a dozen or thereby wide, and six or eight across; the bottom is black, and either dry or half filled with dark and stagnant water. These are the "kinches" or pits once used in the salt manufacture ... no unfit memorials of a dead industry' (p. 51 ).

${ }^{3}$ In the papers of Mr. W. C. Waller, F.S.A., on 'Essex Field Names,' we detect, in Tendring Hundred, a 'Salters field' and 'Salters 10 acres' at Great Oakley, and a 'Salcots' at Brightlingsea ; in that of Dengie a 'Home Saltcoats' at Stow Maries and a 'Salt Coat Marsh' at Burnham; in that of Rochford a 'Saltpan Marsh' at Paglesham, a 'Saltreach field' at Eastwood, and 'East Salts' at Wakering. There is also a 'Salts' at Barking (see Essex Arch. Trans. [n.s.] vols. vi. vii.). Dr. Laver states that the Paglesham saltpans were visible down to 1820 .

4 Essex Arch. Trans. [n.s.] vii. 249-51. 


\section{THE DOMESDAY SURVEY}

that of Suain at Rayleigh. '(There is) now,' we read, ' a park and six arpents of vineyard, and it yields 20 muids (modios) of wine in a good season.' Here both the park and the vineyard were new, new as the castle which Suain had raised, ${ }^{1}$ and this appears to be the only instance in which Domesday mentions a vineyard's yield. Next in interest, and of the same size, is the vineyard at Castle Hedingham, which affords, I think, presumptive evidence that Aubrey de Vere had already made it a seat of his famous house. And here, less, it would seem, than two centuries ago, there were visible 'wild vines bearing red grapes,' the still lingering descendants of the vineyard of its Domesday lord. But Aubrey had also planted another and a larger vineyard, some 4 miles away, on his manor of Belchamp Walter, where he had, I think, another residence. Only one of its eleven 'arpents' had as yet come into bearing. Aubrey seems to have been fond of vineyards, for we find that he had one at Lavenham, across the Suffolk border, and another on his Middlesex manor of Kensington. Next in size to the Belchamp vineyard was that at Great Waltham, which points, I think, to Geoffrey de Mandeville, the lord of that manor, having made the adjoining stronghold at Pleshey his seat already. Next in importance are the vineyards planted by Ranulf Peverel at Debden and at Stebbing. At both these places, which follow one another in Domesday, the vineyards were new, so new indeed that only half was in bearing at either place. There remain only the small vineyards of the two dapiferi, Eudo and Hamo, of whom the former had planted, at Mundon, two arpents since the Conquest, and the latter one arpent at Stambourne or Toppesfield. ${ }^{2}$

Among the live stock mentioned in the second volume of Domesday are the bees, whose importance then was far greater than now. There are numerous entries of rents paid partly in honey in the other volume of Domesday, especially on Crown demesne. ${ }^{3}$ 'Bee-culture reached, to all appearances, a high state of cultivation among the Anglo-Saxons, and was held in peculiar regard by the people as the chief element in a favourite drink.' But it was not only for mead that bees had to be kept. From them was obtained also wax for the church, and the only substitute then available for our own sugar. A careful analysis of the entries suggests no conclusions save that hives appear to have been far more common in the north than in the south of the county. Their numbers fluctuated, we find, greatly; but this may have been sometimes due to mere shifting of the hives, as where we read of Frating and St. Osyth, which had the same under-tenant, that there were six hives at Frating where there had been none, and none at St. Osyth's where there had been $\operatorname{six}$ (fo. $75^{b}$ ).

From the laity we turn to the clergy and their glebes. It was only with the clergy as holders of land that Domesday was really concerned,

1 See p. 346 , note 1 .

In later days one of the manors in West Thurrock is said to have been actually called 'Le Vyneyard ' (Morant). At Ashdon there was an 'acre' of vineyard in 1086.

- Andrews' The Old English Manor, p. 206. Compare p. 335 above.

See p. 420 below. $3^{83}$ 


\section{A HISTORY OF ESSEX}

so that their mention is merely incidental. At Latton we read of a priest who holds no less than half a hide belonging to a church. At Monksbury in Hallingbury there had been a priest who had similarly ' 20 acres,' but these had been taken from the church. So too at Wethersfield Gilbert the son of Warin had obtained possession of ' 30 acres,' which had been held 'in almoin' by a priest in King Edward's time, and of $8 \frac{\mathrm{I}}{2}$ acres 'belonging to another church.' An interesting entry under Horndon-on-the-Hill shows us a deacon holding ' 30 acres' and a fourth share in the church, which is described as of the king's gift (or almoin). At Peldon, where a deacon was the tenant-in-chief,' the church had ' 30 acres,' which was also the extent of the glebe at Downham, while at 'Hacflet,' in Dengie Hundred, it was 40. At High Easter the church had possessed half a hide, but this was held of Geoffrey de Mandeville by one of his retainers at the time of the Survey. An entry, valuable for the origin of glebe, records that at Stifford the 30 acres belonging to the church had been given to it by neighbours. No less important is an entry under Horndon-on-the-Hill, which is suggestive, if one may say so, of an Anglo-Saxon 'squarson.' ' (a) free man' had held there a manor assessed at two hides and a quarter, out of which he had bestowed on 'a certain church' three-quarters of a hide, which 'Suain took away from the church.' It is probable that in all these instances the estimate represents, not the area, but the assessment in hides and 'geld' acres. The most important endowment in the county was that of St. Peter's, Colchester, which had possessed an estate assessed at two hides, and had been held in the Confessor's time by two priests of the king's gift (or almoin). In I086 a quarter of this estate was in the hands of 'Eudo dapifer,' and the rest was claimed by Robert son of Ralf de $\mathrm{Ha}(\mathrm{s})$ tinges. $^{2}$

There are several cases in Essex in which priests are mentioned without glebe. From the evidence afforded by the adjoining counties of Middlesex and Herts it may safely be concluded that in such cases the priest is entered as having, with the villeins, a part in the agricultural system. Three successive entries of manors in the valley of the Roding (fo. $3^{6 b}$ ) are here in point : at Little Canfield there were 'then I priest and 9 villeins; now I priest and 7 villeins'; at the Roding which follows we read of I priest and 8 villeins, while under the next Roding we have the suggestive entry: 'Then 3 villeins; now I priest and 4 villeins.' So too at Little Easton we have: 'Then 5 villeins and I priest; now I priest and 3 villeins'; and on a Leyton manor we have : 'Then 6 villeins; now I priest and I villein.' A similar entry under Great Easton records: "Then I I villeins and I priest; now I 5 villeins and I priest.' At Saling a noteworthy entry reads: 'Then 3 villeins and I priest ; afterwards I ; now 2 villeins and I priest.' These entries, it will be seen, class the priest with the villeins; and where there were no villeins, he is even classed with the bordars. The Saling entry is immediately followed by one relating to Little Maplestead, in which we

$$
1 \text { See p. } 418 \text { below. }
$$




\section{THE DOMESDAY SURVEY}

read: 'Then 2 bordars; afterwards I ; now 5 and I priest.' So too at Chickney, where there were no villeins, we are told that there were 'then 7 bordars; now I priest and I 4 bordars.' The other entries of priests record simply the presence of 'a priest and (so many) villeins.' Such are those on a Writtle manor, at Stanstead Montfichet, Wimbish, Dunmow (fo. 69), Lindsell (fo. 49), Thundersley (fo. $76 b$ ), Latton (78b), and Saling (fo. 84). But a singular entry on fo. 27 reads: 'Then 2 men dwelt there; now I priest.' There is separate mention of a priest at Coggeshall, and at (East or West) Ham we read of three virgates which had been held by Edwine, 'a free priest,' in King Edward's time. This curious phrase may perhaps be compared with the 'priest (a) free man' at Horndon-on-the-Hill.

Among the matters which of late have attracted attention in Domesday are the entries of houses in towns belonging to rural manors. Essex affords us several instances, and they illustrate a state of things which still distinguishes the county, namely that its great towns are not Chelmsford in its centre, but Colchester, which is nearly at one of its extremities, and London, which is beyond the other. These two towns monopolize the houses appendant to rural manors in Essex, though two or three of the latter had rights in Sudbury on the Suffolk border. Beginning with London, the Bishop of Durham had there, as appurtenant to his manor of Waltham (Abbey), I 2 houses 'and a gate which the king gave to the bishop's predecessor'; to Barking (the abbey's manor) there belonged ' 28 houses and the moiety of a church,' and West Thurrock had 7 houses. In Colchester, at the other end of the county, were several houses belonging to manors, which are partly entered under those manors and partly recorded in the survey of the borough itself. Putting together all these, and circling round the town from east to west, we find that Ardleigh had two houses, Elmstead one, West Mersea one, Great Wigborough one, Tolleshunt one, Birch two, Feering two, and Great Tey one. ${ }^{2}$ Further away, Terling to the south-west had five, and Shalford to the west three. The distribution of these manors is worth noting. In Sudbury there belonged to Castle Hedingham I 5 burgesses, and dues were payable thence to each of the manors in Henny (fos. $74,84 b$ ).

Colchester will form the subject of separate treatment below ; but Maldon, the only other town at that time in the county, requires some notice. It had some 180 houses in addition to the sites on which had stood 18 others, and its total render under the Confessor was not much lower than that of Colchester, of which, however, it seems to have been less than half the size. It is remarkable that although the burgesses had ' among them' a considerable amount of live stock, 165 out of the 180 held no land, which presents a striking contrast to the state of things at

1 See Prof. Maitland's Domesday Book and Beyond, on 'Heterogeneous Tenures in the Boroughs' (pp. 179-82).

2 It is not improbable that other manors in the same district, such as Bromley and Peldon, had houses appurtenant in Colchester (see pp. 412,418 below). 


\section{A HISTORY OF ESSEX}

Colchester. The urban portion of Maldon seems to have been wholly the king's, but Count Eustace, Ranulf Peverel, and Suain of Essex all had rural estates in 'Maldon,' the largest and most valuable being that (fo. 73) in which Ranulf had succeeded Siward (' of Maldon') and which was oddly omitted by Morant. The most interesting, however, is that of Suain, for it is entered as sharing with the other 'burgesses' (although agricultural) the duty of finding a horse (caballum) in the host and of providing (faciendam) a ship. The latter part of the service thus incidentally mentioned is explained by the charter of Henry II., known only through a note in Morant's work (i. 33r). The king therein limits the 'forinsec' service of the burgesses to the provision of one ship in the fleet (in exercitu) for forty days at their own cost when they are specially summoned by his letters to provide it.

A few miscellaneous matters may here be grouped together. The frequent allegation of 'exchange' should be observed; it would seem that, when a holder could not produce a satisfactory title to his land, this was the plea usually advanced to account for its possession. A somewhat unusual dispute is referred to under Geoffrey de Mandeville's fief. There are entered together 3 manors, of which we read that the king directed Hugh de Berners to hold them of Geoffrey, if Geoffrey could prove them to belong to his fief (fo. 6r). Hugh was involved in another dispute, which is entered among the 'Invasiones' (fo. Ioob), and of which the record is interesting but obscure. The practice of assigning on manors where a Norman baron was seated 'small holdings' to Norman retainers is illustrated at Hatfield Peverel, where 'Serlo, Ernulf and Richard' are named (fo. 72), at (Castle) Hedingham, where 90 ' acres' are held in varying amounts by four named tenants (fo. $76 b$ ), and at Belchamp Walter (which appears to have been another seat of Aubrey de Vere), where three such tenants are named (fo. 77). Of political events Harold's victory at Stamford Bridge, on the eve of the Conquest, owes its incidental mention to the fact that an Essex thegn from Paglesham took part in his march to the north (fo. 15); and a mysterious ' naval battle against King William' is referred to under Kelvedon Hatch, the lord of which had taken part in it (fo. 1 4b). A small point connected with the currency should not be overlooked. An Englishwoman, who was the holder of 18 acres, paid to the manor of Stanway 32 pence (nommos) a year. The word nummus (or nommus) is rare in Domesday, but the point to observe is that this sum of 32 pence represents two ounces of silver ${ }^{1}$ and illustrates the practice of making payments based on the ounce of sixteen, not of twenty pence.

The remaining portion of this introduction will deal with three important subjects: (I) The identification of Domesday manors in Essex; (2) the administrative division of the county as seen in the Domesday Hundreds; (3) the construction of the text in Domesday Book from the lost original returns for each Hundred.

Morant, the historian of Essex, having given great prominence to

1 Compare Inquisitie comitatus Cantabrigiensis, p. 41, and pp. 378 above, 420,432 below. 386 


\section{THE DOMESDAY SURVEY}

the descent and identification of manors, it has been generally and naturally supposed that he could be safely followed. In spite of the somewhat early date $(1768)$ at which his volumes were published, he enjoyed great advantages in the fruits of his predecessors' labours among the public records, especially in having a complete collection of the Inquisitiones post mortem. His references show that the materials required for this department of his work were as familiar, virtually, to him as to ourselves, while the plea-rolls were even more so. 'I wanted,' he frankly confessed in his Preface, "no materials of any kind, but only the art of digesting them, and how I have executed that part is left to the reader's candour and judgment.' It would be profitless and most unfair to criticize the writer for having failed to utilize records which we ourselves possess in a far more convenient form; nor would one imitate his somewhat ungenerous mention of his predecessor, Salmon, in speaking of the 'poor use he had made of the excellent materials in his possession.' But as, privately and officially, great reliance has been placed on his identification of manors, it will be necessary to give at some length the reasons for rejecting it in certain cases. Where the proof is a simple one, a note to the text will suffice; but at times a somewhat elaborate argument is needed to establish an identity, and as all manorial history rests on right identification, no apology is needed for the length of the indispensable demonstrations which will be found below. Morant had a firm grasp of the key to manorial descent, namely the relation of manors to the great feudal 'Honours'; but where the descent of an Honour conflicted with his own erroneous identification, he appears to have put it aside.

The most frequent error of the older county historians in identifying the names of Domesday manors was that of jumping at some resemblance more or less superficial or remote. It was thus that Morant discovered Pleshey in 'Plesinchou,' Althorne in 'Altenai,' Chigwell in 'Cinguehella,' Riffhams in 'Richeham,' and Beeches in 'Bacheneia.' This erratic guesswork is now, one would hope, obsolete, although we have a startling instance to the contrary in the Red Book of the Exchequer, where 'Alferstone ' (p. 505) is identified with perfect confidence by the official editor as Alphamstone (p. 1089), a sheer guess which the tests he claims to have applied to his identifications (pp. ccclxxix.-ccclxxx.) would have shown at once to be wrong. One has only to consult the index to Morant to discover that 'Alferestuna,' as it is styled in Domesday, was the manor of Bigods in Dunmow, in quite another part of the county. The other extremity of error is reached by those students of 'phonology' who endeavour to apply to Domesday forms what they term the laws of sound, and thus to connect these forms with the names which now represent them. Essex affords some striking examples of the absolute futility of this method. For instance, Odo, Bishop of Bayeux, in 1086 , held land at two places, both named 'Torinduna.' One of these is now Thorndon (corruptly Horndon) in the south-west; the other is Thorrington in the north-east. Even more remarkable is the snare involved 


\section{A HISTORY OF ESSEX}

in 'Legra.' This is, rightly, the equivalent of Layer, the common name of a group of villages in Winstree Hundred. But it is also employed in Domesday, unlikely though it may appear, for Great Lees in the heart of the county, and for Leigh on the Thames as well. On the other hand, one of the Layer manors is actually entered as 'Lega.' Lastly, there is some reason to believe that, in one entry, 'Witham' denotes, not Witham, but a manor of Whettenham in Dengie Hundred, now represented by 'Whitmans' farm.

What is really required for the task of identification is, not a knowledge of 'Aryan roots' or of 'sound-laws' with alarming names, but practical common sense. A working acquaintance with the great record will enable the student to discover the modern equivalents of 'Eltenai' or 'Altenai' and of 'Bacheneia' in such existing names as Iltney and Beckney respectively, and yet to allow for the Domesday scribe's occasional eccentricity, and for the no less eccentric perversions to which local names have been subjected by generations of peasants, by ill-informed constructors of maps, or by too ingenious antiquaries.

I have spoken above of the necessity for checking our identifications of Domesday manors by bearing in mind the descent of the 'Honours' to which they belonged. In Essex the entirely distinct 'Honours' of Peverel of Nottingham and Peverel of London, which at the time of Domesday were respectively held by William Peverel and Ranulf Peverel, were both represented. Fairsted and a manor in Stebbing were held of the latter, but Morant inexplicably confused the two distinct Honours, and accounted for the subsequent possession of these manors by the Ferrers family by the intermarriage of Ferrers with Peverel of Nottingham, the founder of which latter family he made a son of Ranulf Peverel (ii. I 19, 413). ${ }^{1} \quad$ Where Ferrers did, it would seem, succeed the Peverels of Nottingham was at Thurrock, now Grays (Thurrock). For the charter by which Henry 'de Grai' obtained a confirmation of this 'Turroc' in II95 expressly recites that it 'is of the fee of Earl De

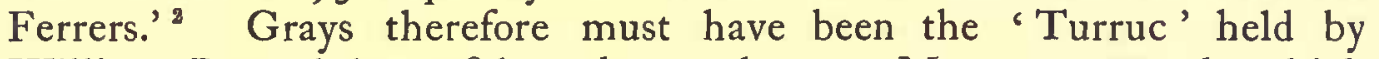
William Peverel in 1086, and not that, as Morant assumed, which was held by the Count of Eu. This latter can be absolutely proved to be identical with West Thurrock. ${ }^{3}$

A curious example of the confused skein that has to be disentangled is afforded by Morant's history of the manor of Braham Hall in Ardleigh. He identified it as that portion of Ardleigh which is entered in Domesday as held by Richard FitzGilbert (de Clare) ; but he traced its descent, as 'Braham,' through the heirs of Montfichet. To account for this he asserted that Richard's 'successors took the name of Montfichet' (i. 439), although the Montfichets, as he well knew, were the successors of Robert Gernon, not of Richard FitzGilbert." The whole difficulty thus created disappears at once when we discover that the 'Braham' held by Montfichet's heirs was the manor of Brantham in Suffolk, which was Robert

\footnotetext{
1 See also p. 346 above.

3 See my paper on 'Castle Guard' in Arch. Journ. lix. 153.

2 Cart. Ant. DD. I 3.

4 See p. 347 above. 


\section{THE DOMESDAY SURVEY}

Gernon's in Domesday and which had nothing to do with Ardleigh. A similar case is that of Burnham, where Morant believed the Hodeng family to have held a considerable estate (i. 364 ; ii. 379). The place however with which they had to do was not the Essex, but the Buckinghamshire Burnham, famous for its beeches. In these instances of course it might be urged that the history of other counties was not so accessible to Morant as it is to ourselves. But this explanation will not account for the cases in which he gave as history a manorial descent which was merely an erroneous guess of his own. The descent of Thorrington was traced by him through three generations of the house of Anestie till it passed by marriage to Montchensy (i. 450). But the house of Anestie had never had anything to do with Thorrington, which was one of those Essex manors which the great house of Montchensy obtained as successors to its Domesday tenant, Ralf the son of Turold. Morant, knowing that they had obtained some Anestie manors by marriage, merely guessed that Thorrington was among them. ${ }^{3}$ Even more extraordinary was his treatment of Blunts Hall, which he asserted to have been held by the great Blund family, and to have passed with their heiress to the house of Valognes (ii. 108), although both statements are altogether imaginary and are even disproved by his own evidence. ${ }^{2}$

The case of Great and Little Birch is a further instance. An Inquisition of May 9, I 275, taken after the death of Aveline, Countess of Lancaster, and cited in two places by Morant himself, ${ }^{3}$ proves that Little Birch was one of a group of manors held of her, as one of the heirs of Robert Gernon's barony, by Robert de Verley. Among these manors were those of Salcot (Verley) and Gernons in Tolleshunt (Darcy), both of which are entered in Domesday as held of Robert Gernon by Robert de 'Verli.' This group was held as four knights' fees, and was one of those which are found as so held in the Montfichet carta of I1 66. From this evidence we learn that the 'Bricia' entered in Domesday as held by Robert Gernon was Little Birch, and that 'Robert,' its undertenant, was Robert de Verli. Yet Morant identified it as Great Birch in the teeth of the evidence printed by himself. Moreover his own history of the manor of 'William à Birches' in Great Birch proves clearly that it was held of the Montfort 'Honour of Haughley' and must therefore be identified with Hugh de Montfort's Domesday manor of Layer ('Legra'), to which it adjoins. And yet he makes that 'Legra' to be identical with two manors in Layer de la Hay, which he could not connect in any way with Hugh de Montfort (i. 4II-2).

The connection of Hugh de Montfort's fief with the constableship of Dover is often of great assistance in helping us to trace his manors. Domesday assigns to him one manor situate in Chelmsford Hundred, makes it the subject of a long entry, and names it 'Bedenesteda.' As

\footnotetext{
1 Sec my paper on 'The Descent of 'Thorrington' in Essex Arch. Trans. [n.s.] viii. 373-4.

- See my paper on 'Tregoz of Tolleshunt Tregoz' in Essex Arch. Trons. [n.s.] viii. $331-2$.

Vol. i. 423 ; ii. 184 . This particular portion of the return appears to be now lost.

- Red Book of the Exchequer, p. 349. It was probably the first on the list.
} $3^{89}$ 


\section{A HISTORY OF ESSEX}

Hugh's fief was subsequently known as the Honour of Haughley or of ' the Constabulary,' we ought to be able to trace this manor among the fees which owed castle ward at Dover, several lists of which are preserved. ${ }^{\mathrm{I}}$ From one of these we fortunately learn that Robert de Scales held of the Honour of Haughley one fee ' in Bedenestede in Essexa.." Morant alleged, somewhat vaguely, that the manor lay in West Hanningfield and Rettendon, and that its name was preserved in 'Bensted Common' (ii. 38-9), which is no longer found on the map. But the above entry leads us to look for some manor in Chelmsford Hundred held by the Scales family; and this we find in Sandon. Moreover Sandon is known to have been held as one fee 'of the castle of Dover.' and to have paid ten shillings to its castle-guard : in both these respects it answers to 'Bedenesteda.' Therefore although ' there is no mention of it,' according to Morant, ' in Domesday' (ii. 26), I cannot hesitate to see it in the 'Bedenesteda' of the Survey. Hugh's manor however was only one portion of it ; another manor is entered in Domesday (although Morant ignored the entry) as in 'Bedenesteda,' and as held of Robert son of Corbutio, the devolution of whose fief is somewhat obscure. It is probable that there were two distinct manors, which Morant, as in another instance, has confused.

The student has also to be warned against a strange liberty which Morant took with his records. The returns of knights' fees in II 66 record the names of knights who held of a tenant-in-chief, but not the names of the places in which their lands were held. Morant supplied the latter out of his own imagination. Kewton or Cuton Hall, for instance, is an ancient manor in Springfield, of which the name would lead us to look for it in Domesday. There is a 'Keuentuna' in its own Hundred of Chelmsford, and when Kewton Hall first appears in I 372 , we find it held of the heir of Geoffrey de Mandeville, the Domesday lord of 'Keuentuna.' Morant however tells us that this Domesday manor was Camseys in Felsted, and was so called because, in the reign of Henry II., ' it was holden by Henry de Camse, as a knight's fee,' of Earl Geoffrey de Mandeville (ii. 418). We turn to his authority only to find that it names no locality, and that Henry's fee might as well have been, and probably was, in East Tilbury, where on his own showing the Camsey family held, under the heirs of Mandeville, one knight's fee (i. 233). Felsted, one may add, is just beyond the border of Chelmsford Hundred, nor is there anything in Domesday or in any subsequent record to connect Geoffrey or his heirs with any land in the parish.

Kewton in Springfield adjoins Boreham, which affords us another example of a modern parish representing more than one of the ancient

\footnotetext{
1 No fewer than four such lists are contained in the Red Book of the Exchequer, and they all name this manor (pp. 614,706,718,742). In one, which is cited in the next note, the editor places it (as 'Bensted ') in Essex; in the other three he assigns it, in inexplicable error, to Kent (compare Arch. Fourn. lix. 155 ).

2 Red Book of the Exchequer, p. 742.

3 See Inquisitions of 10 Hen. V. and I I Hen. VI. cited by Morant under Sandon, and that of 23 Sept. 25 Hen. VIII. (1 533 ) on Thomas Tamworth.
} 


\section{THE DOMESDAY SURVEY}

place-names entered as distinct in Domesday. For I have identified its 'Culverts' with the 'Richeham' of the Survey, ${ }^{1}$ while the 'Walfara' of Domesday preserved its name as a manor in Boreham of which even the identity appears to be now lost. It is of some importance to keep in view this type of Essex parish composed of several distinct 'vills,' because the more salient Essex type is one which will have to be discussed below, namely that in which several parishes represent a single ancient name. It is obvious that the marked contrast between these opposite types-a contrast which the Domesday map brings into strong relief-may have an important bearing on the early settlement of the county. For the present I will only cite two more instances of parishes representing an aggregate of Domesday 'vills.' Finchingfield includes Boyton ('Boituna') and Ashwell ('Assewella') ; and Arkesden comprised the 'vills' of Eynesworth ('Eineswrda') and 'Wiggepet,' of which the very names are now lost, ${ }^{2}$ while their identity was ' not to be distinguished' when Morant wrote (ii. 588). I have succeeded however in tracing them by the help of the (Saffron) Walden cartulary.

We will now turn to what is, perhaps, for the task of identification the most difficult Hundred in the county, namely that of Dengie (the 'Witbrictesherna' of the text). Of the twenty-one parishes in the Hundred, the names of no fewer than seven ${ }^{4}$ are not to be found in Domesday. On the other hand, there are several manors named in the great Survey of which the identity is difficult, if not impossible to determine ; and wild guesses have naturally led to almost hopeless confusion. Althorne is not represented by the 'Eltenai' (or 'Altenai') of Domesday, ${ }^{6}$ which is proved by the St. John's Cartulary to have been lltney in Mundon. The 'Acleta' of Eudo Dapifer cannot represent Asheldam, ${ }^{6}$ which must, from the evidence of records, have been held by Suain of Essex. 'Eistanes' is Little Easton and not Stow Maries." The 'Lachentuna' of Hugh de Montfort is Latchingdon itself (as the very records cited by Morant prove), and not a manor in Purleigh ; and it is nothing but a guess that 'Ulwinescherham' was Steeple (which was 'Stepla' in Domesday) or that 'Weneswic' was Westwick in Burnham, an identity which the records cited by Morant himself put out of the question.

It is easier, in the case of this Hundred, to demolish than to reconstruct. But in one case at least an important identity can be proved. The great parish of Bradwell-by-the-Sea contains rather over 5,000 acres; and in it, as we might expect, were several distinct manors. Morant believed that Bradwell Hall, which formed its south-western portion, was the 'Effecestre' of Domesday, and that Down Hall, to the north, was its 'Duna'; Battails he could not identify in Domesday, and of East $\mathrm{Hall}$ he began the history in 1627 . But $I$ have identified the two

I See p. 387 above, p. 519 below.

2 It would seem possible that the former name is preserved in the surname Ainsworth ; for the - Eilesford' and 'Eilesberia' of Domesday are now Aylesford and Aylesbury. 'See pp. 476, 568 below.

- Althorne, Asheldam, Bradwell, Mayland, St. Lawrence, Snoreham and Stow Maries.

6 Morant, i. 36 I. 6 Ibid. i. 367, and p. 393 below. 7 See p. 303 below. 


\section{A HISTORY OF ESSEX}

portions of which 'Effecestre' was composed in 1086 as the manors of Battails and of East Hall.' The latter was in the eastern portion of the parish towards the chapel of 'St. Peter-on-the-Wall,' which marks the site of 'Ithancestre.' The test of ' pasture for sheep ' applies here again ; for we read that 'Effecestre' had 'pasture for 500,' and the marshes of Bradwell lie on its eastern side. Its infinitely larger manor of 'Duna' had only pasture for I 50. The owners of Battails and of East Hall are brought into conjunction by a fine of 9 John (1 207), when the Abbot of St. Valery granted to Aumari Battaile land lying in ' La Waule' with the marsh of Garemundecote and right of way thereto.' 'La Waule,' doubtless, like the chapel of St. Peter, derived its name from the wall there. ${ }^{3}$

We have still to account for the rest of Bradwell. Morant identified Down Hall with holdings of Eudo Dapifer and Ranulf Peverel in 'Duna,' which amounted to a little over seven hides; but he oddly overlooked Ranulf Peverel's other holding in 'Duna,' which is entered as no less than fourteen hides. Finding that part of Bardulf's fee, which is known to have been Bradwell Hall, was held of the Honour of Peverel, ${ }^{4}$ I strongly suspected that this also had once been part of 'Duna.' And this suspicion became certainty on finding the sheriff accounting in I I 66 for fio from 'Duna,' the king's brother's share. ${ }^{5}$ For 'the king's brother' was William (d. I I64), who had enfeoffed Thomas Bardulf at Bradwell Hall. ${ }^{8}$ The sheriffs of Essex continued to account for this foro a year till Easter, II74, when Seiher le Chien, a Fleming, and Boidin Ailet were given by the Crown the lands in 'Duna' which this rent represented, to hold by serjeanty in war." Such was the origin of the manor of Down Hall, which represents the portion of 'Duna' remaining to William, 'the king's brother,' after he had granted to Thomas Bardulf what was afterwards Bradwell Hall.

Another identity can be established with almost equal certainty. Asheldham, from a very early period, descended with Little Horkesley as part of the Honour of Rayleigh ; ${ }^{8}$ its church was given by Robert

1 For Battails was held of the Honour of Haughley, and was therefore the portion of Hugh de Montfort ; and East Hall belonged to New College, which body had obtained the lands of St. Valery, the Domesday owner of the other portion.

2 Feet of Fines for Essex, p. 42 (No. 232). The Abbey's marsh of 'Gurmonds' occurs in 1308, when the cattle were sometimes prevented by the tide from reaching it (Morant, i. 377).

3 Both East Hall and Battails are entered as in 'Walle' or 'Walla' in 1212 (Testa de Nevill, pp. 268-9), so that this name had at that time replaced 'Effecestre.'

4 Red Book of the Exchequer, p. 740. Compare Testa de Nevill, pp. 264, 278.

5 'De Duna parte fratris Regis' (Pipe Roll, 12 Hen. II. p. 126 ).

8 Testa de Nevill, p. 268 ; Red Book of the Exchequer, p. 499.

7 Pipe Roll, 20 Hen. II. p. 68 . It is specially interesting to note that they received this land 'by writ of Richard de Luci,' who was then in the thick of his struggle with the king's enemies. They were donbtless alien mercenaries brought over by him for war. It is abundantly proved that Seiher received $f_{6} 6$ worth of the land and Boidin $\oint_{4}$ (Red Book of the Exchequer, p. 507 ; Testa de Nevill, p. 268). Seiher's portion passed by gift to Henry de Tibetot, and that of Boidin was subsequently leased by Thomas 'de Duna.' The record from which we learn this speaks of them both as in 'La Waule' (Red Book, p. 804; Testa, p. 272), a place which, naturally enough, baffled the Red Book's editor (see note above). Morant knew nothing of all the above story, and confused the holding of the family of 'de la Dune' ( $\oint_{4}$ a year) with that of Henry de 'Tibetot (i. 376).

8 This is shown by the evidence cited by Morant himself under Asheldham. 


\section{THE DOMESDAY SURVEY}

Fitz Godebold, about the time of Henry I., to the priory he founded at Little Horkesley, and the two manors were subsequently held by the family which took its name from Horkesley. We have then to look for Asheldham among the manors in this Hundred held by Suain of Essex. One of these was at Iltney $;^{1}$ the other was 'Haintuna ' or 'Hainctuna.' 2 We are thus forced to the conclusion that 'Haintuna' and Asheldham were identical, an identity supported by the fact that Domesday assigns to the former some acres of meadow, meadow being rarely met with in the Hundred; for Asheldham is watered by 'Asheldham brook.' The name of 'Haintuna' appears to be lost, but we can recognize it in that 'Aintune' which occurs in a fine of 9 Richard I. (I I 97-8), to which the wife of Walter 'de Aledhorn' [Althorne] is a party.

But perhaps the most unexpected and most interesting discovery in the Hundred is that of the identity, in Domesday, of what is now Stow Maries. Of one grave error we may dispose decisively and at once. The rich manor of 'Eistanes,' held by Walter the Deacon, is placed, no doubt, by Domesday, in Dengie Hundred between two entries relating to Purleigh. It was identified by Morant with the manor of Stow Maries, his grounds being thus stated :-

What makes me conclude that this is the place called in Domesday Book 'Eistanes' is first because Walter the Deacon held it, who had manors in the neighbouring Purley; next that a manor here was called Hayes, which had an alternate in presenting to the living. I would therefore suppose the ancient name [of Stow Maries] to have been 'East Hayes' (i. 350).

Mr. Chisenhale-Marsh, who accepted this conclusion with hesitation, pointed out that Morant had, in this, followed Salmon. The real identity of 'Eistanes' is not a subject for doubt; it is the manor of Little Easton, far away in Dunmow Hundred, the head of Walter's barony. Its extensive woodland, mentioned in Domesday, is now represented by Easton Park. Morant, having thus deprived himself of its chief Domesday equivalent, boldly supplied its place by William de Warenne's 'Estanes' (ii. 430), although his own evidence proves that this was the manor of Blamsters in Great Easton (ii. 434).

As for the manor of Hayes in the parish of Stow Maries, Morant found it in the 'Haintuna' of Domesday, which I have identified with Asheldham, while Mr. Chisenhale-Marsh suggested that it might lurk in the Domesday 'Halesduna.' But the latter appears as a true place-name in a charter which suggests that it should be looked for somewhere in Mundon." And, to prove that there was a manor called 'East Whytenham,' Morant cites a fine of 1342 for the manor of that name 'and

1 It reappears as 'Eltenhey,' held of the Honour of Rayleigh, in 1303 and 1428 (see Feudal Aids, i. 133,217 , where however it is not identified).

I have suggested that the entries under these names are duplicates (see p. 4 ro below).

3 Feet of Fines for Essex, i. 12.

- Warner son of Richard Petitsire granted to the Abbot of Colchester (who was lord of Mundon), 'et hominibus suis de Hailisdune,' right of way on the street running from west to east to the land of Geoffrey de Hauckestune, 'a transversu illius vie que venit de Wiggebruge versus Meldonam ' (Cokchester Cartulaty, p. 623). 


\section{A HISTORY OF ESSEX}

lands in Haylesdon, Munden and Mayland' (i. 349). ${ }^{1}$ 'This manor of 'East Whytenham' leads us to another inquiry. The only manor Morant could discover was that of 'West Whetenham and Flambards' in the parish of Cold Norton (i. 349). Yet he knew that 'in I 294 John de Wytenham held of Philip Burnel in Wytenham in the parish of Stow (Maries) one carucate of land by the service of a knight and a half' (i. 350). Now due east of Flambards, the manor-house of West Whettenham (afterwards 'West Whetnams'), we still find 'Whitmans,' five furlongs off. I feel confident that 'Whitmans' is a mere corruption of Whitnams, and that it represents the lost East Whittenham. ${ }^{2}$ We may now take a step further. Philip Burnel held an estate formed of manors which Robert Gernon had held in I086, and the house of Montfichet after him. Accordingly we find a Roger 'de Wytenham' holding by knight service of Richard de Montfichet; ${ }^{3}$ and, working back to Domesday, we discover Robert Gernon holding a hide and a half in 'Witham' as well as a manor in Purleigh. It has been naturally supposed by the historians of Essex that this entry relates to Witham where Robert Gernon had a manor, which is entered in its proper place. But as Domesday assigns the above 'Witham,' like Purleigh, to Dengie Hundred, it was probably the existing 'Whitnams,' which immediately adjoins Purleigh."

For Stow Maries I have now to suggest a novel identification. The evidence cited by Morant himself (i. 350) shows that it was held of the Bohuns, the heirs of Geoffrey de Mandeville, as two knights' fees. Now Domesday assigns to Geoffrey, in this Hundred, the manors of 'Fenna' (or 'Phenna ' ${ }^{6}$ ) and (apparently) 'Weneswic.' On turning to the carta of his heir, eighty years later, we find a 'Willelmus de Fenna' holding of him two knights' fees ; ${ }^{\circ}$ and these, I suggest, clearly represent Stow Maries. It is interesting to observe that this parish, which from Stow Creek to Clements Green Creek abuts on the Crouch, adjoins Fambridge, which appears to have derived its name 'Fanbruge' or 'Phenbruge' from the fen formed by the Crouch, while, to its west, 'Fen creek' leads up to "Woodham fen."

Althorne, which was wrongly identified by Morant with the

1 The 'Hailesdune' of Domesday became Hellesdon in Norfolk, and in Lincolnshire its ' Haintune' is now 'Hainton.' It is most improbable therefore on this ground that Hayes, in Essex, represents either 'Haintuna' or 'Halesduna.' From the latter, doubtless, the Robert 'de Halesdon' of Ancient Deeds, A. 538 , derived his name.

2 This corruption is similar to that by which, as I have shown in a note to the text (p. 456 ), the 'Samantuna' of Domesday became Sampton, and is now represented by Sampsons. The addition also of the final ' $\mathrm{s}$ ' is found in Dengie Hundred, where the 'Uleham' of Domesday is now 'Uleham's farm.'

3 Testa de Nevill, pp. $263,277$.

4 The Berkshire Wittenham is represented by three entries in Domesday, in all of which it is 'Witeham.'

5 I have suggested that these entries are duplicates (see p. 4 I 0 below).

6 Red Book of the Exchequer, p. 346.

7 I have not been able to identify 'Weneswic' in this Hundred, but it may just conceivably be represented by 'Wellinditch,' a farm in Stow Maries, which adjoins 'Morris ' farm, of which the name is corrupted trom 'Mareys,' the family who gave name to the parish (it is Mareys on Morant's map).

Although one does not associate the word 'fen' with Essex, the name of 'Orsett fen' (as it is still termed) is found at an early date. 'Bulphan fen' is near it. 


\section{THE DOMESDAY SURVEY}

'Altenai' or 'Eltenai' of Domesday (i.e. Iltney), is not named in the great Survey. But its history shows that this was because it was then reckoned, for the most part at least, as belonging to the manor of Southminster. That great manor of the Bishop of London was assessed at thirty hides and probably extended some eight miles, as the crow flies, east and west. The valuable list of the bishop's knights in $1212^{1}$ shows us 'Alestorn' held as three knights' fees and consisting of four carucates; but the first occurrence of the name, perhaps, is found in the earlier list of his knights which belongs to I $66 ;^{2}$ among them occurs Walter ' de Aletor.' The manor of Mayland (Hall) adjoining Althorne and Southminster appears to have been similarly treated as part of the latter in Domesday, where its name is not found. Walter 'de la Maylande' held of the bishop a carucate in Althorne in $12 \mathrm{I} 2$.

There remain however in Dengie Hundred, among its Domesday manors, not only several, mentioned above, of which the identity is doubtful, but others on which it has not yet been possible to throw any light. Such are the king's 'Ulwinescherham,' Bishop Odo's 'Hacflet,' Eudo Dapifer's 'Wringehala,' 'Landuna' and 'Acleta,' Hugh de Montfort's 'Estoleia,' and Hamo Dapifer's 'Carseia.' Of these the most provoking is ' Hacflet,' for a century later we meet with it as 'Hackeflete,' with a glebe reckoned, as in Domesday, at 40 acres, and held apparently by John son of Guy de Rochford, who was then a minor in the king's gift. This should enable us to trace the manor without difficulty, but it does not do so. As for 'Estoleia,' it reappears as 'Scoleghe' under Henry III.," but, even then, cannot be identified.

The prettiest identification perhaps of a Domesday name in the county is that of a mysterious 'Adem,' an evidently valuable manor, which Domesday assigns to Ralf Bainard and places in Tendring Hundred. As there is no name resembling it in that Hundred, Mr. Chisenhale-Marsh abandoned it, naturally enough, in despair. But the Domesday scribe was apt to be misled by the similarity, in MS., of ' $\mathrm{cl}$ ' and ' $d$ '; in Sussex he entered Donnington as 'Cloninctune,' and in Northamptonshire, conversely, he made Clapton into 'Dotone.' If 'Adem ' represents a similar blunder, its true form would be 'Aclem,' and, further, on subtracting the final ' $m$,' which distinguishes the eastern counties Domesday and by which Mr. Seebohm was so strangely misled, we obtain the form 'Acle,' which is the Domesday name of the Suffolk Oakley. Turning to Tendring Hundred for an Oakley held by Ralf, we find at once that Little Oakley (which is supposed to be omitted in Domesday) was always held of his successors, the lords Fitz Walter. And the evidence takes us further. For the two manors which, in Domesday, were held of Ralf by 'Germund' were Little Baddow and 'Adem'; and Little Baddow and Little Oakley were held together of

1 Red Book of the Exchequer, p. 542.

8 Rotulus de Dominabus (1185), p. 39 .

Ibid. p. 187.

4 Red Book of the Exchequer, p. 743.

see The Commune of London and other Studies, p. 14. I have there cited "Accleiam' (Great Oakley) as an instance in point. 


\section{A HISTORY OF ESSEX}

Ralf's successors by the house of Filliol, and both paid 'castle ward' to Baynard's Castle, London. And, lastly, we find that Little Baddow was held as three knights' fees, and Little Oakley as two and a half; and we thus discover that they represent the five and a half knights' fees which were held of Walter Fitz Robert by Richard de Baddow ('Badwan') in I I 66,' as 'Germund' had held them of Ralf eighty years before.

Divided only by Great Oakley from the parish we have just discussed is that which now bears the French name of Beaumont. Morant asserted that "no mention occurs in Domesday Book of this parish, which probably was then included under Mose or some other adjoining parish' (i. 485). But its 'lords paramount,' as he observed, were the Veres, Earls of Oxford; and we turn therefore to the manors held by Aubrey de Vere in Domesday. ${ }^{2}$ In Tendring Hundred he held only Bentley, Dovercourt and 'Fulepet,' the last of which has not been identified. It was a fairly valuable manor, and it must have touched the coast, for it had two saltpans. Moze, which adjoins Beaumont on the shore of Hamford Water, had three; and Oakley beyond had two. Saltpans in Essex were by no means common, and their distribution was local. ${ }^{3}$ Putting together the evidence we may say without hesitation that 'Fulepet' was no other than what is now Beaumont. And I venture to go further, and suggest that the name of 'Beaumont' was intended to express the exact opposite of the English 'Foul hollow' (Fulepet). The identification has a special interest because an Essex locality named 'Fulanpettæ' occurs in an Anglo-Saxon will ${ }^{4}$ about the close of the tenth century, immediately after Dovercourt, that is, in the very same position as 'Fulepet' in Domesday Book.

If in certain cases it is possible thus to identify manors, in others the evidence is conflicting. A question of extreme difficulty is raised by the entry of the considerable manor of 'Walla.' Morant, who held that Domesday placed it in the Half Hundred of 'Thunreslau,' confidently identified it with the later manor of Wallbury in Great Hallingbury, which, he suggested, 'probably extended northward to the parish of Stortford, and southward [eastward ?] to the present Forest, taking in Wall Wood, which still preserves its name; there could not otherwise have been at the Conquest wood for feeding I,500 hogs' (ii. 5 I 5 ). This is plausible enough till we trace the alleged descent. In 1086 it is held of Peter de Valognes, and is worth $\AA_{0} 12$ a year; more than a century later, under John, it is held of the king by two serjeants as two estates in 'Hallingeburia' or 'Hallingebiria de Walla,' each of them worth $E_{0} 3$ a year. ${ }^{5}$ This accounts for only half the value even at the time of Domesday ; and moreover Peter's fief had not escheated to the Crown, which could not therefore make grants out of it to serjeants.

\footnotetext{
1 Red Book of the Exchequer, p. 348 .

2 See p. 535 below.

4 Harl. Cart. 43. C. 4. B Red Book of the Exchequer, pp. 457, 507. 396
} 


\section{THE DOMESDAY SURVEY}

Lastly, when Wallbury thus first comes before us it is spoken of, we see, as if imperfectly detached from Hallingbury rather than a separate place with a name of its own. The identity of name however is so much in Morant's favour that one is loth to reject his view. But we can now assert that his 'Thunreslau' was at the other end of the county, and that 'Walla,' following as it does Loughton and 'Theydon Bois, must be assumed to have been probably in the same Hundred as they were, that is, in Ongar. This is only an assumption, but if we act upon it, and search for such a name in that Hundred, we find that North Weald Bassett itself lies in it, though nearly half the parish is in Harlow. And of North Weald Morant could find no mention in Domesday. Its Domesday equivalent however should be 'Walda,' and the area of meadow land assigned by the Survey to 'Walla' suggests that it lay in a river valley rather than on Cripsey brook.

Reviewing all the evidence the case stands thus. We have to find a Domesday equivalent for North Weald Bassett, a parish of more than 3,400 acres almost equally divided between the Hundreds of Harlow and of Ongar. In the former we have in Domesday two entries under 'Walda' and one under 'Walla'; in the latter apparently we have a great manor entered as 'Walla' and held by Peter de Valognes. One cannot assign much importance to the actual form of the name, for the Rodings not far off occur in Domesday as 'Roinges ' and as 'Rodinges.' Of the 'Walda' entries in Harlow Hundred Morant assigned the one on the fief of Peter de Valognes to Wallbury and the other to Weld in Harlow, an arbitrary and inconsistent identification. He appears to have overlooked the fact that almost half of North Weald lay in Harlow Hundred, for he deals with it only under that of Ongar, and he consequently pitched upon Weld in Harlow itself as 'Walda.' But the form 'Weld' appears to be of rather doubtful authority, and North Weald itself (to which 'Weld' adjoins) is a more likely equivalent for both the 'Walda' entries. The real difficulty is the 'Walla' which I take to be in Ongar Hundred. If it was so, it must have been the Ongar portion of North Weald, and this conclusion is strongly supported by the fact that North Weald was held of the heirs of Peter de Valognes, the Domesday holder of 'Walla'; but even the evidence for this is not so clear as could be wished. ${ }^{2}$ Looking at the whole of the evidence at present available, it appears to favour the identity of 'Walla' with North Weald, although the extent of its meadow-land strongly supports, on the contrary, the view that it lay in the valley of the Stort.

The labour expended on identifying the manors named in Domesday will often prove of the utmost value for the right ascertainment of

1 See p. 405 below.

2 It consists of ( 1 ) an Inq. p. m. of 129I, showing that North Weald was held by the successors of the 'Essex' family, as five knights' fees, of the Castle of Benington (i.e. the head of the Valognes barony in Herts); (2) a return in the Testa de Nevill (p. 263) showing that Henry de Essex held five knights' fees of the Valognes barony (compare Ancient Deeds, A. 768,774). But these five fees were located by the Inquisition in places which cannot be connected with the Valognes fief (compare Morant, i. 149). 


\section{A HISTORY OF ESSEX}

place-names. In Barstable Hundred, for instance, are two adjacent parishes of which Morant wrote, with perfect confidence, as follows :-

North of Fange . . . are two contiguous parishes named Langdon. . . The common name of these two parishes is otherwise written in records Laingdon, Laindon, Laundon, Langenduna, Legniduna, and Leienduna. Langdon Hills is the most southern of the two. By way of distinction from the other the word Hills is added. .. L Langdon with Basildon is north of the other. By way of distinction from it, it is called Langdon Clay (i. 246).

Now, when we turn to Domesday, we find Suain of Essex holding a five-hide manor entered as 'Langenduna'; and this manor, which continued to be held in after times of his Honour of Rayleigh, was demonstrably Langdon 'Hills.' ${ }^{\prime}$ But we also find in Domesday the Bishop of London holding 9 hides at 'Legenduna' and half a hide at 'Leienduna.' These manors can, with equal certainty, be assigned to Morant's 'Langdon Clay,' which is known to have been held by the Bishop of London, and of which, as the Domesday forms would obviously lead us to expect, the true name was Laindon, and not Langdon at all. ${ }^{2}$ How entirely distinct the names were is shown by the feudal surveys, in which these places are regularly entered as 'Langedon' and 'Leyndon' respectively in I 303, I 346 and I 428. ${ }^{3}$ Yet Morant, as we have seen, believed Langdon to be the right name of both parishes, while the Ordnance Survey of to-day has adopted the opposite alternative, and decided to assign to them both the name of Laindon!

Let us take another instance, also from Barstable Hundred. Not far from Langdon and Laindon are the parishes of East and West Horndon, two long strips of land lying side by side. In the same Hundred, separated from them only by the breadth of Bulphan, lies Horndon-on-the-Hill. We will deal first with the last of the three. The Domesday holding of the Count of Boulogne at 'Horninduna' was here, and is the only occurrence of the place in Domesday according to Morant (i. 216). It consisted of the manors of Malgreffs ${ }^{4}$ and Ardern Hall. But the manor of Wythefeld, which is also there, was held, as he knew, of the Honour of Rayleigh, and was clearly the 'Horninduna' held by Suain in Domesday, which is wrongly assigned by Morant to East Horndon (i. 207-8). And there was also 'a manor or capital messuage called Cantis,' which paid castle-guard to the Bishop of London' (i. 2rg). This therefore was the 'Horninduna' assigned

1 'Honor de Reylege . . . Johannes de Langedone I feodum in Langedone in Essexa' (Red Book of the Excbequer, pp. 538, 739). "John de Vere who died in 1421 held the manor of Langdon of the Honour of Raleigh by knight's service. He held also lands and tenements . . . in the several parishes of Leyndon,' etc. (Morant, i. 250).

2 The bishop had licence to enclose a wood there, as at 'Leyndon,' Oetober 1, 1 260, and obtained view of frankpledge for his manor of 'Leyndon,' October 18, 1290 (9th Report on Historical MSS. i. 45). Morant himself cites (i. 248) the foundation (in 1329) of a chantry 'in this Langdon,' where the name of the place and of its church is given as 'Leyndon.'

3 Feudal Aids, ii. 133, 158, 217. They are similarly 'Langedon' and 'Leindone' in the (printed) Hundred Rolls under Edward I. And compare Ancient Deeds, A, 518.

4 So named from the family of Malgreffe, which long held it of his 'Honour' (Red Book of the Exchequer, pp. 501, 579; Feudal Aids, ii. 133,158, 217, 440). In neither of these works is the place identified as Horndon 'on the Hill.' 


\section{THE DOMESDAY SURVEY}

by Domesday to the bishop, which Morant placed in East Horndon (i. 208) although he could find there no trace of the bishop's lordship. Having now cleared out of the way these three holdings, we will turn to East and West Horndon, as they are still known to-day. Morant observed that :-

There are within this hundred three parishes named Horndon, distinguished from each other by the respective appellations of East, and $W_{\text {est, }}$ and on the Hill, so styled from their situation. But those distinctions were not existing at the time of the general survey. The name is derived from the Saxon words Horn and dun, j.e. Horn-hill. It is sometimes written Thorndon; in which case the first syllable would be derived from Thorn. And in records it is called otherwise Horninduna, Torninduna, and Torenduna.

Two names entirely distinct have here again been confused. The first manor entered on Suain's fief in Domesday is that of 'Torninduna,' which was large enough to be assessed at more than 5 hides. This manor was held of that fief 120 years later as one fee by a William 'de Tornindone,' who clearly, like the Langedon family, derived his name from his estate, and it regularly recurs in the feudal aids of the two following centuries as "Thornyndon.' ' Its name is now represented by Thorndon, the well-known seat of Lord Petre, although the parish in which it stands is corruptly known as West Horndon. The identity of this parish (which contains but one manor) with the above 'Torninduna' of Domesday (wrongly identified by Morant as East Horndon) is shown by the fact that the township of ' Westorendon,' in the thirteenth century, advanced the plea that they belonged to 'the king's liberty of Rayleigh,' that is to Suain's Honour.' But the form of the name given in the plea shows that the corruption was of early date.

Passing from West to East Horndon we identify in it the manor of Abbots as held in Domesday, not, as alleged by Morant, by Suain, but, as his own evidence proves, by William Peverel (of Nottingham), who held it as 'Torinduna,' and of whose 'Honour' it was held as 'Torindone' or 'Torrindone' by Henry de Cornhill" and his heirs the Nevills, who gave it to Waltham Abbey, whence its name.

The evidence of Inquisitiones post mortem entirely confirms the view that Thorndon was the true name of both parishes alike. That on John de Bryanzun ( 9 Ed. II.) shows him holding the manor of 'Thorndon' and tenements at 'Horndon' (on the Hill) ; and a list of 'Tany's knights' fees in I I Edward II. includes 'Thorndon parva' held by John de Breanzun."

The inquisitions on the Earl of Oxford in I Henry IV., on Sir John de Vere in 9 Henry V., and on Sir Lewis John in 21 Henry VI. all speak

1 Red Book of the Exchequer, p. 621. The deed of partition between the heirs of 'Sir William de 'Thorendone' is at St. Paul's (9th Report Historical MSS. i. 32).

2 Feudal Aids, ii. 133, 158, 217. Cf. Ancient Deeds, A. 732.

3 'Sunt de libertate Domini Regis de Reilee' (Hundred Rolls, i. 137). Morant was quite unable to trace the descent of the manor, although his own evidence proves that it was held by Briancon under the Tanys of Stapleford Tany, who were themselves great tenants of the Honour of Rayleigh.

1 Red Book of the Exchequer, Pp. 122,584 (where the place is wrongly identified as Thorrington by the editor).

S See note 3 above. 


\section{A HISTORY OF ESSEX}

of the adjoining manors as 'Est' and West 'Thorndon.' The latter knight's will spells the names similarly, and so does that of his descendant in $1527 . .^{1}$ On July $25, \mathrm{I}_{42} 3$, the Crown also presented to the church as to that of 'Est 'Thorndon.' 2 'The returns in Feudal Aids distinguish 'Thorndon' and 'Horndon' as carefully as does Domesday, where 'Torninduna' and 'Horninduna' are entered on the same page. We may therefore safely say that, exactly as with Laindon and Langdon, Morant was mistaken in assuming that the two names were identical, and that Horndon-on-the-Hill is the representative of the 'Horninduna' of Domesday, while its 'Torninduna' is represented by East and West Thorndon, as they used to be, and ought to be, named.

To those who are inexperienced in the study of county history it may seem a matter of small moment that 'Horndon' and 'Thorndon' should have been confused." But without the most scrupulously careful distinction between places similar or identical in name the descent of the manors they contain is reduced to a hopeless jumble, especially where, as is the case in Essex, such similarity or identity is of very frequent occurrence.

Moreover, the facts established above illustrate in a forcible manner the strong tendency on the lips of the people to the corruption of local place-names by wrongful assimilation of the true form to a neighbouring but distinct name. Due west of the Thorndons, and just within the Essex border, we see this process exemplified in the striking case of Walthamstow. Entered in Domesday as 'Wilcumestou,' it continues to occur in records as 'Welcomstowe,' 'Welcumestou,' 'Welcomestowe,' and so forth, down to at least the fourteenth and fifteenth centuries, when it meets us as 'Welcomstowe,' 'Wolcomestoue' and 'Wolkhomstowe.' It is obvious that the modern 'Walthamstow' is a corruption due to the near neighbourhood of the great parish of Waltham. It also appears to me that Shellow owes the addition of its 'Bowells' suffix ${ }^{5}$ to the fact that it was only divided by Fyfield from the neighbouring Shelley, and that here too there was a tendency to confuse on the lips of the people these distinct place-names.

Something has been said above (p. 39I) of one of the two types represented among Essex parishes, namely that in which the parish comprises two or more Domesday manors which appear, from their distinct names, to have been once distinct vills. As this type is detected only by local knowledge or minute research, ${ }^{6}$ it is naturally less familiar

1 Essex Archeological Transactions [n.s.] vi. 54-7.

2 Pat. I Hen. VI. p. 2, m. 3.

3 Horndon-on-the-Hill contains 2,650 acres, and the two Thorndons together 2,925.

4 'The Petre family adhered rightly to the form 'Thorndon,' and even when a new parish church was erected (1 734) for Ingrave and West Horndon a contemporary inscription styles the latter, 'Thorndon Occidentali(s)' (see Morant, i. 2 I 5 ).

5 See p. 356 above.

6 It is somewhat overlooked by Prof. Maitland, who holds that, 'as a general rule, the political geography of England was already stereotyped' in 1086, that when Domesday Book 'mentions the name of a place... speaking very generally we may say that the place so named will in after times be known as a vill and in our own day will be a civil parish.' . . 'A place that is mentioned in Domesday Book will probably be recognized as a vill in the thirteenth, as a civil parish in the nineteenth 


\section{THE DOMESDAY SURVEY}

than that in which a single name is borne by a whole group of parishes. 'The science of village morphology,' Professor Maitland has observed, 'is still very young'; but its fascination and its importance for the early history of our race have led him to devote special attention to this second and more familiar type, of which he found remarkable examples in the eastern counties and especially in Essex. ${ }^{1}$

It will be best to give in his own words the Professor's observations on the subject :-

Very often we find two or more contiguous townships bearing the same names and distinguished only from each other by what we call their surnames. Cases in which there are two such townships are in some parts of England so extremely common as to be the rule rather than the exception. If, for example, we look at the map of Essex, we everywhere see the words Great and Little serving to distinguish two neighbouring villages. Cases in which the same name is borne by three or more adjacent townships are rarer. . . Essex is particularly rich in such groups; close to Layer Marney, Layer de la Hay and Layer Breton are Tolleshunt Knights, Tolleshunt Major and Tolleshunt Darcy. In the same county are High Laver, Little Laver and Magdalen Laver; Theydon Gernon, Theydon Mount, Theydon Bois; also (and this is perhaps the finest example) High Roding, Roding Aythorpe, Leaden Roding, White Roding, Margaret Roding, Abbots (sic) Roding, Roding Beauchamp and Berners Roding. ...

In general, where two neighbouring modern villages have the same name, Domesday does not treat them as two. Let us look at the very striking case of the various Rodings and Roothings, which lie in the Dunmow hundred of Essex." Already six lords have a manor apiece 'in Rodinges'; but Domesday has no surnames for these manors; they all lie 'in Rodinges.' It is so with the various Tolleshunts in the Thurstable Hundred : there are many manors ' in Tolleshunta' (Archacological Revirw, iv. 236-8).

It is a matter of detail and of no great consequence that Domesday does not, as here alleged, uniformly employ the phrases 'in Rodinges' or ' in Tolleshunta.' Out of sixteen entries relating to 'Rodinges' (or ' Roinges,') only one has the prefix 'in '; and out of twelve relating to 'Toleshunta,' only one has that prefix. But this has at least some bearing on the argument. The important thing, however, is the Professor's conclusion. He thinks that these examples 'suggest that in a very large number of cases the territory which was once the territory of a single township or cultivating community has, in course of time, perhaps before, perhaps after the Norman Conquest, become the territory of several different townships.' This would made us 'think of the township ... of very ancient times as being in many cases much larger than the vill or township of the later middle ages, or our own "civil " parish," and would even 'make the vill approach the size of a Hundred.' Therefore, he suggests, " as we look backwards, we seem to see a convergence between the size of the township and the size of the Hundred,'

century,' that 'in general the vill of Domesday Book is still a vill in after days,' and that 'the villa of Domesday Book is in general the vill of the thirteenth century and the civil parish of the nineteenth' (Domesday Book and Beyond, Pp. 9-17).

1 See the paragraphs on 'Fission of vills,' 'Village colonies' and 'New and old villages' in his Domesday Book and Beyond, pp. 14,365,367; and his paper on 'The Sumames of English Villages' in Archaological Review, iv. 233-40.

2 This is an error. It is important to observe that the Rodings are divided between the Hundreds of Dunmow and of Ongar. 


\section{A HISTORY OF ESSEX}

leading us possibly to identify with the latter, in its original form, 'the agricultural community, the community which had common fields.'

The whole argument rests, it will be seen, on the assumption, however unconscious, that all parishes are of the same size. As they are very far from being so, the entire area of a group need not be very large. To take those selected by the writer, the three Lavers only contain 4,082 acres; the three Layers, 5,551; the three Theydons, 6,920; the three Tolleshunts, 7,483 ; and even all the Rodings together no more than I I,839. These, no doubt, are large areas, but so are those of the ' civil parishes' of Thaxted $(6,251)$, Great Waltham $(7,457)$, Hatfield Broadoak (8,809), St. Osyth (8,877), and Barking (12,307). Whatever size therefore we assign to the ancient Hundred, it cannot be said that the groups selected approach it more nearly than sundry 'civil parishes.' So much for the 'evidence which seems to show that the vill of ancient times was often a much larger tract of land than the vill of modern times; that the area belonging to an agricultural community was not unfrequently as large as the area of some of our Hundreds.' I venture therefore to hold that it does not lead us to a 'time when township and Hundred were identical, or rather-for this would be the better way of putting it-when the Hundred, besides being the juridical community, was also an agricultural community.'

Professor Maitland, in his later work, refers us to this argument, but puts the matter rather differently. He writes of the groups in question :-

Doubtless they point to a time when a single village by some process of colonization or subdivision became (sic) two villages... so when we see two different villages called Hamton and Other Hamton, lying next each other, we may be fairly certain that they are not of equal antiquity, and it is not unlikely that the one is the offshoot and daughter of the other. ${ }^{2}$

'Fission of vills' and 'Village colonies' are phrases which seem to me to suggest two opposite theories. The former implies the breaking-up of an originally large area; the latter suggests an area originally small, from which colonists have gone forth to found fresh settlements in the forest belt around.

Domesday, as the writer observes, is vague in its terminology ; ' in a few instances it marks off the little village from the great village of the same name ${ }^{3}$ in some other instances it will speak, for example, of Mordune and Mordune alia, of Emingeforde and Emingeforde alia, or the like, thus showing both that the change has taken place and also that it is so recent that it is recognized only by very clumsy terms.' Let us glance at the Essex instances. 'Great' and 'Little' Birch, as they are styled in Domesday, preserved those names as distinct parishes down to

1 Archacological Review, iv. 235.

2 Domesday Book and Beyond, pp. 14,365. But on p. 367 we return to the 'many cases which seem to tell us that in the oldest days the smallest district that bore a name was often large, and therefore that the territory which subserved a single group of homesteads was often spacious.'

3 'A good many instances,' he observes in a note, 'will be found in Essex and Suffolk.'

4 Domesday Book and Beyond, p. I4. 


\section{THE DOMESDAY SURVEY}

the eighteenth century. Domesday distinguishes also between 'Great' and 'Little' Stanford (Rivers), but this distinction cannot, it seems, be traced subsequently ; part of Colne Engaine is distinguished as 'Little' Colne in the Survey; but of such distinctions there are no more. The villages distinguished by 'other' (alia) are only Fyfield, Navestock and Melesham (if rightly identified) in Great Lees. It is a curious and significant fact that in no one of the three cases do we find any trace of two villages of the name. Here then, it seems, is a further warning against attaching much importance to the terms employed in Domesday or endeavouring to build theories thereon. The case of Stanway is one which caused me much perplexity, because of the difficulty of fixing its locality on the Domesday map. Morant wrote of it as follows :-

There is great reason to believe that this district, in the earliest times, was divided into two distinct parishes. For here are not only two churches partly still standing; but we frequently meet in records with the names of Stanwey magna and Stanwey parva, Great and Little Stanway; the former being the southern part of the present parish, and the latter that which is by the London road. But if they were distinct, it must have been before the year 1366. For, from that time, the church hath been presented to by the name of Great Stanway, with the chapel of Albright, or of Little Stanway, annexed. And for a long time these two names have been considered only as the names of two different hamlets (ii. 190).

There is however in Domesday only one 'Stanewega.' As Stanway is obviously so called from the old Roman highway passing through its northern portion, it is natural to suppose that the original village stood near that highway, where indeed the chapel of St. Albright (Æthelbricht) must, from its invocation, have stood before the Conquest. And Morant, indeed, observes that "the manor-house of Stanway stands on the south side of the London road, near the brook.' On the other hand, his history of the parish appears to confuse the two Stanways, and leaves us in utter doubt as to which of them represents the original village.'

Before leaving this important subject, it may be well to explain that the 'two types,' as I have termed them, of Essex parish must not be confused with the 'two types' which Meitzen, Professor Maitland writes, has taught us to look for. 'The nucleated village and the vill of scattered homesteads,' as he describes them, ${ }^{3}$ are characteristic respectively of the east and the west of England, of the Celtic and of the Saxon land, as we gather from his pages. ${ }^{3}$ The type to which I have endeavoured to draw attention in Essex, that in which two or more vills named as distinct in Domesday are now represented by one 'parish,' owes its form, as it seems to me, more probably to an ecclesiastical than to any other cause. The one and only discoverable feature which imposed unity on the area was the 'parish' or mother church. The

1 Having begun his account of 'the manor of Stanway' by describing its manor-house as above, he ends by telling us that 'Stanway Hall,' adjoining 'Great' Stanway church in the south of the parish, 'stands pleasantly on an eminence by the side of the road from Colchester to Maldon,' and finally speaks of sbis seat as 'Stanway manor-house.' Possibly the 'London road' of the passage quoted in the tert was a slip for 'Maldon road.'

Domesday Book and Beyond, p. 15. 


\section{A HISTORY OF ESSEX}

unit which contained that church gave its name to the whole area; and that area found its unity in no other conceivable cause than in the rights possessed over all of it by the single parish church. As the church on a great scale is said to have given unity to the kingdom, so, on a small one, it seems to me, the church gave to the parish its unity and its form. To take three extreme cases, Hornchurch, Berechurch and St. Lawrence are parishes to-day, but they were at first but the names of buildings. The name of West Donyland has given way to Berechurch, even as, a few miles across the Hertfordshire border, the name of Lefstaneschurch, now Layston, has taken the place of those names found in Domesday Book.' And 'St. Lawrence' has supplanted the Domesday names of (East and West) Newland. In Essex Wimbish and Thunderley were once distinct parishes, and they are the subjects in Domesday of distinct entries. But in 1425 the vicarage of Thunderley was united to that of Wimbish, and ' as to the church of Thunderley,' Morant wrote, 'the place where it stood is now part of a field' (ii. 56r). Thunderley accordingly has vanished from the map. Wimbish, which has the church, now gives name to the whole. In the same way, 'Beauchamp St. Ethelbert' was once a distinct parish, but since $1473^{\text {'Ovington and }}$ Beauchamp St. Ethelbert have been united together and presented to by the name of Ovington with the chapel of Albright ... after which the chapel, growing out of use, was suffered entirely to decay; but there are two distinct parsonage-houses and glebes." ${ }^{2}$ Ovington, because it has the parish church, has long given name to the whole, and indeed I have not even been able to locate Beauchamp St. Ethelbert for the purpose of the Domesday map.

Enough has now been said, I hope, to make it clear that the church is the decisive factor in the local divisions of the county. If Springfield or Boreham, Arkesden or Finchingfield, are each of them but one 'civil parish,' it is because there was in each but one parish church. If Laver or Tolleshunt, on the contrary, is divided into three parishes, it is simply because there were three churches. It was not a matter of area at all. We have in Essex no example in which the ecclesiastical origin of such divisions is as obvious as in the cases cited from Norfolk by Professor Maitland himself. ${ }^{3}$ Nor have we, as in Suffolk, a Domesday instance of the practice." But Chignal St. James is still distinguished, as Beauchamp St. Ethelbert once was, by the invocation of its church, while in Margaret Roding and Margaretting we have two parishes distinguished by their patron saint, St. Margaret, from other Rodings and Ings, as 'Genevieve's Fornham' was distinguished from the other Fornhams in Domesday.

It is only when we look at the Domesday map and compare it with

1 See the Victoria History of Hertfordshire, i. 310.

2 Morant, ii. 338.

3 'Wiggenhall St. Mary the Virgin, Wiggenhall St. German, Wiggenhall St. Peter, Wiggenhall St. Mary Magdalen, Tilney cum Islington, Tilney All Saints, Tilney St. Lawrence, Terrington St. Clement, 'Terrington St. John, Walpole St. Peter, Walpole St. Andrew' (Domesday Book and Beyond, p. 367).

- The present Fornham St. Genevieve is ' Genoveva [printed 'Genoneva '] Forham' in Domesday ( $362 a)$, a distinction unnoticed by Prof. Maitland, and perhaps unique. 


\section{THE DOMESDAY SURVEY}

one divided according to modern parishes, that we realize the great change in local divisions and nomenclature effected by the church. Names which are now either lost or represented only by a manor or farm are there found as those of places as important then as some which have now eclipsed them in our eyes. The terminations of many of these point to their early origin, but the most interesting are the 'thorpes.' So distinctive is the 'thorpe' termination that when Mr. Freeman visited Essex he was incredulous, I have been told, as to its occurrence in the county. Yet even to-day we find on the map the parishes of Gestingthorpe, Easthorpe and Thorpe-le-Soken. The last of these, at the time of the Survey, was included in the soke of 'Eadwulfsness,' and therefore does not occur by name; but, in compensation, Domesday shows us, in the south-east of the county, North and South 'Thorpe,' standing, it should be observed, near Shoeburyness, precisely as Thorpele-Soken adjoins that other ' ness' which once gave name to 'Eadwulfsness,' and gives it now to Walton-on-the-Naze. ${ }^{\text {' }}$ Of these Scandinavian terminations, 'ness' is similarly preserved in Foulness, Wrabness and Eastness (near Clacton-on-Sea), ${ }^{2}$ while 'thorpe' lingered for a while in the now forgotten name of Ingledesthorpe in White Colne.

Stranger than the disappearance from the map of the ancient township names is that of an ancient Hundred. The archaic name of 'Thunreslau,' now wholly lost, occurs twice in the Essex Domesday as that of a 'Half Hundred,' and the most startling achievement, perhaps, of Essex historians in the way of identification was the bold translation of this 'Half Hundred' from the neighbourhood of Sudbury on the Suffolk border to that of Bishop Stortford. Morant observed of this ' uncommon, and at present unknown, district of the Half-Hundred of 'Thunreslau,' that Domesday mentions it-

as comprehending the manors of Belchamp, Belindune, Bineslea and Walla in Great Hallingbury. How these few manors should constitute a Half-Hundred, or whether Thunreslau is an older name for this Half-Hundred than Harlow, we are by no means able to determine (ii. 507).

He identified however the first of these manors with Down Hall in Harlow, 'for the agreableness of its situation'; the second and third he made into the manors of 'Ballington's' and 'the Lea' in Hatfield Broadoak; and the last he placed in Hallingbury. ${ }^{3}$ In all this he was at one with Salmon, who, as pointed out by Mr. Chisenhale-Marsh, adopted these identifications. Yet the Domesday entry which Morant printed as referring to Down Hall had already (ii. 329) been rightly given by him as referring to Belchamp Walter, in the north-east of the county, while that which describes 'Belindune' refers, not to Hatfield,

1 The same variety of form is found in Domesday, which gives us 'Aldulvesnasa' and 'Wrabenasa,' but, across the Stour, 'Colenesse.'

' The position of a corresponding 'Westnesse,' at the mouth of the Colne, which is mentioned in the charter of Richard 1. to Colchester, has been much disputed. 'There are also a 'Tilbury ness' and a 'Stone ness' on the Thames, 2 'Wallasea ness' on the Crouch, a 'Nase wick' in Foulness (adjoining), and at the mouth of the Blackwater 'The Nass.' On the Suffolk bank of the Stour are 'Stutton ness' and ' Ness farm.'

See, for this difficult manor, p. 396 above. 


\section{A HISTORY OF ESSEX}

but to Ballingdon, close to Belchamp Walter, of which Morant could find no mention in Domesday. 'Belindune' was held in Domesday by Peter de Valognes, and it is subsequently found held of his manor of Fakenham in Suffolk, which confirms the identification. Its chapel also is known to have been given to St. Alban's Abbey, to which Peter was a benefactor. The only remaining manor in this Half Hundred ${ }^{1}$ was that of 'Bineslea,' which, although its name is now lost, can be shown to have been in the close vicinity of Belchamp Walter and Ballingdon." The extremely small size of this Half Hundred, together with its name of archaic sound, suggest a possible survival from an earlier period than that at which the great Hundreds by which it is surrounded assumed their present form.

The rest of the Domesday Hundreds have retained their identity and their names with very little alteration. 'Witbrictesherna' is now 'Dengie,' and the 'Liberty of Havering-atte-Bower' appears to have been taken out of Becontree, the 'Beventreu' of Domesday. Broadly speaking, the Essex Hundreds do not, either by their names or their areas, suggest archaic divisions. Nine of them, at least, take their names from parishes within their borders, and usually near their centres; these are Rochford, Chelmsford, Witham, Tendring, Dunmow, Clavering, Harlow, Ongar and Waltham. Lexden, it is important to observe, contains two parishes which are cut off from the rest of the Hundred by the Domesday 'Hundred' of Colchester, a district containing between eleven and twelve thousand acres. This arrangement obviously suggests that the district of Colchester had, at some time, been taken out of Lexden Hundred, a suggestion strongly supported by the fact that Lexden parish itself is within the borough boundary. Becontree and Winstree are ancient names, and I cannot but think that 'Bentry Heath' (now 'Becontree Heath') in Dagenham was at one time the meetingplace of its Hundred, as must have been Hundred Heath (no longer on the map) in Tendring. When the Liberty of Havering was part of the Hundred, it would have been fairly central. Apart from Chelmsford and Rochford, three of the Essex Hundreds, Uttlesford, Hinckford and Chafford, took their name from fords, like several parishes in the county. ${ }^{3}$

On the name of one of these three Hundreds, which has always been deemed an insoluble puzzle, Domesday throws, I think, no uncertain light. The great Hundred of Hinckford is entered in the Survey as that of Hidincfort (2), Hidincforda (2), Hidinghfort (I), Hidinghefort (1), Hidinghafort (2), Hidingeforda (1), Hidingaforda (6), Hidingforda (9), Hidingfort (ro), and Hedingfort ( 1 ); 'but where

1 'Walla' was no more in it than were Theydon and Loughton, which divide it from 'Bineslea' in the text (see pp. 537-8 below).

2 It occurs in the great Hospitallers' cartulary (Nero E. VI. fo. 332d) as a place apparently in the neighbourhood of Middleton and of Goldingham (in Bulmer), and Richard son of Peter de Binesle is found in Ancient Deeds, A. 539, in connection with Bulmer.

- 'Uttlesford Bridge' in Wenden (in about the centre of the Hundred) preserves the memory of the first of these fords. The course of the great London road is marked by Stratford, Ilford, Romford, Widford, Chelmsford, Easterford (Kelvedon), Copford and Empford (Stanway Bridge). 


\section{THE DOMESDAY SURVEY}

the Hiding Ford was from which it took its appellation,' wrote Morant (ii. 249), 'I cannot learn.' Yet we have not to look further than the Hedinghams, lying in the very heart of the Hundred, for the origin of the name. The road by which they were united must have traversed the Colne by a ford, and as roads from the four quarters of the Hundred all met close to that ford, it would form an ideal spot for the Hundred's moot. Local politicians will remember the famous annual meetings of the Hinckford Hundred Conservatives at Castle Hedingham.

The remaining Hundreds are those of Barstable, Thurstable and Freshwell. Of these the first derives its name from Barstable (Hall) in Basildon, a manor entered in Domesday, which is almost in the centre of the Hundred; Thurstable was, no doubt, a place of which the name is now lost ; Freshwell derived, according to Morant, its name from a little stream which flows into the Pant between Radwinter and Great Sandford, and which rises in about the centre of the Hundred. In Domesday, Maldon and 'Thunreslau' are entered as 'Half' Hundreds, Clavering, Freshwell, Harlow, Waltham and Witham sometimes as Hundreds and sometimes as 'Half' Hundreds, but the two first more frequently as the latter, and the three others more frequently as Hundreds. This looseness of expression may prepare us for the fact that Winstree is subsequently styled a 'Half' Hundred in charters, and that on the Hundred Rolls Clavering, Freshwell, Harlow, Thurstable, Winstree and Waltham occur as 'Half' Hundreds, while Uttlesford, as was occasionally the case, is divided into the Hundreds of 'Esthodelesford' and 'Westhodelesford.' On a roll of I 303 Thurstable, Harlow and Clavering are 'Half' Hundreds.' It will have been seen from the foregoing how loose was the classification.

A part from the names, the boundaries of the Hundreds are suggestive of their late formation. The three Thurrocks, in the south of the county, are divided between the Hundreds of Chafford and Barstable; the two Bumpsteads, in its north, between Freshwell and Hinckford; the Rodings are partly in Dunmow Hundred and partly in that of Ongar ; the parishes of Henham and of Stansted Mountfichet are divided between the Hundreds of Clavering and Uttlesford." Other parishes similarly divided by Hundredal boundaries are North Weald Bassett, Epping, Reydon, High Ongar, Great Leighs, Danbury, Little Baddow and Thundersley. In all such cases it may be concluded that the boundary of the parish, or of the group of parishes bearing the same name, is older than that of the Hundred. In Clavering we seem to have a Hundred taken out of Uttlesford for the benefit of Suain of Essex, who appears to have been its lord. ${ }^{3}$

In at least two remarkable instances original settlements are cut

1 Feudal Aids, pp. 129 et seq. Tendring, conversely, is styled 'two Hundreds' in Stephen's charter of disafforestation.

It should, however, be observed that Pledgdon in Henham and Bendfield in Stansted, which are the portions in Clavering Hundred, are distinct hamlets and were separately entered, by their names, in Domesday.

S See p. 345 ; and p. 487 below for his rights in that of Rochford, the other centre of his power. 


\section{A HISTORY OF ESSEX}

asunder by the boundary not only of a Hundred, but of the county itself. The Stour constitutes so clear a boundary between what are now two counties and were once portions of distinct kingdoms that one would hardly expect to find an instance of overlapping. The great lordship of 'Eiland' however, which belonged to Suain of Essex, lay à cheval on the river, and was surveyed in Domesday partly under Essex and partly under Suffolk. It derived its name from the present 'Nayland,' where the site of 'Court Knoll' is still marked by earthworks on the Suffolk side of the stream. This lordship comprised, in Suffolk, Wissington (or Wiston) to the west, Leavenheath to the north, and Stoke to the east of Nayland ; and in Essex, to the south, the two Horkesleys, the name of which accordingly does not appear in Domesday. The lordship had still the same constituents in much later days. ${ }^{3}$ But this case is less remarkable than that of Bures on the same river a little higher up. The portion on the Suffolk side of the stream is the parish of Bures St. Mary ; on the Essex side Bures extends over 3,000 acres, of which the eastern half is in Lexden Hundred, and forms the parish of Mount Bures, while the western portion, 'Bures hamlet,' belongs to the Essex Hundred of Hinckford, although it is a hamlet of the Suffolk parish of Bures St. Mary. ${ }^{2}$ To this anomalous position a reference is made in Domesday, which surveys a holding there under Essex, but adds : ' $\mathrm{Hec}$ terra est in comitatu de Sudfolc' (fo. 846). As at Nayland, the same lord was holding on both sides of the Stour, for Richard de Clare, John Fitz Waleram and Roger 'de Ramis' were all tenants-in-chief at Bures, both in its Essex and its Suffolk portions.

Another anomaly, though less extreme, is found in the case of Ballingdon and Brundon. These are both surveyed under Essex, although they belong, for certain purposes, to Suffolk. ${ }^{3}$ In these, as in similar cases, Domesday follows the Hundred in which they were assessed for 'geld.' One may here, perhaps, refer to the singular fact that, higher up the stream, Kedington on its right bank and Haverhill, although both in Suffolk, were conversely, at one time, hamlets of Sturmere in Essex, according to Morant. This however appears to have been an error on his part. Sturmer, he wrote, was still assessed ' with its hamlets Haverhill and Ketton' (ii. 347) ; but this assessment only referred to the Essex portion of Kedington, known (as in the case of Bures) as Kedington Hamlet, which has now 'been transferred to Suffolk for civil purposes;... it is now only included in Sturmere, Essex, for parliamentary and land tax purposes." " In I 879 a detached part of Haverhill

1 See entry of Nov. 24, 1424, in Calendar of Patent Rolls.

2 Morant ignored all this, and treated Bures hamlet as part of the adjoining parish of Alphamstone. Its ambiguous position is thus set forth in Kelly's Post Office Directory : 'Bures Hamlet, a suburb of and in the parish of Bures St. Mary, Suffolk, ... in the Northern Division of the County [of Essex], Hinckford Hundred, South Hinckford Petty Sessional division (Halstead bench), Sudbury [Suffolk] union and county court district, and in the rural deanery and archdeaconry of Suffolk and diocese of Ely.'

3 'Kelly' states that 'Ballingdon (or Ballington) is a suburb of the town of Sudbury in Suffolk, ... and with Brundon forms a parish ... [in] the Northern division of the County [of Essex], Hinckford Hundred, Sudbury petty sessional division, Sudbury Union and County Court district. ... Ballingdon with Brundon forms a rectory annexed to the vicarage of All Saints Sudbury.' Compare my Ancient Charters (Pipe Roll Society), p. 76. 4 Kelly. 


\section{THE DOMESDAY SURVEY}

was added to Sturmere, and on the other hand a portion of Sturmere has now been transferred to Kedington.' Over 600 acres of Haverhill and over 700 of Kedington are now reckoned as in Essex. On this complication however Domesday appears to be silent.

Even the Thames to the south, like the Stour to the north of the county, does not always form an exact boundary. There belongs to Kent a portion of Woolwich which lies on the Essex bank of the river, and Domesday reckons as in Essex a Gravesend ('Gravesanda') of small extent, which has not been identified.

Before leaving the Hundreds and their boundaries, one may note that the latter, in the east of the county, coincide with the parish boundaries, and that the small geographically compact Hundreds of Thurstable and Winstree are suggestive of ancient origin. All the coast Hundreds are separated by estuaries or creeks, and the quasi-peninsular character of Tendring and Dengie has given them a certain individuality which makes their names still familiar. The 'Lexden and Winstree Board of Guardians and rural district council' preserves the names of two others which figure in Domesday Book. Dengie and Rochford, for some reason, have been locally known as 'The Hundreds.' Broadly speaking, the Hundreds of Essex resemble those of Suffolk ${ }^{2}$ rather than the small ones of Sussex, to which, for racial reasons, one might have expected them to approximate. This would seem to confirm the view that they are mainly of a more recent date than the original settlement.

In Domesday Book the Hundred assumes extreme importance, for the whole country was surveyed, as it was taxed, by Hundreds, that is to say, Domesday Book was compiled from original returns, each of which contained the entries, vill by vill, for a single Hundred on the authority of the 'Hundred' itself, that is, of its sworn representatives. It is possible, in the Essex portion of the Survey, to detect the order in which the returns were arranged for the purpose of compilation. There is no question, in my opinion, that this arrangement began with the Hundred of Barstable and ended with that of Thurstable. The order of the intervening Hundreds is doubtful here and there, but after analysing the fourteen principal fiefs in the county, it may safely be given thus . Barstable, Witham, Harlow, Waltham, Becontree, Dunmow, Dengie (1), Winstree, Uttlesford (I), Clavering, Hinckford, Dengie (2), Lexden, Ongar, Chafford, Chelmsford, Maldon, Tendring, Uttlesford (2), Freshwell, Rochford, Thurstable. The two points to observe here are that the Hundreds of Dengie ${ }^{3}$ and of Uttlesford appear to come twice over,"

I Kelly.

2 Essex has 21, counting Colchester and Maldon (but not Havering); Suffolk, with its slightly smaller area, 23 , counting Ipswich, or 24 counting Bosmere and Claydon as two (as in Domesday).

Dengic follows both Dunmow and Hinckford on the Peverel and Boulogne fiefs, Dunmow and Uttlesford ( $\mathrm{I}$ ) on the king's fief, Dunmow and Clavering on the Mandeville fief, Rochford and Clavering on Suain's fief, and Beventree and Hinckford on the Montfort fief; on the Baynard fief it precedes Dunmow and also follows Hinckford. Uttlesford follows both Dengie (I) and Tendring on the king's fief, and both Winstree and Tendring on the Boulogne and on the Gernon fief.

- Uttlesford was sometimes reckoned as two Hundreds in later days (p. 407 above), but this may be only a coincidence. 


\section{A HISTORY OF ESSEX}

and that geography is thrown to the winds, for the order in which the returns were arranged has no conceivable relation to the position of the Hundreds on the map. The scribes, working from these returns, picked out in each Hundred the manors belonging to the fief they were dealing with in Domesday Book, and, in spite of the liability to confusion resulting from this process, it is recognized that few errors resulted from the rearrangement.

The most interesting of these are the duplicate entries of manors, which possess at times, as I have elsewhere shown, unique value for the light they throw on the treatment by the scribes of the original returns with which they had to deal. ${ }^{1}$

The first of the examples which follow is taken from the fief of Geoffrey de Mandeville and relates to a manor in Dengie Hundred which I identify with Stow Maries. ${ }^{2}$

FENNE tenet Hugo de G[oisfrido] quod tenuit Friebernus liber homo T.R.E. pro Manerio et pro iiii hidis T.R.E. Semper iiii villani. Tunc ii bordarii; modo vii. Tunc ii servi; modo nullus. Semper ii caruce in dominio. Tunc i caruca hominum; modo dimidia. Silva $\mathrm{xl}$ porcis. Pastura $\mathrm{xxx}$ ovibus. Semper val[uit] lx solidos. Habet etiam Idem Hugo i hidam quam tenuit liber homo. Valet xx solidos. Et xxxvii acras habet Idem quas tenuit $i$ liber homo. Tunc dimidia caruca ; modo nulla. Valet $\mathrm{v}$ solidos (fo. 62).
Phennam tenet hugo de verli quod tenuit Friebernus pro Manerio et pro iii hidis. Semper ii villani. Tunc ii bordarii; modo vii. Tunc ii servi; modo nullus. Semper ii caruce in dominio. Tunc $i$ caruca hominum ; modo dimidia. Silva $\mathbf{x l}$ porcis. Pastura xxx ovibus. Tunc $v$ porci $\mathbf{x x x}$ oves, et modo lxx porci. Val[et] $\mathrm{lx}$ solidos. In eadem tenet Idem xxxvii acras. Tunc dimidia caruca; modo nulla. Valet $v$ solidos (fo. 63 ).

Here, it will be seen, dictation is suggested by the phonetic spellings of the name; the numbers of the hides and of the villeins are given differently; and the tenant's name is in one case given and in the other omitted. Moreover the live stock is entered in one case and not in the other, while one of the entries omits a distinct holding of a hide.

The next example is taken from the same Hundred of Dengie and relates to a manor on Suain's fief, which was probably, I have suggested, Asheldam.

Haincrunam tenet Garner' de S[ueno] quod tenuit Godric' libere T.R.E. pro Manerio et prodimidia hida et xxxvii acris. Tunc iii bordarii; modo ii. Semper i caruca, v acre prati. Tunc nichil; modo iii animalia, iiii porci, xi cap[re]. Valet $\mathbf{x x}$ solidos. Hoc manerium habuit $R$ [obertus] filius wimarcæ post adventum regis Willelmi (fo. 46 ).

Haintunam tenet Radulfus de S[ueno] pro Manerio et pro dimidia hida et xxxvii acris quod tenuit I liber homo T.R.E. Semper i caruca. Tunc iii bordarii ; modo ii. $v$ acre prati. Valet $\mathrm{xx}$ solidos. Hanc terram habuit Robertus filius wimarcæ post adventum regis Willelmi (fo. 47).

Here the points to observe are the sharp contradiction as to the name of Suain's tenant, the alternative use of manerium and terra, and the entry of the live stock in one case and not in the other. Its entry appears to have been deemed optional throughout the survey of Essex.

1 See Feudal England, pp. 21-7. And compare my paper on 'the Domesday manor' in Eng. Hist. Review (rv. 299), where I print side by side the survey of Shelford, Cambs., under its own county (D.B. i. I $90 b$ ) and that which is found under Newport, its head manor, in the Essex survey. The discrepancies are great. Sec p. 338 above and Pp. 435-6 below. 2 See p. 394 above. 


\section{THE DOMESDAY SURVEY}

\section{I pass to Hawkswell in Rochford Hundred:-}

Hechwellam tenet Pirot de Eudone quod tenuit Ulmer' T.R.E. pro Manerio et pro iii hidis et dimidia xv acras minus. Tunc xi villani ; modo viii. Semper $v$ bordarii. Tunc ii servi; modo iii. Semper ii caruce in dominio. Tunc vi caruce hominum; modo $\mathrm{v}$. iiii acre prati. Silva $x$ porcis. Tunc ii runcini et $\mathbf{v}$ animalia, cii oves, $\mathbf{x x}$ porci; modo xvi animalia, cvi oves, $x x$ porci, ii vasa apum. Tunc et post valuit vi libras; modo vii (fo. 50).

The variation in the spelling of the name is again suggestive of dictation, while, as there was absolute contradiction in the last instance as to the name of the under-tenant, so here there is no less contradiction between the statement that Hawkswell is held by Eudo in demesne and the statement that, on the contrary, it is held of him by Pirot. In other respects there is close agreement here between the two versions, the live stock being merely arranged in a different manner.

Below is the last example of a duplicate entry in the county, namely that which relates to Braintree. It occurs among the "Invasiones,' and the reader will observe that 'Ledmar' is described as 'Ledmar' of Hempstead in one version and as 'Letmar' the reeve in the other. Probably in the original return he was styled 'Ledmar of Hempstead the reeve.'

In BRANChETREU xxx acras terræ tenuerunt iii liberi homines T.R.E., et val[et] iii solidos. Hanc terram invasit Ledmar' de Hamesteda, et tenuit ad feudum Ricardi, et R. non est inde sibi tutor (fo. 101 b).
In Branchetreu iii liberi homines T.R.E. xxx ac[ras], quas Letmar' prepositus reclamavit ad feudum Ricardi, sed homines illius non testantur, et inde dedit vadem, et val[et] iii solidos (fo. 103).

Here there is very considerable difference between the two accounts of the reeve's failure to justify his action. In the one it is stated that $\mathrm{R}$ [ichard Fitz Gilbert] does not warrant (using that term in the technical sense) his action; according to the other, Richard's men do not testify in his favour, and he has given gage (or wed, i.e. security) to stand trial in the matter (inde).

This phrase introduces us to an aspect of the Domesday Survey as important as it is obscure. It is only by incidental allusions that we are enabled to gather that 'pleas' of some kind were held before the Domesday Commissioners (Legati). Under 'Invasiones super regem in Exsessa' (fo. 99b) we read that certain land was already in the king's hands 'before these pleas took place' (antequam bac placita fierent). A somewhat tantalizing entry under Newport fails to make it certain that it was the commissioners themselves who pronounced an invading clerk at the king's mercy for his body and his goods. ${ }^{3}$ On fo. $25^{b}$ we gather, of half a hide at Alresford, that as no one came forward

1 The words within the brackets have been deleted in the MS.

3 See p. 436 below. 


\section{A HISTORY OF ESSEX}

to prove the right of the Norman 'invader,' it was taken by the Domesday Commissioners into the king's hands $;^{1}$ at Lawford the sokemen's land seized by Richard Fitz Gilbert was forfeited for the same reason. At Hatfield Broadoak they appear to take credit to themselves for having similarly recovered half a hide of which the king had been wrongfully deprived. ${ }^{3}$ In the case of Peldon at least their language is free from doubt; after reciting the seizure by the same offender of certain land they expressly state that they have taken it into the king's hands." Returning to the 'dedit vadem' phrase, we have several examples of its use in the Essex Domesday. In the Rodings (fo. 3) a sokeman of the king has failed to render either service or customary due and has therefore given gage (ideo dedit vadem); at Horndon-on-the-Hill Godwine Cudhen has been guilty of two 'invasions' and has 'given gage' in both cases (fo. 99); Hugh de Berners had denied that he was holding land of the king, but the land has been proved to have been held for the king's use (derationata ad opus regis), and so he has 'given gage' (fo. 1oob)." 'Two small holdings have been ' concealed,' but now they are brought to light, and so the holders have 'given gage' (fo. I O I). At Halstead a king's reeve has been receiving (and pocketing) a small freeman's rent (fo. I $0_{3}$ ), but he too has given gage (inde dedit vadem), as has a reeve of Richard de Clare who was in trouble for his doings at Chawreth (fo. I03). In Colchester Ralf Pinel, whose estate was at Bromley, ${ }^{6}$ has failed to pay the customary due for his 'four houses within the walls,' but he has had to 'give gage' therefor" (fo. I06). While on the subject of legal antiquities we may note that 'vouching to warranty' occurs at Chawreth, where a 'man' of Richard de Clare unsuccessfully vouches Ilbodo (whose connection with the matter is unexplained), and a reeve of Richard, with no more success, vouches Richard himself (fo. I 03 ). We have already seen Richard failing to warrant his reeve's aggressive action at Braintree. ${ }^{8}$ It is the king himself whom the burgesses of Colchester and Maldon vouch to warranty for a remission of the rent

1. - Et hundret nescit quomodo habet hanc terram, et quia neque legatus neque alius homo venit ex parte sua qui derationasset hanc terram, ideo est in manu regis cum alia.' Compare the Goldhanger entry (fo. 54b) : ' non habuit liberatorem, sicut hundret testatur, et ita est in manu regis.'

2. "dimidiam hidam et xv. acras, que modo sunt in manu regis ideo quod nullus fuit ex parte ejus qui dixisset quomodo eos habuerit' (fo. $6 b$ ). 'This would seem to refer to the proceedings before the commissioners.

3 'Postea recuperavimus (sic) dimidiam hidam quam tenuit soc[emannus] Haroldi T.R.E.' (fo. $2 b$ ). But the entry somewhat mysteriously proceeds:- 'modo eam tenet Radulfus de Marcei ad feudum Hamonis.' 'The land referred to is the subject, as 'Siriceslea,' of an entry under Hamo's fief (fo. 55), where there is no hint that it was claimed as belonging to the king. This raises a curious question as to the 'Postea' clause, which may have been entered after the 'Siriceslea' entry had brought the fact to their notice.

4 'Tulit Hamo dapifer lxxx acras ... sicut hundret testatur, et hanc occupationem percepimus (sic) in manu regis' (fo. 94).

5 Compare p. 386 above.

6 See p. 563 below.

7 'Indedit vadem' for 'inde dedit vadem,' a corruption characteristic of the survey of Colchester. On the waging of law by this 'contract with the vadium, wed, or gage' see Prof. Maitland's The Court Baron (Selden Society), p. 17, and compare my Commune of London, p. 153.

8 See pp. 355, 411 above. 


\section{THE DOMESDAY SURVEY}

exacted from them for their mints. ${ }^{1}$ Another form of vouching to warranty is that in which a former sheriff is vouched by the occupant of land as having given him livery of seisin. On the king's manor of Lawford two instances will be found in which Suain was so vouched."

Of the three eastern counties Essex is the first with the Domesday of which I have dealt for the Victoria History. The peculiar character of the volume containing the survey of those counties is largely responsible for the length of this, the first and possibly the only introduction to a portion of its contents.

Discussing the relationship of the 'second,' the eastern counties volume to that which contains the rest of the Domesday Survey, I argued in Feudal England (pp. I $3^{8-42}$ ) that the former was really the first to be compiled. As this conclusion has been accepted by the DeputyKeeper of the Public Records, I may here repeat in part the argument

I have never seen any attempt at a real explanation of the great difference both in scope and in excellence between the two volumes, or indeed any reason given why the eastern counties should have had a volume to themselves. For a full appreciation of the contrast presented by the two volumes, the originals ought to be examined. Such differences as that the leaves of one are half as large again as those of the other, and that the former is drawn up in double, but the latter in single column, dwarf the comparatively minor contrasts of material and of handwriting. So too the fulness of the details in the second volume may obscure the fact of its workmanship being greatly inferior to that of the first. . . The muddled order of the tenants-in-chief for Norfolk and for Suffolk-where laymen precede the church-is another proof of inferiority, but only minute investigation could show the hurry or ignorance of the scribes.

Now all this might, I think, be explained if we took the so-called second volume to be really a first attempt at the codification of the returns. Its unsatisfactory character must have demonstrated the need for a better system, which indeed its unwieldy proportions must have rendered imperative.

I am now prepared to go further and to say that this hypothesis explains and is supported by a feature in the portion devoted to Essex which appears to be unique in Domesday. On fos. $8 b$ and $16 b$ the text ends for the time, and fos. 9 and 17 are blank save for lists of the headings, six and ten respectively, to certain church fiefs. These lists have been deleted by lines drawn across them. The occurrence of these extraordinary breaks right in the middle of the text obviously calls for some explanation, but it proved difficult to account for. We find however that

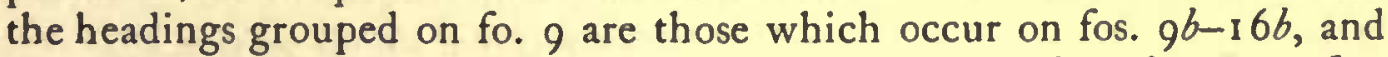
that those similarly grouped on fo. I 7 occur on fos. $17 b-24 b$. But after the second of these lists (fo. I7) there is no further break; the text proceeds continuously.

I now suggest that this is the result of a change of plan as the work proceeded, Essex representing the first portion of the first volume under-

1 'Advocant regem adturtorem' (fo. 107). The phrase should run, 'ad turtorem,' and even then the 'turtor' is 2 corrupt form of 'tutor.' In a case of vouching to warranty at Boreham the word 'defensor' is used instead of 'tutor' (fo. 316 ) ; and at Notley Geoffrey 'clamat regem ad warant' (fo. 60). At Hertford 'protector' is employed: 'de quibus advocat Harduinus regem ad protectorem' (i. 132).

2 'inde vocat liberatorem Suanum . . . inde revocat liberatorem Suanum' (fo. 66). Compare the Tollesbury case on p. 449 below.

3 See Catalogue to the Museum of the Public Record Office (1902). 


\section{A HISTORY OF ESSEX}

taken. The original idea appears to have been to compile the volume in fasciculi of 8 folios each, the contents of which alone should appear on the recto of the first folio. When these fasciculi were bound together to form the volume, the list of their contents would become useless and would therefore be deleted. But it was soon found that this plan would not work in practice, as the fiefs could not be adjusted to fasciculi of 8 folios. The idea was consequently abandoned, and reliance placed only on the list for the whole county which covers the recto of the first folio in the case of all three of the eastern counties.

It would be imagined from this list on the opening page of the volume that the survey of Essex closes with what it terms 'Invasiones.' But these, on the contrary, are followed by a long separate survey of what is styled 'The Hundred of Colchester.' The position here assigned to Colchester is well worthy of notice, for it contrasts with that accorded to Ipswich and to Norwich. The latter, followed by Yarmouth and Thetford, is surveyed at the end of the first division of the king's land in Norfolk (fos. I I6-8), while Ipswich is found at the end of all the king's land in Suffolk (fo. 290). But the three towns have this in common; they are all accorded separate treatment.

I shall now therefore add a short separate introduction to that survey of Colchester which stands altogether apart from that of the rest of the county.

\section{COLCHESTER}

Speaking at the Colchester Congress of the Archæological Institute, in 1876 , Professor Freeman called attention to the rich field of study presented by the lengthy survey of Colchester in Domesday Book. ${ }^{1}$ To this survey I subsequently devoted a series of papers in the Antiquary ( 1882 ), and it is also referred to more than once in Professor Maitland's volume, Domesday Book and Beyond. It is hardly possible, indeed, to accord it adequate treatment in the space here available, more especially as the text is corrupt and some of the entries extremely difficult.

A glance at the Domesday map will show that the 'Hundred of Colchester,' if coterminous, as it doubtless was, with the present borough, comprised a considerable area. Three terms are used in the survey for what it calls Colchester-bundret, civitas and burgus. One must not linger over these terms, tempting though it be to do so; but I will briefly state that I hold the burgus to represent the walled enclosure, Io8 acres in area, the 'burh' repaired by Edward the Elder, where it 'tobroken was,' in $92 \mathrm{I}^{2}$ Civitas, on the other hand, is a difficult term, one of those to which Domesday students have been apt to attach, in my opinion, too definite a meaning. Mr. Freeman, who was always eager to discover an exactness and a significance in a terminology which rejoiced in being free from both, spoke of Domesday as a document ' in

1 Archaological Fournal, vol. xxxiv. 67-70.

2 For the 'due domus in burgo' appurtenant to Greenstead and the 'ii domus in burgo' which formed part of the endowment of St. Peter's must have been within the walls. 


\section{THE DOMESDAY SURVEY}

which cities (civitates) are in a marked and designed way distinguished from other towns which were not cities.' 1 That the term 'city' did not then imply the seat of a bishopric is a point which was rightly made by Mr. Freeman ; where he erred was in holding, most characteristically, that Domesday distinguished clearly between civitates and burgi," and that it reserved the former term for ' the great and important towns.' Norwich, greater and far more important than Colchester or most of Domesday's ' civitates,' is always a 'burgus ' in the record. It may be interesting to note that 'civitas' is applied to York, Lincoln, Chester, Shrewsbury, Hereford, Worcester, Gloucester, Leicester, Exeter, Oxford, Chichester, Canterbury and Rochester, as well as to Colchester. But, as at Colchester, we find 'burgus' as well as 'civitas' used at Chester, Leicester " and Worcester," while at Gloucester we find the phrase 'in burgo civitatis.' It is tempting to conclude that the civitas, at Colchester, represents the entire area as against the burgus or walled space, but at Chester, Hereford and Leicester the phrase murus civitatis ${ }^{\circ}$ distinctly proves that civitas was used for the walled enclosure. In I 882 I suggested that this might be accounted for by that enclosure monopolizing in places the term civitas which had originally belonged to the whole area, while in others, as at Colchester, the differentiation was inchoate.? When, in the case of the Essex town, it was at last effected, the walled space was known as the burgus and the surrounding area as the banleuca, as we see in the charter of Richard $\mathrm{I}$. Whether this explanation be deemed satisfactory or not, I have no better one to offer now.

It is worth noting that of all the towns to which Domesday applies the term 'civitas,' Colchester and Rochester are the only ones which are not now the capitals of their counties; and Rochester, of course, was the capital of west Kent and is still the seat of its bishop's see.

The opening portion of the survey deals with Greenstead, which is still one of the four parishes outside the walls, from which, indeed, it stands some distance off. Four hides which had been held there by Godric were equally divided between his sons, an interesting example of such division. The meadow (or 'meadow and marsh') was also equally divided, ' 12 acres' falling to the share of each brother, and so was the mill (on the Colne). The church, however, which Godric had held, was allotted entire to one portion, probably because it had no endowment. Houses were appurtenant to Godric's estate, and the phrase 'iiii

1 'City and Borough' (Macmillan's Magazine [1889], 1x. 31). He even held that the Normanized Edward and his successor 'taught people to distinguish certain places as civitates' (ibid. p. 33 ).

2 The places to which the name of city is given are clearly the great and important towns, some of them Roman chesters, some of them English settlements which had greatly outstripped their fellows, towns which were local centres and something more, towns which had more or less of an independent municipal constitution,' etc., etc. (ibid. p. 32 ).

- Terra in qua est templum Sancti Petri . . nunquam pertinuit ad Manerium extra civitatem, sed ad burgum pertinet.'

- 'Redditus civieatis . . in codem burgo.' - Consuctudines burgi . . redditus civitotis.'

- The fossarum civiratis occurs at $\mathrm{C}_{2 n}$ terbury.

7 See Antiguary, v. 249, for fuller statement.

- It is remarkable that Colchester was still entered as a 'civitas' in the Pipe Roll of 1130. 


\section{A HISTORY OF ESSEX}

mansiones terræ' is of some interest. 'Mansio' is one of the terms used vaguely in Domesday ; in Essex it clearly means ' manor' in the phrase 'dominus mansionis' found under Hanningfield and Sutton, and, apparently, in the somewhat mysterious ' non est de suis c mansionibus' found under Orsett (fos. $9 b, 26 b$ ); but at Horndon-on-the-Hill (fo. 97) two ' mansiones' have been ' taken away' by Godwine from a manor of one and a half hides, so that these can hardly have been anything but houses. In a single column of a single page in the other volume of Domesday (i. 8) we learn that to one Kentish manor there belonged ' iii mansiones terræ in Rovecestre' and to another ' ii mansuræ terræ in Cantuaria.' Here, it will be seen, we have not only the same phrase as at Colchester, but an obvious equation of it with 'mansuræ terræ.' ' And, further, as the word 'terræ' is surplusage, indifferently used or not after acra, carucata, and so forth, I think the mansurce terre were simply the mansure which meet us throughout the survey of Norwich; and as masura is once used instead of mansura at Norwich, we may treat these words as identical ; indeed, returning to Kent, we have a manor to which were appurtenant ' in Cantuaria iii masuræ' (i. 9). ${ }^{2}$ Lastly, in Fordwich all the houses seem to be entered as 'masuræ terræ,' of which there were nearly a hundred (fo. 12). Here then again we have plain warning of the survey's loose terminology ; and we need not see in Godric's four ' mansiones terræ' more than houses in Colchester.

The next entry is connected with the first as relating to five hides at Lexden which the burgesses asserted to have belonged to Godric's Greenstead estate, although (as the Domesday map shows) Lexden lay on the opposite side of the borough. I showed in my original paper that Mr. Freeman had misread and misunderstood this important passage, and discussed its meaning both there ${ }^{3}$ and at greater length in Domesday Studies (pp. 122-3I). The grievance of the burgesses was the same as at Shrewsbury and, apparently, at Chester. The 'rateable area' had been wrongfully lessened, and the sums due from the portion in dispute were thus lost to the burgesses, from whom however the Crown continued to exact the same total amount. This must imply a fixed commutation, for the grievance would have otherwise no meaning." Oddly enough the same grievance is again found recurring at Colchester some years later in the chronicle of St. John's Abbey, according to which Eudo 'dapifer' came to the rescue of the townsfolk in their difficulty.

Terras damnatorum ... dum nemo coleret exigebantur tamen plenaliter fiscalia, et hac de causa populus valde gravabatur. Has ergo terras Eudo sibi vendicavit ut pro bis fisco satisfaceret et populum eatenus alleviaret. ${ }^{5}$ (fo. 2).

1 On fo. 5 are entered 80 ' mansuræ terræ' in Rochester as appurtenant to two of the bishop's manors.

2 On fo. 10 there are several other instances, and mansure and masura are both used at Canterbury

Antiquary, vi. 7.

in in his Dorset Domesday (p. 72), well puts the point: "A reduced number of contributors had to make good the same total of taxation as had been formerly borne by many.'

6 Printed in the St. John's Cartulary (Roxburghe Club) and in the Monasticon. The authority of the narrative of course can only be accepted valeat quantum, so far as it exalts Eudo, the founder of the abbey, but it is good evidence as to the system and the grievance from which the burgesses suffered. 


\section{THE DOMESDAY SURVEY}

In spite of the clearness of this passage $\mathrm{Mr}$. Freeman came, as I showed in $1882,{ }^{1}$ to extraordinary grief over it, connecting it, in his William Rufus (ii. 464-5), with 'the common land of the burgesses' entered in Domesday and with the Domesday entry of Eudo's houses in Colchester, in which he read ' $\mathrm{d}$ [omus]' as 'denarios'!

I suggested, in my original paper, that the suspicious growth in value of Stanway since the days of the Confessor ${ }^{2}$ might have something to do with the extension of its 'berewite' of Lexden at the hands of the king's officers. ${ }^{3}$

After these two preliminary entries we plunge into a long list of the holders of houses and of land, which is probably unrivalled in Domesday, though short ones of the same character are found under Norwich and Oxford. The number of houses would seem to have been about 450 , both at the death of the Confessor and in 1086 . I may here quote my summary of this remarkable list :-

If we examine the first half headed 'Isti sunt Burgenses Regis qui reddunt consuetudinem' we find the names of 276 burgesses, several of them owning many houses and a few owning none, the grand total of their houses being 355 . Their land, which was divided into unequal plots, amounted to no less than 1,296 acres of arable and $5 \mathrm{I}$ of meadow. Most of the plots were but a few acres in extent, often but one or two, and suggest a very large element of 'peasant proprietors', dwelling probably on their little holdings, of which many must have been distant from the walls. There were also several properties of from 20 to 30 acres; and the whole effect produced is that of a land-owning community, with scarcely any traces of a landless, trading element. Hence, we may presume, the relative sparseness of population; hence also the want of development in the community. Among the burgesses we find seven priests and nearly twenty women, one of the latter, Leofleda, being perhaps the wealthiest of the townsfolk, with her three houses, her 25 acres and her mill. The pure English element is of course predominant in the names, and lingered long among the fields and copses after fashion had banished it from the font. But Hacon and Tovig, Osgod and Segrim, were names that told of Norse descent. And followers of the Conqueror as well figured among the king's burgesses. ${ }^{4}$

The only correction I would now make is that I take the acres to be rather 'geld' acres than measures of area. This view is supported by the prevalence of 20-acre, I5-acre, 10 -acre and 5-acre holdings. Although we cannot divide the list into two sharply defined portionsfor some Normans are found in the first portion and some natives in the second-there is clearly a break where the record, after giving the holdings of the burgesses, adds that 'isti burgenses'-a rather emphatic phrase-have $5 \mathrm{I}$ acres of meadow. The next portion begins with the very interesting entry of the separate estate held by Hamo 'dapifer,' in which, as at Faulkborne and Totham, his predecessor was Thurbern. It included ' $\mathrm{i}$ curia,' an admittedly difficult word. But its use here seems to be illustrated by the entry of the bishop's curia at Norwich, in which were fourteen houses. ${ }^{6}$ In addition, it would seem, to this 'court' he had a 'hall' of his own, which enjoyed the exceptional privilege of being free from dues to the king. His fifteen burgesses

1 Antiquary, vi. 98-9.

2 Antiquary, vi. 7.

2 See p. 432 below.

4 Ibid. vi. 5 .

- 'Et homines episcopi $x$ domus et in propria curia episcopi xiiii mansure' (fo. 117). 


\section{A HISTORY OF ESSEX}

were liable to these dues, but paid only that portion which was due from them personally as a poll-tax (de suis capitibus). This poll-tax is alluded to in two other places in the survey of Colchester, and receives illustration from that of Ipswich, where we read of a hundred poor burgesses who can only contribute to the king's geld a penny each on their polls. ${ }^{1}$ We also read of 20 bordars belonging to Roger Bigot in Thetford that this poll-tax was all they could pay. ${ }^{2}$

Of the houses belonging to manors in the neighbourhood something has been said above (p. $3^{8} 5$ ), but among those enumerated in the second portion of this list I would call attention to the two in which 'William nephew of the bishop' had succeeded Thurkil. For the latter's name is, in Essex, not a common one, and when we find that at Peldon, to the south of Colchester, a 'Turchil' had been succeeded by 'William the deacon,' it is difficult to resist the conclusion that the two Williams are the same and represent a nephew and namesake of William, Bishop of London. If so, Peldon may be added to the list of those manors, such as Wigborough and West Mersea adjoining it, which had houses in Colchester. It is singular, in this connection, that in the charter of confirmation granted to Bishop Maurice by King William the lands held by 'William the deacon and Ralf his brother' are included, ${ }^{3}$ and that Peldon was thenceforth held of the Bishops of London.

The most difficult portion of this survey remains. At the close of the long list of the holders of houses and land we have an entry of which the subject is ' the king's demesne.' This ' demesne ' corresponds roughly with the portion of a manor so described, and I did not hesitate to identify it with the land which was attached from time immemorial to the possession of the royal castle." Its most interesting portion is the Io acres of meadow, for I claim these as identical with the 'ten acres in king's meadow' mentioned in the will of Charles Gray, M.P. (I78I), who was owner of Colchester Castle and the lands which descended with it. These 'ten acres' consist of three detached portions lying in the ancient meadow on the left bank of the river facing the castle, which is of the normal 'dole' type, divided into strips."

In addition to this important meadow, which still remains divided into 'doles,' ${ }^{\prime}$ the extent of meadow recorded in the survey of Colchester is large. We have already heard of the burgesses having $5^{1}$ acres ${ }^{7}$

1 ' C pauperes burgenses qui non possunt reddere ad geltum regis nisi unum denarium de suis capitibus' (fo. 290). 2 'De supradictis bordariis habebat rex scotum de suo capite tantum' (fo. I I 7 ).

s Dugdale's History of St. Paul's, p. 304. The charter is in Old English.

4 Antiquary, vi. 8-9, 95 .

5 In actual area these 'acres' vary, as I pointed out, from $\frac{3}{3}$ to $\frac{4}{5}$ of the modern statute acre. I subsequently found it stated in Mr. Palmer's Ancient Tenures of Land in the Marches of North Wales that 'the normal doles of the old common meadows' in his district are represented by an area of 'a little over three statute roods,' and that they were really 'day's maths,' a form which still survives. I am disposed therefore to treat these meadow acres at Colchester, not as geld acres, but as actual day's maths (Domesday Studies, pp. $218-9$ ).

6 There were 'King's Meads' at Oxford and at Canterbury, and the latter appears to be alluded to in Domesday.

${ }^{7}$ p. $4 \mathrm{I} 7$ above. This may be compared with the well-known Port Meadow at Oxford. 


\section{THE DOMESDAY SURVEY}

Hamo 'dapifer' had 6 acres, St. Peter's Church 12 acres, and the Bishop of London $6 \frac{1}{2}$ acres. Thus, with the king's ' 10 acres,' there were $85 \frac{1}{2}$ acres, to which must be added, it seems, 48 acres at Greenstead. Under Stanway, also, Lexden is credited with 18 acres.

The king's demesne included ' 240 acres' of pasture and scrub (inter pasturam et fructetam), but we find no definite mention of 'the King's Wood' to the north of the town, now known as 'the high woods.' This wood is subsequently found included in the 'ferm' of the borough, which was reduced accordingly by forty shillings when the king took the wood into his own hands. ${ }^{1}$ At the close of the entry on the king's demesne we are given the important information that it is all included among the sources of the king's ferm, ${ }^{2}$ which at once proves that a firma burgi was already paid to the Crown for Colchester in the days of the Conqueror. When we look at the entries which follow we see how clearly the survey distinguishes the payments which are compounded for in the firma from those which are not. ${ }^{3}$

The tenure of this 'firma' is as obscure as it is important. From the earliest pipe roll ( 1 I 30 ) Colchester appears as farmed separately from the rest of the county; and I gather from the incidental reference in the Domesday Survey to Waleran that he had been the 'fermor' at some period during the Conqueror's reign. Another incidental reference leads me to think that he had at one time 'farmed' Norwich with disastrous results to its burgesses." At the time of the Survey he had been succeeded in Essex, Cambridgeshire and Suffolk by his son; but during his tenure of the fief he had given to the Abbey of St. Stephen of Caen his 'little manor' of Panfield and the church of Bures St. Mary. ${ }^{\circ}$ He was charged with depriving the monks of St. Ouen of their house in Colchester and with certain encroachments at Aveley, Henny, Halstead and Lawford; but in this respect he was no worse than other Normans, if so bad.

I have come to the conclusion that the 'fermor' in 1086 was Walchelin Bishop of Winchester. The words 'ten' Walchelin' ep'c' are no doubt obscure, but that Bishop Walchelin was the person meant seems beyond dispute. There is evidence, as I have elsewhere shown, that he exacted extortionate rents from the tenants of his see in Hampshire $;^{\circ}$ and in Berks, Wilts and Somerset there are traces of his similar action." I believe therefore that at Colchester also he was trying to

1 This was shortly before 1169 , when we read : 'Et in defalta bosci de Kingeswuda, qui solebat esse in firma burgi, vi li. de tribus annis' (Pipe Roll, 15 Hen. II. p. 48). So also when Stephen made over to the hospital of St. Magdalen 18 acres of the Crown demesne here, he reduced the frma burgi by 3s. 5d. in consideration thereof. This firma was the sum for which the king's dues were ' Farmed' out.

"Hoc totum jacet ad firmam regis.'

'Et hoc pertinet ad firmam regis ... et hoc non est ad firmam.'

- 'Vastati . . partim per Walerannum' (fo. 1176).

- See my Calendar of Documents preserved in France, and compare p. 342 above.

6 Victoria History of Hampshire, i. 414-5.

7 One of his Berkshire manors is entered in Domesday as rented above its value; in Wilts there is, at Downton, a suspicious rise from $\complement_{60}$ to $\mathcal{L}_{10}$, and equally significant, in Somerset, is the rise on his great manor of Taunton from $\mathcal{L}_{50}$ to $\mathcal{L}_{154}$ 


\section{A HISTORY OF ESSEX}

extort from the burgesses a sum unduly large. But Colchester, after all, was not alone in its grievance. Then, as in much later days, towns complained of the excessive 'ferm' exacted from them by the Crown or its agents; but in 1086 there was reason for such complaint. Ipswich, like Colchester, appears to have paid, under Edward the Confessor, rather over $f_{0}$ i 5 a year; Roger Bigot, the sheriff of Suffolk, farmed it out under William for $f_{4} 40$, but was compelled to reduce the amount to $£ 37$, as the money could not be paid. Thetford, which had suffered heavily by the Conquest, was nevertheless compelled to pay nearly foro as against $£_{3} \circ$ before the Normans came. Norwich, which had also suffered heavily, had to submit to a similar increase, about $f_{\mathrm{s}} \mathrm{oo}$ a year being exacted from it in I086. Again, in Essex, there were rural manors, especially on the king's demesne, which were farmed out for exorbitant sums at the time of the Survey. ${ }^{1}$ These examples help us to understand the figures given for Colchester, although, if they are accurately given, its case was eminently hard. Under the Confessor it had paid only, as a commutation for the king's dues, $\oint_{0} \mathrm{I} 55^{\text {s. }} 3^{d}$. a year, out of which the moneyers provided $6_{4} 4$. At the time of the Survey it was paying $f_{0} 80$, besides some minor payments, which will be discussed below; and what made the grievance worse was that the local mint no longer contributed to the payment, but was now separately farmed at an exorbitant rent.

The reader must again be warned that the text is somewhat corrupt, and that, even allowing for Norman exaction, the figures are strangely high in view of the fact that in the next century the town's firma was f40, which included, as under the Confessor, the payment for the mint. The minor payments spoken of above as exacted in addition to the $f_{0} 80$ were in the first place 6 sestiers of honey, ${ }^{2}$ an archaic due common in towns. Ipswich and Norwich had both been liable to provide the same amount, and Thetford had provided 4 sestiers. Oxford and Warwick had each to supply 6 sestiers a year, and the entry under Warwick that the sestier was valued at I 5 pence leads us to view with some suspicion the statement in the Colchester survey that 40 shillings was the commutation for the 6 sestiers. Moreover, an unintelligible ' iiii' follows this estimate, which may either refer to the obscure consuetudines mellis spoken of at Ipswich and elsewhere, or may be simply a corruption.

The next addition to the $f_{0} 80$ is the curious payment 'for feeding the prebendaries,' which appears to be peculiar to the towns of the three eastern counties. At Colchester it is Ios. 8d., at Ipswich 8s., at Thetford I $6 s$. and at Norwich 2 iss. $4 d$. No significance may at first sight be suggested by these figures, but it will be found that they are based upon a unit of 32 pence, of which units Ipswich pays three, Colchester four, Thetford six and Norwich eight. And this unit represents 2 ounces (or $x$ ) at i 6 pence (instead of 20 pence) to the ounce. ${ }^{3}$ 


\section{THE DOMESDAY SURVEY}

Another of the extra payments was $\oint_{5} 5$ to the sheriff ' de gersuma.' This phrase is one which is always difficult to translate, but the amount is recognizable as that which a town or a county is sometimes entered in Domesday as paying to the queen. Norwich, in 1086, was paying $f_{05}$ a year 'de gersuma regine,' and Warwickshire the same 'reginæ pro gersuma.' $f_{0} 5$ a year also was paid to the queen as a gift by Worcestershire and by Northamptonshire. The county of Oxfordshire also paid $f_{5} 5$ ' de gersumma reginæ.' But, in spite of this association of the $f_{0} 5$ with the queen, I should look upon the payment at Colchester as akin to that which the sheriff received from some royal manors in the county, ${ }^{1}$ and as consideration money for his exclusion from the firma.

The payments we have just been considering were made in addition to the ferm, and Domesday is careful to explain that the render in respect of the mint was also, at the time of the Survey, over and above the ferm.

The passage relating to the local mint is, no doubt, difficult. It has been recently discussed by Mr. Andrew, ${ }^{2}$ but I cannot agree with his conclusions. To understand it we must study it in conjunction with the mint entries for Ipswich and for Thetford. At Ipswich, as at Colchester, the moneyers had paid $\oint_{4} 4$ a year under the Confessor, but their annual payment had been raised to $\oint_{0} 20$ at the time of the Survey, though they were greatly in arrears. ${ }^{3}$ At Colchester, as I read the passage, the annual payment had been similarly raised to $f_{0} 20$, though the burgesses of Maldon shared the burden." But, as at Ipswich, the payment seems to have proved too heavy, for the burgesses claim that the king (or his fermor) had remitted half of it. Nevertheless, they say, Bishop Walchelin, their fermor, is exacting from them $\oint_{4} 4 .^{\circ}$ Enormous as this demand may seem, Thetford was actually paying for its mint no less a sum than this at the time of the Survey.

It must be admitted, however, that sums so large as these are difficult to explain, for at Thetford, as $\mathrm{Mr}$. Andrew points out, the sum of $f_{0} 4$ a year was eventually remitted in express compensation of the loss of four moneyers, while at Colchester $\oint_{0} 3$ a year was similarly remitted ' in defectu monetariorum ' under Henry II. down to his thirteenth year (I 167 ), when the amount rises to $\oint_{0} 4$, which, we have seen, was the annual render from the moneyers at Colchester, as at Ipswich, under Edward the Confessor." Yet, inexplicably large as are the renders due in I086, I cannot agree with Mr. Andrew when he 'bóldly' suggests

1 See p. 363 above.

2 Numismotic Chronicle, ser. 4, i. 161-2.

3 'Monetarii reddebant per annum T.R.E. iiii libras pro moneta ; modo debent reddere xx libras ; sed de quatuor annis non reddiderunt nisi xxvii libras' (fo. 2906).

- Coins of this period were issued from the Maldon mint.

- Reddebant monetarii iiii libras T.R.E. . . Et preter hoc reddunt burgenses de Colecestra et de Melduna xx libras pro moneta ; et hoc constituit Waleramus ; et advocant regem adturtorem quod condonavit illis x libras ; et ten' Walchelinus ep[is]c[opus] querit ab illas xl libras."

6 'Reddit etiam modo regi xl libras de moneta' (fo. I19).

7 It is evident that at Colchester and at Norwich in the twelfth century the remission of $f_{1}$ a year represented the loss of one moneyer. 


\section{A HISTORY OF ESSEX}

that they were not annual renders at all, but 'certain annual instalments which were being paid by the burgesses for the purchase of the lease of the mint from the king,' in fact, 'that the burgesses or grantees of the mint were paying a fine for their charter of the privilege.' ${ }^{1}$ For the language used in the Ipswich entry is decisively opposed to this solution. High payments, indeed, from mints were not exceptional in Domesday; Gloucester and Leicester paid $\oint_{2} 20$, and Lincoln as much as $\oint_{0} 75$.

Coins of the Conqueror with the names of four Colchester moneyers are known. These four are Wulfric, Ælfsige, Wulfwine ${ }^{2}$ and Derman. ${ }^{3}$ Under Henry I. the names of Wulfwine and Ælfsige recur on Colchester coins, while those of Edward and Sægrim (?) make their appearance." Of these names I recognize as holders of houses in the Survey, Wulfric, Ælfsige, Wulfwine and Derman, while we also find a Sacrim' and a Sagrim', but one ought to add that these names, the last excepted, are hardly distinctive enough for identification, and appear, moreover, to have been borne by several burgesses. Extreme caution is needed in dealing with the question of firma, but the language of Domesday appears to leave us in no doubt that the burgesses themselves were called upon to find the fixed annual sum of $f_{4} 4^{\circ}$, instead of the moneyers being liable, as at Ipswich, for the payment. The Thetford entry leaves us, perhaps, in some doubt on the point, though the borough itself there appears as responsible.

We have yet to deal with two payments, one of which is of great interest, and apparently, in its actual form, unique in Domesday. The first of these was due on 'the quinzaine of Easter' (quintodecimo die post pascham) yearly, and was a fixed sum of $f_{\mathrm{r}} \mathrm{6s} .8 \mathrm{~d}$. due from 'the King's burgesses,' and included in the ferm; it may possibly represent the commutation of a due. The other, which was over and above the ferm, was a payment of sixpence from each house, and was connected with military service. Like other passages in this survey, it is by no means free from obscurity, but, bearing in mind that it had to be paid every year, we may, I think, safely render it as meaning that the proceeds of this payment could be applied either to the mercenary soldiers (soldarios) or to the expenses of the national 'landfyrd ' or "scypfyrd '" (expetitionem terra vel maris), but that it had to be paid whether the king engaged soldiers or called out the fyrd or not. ${ }^{\circ}$ We have a payment at Exeter ' ad opus militum,' for which the 'Exon Domesday' gives 'ad soldarios,' and in the Dorset boroughs we have entries of payments 'ad opus

1 Numismatic Chronicle, ser. 4, i. 423.

2 He had coined here also under Harold (Archecologia, iv. 363 ).

4 Numismatic Chronicle, ser. 4, i. 166-7.

- Anglo-Saxon Chronicle, anno 999. See the Victoria History of Hampshire, i. 248-9. At Bedford the phrase is 'in expeditione et in navibus'; at Stamford, 'in exercitu et navigio'; at Leicester we read, 'Quando rex ibat in exercitu per terram... si vero per mare in hostem ibat'; at Exeter, 'Quando expeditio ibat per terram aut per mare'; at Wilton, 'Quando rex ibat in expeditione vel terra vel mari.'

6 For in some places the composition only applied to occasions when the host was actually called out. 


\section{THE DOMESDAY SURVEY}

huscarlium.' These payments deserve to be compared and contrasted with this at Colchester.

Perhaps the most difficult entry in the whole survey of Colchester is that which relates to what appears to be the common land of the burgesses. Professor Maitland writes of it :-

Concerning Colchester there is an entry which perhaps ascribes to the community of burgesses the ownership or the tenancy of fourscore acres of land and of a strip eight perches in width surrounding the town wall; but this entry is exceedingly obscure. ${ }^{1}$

The entry in question runs :-

In commune burgensium iiii. $x x$ acræ terræ; et circa murum viii percæ; de quo toto per annum habent burgenses $\mid \mathbf{x}$ sol. ad servicium regis, si opus fuerit, sin autem in commune dividunt.

The learned Professor observes further, ' as to this most difficult passage,' that -

Perhaps the most natural interpretation of it is that the community or commune of the burgesses holds this land and receives by way of rent from tenants, to whom it is let, the sum of 60 shillings a year, which, if this be necessary, goes to make up what the borough has to pay to the king or otherwise is divisible among the burgesses. But, as $\mathrm{Mr}$. Round rightly remarks, 60 shillings for this land would be a large rent. ${ }^{2}$

The great importance of this passage lies in the fact that, as is pointed out by the same writer, 'traces are few in Domesday Book of any property that can be regarded as the property of a nascent municipal corporation, and even of any that can be called the joint or common property of the burgesses.' 3 I need not here recount these traces as set forth by Professor Maitland, but I may call attention to Domesday's use of the rare phrase 'in commune,' a few pages further on. Of the 'new borough' founded, since the Conquest, at Norwich, we read that-

Tota hec terra burgensium erat in dominio comitis Radulfi, et concessit eam regi in commune ad faciendum burgum inter se et regem (fo. 118 ).

This may possibly serve to illustrate the Colchester entry. As to the land which forms its subject, I advanced the view ${ }^{4}$ that it was doubtless identical with the 'Borough Field' (or 'Fields') which we meet with in old maps and deeds as lying to the south of the London Road, at the back of the present Grammar School, and which appears to have comprised the site of the great Roman cemetery. ${ }^{\circ}$ The 'eight perches about the wall' would seem to represent the ditch and mounds which originally formed its outworks.

The last entry in the Colchester survey is that which relates to St. Peter's church and its endowment. With the exception of Greenstead church, spoken of above, this is the only one mentioned in the survey, which is in striking contrast to the numerous churches and chapels mentioned at Ipswich and Norwich. The explanation of this contrast is found in the fact that Domesday only concerned itself with churches

1 Domesday Book and Byond, p. 201.

- Antiquary, vi. 97.

- A 'Portmannesfeld' is mentioned in an early charter of St. John's Abbey, Colchester (Cartulary, p. 321). There was a 'Portmen's meadow' at Ipswich (compare p. 418, note 7 above). 


\section{A HISTORY OF ESSEX}

in those cases where their endowments made them sources of revenue. Any mention of others would only be incidental. It is certain, however, if only from analogy, that Colchester must already have possessed several churches, and indeed seven priests are named in the survey. Of the large endowment here entered as belonging to St. Peter's church, no trace is found afterwards, so that it would seem to have passed into lay hands. It appears to be implied that the church had been in the king's gift.

The remarkable 'soke' of the Bishop of London within the walls of Colchester is not mentioned in the survey, being entered with his own lands. ' It consisted of two portions, both described as " in Colchester,' one of these, which consisted of fourteen houses and four acres, 'paid no due but scot, except to the bishop'; the other assessed at two hides was held of him by Hugh and paid due(s). It must be the former which is described in a fine of I 206 as a 'soke' bounded by Head Street (on the east) and the town wall (on the west) and extending 'from St. Mary's lane to the lane next Headgate' ('Havedgate'), ' which boundaries remain unchanged. It then belonged to 'the barony of the Bishop of London' and included the 'schools' of the town and the church of St. Mary and chapel of St. Andrew, the advowson of which church was reserved to the bishop, in the gift of whose successors it remained. It is probable that the whole of the bishop's Domesday holding is represented by the existing parish of St. Mary's-at-the-Walls, which stretches out from the church for a mile to the south-east and is reckoned to contain $487 \frac{\mathrm{I}}{2}$ acres. The boundaries and 'detached portions' of the ancient parishes of Colchester preserve, as in other boroughs, traces of its early history.

\section{THE COAST FISHERIES IN DOMESDAY ${ }^{3}$}

The word applied to the coast fisheries and to the river fisheries in Domesday is the same, and when we read, for instance, that at East Mersea there were 'four fisheries,' it seems clear that these also must have been fixed contrivances of some kind. It is at first sight difficult to understand how the principle of the weir fishery, as prevailing, for instance, on the river Lea, could be applied on the open coast, or even in creeks and estuaries. But the provision in 'Magna Carta' that weirs (kydelli) should be taken down 'nisi per costeram maris' implies that it must have been done. Domesday mentions the existence of a 'heiamaris' at Southwold, and this, as Ellis observes, must have been a 'sea-hedge,' though his identification of it with a species of net is doubtful. A sea-weir, it appears, is a contrivance still in use where the coast shelves off, as it usually does in Essex, in 'flats' and 'sands.' We find it thus described ${ }^{4}:-$

On some parts of the coast, where a considerable extent of sand is laid bare at low-water, the weir consists of a wattled fence so placed as to form a number of zig-zags along the line of beach, the lower angles of the weir being just at low-water mark . . . and at the low-water angle a conical wicket basket with a mouse-trap entrance was securely fixed at the place where the two arms or fences nearly met. The manner in which such a weir works is very simple. At high-water the whole weir is covered by the water, and fish may in some cases enter it above the fence ; but as there is nothing to prevent fish from passing round the two ends of the long zig-zag weir, no doubt many of those which are caught enter in that direction, and swimming along between the weir and the shore, find their way into the V-shaped enclosures, from which, as the tide ebbs and the top of the fence appears above water, they cannot make their escape. Ultimately many of the fish make their way into the wicker-baskets we have mentioned.
1 See p. 440 .
3 See p. 380 above.
2 Feet of Fines: Essex, i. 39, (No. 2 ro).
4 Fisheries Exbibition Literature (1 884), i. 318. 


\section{THE DOMESDAY SURVEY}

On the Severn, of which the wattled 'basket weirs' are, as Mr. Seebohm has shown, of great antiquity, and 'meet the difficulty presented by the unusual volume and rapidity of the tidal current,' the 'wattled fence (is) 'technically called a hedge.' ${ }^{1}$ It is probable therefore that the 'heiamaris' was an actual wattled weir such as that described above.

There were, however, other devices for catching fish on the coast by enclosing them, namely the 'stake-net' and 'kettle-net.' The latter can be etymologically connected with the 'kidels' of the Middle Ages, the 'kydelli' of the Great Charter. But this is so imperfectly realized that the New English Dictionary (I90I), while rightly deriving the word under 'kiddle' (p. 690), derives it also from ' kettle' on p. 680! The 'kettle-net' is a variety of 'stake-net,' 'excepting that the enclosure or " pond" is quite simple, and the escape of the fish is cut off by the falling tide.' It is used along the south coast from Beachy Head to Folkestone for the capture of mackerel inshore. ${ }^{2}$ 'By an arrangement of stakes, nets, and a pound, it turns the fish into a particular direction from which there is no escape.' With 'the outer edge of the circle just below low-water mark at neap tides, the interstices between the stakes (from 10 to 12 feet high) are filled in with old nets.' ${ }^{3}$ This contrivance is worked 'where the shore is flat and sandy,' and is condemned as 'perhaps the most objectionable of all sea fishing nets.' ${ }^{4}$ The kettle-net was defined by the late Lord Herschell, in $189 \mathrm{I}$, as follows : 'A kiddle consists of a series of stakes forced into the ground some 700 feet in length with a similar row approaching them at an angle,' etc. (New English Dictionary).

Domesday, however, mentions that seine or draw-nets were in use on the meres of Cambridgeshire and at Hampton on the Thames, and proves that at many places rents were paid in herrings. These can hardly have been caught by the contrivances described above.

Devices of this kind for catching fish are of immemorial antiquity; 'the stake-nets which now fringe the shore of Scotland are identical in principle with the weirs in China, in Malacca, in Brazil, and in Borneo; with the engines which in the sixteenth century were placed on the coasts of Virginia by the aboriginal inhabitants, and which are now placed on the same coast ... the putts and putchers which are confined to a single estuary in England [i.e. the Severn] have all their counterparts in the Dutch East Indies.' ${ }^{5}$

A sea-water fishery on the Essex coast is distinctly mentioned as early as the days of Henry I., when a grant, at one of the Oakleys, to Savigny Abbey by Alvred Gernon and his wife includes a fishery on the sea (in mare). ${ }^{6}$ Domesday records the existence of 'one fishery' at Little Oakley.

1 Fisheries Exbibition Literature (1884), i. 319.

3 Ibid. vii. 47 .

2 Ibid. i. 317,513 .

4 Ibid. x. 422.

5 Ibid. xiii. 7. Compare ii. 455-6. 6 Calendar of Documents preserved in France, p. 292. 


\section{NOTE}

The reader should bear in mind throughout that the date of the Domesday Survey is 1086; that 'the time of King Edward, to which it refers, normally means the date of his death (Jan. 5, 1066); and that the intermediate date, which is sometimes spoken of as 'afterwards' and sometimes as 'when received,' is that at which the estate passed into the hands of the new holder. When the word 'semper' is used it means that the figures were the same in 1086 as in 1066. The Domesday 'hide' was a unit of assessment divided into four quarters called 'virgates,' each of which was reckoned to contain 30 acres ; but these were merely fiscal, not areal measures. In Essex the word 'virgate' is of somewhat rare occurrence, ' 30 acres' being used instead. 'Demesne,' in the Essex survey, is used in two senses: manors held 'in demesne' were those which the tenant-in-chief (who held directly of the Crown) retained in his own hands, instead of enfeoffing under-tenants therein ; but when 'the demesne' of a manor is spoken of, the term denotes that portion which the holder (whether a tenant-in-chief or only an under-tenant) worked as a home farm with the help of labour due from the peasants who held the rest from him. Of the peasantry the three classes are styled, in descending order, villeins, bordars and serfs; above them were the 'free men' and sokemen, survivals from before the Conquest, who are discussed in the introduction. The essential element of the plough ('caruca') was its team of oxen, always reckoned in Domesday as eight in number. Apart from the plough-oxen the live stock on the lord's demesne is generally, though not regularly, entered in the Essex survey, a feature which adds greatly to its length, and is peculiar to the three eastern counties. It comprises horses (usually 'rounceys,' a term familiar to readers of Chaucer), asses and mules, cows, 'beasts,' sheep, swine, goats and hives of bees. Thus the 'astonishing attention to details' spoken of as characterizing the agricultural division of the latest census of the United States, where all these are similarly enumerated even to the swarms of bees, was actually anticipated in Domesday, when the native chronicler bitterly complained that the king's questions were so searching that not 'an ox nor a cow nor a swine was left that was not set down in his writ.'

It must be remembered that when Domesday speaks of a place as held by a certain tenant, it does not follow that the whole of it is meant. It may have comprised other manors, which form the subject of separate entries.

Although a new translation has been made of the whole text for this work, it is but justice to say that that which was issued by the late $\mathrm{Mr}$. Chisenhale-Marsh in I 864 was of remarkable excellence for its date, and that its occasional criticism of Morant's identifications was in the main sound, though a far more sweeping revision has now proved necessary. 


\title{
NOTES TO DOMESDAY MAP
}

\author{
[Compiled by J. Horace Round, M.A.]
}

In this map those manors in which the king had an interest have a scarlet line under them; a blue line (broken) is under the names of those in which the principal ecclesiastical tenants, namely the Bishop of London and the canons of St. Paul's, held land; a green line denotes those of which part or all was held by Count Eustace of Boulogne, the greatest lay tenant in this county as in Herts. The name of a manor or of a Hundred is often given in more than one form by Domesday, but only one of these forms can be shown on the map. As the boundaries of the Hundreds have virtually remained unchanged since Domesday, the modern ones are given on the map, except that the Liberty of Havering is there included in Becontree. In fixing the position of manors the site of the church has been the guide ; for in Essex church and hall usually stood together, occasionally at some distance from the village of to-day. The modern river names have been added for the convenience of the reader.

The entries of meadow in Domesday serve to illustrate the course and extent of the streams, which were also responsible for the water-mills of the text. On the south-east coast of the county blank spaces (shown as 'recent alluvium' on the geological map) represent the marshland, which is specially discussed in the Introduction, and the extent of which is well seen on Chapman and André's maps (1772-4). Blank spaces in the neighbourhood of Colchester represent a belt of heathlands, such as those of West Bergholt, Horkesley, Boxted, Dedham, Ardleigh, and Crockleford to the north, with Stanway, Lexden, Layer and Black Heath to the west and south, which remained such till modern times, the soil of this district being largely glacial loam, with glacial sand and gravel, the 'turnip land' of agricultural writers. Another blank indicates the position of Tiptree Heath, while that between the Colne and the Pant remained sparsely inhabited. The blanks in the south-west of the county are partly due to forest and partly to the great size of some of the manors. 


\section{3axistie \\ TAM YACETMOA OT RATOK \\ [.A.M anuos songoth : [ yd bstigmo?]}

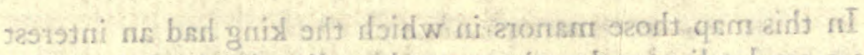

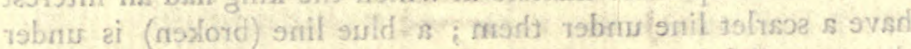

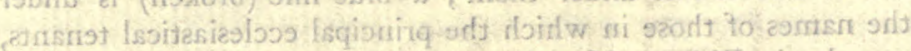

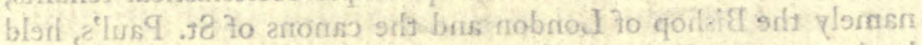

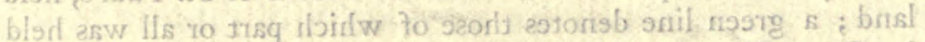

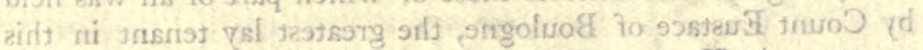
bybinut s to to tonsm s to smisn

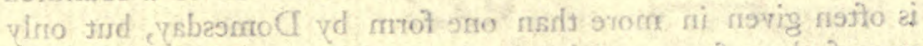

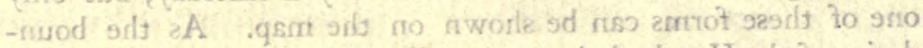

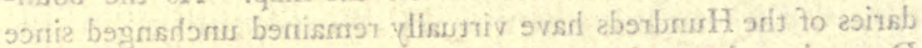

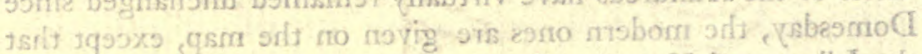

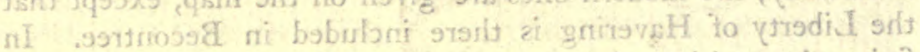

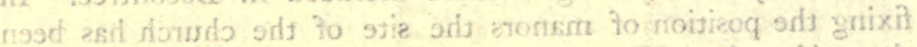

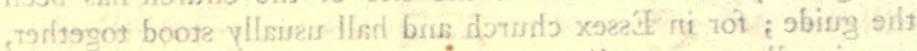

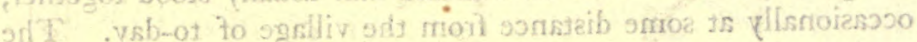

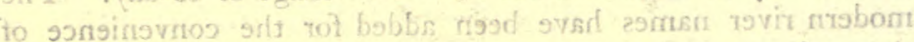
rabser orlt

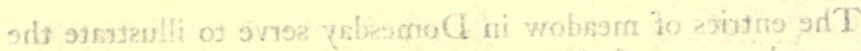

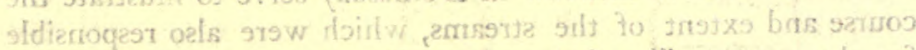

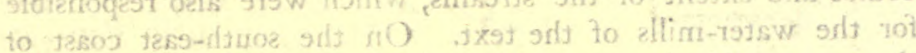

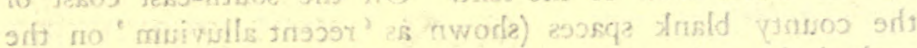

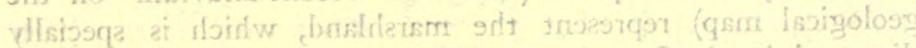

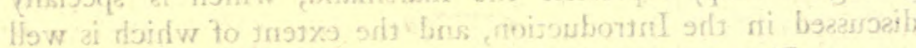

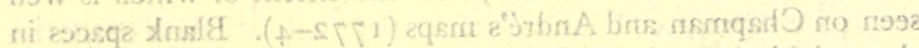

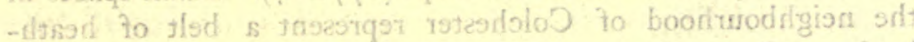

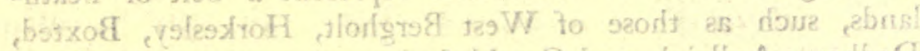

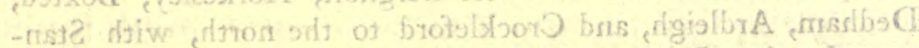

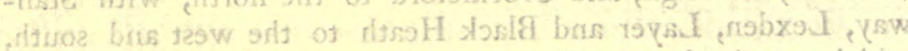

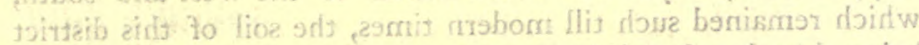

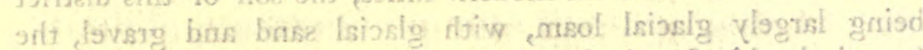

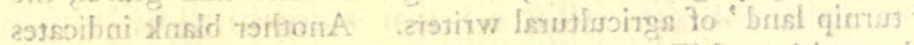

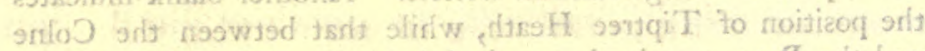

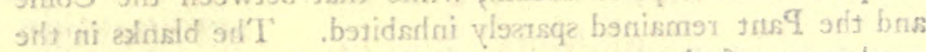

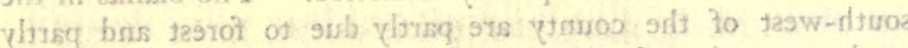

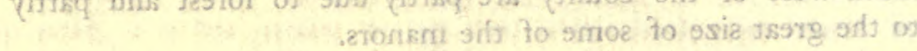


$\int_{1}$ 


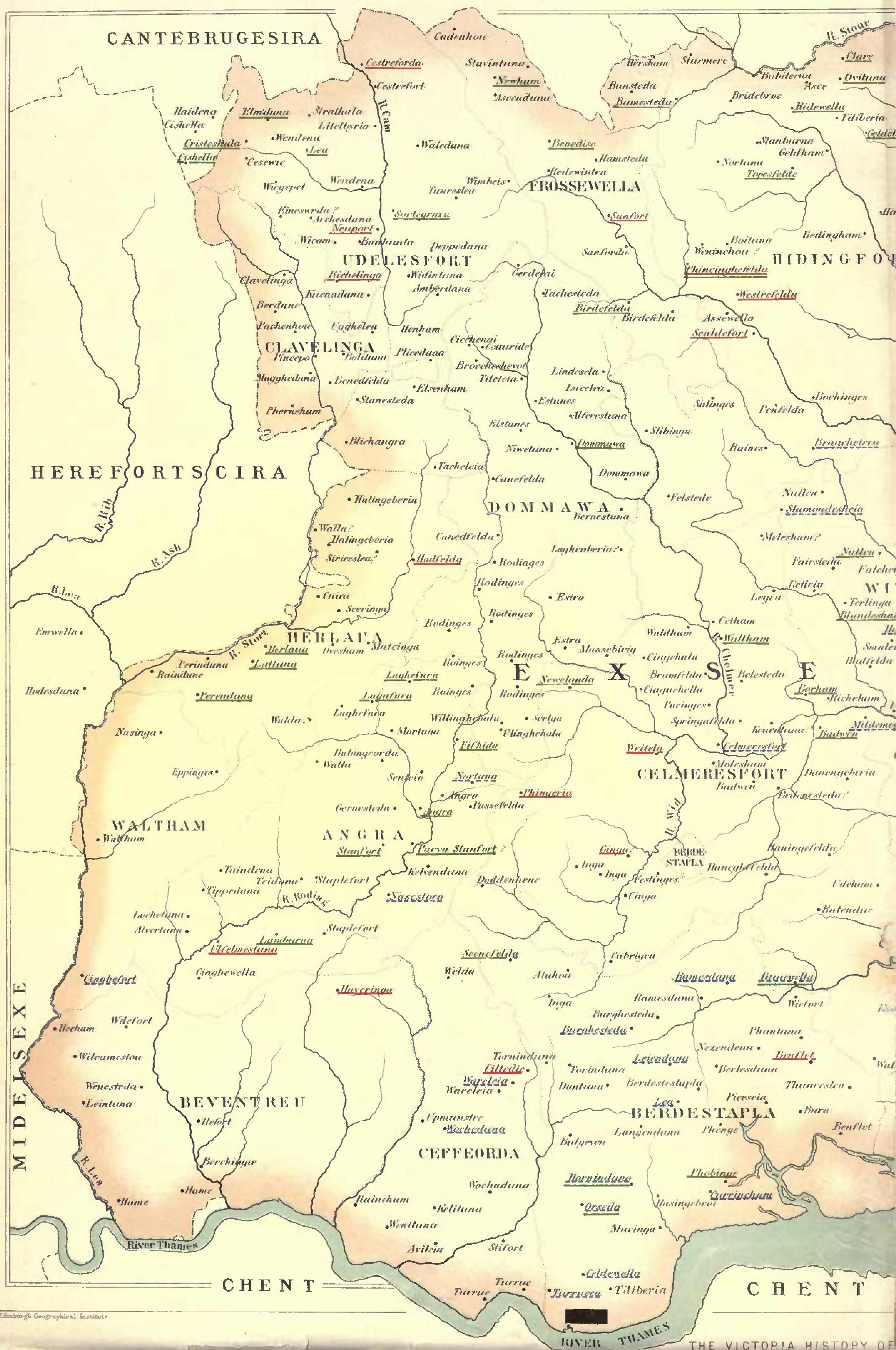




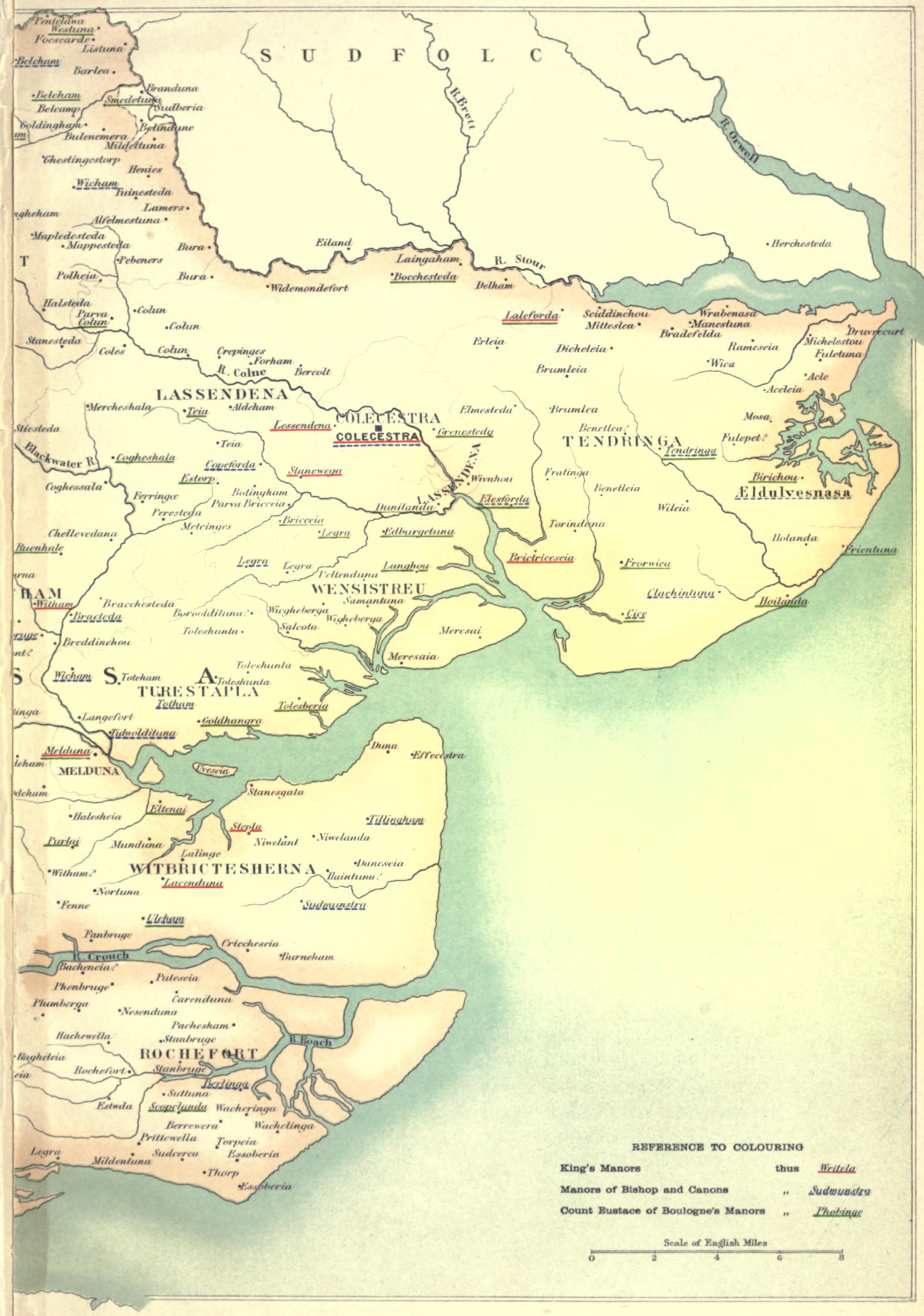





\section{EXSESSA}

\section{[HOLDERS OF LANDS]}

fo. $x$

I William King of the English

II The Holy Trinity of Canterbury

III The Bishop of London

IIII The fief of the same bishop

v The canons of St. Paul's

vi The abbey of Westminster

vir The Bishop of Durham

viII The canons of Waltham

Ix The abbey of [Bark]ing

$x$ The abbey of Ely

xI The abbey of St. Edmund

XII The canons of St. Martin of London

xIII The abbey of Battle

xiIII St. Walery

xv The abbey of the Holy Trinity of Caen

xvI The abbey of St. Stephen of the same [town]

xvir The abbey of St. Ouen

xviII The Bishop of Bayeux

xIx The Bishop of Hereford

xx Count Eustace

xxi Count Alan

xxII W[illiam] de Warene

xxIII Richard son of Count G[ilbert]

xxiv Suen of Essex

xxv Eudo dapifer

xxvi Roger de Otburville

xxvir Hugh de Montfort

xxviII Hamo dapifer

xxvinI Henry de Ferrariis
xLviII W[illiam] Peverel

xLIx Ralf de Limesy

L Robert de Toesni

LI Ralf de Toesni

LII Walter de Doai

LIII Mathew of Mortagne

LIIII The Countess of Aumale

Lv Countess Judith

LVI Frodo brother of the abbot

LVII Saisselin

LVIII Gilbert son of Turold

LIX William Levric

LX Hugh de St. Quintin

LXI Edmund son of Algot

LXII Roger the marshal

LXIII Adam son of Durand

LXIIII Goscelin the lorimer

Lxv John nephew of Waleram

LXVI William the deacon

LXVII Walter the cook

LXviII Moduin

LXIX Ilbodo

Lxx Haghebern

LXXI Tedric Point [el]

LXXII Roger 'God save the ladies.'

LXxiII G[ilbert] son of Salomon

LXxIIII William son of Constantine

LXXv Ansger the cook

LXXVI Robert son of Roscelin

Lxxvir Ralf Pinel

LXXVIII Robert son of Gobert

LXxix Rainald the crossbowman

Lxxx Gonduin

LXXXI Otto the goldsmith 


\section{A HISTORY OF ESSEX}

\begin{tabular}{|c|c|}
\hline $\mathrm{xxx}$ & illa \\
\hline XXXI & The Count of $\mathrm{Ou}[\mathrm{Eu}]$ \\
\hline XXXI1 & Robert Greno [Gernon] \\
\hline XXXIII & Ralf Baignard \\
\hline XXXIIII & Ranulf Peverel \\
\hline $\mathrm{xxxv}$ & Aubrey de Ver \\
\hline XXXVI & Peter de Valognes \\
\hline XXXVII & Ranulf brother of I \\
\hline XXXVIII & Tihel the Breton \\
\hline XXXIIII & Roger de Ramis \\
\hline $\mathrm{XL}$ & John son of Waleram \\
\hline XLI & Robert son of Corbutio \\
\hline XLII & Walter the deacon \\
\hline XLIII & Roger Bigot \\
\hline XLIIII & Robert Malet \\
\hline $\mathrm{XLV}$ & W[illiam] de Scohi \\
\hline XLVI & Roger \\
\hline XLVII & Hug \\
\hline
\end{tabular}

to. $1 \mathrm{~b}$

I. EXSESSA. THE KING'S LANDS

Hundret of Berdestapla [Barstable]

Benflet [Benfleet ${ }^{1}$ ] was held by Harold in the time of King Edward as I manor and as 8 hides. This manor is now in the custody of Ranulf brother of Ilger (and is) in the king's hand(s). ${ }^{2}$ Then 12 villeins; now 21. Then as now (semper) 6 bordars. Then 3 serfs; now 3 (sic). Then 3 ploughs on the demesne; now 2. Then the men had II ploughs; now 5. And there are 30 acres of wood(land). (There is) pasture for I 30 sheep, (and) a moiety of a mill. It was then appraised at 8 pounds; (and) now renders 12 ; but it is only appraised at 8 pounds. In this manor there was at that time a certain free man with (de) half a hide, who has now become (effectus est) one of the villeins and is (included) in the above reckoning. From this manor there was given to a certain church belonging to $(d e)$ another manor, in the time of King Edward half a hide. But, after this manor became part of (venit in) the king's demesne, it was taken away from the church and is again part of (jacet in) the manor. In the whole of this 'Hundret' the king has 18 free men holding half a hide and 49 acres and pasture for 20 sheep. (This) is appraised at

1 It is exceedingly difficult to disentangle the manors in North and South Benfleet as entered in Domesday, but that of the king appears to have been in North Benfleet.

2 That is to say, Ranulf was in charge of it for the king.

\author{
LXXXII Gilbert the priest \\ Lxxxin Grim \\ LXXXIIII Ulveva \\ LXXXv Edward \\ Lxxxvi Turchil \\ LXxxviI Stanard \\ LXXXviII Godwine \\ Lxxxvini Free men of the king \\ xc Aggressions*
}

* It is practically impossible to make a satisfactory translation of such a list of names as this. Those which were Latinized by the scribe have been here translated where possible, and those which were given in a contemporary form have been here retained. But the reader should turn to the entries in the text for fuller information on the names. In the MS. this list of names is arranged in four columns of which the first two are represented by the first of the above columns.

Io shillings. In the demesne of the abovesaid manor are I rouncey ${ }^{3}$ (runcinus), I ass, 30 swine, and 70 sheep.

\section{Half Hundret ${ }^{4}$ of Witham}

WITHAM was held by Harold in the time of King Edward as I manor and as 5 hides. This manor is now in the custody of Peter the sheriff ${ }^{5}$ (and is) in the king's hand(s). Then 2 ploughs on the demesne; now 3 . Then 21 villeins; now 15 . Then 9 bordars; now 10. Then 6 serfs; now 9. Then 23 sokemen; now the same. Then the men had 18 ploughs; now 7 ; and this loss (of plough-oxen) took place (fuit) in the time of Suean and of Baignard the shcriffs and through the death of the beasts. (There is) wood(land) for 150 swine, 30 acres of meadow, (and) pasture (which) used to render 6 pence (and) now (renders) 14 (pence). Then as now (semper) I mill. The aforesaid sokemen hold 2 hides and I virgate and have 2 ploughs. It was then worth in all Io pounds; now 20; but the sheriff, what with his (suas) customary fo. 2

dues and (the profits of) the pleas of the Half Hundret receives thence 34 pounds and 4 pounds fine (gersuma). ${ }^{6}$ Peter took over (recepit) in the demesne of this manor $4^{7}$ and

3 From the French roncin (compare p. 426).

4 For the occasional mention of Essex Hun-

dreds as 'Half' Hundreds see Introduction, p. 407.

5 Peter de Valognes.

- Consideration money for the lease.

7 A word must have been omitted here. 


\section{THE HOLDERS OF LANDS}

24 beasts (animalia) and 136 swine and 101 sheep. The same number is there (totum similiter) now. In this manor there belonged (adjacebant), in the time of King Edward 34 free men who used then to render by custom 10 shillings and II pence. Of these Ilbodo holds 2 with (de) 45 acres; and (they are) worth 6 shillings; and they render to the manor their customary due. Tedric Pointel (holds) 8 with (de) half a hide and $22 \frac{1}{2}$ acres, who render (their) customary due, and are worth 20 shillings. Ranulf Peverel (holds) Io with (de) 2 hides and 45 acres, who do not render (their) customary due and are worth 15 shillings. William son of Grosse (holds) 5 with (de) I hide and 15 acres, (of whom) only one renders (his) customary due, and (they are) worth 3 pounds and 13 shillings. Ralf Baignard (holds) 6 with (de) half a hide and 35 acres; one renders (his) customary due, and (they are) worth 20 shillings. Hamo dapifer holds 1 with (de) half a hide; he renders (his) customary due, and is worth 20 shillings. Goscelin the lorimer has the land of one and does not render (his) customary due; this is (scilicet) I hide, which is claimed by the monks of St. Fthelthryth of Ely ( $(h)$; and (the court of) the Hundret testifies in their favour (eis) concerning a half (of it), and as to the rest (the men of the Hundret) know nothing; it was then worth 100 shillings; now 60; and when Goscelin received it, 100. In all the manor was worth 14 pounds less 2 shillings in the time of King Edward; now 12 pounds and 9 shillings.

\section{Half Hundret of Herlaua [Harlow]}

Hadfelda [Hatfield (Broadoak)] was held by Harold, in the time of King Edward, as I manor and as 20 hides. Then 51 villeins; now 60. Then 19 bordars; now 30 . Then 20 serfs; now 22 . Then 9 ploughs on the demesne; now 8 , and 3 rounceys (runcini) and 40 beasts (animalia) and 195 swine and 1 93 sheep. Then the men had 40 ploughs now $31 \frac{1}{2}$; this loss (of) plough-oxen took place (fuit) in the time of all the sheriffs and through the death of the beasts. (There is) wood(land) for 800 swine, I 20 acres of meadow, (and) pasture which renders 9 wethers (muliones) to (in) the manor and 41 Io. $2 b$

acres of ploughing (aratura). ${ }^{1}$ To the church of this manor there used to belong 1 hide and 30 acres, which were taken away from it by Suen after he lost the shrievalty; and this land used to render a customary due to this

1 i.e. 41 acres on the lord's demesne had to be ploughed in return for the use of the pasture. manor. There also belonged to this manor, in the time of King Edward, I sokeman with half a hide, which G[eoffrey] de Magnavilla took away from it. To this land (terre) there belongs I villein of 1 acre which Count $\mathrm{E}$ [ustace holds; and 30 acres which were held in the time of King Edward by a smith who was put to dcath for theft, and (thereupon) the king's reeve added that land to this manor; and 40 acres of wood(land) which were held by King Edward's reeve; and Osmund the Angevin disseised the king's reeve and the manor both of the land and of the wood(land); Robert Gernon now holds (them). Robert Gernon also holds half a hide which was held by a sokeman in the time of King Edward. In addition to this there belonged (adjacebant) to this manor in the time of King Edward 3 outlying estates (berewita), Herefort [Hertford], Emwella [Amwell] and Hodesduna [Hoddesdon], lying in Hertfordshire (Herefort sira), which are now held by Ralf de Limesay. ${ }^{3}$ And there is I sokeman with (de) 30 acres now as then (semper) belonging to this manor. And the manor was then worth 36 pounds; now 60 ; but the sheriff receives from it $£ 80$ and 100 shillings fine (gersuma). ${ }^{4}$ And the 3 outlying estates (berewite) were then worth 12 pounds, and the land of the sokemen 45 shillings. There is wood(land) for 40 swine. Subsequently we have recovered (sic) half a hide which was held by a sokeman of Harold. It is now held by Ralf de Marcei as belonging to the fee of Hamo. It was then worth 10 shillings; now $70^{5}$

\section{Hundret of Beventreu [Becontree]}

Haveringe ${ }^{6}$ [Havering] was held by Harold in the time of King Edward as 1 manor and as 10 hides. Then 41 villeins; now 40. Then as now (semper) 41 bordars, and 6 serfs, and 2 ploughs on the demesne. Then the men had 41 ploughs; now 40. There is wood(land) for 500 swine, (and) 100 acres of meadow. (There is) now I mill, and (there are) 2 rounceys (runcini), and 10 beasts (animalia), and 160 swine, and 269 sheep. To this manor there belonged in the

2 The text is somewhat obscure here ; but it seems probable that the scribe, as in several other cases, has here used terra indifferently for manerium.

3 This passage is discussed in the Introduction, p. 338 .

4 Consideration money for the lease.

- This important passage relates to the estate of 'Siriceslea' entered under the fief of Hamodapifer (see p. 501 below and Introduction p. 412).

6 'The plural form points to an English 'Haverings.' 


\section{A HISTORY OF ESSEX}

time of King Edward 4 free men with (de) 4 hides which rendered customary dues. Now fo. 3

Robert son of Corbutio holds 3 hides $^{1}$ and Hugh de Montfort the fourth hide ${ }^{2}$; they have not paid the customary due since they had them. And moreover the same Robert (son of Corbutio) holds $4 \frac{1}{2}$ hides which used to be held by a free man as appurtenant to $(a d)$ this manor in the time of King Edward. ${ }^{3}$ There was also appurtenant (attinebat) I sokeman with $(d e) 30$ acres who rendered the customary due; and now John son of Waleram holds (it). And this manor was worth 36 pounds in the time of King Edward; now 40 ; and Peter the sheriff receives from it 80 pounds rent (de censu) and 10 pounds fine (gersuma). ${ }^{4}$ To this manor there belong 20 acres lying in LocheTuNA [Loughton], which were held in the time of King Edward by Harold's reeve ; now the king's reeve holds (them); and they are worth 40 pence.

\section{Hundret of Dommawa [Dunmow]}

In ScElda [Shellow (Bowells)] (are) 3 sokemen with $(d e) 35$ acres, and this is worth 3 shillings and ro pence.

\section{HundRet OF Witbrictesherna [Dengie]}

In Lessenduna [Latchingdon] Alwin', a free man, held in the time of King Edward half a hide and 30 acres. Afterwards Tedric Pointel seized (invasit) it ; and now the king has it. Then as now (semper) half a plough; and it is worth 15 shillings. Of the same estate (terra) I villein holds 30 acres at (ad) Estolleia [ ] and it is worth 5 shillings; and another villein I 5 acres, and it is worth 3 shillings. And 3 men hold half a hide and Io acres, and (there is) half a plough; it was then worth 8 shillings; now 5 shillings and 4 pence.

In LACENDUNa [Latchingdon] Lewin', a free man, (held) 30 acres in the time of King Edward. (There was) then half a plough ;

1 These would seem to be the 3 hides at Leyton (Leintuna) which Domesday enters under the fief of Robert son of Corbutio (p. 546), explaining that they had been held by 8 sokemen who had rendered and who were still rendering (?) their customary dues to the king's manor of Havering (Havelinga).

2 This was certainly one of the 31 hides held by Hugh at Leyton, of which we read (p. 497) that this hide used to pay the customary due to Havering, but did so no longer.

3 These $4 \frac{1}{2}$ hides were similarly at Leyton (see p. 546) and are entered as having been held by Harold.

4 Consideration money for the lease. now none. It was then worth 8 shillings; now 5 (shillings) and 4 pence. In the same (place) there were 8 free men in the time of King Edward; now (there are) 4 with (de) 52 acres; (this) was then worth 8 shillings; now 4 shillings and 4 pence.

In Rodinges [(White) Roding] Golstan, a sokeman of King William, holds 1 hide and has never rendered service or customary due for it, and therefore he has given pledge (ideo dedit vadem $).{ }^{5}$ In this hide there is I plough on the demesne, and I bordar and 3 serfs. (There is) wood(land) for Io swine (and) Io acres of meadow. It was then worth 20 shillings; now 30 .

fo. $3 \mathrm{~b}$

Hundret OF Odelesforda [UTtLesford]

Cestrefforda [(Great) Chesterford] was held by Earl Edgar (sic) ${ }^{6}$ in the time of King Edward as I manor and as Io hides. Now Picot the sheriff $^{7}$ (has the custody of it) in the king's hand(s). Then as now (semper) 4 ploughs on the demesne. Then the men had I 8 ploughs; afterwards and now I 4. Then as now (semper) 24 villeins, and 13 bordars, and 6 serfs. (There is) wood(land) for I,000 swine, (and) I 5 acres of meadow. Then as now (semper) 2 mills. There belongs to (jacet) this manor I $\frac{1}{2}$ hides in Cambridgeshire (cantebruge scira) $;^{8}$ then as now (there were there) 7 villeins and 3 bordars, and a mill, and 3 ploughs belonging to the men. All this was worth then 24 pounds; afterwards and now 30 . In the demesne of this manor are 2 rounceys (runcini), and 7 beasts (animalia), and $6 \mathrm{I}$ swine, and $8 \mathrm{I}$ sheep, and 87 goats. To this manor there belonged (adjacebat) in the time of King Edward I $\frac{1}{2}$ hides which Hardwin 'de Scalariis' holds, but by what right (quomodo) the Hundred (court) knows not. The half hide was of the demesne, and on it dwelt one man; and the other (sic) hide was held by a sokeman who used to render his soke dues (reddebat socam) in the king's manor. ${ }^{9}$

3 See Introduction, p. $4 \mathbf{I} 2$.

6 See ibid. p. 337 and p. 431, note 4, below.

7 Of Cambridgeshire.

8 This must have been at Histon, Cambs, to the north of Cambridge. Domesday expressly states (i. $189 b$ ) that Picot had there $1 \frac{1}{2}$ hides ' of the manor of Chesterford,' which were taxed in their Cambridgeshire Hundred, but 'appraised in Essex.'

9 These two holdings were probably the "half hide' at Babraham held under Hardwin by $\mathrm{Du}$ rand, of which Domesday observes: 'Hec terra est de feudo regis,' and the 'I hide' at Histon held of Hardwin by Durand (fo. 198), which had been held by Estred 'under Earl Filfgar.' 


\section{THE HOLDERS OF LANDS}

And Picot holds half a hide ${ }^{1}$ which was held by a sokeman in the time of King Edward. In these 2 hides are 2 ploughs, and (they) are worth 40 shillings.

Becangra [Birchanger ${ }^{2}$ ] was held by Horolf in the time of King Edward. ${ }^{3}$ Now Tascelin the priest holds it in almoine of the king as 1 hide. Then as now (semper) there were I plough, and 2 bordars, and 2 serfs. (There is) wood(land) for 40 swine, 5 acres of meadow and I mill. Then and afterwards it was worth 20 shillings; now 30.

HUNDRET OF Hidingeforda [HINCKFord]

Celdeforda [Shalford] was held by Earl Algar as I manor and as 5 hides and 30 acres. Afterwards the queen ${ }^{5}$ held (it). Now Otto the goldsmith rents it from the king (ad censum in manu regis). Then as now (semper) 3 ploughs on the demesne. Then the men had 6 ploughs; afterwards and now 5. Then and afterwards (there were) I3 villeins; now 12 . Then as now (semper) 6 bordars. Then 12 serfs; afterwards and now 8. (There is) wood(land) for 100 swine, 20 acres of meadow, (and) I mill. It was then worth 12 pounds; afterwards and now 22. In the demesne are 4 rounceys (runcini), 56 beasts (animalia) -formerly (tunc) 65, and 52 sheep, and 80 swine-formerly (tunc) I I 8 , and 40 goats. This manor is short of 30 acres of wood(land) which the queen gave to Richard son of Count Gilbert. ${ }^{6}$ There used to belong (jacebat) to this manor, in the time of King Edward, half a hide of 'soke' which Walter son of Guibert now holds.?

fo. 4

Phincinghefelda [Finchingfield] was held

1 This must be the $\frac{8}{8}$ hide which Domesday (i. 190) assigns to Picot at Babraham, Cambs, five miles north of Chesterford, adding that the land ' jacet in Cestreforde.'

2 There are two Birchangers in this Hundred. Morant made the above entry refer to the hamlet of that name in Newport, but I know not on what ground. The parish of Birchanger is in Domesday 'Bilichangra' or 'Blichangra.'

8 He had also held at Lindsell some 10 miles away.

4 Earl Elfgar of Mercia son of Earl Leofric.

6 William's wife Matilda.

- Alias Richard de Clare.

7 This is a passage of some importance, for it must refer to the half hide at Shalford ("Scaldefort') held of the king in 1086 by Walter 'the cook,' who was therefore identical with Walter 'the son of Guibert.' This half hide is there entered as having been held 'by a free man as a manor' (p. 559 below). by the same Algar in the time of King Edward and afterwards by the queen. ${ }^{B}$ Now the same Otto rents it (ad censum) as $2 \frac{1}{2}$ hides. Then as now (semper) 3 ploughs on the demesne, and 5 ploughs belonging to the men, and 10 villeins, and 9 bordars. Then 6 serfs; afterwards 4 ; now 2. (There is) wood(land) for 60 swine, 16 acres of meadow, and 1 mill, and 25 beasts (animalia) and 2 rounceys (runcini), 61 swine-formerly (tunc) 63, and 100 sheep. It was then worth 9 pounds; afterwards and now 18 .

WESTREFELDA [Wethersfield] was held by the same Algart in the time of King Edward as a manor and as 2 hides less 15 acres. ${ }^{8}$ Now Picot ${ }^{\theta}$ holds it for the same, (and as) in the king's hand(s). Then (there were) 4 ploughs on the demesne; afterwards 2 ; now 3 . Then and afterwards the men had I 5 ploughs; now 10. Then and afterwards 24 villeins; now 28. Then 7 bordars; afterwards 15; now 24 . Then 7 serfs, afterwards 14; now 7. Then (there was) wood(land) for 800 swine; afterwards and now for 500 ; and there are 24 acres of meadow. Then and afterwards I mill; now 2. There are 10 beasts (animalia)-formerly (tunc) 17, and 100 sheep, (and) 40 swine-formerly 100 , and 40 goats-formerly 61. To this manor there belonged in the time of King Edward 6 sokemen-(there are) now 8-holding 1 hide and 14 acres; then as now (semper) 2 ploughs (were there) and I bordar and 5 acres of meadow. It was (all) then worth 20 pounds; afterwards and now 28. To this manor there belonged (adjacebat) in the time of King Edward 30 acres of land which were held by a priest in almoine-and he rendered 'soke,' and $8 \frac{1}{2}$ acres belonging to another church; these 2 estates (terras) are held by Gilbert son of Warin (Garini) and are worth 10 shillings. There also belonged to this manor $7 \frac{1}{2}$ acres which are held by Count Alan, and 45 acres of demesne which Suen' holds as belonging to (ad) the fief of Richard son of Count Gilbert, ${ }^{10}$ and they are worth 8 shillings.

In this Hundret the king has 18 sokemen; they hold $26 \frac{1}{2}$ acres and have never rendered (any) customary due except the king's service.

8 i.e. $1 \frac{7}{8}$ hides.

- The sheriff of Cambridgeshire.

10 Alias Richard de Clare. Domesday (ii. 40) enters these acres under his manor of Boyton Hall (in Finchingfield), but states that he had taken them from the king's manor of Wethersfield in King William's time. Both entries value them at 8 shillings (see p. 480 below).

Of these three manors of Earl Eilgar's Wethersfield adjoins Finchingfield and Shalford. 


\section{A HISTORY OF ESSEX}

\section{Hundret of Witbrictesherna [Dengie] ${ }^{1}$}

Benflet [Benfleet] was held by Leuard', a free man, in the time of King Edward, (and) afterwards by Tedric Pointel, as I hide. Then as now (semper) I bordar. Then I plough; now none. Pasture for 40 sheep. Then I fishery (piscina); now none. And it is worth 20 shillings.

I0. $4 \mathrm{~b}$

Strpla [Steeple] was held by Aluric, a free man, as I hide. Then I bordar; now none. Then I plough; now half a one. It was then worth 20 shillings; now 16 . In ULwINESCHERHAM [ 2 ] 4 free men held (de) I hide less 6 acres in the time of King Edward; now they are not there; it was then worth 20 shillings; now IO; this land is claimed by Tedric Pointel (as his) by exchange. Free (Franci) men held 5 I acres, and they are not included in the king's ferm (firma) ${ }^{3}$; (they) were then worth 8 shillings; now 5 ; this land is held by a servant (famulus) of the king and does not pay geld. In MELDUNA [Maldon] are 2 free men with $(d \ell)$ 10 acres; of these Ranulf Peverel (piperellus) has 5 acres, and Hugh de Montford 5 acres; it was then worth 10 pence, (and) now 12. Two free men, in the time of King Edward, held 6 acres and belonged to (jacuerunt in) the king's Hundret, and now Baignard has (them).

In the Hundret of Rochesfort [Rochford] Grim the reeve holds now as then (semper) Io acres worth 16 pence.

\section{Hundret of Lassendene [LeXden]}

Stanewega [Stanway] was held by Harold in the time of King Edward as I manor and as $5 \frac{1}{2}$ hides. Now the king has it as the same (pro totidem). Then I 2 villeins; afterwards and now 9. Then 6 bordars; afterwards and now 9. Then as now (semper) 6 serfs and 3 ploughs on the demesne. Then the men had 13 ploughs; afterwards and now $2 \frac{1}{2}$ (ploughs). Then as now (semper) I mill. (There is) wood(land) for 100 swine with 12 acres of meadow, 20 beasts (animalia), 59 swine, 260 sheep, and 11 rounceys (runcini).

1 It is very inexplicable that one should find a wrong Hundredal heading in Domesday prefixed immediately, as here, to the name of a manor. Benfleet was in Barstaple Hundred (see p. 428, note I, above).

2 See Introduction, p. 391.

3 i.e. the receipts from them were not included in the sum for which the king leased out the estate.

- For his holdings in Barstable Hundred see p. ${ }_{564}$ below.
There is also an outlying estate (berewita) of $2 \frac{1}{2}$ hides and 13 acres called LEGRA [Layer], which belongs to (et jacet in) this manor; then as now (semper) 7 villeins (were there), and 2 bordars, and 4 serfs, and 2 ploughs on the demesne; then the men had 2 ploughs, and now $1 \frac{1}{2}$. There also belongs a detached estate (berewita) called Lessendena [Lexden] ${ }^{5}$ of 4 hides; then 6 villeins were there, (and) afterwards and now 5 ; then 10 bordars, (and) afterwards and now 12 ; then 4 serfs, and afterwards and now 5 ; then as now (semper) 2 ploughs on the demesne; then the men had 4 ploughs, and now 3 ; there is wood(land) for 100 swine (with) I 8 acres of meadow; now (there are) 2 mills. And (there are) 16 sokemen with (de) 2 hides and 36 acres; then as now (semper) (they had) $2 \frac{1}{2}$ ploughs. The whole (manor) was then worth 22 pounds; now Peter $^{6}$ receives from it 33 pounds and fo. 5

3 pounds fine (gersuma). ${ }^{7}$ From this manor Reimund Girald' ${ }^{8}$ took I villein with (de) half a hide, who used to render the customary due; now as then (semper) there is there half a plough, and it is worth ro shillings; Norman held this land and rendered the customary due, but Raimund took it away and Roger (de Poitou) likewise. And Roger de Poitou (pictavensis) has taken over (accepit) I villein holding I acre. And Ingelric took away I woman, Bricteva (by name), holding 18 acres, and she used to render 32 pence (nommos) to the manor every year. ${ }^{9}$

\section{Hundret of ANGRe [ONGar]}

UlFelmestuna [Wolverston (in Chigwell)] was held by Harold as a manor and as 3 hides and 40 acres. Now King William (holds it). Then as now (semper) 4 villeins. Then 2 bordars; now 6 . Then the men had I plough between them; now the same. (There is) wood(land) for 60 swine (with) 4 acres of meadow. It was then worth 20 shillings; now 40. A certain free man held 20 acres in the time of King Edward; (there was) then half a plough; now nothing; and it is worth 3 (shillings). He (iste) was always

b Within the liberties of Colchester (compare p. 574 below).

6 Peter de Valognes, the sheriff.

7 Consideration money for the lease.

8 See Introduction, p. 354.

9 This is clearly the customary payment spoken of at Babraham, Belesham, and Iclinton, Cambs. (Domesday, i. 1976, 1906, 198), as 2 ounces (ore or ores) or 32 pence. At the two latter places Domesday records it as 32 pence and the Inquisitio comitatus Cantabrigiensis as 2 ounces (pp. 24, 41). 


\section{THE HOLDERS OF LANDS}

demesne (fuit $d[0 m i]$ nic [us]), but is now in the sherif's hand(s) and included in the king's ferm (ad firmam regis). ${ }^{1}$

\section{Hundret of Cesfeworda [Chafford]}

The king has Phingheria [Fingrith ${ }^{3}$ (in Blackmore)] which was held by Harold in the time of King Edward. (There was) then as now (semper) 1 plough on the demesne; and 6 villeins and 8 bordars have 2 ploughs. In the demesne are 24 beasts (animalia). (There is) wood(land) for 1,000 swine, (with) 3 acres of meadow. It was then worth 4 pounds; now I4. In WochenduNA [Ockendon] the king has I sokeman with (de) 25 acres; it was then worth 32 pence, (and) now 52.

Ginga [(Margarett)ing] " was held by Friebert in the time of King Edward as a manor and as $3 \frac{1}{2}$ hides. Then as now (semper) 6 villeins and 3 bordars. Then 2 serfs; now 1. Then as now (semper) 2 ploughs on the demesne and the men had I plough. (There are) 4 acres of meadow and 88 swine. It is appraised ( $\left.A p p^{\prime}\right)$ in Phingheria [Fingrith]. ${ }^{6}$

Ciltendis [Childerditch] was held by Harold; afterwards by the queen; now the sheriff of Surrey (holds it) for $1 \frac{1}{2}$ hides. Then 3 villeins; now 5. Then 3 bordars;

1 This is a very obscure and probably corrupt passage.

2 In spite of this Hundredal heading, the two manors which follow it are in Chelmsford Hundred. It is not till we reach Childerditch that we find ourselves in Chafford Hundred.

s This place was not identified by Mr. Chisenhale-Marsh, and Morant asserted that there was not any mention of Blackmore in Domesday. This gives some importance to the above identification, which is confirmed by the subsequent occurrence of the three manors entered together in the text as held by the serjeanty of acting as chamberlain to the queen. In The Red Book of the Exchequer (p. 507) we read : "Johannes de Sanford Wolvermestone per serjanteriam in camera Reginx, et Fingret, et Ginges,' etc. In the Testa de Nevill version of the same inquest (I2I2) we similarly read; 'Gilbertus de Saunford . . . Fingrie, Ginges, et partem de Wlfameston per serjant[eriam] quod sit camerarius domine Regine' (p. 266). The first and last names are preserved in Fingrith $\mathrm{Hall}$ and Wolston Lodge.

- This 'Ing' (Ginga) is identified, like Fingrith, by its forming part of the above holding by serjeanty, which explains how the Sandfords came to hold Margaretting. Morant wrongly assigned other Domesday entries, instead of this one, to Margaretting.

- This last sentence and the Childerditch entry which follows have been huddled into the MS. subsequently. now 4. (There is) I serf. Then 1 plough on the demesne; now It. Then the men had 2 ploughs; afterwards and now 1 . (There is) wood(land) for 100 swine, (and) pasture for 60 sheep. It was then worth 3 pounds; now $4 .^{6}$

\section{Hundret of Celmeresfort [Chelmaford]}

Writela [Writtle ${ }^{7}$ ] was held by Harold as a manor and as 16 hides in the time of King Edward. Now King William (holds it) as 14 hides. $^{8}$ Then 97 villeins; afterwards and now 73. Then 36 bordars; afterwards and now 60. Then 24 serfs; afterwards and now 18. Then 12 ploughs on the demesne; fo. sb

afterwards and now 9. Then the men had between them 64 ploughs; afterwards and now 45. Then (there was) wood(land) for 1,500 swine; now for 1,200. (There are) 80 acres of meadow. Then 1 mill; now 2 . Then as now (semper) 9 rounceys (runcini) and 5 colts (pulls) and 40 beasts (animalia) and 318 sheep and 172 swine. This manor then rendered 10 nights' ferm (noctes de firma) ${ }^{9}$ and 10 pounds. It now renders 100 pounds by weight and 100 shillings fine (gersuma). ${ }^{10}$ Ingelric obtained possession of ( $p^{\prime}$ occupavit) 2 hides of the land of Harold's reeve who rendered to this manor all the customary due, that is 12 pounds, after the king came into England; and Count E[ustace] now holds it because his predecessor was seised of it."1 And in Harold's time there was I swineherd rendering the customary due to this manor and seated (sedens) on I virgate of land and 15 acres; but Robert Gernon (grino), after the king came (into) England took (accepit) him from the manor and made him (a) forester of

6 This Childerditch entry has been crowded in afterwards by the scribe on an insufficient blank space.

7 This comprised more than the present parish of Writtle; Roxwell, for instance, which was only a hamlet or chapelry of Writtle.

8 Because Ingelric had annexed 2 hides (as in the text).

9 See Introduction (p. 336) for this phrase.

10 Consideration money for the lease.

11 Under the fief of Earl Eustace (p. 468 below) Domesday states that his manor of Newland (Hall in Roxwell) had been held by Harold 'as 1 manor and as 3 (sic) hides' and had belonged to Writtle in the time of King Edward, but had been seised by Ingelric. As its value had only risen from $C_{5}$ to $\{7$, there seems to be something wrong about the alleged due of 612 from it. And its 3 hides are 2 in the Writtle entry. 


\section{A HISTORY OF ESSEX}

the king's woods (silva). ${ }^{1}$ And I hide was given by Harold to a certain priest of his; but the Hundret (court) knows not whether he gave (it to be held) freely (libera) or in almoine. It is now held by $\mathrm{R}$ [obert] Bishop of Hereford. And (there is) half a hide which was held freely by I sokeman who rendered 'soke' in the manor, but (et tamen) could betake himself (posset ire) with his land whither he would. ${ }^{2}$ Count Eustace added (adjunxit) him to his land. In this manor are still included (semper jacent) 2 sokemen with (de) half a hide and Io acres, who have now as then (semper) half a plough; there are 4 acres of meadow ; (this is) included (appreciatum) in the above roo pounds.

In WIRITELA [Writtle] the same bishop holds 2 hides and 20 acres, of which I hide belonged to (fuit in) the church in the time of King Edward and the other (was) of (in) the king's fee (sic). Then as now (semper) 3 villeins and I priest. Then 2 bordars; now 8. Then 2 serfs; (now none). Then as now (semper) I plough on the demesne and 2 ploughs belonging to the men. (There is) wood(land) for roo swine, (with) 8 acres of meadow ; and it is worth 50 shillings. ${ }^{3}$

\section{Half Hundret of Melduna [Maldon]}

In Malduna [Maldon] the king has I house and pasture for 100 sheep. And (there is) I sokeman with (de) 49 acres who has I bordar; (there was) I plough in the time of King Edward, (and) now a half; it was then worth Io shillings, (and) now 5. In the same (Maldon) the king has 180 houses held by burgesses and 18 messuages (mansuras) that are waste ; 4 of which (burgesses) I 5 hold half a hide and $2 \mathrm{I}$ acres, while (et) the other men fo. 6

hold no more than their houses in the borough. And among them they have 12 rounceys (runcinos) and 140 beasts (animalia) and 103 swine and 336 sheep. From the king's hall (balla) there are always received (exeunt) 6 shillings and 8 pence, and from Suen's land 4 shillings, ${ }^{6}$ and from (the) 2 houses of Eudo dapifer 16 pence which the

1 This is an interesting allusion to Robert's own office of king's forester.

2 i.e. could choose his lord.

3 This entry of the bishop's land in Writtle is repeated below under his own fief (p. 460).

4 This passage seems to imply that 'quas tenent burgenses ' merely means 'inhabited' as opposed to 'vastatas' uninhabited.

5 This is duly entered under Suain's fief below (p. 491) as a 'customary due' received by the king. king has not received (non habuit) since he came into this land. From the aforesaid sokeman Ranulf Peverel has received (babuit) yearly a customary due of (consuetudinem per) 3 shillings; but in King Edward's time his predecessor had only (the man's) commendation. And in King Edward's time the whole together rendered 13 pounds and 2 shillings; and when Peter $^{6}$ received it 24 pounds; now 16 pounds by weight.

\section{Hundret of Tendering [Tendring] AND ... 7}

Brictriceseia [Brightlingsea] was held by Harold as a manor and as Io hides. Now King William (holds it). Then as now (semper) 24 villeins. Then ro bordars; afterwards II; now 16 bordars; and Io bordars who hold no land. ${ }^{8}$ Then 4 serfs; now 5. Then 3 ploughs on the demesne; afterwards and now 2. Then the men had I 6 ploughs; afterwards and now II. (There is) wood(land) for I 00 swine. (There is) now I mill. Pasture for 600 sheep. Then as now (there were) I 6 beasts (animalia) and 5 rounceys (runcini) and 166 sheep and 62 swine. Then Brictriceseia [Brightlingsea] and Herchesteda [Harkstead $]^{9}$ between them rendered 2 nights' ferm (noctes de firma); ${ }^{10}$ and when $\mathrm{P}[\mathrm{eter}]^{11}$ received them 25 pounds; now 22 pounds. But that outlying estate (berewita) lies in Suffolk. ${ }^{12}$ In the demesne are 4 beasts (animalia) and 5 swine.

LALEFORDA [Lawford] was held by Harold as I manor and as Io hides, and is now so (pro totidem) held by King William. Then as now (semper) there were I 5 villeins and 24 bordars. Then 7 serfs; now 6. Then as now (semper) 4 ploughs on the demesne. Then the men had 20 ploughs between them ; and 16 when Baignard held (it) $;^{13}$ but when $\mathrm{P}[\text { eter }]^{14}$ received it, 9 ; and 9 (similiter)

- Peter de Valognes, the sheriff.

7 So read by the Record Commission's edition, but probably 'Tenderinge' only was intended.

8 It is just possible, judging from the entry of Leigh on the Thames below, that these represent a maritime element.

9 In Suffolk, on the north shore of the Stour estuary.

10 See Introduction, p. 336.

11 Peter de Valognes, the sheriff.

12 The meaning of this passage seems to be that the diminution in the value of Brightlingsea is due to the fact that at the time of the survey Harkstead was farmed separately by Peter as a part of Suffolk, where we find it separately valued in 1086 (ii. 2866).

13 i.e. as sheriff.

14 Peter de Valognes, the sheriff. 


\section{THE HOLDERS OF LANDS}

now. There is wood(land) for 15 swine, (with) 12 acres of meadow. Then I mill; now 2. Pasture for 300 sheep. Now I saltpan. It then ' rendered 2 nights' ferm (noctes de firma); ${ }^{11}$ and when Baignard held it, 14 pounds; now II (pounds). To this manor there belonged (jacuerunt) in the time of King Edward I 7 sokemen (with) I hide who rendered all customary due(s); and after the king came into this land, and Bain[ard] was sheriff, Tedric Pointel obtained possession of (occupavit) that land; and when he received it there were dwelling on (manebant in) it I 7 sokemen who had 9 ploughs; they are now in the king's ro. $\mathrm{bb}$

hand(s), and 13 men hold this land and have 4 ploughs; (there is) wood(land) there for 15 swine, with $2 \frac{1}{2}$ acres of meadow ; it was then ${ }^{1}$ worth 4 pounds; and when Tedric Pointel held it 4 pounds; now 40 shillings. Peter (de Valognes) took over (accepit) on the demesne of this manor 21 beasts (animalia) and 4 rounceys (runcinos) and 45 swine and 190 sheep. To this manor there belonged in the time of King Edward an outlying estate (berewita) of 4 hides which Engelric seized (invasit); Count Eustace holds it. ${ }^{2}$ There also used to belong 21 sokemen holding I hide and 2 virgates and 5 acres, whom Roger de Ramis has-in exchange, as he says-and he vouches Suain to warranty (inde vocat liberatorem suanum). ${ }^{3}$ And there were in this manor, in King Edward's time, 4 sokemen who rendered all customary due(s); Richard son of Count Gilbert seized them (invasit) when Suen was sheriff; they hold half a hide and 15 acres, which are now in the king's hand(s), because there was no one on Richard's (ejus) part who could say how he came to have them; then as now (semper) I plough was (there), and in King Edward's time it was worth 13 shillings, and hitherto Richard has had that rent." Waleram seized I sokeman

\section{1 i.e. in King Edward's time.}

2 There is some difficulty in identifying this estate. The count had succeeded Ingelric in several estates lying in 'Tendring Hundred, among which was Dale Hall in Lawford, but this is entered as a manor of only 2 hides; nor, it would seem, is Ingelric charged with seizing more than 3 hide there (see p. 470 below).

3 That is to say he alleged that Swegen of Essex, when in charge of the manor as sheriff, gave him livery of this land (see Introduction, p. 4I3). It cannot be clearly identified among his lands below (pp. 543-4).

4 Under Richard's land (p. 480 below) we only find 37 acres (at 'Aleforda') entered as belonging to Lawford, though held by him at the time of with (de) 30 acres; (there was) then I plough, and now none; and it is worth ro shillings; and Waleram has had that rent till now. Hagebert ${ }^{6}$ holds 30 acres, which were held by I sokeman, and he vouches Suain to warranty (inde revocat liberatorem suanum); (there was) then I plough, (and) now a half; it was then worth 5 shillings and 4 pence, (and) now 32 pence. Count Eustace holds $1 \frac{1}{2}$ hides and 45 acres which were seized by Engelric; and that land was held by 8 sokemen. The Bishop of Bayeux holds half a hide, which Ralf son of Turold holds under him. ${ }^{7}$ Ranulf brother of Ilger holds 15 acres ${ }^{8}$ Hugh de Mon(t)fort 30 acres; Ralf Baignart half a hide and 35 acres; ${ }^{\circ}$ Eudo dapifer $37 \frac{1}{2}$ acres ; Roger, a man of the Bishop of London, ${ }^{10}$ I hide and 30 acres; Walter the deacon 5 acres. All this land used to render every customary due to the abovesaid manor in King Edward's time.

โo. 7

\section{Hundret of Odelesfort [UTtLesford]}

NeUPoRT [Newport] was held by Harold, in King Edward's time, as a manor and as $8 \frac{1}{2}$ hides. Now King William (holds it). Then 18 villeins; afterwards 15 ; now 26 . Then 8 bordars; afterwards 6 ; now 13 . Then 4 serfs; afterwards and now 2. Then 2 ploughs on the demesne; afterwards and now I. Then and afterwards the men had 8 ploughs between them; now 10 . (There is) wood(land) for 100 swine, (with) 24 acres of meadow. Then as now (semper) 2 mills and Io beasts (animalia) and I rouncey (runcinus) (and) 79 swine (and) 102 sheep. It used then ${ }^{1}$ to render 2 nights' ferm (noctes de firma). ${ }^{11}$ There is, moreover, an outlying estate (berewita) of 3 hides and 46 acres, which lies in

the Survey ; and its rent was only 6 shillings (formerly 10).

6 This does not seem to be accounted for under his (son's) land.

8 This was doubeless the Haghebern whose land is entered on p. 561 below, but there is no mention of this there.

7 Under the bishop's land Domesday enters 2 half hide at Alresford as having been seized by Turold (of Rochester)-Ralfs father-and as being in the king's hands in 1086 because Ralf could not prove his right to it (p. 460 below).

8 These are duly entered, under his land, as in the manor of Lawford.

9 This estate is entered under his land, where it is said that he claims to have obtained it by exchange.

10 Probably the 'Roger' who held of him New Hall in Tendring.

11 See Introduction, p. 336. 


\section{A HISTORY OF ESSEX}

Cambridgeshire (Cantebruge sira) and is called Scelfort [Shelford] ${ }^{1}$; then as now (semper) there were (there) 8 villeins and 5 bordars, and I plough on the demesne, and 2 ploughs belonging to the men, and I 5 acres of meadow ; then I rouncey, (and) now none; then as now (semper) to beasts; then 80 swine, (and) now 50; then 80 sheep, (and) now 87; then 13 goats, (and) now 24. This outlying estate (berewita) was included in the above ferm ${ }^{2}$ in King Edward's time, but now (the manor) renders 25 pounds and 16 shillings. Robert Gernon (grino) holds 2 sokemen with (de) $2 \frac{1}{2}$ hides who belong to this manor and render all customary due(s); he received them when Suen was sheriff, and the Hundret (court) knows not how he came to have them, for there came into the Hundred neither writ nor officer (legatus) on the king's behalf (to say) that the king had given him that land. A certain clerk of Count Eustace had obtained possession of (invaserat) 42 acres and was holding them as part of $(a d)$ the fief of Count Eustace; but the Hundret (court) testifies that they (belong) to Newport, and so the king now has (them); and the clerk is adjudged (judicatus) to be at the king's mercy as to $(d e)$ all his possessions (cessu) and his body $;^{3}$ in that land there was then I plough, (and) now none; (there is) I acre of meadow, (and) wood(land) for 6 swine, and it is worth 6 shillings.

Richelinga [Rickling] was held by Harold as a manor and as 8 hides (and is) now so (pro totidem) held by King William. Then 13 villeins; afterwards 16 ; now 20 . Then and afterwards 6 bordars; now IO. Then as now (semper) 4 serfs, and 2 ploughs on the demesne. Then and afterwards the men had 8 ploughs; now 10. (There is) wood(land) ro. $7 \mathrm{~b}$

for 30 swine, (with) 3 acres of meadow. It was then worth 8 pounds; now 12 pounds and 16 shillings. On the demesne are 7 beasts (animalia) and 70 sheep.

\section{Half Hundret of Frosscewella [Fresh- WELL]}

SANFORT [(Great) Sampford] was held by

1 A few miles south of Cambridge (see Introduction, p. 338).

2 i.e. the two estates together provided the two nights' ferm. Compare the case of Brightlingsea with Harkstead above.

3 This entry is suggestive of trial and judgment before the Domesday Commissioners (see Introduction, p. 4II).
Edeva, ${ }^{4}$ (and) afterwards by Earl Ralf, ${ }^{5}$ (and is) now (in charge of) Godric 'dapifer' in the king's hand(s) as a manor and as 7 hides and 30 acres. Then 26 villeins; afterwards 13 ; now I6. Then 9 bordars; afterwards 6 ; now 5. Then as now (semper) 4 serfs, and 2 ploughs on the demesne. Then the men had 22 ploughs between them; afterwards 15 ; now 14. (There is) wood(land) for 150 swine, (with) 30 acres of meadow. Then as now (semper) I mill. It was then worth 20 pounds; afterwards 26 ; now 30 .

\section{Hundret of Turestapla [Thurstable]}

King William has in this Hundret 4 saltpans, of which the sheriff has charge (custodit), and 3 men with (de) ro acres, and (they are) worth 20 pence.

\section{fo. 8}

\section{THE LANDS OF THE HOLY} TRINITY OF CANTERBURY ${ }^{6}[C A N-$

\section{TORBERIA] FOR THE SUPPORT} OF THE MONKS

\section{HUNDRET OF WITHAM}

In Coghessala [(Little) Coggeshall] the Holy Trinity ${ }^{7}$ held in King Edward's time and holds now (modo similiter) 3 virgates of land. Then as now (semper) 2 ploughs. Then I bordar; now 8 . Then 3 serfs; now 1 . (There are) 8 acres of meadow (and) 1 mill. And it is worth 60 shillings. On the demesne are 4 rounceys (runcini), 3 beasts (animalia), 20 sheep, and 7 swine.

Bochinges [Bocking] was always held by the Holy Trinity as a manor and as $4 \frac{1}{2}$ hides; and there are 2 ploughs on the demesne. Then the men had 35 ploughs; now 29. Then 19 villeins; now 18 . Then 25 bordars; now 44. Then 4 serfs; now 2. (There is) wood(land) for 300 swine, pasture for 60 sheep, 22 acres of meadow (and) a mill. And (there are) 6 beasts (animalia), and 100 sheep, and 54 swine. There belong to this manor now as then (semper) 2 hides in Meresai [(Bocking Hall in East) Mersey]; and (there are there) I plough on the demesne, and I plough belonging to the men, and 2 villeins, and I bordar, and pasture for 50 sheep. Then the whole together was worth 24 pounds; now 28.

4 Edith the Fair (see Introduction, p. 350).

5 Of Norfolk, forfeited 1075.

6 i.e. Christchurch.

7 i.e. the cathedral church of Christchurch. 


\section{THE HOLDERS OF LANDS}

Stiesteda [Stisted] was held by the Holy Trinity as a manor and as half a hide. Then 4 ploughs on the demesne; now 3 . Then the men had 5 ploughs; now 6 . Then 8 villeins; now 13. Then 11 bordars; now 25. Then 6 serfs; now 4. (There is) wood(land) for 800 swine, (with) 27 acres of meadow and 1 mill. (There are) 3 rounceys (runcini), and 40 beasts (animalia), and 120 sheep, (and) 77 swine. It was then worth 10 pounds; now 15.

\section{HUNDRET OF WITBRICTESHERNA [DENGIE]}

Lalinge [Lawling '] was held (ten') by the Holy Trinity as a manor and as 14 hides. Then 14 villeins; now 21. Then 16 bordars; now 20. Then 3 serfs; now 4 . Then 2 ploughs on the demesne; now 3. Then the men had $17 \frac{1}{2}$ ploughs; now $16 \frac{1}{\frac{1}{3}}$. Then as now (semper) 1 mill. (There is) wood(land) for 800 swine, and (there are) 3 rounceys (runcini), and 1 mule, and 16 beasts (animalia) and 60 swine and 200 sheep, and 18 goats. It was then worth 12 pounds; now 16 .

Lachenduna [Latchingdon] was held (ten') by the Holy Trinity as a manor and as 2 hides. And there is I plough on the demesne. (There are) now 2 villeins and 1 serf. (There is) pasture for 30 sheep, and (there are) 6 beasts (animalia), and 60 sheep, and 16 swine. It was then worth 20 shillings; now 25.

Niwelant [West Newland " ] was held (ten') by the Holy Trinity as a manor and as 3 hides. Then 1 villein; now 3 . Then as fo. $8 \mathrm{~b}$

now (semper) 2 serfs. Then 2 ploughs; now 1. Then 24 sheep, and now the same. It was then worth 20 shillings; now 40.

\section{HUNDRET OF ROCHEFORT [ROCHFORD]}

Mrrdentuna [Milton (Hall) ${ }^{3}$ ] was held (ten') by the Holy Trinity as a manor and (as) 2 hides. Then as now (semper) 8 villeins. Then 13 bordars; now 15. Then as now (semper) I serf, and 2 ploughs on the demesne, and 6 ploughs belonging to the men. (There is) wood(land) for 60 swine. And (there are) 8 beasts (animalia), and 2 rounceys (runcini), and 25 swine, and 124 sheep. It was then worth 100 shillings; now 8 pounds.

1 In Latchingdon.

2 A manor in St. Lawrence.

In Prittlewell.
SUDCERCA [Southchurch] was held (ten') by the Holy Trinity as a manor and as 4 hides. Then as now (semper) 14 villeins and 5 bordars. Then 2 serfs; now 1. Then as now (semper) 2 ploughs on the demesne, and 6 ploughs belonging to the men. (There is) pasture for 200 sheep, wood(land) for 40 swine, and 2 fisheries. And (there are) 4 rounceys (runcint), and 8 beasts (animalia), and 13 swine, and 150 sheep, and 16 goats. It was then worth 100 shillings; now 7 pounds.

Stanbruge [(Little) Stambridge] was held by the Holy Trinity as a manor and as I hide in King Edward's time. Now Ralf Baignar[d] (holds it) of the church." Then as now (semper) I plough on the demesne. Then 3 bordars; now 7. And (there is) I acre of meadow, (and) pasture for 200 sheep. And (there are) 4 beasts (animalia), and 10 swine, and 58 sheep. It was then worth 30 shillings; now 40.

fo. $g b^{s}$

\section{EXSÆSSA}

\section{THE LAND OF THE BISHOP OF LONDON}

\section{Hundret of Berdestapla [Barstable]}

LegendunA [Laindon ${ }^{6}$ ], which was held by Alftred, a certain worman, in King Edward's time, is held by the bishop as 1 manor and as 9 hides. Then 2 ploughs on the demesne; now 3. Then the men had 7 ploughs; now 6 . Then 8 villeins; now 3 . Now 14 bordars. Then as now 6 serfs. (There is) wood(land) for 100 swine, (and) pasture for 100 sheep. It was then worth 9 pounds; now IO; but the bishop receives thence 14 pounds. Of this manor Ralf and William hold 3 hides and 80 acres of the bishop; and (there are there) I plough on the demesne, and 2 ploughs belonging to the men; and it is worth 100 shillings (which is included) in the above valuation (pretio). The bishop took over (recepit) on the demesne 97 sheep and 10 swine.

ORSEDA [Orsett], which was held by Bishop William in King Edward's time, is held by the bishop as a manor and as 13 hides; but

4 i.e. of Christchurch.

- At the top of fo. 9 is 2 list of the five next tenants-in-chief, which has been delcted. The rest of that folio is blank. A similar list, similarly deleted, is found on fo. 17 of this volume of Domesday (see Introduction, p. 413). below. 


\section{A HISTORY OF ESSEX}

Count Eustace holds one of these, ${ }^{1}$ which does not belong to his 100 manors (qua non est de suis $r$ mansionibus). Then as now (semper) 2 ploughs on the demesne. Then 34 ploughs belonging to the men; now 22 . Then 34 villeins; now 22. Then 6 bordars; now 36. Then 4 serfs; now 2. (There is) wood(land) for 1,000 (swine), ${ }^{2}$ and (there are) 6 beasts (animalia), and I 5 sheep, and 40 swine. It was then worth 35 pounds; now 28. Of this same manor Tidbald', Anschitill, William, (and) Gilbert hold $4 \frac{1}{2}$ hides and 40 acres; and (there are there) 6 ploughs; and it is worth 8 pounds (which is included) in the above valuation (eodem pretio).

Ramesdana [Ramsden (Belhus)] is held of the bishop by William as a manor and as 3 hides. Then as now (semper) I plough on the demesne, and half a plough belonging to the men. Then 6 bordars; now 8 ; and (there is) I serf. Wood(land) for 100 swine. Now I mill. It was then worth 60 shillings; now 40 .

\section{HUNDRET OF WITHAM}

In Slamondesheia [Slamondsay (in White Notley)] Roger holds of the bishop 15 acres; and it is worth 30 pence.

\section{Hundret of Beventreu [Becontree]}

Wenesteda [Wanstead] was held by St. Paul; now Ralf son of Brien (holds it) of the bishop as I manor and as I hide. Then I plough on the demesne; now $1 \frac{1}{2}$. Then as now (semper) 2 ploughs belonging to the men; and 3 villeins. Then 7 bordars; now 8 . Then 2 serfs; now none. Wood(land) for 300 swine. Now I mill. Then as now (semper) I saltpan. And it is worth 40 shillings.

fo. 10

\section{Hundret of Wensistreu [Winstree]}

Legra [Layer (Marney)] was held by 2 free men in King Edward's time; now Roger (holds it) of the bishop as 3 hides. Then as now (semper) I $\frac{1}{2}$ ploughs on the demesne, and 2 ploughs belonging to the men. Then 5 villeins; now 4 . Then 4 bordars; now 6. Then 3 serfs; now 4. Wood(land) for 150 swine and 2 acres of meadow. It was then worth 70 shillings; now 4 pounds.

LEGRA [Layer (Marney)] is held by the same Roger of the bishop, and was (quod)

1 Loft Hall in Orsett (see p. 46I below).

2 The word 'swine' is omitted. held in King Edward's time by I free woman as 3 hides. Then as now (semper) 2 ploughs on the demesne. Now half a plough belonging to the men. Now I villein. Then I bordar; now 4. Then 3 serfs; now 4. Wood(land) for I 50 swine. Now I mill. Then as now (semper) I saltpan. It was then worth 70 shillings; now 4 pounds. Bishop W[illiam] proved his right to (deratiocinavit) these two manors, for the use of (ad opus) his church after King Edward's death by King William's command.

\section{HUndret of Hidinghafort [Hinckford]}

RaInes [Rayne ${ }^{3}$ ] was held by Bishop William in King Edward's time as 4 hides and 30 acres. Then as now (semper) 2 ploughs on the demesne. Then 5 ploughs belonging to the men; now 4. Then 16 villeins; now Io. Then 9 bordars; now 8. Then 4 serfs; now 3 . Wood(land) for 200 swine, (and) 16 acres of meadow. Now I mill. And (there are) 10 beasts (animalia) and 45 sheep and 24 swine. To this manor have been added, in King William's time, I 5 acres which were held, in King Edward's time, by I free man, as the Hundret (court) testifies. It was then worth ro pounds; now 14. In this manor Roger holds of the bishop 3 virgates; and (there are there) I plough and 2 serfs; and it is worth 50 shillings.

\section{HundRET OF Witbrictesherna [DENGIE]}

In Sudmunstra [Southminster] (are) 30 hides which are held by the bishop in demesne. ${ }^{4}$ And in King Edward's time (there were) 22 villeins; now II. Then 23 bordars; now 25. Then as now (semper) 5 serfs, and 3 ploughs on the demesne. Then I 8 ploughs belonging to the men; now II. Pasture for 1,000 sheep. It was then worth 24 pounds; now 16 . In this manor there were, in King Edward's time, 15 free men who held 18 hides and 13 acres; now there are 14 men who hold these of the bishop ; then (there were there) 4 bordars, (and) now

3 This part of the Domesday Rayne was afterwards included in Braintree as the bishop's manor.

4 Originally written 'are held of the bishop by 14 knights,' which was deleted and an interlineation substituted as in the text. The bishop's 30 hides here included more than Southminster itself (see Introduction, p. 395).

5 This would seem to have been the origin of the erroneous entry of the " 14 knights' which (as explained in the preceding note) was deleted. They held this subordinate estate, not the chief manor. 


\section{THE HOLDERS OF LANDS}

I6; then 4 serfs, (and) now 8 ; then 12 ploughs, (and) now 7 ; pasture for 300 sheep ; it was then worth 12 pounds; now 8 . On the demesne of this manor are 11 beasts (animalia), and 696 sheep, and 20 swine. King Canute (Gnut) took away this land, but so. sob

Bishop William recovered it in King William's time.

Copeforda [Copford '] is held by the bishop in demesne as $1 \frac{1}{2}$ hides and 18 acres. Then 16 bordars; now 14 . Then 5 serfs; now 3. Then as now (semper) 2 ploughs on the demesne. Then the men had 7 ploughs; now 5. Wood(land) for 100 swine, and 16 acres of meadow. And (there are) 6 beasts (animalia), and 12 swine and 37 sheep. Then as now (semper) it was worth 8 pounds. To this manor there belonged, in King Edward's time, 12 sokemen-(there are) now roholding I hide and $2 \frac{1}{8}$ acres; and they could not withdraw themselves (recedere) ${ }^{2}$ as the Hundret (court) testifies; (there were) then between them 2 ploughs; now $1 \frac{1}{2}$; the value (of them) is (included) in the above valuation (pretio). Of this land ${ }^{3}$ (terra) Roger holds of the bishop 25 acres, and (there is there) half a plough, and it is worth 15 shillings. In this manor 17 acres, which were held by the bishop in King Edward's time, are now held by Robert Gernon of the king's gift. Robert also holds 1 virgate of land which was held by the bishop; and a certain free man so held it that he could betake himself (irl) whither he would, but the soke remained in the manor.

\section{Hundret of Ceffeorda [Chafford]}

Wareleia [(Little) Warley] was held by Guert as a manor and as 4 hides less 15 acres. Now Humfrey (holds it) of the bishop. Then as now (semper) 5 villeins and 2 bordars. Now 2 serfs. Then 3 ploughs on the demesne; now 2. Then as now (semper) the men had 3 ploughs. Wood(land) for 700 swine. Pasture for 100 sheep. Then and afterwards it was worth 6 pounds; now 7 . Of this manor Tascelin the priest holds 15 acres." This manor was given to Bishop William by King William after he had crossed the sea, because it belonged of old to

1 In Lexden Hundred.

2 i.e. betake themselves to another lord.

3 i.e. of this manor, as in the next clause. The whole entry affords additional illustration of the convertible use of 'terra' and 'manerium' in Domesday.

i.e. to another lord.

- Compare p. 431 above under 'Becangra.' (in antique tempore fuit de) the church of St. Paul.

Celmeresfort [Chelmsford] ${ }^{6}$ was held by Bishop William in King Edward's time. Now the bishop holds it in demesne ${ }^{7}$ as a manor and (as) 8 hides. Then 5 villeins; now 4. Then 2 ploughs on the demesne; now 3 . Then the men had 5 ploughs between them; now 1. Wood(land) for 300 swine, (and) 30 acres of meadow. Then as now (semper) I mill. And (there are) 2 beasts (animalia) and 27 swine, and 100 sheep. And it is worth 8 pounds.

\section{Hundret of Turestapla [Thurstable]}

Wicham [Wickham (Bishops)], which Bishop William held in King Edward's time, is held by the bishop in demesne as a manor and as 3 hides. Then 7 villeins; now 5 . Then I bordar; now 4. Then as now (semper) 4 serfs and 2 ploughs on the demesne. Then the men had 4 ploughs; now $2 \frac{1}{2}$. Wood(land) for 30 swine, (and) 31 acres of meadow. Then as now (semper) I mill. And (there are) 6 beasts (animalia), 50 sheep, Io swine, (and) 20 goats. And it is worth 6 pounds. In it is I free man with (de) 5 acres, so. II

and (he) is worth 12 pence.

\section{Hundret of Tenderinga [Tendring]}

Cicr [Chich ${ }^{8}$ ] is held by the bishop in demesne as a manor and (as) 7 hides. And in King Edward's time (there were) 18 villeins; now 9. Then as now (semper) 5 bordars. Then 3 ploughs on the demesne; now 2. Then the men had between them 9 ploughs; now 5. There are 4 acres of meadow, (and) pasture for 200 sheep. And (there are) 6 beasts (animalia), 150 sheep, and 16 (sic), and 30 swine. It was then worth 18 pounds; now 12.

Clachintuna [Clacton] was always the see's (in episcopatu) as a manor and (as) 20 hides. Then 50 villeins; now 45 . Then 20 bordars; now 50. Then 13 serfs; now 7. Then 4 ploughs on the demesne; now 3. Then the men had so ploughs between them; now 20. Wood(land) for 400 swine, (and) 20 acres of meadow. Then as now (semper) I fishery; now I mill. (There

8 In Chelmsford Hundred. Hall.

8 Now St. Osyths.

9 Possibly for 'and 16 (sheep over).' 


\section{A HISTORY OF ESSEX}

is) pasture for Ioo sheep. And (there are) I rouncey (runcinus) and 7 beasts (animalia), and 30 swine, and 4 I sheep. It was then worth 40 pounds; now 26. Of this same manor 5 knights hold 4 hides, and (there are there) 6 ploughs, and (there are) 2 villeins and 45 bordars and 3 serfs who have 3 ploughs; and it is worth 8 pounds and 2 shillings (included) in the above valuation (eodem pretio).

In Colecestra [Colchester] the bishop has 14 houses and 4 acres, which render no customary due, save scot, to any one but the bishop. ${ }^{1}$ There also (in eadem) Hugh holds of the bishop 2 hides and $I$ acre and renders customary due(s); (there were there) then as now (semper) 2 ploughs on the demesne, and I plough belonging to the men, and 2 villeins, and II bordars, and I serf, and $6 \frac{1}{2}$ acres of meadow; now I mill; then and afterwards it was worth 40 shillings, and now $50 .{ }^{8}$

\section{IIII. (THE) FEE OF THE BISHOP OF LONDON $^{3}$}

\section{Hundret of Ceffeorda [Chafford]}

Wocheduna [Cranham ${ }^{4}$ ] was held by Alvric in King Edward's time as a manor and (as) 3 hides and 40 acres. Now Hugh (holds it) of the bishop. Then 6 villeins; now 8 . Then 5 bordars; now I 5. Then 6 serfs ; now 4. Then as now (semper) 3 ploughs on the demesne, and 4 ploughs belonging to the men. Wood(land) for 500 swine, (and) 20 acres of meadow. (There are) 4 colts (pulli), I 44 sheep, (and) 20 beasts (animalia). Then and afterwards it was worth 4 pounds ; now 6.

Tотенам [(Rok Hall in Little) Totham ${ }^{5}$ ], which Edwolt held as a manor and (as) half a hide and 30 acres, is held of the bishop by William son of Brien. (There is) now I villein. Then as now (semper) 6 bordars, and 2 serfs, and I plough on the demesne. Wood(land) for 60 swine, 4 acres of meadow, and I fisherman (piscator). (There is) pasture for 40 sheep, and I saltpan. (There are) now 4 bcasts (animalia), and 4 swine, (and)

1 'Non reddentes consuet[udinem]preter Scotum nisi episcopo.' The 'scot' was clearly the geld, which was payable to the king.

2 See further the Introduction to the Survey of Colchester (p. 424 above).

3 This heading is not rubricated like the others and is in a cramped space. The initial F of 'Feudum' actually overlaps the text.

4 Otherwise Ockendon episcopi.

5 In Thurstable Hundred.
60 sheep. It was worth then as now (semper) 30 shillings.

fo. Irb

Tотенам [(Rok Hall in Little) Totham], which Alvric held as a manor and (as) half a hide and 30 acres, is held of the bishop by William Balt. Now 3 bordars. Then as now (semper) I plough, and 1 saltpan, and 2 acres of meadow, (and) wood(land) for 30 swine. Then as now (semper) it was worth 30 shillings.

Elesforda [Alresford ${ }^{6}$ ] was held by Edwold as a manor and (as) 2 hides of land. Now Humfrey (holds it) of the bishop. Then as now (semper) 2 villeins. Then 2 bordars; now 6. Then 3 serfs; now 2. Then 2 ploughs on the demesne; now none. Then as now (semper) I plough belonging to the men. It was then worth 40 shillings; now 20.

Tenderinge [(New Hall in) Tendring], which Alward held as I hide and 45 acres in King Edward's time, is held of the bishop by Roger. Then as now (semper) 5 bordars. Then 4 serfs; now 3. Then as now (semper) 2 ploughs on the demesne, and (there are) 3 acres of meadow. Pasture for 50 sheep. Then 3 rounceys (runcini); now 4. Now 3 beasts (animalia). Then 6 swine; now 16 . Then $3^{6}$ sheep; now 66 . Then as now (semper) it was worth 30 shillings.

\section{Hundret of Berdestapla [Barstable]}

Turruca [(Little) Thurrock], which was held by Ulwine, a free man, under King Edward as I manor (and) as 2 hides and 2 acres, is held of the bishop by Anschetil. Then as now (semper) 2 ploughs on the demesne. Then I bordar; now 6. Then 6 serfs; now 1. Wood(land) for 50 swine. Pasture for 50 sheep. Then 1 fishery (piscina); now none. Then 4 beasts; now 5 . Now 2 rounceys (runcini) and 2 colts. Then 12 swine; now 16 . Then 80 sheep; now 128. Then as now (semper) it was worth 30 shillings and 4 pence.

Wella [ ], which was held by the same Ulwine in King Edward's time as a manor and as I hide and 30 acres, is held of the bishop by Ralf and Torold. Then as now (semper) I plough. Then I villein; now none. Then as now (semper) 2 bordars. Wood(land) for 40 swine. And it is worth 20 shillings.

6 In Tendring Hundred. 


\section{THE HOLDERS OF LANDS}

BuRghestedA [(Little) Burstead], which Godwine held in King Edward's time as a manor and as 3 hides, is held of the bishop by Walter. Then as now (semper) 2 ploughs on the demesne, and I plough belonging to the men, and 2 villeins. Then 1 bordar; now 6. Then 4 serfs; now 1. Wood(land) for 60 swine, and 30 acres more (alia) are claimed from King Edward's time. ${ }^{1}$ Now 2 colts and 4 beasts (animalia). Then 5 swine; now 24. Then 50 sheep; now 88 . And 44 goats. It was then worth 60 shillings; now 50.

Currincham [Corringham], which was held by Sigar, a free man, as I manor and as 4 hides and 10 acres, is held of the bishop by 10. $12 b$

William. (It is) now assessed at $3 \frac{1}{3}$ hides and 10 acres. Half a hide has been taken away from it and is held by the Bishop of Bayeux. Then 3 ploughs on the demesne; now $2 \frac{1}{2}$. Then as now (semper) the men had 4 ploughs. Then 3 villeins; now 2. Then 7 bordars; now 25. Then 5 serfs; now 3. Wood(land) for 300 swine. Pasture for 400 sheep. Then as now (semper) I mill. Then 2 rounceys (runcini); now none. Then 3 beasts (animalia); now 6 . Then 8 swine; now 10. Then 400 sheep; now 500 ; and 21 goats. It was then worth 7 pounds; now 7 (pounds) and 6 shillings.

Horninduna [Horndon (on-the-hill ')], which Goduin, a free man, held as I manor and (as) $1 \frac{1}{2}$ hides, is held of the same William. Then as now (semper) I plough on the demesne, and 4 bordars, and I serf. Wood(land) for Io swine, (and) the eighth part of I fishery. Then as now (semper) it was worth 20 shillings. From this manor has been taken away half a hide, which is held by the Bishop of Bayeux.

Celdewella [Chadwell], which Alvric a thegn of King Edward held as a manor and (as) 2 hides, is held of the bishop by Hughling (Hugolinus). Then as now (semper) 2 ploughs on the demesne, and I $\frac{1}{2}$ ploughs belonging to the men. Then 1 priest and 3 bordars; now 1 priest and 7 bordars." Then as now (semper) 4 serfs. Pasture for 100 sheep. Then 1 fishery; now none. (There are) 2 rounceys

\footnotetext{
I 'calumpniantur de tempore R.E.'

i.e. the estate of Cantis there (see Introduction, p. 398).

This is an unusual entry, and so is the mention of a priest (compare Introduction, p. 385).
}

(runcini), I o beasts (animalia), (and) 8 I sheep. Then and afterwards it was worth 40 shillings; now 30 .

Ramesdana [Ramsden (Belhus)], which Godric held as a manor and (as) I hide and 10 acres, is held of the bishop by William. Then as now (semper) I plough on the demesne, and 4 bordars. Wood(land) for 25 swine. There are 8 swine, 50 sheep, (and) 12 goats. It is worth 20 shillings.

Leienduna [Laindon "], which was held by Ulmar as a manor and (as) half a hide in King Edward's time, is held of the bishop by Ralf. Then I serf; now none. And it is worth 6 shillings.

\section{HUNDRET OF WithaM}

BRACTEDA [(Little) Braxted], which was held by Alvric, a free man, as a manor and as I hide, is held of the bishop by Hughling (Hugolinus). Then as now (semper) 2 ploughs on the demesne. Then the men had 2 ploughs; now none. Then 4 villeins; now none. Then 3 bordars; now 8 and 1 priest. ${ }^{6}$ Then 4 serfs; now 2. Wood(land) for 40 swine, (and) I mill. (There are) I rouncey (runcinus), 4 beasts (animalia), I 3 swine, (and) I 30 sheep. Then as now (semper) it was worth 60 shillings.

Hobruge [Hubbridge(Hall)], ${ }^{6}$ which Alwin, a free man, held as a manor and (as) half a hide, is held (of the bishop) by Ralf son of Brien. Then as now (semper) I plough on the demesne, and I plough belonging to the men, and I villein, and Io bordars. Then 2 serfs; now none. Wood(land) for 100 swine, and 12 acres of meadow. (There are) I 6 beasts (animalia), 100 sheep, 20 goats (and) 14 swine. And it is worth 40 shillings.

fo. $12 b$

\section{Half Hundret of Herlaua [Harlow]}

In Halingheberia [Hallingbury] Edith (Edeva) held 30 acres in King Edward's time. Then as now (semper) half a plough and 2 acres of meadow. And it is worth 5 shillings.

- It is of importance here to observe that the Domesday forms 'Legenduna' (p. 437 above) and 'Leinduna,' which denote Laindon (belonging to the Bishop of London) are entirely distinct from 'Langenduna,' which denotes Langdon (Hills) to the south of it (compare Introduction, p. 398).

- See note 3 above.

- A manor in Witham. 


\section{A HISTORY OF ESSEX}

\section{HUNDRET OF WITBRICTESHERNA [DENGIE]}

ULEHAM, ${ }^{1}$ which Goder', a free man, held in King Edward's time as a manor and as 2 hides and 20 acres, is held of the bishop by Hugh. Then 3 villeins; now none. Then 3 bordars; now 1 . Then 4 serfs; now 2. Then as now (semper) 2 ploughs on the demesne. Then the men had I plough; now none. (There is) pasture for 30 sheep. (There are) 3 rounceys (runcini) and 140 sheep. Then and afterwards it was worth 60 shillings; now 40.

Mildemet [Middlemead ${ }^{2}$ ], which Alwin, a free man, held as 1 manor and (as) half a hide and I4 acres, is held of the bishop by Ralf son of Brien. Then 2 villeins; now none. Then as now (semper) 3 bordars. Then I serf; now 2. Then as now (semper) I plough. Wood(land) for 20 swine, (and) 8 acres of meadow. It is worth 20 shillings.

\section{THE LAND OF THE CANONS OF ST. PAUL'S IN ESSEX (EXSESSA)}

\section{Hundret of Berdestapla [Barstable]}

LEA [(West) Lee ${ }^{3}$ ] was held freely by Edeva in King Edward's time as a manor and (as) half a hide and 30 acres. Then 2 ploughs on the demesne and 2 ploughs belonging to the men; now none. ${ }^{4}$ Then 2 villeins; now 6. Then 6 bordars; now 5 . Then 2 serfs; now 3. Wood(land) for 25 swine. Pasture for I 00 sheep. (There are) I beast (animal), I pig, and 7 sheep. It was then worth 40 shillings; now 20. This land is claimed for the king's use (ad opus regis).

\section{HundRET of Waltham}

Cinghefort [Chingford (St. Pauls)] was held by St. Paul in King Edward's time as I manor and as 6 hides. Then as now (semper) 2 ploughs on the demesne. Then the men had 3 ploughs; now 4. Then 7 villeins; now 8 . Then 3 bordars; now 6 . Then as now (semper) 4 serfs. Wood(land) for 500 swine, 50 acres of meadow, and 2 fisheries. (There are) 9 beasts (animalia), 2

1 A manor in Lawling. Now 'Ulehams farm.'

2 A manor in Baddow (in Chelmsford Hundred), including the later manors of Videlews and Bassets. It was afterwards 'Middlemead hamlet,' which, though in Little Baddow, was in Dengie Hundred, being just across the border.

3 Alias Lee Chapel (extra-parochial).

4 This is a difficult passage, as it seems unlikely that all four plough(team)s would have disappeared, especially as the villeins had increased. The value however had diminished by half. rounceys (runcini), 27 swine, (and) Ioo sheep. It was then worth 4 pounds; now 100 shillings. From this manor Peter de Valognes took away I hide (of land) and 8 acres of meadow, which belonged to this manor in King Edward's time, with (et) wood(land) for 50 swine $;^{6}$ it is worth ro shillings. From the same manor Geoffrey de 'Magna villa' took (away) 10 acres of meadow.

\section{Hundret OF Hidingaforda [Hinckford]}

Belcham [Belchamp (St. Pauls)] was held by St. Paul in King Edward's time as a manor and (as) 5 hides. Then as now fo. 13

(semper) 2 ploughs on the demesne, and 12 ploughs belonging to the men. (There are) 24 villeins, Io bordars, (and) 5 serfs. Wood(land) for 60 swine, (and) 30 acres of meadow. (There are) 9 beasts (animalia), 2 rounceys (runcini), 40 swine, Ioo sheep, (and) 5 goats. Then as now (semper) it was worth 16 pounds.

Wicham [Wickham (St. Pauls)] was held by St. Paul in King Edward's time as a manor and (as) 3 hides less I virgate. Then I plough in the demesne; now 2. Then 4 ploughs belonging to the men; now 3. Then 6 villeins; now 5. Then 4 bordars; now 10. Then I serf; now 3 . Wood(land) for 200 swine, (and) 10 acres of meadow. (There are) 2 rounceys (runcini), 4 beasts (animalia), 23 swine, 50 sheep, 24 goats, and 2 hives of bees. It was then worth 40 shillings; now 4 pounds.

\section{HUNDRET OF WitbRictesherna [Dengie]}

Tillingham was held by St. Paul as a manor and (as) 20 bides and 6 acres. Then as now (semper) 20 villeins, and 8 bordars, and 4 serfs. Then 3 ploughs on the demesne; now 4. Then as now (semper) the men had Io ploughs. (There is) pasture for 400 sheep. Now I mill and I fishery. (There are) 15 beasts (animalia), 30 swine, (and) 340 sheep. In addition to this land there were given to the church 10 acres, which belong (jacent) to this manor. The whole was then worth 10 pounds; now 15 .

\section{HundRet of ANGRa [Ongar]}

Nortuna [Norton (Mandeville)] was held in King Edward's time by Godid, a certain

5 This hide (with appurtenances) was entered in the 1181 Inquisition as "ruthehydam quam occupatam detinet Robertus de Valoniis' (Domesday of St. Paul's, p. I44). 


\section{THE HOLDERS OF LANDS}

woman, as half a hide. Now St. Paul (holds it). Then as now (semper) I plough and 2 bordars. Wood(land) for 40 swine, (and) 4 acres of meadow. There are I rouncey (runcinus) (and) 5 beasts (animalia). It is worth 20 shillings. Godid gave this land to St. Paul after the king came into England; but (the canons) do not produce (ostend $[u n] t$ ) the king's writ or permission. 1

NAsestoca [Navestock] was held by 2 free men, Houard and Ulsi, as 2 manors and as 5 hides less 20 acres; now St. Paul has it as the same (pro totidem) since the king came into this land and (the canons) say that they had it by the king's gift. Then as now (semper) 12 villeins and 11 bordars. Then 4 serfs; now 2. Then as now (semper) 4 ploughs on the demesne, and 4 ploughs belonging to the men. Wood(land) for 600 swine, and 44 acres of meadow. Then as now (semper) 13 beasts (animalia), 2 rounceys (runcini), I 16 sheep, 24 swine, 24 goats, and 4 hives of bees. Then as now (semper) it was worth 10 pounds.

The other Nessetocha [Navestock] ${ }^{2}$ was held by Turstin the red (ruff[us]) as a manor and as I hide and 40 acres. Now St. Paul has seized it (invasit), and it is with the other land, and he holds it for the same amount (tantundem). Then I bordar; now 2. Then as now (semper) 2 ploughs. Wood(land) for 100 swine. Then as now (semper) it was worth 30 shillings. In the same vill 7 free fo. $x$ b

men held 2 hides, which St. Paul holds in like manner ${ }^{3}$ and (there are) now in this land 12 men; now 3 bordars; then as now (semper) 4 ploughs; wood(land) for 2 ro swine, (and) 7 acres of meadow; then as now (semper) it was worth 40 shillings. In Nassestoca [Navestock] I priest holds half a hide and 20 acres; but the Hundret (court) bears witness that it is St. Paul's; then as now (semper) 2 bordars (were there); then I plough, (and) now a half; then as now (semper) it was worth ro shillings; it is now in the king's hand(s).

\section{Hundret of Celmeresforda [Chelmsford]}

Runewella [Runwell] is held now as then (semper) by St. Paul as 8 hides. Then as now (semper) 8 villeins and 8 bordars. Then

1 Without which the land could not be lawfully given.

2 Compare Introduction, p. 403.

i.e. (probably) as 2 hides.
2 serfs; now 1 . Then $3 \frac{1}{2}$ ploughs on the demesne; and now the same. Then the men had $2 \frac{1}{2}$ ploughs between them. Wood(land) for 200 swine. (There are) 2 rounceys (runcini), I beast (animal), 8 swine, (and) 100 sheep. Then as now (semper) it was worth 8 pounds.

\section{Hundret of Turestapla [Thurstable]}

Tidwoldituna [Heybridge] is held by St. Paul as 8 hides and as I manor; but Ralf Baignard holds half a hide, and the Hundret (court) knows not how he came to have it." Then as now (semper) 16 villeins, and 4 bordars, and 4 serfs. Then 2 ploughs on the demesne; now $1 \frac{1}{2}$. Then 8 ploughs belonging to the men; now 3. Wood(land) for 60 swine, (and) 30 acres of meadow. Pasture for 160 sheep. Then as now (semper) 1 mill, and I saltpan. There are I rouncey (runcinus), 8 beasts (animalia), 12 swine, 150 sheep, and 3 hives of bees. Then as now (semper) it was worth 8 pounds.

\section{Hundret of TENDRINGA}

Eldulvesnasa [The Sokens] ${ }^{5}$ is held now as then (semper) by St. Paul as a manor and as 27 hides. Then 86 villeins; now 63 . Then 40 bordars; now 50 . Then as now 6 serfs and 6 ploughs on the demesne. Then the men had 60 ploughs between them; now 30. Wood(land) for 300 swine, (and) 9 acres of meadow. Now 2 mills. Then 3 salteans; now 2. Pasture for 300 sheep. (There are) 22 beasts (animalia), 30 swine, 200 sheep, (and) 4 hives of bees. It was then worth 26 pounds; now 30 and I marc of silver. ${ }^{6}$

\section{HUNDRET OF ROCHEFORT [ROCHFORD]}

Berlinga [Barling] is held now as then (semper) by St. Paul as 1 manor and as $2 \frac{1}{1}$ hides less 15 acres. Then 2 villeins; now none. Then 5 bordars; now 9. Then as now (semper) I serf, and I plough on the demesne and 2 ploughs belonging to the men. Pasture for 40 shcep. (There are) 2 rounceys (runcini), 2 beasts (animalia), 4 swine, and 160 sheep. It was then worth 4 pounds and 10 shillings; now 6 pounds. In the same (Barling) I free man held half a hide and 10

- This must be the half hide recorded below under Ralf's manor of Langford, where it is entered as having formerly been held of St. Paul's by Ethelmar at a money rent (ad censum).

5 Walton-le-Soken, Kirby-le-Soken, and Thorpelc-Soken.

$$
6 \text { i.e. } \mathcal{L} 30.13 \text { s. } 4 \text { d. }
$$




\section{A HISTORY OF. ESSEX}

fo. 14

acres in King Edward's time ; now St. Paul (holds it); then as now (semper) I plough ; and it is worth 20 shillings; the canons obtained possession of (occupaverunt) this land after the king came into England.

\section{THE LAND OF ST. PETER OF WESTMINSTER}

\section{Hundret of Berdestapla [Barstable]}

In Benflet [South Benfleet] St. Peter has 7 hides and 30 acres which used to belong to (jacebant in) the church of St. Mary ${ }^{1}$ in King Edward's time; but King William gave the church with the land to St. Peter of Westminster, In which land (there are) 2 ploughs on the demesne, and 5 ploughs belonging to the men. Then as now (semper) I 5 villeins. Then 7 bordars; now 12 . Pasture for 200 sheep. (There is) now a moiety of a mill. (There are) 50 sheep, and 3 swine. ${ }^{2}$ It was then worth 4 pounds; now 6. (An) eighth hide belonging to (de) the same church of St. Mary ${ }^{1}$ was given by Ingelric to St. Martin ${ }^{3}$ and still belongs to it (ibi est) as the county (consulatus) bears witness, without the king's command."

In Phantuna [Fauton (Hall) ${ }^{6}$ ] (are) 4 hides and 30 acres. Then as now (semper) I plough on the demesne. Then 4 ploughs belonging to the men; now I. Then 6 villeins; now I. Then 4 serfs. Then I bordar; now 9 And in the same vill there can be (employed) 2 ploughs more (adbuc) on the demesne. There are 30 acres of wood(land) which are waste (silve vasta), ${ }^{6} 2$ rounceys (runcini) and 30 sheep. It was then worth 60 shillings; now 6 pounds.

In Bura [Bowers (Gifford)] St. Peter has 50 acres which are held of him (eo) by I Englishman. Then as now (semper) I villein. And it is worth 50 pence.

1 This has been identified by the historians of Essex as Barking Abbey, but it is singular that there is no reference to the loss under the lands of that abbey below. Such an act of spoliation, moreover, would be very remarkable.

2 This sentence is interlined.

3 St. Martin-le-Grand, London. This hide cannot be indentified among the holdings of that house or of Count Eustace (Ingelric's successor) below.

4 'That is to say that the king had not sanctioned the gift.

5 Or Fan Hall, a manor in North Benfleet.

6 'Waste' was a technical term for the extensive felling of trees in a wood (Dialogus, i. 13).
Phantuna [Fanton (Hall) ${ }^{7}$ ] was held in King Edward's time by Alestan Stric as a manor and (as) I hide. Then I plough ; now none. Then as now (semper) I bordar. Then and afterwards it was worth 20 shillings; now 10. This land is claimed for the king's use (opus) on the ground that (quod) it came to the church through a forged (falsum) writ. In the demesne (are) 2 rounceys (runcini), (and) 30 sheep.

\section{HUNDRET OF WITHAM}

In Chellevedana [Kelvedon], in King Edward's time, (there were) 5 hides, which were held by St. Peter. Then as now (semper) 2 ploughs on the demesne. Then 8 ploughs belonging to the men; now 4 . Then 20 villeins; now 18 . Then 3 bordars; now 7. Then as now (semper) 3 serfs. Wood(land) for 50 swine, and 25 acres of meadow. (There is) I mill. It was then worth IOO shillings; now 8 pounds; and the abbot has thence 12 pounds. In the demesne are 2 rounceys (runcini), 6 beasts (animalia), 35 swine, (and) 35 sheep.

fo. $14 \mathrm{~b}$

\section{Hundret of Beventreu [Becontree]}

HAME [(East ?) Ham] was held by St. Peter in King Edward's time as a manor and (as) 2 hides. Then as now (semper) I plough. Then 3 bordars; now 5. Wood(land) for 8 swine. It was then worth 20 shillings; now 60 .

In Leituna [Leyton] Ralf Baignard holds of the abbot I hide, which was held by Tosti in King Edward's time. Then I plough ; now a half. Now 5 bordars. (There are) 20 acres of meadow, (and) I mill. It was then worth 30 shillings; now 40.

\section{Hundret of Lexendena [Lexden]}

Phering ${ }^{8}{ }^{8}$ [Feering] was held by Harold in King Edward's time as 4 hides and 30 acres. Now St. Peter holds (it). Then 34 villeins; now 27. Then Io bordars; now 24. Then as now (semper) I I serfs and 4 ploughs on the demesne. Then I 5 ploughs belonging to the men; now ro. Wood(land) for 500 swine, 20 acres of meadow, (and) 3 mills. And, in addition to this abovesaid land, (there were) I 2 sokemen dwelling on (manentes in) $2 \frac{1}{2}$ hides, who could not withdraw themselves (recedere) ${ }^{9}$ under them now

7 Or Fan Hall, a manor in North Benfleet.

8 This Latin form points to an English 'Feeringes.' The adjacent vill of Messing appears in Domesday as ' Metcinges.'

9 i.e. could not choose another lord. 


\section{THE HOLDERS OF LANDS}

as then (semper) are 6 bordars and $2 \frac{1}{2}$ ploughs; wood(land there) for 20 swine (and) 12 acres of meadow. And (there are) 2 houses in Colchester (cole castro) which belong (jacent) to this manor. In the demesne are 5 rounceys (runcini), I 6 beasts (animalia), 60 swine, (and) 84 sheep. It was then worth 22 pounds and 10 shillings; now 34 pounds and 10 shillings. Roger 'de Ramis' holds of the abbot 85 acres and renders, every year, to the abbot as his service 10 shillings. ${ }^{1}$ Mauger (Malgerus), a man of the archbishop, ${ }^{2}$ seized to the king's wrong (invasit super regem) I free man, who belonged to (erat de) St. Peter's manor in King Edward's time, a holder of half a virgate; and (it) is now in the king's hand(s); then as now (semper) half a plough (there); and it is worth 5 shillings.

\section{Hundret of Angra [Ongar]}

Kelvenduna [Kelvedon Hatch] was held by Ailric in King Edward's time as a manor and (as) 2 hides. Now St. Peter (holds it). Then as now (semper) I villein. Then 5 bordars; now 10. Then as now (semper) 2 serfs, and 2 ploughs on the demesne, and I plough belonging to the men. Wood(land) for 200 swine, and 16 acres of meadow. Now I mill. It was then worth 40 shillings; now 6o. This abovesaid Ailric went (to take part) in a naval battle (navale praelium) against King William ; and when he returned, fell ill (eccidit in infirmate), (and) then gave this manor to St. Peter; but none of the men from the county (ex comitatu) knows this but one; and hitherto St. Peter has thus (tali modo) held the manor, and (the monks) have had neither writ nor officer from the king (fanulum regis ex parte) since the king came fo. 85

into this land."

In Wochenduna [(North) Ockendon] William the chamberlain holds of the abbot 1 hide. And (there is) I plough on the demesne, and I plough belonging to the men. (There are) 4 villeins. It is worth 40 shillings.

1 Roger held an adjacent manor at Messing.

$2 \mathrm{He}$ held Orpington, Kent, as one of the archbishop's ' knights.'

3 'This phrase does not imply that St. Peter (Westminster Abbey) had held the manor in King Edward's time.

- No such gift could be valid without the king's express sanction, and none of his officers had come down to give them seizin of the land.

\section{Hundret of Ceffeorda [Chafford]}

Wochenduna [(North) Ockendon] was held by Harold as a manor and (as) 2 hides less 40 acres in King Edward's time. Now St. Peter holds (it). Then 8 villeins; now 7. Then 5 bordars; now 8 . Then as now (semper) 4 serfs, and 2 ploughs on the demesne. Then 6 ploughs belonging to the men; now 4. Wood(land) for 300 swine. There are 1 rouncey (runcinus), 6 beasts (animalia), 30 swine, and I ro sheep. It was then worth 4 pounds; now 10 pounds. This land has been obtained by (est pro) exchange since the king crossed the sea (transfretavit).

Wemtuna ${ }^{6}$ [Wenington] is held now as then (semper) by St. Peter as a manor and (as) $2 \frac{1}{2}$ hides. Then 3 villeins; now 2. Then 3 bordars; now 1 . Then 2 serfs; now none. Then 1 plough on the demesne; now a half. Then I plough belonging to the men; now a half. (There are) I rouncey (runcinus), I cow, 4 swine, (and) 60 sheep. It was then worth 40 shillings; now 60. One free man gave St. Peter (misit in Sancto Petro) half a hide, but Robert 'invesiatus,' a man of Robert Gernon (grenonis) secured possession ( $p[r<]$ occupavit). And it renders 20 pence a year.

Geddesduna [ $\quad{ }^{7}$ is held by St. Peter as I hide. Then as now (semper) I villein and I bordar. Then half a plough; now 1. It was worth then as now (semper) 20 shillings.

\section{Hundret of Celmeresfort [Chelmsford]}

Molesham [Moulsham] is held now as then (semper) by St. Peter as 5 hides less 30 acres. Then 8 villeins; now 3. Then 4 bordars; now 21. Now 2 serfs. Then as now (semper) 3 ploughs on the demesne, and 4 ploughs belonging to the men. Wood(land) for 400 swine, (and) 30 acres of meadow. (There is) I mill. (There are) I rouncey (runcinus), 2 cows, 36 swine, (and) roo shcep. It was then worth 9 pounds; now 12.

\section{HUNDRET OF ROCHEFORT [ROCHFORD]}

Pachesham [Paglesham] is held by St. Peter as a manor and as $I \frac{1}{2}$ hides. Then 2 bordars; now I1. Then 4 serfs. Then 2

- This Hundredal heading should have come before the preceding entry.

6 This is probably a scribal error for 'Wenituna."

7 This name has been much discussed, but the place has not been identified. 


\section{A HISTORY OF ESSEX}

ploughs on the demesne; now 1. Then as now (semper) I plough belonging to the men. (There is) pasture for 20 sheep. (There are) 1 rouncey (runcinus), 4 beasts (animalia), (and) 100 sheep. It was then worth 4 pounds; now 6. This land was given to the church by I thegn when he went with Harold to York to the battle (ad bellum in Eurewic).

ro. $15 \mathrm{~b}$

\section{THE LANDS OF THE BISHOP OF DURHAM IN ESSEX (EXSESSA)}

\section{Half Hundret of Waltham}

W ALHAM [Waltham (Abbey)] was held by Harold in King Edward's time as I manor and (as) 40 hides. Then as now (semper) 80 villeins and 24 bordars. Then 6 serfs; now 7. Then 7 ploughs on the demesne; now 6 . Then as now (semper) 37 ploughs belonging to the men. Wood(land) for 2,200 swine, (and) 80 acres of meadow. There are 2 rounceys (runcini), 20 beasts (animalia), 80 sheep, 12 goats, (and) 40 swine. There is pasture there which is worth 18 shillings. Then 1 mill; now 3. (There are) 5 fisheries (piscina). And (there were) then 20 rent-paying tenants (censarii); now 36. And I plough more could be employed on the manor." 'To this manor belong (adjacent) 2 sokemen, who held (tenentes) 6 hides in King Edward's time, (and) now 5; half of the sixth hide is held by (the abbey of) the Holy Cross, and the other half (partem) was taken by William de War[enne]. And (there belong) 4 sokemen with (de) 2 hides and half a virgate; and there also belonged to this manor I hide less 15 acres which was taken by the same William. ${ }^{2}$ And Ranulf brother of Ilger has taken 30 acres of land and 4 of meadow. ${ }^{3}$ All those sokemen who are there now have between them 7 hides and 15 acres ; and they used to have on their demesne in King Edward's time 4 ploughs; now $4 \frac{1}{2}$; and (there was) then as now (semper) I villein; then 6 bordars, and

1 'I car[uca] potest in manerio restaurari.' That is to say, the 'stock' used to include one more plough(team), which might be replaced.

2 The lands thus seized do not appear under William's fief.

3 This is entered, under Ranulfs fief, as "I virgate of land,' which the Hundred charged him with having taken from Waltham and added to his manors of Nazing and Epping.

4 This is the sum of the 5 hides entered as held by 2 sokemen and the 2 hides and half a virgate entered as held by 4 sokemen. Thus here, as in the preceding note, the 'virgate' is treated as the equivalent of ' 30 acres,' the appurtenant meadow in both cases being reckoned separately. (now) 8 ; then 2 serfs, and now none; wood(land) for 182 swine; $16 \frac{1}{2}$ acres of meadow, and 4 acres of pasture. From all this Harold used to have in King Edward's time 36 pounds; and the bishop's men appraise it at 63 pounds and 5 shillings and 4 pence. But now, as (the) other men of the Hundret testify, it is worth 100 pounds. And in London (Londonia) there belong to the manor 12 houses which render 20 shillings, and one gate which the king gave to the predecessor of the bishop and which also renders 20 shillings.

\section{THE LANDS OF THE CANONS OF THE HOLY CROSS OF WALTHAM}

\section{HUNDRET OF Waltham}

EPINGa [Epping] is held by the Holy Cross as a manor and (as) 2 hides and 15 acres. Then as now (semper) $1 \frac{1}{2}$ ploughs on the demesne, and 2 bordars, and 2 serfs. Wood(land) for 50 swine, (and) 3 acres of meadow. (There are) 10 beasts (animalia), 1 rouncey fo. 16

(runcinus), 20 swine, 20 sheep, (and) 8 goats. And it is worth 15 shillings.

Nasinga [Nazing] is held now as then (semper) by the Holy Cross as 5 hides. Then I plough on the demesne; now $1 \frac{1}{2}$. Then I plough belonging to the men; now $1 \frac{1}{2}$. Then as now (semper) 5 villeins. Now 2 bordars. Then 2 serfs; now none. Wood(land) for 50 swine, (and) 13 acres of meadow. (There is) a moiety of a fishery. (There are) I rouncey (runcinus), 4 beasts (animalia), 10 swine, (and) 15 sheep. It was then worth 40 shillings; now 60.

\section{Hundret of Beventreu [Becontree]}

WDEFort [Woodford] is held now as then (semper) by the Holy Cross in King Edward's time (sic) as 5 hides. Then as now (semper) 2 ploughs on the demesne. Then 13 ploughs belonging to the men; now 7 . Then as now (semper) 13 villeins. Then 4 bordars; now 7. Then 4 serfs; now none. Wood(land) for 500 swine, and 26 acres of meadow. Then I mill; now none. Then I beast (animal); now 6. (There are) 100 sheep, 50 swine, (and) 40 goats. Then as now (semper) it was worth 100 shillings.

Lochintuna [Loughton] is held now as then (semper) by the Holy Cross as a manor and (as) 4 hides and 20 acres. Then 2 


\section{THE HOLDERS OF LANDS}

ploughs on the demesne; now I. Then as now (semper) I plough belonging to the men, and 2 villeins. Then 2 bordars; now 5 . Wood(land) for 100 swine, (and) 5 acres of meadow. One plough more could be employed.' (There are) 5 beasts (animalia) (and) 5 sheep. And it is worth 40 shillings.

Lochintuna [Loughton] is held by the Holy Cross as a manor and (as) $2 \frac{1}{2}$ hides. Then as now (semper) I plough on the demesne. Then 2 bordars; now 4. Wood(land) for 40 swine, (and) 4 acres of meadow. There are 9 beasts (animalia), 10 swine, (and) 20 sheep. And it is worth 20 shillings.

\section{Hundret of Angra [Ongar]}

Passefrlda [Passelow ] is held now as then (semper) by the Holy Cross as a manor and (as) 2 hides less 30 acres. Then 6 villeins; now 5. Now 4 bordars. Then 7 serfs; now 3. Then 2 ploughs on the demesne; now 3 . Then 3 ploughs belonging to the men; now 2. Wood(land) for 700 swine, (and) 8 acres of meadow. Then 3 beasts (animalia); now 6. Then 20 swine; now 30. (Now) 50 sheep. Then 16 goats; now 36. Now 1 rouncey (runcinus). Then as now (semper) it was worth 6 pounds.

Alvertuna [Alderton (Hall) ${ }^{3}$ ] is held now as then (semper) by the Holy Cross as a manor and (as) $4 \frac{1}{2}$ hides and 10 acres. Then 7 villeins; now 9. Then 2 bordars; now 6 . Then 5 serfs; now 3 . Then as now (semper) 2 ploughs on the demesne. Then 3 ploughs belonging to the men; now 2 . Wood(land) for 400 swine, (and) 15 acres of meadow. (There are) 2 beasts (animalia), 8 sheep, Io swine, and 15 goats. Then as now (semper) it was worth 4 pounds.

Tippedana [Debden "] is held now as then (semper) by the Holy Cross as a manor and (as) 3 hides and 40 acres. Then as now (semper) 4 villeins and 7 bordars. Then 4 serfs; now none. Then 2 ploughs on the demesne; now 1. Then 2 ploughs belonging to the men; fo. 166

now 1. Wood(land) for 300 swine, (and) 6 acres of meadow. (There are) 2 beasts (animalia), 8 swine, (and) 9 sheep. Then as now (semper) it was worth 40 shillings.

A certain free man held 40 acres, which

1 'I car' pot' restaurari' (sec p. 446, note 1).

* A manor in High Ongar.

In Loughton. Ibid. the church ${ }^{5}$ seized (invasit) after the king came into this land and (which it) still holds. Then I plough; now none; and when they obtained the land (quando recep') a half. There are 4 acres of meadow. It was then worth 6 shillings and 8 pence; now 5 shillings and 4 pence.

\section{Hundret of Cefferorda [Chafford]}

Welda [(South) Weald] is held now as then (semper) by the Holy Cross as one manor, and, in King Edward's time as 2 hides; now as I $\frac{1}{2}$. Geoffrey 'de magna villa' has the other half (hide), but the Hundret knows not why he has (it); and Geoffrey says that he has it by exchange (pro escangio). Then as now (semper) ro villeins, and 6 bordars, and 3 serfs, and 2 ploughs on the demesne. Then 6 ploughs belonging to the men; now 4 . Wood(land) for 200 swine, (and) I $\frac{1}{2}$ acres of meadow. Now 4 beasts (animalia). Then 10 swine; now 25. Then 25 sheep; now 65. And it is worth 6 pounds. In this manor (there) belonged (jacuit) I sokeman who held I carucate of land; Robert Gernon has (it) now by the king's gift, as he himself says.

UPMONSTRA [Upminster] is held by the Holy Cross as $2 \frac{1}{2}$ hides and 40 acres. Then 8 villeins; now 6 . Then 2 bordars; now 4. Then 4 serfs; now 3. Then as now (semper) 2 ploughs on the demesne, and 4 ploughs belonging to the men. Wood(land) for 300 swine, and 6 acres of meadow. There are 2 beasts (animalia). Then 20 sheep; now 50. Then II swine; now 30. Then as now (semper) it was worth 4 pounds. To this manor belongs I sokeman with (de) 30 acres and half a plough; and (it) is worth 20 pence.

Walcrara [Walkfares "] is held now as then (semper) by the church ${ }^{8}$ as 4 hides less 40 acres. Then 4 bordars; now 10 . Then 6 serfs; now 3. Then as now (semper) 2 ploughs on the demesne, and I plough belonging to the men. Wood(land) for 30 swine, (and) i 8 acres of meadow. (There is) now I rouncey (runcinus). Then as now (semper) 5 beasts (animalia), 5 swine, 40 sheep, (and) 2 hives of bees.

B i.c. the canons of the Holy Cross.

- This appears to be represented by the I hide in 'Walda,' which is entered under Robert's fief as held by him in 1086, and as having been held by Sprot as 2 'manor.' The story there told is that he got it 'by exchange' (see p. 518 below).

7 In Borcham.

i.c. by the canons of the Holy Cross. 


\section{A HISTORY OF ESSEX}

fo. $17 \mathrm{~b}$ 1

\section{THE LAND OF ST. MARY OF BARKING [BERCHINGES]}

\section{Hundret of Berdestapla [Barstable]}

Mucinga [Mucking] is held by St. Mary ${ }^{2}$ as 7 hides; and Turold de Rovecestra [Rochester] took away from it (inde) 30 acres, and they (now) belong to (jacent ad) the fief of the Bishop of Bayeux. ${ }^{3}$ And there was I plough on the demesne in King Edward's time; now 2. Then as now (semper) 9 ploughs belonging to the villeins, ${ }^{4}$ and 12 villeins. Then I 4 bordars; now 25. Then 4 serfs; now none. Wood(land) for 300 swine, pasture for 300 sheep, (and) 40 acres of meadow. Now I mill. (There is) I fishery. (There are) Io beasts (animalia), 2 rounceys (runcini), I 8 swine, (and) 250 sheep. Then as now (semper) it was worth 10 pounds.

Bulgeven [Bulphan] is held by St. Mary as 7 hides. Then 1 plough on the demesne; now 2. Then 7 ploughs belonging to the men; now 10. Then 10 villeins; now 16. Then 5 bordars; now 16 . (There are) 3 serfs. Wood(land) for 500 swine. (There are) 8 beasts (animalia), 15 swine, I rouncey (runcinus), (and) 80 sheep. It was then worth 8 pounds; now IO. From this land Ravengar took (away) 24 acres.

In Fantuna [Fanton (Hall $\left.\left.{ }^{5}\right)\right]$ I villein holds 40 acres of land; then as now (semper) half a plough (there); and it is worth 40 pence.

Of $\left(D_{\ell}\right)$ the abovesaid manor, namely Muchinga [Mucking] William holds half a hide and 30 acres; and (there are) 3 bordars; and it is worth 18 shillings of (in) the abovesaid appraisement of the same manor.

In this Hundred are 6 free men who hold 2 hides and 50 acres. Then as now (semper) 2 ploughs (were there). Then 3 bordars; now 6 . Then I serf; now none. Then wood-

1 At the top of fo. 17 is a list of the ten next tenants-in-chief, which has been deleted. The rest of that folio is blank (compare p. 413 and p. 437 , note 5 , above).

2 Barking Abbey.

3 I feel no doubt that these are entered below (p. 456), under the fief of the Bishop of Bayeux, at Chadwell (held of him by 'the son of Turold '), where we read that 30 acres of the land there had belonged ' to another estate' (terram).

4 'Villanis,' not 'hominum' (as usual).

5 A manor in North Benflet. (land) for Ioo swine; now for 55. (There is) a 1 $3^{\text {th }}$ part of I fishery. The whole is worth 30 shillings. These free men belonged to (exstiterunt ad) Barking (berchingum); but now the king can do with them (ex ipsis) what be likes (quod sibi placuerit). From the wood(land) of this estate (terra) Robert Gernon ${ }^{6}$ (grinon) has 50 swine. And of the abovesaid estate (terra) Godwine cudhen holds 3 virgates; and it is worth 10 shillings.

\section{Half Hundret of Herlaua [Harlow]}

In Perenduna [Parndon] St. Mary holds now as then (semper) half a hide. Half a plough (is there, and) I bordar. Wood(land) for 10 swine, and 5 acres of meadow. It is worth Io shillings.

\section{Hundret of Beventreu [Becontree]}

BERCHING ${ }^{7}$ [Barking] is held now as then (semper) by St. Mary as 30 hides. Then 4 ploughs on the demesne; now 3 , and a $4^{\text {th }}$ could be (employed). Then 70 ploughs belonging to the men; now 68 . Then 100 villeins; now 140. Then 50 bordars; now 90. Then 10 serfs; now 6 . Wood(land) for 1,000 swine, (and) 100 acres of meadow. (There are) 2 mills, I fishery, 2 rounceys (runcini), 34 beasts (animalia), 150 swine, II 4 sheep, 19 goats, (and) 10 hives of bees. In London (there are appurtenant) 28 houses, fo. 18

which render ${ }^{8}$ I 3 shillings and 8 pence, and a moiety of a church which, in King Edward's time, used to render 6 shillings and 8 pence, and now does not. This manor was worth, in King Edward's time, 80 pounds ; and now the same (similiter) as the English say; but the French appraise it at 100 pounds. To this manor there used to belong, in King Edward's time, 24 acres, which Goscelin the lorimer has taken from it. ${ }^{9}$ And 3 knights hold 2 hides; and (there are there) 3 ploughs, and 3 villeins, and Io bordars; and it is worth 45 shillings of the above sum (in eodem pretio). ${ }^{10}$

\section{Hundret of Wensistreu [Winstree]}

Wicgheberga [Wigborough ${ }^{11}$ ] is held by St. Mary now as then (semper) as I I $\frac{1}{2}$ hides and 13 acres. Then $2 \frac{1}{2}$ ploughs on the demesne ;

- The king's forester.

7 Compare p. 444 , note 8 , above.

8 A slight gap here in the MS.

9 His own estate was at Little liford close by.

10 The entry of the 3 knights' holding was crowded in subsequently.

11 i.e. the manor of Abbess Hall in Great Wigborough. 


\section{THE HOLDERS OF LANDS}

now 2. Then 10 ploughs belonging to the men; now 9. Then 9 villeins; now 10. Then 24 bordars; now 33. Then as now (semper) 8 serfs. Wood(land) for 100 swine, (and) pasture for 100 sheep, which renders 16 pence. Six saltpans. Then 12 beasts (animalia), and now the same (similiter), (with) 2 rounceys (runcini), I 4 swine, (and) 230 sheep. It was then worth 12 pounds; now 10. To this manor belong 3 houses in Colchester (cole castro).

\section{Hundret of Ceffeorda [Chafford]}

W ARElE1A [(Great) Warley ${ }^{1}$ ] is held now as then (semper) by St. Mary as 3 hides. Now as then (semper) 9 villeins. Then 8 bordars; now I0. Then 3 serfs; now 5. Then as now (semper) 2 ploughs on the demesne. Then 8 ploughs belonging to the men; now 6. Wood(land) for 200 swine, (and) pasture for 100 sheep. There are 8 beasts (animalia), I I swine, I 50 sheep, (and) I hive of bees. Then as now (semper) it was worth 7 pounds. In STIForda [Stifford] St. Mary has 40 acres. There are 2 villeins-formerly 1 , and 2 bordars; and $\mathrm{I}$ acre of meadow. Then $\mathrm{I}$ plough was there; now a half; and it is worth 3 shillings. There were also (belonging) to this estate (terram) 30 acres which William de War(ense) has ${ }^{2}$ - by (pro) exchange as he says himself. There are also 30 acres more (alia) with (et) $2 \frac{1}{2}$ acres of meadow; and (this is) worth 3 shillings.

\section{Hundret of Celmeresfort [Chelmsford]}

INGA [Ing(atestone)] is held now as then by St. Mary as $3 \frac{1}{2}$ hides and 10 acres. Then as now (semper) 2 villeins. Then 6 bordars; now 7. Then as now (semper) I serf, and I plough on the demesne. Then the men had It ploughs; now I. (There is) wood(land) for 500 swine. And (there is) I sokeman with 30 acres. (There are) I rouncey (runcinus), 9 beasts (animalia), 20 swine, (and) 16 sheep. It was then worth 70 shillings; now 60.

Festinges [Fresling ? '] is held by St. Mary as $1 \frac{1}{2}$ virgates. Then 3 bordars; now 4 . Then I serf; now none. Then as now (semper) I plough. Wood(land) for 200

1 Alias Abbess Warley.

2 His own estate in this Hundred was at Aveley adjoining. 'Exchange' was his usual plea.

3 Alias Thyrstlinge Hall, a manor in Butsbury. This is Morant's identification, but neither the form of the name nor the history of the manor confirms it. swine. (There are) 4 beasts (animalia), 37 sheep, (and) 10 goats. It was then worth 8 shillings; now 10.

รo. $18 \mathrm{~b}$

\section{HUNDRET OF ROCHEFORT [ROCHFORD]}

Hocheleia [Hockley] is held now as then (semper) by St. Mary as a manor and (as) $7 \frac{1}{2}$ hides. Then 24 villeins; now 27. Then as now (semper) 12 bordars. Then 3 serfs; now none. Then as now (semper) 2 ploughs on the demesne, and 15 ploughs belonging to the men. Pasture for 200 sheep, (and) I mill. (There are) 2 rounceys (runcini), 8 beasts (animalia), I 5 I sheep, (and) 26 swine. Then as now (semper) it was worth 10 pounds. Of this manor William de Bursigni holds of the abbey (ecclesia) 3 virgates; and I plough (is there); and it is worth 21 shillings of the above total (in codem pretio).

\section{Hundret of Turestapla [Thurstable]}

Tolesberia [Tollesbury "] is held now as then (semper) by St. Mary as a manor and as 8 hides. Then II villeins; now 12 . Then 14 bordars; now 16. Then 5 serfs; now 7. Then as now (semper) 2 ploughs on the demesne. Then 8 ploughs belonging to the men; now 7. Wood(land) for 500 swine, (and) pasture for 400 sheep. (There are) now I mill, and I fishery, and 2 saltpans. (There are) 2 rounceys (runcini), 10 beasts (animalia), 28 swine, (and) 300 sheep. Then as now (semper) it was worth 10 pounds. Ranulf Peverel (piperellus) holds I hide which was held by Siward of the abb(ey), and he himself is willing to do such service as his predecessor did, but the abbess is not willing, because (the land) was appropriated to the maintenance of the nuns (erat de victu ecclesia). ${ }^{b}$ Odo a man of Suain (suani) has obtained (accepit) ro acres which belonged to the abbey (fuerunt de ecclesia), and the Hundret bears witness to this; but he vouches his lord to warranty for them (inde vocat dominum suum ad tutorem); now as then (semper) they are worth 16 pence. ${ }^{6}$

4 i.c. St. Mary's manor there.

6 Siward was an Essex thegn with many scattered manors, almost all of which had been obtained by Ranulf Peverel. Among these was Tolleshunt (Darcy) adjoining Tollesbury, which accounts for Siward's appearing here. The abbess evidently denied that this was 'thegnland' and claimed it as part of the inalienable demesnes of her house.

Here again a neighbour had encronched on the nuns. For Odo was Suain's under-tenant at Tolleshunt adjoining. 


\section{A HISTORY OF ESSEX}

$X$. THE LANDS OF ST. ETHELTHRYTH (ADELDRED死) OF ELY

\section{Hundret of Dommaua [Dunmow]}

Broccheshevot [Broxted] is held now as then (semper) by St. Æthelthryth as a manor and (as) 3 hides. Then as now (semper) 2 ploughs on the demesne, and 4 ploughs belonging to the men. (There are) 16 villeins. Then 2 bordars; now 5. (There are) 5 serfs. Wood(land) for 250 swine, (and) 30 acres of meadow. Then and now 16 beasts (animalia), 2 rounceys (runcini), 70 sheep, and 2 hives of bees. It was then worth ro pounds; now 8 . From this manor were taken away, in King William's time, 9 acres of land, which are held by Eudo 'dapifer,' and moreover 2 carucates of land from the demesne, which are held by the same Eudo, and (this) is worth 4 pounds. $^{1}$

fo. 19

Rodinges [(Aythorp?) Roding] is held now as then (semper) by St. Fthelthryth, and (was assessed) at 3 hides and 45 acres in King Edward's time; now at 2 hides and 45 hides; and William de Warenne has taken the third hide from the demesne, to which it belonged in King Edward's time. ${ }^{2}$ Then as now (semper) 8 villeins, I priest, 2 bordars, (and) 4 serfs. Then 3 ploughs on the demesne ; now 2. Then as now (semper) 4 ploughs belonging to the men. Wood(land) for I 00 swine, (and) 20 acres of meadow. There are 2 rounceys (runcini), 9 beasts (animalia), 28 swine, (and) 15 sheep. And there belong to this manor 3 sokemen with (et) II bordars and 3 serfs. It was then worth 4 pounds; now 6 .

Ratenduna [Rettendon] was held by St. Ethelthryth in King Edward's time as $\mathbf{I}$ manor and as 20 hides; it is now held as $16 \frac{1}{2}$ hides. Then as now (semper) 26 villeins and 6 bordars. Then 7 serfs; now 6 . Then as now (semper) 3 ploughs on the demesne, and 12 ploughs belonging to the men. Wood(land) for 300 swine. (There are) 9 beasts (animalia), 4I swine, (and) $\mathrm{I}_{4}$ sheep. It was then worth 17 pounds; now 20. And

1 This is entered below, under Eudo's fief, as his manor of Broxted, assessed at 9 acres and valued at 4 pounds, which makes the assessment nominal. It is there stated to have been held of the abbey by 2 sokemen.

2 This was again an aggression by a neighbour. William de Warenne was lord of Leaden Roding adjoining, and under his fief Domesday mentions that he had added this hide to it, thus raising its assessment from $2 \frac{1}{2}$ to $3 \frac{1}{2}$ hides.
I hide and 30 acres were held (tenet) by Siward of St. Æthelthryth, and are now held by Ranulf Peverel (piperellus) of the king. But the Hundret testifies that they are the abbey's (testatur de abbatia). ${ }^{3}$ And (there are) 2 hides and 30 acres $^{4}$ which were held by the abbey (ecclesia), and of the abbey (de ea) by Levesun, in King Edward's time; now Eudo holds (the land) of the abbot because his predecessor held it; but the Hundret bears witness that he was not able to sell it without the abbot's leave. ${ }^{5}$

\section{Half Hundret of Frossewella [Fresh- WELL].}

Cadenhou [Hadstock ${ }^{6}$ ] is held now as then (semper) by St. Ethelthryth as I manor and as 2 hides. Then 8 villeins; now 12. Then 8 bordars; now I3. Then 4 serfs; now 2. Then as now (semper) 2 ploughs on the demesne. Then 3 ploughs belonging to the men; now 4. Wood(land) for 100 swine, and 6 acres of meadow. Then $I$ mill; now none. There are 1 rouncey (runcinus), 4 beasts (animalia), 16 swine, 36 sheep, (and) 8 goats. It was then worth 6 pounds; now 10.

\section{HUNDRET OF UDELESFORT [UTTLESFORD]}

LITELBYRIA [Littlebury] is held now as then (semper) by St. Fthelthryth as I manor and (as) 25 hides. Then as now (semper) 39 villeins, and 19 bordars, (and) 7 serfs. Then 5 ploughs.on the demesne; now 4. Then I7 ploughs belonging to the men; now 15 . Wood(land) for 160 swine, (and) 55 acres of meadow. Then as now (semper) 4 mills, 2 rounceys (runcini), 32 swine, 80 sheep, (and) 3 hives of bees. It is worth 20 pounds. There is also an outlying estate (berewita) which is called Strathala [Strethall], which was held by 2 men William ${ }^{7}$ and Elwi as 5

3 This is duly entered under Ranult's fief, as having been held as a manor by Siward (see p. 449 above), with a note that the Abbot of Ely claims it.

4 It will be observed that these two holdings amount to 3 hides and 60 acres, which, being deducted from 20 hides, leaves the " $16 \frac{1}{2}$ hides" at which the abbey's estate was assessed in 1086 .

5 This holding is duly entered under the fief of Eudo 'dapifer' as having been held as a 'manor' by Levesun, with a note that it is claimed by the Abbot of Ely and that the Hundred supports the claim.

6 As this was the only holding of the abbey of Ely in the Hundred, it must be represented by 'Cadenhou,' though the latter name is now lost.

7 The occurrence of this distinctively Norman name as that of a former holder is noteworthy. 


\section{THE HOLDERS OF LANDS}

hides; and they could not withdraw themselves (recedere) from the land 1 without the fo. $x \mathrm{gb}$

abbot's leave; now Hugh holds (it) under the abbot; then 7 villeins (were there, and) now 6 ; then 4 bordars, (and) now 7. Then as now (semper) 6 serfs, and 3 ploughs on the demesne. Then 3 ploughs belonging to the men, and now 5 ; wood(land) for 10 swine, I 2 acres of meadow, and I mill; it was then worth 7 pounds, (and) now 8; in the demesne are 7 beasts (animalia), 100 sheep, 22 swine, (and) 2 hives of bees.

There is also (adbuc) an outlying estate (berewita) which is called HAINDENA ${ }^{2}$ [Heydon], which Elwi held as half a hide and 15 acres. Then 2 ploughs on the demesne; now 1 . Then 4 serfs; now none. Then and now (semper) 55 sheep. It was then worth 60 shillings; now 30. Of this manor William Cardon, a man of Geoffrey 'de Magna villa,' secured (accepit) 24 acres of wood(land), when Suain (Suanus) was sheriff, as the Hundret testifies.

\section{THE LAND OF ST. EDMUND *}

\section{HUNDRET OF WithaM}

BREDDINCHOU [Bennington (Hall) ${ }^{8}$ ] is held of the abbot by William son of Grosse as I hide and 15 acres. Then 2 ploughs on the demesne; now I. Then as now (semper) I plough belonging to the men, (and) 4 villeins, (and) 3 bordars. (There is) now 1 mill. Wood(land) for 50 swine, (and) 20 acres of meadow. (There are) 2 rounceys (runcini), 6 beasts (animalia), i 2 swine, (and) 5 goats. It is worth 50 shillings.

\section{Half Hundret of Herlaua [Harlow]}

Herlaua [Harlow] is held now as then (semper) by St. Edmund as I manor and (as) $1 \frac{1}{2}$ hides. Then as now (semper) 2 ploughs on the demesne, and 6 ploughs belonging to the men, and 12 villeins, and 15 bordars, and 4 serfs. Wood(land) for 150 swine, 30 acres of meadow, (and) I mill. (There are) 4 rounceys (runcini), 25 beasts (animalia), 3 colts (pulli), 50 swine, 60 sheep, (and) 5 hives of bees. To this manor have been added, in King William's time, 3 hides which were

1 i.e. seek another lord.

2 'Hamdena' in the Record Commission's edition, but 'Haindena' apparently in the MS.

3 He held of Geoffrey the adjoining manor of Great Chishall.

- The abbey of Bury St. Edmunds.

- In Witham. held by 5 free men in King Edward's time; in these there are now as then (semper) 6 ploughs on the demesne, 8 bordars, (and) 4 serfs; wood(land) for 100 swine, and 14 acres of meadow. The manor was then as now (semper) worth 8 pounds; and the 3 hides were worth then 70 shillings; now 4 pounds.

Lattuna [Latton], which was held in King Edward's time by Turgot, a free man, is held by St. Edmund as a manor and as $3 \frac{1}{2}$ hides. Then as now (semper) 2 ploughs on the demesne, and 1 plough belonging to the men. There are 4 villeins. Then 4 bordars; now fo. 20

5. Then as now (semper) 4 serfs. Wood(land) for 200 swine, and 35 acres of meadow. There are 4 beasts (animalia), 50 swine, 30 sheep, and 25 goats. Then as now (semper) it was worth 6 pounds.

\section{HUNDRET OF HiDINGHEFORT [HINCKFORD]}

In Alfelmestuna [Alphamstone] St. Edmund holds half a hide. (There is) I plough on the demesne. Then I serf; now 3 bordars. (There are) 2 acres of meadow. It was then worth 10 shillings; now 20.

\section{HUNDRET OF LAXEFELDA ${ }^{8}$ [LeXDEN]}

In Colun [ Colne] St. Edmund holds $3^{6}$ acres. Then 3 bordars; now 4 . Then as now (semper) half a plough. Wood(land) for 40 swine, (and) 3 acres of meadow. It is worth 20 shillings.

\section{HUndRet of ANGRa [Ongar]}

STAPLEForT [Stapleford (Abbots)] is held now as then (semper) by St. Edmund as $3 \frac{1}{2}$ hides and $6 \frac{1}{2}$ acres. Then 8 villeins; now 9 . Then as now (semper) 5 bordars, and 2 serfs, and I plough on the demesne. Then 4 ploughs belonging to the men; now 3 . Wood(land) for 250 swine, and 12 acres of meadow. There are 20 beasts (animalia), I rouncey (runcinus), 48 sheep, 43 swine, (and) 3 colts (pulli). And in the soke of the manor ${ }^{7}$ are 2 free men with $(d e) 36 \frac{1}{8}$ acres; 1 plough (is there); wood(land) for 40 swine, and 2 acres of meadow. It was then worth 45 shillings; now 50.

\section{Hundret of Celmeresfort [Chelmsford] \\ Waltham [(Little) Waltham $\left.{ }^{8}\right]$, which was \\ - Sic. \\ 7 This is an exceptional phrase in Essex. \\ 8 i.e. the manor of Channels therein.}




\section{A HISTORY OF ESSEX}

held by Stanhard in King Edward's time as I manor and (as) 2 hides less I 5 acres, is held of the abbot by Albert. And St. Edmund (has it) of the king's gift. Then as now (semper) I villein, and 7 bordars, and 2 serfs, and 2 ploughs on the demesne, and I plough belonging to the men. Wood(land) for 30 swine, (and) 7 acres of meadow. (There are) I beast (animal), 50 sheep, 2 swine, (and) Io goats. It was then worth 40 shillings; now 60.

\section{Hundret of Tendringa [Tendring]}

Wrabenasa [Wrabness] is held now as then (semper) by St. Edmund as I manor and as 5 hides. Then as now (semper) 6 villeins, 8 bordars, (and) 6 serfs. Then 3 ploughs on the demesne; now 2. Then 6 ploughs belonging to the men; now $5 \frac{1}{2}$. There is 1 acre of meadow, and now I mill, and I saltpan. (There are) 2 colts (pulli), 30 swine, 200 sheep, (and) 5 hives of bees. It is worth 6 pounds.

fo. $20 \mathrm{~b}$

\section{THE LAND OF ST. MARTIN OF LONDON ${ }^{1}$}

Estra [(Good) Easter] was held by Ailmar, a thegn of King Edward, and Count (consul) Eustace gave it to St. Martin as I manor and (as) 4 hides and 50 acres. Then 3 ploughs on the demesne; now 2. Then as now (semper) 8 ploughs belonging to the men, and 8 villeins. Then 16 bordars; now $2 \mathrm{I}$. Then 8 serfs; now 3. Wood(land) for 60 swine, (and) 20 acres of meadow. (There is) now I mill. It was then worth 8 pounds; now 10. To this manor there belonged in King Edward's time an outlying estate (attinebat I berewita) of half a hide and 20 acres, but Count (consul) Eustace has retained it for himself (sibi); and it lies in the Hundret of Celmeresfort (Chelmsford). ${ }^{2}$

\section{THE LAND OF ST. MARTIN OF BATTLE ${ }^{3}$}

\section{Hundret of Berdestapla [Barstable]}

AтAHOU [Hutton] was held by Goti, a free man, in King Edward's time, as I manor and (as) 3 hides less 20 acres. Then as now (semper) 2 ploughs on the demesne, and 3 ploughs belonging to the men. Then I villein; now 2. Then Io bordars; now I 5.

1 St. Martin-le-Grand, founded by Ingelric, the predecessor of Count Eustace.

2 Good Easter itself lies just within Dunmow Hundred.

3 Battle Abbey.
(There are) 4 serfs. Wood(land) for 1,000 swine. Then I fishery; now none. Then 2 rounceys (runcini); now 3. Then 4 beasts (animalia); now I9. (There are) 100 sheep. Then 60 swine; now 92. (There are) 4 hives of bees. And (there are) 3 sokemen with $(d e)$ I hide and 30 acres; then as now (semper) I plough (is there); and (there are) I 5 acres of free land (liberce terre ${ }^{4}$ ). It was then worth Ioo shillings; now 6 pounds; and those 15 acres are worth 30 pence.

\section{HundRET OF HidingForda [HinckFord]}

Hersam [Hersham (Hall) ${ }^{5}$ ] was held, in King Edward's time, by Orgar, a free man, as a manor and as I hide. Then as now (semper) 2 ploughs on the demesne, and I plough belonging to the men. Then and afterwards 5 villeins; now 3 . Then I bordar; now 3 . Then 3 serfs; now 2. (There are) I 3 acres of meadow, 8 beasts (animalia), Io swine, (and) 25 sheep-formerly $28 .^{6}$ There are 3 hives of bees. It is worth 40 shillings.

\section{XIIII. THE LAND OF ST. WALERY?}

\section{Hundret of Herlaua [Harlow]}

Metcinga [Matching ${ }^{8}$ ] was held in King Edward's time by Godric, a free man, as 40 acres. Then I plough; now none. It is worth 10 shillings and 8 pence.

Lindesela [Lindsell ${ }^{9}$ ] was held in King Edward's time by Horolf, a free man, ${ }^{10}$ as I manor and as 1 hide. Now St. Walery (holds fo. $2 x$

it). Then as now (semper) 2 ploughs on the demesne, and 3 ploughs belonging to the men. Then 8 villeins; now 9. Then 4 bordars; now 15 . Then 4 serfs; now none. Wood(land) for 50 swine, (and) 6 acres of meadow. (There are) 4 beasts (animalia), 40 swine, 28 sheep, (and) 5 hives of bees. Then and afterwards it was worth 100 shillings; now 6 pounds.

4 This is a singular phrase. It is not easy to say what it means, unless it denotes exemption from 'geld.'

5 In Bumpsted Helion. It is now just within Freshwell Hundred.

6 ' iii ' has been interlined above 'xxv.'

7 See Introduction, p. 342.

8 Matching-Barnes with Brent-Hill in Hatfield Broad-Oak.

9 i.e. the manor of Prior's Hall in Lindsell (which is in Dunmow Hundred).

10 Compare p. 431 , note 3 , above. 


\section{THE HOLDERS OF LANDS}

\section{HUNDRET OF UDELESFORT [UTTLESFORD]}

TAcheleia [Takeley ${ }^{1}$ ], which was held in King Edward's time by Turchill, a free man, as half a hide, is held by St. Walery. Then as now (semper) 2 ploughs on the demesne, and 3 ploughs belonging to the men. (There are) 8 villeins. Then and afterwards 3 bordars; now 5. Then as now (semper) 2 serfs. Then and afterwards wood(land) for 1,000 swine; now for 600. (There are) 24 acres of meadow. Then and afterwards I mill ; now a moiety (of a mill). (There are) 3 rounceys (runcini), 4 beasts (animalia), 30 swine, 28 sheep, 50 goats, (and) 5 hives of bees. Then and afterwards it was worth 6 pounds; now 7 .

Brlichangra [Birchanger] was held by the same Turchill as 2 hides and as I manor. Then and afterwards 2 ploughs on the demesne; now I. Then as now (semper) 2 ploughs belonging to the men, (and) I villein, and 5 bordars. Then 2 serfs. Then wood(land) for 100 swine; now for 50. (There are) 6 acres of meadow, (and) I mill. (There are) 2 rounceys (runcini), 6 beasts (animalia), 28 swine, and 36 goats. Then and afterwards it was worth 60 shillings; now 50.

Widituna [Widdington "] was held by the same Turchill as a manor and (as) $4 \frac{1}{2}$ hides. Then and afterwards 3 ploughs on the demesne; now 2. Then as now (semper) 6 ploughs belonging to the men. Then and afterwards 8 villeins; now II. (There are) 20 bordars, $^{3}$ (and) 6 serfs. Wood(land) for 10 swine, (and) 12 acres of meadow. (There are) 5 beasts (animalia), 24 swine, (and) 50 sheep. Then as now (semper) it was worth 7 pounds. To this estate belong (terre jacent) 2 hides which are held now as then (semper) by 4 sokemen, and are worth 33 shillings."

\section{Hundret of Witbrictesherna [Dengie]}

EFfecestra [Bradwell ${ }^{6}$ ] was held in King Edward's time by Turchill, a free man, as $I \frac{1}{3}$ hides and 20 acres. Then 2 bordars; now 3 . Then as now (semper) 2 serfs and 1 plough. (There is) pasture for 300 sheep, (and) I fishery. (There are) 3 beasts (animalia), 20 swine, (and) 216 sheep. It was worth 40 shillings; now 70. In the same (vill) are 3

\footnotetext{
1 i.e. St. Walery's (or Warish) Hall in Takeley.

i.e. Prior's Hall in Widdington.

'Ov[es]' in the MS._-an obvious scribal error.

- 'iii' is interlined above ' $x x x$.'

b i.e. the manor of East Hall there (see Introduction, p. 392).
}

free men with (de) $1 \frac{1}{2}$ hides; 1 plough (is) there; it is worth 20 shillings.

Daneseia [Dengie] was held by the same (Turchill) as $2 \frac{1}{2}$ hides. There are 4 villeins. Then I bordar; now 8 . Then as now (semper) 4 serfs and 2 ploughs on the demesne, and 2 ploughs belonging to the men. (There is) pasture for 200 sheep. Then (it was worth) 4 pounds; now 100 shillings. In the fo. $2 \mathrm{xb}$

same vill 50 acres are held by 4 free men and are worth 5 shillings.

\section{$X V$. THE LAND OF THE HOLY TRINITY OF CAEN ${ }^{\circ}$}

\section{HUNDRET OF HidingFoRT [HINCKFORD]}

Phensteda [Felstead] was held in King Edward's time by Earl Algar ${ }^{7}$ as 5 hides, (and is) now held by the Holy Trinity as 4 hides. Then as now (semper) 3 ploughs on the demesne, and 16 ploughs belonging to the men. Then 22 villeins; afterwards and now 20. Then and afterwards 23 bordars; now 33. Then as now II serfs. Wood(land) for 600 swine, 36 acres of meadow, and 2 mills. (There are) 2 I beasts (animalia), 200 swine, 58 sheep, 30 goats, (and) I rouncey (runcinus). To this manor belonged in King Edward's time 55 acres, which were held by 3 sokemen, (and are) now (held) by 4 ; then 2 ploughs (were there), and now 3 ; there are now 2 bordars; wood(land) for 30 swine, (and) 12 acres of meadow. It was then worth 20 pounds; afterwards 30 ; now 32 . The fifth hide is not now (belonging) to this manor, for King William gave to Roger 'God save the ladies' (dominus salvat dominas) 3 virgates and to Gilbert son of Salomon the $4^{\text {th }} .^{8}$

\section{Hundret of Celmeresforda [Chelmsford]}

Baduuen [(Great) Baddow] was held by Earl Algar ${ }^{7}$ as I manor and as 8 hides. Now the Holy Trinity holds it for as much. Then as now (semper) I 6 villeins. Then 8 bordars;

6 The Abbaye aux Domes.

7 Earl Elffgar of Mercia, son of Leofric.

8 Both these holdings will be found below (pp. 562,563 ) under the names of these two men respectively. The first is there entered 2 ' half a hide and 30 acres,' and as having been held by 'Ulsius' under Earl Elfgar, while the latter is entered as 30 acres, and as having been held by a free man. It should be observed that these Felstead entries well illustrate the fact that 30 acres were reckoned to the virgate and 4 virgates to the hide in the geld assessment (see p. 334, note 4, above). 


\section{A HISTORY OF ESSEX}

now I 5. Then as now (semper) 6 serfs, and 3 ploughs on the demesne. Then 8 ploughs belonging to the men; now I2. Wood(land) for 400 swine, 45 acres of meadow, (and) I mill. There are I rouncey (runcinus), and 1 colt (pullus), and 14 beasts (animalia), 96 swine, $3^{8}$ sheep, (and) 13 goats. And (there are) 3 sokemen with (de) I virgate and $20 \frac{1}{2}$ acres, who could not withdraw themselves fo. 22

(recedere). ${ }^{1}$ It then rendered 8 nights' ferm (noctes de firma); now 17 pounds.

\section{THE LAND OF ST. STEPHEN OF CAEN ${ }^{2}$}

\section{Hundret of Hidinghfort [Hinckford]}

Penfelda [Panfield] was held in King Edward's time by I free woman as I hide and 3 virgates in King Edward's time (sic). Then 4 ploughs on the demesne; now 3 . Then 2 ploughs belonging to the men; when received, none; now half (a plough). Then 4 villeins; now none. Then as now (semper) 8 bordars. Then 8 serfs; now 7. Wood(land) for 200 swine, (and) I 2 acres of meadow. (There are) 2 rounceys (runcini), I 2 beasts (animalia), I 65 sheep, (and) 37 swine. It was then worth 10 pounds; afterwards I 00 shillings; now Io pounds.

\section{THE LAND OF ST. OUEN ${ }^{3}$}

\section{Hundret of Wensistreu [Winstree]}

Meresaia [(West) Mersea ${ }^{4}$ ] was held by St. Ouen (Audoenus) in King Edward's time as 20 hides. Then 4 ploughs on the demesne; now 6. Then as now (semper) 16 ploughs belonging to the men. (There are) 36 villeins, (and) 62 bordars. Then 10 serfs; now 3. (There are) I I rounceys (runcini), 2 colts (pulii), 16 beasts (animalia), 34 swine, (and) 300 sheep. To this manor belongs (adjacet) half a hide, which is held now as then (semper) by I priest and is worth ro shillings. Wood(land) for 200 swine, (and) pasture for 300 sheep. (There was) then I fishery. It was then worth 26 pounds; now 22. There is also in Colchester 1 house which belonged to this estate $\left(\right.$ terr $\left.e^{5}\right)$, but Waleram took it

1 i.e. betake themselves to another lord.

2 The Abbaye aux Hommes.

3 The Abbey of St. Ouen, Rouen, which received this estate from Edward the Confessor.

4 Including the manors of Fingringhoe and Peete on the mainland.

5 Here again 'manerium' and 'terra' are used indifferently. away. ${ }^{6}$ And in the Hundret of Wensistreu [Winstree] there are 8 sokemen of the king holding 107 acres and worth 10 shillings; of these St. Ouen has two-thirds (II partes). And 2 sokemen with (de) half a hide and 30 acres were taken (away) by Ingelric; Count $\mathrm{E}$ (ustace) has them now. And (there were) 2 sokemen who have been added to LEgra [Layer], a manor of the king in another Hundret. ${ }^{7}$ And of all this soke St. Ouen has now as then (semper) two-thirds (partes) and the king a third. And (St. Ouen has) now as then (semper) two-thirds (II partes) of the forfeitures of the Hundret. ${ }^{8}$

fo, $22 b$

\section{THE LANDS OF THE BISHOP}

\section{OF BAYEUX IN ESSEX [EXSESSA]}

\section{Hundret of Berdestapla [Barstable]}

Phenge [Vange], which was held by 2 free men as $5 \frac{1}{2}$ hides, is held of the bishop by (Ralf) the son of Turold. ${ }^{9}$ Then as now (semper) 2 ploughs on the demesne and 4 ploughs belonging to the men. (There are) 6 villeins, 9 bordars, (and) 1 serf. (There is) half a hide of wood(land). ${ }^{10}$ Pasture for 120 sheep, (and) I fishery. (There is) now I mill. There are 2 rounceys (runcini), 4 beasts, (and) 4 swine. Then 67 sheep; now 270. Of this estate (terra) 30 acres were held by I free man, and were added in King William's time to the aforesaid land, and it is not known how. It was then worth 100 shillings; now 8 pounds.

Burghesteda [(Great) Burstead], which Ingar (the) thegn ${ }^{11}$ held in King Edward's time as I manor and (as) ro hides, is held by the bishop in demesne. Then as now (semper) 3 ploughs on the demesne. Then 12 ploughs belonging to the men; now II. Then 20 villeins; now 22. Then 5 bordars; now 10. Half a hide of wood(land), ${ }^{10}$ (and) pasture for 150 sheep. There are 2 rounceys (runcini), I I beasts (animalia), 106 swine, 2 I 9 sheep. It is worth 20 pounds. To this manor have been added in King William's time 28 free men holding 28 hides and 5 acres, on which were then 16 ploughs, (and) now 13; (there are) 5 hides of wood(land), ${ }^{10} 23$ acres of meadow, and pasture for 250 sheep ; (there are)

6 See p. 419 above.

7 See p. 432 above, where 'Legra' is styled a mere 'berewita" of Stanway.

8 i.e. the penalties imposed in it.

9 See p. 342 above.

10 This unusual reckoning of woodland in terms of the hide should be observed (see p. 376 above).

It See Introduction, p. 352. 


\section{THE HOLDERS OF LANDS}

54 bordars, and 4 serfs; this addition is worth 16 pounds, (and) was then worth 20.

Dantuna [Dunton], which was held by a priest - a free man (presbyter liber bomo)-in King Edward's time as 7 hides and 40 acres, is held by the bishop in demesne. Then 4 ploughs on the demesne; now 2. Then as now (semper) 4 ploughs belonging to the men. Then 7 villeins; now 2, and 6 bordars. Then 5 serfs; now 2. There are 2 rounceys (runcini), 2 beasts (animalia), 15 swine, 34 sheep. It was then worth 12 pounds; now 7 .

Berdestapla [Barstable (Hall)], ${ }^{1}$ which was held by a free man as $5 \frac{1}{2}$ hides and 30 acres is held of the bishop by (Ralf) the son of Turold. And (there are) 30 acres of wood(land) (and) pasture for 100 sheep. ${ }^{2}$ Then as now (semper) 3 ploughs on the demesne, and 2 belonging to the men. (There are) 6 villeins (and) I I bordars. It was then worth 4 pounds; now 100 shillings. (There were) then in the demesne 2 rounceys (runcini), 5 beasts (animalia), 18 swine, (and) 36 sheep; now I rouncey (runcinus), 9 beasts (animalia), 24 swine, (and) 80 sheep.

InGA [Ingrave], which was held in King Edward's time by a free man as 2 hides, is held of the bishop by (Ralf) the son of Turold. Then as now (semper) I plough on the demesne, and I plough belonging to the men. (There is) I villein. Then I bordar; now 5. (There are) 3 serfs, and $1 \frac{1}{8}$ hides of fo. 23

wood(land). ${ }^{3}$ (There are) 3 rounceys (runcini), (and) 8 beasts (animalia). Then 30 swine; now 58. Then 40 sheep; now 76. Then 32 goats; now 14. It was then worth 60 shillings; now 70. To this manor have been added in King William's time 7 free men with (de) 8 hides; then as now (semper) 5 ploughs (were there); (there are) $1 \frac{1}{2}$ hides of wood(land), II bordars, (and) 4 acres of meadow; ${ }^{4}$ this was then worth 4 pounds; now 40 shillings.

Ramesdana [Ramsden $\left(\mathrm{Cray}^{6}\right)$ ] is held of

1 A manor in Basildon.

2 This woodland and pasture clause is interlined here, but seems to be misplaced.

3 Here again this reckoning of the woodland in hides should be observed.

- Here the order should be observed as well as the 'hides' of woodland.

3. The only ground I can find for this identification by Morant is that Ramsden Belhouse was all held by the Bishop of London. the bishop by 2 knights, and was held as 3 hides by 2 free men; and, according to the English (jurors), Ravengar took away the land from one of them, and Robert Fitz Wimarc the land (alteram terram) from the other, and now they know not how it came to the bishop. (These men) had then 2 ploughs; now there is no plough there. Then 5 bordars; now 7. (There is) half a hide of wood(land), (and) pasture for 100 sheep. It was then worth 3 pounds; now 4 .

In WATEleia [Wheatley ${ }^{\circ}$ ] and in WincFORT [Wickford] Pointel and Osbern hold 2 hides which were held in King Edward's time by 2 free men. Then 2 ploughs; now I. (There are) 4 bordars. (There is) I hide of wood(land), 25 acres of meadow, (and) pasture for 40 sheep. It was then worth 40 shillings; now 30 . And this land was taken away from the free men by Ravengar; and now the English know not how it has come into the bishop's hand(s).

WICForT [Wickford], which was held in King Edward's time by 5 free inen as 2 hides and 48 acres, is held of the bishop by (Ralf) the son of Turold. Then as now (semper) 2 ploughs, 5 bordars, and 2 serfs. Woodland for 30 swine. It is worth 40 shillings.

WICFORT [Wickford] is held of the bishop by Teher, and was held in King Edward's time by Godric, a free man, as I hide. Then as now (semper) I plough. Then I bordar; now 2. Wood(land) for 30 swine, and 8 acres of meadow. It is worth 20 shillings.

Hasinghebroc [Hassingbroke 7], which was held in King Edward's time by 16 free men as 12 hides and $13 \frac{1}{2}$ acres, is held by (Ralf) the son of Turold. Then I I ploughs; now 7. There are now $I_{4}$ bordars (and) 20 sokemen (soc'). Wood(land) for 200 swine, 16 acres of meadow, and pasture for 400 sheep. It is worth 10 pounds.

Celdewella [Chadwell], which was held by Edwolt, a reeve of $\mathrm{King}$ Edward, as $I \frac{1}{2}$ hides, is held of the bishop by the same Ralf. Then as now (semper) it ploughs on the demesne, (and) half a plough belonging to the men. Then 6 bordars; now 7. Then 2 serfs; now 1. (There is) a (quidam) sokeman

- A manor in Rayleigh, and therefore within Rochford Hundred now. But both here and on p. $4^{8} 4$ below it is entered 25 then in Barstable Hundred.

7 In Stanford-le-Hope. 


\section{A HISTORY OF ESSEX}

with (de) 30 acres. Wood(land) for 80 swine, (and) pasture for 100 sheep. Then I fishery; fo. 23b

(there is) now none, but there could be. Of this estate (terra) 30 acres belonged to (fuerunt ad) another estate (terram) in King Edward's time. ${ }^{1}$ It was then worth 40 shillings; now, including the addition (totum simul), 30 shillings.

In Torinduna [Thorndon ${ }^{2}$ ] the bishop has 20 acres which were held by a free man in King Edward's time. It is worth 30 pence. 3

\section{HUNDRET OF WITHAM}

In Hafelda [Hatfield (Peverel)?] (the bishop has) 15 acres which were held by a sokeman. It was then worth 3 shillings; now 4.

\section{HUNDRET OF ROCHEFORT [ROCHFORD]}

Stanbruge [(Great) Stambridge], which was held by Osward in King Edward's time as $3 \frac{1}{2}$ hides and 30 acres, is held of the bishop by Suen.4 Then 7 villeins; now none. Then 5 bordars; now 10 . Then 3 serfs; now none. Then as now (semper) 2 ploughs on the demesne. Then 3 ploughs belonging to the men; now 4. Pasture for 300 sheep, (and) I mill. Now I rouncey (runcinus). Then 4 beasts (animalia); now 2. Then I 5 swine; now 25. Then Ioo sheep; now 58. Then as now (semper) it was worth 6 pounds.

Bacheneia [Beckney? $\left.{ }^{5}\right]$, was held by Ravengar, and is now (held by) the bishop in demesne as half a hide. Then I serf; now I bordar. Then as now (semper) I plough on the demesne. (There is) pasture for 30 sheep. It was then worth 20 shillings; now

1 See p. 448 , note 3 , above.

2 i.e. in what is now (East and West) Horndon.

3 This small holding is not identified.

i.e. Suain of Essex, the great baron of the district.

6 This has been identified as Beeches in Rawreth ; but as that manor was held of the Honour of Rayleigh, it must be sought among the lands of Suain of Essex below.

I feel no doubt myself that 'Bacheneia' was really Beckney, a detached portion of Assingdon, which was ' $a$ considerable estate' and even 'a manor' in the sixteenth century (Morant, i. 32I-2). The form of the name makes the identity practically certain, and the 'pasture for sheep' confirms it ; but owing to the breaking up of the Bishop of Bayeux's fief, it is often difficult to prove the descent of its manors.
30. In this valuation of 30 shillings are included (adhuc) 30 acres and I bordar and half a plough. ${ }^{6}$

Berlinga [Barling ${ }^{7}$ ], which was held by a free man as half a hide, is held by the bishop in demesne. Then as now (semper) I bordar. Then I plough; now none; but there could be (one employed there). It is worth Io shillings.

Soberia [Shoebury ${ }^{8}$ ], which was held by a free man as I hide and 30 acres, is held by the bishop in demesne. Then as now (semper) 2 villeins. Then 2 bordars; now 3. Then 1 plough on the demesne; now 2 oxen. ${ }^{9}$ Then as now (semper) I plough belonging to the men. Pasture for 40 sheep. It was then worth 40 shillings; now 55 .

\section{Hundret of Witbrictesherna [DEngie]}

Criccheseia [Cricksea], which was held by Edric, a free man, in King Edward's time as I manor and as I hide, is held of the bishop by Suen. ${ }^{10}$ Then 2 bordars; now 3 . Then as now (semper) 2 serfs and I plough on the demesne. Wood(land) for 20 swine, (and) pasture for 20 sheep. (There were) then 4 beasts; now the same. It was worth 23 shillings then and afterwards; now 30.

Criccheseia [Cricksea], which was held by Leuric in King Edward's time as half a hide, is held of the bishop by Pointel. Then half a plough; now none. It was then worth Io shillings; now 5 .

fo. 24

\section{Hundret of Wensistreu [Winstree]}

Samantuna [Sampton ${ }^{11}$ ], which was held by 2 free men as half a hide and 35 acres, is

6 i.e. this was in addition to the 'half hide" estate.

7 i.e. the manor of Mucking Hall there.

8 The actual manor has not been identified.

9 i.e. a quarter of a plough team.

10 i.e. Suain of Essex, the Domesday baron.

11 This entry was placed by Morant under Salcot Verli, but on the ground of evidence which places it, on the contrary, in Peete (i. 424). The manor of Peete lay in Mersea and Peldon, and an Inquisition on Thomas Tey in 1543 assigns to him 'a capital messuage called Samptons Wyke in Peldon and Sampton,' and 'closes in Peldon and Sampton,' formerly belonging to the abbot of St. Osyth (i. 419). I can feel, therefore, no doubt that Sampton is represented by the 'Sampsons' shown on Morant's map (1768) and now known as 'Sampson's farm,' about a mile to the south of Peldon. 'Sampson's Creek' lies to the south of it. 


\section{THE HOLDERS OF LANDS}

held of the bishop by Ralf son of Turold. Then as now (semper) half a plough. Now 2 bordars. It was then worth 16 shillings; now 15.

\section{HUNDRET OF HidincFort [HINCKFORd]}

Nepsteda [(Little) Maplestead ? '], which was held in King Edward's time by 8 free men as $22 \frac{1}{2}$ acres, is held of the bishop by Aubrey's wife. Then as now (semper) I plough. Wood(land) for 20 swine, (and) 6 acres of meadow. Then as now (semper) it was worth 30 shillings.

In this Hundret Tihel de Herion " holds 22 free men with $(d e) 2$ hides and $13 \frac{1}{2}$ acres. Then as now (semper) 5 ploughs (were theirs). Then and afterwards I bordar; now 9 . Then as now (semper) I serf. Wood(land) for 4 swine, and 31 acres of meadow. Then and afterwards it was worth 60 shillings ; now 4 pounds.

\section{Hundret of Witbrictesherna [Dengie]}

Daneseia [Dengie], which was held in King Edward's time by Siric as $2 \frac{1}{2}$ hides, is (now) held by one of the bishop's knights. Then as now (semper) 2 villeins. Now 6 bordars. Then as now (semper) 3 serfs, and 2 ploughs on the demesne and I plough belonging to the men. Pasture for 160 sheep. It was then worth 4 pounds; now 100 shillings. In the demesne are 150 sheep, I rouncey (runcinus), and 13 swine. There belonged (erant) to this manor in King Edward's time 2 free men with (de) 47 acres, of whom the above knight of the bishop has taken possession (occupavit); then as now (semper) it was worth 4 shillings.

HACFlet [ s], which was held by Alward, a free man, as 2 hides and 30 acres, is (now) held by one of the bishop's knights. Then 4 bordars; now 10 . Then as now (semper) I plough. (There is) pasture for 260 sheep, (and) I fishery. The church holds 40 acres. It was then worth 60 shillings; now 4 pounds and I I shillings. In this vill was a free man with (de) 30 acres, who was outlawed (et udlagav[it]); now Suen's men have

1 This place seems to be clearly identical with the 'Mappesteda' entered on p. 569 below as held by Aubrey's wife.

'This was Tihel 'the Breton,' who held Bumpstead Helion and other manors in the neighbourhood (see p. 541). His surname ("Herion' or 'Helion') appears here only in the survey of Essex.

- See Introduction, p. 395. taken (acceperunt) the land and are still holding it."

\section{Hundret of Lassendene [Lexden]}

Aldeham [Aldham] was held by Leueva as 1 hide less 5 acres in King Edward's time. Now the wife of Aubrey holds it of the bishop. Then 1 villein; now none. Then as now (semper) 4 serfs and 2 ploughs on the demesne. Wood(land) for 12 swine, (and) 3 acres of meadow. (There are) I rouncey (runcinus) (and) 6 beasts (animalia). Then and afterwards it was worth 30 shillings; now 60.

\section{HUNDret OF ANGra [ONGar]}

Kelenduna [Kelvedon (Hatch)], which was held by Algar, a free man, as half a hide and 20 acres, is held of the bishop by (Ivo) the nephew of Herbert. ${ }^{5}$ Then as now (semper) 4 bordars and I plough. Wood(land) So. 24 b

for 60 swine, and $7 \frac{1}{2}$ acres of meadow. (There are) I beast (animal), 5 swine, and 47 sheep. It is worth 20 shillings.

\section{Hundret of Ceffeorda [Chafford]}

UPMUNSTRA [Upminster], which was held by Ulwin as $1 \frac{1}{2}$ hides, is held of the bishop by Mauger. ${ }^{6}$ Then 2 bordars, and now the same. 'Then as now (semper) I plough. It was then worth 20 shillings; now 30.

Alvithelea [Aveley], which was held by Edward, a free man, as 1 hide and 30 acres, is held by the same Mauger. Then as now (semper) 6 bordars, and I plough on the demesne, and I plough belonging to the men. It was then worth 20 shillings; now 30.

Turocha [Thurrock ${ }^{7}$ ], which was held

- This might suggest that 'Hacflet' must have adjoined a manor of Suain of Essex, who held in this Hundred Iltney and 'Hainctone' (which latter I identify with Ashcldham). But the action may have been taken when Suain was sheriff.

"Iro nephew of Herbert" was a considerable under-tenant of the bishop in Beds and in Kent.

6 Doubtless the same as the Mauger who held of the bishop at Orpington and some other places in Kent.

7 This and the two other manors of the bishop at 'Thurrock' must have been in West Thurrock or Grays (Thurrock), as they were in Chafford Hundred. Morant placed them in West Thurrock, but (as is often the case with Odo's manors) this can only be conjectural. Moreover I have proved that the Count of Eu's great manor was at West Thurrock, not, as Morant guessed, at Grays.
58 


\section{A HISTORY OF ESSEX}

by Alward, a free man, as I hide and 40 acres, is held of the bishop by Hugh. Then as now (semper) 2 bordars. Then 2 ploughs; now I. Wood(land) for ro swine, 8 acres of meadow, (and) pasture for 50 sheep. It was then worth 30 shillings; now 40 . (There were) then I rouncey (runcinus), (and) I beast (animal); now 2 (beasts). Then 25 swine; now 9. Then 50 sheep; now 48.

Turocha [Thurrock ${ }^{1}$ ], which Mannic, a free man, held in King Edward's time, as $2 \frac{1}{2}$ hides and 40 acres, is held of the bishop by Anschetil. ${ }^{2}$ (There are) now 2 villeins. Then 3 bordars; now 8. Then 6 serfs; now none. Then as now (semper) I plough on the demesne, and I plough belonging to the men. (There are) 8 acres of meadow. It was then worth 3 pounds; now 4 .

RENEHAM [Rainham ${ }^{3}$ ], which was held in King Edward's time, by Alsi, a free man, as a manor and as 4 hides, is held of the bishop by Hugh. Then as now (semper) 8 villeins. Then 3 bordars; now 5. Then 4 serfs; now none. Then 3 ploughs on the demesne, and when (the manor was) received ${ }^{4} 2$; now none. Then and afterwards ${ }^{4} 3$ ploughs belonging to the men; now 2. Then and afterwards it was worth 6 pounds; now 40 shiilings.

In Turoc [Thurrock ${ }^{1}$ ] half a hide, which Ulwin held, is now held of the bishop by Hugh. 'Then 1 plough; now none. Wood (land) for 5 swine, 8 acres of meadow, (and) pasture for 50 sheep. It is worth 20 shillings.

Estinfort [Stifford] was held by Alvric, a free man, as I hide and 30 acres. Now the same Hugh holds it of the bishop. Then as now (semper) I bordar, I plough, (and) 5 acres of meadow. It is worth 30 shillings. Of this estate (terra) I 5 acres are in the soke of William Peverel (piperelli) of Turoc [Thurrock $]^{5}$ as the county (court) testifies. To the church of this manor (sic) there belong 30 acres given by (the) neighbours in almoine.

1 See p. 457 , note 7 , above.

2 See p. 553, note 5 , below.

3 i.e. the manor of Southall there.

4 This is a good instance of the indifferent use of 'when received' and 'afterwards' to denote the intermediate stage.

6 The jurisdiction over them belong to his manor of (Grays) Thurrock (on which see p. 553 below). This passage is of value for the distinction it draws between the tenure of the land and the jurisdiction over it.
Craohu [ $\left.{ }^{6}\right]$, which was held by Alwin, a free man, as a manor and as $1 \frac{1}{2}$ hides, is held of the bishop by Hugh. Then as now (semper) I villein and I bordar. Then I plough; now half (a one). Wood(land) for I 00 swine, (and) $I \frac{1}{2}$ acres of meadow. Then and afterwards it was worth 50 shillings; now 20.

In Estinfort [Stifford] Gilbert, a man of the Bishop of Bayeux, held $I \frac{1}{2}$ hides, which are fo. 25

(now) held of the bishop by (Ralf) the son of Turold. Then as now (semper) 3 villeins, and 4 borders, and 2 ploughs on the demesne. It is worth 30 shillings. The Hundret (court) testifies that this hide (sic) in King Edward's time belonged to (jacuit in) Turroc [(Grays) Thurrock], a manor of William Peverel (piperelli), save 10 acres. $^{7}$

\section{LimpWELla [}

] which was held by Edric, a free man, as I manor and (as) half a hide, is held of the bishop ${ }^{8}$ by Hugh. Then I bordar; now 2. Then I plough; now half (a one). Wood(land) for 20 swine, (and) pasture for 20 sheep. It was then worth Io shillings; now 20.

\section{Hundret of Celmeresfort [Chelmsford]}

HANEGHEFELDA [(South) Hanningfield] was held by Fricbert in King Edward's time as I manor and as 9 hides. It is now held of the bishop by Ralf the son of Turold. ${ }^{9}$ Then as now (semper) 3 villeins. Then 2 bordars; now 5. Then 4 serfs; now 8. Then 2 ploughs on the demesne; now 3 . Then as now (semper) 2 ploughs belonging to the men. (There is) wood(land) for 60 swine. (There are) 3 rounceys (runcini), I 6 beasts (animalia), 32 swine. Then I 7 sheep; now 810 (sic). It was then worth 100 shillings; now 7 pounds.

In the same (vill) I 4 hides were held by 23 free men, who could withdraw themselves

6 This place has not been identified, but, although the name is now lost, I suspect that it is the 'Crawenho' which occurs in a plea of 1234 (Bracton's Note Book, ii. 53x). Its tenant is there charged by John de Beauchamp, its owner, with cutting down oaks on it and giving twenty of them to the parson of Aveley. As twenty oaks are not likely to have been sent far, the place was probably near Aveley.

7 See the relative entry, under William Peverel's fief, on p. 553 below.

8 The scribe had written 'comite,' but has deleted it and substituted 'episcopo.'

9 See p. 342 above. 


\section{THE HOLDERS OF LANDS}

(recedere) without (sceking) leave of the lord of the said manor." These (men) are held by the bishop, but the county (court) knows not how he came to have them (eos habuerit). (There were there) then as now (semper) I villein, and 18 bordars, and 8 serfs. Then I I ploughs; now Io. (There is) wood(land) for 150 swine. It was then worth 8 pounds; now 7 pounds and 2 shillings. These hides were originally seized (preoccupavit) by Turold ${ }^{2}$ of Rovecestra [Rochester].

And the abbey of Ely claims 2 hides and 3 virgates, which were held by 2 men; and the Hundret (court) testifies that these men (ipsi) held their land freely and were only 'commended' to the abbot of Ely. ${ }^{3}$

Berewic [ ] was held by Oin the Dane, a free man, in King Edward's time. Now Turold ${ }^{5}$ (holds it) of the bishop as $6 \frac{1}{2}$ hides and 37 acres. Then 4 villeins; now 6 . Then 4 bordars; now 6 . Then 3 serfs; now 5. Then as now (semper) 3 ploughs on the demesne, and 2 ploughs belonging to the men. Wood(land) for 100 swine, (and) 3 acres of meadow. Then 3 rounceys (runcini); now 5, and 10 colts (pulli). Then 4 beasts; now 18 . Then 16 swine; now 6i. Then 60 sheep; now 126. It was then worth 4 pounds; now 6 .

LAGHenberia [(Old) Lawn $\left.{ }^{6}\right]$ was held by Turchil in King Edward's time as a manor (and) as $2 \frac{1}{2}$ hides and 6 acres. Now R[alf the son of Turold holds it] of the bishop similarly (pro tantundem). Then 2 villeins; now 1. Then as now (semper) 5 bordars, and 2 serfs and I plough on the demesne, and I plough belonging to the men. Wood(land) for 100 swine, (and) 17 acres of meadow. Then 3 rounceys (runcini); now 1. Then 5 beasts (animalia); now 9. Then 19 swine;

1 'ipsius mansionis.' This is one of the interesting cases in which the scribe uses 'mansio' for a manor (compare p. 416 above).

2 Father of Ralf their tenant in 1086.

3 The abbey held the manor of Rettendon adjoining South Hanningfield on the south-east.

' 'Oin' dacus.'

5 This I suspect to be a scribal error for ' Ralf the son of 'Turold.'

- As the Domesday 'Laghemannus' (see fo. 956 below) represents Lawman, we should expect 'Laghenberia' to represent some such form as Lawnbury. Now in Great Waltham, which is close to Broomfield and Boreham, there was a manor of 'Lawn Hall' or 'Old Lawn,' and '-bury' is merely the manorial suffix as in Mashbury, Plesheybury and Walthambury just to the south, and Felstedbury to the north. now 40. Then 45 sheep; now 110 . Then and afterwards it was worth 40 shillings; now 60.

fo. $2 \% \mathrm{~b}$

Walfara [Walkfare(s) '] was held by Anunt the Dane (dacus) in King Edward's time as a manor ${ }^{6}$ and as $1 \frac{1}{2}$ hides. Now $\mathrm{R}$ [alf the son of Turold holds it] of the bishop. Then as now (semper) 2 bordars, and I serf, and I plough. Woodland for 60 swine, (and) 15 acres of meadow. (There is) I rouncey (runcinus). Then 5 beasts (animalia); now 4. Then I5 sheep; now 50. Then I I swine; now I7, (and) I goat. It was then worth 20 shillings; now 30 .

Pacing ${ }^{2}$ [Patching (Hall) $\left.{ }^{10}\right]$ was held by Segar in King Edward's time as a manor and as 2 hides and 30 acres. Now R[alf the son of Turold holds it] of the bishop. Then I villein; now 3. Then as now (semper) 4 bordars, and I serf, and I plough on the demesne, and I plough belonging to the men. Woodland for 15 swine, 8 acres of meadow, and I mill. Then 3 rounceys (runcini); now 4. Then 2 beasts (animalia); now 4. Then I I sheep; now 23. It is worth 40 shillings.

Melesham [(Great) Mulsham ? $\left.{ }^{11}\right]$ was held by Godric as a manor and as $2 \frac{1}{2}$ hides and 30 acres. Now R[alf the son of Turold holds it] of the bishop. Then I villein; now 2. Then I bordar; now 6 . Then 4 serfs; now 3. Then as now (semper) 2 ploughs on the demesne. Then $1 \frac{1}{2}$ ploughs belonging to the men; now 1. Wood(land) for 60 swine, (and) 10 acres of meadow. Then as now (semper) 1 mill. Then 3 rounceys (runcini) and I colt (pullus); now 2 rounceys and 4 colts. Then 9 beasts (animalia); now 28. Then 47 sheep; now 140. It was then worth 50 shillings; now 4 pounds.

\section{The other Molesham [(Little)Mulsham ? $\left.{ }^{11}\right]$}

7 In Boreham.

8 'M[anerium]' has been interlined above 'III,' and, as the latter has not been deleted, the reading is left doubtful. But the text above is probably correct.

- The plural represents an English 'Patchings.' 10 In Broomfield.

11 In Great Leighs. Morant assigned these entries to Mulsham in Great Lees, but the only ground that he can have had, so far as I know, for doing so is that the manor of Moulsham in Chelmsford seems to have belonged wholly to Westminster Abbey. And Mulsham in Great Leighs is in the Witham (not the Chelmsford) Hundred portion of the parish. 


\section{A HISTORY OF ESSEX}

was held by Ulmar, a free man, as a manor and as $I$ hide and 40 acres. Now R[alf the son of Turold holds it] of the bishop. Then 1 bordar. Then as now (semper) 2 serfs and 1 plough." Wood(land) for 40 swine, (and) Io acres of meadow. It is worth 20 shillings.

\section{Hundret of Tendringe}

Torinduna [Thorrington] was held by Adstan as I (uno) manor and as 4 hides. Now Ralf (the son of Turold holds it) of the bishop similarly (pro tantundem). And (it was) Turold of Rivecestra [Rochester] ${ }^{2}$ who seized (invasit) this land. Then as now (semper) 3 villeins, 9 bordars, and 5 serfs. Then 2 ploughs on the demesne; now $1 \frac{1}{2}$; but a third (plough) could be employed (potest esse). Then the men had between them (inter bomines) $2 \frac{1}{2}$ ploughs; now $1 \frac{1}{2}$. Wood(land) for 100 swine, (and) 1 acre of meadow, pasture for 100 sheep. (There are) now I mill, (and) I saltpan. Then as now (semper) it was worth 4 pounds.

A certain man held in Eilesforda [Alresford] half a hide, which Turold seized (invasit) like (sicut) the other land; and when he received it (recepit), there was half a plough; now (there is) none; but there could be. And the Hundret (court) knows not how he had (b't) this land; and, as neither a representative $\left(\right.$ Legatus $^{3}$ ) nor any other man came on his behalf to prove his right to this land, it is (taken) in(to) the king's hand with the rest. Then and afterwards it was worth 10 shillings; now 5 (shillings) and 4 pence.

\section{Hundret of Turestapla [Thurstable]}

Toleshunta [Tolleshunt ${ }^{4}$ ] was held by Oslac, a free man, as I hide. Now the bishop holds it similarly (protantundem). Then fo. 26

2 bordars; now 3 ; now 1 serf. Then I plough; now a half. Wood(land) for 30 swine, and pasture for 60 sheep. It was then worth 20 shillings; afterwards and now 30.

1 The words 'on the demesne' are probably omitted here.

2 Father of Ralf the tenant.

3 This use of 'Legatus' for the representative of any one but the king is remarkable. The entry possibly refers to a half hide spoken of under the king's manor of Lawford (see P. 435, note 7 , above and Introduction, p. 412).

- This manor has not been identified.

\section{THE LAND OF THE BISHOP OF HEREFORD}

In WRITA [Writtle] the bishop holds 2 hides and 20 acres, of which (hides) one was the church's (in ecclesia) in King Edward's time, and the other (in) Harold's fee (feudo). Then as now (semper) 3 villeins and I priest. Then 2 bordars; now 8. Then 2 serfs; now none. Then as now (semper) I plough on the demesne and 2 ploughs belonging to the men. Wood(land) for 100 swine, and 8 acres of meadow. It is worth 50 shillings. ${ }^{6}$

\section{$X X$. THE LANDS OF COUNT EUSTACE $^{6}$ IN ESSEX (EXSESSA)}

\section{Hundret of Berdestapla [Barstable]}

Phobinge [Fobbing] was held by Brictmar, a thegn of King Edward, as 5 hides and as I (uno) manor. Now Count Eustace holds it in demesne. Then as now (semper) 4 ploughs on the demesne, and 5 ploughs belonging to the men. Then 8 villeins; now 3. Then 8 bordars; now 22. Then I 2 serfs; now 6. Wood(land) for 700 swine, pasture for 700 sheep, (and) a moiety of a fishery (piscinee). (There are) 3 I swine, 700 sheep, and 17 (goats?). From this land 30 acres were taken by Turold and are (now appurtenant) to the Bishop of Bayeux' fief.' Ingelric, ${ }^{8}$ besides this, added to this manor 22 free men holding $15 \frac{1}{2}$ hides and $15 \frac{1}{2}$ acres, in whose (qua) land there were and are (semper) I 2 ploughs, and 20 bordars, and 3 serfs; wood(land there) for 50 swine, 10 acres of meadow, (and) pasture for 400 sheep; (there is) a third of a fishery (piscina), and there could be added $3 \frac{1}{2}$ ploughs. The manor was then worth 20 pounds, and the land of the sokemen ${ }^{9} 12$ pounds; now the whole together (inter totum) 36 pounds.

Horninduna [Horndon (on the hill)], which was held by Ulvric, a free man, as I (uno) manor and as 2 hides and 50 acres, is held of

6 This is a duplicate entry (see p. 434 above). It is noteworthy that 'the king's fee' of the other entry becomes here 'Harold's fee' (compare p. 336 above).

6 Of Boulogne.

7 See under Vange (p. 454 above).

8 The count's predecessor.

9 It is important to observe that these socemanni are the liberi bomines spoken of just before. Here then the two terms are distinctly equated (see Introduction, p. $35^{8}$ ). 


\section{THE HOLDERS OF LANDS}

the count by Garner." Then as now (semper) 2 ploughs on the demesne. Then 2 villeins; now none. Then 7 bordars; now 12 . fo. $26 \mathrm{~b}$

Then 2 serfs; now 3. (There are) 12 acres of meadow, (and) pasture for 60 sheep. (There are) 2 cows, 10 swine, (and) 110 sheep. Besides this (there are) I 5 acres belonging to the church in almoine (ad elemosinam ecelesia). It was then worth 60 shillings; now 50.

SCENEFrlda [Shenfield], which was held in King Edward's time by Bodd', a free man, as I manor and as 2 hides, is held of the count by Roger. Then 2 ploughs on the demesne; now I. Now half a plough belonging to the men. Then I bordar ; now 6. There 2 serfs; now none. Wood(land) for 40 swine. (There are) 2 beasts (animalia), 20 swine, (and) 15 goats. It is worth 60 shillings.

Dorseda [Orsett "], which was held in King Edward's time by the Bishop of London, (and) which Ingelric ${ }^{3}$ held of (his) church, is held by the count. Then as now (semper) 1 plough on the demesne; and I priest has there I plough. It is worth 20 shillings. This hide does not belong to (jacet ad) his hundred manors (c man'). ${ }^{6}$

Gravesanda [Gravesend ? "] was held by Harold, and by Ingelric of him, as a manor and as I hide. Then as now (semper) I plough. Then I villein; now 2. It was then worth 10 shillings; now 20. And this hide does not belong to (adjacet) his hundred manors (c maneriis). ${ }^{7}$

\section{HUNDRET OF WITHAM}

Nutlea [(White) Notley], which was held by Harold in King Edward's time, is held ${ }^{8}$

1 Gamer[ius]. The name is the same as 'Warner.'

i.e. the manor of Loft Hall there.

3 The count's predecessor.

- i.e. as the bishop's tenant.

- The same observation is made on this hide where it is mentioned under Orsett above (p. 438). The allusion to the count's 100 manors is obscure and has not been explained.

- It is not known what place is represented by 'Gravesanda.' Gravesend in Kent is not mentioned under that name in Domesday (compare p. 409 above.

7 See note 5 above.

8 The scribe (doubtless misled by the tenant's English name) first wrote 'tenuit,' but altered it of the count by Alvric the thegn as I (uno) manor. Then and afterwards 3 ploughs on the demesne ; now 2. Then and afterwards 5 ploughs belonging to the men; now 3 . Then and afterwards 10 villeins; now 6. Then 3 bordars; afterwards and now 16. Then 9 serfs; now 4. Then wood(land) for 200 swine; now for 100. (There are) 30 acres of meadow (and) pasture for 100 sheep. ${ }^{\circ}$ (There are) now 2 mills. (There are) 5 cows (vacas), 14 swine, 100 sheep, 7 goats, and 3 horses (equos). From this manor Ralf de Marci took 30 acres, and they are (jacent) in the fief of (Hamon) the son of Hamon. ${ }^{10}$ Then as now (semper) it was worth 10 pounds.

Cogheshala [Coggeshall], which was held in King Edward's time by Colo, a free man, is held by the count in demesne as 1 (uno) manor and as $3 \frac{1}{2}$ hides and 33 acres. Then as now (semper) 113 ploughs on the demesne; and when he received the land $(\mathrm{eam})$ I plough. Then 16 ploughs belonging to the men; afterwards and now 14. Then II villeins; afterwards and now 9. Then 22 bordars; now 31 . Now 4 serfs. Then wood(land) for 600 swine; now for 500 . (There are) $3^{8}$ acres of meadow, and tenpence worth of pasture. ${ }^{18}$ Then as now (semper) 1 mill. (There are) I rouncey (runcinus), 15 swine, 4 goats, 4 hives of bees. To this manor belong I I sokemen, and I priest, and I swineherd, and I hired servant (mercennarius). ${ }^{13}$ To this estate (terra) have been added 38 (acres) which I free man holds (tenet) of the 8. 27

king. This manor was then worth 10 pounds ; now 14 ; but it renders 20 pounds nevertheless; and the abovesaid $3^{8}$ acres are worth ro shillings.

Ruenhale [Rivenhall], which was held by Queen Edeva 14 in King Edward's time as I (uno) manor and as $2 \frac{1}{s}$ hides, is held by the count in demesne. Then 3 ploughs on

to 'tenet' on realizing that Alvric was the undertenant at the time of the Survey.

9 This is a remarkable feature in a manor so far from the sea.

10 They are duly entered under the fief of Hamon (dapifer) at White Notley (p. 500 below).

11 It should be observed that semper is here used strictly in the sense of 'then as now,' the intermediate stage being denoted by quando cam recepit.

1. Tanium pasture qua valet $x d$.

13 This accurrence of the word appears to be unique in Domesday.

3 Eadgyth, wife of Edward the Confessor. 


\section{A HISTORY OF ESSEX}

the demesne; now 2. Then 8 ploughs belonging to the men; now 6 . Then 12 villeins; now 13. Then 8 bordars; now 14. Then as now (semper) 6 serfs. Then (there was) wood(land) for 400 swine; now for 350 (ccc et dim). (There are) 30 acres of meadow, (and) pasture from which are received 3 shillings. Then 1 mill; now a moiety. ${ }^{3}$ There are I sokeman with (de) I 5 acres, and a burgess at Colchester (de colecastro). And a moiety of the mill was taken away by Richard de Sachevilla. ${ }^{1}$ (There are) I rouncey (runcinus), 6 beasts (animalia), 40 swine, 8 goats, (and) 2 hives of bees. It was then worth 9 pounds; now 12 , but it renders 20 pounds nevertheless.

RuENHALA [Rivenhall], which was held by Harold as I manor and as $\mathrm{I}$ hide and I 5 acres is held by the Count in demesne. Then 2 ploughs on the demesne; now 1 . Then as now (semper) I plough belonging to the men. Then 2 villeins; now 5. Then I bordar; now 2. Then 5 serfs; now 4. And (there are) 2 I acres of meadow (with) pasture worth (de) 6 pence. (There are) Io swine, (and) 27 sheep. It was then worth 60 shillings; now 30 .

Blundeshala [Blunts Hall ${ }^{2}$ ], which was held in King Edward's time by I free woman as I manor and (as) half a hide, is held by the count in demesne. Then as now (semper) I plough on the demesne and I bordar. (There are) 6 acres of meadow. It was then worth 20 shillings; now 10.

WITHAM, ${ }^{3}$ which was held by Harold as 51 acres, is held of the count by Richard. Then as now (semper) I plough on the demesne and $I$ bordar. (There are) $2 \frac{1}{2}$ acres of meadow. It is worth 20 shillings.

\section{Hundret of Herlaua [Harlow]}

Perenduna [(Great) Parndon], which was held in King Edward's time by Ulf a thegn of King Edward as I (uno) manor and as $3 \frac{1}{2}$ hides, is held of the count by Iunain (sic). Then as now (semper) 2 ploughs on the demesne and 2 ploughs belonging to the men. Then 4 villeins; now 3 . Then 4 bordars;

1 See Introduction, p. 379.

2 In Witham.

3 Morant assumed that this was a part of Blunts Hall manor, but it seems more probable that its tenant was the Richard who held of the Count at Rivenhall and that the land would be on the Rivenhall side of Witham. now 5. Then as now (semper) 2 serfs. Wood(land) for 200 swine, (and) I 4 acres of meadow. It is worth 4 pounds.

Latruna [Latton ${ }^{4}$ ], which was held in King Edward's time by Ernulf, a free man, as I (uno) manor and as $1 \frac{1}{2}$ hides and 30 acres, is held of the count by Adelolf(de Merc). ${ }^{5}$

fo. $27 \mathrm{~b}$

Then 2 ploughs on the demesne; now 1 . Then as now (semper) I villein and 2 bordars. Then 4 serfs; now 2. Wood(land) for 300 swine, (and) 35 acres of meadow. And there is I priest, who holds half a hide belonging to one church. It was then worth 50 shillings ; now 60 .

Herlaua [Harlow], which was held in King Edward's time by Brictnar, ${ }^{6}$ a free man, as half a hide, is held of the count by Geoffrey. Then as now (semper) half a plough. Wood(land) for 40 swine, (and) 3 acres of meadow. It is worth I I shillings.

\section{Hundret of Dommawa [Dunmow]}

Dommawa [Dunmow ${ }^{7}$ ], which was held in King Edward's time by Edmar, a free man, as $I$ (uno) manor and as 2 hides and 30 acres, is held of the count by Adelolf de Merc. ${ }^{5}$ Then 3 ploughs on the demesne; now 2 . Then I plough belonging to the men; now 3. Then 3 villeins; now 13 . Now 9 bordars. Then ro serfs; now 4. Wood(land) for 300 swine, and 36 acres of meadow. And I plough (more) could again be employed (restaurari). There are I 2 beasts (animalia), 50 swine, roo sheep, I rouncey (runcinus), (and) 4 hives of bees. It is worth 8 pounds.

\section{HundRET OF WITBRICTESHERNA [DENGIE]}

EltenaI [Iltney ${ }^{8}$ ], which was held in King Edward's time by Ingelric as I (uno) manor and as 2 hides, is held by the count in demesne. Then 1 serf; now 2 bordars. Then as now (semper) I plough on the demesne. Pasture for 50 sheep. It is worth 30 shillings.

\section{Purlar [Purleigh ${ }^{9}$ ] was held in King}

4 i.e. the manor of Marks Hall there, which derives its name from the family descended from the Domesday under-tenant.

5 See Introduction, p. 344.

6 Probably an error for Brictmar.

7 i.e. the manor of Merks in Great Dunmow, which took its name from Adelolf's family.

8 In Mundon (see Introduction, P. 391).

9 The actual manor has not been identified. 


\section{THE HOLDERS OF LANDS}

Edward's time by Edeva as I (uno) manor and as 1 hide and 30 acres; but was not (part) of Ingelric's ${ }^{1}$ fief; and now Count Eustace has it. It was then worth 16 shillings and 8 pence; now 23 shillings. Then 2 men dwelt there; now I priest.

\section{Hundret of Dommawa [Dunmow]}

Plesinchou [ ${ }^{2}$ ], which was held in King Edward's time by I free man as half a hide is held of the count by Bernard. Then as now (semper) half a plough. Then 2 bordars; now I serf. Wood(land) for 20 swine, (and) 5 acres of meadow. It is worth 10 shillings.

\section{HUNDRET OF WENISTREU [WINSTREE]}

LangHOU [Langenhoe] was held in King Edward's time by Ingelric as I (uno) manor and as 7 hides. Now the count holds it in demesne. Then 5 ploughs on the demesne; afterwards 4 ; now 3 . Then and afterwards It ploughs belonging to the men; now 2 . Then 5 villeins; now 9. Then as now (semper) 7 bordars. Then 12 serfs; now 8. Wood(land) for 200 swine, 1 acre of meadow, fo. 28

and pasture for 500 sheep. (There are) I mill, (and) I saltpan. (There are) 2 beasts (animalia), 300 sheep, 13 swine, and 3 rounceys (runcini). To this manor Ingelric added, in King William's time, 2 hides which were held, in King Edward's time, by I free man, and half a hide, which was held, in King Edward's time, by 3 free men ; in these (two) hides and $a$ half there are now as then (semper) 2 ploughs; now 4 bordars; (there is) pasture for 100 sheep. Then the whole together (simul) was worth 17 pounds; and now 17 (pounds) and 5 shillings; and when received, the same.

Edburghetuna [Abberton], which was held in King Edward's time by Siward, a free man, as I (uno) manor and as I t hides and I virgate, is held of the count by Ralf de Marci. Then as now (semper) I plough on the demesne. Then half a plough belonging to the men; and now the same. Then 4 bordars; now 3. Then I serf; now none. Wood(land) for 100 swine, (and) 4 acres of meadow. (There are) 4 beasts (animalia),

1 Count Eustace's predecessor.

2 Not Pleshey, 23 believed by Morant, but a tenement in the Willingales of which the name is now lost (see my proof of this in Essex Archecological Transactions [n.s.], viii. 333-4, 376).
100 sheep, 30 swine, and 2 rounceys (runcini). It is worth 60 shillings.

Legra [Layer (De La Hay)] was held, in King Edward's time, by Alric, a free man, as $2 \frac{1}{2}$ hides and I virgate. ${ }^{3}$ Then I $\frac{1}{2}$ ploughs on the demesne; now 2. Then I bordar ; now 3. Then 2 serfs; now 1. Wood(land) for 40 swine. Now I mill. Then I rouncey; now 2. Then 3 beasts (animalia); now 5. Then 38 sheep; now 146 . (There arc) 6 hives of bees. It was then worth 4 pounds; now 3 .

\section{Hundret of Odelesforda [UtTlesford]}

Sortegrava [Shortgrove "] was held, in King Edward's time, by I free man. Now Adelolf (de Merc) holds it of the count as I (uno) manor and as I hide and 30 acres. ${ }^{5}$ Then and afterwards I plough on the dcmesne; now 2. Then and afterwards I villein; now none. Then and afterwards I bordar; now 3. Then I serf; now none. (There are) 9 acres of meadow. (There are) 3 beasts (animalia), 2 rounceys (runcini), I I swine, (and) 90 slieep. It is worth 40 shillings. This land was seized (occupavit) by Ingelric in King William's time.

\section{HUNDRET OF HidincForda [HincKFord]}

RIDEwella [Ridgwell] was held, in King Edward's time, by I free man, named Goduin, as 1 (uno) manor and as 2 hides and 3 virgates. Then 5 ploughs on the demesne; afterwards and now 4. (There are) I 4 villeins, 14 serfs, and 3 bordars. Wood(land) for 80 swine, and 36 acres of meadow. (There are) 22 beasts (animalia), 44 swine, 102 sheep, 30 goats, and 2 rounceys (runcini). To this manor belong now as then (adjacent semper) 14 sokemen with (de) $67 \frac{1}{2}$ acres, who have I $\frac{1}{2}$ ploughs; there are 6 acres of meadow. The whole was then worth 18 pounds; afterwards and now 24. The count holds this in demesne.

\section{5o. $28 \mathrm{~b}$}

Sortegrava [Shortgrove ${ }^{8}$ ], which was held in King Edward's time by a free man as I (uno) manor and as I hide and 30 acres, is held of the count by Adelolf (de Merc). ${ }^{5}$

8 The name of the tenant in 1086 is not given.

- In Newport.

s It should be observed that the assessment of the two manors in Shortgrove is identical, suggesting that an original one had been equally divided; but the other figures differ considerably.

- In Newport. 


\section{A HISTORY OF ESSEX}

Then I plough on the demesne; now none. Then as now (semper) I villein and I bordar. And (there is) 1 acre of meadow. Then and afterwards it was worth 30 shillings; now 33 .

Clare [Claret ${ }^{1}$ ] was held, in King Edward's time, by Ledmar, a free man, as $I \frac{1}{2}$ hides and 35 acres. Then 5 ploughs on the demesne; afterwards and now 3 . Then as now (semper) 2 ploughs belonging to the men. Then 7 villeins; afterwards and now 4 . Afterwards and now 12 bordars. Then 10 serfs; afterwards and now 4. (There are) 27 acres of meadow, (and) I mill. (There are) 3 rounceys (runcini), 8 beasts (animalia), 40 swine, (and) 239 sheep. To this manor belongs now as then (semper) a detached estate (berewita), called Geldeham [(Little) Yeldham], of 2 hides and 18 acres; then 3 ploughs on the demesne, (and) afterwards and now 2 ; then as now (semper) 2 ploughs belonging to the men; then 8 villeins, (and) afterwards and now 6 ; afterwards and now 8 bordars; then 8 serfs, and afterwards and now 6 ; (there are) 18 acres of meadow. Further (there) belong (adjacent) to this manor 7 sokemen with 35 acres of land, who have I plough. This manor was then worth 18 pounds; afterwards and now 22. To this manor also Ingelric added, in King William's time, I free man, who used to have 15 acres and I plough; and it is worth 10 shillings. The count holds this manor in demesne. ${ }^{2}$

Belcham [Belchamp (Otton)] was held, in King Edward's time, by Ledmar, a free man, as I hide and 45 acres. It is now held of the count by Ulmar. ${ }^{3}$ Then as now (semper) 2 ploughs on the demesne, and 2 ploughs belonging to the men, and 4 villeins. Then and afterwards 4 bordars; now 5 . Then and afterwards 4 serfs; now 2 . Wood(land) for 20 swine, (and) 8 acres of meadow. To this manor belong (jacent) 5 sokemen, 2 of

1 Claret Hall manor in Ashen.

2 It should be observed that, although the holder in King Edward's time is not said to have held this estate 'as a manor' (pro manerio), it is styled a 'manor' five times in the course of the entry. This may serve to illustrate further the absence of importance to be attached to the words 'pro manerio' (see my paper on 'The Domesday Manor' in English Hist. Rev. xv. 293-302).

3 In the 1212 Survey of the Honour of Boulogne it is entered as held by William 'filius Otonis,' from whose family (on whom see p. 351 above) it derives its name.

4 Here again the omission of the words "pro manerio' is shown to be of no consequence by this incidental mention of the estate as a manor. whom were seized (occupavit) by Ingelric in King William's time and were previously (qui tunc erant) free men ; ${ }^{5}$ and they have 35 acres of land. On the demesne (are) 9 beasts (animalia), 2 rounceys (runcini), 20 swine, (and) 100 sheep. It was then worth 40 shillings; afterwards and now 4 pounds.

Bummesteda [(Steeple) Bumpstead ${ }^{6}$, which was held, in King Edward's time, by I free man, as a manor and as half a hide, is held of the count by Adelolf de Merc. ${ }^{7}$ Then 3 ploughs on the demesne; afterwards and now 2. Then as now (semper) 2 ploughs belonging to the men, 7 villeins, I I bordars, (and) 4 serfs. (There are) 15 acres of meadow. (There are) 1 rouncey (runcinus), and 3 beasts (animalia). And to this manor Engelric added I free man (with) $3 \frac{1}{2}$ acres. $^{8}$ It was then worth 4 pounds; afterwards and now roo shillings.

fo. 29

Belcham [Belchamp (St. Ethelbert)], which was held, in King Edward's time, by Etnod, a free man, as half a hide and 10 acres, is held of the count by Bernard. Then as now (semper) I plough on the demesne. (There are) now 2 bordars, 2 serfs, 4 acres of meadow, I sokeman, with 20 acres, I rouncey (runcinus), (and) 4 cows. ${ }^{10}$ Then 14 swine; now none. Then as now (semper) 50 sheep. It is worth 30 shillings.

Westuna [Weston ${ }^{11}$ ], which was held, in King Edward's time, by $I$ free man, as 30 acres, is held of the count by Adelolf. ${ }^{12}$ Then as now (semper) I plough and 4 acres of meadow. It was then worth 20 shillings ; now 25.

Phincingefelda [Finchingfield], which was held, in King Edward's time, by Norman as a manor and as half $a$ hide and ro acres, is held of the count by Guy.

6 This is a passage to be observed for its bearing on the terms 'sokemen' and 'free men.'

6 'The manor of 'Gernons' there.

7 See p. 344 above.

8 This clause is interlined.

- In Ovington (Morant).

10 The separate mention of cows is exceptional.

11 Entered in the 1212 survey as "Weston juxta Clare,' probably to distinguish it from 'Weston near Beauchamp,' a Bigot manor in Foxearth. The name of the count's Weston has now disappeared from the map.

12 Adelolf de Merc (see p. 344 above). 


\section{THE HOLDERS OF LANDS}

Then as now (semper) I plough on the demesne, and I bordar, and I serf. Wood(land) for 20 swine, and 9 acres of meadow. There are 3 beasts (animalia) (and) I 9 (swine?). ${ }^{1}$ It was then worth 20 shillings; now 40.

Phrocinghefelda [Finchingfield] was held by Ulvric, a free man, in King Edward's time. Now the same Guy holds it of the count as 37 acres. Then as now (semper) 1 plough. Then I serf; now 2 bordars. Then wood(land) for 20 swine; now for 5 . (There are) 4 acres of meadow (and) I mill. It is worth 16 shillings.

Smedetuna [Smeeton (Hall) "], which was held, in King Edward's time, by I free woman as I manor and as 3 hides, is held of the count by Raner. Then 4 ploughs on the demesne; afterwards and now 2. Then and afterwards $1 \frac{1}{1}$ ploughs belonging to the men; now 1. Then and afterwards 4 villeins; now 3 . Then as now (sensper) 14 bordars and 2 serfs. Wood(land) for 20 swine, (and) 20 acres of meadow. It was then worth 7 pounds; now 8. These manors were held by Ingelric. ${ }^{3}$

Topesfelda ['Toppesfield], which was held, in King Edward's time, by I free man as 15 acres, is held of the count by Bernard. Then as now (semper) I plough on the demesne, and (there are) I villein, and I bordar. Then I serf; now none. Wood(land) for 10 swine, (and) 6 acres of meadow. It is worth 20 shillings.

\section{HUNDRET OF Witbrictesherna [DENGIE]}

Melduna [Maldon], which was held, in King Edward's time, by I free man, as It hides and 30 acres, and afterwards by Ingelric, is held of the count by St. Martin of London." (There were) then as now (semper) 6 bordars and 2 serfs and 2 ploughs. Wood(land) for 30 swine, (and) pasture for 100 sheep. On the demesne (there are) 2 cows, 14 swine, (and) 100 sheep. It was Po. $2 g \mathrm{~b}$

then worth 4 pounds; now 100 shillings. There also (In eadem) 30 acres were held in King Edward's time by I free man, whom Ingelric annexed-St. Martin holds (it) now

1 The word is omitted in the MS.

- In Bulmer.

'The count's predecessor. It is not clear to how many of the above manors the phrase applics.

- St. Martin-le-Grand, Ingelric's foundation.

6 See P. $4^{6} 4$, note 10 , above.

I of the count-with (et) another free man who had (de) 30 acres. Ingelric attached (posuit) these men to his hall. ${ }^{6}$ In their land there is and was (est semper) I plough; and it is worth 20 shillings.

Ulemam [Uleham '], which was held in King Edward's time by I free man, and by Ingelric afterwards, as I hide, is held of the count by Robert. It was then worth 8 shillings and 4 pence; now 14 shillings.

\section{Hundret of Lassendena [Lexden]}

Tera [(Great) Tey] was held, in King Edward's time, by 1 free man as $3 \frac{1}{s}$ hides. Now Count Eustace (holds it). (There were) then 6 villeins; now 2. Then 16 bordars; now 35 . Then 9 serfs; now 10. Then 4 ploughs on the demesne; now 2. Then 6 ploughs belonging to the men (inter bomines); now 4. (There is) wood(land) for 160 swine, (and) 20 acres of meadow. There are 3 rounceys (runcini), 7 beasts (animalia), 68 swine, 80 sheep, (and) 34 goats. To this manor belongs an outlying estate (jacet una berewita) of $1 \frac{1}{2}$ hides less 10 acres; then as now (semper) I bordar and 2 serfs (were there); then 2 ploughs on the demesne, (and) now I ; woodland for 24 swine. And (there are) in this manor 17 sokemen holding 2 hides and 5 acres, which land is now lield by 16 sokemen. Under them (there were) 6 bordars then as now (semper); (and) then 2 serfs, (and) now none. Then 6 ploughs between them, (and) now 4. (There is) wood(land) for 30 swine, (and) 12 acres of meadow; and these sokemen could not withdraw themselves (recedere) from this manor. And there also belongs (jacet) to this manor 1 house in Colchester (colecestra). This manor was then worth 16 pounds; and the same when received. It is now worth 22 pounds blanch (candidas). ${ }^{8}$

There also (In eadem) 5 free men held 60 acres and 28 acres (sic), which (free men) did not belong to (erant de) this manor, (and) whom the count now has because his predecessor $^{9}$ was seised (of them); and the value of this land is (included) in the above value (of the manor).

Bocchested [Boxted] was held by Alvric as $4 \frac{1}{2}$ hides. Now the count (holds it) in

- This phrase is of importance.

7 Now Ulehams farm in Lawling.

8 i.e. assayed by fire. Compare Dialogis de Scaccario [Clarendon Press, 1902], Pp. 34-5. But there are four instances here (pp. $46_{5}-7$ ), not three as there stated. 8 i.c. Ingelric. 


\section{A HISTORY OF ESSEX}

demesne. Then as now (semper) 5 villeins and 18 bordars. Then 2 serfs; now none. Then 2 ploughs on the demesne, (and) now the same. Then as now 6 ploughs belonging to the men. (There is) wood(land) for 300 swine and 8 acres of meadow. Then I mill; now none. And (there is) I sokeman, who could not withdraw himself (recedere), holding half a hide; then half a plough (was there, and) now none. (There are) 2 acres of meadow, 13 beasts (animalia), 35 swine, I 40 sheep, 25 goats, (and) 3 rounceys (runcini). Then and afterwards fo. 30

it was worth 8 pounds; now 12 (pounds) blanch (candidas). ${ }^{1}$

Dunulanda [(East) Donyland] was held by Edric as a manor and as $1 \frac{1}{2}$ hides. It is now held by the count in demesne. Then as now (semper) 10 bordars. Then 4 serfs; now I. Then 2 ploughs on the demesne; now 1. Then 2 ploughs belonging to the men; now I. (There is) wood(land) for 100 swine, 6 acres of meadow, (and) pasture for 100 sheep. Then and afterwards it was worth 40 shillings; now 3 pounds. On the demesne are 80 sheep. There also I free man held half a hide, which is now held by the count; but Ingelric had it, and the Hundred (court) knows not how he came to have (babuerit) it. It is worth 5 shillings.

Bricceia [(Great) Birch], which was held by Edric as I manor and as 3 hides, and afterwards by Ingelric, is held of the count by Hugh. Then 13 villeins; now 6 . Then 5 bordars; now I 7. Then 6 serfs; now 4. Then 3 ploughs on the demesne; now $2 \frac{1}{2}$. Then 8 ploughs belonging to the men ; now 6. There is wood(land) for 100 swine (and) I 6 acres of meadow; and (there are) 2 houses in Colchester (colecastro) which belong (jacent) to this manor, and I sokeman, who could not withdraw himself (recedere), with (de) I 3 acres; now as then (semper) he has half a plough. In the demesne (were) then I rouncey (runcinus), now 3 ; then 20 beasts (animalia), now 10 ; then 35 swine, now 34 ; then 140 sheep, now 120 ; then 40 goats, now 20 . Then and afterwards it was worth 6 pounds; now I 00 shillings.

Estorp [East Thorpe], which was held in King Edward's time by Edric, a free

$$
1 \text { See p. } 465 \text {, note } 8 \text {, above. }
$$

man, as a manor and as I hide and 25 acres, is held of the count by the same (Hugh). Then 2 bordars; now 8. Then 4 serfs; now 2. Then 2 ploughs on the demesne; now 1 . Then 1 plough bclonging to the men (inter bomines); now 3 . Wood(land) for 30 swine, (and) 6 acres of meadow. Then 1 rouncey (runcinus) and I 6 beasts (animalia), and I 5 swine, and 30 sheep; now Io swine and I rouncey. It was then worth 40 shillings; now 30 .

Colun [Colne (Engaine) ${ }^{2}$ ], which was held by Alvric biga, in King Edward's time, as I virgate and Io acres, is held of the count by Robert. Then I bordar; now 3. Then as now (semper) 2 ploughs on the demesne; now I plough belonging to the men (inter homines). Then 5 serfs; now 3. (There are) 13 acres of meadow, (and) wood(land) for 40 swine. It was then worth 30 shillings; now 40. This Alvric held this land freely, but Ingelric had it after the king came, and the Hundred (court) knows not how.

Dunilanda [(East) Donyland] which was held by Godric of Colchester (cole castro ${ }^{3}$ ) as 25 acres, is held by the same (Robert). It is worth 12 pence.

fo. $3^{\circ \mathrm{b}}$

\section{Hundret of Angra [Ongar]}

Stanfort [Stanford (Rivers)] was held by Lewin in King Edward's time, and afterwards by Ingelric, as I manor and as 9 hides. Now the count holds it in demesne as the same (pro tantundem). Then as now (semper) 24 villeins. Then 2 bordars; now 17. Then 22 serfs; now 16 . Then 10 ploughs on the demesne; and when (the manor) was received, 7 ; now 5 . Then as now (semper) 15 ploughs belonging to the men. (There is) wood(land) for 400 swine, (and) 50 acres of meadow. Then as now (semper) I mill, 4 rounceys (runcini), 40 beasts (animalia), I I swine, (and) 233 sheep. It was then worth 24 pounds, and the same when received; now 40 pounds blanch (blancas). 4

There also (In eadem) a free man held 40 acres, but Ingelric took him and added him to this estate (accepit eum adjungens isti terre);

2 Wrongly identified by Morant and his successors as Wakes Colne (sec my paper on 'The Manor of Colne Engaine' in Essex Archacol. Trans. [n.s.] viii. 192-8).

3 See pp. 415-6 above.

4 i.e. assayed by fire (see p. 465 , note 8 , above). 


\section{THE HOLDERS OF LANDS}

now as then (semper) there is there half a plough ; wood(land) for 20 swine; it is worth now as then (semper) 5 shillings. And Brictwin held 20 acres, which Ingelric added to his own land, and it is appraised in the above (40) pounds.

Parva Stanfort ${ }^{1}$ [(in) Stanford (Rivers)] was held, in King Edward's time, by Alvric's father as I manor and as I hide and 80 acres. Now Count Eustace (holds it) for the same (pro tantum) as of Ingelric's fee (foudo). Then 3 villeins; and when (he) received (it), 5; now the same (number). Then as now (semper) 3 serfs. Then 2 ploughs on the demesne; now none. Then as now (semper) I plough belonging to the men. Wood(land) for 100 swine, 6 acres of meadow, 6 beasts, (animalia), (and) 213 sheep. It is worth 40 shillings.

Of this manor Alvric holds of the count half a hide, which is valued at 10 shillings in the said total (pretio).

Lagafara [(High ?) Laver $\left.{ }^{2}\right]$ was held, in King Edward's time, by Lewin as I hide and 40 acres; and Alwin held another part of that manor as $I$ hide and 40 acres (and) as a manor; but Ingelric added (it) to his own manor. Now Count Eustace (holds it) in demesne. Then as now (semper) 7 villeins and 10 bordars and 15 serfs and $5 \frac{1}{2}$ ploughs on the demesne and 5 ploughs belonging to the men. Wood(land) for 200 swine, $37 \frac{1}{2}$ acres of meadow, 2 beasts (animalia), II swine, 80 sheep, (and) 3 rounceys (runcini). Then and afterwards it was worth 16 pounds; now 20 (pounds) blanch (candidas). ${ }^{3}$

Of this manor Ralf holds 80 acres; and (there are) 1 villein and 3 bordars and $I$ plough, and it is worth 20 shillings (which are included in the said total (pretio).

There also a free man held 40 acres, which Ingelric added to this estate (terra). It is now held of the count by Ralf, and is (included) in the said valuation, and it worth ro shillings.

Angra [(Chipping) Ongar] was held by Ailida as I hide and as I manor. Now the count (holds it) in demesne. Then as now

1 Compare p. 403 above.

- Count Eustace held both at High and at Little Laver. It is hardly safe to distinguish between the two in Domesday.

i.e. assayed by fire. fo. 38

(semper) 8 villeins and 8 bordars and 3 serfs and 2 ploughs on the demesise and 3 ploughs belonging to the men. Wood(land) for 1,000 swine, 28 acres of meadow, 2 rounceys (runcini), 10 beasts (animalia), 36 swine, (and) 112 sheep. It was then worth 100 shillings; now 8 pounds.

There also I frec man held half a hide which belonged to (fuit de) this manor; now Ralf Baignard holds (it).

LAGHEFARA [(Little !) Laver $\left.{ }^{\dagger}\right]$, which was held by Brictmar as 40 acres and as I manor, is held of the count by Richard. Then as now (semper) I serf, and I plough. There are 6 acres of meadow. It is worth Io shillings.

LAmburna [Lambourne], which was held by Lefsi as I manor and as 2 hides and 80 acres, is held of the count by David. Then as now (semper) I villein. Then 10 bordars; now 12. 'Then as now (semper) 1 serf and 2 ploughs on the demesne, and 1 plough belonging to the men. Wood(land) for 100 swine, (and) 20 acres of meadow. It was then worth 40 shillings; now 60. On the demesne (are) 9 beasts (animalia) and 80 sheep.

Fifhida [Fyficld], which was held, in King Edward's time, by Brictmar as 40 acres and as 1 manor, is held of the count by Richard. Then as now (semper) 3 serfs and I plough on the demesne. Wood(land) for 24 swine, (and) 20 acres of meadow. It was then worth Io shillings; now 20. A free (man) held 10 acres, but Ingelric annexed him (invasit); then as now (semper) 3 serfs were there (and) wood(land) for 24 swine, and 4 acres of meadow; it was then worth 5 shillings, now Io shillings. ${ }^{3}$

Fifrida [Fyfield], which was held, in King Edward's time, by Alwin, as I manor and as 80 acres, is held of the count by 'Iuman[us].' ${ }^{\circ}$ Then as now (semper) I villein. Then 4 bordars; now 6. Then as now (semper) 2 serfs and I plough on the demesne, and I plough belonging to the men. ('lhere is) wood(land) for 50 swine, (and) 10 acres of meadow. It was then worth 30 shillings; now 40.

- Sce note 2 above.

s The entry of this free man's holding was crowded in subsequently. above).

The count's tenant at Great Parndon (p. 462 


\section{A HISTORY OF ESSEX}

\section{Hundret of Celmeresfort [Chelmsford]}

Newelanda [Newland (Hall)]', which was held, in King Edward's time, by Harold as I manor and as 3 hides, is held of the count by Mauger (Malgerus). Then as now (semper) 15 villeins, and 7 bordars, and 2 serfs, and 2 ploughs on the demesne, and 2 ploughs belonging to the men. (There is) wood(land) for 100 swine and 20 acres of meadow. It was then worth 100 shillings; now 7 pounds. Ingelric annexed (invasit) this manor, and the Hundred (court) testifies that it belonged to (jacuit in) Writtle in King Edward's time, and now Count Eustace holds it.

BADWEN [(Little) Baddow ${ }^{3}$ ] was held, in King Edward's time, by Lewin as 5 hides. Now Lambert holds (it) of the count for the same (protantundem). Ingelric annexed (invasit) this land also after the coming of the king. Then and afterwards 3 villeins; now none. Then and afterwards 4 bordars; now 8 . Then and afterwards 6 serfs; now 3 . Then as now (semper) 3 ploughs on the demesne. fo. 3 sb

Then and afterwards $\mathrm{I}$ plough belonging to the men; now none. Wood(land) for 100 swine, 24 acres of meadow, 1 rouncey (runcinus), 15 beasts (animalia), 50 swine, (and) 135 sheep. Then and afterwards it was worth 100 shillings; now 6 pounds.

Runewella [Runwell], which was held, in King Edward's time, by Lefstan as a manor and as I hide, is held of the count by the same Lambert; and Ingelric annexed (invasit) this (also). Then 2 bordars; now 3. Then as now (semper) I plough. Wood(land) for 50 swine, 2 acres of meadow, I 3 beasts (animalia), 20 swine, (and) 36 sheep. It is worth 20 shillings.

RunEwella [Runwell], which was held, in King Edward's time, by Edeva as I manor and as 4 hides, is held of the count by Adelolf (de Merc) ${ }^{4}$; and Ingelric annexed (invasit) this (also). Then 4 bordars; now 5. Then 2 serfs; now I. Then and afterwards half a plough on the demesne; now $2 \frac{1}{2}$ (sic). Then as now (semper) half a plough

1 A manor in Roxwell.

2 This 'manor' appears to be the estate spoken of under Writtle ( $p .433$ above) as seized by Ingelric and held by Count Eustace as his successor; but it is there entered as 2 hidcs, and its value is given differently.

3 i.e. the manor of Bassets or Videlowes there.

4 See p. 462, note 5, above. belonging to the men. Wood(land) for 80 swine. Then and afterwards it was worth I 00 shillings; now 6 pounds.

W ALtham [(Little) Waltham], which was held, in King Edward's time, by Lefstan as I manor and as 2 hides and I virgate, is held of the count by Lambert; and Ingelric annexed (invasit) this (also). Then and afterwards 4 bordars; now 7 . Then 2 serfs; now 1. Then and afterwards 2 ploughs on the demesne; now $1 \frac{1}{2}$. Then as now (semper) half a plough belonging to the men. Wood(land) for 10 swine, 12 acres of meadow, I rouncey (runcinus), 8 beasts (animalia), (and) 100 sheep. Then and afterwards it was worth 50 shillings; now 60 .

Borham [Boreham], which was held, in King Edward's time, by 14 free men as 8 hides and 23 acres, is held of the count by Lambert; and Ingelric annexed (invasit) this (also) after the king came into this land. Under these men (ipsis) were then 4 bordars; now 8. Then as now (semper) 3 serfs and 2 ploughs on the demesne. The men had then between them I 3 ploughs; when (the manor was) received, and now, 2. (There is) wood(land) for 10 swine and 54 acres of meadow. (There is) now 1 mill. There are I rouncey (runcinus), 15 beasts (animalia), (and) 132 sheep. It was then worth 12 pounds; and when (the manor was) received 6 pounds; now 8 (pounds).

There also (In eadem) $x$ free man holds 5 acres, and it is worth 10 pence.

Ranulf Peverel (piperellus) claims half a hide and 18 acres, which belong to (jacent $a d)$ the church of this manor, and a moiety of the church, and Ingelric was not seised (thereof); but Count Eustace gave (it) to a certain knight of his, who vouches him to warranty for it (unde revocat cam [sic] ad defensorem); and (he) also claims 30 acres fo. 32

which used to pay 12 pence a year to Ranulf Peverel's predecessor, says the Hundred (court). ${ }^{5}$

\section{Hundret of Turestapla [Thurstable]}

Toleshunta [Tolleshunt (Guines) ${ }^{6}$ ], which was held by Torbern as I manor and as $8 \frac{2}{2}$ hides, is held of the count by Adelolf ${ }^{4}$ (de

5 Ranulf held the adjacent manor of Springfield.

6 In Tollesbury. The Count of Guines held it afterwards of the Honour of Boulogne. 


\section{THE HOLDERS OF LANDS}

Merc). Then 5 villeins; now 3. Then 16 bordars; now 14. Then 8 serfs; now 4 . Then 4 ploughs on the demesne; now 3 . Then 4 ploughs belonging to the men; now 2. (There is) wood(land) for 60 swine (and) pasture for 300 sheep. Then 12 saltpans; ${ }^{1}$ now 5. There are 2 rounceys (runcini), 16 beasts (animalia), 40 swine, (and) 400 sheep. It was then worth 10 pounds; now 100 shillings.

There also (In eadem) 3 free men held half a lide and I acre (which is) worth Io shillings.

Goldhangra [Goldhanger], which was held by Elric as I hide and 15 acres, is held of the count by the same Adelolf (de Merc). (There are) now 4 bordars. Then 2 serfs; now none. Then as now (semper) I plough on the demesne, (and) now half a plough belonging to the men. Wood(land) for 40 swine, $3 \frac{1}{2}$ acres of meadow, (and) pasture for 50 sheep. It was then worth 20 shillings; now 30 .

Toleshunta [Tolleshunt ${ }^{2}$,' which was held by Almar as 2 hides, and 5 acres, is held by the count in demesne. Then 3 bordars; now 5. Then as now (semper) 2 serfs and I plough on the demesne, and I plough belonging to the men. Wood(land) for 100 swine, (and) pasture for 160 sheep. (There are) 50 sheep. It was worth 40 shillings then, and I 5 shillings when received; now 20 .

Toleshunta [Tolleshunt], which was held by Ulvric, a free man, as I manor and as I hide and 35 acres, is held of the count by St. Martin." Then as now (semper) 2 bordars and I plough. Wood(land) for 30 swine. (There is) I beast (animal). It is worth 30 shillings.

In BLACHAM [ ] 4 free men held half a hide, which they could sell. Count Eustace holds it now. Then as now (semper) 1 plough. It was worth ro shillings (then), and 10 shillings when received; now 7 shillings.

Tolesberia [Tollesbury], which Gudmund, a free man, held as I manor and as

1 Of which the memory is preserved in the name of the adjacent Salcote (see Introduction).

In Tollesbury. This was afterwards held of the Honour as I fee by the family of Loholt.

s "past.' clx ov.' I ov." The rendering is perhaps doubtful.

St. Martin-le-Grand, London.
3 hides in King Edward's time, is held of the count by Alm[er]frid. And this is of Ingelric's fee. Then 4 bordars; now 3 . Thien 4 serfs; now 2. Then 3 ploughs on the demesne; now 2. Then as now (semper) half a plough belonging to the men. (There is) pasture for 100 sheep, (and) I saltpan. It was then worth 4 pounds; afterwards and now 3 .

fo. $32 \mathrm{~b}$

\section{Hundret of Tenderinga [Tendring]}

Cita [Chiche ${ }^{5}$ ], which was held by Edward as 1 manor and as 3 hides in King Edward's time, and afterwards by Ingelric, is held by the count in demesne. Then 9 villeins; afterwards and now 7 . (There are) now 2 bordars. Then 8 serfs; afterwards and now 2. Then I plough on the demesne; and when (the manor was) received, none; now I. Then 6 ploughs belonging to the men; afterwards and now 3. (There is) wood(land) for 400 swine and 6 acres of meadow. (There are) I cow, (and) I I shcep. It was then worth 12 pounds; and 40 shillings when received; now Io pounds. To this manor belongs (jacet) I outlying estate (berewita) called FRATINGA [Frating] of 40 acres, (where is) now half a plough; it is appraised above. ${ }^{6}$ And at Burna ${ }^{7}$ [ ] there are 30 acres, (where was) then I plough; now a half; it is worth 20 shillings. And in Frorwica [Frowick (Hall)] ${ }^{8}$ are 50 acres, (where were) then as now (semper) 3 bordars, and $I$ serf, and $I \frac{1}{2}$ acres of meadow ; (there is) now I plough; wood(land) for I 2 swine; it is worth 10 shillings.

Tendringa ['Tendring ${ }^{9}$ ] was held, in King Edward's time, by Frewin as I manor and as half a hide. Now the count holds it in demesse for the same (tantundem). Then as now (semper) I villein, and 2 bordars, and 2 serfs. Then 2 ploughs on the demesne; afterwards and now 1. Then as now (semper) I plough belonging to the men. (There is)

6 Now St. Osyth. This manor is that of Earl's Hall there. The name in the MS. is clearly ' Cita,' as sead in the Record Commission's edition, which is an interesting scribal error; for in the two other entries relating to the place the name is 'Cice,' and it ought to be 'Cica' here. Such an error would seem to imply that the scribe was copying from a document which he misread (compare p. 395 above).

6 i.e. included in the ' 10 pounds.'

7 'Ad Burnam.' This leaves it doubtful whether 'Burna' or 'Burnam' is intended.

8 In St. Osyth ('Chiche').

i.e. the manor of Old Hall there. 


\section{A HISTORY OF ESSEX}

wood(land) for 30 swine and 2 acres of meadow. Then 2 rounceys (runcini); now 4. Then 4 beasts (animalia); now 7. Then as now (semper) 20 swine. Then 40 sheep; now 100. Then I 4 goats; now 20. It was then worth 40 shillings; now 60.

Elesforda [Alresford], which was held by Edward as 1 manor and as 2 hides and 50 acres, is held of the count by Haco[n]. Then 4 bordars; now 7. Then 6 serfs; now 2 . Then 2 ploughs on the demesne; and when (the manor was) received none; now half (a plough). Then I plough belonging to the men; now a half. There is wood(land) for 100 swine, 3 acres of meadow, (and) pasture for 20 sheep. It is worth 60 shillings.

Frietuna [Frinton], which was held by Harold, in King Edward's time, as I manor and as 3 hides, and was afterwards held by Ingelric, is held of the count by Ralf de Marci. Then 6 villeins; now 4. Then 3 bordars; now none. Then 2 serfs; naw 1 . Then as now (semper) I plough on the demesne. Then 2 ploughs belonging to the men; now half (a plough). (There is) pasture for 60 sheep. (There are) 2 beasts (animalia), 7 swine, (and) 20 sheep. It was then worth 60 shillings; now 4 pounds and 10 shillings.

BIRICHOU [Bircho'], which was held by Ingelric of St. Paul('s) of London ${ }^{2}$ as I manor and as 3 hides, is held of the count by Robert. $^{3}$ Then 6 bordars; now 8. Then fo. 33

2 serfs; now 1 . Then 2 ploughs on the demesne; now none. Then I plough belonging to the men (inter bomines); now 2 . There is wood(land) for 10 swine, (and) pasture for 100 sheep. Then 2 rounceys; now none. Then 8 beasts (animalia); now none. Then 13 sheep; now none. Then 6 swine; now none. It was then worth 60 shillings; now 4 pounds and 7 shillings.

Horlanda [(Little) Holland], which was held by Lefstan as 1 manor and as 4 hides

1 In Kirby ; now, by corruption, Birch Hall.

2 It had clearly been part of the soke of Eadwulfsness, which belonged to the canons of St. Paul's and which included Kirby.

3 Who also held of him at Colne (Engaine).

4 This is a remarkable instance of a manor on which the plough-teams had decreased from 3 to 2 , while all the other live stock had disappeared, being valued nearly 50 per cent higher than it was before! in King Edward's time, and afterwards by Ingelric, is held of the count by Adelolf (de Merc). Then I I villeins; now 8. Then as now (semper) 5 bordars. Then 2 serfs; now I. Then 2 ploughs on the demesne; now 1. Then 6 ploughs belonging to the men (inter bomines); now 2. (There is) wood(land) for 50 swine, (and) pasture for I 00 sheep. (There are) 13 swine, (and) 14 sheep. It was then worth 6 pounds; now 4.

LELEFORDA [Lawford ${ }^{5}$ ], which was held by Alvric in King Edward's time, and afterwards by Ingelric, as a manor and as 2 hides, is held of the count by the same (Adelolf). Then 4 villeins; now 1. Then 7 bordars; now 10 . Then 4 serfs; now 1 . Then 2 ploughs on the demesne; now 1. Then 4 ploughs belonging to the men (inter homines); now 2 . Wood(land) for 10 swine, 6 acres of meadow, pasture for 200 sheep, 4 beasts (animalia), 80 sheep, I rouncey (runcinus), (and) 8 swine. Then as now (semper) it was worth ro pounds. There also (In eadem) half a hide and 30 acres were held by 3 sokemen, whom Ingelric annexed (invasit); and Count Eustace now holds them, ${ }^{6}$ and the same Adelolf (holds them) of him; they had (inter eos) then 2 ploughs, now I ; there are 2 acres of meadow; it is worth 20 shillings.

Tendringe ['Tendring ${ }^{7}$ ], which was held by Etnod as a manor and as I hide less I 5 acres, is held of the count by Bernard; and this is of Ingelric's fee (feudo). Then 8 villeins; now 6. Now 6 bordars. Then 6 serfs; now 1. Then as now (semper) 2 ploughs on the demesne, and 3 ploughs belonging to the men. (There is) wood(land) for 200 swine, (and) 2 acres of meadow. Then as now (semper) it was worth 4 pounds.

\section{HUNDRET OF UDELESFORT [UTTLESFORD]}

CRisteshala [Chreshall] was held by Ingwar $^{8}$ as 1 manor and as 6 hides in King Edward's time. Now Count Eustace holds it in demesne (as) of Ingelric's fee (feudo). Then as now (semper) 32 villeins. Then 6 bordars; now I3. Then as now (semper) 6 fo. $33^{\mathrm{b}}$

serfs and 3 ploughs on the demesne, and 16 ploughs belonging to the men. There is wood(land) for 200 swine, and 8 acres of

\footnotetext{
5 i.e. Dale Hall in Lawford.

6 Compare p. 435 above, where Ingelric's aggressions at Lawford are differently stated.

7 i.e. Old Hall in Tendring.

8 See Introduction; p. 352.
} 


\section{THE HOLDERS OF LANDS}

meadow. There are I rouncey (runcinus), 40 swine, 150 sheep, 24 goats, and 4 hives of bees. Then as now (semper) it was worth 15 pounds. To this manor belong 2 sokemen with (de) 8 acres, and I sokeman with (de) 8 acres whom (quem) Ingelric annexed (occupavit) in King WVilliam's time; on (in) those 8 acres are 4 bordars, and (this) is worth 16 pence. To this manor there used to belong (attinebat), in King Edward's time, I sokeman with (de) 3 virgates, who is now held by William Cardun (as belonging) to the fief (foudum) of G[eoffrey] de 'Magna Villa," and (who) used to pay 2 pence a year.

Cishella [(Little) Chishall], which was held by Sired, a free man, in King Edward's time, as a manor and as 6 hides and 30 acres, is held of the count by Guy. ${ }^{2}$ Then 5 villeins; now 6 . Then 3 bordars; now 5 . Now as then (semper) 6 serfs and 3 ploughs on the demesne, and 5 ploughs belonging to the men, and 8 acres of meadow. (There are) 24 swine, (and) 250 sheep. Then and afterwards it was worth 100 shillings; and now 6 pounds.

Cishelua [(Little) Chishall] was held by Godric, a free man, in King Edward's time. Now the same Guy holds it of the count as I manor and as $2 \frac{1}{2}$ hides. It is worth 60 shillings.

There also (In eadem) I free man held half a hide which Ingelric seized (occupavit) in King William's time; and now Anselm (Enselmus) holds it of the count. In that land are and were (sunt semper) 2 bordars and 1 plough and 2 acres of meadow. It is worth 10 shillings.

ELM[ER]duna [Elmdon], which was held by Almar, a free man, in King Edward's time, is held of the count by Roger de Sumeri. And Ingelric seized (occupavit) this manor in King William's time. Now as then (semper) there are 14 hides, $^{3}$ and 26 villeins and 15 bordars. Then 12 serfs; now none. Then 6 ploughs on the demesne; and 3 when (the manor was) received; now 4 . Then as now (semper) 1o ploughs belonging to the men. (There is) wood(land) for 250 swine, (and) 7 acres of meadow. (There are) 20 swine, (and) 288 sheep." It was then

1 He held of Geoffrey the adjoining manor of Great Chishall.

2 This was Guy 'the Angevin,' who was the under-tenant of the count on his Norfolk manors.

This formula is, in Essex, quite abnormal.

4 "ce ov' et Ixxxviii ov'." The use of this worth 16 pounds, and (the same) when received; now 20 pounds.

LEA [Leebury $\left.{ }^{6}\right]$, which was held by Brictulf, a free man, in King Edward's time, as a manor and as $2 \frac{1}{2}$ hides, was afterwards held fo. 34

by Ingelric. Now the same Roger (holds it) of the count. Then as now (semper) 5 villeins. Then 1 bordar; afterwards and now 8. Then 4 serfs; now none. Then 3 ploughs on the demesne; afterwards and now 2. Then 4 ploughs belonging to the men; and 3 when (the manor was) received; and now the same (similiter). Wood(land) for 50 swine. Then and afterwards it was worth 4 pounds; now 100 shillings.

Crawelaea [Crawleybury ${ }^{6}$ ], which was held, in King Edward's time, by Lefsi, a free man, as 30 acres, and was seized by Ingelric afterwards, is held of the count by the same Roger. Then as now (semper) 2 bordars. Then I serf. Then as now (semper) 1 plough. (There are) 2 acres of meadow. It is worth 10 shillings.

\section{Half Hundret of Frossewella ${ }^{7}$ [Fresh- WELL]}

Benedisc [Bendish $(\mathrm{Hall})^{8}$ ] was held, in King Edward's time, by Ledmar the priest ${ }^{9}$ as a manor and as $4 \frac{1}{2}$ hides. Ingelric held (it) afterwards. Now the count (holds it) in demesne. Then as now (semper) 8 villeins, and 3 bordars, and 8 serfs, and 4 ploughs on the demesne. Then 4 ploughs belonging to the men (inter bomines); afterwards and now 3. (There is) wood(land) for 100 swine and 8 acres of meadow. (There are) 28 swine, (and) I 12 sheep. And I sokeman held I acre and I rood (pertic[atam]); Ingelric annexed (invasit) him, and now the count holds (him). The whole was then worth I I pounds; now 12.

Newham [Newenham ${ }^{10}$ ] was held, in King Edward's time, by Alsi as I hide; Ingelric held (it) afterwards. Now the count holds (it) in demesne. Then 6 villeins; now 9. Then 2 bordars; afterwards and now 7 . Then as now (semper) 6 serfs and 3 ploughs

cumbrous phrase may be due to the fact that ' $c c$ ' meant 240 , being reckoned by 'the long hundred.'

- In Elmdon.

- In Chreshall.

7 'Hund' de Frossewella dimidium' (sic).

8 In Radwinter. 9 See p. 348 above.

10 A manor in Ashdon. 


\section{A HISTORY OF ESSEX}

on the demesne. Then 4 ploughs belonging to the men; afterwards and now 3. There is wood(land) for 20 swine and 5 acres of meadow. There are 14 swine, 56 sheep, (and) I rouncey (runcinus). To this manor belonged (fuerunt) 5 sokemen holding half a hide and 35 acres, who could not leave their soke (remanentes cum soca ${ }^{1}$ ) ; 3 ploughs (were there) then; afterwards and now 2 ; (there are) 5 acres of meadow. (The whole) was then worth I I pounds; now I 2.

Birdefelda [(Little) Bardfield], which was held, in King Edward's time, by Norman as 2 hides and I virgate, and afterwards by Ingelric, who annexed him (et invasit eum), is held of the count by Adolof (de Merc). Then as now (semper) 6 villeins. Then and afterwards I bordar; now I2. Then as now (semper) 4 serfs and 3 ploughs on the demesne, and 2 ploughs belonging to the men. (There is) wood(land) for 200 swine and 49 acres of meadow. (There are) 5 beasts (animalia), 25 swine, 2 hives of bees, 30 goats, (and) I fo. $34 \mathrm{~b}$

rouncey (runcinus). Then as now (semper) I mill. Now I fishery. It was then worth 8 pounds; now Io pounds.

\section{HUNDRET OF ROCHEFORT [ROCHFORD]}

Scopelanda [Shopland] was held, in King Edward's time, by I free man as 5 hides. Ingelric held (it) afterwards. Now Count Eustace (holds it) in demesne. Then as now (semper) 5 villeins and 2 sokemen; and their lord used to have 'soc and sac' (et dominus corum babebat socam et sacam). ${ }^{2}$ Then as now (semper) 9 bordars, and 2 ploughs on the demesne, and 5 ploughs belonging to the men. (There is) wood(land) for 40 swine, (and) pasture for 400 sheep. (There are) 2 beasts (animalia), 54 sheep, I 4 swine, I 3 goats, (and) 3 rounceys (runcini). It was then worth 6 pounds; now IO. There also I free man held half a hide and 30 acres, which (quod) Ingelric seized (occupavit); then as now (semper) I plough (was there) and 3 bordars; and this is appraised as part of the (in) 10 pounds. ${ }^{3}$

1 The rendering of this difficult phrase can only be conjectural.

2 This is an important phrase, but its meaning is somewhat uncertain.

3 Here again is a manor which has nearly doubled its value, though the plough-teams have not increased. The addition to it of the relatively small estate seized by Ingelric seems quite insufficient to account for the rise.

\section{THE LAND OF COUNT ALAN}

\section{Hundret of Herlaua [Harlow]}

Eppinga [Epping] was held, in King Edward's time, by Wisgar, a free man, as I manor and as $I \frac{1}{2}$ hides and half a virgate. Then as now (semper) I plough on the demesne, and half a plough belonging to the men, and 2 villeins and 2 bordars. There is wood(land) for Ioo swine (and) 8 acres of meadow. It was then worth 20 shillings, now 30 . This manor is held of the count by Osbern.

\section{Hundret of Dommaua [Dunmow]}

UlingheHala [Willingale (Spain)], which was held, in King Edward's time, by Edeva ${ }^{6}$ as I manor and as $I$ hide and $I \frac{1}{2}$ virgates, is held of the count by Hervey ("de Ispania'). Then as now (semper) 3 ploughs on the demesne, and $I \frac{1}{2}$ ploughs belonging to the men, and 4 villeins, and 8 bordars, and 4 serfs. (There is) wood(land) for 250 swine, (and) I 2 acres of meadow. It was then worth 60 shillings; now 100.

CAnefredda [(Great) Canfield], which was held, in King Edward's time, by Edeva ${ }^{5}$ as I hide and 30 acres, is held of the count by Aubrey (Albericus) de Ver. ${ }^{6}$ Then as now (semper) I plough on the demesne, and $\mathrm{I} \frac{1}{2}$ ploughs belonging to the men. Then 3 villeins; now I. Then 5 bordars; now 10. (There is) wood(land) for Ioo swine, (and) 48 acres of meadow, counting meadow and marsh (inter pratum et maresc ${ }^{7}$ ). Then as now (semper) it was worth 60 shillings.

\section{Hundret of Hidinghafort [Hinckford]}

Phincingefelda [Finchingfield ${ }^{8}$ ], which was held, in King Edward's time, by 3 free men, under Edeva, ${ }^{3}$ as $2 \frac{1}{2}$ hides, is held of the count by Hervey ('de Ispania'). Then as now (semper) 5 ploughs on the demesne, and 7 ploughs belonging to the men, and 3 villeins, and $50\left(\right.$ sic $\left.^{9}\right)$ bordars, (and) 5 serfs. (There is) wood(land) for 160 swine, (and) 16 acres of meadow. It was then worth 100 shillings; now 8 pounds.

4 Of Brittany (see Introduction, p. 350). This heading is in large lettering.

5 Edith 'the fair' (see Introduction).

6 Who also held Canfield as a tenant in chief (see p. 532 below).

7 This is an unusual phrase.

8 i.e. the manor of Spain's Hall there.

9 The number is suspiciously large. 


\section{THE HOLDERS OF LANDS}

IN Bumesteda [(Steeple) Bumpstead] I knight (miles) holds $7 \frac{1}{2}$ acres, which were held, in King Edward's time, by I sokeman under Edeva, ${ }^{b}$ and $\mathrm{I} \frac{1}{2}$ acres of meadow. It was then worth 2 shillings; now 3 .

In Gerham [

] are 42 acres which were held, in King Edward's time, by I free fo. $35 b$

man. Then as now (semper) I plough, and 3 bordars. Then 2 serfs; now I. (There is) wood(land) for 15 swine, (and) 5 acres of meadow; now I mill. It was then worth 20 shillings, (and) now 25.

In Phincingefelda [Finchingfield] the count holds in demesne $38 \frac{1}{2}$ acres, which were held by 2 sokemen and I free man in King Edward's time. Then as now (semper) half a plough, and 2 bordars, and 2 acres of meadow. It is worth 5 shillings.

\section{Hundret of Angra [Ongar]}

RoInges [(Beauchamp) Roding], which was held, in King Edward's time, by Lewin and Etsi as a manor and as $\mathrm{I} \frac{1}{2}$ hides, is held of the count by Aubrey (Albericus) de Ver. Then as now (semper) 2 villeins, and 13 bordars, and 3 ploughs on the demesne, and I plough belonging to the men. (There is) wood(land) for 200 swine, (and) 50 acres of meadow. It was then worth 4 pounds; afterwards and now 100 shillings.

\section{Hundret of Tendringa [Tendring]}

BenETLEA [(Little) Bentley], which was held by Elwin as $42 \frac{1}{2}$ acres freely (libere), is held of the count by Hervey 'de Ispania.' This land was held by Earl R[alf]. ${ }^{1}$ Then as now (semper) 3 villeins, and half a plough, and $I$ acre of meadow. (There is) wood(land) for 6 swine. It is worth 3 shillings. The same (Iste idem) held half a hide. Then as now (semper) 4 villeins (were there), and 1 plough. (There is) wood(land) for 6 swine, (and) half an acre of meadow. It is worth 10 shillings.

\section{HUNDRET OF UDELESFORDA [UTTLESFORD] \\ Monehala [Manhall ${ }^{2}$ ], which was held}

1 Ralf, Earl of Norfolk, whom Count Alan had succeeded similarly in Norfolk, in sundry manors, after his forfeiture (fos. 144, 147, 149).

2 In (Saffron) Walden. The name was preserved in 'Manhall wood,' which forms a prominent feature on Chapman and André's map $(1772-4)$ but which is now reduced to the southern portion of Little Chesterford Park 2s 'Emanuel wood' (Ordnance map)! by Siward as I hide, is held of the count by the same H[ervey]. Then as now (semper) 2 villeins. Then I serf; now none. Now I bordar. Then as now (semper) half a plough. There are 7 acres of meadow, and two-thirds of a mill. It is worth 20 shillings.

\section{Half Hundret of Frossewella [Fresh- WELL]}

In RoDA [Rothe (End) ${ }^{3}$ ] the same (Hervey) holds 30 acres, which were held by Edeva. Then as now (semper) half a plough. There is wood(land) for 8 swine and $2 \frac{1}{2}$ acres of meadow. It was then worth 5 shillings; now 10.

In Stavintuna [Stevington (End) ${ }^{4}$ Edeva $^{6}$ held 5 acres, which Hervey holds. It is worth 2 shillings.

รo. 36

\section{THE LAND OF WILLAM DE WARENNA IN ESSEX}

\section{HundRet of Berdestapla [Barstable]}

UPнам [ ] was held, in King Edward's time, by a certain woman, Edeva, as half a hide and 30 acres. Now William (holds it) in demesne. It is worth 10 shillings.

Tiliberia [Tilbury ${ }^{6}$ ], which was held, in King Edward's time, by Sueting, a free man, as 30 acres, is held of William by Ranulf. Then as now (semper) I bordar. (There is) pasture for 40 sheep, (and) I acre of meadow. It was then worth 7 shillings; now 14.

\section{Half Hundret of Herlaua [Harlow]}

OUesham [Housham $\left(\mathrm{H}_{a} \mathrm{ll}\right)^{7}$ ], which was held, in King Edward's time, by Holefest, a free man, as I manor and as 1 hide and 3 virgates, is held of W[illiam] by Richard. Then 2 ploughs on the demesne; now I. Then $3 \frac{1}{2}$ ploughs belonging to the men; now 5. Then 6 villeins; now 10. 'Then as now (semper) 3 bordars. Then 3 serfs; now 1 . ('There is) wood(land) for 50 swine, and 10 acres of meadow. When (the manor was) received there were 5 beasts (animalia), I calf, and 40 swine, (and) 40 sheep. Now 6 beasts, and 50 swine, 90 sheep, (and) 3 hives of bees. To this manor (has been) added, in King Willian's time, I virgate, which was held, in King Edward's time, by Ulvric, a free man; then half a plough (was there); now none. Then as

3 In Ashdon, 18 miles south of the village.

- In Ashdon. $\quad$ See p. 472 , note 5.

"The exact manor has not been ascertained.

7 In Matching. 


\section{A HISTORY OF ESSEX}

now (semper) I bordar; (there is) wood(land) for 10 swine, (and) 2 acres of meadow; it was then worth 4 shillings; now 6. And the manor was then worth 6 pounds; now 7 .

Curca [Quick (Bury) ${ }^{1}$ ], which was held, in King Edward's time, by Alwin 'Godtuna,'? as 3 hides, is held of William by the same Richard. Then as now (semper) 2 ploughs on the demesne. Then $3 \frac{1}{2}$ ploughs belonging to the men; now 3 . Then 7 villeins; now 6. Now 6 bordars. Then 5 serfs; now 2 . ('There are) 20 acres of meadow. Then as now (semper) I mill. Then 47 sheep; now 52; and 2 colts $(p u l l i)$. It is worth 100 shillings.

\section{Hundret of Dommaua [Dunmow]}

Estanes [(Great) Easton $\left.{ }^{3}\right]$ was held, in King Edward's time, by Duna, ${ }^{4}$ a free woman, as a manor and as 2 hides. Now William (holds it) in demesne. Then as now (semper) 2 ploughs on the demesne. Then 4 ploughs belonging to the men; now 2. Then as now (semper) 4 villeins. Then 3 bordars; now 8. Then 3 serfs; now 2. (There was) then wood(land) for 200 swine; now for I 50. (There are) 52 acres of meadow. Then I rouncey (runcinus), and 7 beasts (animalia), and 60 swine, and 60 sheep. Now I rouncey, 23 beasts, 20 swine, 70 sheep, (and) 4 hives of bees. It is worth I 00 shillings.

fo. $35 \mathrm{~b}$

Canefelda [(Little) Canfield] was held, in King Edward's time, by 2 free men as 2 hides less 8 acres. Now William (holds it) in demesne. Then 4 ploughs on the demesne; now 2. Then 8 ploughs belonging to the men ; now 6 . Then 1 priest and 9 villeins; now I priest and 7 villeins. Then 3 bordars; now I 7. Then as now (semper) 2 serfs. Now I mill. (There was) then wood(land) for 160 swine; now for 120 . There are 70 acres of meadow. Then I rouncey (runcinus), and 8 beasts (animalia), and I0O swine, and 200 sheep. Now I rouncey, I 5 beasts, 50 swine, 70 sheep and 9 goats. It was then worth 8 pounds; now $9 .^{5}$

1 In Sheering. Alias Cowick Bury.

$2 \mathrm{He}$ had held land in Stanstead and its neighbourhood, across the Hertfordshire border, to the west.

3 i.e. the manor of Blamsters there. Wrongly identified by Morant as Little Easton (compare Introduction, p. 393).

4 Or perhaps 'Duua.'

5 Here is a manor on which the plough-teams
Rodinges [(High) Roding], which was held, in King Edward's time, by the Abbot of Ely as I manor and as $2 \frac{1}{2}$ hides, is held of William by William de Wateville. ${ }^{6}$ Then as now (semper) 3 ploughs on the demesne, and 3 ploughs belonging to the men, and I priest and 8 villeins. Then 12 bordars; now I I. Then as now (semper) 7 serfs. Wood(land) for 300 swine, (and) 42 acres of meadow. Then as now (semper) 3 rounceys (runcini), 8 beasts (animalia), and 120 sheep. (There are) now 7 swine. It was then worth Io pounds; and when (the manor was) received, 12 ; now 18.

Rodinges [(Leaden) Roding], which was held, in King Edward's time, by a free woman as 1 manor and as $2 \frac{1}{2}$ hides, is held of William by Walter. And now there are $3 \frac{1}{2}$ hides. $^{7}$ Then 3 ploughs on the demesne; now 2 ; and when (the manor was) received 3. Then as now (semper) I plough belonging to the men. Then 3 villeins; now I priest and 4 villeins. Then 4 bordars; now I3. Then 4 serfs; now 2. (There is) wood(land) for 50 swine, (and) 30 acres of meadow. (There are) now 4 beasts (animalia), and 40 swine, 83 sheep, (and) I hive of bees. It is worth 8 pounds. And that hide which is added to this belonged (adjacebat), in King Edward's time, to the abbey of Ely, as the Hundred (court) testifies.

Dommaua [Dunmow ${ }^{8}$ ], which was held by Earl Elfgar ${ }^{9}$ (Algarus), in King Edward's time, as half a hide, is held of William by Guibert. Then as now (semper) half a plough on the demesne. Now 3 bordars. Then 3 serfs; now none. ${ }^{10}$ (There is) wood(land) for 40 swine, and 7 acres of meadow. Then Io swine, and 30 sheep; now 9 beasts (animalia), 30 swine, 80 sheep, 12 goats, (and) 8 hives of bees. It was then worth 20 shillings; and when received, 30 shillings; now 35 shillings.

have decreased from 12 to 8 , and the woodland has considerably diminished, while the swine and sheep have been greatly reduced in number. Yet its total value is entered as greater than it was.

$6 \mathrm{He}$ and his wife held several manors of William de Warenne in what is now Brighton and its neighbourhood.

7 This increase is explained at the end of the entry.

8 i.e. the manor of Southall there.

9 Of Mercia, son of Earl Leofric.

10 This looks like a clear case of the conversion of serfs into bordars. 


\section{THE HOLDERS OF LANDS}

fo. 37

Half Hundret of Clavelinga [Clavering]

Pachen hou [Payton Hall ${ }^{1}$ ], which was held, in King Edward's time, by 1 free man as a manor and as $I$ hide and 30 acres, is held of William by Simond. Then as now (semper) I plough on the demesne, and I plough belonging to the men. Then and afterwards 3 villeins; now 2. Then and afterwards 3 bordars; now 7. (There are) 7 acres of meadow. Then 1 rouncey (runcinus) and 9 swine. Now I rouncey, 9 swine, and 40 sheep. It was then worth 20 shillings; now 25.

\section{HUNDRET OF HIDINGForda [HinCKFoRd]}

In Haltesteda [Halstead ${ }^{2}$ ] William de Gar[enne] holds 2 hides less 4 acres, which were held, in King Edward's time, by 30 free men. ${ }^{3}$ In that land there are and were (sunt semper) 1o ploughs on the demesne, and 3 ploughs belonging to the men, and 8 villeins, and 23 bordars, and 6 serfs. (There is) wood(land) for 140 swine, and 46 acres of meadow. (There are) 2 mills. Then 6 beasts (animalia), 40 sheep, (and) 12 swine. Now 14 beasts, 36 sheep, 20 swine, 2 rounceys, (and) 2 hives of bees. Then and afterwards it was worth 10 pounds; now 13 pounds 17 shillings and 4 pence. Of this land Richard holds 34 acres, and it is worth ro shillings in the above valuation (pretio).

In Bumesteda [(Steeple) Bumpstead "] Gulbert holds ${ }^{5} 3$ hides and 18 acres, which were held, in King Edward's time, by 12 free men. ${ }^{6}$ In that land are and were (sunt semper) 9 ploughs, and 3 villeins, and 18 bordars, and 5 serfs. (There is) wood(land) for 20 swine, (and) 40 acres of meadow. Then 1 rouncey (runcinus), 40 sheep, (and) 30 swine. Now I rouncey, 16 beasts (animalia), roo swine, 100 sheep, (and) 4 hives of bees. Then and afterwards it was worth 10 pounds; now 12.

1 In Manuden ; styled 'Pakenhoo-hall' in 1524.

The manor of Hipworth Hall therein.

8 The very large number of its former tenants should be observed; also the low assessment, and the abnormal proportion of the ploughs on the demesne to those of the men, a result of its former tenure.

i.e. Moyns manor therein.

i.e. of William.

- Here again the number of former holders is large, though the case is less extreme than in the Halstead case.

In Pebmarsh. ro. $37 \mathrm{~b}$

In Polmeis [Polhey ${ }^{7}$ William holds $3 \frac{1}{2}$ hides and 13 acres. Of this land 25 acres are held by Richard, and 3 virgates by Gladiou. The whole estate (terra) was held by 23 men in King Edward's time. ${ }^{6}$ Then they had 10 ploughs; afterwards (there were), and are there now 8 ploughs. (There are) now 6 bordars. Then 7 serfs; "now nones (sic). (There is) now I mill. (There was) then wood(land) for 60 swine; now for 40 , (with) 30 acres of meadow. (There were) 8 beasts (animalia), 20 swine, (and) 20 sheep; now 12 beasts, 30 swine, 60 sheep, (and) 2 hives of bees. It was then worth 10 pounds; now fo. $37 \mathrm{~b}$

14 pounds and 16 shillings. William claims (that he obtained) these lands by exchange. ${ }^{8}$

\section{Hundret of Ceffeurda [Chafford]}

Kelituna [Kenningtons ${ }^{9}$ ] was held, in King Edward's time, by 3 free men as 4 hides. Now William (holds it) for the same (tantundem) by exchange, as he says; and Wlbert (holds it) of him. Then I villein; now 7 . Now I bordar. Then 3 serfs; now 1. Then, in all (inter totum ${ }^{10}$ ), 3 ploughs; now It . (There is) wood(land) for 100 swine, and 8 acres of meadow. Then 2 beasts (animalia), and 15 swine, (and) 20 sheep; now 2 beasts, 15 swine, and 50 sheep. It was then worth "shillings; and when (the manor was) received, 30 ; now 97 shillings. ${ }^{18}$ Ranulf (sic) has also half a hide, which was held by Ulwin, a free man, in King Edward's time; then I plough (was there); now a lialf. It is worth 6 shillings.

\section{Hundret of Celmeresfort [Chelmsford]}

Haningefelda [(West) Hanningfield] was held by 3 free men as 3 manors and as 4 hides and 27 acres. Now William holds it for the same (tantundem), by his exchange; and Ulbert holds it of him. Then as now (semper) 3 bordars and 2 serfs. Then 3 ploughs on the demesue; now 4. (There is) wood(land) for 40 swine, 2 acres of meadow, and pasture for 100 sheep. Then 2 rounceys (runcini), and 12 beasts (animalia), 60 sheep, (and) 40 swine; now 2 rounceys, 30 beasts,

8 'Istas terras reclamat Willelmus pro escangio.' This probably refers to the lands at Bumpstead and Polhey. William's persistent reference to 'exchange' 2 s the source of his title should be observed.

- In Aveley (sce p. 490, note 10).

10 This probably means those on the demesne and the others taken together.

11 The figure is omitted in the MS.

12 "c sol" iii sol' minus." 


\section{A HISTORY OF ESSEX}

Ioo sheep, (and) 15 swine. It was then worth 60 shillings; now 4 pounds.

Haningefelda [(West) Hanningfield], which was held, in King Edward's time, by Godric scipri as I manor and as 2 hides less 30 acres, is held of William by Ranulf. Then 2 serfs; now none. Then as now (semper) 1 plough. (There are) 3 acres of meadow. It was then worth 30 shillings; now 40.

BORHAM [Boreham], which was held by Anschill as a manor and as half a hide, is held by Willian in demesne. Then as now (semper) I bordar. Then I serf; now none. Then I plough; now a half. (There are) 5 acres of meadow. Wood(land) for 20 swine. It is worth 10 shillings.

Belesteda [Belstead (Hall) ${ }^{1}$ ], which was held by Godric poinc as a manor and as I hide less 10 acres, is held of William by Richard. Then 2 serfs; now 1. Then 2 ploughs on the demesne; now 1. (There are) 6 acres of meadow. Wood(land) for 20 swine. It is worth 40 shillings.

fo. $3^{8}$

\section{HUNDRET OF UdELESFORT [UTTLESFORD]}

Wendena [(Little) Wenden], which was held by Ulinar as a manor and as $1 \frac{1}{2}$ hides and 30 acres, is held of William by Richard. And this is (William's) by exchange (pro escangio). Then as now (semper) 2 villeins and 7 bordars. Then and afterwards I plough on the demesne; now $1 \frac{1}{2}$. Then as now (semper) I $\frac{1}{2}$ ploughs belonging to the men. (There are) 16 acres of meadow. Then 17 swine; now none. Then as now (semper) 50 sheep. It was then worth 40 shillings; now 60.

\section{EIneswrda [Eynsworth ${ }^{2}$, which was}

1 In Broomfield.

2 Morant identifies this as Wood Hall in Arkesden, but the Arkesden manors are difficult to distinguish, and their names have been changed or lost. I have had to ascertain their identity through charters entered in the cartulary of (Saffron) Walden (Harl. MS. 3697). We have there a grant by Ralf de Arden, Kt., in 24 Hen. III. (1239-40) of 'totum tenementum de Eynesworth in parochia de Arkesden de feodo domini Comitis Warennæ " (fo. I 40), references to the 'capella de Eynesworth' and its endowment (fos. 134d, 139), and lastly mention of an acre of meadow 'in villa de Eynesworth,' abutting on the road from Arkesden to 'Wyggefosse' (fo. 1 33d). Now 'Wyggefosse' can be definitely identified as another manor in Arkesden, which appears in Domesday as 'Wigghepet' and which is now represented by Rockell's. held by Ulmar as a manor and as $2 \frac{1}{2}$ hides, is held (of William) by the same R[ichard]. Then 4 villeins; now 3 . Then 3 bordars; now 8. Then 2 serfs. Then $1 \frac{1}{2}$ ploughs on the demesne; and none (nichil) when (the manor was) received; now $I \frac{1}{2}$ ploughs. Then as now (semper) I $\frac{1}{2}$ ploughs belonging to the men. (There are) 10 acres of meadow. There was no stock on the manor when received ( $\mathcal{T}$ unc nichil recepit); now (there are) 32 swine, 52 sheep, 2 bcasts (animalia), and 3 hives of bees. It was then worth 40 shillings; now 60.

In Cishella [(Great) Chishall ${ }^{4}$ ] 8 free men held I hide and 45 acres. ${ }^{5}$ Now William de War[enne] (holds it) by exchange; and the same R[ichard] of him. Then 3 ploughs; now 2; and when (it was) received, none (nichil). (There are) 2 acres of meadow. It is worth 30 shillings.

\section{HuNDRET OF ROCHEFORT [ROCHFORD]}

In Pachesham [Paglesham ${ }^{6}$ William de $\operatorname{Gar}\left[\right.$ enne] ${ }^{7}$ holds in demesne I hide, which was held by I free man in King Edward's time. Then as now (semper) I plough on the demesne. Then 4 serfs; now 3. (There is) pasture for 100 sheep. It is worth 20 shillings.

In Plumberga [Plumberow ${ }^{8}$ ] Ranulf holds of W[illiam] 30 acres, which were held by I free man in King Edward's time. Then half a plough; now I. Then (it was worth) 5 shillings; now IO. He claims (that he obtained) these estates in exchange for (lands in) Normandy. ${ }^{9}$

\section{Hundret of Lexsendena [Lexden]}

In Forham [Fordham] Alvric held freely (libere) 25 acres. Now William holds them in virtue of the same exchange (pro eodem

Consequently the road spoken of is that along the Wenden Water, and 'Eineswrda,' therefore, cannot have been Wood Hall, and is probably represented by Chardwell (see also p. 391, note 2 above).

3 The figure is omitted in the MS.

i.e. the manor of Tewes or Lisles there.

5 Here again William is found in possession of an estate which had been held by a number of free men, and alleging exchange as his title.

6 i.e. the manors of East Hall and South Hall therein.

7 i.e. Warenne.

8 In Hockley.

9 ' has terras reclamat pro escangio de Normannia.' 


\section{THE HOLDERS OF LANDS}

escangio). Then as now (semper) half a plough. (There are) $1 \frac{1}{2}$ acres of meadow. It was then worth 10 shillings; now 6 shillings and 8 pence. This land is of the king's soke (socna).

fo. $3^{8 b}$

\section{THE LAND OF RICHARD SON OF COUNT GILBERT ${ }^{1}$}

\section{Hundret of Herlaua [Harlow]}

WALLA [Wallbury ? ${ }^{2}$, which was held, in King Edward's time, by Toti, a free man, as I manor and as I hide, is held by Richard in demesne. Then 2 ploughs on the demesne; now 1 . Then as now (semper) I plough belonging to the men. Then 2 bordars; now 6. Then 2 serfs; now none. (There is) wood(land) for 100 swine, (and) 24 acres of meadow. It was then worth 30 shillings; now 40.

\section{Hundret of Dommawa [Dunmow]}

TACHeSTEDA [Thaxted] was held by Wisgar $^{3}$ in King Edward's time. Now $R$ [ichard] (holds it) in demesne as I manor and as $9 \frac{1}{2}$ hides. Then 8 ploughs on the demesne; now 7 . Then 34 ploughs belonging to the men; now 18 . Then 55 villeins; now 52. Then as now (semper) 24 bordars and 16 serfs. (There was) then woodland for 1,000 swine; now for 800 . There are 120 acres of meadow. Then I mill; now 2. The stock could be increased by 16 ploughs. ${ }^{4}$ Then as now (semper) 4 rounceys (runcini), and 36 beasts (animalia), (and) 128 swine. Then 200 sheep; now 320. Then 10 hives of bees; now 16 . It was then worth 30 pounds; and when (it was) received, the same. It is now worth 50 pounds, say the French and the English, ${ }^{5}$ but Richard has given it on lease (ad censum) to a certain Englishman at 60 pounds; but

I Alias Richard de Clare (from his Suffolk lordship of Clare) and Richard de Tonbrige (from his Kent lordship of Tunbridge).

2 A manor in Great Hallingbury (compare Introduction, p. 397).

- This was the English lord of Clare, whose wide possessions Richard had obeained.

- Adhuc possunt restaurari xvi caruca." This information is very rare in the survey of Essex.

- The men of the Hundred were represented before the Domesday Commissioners by foreigners and natives in equal proportion. It should be observed that, here again, a great decrease in the plough-teams and a diminution of the woodland are accompanied by a marked increase of value. he looses (deficiunt illi) at least 10 pounds every year. ${ }^{6}$ To this manor belong now as then (adjacent semper) 3 sokemen with (de) 2 hides and 15 acres, whom Garner holds of $R$ [ichard]; then 4 ploughs (were there), now $3 \frac{1}{2}$; then 10 villeins, now 2 ; then 2 bordars, now 10 ; then 4 serfs, now none; (there is) wood(land) for 50 swine, (and) 34 acres of meadow; it is worth 6 pounds. And of this estate (terra) I sokeman of the king held, in King Edward's time $7 \frac{1}{2}$ acres, which have been added to this manor in King William's time, and have not paid the king's due (consuetudinem).

Dommawa [(Great) Dunmow] was held by Wisgar, ${ }^{3}$ in King Edward's time, as I manor and as 2 hides and 30 acres. Then as now (semper) 2 ploughs on the demesne, and 2 ploughs belonging to the men, and 5 villeins. Then 4 bordars; now 7 . Then as now (semper) 4 serfs. (There was) then wood(land) for 500 swinc; now for 300 . There are 15 acres of meadow. Then as now (semper) I mill. Then and afterwards it was worth 60 shillings; now 100 . And this land is claimed by Vital, I knight (t miles), as having been held, he asserts,

fo. 39

by $\mathbf{t}$ free man in King Edward's time. In this manor I priest holds, as he held (tenet semper), half a hide in almoin; and half a plough (was there) then as now (semper), and 2 bordars. This manor is held by Ernald (of William).

\section{HundReT OF HidincForda [HinckFord]}

Ghestingetorp [Gestingthorpe], which was held, in King Edward's timc, by Ledmar the priest ${ }^{7}$ as half a hide, is held of R[ichard] by W. Peche ${ }^{8}$ (peccatum). Then as now (semper) 3 ploughs on the demesne, and 3 ploughs belonging to the men, and 8 villeins. Now 9 bordars. Then as now (semper) 6 serfs. (There is) wood(land) for 20 swine, (and) 20 acres of meadow. Then I mill; now none. To this estate (terra) there belongs then as now (semper jacet) I sokeman

6 See Introduction, p. 363.

7 He was set over the collegiate church founded at Clare by Xlfric father of Wisgar, Richard's predecessor. His manor here was one of the two into which Gestingthorpe was divided, the other being held in copite by Otto the Goldsmith at the time of Doniesday.

$8 \mathrm{He}$ also held of Richard at Clopton and Dalham in Suffolk, and he had a house at Colchester. 


\section{A HISTORY OF ESSEX}

with (de) I 5 acres; and he has half a plough and 2 bordars and $I$ acre of meadow. It was then worth 100 shillings,; now 7 pounds.

Phincinghefelda [Finchingfield] was held, in King Edward's time, by 2 sokemen as 48 acres. Now Elinant holds it of $\mathrm{R}$ [ichard]. Then as now (semper) I $\frac{1}{2}$ ploughs. Then and afterwards 4 bordars; now 7 . (There is) wood(land) for 6 swine, and $6 \frac{1}{2}$ acres of meadow. Then 1 rouncey; now none. Then Io beasts (animalia); now 8. Then 20 swine; now 26. Then 100 sheep; now 127. It was then worth Io shillings; now 30.1

Penfelda [Panfield ${ }^{2}$ ], which was held, in King Edward's time, by Wisgar as I manor and as $I \frac{1}{2}$ hides and 30 acres, is held of $\mathrm{R}$ [ichard] by Robert. Then 4 ploughs on the demesne; afterwards and now 2. Then as now (semper) 5 ploughs belonging to the men. Then and afterwards Io villeins; now 8 . Then and afterwards 8 bordars; now I5. Then and afterwards 8 serfs; now 7. (There is) wood(land) for I 20 swine (and) I 3 acres of meadow. And the stock could be increased by 2 ploughs (2 carruce possunt restaurari). ${ }^{3}$ Then and afterwards it was worth 8 pounds; now Io.

In Geldham [(Great) Yeldham] Goismer holds (of Richard) I hide and 5 acres, which were held, in King Edward's time, by 8 sokemen under Wisgar. ${ }^{4}$ Then as now (semper) $3 \frac{1}{2}$ ploughs on the demesne, and half a plough belonging to the men. Then and afterwards 5 bordars; now 8. Then and afterwards 5 serfs; now 2. (There is) wood(land) for 20 swine, (and) 23 acres of meadow. (There was) then I mill. Then and afterwards it was worth 60 shillings; now 100 shillings.

In WICAM [Wickham (St. Paul's) ?] Ernald holds of R[ichard] half a hide and

I Here again is a great and inexplicable increase of value.

2 The manor of Panfield.

3 i.e. on the demesne. See p. 477 , note 4 , for this formula.

4 Goismer will be found again on p. 571 below holding of Richard an estate of about half this size, apparently in the same part of the county, which had been similarly held by four small tenants in the time of Edward the Confessor.

This manor and several others among those which follow illustrate the small holdings of the 'sokemen' in the north of the county.
Io acres, which was held, in King Edward's time, by 2 sokemen under Wisgar. Then as now (semper) 2 ploughs on the demesne. Then and afterwards 5 bordars; now 10. Then and afterwards I serf; now none. Then wood(land) for 40 swine; now for 20 . (There are) 10 acres of meadow. Then fo. $39 \mathrm{~b}$

and afterwards it was worth 30 shillings ; now 40. In Fincinghefelda [Finchingfield] the same Ernald holds 38 acres, which were held, in King Edward's time, by 2 sokemen under Wisgar. Then as now (semper) I plough; now 3 bordars, and I serf; and (there are) $4 \frac{1}{2}$ acres of meadow; it is worth 10 shillings.

In Bineslea [

5] Wielard holds (of Richard) I hide, which was held by I sokeman under Wisgar; then as now (semper) I plough on the demesne, and half a plough belonging to the men; and there are 2 villeins. Then and afterwards 16 bordars; now 7 . Then 2 serfs; now none. (There is) wood(land) for 20 swine, (and) 4 acres of meadow. It was then worth 20 shillings; afterwards and now 40.

In Alreforda [Alderford ? ${ }^{6}$ ] 2 knights hold 36 acres which were held by 3 sokemen under Wisgar. Then as now 2 ploughs and 4 bordars. (There is) wood(land) for 12 (swine), and 9 acres of meadow. (There are) 30 sheep. It was then worth 40 shillings; afterwards and now 60.

At (Ad) Asce [Ashen ${ }^{7}$ ] Richard holds in demesne half a hide and 40 acres, which were held, in King Edward's time, by 2 sokemen

5 See Introduction, p. 406, for the locality of this place, of which the name appears to be now lost.

6 This name appears to be now lost; but, as 'Alretuna' in Suffolk became Alderton, 'Alraforda' in Horsham (Norfolk) Alderford, 'Alresawe' in Staffordshire Aldershaw, and 'Alrelie' in Gloucestershire Alderley, it is probable that an 'Alderford' is indicated. In any case the place cannot be, as has been supposed, Alresford, which was in another Hundred, and of which the right Domesday form was Elesford or Eilesford.

7 This is another instance of Morant's curious blindness to his own evidence. He duly mentions that the church of Ashen (as that of 'Esse') was given by Gilbert de Clare to his priory at Clare only four years after Domesday; he knew that the place was originally called 'Esche,' 'Ash,' etc.; and yet he expressly states that it is not named in Domesday Book (compare Introduction, pp. 389, 39I, 393 above). 


\section{THE HOLDERS OF LANDS}

under Wisgar. Then as now (semper) I plough. Then and afterwards 2 bordars; now 6. (There are) 9 acres of meadow, (and) now I mill. It was then worth 20 shillings; afterwards and now 35.

At ( $A d$ ) Fincingefelda [Finchingfield] 2 knights hold of $R$ [ichard] 36 acres, which were held, in King Edward's time, by 3 sokemen under Wisgar. Then as now (semper) 2 ploughs and 4 bordars. Then 4 serfs ; afterwards and now 2. (There is) wood(land) for 10 swine, (and) 7 acres of meadow. Then and afterwards it was worth 40 shillings; now 65 .

In Bulenemera [Bulmer] Mascerel holds (of Richard) half a hide and 30 acres, ${ }^{1}$ which were held by I sokeman under Wisgar. Then as now (semper) 2 ploughs. Now I bordar. There is wood(land) for 5 swine, (and) 2 acres of meadow. And it is worth 22 shillings and 2 pence.

At ( $1 d)$ Weninchou [? How Hall ${ }^{2}$ ] Germund holds (of Richard) $32 \frac{1}{2}$ acres, $^{3}$ which were held by 3 sokemen under $W$ isgar. Then as now (semper) 2 ploughs, and 5 bordars, and 3 serfs. (There is) wood(land) for 30 swine, (and) 8 acres of meadow. Then 5 beasts (animalia); now 8. Now 4 swine. Then 20 sheep; now 83. Now 32 goats. Then and afterwards it was worth 30 shillings; now 50.

In Buro [Bures "] Richard has in demesne 13 sokemen with (de) 35 acres. Then as now (they had) 4 ploughs. Then 9 bordars; fo. 40

now 16. Then I serf; now none. (There is) wood(land) for 20 swine, (and) I I acres of meadow.

In Focsearde [Foxearth] (are) ig sokemen with $I \frac{1}{2}$ hides and 15 acres. Then as now (semper) 5 ploughs, and 10 bordars, and

1 Afterwards the manor of Butler's Hall, so named from the Butler family, which held it under Clare.

I have little doubt that this was How Hall (otherwise Woburnes or Oburnes) in Finchingfield, which was 'holden;' says Morant, 'of the honour of Clare,' and of which he adds 'we have no account' till the reign of Henry VIII.

3 He also held $37 \frac{t}{t}$ acres of him there (see p. 57 I below).

This is Bures hamlet in Hinckford Hundred which was part of Bures St. Mary (see Iniroduction, p. 408).
I serf; (there are) 22 acres of meadow. And in Pebenhers [Pebmarsh] are 18 sokemen with (de) half a hide and 12 acres; then as now (semper) 3 ploughs (were there) and 3 bordars; and (there are) 3 acres of meadow.

In Alfelmestuna [Alphamstone] I hide, less 15 acres, is held now as then (semper) by 15 sokemen; and they have 2 ploughs; and (there are) 3 bordars. (There is) wood(land) for 5 swine, (and) 4 acres of meadow.

In Mildeltuna [Middleton] (are) I 3 sokemen with (de) $1 \frac{1}{2}$ hides and 30 acres. Then as now (semper) 3 ploughs (were there); and 8 bordars. (There is) wood(land) for 8 swine and 13 acres of meadow.

In Bumesteda [(Steeple) Bumpstead] (are) 3 sokemen, who hold now as then (semper) 25 acres. Then as now (semper) I plough (was there), and 2 bordars. (There are) 6 acres of meadow. In Phincinchefelda [Finchingfield] (are) I I sokemen with (de) half a hide; then as now (semper) I plough (was there); and (there are) 3 acres of meadow.

In Celvestuna ${ }^{\circ}$ [ ] (are) 5 sokemen with (de) half a hide less 5 acres. Then as now (semper) I plough (was there); (there are) 2 acres of meadow.

In TumestedA ${ }^{6}$ [Twinstead] (are) 18 sokemen with (dt) half a hide and 15 acres. Then as now (semper) 2 ploughs (were there), and 7 bordars. (There is) wood(land) for 8 swine, (and) 3 acres of meadow. In CHENEBOLTUNA [ [ ${ }^{7}$ ] are is sokemen with half a hide and 5 acres; then as now (semper) I $\frac{1}{2}$ ploughs (were therc), and 3 bordars; (there) are 4 acres of meadow.

In Halsteda [Halstead] 22 sokemen hold half a hide and $I I$ acres. Then as now (semper) 5 ploughs. And (there are) I villein, I 5 bordars, (and) 2 serfs. There is wood(land) for 50 swine, 19 acres of meadow, (and) I mill.

- A place of the same name and probably identical with it occurs below (p. 570) among the 'Invasiones' of Ralph Bainard. The name appears to be now lost, but can be recognized in the 'Chelveston' which occurs in an Inq. p.m. of 2 Edward III. (1328-9) as held of Robert Fitz Walter (holder of the Bainard fief) with Pentlow by Master Robert de Redeswell.

- An error of the scribe for 'Tuinsteda.'

7 This name would be represented by Kimbol. ton, but the name seems to be lost. 


\section{A HISTORY OF ESSEX}

In SuDbERIA [Sudbury] are 5 burgesses, who hold 2 acres. These with all (those) aforesaid ${ }^{1}$ pay $\mathrm{I} 5$ pounds and 6 shillings and 6 pence; and all this (totum) is in Richard's demesne.

In Boituna [Boyton (Hall) ${ }^{2}$ ] Colfege, a free man, held half a hide and 10 acres in King Edward's time. Then as now (semper) 2 ploughs on the demesne. Then 3 ploughs belonging to the men; now 2 . Then as now (semper) I villein. Then 7 bordars; afterwards and now 8 . Then and afterwards 4 serfs; now 2. (There is) wood(land) for 30 swine, (and) 8 acres of meadow. It was then worth 40 shillings; afterwards and now 4 pounds. To this manor have been added in King William's time 45 acres, which belonged to Westrefelda [Wethersfield], the king's manor; half a plough (was there) then, now fo. $4 \mathrm{ob}$

none; then and afterwards I bordar, now 2 ; (there is) wood(land) for ro swine, (and) 2 acres of meadow; it is worth 8 shillings. ${ }^{3}$

In Bura [Bures ${ }^{4}$ ] Leueva, a free woman, held 40 acres. Then as now (semper) $1 \frac{1}{2}$ ploughs belonging to the men, and I villein. Then and afterwards 2 bordars; now 3 . Then as now (semper) 2 serfs. (There is) wood(land) for 20 swine, (and) 5 acres of meadow. It is worth 30 shillings. Richard has this land, namely Boituna [Boyton] and Buro [Bures], by exchange, as his men assert.

RoINGEs [Roding Morell ${ }^{5}$ ] was held in King Edward's time by Coleman as 3 virgates. Now Richard holds it for as much (tantundem) in demesne. And Coleman (iste) was so free that he could betake himself (ire) whither he would with (his) soc and sac (sacna); and yet (sed tamen) he was the man of Wisgar, Richard's predecessor. Then as now (semper) I villein, and 2 bordars. Then 4 serfs; now 1. Then as now (semper) 2 ploughs on the demesne, and half a plough belonging to the men. (There is) wood(land)

1 i.e. all the men mentioned from Bures to Sudbury, both inclusive, none of the entries containing a separate valuation. It should be observed that the payment is a fixed one, and not dependent on the varying profits of jurisdiction (soca). For remarks on these sokemen see Introduction, p. 358 .

2 In Finchingfield.

3 For this Wethersfield land see p. 431 above, where it is similarly valued at 8 shillings.

4 Probably Bures hamlet (see p. 479 , note 4 ).

5 Formerly a separate parish; now in White Roding. for 200 swine, (and) 20 acres or meadow. It was then worth 60 shillings; afterwards 40 shillings; now 4 pounds.

\section{Hundret of Tendringe [Tendring]}

Menethea ${ }^{6}$ [(Little) Bentley] was held by Wisgar as I hide and I manor. It is now held of Richard by Roger. Then as now (semper) 3 villeins, and 4 bordars. Then I serf; now none. Then as now (semper) I plough on the demesne, and I plough belonging to the men. (There is) wood(land) for 100 swine, (and) 3 acres of meadow. It was then worth 40 shillings; now 50.

Brumlea [(Little) Bromley ${ }^{7}$ ] was held by Alwin freely (libere) as I manor and as half a hide; and he was commended to Wisgar, (but was) able (potens) to sell his land. ${ }^{8}$ Now $\mathrm{R}$ [oger] holds it under Richard. Then as now (semper) I villein. Now 2 bordars. Then I plough on the demesne; now none. (There is) wood(land) for 100 swine, (and) 2 acres of meadow. (There are) now I I sheep. It is worth 40 shillings.

Aleforda [Alresford ? ${ }^{9}$ ] was held by Algar, in King Edward's time, as 37 acres. Now he holds it under $\mathrm{R}$ [ichard]. ${ }^{10}$ And this is of the king's soke of Laleforda [Lawford], as the Hundred (court) testifies. Then I plough; now none. There is pasture for 40 sheep. It was then worth Io shillings; now 6 .

\section{HuNDRET OF LAXEDANa [LeXden]}

In King Edward's time there were 5 sokemen held by Wisgar, (namely) Ulwin and

6 By a similar error the scribe has written 'Molebec' for 'Bolebec' in the other volume of Domesday (fo. 147).

7 i.e. the manor of Braham Hall there, which was subsequently held of the Honour of Clare.

8 See Introduction, pp. 358-9. These cases at Roding and Bentley should be compared with the instances there given of men who were personally commended to a lord without giving him rights over the land, and with the list (on p. 572 below) of holdings which Richard had annexed though his predecessor Wisgar had only the "commendation' of those who held them.

9 It is difficult to identify positively this holding, which has been assumed to be at Alresford (which was 'Elesford' or 'Eilesford' in Domesday). It is just possibly meant for Lawford ('Laleford ') with the ' $L$ ' omitted.

10 This is one of the rare cases in which the former holder was allowed to retain his land as an under-tenant of the new one. That of Gunner at Totham was another. 


\section{THE HOLDERS OF LANDS}

his 2 sisters in Colun [Colne ${ }^{1}$ ] holding 64

Io. 43

acres, and Leuric holding 30 acres in the same vill; and these could not withdraw themselves from Wisgar's soke; under them (were) then as now (semper) 2 bordars, and I plough. (There is) wood(land) for 12 swine, and 9 acres of meadow. Then as now (semper) I mill ; it is worth 20 shillings. In FORDEHAM $^{2}$ [Fordham] Ulmar ${ }^{3}$ held 40 acres under Wisgar, and (now) holds (them) under $\mathrm{R}$ [ichard]; and he could not withdraw himself (recedere) from (the) soke. Then 3 bordars were there; now 6 . (There is) half a plough, wood(land) for 10 swine, (and) 3 acres of meadow. It is worth ro shillings."

In Bercolta [(West) Bergholt] Lefcild held $31 \frac{1}{2}$ acres. Now Goding holds (them) under Richard. Then 2 bordars; now 6 . Now I serf. Then as now (semper) half a plough. (There is) wood(land) for 16 swine, (and) 3 acres of meadow. Then I mill; now none. It is worth 10 shillings.

In Witesworda [ ] Algar held under Wisgar I $2 \frac{1}{2}$ acres, and (qui) could not withdraw himself (recedere) from (the) soke. Now I bordar; and (there is) I acre of meadow. It is worth 3 shillings.

Laingaham [Langham], which was held by Phin the Dane (dacus) ${ }^{b}$ as $2 \frac{1}{2}$ hides and as I manor, is held of $\mathrm{R}$ [ichard] by Walter Tirel. ${ }^{6}$ Then 22 villeins; now 17. Then 9 bordars; now 27. Then 4 serfs; now none. Then as now (semper) I plough on the demesne. Then II ploughs belonging to the men; now 7. (There is) wood(land) for 1,000 swine, (and) 40 acres of meadow. Then I mill; now 2. Then 6 rounceys (runcini); now none. Then as now (semper) 22 beasts (animalia). Then 46 swine; now 80. Then 54 sheep; now 200. Then 62 goats; now 8o. Then 3 hives of bees; now none. It was then worth 12 pounds; now I5.

1 Berwick Hall in White Colne and Creping Hall in Wakes Colne were held of the Honour of Clare. The former appears to be here meant (see p. 534, note II, below).

'The Record Commission's edition reads 'Sordeham,' but the first letter was probably intended for a' $F$.'

This was the fifth of the above sokemen.

- This Fordham entry appears to have been crowded in after the text was written.

s See Introduction, p. $34^{8}$.

6 Ibid. p. 349.

\section{Half Hundret of Frossewella [Fresh- WELL]}

Birdefelda [(Great) Bardfield] was held by Wisgar as I manor and as 4 hides. Now Richard holds (it) in demesne. Then 24 villeins; now 20. Then and afterwards 7 bordars; now 22. Then as now (semper) 8 serfs. Then as now 4 ploughs on the demesne. Then and afterwards 21 teams (belonging to the men); now 9. Wood(land) for 800 swine, and 32 acres of meadow. Then as now (semper) 2 mills. Then 4 rounceys (runcini); now 5. Then 28 beasts (animalia); now 41. Then 60 swine; now 107. Then 100 sheep; now 200. It is worth now as then (semper) 16 pounds.

Sanforda [(Little) Sampford] was held by Wisgar as I manor and as 5 hides. Now Richard holds (it) in demesne. Then 23 villeins; now 14 . Then 2 bordars; now 18 . Then 6 serfs; now 4. Then as now 3 ploughs on the demesne. Then 2 I ploughs belonging to the men; now 10. (There is) to. 4rb

wood(land) for 60 swine, (and) 22 acres of meadow. Then I mill; now none. It was then worth 12 pounds; now I 7 . When Richard received this manor, he found there at that time (tunc) 3 rounceys (runcinos); now (there are) 2. Then I 9 beasts (animalia); now 9. Then 50 swine; now 30. Then 100 sheep; now 88 . Then 3 hives of bees; now 1. Of this manor and of the abovesaid 5 hides 2 Frenchmen hold $I \frac{1}{2}$ hides; and (there are there) 9 bordars, and 2 ploughs, and 16 acres of meadow; this is appraised above. ${ }^{7}$

Hamsteda [Hempstead] was held by Wisgar as I manor and as 4 hides less 30 acres in King Edward's time. Now Robert de Watevill' (holds it) of R[ichard]. Then as now (semper) 22 villeins. Then 6 bordars; now 10. Then 8 serfs; now 7. Then on the demesne 4 ploughs; now 3 . Then 14 ploughs (belonging to the men); now 10 . (There is) wood(land) for 200 swine, and 15 acres of mcadow. It was then worth 12 pounds; now 16 .

In B[ER]DEFrLDA [Bardfield (Saling !) ${ }^{6}$ ] Wielard holds (of Richard) I hide which

7 i.e. its value is included in that of the whole manor.

B This is Morant's identification. But it is probably unsafe to distinguish it from Great Bardfield in Domesday. 81 


\section{A HISTORY OF ESSEX}

was held by 2 servants (servientes) of $W$ isgar ; and they used not then to render due or geld (consuctudinem vel gelt ${ }^{1}$ ) to the king, nor could they withdraw themselves (abire) without their lord's bidding (jussu), as the Hundret (court) testifies. Then as now (semper) I plough (was there) on the demesne. It is worth 20 shillings.

\section{HUNDRET OF ROCHEFORT [ROCHFORD]}

BERREWERA [Barrow (Hall) ${ }^{2}$ ] was held by Phin the Dane (dacus) $^{8}$ (as) $1 \frac{1}{2}$ hides. Now $\mathrm{R}$ [ichard] holds it in demesne. Then as now (semper) 3 bordars, and 3 serfs, and 2 ploughs. There is wood(land) for 30 swine. It was then worth 40 shillings; now 4 pounds. ${ }^{4}$

fo. 42

\section{XXIIII. THE LAND OF SUEN OF ESSEX $^{5}$}

\section{HUNDRET OF B[ER]DESTAPLA [BARSTAPLE]}

Torninduna [(West) Thorndon $\left.{ }^{6}\right]$ was held, in King Edward's time, by Alwin, a thegn of King Edward; and King William gave it to Robert. ${ }^{7}$ Now Suen holds it, and Siric ${ }^{8}$ of him, as I manor and as 5 hides and 15 acres. Then as now (semper) 2 ploughs on the demesne, and 3 ploughs belonging to the men, and 3 villeins. Then 7 bordars; now 10. Then 4 serfs; now I. (There are) 2 hides of wood(land) $;^{9}$ and (there are) 2 sokemen with (de) 50 acres, who had and have (babentes semper) half a plough. In this manor Suen received I rouncey (runcinum), 8 beasts (animalia), 20 swine, (and) 60 sheep; (there are) now 4 beasts, 12 swine, and 50 sheep. It is worth 100 shillings.

Langenduna [Langdon ${ }^{10}$ ], which was held by Alric, a thegn of King Edward, as a manor and as 5 hides, is held of Suen by Walter. Then as now (semper) 2 ploughs on the demesne, and 3 ploughs belonging to the men, and 5 villeins. Then 4 serfs; now

1 This is an exceptional phrase which should be noted.

2 A manor in Wakering.

3 See Introduction, p. 348.

4 It has doubled in value without, it would seem, changing in any way.

5 'Exssessa.' See, for Suain (Suenus), p. 345 above.

6 Now corruptly West 'Horndon' (sce Introduction, p. 399).

7 Robert Fitz Wimarc, Swcgen's father.

8 See p. 49I, note 4.

- This is an abnormal formula (see Introduction, p. 376).

10 See Introduction, p. 398.
4. And (there is) I hide of wood(land). ${ }^{11}$ There is pasture for 100 sheep. Then 5 beasts (animalia) and 10 swine, (and) 60 sheep; now 10 swine (and) 42 sheep. It was then worth 100 shillings; now 6 pounds.

Tiliberia [(West) Tilbury], which was held, in King Edward's time, by Alvric the priest, a free man, as 1 manor and as 2 hides, is held of Suen by 2 Frenchmen, namely Osbern and Ralf. Then as now (semper) 2 ploughs on the demesne, and 4 ploughs belonging to the men, and I villein, and I I bordars, and 2 serfs; and (there are) 4 hides of wood(land). ${ }^{11}$ There is pasture for 300 sheep, and I fishery. Then I rouncey (runcinus) and 60 sheep. Now I rouncey, and 12 colts, and 31 beasts (animalia), 9 swine, and 260 sheep. It was then worth 8 pounds; now 100 shillings.

Ciltedic [Childerditch], which was held, in King Edward's time, by Alwen, a free woman, is held of S[uen] by Osbern, and it is not known how it came to Robert Fitz Wicmarc ${ }^{12}$ (sic). Now as then (semper) there is there 1 hide and 40 acres. ${ }^{13}$ Then as now (semper) I plough on the demesne. Then half a plough belonging to the men; now none (nicbil). Then I villein; now none. Then I bordar; now 4. Then 2 serfs; now 1. There is wood(land) for 100 swine, (and) pasture for 100 sheep. Then I beast (animal); now ro beasts. It is worth 40 shillings.

HORNINDUNA [Horndon (on the hill ${ }^{14}$ )] was held, in King Edward's time, by Alvric the priest, a free man, as I manor and as 2 hides and 30 acres. Then as now (semper) I plough on the demesne, and half a plough belonging to the men, and I I bordars, and 3 serfs. Of fo. $42 \mathrm{~b}$

this land Alvric the priest gave to a certain church half a hide and 30 acres; but Suen took it from the church. Then as now (semper) I rouncey (runcinus) and 2 beasts (animalia). It is worth 30 shillings. This manor is held of Suen by Payn.

HASINGEBROC [Hassingbroke ${ }^{15}$ ], which Leffstan, a free man, held, in King Edward's

11 See note 9 above.

12 Suain's father.

13 i.e. its assessment. The formula is an abnormal one for Essex (see p. 471, notc 3).

I4 i.e. the manor of Wythefeld there (see Introduction, p. 398 ).

"15 In Stanford-le-Hope. 


\section{THE HOLDERS OF LANDS}

time, as I hide and 30 acres, is held of S[uen] by Turold. Then as now (semper) I plough on the demesne. Then 2 bordars; now 3 . Then 2 serfs; now none. (There are) 6 acres of meadow. Then ro sheep; now 13 , and 5 swine. It is worth 20 shillings.

Belesduna [Basildon ${ }^{1}$ ], which the same Leffstan held, in King Edward's time, as I hide and as a manor and 15 acres, ${ }^{2}$ is held of Suen by the same Turold. Then as now (semper) 1 plough. Then 3 bordars; now 1. Then as now (semper) 2 serfs. ('There is) pasture for 100 sheep. Then 2 rounceys (runcimi) and 7 swine, and 15 sheep; now I rouncey, and I cow, and I pig, and 95 sheep. It was then worth 20 shillings; now 25.

Berlesduna [Basildon "], which was held, in King Edward's time, by Godet, a certain free man," as a manor and as 3 hides, is held (of Suen) by W. Then 3 ploughs on the demesne; now $2 \frac{1}{2}$. Then I plough belonging to the men; now $1 \frac{1}{2}$. Then 2 villeins; now 1. Then 4 bordars; now 3. Then 4 serfs; now none. (There is) wood(land) for 40 swine, (and) pasture for 100 sheep. Then I rouncey (runcinus), and 17 sheep; now 5 beasts (animalia), and 16 swine, and 39 sheep. It is worth 60 shillings.

WICFORT [Wickford], which was held freely (liberc) by Leftan as a manor and as half a hide and 35 acres, is held (of Suen) by Turchil. Then as now (semper) I plough, and I bordar. Then I serf; now none. (There are) 30 acres of wood(land), ${ }^{6}$ (and) 3 acres of meadow. Then 2 rounceys (runcini), and 16 beasts (animalia), and 3 swine, and roo sheep; now 3 rounceys, and 8 beasts, and $I I$ swine, and 60 sheep. In addition to this land Bricteva, a free woman, held half a hide and 15 acres, which Suen added to the said land, (and) in which was then I plough ; now none; then as now (semper) 2 bordars (were there), and I villein; there are 20 acres of woodland." He also added 3 free

1 Morant distinguished this, as the manor of 'Belesdun or Botelers' in Basildon, from the 'Berlesduna' two entries lower down, which he styled the manor of Battleswick 'anciently called Bartlesdon' there. But one cannot doubt that, as with the entries of 'Rageneia ' and 'Ragheleia,' 'Belesduna' and 'Berlesduna' are but forms of the same name, which has now become Basildon.

2 i.e. as 1 hide and 15 acres.

3 See note 1 above.

- 'Godet' was probably a woman's name.

6 Here the measurement of the woodland by area begins again. men with $(d e) 45$ acres, in which was then I plough; now a half. He also added I free man with (de) 9 acres. The whole was then worth, in King Edward's time, 60 shillings; now 50.

WICFORT [Wickford], which was held by Goduin, a thegn of King Edward, as I fo. 43

manor and as 10 hides, is held by Suen in demesne. Then as now (semper) 2 ploughs on the demesne. Then 6 ploughs belonging to the men; now 4. Then as now (semper) 7 villeins. Then 2 bordars; now 12 . Then 6 serfs; now none. Then 12 hides of wood(land) ; ${ }^{6}$ now 6 acres. Then I rouncey (runcinus), and 12 sheep, and 17 goats, and 2 hives of bees; now I cow, and 20 sheep, and 2 colts (pulli), and 3 hives of bees. It was then worth 16 pounds; now $9 .^{7}$

WICFORT [Wickford], which was held, in King Edward's time, by Dot, a free man, as a manor and half a hide and 45 acres, is held (of Suen) by William Fitz Odo. Then as now (semper) I plough on the demesne, and I bordar. ('There is) wood(land) for 10 swine. It is worth ro shillings.

WICFORT [Wickford], which was held, in King Edward's time, by Godric as 30 acres, is held (of Suen) by Mainard. It is worth 5 shillings. 8

Brnflet [(South) Benfleet $\left.{ }^{9}\right]$, which was held, in King Edward's time, by Alwine, a free man, as a manor and as 2 hides, is held by Suen in demesne. Then 3 ploughs on the demesne; now I ; and I plough could be added to the stock (posset restaurari). ${ }^{10}$ (There are) now 5 bordars and 2 serfs. (There is) pasture for 250 sheep. It is worth 40 shillings.

- The amount is suspiciously large, especially when contrasted with the ' 6 acres,' and with the " 10 hides" at which the whole manor is assessed. If the figures are correct, they appear to record the greatest destruction of woodland in the county.

7 Here is a heavy fall in value, unaccountable unless the destruction of timber is responsible.

8 The four Wickford entries well illustrate the practice of Domesday in speaking of a place as if the whole was meant, though only a portion of it is referred to.

- This is said to be represented by the manors of Southall and Jervois there. Such is Morant's identification, but the history of the Benfleet manors has not yet been established.

10 It should be observed that only one plough could, it was reckoned, be added, though three in all had been employed there before. 


\section{A HISTORY OF ESSEX}

Watelea [Wheatley ${ }^{1}$ ], which was held, in King Edward's time, by Edric as a manor and as half a hide, is held of Suen by Walter. Then as now (semper) I plough. There is I bordar, and 15 acres of pasture. It is worth Io shillings.

Watelea [Wheatley ${ }^{1}$ ], which was held, in King Edward's time, by Levecilt, a king's thegn, as I manor and as 5 hides, is held by Suen in demesne. Then 2 ploughs (on the demesne), and I plough belonging to the men; and now the same (similiter). Then I villein; now none. Then 10 bordars; now I I. (There is) half a hide of wood(land) that has been laid waste (vastate), ${ }^{2}$ (and) pasture for 100 sheep. Then I fishery; now 2. Then 3 rounceys (runcini), and 5 beasts (animalia), and 20 swine, and 100 sheep. Now I rouncey, and I colt, and 7 beasts, and 70 sheep. It was then worth 60 shillings; now 4 pounds.

Thunreslea ['Thundersley], which was held, in King Edward's time, by Godric, a king's thegn, as I manor and as 5 hides and 15 acres, is held by S[uen] in demesne. Then as now (semper) 2 ploughs on the demesne, and 2 ploughs belonging to the men, and 5 villeins, and 5 bordars. Then 4 serfs; now 2. (There is) pasture for 200 sheep, (and) wood(land) for 50 swine. Then 2 rounceys (runcini), and 7 beasts (animalia), and 16 swine and 200 sheep, and 2 hives of bees. Now 3 rounceys, and I rouncey (sic), I 4 beasts, 36 swine, 200 sheep, (and) 2 hives of bees. It was then worth 102 shillings; now 100 shillings. ${ }^{3}$

fo. $43 \mathrm{~b}$

\section{HUNDRET OF ROCHEFORT [ROCHFORD]}

Rageneia [Rayleigh] is held by Suen in demesne as I manor and as 5 hides. Then 2 ploughs on the demesne; now 3 . Then as now (semper) Io ploughs belonging to the men. Then 21 villeins; now 6 . Then 6 bordars; now I5. Then as now (semper) 2 serfs. (There are) Io acres of meadow, (with) wood(land) for 40 swine. Now there is I park, and 6 arpents of vineyard, and (it) renders 20 muids (modios) of wine if it does well (si bene procedit). ${ }^{4}$ Then 4 rounceys (runcini) and 13 beasts (animalia), 25 swine, and 105 sheep; now 5 rounceys, and 2

1 A manor in Rayleigh (see p. 445, note 6).

2 Compare Introduction, p. 376.

3 This should be observed as an exceptional instance of exact valuation.

4 See Introduction, p. $3^{8} 3$. colts (pulli), and 20 beasts (animalia), and I I swine, and 80 sheep, and I I goats. It was then worth Io pounds; now the same amount, without counting (tantundem prater) the wine. And in this manor Suen has made his castle (fecit suum castellum)..$^{5}$ Of this manor 4 Frenchmen hold 2 hides, ${ }^{B}$ (where are) 4 ploughs and 4 bordars; and (this) is worth 60 shillings in the above total (eodem pretio).

Ragheleia [Rayleigh], which was held, in King Edward's time, by I free man as a manor and as $2 \frac{1}{2}$ hides, is held by Suen in demesne. ${ }^{7}$ Then as now (semper) 2 ploughs on the demesne. Then 3 villeins; now 2. Then 5 bordars, now 6 , who had (babentes ${ }^{8}$ ) then $2 \frac{1}{2}$ ploughs; now only half a plough. Then I rouncey (runcinus), and 2 beasts (animalia), and I 5 sheep; now 2 rounceys, 9 beasts, 9 swine, (and) 20 sheep. Then and afterwards it was worth 30 shillings; now 40.

Hocheleia [Hockley] is held of Suen by 2. Frenchmen : Godebold (holds) I hide, and Odo 30 acres. And this manor was held by I free man in King Edward's time. Then as now (semper) $2 \frac{1}{2}$ ploughs on the demesne. Then 3 bordars; now 5. Then 5 serfs; now 3. (There is) pasture for 100 sheep. Then as now (semper) I mill. Then 5 beasts (animalia), and 10 swine, and roo sheep, and 7 goats. Now I rouncey (runcinus), and I 3 beasts, and 22 swine, and roo sheep, and 4 hives of bees. It was then worth 30 shillings; afterwards and now 40.

Estwda [Eastwood] is held by Suen in demesne, and was (quod) held by his father, ${ }^{9}$ in King Edward's time, as 1 manor and as $3 \frac{1}{2}$ hides. Then as now (semper) 3 villeins, and 2 ploughs on the demesne. Then 8 ploughs belonging to the men; now 5 . Then 21 bordars; now 30. Then as now (semper) 2 serfs. (There are) 4 acres of meadow. (There was) then wood(land) for 50 swine; now for 30 . (There is) now I

6 See p. 300 above.

6 It was customary, in the case of a manor on which the tenant-in-chief resided, to find his under-tenants by knight-service holding small estates there.

7 It is probable that this manor is entered separately because it had been held by a different holder in King Edward's time. Compare p. 483 , note 8 , above.

8 This must include the villeins as well as the bordars.

${ }^{9}$ Robert Fitz Wimarc. 


\section{THE HOLDERS OF LANDS}

mill. Pasture for 300 sheep. ${ }^{1}$ Then 2 rounceys (runcini), and 6 beasts (animalia), 30 swine, (and) 300 sheep. Now 2 rounceys, and 2 colts (pulli), and 33 beasts, 40 swine, and 136 sheep. It was then worth 6 pounds; now 10 pounds." Of this manor Geoffrey ro. 44

holds half a hide; and there is there I bordar, and I plough; and it is worth 20 shillings in the above valuation (in eodem pretio).

Wachelinga [(Great) Wakering] is held by Suen in demesne as $5 \frac{1}{2}$ hides. Then as now (semper) 2 villeins, and 18 bordars, and 2 ploughs on the demesne; and a third could be employed (fieri). Then 3 ploughs belonging to the men; now 5. (There is) wcod(land) for 40 swine, (and) pasture for 300 sheep. Then 4 rounceys (runcini), 9 beasts (animalia), $3^{8}$ swine, (and) I 5 sheep. Now 4 rounceys, 2 beasts, 1 IO sheep, (and) 27 swine. It was then worth 9 pounds; now 10. Of this manor Garner and W[

hold I hide, and have 2 ploughs; and it is worth 30 shillings in the above valuation (in codem pretio).

Pritte wella [Prittlewell ${ }^{3}$ ] is held by Suen in demesne as $7 \frac{1}{2}$ hides. Then 7 villeins; now 4. Then 14 bordars; now 23. Then 2 ploughs on the demesne; now 3. Then 7 ploughs belonging to the men; now 9. There is pasture for 12 swine, (and) pasture for 200 sheep. Then 2 rounceys (runcini), 8 beasts (animalia), 30 swine, and 100 sheep. Now I rouncey, 3 colts ( $p$ ulli), 13 beasts, 65 swine, 196 sheep, $^{6} 66$ goats, (and) 9 hives of bees.

Of this land I free man holds I virgate, which he had power to sell, but the soke ${ }^{6}$ belonged to (jacuit in) this manor. And to the church of this manor 30 acres of another estate (terra) were added by 2 men. (The manor) was then as now (semper) worth 12 pounds. Of this manor Grapinel ${ }^{7}$ holds

1 Compare Introduction, p. 371.

2 Here again is a great increase in value, where the details do not suggest it, and might rather lead us to expect a fall.

3 i.e. the manor of Prior's Hall there.

- 'Pastura, evidently a scribal error for 'silva' (i.e. wood[land]).

b 'cc oves, iiij minus.' If, as is probable, the 'long hundred ' was meant, this would denote 236.

8 The profits of jurisdiction. Compare Introduction, p. $35^{8}$.

7 Evidently the ancestor of Warin Grapinel who held a third of a knight's fee in Prittlewell, of the Honour of Rayleigh, temp. Henry III. (Red Book of the Exchequer, p. 739). half a hide; and 2 bordars (are there), and I plough; and it is worth 10 shillings in the above valuation (in eodem pretio).

Essoberia [Shoebury ${ }^{8}$ ] was held by Robert Fitz Wimarc (W imarce) after King Edward's death. ${ }^{9}$ Now Suen (holds it) in demesne as I manor and as 5 hides. Then as now (semper) 9 villeins. Then 4 bordars; now 6 . Then as now (semper) 2 ploughs on the demesne, and 8 ploughs belonging to the men. There are 3 acres of meadow, (with) wood(land) for 20 swine. Then 2 rounceys (runcini), 4 bcasts (a nimalia), 12 swine, (and) 100 sheep. Now 2 rounceys, 16 swine, (and) 64 sheep. Then and afterwards it was worth 6 pounds ; now $10 .{ }^{10}$

Carenduna [Canewdon] is held by Suen in demesne as $6 \frac{1}{2}$ hides and 30 acres. Then 22 villeins; now 16 . Then 2 bordars; now 8. Then 3 serfs; now I. Then 2 ploughs on the demesne; now 3 , and a fourth could be employed (feri). Then io ploughs belonging to the men; now 6 . (There is) pasture for 600 sheep. ${ }^{11}$ Then 3 rounceys (runcini), Io beasts (animalia), 24 swine, and 336 sheep. Now 3 rounceys, and 5 beasts, 20 swine, (and) 342 sheep.

fo. $44 b$

It was then worth 12 pounds; now I 3 . In this manor Hugh de Moutfort (monteforti) has I hide; and it is worth 20 shillings. Of this manor 2 Frenchmen hold (as follows):-Girold I hide, and John 30 acres; and 3 bordars are there and $I$ plough; and it is worth 40 shillings in the above valuation (in codem pretio). S[uen] has also (here) I hide, with (et) 4 bordars and I plough, which was held, in King Edward's time, by I free man, who had its soke (cum soca); it is worth 20 shillings.

TORPEIa [(Nor)thorp $\left.{ }^{12}\right]$, which was held by Godric, a thegn of King Edward, is held of

8 It is hardly possible to distinguish with certainty between North and South Shoebury in Domesday, for they were both held by Suain of Essex, but as South Shoebury was subsequently given by his heir to Prittlewell Priory, it was probably the manor which Suain retained in demesne, as entered in the text above.

- It is possible that this is a euphemism for Harold's reign, which the Normans treated as an interregnum.

10 Here again is a great rise, for which it seems impossible to account.

il See Introduction, p. 371.

12 In Southchurch. 


\section{A HISTORY OF ESSEX}

S[uen] by Odo; and Robert Fitz Wimarc (Wimarce) had (it), after King Edward's death, ${ }^{1}$ as I manor and as I hide and 30 acres. Then I villein; now 2 . Then 4 bordars; now 6 . Then 4 serfs; now 1 . Then as now (semper) 2 ploughs on the demesne, and I plough belonging to the men. There is pasture for 100 sheep. Then I rouncey (runcinus), and 7 beasts (animalia), I9 swine, (and) 68 sheep; now 6 beasts, 34 swine, 160 sheep, and 2 hives of bees. It was then worth 40 shillings; afterwards and now 60.

ROCHEFORT [Rochford], which was held, in King Edward's time, by I free man as a manor and as $2 \frac{1}{2}$ hides, is held of Suen by Alvred. Then as now (semper) 5 villeins. Then 4 bordars; now I 2 . Then 2 serfs; now 3. Then 2 ploughs on the demesne; now 3. Then 3 ploughs belonging to the men; now 4. And I free man holds 30 acres. And there belong (jacent) further to this manor 2 acres of meadow, wood(land) for 20 swine, (and) I mill. Then I rouncey (runcinus), and 8 swine, and I I sheep; now 3 rounceys, and 2 colts (pulli), and io beasts (animalia), and 21 swine, and 160 sheep and 23 sheep. ${ }^{3}$ It was then worth Ioo shillings; now 7 pounds.

Stanbruge [(Great) Stambridge ${ }^{3}$ ], which was held, in King Edward's time, by I free man as $I$ manor and as $I \frac{1}{2}$ hides and $7 \frac{1}{2}$ acres, is held of S[uen] by Wiard. Then as now (semper) 2 bordars, and I serf. And half a plough (was there) then; now I. (There is) pasture for 100 sheep. It was then worth Io shillings; now 25.

Essoberia [Shoebury ${ }^{4}$ ], which was held, in King Edward's time, by I free man as I manor and as 4 hides, is held of S[uen] by Walter. Then as now (semper) 4 villeins. Then 6 bordars; now 8 . Then 2 serfs; now none. Then 2 ploughs on the demesne; now 3. Then as now (semper) 2 ploughs belonging to the men. (There is) wood(land) for 12 swine. The fourth hide

1 See p. 485 , note 9 , above.

2 This entry is very suggestive of the sheep being reckoned by the 'long score' of 24 . In that case ' 160 ' means 8 score, i.e. 192. But it is quite possible that the scribe here made one of his slips, and that his 23 'sheep' are goats, for at Prittlewell above we find that goats had been added since the Conquest.

3 i.e. the manor of Barton Hall there.

4 See p. 485 , note 8 , above. of the four $\left(e x b^{\prime}\right)$ is held by I free man. ${ }^{6}$ (There is) pasture for 100 sheep. Then I fo. 45

rouncey (runcinus), and 2 beasts (animalia), and 40 sheep; now I rouncey, and 6 beasts, I pig, (and) I I 5 sheep. Then and afterwards it was worth 6 pounds; now 8 .

WACHERINGA [(Little) Wakering], which was held, in King Edward's time, by I free man as a manor and as 2 hides, is held by S[uen]. And this was held by Robert Fitz Wimarc (Wimarce) after King Edward's death. ${ }^{6}$ Then I bordar, and ${ }^{1} 5$ serfs $^{7}$; now 10 bordars. Then as now (semper) 2 ploughs on the demesne, and I plough belonging to the men. (There is) pasture for 300 sheep. Then 2 beasts (animalia), and 100 sheep. Now I rouncey (runcinus), and 2 beasts, II 5 sheep, and $I$ hive of bees. It was then worth 3 pounds; afterwards and now 4. Of this same manor Robert holds I hide and Godric a half, and (this is) worth 40 shillings in the above valuation (in eodem pretio).

Sutruna [Sutton], which was held, in King Edward's time, by 2 free men as a manor and as $2 \frac{1}{2}$ hides and 30 acres, is held of S[uen] by Ascelin. (There are) now 8 bordars. Then 4 serfs; now none. Then as now (semper) 2 ploughs on the demesne, and half a plough belonging to the men. (There is) pasture for 300 sheep. Then 2 rounceys (runcini) and 40 swine, (and) 200 sheep; now 7 beasts (animalia), (and) 160 sheep. Then and afterwards it was worth 60 shillings; now 4 pounds.

Plumb[er]ga [Plumberow ${ }^{8}$, which was held by Robert Fitz Wimarc (Wimarcee) as a manor and as I hide, is held of S[uen] by the same $A$ [scelin]. Then I bordar and I serf; now 8 bordars. Then $1 \frac{1}{2}$ ploughs on the demesne; now I, (and) half a plough belonging to the men. (There is) wood(land) for 30 swine, (and) pasture for 100 sheep. (There is) now I mill. Then I rouncey (runcinus), 7 beasts (animalia), 30 swine, Ioo sheep, (and) 40 goats; now 2 rounceys and I colt ( $p$ ullus), 3 beasts, 20 swine, 100 sheep, (and) 23 goats. It was then worth 20 shillings; now 40.

5 This entry is obviously misplaced.

6 See note I above.

7 This number is so exceptionally large as to excite suspicion.

8 A manor in Hockley. 


\section{THE HOLDERS OF LANDS}

Putesera [Putsey] $]^{1}$, which was held, in King Edward's time, by I free man, as a manor and (as) $52 \frac{1}{2}$ acres, is held of S[uen] by the same Ascelin. Then as now (semper) 2 bordars and 1 plough. (There is) pasture for 30 sheep, (and) now I mill. Then I rouncey (runcinus), and I colt (pullus), and I beast (animal), and 3 swine, and 80 sheep ; now the same (similiter). Then and afterwards it was worth 20 shillings; now 30.

Hacheleia [Hockley] is held of S[uen] by Payn as I manor and as I hide. Then as now (semper) I 2 bordars, and I plough on the demesne. Then 2 ploughs belonging to the men; now 1. (There is) wood(land) for 30 swine, pasture for 200 sheep, (and) now I mill. Then 2 rounceys (runcini), and 2 beasts (animalia), and 12 swine, and 160 sheep, and 30 goats; now 4 rounceys, I0 beasts, 24 swine, 300 sheep, 53 goats, (and) 80. $45 \mathrm{~b}$

6 hives of bees. It was then worth 3 pounds ; now 4.

Puteseia [Putsey ${ }^{1}$ ], which was held, in King Edward's time, by I free man as a manor and as $1 \frac{1}{2}$ hides and 30 acres, is held of $\mathrm{S}$ [uen] by John. Then as now (semper) 8 bordars. (There is) pasture for 50 sheep. Then I rouncey (runcinus), and 8 swine and 25 sheep; now I I swine and 86 sheep. It is worth 40 shillings.

SutTuna [Sutton], which was held by Robert Fitz Wim[arc] after King Edward's death, as 1 manor and as I hide and 15 acres, is held of S[uen] by Alvid, an Englishwoman (quedam Anglica). Then as now (semper) 3 bordars. Then 2 serfs; now none. Then as now (semper) 1 plough on the demesne. Then 2 rounceys (runcini), and 10 beasts (animalia), and II swine, and 100 sheep; now 10 beasts, 10 swine, and 63 sheep. It is worth 30 shillings.

Puteseia (Putsey ${ }^{1}$, which was held by a sokeman of Robert (Fitz Wimarc) as a manor and as half a hide and 15 acres, is held of $\mathrm{S}$ [uen] by Almar. Then as now (semper) 3 bordars, and I plough on the demesue. There is pasture for 50 sheep. Then I rouncey (runcinus), and 8 swine, and 25 sheep; now I I swine and 86 sheep. It is worth 30 shillings.

1 In Canewdon (compare p. $4^{8} 3$, note 8 , above).

See p. 485 , note 9 , above.
Putesera [Putsey ${ }^{1}$ ], which was held, in King Edward's time, by I free man, while (et) Robert (Fitz Wimarc) had the soke, ${ }^{3}$ is held of S[uen] by Hugh as a manor and (as) 38 acres. Then I villein; now 2 . Then as now (semper) half a plough. (There is) pasture for 30 sheep. Then I rouncey (runcinus), and 2 beasts (animalia), and 10 swine, (and) 75 sheep; now I rouncey, and I cow, and I 14 sheep. It is worth 10 shillings.

In Nesenduna [Ashingdon "] half a hide, which was held by Robert (Fitz Wirnarc), is held of S[uen] by Roger. Then as now (semper) I boldar. (There is) pasture for 40 sheep. Then I plough; now a half; and a whole one could be employed (tota potest fieri). It is worth 10 shillings.

In Suttuna [Sutton] half a hide, which was held, in King Edward's time, by Robert (Fitz Wimarc), is held (of Suen) by Roger. Then as now (semper) I plough. (There is) pasture for 40 sheep. It is worth 20 shillings.

In Hachewella [Hawkswell] Godfrey bolds (of Suen) 15 acres. And (there is there) half a plough and I bordar. It is worth ro shillings.

In Nestuda [Eastwood ?] Robert holds of S[uen] 30 acres. And (there are) 5 bordars. Then half a plough; now I (plough). It was then worth IO shillings; now 20 shillings. And in this said Hundret Suen receives (babet) 100 shillings from the pleas. ${ }^{6}$

\section{Hundret of Witbrictesherna [Dengie]}

Altenal [Iltney ${ }^{6}$ ], which was held freely 10. $4^{5}$

(libere) by Leftan as a manor and as half a hide and 40 acres, is held of Suen by Ralf. Then as now (semper) I villein and I bordar. Then 2 serfs; now 1. Then as now (semper) I plough on the demesne, and half a plough belonging to the men. There is pasture for 50 sheep. Then 5 beasts (animalia) and 40 sheep; now 5 beasts, and 60 sheep, and 26

8 i.e. the profits of jurisdiction.

- There can be no doubt that this is Ashingdon just as 'Nestuda' (three entrics below it) is Eastwood. Moreover Ashingdon is known to have been held of the Honour of Rayleigh. The modern 'ing' is a corruption, as in Huntingdon ; the name is Assindon' in Harl. Cart. 48 G. 4 , and 'Assandun' in the A.S. Chronicle.

S See p. 407, note 3, above; and compare p. 454 for Winstree Hundred and p. 489 for Clavering Half Hundred.

6 In Mundon (see pp. 387, 381, 393 2bove). 


\section{A HISTORY OF ESSEX}

swine, and 2 rounceys (runcini). Then and afterwards it was worth 20 shillings; now 26.

HaInctuna [Asheldham ? ${ }^{1}$ ], which in King Edward's time was held freely by Godric as a manor and as half a hide and 37 acres, is held of S[uen] by Garner. Then 3 bordars ; now 2. Then as now (semper) I plough. (There are) 5 acres of meadow. (There was) then no stock (nichil); now 3 beasts (animalia), 4 swine, (and) 11 goats. It is worth 20 shillings. Robert Fitz Wimarc (Wimarce) had this manor after the coming of King William. ${ }^{2}$

\section{Hundret of Witham}

Ruwenhal.A ${ }^{3}$ [Rivenhall], which was held, in King Edward's time, by Leftan, a free man, as 30 acres, is held of S[uen] by Clarenbald. Then as now (semper) I plough on the demesne, and half a plough belonging to the men. Then 5 bordars; now 6 . Then as now (semper) 2 serfs. (There are) 10 acres of meadow. Pasture worth (de) 4 shillings." And there is I sokeman with (de) 5 acres. Then 2 beasts (aninalia), and 2 rounceys (runcini), and 15 sheep; now 2 beasts, 2 rounceys, I oo sheep, 6 swine, 8 goats, (and) 2 hives of bees. It was then worth 40 shillings; now 30 .

Nuthlea [ Notley ${ }^{5}$, which was held, in King Edward's time, by Achi, a free man, as I manor, is held (of Suen) by Godebold as half a hide and 30 acres. Then 2 ploughs on the demesne ; now 1. Then 2 ploughs belonging to the men; now 1 . Then 4 villeins; now 2. Then 4 bordars; now 5. Then 2 serfs; now none. (There was) then wood(land) for 40 swine; now for 30 . (There are) Io acres of meadow. Then I rouncey (runcinus) and 2 cows. Now 2 rounceys, and 8 beasts (animalia), 30 swine, I I sheep, (and) 10 hives of bees. It was then worth 40 shillings; now 60.

\section{Hundret of Herlaua [Harlow]}

HaLingebia $^{6}\left[(\right.$ Little $)$ Hallingbury $\left.^{7}\right]$, which

I See pp. 391, 393, 410 above.

- Compare the Dunmow entry on this page.

3 In the MS. it is 'Ruuuenhala.'

4 This is a somewhat uncommon formula in Essex (see Introduction, p. 378).

5 It has not been established in which of the Notleys this holding lay. The name of its tenant is so uncommon that he was doubtless the Godebold who held of Suain at Horkesley.

6 A scribal error for 'Halingeberia.'

7 Alias Hallingbury-Nevill. The identity is proved by the Red Book of the Exchequer (p. 738). was held by Godric, a free man, as I manor and as $2 \frac{1}{2}$ hides, is held of S[uen] by Walter. Then as now (semper) 2 ploughs on the demesne. Then 3 ploughs belonging to the men; now 4. Then 8 villeins; now 10. Now 17 bordars. Then as now (semper) 4 serfs. (There was) then wood(land) for 150 swine; now for I00. (There are) 30 acres of meadow, (and) now a moiety of a mill. Then 2 rounceys (runcini), and 6 beasts (animalia), and 24 swine, 30 sheep, (and) 30 goats; now 2 colts (pulli), and 7 beasts, and 13 swine, 50 sheep, 32 goats, (and) 7 hives fo. $46 \mathrm{~b}$

of bees. It was then worth 100 shillings; now 6 pounds.

\section{Hundret of Dommawa [Dunmow]}

Willingehala [Willingale ${ }^{8}$ ], which was held, in King Edward's time, by I free man as 20 acres, is held of Suen by Garner. It was then worth 4 shillings; now 8 .

Dommawa [Dunmow ${ }^{9}$ ], which was held, in King Edward's time, by I free man, is held of S[uen] by Edmar as 37 acres, of which (et ille) 7 acres were added after the coming of King William and belonged to (que fuerunt) a certain other free man. Then half a plough; now I (plough). Then 2 bordars; now 3. Then as now (semper) I serf. (There is) wood(land) for 30 swine and 5 acres of meadow. Now 1 mill. Then 4 beasts (animalia), 9 swine, 1 I sheep, and 5 goats; now 5 beasts, 8 swine, 13 sheep, (and) 7 goats. It was then worth 10 shillings; now 20.

\section{Hundret of Wensistreu [Winstree]}

MeresaI [(East) Mersea], which was held, in King Edward's time, by Robert Fitz Wimarc (Wimarce) as a manor and as 6 hides, is held by Suen in demesne. Then as now (semper) 2 ploughs on the demesne. Then 8 ploughs (belonging to the men); now 6. Then 9 villeins; now 8 . Then 12 bordars; now 14 . Then 3 serfs; now none. (There was) then wood(land) for 40 swine. ${ }^{10}$ (There are) 5 acres of meadow, (and) 4 fisheries. Then I rouncey (runcinus), 9 beasts (animalia), 25 swine, (and) 107 sheep;

8 The holding was so small that it is uncertain in which of the Willinghales it lay.

9 The identity of this small estate is uncertain.

10 This is not followed by an entry of the amount of woodland remaining in 1086 . 


\section{THE HOLDERS OF LANDS}

now 3 rounceys, 12 beasts, 10 swine, 100 sheep, (and) I hive of bees. It is worth 10 pounds.

Peltenduna [Peldon], which was held, in King Edward's time, by I free man as a manor and as half a hide, is held of Suen by Odo. Then as now (semper) half a plough. It is worth 10 shillings.

Edburgetuna [Abberton'] is held (of Suen) by the same (Odo) as 15 acres, which were held, in King Edward's time, by $I$ free man. Then I free man; now I bordar.? There are 5 acres of meadow. It is worth 5 shillings.

The Half Hundret of Clavelinga [Clavering] is Suen's, and the pleas of the said Hundret are worth (reddunt) to him 25 shillings a year.

\section{Half Hundret of Clavelinga [Clavering]}

Clavelinga [Clavering ${ }^{*}$ ], which was held, in King Edward's time, by Robert Fitz Wimarc (Wimarce) as 1 manor and as 15 hides. ${ }^{6}$ Then and afterwards 4 ploughs on the demesne; now 5. Then as now (semper) 25 ploughs belonging to the men, and 17 villeins. Then and afterwards 9 bordars; now 37. Then and afterwards 8 serfs; now 12. (There was) then wood(land) for 800

\section{fo. 47}

swine; now for 600 . (There are) 35 acres of meadow. (There was) then 1 mill. And 1 plough (more) could again be employed (potest restaurari) in this manor. ${ }^{6}$ Then 3 rounceys (runcini), and 25 beasts (animalin), 50 swine, 40 sheep, 15 goats, (and) 12 hives of bees; now 2 rounceys, and I colt ( $p u l l u s$ ), 14 beasts, 2 I swine, 90 sheep, 23 goats, (and) 5 hives of bees. It was then worth 20 pounds ; now 30 .

\section{I i.e. the manor of Badcocks there.}

2 This should be observed as an instance of the process of social depression (see Introduction, p. 361).

3 See Introduction, p. 345 , and p. 487 , note 5 .

Including Langley.

- See Introduction, p. 345 and p. 292 above.

- It will be observed that this estimate does not tally with the figures above, which show that the ploughs were not deficient but were actually one more in number than they had been. The word 'restaurari' seems to exclude the hypothesis that the arable area had been increased by the diminution of the woodland. Possibly the scribe reversed the figures of the demesne ploughs by a slip.
Berdane [Berden] was held, in King Edward's time, by Godman, a sokeman of Robert (Fitz Wimarc). It is now held of S[uen] by Alvred as a manor and as 2 hides. Then as now (semper) I plough on the demesne, and 2 ploughs belonging to the men, and 4 villeins, and 5 bordars. Then and afterwards 4 serfs; now none. (There is) wood(land) for 10 swine, and 2 acres of meadow. Then 14 swine, and 25 sheep; now 3 rounceys (runcini), and 2 colts (pulli), and 13 beasts (animalia), and 21 swine, 122 sheep, 8 goats, (and) I hive of bees; it was then worth 30 shillings; now 40.

\section{Hundret OF Wibrictesherna [DEngie]}

Haintuna [Asheldham? "], which was held, in King Edward's time, by 1 free man, is held of S[uen] by Ralf as a manor and as half a hide and 37 acres. Then as now (semper) 1 plough on the demesne. Then 3 bordars; now 2. (There are) 5 acres of meadow. It is worth 20 shillings. Robert Fitz Wimarc (Wimarce) had this land after the coming of King William. ${ }^{8}$

Of the abovesaid manor, namely CLAveLINGa [Clavering], Ansgot holds of Suen half a hide and 30 acres; and Wicard 3 virgates, and Robert half a hide and 15 acres; and Ralf 15 acres. $^{\circ}$ And among them all (inter totum) there are 14 bordars, and $3 \frac{1}{2}$ ploughs. And the whole is worth 4 pounds in the above valuation (in eodem pretio). ${ }^{10}$

\section{Hundret of Lexendena [Lexden]}

Eiland [Horkesley ${ }^{11}$ ] was held by R[obert] as I manor and as $5 \frac{1}{2}$ hides. Now S[uen] holds it in demesne. Then as now (semper) 18 villeins. Then 33 bordars; now 42 . Then as now (semper) 7 serfs and 2 ploughs on the demesne, and 10 ploughs belonging to the men. (There is) wood(land) for 600

7 See P. 488 , note I, above.

8 It will be observed that this entry of a manor in Dengie Hundred is interpolated in the midst of the account of Clavering and its Half Hundred. I suspect it to be a duplicate (see Introduction, p. 4 10).

9 Compare p. 484 , note 6 , above.

10 This entry should obviously have followed immediately on that of Clavering.

11 Then part of the great manor of 'Eiland' (now Nayland), divided by the Stour into two portions, of which one lay in Suffolk and the other, consisting of the two Horkesleys, in Essex. The whole had been held by Robert Fitz Wimarc (see Introduction, p. 408). 


\section{A HISTORY OF ESSEX}

swine, and 24 acres of meadow. ${ }^{1}$ Then as now (semper) I mill. It was then worth Io pounds ; now 12. Of this manor Godebold ${ }^{2}$ holds of Suen $I \frac{1}{2}$ hides and 30 acres; and 2 villeins (are there) and 8 bordars, and 2 ploughs on the demesne, and 2 ploughs belonging to the men; and it is worth 60 shillings in the above valuation (in eodem pretio). Moreover the same (Godebold ?) holds 37 free men, dwelling (in) 3 hides of land, whom Robert had in King Edward's time and Suen afterwards; (there were) then between them 4 (ploughs); now 5 ; fo. $47 \mathrm{~b}$

now I mill; (there is) wood(land) for 60 swine, (and) 14 acres of meadow; it was then worth 4 pounds; now 100 shillings. And a certain free man, (who) was commended ${ }^{3}$ to Robert, held $7 \frac{1}{2}$ acres, and could betake himself (ire) whither he would, ${ }^{4}$ and Suen has that land; it is worth 5 shillings.

\section{Hundret of Celmeresforda [Chelmsford]}

BORHAM [Boreham ${ }^{5}$ ], which was held, in King Edward's time, by Turchil as I manor and as I hide, is held of [Suen] by Osbern. Then as now (semper) I bordar. Now I serf. Then I plough; now none. There are 8 acres of meadow. It is worth 20 shillings.

\section{Hundret of ANgra [Ongar]}

Staplefort [Stapleford (Tany)], which was held by Godric as 1 manor and as 5 hides-of which 5 hides he gave to his Io free men freely 4 hides, retaining I hide in demesne ${ }^{6}$ - is held of Suen by Siric. $^{7}$ And after King (William) came, Robert had (the) I hide by the king's gift and his son Suen added the 4 hides thereto (cum ista) after his father's death. In (the) I hide (there) was then no bordar, and in the 4 hides (there were) then 6 bordars; now 2 villeins and 18 bordars (in the 5 hides). (There is) wood(land) for 300 swine, (and)

1 Only 10 acres of meadow are assigned to the Suffolk portion of 'Eilanda,' which has now a good expanse. Probably the area under water was then considerably larger.

2 The father of ' Robert son of Godebold' who founded Little Horkesley Priory.

3 See Introduction, P 358.

4 i.e. choose his lord.

5 The identity of the manor has not been ascertained.

6 'et de his $\mathrm{v}$ hidis dedit suis $\mathrm{x}$ liberis hominibus libere iiii hidas, et i retinuit in dominio.' This is an interesting passage.

7 See p. 491 , note 4 , below.
20 acres of meadow. Then as now (semper) I mill. It was then worth 8 pounds; now Io pounds. Then, in the demesne, I cow, and 13 sheep; now 8 beasts (animalia), and I 7 swine, 1 I 8 sheep, and 2 hives of bees.

Teidana [Theydon (Mount)], which was held by Godric as I manor and (as) 3 hides and 80 acres, is held of S[uen] by Robert. And S[uen] holds this manor of the gift of King William, who gave it to his father Robert. Then 5 villeins; now I. Then 3 bordars; now I7. Then 4 serfs; now none. Then 2 ploughs on the demesne; now 3. Then the men had (inter homines) 4 ploughs; now 3 . (There is) wood(land) for 500 swine, (and) 28 acres of meadow. Then I rouncey (runcinus), and 12 beasts (animalia), 60 swine, (and) Ioo sheep; now 3 rounceys, 3 colts (pulli), I 3 beasts, 39 swine, (and) I 48 sheep. It was then worth 6 pounds; and the same when received; it is now worth 9 (pounds).

\section{Hundret of Ceffeurda [Chafford]}

WARLEIa [Warley (Franks) ${ }^{8}$ ] was held by Godric freely (libere), in King Edward's time, as I manor and as 2 hides. Now S[uen] holds it similarly in his demesne. Then 2 villeins; now 3 . Then 2 bordars; now 8 . Then 3 serfs; now I. Then as now (semper) 2 ploughs on the demesne. Then the men had (inter bomines) I plough; now $2 \frac{1}{2}$. (There is) wood(land) for 150 swine, (and) 3 acres of meadow. Then 2 rounceys (runcini), and 7 beasts (animalia), and 17 swine. ${ }^{9}$ fo. 48

It was then worth 4 pounds; and the same when received; now 6 pounds.

Helituna ${ }^{10}$ [Kenningtons], which was held by Ustan ${ }^{11}$ freely (libere) as a manor and as I hide in King Edward's time, is held of (Suen) by Lewin. Then 3 bordars; now 4. And (there is) I plough. (There are) I cow and 2 beasts (animalia), I 6 swine, (and) 30 sheep. It is worth 20 shillings.

8 In Great Warley.

9 The amount of the live stock in 1086 is not given, possibly because the scribe at this point had to begin a fresh leaf and overlooked it.

10 rectius 'Kelituna,' a manor in Aveley, of which the name is preserved in 'Kenningtons.' There are other instances in Essex of this addition of an ' $s$ ' (see p. 456, note 11 ). Afterwards known as the manor of Bretts from the Bret family, which held it as of the Honour of Henry of Essex.

11 This name was probably intended for 'Ulstan.' 


\section{THE HOLDERS OF LANDS}

\section{Half Hundret of Melduna [Maldon]}

In Melduna [Maldon '] Robert (Fitz Wimarc held half a hide. Now S[uen] holds (it) and Guner' of him. And in this land the king receives (babet) 4 shillings of customary duc, and (it) does its share (facit adjutorium) with the other burgesses in finding a horse for the host (invenire caballum in exercitu) and towards (ad) making a ship. ${ }^{3}$ But Suen receives (babet) the other dues. Then as now (semper) I bordar and I plough. And it is worth 20 shillings.

\section{Hundret of Tendringe}

Almesteda [Elmstead] was held by Robert Fitz Wimarc. Now Suen (holds it), and Siric' of him, as 1 manor and as 8 hides. Then 14 villeins; now 13. Then 31 bordars; now 36. Then 6 serfs; now 1. Then 3 ploughs on the demesne; now 4. Then 19 ploughs belonging to the men; now 18 . (There is) wood(land) for 500 swine, 22 acres of meadow, and pasture for 60 sheep. Then as now (semper) I mill, and I saltpan. Then 3 rounceys (runcini), and I 8 beasts (animalia), and 30 swine, 150 sheep, 40 goats, and 5 hives of bees; now 5 rounceys, 10 beasts, 32 swine, 190 sheep, 80 goats, (and) 2 hives of bees. It was then worth 9 pounds; now 10.

Fuletuna [Foulton ${ }^{8}$ ], which was held by Bricsi as I hide less Io acres and as I manor, is held of S[uen] by Odard. This (Bricsi) held this land freely (libere); and when the king came into this land ${ }^{8}$ he became an outlaw, and R[obert Fitz Wimarc] received his land. S[uen] had (it) afterwards. Now as then (semper) there is there I bordar, and I serf, and 1 plough. And (there are) 2 acres of meadow, (with) pasture for Ioo sheep. He received nothing then $;^{7}$ now (there are) 6 beasts (animalia), and 10 swine, and 20 sheep, and 2 hives of bees. It was then worth 10 shillings; now 20.

1 This secms to represent the manor of Southouse and Sayers there.

"This was probably the 'Gunner' who held of him at Little Totham (below).

3 This passage is discussed in the Introduction, (p. 386). Its construction may be open to question.

$1 \mathrm{He}$ also held of Suain manors at Stapleford (Tany) and West Thorndon, which all descended togerher.

8 In Ramsey.

- The euphemism for the Norman Conquest.

7 i.e. there was no live stock on the demesne when it came into Robert's hands.

\section{Hundret of Turestapla [Thurstable]}

Toleshunta [Tolleshunt ${ }^{8}$ ], which was held by Brun as a manor and as $\mathrm{I} \frac{1}{2}$ hides and 40 acres, is held of S[uen] by Odo. Robert 10. 4 bb

had (it) after the king came into this land, ${ }^{6}$ and now S[uen] has (it). There are now there 4 bordars. Then (there were) 2 serfs; now 1. There is wood(land) for 12 swine, (and) pasture for 20 sheep. Then 2 beasts (animalia), and I rouncey (runcinus), and 20 sheep; now 12 beasts, 2 rounceys, 12 swine, (and) 80 sheep. It was then worth 20 shillings; now 25.

Tотнам [(Little) Totham] was held, in King Edward's time, by Gunner ${ }^{2}$; and he still holds (it) under Suen as 30 acres. Then as now 3 bordars. Then half a plough; now the same (similiter). (There is) wood(land) for 20 swine, (and) pasture for 60 sheep. It is worth 10 shillings.

1o. 49

\section{THE LAND OF EUDO DAPIFER ${ }^{10}$}

\section{HUNDRET OF WITHAM}

Brachesteda [(Great) Braxted], which was held by a king's thegn as I manor and as 2 hides less 15 acres, is held of E[udo] by Richard." Then as now (semper) 2 ploughs on the demesne, and 3 ploughs belonging to the men. Then 5 villeins; now 6 . Then 4 bordars; now 6 . Then 2 serfs; now none. (There is) wood(land) for 300 swine, (and) 30 acres of meadow. Now half a mill. (There is) I sokeman of 4 acres. Then 2 rounceys (runcini) and 14 beasts (animalia), 40 swine, (and) 80 sheep; now I rouncey, 6 beasts, 46 swine, 1 10 sheep, (and) 4 hives of bees. It is worth 8 pounds.

\section{Half Hundret of Herlaua [Harlow]}

Herlaua [Harlow ${ }^{12}$ ], which was held, in

8 This estate has not been satisfactorily identiGed.

0 See p. 355, note 3, above.

10 I preserve the name in this familiar form, though the meaning of Dapifer is 'seneschal,' which was the office held by Eudes (son of $\mathrm{Hu}$ bert de Ryes).

Eudo's manors are difficult in some cases to distinguish because the fief was dislocated at his death (see, for him, Introduction, p. 347).

11 This was Richard de Sackville (see Introduetion, p. 379).

18 This holding, large though it is, cannot, it scems, be identified. 


\section{A HISTORY OF ESSEX}

King Edward's time, by Goduin, a free man, as a manor and as $I$ hide and 3 virgates, is held of Eudo by Turgis. ${ }^{1}$ Then 2 ploughs on the demesne; now I. Then I plough belonging to the men; now none. Then 3 villeins; now none. Now 2 bordars. Then 2 serfs; now I. (There is) wood(land) for 50 swine, (and) Io acres of meadow. Then I beast (animal) and 30 sheep; now I 8 beasts, 4 rounceys (runcini), I 9 swine, 75 (sheep ? ${ }^{2}$ ), 2 hives of bees. Of this estate (terra) are 50 acres, which were added (to it) in King William's time; and Lefsi ${ }^{3}$ added them to this estate. Then as now (semper) it was worth 40 shillings.

\section{Hundret of Dommawa [Dunmow]}

Rodinges [Roding (Morel) ${ }^{4}$ ], which was held, in King Edward's time, by Samar, a free man, as $1 \frac{1}{2}$ hides and 45 acres, is held of Eudo by Turgis. ${ }^{5}$ Then as now (semper) 2 ploughs on the demesne. Then 2 ploughs belonging to the men; now I. Then 9 villeins; now 3 . Then I bordar; now 3 . Then 3 serfs; now I. There is woodland for 100 swine, (and) I 9 acres of meadow. Then I rouncey (runcinus); now 7. Then

1 This was clearly the Turgis who held of Peter de Valognes in the adjoining manor of Latton, and who held of Eudo himself in Roding.

2 The word is omitted in the MS.

3 I strongly suspect this English name (Leofsige), for which it seems impossible to account, to be an error of the scribe for 'Lisois,' the name of Eudo's predecessor (see note I I below).

4 To distinguish, in Domesday, the various Rodings is a task of great difficulty. For Eudo's manors there we naturally turn to the Colchester Cartulary, where we find an episcopal confirmation to the abbey of the whole tithes of Fulc Dapifer in 'Roinges' Abbess, and of the whole tithe of the demesne of Ralf Morel in 'Roinges Morel' with two-thirds of the tithe of the demesne of Walter de Merc there. Walter's manor of 'Merks,' though in White Roding, adjoins Roding Morel, which is itself now a hamlet in White Roding, so that we may fairly identify the place in the text as above. Turning to Eudo's other manor, Domesday places it in Ongar Hundred, and Roding Abbess is one of the two Rodings in that Hundred, so that its identity seems tolerably certain. And although Fulc Dapifer does not occur in Domesday we find him in the Colchester Cartulary as a knightly tenant of Eudo under Henry I. Morant, followed by Mr. Chisenhale-Marsh, assigned both the manors of Eudo to Aythorp Roding, but on what ground I do not know. His account of the parish shows no reason for this identification, and he admits that Eudo's supposed grant of its tithes 'did not take effect.'

5 See note I above.
Io beasts (animalia); now 25. Then 6 swine; now 89. Then 50 sheep; now 225. Now 55 goats and 8 hives of bees. It was then worth Io0 shillings; now 6 pounds. This manor is claimed by the Abbot of Ely, says (teste) the Hundret (court). ${ }^{6}$

Lindeseles [Lindsell], which was held, in King Edward's time, by Ulmar, a free man, ${ }^{7}$ as I manor and as I hide, is held by Eudo in demesne. Then as now (semper) 2 ploughs on the demesne, and 3 ploughs belonging to the men. There are 9 villeins and I priest. Then I bordar; now 9. Then 4 serfs; now ${ }^{\circ}$. (There is) wood(land) for 30 swine, 6 acres of meadow, (and) now I mill. Then I rouncey (runcinus), and 5 beasts (animalia), and 60 swine; now I rouncey, and ... It was then worth fo. $49 \mathrm{~b}$

Ioo shillings; now 6 pounds. And this manor was worth the same (tale erat) when (he) received (it). ${ }^{9}$

\section{Hundret of Witbrictesherna [Dengie]}

Munduna [Mundon] was held by Goduin, a king's thegn, as I manor and as ro hides. Now Eudo holds (it) in demesne. Then Io villeins; now 15 . Then 8 bordars; now I 4. Then 9 serfs; now 7. And (there were) 2 French men (franci bomines ${ }^{10}$ ) who have half a hide, which Lisois $^{11}$ seized (occupavit) because one of them became an outlaw (utlagavit). In this manor (there) are 4 ploughs on the demesne. Then 8 ploughs belonging to the men; now Io. And (there are) 2 arpents of vineyard (vinea). (There is) wood(land) for 24 swine, (and) pasture for 200 sheep. Then 4 rounceys (runcini) and 8 beasts (animalia), 40 swine, (and) 250 (sheep); now 4 rounceys, and 15 beasts, and

${ }^{6}$ It is interesting to observe that this last sentence has been crowded in after the entry had been written.

7 This must be Wulfmar of Eaton, a great Bedfordshire thegn, who is found as Eudo's predecessor in that county. In Essex we find him succeeded by Eudo at Hawkwell, Shellow, Takeley, Theydon, and Roding (Abbess ?), as well as at Lindsell.

8 The folio ends here.

9 This seems to be the best rendering of this abnormal formula; for values were usually given as for these three periods.

10 There is always considerable doubt whether this phrase may not imply free holders instead of 'French men.'

11 Eudo's predecessor, Lisois de Moustiers (de Monasteriis). 


\section{THE HOLDERS OF LANDS}

65 swine, 354 sheep, (and) 4 hives of bees. It was then worth 10 pounds; now 17 ; and it was leased for (fuit ad frmam ad) 30 pounds under Eudo himself. ${ }^{1}$ To this manor there belong (adjacent) 30 acres; they were worth 30 pence; now 36 . There also belong 20 acres of WRINGEHALA [ ] which arc held by I sokeman; (they were) then worth 20 pence; now 3 shillings.

LALINGE [Lawling ${ }^{9}$ ], which was held by Ulvric cassa, in King Edward's time, as a manor and as $3 \frac{1}{2}$ hides ; $^{3}$ is held of $E$ [udo] by Richard. Then 4 serfs; now 3. Now 1 bordar. Then 2 ploughs on the demesne; now I. Then I rouncey (runcinus); now none. Then 87 sheep; now 63 . It was then worth 60 shillings; when (the manor was) received 40 shillings; now 4 pounds.

StEPLA [Steeple], which was held, in King Edward's time, by Norman as a manor and as 3 hides and 35 acres, is held of $E$ [udo] by the same R[ichard]. Then as now (semper) 1 bordar, and 2 serfs, and 2 ploughs. (There is) wood(land) for 10 swine. Then 6 beasts (animalia); now 27. Then as now 1 rouncey (runcinus) and 15 swine. Then 120 sheep; now 160 . It is worth 4 pounds.

Dona [Down (Hall) ${ }^{4}$, which was held, in King Edward's time, by Modinc as a manor and as 2 hides and 20 acres, is held of E[udo] by the same $R$ [ichard]. Then as now (semper) 2 bordars, and 2 serfs, and 1 plough. (There is) pasture for 100 sheep. Then I rouncey (runcinus); now 3. Now 3 beasts (animalia). Then 120 sheep; now 160 less I. It is worth 60 shillings.

Landuna [ ${ }^{5}$ ], which was held, in King Edward's time, by 4 free men as half a hide and 20 acres, is held of E[udo] by the same $R$ [ichard]. Then as now (semper) half a plough. It is worth 10 shillings.

Acleta [ ${ }^{6}$ ], which was held, in King Edward's time, by Modinc as a manor

1 This last clause is interlined.

8 In Latchingdon.

' pro iii hidis T.R.E. et dim',

- In Bradwell-by-Sca (see Introduction, p. 392).

s The present 'Eastlands' in Bradwell-by-Sea is styled 'Land farm' in Chapman and Andre's map (1772-4), but I know of nothing to identify it as 'Landuna.'

- There is a 'Hockley' in Bradwell-by-Sea, but one can hardly suggest so great a distortion of the name, nor is there anything to suggest the identification. and as I thides) ${ }^{7}$ and 10 acres, is held of $\mathrm{E}$ [udo] by the same (Richard). Then as now (semper) I bordar and I plough. (There fo. 50

is) pasture for 100 sheep. Then as now (semper) 2 beasts (animalia), and 80 sheep, and 9 swine. Then and afterwards it was worth 40 shillings; now 50.

\section{HUNDRET OF ROCHEFORT [ROCHFORD]}

HeChwella [Hawkwell], which was held, in King Edward's time, by Ulmer as a manor and as $3 \frac{1}{2}$ hides less 15 acres, is held of Eudo by Pirot. ${ }^{8}$ Then 1 I villeins; now 8. Then as now (semper) 5 bordars. Then 2 serfs; now 3. Then as now (semper) 2 ploughs on the demesne. Then 6 ploughs belonging to the men; now 5 . There are 4 acres of mcadow, (with) woodland for 10 swine. Then 2 rounceys (runcini), and 5 beasts (animalia), 102 sheep, (and) 20 swine; now 16 beasts, 106 shecp, 20 swine, (and) 2 hives of bees. Then and afterwards it was worth 6 pounds; now $7 .^{\circ}$

In the abovesaid Hundret of Dommawa [Dunmow] Richard holds of Eudo 1 manor of 9 acres which is called Brocheshevo's [Broxted], which, in King Edward's time, was held of the Abbot of Ely by 2 sokemen. ${ }^{10}$ Then 3 ploughs on the demesne; now $2 \frac{1}{2}$. Now I plough belonging to the men, and 2 villeins. Then 3 bordars; now 5. Then 3 serfs; now 1. (There is) wood(land) for 100 swine, (and) 6 acres of meadow. Then 1 rouncey (runcinus), and 3 beasts (animalia), and 16 swine; now 5 beasts, (and) 33 swine. Then and afterwards it was worth 60 shillings; now 4 pounds.

Scelga [Shcllow], which was held, in King Edward's time, by Ulmar, a free man, as a manor and as half a hide, is held by Eudo in demesne. Then as now (semper) half a plough on the demesne. (There arc) now 2 bordars. (There is) wood(land) for 16 swine, (and) 4

7 The word is omitted in the MS.

8 From whom the family of Perot which subsequently held the manor, by knight service, of the Honour of Rayleigh. He was an under-tenant of Eudo in other counties also.

2 This entry is duplicated below (see Introduction, p. 4 II).

10 See p. 450 above, where the former tenure of the land by sokemen is ignored.

The circumstance that the title to this estate was contested is doubtless the cause of its being entered here out of due course, instead of under Eudo's holding in the Hundred of Dunmow. 


\section{A HISTORY OF ESSEX}

acres of meadow. It was worth then as now (semper) to shillings.

Dommawa [Dunmow ${ }^{1}$ ], which was held, in King Edward's time, by I free man as a manor and as $37 \frac{1}{2}$ acres, is held of $E$ [udo] by Ralf. Then as now (semper) half a plough on the demesne, and half a plough belonging to the men, and 2 villeins. ('There are) now 2 bordars. Then I serf; now none. (There is) woodland for 15 swine, (and) 4 acres of meadow. Then and afterwards it was worth Io shillings; now 20. And in the same vill (there are) also (alie) $37 \frac{1}{2}$ acres, which were held by another free man, in which there is the same as in the others; and they are worth the same amount. ${ }^{2}$

\section{HuNDRET OF UDELESFORT [UTTLESFORD]}

Tacheleia [Takeley ${ }^{3}$ ], which was held, in King Edward's time, by Ulmar, a free man, as a manor and as 1 hide and 15 acres, is held by $\mathrm{E}$ [udo] in demesne. Then as now (semper) 2 ploughs on the demesne, and 2 ploughs belonging to the men. Then 3 villeins; now 5, and I priest. Then 3 bordars; afterwards and now ro. Then as now (semper) 2 serfs. (There was) wood(land) for 1,000 swine; afterwards and now for $600 .{ }^{4}$ There are 16 acres of meadow. Then $I$ rouncey (runcinus), and $\mathrm{I}_{4}$ beasts (animalia), 30 swine, 30 goats, (and) 80 sheep; now 2 rounceys, 20 beasts, 43 swine, ro 3 sheep, fo. 50 b

(and) 40 goats. Then and afterwards it was worth 8 pounds; now Io.

\section{Hundret of Clavelinga [Clavering]}

Plichedana [Pledgdon ${ }^{5}$ ], which was held, in King Edward's time, by 2 free men as a manor and as 5 hides less 20 acres, is held of $\mathrm{E}$ [udo] by Richard. Then 4 ploughs on the demesne; afterwards and now 2. Then and afterwards I plough belonging to the men; now 3. Then and afterwards 2 villeins; now 6. Then and afterwards 2 bordars; now 16.

1 This small estate has not been identified.

2 This would seem to be a complicated way of stating that an estate here of 75 (geld) acres had been held by 2 free men in absolutely equal shares (suggesting recent division), and that Eudo had obtained the whole:

3 i.e. the manor of Colchester Hall there.

4 This must have been part of Hatfield (otherwise Takeley) Forest.

b A hamlet in Henham, being that part of the parish which was in Clavering Hundred. Eudo's manor was afterwards known as Prison Hall.
Then and afterwards 2 serfs; now none. (There is) wood(land) for 20 swine, (and) 20 acres of meadow. Then 2 rounceys (runcini); now none. Then 2 beasts (animalia). Now 66 swine. Then 300 sheep; now 200. (There are) 6 hives of bees. Then and afterwards it was worth 100 shillings ; now 8 pounds. Of this estate (terra) 2 hides less 20 acres are claimed by G[eoffrey] 'de Magna villa,' and the Hundred (court) supports his claim (testatur ei).

\section{Hundret of Laxendena [Lexden]}

Bucchesteda [Boxted ${ }^{6}$ ], which was held by Grim as a manor and as I hide, is held of E[udo] by Artur. Then 1 villein; now none. Then 2 bordars; now 9 . Then as now (semper) I plough on the demesne. Then 2 ploughs belonging to the men; now 1. (There is) wood(land) for 42 swine, (and) 2 acres of meadow. Then 6 beasts (animalia); now 4. Then 30 sheep; now 64. Then 10 swine; now 13. (There are) now I 3 goats, and I hive of bees. It was then worth 20 shillings; now 40 . And a certain free (man ${ }^{7}$ ) held (there) 5 acres, (which) the same Artur now holds of $\mathrm{E}$ [udo]; then as now (semper) half a plough was there; it is worth 5 shillings.

\section{Hundret of Angra [Ongar]}

Taindena [Theydon (Gernon ?)], which was held, in King Edward's time, by Ulmar as I hide and 40 acres, is held by Eudo in demesne. Then 4 villeins; now 6 . Then 2 bordars; now 4 . Then 4 serfs; now 1 . Then as now (semper) 2 ploughs on the demesne, and 2 ploughs belonging to the men. (There is) wood(land) for 400 swine, (and) 5 acres of meadow. Then as now (semper) 2 rounceys (runcini). Then 8 beasts (animalia); now I3. Then 35 swine; now 66 . Then 87 sheep; now 100 , and 15 goats. Then 2 hives of bees; now 6 . Then and afterwards it was worth 40 shillings; now 4 pounds. And I sokeman held 6 acres, and could sell his land; but the soke ${ }^{8}$ remained attached to (in) the manor; (this is) worth 12 pence.

RoINGEs [Roding (Abbess ?) ${ }^{8}$ ], which was held, in King Edward's time, by Ulmar as a manor and as 3 hides, is held by Eudo in demesne. Then as now (semper) 7 villeins. Now

6 The identity of this manor there seems to be doubtful.

7 The MS. omits the word.

8 (Profits of) jurisdiction there.

9 See p. 492, note 4, above. 


\section{THE HOLDERS OF LANDS}

2 bordars. Then as now (semper) 4 serfs, and 2 ploughs on the demesne, and 3 ploughs belonging to the men. (There is) wood(land) for 20 swine, (and) 20 acres of meadow. Then I rouncey (runcinus); now 3. Then 10 beasts (animalia); now 14. Then 40 swine; now 60. Then 100 sheep; now 131. And (there) is 1 sokeman, holding half a virgate and $8 \frac{1}{2}$ acres, who could sell his fo. 5 s

land, though (sed) the soke ${ }^{I}$ remained attached to (in) the manor; then and afterwards I $\frac{1}{2}$ ploughs were there; then as now (semper) I serf. Then and afterwards the whole was worth 8 pounds; now 12.

\section{Hundret of Celmeresfort [Chelmsford]}

Ratenduna [Rettendon], which was held, in King Edward's time, by Levesun as a manor and as 2 hides and 30 acres, is held of $\mathrm{E}$ [udo] by Richard. And this land is claimed by the Abbey (Ecclesia) of Eli ; and the Hundret (court) supports the claim (fert testimonium). Then as now (semper) 4 bordars, and 2 serfs, and 1 plough on the demesne, and 1 plough belonging to the men. Then 2 rounceys (runcini); now 4. Then 4 beasts (animalia); now 7. Then Io swine; now 33. Then 80 sheep; now roo less 3 . It was then worth 40 shillings; now 70 .

LEGA [Lees], which was held by Edric as a manor and as 2 hides, is held of $E$ [udo] by Richard. Then as now (semper) 3 villeins. Then 2 bordars; now 9. Then 7 serfs; now 2. Then 2 ploughs on the demesne; now I $\frac{1}{2}$. (There is) wood(land) for 800 swine, $^{3}$ (and) 16 acres of meadow. (There is) now I mill. Then 3 rounceys (runcini); now 1. Then 10 beasts (animalia); now 9. Then 40 swine; now 35 . Then 50 sheep; now 63 ; and 11 goats. It was then worth 60 shillings; now 4 pounds.

\section{Hundret of Tendringa [Tendring]}

Wileia [Weeley] was held by Goduin as a manor and as 3 hides and $3^{8}$ acres. Now $E$ [udo] holds (it) in demesne. Then 13 villeins; now 11. Then 4 bordars; now 9. Then 8 serfs; now 4.4 (There is) wood(land) for 200 swine, 6 acres of meadow, and pasture for 100 sheep. And 2 sokemen held

1 i.c. (the profits of) jurisdiction.

2 See p. 450 above.

- This extensive woodland was represented subsequently by the large park there, which was of early date.

There is no mention of the ploughs.
2 hides and 45 acres, which used to belong (adjacebant) to this manor; then as now (semper) 5 bordars (were there), and 2 ploughs; (there is) wood(land) for 30 swine, 3 acres of meadow, (and) pasture for 60 sheep. (There were) then on the demesne 15 beasts (animalia); now 16. Then 60 swine; now 30. Then as now (semper) 240 sheep. Then 5 hives of bees; now 2. The whole together was then worth 8 pounds; now I9 pounds and I ounce of gold.

\section{HUNDRET OF UDELESFORT [UTTLESFORD]}

Kuenadana [Quendon], which was held by Aldred ${ }^{6}$ as a manor and as 2 hides, is held of $E$ [udo] by Richard. Then 6 villeins ; afterwards and now 3. Now 4 bordars. Then as now 3 serfs, and 2 ploughs on the demesne. And the men had (inter bomines) then 3 ploughs; now 2. (There is) wood(land) for 40 swine, (and) 6 acres of meadow. Then 7 rounceys (runcini); now 5. Then 6 beasts (animalia); now 9. Then 32 swine; now 50. Then 80 sheep; now 200. Now 44 goats. Then 4 hives of bees; now 17 . It was then worth 8 pounds; now $6 .^{8}$

fo. $53 \mathrm{~b}$

\section{Half Hundret of Frossewella [FRESHWELL]}

In Redewintra [Radwinter] Richard holds 15 acres, which were held by Alvric $W$ and. ${ }^{9}$ 'Then as now (semper) I villein, and I bordar, and I serf, and I plough. There are 5 acres of meadow. Then 5 beasts (animalia); now 8. Now 2 rounceys (runcini). Then 5 sheep, and 3 swine; now none. It was then wortl 10 shillings; now $30 .^{10}$

\section{HUNDRET OF ROCHEFORT [ROCHFORD]}

(Hacwella [Hawkwell]), " which was held, in King Edward's time, by Ulmar, a free man, as a manor and (as $3 \frac{1}{2}$ hides ") less 15 acres, (is held by Eudo in demesne ${ }^{11}$ ). Then II villeins; now 8 . Then as now (semper) 5

6 This enormous rise in value seems to be unaccounted for.

6 This was very probably the Aldred, 'thegn of King Edward,' whom Eudo had succeeded at Aspenden in Hertfordshire, some 10 miles to the west, and at Newsells in Barkway north of it.

7 The MS. omits the number.

8 Here is a fall in value of 25 per cent concurrent with a large increase in the live stock.

9 See p. 496, note 2 , below.

10 Here the value has tripled with nothing to account for the rise.

11 The words within the parentheses have been deleted by the scribe. 


\section{A HISTORY OF ESSEX}

bordars. Then 2 serfs; now 3. Then as now (semper) 2 ploughs on the demesne. Then 6 ploughs belonging to the men; now 5 . There are 4 acres of meadow, (with) wood(land) for Io swine. Then 2 rounceys (runcini); now 6. Then 5 beasts (animalia); now I6. Then I02 sheep; now r06. Then as now (semper) 20 swine. Now 2 hives of bees. It was then worth 6 pounds; now $7 .^{1}$

\section{HUNDRET OF UdELESFORda [UTTLESFORd]}

Archesdana [Arkesden], which was held by Alvric Wants ${ }^{2}$ as a manor and as 2 hides less 15 acres, is held by $E$ [udo] in demesne. Then as now (semper) 2 villeins, and 7 bordars, and 2 serfs. Then and afterwards 2 ploughs on the demesne; now I. Then as now (semper) 2 ploughs belonging to the men. (There is) wood(land) for 20 swine, (and) ro acres of meadow. It is worth I00 shillings. fo. $5^{2}$

\section{THE LAND OF ROGER DE OTBURVILLA}

\section{Hundret of Herlaua [Harlow]}

HALINGEBERIA [(Great) Hallingbury] was held, in King Edward's time, by 2 free men as a manor and as 3 hides and $3^{8}$ acres. Then 6 ploughs on the demesne; now 3. Then I $\frac{1}{2}$ ploughs belonging to the men; now $2 \frac{1}{2}$. Then 18 villeins; now 8 . Then 4 bordars; now 5. Then I serf; now none. (There is) wood(land) for 600 swine, 25 acres of meadow, pasture worth 28 pence, (and) I mill. And 9 ploughs could be added to the stock (restaurari). ${ }^{3}$ And one of these manors used to be worth, ${ }^{4}$ in King Edward's time, 8 pounds; and when received (it was worth) 100 shillings; now 4 pounds. And the other was then worth 60 shillings; now $40 .{ }^{5}$ Roger took over (recepit) on the demesne I rouncey (runcinum), and 3 beasts (animalia), and 30 sheep, and 40 swine; now (there are) I rouncey and 8 beasts, and 80 swine, and 120 sheep, and 3 hives of bees. ${ }^{6}$

1 This is the duplicate entry discussed in the Introduction (p. 411).

2 This is the Alvric 'Wand' who held of Eudo at Radwinter (see Introduction, p. 355).

3 Yet there had been a decrease of il ploughs since the time of the Confessor, so that (if the figures are correct) either the estate had then too many, or the arable land had decreased.

4 ' unum manerium ex istis valebat.'

- This passage is of some importance for the use of the word 'manerium.'

6 This was clearly the principal manor in the Hallingburys, and must have been lost by Roger de Otburvilla, and granted to Eudo Dapifer after

\section{Hundret of Dommaua [Dunmow]}

Rodinges [ ] was held, in King Edward's time, by Turchil, a free man, as a manor and as 2 hides. Then [ ploughs] on the demesne; now $1 \frac{1}{2}$. Then 3 villeins; now I priest and 2 villeins. Then 2 bordars; now 5. Then 4 serfs; now 3 , who have I plough. ${ }^{6}$ (There is) wood(land) for 30 swine, (and) 24 acres of meadow. It was then worth 6 pounds; afterwards and now 100 shillings. And when (Roger) received (it), he found there only the land (itself ${ }^{9}$ ) and I plough.

\section{HUNDRET OF UdELESFORT [UTTLESFORD]}

ARChesdana [Arkesden] was held by Lewin freely (libere) as a manor and as I hide; and Roger (holds it) by exchange (in suo escangio). Then 2 villeins; afterwards and now 1. Then as now (semper) 3 bordars. Then I plough on the demesne; when he received (the manor), none; now I. Then and afterwards I plough belonging to the men; now none. There are 7 acres of meadow, (with) wood(land) for 10 swine. Then I beast (animal) and 19 sheep; now I colt (pullus), I 4 swine, (and) 90 sheep. It was then worth 40 shillings; now 50.

In the same vill Ulfo held I hide freely (libera) in King Edward's time; and Roger (holds it) by exchange (pro escangio). Then 2 villeins; afterwards and now I. Then as now (semper) 3 bordars. Then I plough on the demesne; and when he received (the manor), none; now $\mathbf{I}$. Then and afterwards I plough belonging to the men; now none. (There are) 7 acres of meadow, (with) wood(land) for Io swine. It was then worth 40 shillings; now $50 .^{10}$

fo. $52 \mathrm{~b}$

Cishella [Chishall ${ }^{11}$ ] was held by Edric as

Domesday; for it passed to St. John's Abbey under Eudo's grant. The descent of Roger's other manors, and therefore their exact identity, appears to be obscure.

7 This is omitted in the MS.

8 'habentes I carrucam.' This appears to refer to the serfs, but must be intended to refer to the villeins and bordars. The 3 serfs, it is interesting to note, would be exactly the right proportion for the $1 \frac{1}{2}$ ploughs on the demesne in 1086.

9 'solam terram,' an exceptional phrase.

10 The close correspondence between the figures for these two holdings at Arkesden should be observed. It suggests recent and equal division.

11 This is identified by Morant with the manor of Over Chishall in Great Chishall; but it was not improbably the manor of 'Lisles' there, which 


\section{THE HOLDERS OF LANDS}

a manor and as $3 \frac{1}{2}$ hides. Then 8 villeins; afterwards and now 6 . Then as now (semper) 2 bordars. Then 2 serfs; now 1. Then and afterwards 2 ploughs on the demesne; now 1. Then and afterwards 3 ploughs belonging to the men; now 2. (There is) wood(land) for 40 swine, (and) 6 acres of meadow. Then 1 rouncey (runcinus), and 2 swine, and 213 sheep. Now 2 rounceys, and I beast (animai), 32 swine, (and) 200 sheep. Then as now (semper) it was worth 4 pounds.

\section{THE LAND OF HUGH DE MONTFORT}

\section{Hundret of Berdestapla [Barstable]}

RamesDANA [Downham ${ }^{1}$ ], which was held, in King Edward's time, by 3 free men as a manor and as 2 hides and 40 acres, is held of Hugh by Osbern. Then as now (semper) I plough on the demesne. Then half a plough belonging to the men; now 1 . Then 3 bordars; now 5. Then I serf; now none. (There is) wood(land) for 60 swine, (and) 3 acres of meadow. Then 2 beasts (animalia), and 3 swine, and 60 sheep; now 1 rouncey (runcinus), and 2 beasts, and 9 swine, and 70 sheep. It is worth 40 shillings. In the same vill are 30 acres which belong to the church and are worth 30 pence.

\section{HUNDRET OF WithaM}

Chellevadana [Kelvedon], ${ }^{2}$ which was held, by Gudmund, a king's thegn, ${ }^{3}$ as a manor and as $3 \frac{1}{2}$ hides, is held of Hugh by

was held of the Honour of Lisle, in which case it would have descended with Eudo's manor in Arkesden, where Roger also had a manor. As Eudo obtained Roger's manor of Hallingbury, he may have secured other manors of his also.

1 This considerable manor has not hitherto been identified. Morant ignores the entry altogether, and Mr. Chisenhale-Marsh assigned it vaguely to Ramsden. The clue is found in the lists of fees in Hugh de Montfort's honour (that of 'the Constable') owing ward to Dover Castle. Among the Essex ones 'Dunham' figures as one fee (Red Book of the Exchequer, pp. 614,707,718); and 'Dunham' is clearly Downham, which adjoins the Ramsdens, and which does not occur by name in Domesday. This 'Dunham' is wrongly placed by the editor of the Red Book in Kent (p. 1162) he does not know where.

2 This valuable manor was that of Felix Hall, as it was subsequently named, and seems to have extended into Little Coggeshall, Bradwell, Great Braxted and Inworth.

3 See the Introduction, p. 346.
William son of Grossa (grossa). Then as now (semper) 2 ploughs on the demesne, then 4 ploughs belonging to the men; now 1 . Then as now (semper) 9 villeins, and 3 serfs, and 5 bordars. (There is) wood(land) for 50 swine, 25 acres of meadow, (and) I mill. Then I rouncey (runcinus), and 4 beasts (animalia), and 7 swine, and 40 sheep; now 2 rounceys (and) 140 sheep. It was then worth 6 pounds; now 7 .

\section{Hundret of Beventreu [Becontree]}

LeINTuna [Leyton] which was held, in King Edward's time, by Alsi as a manor and fo. 53

as 3 hides and 30 acres, is held by Hugh in demesne. Then 2 ploughs on the demesne; now 1 . Then 1 plough belonging to the men; now 51 . Then 6 villeins; now 1 priest and villein. Then 4 bordars; now 3. Then 2 serfs; now none. (There is) wood(land) for 150 swine, (and) 30 acres of meadow. Then 60 sheep; now 4 swine, and 60 sheep. It was then worth 30 shillings; now 40. And one of these hides used to pay, in King Edward's time, a customary due (consuetudinem) to Havelingx [Havering] a manor of the king; and now it does not pay. ${ }^{\circ}$

\section{HUNDRET of Witbrictesherna [Dengte]}

Purlai [Purleigh], which was held, in King Edward's time, by Gudmund, ${ }^{6}$ a free man, as a manor and as 4 hides, is held by Hugh in demesne. Then as now (semper) 5 villeins. Then 6 bordars; now 7. Then 6 serfs; now 5. Then as now (semper) 2 ploughs on the demesne. Then 3 ploughs belonging to the men; now 2 ; and a third could be employed (feri). There is wood(land) for 700 swine. Then as now (semper) 3 rounceys (runcini) and 16 beasts (animalia). Then 300 sheep; now 306 . Then 30 swine; now 35. It was then worth 8 pounds; afterwards and now 7 .

Lachentuna [Latchingdon ${ }^{7}$ ] was held by

- See p. 567 below for the aggression of this tenant in conjunction with his lord. He was also under-tenant of Hugh at Dagworth (near Haughley), Suffolk, and at Bonnington in Kent.

6 See p. 430 above for the reference to this under Havering.

6 See note 3 above.

7 Latchingdon itself, not, as supposed by Morant, Purleigh (or Latchingdon) Barns in Purleigh (sec Introduction, p. 391). It was subsequently granted,
63 


\section{A HISTORY OF ESSEX}

Gudmund ${ }^{1}$ as a manor and as $3 \frac{1}{2}$ hides and 20 acres. Then as now (semper) 2 villeins. Then 2 bordars; now 4. Then 5 serfs; now 4. Then as now (semper) 2 ploughs on the demesne, and half a plough belonging to the men. (There is) pasture for 200 sheep, (and) wood(land) for Ioo swine. It was then worth 7 pounds; afterwards and now 100 shillings. Of this same manor Humfrey holds 2 hides of Hugh, and Ulmar I hide; and these are worth 60 shillings out of the above amount (in eodem pretio).

In Purlai [Purleigh] 10 free men held 7 hides, which Hugh received as 2 manors. ${ }^{2}$ But the Hundret (court) has no knowledge of this (boc nescit ${ }^{3}$ ). There were then on this land (in hac terra) 4 bordars; now 8 . Then I serf; now none. Then 8 ploughs; now 6. (There is) wood(land) for I 5 swine, (and) pasture for 100 sheep. Then and afterwards it was worth 6 pounds; now 100 shillings.

Hugh holds further (adbuc) in PurlaI [Purleigh] I manor of $1 \frac{1}{2}$ hides and $8 \frac{1}{2}$ acres, which was held, in King Edward's time, by 3 free men with (the) soke. ${ }^{4}$ Then as now (semper) I $\frac{1}{2}$ ploughs. There is pasture for 40 sheep. Then as now (semper) it was worth 20 shillings. The whole abovesaid estate was worth, when he received it, 30 pounds. ${ }^{5}$ fo. $53 \mathrm{~b}$

\section{Halesduna [ ${ }^{6}$ ], which was held,}

as an escheat, to a family which took its name. The manor held by Hugh must be that of Tiled Hall, a sit paid castle-guard rent to Dover. Morant wrongly identified this manor as that which Phin's widow held in 1086 .

1 See p. 497, note 3, above.

2 This passage should be noted as bearing on the use of the word 'manor.'

3 The statement seems to have been made on Hugh's behalf; and the men of the 'Hundred' probably stated that they had not seen any one give him seizin of the land or any writ of the king to that effect.

4 i.e. the soke of the land was vested in them.

5 This appears to refer to his lands in Latchingdon and Purleigh, but the estimate is a high one. His Purleigh estate alone was assessed at over I $2 \frac{1}{2}$ hides, but Purleigh is a parish containing over 5,000 acres, and its detached portion, 'Gibcrakes,' in Danbury and Sandon was included in Hugh's holding, as is shown by the fact that, with Southhouse in (St. Mary's) Maldon and lands in Snoreham, it passed to John de Grey, who received Purleigh as an escheat from Henry III. (Hundred Rolls, i. 159), and was held by his descendants the Greys of Wilton.

6 The name appears to be now lost, but the place was in or close to Mundon (see Introduction, p. 393). in King Edward's time, by Alwin, a thegn, as a manor and as 2 hides, is held by Hugh in demesne. Then I bordar, and I villein; now the same. Then as now (semper) I serf and I plough on the demesne. (There is) pasture for 40 sheep. It was then worth 30 shillings; when he received it, 20 shillings; now 30 . Estolela [
8 is held by Hugh in demesne. Then as now (semper) 2 villeins. Then 2 bordars; and now the same. And (there was) I $\frac{1}{2}$ ploughs, and (are) now the same. It is worth 30 shillings.

\section{HundRET OF Wensistreu [Winstree]}

LEgra [Layer ${ }^{9}$ ], which was held, in King Edward's time, by Liwin, a free man, as a manor and as $1 \frac{1}{2}$ hides and 18 acres, is held by Hugh in demesne. Then as now (semper) I $\frac{1}{2}$ ploughs on the demesne. Now half a plough belonging to the men. Now 3 bordars. Then 3 serfs; now none. Then as now (semper) 3 cows. Then 20 sheep; now 6o. (And there are) now 14 swine, and 1 rouncey (runcinus) and 7 goats. It was then worth 50 shillings; and when he received (it), 20 shillings; now 40 shillings.

\section{HUNDRET OF Hidingaforda [HinckFord]}

RaINEs [Rayne (Hall)], which was held by Gudmund ${ }^{10}$ as a manor and as 2 hides less 20 acres, is held of Hugh by Alcher. Then as now (semper) 3 ploughs on the demesne. Then and afterwards 7 ploughs belonging to the men; now $2 \frac{1}{2}$. Then and afterwards I 8 villeins; now 5. Then and afterwards 6 bordars; now 7. Then and afterwards 6 serfs; now 4. (There is) wood(land) for I 50 swine, (and) 16 acres of meadow. Then as now (semper) I mill, and I rouncey (runcinus). Then 18 beasts (animalia); now 17. Then as now (semper) 70 sheep, and 10 goats. Then and afterwards it was worth 6 pounds; now 7.

7 This place has not been identified. $\mathrm{Mr}$. Chisenhale-Marsh suggested that it might be Stow Maries, but, as it occurs above as 'Estolleia,' and is found in the thirteenth century as 'Scolee' or 'Scoleghe' (i.e. 'Stolee' or 'Stoleghe '), its second syllable is well established. In Devonshire the 'Stolei' of Domesday is now Stoodleigh.

8 The name of the former holder is omitted in the MS., which reads, moreover: 'quod tenent semper ii villani.'

9 The identity of this manor seems to be uncertain.

10 See p. 497 , note 3 , above. 


\section{THE HOLDERS OF LANDS}

Hundret OF Wibrictesherna [Dengie]

EFfecestre [Bradwell-on-Sea ${ }^{1}$ ], which was held, in King Edward's time, by Ingulf, a free man, as a manor and as $1 \frac{1}{2}$ hides, is held of Hugh by Ulmar. Then as now (semper) 2 bordars. Then 1 serf; now none. (There is) I plough on the demesne, and half (a plough) belonging to the men. (There is) pasture for 200 sheep. It is worth 30 shillings.

\section{HUNDRET OF LAXENDENa [LEXDEN]}

Mercheshala [Markshall], which was held, in King Edward's time, by Gudmund as I manor and as half a hide and I 3 acres, is held of Hugh by Nigel. Then as now (semper) 2 villeins. Then 7 bordars; now 8 . Then as now (semper) 5 serfs. Then 2 ploughs on the demesne; now $1 \frac{1}{2}$. Then as now (semper) i $\frac{1}{2}$ ploughs belonging to the men. (There is) wood(land) for 200 swine, (and) I acre of meadow. Then as now 10. 54

(semper) I rouncey (runcinus). Then 2 beasts (animalia); now 10. Then 30 sheep; now 80. Then as now (semper) i 2 swine. (There are) now 3 hives of bees. It was then worth 40 shillings; now 60.

\section{Hundret of Celmeresfort [Chelmsford]}

Bedenesteda [Sandon "], which was held, in King Edward's time, by Gudmund as a manor and as 4 hides, is held of Hugh by Robert. Then I villein; now none. Then 9 bordars; now 10 . Then and afterwards 6 serfs; now I. Then and afterwards 2 ploughs on the demesne; now I. Then as now (semper) I plough belonging to the men. (There are) 5 acres of meadow. Then 3 rounceys (runcini) now none. Then 25 beasts (animalia); now (only) I cow. Then 100 swine; now 14. Then 108 sheep; now 24. Then 60 goats; now none. It was then worth 8 pounds; and when received the same; now 4 pounds. ${ }^{\circ}$ And 5 free men held $1 \frac{1}{8}$ hides and 23 acres, which are held of Hugh by the same Robert; then as now (semper) 5 bordars (were there), and $2 \frac{1}{2}$ ploughs, (with) wood(land) for 40 swine and 4 acres of

1 Not, as supposed by Morant, the manor of Bradwell Hall, but that of Battails, which was always held of the Montfort 'Honour of Haughley' (see Introduction, p. 392).

2 See p. 497 , note 3 , above.

See Introduction, p. 389.

- See note 2 above.

b This is a good instance of a sweeping reduction in the live stock being accompanied by a reduction of one half in the value. meadow; then as now (semper) it was worth 50 shillings. This manor is claimed by the monks of Ely as having been (quod fuit) held in demesne by the abbey (in abbatia in dominio) in King Edward's time; and the Hundret (court) testifies (to) this.

\section{Hundret of Tendringa [Tendring]}

WICA [Wix ${ }^{6}$ ] was held, in King Edward's time, by Queen Edith as a manor and as I hide. It is now held of Hugh by Roger. Then as now (semper) 2 villeins. Then 2 bordars; now 8. Then 2 serfs; now none. Then as now (semper) I plough. (There is) wood(land) for ro swine (and) 3 acres of meadow. It is worth 10 shillings. This land is held by Roger, and the Hundret (court) knows not how; and the queen had the soke.

\section{Hundret of Turestapla [Thurstable]}

Totham [(Little) Totham], which was held by Cola, (and) afterwards by Richard, as a manor and (as) 2 hides and 32 acres, is held of Hugh by Hugh the son of Mauger (Malgeri). Then 4 bordars; now 3. Then 4 serfs; now 5. Then 2 ploughs on the demesne; now I. (There is) wood(land) for 20 swine, pasture for 100 sheep, (and) 3 acres of meadow. Then I saltpan; now 3. Then 3 rounceys (runcini); now 2. Then 16 swine; now 20. Then 48 goats (sheep ${ }^{6}$ ); now 93 . (There are) now I 8 goats. It was then worth 40 shillings; and when received, Io shillings; it is now worth 40 shillings.

Golohangra [Goldhanger], which was held by Lewin, (and) afterwards by 'hagra,' as a manor and as I hide and 15 acres, is held of Hugh by the same (Hugh). ${ }^{10}$ Then as now (semper) I villein, and 6 bordars, and 4 serfs. Then I plough; now half (a plough). fo. $54 \mathrm{~b}$

(There is) wood(land) for 60 swine, 7 acres

6 Morant alleged this to be the manor of Hamstalls there, but his account of it gives no support to this view. The other and larger portion of Wix had also been Edith's, but had been given by her, since the Conquest, to Walter the Deacon (see p. $54^{8}$ below). As it was a four-hide manor, the total assessment of Wix was five hides.

7 i.e. the profits of jurisdiction.

8 The word is 'copre,' but it is clearly a scribal error for 'oves.'

- The reading is doubtful ; the MS. has 'Lewin' posthagra'; but in the previous entry we have the phrase 'Cola Post Ricardus,' which suggests the reading given in the text.

10 The result of this common tenure was that the two holdings became fused as the "manor of 'Totham with Goldhanger.' 


\section{A HISTORY OF ESSEX}

of meadow, and pasture for 60 sheep. Then half a saltpan; now one and a half. It was then worth 30 shillings; and when received, Io shillings; it is now worth 20 shillings. And 9 free men dwelt on (manserunt in) half a hide; and one man, a thegn (unus bomo tegnus) held 30 acres; and 2 other free men held ro acres; (in all this ${ }^{1}$ there was) then I plough; now half (a plough); (all this was) then worth 26 shillings and 8 pence; now 8 shillings. A certain knight of Hugh de Montfort, by name Hugh son of Mauger ${ }^{3}$ took (accepit) 15 acres from a free thegn ${ }^{3}$ and put them (misit) with his own land; and no one gave him livery, according to the Hundret (court), ${ }^{4}$ and so (the land) is in the King's hand. ${ }^{\circ}$

Toleshunta [Tolleshunt (Darcy ?)], which was held, in King Edward's time, by Ulsi as a manor and as half a hide and 30 acres, is held of Hugh by Humfrey. ${ }^{6}$ Then as now (semper) 2 bordars and I plough. (There is) wood(land) for 30 swine and $2 \frac{1}{2}$ acres of meadow. It is worth 20 shillings.

\section{THE LAND OF HAMO DAPIFER.7}

\section{Hundret of Berdestapla [Baretable]}

Ateleia [ ] which was held by Goti $^{8}$ of Harold, in King Edward's time, as a manor and as I hide, is held of Hamo by

1 All these holdings had evidently been annexed to the manor, but are valued apart from it as a whole. The entire passage is of interest for tenure and status.

2 This was the actual tenant of the manor, so that the phrase is an odd one here. It may have been inserted in another place on the original returns and added in Domesday Book to the Goldhanger entry by the scribe.

3 'Uno franco teigno.' A singular phrase, important for its use of 'francus' in the sense of 'free,' not 'French.'

4 'Non habuit liberatorem, sicut hundret testatur.'

3 This phrase also is suggestive of the passage having been inserted elsewhere on the original return (compare p. 566 below).

6 This may well have been the same Humfrey as the one who held at Tolleshunt Darcy under Ranulf Peverel.

7 Brother of Robert Fitz Hamon, whose daughter and heiress brought this fief to her husband the first Earl of Gloucester.

6 This name, which appears below as 'Gotild,' was that of a woman, although she is styled 'a free man,' under Little Wigborough (see also p. 503, note 2 , below.
Serlo. ${ }^{9}$ Then as now (semper) I plough, and I bordar, and I serf. It is worth 20 shillings.

\section{HUNDRET OF WITHAM}

Falcheburna [Faulkbourne], which was held by Turbern, ${ }^{10}$ in King Edward's time, as a manor and as $I \frac{1}{2}$ hides and $7 \frac{1}{2}$ acres, is held of Hamo by Ralf. ${ }^{9}$ Then as now (semper) 2 ploughs on the demesne. (There are) now 8 bordars. Then 6 serfs; now 3. (There are) 5 acres of meadow. Then I mill; now none (non). It is worth 50 shillings.

fo. 55

NutLeA [ Notley" ], which was held by Alestan, a freeman, as a manor and as half a hide and 30 acres, is held of Hamo by Ralf. Then as now (semper) I plough. (There is) now I bordar. Then 2 serfs; now I. (There is) an acre and a half of meadow. It is worth 30 shillings. There also (In eadem) the same (Ralf) holds 30 acres which were held by Alvric in King Edward's time ; then as now (semper) half a plough was there; and it is worth 5 shillings.

RaINEs [Rayne ${ }^{12}$ ] which was held by Goding as a manor and as half a hide, is held of Hamo by the same Ralf. Then as now (semper) I plough and I bordar. And (there-are) 2 acres of meadow. It is worth 20 shillings.

Bracchesteda [(Great) Braxted ${ }^{18}$ ], which was held, in King Edward's time, by Turbern ${ }^{14}$

9 There can be no doubt that the Serlo and Ralf who held so largely of Hamo Dapifer were both named 'de Marci.' Eighty years later (1166) we find Richard de Marcy and Ralf de Marcy holding respectively of the Earl of Glowcester four and three knights' fees (Red Book of the Exchequer, p. 290). And again, under John, Serlo de Marcy and Ralf de Marcy held respectively four knights and two knights of the Honour of Gloucester (see note 7 above) as part of the Honour of Ongar (ibid. p. 6ri I). Of these Serlo held $1 \frac{1}{2}$ fees 'in Roinges' (ibid. p. 505), that is in Roothing Marci, where his ancestor Ralf de Marci had held of Hamo Dapifer in 1086.

The family of Marci, so strangely confused by Morant with that of Merk, occurs frequently under Essex on the Pipe Rolls of Henry II., and Ralf de Marci was sheriff of the county in $1160-1$. The Marcis also held of the Honour of Boulogne.

10 See Introduction, p. 350.

I1 It is uncertain in which of the Notleys this manor lay.

12 This estate has not been identified.

13 This holding must have been Westhall there, which was returned in an Inq. p.m. of $7 \mathrm{Edw}$. II. as held of the Earl of Gloucester (see note 7).

14 Sce Introduction, p. 350. 


\section{THE HOLDERS OF LANDS}

as a manor and as 1 hide and 35 acres, is held (of Hamo) by Gudmund. Then 2 ploughs on the demesne; now I. Then I plough belonging to the men; now none. Then 3 villeins; now 1. Then 4 bordars; now 6 . Then 4 serfs; now 2. Then wood(land) for I 00 swine; now for 80 . There are 15 acres of meadow. Then 20 sheep; now 50. Then 16 swine; now II. It was then worth I00 shillings; and when he received it, 4 pounds; now 60 shillings.

\section{Hundret of Herlaua [Harlow]}

Siriceslea [Rise-Marses '], which was held by Harold as half a hide, in King Edward's time, as belonging to (ad) the manor of Hatfelde [Hatfield Broadoak] is held of Hamo by Ralf. Then I plough on the demesne; now a half. Then I serf; now I villein. (There is) wood(land) for 20 swine, (and) $3 \frac{1}{2}$ acres of meadow. It was then worth 10 shillings; now 7 .

\section{Hundret of Dommawa [Dunmow]}

Dommawa [Dunmow ${ }^{3}$ ], which was held, in King Edward's time, by I free man as 30 acres-and $7 \frac{1}{2}$ acres have been added in King William's time-is held of Hamo by Serlo. Then as now (semper) half a plough on the demesne, and 2 bordars. (There is) wood(land) for 40 swine, (and) 4 acres of meadow. It is worth 16 shillings.

Rodinges [Roding Marci ${ }^{4}$, which was held of Harold by Widi', in King Edward's time, as a manor and as $1 \frac{1}{2}$ hides, is now held

1 In Hatfield Broadoak. The suffix 'Marses' makes it practically certain that this must represent Ralf de Marci's holding in Hatfield. There was however a reputed manor called 'the Lea' in another part of Hatfeld, which Morant identified with the 'Bineslea' of Domesday owing to his curious error in supposing that the Hundred of - Thunreslau' lay in this part of the country.

2 This is the entry which definitely proves that 'Ralf' was Ralf de Marci (see p. 500, note 9, above).

3 The holding is too small to be identified.

- In Margaret Roding, but formerly a chapelry of Stondon Marci (see Morant ii. 189). It is now the manor of Marks in the south of Margaret Roding. I assume the identity from the suffix Marci being added to both the places, and from the fact that the name of Marks must have been derived from the family of Mark or Merc of whom Stondon also was held. It should, however, hardly be necessary to observe that the name of this family was wholly distinct from that of the Marcis with which Morant so strangely confused it. He further suggested that this manor of Marks might have been named 'from Marcellus who had it at the time of the general survey,' as tenant of Hamo by Serlo (as) I hide and I 5 acres." Then as now (semper) 2 ploughs on the demesne and I plough belonging to the men. Then 4 villeins; now 3. Then 2 bordars; now I1. Then 2 serfs; now I. (There is) wood(land) for 100 swine, (and) 16 acres of meadow. It was then worth 4 pounds; and when received 40 shillings; now 100 shillings. Of this land Eudo Dapifer holds 45 fo. $35 \mathrm{~b}$ acres, which Hamo claims. 6

\section{Hundret of Wensistrev [Winstree]}

Wigheberga [(Little) Wigborough], which was held, in King Edward's time, by Goti', a free man, as a manor and as 7 hides of land and 1 of wood(land), ${ }^{7}$ is held of Hamo by Viel (Vitalis). Then as now (semper) 2 ploughs on the demesne. Then 2 ploughs belonging to the men; now I. Then as now (semper) 3 villeins and I bordar. Then 6 serfs; now 4. (There is) pasture for 200 sheep. Then Io beasts (animalia); now 14. Then 60 sheep; now 260. Then as now (semper) 6 rounceys (runcini), and Io swine. Then as now it was worth 7 pounds. Of this land Bernard has taken away (tulit) the abovesaid hide of wood(land) and holds it (as belonging) to the fief of Baignard, ${ }^{8}$ and Engelric took away (tulit) half a hide of land, which is (now) held by Count Eustace. ${ }^{9}$

of William de Warenne. But his own footnotes show that William had nothing here; and the 'Marcellus' of whom he speaks was really a 'Martel' and a tenant of Geoffrey de Mandeville. Nor is there any evidence that he held this manor.

The above identification is confirmed by the cartulary of Tiltey Abbey in Lady Warwick's possession, in which is entered (fos. 32b-33) a quitclaim to Hamo de Marci of half a virgate held ' in villa de Roinges Serlonis de Marci de eodem Serlone.'

- The difference is accounted for by the fact that Eudo had taken away, as stated in the text, 45 acres. It will be observed that this reckoning again implies that the (geld) hide was composed of 120 (geld) acres.

6 See p. 492 above for Eudo's holdings in the Rodings.

7 Compare Introduction, p. 376.

8 It must have been annexed to the manor of Barnwalden (now Barn Hall) in Tolleshunt Knights, which was held by Bernard of (Ralf) Baignard 1086. No other manor in the neighbourhood satisfies this condition. The rare mention of a 'hide' of woodland should be observed. Domesday assigns to Barnwalden woodland for 200 swine.

- This must refer to Langenhoe, to which, it is recorded in Domesday, Engelric had added inter alia half a hide under King William. 


\section{A HISTORY OF ESSEX}

\section{Hundret of Clavelinga [Clavering]}

In Pherneham [Farnham ${ }^{1}$ ] Serlo holds of Hamo half a hide which was held by a free man in King Edward's time. It is worth 10 shillings.

\section{HUNDRET OF HidingFort [HinckFord]}

In STANBurne ${ }^{2}$ [Stambourne] and in TopesFELDe [Toppesfield] Hamo holds in demesne, as a manor, I hide which was held by Goti[ld] in King Edward's time. Then and afterwards 4 ploughs on the demesne; now 3 . Then as now (semper) 3 ploughs belonging to the men. (There are) 14 villeins, and so bordars, and 6 serfs. (There is) wood(land) for 40 swine, (and) I 5 acres of meadow. Then as now (semper) 3 rounceys (runcini). Then 24 beasts (animalia); now 13. Then 40 swine; now 20. Then 120 sheep; now 10o. (There are) 4 hives of bees. And 15 sokemen belong (adjacent) to this manor, and hold half a hide less Io acres, and have 3 ploughs; and 12 acres of meadow (are there), and 5 bordars. 'There is I 'arpent' of vineyard. ${ }^{3}$ This estate lay (terra fuit) in 2 manors in King Edward's time. Stanburna [Stambourne] was then worth 100 shillings; afterwards and now 6 pounds. And Topesfelda ['Toppesfield] was then worth 7 pounds; afterwards and now 8 pounds. Of this manor 5 knights (milites) hold 58 acres, and (this) is worth 20 shillings of the above amount (in eodem pretio). ${ }^{4}$

1 This small estate has not been identified.

8 The Record Commission's edition reads 'Scanburne.'

3 The text does not determine to which of these places this vineyard belonged, but a vineyard in Domesday usually implies the residence of a baron and belonged to it. The mention of the 5 knights suggests similarly that this was the head of Hamo's fief.

4 This is in several ways a curious and important entry. Stambourne and Toppesfield contain between them over 5,000 acres, and Hamo's holding comprised a valuable manor in each. Yet the whole is assessed only at 1 hide, an almost nominal amount. In Stambourne there were only two other holdings, making five-sixths of a hide, of Geoffrey de Mandeville's, valued at 80 or 90 shillings, while in Toppesfield there were three other holdings of 15 (geld) acres each, worth in all from $\ell_{4}$ 1os. od. to $\ell_{5} 5$ ros. od. Thus the whole assessment of the two parishes was only 2 hides 25 acres, though they were valued at the time of the Survey as worth $\oint_{0} 24$ a year. This is altogether abnormal.

It should be observed that Hamo's holding is spoken of both as 'terra' and 'manerium,' and that although it had but one holder under the Confessor it was then reckoned as two manors.

\section{HUNDRET OF WitBrictesherna [DENGie]}

Carseia [Northey (isle) ${ }^{5}$ ], which was held, in King Edward's time, by Turbern, a free man, as a manor and as 4 hides and 40 acres, is held of Hamo by Richard. Then 2 villeins; now 3 . Then as now (semper) 4 serfs and 2 ploughs on the demesne, and I plough belonging to the men. (There is) pasture for 60 sheep. It was then worth 60 shillings; now 4 pounds.

fo. 56

\section{Hundret of Angra [Ongar]}

Gernesteda [Greensted], which was held, in King Edward's time, by Gotild as a manor and as 2 hides, is held by Hamo in demesne. Then as now (semper) ro villeins. Then 4 bordars; now 9. Then 6 serfs; now 4 . Then 3 ploughs on the demesne; and when he received (it), 2 ; now 1 . Then and afterwards $5 \frac{1}{2}$ ploughs belonging to the men; now $3 \frac{1}{2}$. (There is) wood(land) for 400 swine, 16 acres of meadow, (and) now I mill. Then 2 rounceys (runcini); now I. Then 4 beasts (animalia); now 3 . Then 30 swine; now 14. (There are) now 40 goats and 20 sheep. It was then worth 4 pounds; and when he received (it), 40 shillings; it is now worth 100 shillings. Of this manor Serlo holds 40 acres, and (this) is worth 10 shillings of the above amount (in eodem pretio). There also (in eadem) 3 free men held half a hide and 45 acres; under them were then 10 bordars, (and) now 16; (and) then 3 serfs, and now 2 ; then as now (semper) $3 \frac{1}{2}$ ploughs (were there); wood(land) for 120 swine (is there, and) I 9 acres of meadow; it was then worth 35 shillings; now 60. Of this land Ralf holds half a hide and 5 acres, and it is worth 40 shillings of the above sum. ${ }^{6}$

\section{Astoca [Navestock ${ }^{7}$ ], which was held by}

5 This is nothing but a guess based on the fact that the adjacent island of 'Uveseia,' which had been similarly held by Turbern, was also held by 'Richard' of Hamo, was assessed at 4 hides and had pasture for 60 sheep. The two islands were in different parishes and Hundreds.

6 This is a somewhat confused passage, for it is not clear whether the holding of the 3 free men was valued as part of the main manor or not; nor, if it were not, is it clear of which of the two portions Ralf's holding formed part.

7 Morant suggested that 'Astoca' might be North Weald, which he could not identify in Domesday. But I make it to be part of Navestock, because Ralf de Marci is known to have held lands at Navestock which were claimed by the canons of St. Paul's (see my paper in Domesday Studies, pp. 


\section{THE HOLDERS OF LANDS}

Gotil as a manor and as 80 acres, in King Edward's time, is held of Hamo by the same (Ralf). Then 2 bordars; now 5. Then 1 plough; now none; but there could be (one) there. (There is) wood(land) for 50 swine, (and) 2 acres of meadow. It was then worth 12 shillings; and when he received (it), 8 shillings; now 15.

Kalenduna [Kelvedon (Hatch) ${ }^{1}$ ], which was held by Leueva as 1 hide and 45 acres and as I manor, is held of Hamo by Ralf. And Hamo says that he has that land as part of his fief (in suo foudo). Then 2 villeins; now 1. Then 2 bordars; now 7. Then 2 serfs; now 1. Then 2 ploughs on the demesne; now $1 \frac{1}{2}$. Then the men had I plough among them; now a half. (There is) wood(land) for 20 swine, (and) 17 acres of meadow. It was then worth 30 shillings; and when he received (it), 20 ; now 35 shillings.

Nortuna [Norton (Mandeville)], which was held by Gotil as a manor and as $t \frac{1}{2}$ hides and 15 acres, ${ }^{2}$ is held of Hamo by Wimund. Then 4 villeins; now 6 . Then as now (semper) 4 bordars and 4 serfs. Then 2 ploughs on the demesne; now 1. Then the men had among them I plough; now $1 \frac{1}{2}$. There is wood(land) for 200 swine, (and) 10 acres of meadow. Then as now (semper) 2 beasts (animalia). (There are) now 1 rouncey (runcinus), 40 sheep, and 20 goats. Then 16 swine; now 26. Then and afterwards it was worth 40 shillings; now 4 pounds.

\section{Hundret of Turestapla [Thurstable]}

Tотвнам [(Great) Totham], which was held by Turbert as I manor and as 5 hides in King Edward's time, is held of Hamo by Richard. Then ro villeins; now 9. Then

553-5), which suggests thas he held other land there. The presence or absence of the initial - $N$ ' is of little consequence in Domesday.

1 Kelvedon Hatch adjoins Navestock, and is separated to the north from Norton Mandeville (the subject of the next entry) by Stondon Marci (now corruptly 'Massey '). I believe this Stondon (which is said not to be mentioned in Domesday) was comprised in the above ' Kalenduna' entry. It is difficult to trace any succession to Hamo or his tenants at Kelvedon or Norton ; but this remark, one must add, applies also to Stondon, though its suffix 'Marci' seems decisive.

'This virtually identifies the 'Gotil,' 'Goti,' or 'Gotild' of these entries with the 'Godid quedem femina' who had given half a hide at Norton to the canons of St. Paul's since the coming of King William (see p. 443 above). fo. $56 b$

as now (semper) 16 bordars. Then 12 serfs; now 13. Then 4 ploughs on the demesne; now 3. Then as now (semper) 5 ploughs belonging to the men. There is wood(land) for 100 swine, (with) 16 acres of meadow, (and) 2 saltpans. Then as now (semper) 20 beasts (animalia), and 40 swine. Then 5 rounceys (runcini); now 2. Then 100 sheep; now 150. Then as now (semper) 40 goats. Then and afterwards it was worth 100 shillings; now 6 pounds. There also 8 free men held $1 \frac{1}{2}$ hides, which are held by the same Richard; then as now (semper) 2 ploughs (were there). (There are) 3 acres of meadow. It is worth 20 shillings.

Uveseia [Ovesey (isle)], which was held by Turb[ert] as a manor and as 4 hides in King Edward's time, is held (of Hamo) by the same Richard. Then I bordar; now none. Then as now (semper) 3 serfs. (There is) I fishery. There is pasture for 60 sheep. It is worth 60 shillings.

\section{XXVIIII. THE LAND OF HENRY DE FERRERIIS}

\section{Hundret of Dommawa [Dunmow]}

Tileteia [Tiltey], which was held, in King Edward's time, by Doding as a manor and as half a hide, ${ }^{3}$ is held by Henry in demesne. Then as now (semper) 2 ploughs on the demesne, and I plough belonging to the men. Then as now (semper) 3 villeins. Then 2 bordars; now 6 . Then 3 serfs; and now the same. (There are) 30 acres of meadow, (and) 20 acres of marsh." Now (there are) 40 beasts. It was then worth 100 shillings; now 7 pounds.

\section{Hundret of Hidingaforda [Hinckford]}

Stibinga [Stebbing], which was held by Siward as a manor and as 2 hides and 30 acres, is held by $\mathrm{H}[\mathrm{enry}]$ in demesne. Then and afterwards 2 ploughs on the demesne; now 3. Then the men had between them 4 ploughs; now $6 \frac{1}{3}$. Then 6 villeins; now 8. Then 16 bordars; now 33. Then 2 fo. 57

serfs; now 1. (There is) wood(land) for

3 This is an almost nominal assessment 25 in the case of Gestingthorpe (see p. 354 above).

4 The mention of ' maresc' is most exceptional. This marsh may have been caused by the two small streams which here flow into the Chelmer. 


\section{A HISTORY OF ESSEX}

I 50 swine, (and) 9 acres of meadow. When he received (it) there was a moiety of a mill; now none. Now as then (semper) I priest is there. Then 7 beasts (animalia), and 40 sheep, and 60 swine, and I rouncey (runcinus); now I 8 beasts, and I 40 sheep, and 80 swine, and $I$ rouncey. It was then worth Io pounds; now I2; and in King Edward's time it was all the same (totum similiter) ${ }^{1}$ and it was worth as .much (tantum) when received.

\section{HUNDRET OF Witbrictesherna [DEngIE]}

Stepla [Steeple], which was held by Bondi', a free man, as a manor and as $3 \frac{1}{2}$ hides in King Edward's time, is held by $\mathrm{H}$ [enry] in demesne. Then as now (semper) 2 bordars. Then 4 serfs; now 3. Then as now (semper) I plough on the demesne; and half a plough belonging to the men. 'Then 100 sheep; now I 30 . It is worth now as then (semper) 60 shillings.

\section{Hundret of Celmeresfort [Chelmsford]}

UDEHAM [Woodham (Ferrers)], which was held by Bundi' ${ }^{1}$ as I manor and as 14 hides, is held by $\mathrm{H}$ [enry] in demesne. Then as now (semper) 24 villeins. Then 8 bordars; now $3 \mathrm{I}$. Then 6 serfs; now 4 . Then as now (semper) 3 ploughs on the demesne, and 16 ploughs belonging to the men. (There is) wood(land) for 800 swine. Now (there is) I mill. Then he received ${ }^{3} 20$ beasts (animalia), and $I_{3}$ rounceys (runcinos), and 300 sheep, and 60 swine; now (there are) 28 beasts, I 5 rounceys, 300 sheep, and 100 swine, and 35 goats. It was then worth 20 pounds; now 28.

Cinga [Butsbury ${ }^{4}$, which was held by Bondi' as a manor and as $5 \frac{1}{2}$ hides, is held of Henry by his seneschal (dapifer). Then 6 villeins; now 4 . Then 8 bordars; now 12. Then 4 serfs; now 3. Then as now (semper) 2 ploughs on the demesne, and 4 ploughs belonging to the men. (There is) wood(land) for 500 swine, (and) pasture for 100 sheep. Then 20 beasts (animalia), and 50 swine, and 60 sheep; now 7 beasts, and 100 sheep, and 40 swine. Then as now (semper) it was worth 7 pounds.

1 This clause is very obscure.

2 This is the Bondig who occurs as his predecessor also in Berks, Oxon and Northants (see Introduction, p. 350 ).

3 This is an abnormal formula.

4 Formerly Ging-Joyberd-Laundry. fo. $57 \mathrm{~b}$

\section{THE LAND OF GEOFFREY DE MAGNA VILLA ${ }^{5}$}

\section{HUNDRET OF LAXENDENa [LEXDEN]}

Tera [(Marks) Tey ${ }^{6}$ ], which was held by Ulvric as a manor and as $I \frac{1}{2}$ hides and 20 acres in King Edward's time, is held by G[eoffrey] in demesne. Then I I bordars; now 15. Then as now (semper) 4 serfs and 2 ploughs on the demesne. 'Then the men had between them 3 ploughs; now $2 \frac{1}{2}$. (There is) wood(land) for roo swine, (and) 20 acres of meadow. Then G[eoffrey] received 7 250 sheep, and 8 beasts (animalia), and 6 calves (vit'), ${ }^{8}$ and 2 rounceys (runcinos), 28 swine, (and) 2 hives of bees; now (there are) 67 sheep, and 8 beasts, and 6 calves, and 2 rounceys, and $2 \mathrm{I}$ swine. There also (In eadem) 20 sokemen held $I \frac{1}{2}$ hides and $3 I$ acres; now that land is held by 30 sokemen; and they could not withdraw themselves (recedere) from that manor; ${ }^{9}$ now as then (semper) they have 3 ploughs; there are 6 acres of meadow. Then and when received (the whole) was worth 7 pounds; now 10. And there were there 3 free men holding 12 acres; but they did not belong to (non fuerunt de) that manor which G[eoffrey] has; but he himself vouches (to warranty) him who gave him livery of seisin (ipse revocat liberatorem) $;{ }^{10}$ now as then (semper) I plough is there; and it is worth 40 shillings.

\section{Hundret of Hangra [Ongar]}

SEnLEIa [Shelley], which was held by Levedai as a manor and as 80 acres, and was not of Ansgar's fief ${ }^{11}$ (feudo)-for (Levedai) was only (sed tantum fuit) his man ${ }^{12}$-is held of Geoffrey by Rainald. Then 4 villeins; now 5. (There are) now 5 bordars. Then 2 serfs; now 3 . Then and afterwards 2 ploughs on the demesne; now I. Then the

5 Better known as Geoffrey de Mandeville.

6 Alias Teye Maundeville.

7 This is an abnormal formula.

8 The mention of calves, for which Essex has been so famous since, is quite exceptional.

9 This is a noteworthy phrase, which is introduced to set on record their status before the Conquest. Its actual meaning, probably, is that they could not 'betake themselves elsewhere' without the lord's permission.

10 On vouching to warranty see Introduction, p. 412 .

11 Ansgar the staller was Geoffrey's recognized predecessor.

12 That is, he had only commended himself personally to Ansgar (see Introduction, p. 358 , and compare P. 505, note 3 , below). 


\section{THE HOLDERS OF LANDS}

men had between them 1 plough; now 2 . There is) wood(land) for 150 swine, (and) 20 acres of meadow. Then and afterwards it was worth 60 shillings; now 4 pounds.

RoInges [(Abbess) Roding ${ }^{1}$ ], which was held by Leuild ${ }^{2}$ as a manor and as 3 virgates, is held of G[eoffrey] by Geoffrey Martel. Then as now (semper) 1 villein and 2 bordars. Then I serf; now none. Then as now (semper) I plough on the demesne, and half a plough belonging to the men. (There is) wood(land) for 40 swine, (and) 15 acres of meadow. Then and afterwards it was worth 30 shillings; now 40. And this land, which is now held by G[eoffrey], was in (possession of) the abbey of Berchinges [Barking], as the Hundret (court) testifies, and (sed) he who held this land was only (tantum modo) the man of Geoffrey's predecessor, and had no power to put (mittere) this land in the possession of any one but the abbey (in aliquo loco nisi in abbatia. ${ }^{3}$ )

Hundret of Ceffeorda [Chafford]

Wochaduna [(South) Ockendon], which was held freely by Frebert, a thegn (Frebertus liber tainnus), as 1 manor and as $10 \frac{1}{2}$ hides and 20 acres, is held of G[eoffrey] by Turold; ro. 58

and Geoffrey has it by exchange (pro escangio) as he says. Then as now (semper) 3 villeins (and) 34 bordars. Then 3 serfs; now none. Then 2 ploughs on the demesne; now 3 . Then the men had 7 ploughs between them; now 8. (There is) wood(land) for 150 swine, 8 acres of meadow, pasture for 100 sheep, (and) now 1 mill. Then 5 beasts (animalia) and 18 sheep; now 18 beasts and I rouncey (runcinus), 35 swine, 220 sheep, (and) I hive

1 Morant, finding that this manor was subsequently held by Barking Abbey, assumed that it was so held in 1086, though not entered in Domesday, and that what Geoffrey held there was 'another manor,' namely Rookwood Hall (i. 1 37). But Mr. Chisenhale-Marsh, in his Domesday Book relating 10 Essex, rightly questioned this conclusion, pointing out that Barking Abbey probably regained this manor as a result of the very return here recorded. This is a point of some importance as bearing on the Survey and its results. It may be added that the Rookwood Hall manor was subsequently held, not of the heirs of Geoffrey de Mandeville, but of those of Aubrey de Vere, for, as Morant puts it, 'The lords paramount were the Earls of Oxford.'

- This was probably a woman's name (compare p. 512 below).

3 This passage is of some importance as drawing a clear distinction between the personal commendation of the holder and the right over the land itself. of bees. Then and when received it was worth 7 pounds; it is now worth 16 pounds. In this estate (terra) are (included) 13 sokemen who hold freely (libere) $8 \frac{1}{2}$ hides and 20 acres and have 12 bordars (under them); and they are farmed with the estate for 16 pounds. And there are also 40 acres and 4 bordars (who hold them ?).

\section{Hundret of Celmeresfort [Chelmsford]}

WALDHAM [(Great) Waltham], which was held by Ansgar as a manor and as 8 hides in King Edward's time, is beld by G[eoffrey] in demesne. Then as now (semfer) 72 villeins, and 28 bordars. Then 14 serfs; now 13. Then 6 ploughs on the demesne; now 5 . Then the men had between them 42 ploughs; now $36 .^{\circ}$ (There is) wood(land) for 1,200 swine, (and) 44 acres of meadow. Now as then (semper) there are 2 mills, and now 10 arpents (arpenni) of vineyard. ${ }^{6}$ Then 5 rounceys (runcini), 12 cows, 50 swine, and 80 goats; now 3 rounceys, II cows, ${ }^{7} 60$ swine, I 32 sheep, 7 goats, (and) 20 hives of bees. $^{8}$ It was then worth 50 pounds; now 6o. Of this manor Hubert holds 1 virgate, and (has) half a plough, and it is worth 5 shillings of the above amount (in eodem pretio); and Walter (holds) I virgate, and (has) half a plough, and it is worth 5 shillings of the above amount. Turchill (holds) I virgate, and (has) 2 bordars and half a plough, and it is worth 5 shillings of the above amount. ${ }^{9}$ And Walter (holds) 30 acres, and Turchill 30 acres, and Herbert 30 acres. $^{9}$

- 'Jacent ad hanc firmam de xvi libris.' This passage has a double value: first, as showing that the sum which this estate was valued as worth was really the annual rent (firma) received from it (see Introduction, p. 364); second, that the profits arising from the dues of these sokemen formed part of the total rent received from the estate.

b All these are large figures, but it must be remembered that Great Waltham, the whole of which is comprised in this and the two entries which follow, contains nearly 7,500 acres.

- The word 'now' should be obscrved, for it implies that this vincyard had been planted since the coming of the Normans. As a vineyard, in my opinion, implies a baron's residence, I infer from this passage that Geoffrey had already made Pleshey his castle.

7 Geoffrey had 7 cows on his adjoining manor of (High) Easter, so that he had around his castle 18 in all, an exceptionally large number.

8 See p. 509, note 6, below.

- Small holdings of this character generally imply the residence of a baron (see p. 484 , note 6 ). It is difficult to resist the impression that the three holdings of a virgate are here merely repeated as holdings of 30 acres. 


\section{A HISTORY OF ESSEX}

In WaLthaM [(Great) Waltham] Ulwin' held freely (libera), with the soke (cum soca), ${ }^{1}$ I hide and 50 acres. Roger holds (it) now of G[eoffrey] as a manor and as I hide and 50 acres (pro tantundem). Then as now (semper) 3 villeins. Then 4 bordars; now 6 . Then 2 ploughs on the demesne; now $I \frac{1}{2}$. Then as now (semper) I plough belonging to the men and I serf. (There are) 7 acres of meadow and I mill. It was then worth 40 shillings; now 60.

Cetham [Chatham ${ }^{2}$ ] was held by Edward as a manor and as 2 hides and 30 acres. Walter holds (it) now of Geoffrey for as much (pro tantundem). Then as now (semper) 2 villeins. Then 2 bordars; now 5. Then as now 6 serfs and 2 ploughs on the demesne, and I plough belonging to the men. (There is) wood(land) for 100 swine, (and) 6 acres of fo. $5^{8 b}$

meadow. Then and afterwards it was worth 40 shillings; now 60.

Pacinges [Patching ${ }^{3}$ ] was held, in King Edward's time, by the same Edward as a manor and as 2 hides. Now the same Walter holds (it) of G[eoffrey]. Then as now (semper) I serf, and I plough. (There is) wood(land) for 30 swine and 9 acres of meadow. It is worth 20 shillings.

Brumfelda [Broomfield] was held by Saulf as a manor and as 4 hides. Now the same Walter holds (it) of Geoffrey. Then as now (semper) 9 villeins. Then 4 bordars. ${ }^{4}$ Then 5 serfs; now 4. Then as now (semper) 2 ploughs on the demesne, and 4 ploughs belonging to the men. (There is) wood(land) for 50 swine and 14 acres of meadow. Then as now (semper) I mill (was there). Then and afterwards it was worth 100 shillings; now 6 pounds.

Cingehala [Chignal ${ }^{5}$ ] was held, in King Edward's time, by 3 free men as $\mathrm{r}$ hide and 15 acres. Now Richard holds (it) of G[eoffrey] as the same amount (pro tant'). Then 2 bordars; now 10. (There are) now 3 vil-

1 i.e. with the (right to the profits of jurisdiction. The phrase should be observed.

2 A manor in Great Waltham.

3 In Broomfield. This manor was probably absorbed in that of Broomfield Hall, in consequence of their being both held of Geoffrey by the same under-tenant.

4 Their number (if there were any) at the time of the Survey is not stated.

5 'This entry, with those which follow, comprises both the Chignals. leins. ${ }^{6}$ Then as now (semper) 3 serfs. Then and afterwards 2 ploughs on the demesne ; now I. Now the men have between them I plougl. ${ }^{8}$ (There is) wood(land) for 10 swine, (and) is acres of meadow. It was then worth 30 shillings; now 45.

Cingehala [Chignal] was held, in King Edward's time, by Godwine the deacon as a manor and as $1 \frac{1}{2}$ hides less 5 acres. Now Richard Gernet holds (it of Geoffrey) as a manor and as the same amount (pro tant'). Then as now (semper) I villein. Then I bordar; now 3. Then 3 serfs; now 2. Then as now (semper) I plough on the demesne. Then the men had I plough between them; now a half. (There is) wood(land) for 12 swine, (and) 16 acres of meadow. It was then worth 30 shillings; now 40.

There also (In eadem villa) Ulwin' held 45 acres in King Edward's time. Now Ralf holds (them) of G[eoffrey] as a manor and as the same amount (pro tant'). Then as now (semper), 3 bordars and I plough. And (there are) 3 acres of meadow. It is worth 10 shillings.

There also Lefsun' holds of G[eoffrey] I virgate, which was held by himself in King Edward's time; then as now (semper) I plough; and (there are) 5 acres of meadow; it is worth 5 shillings. And Leuric' held, and holds under Geoffrey, 30 acres; then half a plough; now none; (there are) 7 acres of meadow; it is worth 3 shillings. And Lewin' held and holds 15 acres; and (there are) 2 acres of meadow; it is worth 30 pence. And Alestan' holds now as then (semper) 10 acres; and (there are) 3 acres of meadow ; it is worth 2 shillings. ${ }^{9}$

6 The appearance of villeins at the time of the Survey where there had been none before is most exceptional and very suggestive in view of the fact that their number is the same as that of the "free men' by whom the land had been held, for the first entry in the Survey of Essex speaks of a free man who had become one of the villeins on the land he had held (p. 428 above).

7 'The scribe has written 'car' hom' d'nio' (or 'car hoin d 'nio ') instead of the normal 'car' in d'nio.' As his phrase cannot be construed, it is probably only a slip arising from confusion with the 'car' hom' formula.

8 The total number of ploughs remained the same, but the land was now worked as a manor and divided accordingly between the lord and his 'men.'

9 These are among the few cases of small English holders being allowed to retain their lands as undertenants of the conquerors (see Introduction p. $\mathbf{3 5 5}$, note 3 ). 


\section{THE HOLDERS OF LANDS}

In Massebirig [Mashbury] Eduin' held, and holds under G[eoffrey], 45 acres. Then as now (semper) 3 bordars. Then half a plough ; now none. It is worth 10 shillings. ${ }^{1}$

fo. 59

Danengeb[ER]ia [Danbury] was held by Arling' as a manor and as $2 \frac{1}{2}$ hides. Now William (holds it) of Geoffrey as the same amount (pro tant'). Then as now (semper) I villein. Then 3 bordars; now 9. Then 4 serfs; now 1. Then as now (semper) I plough on the demesne, and I plough belonging to the men. (There is) wood(land) for 100 swine, (and) 16 acres of meadow. It was then worth 30 shillings; now 40.

In Cingehala [Chignal ' ${ }^{1}$ Sauin' the priest held 15 acres. Now Richard (holds them) of G[eoffrey]. Then half a plough ; now nothing. ${ }^{2}$ It is worth 5 shillings.

There also (In eadem villa) Erfin' held i 5 acres. Now the same $R$ (ichard holds them of Geoffrey. There are) 2 acres of meadow; it is worth 3 shillings. The abovesaid (Sauin' and Erfin') were free to that extent (liberi ita) that they could sell the land with its sac and soke to whom (quo) they would, as the Hundret (court) bears witness.

Legra [Lees ${ }^{3}$ ] was held by Ansgar as a manor and as $2 \frac{1}{2}$ hides and 15 acres. Now W. (holds it) of G[eoffrey] as the same amount (pro tant'). Then 4 villeins; now 2. Then 8 bordars; now 12. Then 3 serfs; now 4. Then 2 ploughs on the demesne; now 3. Then as now (semper) 2 ploughs belonging to the men. (There is) wood(land) for 40 swine, (and) 6 acres of meadow. Then as now (semper) I mill. (There are) now 10 beasts, 10 swine, (and) 10o sheep. Then and afterwards it was worth 4 pounds; now 4 pounds and 10 shillings. And this (Istud queque) manor was given by Esgar to Harold in King Edward's time, and Harold in turn (iterum) gave it to a housccarl (buscarlo) of his, Scalpin by name, ${ }^{5}$

1 See p. 506, note 9, above.

2 i.e. no oxen.

3 There seems to be no reason to doubt this identification, for Great Lees, at any rate, was held of Geoffrey's heirs. But, as a name, 'Legra' was the Domesday equivalent of Layer. It is, however, also found in Domesday as representing Leigh on the Thames (see p. 532).

- This is the same name 25 'Ansgar' just before, which affords an excellent illustration of the looseness of Domesday in the spelling of names.

- See Introduction, p. 352. and this Scalpin gave it in dower to his wife in the sight of two men, namely Roger the marshal ${ }^{6}$ and a certain Englishman, and the (men of the) Hundret testify that they heard Scalpin's right acknowledged. ${ }^{7}$ And after the king came into this land Scalpin (ipse) held (it) until he went where he died, (namely), in Evreux (ebroica), in outlawry.

Keuentuna [Kewton (Hall) $!^{9}$ ] was held by Toli as a manor and as 2 hides and I virgate. Now Osbert (holds it) of G[eoffrey] as acquired by exchange (pro suo escangio), he says. Then as now (semper) 1 villein. Then 6 bordars; now 4. Then as now (semper) 3 serfs and 2 ploughs on the demesne. Then the men had I plough between them; now a half. There are 18 acres of meadow. Then as now (semper) 1 mill. Then 2 cows, 13 sheep, (and) 12 swine; now 8 beasts (animalia), 32 sheep, 20 swinc, 14 goats, 2 rounceys (runcini), (and) 5 hives of bees. It was then worth 40 shillings; now 60.

\section{Hundret of Tendringa [Tendring]}

Mosa [Moze ${ }^{10}$ ] was held by Levesun' as a manor and as 4 hides. Now Geoffrey (holds it) in demesne. Then as now (semper) 14 villeins. (There arc) now I 3 bordars. fo. $59 \mathrm{~b}$

Then 13 serfs; ${ }^{11}$ and when he received the manor II; now 3. Then and afterwards 4 ploughs on the demesne; now 2. Then and afterwards 6 ploughs belonging to the men; now 4. There is wood(land) for 150 swine, (and) $6 \frac{1}{2}$ acres of meadow. Then I mill; now none. (There is) pasture for 150 sheep. (There are) 3 saltpans. And the king gave this manor to $\mathrm{G}$ [coffrey] during

6 He had a few small holdings in the county as tenant-in-chicf (p. 558 below).

7 'audicrunt recognoscere Scalpino.' The phrase is a difficult one to translate.

${ }_{6} \mathrm{Mr}$. Freeman rendered this as York, but the mention of outlawry seems to make Evreux (Ebroica) more likely; and the form of the name is nearer to it than to York.

- A manor in Borcham. I have given in the Introduction (p. 390) my reasons for believing this to be the right identification, and not, $2 s$ Morant asserted, Camseys in Felsted.

10 Now combined with Beaumont as one parish.

11 The large number of serfs should be observed. At the time of the Survey they had been reduced from 13 to 3 , and no fewer than 13 bordars had been introduced, a typical and suggestive change. 


\section{A HISTORY OF ESSEX}

his stay in London (quando remansit Londonia). ${ }^{1}$ Then 2 rounceys (runcini), and 9 beasts (animalia), I 80 sheep, (and) I 4 swine; now 2 rounceys, I 4 beasts, I 5 swine, I60 sheep, 50 goats, (and) 3 hives of bees. It was then worth 8 pounds; and when received, the same; it is now worth 9 pounds.

Frientuna [Frinton], which was held by Levesun' as a manor and as $3 \frac{1}{2}$ hides, is held of G[eoffrey] by Renelm'.2 'Then and afterwards 3 villeins; now 1 . Then and afterwards 4 serfs; now 3 . Then as now 2 ploughs on the demesne. And then (there were) 2 ploughs belonging to the men; and when (the manor was) received, I $\frac{1}{2}$; now only a half. (There are) $3 \frac{1}{2}$ acres of meadow, (with) pasture for 50 sheep. Then 49 sheep ; now 2 rounceys (runcini), and 4 swine and 40 sheep. It was then and afterwards worth 7 pounds; now 4 .

Erleia [Ardleigh ${ }^{3}$ ], which was held by 2 free men, Bund' and Alric', brothers, who (sed) could not withdraw themselves (recedere) without permission of that Elfgar (licentia illius Algari ${ }^{4}$ ), as 2 hides and as 2 manors, is held of $\mathrm{G}$ [eoffrey] by William. Then as now (semper) 5 villeins and 8 bordars. Then I serf; now none. Then as now (semper) 2 ploughs on the demesne. Then and afterwards 5 ploughs belonging to the men; now 4. (There is) wood(land) for Ioo swine, 12 acres of meadow, (and) pasture for 50 sheep. Then and afterwards it was worth 4 pounds; now 40 shillings.

In the Hundret of Berdestapla [Barstable] ${ }^{5}$ there were, in King Edward's time, 6 free men, whom G[eoffrey] has annexed to the wrong of (invasit super) King Willam; ${ }^{B}$ they held (tenentes) 12 hides of land, which are held of Geoffrey (eo) by 5 knights. Then as now (semper) $9 \frac{1}{2}$ ploughs. Then I villein; now none. Then 10 bordars; now 36 .

$1 \mathrm{Mr}$. Freeman considered that these words referred to 'the very first days of William's reign,' immediately after his coronation (Norman Conquest, iv. 19).

2 As Frinton and Shelley were held together of Geoffrey's heir, the Earl of Hereford, who died in 1298 , it is highly probable that this Renelm' was the Rainald' who held of Geoffrey at Shelley (see p. 504 above).

3 i.e. the manor of Martells Hall there.

4 This phrase appears inexplicable.

5 See Introduction (p. 374) for proof that this estate was East 'Tilbury on the Thames.

6 i.e. they ought to have appeared among the king's own possessions (see Introduction, p. 354).
Then I 4 serfs; now 7. Then wood(land) for 100 swine; now for 50. (There is) pasture for 300 sheep, 10 acres of meadow, (and) I fishery. Of these I 2 hides Ravengar took away (tulit) 12 acres of land and added them (apposuit) to his own fief. ${ }^{7}$ And Suen' took away thence (tulit) 30 acres, and put them in his manor of Tiliberia [(West) Tilbury]. The whole together was then worth 7 pounds, and now the same.

\section{HUNDRET OF WITHAM}

Nutrea [(Black) Notley], which was held by Esgar $^{8}$ as a manor and as $\mathrm{I} \frac{1}{2}$ hides and 45 acres, is held of G[eoffrey] by Walter. Then fo. 60

as now (semper) 2 ploughs on the demesne, and 4 ploughs belonging to the men. Then as now (semper) Io villeins, and 5 bordars, and 4 serfs. (There is) wood(land) for 100 swine, (and) now I mill. And (there are) 2 free men with 40 acres; and concerning them he vouches (clamat) the king to warranty. ${ }^{9}$ Then 6 beasts (animalia), and I rouncey (runcinus), and 12 swine, (and) 60 sheep; now 8 beasts, 16 swine, Ioo sheep, (and) I rouncey. It was then worth 100 shillings; now 6 pounds.

RetLeIa [Ridley (Hall) ${ }^{10}$ ], which was held by Esgar ${ }^{8}$ as a manor and as I hide in King Edward's time, is held of G[eoffrey] by Walter. Then as now (semper) I plough on the demesne, and half a plough belonging to the men. (There are) now 3 bordars. Then 3 serfs ; now I. (There is) wood(land) for 10 swine, (and) 4 acres of meadow. To this estate used to belong (terre adjacebant), in King Edward's time, 30 acres, of which G[eoffrey] de Magnavilla has 20 acres, and Richard son of Count Gilbert ro acres; but the Hundret (court) bears witness that the whole rightly belongs to Geoffrey's estate (terram). The whole (manor) together is worth 30 shillings.

\section{Hundret of Herlaua [Harlow] \\ HaLINGERERIA [(Little) Hallingbury $\left.{ }^{1}\right]$,}

7 Domesday accuses him of similar conduct at Wickford, Ramsden and Bulphan. He seems to have been no longer in possession at the time of the Survey.

8 i.e. Ansgar the staller.

9 Compare Introduction, p. 413.

10 A manor in Terling.

11 i.e. the manor of Monkbury there. This identification is well ascertained, for Geoffrey Martel gave a hide of land at 'Halyngbury,' with Geoffrey de Mandeville's consent, to Bermondsey 


\section{THE HOLDERS OF LANDS}

which was held by Esgar as a manor and as I hide in King Edward's time, is held of $\mathrm{G}$ [eoffrey] by Martel. Then 2 ploughs on the demesne; now I. Then I priest and I villein with (de) 20 acres which belonged (attinebant) to the church; now they do not belong (sunt) to the church. (There are) now 4 bordars. Then 3 serfs; now 2. (There is) wood(land) for 100 swine, 20 acres of meadow, (and) now a moiety of a mill. ${ }^{1}$ Then as now (semper) it was worth 40 shillings.

Matcinga [Matching ] was held by Esgar as a manor and as 40 acres, which (manor) $\mathrm{G}$ [eoffrey] holds in demesne. Then as now (semper) I plough. Then I serf; now none. (There is) wood(land) for ro swine, (and) 3 acres of meadow. It is worth 10 shillings.

Hallingeberia [Hallingbury ${ }^{3}$ ], which was held, in King Edward's time, by Godid, a free woman, as a manor and as half a hide less 8 acres, is held of G[eoffrey] by Hugh. Then half a plough; now none. Then 2 villeins; now none. There are 5 acres of meadow. It is worth 5 shillings.

\section{Hundret of Dommawa [Dunmow]}

Estra [(High) Easter] was held by Esgar, in King Edward's time, as a manor and as 2 hides. Now G[eoffrey] (holds it) in demesne. Then as now (semper) 4 ploughs on the demesne, and 12 ploughs belonging to the men. Then 46 villeins; now 47 . Then 14 bordars; now 33. Then as now (semper) 9 serfs. (There is) wood(land) for 600 swinc, and 30 acres of meadow. And a fifth plough could be employed (fieri) on the demesne. fo. $60 \mathrm{~b}$

Then 3 rounceys (runcini), and 7 beasts (animalia), and 60 swine, and 60 sheep, (and) 30

Abbey in 1093. It was from the monks of Bermondsey that the manor derived its name. It may safely be inferred from this gift that the "Martel" of the text was the 'Geoffrey Martel' who held of Geoffrey de Mandeville at Abbess Roding (see above). Ralf Baignard is similarly spoken of sometimes as 'Baignard' only.

1 As there is a similar entry under the manor of Little Hallingbury Hall, it would seem that a mill had been erected here under the Conqueror, and a moiety of it assigned to each of the two manors.

i.c. the manor of Stock $\mathrm{H}_{2}$ ll there. ful.

3 The identity of this small estate seems doubt-

The very low hidation of this great and valuable manor should be observed. It appears to have included Pleshey (see Introduction, P. 343). goats, (and) 10 hives of bees. Now 3 rounceys, and 7 cows, $^{5} 27$ swine, 50 sheep, and 4 goats, and 17 hives of bees. ${ }^{6}$ Then and afterwards it was worth 20 pounds ; now $30 .^{7}$

To this manor belong now as then (adjacent semper) 6 sokemen with $(d e)$ I $\frac{1}{2}$ hides. Then 2 ploughs; now 1 ; (there are) now 3 bordars; ${ }^{8}$ (there are) 8 acres of meadow; it was then worth 20 shillings; now 30.

There also belong (adjacent) to this manor 2 hides and 1 virgate which were held by 2 sokemen in King Edward's time, (and) in which there are now as then (semper) 4 ploughs on the demesne, and $1 \frac{1}{2}$ ploughs belonging to the men. Then 8 villeins; now 7. Then 6 bordars; now 7. Then as now (semper) 3 serfs. (There is) wood(land) for 60 swine, (and) 24 acres of meadow. Then and afterwards it was worth 100 shillings; now 10 pounds. This is held of Geoffrey by 4 knights.

And there belongs further (adbue jacet) to this manor half a hide which used to belong to the church of the manor in King Edward's time, and which (eam) is now held of G[eoffrey] by Gutbert. Then as now (semper) I plough. Then I bordar; now 3 ; and (there is) I serf. (There is) wood(land) for 20 swine, (and) 5 acres of meadow. It was then worth 20 shillings; now 30.

And this abovesaid manor is claimed by the Abbot of Ely, and the Hundret (court) testifies that it was in (possession of) the abbey in King Edward's time, but (that) Ansgar held this manor on that day on which King Edward was alive and dead. ${ }^{\circ}$

5 Here the cows seem to represent the "animalia' mentioned just before.

6 The hives had here increased from 10 to 17, and on his adjoining manor of Great Waltham from none to 20 , giving on the whole estate an increase from 10 to 37 . It is worth noting that on the great manor of (Saffron) Walden, his other seat in the county, the hives had increased from 4 to 30 .

7 Here is an increase in value of 50 per cent. with no increase in ploughs and a slight decrease in the live stock.

8 This implics that these sokemen had tilled their own land and had no peasants under them.

9 i.c. on the day of his death. For the abbot's claim to this manor see Liber Eliensis (Ed. Anglia Christiana Society), pp. 216-8. The abbey alleged that Ansgar the staller had seized this manor, that Abbot Wulfric and the monks appealed to King Edward in vain, and that they were ultimately obliged to grant it to Ansgar for his life. As in other cases, his Norman successor took possession of all the land he had held by whatever title. 


\section{A HISTORY OF ESSEX}

Niwetuna [Newton (Hall) ${ }^{1}$ ], which was held by Ulvric cawam ${ }^{2}$ as a manor and as 2 hides and I virgate in King Edward's time, is held of G[eoffrey] by Hugh de Berners [Berneris]. Then 2 ploughs on the demesne; now I $\frac{1}{2}$. Then as now (semper) I plough belonging to the men, and 5 villeins. Then I bordar; now 5. Then as now (semper) 2 serfs. (There is) wood(land) for 160 swine, (and) 12 acres of meadow. It was then worth 60 shillings; and when received, 40 shillings; now 4 pounds.

Bernestuna [Barnston ${ }^{3}$ ], which was held by Ulwin' as a manor and as 2 hides and 30 acres in King Edward's time, is held (of Geoffrey) by the same (Hugh). Then as now (semper) 2 ploughs on the demesne, and 3 ploughs belonging to the men. Then 6 villeins; now 7. Then 5 bordars; now 7 . Then as now (semper) 2 serfs. (There is) wood(land) for 200 swine, (and) 20 acres of meadow. It was then worth 4 pounds; now 100 shillings; and when received, the same.

Rodinges [(Berners) Roding], which was held by Ulvric as a manor and as $2 \frac{1}{2}$ hides in King Edward's time, is held (of Geoffrey) by the same (Hugh). Then as now (semper) 2 ploughs on the demesne, and $1 \frac{1}{2}$ ploughs belonging to the men. Then as now (semper) 4 villeins, and 3 bordars, and 4 serfs. (There fo. $6 x$

is) wood(land) for 100 swine, (and) 27 acres of meadow. Then as now (semper) 1 mill. Then and afterwards it was worth Ioo shillings; now 7 pounds. And the king commanded, through Robert. d'Oilli (de Oilleio) that Hugh should hold these 3 manors of Geoffrey de Magna villa if Geoffrey could prove that they belonged (ea deratiocinari) to his fief; and before Geoffrey proved that they belonged to his fief, Hugh held them of Geoffrey."

\section{Alferestuna [Bigods ${ }^{5}$ ], which Ansgar}

1 A manor in Great Dunmow.

2 The form of this name is very doubtful.

3 It has naturally been suggested that the place derived its name from Hugh de Berners, its holder. But this, of course, is only possible if it had been given a fresh name since the Conquest.

4 Hugh evidently claimed to hold them in capite, but came to a compromise with Geoffrcy. He held land under the Bishop of London at Stepney.

5 In Great Dunmow. This identity is clearly proved by entries in the Red Book of the Exchequer (p. 804) and the Testa de Nevill (pp. 266, 272), which show us Bartholomew le Bigod holding at held as 1 manor and as 4 hides and 10 acres in King Edward's time, is held of G[eoffrey] by Martell'. ${ }^{6}$ Then as now (semper) 3 ploughs on the demesne, and 2 ploughs belonging to the men. Then II villeins; now 7. Then 6 bordars; now 24 . Then 6 serfs; now 4. (There was) then wood(land) for 400 swine; now for 350 . (There are) 36 acres of meadow. Then as now (semper) 1 mill. Then and afterwards it was worth 7 pounds; now 10 pounds.

Dommawa [(Little) Dunmow $\left.{ }^{7}\right]$, which was held by the same Ansgar as a manor and as $I \frac{1}{2}$ hides in King Edward's time, is held of G[eoffrey] by the same (Martell'). Then as now 2 ploughs on the demesne, and 2 ploughs belonging to the men. Then 13 villeins; now 5. Then 7 bordars; now 6. Then I serf ; now 3. (There is) wood(land) for 200 swine, (and) 26 acres of meadow. It was then worth 100 shillings; now 7 pounds.

ScELGA [Shellow (Bowells)], which was held by $A\left[\right.$ nsgar] as a manor and as $1 \frac{1}{2}$ hides in King Edward's time, is held of G[eoffrey] by Lambert. ${ }^{8}$ Then as now (semper) 2 ploughs on the demesne. Then 2 villeins; now 1 . Then 5 bordars; now 8 . Then 2 serfs; now I. (There is) wood(land) for 150 swine, (and) 10 acres of meadow. (There are) 3 beasts (animalia), 3 swine, 25 sheep, (and) now I hive (vasa) of bees. Then and afterwards it was worth 40 shillings; now $600^{\circ}$

'Alferstone,' which had belonged to the Count of St. Pol, and which is strangely pronounced by the editor of the Red Book to be Alphamstone. The Bigod family gave its present name to the estate.

6 See p. 508, note 11 , above.

7 Morant assigned this entry to the manor of Martels in Great Dunmow, but the Testa and Red $B o o k$, as cited above, show that the manors held by 'Martell' descended together and expressly place this one in 'Little' Dunmow. The actual manor seems to have been South Hall (on the Little Dunmow side of Great Dunmow, near Martels

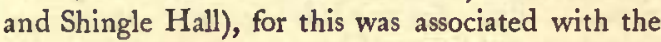
Count of St. Pol.

8 This was probably Lambert ' de Buelle,' from whose family the place derived its suffix. For, eighty years later (I 166), a Lambert de Buelle is found holding one knight's fee of Geoffrey's greatgrandson (Red Book, p. 346). The earliest mention of the family known to Morant was in 39 Hen. III. (1 $254-5)$.

9 Here is an increase in value of 50 per cent with no increase in ploughs and a slight decrease in the live stock. 


\section{THE HOLDERS OF LANDS}

Scelga [Shellow (Bowells)], which was held of Harold, in King Edward's time, by Ulvric, a free man, as a manor and as 2 hides, is held by Geoffrey in demesne. Then as now (semper) 2 ploughs on the demesne. Then I plough belonging to the men; now a half. Then 2 villeins; now 1 . Then 2 bordars; now 4 . Then 4 serfs; now 6 . (There is) wood(land) for 150 swine, (and) 12 acres of meadow. And I more plough could be employed (feri). It was then worth 4 pounds; now 100 shillings. To this estate belongs (terre adjacet) half a hide of land, which is held now as then (semper) by I sokeman; then I plough on the demesne; now a half; then as now (semper) I bordar; and there are $1 \frac{1}{2}$ acres of meadow; and half a plough could be added to the stock (restaurari); it is worth 10 shillings.

fo. 6 tb

Rodinges [(White) Roding '], which Ansgar held as a manor and as 2 hides in King Edward's time, is held of Geoffrey by (Geoffrey ?) Martell'. Then as now (semper) 2 ploughs on the demesne. Then 3 ploughs belonging to the men; now 2 ; and $a$ third could be added to the stock (restaurari). Then 6 villeins; now 8 . Then I bordar; now 5 . Then I serf; now none. (There is) wood(land) for 20 swine, (and) 20 acres of meadow. Then and afterwards it was worth 100 shillings; now 6 pounds.

Dommawa [Dunmow ${ }^{\text {? }}$, which was held by the same $A$ [nsgar] as half a hide and 15 acres in King Edward's time, is held (of Geoffrey) by William. Then as now (semper) I plough on the demesne. Then 4 villeins; now 1 ; and 4 bordars. (There is) wood(land) for 50 swine, (and) 16 acres of meadow. Then and afterwards it was worth 20 shillings; now $60 .^{3}$

Estanes [Easton ${ }^{4}$ ], which was held by I

1 i.e. the manor of Maskelsbury there. This identity is proved absolutely, not only by Maskelsbury, like (Geoffrey) Martel's manors at Bigods and Dunmow (see above), descending to the count of St. Pol, but by the Tessa de Nevill and Red Book of the Exchequer (see note above), where the count's holding is placed in 'Alba Roynge.' Morant wrongly identified the 'Rodinges' of the text as Marks in Margaret Roding (ii. 473).

2 Possibly, as Morant held, Shingle Hall in Great Dunmow, which was afterwards held of Bohun.

3 There seems to be nothing to account for this great rise.

- The identity of this small estate has not been ascertained. free man as a manor and as half a hide in King Edward's time, is held of G[eoffrey] by Richard. Then as now (semper) I plough on the demesne. Then I serf; now I bordar. There are 12 acres of meadow. Then and afterwards it was worth 10 shillings; now 30.6

Chenefelda [(Little) Canfield $\left.{ }^{\circ}\right]$, which was held by $A[$ [nsgar] as a manor and as half a hide and 16 acres in King Edward's time, is held of $\mathrm{G}$ [eoffrey] by Richard. Then 2 ploughs on the demesne; now 1. (There is) now I plough belonging to the men, (with) 2 villeins. Then 8 bordars; now 4. (There is) wood(land) for 30 swine, (and) 16 acres of meadow. It was then worth 40 shillings; and when received, the same; now 60.

Rornges [Roding 7], which was held by $A$ [nsgar] as a manor and as 2 hides less 10 acres in King Edward's time, is held of $\mathrm{G}$ [coffrey] by Rainalm. Then as now (semper) 2 ploughs on the demesne. (There are) now 8 bordars. Then as now (semper) 2 serfs. (There is) wood(land) for 20 swine, (and) 32 acres of meadow. Then and afterwards it was worth 60 shillings; now 100. And I plough more (adhuc) could be added to the stock (restaurari). To this estate (terre) have been added 10 acres which were held by I free man in King Edward's time; and now the whole Hundret (court) testifies that they (are) of King William's demesne.

Rodinges [Roding ${ }^{8}$ ], which was held by $I$ free man as a manor and as I hide and 3 virgates in King Edward's time, is held (of Geoffrey) by William. Half of this land owed soke to Ansgar, and the other half was free and was given by the king to Geoffrey, $^{8}$ as his men say. Then $1 \frac{1}{2}$

6 Here again, as in the entry preceding, the value has tripled for no apparent reason; and the tenant was different.

$B$ i.e. the manor of Langthorns there, which, as Morant points out, was afterwards held of the Bohuns.

7 The identity of these two estates seems doubtful.

8 ' Hec terra dimidia reddebat socam Ansgaro, et altera pars erat libera, quam rex dedit G.' This is a difficult but important passage as bearing on 'soke' and on the meaning of the word 'libera.' Its gist appears to be that Geoffrey had obtained half of it as Ansgar's recognized successor and the other half by special gift of the Crown. It should be observed that the whole estate had been held by one man and 'as a manor,' although the tenure of its two portions thus differed. 


\section{A HISTORY OF ESSEX}

ploughs on the demesne; now I. (There is) now I plough belonging to the men. Then as now (semper) 4 villeins. (There are) now 2 bordars. Then 2 serfs; now none; and none (nec) when he received (it). (There is) wood(land) for 30 swine, (and) 16 acres of meadow. Then and afterwards it fo. 62

was worth 40 shillings; now 4 pounds.

SCElga [Shellow (Bowells)], which was held by I free man as 35 acres in King Edward's time, is held of G[eoffrey] by William. (There is) wood(land) for 20 swine, (and) 4 acres of meadow. It was then worth 5 shillings; now IO. This estate (terra) belonged to Rodinges [Roding], ${ }^{1}$ a manor of Eudo Dapifer, in King Edward's time, and the Abbot of Ely claims, with the Hundret (court) as his witness (teste bundret), both the estate (terram) and the manor of Rodinges.

In Dommaua [Dunmow] Geoffrey holds in demesne 30 acres, which were held by a sokeman of Ansgar. Then as now (semper) half a plough. Then I bordar; now 3 . (There is) wood(land) for 10 swine, (and) 4 acres of meadow. It was then worth 7 shillings; now 10.

Rodinges [(White) Roding ${ }^{1}$ ], which was held, in King Edward's time, by Ansgar, and by a certain woman, Leuid', under Ansgar, as half a hide, is held (of Geoffrey) by (Geoffrey ?) Martell'. (There are) 4 acres of meadow. It was then worth 10 shillings; now 12.

\section{Hundret of Witbrictesherna [Dengie]}

Fenne [Stow Maries ? '], which was held by Friebern, a free man, in King Edward's time, as a manor and as 4 hides in King Edward's time, ${ }^{3}$ is held of G[eoffrey] by Hugh. Then as now (semper) 4 villeins. Then 2 bordars; now 7. Then 2 serfs; now none. Then as now (semper) 2 ploughs on the demesne. Then I plough belonging to the men; now a half. (There is) wood(land) for 40 swine, (and) pasture for 30 sheep. Now as then (semper) it is worth 60 shillings. The same Hugh has also I hide which was held by a free man (and was)

1 See p. 492, and p. 505, note 2, above.

2 See Introduction, p. 394. This is a duplicate entry (ibid p. 410).

3 These words are repeated as above in the MS. worth 20 shillings. And he also (Idem) has 37 acres, which were held by I free man; then half a plough (was there, and) now none ; it is worth 5 shillings.

\section{HUNDRET OF UdELESFORDA [UTTLESFORd]}

Waledana [(Saffron) Walden], which was held by Ansgar as a manor and as $19 \frac{1}{2}$ hides in King Edward's time, is held by G[eoffrey] in demesne. Then and afterwards 8 ploughs on the demesne; now IO. Then as now (semper) 22 ploughs belonging to the men. Then and afterwards 66 villeins; now 46 . Then and afterwards 17 bordars; now 40. Then and afterwards 16 serfs; now 20 Then and afterwards (there was) wood(land) for 1,000 swine; now for 800 . And (there are) 80 acres of meadow. Then as now (semper) I mill. To this manor there used to belong, in King Edward's time, I3 sokemen-(there are) now I 4-holding $6 \frac{1}{2}$ hides; fo. $62 \mathrm{~b}$

then and afterwards $8 \frac{1}{2}$ ploughs (were there); now 8 ; then and afterwards 10 bordars; now 14; then and afterwards (they had) wood(land) for 50 swine; now for 30 ; (there are) 20 acres of meadow, (and) the third part of a mill. Then 6 rounceys (runcini), II beasts (animalia), 200 sheep, 110 swine, 40 goats, (and) 4 hives of bees; now 9 rounceys, Io beasts, 243 sheep, 100 swine, 20 goats, (and) 30 hives of bees. Then and afterwards it was worth 36 pounds ; it is now worth 50 pounds.

Of this manor Odo holds I hide and I virgate, and Renald' I hide less I 2 acres; and 2 ploughs (are there), and I 3 bordars; and (this) is worth 50 shillings in the above valuation (in eodem pretio). ${ }^{4}$

Cishella [(Great) Chishall $\left.{ }^{5}\right]$, which was held by Ulfeih, a free man, as a manor and as $2 \frac{1}{2}$ hides in King Edward's time, is held of G[eoffrey] by William Cardon. ${ }^{6}$ Then 3 ploughs on the demesne; afterwards and now 2. Then 3 ploughs belonging to the men; afterwards and now none. Then and afterwards 9 villeins; now none. Then as

4 This great and valuable manor was the seat of the other Mandeville castle (see p. 301 above). Here again we have two small holdings of Norman followers, pointing to a baron's residence; and, as at Pleshey (p. 509, note 6, above), there is great increase in the bee hives.

5 i.e. the manor of Cardons there, which derived its name from its Domesday undertenant or his heirs. See also pp. 451, $47^{1}$ above and p. 569 , note 8 , below. 


\section{THE HOLDERS OF LANDS}

now (semper) 6 bordars. Then and afterwards 6 serfs; now I. (There is) wood(land) for 30 swine, (and) 6 acres of meadow. Then 200 sheep and 10 swine; now 220 sheep, 30 swine, 66 goats, (and) 3 beasts. Then and afterwards it was worth 6 pounds; now 100 shillings. ${ }^{1}$ There also (In eadem villa) the same (Hugh) holds 3 hides and 17 acres, which were held by 5 free men in King Edward's time; then 5 ploughs (were there); and when he received (it) 2 ; now none; (there are) now 1 villein and 3 bordars; (there are) 4 acres of meadow; then and afterwards it was worth roo shillings; now 40; G[eoffrey] claims (to have obtained) these lands by exchange (pro escangio).

In Munehala [Manhall ${ }^{2}$ ] a certain Englishman holds of $G$ [eoffrey] 3 virgates which were held by a free man in the time of King Edward; and in King William's time he became (effectus est) Geoffrey's man of his own accord ${ }^{3}$; and the men of Geoffrey say that afterwards the king granted (it) to Geoffrey in exchange (pro escangio), but neither the man himself nor the Hundret (court) bears witness in favour of Geoffrey (testimonium Goisfrido perbibent). In that land was then I plough; now I half. Then as now (semper) 3 bordars; and there are 7 acres of meadow. It is worth 10 shillings.

Blichangra [Birchanger ${ }^{4}$, which was held by I sokeman of Ansgar as half a hide in King Edward's time, is held of G[eoffrey] by Germund." Then as now (semper) I plough on the demesne, and 3 bordars. Then and afterwards (there was) wood(land) for 40 swine; now for 30 . It was then worth 20 shillings; now 10.

\section{Hundret of Clavelinga [Clavering]}

In Plicedana [Pledgdon ${ }^{6}$ ] Richard holds (of Geoffrey what was held by) a sokeman of Ansgar (as) I hide and 20 acres $^{7}$ in King Edward's time. Then I plough; now none.

1 A rather small decrease in view of the total disappearance of all the villeins and theis ploughs.

A manor in (Saffron) Walden (see p. 473, note 2 , above.

See Introduction, p. 358.

- Not the manor of Birchanger Hall, which belonged to St. Valery.

- This was Germund de St. Ouen, who held of Geoffrey also in Herts and Bucks.

- A hamlet in Henham, which however was assessed in Clavering Hundred.

7 'tenet Ricardus soc' Angari I hidam et $x x$ acres.' I have no hesitation about supplying in the text the words within brackets, which must have been omitted by a scribal error.
Then as now (semper) 3 bordars. (There is) wood(land) for 10 swine, (and) 10 acres of fo. 63 meadow. It is worth now as then (semper) 2 I shillings.

\section{Hundret OF Witbrictesherna [DEngie]}

Phenna [Stow Maries?], which was held by Friebern as a manor and as 3 hides, is held (of Geoffrey) by Hugh de Verli. Then as now (semper) 2 villeins. Then 2 bordars; now 7. Then 2 serfs; now none. Then as now (semper) 2 ploughs on the demesne. Then I plough belonging to the men; now a half. (There is) wood(land) for 40 swine, (and) pasture for 30 sheep. Then 5 swine, (and) 30 sheep; and now 70 swine. It is worth 60 shillings. There also (In eadem) the same (Hugh) holds 37 acres; then half a plough (was there); now none; it is worth 5 shillings. 8

WENESWIC [ ${ }^{9}$ ], which is held (of Geoffrey) by Godfrey and Evrard, was held by Ansgar, in King Edward's time, as 5 hides and 40 acres. Then as now (semper) 2 villeins. Then 4 bordars; now 7 . Then as now (semper) 3 serfs, and 2 ploughs on the demesne. Then 2 ploughs belonging to the men; now $I \frac{1}{2}$. It is worth 4 pounds. There also (In eadem) 6 free men held I hide and 40 acres, which is (now) held by the same Godfrey and Evrard; it was then worth 20 shillings; now 10.

\section{THE I,AND OF THE COUNT OF OU [EU]}

Turruc [(West) Thurrock $\left.{ }^{10}\right]$, which was held by Harold as a manor and as 13 hides, is held by the count in demesne. Then 12 villeins; now 17 . Then 16 bordars; now 45. Then 16 serfs; now 8 . Then 6 ploughs on the demesne; now 5. Then 10 ploughs belonging to the men; now 13. (There is) wood(land) for 200 swine, 40 acres of meadow, (and) pasture for 500 sheep. Then I fishery; now 2. Then as now (semper) 5 cows, 3 rounceys (runcini), 16 swine, (and) 550 sheep. It was then worth 12 pounds; now 30. And there are 7 houses at London which belong (jacent) to this manor and are (included) in this rent (frma). ${ }^{11}$

8 This is the duplicate entry (see p. 512 above).

- This manor, although considerable, has not been identified.

${ }_{10}$ Wrongly identified as Grays Thurrock by Morant (sec Introduction, p. 388).

11 Here again the valuation proves to be the actual rent, which is significant in view of an increase of 150 per cent (sce p. 364 above). 


\section{A HISTORY OF ESSEX}

fo. 63b

\section{THE LANDS OF ROBERT GRENO [GERNON]}

\section{Hundret of Berdestapla [Barstable]}

RAMESDANA ${ }^{1}$ [Ramsden], which was held, in King Edward's time, by 3 free men as a manor and as $3 \frac{1}{2}$ hides and 30 acres, is held by Robert in demesne. Then as now (semper) 2 ploughs on the demesne, and I plough belonging to the men. Then 3 villeins; now 2. Then 3 bordars; now 13. Then 3 serfs; now 4. (There is) wood(land) for 90 swine. Then 1 rouncey (runcinus); now 2. Then 2 beasts (animalia); now ro. Then as now (semper) 60 sheep and 40 swine. (There are) now 2 hives of bees. It is worth 50 shillings.

Ramesduna ${ }^{1}$ [Ramsden], which was held by Alvric freely (libere) as a manor and as 2 hides, is held of Robert by Anschetil. Then as now (semper) I plough on the demesne, and half a plough belonging to the men. Then 2 villeins; now 1. Then as now (semper) 6 bordars. Then 2 serfs; now none. (There is) wood(land) for 40 swine. Then as now (semper) I rouncey (runcinus). Then 7 swine; now 20. (There are) now 6 beasts (animalia). Then 20 sheep; now 80 . (There are) 2 hives of bees. It is worth 30 shillings.

\section{HuNDRET OF WITHAM}

WITHAM [(Powers Hall in) Witham "], which was held by Burcard, a free man, as I manor and as 4 hides in King Edward's time, is held of R[obert] by Hugh. Then 4 ploughs on the demesne; now 2. (There are) now 2 ploughs belonging to the men, ${ }^{3}$ and 2 villeins, and 6 bordars. Then 6 serfs; now 3. (There are) 6 acres of meadow and 1 mill. Then $I$ rouncey (runcinus), and 2 beasts (animalia), and 80 sheep, and 12 swine; now I rouncey, and 4 beasts, and 100 sheep, and 20 swine, and 3 hives of bees. It is worth now as then (semper) 4 pounds.

HoBRUge [Hubbridge (Hall) ${ }^{4}$ ], which was held by Brictmar' as a manor and as $2 \frac{1}{2}$ hides in King Edward's time, is held of R[obert] by Richard. Then as now (semper) 2 ploughs on the demesne, and I plough belonging to

1 These manors have not been satisfactorily identified.

2 Alias Witham Parva.

3 This is an interesting change in the distribution of the ploughs. The text leaves it rather uncertain whether the villeins and bordars had been on the land previously or not.

\& A manor in Witham. the men, and 2 villeins, and 6 bordars. Then 6 serfs; now none. (There is) wood(land) for 40 swine, I I acres of meadow, (and) I mill. Then 2 beasts (animalia); now 4 . Then I rouncey (runcinus); now none. Then 12 swine; now 40 . Then 30 sheep; now 54. (There are) now 24 goats. It is worth 40 shillings.

RIWEHALA [Rivenhall ${ }^{6}$ ], which was held by Alestan, a free man, as a manor and as half a hide in King Edward's time, is held of $\mathrm{R}$ [obert] by Ascelin'. Then as now (semper) I plough on the demesne. Then I bordar; now 8. Then I serf; now none. (There is) wood(land) for to swine, (and) 8 acres of meadow. There are now 8 swine. It is worth 20 shillings.

fo. 64

\section{Hundret of Herlaua [Harlow]}

Matcinga [Matching], which was held by Alvric Cild, a free man, as a manor and as I hide in King Edward's time, is held of Robert by Hugh. Then as now (semper) I plough on the demesne. Then half a plough belonging to the men; now none. Then I villein; now none. Then I bordar; now 4. Then 3 serfs; now none. (There is) wood(land) for 40 swine, (and) 8 acres of meadow. Then I rouncey (runcinus) and 8 swine; now 16 swine, and 12 sheep, and 8 goats, and 4 beasts (animalia). It was then worth 20 shillings; now 30 .

\section{HUNDRET OF WALThaM}

Cingefort [Chingford ${ }^{6}$ ], which was held by I free man as a manor and (as) 5 hides in King Edward's time, is held of Robert by Orgar the thegn (teinnus). And it renders Io pence to Waltham as payment for soke (de soka). Then 2 ploughs on the demesne; now I. Then 3 ploughs belonging to the men; now 2. Then as now (semper) 7 villeins, and 6 bordars, and 4 serfs. (There is) wood(land) for 500 swine, (and) 50 acres of meadow. Then as now (semper) I mill ${ }^{7}$ and 4 fisheries. And 2 ploughs more could be added to the stock, one (of them) on the demesne, and the other to the villeins. Then I I beasts (animalia); now none. Then 30 swine; now 21 . It is worth now as then (semper) 70 shillings.

6 i.e. the manor of Archers in Rivenhall, Bradwell and Great Braxted.

6 i.e. the manor of Earl's Chingford.

7 There is still a water-mill on the Lea close to Chingford Hall. 


\section{THE HOLDERS OF LANDS}

\section{Hundret of Beventreu [Becontree]}

Hame [(West) Ham ${ }^{1}$ ], which was held by Alestan', a free man, as a manor and as 8 hides and 30 acres in King Edward's time, is held by Robert in demesne. And this manor was given by King William to Ranulf Peverel (piperello) and Robert Gernon (grenoni). Then 5 ploughs on the demesne; now 4. Then 8 ploughs belonging to the men; now 12 . Then 32 villeins; now 48 . Then 16 bordars; now 79. Then as now (semper) 3 serfs. (There is) wood(land) for 100 swine, (and) 60 acres of meadow. (There were) then 9 mills; now 8.2 It was then worth 16 pounds; and when they received (it) 12 pounds; it is now worth 24 pounds. And of this manor $\mathrm{R}$ [anulf] Peverel (piperellus) has a moiety. ${ }^{3}$ And in Robert's demesne $\mathrm{R}$ [obert] received I rouncey (runcinum), which $(e t)$ is now similarly there. Then I cow ; now 9 beasts (animalia). Then 6 sheep; now 12. Then 5 swine; now 11. Of this manor Osbern holds of Robert 30 acres with (et) half a plough, and it is worth 10 shillings in the above valuation (in eodem pretio).

Hame [(East) Ham], which was held by Levred', a free man, as a manor and as 7 hides in King Edward's time, is held by Robert in demesne. Then as now (semper) 3 ploughs on the demesne. Then 7 ploughs belonging to the men; now 13. Then 34 villeins; now 38 . Then 3 bordars; now 26 . Then fo. $64 \mathrm{~b}$

19 serfs; now 3. (There is) wood(land) for 700 swine, ${ }^{5}$ (and) 50 acres of meadow. Then 8 beasts (animalia); now 15. Then 20 swine; now 34. (There are) now 200 sheep less 20. (And there are) now 4 rounceys (runcini) and 3 hives of bees. And to this

1 It is extremely difficult to distinguish between East and West Ham, as they both belonged to Robert Gernon and afterwards to Stratford Langthorn Abbey.

These mills are virtually decisive in favour of the identity of this manor with West Ham, for they would stand on the Lea and its branches, and are still represented by Temple Mills. East Ham is not sufficiently on the Rothing to be rich in mills.

See p. 527 below, under Ranulf's fief, for the duplicate entry of this manor which is identical with that in the text thus far mutatis mutandis.

- The demesne is treated as one so far as the ploughs on it are concerned; but Robert and Ranulf had separate portions of it, with live stock of their own on each.

- It should be observed that the woodland of East Ham was reckoned to be seven times as extensive as that of West Ham. The forest must at that time have reached down to it. estate (terre) have been added, in King William's time, 3 virgates which werc held by Eduin', a free priest, in King Edward's time; then I plough (was there); now a half; (there are) now 2 bordars; wood(land) for 10 swine (is there), and 9 acres of meadow. And this manor was worth 10 pounds in King Edward's time; and when received, 7 pounds; now 18 pounds. And to this manor belong (adjacent) 30 acres which (are ?) held by I sokeman. Of this manor Ilger holds 40 acres, and (has) 2 bordars and I plough; and it is worth 15 shillings in the above valuation (in eodem pretio).

In Leituna [Leyton] Robert holds in demesne half a hide, ${ }^{6}$ which was held by I free man in King Edward's time. Then as now (semper) half a plough, and 2 bordars. (There are) 5 acres of meadow. It is worth 5 shillings.

In Lochetuna [Loughton] W. Corbun holds of R[obert] 44 acres, ${ }^{1}$ which were held by I free man in King Edward's time. Then as now (semper) half a plough, and 2 bordars. (There is) wood(land) for 20 swine and I acre of meadow. It is worth 10 shillings.

\section{HundRet of Witbrictesherna [DEmgie]}

Purlal [Purleigh], which was held by Algar', a free man, as a manor and as 2 hides and 15 acres, ${ }^{7}$ is held of R[obert] by Richard. Then I serf; now I bordar. Then as now (semper) I plough. It was then worth Io shillings; and when he received (it), 20; now 30. On the demesne are now 34 sheep; and (there was) nothing (when) he received (it).

Witham [(East) Whettenham ? $\left.{ }^{8}\right]$, which was held by Leftan', a free man, as a manor and as 1 hide and a half in King Edward's time, is held of R[obcrt] by Anschetil. Then 2 villeins; now none. Then 4 bordars; now 8. Then as now (semper) I serf, and 2 ploughs on the demesne. Then $1 \frac{1}{2}$ ploughs belonging to the men; now 1. (There is) wood(land) for 150 swine. Then 2 cows; now 8 beasts (animalia). Then 100 sheep; now 140. Then 16 swine; now 20. Then as now (semper) I rouncey (runcinus). It was then worth 40 shillings; and when he received (it), 30. It is now worth 4 pounds.

B The identity of this small estate is doubtful.

7 The identity of this manor is doubtful.

8 Apparently this manor in Stow Maries, now 'Whitmans' farm (sec Introduction, p. 394). 


\section{A HISTORY OF ESSEX}

\section{Hundret of Wensistreu [Winstree]}

LEGA [ 1 1], which was held by Gotre, a free man, as a manor and as $4 \frac{1}{2}$ hides in King Edward's time, is held of Robert by Robert de Verli. Then 3 ploughs on the demesne; now 2. Then as now (semper) 3 ploughs belonging to the men. Then 7 villeins; now 5 . Then 5 bordars; now 12. Then 7 serfs; now 3. (There is) wood(land) for roo swine, (and) now I mill. Then I fo. 65 .

rouncey (runcinus); now 8 . Then 160 sheep; now 80. Then 20 swine; now none. It is worth now as then (semper) 4 pounds.

Salcota [Salcot (Verley) ${ }^{2}$ ], which was held by 1 free man as a manor and as $1 \frac{1}{2}$ hides in King Edward's time, is held of Robert (de eodem) by the same R[obert de Verli]. Then as now (semper) 1 plough on the demesne. Then 4 bordars; now 3 . Then as now (semper) I serf. Then no live stock (nichil); now 2 rounceys (runcini), 20 swine, 80 sheep, (and) 2 beasts (animalia). It was then worth 26 shillings; now 30 .

\section{HUNDRET OF WDELESFORDA [UTTLESFORD]}

Stanesteda [Stansted (Mountfichet)], which was held by a free man as a manor and as 6 hides in King Edward's time, is held by Robert in demesne. ${ }^{3}$ Then 4 ploughs on the demesne; afterwards 2 ; now 3 . Then as now (semper) ro ploughs belonging to the men, and I I villeins, and I priest. Then and afterwards 4 bordars; now 18. Then 8 serfs; afterwards 4 ; now 3. (There is) wood(land) for 1,000 swine, (and) 20 acres of meadow. Then as now (semper) I mill. Then 8 beasts (animalia); now 16 . Then 140 sheep; now 120. Then 20 swine; now 60. Then 40 goats; now 24. (There are) now 2 rounceys (runcini) and 5 asses. To this manor belongs (adjacet) I detached estate (berewita), which is called Magghedana [Manuden], of I hide;

1 This manor, in spite of its size, has not been identified. If its name is a scribal error for 'Legra,' it would be somewhere in the Layers ; but a long search has failed to trace any manor there held of the Stanstead Barony. It should be observed that Gotre or Gotra, the English predecessor here, had also preceded Robert de Verli and his overlord at Tolleshunt (Darcy).

2 Now known as Verley. 'Salcot Wigborough,' now known as Salcott, is immediately adjacent; only the narrow 'Salcott Creek' divides them.

3 This manor was the head of the barony (see p. 301 above for its castle), and yet (as with Bendfieldbury below) the name of the English holder is not even recorded. then as now (semper) I plough (was there) on the demesne, and 2 bordars; wood(land) for ro swine is there. Then and afterwards (this manor) was worth 8 pounds; now $1 \mathbf{I}$.

TAcheleia [Takeley ${ }^{4}$ ], which was held by $I$ free man as a manor and as 3 hides and I 5 acres in King Edward's time, is held by $\mathrm{R}$ [obert] in demesne. Then as now (semper) 2 ploughs on the demesne, and 3 ploughs belonging to the men, and 3 villeins. (There are) now 8 bordars. Then and afterwards 3 serfs; now 2. There is wood(land) for 200 swine, (and) 20 acres of meadow. Then" 2 rounceys (runcini); now I. Then I 2 beasts (animalia); now 3. Then 16 sheep; now 10. Then 20 swine; now 38 . It is worth now as then (semper) 100 shillings. Peter holds of $\mathrm{R}$ [obert] half a hide, and $\mathrm{I}$ ox $\left(b^{\prime}\right)$ (is there); (this) is worth 12 shillings.

Wendena [(Great) Wendon], which was held by I free man as a manor and as 7 hides less 6 acres in King Edward's time, is held of $\mathrm{R}$ [obert] by Hugh. Then as now (semper) 3 ploughs on the demesne. Then 4 ploughs belonging to the men; and when he received (it), the same; now 5. Then and afterwards 8 villeins; now 9. There are now 5 bordars. Then and afterwards 6 serfs; now 5. (There are) 24 acres of meadow. Then and afterwards (there was) I mill; now 2. Then 5 sheep, and 7 swine; now 3 colts (pulli), and 30 swine, and 67 sheep. Then and afterwards it was worth 7 pounds; now 8 .

\section{Half Hundret of Clavelinga [Clavering]}

BenedFelda [Bendfield(bury) $\left.{ }^{5}\right]$, which was held by 1 free man $^{6}$ as a manor and as 5 hides in King Edward's time, is held by $\mathrm{R}$ [obert] in demesne. Then as now (semper) fo. $65 \mathrm{~b}$

3 ploughs on the demesne. Then 7 ploughs belonging to the men; afterwards 6 ; now 4 . Then 10 villeins; afterwards and now 9. Then and afterwards 2 bordars; now 11 . Then and afterwards 7 serfs; now 4. (There is) wood(land) for 200 swine, 16 acres of meadow, (and) I mill. Then 2 rounceys

4 i.e. the manor of Bassingborns there.

5 A manor and hamlet in Stansted Mountfichet, but reckoned as in Clavering Hundred.

6 As with the manor of Stansted (Hall) above his name is not given, but I take him to be the Godwine de Benefelle who is mentioned in the Domesday Survey of Hertfordshire (see the Victoric History of that county, i. 277). 


\section{THE HOLDERS OF LANDS}

(runcini); now 3. Then I beast (animal); now 14. Then 80 sheep; now 30 . Then 50 swine; now 40. Then and afterwards it was worth I00 shillings; now 7 pounds. To this estate belongs (terre adjacet) now as then (semper) I sokeman with (de) 30 acres.

In Bolituna [Bollington "] Robert holds in demesne $1 \frac{1}{2}$ hides and 15 acres. Then $I \frac{1}{2}$ ploughs; afterwards and now 1. Then as now (semper) 2 bordars. Then 10 swine, and 28 sheep; now I beast (animal), 2 swine, and 4 sheep. It is worth now as then (semper) 25 shillings. In this manor Robert holds of $\mathrm{R}$ [obert] half a hide, and has half a plough; and it is worth 10 shillings in the above valuation (in eodem pretio).

Phernham [Farnham '], which was held by I free man as a manor and as 2 hides in King Edward's time, is held by Robert in demesne. Then as now (semper) 2 ploughs on the demesne, and 2 ploughs belonging to the men. Then and afterwards 2 villeins; now 1 ; then as now (semper) 8 bordars; then and afterwards 8 serfs; now 1 . Then and afterwards wood(land) for 200 swine; now for I 50. (There are) 10 acres of meadow. Then 4 rounceys (runcini); now 2 . Then 15 beasts (animalia); now none. Then 40 swine; now I7. Then 60 sheep; now 30. (There are) now 39 goats, and 3 hives of bees. It was worth 40 shillings; now 50.

Menghedana [Manuden ${ }^{3}$ ] was held by 4 free men as a manor and as 4 hides in King Edward's time. It is now held of $R$ [obert] by 4 knights. Then as now (semper) 3 ploughs, and 2 villeins, and 5 bordars, and 1 serf. (There is) wood(land) for 30 swine, (and) I 3 acres of meadow. Then 8 beasts (animalia), and 80 sheep, and 20 goats, and 20 swine; now 5 beasts, and 33 swine, and I colt (pullus), and 44 sheep, and 8 goats. It was then worth 50 shillings; now 60 .

\section{HUNDRET OF HidingForda [HINCKFORD]}

Mapledesteda [(Great) Maplestead], which was held by Ulwin', a free man, as a manor and as half a hide in King Edward's time, is held of R[obert] by Ilger'. Then as now (semper) 2 ploughs on the demesne, and 3 ploughs belonging to the men, and 5 villeins. Then and afterwards 2 bordars; now 6 .

1 A manor in Ugley.

i.e. the manor of Hertisho-bury there.

- i.e. the manor of Manuden Hall there.

- See note 5 below.
Then and afterwards 4 serfs; now 2. Then 50. 60

wood(land) for 100 swine; now for 60. (There are) 26 acres of meadow. Then I rouncey (runcinus), and 8 beasts (animalia), and 10 swine, and 20 sheep, and 20 goats; now I rouncey, and 14 beasts, and 18 swine, and 80 sheep, and 23 goats, and 2 hives of bees. It is worth 60 shillings.

\section{Hundret of Laxedana [Lexden]}

WIDEMONDEFORT [Wormingford], which was held by Goduin' as a manor and as $1 \frac{1}{2}$ hides and Io acres, is held of R[obert] by Ilger'.5 Then 3 villeins; now 4 . Then 2 bordars; now 8 . Then as now (semper) 4 serfs. Then 3 ploughs on the demesne; now 4. Then as now 2 ploughs belonging to the men. (There is) wood(land) for 100 swine, 16 acres of meadow, (and) now I mill. (There is) I fishery. ${ }^{6}$ Then I rouncey (runcinus); now 6. Then 5 beasts (animalia); now 33. Then 40 swine; now 60 . Then 6 sheep; now 200. Then 15 goats; now 47. (There are) now 7 hives of bees. It was then worth 4 pounds; now 6 . And in King Edward's time (there were) I 9 sokemen holding $2 \frac{1}{2}$ hides less 6 acres, whom Robert has by exchange (in suo escongio), as he says, (and) who are held of him by the same Ilger'; and they have 8 bordars; 2 ploughs (are there) now as then (semper); (there are) 4 acres of meadow, (with) wood(land) for 16 swine; it is worth now as then (semper) 40 shillings; and these sokemen, as the county (court) testifies, could not withdraw themselves (removere) from that manor. And I villein, of whom Robert was seised, was taken away by Reimund' Girald', ' and Roger of Poitou has (him) still. ${ }^{8}$

Wivnhou [Wivenhoe ${ }^{8}$ ], which Alvric held as a manor and as 5 hides less 15 acres, is held of R[obert] by Nigel. Then as now (semper) 5 villeins. Then 6 bordars; now 20. Then I serf; now 2. Then as now (semper)

s It can be shown that Ilger was succeeded in this as in the preceding manor by the family of de Windsor as under-tenants (see The Ancestor, $\mathrm{i}$. 125).

6 This is far away from the other fisheries in the county.

7 Predecessor of Roger of Poitou (see p. 432, note 8 , above).

- Roger held the adjoining manors of Mount Bures and West Bergholt.

yhich forms a detached portion of Lexden Hundred. 


\section{A HISTORY OF ESSEX}

2 ploughs on the demesne. Then the men had between them 3 ploughs; now 2. (There is) wood(land) for 100 swine, 12 acres of meadow, pasture for 60 sheep, (and) now I mill. Then 8 beasts (animalia); now 10. Then I rouncey (runcinus); now 2. Then 60 sheep; now 87 . Then 30 goats; now 20. Then 20 swine; now 24. It is worth now as then (semper) 40 shillings. ${ }^{1}$ And 1 free man held 20 acres, which Robert holds of the king's gift and Nigel (holds) of him. Then as now (semper) half a plough (was there); it is worth 3 shillings. And another free (man) held 20 acres, which are (now) held by the keeper (custos) of the Hundret ${ }^{2}$; it is worth 3 shillings and is held by the same Nigel.

Bricia [(Little) Birch $\left.^{3}\right]$, which was held by Ulwin' as a manor and as 2 hides less $4 \frac{1}{2}$ acres, is held of R[obert] by Robert. ${ }^{4}$ Then as now (semper) 12 bordars. Then 6 serfs; fo. $66 \mathrm{~b}$

now 5. Then as now (semper) 2 ploughs on the demesne and 2 ploughs belonging to the men. (There is) wood(land) for 40 swine, (and) 12 acres of meadow. Then as now (semper) 1 mill. Then 2 beasts (animalia); now 7. Then $3^{8}$ sheep; now 80. (There are) now 33 goats. Then 5 swine; now 33 . (There are) now 2 rounceys (runcini). It is worth now as then (semper) 60 shillings.

\section{Hundret of Angra [Ongar]}

STAPLEForda [Stapleford (Abbots) ${ }^{5}$ ], which was held by 5 free men as $2 \frac{1}{2}$ hides and $6 \frac{1}{2}$ acres, is held by $\mathrm{R}$ [obert] in demesne. Then 8 bordars; now I 4. Then the men had 5 ploughs between them; now 4 . (There is) wood(land) for 200 swine, and 21 acres of meadow. Then and afterwards it was worth 50 shillings; now 60 . Of this manor Nigel holds $I \frac{1}{2}$ hides; and 3 villeins (are there), and 6 bordars, and 2 ploughs; and it is worth 28 shillings in the above valuation (in eodem pretio).

\section{Hundret of Ceffeorda [Chafford]}

RENAHAM [Rainham ${ }^{6}$ ], which was held by Aluard' as a manor and as $3 \frac{1}{2}$ hides, is held of $\mathrm{R}$ [obert] by Robert. Then 4 villeins; now

1 This value seems strangely low.

2 This appears to be the only mention of such an officer in Domesday. He represents the later 'bailiff' of the Hundred.

3 See Introduction, p. 389.

4 This was Robert de Verli (see Introduction, p. $3^{89}$ ).

B.i.e. the manor of Batayles there.

i.e. the manor of Berwick there (?)
5. Then and afterwards 6 bordars; now 4 . Then 2 serfs; now none. Then as now (semper) 2 ploughs on the demesne. Then the men had between them $2 \frac{1}{2}$ ploughs; now 1. Then 3 rounceys (runcini), and 14 beasts (animalia), and 6 swine, and Ioo sheep; now 4 rounceys, and I I beasts, and 24 swine, and 80 sheep, and $\mathrm{I} 2$ hives of bees. It was then worth 6 pounds; and when received (the same); it is now worth 4 pounds. And 1 hide was held by I free man who afterwards forfeited it because he committed theft (furatus est); and (it) was in the king's hand(s). But Robert 'lascivus' 7 seized it (invasit) as the Hundret (court) testifies; then I plough (was there); afterwards and now none; it is worth now as then (semper) 20 shillings; this (boc) is held of R[obert] by the same Robert.

WALDA [(South) Weald $\left.{ }^{8}\right]$, which was held by Sprot as a manor and as I hide, is held of $\mathrm{R}$ [obert] by Ralf. (There is) now I villein, and (there are) 6 bordars, and I plough. (There is) wood(land) for 40 swine. It is worth 20 shillings. This land is held by $\mathrm{R}$ [obert], as he says, in exchange (pro escangio) by (the livery of) Hubert de Port (portu), and it has never paid (Dane)geld (reddidit geltum), and neither the last (?). ${ }^{10}$

\section{Hundret of Celmeresforda [Chelmsford]}

INGA [Frierning ?], ${ }^{11}$ which was held by Siward as a manor and as 3 hides in King Edward's time, is held by Robert in demesne. Then as now (semper) 1 villein. Then 3 bordars; now 9. Then I serf; now 3 . Then as now (semper) i plough on the demesne. Then half a plough belonging to the men; now 1. (There is) wood(land) for 400 swine. fo. 67

Then 5 beasts (animalia); now 4. Then 28 sheep; now 26. Then 12 swine; now 17. It was then worth 30 shillings; now 20 .

7 This was probably the Robert 'invesiatus,' a man of Robert Gernon, who was charged with aggression in the adjoining parish of Wennington p. 445 above).

8 i.e. the manor of Caldecots there.

- The Domesday tenant-in-chief of Mapledurwell, Hants. He occurs in the Suffolk Domesday (ii. 377) as having given seisin to the Bishop of Bayeux of certain free men.

10 'et neque ultimum.' The phrase is obscure, and the reference may be to the 'last' levy.

11 The number of the Ings lying together makes their identification difficult. Morant asserted the above manor to be Margaretting, but Frierning seems to be the only one with which it is possible to connect Robert Gernon directly. 


\section{THE HOLDERS OF LANDS}

INGA [Frierning ?'] was held by Eduin' Grut as a manor and as $I$ hide and 33 acres. It is now held of Robert by Ilger. Then as now (semper) I bordar, and I plough. (There is) wood(land) for 40 swine and 2 acres of meadow. It is worth 20 shillings. $\mathrm{R}$ [obert] had this land as part of that which he obtained by exchange (babuit $R$. in suo escangio).

Cinguenella [Chicknal (Zoyn) ${ }^{2}$, which was held by Doth as a manor and as 2 hides, is held of R[obert] by Anschetil. Then as now (semper) 1 villein, and 2 bordars, and 2 ploughs on the demesne, and I plough belonging to the men. (There is) wood(land) for 30 swine, (and) 20 acres of meadow. Then as now (semper) I rouncey, and 6 beasts (animalia), and 12 sheep, and 14 swine. It was then worth 40 shillings; now 4 pounds.

SPRINGINGheFELdA [Springfield ${ }^{3}$ ], which was held by Godric as a manor and as 2 hides and 40 acres, is held of R[obert] by Corp. Then as now (semper) 4 villeins, and 7 bordars, and 2 ploughs on the demesne, and I plough belonging to the men. (There is) wood(land) for 30 swine, 20 acres of meadow, (and) I fishery. Then I rouncey (runcinus); now 10. Then 5 beasts (animalia); now 30 . Then 4 sheep; now 100. Then 13 swine; now 40. It was then worth 40 shillings; now 60.

INGA [Frierning ? ], which was held by

1 See p. 518 , note 11 , above.

- A manor in Chicknal St. James. Although it is here entered in the midst of Chelmsford Hundred manors, Morant identified it as being in Chigwel] (in Ongar Hundred), with which Robert Gernon had nothing to do. Its true identity is revealed by the Inq. p. m. on Philip Burnel (Dec. 20, 1294 ), cited by Morant himself (ii. 80), where it is found among the Gernon manors which the Burnel family had acquired, as held of Philip by Margery de Moese. In 1303 this Margery is returned as holding $1 \frac{1}{2}$ fees in Chicknal 'Tany' and t fee in Chicknal 'Scyn,' which were both in Chicknal St. James (Feudal Aids, ii. 133). Morant no doubt jumped at the conclusion that 'Cinguehella' was more like the 'Cinghewella' (Chigwell) of Domesday than it was to its 'Cingehala' (Chicknal). Compare p. 387 above.

s This is identified by Morant as the manor of Springfield Barnes, the history of which, as given by himself (ii. 8), is inconsistent with that identification. It was probably represented by the half fee held, at his death in 1360 , by Richard de Plaiz, one of the co-heirs of the Gernon estates. From the Plaiz family, probably, it passed to the De Veres, Earls of Oxford.

4 See note I above.
Selva and Topi as a manor and as $2 \frac{1}{2}$ hides and 31 acres, is held of R[obert] by William. And Robert has it by exchange (in escangio). Then as now (semper) I villein, and 14 bordars; and I $\frac{1}{2}$ ploughs on the demesne, and $I \frac{1}{2}$ ploughs belonging to the men. (There is) wood(land) for 100 swine, (and) 4 acres of meadow. Then 10 beasts (animalia); now the same. Then I rouncey (runcinus); now 5. Then as now (semper) 20 sheep. Then 30 swine; now 16 . (There are) now 2 hives of bees. It is worth now as then 4 pounds. And 30 acres were held by Borda, and $\mathrm{R}$ [obert] (holds them) now ; then as now (semper) half a plough (was there); and (there are) $2 \frac{1}{2}$ acres of meadow; it is worth 10 shillings.

Pacinge ${ }^{5}$ [Patching (Hall Picot) ${ }^{6}$ ], which was held by Borda as a manor and as $2 \frac{1}{8}$ hides in King Edward's time, is held (of Robert) by Picot. Then I villein; now none. (There are) now 6 bordars. Then 4 bordars; now none. Then 2 ploughs on the demesne; now I. Then as now (semper) half a plough belonging to the men. (There is) wood(land) for 50 swine, (and) 10 acres of meadow. Then 4 beasts (animalia), and 20 swine, and 20 sheep; now (there is) nothing. Then as now (semper) it was worth 40 shillings. $\mathrm{R}$ [obert] has this land in exchange (in escangio).

Of the fee of Richenam ${ }^{7}$ [Culverts ${ }^{8}$ ], Asso holds of $\mathrm{R}$ [obert] what was held by Goduin' as a manor and as $1 \frac{1}{\frac{1}{2}}$ hides.

fo. $67 \mathrm{~b}$

Then I villein and I serf; now 2 bordars. Then as now (semper) I $\frac{1}{2}$ ploughs on the demesne. And (there are) Io acres of meadow. Then as now (semper) I mill. It is worth now as then (semper) 30 shillings.

- This form points to an English 'Patchings.'

- A manor in Broomfield. This is another of the Gernon estates which passed eventually to the Burnel family.

7 'De feudo Richeham.'

8 A manor (now a farm) in Boreham, which derived its name from the Coleworth family in the thirteenth century. Richard de Coleworth is named in a charter of William de 'Rykham' (obviously the 'Richeham' of Domesday), 'who seems to have been lord of this and other estates in and about this parish' (Morant, ii. 12). Nevertheless Morant himself (ii. 25) identified the manor in the text as 'Rifehams' in Danbury, which had nothing to do with Robert or his successors. 'Culverts' was among those manors of his which were afterwards held by the Burnels. 


\section{A HISTORY OF ESSEX}

In Toleshunta [Tolleshunt (Darcy)] Robert de Verli holds (of Robert) 40 acres which belong to (jacent in) this Hundret and are appraised in (his) manor. ${ }^{1}$

\section{Hundret of Tendringa [Tendring]}

Accleia [(Great) Oakley], which was held by Alvric Camp ${ }^{2}$ as a manor and as ro hides in King Edward's time, is held by Robert in demesne. Then and afterwards 12 villeins; now 11. Then and afterwards 20 bordars; now 30 . Then and afterwards Io serfs; now 5. Then as now (semper) 3 ploughs on the demesne. Then 10 ploughs among the men; now 9. (There is) wood(land) for roo swine, 8 acres of meadow, (and) now I mill. (There are) 2 salt-pans. ('There is) pasture for 20 sheep. Then ro rounceys (runcini); now 4. Then ro beasts (animalia); now 5. Then as now (semper) 200 sheep less 20 . Then 20 swine; now 15. It was then worth II pounds; and when received, (the same); it is now worth 16 pounds. Of this manor Ralf holds 2 hides and 10 acres; and 13 bordars (are there), and I plough; and it is worth 30 shillings in the above valuation (in eodem pretio). And the land of a certain free man, which is called Tendringa, is held by Robert, and Walter holds it of him as a manor and as I hide less 15 acres. $^{3}$ Then 5 villeins; now 2. Then 3 bordars; now 7. Then 3 serfs; now none. Then as now (semper) I plough on the demesne. Then 3 ploughs among the men; now 2. (There is) wood(land) for 20 swine and 1 acre of meadow. Then 2 rounceys (runcini); now 4. Then 2 beasts (animalia); now ro. Then 20 swine; now 27. Then 49 sheep; now 60 . Then 24 goats; now 37. (There are) now 3 hives of bees. It was then worth 20 shillings; now 30. $\mathrm{R}$ [obert] received this in exchange (in suo escangio).

Dicheleia [Dikeley ${ }^{4}$ ], which Alestan' held as a manor and as I hide and $37 \frac{1}{2}$ acres, is held of $R$ [obert] by Nigel. Then as now (semper) 8 bordars. Then I serf; now none. Then 2 ploughs on the demesne; now $1 \frac{1}{2}$. Then as now (semper) 2 ploughs belonging to

1 See below. The Tolleshunts abut on Winstree, not on Chelmsford Hundred, and no portion of Tolleshunt Darcy is now in either of them, though these ' 40 acres' were assessed in Chelmsford Hundred at the time of Domesday.

2 See Introduction, p. 353.

3 This must be the manor of 'Gernons' there which descended with Great Oakley to the family of Plaiz.

4 A manor in Mistley (now Dickley Hall). the men. ('There is) wood(land) for ro swine and 2 acres of meadow. Then 7 beasts (animalia); now 8. Then I rouncey (runcinus); now 4. Then 37 sheep; now 51. Then 7 swine; now 15. Then as now (semper) 20 goats. It is worth 20 shillings.

Erleia [Ardleigh], 5 which was held by Scapi' as a manor and as half a hide and 30 acres, is held of R[obert] by William. And fo. 68

it is appurtenant (jacet) to a certain manor in Sudfolc [Suffolk ${ }^{6}$ ], but belongs to (pertinet in) this Hundret. ${ }^{7}$ Then I villein; now none. Then as now (semper) I serf. Then 2 ploughs on the demesne; when he received (it), I ; now none. Then 2 bordars; now none. (There is) I acre of meadow. It was then worth 40 shillings; and when received, 20 ; now 5 .

\section{HUNDRET OF UDELESFORT [UTTLESFORD]}

WIDINTUNA [Widington], which was held by Ingulf as a manor and as 3 hides and I virgate, is held of $\mathrm{R}$ [obert] by Robert. And Robert (Gernon), as he says, has (it) by exchange (in escangio). Then 5 villeins; now 4 . Then 3 bordars; now 5. Then as now 5 serfs, and 2 ploughs on the demesne. Then 4 ploughs belonging to the men; now 2 . (There are) Io acres of meadow. Then 3 sheep; now 65. Then 24 swine; now 49. It was then worth 60 shillings; now 4 pounds.

SCortegrava [Shortgrove ${ }^{8}$ ], which was held by Ulwin' and Grinchel as a manor and as 2 hides, is held (of Robert) by the same Robert. ${ }^{9}$ And Robert (Gernon) has (it) by

5 Morant identifies this as the manor of Mose there, but on what grounds there is nothing to show.

6 This is a very important clause, for it identifies Scapi', the former holder, as the Scapi' or Scalpi', a ' thegn of Harold,' whose manors in Suffolk had been obtained by Robert Gernon, who had enfeoffed in them, as his under-tenant, William 'de alno' (ii. fos. 319-20). This gives us the name of the William who, at Ardleigh also, was his under-tenant, and who was obviously the ancestor of the Richard 'de Aune' who held 4 knight's fees of Robert's successor in 1166 (Red Book of the Exchequer, p. 349). These four fees fell eventually to the share of Aveline, wife of Edmund, Earl of Lancaster, at whose death they were found to include land in Ardleigh.

7 i.e. for purposes of assessment.

8 In Newport.

9 This estate adjoined Widington, and the two descended together. It is probable also that 


\section{THE HOLDERS OF LANDS}

exchange (in escangio '). Then and afterwards 6 serfs; now 3 . Then 3 ploughs on the demesne; afterwards and now 2. (There are) 12 acres of meadow. Then I mill; now none. Then 3 rounceys (runcini); now none. Then 3 cows; now none. Then as now (semper) 100 sheep. Then 60 swine; now none. Then 23 hives of bees; now II. It was then worth 4 pounds; and when received, 50 shillings; now 60 .

Archesdana [Arkesden '], which was held by Grinchel as a manor and as 1 hide less 8 acres, is held of R[obert] by Picot. And Robert has (it) by exchange (in escangio). (There are) now 4 bordars. Then as now (there were) 2 serfs, and I plough. (There are) 6 acres of meadow. (There are) now 2 beasts (animalia). Then as now (semper) 12 swine and 32 sheep. (There are) now 2 hives of bees. It is worth 20 shillings.

Elsenham, ' which was held by Leftan' as a manor and as $I$ hide, is held of $R$ [obert] by Peter. And Robert has (it) by exchange (in escangio). Then 4 villeins; afterwards and now 3. Then and afterwards 3 bordars; now 6 . Then 4 serfs; now none. Then and afterwards 2 ploughs on the demesne; now 1. Then and afterwards 2 ploughs belonging to the men; now 3 . (There is) wood(land) for 100 swine and 20 acres of meadow. Then as now (semper) I rouncey (runcinus). Then 7 beasts (animalia); now 1 calf (vitulus). Then 16 sheep; now none. Then 8 swine; now 18. Then 20 goats; now none. It is worth now as then (semper) 40 shillings.

\section{Hundret of Turestapla [Thurstable] \\ Toleshunta [Tolleshunt (Darcy) ${ }^{5}$ ], which}

'Robert,' their Domesday under-tenant, was the 'Robert' who held 'Rainham ' of Robert Gernon, for all these estates descended together to the Plaiz family as co-heirs of Robert Gernon's fief.

1 It should be observed that this group of four manors in Uttlesford is entered separately from the two in that Hundred above (p. 516 ), and that each of the four is alleged to have been obtained by exchange.

2 i.c. the manor of Mynchens there, so named from the nuns of Campes, whose house held it under the Plaiz family.

3 The identity of this manor seems to have been lost in that of the main and greater manor of Elsenham Hall.

1 This was probably the 'Peter' who held some land of him in Takeley close by.

b i.e. the manors of Gernons and Verli there. was held by Gotra ${ }^{\circ}$ as a manor and as $5 \frac{1}{2}$ hides, is held of R[obert] by Robert de Verli. fo. $68 \mathrm{~b}$

Then 4 villeins; now 7. Then 6 bordars; now 14. Then 3 serfs; now 5. Then as now (semper) 2 ploughs on the demesne, and 2 ploughs belonging to the men. (There is) wood(land) for 200 swine, I acre of meadow, pasture for 40 sheep, (and) I saltpan. Then 3 rounceys (runcini); now none. Then 14 beasts (animalia); now none. Then 40 swine; now 20. Then 100 sheep; now 6o. Then 30 goats; now 20. (There are) now 8 hives of bees. Then and afterwards it was worth 4 pounds; now 100 shillings. And 2 free men held 30 acres; then I plough was there; now none; it is worth now as then (semper) 10 shillings; and (Robert) says that he has this land by exchange (in suo escangio).

\section{THE LAND OF RALF BAIGNARD}

\section{HUNDRET OF WITHAM}

UltingA [Ulting], which was held by Hacon as a manor and as 1 hide and 40 acres in King Edward's time, is held of Ralf Baignard by Girard. Then as now (semper) 4 ploughs on the demesne. Then 3 ploughs belonging to the men; now $1 \frac{1}{2}$. Then 7 villeins; now 4. (There are) now 12 bordars. Then 6 serfs; now none. (There is) wood(land) for 100 swine, (with) 20 acres of meadow, (and) now as then (semper) 2 mills. And 5 acres of land have been added in King William's time and owe him dues (sunt de sua consuctudine). Then 5 rounceys (runcini), 20 beasts (animalia), 7 swine, (and) 70 sheep; now 4 rounceys, 9 beasts, 24 swine, 35 sheep, (and) 2 hives (of bees). It was then worth 4 pounds; and when received, (the same); it is now worth 100 shillings.

In LANGEFoRT [Langford ${ }^{7}$ ] Geoffrey holds of $\mathrm{R}$ [alf] 5 free men with (de) 3 virgates of land and 1 acre, and they (qui) used to render fo. 69

to the king a customary due of 15 pence ( $x v d$. de consuctudine) in King Edward's time. Now as then (semper) they have $1 \frac{1}{2}$ ploughs and I bordar. (There are) 3 acres (of

- See p. 516, note 1 , above.

7 In Thurstable Hundred (see below), but only divided from Ulting by the Blackwater. Ulting manor is subsequently found extending into Langford. 


\section{A HISTORY OF ESSEX}

meadow ?). ${ }^{1}$ It was then worth ro shillings; now 20.

\section{HUNDRET OF WITBRICTESHERNA [DENGIE]}

Nortuna [(Cold) Norton], which was held by Ulfric, a free man, as a manor and as 8 hides in King Edward's time, is held by $\mathrm{R}$ [alf] in demesne. Then as now (semper) 5 villeins, and I I bordars. Then 2 serfs; now none. Then 2 ploughs on the demesne; now 3. Then 4 ploughs belonging to the men; now 3. Of these hides 2 are of woodland (silve). ${ }^{2}$ (There is) pasture for 40 sheep, (and) now I mill. Then 4 rounceys (runcini), and 15 beasts (animalia), 20 swine, and I50 sheep; now 6 rounceys, 8 beasts, 20 swine, and 60 sheep. It was then worth 6 pounds; now 7 . Robert has also as a manor 3 hides and 45 acres which 6 free men hold now as then (semper); then 5 ploughs (were there); now 3 ; (this) was then worth 40 shillings; now 30. This was delivered (to Ralf) in exchange (liberatum est pro escangio). Of this manor Walicher[ius] holds half a hide, and (this) is worth 10 shillings in the above valuation (in eodem pretio).

WDEHAM [Woodham (Walter)], which was held by Leveva as a manor and as 7 hides, is held of R[alf] by Pointel. ${ }^{3}$ Then 12 villeins; now 6 . Then as now (semper) 4 bordars. Then 6 serfs; now 4. Then as now (semper) 3 ploughs on the demesne. Then 4 ploughs belonging to the men; now I. (There are) 24 acres of meadow, (with) wood(land) for 500 swine. Then 1 mill; now 2. Then 2 beasts (animalia) and 7 swine, (and) 37 sheep ; now 8 beasts, 2 I swine, 6 asses, 130 sheep, (and) 13 hives of bees. It was then worth 8 pounds; and when received, 40 shillings; ${ }^{4}$ it is now worth 7 pounds.

CurLaI [Purleigh ? ${ }^{5}$, which was held by

1 'et I bor[darius] iii. ac.' The sense is doubtful.

8 The reason for inserting this clause here was that the woodland is regularly entered just before the pasture for sheep. On the 'hides' of woodland see pp. $376-7$ above.

3 This was doubtless the Thierri (Tedricus) Pointel who held North Fambridge, in this Hundred, as a tenant-in-chief, and who also, held at Cricksea as an under-tenant and claimed land at Steeple.

4 This is an unusually sharp drop in value for the intermediate period in Essex.

5 This is one of the mysterious manors of the most difficult Domesday Hundred in the county (see p. 391 above). Morant assumed that it lay
Grim as a manor and as I hide in King Edward's time, is held of the same (Ralf) by the same (Pointel). Then 2 villeins; now 4. Then as now (semper) 9 bordars. Then 4 serfs; now none. Then as now (semper) 2 ploughs on the demesne, and I plough belonging to the men. (There are) 22 acres of meadow, (with) wood(land) for 40 swine. (There was) then I mill; now none. Then and afterwards it was worth 40 shillings; now 4 pounds. Godric also holds (babet) of $\mathrm{R}$ [alf] half a hide, which (Ralf) has, he says, by exchange (pro escangio); but the Hundret (court) knows nothing of this (nescit). Then as now (semper) half a plough was there; it is worth ro shillings.

\section{Hundret of Dommawa [Dunmow]}

Dommawa [(Little) Dunmow $\left.{ }^{6}\right]$, which was held freely (libere) by a certain woman, Ailid, as a manor and as $4 \frac{1}{2}$ hides, is held by $\mathrm{R}$ [alf] in demesne. Then as now (semper) 3 ploughs on the demesne. Then 7 ploughs belonging to the men; now 6 . Then as now (semper) I 5 villeins, and I priest. Then 12 bordars; now 16. Then as now (semper) fo. $6 \mathrm{gb}$

Io serfs. (There is) wood(land) for 150 swine, 50 acres of meadow, (and) now I mill. Then 3 rounceys (ruxcini), I I beasts (animalia), 40 swine, 15 sheep, (and) 23 goats; now II rounceys, 2 I beasts, 30 swine, 104 sheep, 53 goats, (and) 8 hives of bees. Then and afterwards it was worth 8 pounds; now IO. To this estate (terre) has been added I hide which was held by I free man in King Edward's time. Then as

in Purleigh (the 'Purlai' of Domesday), but could not identify there a manor held of this ficf. Its amount of meadow is significantly large, especially as none of the entries undoubtedly relating to Purleigh (a parish away from any river) mention an acre of meadow. It is clear from the extent of its meadow that 'Curlai' must have been on a river, and this river can only have been the Chelmer. As the manors of Woodham Walter and ' Curlai' were held together by 'Pointel,' it appears to me that 'Curlai' was probably in Woodham Walter and became absorbed in the main manor owing to their having the same lord. Woodham Walter, with a frontage of some three miles to the Chelmer and a brook of its own as well would of course be rich in meadow.

This suggestion is supported by the fact that 'Woodham,' which had but I mill before the Conquest, had now 2, while 'Curlai,' which then had 1, had now none. This probably implies that one of the mills had been annexed since the Conquest to the main manor.

6 This was afterwards the caput of the barony. 


\section{THE HOLDERS OF LANDS}

now (semper) I plough (was there), and I villein, and I bordar, and I serf; (there is) wood(land) for 24 swine, (and) 10 acres of meadow; it is worth 20 shillings. And to this manor' ${ }^{2}$ there belongs (adjacet) further half a hide which I sokeman of Baignard's predecessor (antecessoris baignardi ${ }^{2}$ ) held and still holds; then I $\frac{1}{2}$ ploughs (were there) on the demesne; now 1. Then as now (semper) 1 villein, and I serf; (there is) wood(land) for 20 swine, (and) 9 acres of meadow ; it is worth now as then 20 shillings.

Wimbers [Wimbish ${ }^{3}$ ], which was held by Ailid as a manor and as 8 hides in King Edward's time, is held by $\mathrm{R}$ [alf] in demesne. Then as now (semper) 3 ploughs on the demesne. Then 2 I ploughs belonging to the men; now 15. Then as now (semper) 26 villeins and I priest. Then I9 bordars; now 55. Then 6 serfs; now none. Then wood(land) for 500 swine; now for 400 . (There are) 40 acres of meadow. Then 2 rounceys (runcini), and 4 beasts (animalia), 60 swine, 120 sheep, and 4 hives of bees; now 2 rounceys, 4 beasts, 28 swine, 80 sheep, (and) 4 hives of bees. It was then worth 12 pounds; now 20.

\section{HUNDRET OF WENSISTREU [WINSTREE]}

Borooldituna [Barnwalden ?], which Alvric, a free man, held, in King Edward's time, as a manor and as I hide, is held of $\mathrm{R}$ [alf] by Modbert. Then as now (semper) I plough on the demesne. Then 3 bordars; now 4. (There is) wood(land) for 20 swine. Then 2 rounceys (runcini), I beast (animal), I pig, (and) 15 sheep; now 2 rounceys, I

1 This is one of the many cases in which terro and monerium are used indifferently by the scribe.

2 This is a good instance of the omission of a Christian name, Ralf Baignard being spoken of as 'Baignard' only.

3 Wimbish is in Uttlesford Hundred.

- A manor in Tolleshunt Knights, which was held of Ralt's successors, the Lords Fitz Walter, and which is now represented by 'Barn Hall.' The ' $n$ ' is intrusive, for the name of the manor, in the fourteenth century, was 'Barwaldone' or 'Berwaldon.' No attempt has been made hitherto to identify 'Boroolditune' (which seems to be formed like 'Tidwolditune,' now Heybridge), and Morant identified Ralf' 'Toleshunt' (see p. 526 below) as Barnwalden. No place of any such name as 'Boroolditune' is found in Winstree Hundred, nor can any manor there be traced up to Ralf Bainard. Barnwalden, though in Thurstable Hundred, stood just on the edge of that of Winstree. beast, 2 swinc, 33 sheep, and 34 goats. It is worth 30 shillings.

Metcinges [Messing ${ }^{6}$ ], which was held by a free woman as a manor and as half a hide in King Edward's time, is held of R[alf] by Bernard.' (There is) now I bordar. (There is) wood(land) for 12 swine. It was then worth 10 shillings; now 3 .

\section{Hundret of Clavelinga [Clavering]}

In Magellana [Manuden], I free man held in King Edward's time 30 acres, which (quod) Amelfrid' (now) holds of R[alf]. Then as now (semper) I plough. It was then worth 5 shillings; now 10.

\section{Hundret of Hidingforda [Hinckford]}

Pentelawa [Pentlow] was held by a free woman as a manor and as 4 hides and 3 virgates in King Edward's time. ${ }^{7}$ Then as now (semper) 3 ploughs on the demesne, and 5 ploughs belonging to the men, and 8 vilfo. 70

leins. Then and afterwards I bordar; now 8. Then 8 serfs; now none. (There is) wood(land) for 200 swine, (and) 30 acres of meadow. Then as now (semper) I mill. Then two rounceys (runcini), 22 beasts (animalia), $4^{8}$ swine, 1 sheep, (and) 8 hives of bees; now 3 rounceys, 24 beasts, 20 swine, 80 sheep, (and) 8 hives of bees. And (there are) 18 sokemen with (de) 2 hides and 30 acres; and they have 5 ploughs; then 4 serfs; now I ; (there are) now 4 bordars; (there is) wood(land) for ro swine, (and) 10 acres of meadow. The whole was worth 10 pounds in King Edward's time; now 16. Of this manor Galicer[ius] ${ }^{8}$ holds 30 acres; and (this) is worth 10 shillings in the above valuation (in codem pretio).

\section{Hundret of Witbrictesherna [DEngie]}

BURNEHAM [Burnham], which was held by Alwart, a free man, as a manor and as 4 hides and 12 acres in King Edward's time, is held by $\mathrm{R}$ [alf] in demesne. Then as now

- Messing is in Lexden Hundred, but adjoins Tolleshunt Knights.

- The identity of this small estate cannot be determined, but its holder was doubtless the Bernard who held 'Toleshunta' also of Ralf.

7 The usual information as to whether the manor was held in demesne or by an undertenant in 1086 is not given.

- Identical with the 'Walicherius' entered above as holding at Cold Norton. 


\section{A HISTORY OF ESSEX}

(semper) I villein. Then 6 bordars; now 12. Then 4 serfs; now none. Then as now (semper) 2 ploughs on the demesne, and I plough belonging to the men. (There is) pasture for 300 sheep. Then 2 rounceys (runcini), 4 beasts (animalia), 12 swine, (and) 200 sheep; now 6 rounceys, 13 beasts, 16 swine, (and) 336 sheep. It was then worth 4 pounds; now 100 shillings. In the same vill (there were), in King Edward's time, Io free men, who had 8 hides and 28 acres; and this (quod) is (now) held by Robert in demesne. Then 8 bordars; now I6. Then as now (semper) 7 serfs and 8 ploughs. (There is) now I mill. (There is) pasture for 600 sheep; then and afterwards (this) was worth 7 pounds; now 8 pounds; this land is claimed by Ralf Baignard (as obtained) by exchange (pro escangio).

\section{Hundret of Celmeresfort [Chelmsford]}

BADwEN [(Littlc) Baddow], which was held by Lewin' as a manor and as 4 hides, is held of R[alf] by Germund. ${ }^{1}$ Then as now (semper) 2 villeins, and 2 bordars. Then 9 serfs; now 7. Then as now (semper) 4 ploughs on the demesne. Then I plough among the men; now none. (There is) wood(land) for 100 swine, (and) I acre of meadow. Then as now (semper) I mill. Then 7 rounceys (runcini), 47 beasts (animalia), 108 swine, 80 sheep; now 10 rounceys, 53 beasts, (and) 163 sheep. It was then and afterwards worth 100 shillings; now 6 pounds. And 5 free men held 2 hides and $3 \mathrm{I}$ acres and (qui) could betake themselves (ire) whither they would ; ${ }^{2}$ now the same Germund and 4 Frenchmen (franci) hold (this); then as now (semper) 3 bordars, and 1 serf; then 2 ploughs (were there); now I ; (there is) wood(land) for 26 swine, (and) 13 acres of meadow. It is worth now as fo. $7 \mathrm{ob}$

then (semper) 20 shillings.

HaningeFelda [Hanningfield ${ }^{3}$ ], which was held by Norman as a manor and as 3 hides, is held of $\mathrm{R}$ [alf] by Berenger. Then 3 villeins; now none. (There are) now 9 bordars. Then as now (semper) 2 serfs. Then 2 ploughs on the demesne; now 1 . Then I plough belonging to the men; now a half. (There is) wood(land) for 200 swine. (There are) now 3 beasts (animalia), 23 swine,

1 See note 6 below.

2 i.e. they could choose their lord.

3 i.e. the manor of Claydons in East Hanningfield, which was held of the Lords FitzWalter.
47 sheep, and 4 goats. Then and afterwards it was worth 70 (? $)^{4}$ shillings; now 4 pounds.

\section{Hundret of Tendringa [Tendring]}

ADEM $^{5}$ [(Little) Oakley], which was held by Ednod as a manor and as $5 \frac{1}{2}$ hides, is held of $\mathrm{R}$ [alf] by Germund. ${ }^{6}$ Then 7 villeins ; now 17. Then as now (semper) 4 bordars, and 8 serfs, and 3 ploughs on the demesne, and 3 ploughs belonging to the men. (There is) wood(land) for 33 swine, 2 acres of meadow, I fishery, (and) pasture for 100 sheep. Then 2 rounceys (runcini), and 13 beasts (animalia), 50 swine, (and) 50 sheep; now 3 rounceys, 4 beasts, 27 swine, (and) I 8 sheep. Then and afterwards it was worth 7 pounds; now 9 .

Rameseia [Ramsey], which was held by Alvric Camp ${ }^{7}$ as a manor and as 7 hides and 35 acres, is held (of Ralf) by Roger. Then as now (semper) i 8 villeins. Then 6 bordars; now 9. Then as now (semper) 6 serfs, and 3 ploughs on the demesne. Then the men had 7 ploughs among them; now 5 . (There is) wood(land) for 60 swine, 8 acres of meadow, (and) now I mill. (There is) I saltpan. It was then worth 12 pounds; now I 5. Then I rouncey (runcinus), and 20 beasts (animalia), 22 swine, (and) I 15 sheep; now 2 rounceys, 20 beasts, 49 swine, 309 sheep, (and) 8 hives of bees.

Michelestou [Michaelstow ${ }^{8}$ ], which was held by Alric' as a manor and as $2 \frac{1}{2}$ hides, is held of $\mathrm{R}$ [alf] by Bernard. Then 3 bordars; now 1 . Then 3 serfs; now none. Then as now (semper) 2 ploughs on the demesne. Then the men had half a plough among them; now none. (There are) 4 acres of meadow. Then 2 rounceys (runcini), 6 beasts (animalia), 27 swine, (and) 150 sheep; now 25 swine, (and) 83 sheep. It was then worth 70 shillings; now 4 pounds. And R[alf] holds 2 sokemen by exchange (in suo escangio) as his men say-but they alone ${ }^{9}$-belonging to $(d e)$ the manor which

4 ' $x \mid x^{\prime}$ (? Ixx) in the MS.

5 A clerical crror for 'Aclem ' (see Introduction, p. 395).

6 Who also held of him Little Baddow (see note I above).

7 He had held land also at Dedham, Bradfield, and Great Oakley in Essex, and other lands in Suffolk and Cambs (see Introduction, p. 353).

8 A manor in Ramsey, so named from the patron saint of the church.

8 'sed alii non testantur nisi ipsi soli.' 


\section{THE HOLDERS OF LANDS}

is called Laleforda [Lawford '], (and) holding half a hide and 35 acres; this is held of $\mathrm{R}$ [alf] by the same $\mathrm{B}$ [ernard]; then 1 plough (was there); now half; it was then worth 8 shillings; now ro. And in Witelebroc [ ] Roger holds of Ralf I hide which Alvric held as a manor. Then as now (semper) I bordar (was there), and I plough, and (there is) I acre of meadow; it is worth 10 shillings. This estate (terra) did not belong to (jacuit in) the other (two) estates (terris). These fo. $7 x$

3 manors $^{2}$ are worth 20 pounds.

\section{Hundret of Udelesfort [UtTlesford]}

WENDENa [Wenden (Loughts ${ }^{3}$ )], which was held by I free man, Alwin' Stille, as a manor and as $1 \frac{1}{2}$ hides and 30 acres, is held (of Ralf) by Amelfrid[us]. And R[alf] has (it) by exchange (in escangio). Then as now (semper) 5 villeins, and 3 bordars, and 2 serfs, and 2 ploughs on the demesne, and I plough belonging to the men. There is wood(land) for 80 swineand 3 acres of meadow. It was then worth 4 pounds; now 5 .

\section{Half Hundret of Frossewella [FRESHWELL $]$}

Henham, which was held by Ailid' as a manor and as $13 \frac{1}{2}$ hides less 10 acres, is held by $R$ [alf] in demesne. Then and afterwards $\mathrm{i} 8$ villeins; now 8 . Then and afterwards 5 bordars; now 38 . Then and afterwards 8 serfs; now none. Then as now (semper) 4 ploughs on the demesne, and 8 ploughs belonging to the men. (There is) wood(land) for 200 swine, (and) 16 acres of

1 See the relative entry, under Lawford, on p. 435 above.

'This is a good instance of 'terra' and 'manerium' being used interchangeably. The ' 3 manors' are Ramsey, Michaelstow and 'Witelebroc.' As to the last, a considerable 'brook' runs by Ramsey and Michaelstow.

- Now, corruptly, Wenden Lofts. It derived its name from a family which held it as undertenants. Henry 'Loholt' held two knight's fees of Walter Fitz Robert (Ralfs successor) as early as 1166. The name occurs also as 'Lohout,' and the same family held under the Counts of Boulogne at Tolleshunt in Tollesbury. This is of special interest because that manor was held of Count Eustace, in 1086, by 'Alm'fridus (see p. 469 above), who is thus shown to be identical with 'Amelfridus,' Rall's tenant at Wenden and at Manuden (see p. 523 above).

Members of the family of Lohout or Loholt occur frequently in the cartulary of Saffron Walden, especially in the Arkesden charters. meadow. Then 3 rounceys (runcini), 8 beasts (animalia), 80 swine, 160 sheep, (and) 16 hives of bees; now 8 rounceys, 7 beasts, 100 swine, 80 sheep, and 10 hives of bees. It was then worth 12 pounds; now 20.

Ascenduna [Ashdon], which was held by Ailid' as a manor and as 2 hides, is held by $R$ [alf] in demesne. Then 14 villeins; now 20. Then 3 bordars; now 9. Then 2 serfs; now none. Then as now (semper) 2 ploughs on the demesne, and 4 ploughs belonging to the men. (There is) wood(land) for 100 swine, 6 acres of meadow, (and) I acre of vineyard. Then 2 rounceys (runcini), 5 beasts (animalia), 60 swine, 200 sheep, (and) 10 hives of bees; now I rouncey, 7 beasts, 60 swine, 65 sheep, (and) 3 hives of bees. It was then worth 6 pounds; now 8 . And (there are) 2 sokemen holding 15 acres freely (libera). These were received by $\mathrm{R}$ [alf] in exchange, (and are) worth 3 shillings.

\section{HundRet of Rochefort [ROchford]}

In Pachesham [Paglesham], Thierri (Tedricus) Pointel ${ }^{6}$ holds half a hide and 15 (acres), which were held by 1 free man. Then 2 bordars; now 5. Then as now (semper) I plough. There is pasture for 50 sheep. It is worth now as then (semper) 20 shillings. $\mathrm{R}$ [alf] claims to hold this by exchange (pro escangio).

\section{Hundret of Turestapla [Thurstable]}

LANGHEFORDA [Langford] was held by Gola and Ethelmær (Agelmar[us]) as a manor and as three hides and $a$ half; and this half hide was held at rent (ad censum) of St. Paul by Ethelmær; but $R$ [alf] is now seised thereof. And Geoffrey holds of $R$ [alf] the whole. Then as now (semper) I villein. Then 4 bordars; now 9. Then 4 serfs; now 3. Then 3 ploughs on the demesne; now 2 . fo. 7 ib

(There is) wood(land) for 20 swine, 25 acres of meadow, (and) now as then (semper) I mill. Then 3 rounceys (runcini), 5 beasts (animalia), 24 swine, (and) 40 sheep; now 2 rounceys, 4 beasts, 40 swine, (and) 80 sheep. It was then worth 100 shillings; and when received,

- Except in this and one other instance vineyards were measured by arpents.

- See p. 522, note 3, above.

- See p. 443 above, under Heybridge ("Tidwoldituna'), a manor of the canons, where it is duly noted that Ralf holds this half hide, though the Hundred (court) knows not by what right. 


\section{A HISTORY OF ESSEX}

the same; now 4 pounds. Then there were there 5 free men with $\mathrm{I} \frac{1}{2}$ hides; now (there are) 4 men; then $1 \frac{1}{2}$ ploughs (were there); now 1 . Then I bordar; now 3. Then I serf; now none; it was then worth 30 shillings; now 20.

Toleshunta [Tolleshunt ${ }^{1}$ ], which was held by Ailmar' 2 as a manor and as 3 hides and 8 acres, is held of R[alf] by Bernard. Then 4 villeins; now 8 . Then as now (semper) 5 bordars. Then 4 serfs; now 1 . Then as now (semper) $\mathrm{r} \frac{1}{2}$ ploughs on the demesne, and 2 ploughs belonging to the men. (There is) wood(land) for 200 swine, (and) pasture for 20 sheep. (There are) 5 saltpans. Then 2 rounceys (runcini), 6 beasts (animalia), 20 swine, (and) roo sheep; now 2 rounceys, 5 beasts, 20 swine, roo sheep, (and) 28 goats. It is worth now as then (semper) 60 shillings. In the same vill (are) 8 free men with $(d e) 1_{\frac{1}{2}}^{\frac{1}{2}}$ hides and 14 acres; then as now (semper) 2 bordars (were there), and 2 ploughs; it is worth 20 shillings; R[alf] Baignard has this land by exchange (pro escangio).

\section{XXXIIII. THE LANDS ${ }^{3}$ OF RANULF PEVEREL [PIPERELLI]}

Hundret of Berdestapla [Barstable]

In BURA [Bowers (Gifford ${ }^{4}$ )] Serlo holds of Ranulf I hide. ${ }^{5}$ (There is) I plough (with) I serf. This was held by Alestan, a free man. (There is) pasture for 120 sheep. Then I rouncey (runcinus), roo sheep, I4 swine, (and) 4 calves (vituli); now 2 rounceys, roo sheep, 14 swine (and) 4 calves. It was then worth 20 shillings; now 40.

Phenge $\left[\right.$ Vange $\left.^{6}\right]$, which was held by a

1 The identity of this manor is not satisfactorily proved. Morant placed it, as Barnwalden (see note 523 above), in Tolleshunt Knights, but the mention of marsh ('pasture for sheep ') and of saltpans points to its touching the coast, which Tolleshunt Knights does not, though the other Tolleshunts do.

2 This was, not improbably, the "Agelmarus' of the preceding entry. Bishop Ethelmær of East Anglia was entered in Domesday both as 'Agelmarus' and as 'Ailmarus.' In any case this Ailmar' can be absolutely identified as the 'Ailmar' melc' of an entry in the Survey of Colchester ( $p$. 577 , note 12 , below)

3 The plural form (terre) is here employed.

4 This estate must have been granted out by the Crown to be held in serjeanty after the escheat of Ranulf's fief.

b 'I hide' is interlined.

6 This estate cannot be traced, unless it was combined with the one preceding it. free man as a manor and as I hide, is held or $R$ [anulf] by the same Serlo. The free man (qui) became the man of Ranulf Peverel's predecessor in King William's time, but did not give him his land. When the king gave (the) land to Ranulf, he took seisin of this (saisivit illam) with the rest. ${ }^{7}$ In this land (qua) there fo. 72

was then I plough; now none. (There is) pasture for 30 sheep. It was then worth 20 shillings; now 10.

INGA [ ], which was held by Alsid' as a manor and as I hide and 20 acres in King Edward's time, is held (of Ranulf) by the same Serlo. Then as now (semper) I plough. Then 3 bordars; now 4. (There is) wood(land) for 30 swine. It was then worth 20 shillings; now ro.

\section{HUNDRET OF WITHAM}

HadFELda [Hatfield (Peverel)], which was held by Ailmar' as a manor and as 9 hides and 82 acres, is held by $R$ [anulf] in demesne. Then as now (semper) 5 ploughs on the demesne. Then I 3 ploughs belonging to the men; now II. Then 12 villeins; now 13. Then 12 bordars; now 38 . Then 10 serfs; now 7. (There is) wood(land) for 700 swine, (and) 50 acres of meadow. Then 2 mills; now $x$. Then 6 rounceys (runcini), and 4 colts ( $p u l l i)$, and 6 cows, and 8 calves (vit'), 150 sheep, (and) 100 swine; now 5 rounceys, 4 colts, 5 cows, 7 calves, 57 sheep, 39 swine, (and) 20 goats. It was then worth 16 pounds; now 20; and the same when he received it. ${ }^{8}$ Of this manor Serlo and Ernulf and Richard hold 3 hides and 20 acres ; ${ }^{9}$ and (this) is worth 4 pounds in the above valuation (in eodem pretio). And 5 knights (milites) hold of R[anulf] 4 hides and I 5 acres, which were held by 13 free men in King Edward's time; then as now 7 ploughs (were there, and) 16 bordars, (and) 2 villeins, (and) 2 serfs, and $x$ mill ; (this) is worth 4 pounds.

Blundeshala [Blunts Hall ${ }^{10}$ ], which was held by Brictmar as a manor and as $2 \frac{1}{2}$ hides in King Edward's time, is held of $\mathrm{R}$ [anulf] by Humfrey. ${ }^{11}$ Then as now (semper) 2

7 This is an important, but difficult passage. 8 'Et hoc manerium recepit tantum valens ut modo.'

9 Here again we find on the chief manor of the baron small holdings in the hands of his Norman followers (see p. 484 , note 6 , above).

10 A manor in Witham.

11 See p. 532, note 5, below. 


\section{THE HOLDERS OF LANDS}

ploughs on the demesne. Then I plough belonging to the men; now $1 \frac{1}{2}$. Then as now (semper) 2 villeins. Then 3 bordars; now 5. Then 6 serfs; now 4. (There are) 18 acres of meadow, and I mill, and I sokeman with (de) I 5 acres. Then I rouncey (runcinus), 4 beasts, and 4 calves, 60 sheep, (and) 16 swine; now 2 rounceys, 4 cows, ${ }^{1}$ and 4 calves, 80 sheep, (and) 36 swine. It is worth now as then (semper) 4 pounds.

Terlinga [Terling], which was held by Ailmar', a king's thegn, ${ }^{2}$ as a manor and as $2 \frac{1}{2}$ hides and 30 acres in King Edward's time, is held of $\mathrm{R}$ [anulf] by Richard. Then as now (semper) 2 ploughs on the demesne, and 3 ploughs belonging to the men. Then 11 villeins; now 5. (There are) now I I bordars. Then 5 serfs; now none. (There is) wood(land) for I 50 swine, 20 acres of meadow, (and) fo. $\mathrm{rab}$

pasture for 100 sheep. $^{3}$ Then I mill; now 2. And (there belong to this manor) 2 houses in Colchester; one renders 6 pence, and the other I 4 (pence). And (there is) I free man with (de) 5 acres, and he used to render 10 pence to Ranulf's predecessor, and $\mathrm{R}$ [anulf] now receives the same (simil). Then 12 beasts (animalia), 180 sheep, 50 goats, (and) 40 swine; now 2 rounceys (runcini), and 2 colts (pulli), 8 beasts, 75 sheep, 16 goats, (and) 34 swine. It was then worth 8 pounds; and when received, the same; now 6 pounds.

Fairsteda [Fairsted], which was held by Brictmar as a manor and as 55 acres in King Edward's time, is held (of Ranulf) by Turold. Then as now 2 ploughs on the demesne, and 2 ploughs belonging to the men, and 4 villeins. Then 7 bordars; now 10 . Then 4 serfs; now 3. (There is) wood(land) for 100 swine, 40 acres of meadow, pasture worth (de) 4 pence, (and) now I mill. Then I rouncey (runcinus), 13 sheep, (and) 6 swine ; now 2 rounceys, 124 sheep, 32 swine, 4 cows with calves, (and) 3 hives of bees. And, in King Edward's time, 15 acres belonged (jacebant) there, of which Saswal'

I Here the cows (rocce) obviously represent the beasts (onimalia), as if the terms had the same meaning (see Introduction, p. 367, and p. 532, note 2 , below.

2 This would clearly be the Ailmar' who had held Hatficld (Peverel).

This is one of the exceedingly rare cases of such pasture being mentioned as appurtenant to an inland manor (compare Introduction, p. 369).

4 This is a strangely low assessment. disseised (him), and they (now) belong (jacens) to the fief of Geoffrey de Magna Villa. It was then worth 4 pounds; now 100 shillings.

\section{HundRet of Beventreu [Becontree]}

HAME [(East and West) Ham $\left.{ }^{6}\right]$, which was held by Alestan, a free man, as a manor and as 8 hides and 30 acres in King Edward's time, is held by R[anulf] in demesne. And King William gave this manor to $R$ [anulf] Peverel (piperello) and Robert Gernon (grenoni). Then 5 ploughs on the demesne; now 4 . Then 8 ploughs belonging to the men; now 12. Then 32 villeins; now 48 . Then 16 bordars; now 79. Then as now (semper) 3 serfs. (There is) wood(land) for 100 swine, (and) 60 acres of meadow. Then 9 mills; now 8.7 Then 1 rouncey (runcinus), 1 cow, (and) 3 swine; now 2 rounceys, 2 colts (pulli), 2 cows with calves, 20 swine, (and) 60 sheep. It was then worth 16 pounds; and when they received (it), 12 pounds. It is now worth 24 pounds. And of this manor $\mathrm{R}$ [obert] Greno has a moiety.

\section{Hundret of Dommawa [Dunmow]}

Cicchenal [Chickney], which was held by Siward, a ("I ) thegn of King Edward, ${ }^{8}$ as a manor and as $2 \frac{1}{2}$ hides, is held of $R$ [anulf] by Garin'.9 Then as now (semper) 3 ploughs on the demesne, and 2 ploughs belonging to the men. Then 2 villeins; now none. Then 7 bordars; now I priest and I4 bordars. (There is) wood(land) for 60 swine, (and) 20 acres of meadow. Then 2 rounceys (runcini), 3 cows with calves, 60 sheep, 20 swine, (and) 24 goats; now 3 rounceys, 6 cows (with) calves, 100 sheep, 30 swine, (and) 30 goats.

fo. 73

It was then worth 100 shillings; now 7 pounds.

- Geoffrey de Mandeville held at Notley and Ridley Hall close to Fairstead, but his tenant at both was Walier. There is no mention of these is acres under Geoffrey's fief, and Sewal (Saswolo), though an under-tenant of his in other counties, docs not occur as such in Essex.

6 This is the duplicate, mutatis musandis, of the entry on p. 515 above.

7 See p. 515 , note 2.

8 See Introduction, p. 346.

$8 \mathrm{He}$ was also the under-tenant of all Ranulf's manors in Norfolk except Billingford, which was held by Humfrey (on whom see p. 532, note 5, below). His holding was represented under John by 5 knight's fees, then in the hands of William, and afterwards of Mathew, Peverel. 


\section{A HISTORY OF ESSEX}

WILLINGEHALA [Willingale (Doe) ${ }^{1}$ ], which was held by Siward ${ }^{2}$ as a manor and as I hide and $1 \frac{1}{2}$ virgates in King Edward's time, is held of R[anulf] by Rauenot. Then as now (semper) 3 ploughs on the demesne. Then half a plough belonging to the men; now I. Then I villein; now 3. Then as now (semper) 6 bordars. Then 6 serfs; now 4 . (There is) wood(land) for I 20 swine, (and) 12 acres of meadow. Then 3 rounceys (runcini), 16 beasts (animalia), 30 swine; now 3 rounceys, 4 colts, 16 beasts, 100 sheep, 65 swine, (and) 5 hives of bees. It was then worth roo shillings; and when received, 6 pounds; now 10.

To this estate (terra) has been added I sokeman, who was held by R[anulf] Peverel's predecessor; and he is still (adbuc) held by $\mathrm{R}$ [anulf], and of him by Rauenot. And there have further (adbuc) been added to this estate, in King William's time, 30 acres which were held by a free man in King Edward's time, (and are) worth 10 shillings.

\section{Hundret of Wibrictesherna [Dengib]}

Odeham [Woodham (Mortimer)], which was held by Siward ${ }^{8}$ as a manor and as 5 hides in King Edward's time, is held by R[anulf] in demesne. Then as now (semper) 4 villeins. Then 9 bordars; now 8. Then 5 serfs; now 2. Then as now (semper) 2 ploughs on the demesne. Then 4 ploughs belonging to the men; now $1 \frac{1}{2}$. (There are) 3 acres of meadow, (with) wood(land) for 200 swine. Then 2 rounceys (runcini), 6 cows, 4 calves, 60 sheep, 20 swine, (and) 45 goats; now 3 rounceys, 2 colts (pulli), 4 cows, 4 calves, I 35 sheep, 46 swine, (and) 5 goats. It is worth now as then (semper) roo shillings.

Meldona [(Little) Maldon], which was held by Siward ${ }^{2}$ as a manor and as $5 \frac{1}{2}$ hides and 10 acres, is held by Ranulf in demesne. Then 16 villeins; now 9. (There are) now ro bordars. Then as now (semper) 3 serfs, and 2 ploughs on the demesne. Then 10 belonging to the men; now 5. (There are) ro acres of meadow. (There is) wood(land) for 50 swine, (and) $x$ mill. Then 2 rounceys (runcini); now the same. And (there are) now 3

1 Alias Willingale Rokele. Temp. Hen. III. ' the heirs of William de Rokele' held $\mathrm{I} \frac{1}{2}$ fees in Willingale of the Honour of Peverel (Red Book of the Exchequer, p. 740), which proves the identity (see my note on Willingale Doe in Essex Arch. Trans. n.s. vii. 375).

2 See Introduction, p. 346. cows, 4 calves, 140 sheep, (and) 29 swine. It is worth now as then (semper) 12 pounds. ${ }^{3}$

Haleshera [Hazeleigh ${ }^{4}$ ], which was held by Serlo as a manor and as $4 \frac{1}{2}$ hides, is held of $\mathrm{R}$ [anulf] by the same Serlo. Then as now (semper) 4 villeins. Then 4 serfs; now 3 . Then 2 ploughs (on the demesne); now $I$. Then I plough belonging to the men; now a half. (There is) wood(land) for 60 swine. Then 2 rounceys (runcini), 2 cows, 2 calves, 60 sheep, (and) 5 swine; now 2 rounceys (runcini), 4 cows, 100 sheep, (and) 9 swine. It is worth 4 pounds.

fo. $73 \mathrm{~b}$

Halesleia [Hazeleigh ${ }^{6}$ ], which was held by Ailmar', ${ }^{\circ}$ a free man, as half a hide and 20 acres in King Edward's time, is held of $\mathrm{R}$ [anulf] by Godric. Then as now (semper) I villein. Then 2 bordars; now none. Then as now (semper) I plough on the demesne. There is wood(land) for 80 swine. It is worth 20 shillings.

\section{HUNDRET OF WENSISTREU [WinstreE]}

LEGRA [Layer ${ }^{7}$ ], which was held by A. ${ }^{8}$ (sic) as a manor and as I hide less $12 \frac{1}{2}$ acres, is held of R[anulf] by Turold'. Then as now (semper) I plough on the demesne. (There is) now half a plough belonging to the men. Then I bordar; now 4. Then 4 serfs; now I. (There is) wood(land) for 16 swine. Then I rouncey (runcinus), 5 cows, 5 calves, (and) roo sheep; now 2 rounceys, 4 cows, 5 calves, (and) $\mathrm{rO}_{3}$ sheep. It was then worth 30 shillings; now 20.

3 See the other Maldon entry on p. 531 below.

4 This and the manor which follows it appear to be the 'Great' and 'Little' Hazeleigh which were held of the Honour of Peverel, under John, as 2 fees and $\frac{1}{4}$ fee respectively.

5 'This is what was known as 'Little' Hazeleigh (see preceding note). In the Red Book of the $E x$ chequer (p. 741) we read: 'Terra Hardekyn 1 quarter' in Harleslega in Essexa'; and though the editor queries the identity of this as Hazeleigh, the point is settled absolutely by the Testa de Nevill (p. 267): 'Hardekinus de Hailesl[ea] tenet Hailesl[eam], set nescimus quomodo, et valet 20 solidos.' An interesting Essex plea of 13 Ed. I., cited by Morant (i. 342), reveals the fact that Hardekin held his land by the tenure of rearing one of the king's hounds. As the plea describes it as in Woodham Mortimer it was probably in the two parishes.

6 'This was possibly the Ailmar' who had preceded Ranulf at Langford and Tolleshunt.

7 It has not been ascertained in which of the Layers this manor was situated.

8 Probably 'A[ilmarus].' 


\section{THE HOLDERS OF LANDS}

Edburgetuna [Abberton], which was held by $I$ free man as a manor and as $1 \frac{1}{2}$ hides and I virgate, is held by $R$ [anulf] in demesne. Then as now (semper) I plough on the demesne, and half a plough belonging to the men, and 4 bordars and 1 serf. (There is) wood(land) for 60 swine, (and) 4 acres of meadow. It was then worth 60 shillings; now 50.

WIGHEBERGA [Wigborough ${ }^{1}$ ], which was held by 1 free man as a manor and as half a hide in King Edward's time, is held of $\mathrm{R}$ [anulf] by Algar'. 'Then as now (semper) 1 plough. Then 1 bordar; now 2. It is worth 10 shillings.

\section{HUNDRET OF WDELESFORT [UंTTLESFORD]}

Deppedana [Debden], which was held by Siward as a manor and as $16 \frac{1}{2}$ hides, is held by $\mathrm{R}$ [anulf] in demesne. Then as now (semper) 6 ploughs on the demesne and 11 ploughs belonging to the men; and 36 villeins. Then and afterwards 1 bordar; now 17. Then as now (semper) 12 serfs. (There is) wood(land) for 1,000 swine, 40 acres of meadow, (and) now as then (semper) I mill. There are now 2 arpents (arpenni) of vineyard in bearing (portantes), and 2 not (yet) in bearing. Then 6 rounceys (runcini), 28 beasts (animalia), 150 sheep, 250 swine, (and) 6 hives of bees; now 7 rounceys, 2 colts (pulli), 1o beasts, 168 sheep, I 10 swine, and 3 hives of bees. Then and afterwards it was worth 24 pounds; now 30 . Of this manor $V$ ital [is] holds of R[anulf] 15 acres, and (this) is worth 10 shillings in the above valuation (in eodem pretio). ${ }^{3}$

Amberdana [Amberden "], which was held by Siward ${ }^{5}$ as a manor and 5 hides, is held by $\mathrm{R}$ [anulf] in demesne. Then as now (semper) 3 ploughs on the demesne, and 6 ploughs belonging to the men. Then and afterwards ro. 74

13 villeins; now 19. Then I bordar; afterwards 2 ; now 7 . Then as now (semper) 6 serfs. Then and afterwards (there) was wood(land) for 250 swine; now for 200. (There are) 30 acres of meadow. Then 2 rounceys (runcini), 6 beasts (animalia), 40 sheep, 40 swine, (and) 5 hives of bees; now 3 rounceys, I colt (pullus), 14 beasts, 68 sheep, 30 swine, (and) I hive of bees. It is worth

1 This small estate has not been identified.

2 See Introduction, p. 346.

See note 9 below.

- A manor in Debden.

- Sec Introduction, p. $34^{6}$.

I now as then 12 pounds; but $R$ [anulf] has received (babuit) i 8 pounds a year, thence for 3 years. This vill is claimed by the Abbot of Ely (eli), and the Hundred (court) testifies that it belonged to the abbey (jacuit ad acclesiam).

\section{HUNDRET OF HidingForda [HinckFord]}

Stabinga [Stebbing], which was held by Siward ${ }^{5}$ as a manor and as 3 hides and 30 acres in King Edward's time, is held by $R$ [anulf] in demesne. Then ${ }^{6}$ ploughs on the demesne; and when he received (it), 6 ; now 5. Then as now (semper) 11 ploughs belonging to the men. Then and afterwards 18 villeins; now 19. Then and afterwards 14 bordars; now 31 . Then and afterwards 13 serfs; now I1. (There is) wood(land) for 200 swine, (and) 24 acres of meadow. Then I mill; and when he received (it) $1 \frac{1}{2}$; now 2. (There are) now $2 \frac{1}{2}$ arpents (arpenni) of vineyard and only the half is in bearing. ${ }^{7}$ Then 5 rounceys (runcini), 5 cows, 100 sheep, 50 swine, (and) 5 hives of bees. It was then worth 10 pounds; afterwards 12 ; now 16 pounds. Of this manor Vital[is] (holds) 35 acres, and it is worth 10 shillings in the above valuation (in eodem pretio). ${ }^{9}$

Henies [(Great) Henny], which was held by Ulwin, a free man, as a manor and as $2 \frac{1}{2}$ hides and 45 acres in King Edward's time, is held of R[anulf] by Turold. Then as now (semper) 2 ploughs on the demesne, and 3 ploughs belonging to the men, and 5 villeins, and $I I$ bordars. Then and afterwards 2 serfs; now none. (There is) wood(land) for 80 swine, 12 acres of meadow, (and) now as then (semper) I mill. Then 2 rounceys (runcins), 5 cows with calves, 50 sheep, 14 swine, (and) 3 hives of bees; now 1 rouncey, 9 cows with calves, I 34 sheep, (and) 36 swine. And to this manor belongs a customary due of 22 pence (xxiid. de consuetudine) from Sudberia [Sudbury]. It was then worth 40 shillings; now 4 pounds.

LAMERS [Lammarsh], which was held by Algar as a manor and as $3 \frac{1}{2}$ hides in King Edward's time, is held of R[anulf] by Turold. ${ }^{10}$

- The number is omitted in the MS.

7 'The sense is somewhat doubtful, as dimidi' might possibly refer to the half arpent.

8 'The live stock in 1086 is not numbered.

8 He similarly held " 15 acres" (of the same value) in Ranulfs demesne manor of Debden, 2 few miles away.

10 Lammarsh, Henny and Terling, which were all among the manors held of Ranulf by Turold, 529
67 


\section{A HISTORY OF ESSEX}

Then as now (semper) 2 ploughs on the demesne. Then and afterwards $2 \frac{1}{2}$ ploughs belonging to the men; now 2. Then as now (semper) 4 villeins. (There are) now 8 bordars. ${ }^{1}$ (There is) wood(land) for 70 swine, (and) I 3 acres of meadow. Then 6 cows with calves, 54 sheep, (and) II swine; now 7 rounceys, 5 colts ( $p$ ulli), Io cows, 8 calves, 20 sheep, 54 swine, 60 goats, (and) 6 hives of bees. It was then worth 4 pounds; now 6 . fo. 74

In Lamers [Lammarsh] Alward held I $\frac{1}{2}$ bides as a manor in King Edward's time; now the same $T$ [urold] holds it of Ranulf; then as now (semper) I plough on the demesne, and I plough belonging to the men, and 2 villeins. Then 3 bordars; now 9; (there is) wood(land) for 30 swine and 7 acres of meadow ; it was then worth 40 shillings; now 60 . These two estates (terra) were thus divided between two brothers (divisa duobus fratribus) in King Edward's time. ${ }^{2}$ Afterwards they were given to Ranulf as (pro) I manor, as his men say. ${ }^{3}$

\section{Hundret of Witbrictesherna [Dengie]}

Duna [Down ${ }^{4}$, which was held by Siward' as a manor and as 14 hides, is held by $R$ [anulf] in demesne. Then 2 villeins; now 4. Then 3 bordars; now 15. Then 12 serfs; now 6. Then as now (semper) 5 ploughs on the demesne. Then 2 ploughs belonging to the men; now 3. (There is) wood(land) for 50 swine, (and) pasture for 50 sheep. Then and afterwards it was worth Io pounds; now I3. Of this manor Ascelin' holds $I \frac{1}{2}$ hides of $R$ [anulf]; and (this) is worth 20 shillings in the above valuation (in eodem pretio).

Lalinge (Lawling ${ }^{6}$ ], which was held by Brun, a free man, as a manor and as $2 \frac{1}{2}$ hides

appear to have been subsequently granted by the Crown to the Earls of Huntingdon, and to have passed from them with a co-heiress to the family of Brus.

1 No serfs are mentioned. They are possibly omitted by mistake.

2 The inequality of their shares should be observed. Lammarsh seems to have been a five-hide manor (see Introduction, p. 334), which was divided between the two brothers in the proportion, as nearly as possible, of two-thirds to the one and one-third to the other.

3 This may imply that there was a doubt whether Ranulf was entitled to both the shares.

4 In Bradwell-by-Sea (see Introduction, p. 392).

5 In Latchingdon. This appears to have been the manor of 'Peverells' there. and 35 acres, is held by $\mathrm{R}$ [anulf] in demesne. Then as now (semper) 2 serfs and 2 ploughs. (There is) wood(land) for 20 swine, pasture for 50 sheep, and (now) I fishery. Then and afterwards it was worth 4 pounds; now 3 pounds and 15 shillings.

In Duna [Down ${ }^{8}$ ] 8 free men held 5 hides less 6 acres, which are now held by $R$ [anulf] in demesne. Then as now (semper) 6 bordars, and $2 \frac{1}{2}$ ploughs. Then and afterwards it was worth 60 shillings; now 4 pounds and Io shillings.

Stanesgata [Stangate ${ }^{7}$, which was held by Siward as a manor and as $9 \frac{1}{2}$ hides in King Edward's time, is held (of Ranulf) by Ralf son of Brien'.8 Then as now (semper) 2 villeins. Then 22 bordars; now I 8 . Then 8 serfs; now 3 . Then $4 \frac{1}{2}$ ploughs on the demesne; now 4 . Then as now (semper) 3 ploughs belonging to the men. (There is) wood(land) for 60 swine, (and) pasture for 60 sheep. Then and afterwards it was worth 10 pounds; now 8.

\section{Hundret of Lassendena [Lexden]}

Peresteda [Prested ${ }^{9}$ ], which was held by Brictmar' as a manor and as $1 \frac{1}{2}$ hides in King Edward's time, is held (of Ranulf) by the same R[alf son of Brien]. ${ }^{10}$ Then 5 bordars; now 10. Then 4 serfs; now none. Then as now (semper) 2 ploughs on the demesne. (There is) wood(land) for roo swine, (and) 8 acres of meadow. Then 2 rounceys (runcini), 10 beasts (animalia), 80 sheep, 15 swine, 20 goats, (and) 2 hives of bees; now I mare fo. 75

(equa ${ }^{11}$ ) and I colt (pullus), 60 sheep, 20 swine, 9 goats, (and) 2 hives of bees. It is worth now as then (semper) 4 pounds. And I free man holds now as then (semper) 5 acres; and he was commended to R[anulf]'s predecessor, but could betake himself (ire) with his land whither he would ; ${ }^{12}$ and now R[anulf] has

6 See note 4 above.

7 In Steeple.

8 He appears to have been the founder of Stangate Priory in the days of Henry I. See my Ancient Charters (Pipe Roll Society), pp. $13,15$.

9 A manor in Feering.

10 See note 8 above.

11 The mares at Earls Colne (p. 534, note 9, below) appear to be the only others mentioned in the county.

12 This important clause should be compared with the entry of Ranulf's manor of Vange on p. 526 above, and with the remarks in the Introduction (p. 358). 


\section{THE HOLDERS OF LANDS}

(him). Then I plough (was there); now a half; it was then worth 16 shillings; now 12.

\section{Hundret of Angra [Ongar]}

Plumtuna [ ${ }^{1}$ ], which Ulvric the priest held of Harold freely (libere) as 14 acres, is held of Ranulf by Ravenot." And R [anulf] has (it) now because his predecessor was seised (thereof); but it did not belong to him according to the county (court)'s testimony (sicut comitatus testatur). Then as now (semper) I villein and half a plough. There is wood(land) for 20 swine, (and) $1 \frac{1}{2}$ acres of mcadow. It is worth 5 shillings.

\section{Hundret of Celmeresfort [Chelmsford]}

Springafelda [Springfield ${ }^{3}$ ], which was held by Alestan' as a manor and as 5 hides and 20 acres, is held of $R$ [anulf] by Robert. Then 6 villeins; now 4. Then 3 bordars; now 10. Then 8 (serfs); now 6. Then as now (semper) 3 ploughs on the demesne. Then and afterwards 3 ploughs belonging to the men; now 2. (There is) wood(land) for 30 swine, 25 acres of meadow, (and) now as then (semper) I mill. Then 2 rounceys (runcini), 12 beasts (animalia), 100 sheep, (and) 50 swine; now 4 rounceys, 5 colts (pulli), 26 beasts, 40 sheep, 25 swine, 12 goats, 2 asses, (and) 1 hive of bees. It was then worth 5 pounds; now 6 . And two free men held 13 acres, which $R$ [anulf] now has; this is worth 2 shillings.

Radenduna [Rettendon ${ }^{6}$ ], which was held by Siward ${ }^{6}$ as a manor and as $I$ hide and 30 acres, is held (of Ranulf) by Ralf son of Brien. Then as now (semper) I bordar, and I plough on the demesne. (There is) wood(land) for 6 swine. It is worth now as then (semper) 25 shillings, and is claimed by the abbey of Ely.

\section{Half Hundret of Melduna [Maldon]}

In Melduna [Maldon] $\mathrm{R}$ [anulf] holds in demesne half a hide and 24 acres which was held by Siward ${ }^{8}$ as a manor in King Edward's

1 Morant asserted that Domesday Book placed this small holding 'under Stondon' (i. 189); but this it will be seen is an error. There is nothing to show where the place was, and it is too small to be identified. Sec p. 528 .

The manor of Springficld Hall.

- 'bor[darii]' in MS. - an obvious error.

- The identity of this estate has not been ascertained. It may have been recovered by the abbey of Ely, of which the whole of Rettendon seems to have been subsequently held.

- See Introduction, p. 346 . time. Then I bordar; now 3. It is worth 5 shillings. This land is valued as part of (in) the 12 pounds from Maldon (de melduna ${ }^{7}$ ).

\section{Hundret of Tendringa}

Tendringa [Tendring ${ }^{8}$ ], which was lield by Olui' frecly (libere) as a manor and as half a hide and 30 acres, is held by $R$ [anulf] in demesne. And R[anulf] has it by (in) cxchange. Then 2 serfs; now 1. Then 2 ploughs; afterwards and now 1. (There is)

5o. $75 \mathrm{~b}$

wood(land) for 30 swine, (and) 2 acres of meadow. Then and afterwards it was worth 20 shillings; now 60.

Cice [St. Osyth ${ }^{9}$ ], which was held by Siward ${ }^{6}$ as a manor and as $2 \frac{1}{2}$ hides, is held of $\mathrm{R}$ [anulf] by Turold. Then and afterwards 9 villeins; now 6 . Then and afterwards 12 bordars; now I1. Then as now (semper) 7 serfs. Then and afterwards 4 ploughs on the demesne; now 3. Then and afterwards 7 ploughs belonging to the men; now 5 . (There is) wood(land) for 800 swine, ${ }^{10} 4$ acres of meadow, pasture for 200 sheep, (and) now as then (semper) 1 mill. Then 6 rounceys

7 See p. 528 above.

8 The identity of this manor is doubtful.

- The manors in the great parish of St. Osyth are by no means easy to disentangle. But this one seems to be that which is now St. Clerc's Hall. This conclusion is based on the following reasoning. Maurice 'de Chiche' (who is shown by the Colcbester Cartulary, pp. 229-31, to have been father of Richard and grandfather of Gilbert) occurs in 1141 as holding 5 fees (sce my Geoffrey de Mandeville, p. 142), which were apparently part of the Honour of Peverel of London. Roger - Ridel,' under John, held 5 fees of that Honour, and a tenant of the same name held of it, rather later, 5 fees 'in Chikene et Seirefeud' (Red Book of the Excbequer, p. 740). As it is known that a manor in St. Osyth was named 'Chich-Ridel, and as Roger son of Geoffrey Ridel gave land at Chiche to St. John's Abbey (Colchesier Cartulary, pp. 247-8, 651 ), I suspect that this 'Chikene' was really ChichRidel, and not (as the editor makes it) Chickney, with which the Ridels had nothing to do. If so, Chich-Ridel was Peverel's portion of St. Osyth ; and as Chich-Ridel, according to Morant, is styled 'alias St. Clere's Hall' in the time of Henry VIII., the above identity follows.

10 Such extensive woodland as this is most abnormal on the coast in the Essex of 1086 , and is made still more so by the fact that, in addition, Count Eustace's manor in St. Osyth is credited with woodland for 400 swine. But there was much woodland in Osyth down to recent times. 


\section{A HISTORY OF ESSEX}

(runcini), 50 beasts ${ }^{1}$ (animalia), 300 sheep, 40 swine, (and) 6 hives of bees; now 4 rounceys, 4 beasts, 68 sheep, 37 swine, (and) 18 goats. Then and afterwards it was worth 9 pounds; now 8.

Fretinga [Frating], which was held by Ketel as a manor and as 2 hides, is held of $\mathrm{R}$ [anulf] by the same T[urold]. Then 2 bordars; now 3. Then 3 serfs; now 2 . Then 2 ploughs on the demesne; now 1 . Then as now (semper) I plough belonging to the men. (There is) wood(land) for 150 swine, (and) 4 acres of meadow. Then I rouncey (runcinus), 4 beasts ${ }^{2}$ (animalia), 4 calves, 100 sheep, 40 swine; now I rouncey, 2 cows, ${ }^{2} 2$ calves, 66 sheep, 20 swine, (and) 6 hives of bees. It was then worth 40 shillings; now 60.

\section{HundRet OF ROCHEFORT [ROCHFORD]}

LEGRA [Leigh], which was held by 1 free man as a manor and as 1 hide, is held by $\mathrm{R}$ [anulf] in demesne. Then as now (semper) 2 villeins, and 2 bordars, and I plough on the demesne, and half a plough belonging to the men, and 5 bordars by the water (super aquam), ${ }^{3}$ who hold no land. There is pasture for 100 sheep. Then I rouncey (runcinus), 5 cows, 5 calves, (and) 100 sheep; now 2 rounceys, 4 cows, 5 calves, (and) 103 sheep. It was then worth 40 shillings; now 100.4

\section{Hundret of Turestapla [Thurstable]}

Toleshunta [Tolleshunt (Darcy) ${ }^{5}$ ], which was held by Siward as a manor and as $4 \frac{1}{2}$ hides and 30 acres, is held of R[anulf] by Humfrey. Then 9 villeins; now ro. Then 4 bordars; now 13. Then I0 serfs; now 6. Then as now (semper) 3 ploughs on the demesne and 3 ploughs belonging to the men. (There is) I saltpan, 5 acres of meadow, pasture for 30 sheep, and wood(land) for 150 swine. Then 3 rounceys (runcini), 20 beasts (animalia), 80 sheep, (and) 60 swine; now 3

1 This is an exceptionally large number, and is suggestive of scribal error.

2 This is a clear case of 'animalia' being used for cows, as at Blunts Hall, p. 527 , note 1 , above.

3 This phrase seems to correspond to our " a house on the river' and, in its origin, to the surname Surtees.

4 There seems to be nothing whatever to account for this great rise in value of 150 per cent.

3 Previously Tolleshunt Tregoz. See my paper on 'Tregoz of 'Tolleshunt 'Tregoz' in Essex Arch. Trans. [n.s.] viii. 330 , for the succession of the Tregoz family to 'Humfrey' as under-tenant on the Peverel fief. rounceys, 20 beasts, I60 sheep, 37 swine, (and) I 8 goats. It is worth now as then (semper) 100 shillings. In this manor 4 free men held half a hide and 5 acres; but Ralf fo. 76

Baignard has it and Hugh de Montfort (sic). ${ }^{6}$

GoLDHANGRA [Goldhanger], which was held by Lewin' and Ulward the priest as a manor and as $2 \frac{1}{2}$ hides and 25 acres, is held of R [anulf] by Richard. ${ }^{7}$ Then 3 bordars; now 14. Then as now (semper) 2 serfs. Then 2 ploughs on the demesne; now I. (There is) now I plough belonging to the men. (There is) wood(land) for 80 swine, pasture for 50 sheep, (and) $3 \frac{1}{2}$ acres of meadow. Then 51 sheep, (and) 8 swine; now I rouncey, I cow, 3 sheep, (and) 3 swine. It is worth now as then (semper) 40 shillings. There also (in eadem) (are) 2 free men with (de) $7 \frac{1}{2}$ acres; and (this) is worth 20 pence.

\section{THE LAND OF AUBREY (ALBERICI) DE VER}

\section{Hundret of Dommawa [Dunmow]}

Canedfelda [(Great) Canfield], which was held by Ulwin' ${ }^{8}$ as a manor and as 2 hides in King Edward's time, is held by Aubrey (Albericus) in demesne. Then as now (semper) 2 ploughs on the demesne. Then 4 ploughs belonging to the men; now 3 . Then as now (semper) Io villeins. Then 4 bordars; now 9. Then as now (semper) 4 serfs. (There is) wood(land) for 160 swine, 51 acres of meadow, (and) I mill. Then 7 beasts (animalia), 2 rounceys (runcini), 20 swine, 80 sheep, (and) 3 hives of bees; now 8 beasts, 3 rounceys, 30 swine, 100 sheep, (and) 3 hives of bees. It is worth now as then (semper) 6 pounds. 9

6 This passage is of some importance for the light it throws on the identity of the various Tolleshunts in Domesday. As the identity of the Peverel manor is ascertained-its hall adjoined the church of Tolleshunt Darcy-it may be inferred that the 'Toleshunt' of Hugh de Montfort (p. 500) and that of Ralf Baignard must have adjoined it.

7 This was doubtless the 'Richard' who held Count Eustace's manor there.

8 This was the great English predecessor of Aubrey in his estates (see Introduction, p. 343).

9 There is nothing in this entry to suggest that Aubrey had a residence there or to account for its castle earthworks (p. 290 above) ; but in a thirteenth century grant to Tiltey Abbey Robert Earl of Oxford styles the manor 'Canefeld Castel' (Tilley Cartulary, vol. i. fo. 24). 


\section{THE HOLDERS OF LANDS}

Udecheshale [ ], ${ }^{1}$ which was held by Ulwin as a manor and as I hide, is held by Aubrey in demesne. Then as now (semper) 2 ploughs on the demesne. Then 3 ploughs belonging to the men; now 1 . Then 11 villeiss; now 6. Then 2 bordars; now 4. Then as now (semper) 4 serfs. (There is) wood(land) for 100 swine (and) 48 acres of meadow. Then 6 beasts (animalia), 2 rounceys (runcini), 20 swine, 60 sheep, (and) 3 hives of bees; now 8 beasts, 2 rounceys, $3^{\circ}$ swine, 80 sheep, (and) 3 hives of bees. It is worth now as then (semper) 60 shillings. To fo. $76 \mathrm{~b}$

this estate (terre) have been added 1 virgate and 8 acres, which were held by a free man in King Edward's time; now Ralf holds (it) of A[ubrey]; then as now (semper) I plough (was) on the demesne; then I bordar; now 3 ; (there is) wood(land) for 30 swine, (and) 9 acres of meadow; it was then worth 16 shillings; now 30 .

\section{HUNDRET OF UDELESFORT [UTTLESFORD]}

Tunreslea [Thunderley ${ }^{*}$ ], which was held by Ailmar', a free man, as a manor and as 5 hides in King Edward's time, is held of A[ubrey] by Ralf. Then and afterwards 2 ploughs on the demesne; now 3 . Then as now (semper) 3 ploughs belonging to the men, and I priest, and I I villeins, and 5 bordars. Then and afterwards (there was) wood(land) for 100 swine; now for 80 . (There are) 12 acres of meadow. Then 120 sheep, 40 swine, 60 goats, 8 beasts (animalia), 3 rounceys (runcini), (and) 5 hives of bees; now 140 sheep, 60 swine, (and) the rest unchanged (aliud similiter). Then and afterwards it was worth 6 pounds; now 7 .

\section{Half Hundret of Clavelinga [Clavering]}

UGGhelea [Ugley ${ }^{8}$ ], which was held by Ulwin as a manor and as 5 hides, is held of A[ubrey] by Ralf. Then as now (semper) 3 ploughs on the demesne, and 4 ploughs belonging to the men. Then Io villeins; afterwards and now 7. Then and afterwards I bordar; now 10. Then and afterwards 6 serfs; now 2. Then and afterwards (there was) wood(land) for 200 swine; now for 160. There are 25 acres of meadow. Then 5

1 This place has not been identified. The abundance of meadow points to its lying in a river valley.

2 Now united with Wimbish.

3 Sce, for the descent of Ugley, my paper on 'A charter of Alice of Essex' in Essex Arch. Trans. [n.s.] viii. 330 . beasts (animalia), 50 swine, 160 sheep, 2 rounceys (runcimi), 50 goats, (and) 2 hives of bees; now 3 beasts (animalia), 22 swine, 80 sheep, 4 rounceys, 20 goats, (and) 2 hives of bees. It was then worth 6 pounds; now 8 .

\section{HUNDRET OF HidingForda [HINCKFORD]}

Hainghenam [(Castle) Hedingham], which was held by Ulwin' as a manor and as 2 hides, is held by Aubrey in demesne. Then as now (semper) 4 ploughs on the demesne, and 6 ploughs belonging to the men, and 15 villeins, and 7 bordars, and 8 serfs. (There is) wood(land) for 200 swine, and 30 acres of meadow. (There was) then I mill; now none. (There are) now 6 arpents (arpenni) of vineyard. Then 11 beasts (animalia), 140 sheep, 80 swine, and 4 rounceys (runcins); now 160 sheep, I 00 swine, I rouncey, (and) Ioo goats. And (there were ?) 13 sokemen who could not withdraw themselves (receder e), holding I hide and 10 acres; then as now (semper) $7^{4}$ ploughs (were there); then 15 villeins; now 18 ; (there are) now 22 bordars; then 6 serfs; now 2, having 3 ploughs; (there is) wood(land) for 60 swine, (and) 43 acres of meadow; then as now (semper) 1 mill was there. It ${ }^{6}$ was then worth 13 pounds; now 20. To this manor ${ }^{8}$ belong (jacent) 15 burgesses in Sudberia [Sudbury], and they are appraised in (the total of) those 20 pounds. Of this manor ${ }^{6}$ Robert Blund' holds 35 acres; Garin' 25 acres; Pincun' 15 acres; Godun 15 acres; (and) they have 5 ro. 77

ploughs; and (these holdings) are worth 7 pounds in the above valuation (in eodem pretio). ${ }^{7}$

4 ' $\mathrm{ji}$ ' is interlineated above $v$, as if to change 5 into 7.

- This of course must not be taken as implying that these ploughs belonged to the serfs. They were probably the ploughs employed on that portion of this estate which had now been turned into demesne.

6 It should be observed that this estate is valued as a whole and is spoken of as a 'manor,' although it was clearly divided, under Edward, between the 'manor' of Wulwine and the estate of the sokemen, the latter having its own woodland, meadow and mill. This therefore is a good instance of a Norman lord fusing into one 'manor' the lands of his English predecessor and those of the latter's sokemen.

7 These (comparatively) small holdings on 2 large manor in the hands of foreigners are, like vineyards, 2 sign of the residence of a Norman baron, and imply consequently that Aubrey had already a residence at Hedingham (Castle), the seat of his descendants (compare pp. 294, 383, 484, note 6).

It should be observed that these holdings are 


\section{A HISTORY OF ESSEX}

\section{Half Hundret of Thunreslau 1}

Belcamp [Belchamp (Walter)], which was held by Ulwin' as a manor and as $2 \frac{1}{2}$ hides in King Edward's time, is held by A[ubrey] in demesne. Then as now (semper) 4 ploughs (on the demesne), ${ }^{2}$ and 7 ploughs belonging to the men. Then and afterwards 13 villeins; now 15. Then and afterwards 9 bordars; now 14. Then and afterwards 6 serfs; now 8. (There is) wood(land) for 20 swine, 60 acres of meadow, (and) now 11 arpents (arpenni) of vineyards, (of which) $I$ is in bearing (portat). Then 24 beasts (animalia), I6o sheep, 80 swine, (and) 2. rounceys (runcini); now 28 beasts, 200 sheep, 100 swine, (and) 2 rounceys. To this manor belong now as then (adjacent semper) 7 sokemen with (de) $\mathrm{I} \frac{1}{2}$ hides and 15 acres; then as now (semper) $3 \frac{1}{2}$ ploughs were there ; 4 bordars (are there) now; (there are) $10 \frac{1}{2}$ acres of meadow. Then and afterwards it was worth 14 pounds; now 18 . Of this manor Enisant holds of $A$ [ubrey] half a hide and 30 acres; William Peche (peccatum) half a hide ; Suad' 30 acres ; and (these holdings) are worth 4 pounds in the above valuation (in eodem pretio $^{3}$ ).

\section{Hundret of Hidingaforda [Hinckford]}

HERSAM [Hersham (Hall) ${ }^{4}$, which was held of A[ubrey]'s predecessor by 2 sokemen on the terms that (ita quod) they could not withdraw themselves (recedere) without his permission (licentia), is held of A[ubrey] by Adelelm. ${ }^{5}$ (There are) 45 acres. $^{6}$ Then as

valued at the high sum of 67 out of the $\{20$ which was the total value of the manor. But though their assessment ( 90 acres) is low, they had 5 ploughs among them. Yet even so their value is remarkable, for there seems to have been 20 plonghs in the rest of the manor.

1 For this mysterious Half Hundred see the Introduction (p. 405).

2 car' bom' in the MS., an obvious error for car' in d'nio.

3 The value of these holdings was only $£_{4}$ out of $\ell_{1} 18$; yet their total assessment was $1 \frac{3}{2}$ hides out of $4 \frac{1}{8}$, a high proportion, and one which contrasts with the manor preceding, where a value of $\{7$ out of $\{20$ accompanies an assessment of only 3 hide out of (apparently) $3 \frac{6}{6}$.

On the other hand the division of these two demesne manors of Aubrey is curiously similar, and they deserve to be carefully compared.

4 A manor of which the hall is in Helions Bumpstead, which parish is in Freshwell Hundret (see p. 535 below).

5 This is the Adelelm who held of him at 'Bumesteda' (see p. 535 below), and at Burgate in the north of Suffolk.

6 This clause is interlined. now (semper) I $\frac{1}{2}$ ploughs. Then 5 bordars; now 10. (There was) then wood for 40 swine; now for 30 . (There are) 7 acres of meadow. It is worth 20 shillings.

\section{HUNDRET OF LEXeNDANa [LEXDEN]}

Coles [(Earls) Colne], which was held by Ulwin as a manor and as 5 hides, is lield by A[ubrey] in demesne. Then as now (semper) 7 villeins, and 13 bordars, and 6 serfs. Then 3 ploughs on the demesne; now 5. Then among the men (were) 3 ploughs; now 4. (There is) wood(land) for 400 swine, 40 acres of meadow, (and) 2 mills. Then 20 cows and 19 beasts (animalia); 8 120 sheep, 60 swine, 60 goats, (and) 3 rounceys (runcini); now 45 beasts (animalia), 160 sheep, 80 swine, 80 goats, 4 rounceys, and 6 asses, and 20 mares. ${ }^{\circ}$ And 4 sokemen dwelt on (in) these 5 hides and (had) ro bordars and 4 serfs. ${ }^{10}$ (The whole) was worth 10 pounds then and afterwards; now 12. Of this manor Miblanc (Dimidi[us] blanc[us]) holds I hide; and (there are) 7 bordars and 2 ploughs on the demesne, and I plough belonging to the men; and it is worth 45 shillings in the above valuation (in eodem pretio). II

\section{The number is omitted in the MS.}

8 This is one of the most noteworthy entries of live stock in the whole survey of the county. The cows and beasts, it should first be observed, are treated as quite distinct in the return for the earlier period; but as there had been a general increase in the live stock on the manor, I suspect that the 45 'animalia' of the later period, who replace the 20 cows and 19 'animalia' (total 39), included cows, and that we have here another instance of the Domesday scribe's varying terminology.

9 This is the only entry of mares in Essex save for a single mare at Prested (in Feering) and one of the six entries of asses in the county.

10 There is no entry of ploughs and no valuation of these holdings, nor is their assessment recorded. They would seem to have been swept away.

11 It seems to be clear that this sub-manor was that which appears as Colne 'Miblanc' not long afterwards, and which is now White Colne or part thereof. Morant assigned to White Colne this part of the entry, but held it 'certain that one Blancus held it at the time of the general Survey' as 'half' of the manor of Earls Colne; for he read the text as 'tenuit dimidium Blancus' (ii. 210, 215). The entry under Radwinter below shows that his reading was wrong, and that 'Dimidius blancus' must represent the 'Miblanc' from which was derived the name (known to him) of Colne-Miblanc. 'Demiblanc' is found as the name of a certain coin in old French, which suggests that 'Dimidius blancus' may have been a nickname. It occurs again below under Colchester, 


\section{THE HOLDERS OF LANDS}

10. $77 b$

\section{HUNDRET OF TENDRINGA}

Benetleia [(Great) Bentley], which was held by Ulwin as a manor and as 3 hides, is held by $A$ [ubrey] in demesne. ${ }^{1}$ Then and afterwards 7 villeins; now 6 . Then 5 bordars; now 10. Then as now (semper) 4 serfs. Then 4 ploughs on the demesne; now 3 . Then among (the men ${ }^{2}$ were) 5 ploughs; now 4. (There is) wood(land) for 150 swine, 6 acres of meadow, pasture for 150 sheep, (and) 1 saltpan. Then 3 rounceys (runcini), 100 sheep, 20 beasts (animalia), and 40 swine; now 100 sheep, and 3 rounceys, 26 beasts, (and) 40 swine. It was then worth 6 pounds; now 10.

Druvrecurt ${ }^{3}$ [Dovercourt], which was held by Ulwin' as a manor and as 6 hides, is held by $A$ [ubrey] in demesne. ${ }^{4}$ Then 8 vil. leins; now 6. Then 6 bordars; now 12 . Then as now (semper) 6 serfs, and 3 ploughs on the demesne, and 6 ploughs belonging to the men. (There are) 3 acres of meadow, (with) pasture for 200 sheep. Then 3 rounceys (runcini), 12 beasts (animalia), 200 sheep, (and) 40 swine; and now the same (similiter). It was then worth 6 pounds; now $12 .^{\circ}$

Fuleper [Beaumont ${ }^{8}$ ], which was held by Ulwin' as a manor and as 2 hides, is held of A [ubrey] by Edward. Then as now (semper)

where a house was held by the man who bore this name (p. 576).

White Colne, as a parish, is only half the size of that of Earls Colnc, but can hardly be represented by Miblanc's holding alone. Here, as in so many cases, Morant did not use properly the cvidence given by himself. In White Colne there were two manors, Barwick Hall and Ingledesthorp, of which the latter is of interest to the student of place-names as an addition to the small list of Essex 'thorpes.' It is clear, from Morant's owen evidence, that Barwick Hall was held of the Clares, and is therefore Richard Fitz Gilbert's holding ' in colun' (fos. 40b-41), which Morant nowhere identifics. Ingledesthorp I hold (also from his own evidence) to have been obtained, with Dovercourt, ' in marriage' by Bigot from de Vere and held accordingly.

1 It continued to be so held by the family for more than 500 years, and one of their seats was there.

2 'homines' is omitted in the MS.

3 The name, which is Druurecurt in the MS., should probably be read as above. The Kentish Dover is twice entered as Dovre.

4 It included the site of Harwich.

- There is, apparently, nothing whatever to account for this doubling of value.

- For this identification see the Introduction (p. 396).
17 villeins. Then 3 bordars; now 1 . Then 3 serfs; now none. Then 2 ploughs on the demesne; now I. Then as now (semper) 5 ploughs belonging to the men. (There is) wood(land) for 15 swine, 10 acres of mcadow, (and) 2 saltpans. Then 12 beasts (animalia), 150 sheep, 30 swine, (and) 2 rounceys (run(ini); now 4 beasts, I00 sheep, 30 swine, I rouncey, (and) 3 hives of bees. It was then worth 100 shillings; now 8 pounds. To this manor belongs I sokeman, who could not withdraw himself (recedere) from the land without permission (licentia) of Aubrey's predecessor, and who holds (tenens) 2 hides less 15 acres; then 2 villeins (were there); now none; then 2 bordars; now 3 ; then I serf; now none; then as now (semper) I plough (was) on the demesne; then I plough among the men; now none; (there is) wood(land) for 50 swine, (and) 2 acres of meadow; it was then worth 20 shillings; now $40 .^{7}$

\section{Half Hundret of Frossewella [Fresh- WELL]}

Bumesteda [(Helions) Bumpstead $\left.{ }^{8}\right]$, which was held by Ulwin' as a manor and as 2 hides, is held of A[ubrey] by Adelelm'. ${ }^{9}$ Then as now (semper) 7 villeins, and 3 bordars, and 4 serfs. Then and afterwards 2 ploughs on the demesne; now $2 \frac{1}{2}$. Then and afterwards 2 ploughs belonging to the men; now $1 \frac{1}{2}$. (There is) wood(land) for 20 swine, (and) 5 acres of meadow. Then 7 beasts (animalia), 8 swine, I rouncey (runcinus), 5 sheep, I 5 goats, (and) 3 hives of bees; now 12 beasts, 40 swine, 5 rounceys, 80 sheep, 40 goats, (and) 5 hives of bees. It was then worth 5 pounds; now 8.

\section{ro. 78}

REDEWINTRA [Radwinter ${ }^{10}$ ] was held as a manor and as half a hide and 15 acres by Alvric (the) sokeman; he could sell the land, but the soke and sake" remained (in that case) with Aubrey's predecessor (remanebat antecessori Alberici). Miblanc (Dinz[idius] blanc $[u s])^{12}$ holds it of A[ubrey]. Then 4 villeins; now 2. Then I bordar; now 5 . Then I serf; now 2. Then I plough on the demesne; now 2. Then 2 ploughs belonging to the men; now $I$. (There is)

7 This holding, with its ' 2 villeins' is an exceptionally large one for a sokeman.

8 i.c. the manor of Bumpstead Hall there.

- See p. 534, note 5, above.

10 See p. 495 , note 9 , above.

11 i.c. the (profits of jurisdiction.

12 See p. 534, note 11 , above. 


\section{A HISTORY OF ESSEX}

wood(land) for 30 swine, (and) 9 acres of meadow. It was then worth 20 shillings; now 60.1

In Stavintuna [Stevington (end) ${ }^{2}$ ] Renold holds of $A[u b r e y] 30$ acres which were held by Alwin'; and Ordric held 15 acres (which are now Aubrey's); and these two (men) were in the king's soke, but he gave them to Aubrey. Then as now (semper) 3 villeins, and 2 bordars, and 1 plough. (There is) wood(land) for Io swine, (and) 3 acres of meadow. It was then worth 20 shillings; now 30. There also (In eadem) a certain Englishman holds of A[ubrey] 40 acres which were held by Alvric (the) sokeman, who had power to sell the land; but the soke and sake remained (in that case with Aubrey's predecessor); then as now (semper) 2 bordars (were there), and I plough; it is worth Io shillings.

\section{THE LAND OF PETER DE VALOGNES [VALONIENSIS]}

\section{Hundret of Herlaua [Harlow]}

SCERINGA [Sheering], which was held by 3 free men as a manor and as 5 hides and 30 acres in King Edward's time, is held by Peter in demesne. Then as now (semper) 5 ploughs on the demesne, and I plough belonging to the men, and 3 villeins. Then 3 bordars; now 6. Then as now (semper) 8 serfs. There is wood(land) for 100 swine, 32 acres of meadow, (and) now as then (semper) I mill. Then 8 cows with calves, and I rouncey (runcinus), 35 sheep, (and) 16 swine; now 2 rounceys, and I mule, ${ }^{3}$ and 1 ass, 84 sheep, 56 swine, (and) 3 hives of bees. Then and afterwards it was worth 100 shillings; now 6 pounds.

LatTuna [Latton ${ }^{4}$ ], which was held by a free man as a manor and as $2 \frac{1}{2}$ hides and 30 acres, is held of P[eter] by Turgis. Then 2 fo. $7^{8 \mathrm{~b}}$

ploughs on the demesne; now I. (There is) half a plough belonging to the men. Then as now (semper) I villein, and I priest. (There are) now 4 bordars. Then 4 serfs; now

1 The tripling of value should be observed.

2 Now the manor of Waltons in Ashdon.

3 This is one of what appear to be the only two entries of mules (muli) in Domesday; the other is at Rudham in Norfolk.

4 Latton was divided into three manors at the time of Domesday. Peter's manor has not been identified. none. (There is) wood(land) for 350 swine, (and) 35 acres of meadow. It is worth now as then (semper) 60 shillings.

Perinduna [(Little) Parndon], which was held by I free man as a manor and as 3 hides in King Edward's time, is held of P[eter] by Roger. Then 2 ploughs on the demesne; now $I \frac{1}{2}$. (There is) now half a plough belonging to the men. Then I bordar; now 5. Then as now (semper) 3 serfs. (There is) wood(land) for roo swine, (and) 45 acres of meadow and marsh (inter pratum et maresc ${ }^{5}$ ). Then as now (semper) I mill. And 5 acres of land have been added which were held by a free man in King Edward's time. Then 8 beasts (animalia) and $4 \mathrm{I}$ sheep; now 14 beasts, and I rouncey (runcinus), and 76 sheep, and 26 swine, and 3 hives of bees. Then and afterwards it was worth 40 shillings; now 60.

In W ALDA [ $\quad{ }^{6}$ ] Ralf holds of P[eter] 30 acres, which were held by a free man as a manor in King Edward's time. Then as now (semper) I plough, and 2 serfs, and I bordar. (There is) wood(land) for 100 swine, (and) 2 acres of meadow. It is worth 20 shillings.

\section{Hundret of Beventreu [Becontree]}

Leintuna [Leyton 7], which was held by Suen' Suart ${ }^{8}$ as a manor and as 3 hides, is held by $\mathrm{P}$ [eter] in demesne. Then as now (semper) I plough on the demesne. Then I plough belonging to the men; now 2. Then 7 villeins; now 10 . Then as now (semper) 2 bordars. (There is) wood(land) for 30 swine, (and) 24 acres of meadow. Then (there was) I mill; now none; and it has been taken away thence ${ }^{9}$ (inde ablatus) in King William's time. Then 2 fisheries; now none. (There is) now I rouncey (runcinus), and I I swine. It was then worth 20

8 This is an exceptional phrase. Little Parndon lies on the Lea, and the parish and county boundary here crosses the stream and embraces the right bank of the river.

6 Identified by Morant here as Wallbury, though the 'Walda' of the next fief (that of Ranulf brother of Ilger), which is entered, as here on Peter's fief, immediately after Parndon, was identified by him with Weld, alias Sewals, a manor in Harlow. For the possible identity of this Walda with the Harlow Hundred portion of

North Weald see Introduction, p. 397.

7 It is not clear which of the manors in Leyton is represented by this entry.

8 i.e. Suain the Swarthy.

9 Compare Introduction (p. 378). 


\section{THE HOLDERS OF LANDS}

shillings; and when he received it, there was nothing there but the land ${ }^{1}$; and now it is worth 40 shillings.

Heснам [Higham (Bensted ${ }^{2}$ )], which was held by Haldan', a free man, as a manor and as 5 hides in King Edward's time, is held by Peter in demesne. Then as now (semper) 2 ploughs on the demesne, and 4 ploughs belonging to the men. Then 8 villeins; now 10 . Then 2 bordars; now 3. Then as now (semper) 4 serfs. (There is) wood(land) for 300 swine, (and) 18 acres of meadow. Then (there were) $3 \frac{1}{2}$ fisheries; now none. Then I ox (bov'); now 15 beasts (animalia), and I rouncey (runcinus), and 37 swine, and 2 hives of bees. It was then worth 60 shillings; now 4 pounds and 10 shillings. And when he received this manor, he did not find (there) more than (preter) I ox and I acre sown. And of these 5 hides which we have spoken of above ${ }^{3}$ I was held by 2 free men in King Edward's time, and was added to this manor fo. 79

in King William's time, and was worth 10 shillings in King Edward's time, (and) now 20 ; and William holds this of Peter de Valognes (valonienss).

Lochetuna [Loughton "], which was held by Ulvric, a free man, as a manor and as I hide and 30 acres, is held of $\mathrm{P}$ [eter] by Ralf. Then as now (semper) I plough on the demesne. (There are) now 5 bordars. (There is) wood(land) for 80 swine, (and) 6 acres of meadow. It was then worth 10 shillings; now 20.

\section{Half Hundret of Thunreslau ${ }^{\circ}$}

Belindune [Balingdon ${ }^{6}$ ], which was held by Alvric, a free man, as a manor and as $3 \frac{1}{2}$ hides in King Edward's time, is held of Peter by Ralf 'fatatus.' Then as now (semper) 2 ploughs on the demesne, and I plough belong-

1 ' $n$ [on] erat ibi prater sola terra'; i.e. there was no farm stock.

- A manor and hamlet in Walthamstow.

3 This is one of the very rare instances in which the Domesday Commissioners are entered as speaking in their own persons.

4 Loughton is in Ongar Hundred. The identity of this manor in Loughton seems to be doubtful.

S See, for this mysterious district, the Introduction (p. 405). The two manors of 'Belindune' and 'Bineslea' here entered under it are interpolated between two entries relating to Loughton, which is in Ongar Hundred.

- See pp. 405-6. ing to the men. Then and afterwards 3 bordars; now 9. Then as now (semper) 4 serfs. (There are) 33 acres of meadow. ${ }^{7}$ Then 5 cows with calves, and 30 swine; now 33 beasts (animalia), and 28 swine. It was then worth 40 shillings; now 100.

Binestea [ ${ }^{8}$ ], which was held by Ulwin' as I hide in King Edward's time, is held by Peter in demesne. Then as now (semper) I plough on the demesne, and half a plough belonging to the men, and 13 bordars. Then and afterwards 2 serfs ; now 1. (Therc is) wood(land) for 20 swine and 4 acres of meadow. It is worth 20 shillings. P [eter] (holds ?) this land in mortgage (in vadimonio) by the ki:rg's command, but so that the dues should not be lost, the Bishop of Bayeux being witness.

Lochintuna [Loughton ${ }^{10}$ ], which was held by Leofcild as a manor and as 1 hide, is held by Peter in demesne. Then 3 bordars; now 2. Then 2 serfs; now none. Then as now (semper) I plough. (There is) wood(land) for 30 swine, (and) 4 acres of meadow. Then as now (semper) 1 mill. It was then worth 20 shillings; and when received, 30 ; it is now worth 20 shillings.

TaIndena [Theydon (Bois) ${ }^{11}$ ], which was held by Hacun as a manor and as $3 \frac{1}{2}$ hides and 80 acres, ${ }^{13}$ is held by Peter in demesne. Then 7 villeins; now 12 . Then 3 bordars; now 4. Then as now (semper) 5 serfs. (There is) wood(land) for 400 swine, 16 acres of meadow, (and) I mill. Then 2 cows, and 3 rounceys (runcini), and 54 swine, and 47 sheep; now 2 rounceys, and 92 swine, and 157 sheep, and 12 hives of bees. It was then worth 60 shillings; now roo. And 7 free men held 2 hides and $1 \frac{1}{2}$ virgates, which (quod) is now held by Petcr; then as now (semper) 2 serfs (were there), and I bordar. Then and afterwards 6 ploughs; now 4; fo. $79 \mathrm{~b}$

(there is) wood(land) for 140 swine, (and) 20 acres of meadow; it is worth now as then (semper) 46 shillings; and this is (held) by

7 Balingdon lies on the Stour.

8 See Introduction, p. 406.

- 'ne tamen perderet suam consuetudinem.' The sense of the passage is most obscure.

10 See note 4 above. With this manor the text returns to Ongar Hundred.

11 So named from the family of de Bois, which held here as under-tenants.

12 "p' iii. hid' et d. et lxxx ac"." This is a very abnormal formula, as half a hide was 60 ' 2cres.' 


\section{A HISTORY OF ESSEX}

exchange (pro escangio), as Peter himself says. And Walter holds of P [eter] half a hide and 40 acres, which (quod) Ulwin' held; and Peter has it in mortgage (in vadimonio) by the king's permission, as he himself says; then I villein (was there); now none; (there are) now 3 bordars; then 1 serf; now none; then 2 ploughs; afterwards and now 1; (there is) wood(land) for roo swine, (and) 7 acres of meadow; it was then worth 16 shillings; now 20.

W ALla [(North) Weald (Basset) ? $\left.{ }^{1}\right]$, which was held by 2 free men as 2 manors and as 2 hides and 40 acres in King Edward's time, is held of P[eter] by Ralf 'fatat[us].' And Peter has (it) by (in) exchange. Then and afterwards 7 villeins; now 13 . Then and afterwards 3 bordars; now 8 . Then and afterwards 9 serfs; now 7 . Then 5 ploughs on the demesne; afterwards 3 ; now 2. Then and afterwards $2 \frac{1}{2}$ ploughs belonging to the men ; now 5 . (There is) wood(land) for I,500 swine, (and) 40 acres of meadow. Then 3 cows, and I rouncey (runcinus), and 35 swine, and 5 sheep, and 3 goats; now 17 beasts (animalia), and 1 rouncey, and 28 swine, and 70 sheep, and 5 hives of bees. It was then worth 7 pounds; and when received, 6 pounds; it is now worth 12 pounds. And a certain man held freely (libere) 40 acres, whom (quem) Peter has by (in) exchange; then as now (semper) 4 villeins (were there); now (there are) 2 bordars; there is wood(land) for 60 swine, (and) 5 acres of meadow; then as now (semper) I plough; and it is worth 20 shillings.

\section{THE LAND OF RANULF BROTHER OF ILGER ${ }^{2}$}

\section{Hundret of Berdestapla [Barstable]}

INGA [ ], which was held by Oslac and (as) 2 hides in King Edward's time, is held of R[anulf] by W[ ]. Then as now (semper) I plough on the demesne, and I plough belonging to the men. Then 5 bordars; now 9. Then 2 serfs; now none. (There is) wood(land) for 100 swine. Then 14 beasts (animalia), 60 sheep, (and) 60 swine; now 8 beasts, 100

1 For this identification see the Introduction (p. 397).

8 There is great difficulty in identifying the manors on this fief owing to its subsequent escheat and dispersal by fresh grants.

${ }^{3}$ Doubtless the Humfrey who held of him in Norfolk (fo. 261). sheep, 20 swine, (and) 3 hives of bees. It was then worth 40 shillings; now 30 .

RaMesDana [Ramsden], which was held freely (libere) by Siric as 2 hides and 30 acres, is held of $\mathrm{R}$ [anulf] by Humfrey. ${ }^{3}$ fo. 80

Then 2 ploughs on the demesne; now $1 \frac{1}{2}$. (There is) now half a plough belonging to the men. And (there is) I free man. Then as now (semper) 3 serfs, and I bordar. (There is) wood(land) for roo swine, (and) 2 acres of meadow. $\mathrm{He}$ found (there) no live stock (nichil); now (there are) 4 beasts (animalia), 2 rounceys (runcini), 58 sheep, (and) 2 I swine. It was then worth 60 shillings; now 40.

\section{Hundret of Herlaua [Harlow]}

Ruindune [Roydon], which was held by Inguar[a], a free man, ${ }^{4}$ as a manor and as 6 hides in King Edward's time, is held by $\mathrm{R}$ [anulf] in demesne. Then as now (semper) 3 ploughs on the demesne, and 4 ploughs belonging to the men. Then 12 villeins; now 8. Then 2 bordars; now 12. Then 8 serfs; now 3. (There is) wood(land) for 120 swine, (and) 60 acres of meadow, pasture worth 2 shillings, (and) I mill. Then 6 beasts (animalia), 60 sheep, (and) 30 swine; now 10 beasts, 30 swine, (and) 10 horses (equi). ${ }^{6}$ It was then worth 6 pounds; now 9. To this manor belongs I outlying estate (berewita), Herlaua [Harlow ${ }^{7}$ ], which is held of R[anulf] by Richard as I hide and I virgate; then as now (semper) I plough (was there); then 2 villeins; now I; (there is) wood(land) for 50 swine, (and) 7 acres of meadow; then and afterwards it was worth 25 shillings; now 30 . To this estate (terra) have been added 4 hides of land, ${ }^{8}$ which were held by 5 free men in King Edward's time; then as now (semper) 4 ploughs (were there); then 3 villeins; now 2 ; then 5 bordars; now 7 ; then I serf; now none; (there is) wood(land) for

4 See Introduction, p. 352.

5 This is an exceptionally large amount, but Roydon has a long 'frontage' to the Stort, and, as with the adjoining parish of Parndon, the county boundary here crossed the river and took in some of the right bank. Ranulf owned also the large and valuable manor of Stanstead (Abbots) facing Roydon on the other side of the Stort.

6 The entry of horses as such (equi) is very rare. For mares see the note on Earls Colne, p. 534 above.

7 The identity of this estate in Harlow is doubtful.

8 'The addition of 'terrx' to 'hidx' is mere surplusage. 


\section{THE HOLDERS OF LANDS}

60 swine, (and) 25 acres of ineadow ; ${ }^{1}$ (this) is worth now as then (semper) 4 pounds.

Perenduna [(Great ?) Parndon $\left.{ }^{2}\right]$, which was held by Alsi bolla, a free man, as a manor and as 2 hides in King Edward's time, is held of R[anulf] by Roger. ${ }^{3}$ Then I plough on the demesne; now $1 \frac{1}{2}$. Then I villein; now 5 bordars. Then as now (semper) I serf. (There is) wood(land) for 140 swine, (and) 18 acres of meadow. Then 12 beasts; now 8 . (There are) 34 swine, (and) 80 sheep. It was then worth 30 shillings; now 40.

Perenduna [(Great ?) Parndon '], which was held by Alveva, a free woman, as a manor and as half a hide, is held of R[anulf] by Alvred'. 'Then as now (semper) half a plough, and I bordar. (There is) wood(land) for 30 swine, (and) 5 acres of meadow. It is worth II shillings.

In Perenduna [(Great ?) Parndon ${ }^{4}$ Roger ${ }^{3}$ holds of $R$ [anulf] 35 acres, which were lield by Turstin, a free mail, il King Edward's time. Then as now (semper) half a plough. (There is) woodland for 20 swine, (and) 2 acres of meadow. It is worth 6 shillings.

WALDA [ $\left.{ }^{6}\right]$, which was held by Goduin', a frec man, as a manor and as half a hide and 15 acres, is held of R[anulf] by Richard. Then as now (semper) I plough on the demesue, and I plough belonging to the men. Then I villein; now 2. Then as ro. $80 \mathrm{~b}$

now (remper) I bordar. Then 2 serfs; now 1. (There is) wood(land) for 200 swinc, (and) 2 acres of meadow. Then 20 swine; now 6o. (There are) 17 beasts (animalia), 65 sheep, and 3 rounceys (runcini). It was then worth 20 shillings; now 30.

In Nasinga [Nazing ${ }^{6}$ ] Odo holds of $\mathrm{R}$ [anulf] I hide; and (there are) I villein, and 4 bordars, and 1 plough; and it is worth 20 shillings.

\section{HUNDRET OF WALThaM}

Nasinga [Nazing] and Epinga [Epping]

1 Sce p. 538, note 5, above.

There secms to have been no manor in Little Parndon but that of Peter de Valognes.

3 Roger was the name of Peter's tenant at Little Parndon.

- See note 2 above.

S See p. 536, note 6 , above for this difficult manor.

6 All Nazing is in Waltham Hundred. were held by 2 free men as a manor (Man') and as $4 \frac{1}{2}$ hides less 15 acres in King Edward's time. ${ }^{7}$ Then 3 ploughs on the demesne; now 2. Then as now (semper) 3 ploughs belonging to the men. Then 11 villeins; now 7. (There are) now 9 bordars. Then 3 serfs; now none. (There is) wood(land) for 100 swine, 54 acres of meadow, (and) pasture worth (de) 32 pence. Then (there was) I mill; now none. Then 7 beasts (animalia) and 30 swinc; now 2 beasts and 18 swine, that is (to say), in Nasınga [Nazing], and in EPpinges 2 beasts, and 26 sheep, and 6 swinc. They are worth now as then (semper) 4 pounds, (that is) Nastnga 60 shillings, and EPPING' 20 shillings. And, in addition to this, there has been added to this estate (terre) I hide which was held by a free man in King Edward's time, and still is; then I plough (was there); now a half; then 2 bordars; now 3 ; (there is) wood(land) for 20 swine, (and) I 2 acres of meadow; it was then worth 10 shillings; now 20. And there is further I virgate which has been added in King William's time, and (which) used to belong to Waltham in King Edward's time and was taken from it by $R$ [anulf] brother of Ilger, as the Hundret (court) testifies; and (it) is worth 3 shillings. ${ }^{8}$ All this is held by R[anulf] in demesne.

\section{HUNDRET OF ROCHEFORT [ROCHFORD]}

'ThORP, ${ }^{9}$ which was held by Inguar' 10 as a manor and as $2 \frac{1}{2}$ lides in King Edward's time, is held of R[anulf] by Odo. Then as now (semper) 4 villeins, and 4 bordars, and 4 serfs, and 2 ploughs on the demesne, and 3 ploughs belonging to the men. (There is) wood(land) for 60 swine, (and) pasture for 100 sheep. Then 2 beasts (animalia), and 2 rounceys (runcini), and 100 shecp, and 30 swine; now 2 beasts, and I rouncey, and 100 sheep, and 7 swinc, and 18 goats, and 4 hives of bees. Then and afterwards it was worth 4 pounds; now 6 .

\section{HundRet of Hidingforda [Hinckford]}

BRIDEBROC [Birdbrook], which was held by I free man as a manor and as 2 hides in $\mathrm{King}$

7 Their tenure in 1086 is given at the end of the entry.

8 Under Waltham (fief of the Bishop of Durham) it is recorded that this Ranulf had abstracted 30 acres of land and 4 of meadow, which is the 'virgate' of the text.

- A manor in Southchurch, now represented by Thorpchall farm.

10 Sec Introduction, p. 352. 


\section{A HISTORY OF ESSEX}

Edward's time, is held by $\mathrm{R}$ [anulf] in demesne. Then 3 ploughs on the demesne; afterwards 2 ; now 3 . Then as now (semper) 3 ploughs belonging to the men. Then and afterwards 7 villeins; now 6 . Then and afterwards 1 bordar; now 9. Then as now (semper) 4 serfs. (There is) wood(land) for I 6 swine, (and) 22 acres of meadow. Then fo. $8 \mathrm{I}$

I 5 beasts (animalia), and 50 swine, and 80 sheep and $13,{ }^{1}$ and 25 goats; now 4 beasts, and ro swine, and 55 sheep, and 2 rounceys. Then and afterwards it was worth 8 pounds; now 9 .

Babiterna [Bapthorne ${ }^{2}$ ], which was held by Inguar' ${ }^{8}$ as a manor and as 2 hides in King Edward's time, is held by $R$ [anulf] in demesne. Then as now (semper) 2 ploughs on the demesne, and 4 ploughs belonging to the men, and 6 villeins. (There are) now 7 bordars. Then and afterwards 2 serfs; now 3 . (There are) $3^{1}$ acres of meadow, (with) I mill now as then (semper). Then and afterwards it was worth 7 pounds; now 8. To these two manors ${ }^{3}$ belong now as then (adjacent semper) 2 sokemen with (de) 5 acres.

Geldham [Yeldham ${ }^{4}$, which was held by a free man as a manor and as half a hide in King Edward's time, is held of R[anulf] by Walter. Then I plough; afterwards none; now I. (There are) 9 acres of meadow. (There was) then no live stock (nichil); now 2 beasts (animalia), and I rouncey (runcinus), and 30 sheep, and 2 swine. It is worth 20 shillings.

\section{HUNDRET OF Witbrictesherna [DENGIE]}

Niwelanda [Newland ${ }^{5}$ ], which was held by Ingwar' 8 as a manor and as $1 \frac{1}{2}$ hides and 35 acres in King Edward's time, is held of $\mathrm{R}$ [anulf] by W[ ]. (There are) now 4 bordars. Then as now (semper) I serf, and I plough on the demesne. It was then worth 20 shillings; afterwards and now 30. And (there are) $7 \frac{1}{2}$ acres which are held by I free man and are worth 7 pence.

Bubingeorda [Bobbingworth ${ }^{6}$ ], which was held by 2 free men as I hide and 30

1 i.e. 93 sheep (unless by the 'long score').

2 A manor in Birdbrook, now 'Baythorne.'

3 i.e. Birdbrook and Bapthorne.

The identity of this holding is doubtful.

5 Apparently East Newland in St. Lawrence.

${ }^{6}$ In Ongar Hundred. The scribe has omitted the Hundredal heading. acres in King Edward's time, is held of $\mathrm{R}$ [anulf] by Richard. Then I bordar; now 2. Then 4 serfs; now 2. Then 2 ploughs on the demesne; afterwards and now $I$. (There is) wood(land) for 80 swine, (and) 4 acres of meadow. Then as now (semper) I cow, and 3 swine, and 107 sheep. It was then worth 40 shillings; now 60 .

\section{Hundret of Celmeresfort [Chelmsford]}

GingA [Mountnessing ? 7 , which was held by Ingwara ${ }^{8}$ as a manor and as 9 hides, is held by $R$ [anulf] in demesne. Then 18 villeins; now 16 . Then 8 bordars; now 20. Then 5 serfs; now 7. Then 2 ploughs on the demesne; now 1. Then 12 ploughs among the men; now 9. (There is) wood(land) for 700 swine. (There are) now 7 beasts (animalia), and 60 sheep. It was then worth 8 pounds; now 10. And I free man holds 20 acres, and (this) is worth 3 shillings. There also (in eadem) William de Bosc holds 2 hides and 26 acres of $\mathrm{R}$ [anulf] and has (it) by exchange (in suo escangio) $;^{9}$ (this) was held by Alfega and Algar in King Edward's time; (there are) now 3 bordars; then 2 serfs; now 1 ; then fo. $8 \mathrm{xb}$

2 ploughs on the demesne; now I ; there is wood(land) for 60 swine, and pasture for 100 sheep ; (this) is worth 40 shillings. ${ }^{10}$

Cubrigea [Cowbridge ${ }^{11}$ ], which was held by Alwin as a manor and as half a hide and $6 \frac{1}{2}$ acres, is held of R[anulf] by William. And half a plough can be (employed there ${ }^{12}$ ). (There is) 1 acre of meadow, ${ }^{13}$ (and) wood(land) for 20 swine. It is worth 10 shillings.

7 This is Morant's identification, but there seems to be no other ground for it than that Cowbridge is in Mountnessing. On the other hand there does not seem to be anything against it.

8 See Introduction, p. 352.

9 The probable meaning of this is that Ranulf himself obtained it by exchange.

10 The total assessment in hides recorded in this and the two entries which follow is very large, but Mountnessing is a parish of more than 4,000 acres. The absence of meadow is very strange, as the river Wid flows through it, and the 'pasture for sheep' is one of the very few instances of such a phrase in the survey of an inland parish.

11 A manor in Mountnessing, now represented by two farms.

12 This is a rare phrase in the Essex survey and implies that the half plough (team) was not there in 1086.

18 The scarcity of meadow should be observed. 


\section{THE HOLDERS OF LANDS}

Ginga [Mountnessing ? '] was held by two free maidens ${ }^{2}$ as 80 acres. Now $R$ [anulf] (holds it) by exchange (in swo escangio), and IV [illiam ?] of him. Then as now (semper) 1 plough. It is worth 15 shillings.

\section{HUNDRET OF TENDRINGA}

In Derleia [Ardleigh ${ }^{3}$ ] Edric of Estorp [Easthorpe] held I manor of $2 \frac{1}{2}$ hides. Now R[anulf] holds it as $1 \frac{1}{2}$ hides, and Roger (holds it) of him. ${ }^{5}$ Then 2 villeins; now I. Then I serf; now none. Then and afterwards $I$ plough on the demesne; now a half. Then and afterwards I plough belonging to the men; now none. And 3 ploughs can be (employed there). There is wood(land) for 20 swine, (and) 4 acres of meadow. Then and afterwards it was worth 30 shillings; now 10. R[anulf] has this land by exchange (pro escangio). He also has in the soke of Laleforda [Lawford] 15 acres; and there dwells 1 man who renders 7 shillings and 8 pence. $^{6}$

\section{THE LAND OF TIHEL THE BRETON ${ }^{7}$ (BRITTONIS)}

\section{HUNDRET OF UdELESFORdA [UTTLESFORD]}

Gerdelai [Yardlcy ${ }^{8}$ ] was held by 2 free men as a manor and as 1 hide in King Edward's time. Then as now (semper) I plough on the demesne. And (there were) 2 bordars; now 7. Then (there was) wood(land) for 40 swine; afterwards and now for 30. (There are) 10 acres of meadow. Then 5 beasts (animalia), 14 sheep, and 26 swine,

1 See p. 540, note 7 , above.

2 'puella libera.' But 'liberx' occurs at times for 'libere,' so that the entry might be read 'tenuerunt libere.'

s Ardleigh is 'Erleia' in three entries (fos. $596,676,89 b)$. The prefixed ' $D$ ' here and on fo. $95 b$, where the name becomes 'Dereleia' is of interest for comparison with 'Orseda' and 'Dorseda,' the Domesday names of Orsett.

- It is common in Hertfordshire, but very rare in Essex, to find the English predecessor distinguished by the name of his chief estate. 'Edric' is duly entered under Easthorpe, which had passed to Count Eustace, as its previous holder (see p. 466 above).

5 The identity of this manor is doubtful. Ardleigh, 2 large parish of more than 5,000 acres, was much divided in 1086.

6 The relative entry under Lawford (p. 435 above) duly states that Ranulf held these is acres.

7 Alias Tihel de Helion (or Herion), ancestor of the Essex Helions (see pp. 350,457 above).

8 A manor in Thaxted. and 32 goats, and I rouncey (runcinus), and I hive of bees; now 4 beasts, and 14 swine, and 38 sheep, and 3 hives of bees, and I rouncey. This is held of Tihel by Serlo. Tihel claims (to hold) this land of the king's gift. It was then worth 16 shillings; now 20 .

\section{Hundret of Frossewella [Freshwell]}

Stevituna [Stevington (End) ${ }^{9}$, which was held by Oslac, a free man, as a manor and as $42 \frac{1}{2}$ acres in King Edward's time, is held by Tihel in demesne. Then as now (semper) 2 ploughs on the demesne. Then and afterwards I bordar; now 3 . Then as now (semper) 4 serfs. (There are) 5 acres of meadow. Then 5 beasts (animalia), and 5 swine, and ro sheep, and 2 hives of bees; now 5 cows, and 1 rouncey (runcinus), and 30 swine, and 50 sheep, and I hive of bees. Then and afterwards it was worth 60 shillings; now 100 shillings and I ounce of gold.

REDEwintra [Radwinter $\left.{ }^{10}\right]$, which was held by Lefsiu as a manor and as half a hide and half a virgate in King Edward's time, is held of $T$ [ihel] by Goderet. Then as now (semper) 2 plouglis on the demesne, and I plough belonging to the men, and 4 villeins. Then 5 bordars; now 7. (There is) wood(land) for 60 swinc, (and) 8 acres of meadow. Then 6 beasts (animalia); now 4. And (then) 18 swine; and now the same. Then 49 sheep; now 32 . (There are) 4 hives of bces. Then 20 goats; now none. It was then worth 20 shillings; now 60 . Tiliel claims (to loold) this of the king's gift.

Bunsteda [(Hclion) Bumpstead "], which was held by Lewin cilt ${ }^{12}$ as a manor and as 4 hides in King Edward's time, is held by $\mathrm{T}$ [ihel] in demesnc. Then as now (semper) 4 ploughs on the demesne. Then 4 ploughs

9 Now the manor of Waltons in Ashdon. The Record Commission's edition reads the name as 'Stcintuna,' but it should probably be read as 'Steuituna' (for 'Stevituna')

10 These two manors (Stevington and Radwinter) were held together of the Honour of Helion by Warine Fitz Gerold temp. John (Red Book of the Exchequer, pp. 358, 504, 601).

11 Of the two Bumpsteads this is the one that lies in Freshwell Hundred. Tihel's share of it was the manor of Helions.

12 An Englishman of the same name had held an estate at Purleigh (see p. 548 below). But whether these were the same, and whether, if so, they were identical with the Bedfordshire thegn of the name, is uncertain (but see Introduction, p. 351). 


\section{A HISTORY OF ESSEX}

belonging to the men; now 2. Then 9 villeins; now 7. Then as now (semper) 8 bordars, and 8 serfs. (There is) wood(land) for 100 swine, (and) 7 acres of meadow. Then as now (semper) 6 beasts (animalia). Then 24 swine; now 40. Then 40 sheep; now II 5. Then I rouncey (runcinus); now 1 and I colt (pullus). Then 1 hives of bees; now 3. It was then worth 6 pounds ; now 9.

\section{Hundret of Hidingaforda [Hinckford]}

Bumesteda [(Steeple) Bumpstead ${ }^{2}$ ], which was held by a free man as a manor and as I hide and I virgate in King Edward's time, is held by $T[$ ihel] in demesne. Then as now (semper) 3 ploughs on the demesne, and 2 ploughs belonging to the men, and 5 villeins, and 13 bordars, and 6 serfs. ('There is) wood(land) for 20 swine, I 5 acres of meadow, (and) now as then (semper) I mill. Then and afterwards it was worth 60 shillings; now 6 pounds.

STURMERE [Sturmer], which was held by a free woman as a manor and as $1 \frac{1}{2}$ hides and $\mathbf{I} 5$ acres in King Edward's time, is held by $\mathrm{T}$ [ihel] in demesne. Then as now (semper) 2 ploughs on the demesne, and I plough belonging to the men, and 2 villeins, (and) 3 bordars. Then and afterwards I serf; now 2. (There are) 16 acres of meadow. Then ${ }^{3}$ cows, and 2 rounceys (runcini), and 6o swine, and 3 hives of bees; now 4 beasts (animalia), and I rouncey, and fo. $82 \mathrm{~b}$

1 colt (pullus), and 44 swine, and 72 sheep, and 3 hives of bees. It was then worth 40 shillings; now 60.4

Sturmere [Sturmer ${ }^{5}$ ], which was held by a free man as a manor and as $1 \frac{1}{2}$ hides in King Edward's time, is held by 'T[ihel] in

1 The number is omitted in the MS.

2 This is the Bumpstead in Hinckford Hundred. Morant (ii. $34^{8}$ ) was unable to determine whether one of its manors was held by the Helions, but his own evidence (p. 349) distinctly proves that the manor of Wantons or Waltons there was held of them. The family of Wanton seems to have succeeded that of Chamberlain (see the next manor) as their tenants here.

3 The number is omitted in the MS.

4 Sturmer, which adjoins Steeple Bumpstead, was held, in two portions under Helion, temp. John, by Philip de Burnham and John the Chamberlain as I knight's fee. Chamberlain's share was half a fee (Red Book of the Exchequer, pp. $358,503,601$ ).

5 See preceding note. demesne. Then as now (semper) 2 ploughs on the demesne, and 1 villein, and 6 serfs. (There are) 20 acres of meadow, (and) I mill. Then 6 beasts (animalia), and I rouncey (runcinus), and 12 swine, and 60 sheep; now 12 beasts, and 30 swine, and 100 sheep less $2,{ }^{6}$ and I rouncey, and 3 colts (pulli). Then and afterwards it was worth 40 shillings; now 60.

Trliberia [Tilbury (by Clare)], which was held by a free man as a manor and as I hide and 38 acres in King Edward's time, is held by $\mathrm{T}$ [ihel] in demesne. Then as now (semper) 3 ploughs on the demesne, and I plough belonging to the men, and 5 villeins, and $I$ bordar, and 6 serfs. (There is) wood(land) for 20 swine, (and) I 9 acres of meadow. Then 15 beasts (animalia), and 40 swine, and 80 sheep, and 6 hives of bees; now 5 beasts, and I rouncey (runcinus), and 36 swine, and 63 sheep. Then and afterwards it was worth 60 shillings; now 100 .

\section{XXXVIIII. THE LAND OF ROGER 'DE RAMIS'}

\section{Hundret of Hidingforda [Hinckford]}

RaInes [Rayne 7], which was held by Alwin', a free man, as a manor and as I hide and 20 acres in King Edward's time, is held by Roger in demesne. Then as now (semper) 2 ploughs on the demesne. Then and afterwards 4 ploughs belonging to the men; now 3. Then and afterwards 9 villeins; now 8 . Then as now (semper) 5 bordars. Then and afterwards 4 serfs; now 3. (There is) wood(land) for 100 swine, and III acres of meadow. ${ }^{8}$ (There is) 1 mill. Then 8 cows; now 3 . Then I rouncey; now none. Then as now (semper) I00 sheep. Then 30 swine; now 40 . It is worth now as then (semper) 4 pounds.

Of this manor Roger holds 30 acres of $\mathrm{R}$ [oger], and Wiberga 30 acres; and this is worth 20 shillings in the above valuation (in eodem pretio).

6 i.e. 98 , unless, as is possible, they were here reckoned by the long hundred (120).

7 i.e. the manor of Old Hall there. Morant, not unnaturally, held (ii. 403) that ' undoubtedly this Roger took the surname of Raines or Ramis from this parish,' in which the family had its chief seat. But there is no ground for his supposition that 'Ramis,' which occurs regularly, is a mistake for Raines.

8 The meadow clause is interlined, and the amount, though clear, is so abnormally large that we should probably suspect error. 


\section{THE HOLDERS OF LANDS}

\{0. 83

Raines [Rayne ${ }^{1}$, which was held by Edric, a free man, as a manor and as 1 hide in King Edward's time, is held by R[oger] in demesne. Then 2 ploughs on the demesne; afterwards and now 1. (There is) now half a plough belonging to the men, and 3 bordars. Then and afterwards 6 serfs; now 3. (There is) wood(land) for 40 swine, (and) 13 acres of meadow. It is worth now as then (semper) 60 shillings.

Hedingham [(Sibil) Hedingham "], which was held by Goduin, a free man, as a manor and as half a hide in King Edward's time, is held of R[oger] by Garenger'.3 Then as now (semper) 2 ploughs on the demesne, and 3 ploughs belonging to the men, and 8 villeins. Then and afterwards I bordar; now 3. Then 4 serfs; afterwards and now 2. Then and afterwards (there was) wood(land) for 600 swine; now for 500. (There are) 18 acres of meadow. To this belong now as then (semper adjacent) 2 sokemen with 3 acres. Then and afterwards it was worth 4 pounds; now 100 shillings.

\section{Hundret of Lassendana [Lexden]}

Metcinges [Messing], which was held by Ormar, a frec man, as a manor and as half a hide in King Edward's time, is held by $\mathrm{R}$ [oger] in demesne. Then 6 villeins; now 3. Then 12 bordars; now 18. Then 6 serfs; now 4. Then as now (semper) 2 ploughs on the demesne. Then among the men (were) 5 ploughs; now 3. (There is) wood(land) for 40 swine, 20 acres of meadow, (and) now 1 mill. Then as now (semper) 2 rounceys (runcini), and 2 cows with calves, and 100 sheep. Then 30 swine; now 20. Then as now (semper) 35 goats. It is worth now as then (semper) 100 shillings. Of this manor Anschetil holds of R[oger] 16 acres, and (this) is worth 5 shillings in the above valuation (in eodem pretio). And 3 sokemen, who hold freely (libere) 18 acres, belong to this manor; Gerold holds them of Roger, and Roger says that he has them by (in) excliange; then as now (semper) half a plough was there; then and afterwards it was worth 10 shillings; now 3 .

1 See p. 542 , note 7 , above.

2 i.e. the manor of Greys there. This was the 'Heingham' of which the holder of the fief in 1166 complained that Simon de Cantilou was withholding from him the service due from it.

3 He held the manor of Prayers here under Roger Bigot.
Delnam [Dedham], which was held by Alvric camp as a manor and as $2 \frac{1}{2}$ hides, is held by $\mathrm{R}$ [oger] in demesne. Then 7 villeins; now 5. Then as now (semper) 24 bordars. Then 4 serfs; now 3 . Then 2 ploughs on the demesne; now 3 . Then among the men (were) 10 ploughs; now 5 . (There is) wood(land) for 250 swine, (and) 40 acres of meadow. Then (there was) I mill; now 2. Then 2 rounceys (runcini); now 10. Then 5 cows; now 3 . Then 40 sheep; now 100 . Then 25 swine; now 30. It is worth now as then (semper) 12 pounds. Of this manor Gerold holds 30 acres, and it is worth ro shillings in the above valuation (in eodem pretio). In BURA [Bures] $\mathrm{R}$ [oger] has 25 acres; then as now (semper) 3 bordars (were there) and half a plough; (there is) wood(land) for 15 swine, fo. $83 \mathrm{~b}$

and $I$ acre of meadow ; it is worth 7 shillings.

Hundret of Tendringa [Tendring]

BRADEFELDA [Bradfield], which was held by Alvric camp ${ }^{6}$ as a manor and as $4 \frac{1}{2}$ hides, is held by $R$ [oger] in demesne. Then 7 villeins; afterwards and now 4. Then as now (semper) 10 bordars, and 2 serfs, and 2 ploughs on the demesne. Then and afterwards 7 ploughs belonging to the men; now 3. (There is) wood(land) for 30 swine, (and) 1 saltpan. Then 4 cows with calves; now none. Then as now (semper) 100 sheep. Then 20 swine; now 33. Then and afterwards it was worth 7 pounds; now 60 shillings. Of this manor the (quedam) wife of a knight of his holds half a hide, and it is worth 10 shillings in the above valuation (in eodem pretio).

ERLEGA [Ardleigh ${ }^{6}$ ], which was held by Bond' as a manor and as 1 hide, is held by $\mathrm{R}$ [oger] in demesne. Then as now (semper) I villein. Then I I bordars; now 10 . Then I serf; now none. Then as now (semper) 2 ploughs on the demesne. Then and afterwards 9 ploughs belonging to the $\operatorname{men}^{7}$; now 1. (There is) wood(land) for 40 swine, and $4 \frac{1}{2}$ acres of meadow. Then 40 sheep; now 100 . Then 2 cows and 3 rounceys;

- He also held important manurs at Bradfield (which follows), Ramsey, and Oakley in Tendring Hundred, besides lands in Suffolk and Cambridgeshire. But his estates were broken up at the Conquest (see Intraduction, p. 353).

6 See preceding nate.

6i.e. the manor of Picotts there.

It will be observed that the recorded peasants were very few for this number. 


\section{A HISTORY OF ESSEX}

now none. Then and afterwards it was worth 4 pounds; now 30 shillings. ${ }^{1}$ Of this manor Ralf de Hastinges holds 30 acres, and (this) is worth ro shillings in the above valuation (in eodem pretio).

Manestuna [(Bradfield) Manston], which was held by Alfelm as a manor and as I hide and 25 acres in King Edward's time, is held by $\mathrm{R}$ [oger] in demesne. Then as now (semper) I villein. Then and afterwards 4 bordars; now 3. Then as now (semper) I serf. Then and afterwards 2 ploughs on the demesne; now I. Then among the men (was) I plough; now none. There is wood(land) for 15 swine, $1 \frac{1}{2}$ acres of meadow, pasture for 15 sheep, (and) now I saltpan. Then and afterwards it was worth 4 pounds; now 20 shillings. $^{2}$

Mrtteslea [Mistley], which was held by Alric as a manor and as I hide, is held of $\mathrm{R}$ [oger] by the wife of Henry. ${ }^{3}$ Then as now (semper) I bordar. Then 2 ploughs; now none. It was then worth 20 shillings; now 2 shillings.

\section{In Cuiva [}

4] $\mathrm{R}$ [oger] holds in demesne 8 free men with $(d e) 30$ acres and I plough. And (this) is worth 5 shillings.

In HERLEGA [Ardleigh] R[oger] holds in demesne 6 free men with $(d e)$ I hide and 2 ploughs. And (this) is worth 40 shillings. Of this Ralf holds 10 acres, and Restolt 40 acres, which are worth 20 shillings in the above valuation (in eodem pretio). This is (acquired) by (pro) exchange.

\section{THE LAND OF JOHN SON OF WALERAM}

\section{HUNDRET OF WITHAM}

NutLea [(Black ?) Notley], which was held by Harold as a manor and as 4 hides and 30 acres in King Edward's time, is held of John by John son of Ernuc[i]un. Then 5 ploughs on the demesne; now 3 . Then 4 ploughs

1 Here is a sharp fall in value, which is fairly accounted for by the disappearance of ploughteams.

2 The very sharp fall in value on these Tendring Hundred manors should be observed.

3 Doubtless that 'knight's wife' who is entered as holding under him at Bradfield. The word ' uxor' is ambiguous, being often used for a widow. It is singular that 'Henrici' is here written above 'Alberici,' which has been deleted.

* This place has not been identified. belonging to the men; now 2. Then 7 villeins; now 5. Then 13 bordars; now I I. Then 4 serfs; now none. Then (there was) wood(land) for 330 swine; now for 200 . (There are) 24 acres of meadow. Then as now (semper) I mill. (There is) pasture worth (de) 6 pence. Then I rouncey (runcinus) and 2 cows; now no live stock (nichil). It was then worth 7 pounds; now 6 .

\section{Hundret of HidingForda [HinckFord]}

SALINGES [(Great) Saling], which was held by I free man as a manor and as half a hide in King Edward's time, is held of John by Turstin'.5 'Then 2 ploughs on the demesne; afterwards none; now I. Then $I \frac{1}{2}$ ploughs belonging to the men ; afterwards none; now half (a plough). Then 3 villeins and I priest ; afterwards I (sic); now 2 villeins and I priest. Then and afterwards 3 bordars; now 5. Then 4 serfs; afterwards and now 3 . Then and afterwards (there was) wood(land) for 250 swine; now for 200. (There are) Io acres of meadow. It is worth 60 shillings.

Mapledesteda [(Little) Maplestead], which (was held by) Grim, a free man, as a manor and as half a hide in King Edward's time, is held of John by Osmund. Then 2 ploughs on the demesne; afterwards none; now 1. Then 2 bordars; afterwards 1 ; now 5 , and I priest. Then as now (semper) 2 serfs. Then (there was) wood(land) for 60 swine; afterwards and now for 16 . (There are) 3 acres of meadow. Then (there was) I mill, which is (now) held by William de Warenne ${ }^{6}$ (garenda) in mortgage (pro vadimonio). Then (Osmund) received no live stock (nichil); now (there are) 2 cows, and 14 swine, and 57 sheep. It was then worth 40 shillings; afterwards and now 30 .

HENI [Henny ${ }^{7}$ ], which was held by a free man as a manor and as $2 \frac{1}{2}$ hides in King Edward's time, is held of John by Roger. Then 2 ploughs on the demesne; afterwards I ; now 2. Then as now (semper) I plough belonging to the men. Then and afterwards I villein; now none. Then as now (semper) 3 bordars, and 2 serfs. Then (there was) wood(land) for 60 swine; afterwards and now

5 This was probably the Turstin 'Wiscart' who is entered under Colchester as holding of John son of Waleram an estate there (see p. 577 below).

6 $\mathrm{He}$ held manors at Polhey in Pebmarsh and Hipworth in Halstead, both adjoining Little Maplestead.

7 The identity of this manor is uncertain. 


\section{THE HOLDERS OF LANDS}

fo. 8 b

for 30. There are 12 acres of meadow. Then 6 beasts (animalia), and 15 swine, and 11 sheep; row 5 rounceys (runcini), and 8 beasts, and 30 swine, and 66 sheep, and 15 goats. To this manor belongs a customary due (jacet una consuetudo) of $22 \frac{1}{2}$ pence which is (payable) from Sutberia [Sudbury]. It was then worth 40 shillings; afterwards and now 50.

In Bura [Bures (St. Mary) ${ }^{1}$ Hugh holds of $\mathrm{J}$ [ohn] 15 acres, which were held by Tosti', a free man. Then as now (semper) half a plough (was there) and 2 villeins, and 2 bordars. (There is) wood(land) for 4 swine, (and) I acre of meadow. It is worth 6 shillings. This land is in the county of Sudfolc.

\section{HUNDRET OF ANGRa [Ongar]}

Fifhida [Fyfield ${ }^{2}$ ], which was held by Leuric as a manor and as $1 \frac{1}{2}$ hides and 30 acres in King Edward's time, is held of John by Roger." Then 12 villeins; now 7. Then and afterwards 2 bordars; now 10. Then as now (semper) 4 serfs, and 2 ploughs on the demesne. Then and afterwards 4 ploughs belonging to the men; now 3. (There is) wood(land) for 400 swine, 10 acres of meadow, (and) now I mill. (There are) now I I cows, and $I 1$ swine and 60 sheep, and I hive of bees. Then and afterwards it was worth 5 pounds; now 7 .

The other (Altera $\left.{ }^{4}\right)$ Fifhida [Fyfield], which was held by Alestan' as a manor and as 30 acres, held of the same (John) by the same (Roger). Then as now (semper) 3 bor-

1 i.c. the portion of it which lies in Hinckford Hundred (see Introduction, p. 408).

- It seems clear that the Tanis were John's successors both here and at Aveley.

5 'This was doubtless the 'Roger' who gave its tithes to Bermondsey, with John's consent, in 1094 (compare my note on "Fyficld church' in Essex Arch. Soc. [n.s.] viii. 104).

4 This word is sometimes used to distinguish two adjacent parishes of the same name; but it seems here only to distinguish one manor in the parish from another (comparc Introduction, pp. 402-3).

It is not improbable that this estate represents the ' 30 acres' entered under the royal manor of Havering (p. 430 above) as having been held by a sokeman who had rendered dues to it, but as being in John's hands at the time of the Survey. For under the next fief we find entered an even more distant appendage of Havering, though its former connexion with that manor is there also ignored (p. 546, note 7 , below). dars. Then I plough; now none. (There is) wood(land) for 40 swine, (and) 6 acres of meadow. It is worth now as then (semper) 20 shillings.

ANGra [(High) Ongar], which was held by Leuric as a manor and as 3 virgates, is held of the same (John) by the same (Roger). ${ }^{8}$ Then as now (semper) 6 bordars, and 1 serf, and 1 plough on the demesne. (There is) wood(land) for 200 swine, (and) 8 acres of meadow. (There are) now 30 swine and 40 sheep. It was then worth 40 shillings; and when received, 20 shillings; it is now worth 40 shillings.

\section{Hundret of Ceffeorda [Chafford]}

Avileia [Aveley] was held freely (liberc) by Suan' as a manor and as $3 \frac{1}{8}$ hides in King Edward's time; now John holds it in demesne as the same amount (pro tantundem). Then 8 villeins; now 6. Then 3 bordars; now 5. Then 4 serfs; now 1. Then 2 ploughs on the demesne; now 1 . Then among the men (were) 3 ploughs; now 2. (There are) 60 acres of meadow. Then and afterwards it was worth 8 pounds; now 100 shillings. And a certain free man, Ulsi', held half a hide, which he had power to sell; but Waleram, ${ }^{7}$ father of John, added him (cum) to this manor; then as now (semper) I villein and I bordar (were there); then half a plough; now no oxen (nichil); it was then fo. 85 worth 10 shillings, and when received (sic), the same; it is now worth 7 shillings.

\section{THE LAND OF ROBERT SON OF CORBUTIO ${ }^{8}$}

\section{HUNDRET OF Berdestapla [BARSTABLE]}

Doddenhenc [Doddinghurst], which was held freely (libere) by Alvric' as a manor and as 1 hide and 17 acres in King Edward's time, is held of R[obert] by Girard'. 'Then as now (semper) I plough. (There is) wood(land) for 20 swine. It is worth 20 shillings.

- Therefore it is clearly the 'Little Ongar' (parva Angra) which "was of the barony of Gilbert de 'Tani' (Tessa de Nevill, p. 269), who must have succeeded John there as at Fyfield.

7 He gave the tithe of his lands here to St. Stephen's of Caen (see Introduction, p. 342. And, for his doings in the county, sec p. 419 above).

8 A tenant-in-chief in the three eastern counties. 


\section{A HISTORY OF ESSEX}

\section{HUNDRET OF WithaM}

Smalelant [Smalland ${ }^{1}$ ], which was held by Earl Algar' ${ }^{2}$ as a manor and as 2 hides, is held of $\mathrm{R}$ [obert] by Nigel. Then as now (semper) I plough, and I bordar, and I serf. (There are) 9 acres of meadow, (and) now two-thirds (partes) of a fishery. Then 2 beasts (animalia); now 4. Then I pig; now 25. (There are) now 2 colts (pulli). Then 6 sheep; now 35. Then 6 goats; now none. It is worth now as then (semper) 20 shillings.

\section{Hundret of Beventreu [Becontree]}

Leintuna [Leyton], which was held by Harold as a manor and as $4 \frac{1}{2}$ hides in King Edward's time, is held by R[obert] in demesne. Then 2 ploughs on the demesne; now none. Then as now (semper) I plough belonging to the men. Then 3 villeins; now 5, and I priest. Then 4 bordars; now 6. Then 4 serfs; now none. (There is) wood(land) for 300 swine, (and) 40 acres of meadow. Then 7 fisheries; now none. Then I mill; now none. And 2 ploughs more $(a d b u c)$ could be added to the stock (restaurari). It was then worth 4 pounds; now 20 shillings.

In Leintuna [Leyton] R[obert] holds 3 hides which were held by $8^{3}$ sokemen in King Edward's time. Then 4 ploughs; now none. (There are) now 6 villeins, and I bordar. (There is) wood(land) for Io swine, (and) 30 acres of meadow. Half a fishery (was there) then; now none. It was then worth 60 shillings; now 20. And these sokemen used to pay a customary due (reddebant consuetudinem) to Havelinga [Havering], the king's manor, in King Edward's time, and now (do not ?) render (it). ${ }^{4}$

1 Alias Marshalls, a manor in Hatfield Peverel.

2 See Introduction, p. 337.

3 This figure is so read in the Record Commission's edition, but is very doubtful, as it has been altered in the MS.

4 This is an important passage because it refers directly to the Havering entry on p. 430 above, where we read that there used to belong to that manor, in King Edward's time, 4 'frec men' with 4 hides, who used to pay a customary due to it, but had ceased to do since these hides had been obtained, one of them by Hugh de Montfort, and the other three by Robert son of Corbutio. It will be observed that the 3 'free men' there entered as the previous holders of Robert's hides are here replaced by 8 (?) 'sokemen,' a notable and suggestive discrepancy. The figure ' 8 ,' however, appears to have been altered from ' 4 ' ('iiii').
Lalinge [Lawling ${ }^{5}$ ], which was held by Leuinc, ${ }^{6}$ a free man, as a manor and as $4 \frac{1}{2}$ hides in King Edward's time, is held of $\mathrm{R}$ [obert] by W[ ]. Then 3 borfo. $85 \mathrm{~b}$

dars; now 5. Then as now (semper) 4 serfs, and 2 ploughs. (There is) pasture for 40 sheep. Then 2 rounceys (runcini); now 3. Then 7 beasts (animalia); now 9. Then I07 sheep; now 124. Then 6 goats; now none. It was then worth 3 pounds; now $4 .^{7}$

\section{Hundret of Celme[Re]sfort [Chelmsford]}

HaNingeferda [Hanningfield ${ }^{8}$ ], which was held by Alestan, a free man, as a manor and as $I \frac{1}{2}$ hides in King Edward's time, is held of $\mathrm{R}$ [obert] by Ranulf. (There are) now I bordar, and I serf, and now as then (semper) I plough. (There are) 2 acres of meadow, (with) wood(land) for I 2 swine. It is worth now as then (semper) 30 shillings.

WALTHAM, ${ }^{9}$ which was held by Ulsi as a manor and as I hide and 30 acres, is held of $\mathrm{R}$ [obert] by W[ ]. Then I villein; now none. Then 9 bordars; now II. Then as now (semper) I serf, and I plough. There is wood(land) for 30 swine, (and) 8 acres of meadow. Then as now (semper) I mill (was there). It was then worth 30 shillings; now 40.

There also (in eadem ${ }^{9}$ ) Ranulf holds of $\mathrm{R}$ [obert] I free man with (de) 30 acres, whom R[obert] took possession of (invasit). Then as now (semper) half a plough (was there). It is worth 4 shillings.

Bedenesteda [Sandon ${ }^{10}$ ], which was held

5 A manor in Latchingdon (Dengie Hundred).

6 The reading of this manor is doubtful.

7 Under Havering (see note 4 above) Domesday further states that Robert holds $4 \frac{1}{2}$ hides which were held of that manor by a free man in King Edward's time. This can only refer to the above 'Lalinge,' which is Lawling on the south shore of the Blackwater, its position on the coast accounting for its pasture 'for 40 sheep.' But in this entry, it will be observed, there is no reference to Havering. It is, no doubt, most singular that an estate so far off should be held of the manor of Havering, but this is a peculiar feature of royal manors in Essex (see Introduction, p. 338).

8 This manor has not been identified in the Hanningfields.

9 These two holdings in the Walthams have not been identified.

10 See Introduction (p. 390). But this manor there has not been identified. 


\section{THE HOLDERS OF LANDS}

by Stercher as a manor and as $3 \frac{1}{2}$ hides, is held of R[obert] by Nigel. ${ }^{1}$ Then 2 villeins; now none. Then as now (semper) 7 bordars, and 2 serfs, and 1 plough on the demesne, and 1 plough belonging to the men. (There is) wood(land) for 100 swine, (and) $1 \frac{1}{2}$ acres of meadow. Then 1 rouncey (runcinus), and 4 cows with calves; now none. Then 40 sheep; now 30 . Then 16 swine; now 7. It was then worth 40 shillings; now 50. And a certain free man held half a hide, which $\mathrm{R}$ [obert] has taken possession of (invasit) ; Godfrey now (holds it) (of him); then and afterwards half a plough (was there); now none; (there is) wood(land) for 10 swine; it is wortl 10 shillings.

\section{Hundret of Tendringa [Tendring]}

Fuletuna [Foulton "], which was held by Ednod, a free man, as a manor and as $2 \frac{1}{2}$ hides and 20 acres in King Edward's time, is held of R[obert] by Girard'. Then I villein; now 4. Then as now (semper) 2 bordars and 2 serfs, and 2 ploughs on the demesne. Then 1 plough belonging to the men; now none. (There are) 3 acres of meadow, (with) pasturc for 60 sheep. Then fo. 86

4 beasts (animalia); now 3. Then 1 rouncey (runcinus); now none. Then lo swine; now 20. Then 40 sheep; now 20. It was then worth 50 shillings; and when received, 20 shillings; it is now worth 50 shillings.

\section{HUNDRET OF ROCHEFORT [ROchFoRd]}

Pachesham [Paglesham ${ }^{3}$ ], which was held by a free man as a manor and 2 s half a hide and 30 acres, is held of R[obert] by the same $\mathrm{G}$ [irard']. Then as now (semper) 2 bordars and 1 plough on the demesne. It was then worth 40 shillings; now 5.4

\section{Hundret of Turestapla [Thurstable] \\ Toleshunta [Tolleshunt (Major) ${ }^{5}$ ], which}

1 This was doubtless his tenant at Smalland in Hatfield Peverel.

In Ramsey. Although Robert's share of Foulton was about three times as large as that of Suain of Essex, it was probably represented by 'Foulton Bernes,' for this manor is found held of the Earls of Oxford, as was Doddinghurst, the other manor held of Robert by Girard.

- This manor has not been identified.

- Here, if the figures are correct, is a fall in value to onc-eighth, with absolutely nothing to account for it. There is 2 gap between 'modo' and ' $v$ ' (5) in the MS.

- A corruption of Tolleshunt Mauger, which name was derived from the tenant in the text. was held by Sercar as a manor and as I hide, is held of $\mathrm{R}$ [obert] by Mauger [Malgerus]. Then 5 villeins; now 4. Then 1 bordar; now 6. Then 5 serfs; now 2 . Then and afterwards 2 ploughs on the demesne; now 1. Then and afterwards 2 ploughs belonging to the men; now 1. (There is) wood(land) for I oo swine, I acre of meadow, (and) pasture for 60 sheep. Then 15 beasts (animalia); now 2 cows and I calf. Then 50 shcep; now 25. Then I rouncey (runcinus); now none. Then 2 hives of bees; now none. It was then worth 4 pounds; afterwards 3 ; now 40 shillings.

And 8 free men held 4 hides and 2 acres, and could betake themselves (ire) whither they would. ${ }^{7}$ Robert took possession of (invasit) them; and now 4 kuights hold (them) of Robert. Then 4 serfs (were there); now 2. Then as now (semper) 2 ploughs. (There is) $\operatorname{wood}($ land) for 120 swine, pasture for 60 sheep, (and) I saltpan. It is worth 50 shillings.

\section{THE LAND OF WALTER THE DEACON ${ }^{8}$}

\section{Hundret of Berdestapla [Barstable]}

In BURA [Bowers (Gifford) ${ }^{9}$ ] Walter holds 2 hides of the land of Tedric (Teddrici) his brother, and a certain knight holds (it) of him. Then as now (semper) I plough was there, and I serf, and 30 acres of wasted (vastate) wood(land). ${ }^{10}$ (There is) pasture for 60 sheep. To this manor have been added, in King William's time, 40 acres which were held, in King Edward's time, by a frec man ; and 'Tedric' had them. And the aforesaid hides were worth then 40 shillings; and now the same. And the 40 acres are worth 8 shillings and 4 pence. On the demesne fo. $86 \mathrm{~b}$

Walter received 4 beasts (animalia); (there are) now the same (number). Then 2 rounceys (runcini); now I. Then 100 sheep less $2^{11}$; now 55. Then... ${ }^{12}$ swine; now 11 .

6 'The words 'in dominio' are inserted here instead of after ' 2 ploughs' 23 they should be.

7 i.e. choose their lord.

8 His fief lay in Essex, Suffolk, Gloucestershire, and Dorset, but its head was in Essex (see Introduction, pp. 349,351 ).

8 The identity of this manor has not been established.

10 See Introduction, p. 376.

11 If reckoned by 'the long hundred' this would represent 118 .

13 The MS. reads' $x \ldots$. ' 


\section{A HISTORY OF ESSEX}

\section{Hundret of Witbrictesherna [Dengie]}

Purlai [Purleigh ${ }^{1}$ ], which was held by Lewin as a manor and as $3 \frac{1}{2}$ hides, is held by Walter in demesne. Then as now (semper) 2 villeins. (There is) now I bordar. Then 3 serfs; now 1 . Then 2 ploughs on the demesne; now $1 \frac{1}{2}$. Then as now (semper) half a plough belonging to the men. (There is) wood(land) for 60 swine. Then as now (semper) 8 beasts (animalia). Then 5 rounceys (runcini); now 4. Then 152 sheep; now 80 . Then 62 swine; now 47 . (There are) now 23 goats. It is worth now as then (semper) 60 shillings.

Eistanes [(Little) Easton $\left.{ }^{2}\right]$, which was held by Dodinc as a manor and as 2 hides in King Edward's time, is held by Walter in demesne. Then 6 ploughs on the demesne; now 4. Then 5 villeins, and I priest; now 1 priest, and 3 villeins. Then 2 bordars; now 25. Then 7 serfs; now 1. Then (there was) wood(land) for 800 swine; now for 400. (There are) 26 acres of meadow, and 1 mill. Then as now (semper) 6 cows, and 4 calves. (There are) now 15 beasts. Then 2 rounceys (runcini); now 6 . Then 80 sheep; now 120 . Then 74 swine; now 62. Then 24 goats; now 34. (There are) 2 hives of bees. It was then worth 7 pounds ; now 8 .

Purleigh [Purleigh ${ }^{3}$ ], which was held by Lewin cilt ${ }^{4}$ as a manor and as 5 hides in King Edward's time, is held by Walter in demesne. Then so villeins; now 5. Then I bordar; now 6 . Then as now (semper) 4 serfs, and 3 ploughs on the demesne, and 4 ploughs belonging to the men. (There is) wood(land) for roo swine (and) pasture for 100 sheep. It was then worth 7 pounds; it is now worth 6 pounds.

Fenna [Stow Maries ? ${ }^{5}$ ], which was held by a free man as a manor and as 2 hides, is held of Walter by 1 knight. Then as now (semper) 2 bordars, and I serf, and I plough. And it is worth 50 shillings.

1 See note 3 below.

2 In Dunmow Hundred (see Introduction, p. 393).

3 These holdings of Walter at Purleigh certainly seem to be represented, as Morant showed, by the manors of Frerne and Jakelets there.

4 See p. 541, note 12. It is probable that this was also the Leofwine (Lewin') who had preceded him in his other Purleigh holding and possibly his predecessor at 'Colne' (see note 6 below).

5 See p. 5 I 2.

\section{Hundret of Lassendena [Lexden]}

Couun [Colne (Engaine) ${ }^{6}$ ], which was held by Lewin as a manor and as half a hide and 13 acres, is held of Walter by 1 knight. Then as now (semper) 12 bordars, and 2 serfs, and 2 ploughs on the demesne, and I plough belonging to the men. (There is) wood(land) for 100 swine, 13 acres of meadow, (and) then as now (semper) I mill. Then 6 beasts (animalia); now 2. Then 2 rounceys (runcini); now none. Then 12 sheep; now 24. Then 16 swine; now I4. (There are) now 13 goats and 3 hives of bees. It is worth now as then (semper) 40 shillings.

fo. 87

\section{Hundret of Tendringa [Tendring]}

WICA [Wix], which was held by Queen Edith (Edeva) as a manor and as 4 hides, is held by Walter in demesne. Then as now (semper) 14 villeins. Then 18 bordars; now 28. Then 4 serfs; now 3. Then as now (semper) 4 ploughs on the demesne. Then and afterwards 12 ploughs belonging to the men ; now 8. (There is) wood(land) for 100 swine, (and) 8 acres of meadow. Then 12 beasts (animalia); now I4. Then as now (semper) 2 rounceys (runcini). Then I 00 sheep; now 84 . Then 40 swine; now 71. Then 30 goats; now 34. Then 7 hives of bees; now IO. Then and afterwards it was worth 6 pounds and 10 shillings; it is now worth 10 pounds. And Queen E[dith] gave this land to Walter after the coming of King William.

Brumleia [(Little) Bromley], which was held by Queen E[dith] as a manor and as 2 hides less 20 acres, is held of Walter by I knight. Then as now (semper) I villein. Then 17 bordars; now 15 . Then 4 serfs; now 3. Then as now (semper) 2 ploughs on the demesne. Then among the men (were) 6 ploughs; now 4. (There is) wood(land)

6 Morant made no mention of this entry under the Colnes, and Mr. Chisenhale-Marsh had to leave it unidentified. It can, however, be shown conclusively to relate to the manor of Overball in Colne Engaine. For Morant observed that 'this manor is ancient, and an entire lordship, not holding of any of the adjoining manors of Colne Engaine, Wakes, or Earls, but of the manor of Witnesham with Cockefelde in Suffolk, paying a peppercorn yearly if demanded' (ii. 219). Now Witnesham was held in Domesday by Walter the deacon, and, moreover, had been previously held by 'Lewin a free man' (fo. $427 b$ ), who was clearly identical with his predecessor at Colne Engaine (compare Introduction, p. 351 ). 


\section{THE HOLDERS OF LANDS}

for 40 swine (and) 4 acres or meadow. Then 9 beasts (animalia); now 7. Then 2 rounceys (runcini); now 4. Then 100 sheep; now 200. Then 12 swine; now 30. (There are) now 2 hives of bees. It was then worth 5 pounds; now 4 .

\section{HUNDRET OF UdELESFORdA [UTTLESFORD]}

Cestrefort [(Little) Chesterford], which was held by Queen E[dith] as a manor and as 5 hides, is held of Walter by I knight.' Then as now (semper) 10 villeins. Then 4 bordars; now 16. Then 4 serfs; now 1. Then as now (semper) 2 ploughs on the demesne, and 3 ploughs belonging to the men. (There is) wood(land) for 20 swine, 8 acres of meadow, (and) now as then (semper) 1 mill. Then 2 beasts (animalia); now 4 . Then I rouncey (runcinus); now none. Then 36 sheep; now 43. Then 16 swine; now 34. (There are) now 23 goats. It was then worth 100 shillings; now 6 pounds.

\section{fo. $87 \mathrm{~b}$}

\section{THE LAND OF ROGER BIGOT ${ }^{2}$}

\section{Hundret of Hidingfort [Hinckford]}

Hidingham [(Sibil) Hedingham], which was held by 15 free men in King Edward's time, is held of R[oger] by Garenger ${ }^{3}$ as 25 acres." Then as now (semper) $5 \frac{1}{2}$ ploughs were there, and I villein, and 2 serfs. There is wood(land) for 70 swine, (and) I I acres of meadow. It was then worth 40 shillings; now 4 pounds. There also (in eadem villa) 3 free men beld $48 \frac{1}{2}$ acres of land in King Edward's time; now they are held of R[oger] by the same G[arenger]. Then as now (semper) 2 ploughs on the demesne, and 2 ploughs belonging to the men, and 5 villeins. Then 6 serfs; now 4. Then (there was) wood(land) for 200 swine; now for 160 .

1 The persistent repetition of this phrase (" I miles') on Walrer's fief is 2 characteristic freak of the Domesday scribe.

- A tenant-in-chief in the three eastern counties and ancestor of the Bigots, Earls of Norfolk.

- He was also under-tenant of that portion which was held by Roger 'de Ramis' (see p. 543 above). In Suffolk he held 2 similar position as under-tenant of both; and this led to trouble. For Roger 'de Raimis' there laid claim to all the free men that Warenger was holding, as in the entry above, of Roger Bigot, and the Hundred Court could not say which of the Rogers was in the right, 'because Warenger was a tenant of both' (fo. 350b).

4 This low assessment should be noted.
There are 24 acres or meadow, (and) now I mill. It was then worth 40 shillings; now 6o. Of these $4^{8}$ acres the Hundred (court) does not testify that Roger was seised of them by the king's act (de parte regis). These two estates (terras) are held by Garenger; and Roger claims them; but the Hundred (court) does not testify in his favour (sed nec bundret ei testatur).

Pebeners [Pebmarsh], which was held by 3 free men in King Edward's time, ${ }^{6}$ is held of R[oger] by the same G[arenger]. Then as now (semper) It $\frac{1}{2}$ ploughs, and I bordar. (There is) wood(land) for 8 swine, and $3 \frac{1}{2}$ acres of meadow. It was then worth 40 shillings; now 4 pounds.

Oviruna [Ovington], which was held by a free man as a manor and as I hide and 30 acres in King Edward's time, is held by $\mathrm{R}$ [oger] in demesne. Then as now (semper) 2 ploughs on the demesne, and 2 ploughs belonging to the men. Then 4 villeins; afterwards and now 3. Then 6 bordars; afterwards and now 5. Then as now (semper) 2 serfs. (There are) 24 acres of meadow. It was then worth 40 shillings; now 4 pounds.

Belcham [Belchamp (Otton) $\left.{ }^{6}\right]$, which was held by 6 free men as 1 hide and $38 \frac{1}{2}$ acres in King Edward's time, is held of $\mathrm{R}$ [oger] by Robert de Vaux (vals). Then as now (semper) 3 ploughs on the demesne. Then and afterwards I plough belonging to the men; now a half. Then 3 villeins; afterwards and now 2 . Then and afterwards 9 bordars; now 12 . Then 4 serfs; afterwards and now 1. (There is) wood(land) for 30 swine, (and) I 5 acres of meadow. It was then worth 60 shillings; now 100.

HENI [(Little ?) Henny ${ }^{7}$ ], which was held by 5 free men as $1 \frac{1}{2}$ hides less 4 acres in King Edward's time, is held of R[oger] by the same $R$ [obert de Vaux]. Then as now 8. 88

(semper) 4 ploughs on the demesnc. Then 4 villeins; afterwards and now 1. Then and

6 The assessment is not mentioned.

6 i.e. the manor of $V_{2 u x}$ there, so named from the Domesday under-tenant and his descendants.

7 It is difficult to identify precisely the Domesday entries under Henny; but Great Henny certainly belonged to Ranulf Peverel, and as Little Henny is subsequently found in the hands of the De Veres, I imagine that it came to them from Bigot. 


\section{A HISTORY OF ESSEX}

afterwards 2 bordars; now 3. Then as now (semper) 2 serfs. Then and afterwards (there was) wood(land) for 30 swine; now for 20. (There are) i 8 acres of meadow. Then and afterwards it was worth 40 shillings; now 64 .

Westuna [Weston ${ }^{1}$ ], which was held by 4 free men, who were of (Earl) Algar's soke, as I hide and 50 acres in King Edward's time, is held (of Roger) by Hugh de Hosdenc. Then as now (semper) 5 ploughs on the demesne. Then and afterwards 5 bordars; now IO. Then and afterwards 9 serfs; now 4. (There is) wood(land) for 6 swine, 24 acres of meadow, (and) now I mill. Then and afterwards it was worth 60 shillings; now 4 pounds.

\section{XLIIII. THE LAND OF ROBERT MALET $^{2}$}

\section{HUNDRET OF HEDingFort [HincKFoRd]}

Stanesteda [Stansted (Hall) ${ }^{3}$ ], which was held by Goduin', a free man, as a manor and as I hide in King Edward's time, is held of Robert by Hubert. Then as now (semper) 2 ploughs on the demesne. Then and afterwards 5 ploughs belonging to the men; now 4. Then Io villeins; afterwards 8 ; now 4. Then as now 7 bordars. Then 7 serfs; now 6. Then (there was) wood(land) for 500 swine; now for 400 . (There are) 10 acres of meadow. Then (there was) I mill; now 2. To this manor belong (adjacet) $1 \frac{1}{2}$ hides and 52 acres, which were held by ${ }^{5}$ sokemen in King Edward's time. Then 4 ploughs (were there); now $4 \frac{1}{2}$. Then and afterwards 6 bordars; now 24. Then 4 serfs; now 1. (There is) wood(land) for 30 swine, (and) I 6 acres of meadow. Then 16 beasts (animalia), 5 rounceys (runcini), 60 sheep, 50 goats, 40 swine, (and) Io hives of bees; now Io beasts, 50 sheep, 26 goats, 40 swine, (and) 8 hives of bees. It was then worth 6 pounds; now $9 .^{6}$ And (there is) 1 sokeman, who could not withdraw himself from the land (recedere a terra), holding 10 acres; and (this) is worth 2 shillings.

1 Alias Westons, a manor in Foxearth and Liston.

2 Lord of the great fief afterwards known as the Honour of Eye.

3 A manor in Halstead.

4 This was Hubert de Monchensy, who held of him several manors in Suffolk, including Edwardstone, which he made his chief seat.

5 Their number is not mentioned.

6 See the closing lines of 'Parva Colun' in the text (p. 55 I, col. I).
Goldingham, ${ }^{7}$ which was held by a free man, Goduin', as a manor and as 2 hides in King Edward's time, is held of R[obert] by the same Hubert. 'Then 3 ploughs on the demesne; afterwards and now 2. Then as To. $88 \mathrm{~b}$

now (semper) 6 villeins, and 5 bordars. Then and afterwards 6 serfs; now 2. Then as now (semper ${ }^{8}$ ) 16 acres of meadow. To this manor there used to belong (adjacebant) 4 sokemen with (de) I 7 acres and I acre of meadow. Then 10 beasts (animalia) and 2 rounceys (runcini), 50 sheep (and) 40 swine (?) ${ }^{9}$; now I 2 beasts, I rouncey, 260 sheep, 65 swine, (and) 5 hives of bees. It was then worth 60 shillings; now 6 pounds.

\section{Hundret of Lassendena [Lexden]}

Colun [(Wakes) Colne $\left.{ }^{10}\right]$, which was held by Assorin as a manor and as I hide and 30 acres, is held by $\mathrm{R}$ [obert] in demesne. Then as now (semper) 7 villeins, and I 5 bordars. Then 4 serfs; now 3. And then as now (semper) 3 ploughs on the demesne. Then among the men (were) 5 ploughs; now 4 . (There is) wood(land) for 400 swine, I mill now as then (semper), (and) I 3 acres of meadow. Then 12 beasts (animalia), 3 rounceys (runcini), 60 swine, 40 goats, (and) 20 sheep; now 6 beasts, 20 swine, 30 sheep, (and) 3 hives of bees. It is worth now as then (semper) 6 pounds. And there was then 1 sokeman who held freely (libere) I virgate; Robert has (it) now; then as now (semper) half a plough was there; it was then worth 8 shillings; now 7 .

Parva Colun [Colne (Engaine)], which was held by Goduin' as a manor and as I hide and I virgate, is held of R[obert] by Walter. ${ }^{11}$ Then 8 bordars; now 17. 'Then 4 serfs; now I. (There is) wood(land) for

7 A manor in Bulmer.

8 In other cases it is taken for granted that the meadow land is unchanged.

$\theta$ 'xl. cap'orc' in MS.

10 This identification is clearly proved, as Morant showed, by the entry in the Red Book of the Exchequer (p. 504): 'Comes Wintonix ij feoda in Columb de bonore de Eye.' From this Saer de Quenci, Earl of Winchester (whence the names 'Colne Saer' and 'Colne Quincy'), the manor descended to the Wakes. So late as 1428 its church was returned as that of 'Colne Quincy' (Feudal Aids, ii. 193).

11 This was Walter de Caen, who held largely under Robert in Norfolk and Suffolk (see my paper on 'The Manor of Colnc Engaine' in Essex Arch. Trans. [n.s.] viii. 192-8). 


\section{THE HOLDERS OF LANDS}

30 swine, (and) I I acres of meadow, (and) I mill. It was then worth 40 shillings; now 60 ; and (this) is (included) in the valuation of Stansteda [Stansted in Halstead], (that is) in (the) 9 pounds. ${ }^{1}$

\section{THE LAND OF WILLIAM DE SCOHIES *}

\section{Hundret of Angra [Ongar]}

Mortuna [Moreton], which was held by Sexi' as a manor and as 1 hide and 20 acres, is held by William in demesne. ${ }^{3}$ Then 4 villeins; now 3. Then as now (semper) I6 bordars. Then 6 serfs; now 4. Then and afterwards 3 ploughs on the demesne; now 2. Then and afterwards 2 ploughs belonging to the men; now $1 \frac{1}{2}$. (There is) wood(land) for 400 swine, (and) 20 acres of meadow. Then rounceys (runcini); now 4. Then 8 cows and 6 calves; now II beasts (animalia). (There are) now 36 sheep. Then 60 swine; now 14. Then 30 goats; now 6o. It was then worth 8 pounds; now 10. And I free man held $43 \frac{1}{2}$ acres; now William has annexed them (invasit); and (the man) did not belong to this manor; Ralf holds (this) of William (de eo); then as now (semper) I villein (was there), and 2 bordars, and I serf, and I plough on the demesne, and fo. 89

half a plough belonging to the men; it is worth now as then (semper) 20 shillings, but hitherto (William) has had 30 shillings. ${ }^{6}$

\section{THE LAND OF ROGER OF POITOU [PICTAVENSIS] ${ }^{7}$}

\section{HundRet of Lessendena [LeXden]}

Bura [(Mount) Bures] was held by Ulmer as a manor and as I hide. Now R [oger] holds it for as much (pro tantundem). Then 6 villeins; and the same when (he) received ${ }^{8}$ (it); now 5. Then as now (semper) 9 bordars. Then and afterwards ${ }^{8} 6$ serfs; now

1 See p. 550, note 6, above.

2 A tenant-in-chief in the three eastern counties, in Dorset, and on the Welsh border.

3 It was he who gave the church of Moreton to the Abbey of St. Stephen, Caen.

4 The number is omitted in the MS.

- Here again animatia seems to be used to denote or to include cows.

6 Compare the cases in Introduction, pp. 363-4.

7 A younger son of Roger de Montgomeri, Earl of Shrewsbury, and holder, Jike his father, of a vast fief.

8 'This is a good instance of the formula ' quando recepit' and 'post' being used indifferently to
4. Then and afterwards 3 ploughs on the demesne; now 2. Then and afterwards 3 ploughs belonging to the men; now $1 \frac{1}{2}$. (There is) wood(land) for 300 swine, 12 acres of meadow, and now as then (semper) 1 mill. And further (adhuc) there belong now as then (semper) 3 villeins and 2 bordars who have I plough. 9 (There were) then 2 rounceys (runcini), I 4 beasts (animalia), 80 sheep, 28 swine, (and) 26 goats; now 7 beasts, 54 sheep, (and) 6 swine. It was then worth 7 pounds; now II; and when received, the same. ${ }^{10}$ And 8 free men held half a hide and 30 acres; then as now (semper) 3 ploughs (were there), and (there are) 3 acres of meadow, (with) wood(land) for 30 swine; this is appraised above. ${ }^{11}$

Bercolt [(West) Bergholt] was held by Lewin Croc ${ }^{12}$ as a manor and as I hide and 25 acres. Now Roger holds it similarly (similiter ${ }^{13}$ ). Then 7 villeins; afterwards and now 5. Then 5 bordars; and when (he) received (it) 7 ; now 5 . Then as now (semper) 2 serfs. Then and afterwards 2 ploughs on the demesne; now 1 . Then and afterwards 2 ploughs belonging to the men; now I. (There is) wood(land) for 300 swine, 8 acres of meadow, (and) now as then (seniper) I mill. To this manor belongs a detached estate (I berewita) which is called BrADEFELDA ${ }^{14}$ [Bradfield ?] (and is held) as

denote the intervening date between 1066 and 1086.

9 This is an abnormal clause.

10 i.e. 11 pounds.

II i.e. the value of this holding is included in that of the whole manor.

12 As Lefwin' (i.e. Leofwine) Croc he had similarly preceded Roger in possession of the manor of Buxhall, Suffolk (fo. 350), of which an intervening holder was Girald', that is to say, the 'Reimund Girald' who had similarly been the intervening holder, I have suggested (p. 354 above), in Essex.

13 This is the equivalent of 'pro tantundem' in the entry of the manor preceding.

14 This is a very difficult passage. It will be seen on the next page that Bradfield in Tendring Hundred was and had been held by the same lord, but it seems improbable that part of this distant parish should be entered 25 a mere berewite of Bergholt, and then another part entered under Bradfield itself. Moreover the local pronunciation of Bergholt as 'Barfel' or 'Barfold ' may preserve the memory of a lost place-name. On the other hand it will be observed that the spelling of the name 'Bradefejda' is alike in both entries.

Lastly, 'Bradefelde' is the name of a 'terra' in Fordham or Bergholt mentioned in the cartulary of St. John's, Colchester (pp. 278, 279, 469), but hardly as a separate estate. 


\section{A HISTORY OF ESSEX}

half a hide and 30 acres; then and afterwards I plough (was there); now none. Roger there received in the demesne I rouncey (runcinum), and 14 beasts (animalia), and 48 sheep, ${ }^{1}$ and roo sheep, ${ }^{1}$ and 6 swine, (and) 32 goats; now (there are) 4 beasts, 80 sheep, (and) I I swine. It was then worth 6 pounds; and when received, 7 ; it is now worth 60 shillings. And 7 free men held half a hide and $I \frac{1}{2}$ acres; then and afterwards 2 ploughs (were there); now I; (there are) 2 acres of meadow; and (this) is valued in the abovesaid pounds. ${ }^{2}$

\section{Hundret OF TENDRINGa}

In BRADEFELDA [Bradfield ${ }^{3}$ ] Lewin held half a hide and I 5 acres. Then I bordar (was there), and I serf; now none. Then and afterwards 1 plough; now none. It was then worth 40 shillings; and when refo. $8 \mathrm{gb}$

ceived, 30 shillings; it is now worth 5 shillings.

\section{THE LAND OF HUGH DE GURNAI 4}

\section{HUNDRET OF Hidingaforda [HinckFord]}

LisTuna [Liston], which was held by a free man as a manor and as half a hide and 30 acres, is held (of Hugh) by Geoffrey 'Talebot. Then as now (semper) 2 ploughs on the demesne, and I plough belonging to the men. Then and afterwards 6 bordars; now 5. Then and afterwards 3 serfs; now none. (There are) 30 acres of meadow, (and) half a mill. Then 3 cows with calves, I 2 sheep, (and) 7 swine; now 3 cows with calves, 22 sheep, (and) 8 hives of bees. It is worth now as then (semper) 68 shillings.

\section{Hundret of Tendringa [Tendring]}

Erleia [Ardleigh ${ }^{6}$ ] was held by Osbert as a manor and as $2 \frac{1}{2}$ hides. Now Agnes

1 This is a literal translation, but the double entry is hard to understand, unless it is due to the use of 'the long hundred' and implies a total of 168.

2 i.e. its value is included in the total sum given just before.

3 This manor in Bradfield has not been identified (compare p. 551, note 14).

4 In Wace's Roman de Rou we read, of the Conqueror's followers :-

'I vint li viel Hue de Gornai Ensemble o li sa gent de Brai.'

6 This manor has not been satisfactorily identified. Morant made it Bovills in Ardleigh, apparently because he had accounted for the holds (it of Hugh). Then 16 villeins; afterwards and now 7 . Then 4 bordars; now none. Then 4 serfs; now none. Then as now (semper) 2 ploughs on the demesne. Then among the men 8 ploughs; and when (he) received (it), 6 ; now 3. (There is) wood(land) for 40 swine, 3 acres of meadow, and (now) 2 mills. Then 30 sheep (and) 5 swine ; now 44 sheep, 8 swine, 7 beasts (animalia), 10 goats, (and) 3 hives of bees. It was then worth 6 pounds; afterwards and now 4.

\section{Hundret of Lassendena [Lexden]}

Forham [Fordham], which was held by Esbern as a manor and as 2 hides, is held of Hugh by Geoffrey. ${ }^{6}$ Then Io villeins; now 7. Then 5 bordars; now II. Then 5 serfs; now 4. Then as now (semper) 3 ploughs on the demesne. Then 5 ploughs belonging to the men; now 3. (There is) wood(land) for I 00 swine, 12 acres of meadow, and now as then (semper) I mill. Then 2 rounceys (runcini), and 3 cows with calves, 60 sheep, 12 goats, 8 swine, (and) 10 hives of bees; now 2 rounceys, 8 beasts (animalia), 80 sheep, 25 goats, ro swine, (and) 6 hives of bees. And 3 free men held 13 acres; then as now (semper) half a plough (was there). It is worth now as then (semper) 7 pounds. And Roger of Poitou (Pictavensis) took away 10 acres from this manor, as the Hundret (court) says. ${ }^{7}$

fo. 90

\section{THE LAND OF WILLIAM PEVEREL [PIPERELLI]}

Torinduna [(East T)horndon $\left.{ }^{8}\right]$, which was held by Ailmar', a free man, as a manor and as $1 \frac{1}{2}$ hides in King Edward's time, is held of William by Drogo. Now there are $3 \frac{1}{2}$ hides and 21 acres. ${ }^{9}$ Then as now (semper) 2 ploughs on the demesne. Then 2 ploughs belonging to the men; now 3 . Then I villein; now none (non). Then 4

other manors there; but Bovills, according to him, was held of the Honour of Clare. It is difficult to see what this manor was unless it was Bovills, but there is nothing to show if or how it came into the hands of the Clares.

6 Probably Geoffrey Talbot, his under-tenant at Liston.

7 Roger held the adjoining manors of Mount Bures and West Bergholt.

8 i.e. the manor of Abbots there (see Introduction, p. 399).

9 This is a curious and abnormal clause, which appears to be connected with the sokemen's holding lower down in the entry. 


\section{THE HOLDERS OF LANDS}

bordars; now 11. Then 3 serrs; now 2. Then I cow, 60 sheep, (and) I I swine; now 5 cows, 15 swine, (and) 60 sheep. Then 4 sokemen, and now the same (similiter), holding $2 \frac{1}{2}$ hides and 21 acres of the same land; and 56 acres have been taken thence. ${ }^{1}$ (There is) wood(land) now as then (semper) for 100 swine, (and) pasture for 60 sheep. It was then worth 60 shillings; now 100 .

\section{Hundret of Ceffeurda [Chafford]}

Turruc [(Grays) Thurrock $\left.{ }^{2}\right]$, which was held by Ailmar' as a manor and as 3 hides and 42 acres in King Edward's time, is held by $W$ [illiam] in demesne. Then 2 villeins; now 3. Then 11 bordars; now 18 . Then as now (semper) 2 serfs, and 2 ploughs on the demesne. Then 4 ploughs belonging to the men; now 5. (There is) pasture for 100 sheep, (and) now as then I fishery. Then 2 villeins (vill[ani]), 58 sheep, I rouncey (runcinus); now 5 cows, 4 calves, 85 sheep, (and) 8 swine. It was then worth 6 pounds; and when received, (the same); now 12 pounds and an ounce of gold. To this manor there belonged (In boc manerio jacebant) in King Edward's time 9 sokemen holding 3 hides; now there are 5 sokemen, and they hold I $\frac{1}{2}$ hides; and Gilbert, a man of the Bishop of Bayeux, holds $1 \frac{1}{2}$ hides less 10 acres, and the Hundret (court) knows not how ; 20 acres also, which used to belong to this manor (jacebant in boc manerio) in King Edward's time, are held by Anschetil, a man of the Bishop of London, and the Hundret (court), similarly, knows not (how). ${ }^{6}$

\section{THE LAND OF RALF DE LIMESI (LIMESEIO)}

Branduna [Brundon ${ }^{6}$ ], which was held

1 It is not clear whether this clause refers to the holding of the sokemen or to the whole manor. The latter, perhaps, is the more probable.

2 See Introduction, p. 388.

3 This is clearly a scribal error, for the clause relates to live stock. The scribe seems to have repeated the 'then 2 villeins' from above.

- On reference to p. $45^{8}$ above we see that this Gilbert is entered as having held a hide and 2 half in Stifford of the bishop, although at the time of the Survey he had been succeeded by (Rall) son of Turold. The entry adds that this hide (sic), 'except 1o acres,' had belonged to William Peverel's manor of Thurrock in King Edward's time.

- On page $45^{8}$ also this Anschetil is entered as holding at Thurrock of the Bishop of Baycux, but he also held there of the Bishop of London (p.440). - In Hinckford Hundred. by a free man, in King Edward's time, as a manor and as $2 \frac{1}{2}$ hides less 15 acres, is held by Ralf in demesne. Then as now (semper) 2 ploughs on the demesne, and 3 ploughs belonging to the men, and 7 villeins, and 7 fo. gob

bordars, and 4 serfs. (There is) wood(land) for 10 swine, 32 acres of meadow, (and) 1 mill. It was then worth 4 pounds; afterwards and now 6. To this manor Harduin'7 added, in King William's time, 20 acres; then as now (semper) half a plough (was there); (there is) now I bordar; (there was) then wood(land) for 20 swine; now for 6 ; it is valued above. ${ }^{8}$

In Niuetuna ${ }^{9}$ [ ] belongs (jacet) I sokeman, who has half a plough now as then (semper); and (this) is worth 3 shillings.

\section{Hundret OF ANGra [Ongar]}

Cinghe wella [Chigwell ${ }^{10}$ ], which was held by Harold of King Edward as a manor and as 7 hides, is held by $\mathrm{R}$ [alf] in demesne. ${ }^{11}$ Then as now (semper) 19 villeins, and 2 bordars, and 2 ploughs on the demesne. Then 16 ploughs belonging to the men; now II. (There is) wood(land) for 800 swine, 3 I acres of meadow, (and) now as then (semper) I mill. It was then worth 8 pounds; now 10. And 6 free men dwelt in 2 hides and 15 acres; Robert Gernon (Greno) has them now by the King's gift, as he says; ${ }^{12}$ and they then had 3 ploughs; now 2; wood(land is there) for 40 swine, and 8 acres of meadow; I mill (was there) then; now none; (this) is worth 40 shillings now as then (semper). And a certain free man holds and held 30 acres; Peter the

7 Not, as Morant assumed, Hardwin de Scalers, but, probably, the Hardwin who had preceded William de Scohies in the possession of certain lands in Norfolk and Suffolk, in which counties he is charged with similar action. It would appear by an entry on fo. 383 that he had lost his land by forfeiture.

8 i.e. the value of this holding is comprised in that which has been given for the whole manor.

${ }^{\circ}$ This small holding has not been identified.

10 The manor of Chigwell Hall.

11 For his similar succession to Harold at Amwell, Herts, see the Introduction, p. 338. It should be observed that Harold is here described as holding 'of King Edward,' but this does not affect the conclusion enunciated on Pp. $336-7$ above.

18 Yet they are not mentioned in the entry of his holding in that Hundred on p. 518 above. 


\section{A HISTORY OF ESSEX}

sheriff has him now $\dot{1}^{1}$ then I plough (was there); now a half; (there is) wood(land) for 30 swine, (and) 2 acres of meadow; it is worth 5 shillings; Peter had livery (liberatorem) of this land with (the rest of) his fief.

In the abovesaid manor of BRUMduna [Brundon] R[alf] received 3 beasts (animalia), I5 sheep, 15 swine, (and) I rouncey (runcinum); (there are) now 6 beasts, 24 sheep, I 8 swine, and I rouncey. And in CingheWELLA [Chigwell] he received 6 beasts, and I 7 sheep, and I I swine; (there are) now 10 beasts, 60 sheep, and 20 swine. Ralf de Limesi (Limeseio) holds 6 acres of the King's soke, but his predecessor annexed them (invasit).

\section{THE LAND OF ROBERT DE TOESNI [TODENEIO] ${ }^{2}$}

\section{HUNDRET OF UDELESFORT [UTTLLESFORD]}

CESEwic [Cheswick (Hall) ${ }^{3}$ ] was held, in King Edward's time, by I free man as a manor and as $\mathrm{I} \frac{1}{2}$ hides. Then as now (semper) I plough on the demesne, and 2 ploughs belonging to the men. Then and afterwards 4 villeins; now 3 . (There are) now 2 bordars. (There is) wood(land) for 100 swine, (and) 4 acres of meadow. It is worth 40 shillings.

fo. 9 I

\section{THE LAND OF RALF DE TOESNI [TODENEIO] ${ }^{4}$}

\section{HundRet of Herlaua [Harlow]}

OUESHAM [Housham (Hall) ${ }^{5}$ ] is held of $R$ [alf] by Roger (as) half a hide which was held by Etmar. Then as now (semper) I plough. It was then worth 10 shillings; now 15.

\section{LAGHEFARA [(Magdalen ?) Laver ${ }^{6}$ ], which}

1 No reference to this holding can be detected in the account of Peter de Valognes's fief.

2 The lord of the great Belvoir fief. His name was derived from Toesni (Tosny) in Normandy.

3 A manor in Chreshall.

4 The head of his barony was at Flamstead, Herts, and the origin of his name was the same as Robert's.

5 A manor (formerly a hamlet) in Matching.

6 All the Lavers were in Ongar (not Harlow) Hundred. Morant probably assigned this Hundred to Magdalen Laver because the other Laver entries clearly refer to High and Little Laver. This is a sound conclusion, but the manor is not found, it would seem, in the hands of Ralf's heirs. was held by Sexi' 7 as a manor and as 1 hide, is held of R[alf] by Roger. Then 4 villeins; now 3. (There are) now 7 bordars. Then 4 serfs; now 3. Then 2 ploughs on the demesne; now I. (There is) wood(land) for 30 swine, (and) 16 acres of meadow. Then as now (semper) 13 swine, and 60 sheep, and 4 cows. It is worth now as then (semper) 70 shillings.

\section{THE LAND OF WALTER DE DOAI ${ }^{8}$}

\section{Hundret of Ceffeurda [Chafford]}

UPMUNSTRE [Upminster ${ }^{9}$ ], which was held by Suen' suart as a manor and as $6 \frac{1}{2}$ hides and 30 acres, is held by Walter in demesne. Then as now (semper) 8 villeins. Then 5 bordars; now 7. Then as now (semper) 4 serfs, and 2 ploughs on the demesne. Then 5 ploughs belonging to the men; now 4. (There is) wood(land) for 200 swine (and) 8 acres of meadow. Then I colt (pullus); now none. (There are) now 85 sheep (oves) and 25 sheep (oves). It was then worth 7 pounds; now 8. And there belonged to (jacuerunt in) this manor 10 acres which are held by Geoffrey de 'Magnavilla' in exchange (in suo escangio), as he says.

ReINeHAM [Rainham ${ }^{10}$ ], which was held by Lefstan' the reeve as a manor and as 8 hides, is held by Walter in demesne. Then 3 ploughs on the demesne; now 2. Then 6 ploughs belonging to the men; now 5 . Then as now (semper) 12 villeins. Then 2 bordars; now 9. Then 5 serfs; now 4. (There are) 105 sheep, 20 swine, 1 rouncey (runcinus). It is worth now as then (semper) Io pounds. To this manor has been added half a hide, which used to be held by 3 free men in King Edward's time; and, after King William came, Walter added them to his manor to which they did not belong in King Edward's time, as the county court (consulatus) testifies; and they then had I plough; now a half; and when (Walter) received (this), a half; (this) is worth 20 shillings.

\section{Hundret of Tendringe}

HoLANDA ${ }^{11}$ [Holland] was held by Lestan'

7 This was probably the 'Sexi, housecarl of King Edward,' who had preceded Ralf at Westmill, Herts.

8 See Introduction, p. 350.

9 i.e. the manor of Gaines there.

10 The identity of this manor there is uncertain.

11 It is not clear in which of the Hollands, or where, this manor lay. 


\section{THE HOLDERS OF LANDS}

as $6 \frac{1}{8}$ hides. Then as now (semper) 17 villeins. Then and afterwards 10 bordars; now 11 . ro. gib

Then and afterwards 5 serfs; now 3 . Then and afterwards 4 ploughs on the demesne; now 3. Then and afterwards I I ploughs belonging to the men; now 8. (There is) wood(land) for 100 swine, (and) 14 acres of meadow. It is worth now as then (semper) 14 pounds.

\section{THE LAND OF MATHEW OF MORTAGNE (MAURITANIENSIS)}

\section{Hundret of Dommawa [Dunmow]}

Estanes [(Great) Easton], which was held by Achi', a free man, as a manor and as 5 hides in King Edward's time, is held by $\mathrm{M}$ [athew ${ }^{1}$ ] in demesne. Then 5 ploughs on the demesne; and when (he) received (it), 4 ; now 3. Then 10 ploughs belonging to the men; now 7. Then II villeins, and I priest; now 15 villeins, and 1 priest. Then 10 bordars; now 16. Then 10 serfs; now 9. (There was) wood(land) then for 200 swine; now for 150. (There are) 67 acres of meadow, (and) now as then (semper) I mill, and 1 rouncey (runcinus), and 8 beasts (animalia), and 120 swine, and 60 sheep, and 10 goats, and 3 hives of bees. It was then worth 10 pounds; and when received, the same; it is now worth 15 pounds.

\section{Hundret of Celmeresfort [Chelmsford]}

GingA [(Margarett)ing $\left.{ }^{4}\right]$, which was held by Anschil as a manor and as 5 hides, is held by $M\left[\right.$ athew $\left.{ }^{6}\right]$. Then as now 7 villeins, and 8 bordars, and 4 serfs, and 2 ploughs on the demesne, and 3 ploughs belonging to the men. (There is) wood(land) for 300 swine, and (there are) I rouncey (runcinus), 5 beasts

I The initial ' $M$ ' here and in the next entry is the symbol normally employed to denote ' $M$ (anor).'

This is a large proportion of meadow, but the adjoining manor of Tiltey, though smaller, had 50 of meadow and 'marsh,' and the great parish of Thaxted to their north about 160 , the valley of the Chelmer being thus well marked.

3 Here is an increase in value from 10 pounds to 15 pounds concurrent with a decrease in ploughs from is to 10 and of 25 per cent in the woodland, while the live stock remained stationary !

4 This identification is supported by the fact that Margaretting, like Great Easton and manors of his in other counties, was subsequently granted out to be held by serjeanty.

- See note I above. (animalia), 20 swine, (and) 30 sheep. It was then worth ( 100 ? $\left.^{6}\right)$ shillings; now 6 pounds.

\section{LIIII. THE LAND OF THE COUN- TESS OF AUMALE (ALBEMARLA)}

\section{HUNDRET OF HidingFort [HinCKFoRd]}

BARLRA [Borley], which was held by Lewin', a free man, as a manor and as 2 hides and 30 acres in King Edward's time, is held in demesne (by the countess). Then 3 ploughs on the demesne; afterwards and now 2. Then as now (semper) 5 ploughs belonging to the men, and 10 villeins, and 5 bordars. (There is) wood(land) for 30 swine, (and) 40 acres of meadow. And (there are) 7 beasts (animalia), and 25 sheep, and 24 goats, 28 swine, and 2 hives of bees. Then and afterwards it was worth 8 pounds; now 12.

\section{HUNDRET OF TENDRINGa}

Scrodinchou [Manningtree ${ }^{7}$ ], which was held by Alvric as a manor and as 2 hides, is held in demesne (by the countess). Then as fo. 9

now (semper) 15 bordars. Then 4 serfs; afterwards and now I. Then 2 ploughs on the demesne; afterwards and now I. Then 4 ploughs belonging to the men; afterwards and now 2 (There is) wood(land) for 40 swine, (and) 6 acres of meadow. Then (there was) I mill, and I fishery; now none. There is pasture for 40 sheep. Then 3 cows, 3 calves, 40 sheep, 2 rounceys (run(int), 30 swine; now I rouncey, 3 beasts (animalia), 48 sheep. It is worth now as then (semper) 60 shillings.

\section{THE LAND OF COUNTESS JUDITH $^{8}$}

\section{Hundret of Beventreu [Becontree]}

WILcumestou [Walthamstow] was held by Earl Waltheof $\left(\right.$ Wallef $\left.{ }^{9}\right)$ in King Edward's time as a manor and as $10 \frac{1}{2}$ hides. Then as now (semper) 2 ploughs on the demesne. Then 15 ploughs belonging to the men; now

- The figure is omitted in the MS.

7 The descent of the manor renders certain this identification, which, indeed, was fully recognized by Morant (i. 46I), though he oddly spoke on the opposite page of 'Mistley Hall or Sciddinghou Hall.' The manors of Mistley ('Mitteslea') and Manningeree ('Sciddinghou') were distinct from the first.

8 Niece of the Conqueror.

- Her late husband. 


\section{A HISTORY OF ESSEX}

22. Then 25 villeins; now 36 . Then $\mathrm{I}$ bordar; now 25. Then as now (semper) 4 serfs. (There is) wood(land) for 300 swine, 80 acres of meadow, pasture worth (de) 8 shillings, and now as then (semper) I mill. Then 6 fisheries; now I. (There are) now 8 beasts (animalia), I rouncey (runcinus), 35 swine, 60 sheep, and 20 goats. It was then worth 15 pounds; now 28 pounds and 2 ounces of gold.

\section{THE LAND OF FRODO BROTHER OF THE ABBOT ${ }^{2}$}

REDEWINTRA [Radwinter], which was held by Orgar as a manor and as $I$ hide and I virgate, is held by $F[$ rodo] in demesne. Then as now (semper) 15 villeins, and 6 bordars, and 3 (serfs ? ${ }^{2}$ ), and 3 ploughs on the demesne, and 6 ploughs belonging to the men. (There is) wood(land) for 100 swine, and 30 acres of meadow. Then ro beasts (animalia), 60 sheep, 50 swine, 25 goats, (and) I hive of bees; now I 8 beasts, I 40 sheep, 37 swine, 30 goats, and 4 hives of bees. It was then worth 8 pounds; now 15 . Of this manor Alger' holds of Frodo 30 acres, and (this) is worth 10 shillings in the above valuation (pretio)

fo. $92 b$

\section{THE LAND OF SASSELINUS}

\section{Hundret of Berdestapla [Barstable]}

STANTMERE [

1] and WINTHELIE

[ 4], which are held by S[asselinus], were held by Alric' and Ulwin' as a manor and as 2 hides and 30 acres. Then as now (semper) 2 ploughs on the demesne, and 2 oxen ${ }^{5}$ (boves) belonging to the men. (There is) wood(land) for 40 swine. (There were) then I rouncey (runcinus), and 7 swine, and

1 i.e. of Baldwin abbot of St. Edmund's.

8 The word is omitted in the MS.

3 A tenant-in-chief, as 'Saisselinus,' in Suffolk. As the descent of his fief cannot be traced, the identification of its manors is difficult.

4 Both these names appear to be now lost, but there can be little doubt that 'Winthelle' was identical with 'la Windhill,' which occurs in connexion with Ramsden and Downham in 2 fine of 4 John $(1202-3)$ and with 'Windhull' which appears in one of the preceding year (Feet of Fines for Essex, i. 24, 25), and finally with ' 16 messuages called Wyndellond' held in Ramsden Crays by Sir Thomas Tyrrell at his death in 1476 . Morant placed the manors (one cannot tell for what reason) in Stanford-le-Hope.

b i.e. a quarter of a plough-team.
I5 sheep; now I rouncey, 70 sheep, I 8 swine, (and) 20 goats. It is worth now as then (semper) 50 shillings.

\section{HUNDRET OF WITHAM}

In Nutrea [Notley ${ }^{6}$ ] S[asselinus] holds half a hide and 22 acres, which were held by Levechild in King Edward's time. Then I plough; now a half. Then I beast (animal); now 4 (beasts), and 12 sheep, 6 swine, (and) I rouncey (runcinus). It is worth ro shillings.

\section{Hundret of Wensistreu [WINSTREe]}

LEGRA [Layer], which was held by 2 free men as a manor and as 8 hides in King Edward's time, is held by S[asselinus]. Then 4 ploughs on the demesne; now 2 . Then as now (semper) 2 ploughs belonging to the men, and 1 villein, and 17 bordars. Then 8 serfs; now 3. (There was) then wood(land) for 100 swine; now for 60. (There are) 7 acres of meadow. (There were) then 24 beasts (animalia), 200 sheep, 23 swine, 3 rounceys (runcini), 4 hives of bees; now 7 beasts, 125 sheep, 9 swine, 3 rounceys, 4 hives of bees. It is worth now as then (semper) 7 pounds. ${ }^{7}$

\section{Half Hundret of Clavelinga [Clavering]}

Pincepo [Pinchpoles ${ }^{8}$ ], which was held by a free man as a manor and as I hide, is held by $\mathrm{S}$ [asselinus]. Then as now (semper) I plough. (There are) now 3 bordars, and I serf. And (there are) 4 acres of meadow. And (there are) 18 sheep and 18 swine. It is worth 20 shillings.

\section{Hundret of Ceffeurda [Chafford]}

In Ciltedic [Childerditch] S[asselinus] holds I manor of $1 \frac{3}{2}$ hides and 30 acres, which was held by Orgar, a free man, in King Edward's time. Then I plough on the demesne; now $I \frac{1}{2}$. Then as now (semper) 2 ploughs belonging to the men. Then 3

- The identity of this small estate is undetermined.

7 Although the assessment and valuation of this manor in Domesday make it the most important of those in the Layers, it is altogether omitted by Morant. I strongly suspect that it was Layer Breton, to which Morant assigned only a holding of less than a hide in the hands of Ranulf Peverel. For, as with other of Sasselin's manors, it is afterwards found in the hands of a family, the Bretons, who did not hold it of any fief.

8 A manor in Manuden. 


\section{THE HOLDERS OF LANDS}

villeins; now 4. Then as now (semper) 6 bordars. Then 2 serfs; now none. (There is) wood(land) for 100 swine, (and) pasture for 60 sheep. (There were) then 50 sheep, 24 swine, 4 rounceys (runcini), 12 beasts (animalia); now 4 beasts, 12 sheep, 6 swine, 1 rouncey. It was then worth 60 shillings; now 4 pounds. And there was on (in) this land I sokeman with (de) I 5 acres, which he had power to sell; but the soke belonged to (jacebat in) Warleia [Little Warley], St. Paul's land; then as now (semper) half a ใo. 93

plough (was there); it is worth 3 shillings.

\section{Hundret of Udelesfort [UTtLesford]}

Banhusta [Bonhunt ${ }^{1}$ ], which was held by Alvric, a free man, as a manor and as 2 hides in King Edward's time, is held by $\mathrm{S}$ [asselinus] as a manor. ${ }^{2}$ When he received (it, there were) 4 bordars; and now (the same). Then as now (semper) I plough on the demesne. (There is) now half a plough belonging to the men. (There are) 10 acres of meadow. Then I beast (animal) and I pig; now 30 sheep, 2 beasts, (and) I rouncey (runcinus). Then and afterwards it was worth 40 shillings; now 55 .

\section{THE LAND OF GILBERT FIT'Z TUROLD ${ }^{3}$}

\section{HundRet of Udelesfort [UtTlesford]}

Wicam [Wickham (Bonhunt)] was held by Sexi', a free man, as a manor and as 3 hides and 13 acres in King Edward's time. Then and afterwards 8 villeins; now 9. Then and afterwards 8 bordars; now II. Then as now (semper) 3 serfs and 2 ploughs on the demesne, and 3 ploughs belonging to the men. Then and afterwards (there was) wood(land) for 100 swine; now for 60 . (There are) Io acres of meadow. It is worth now as then (semper) 7 pounds. Then (there were) I rouncey (runcinus), 50 sheep, 30 swine, 36 goats; now I rouncey, 40 shecp, 30 goats, 26 swine, 2 beasts (animalia).

1 A manor in Wickham Bonhunt.

2 This is a good example of the meaningless addition of 'pro manerio.'

3 A tenant-in-chief in seven counties and an under-tenant in four. He had held an important position on the Welsh border under William Fitz Osbern, Ear] of Hereford (see the Vicforia Hisfory of Worcestershire, i. 241, 266).

\section{THE LAND OF WILLIAM LEVRIC *}

Scilcheham [

3] was held by Ansgot, a free man, as a manor and as 8 hides in King Edward's time. Then as now (semper) 6 villeins. Then 8 bordars; now 10. Then as now (semper) 3 serfs and 2 ploughs on the demesne, and 3 ploughs belonging to the men. (There is) pasture for 100 sheep. It is worth now as then (semper) 6 pounds.

\section{THE LAND OF HUGH DE ST. QUINTIN ${ }^{\circ}$}

Horninduna [Horndon (on the hill) ${ }^{7}$ ] was held by Winge as a manor and as $1 \frac{1}{2}$ hides in King Edward's time. Then as now (semper) I plough on the demesne. Then 3 bordars; now 4. ('There is) wood(land) for 10 swine, (and) the 8th part of a fishery. Then as now (semper) there were I rouncey (runcinus), I beast (animal), 30 sheep, I pig. It is worth 20 shillings. Of this land Goduin' abstracted (abstulit) 2 'mansiones.' 8

\section{HuNDRET OF WENSISTREU [Winstree]}

WigheBerga [Wigborough ${ }^{9}$ ] was held by Alvric, a free man, as a manor and as 2 hides. fo. $93 \mathrm{~b}$

Then as now (semper) I plough on the de-

- This singular name is well ascertained, and its abnormal character attracted the notice of Prof. Freeman. William's chief estate was in Gloucestershire, but he also had some land in Oxfordshire.

5 This manor, although considerable, as its assessment and valuation show, has not been identified, nor can the descent of William's fief be traced. The mention of pasture for sheep implies that 'Scilcheham' was on the coast, but it is not assigned to any Hundred either here or on p. 574 below, where it occurs as 'Sciddeham.' The latter form is distinct from the other, and suggests that there has been some ronfusion on the part of the scribe betwcen 'ch' and 'd.' 'There are cases in Domesday of ' $c$ ' and ' $d$ ' being so confused.

- The rest of Hugh's fief was in Dorset and Hants. It seems to have been broken up, and Morant's statements on the subject are crroneous.

7 See Introduction, p. 398. Morant does not mention this estate under Horndon.

8 The offender was Godwine 'Gudhen' (or ' Cudhen '), and his aggression heads the list of such actions on p. 566 below. 'Mansiones' is a rare and difficult word in Domesday. At Hanningfield (p. 459 above) it is used of a manor, while in towns it denotes a house (see Introduction, p. 416). In Suffolk (fo. 415) 'II mansiones' is used to denote two considerable manors.

- Morant asserted this to be the manor of Mulshams in Great Wigborough, but appears to have had no ground for that assertion. 


\section{A HISTORY OF ESSEX}

mesne. Then I bordar; now 2. Then 2 serfs; now 3. Then I mill; now none. Then as now (semper) I rouncey (runcinus) and 7 beasts (animalia), and I pig. Then (there were) 55 sheep; now 45 . It is worth now as then (semper) 30 shillings.

\section{HundRet of Laxendena [LEXDEN]}

Parva Bricceia [Little Birch ${ }^{1}$ ] was held by Wlward as a manor and as half a hide and I5 acres in King Edward's time. Hugh holds (it) now, of the queen's gift, for as much (pro tantundem). (There is) wood(land) for 10 swine, (and) 4 acres of meadow. Then I bordar, and I serf; and now the same. Then as now (semper) I rouncey (runcinus), 7 beasts (animalia), 25 swine, 53 sheep. Then and afterwards it was worth 20 shillings; now 16.

\section{THE LAND OF EDMUND SON OF ALGOT 2}

\section{Hundret of Berdestapla [Barstable]}

Horninduna [Horndon-on-the-hill ${ }^{3}$ ] was held by 2 free men as a manor and as $2 \frac{1}{2}$ hides and 15 acres in King Edward's time. Then 3 ploughs on the demesne; now 2 . Then 2 ploughs belonging to the men; now 1. Then as now (semper) I villein. Then 14 bordars; now 16 . Then 3 serfs; now none. (There is) pasture for 50 sheep, (and) 12 acres of meadow. Then (there were) 5 beasts (animalia), I rounccy (runcinus), 20 swine, I 50 sheep; now (there are) 35 sheep. It is worth 50 shillings. There also (in eadem villa) there is a certain deacon who has 30 acres and a fourth part of the church; and it is in the king's gift (jacet ad elemosinam regis).

Matcinge [Matching ${ }^{4}$ ], which was held by Almar Holefest ${ }^{6}$ as $1 \frac{1}{2}$ hides and as a

1 Morant assumed this to be the whole manor of Little Birch, but his whole account is here mistaken (see Introduction, p. 389).

2 This is one of the rare instances of an English tenant-in-chief. It will be seen, however, that his lands had previously belonged to others.

3 See Introduction, p. 398. Morant makes it 'West Horndon,' i.e. West Thorndon, but it must be one of the manors in Horndon-on-the-hill.

4 Morant placed this entry tentatively under Mucking, but the form of the name makes it certain that Matching is meant, and that the scribe has omitted the Hundredal heading assigning it to Harlow.

6 This must have been the 'Holefest' whose estate of Housham Hall in Matching had been secured by William de Warenne (p. 473 above). The case is parallel to that of Ralf Baignard being also entered simply as 'Baignard.' manor in King Edward's time, is held by $\mathrm{E}$ [dmund]. Then 2 ploughs on the demesne; now 1 . Then $3 \frac{1}{2}$ ploughs belonging to the men ; now 3. Then 7 villeins; now 9. (There are) now 4 bordars. Then 4 serfs; now none. (There is) wood(land) for 50 swine, (and) 8 acres of meadow. Then (there were) 7 cows, I pig, roo sheep less 5, 40 goats, 1 rouncey (runcinus), and 6 hives of bees; now 4 beasts (animalia), ${ }^{6} 9$ swine, 24 fo. 94

sheep, (and) 2 hives of bees. It is worth now as then (semper) roo shillings.

\section{THE LAND OF ROGER THE MARSHAL}

\section{Hundret of Berdestapla [Barstable]}

Nezendena [Newenden '] was held by Alward Dore as a manor and as 40 acres in King Edward's time. It is now held by $\mathrm{R}$ [oger]. Then half a plough; now none. It is worth now as then (semper) 4 shillings. And in Nutlea [Notley ${ }^{8}$ ] (are) 5 acres which were held by Cola, a free man, and are worth 4 shillings.

Bertuna [ ${ }^{9}$ ] was held by Ulwin Hapra as a manor and as half a hide. Now R[oger] (holds it). Then I plough; now a half. (There is) I acre of meadow. It was then worth 10 shillings; now 5.

Lohou [ $\left.{ }^{9}\right]$ was held by Alwin as a manor and as 40 acres. Now R[oger] (holds it). Then as now (semper) half a plough. (There is) wood(land) for 3 swine. It is worth 5 shillings.

\section{THE LAND OF ADAM SON OF DURAND MALSOUER (MALIS OPERIBUS ${ }^{10}$ )}

\section{Hundret of Dommawa [Dunmow] WillingheHala [Willingale ${ }^{11}$ ] was held}

6 This appears to be a case in which the 'beasts' represent or include the cows.

7 Corruptly 'Nevendon.'

8 Black and White Notley are in Witham Hundred, far away from Newenden.

9 These small holdings of Roger have not been identified.

10 This curious Latinization of a name must be construed in light of the fact that Fulcher 'mala opera,' who is entered under Rutland, can be identified as the ancestor of the family who gave name to 'Thorpe Malsor' in Northamptonshire, which was held by him as 'Alidetorp' in 1086.

11 It has not been ascertained in which of the Willingales this small estate lay. 


\section{THE HOLDERS OF LANDS}

by 5 free men as a manor and as half a hide in King Edward's time. Then 2 ploughs; now 1. (There are) now 6 bordars. It is worth 10 shillings.

\section{HUNDRET OF HidingFort [HinckFord]}

HORSTEDAFORT [

1] was held by

Godric, a free man, as 15 acres in King Edward's time. It is now held by A[dam]. Then and afterwards I plough; now a half. Then as now (semper) 5 bordars. (There is) wood(land) for 11 swine, (and) 3 acres of meadow. It was then worth 10 shillings; now 13.

\section{LXIIII. THE LAND OF GOSCELM THE LORIMER * (LOREMARII)}

\section{HUNDRET OF BEVENTREU [BECONTREE]}

ILEFORT [Ilford] was held by 2 free men as a manor and as 3 hides less 30 acres in King Edward's time. Then 2 ploughs on the demesne; now 1. Then $2 \frac{1}{2}$ ploughs belonging to the men; now 1. Then 7 villeins; now 4 . Then 4 bordars; now 6 . ro. grb

Then I serf; now none. (There is) wood(land) for 20 swine, 20 acres of meadow, (and) now I mill and I fishery. It is worth now as then (semper) 4 pounds.

\section{THE LAND OF JOHN} NEPHEW (NEPOTIS) OF WALERAM ${ }^{3}$

\section{HundRet OF Wdelesfort [UTtLesFord]}

Alsenham [Elsenham] was held by Meruena, a free woman, as a manor and as 4 hides in King Edward's time. Then as now (semper) 2 ploughs on the demesne. Then and afterwards 7 ploughs belonging to the men; now 6. Then as now (semper) 8 villeins. Then and afterwards 1 bordar; now 12. Then as now (semper) 5 serfs. Then

1 Suggests one of the old fords on the Colne or the Blackwater in this Hundred; but the name seems to be now lost, unless it is represented by 'Hersted' (now Herksted) Hall on the western edge of the Hundred, in a detached portion of Birdbrook, which is shown on Chapman and André's map with 'Hersted Green' adjoining it. But it is away from any ford.

i.e. 2 maker of horses' bits. He is entered under the king's manor of Witham as holding a hide which had owed dues to it, and under Barking as having abstracted 24 acres from the nunnery's manor there.

- He gave the church of Elsenham to the abbey of St. Stephen at Caen, to which house his uncle Waleram had been a benefactor in Essex. (there was) wood(land) for 1300 swine ; and when he received (it), for 1100 ; now for 1000. (There are) 12 acres of meadow, (and) now as then (semper) I mill. And (there are) 220 sheep, and 8 cows, and 60 swine, and I rouncey (runcinus), and I colt (pullus). Then and afterwards it was worth 6 pounds; now 8 .

\section{THE LAND OF WILLIAM THE DEACON "}

\section{Hundret of Wensistreu [Winstree]}

Peltenduna [Peldon] was held by Turchil, a free man, as a manor and as 5 hides in King Edward's time. Then as now 2 ploughs on the demesne, and 2 ploughs belonging to the men. Then 4 villeins; now 3. Then 9 bordars; now 10. Then 2 serfs; now 4. (There is) wood(land) for 60 swine, I saltpan, and I church with (de) 30 acres (of glebe, on which) now as then (semper) is half a plough. And there is I sokeman with (de) 17 acres. Of these 5 hides Hamo Dapifer took away (tulit) 80 acres of arable land and 200 acres of marsh, all of which belonged to this manor (both) in King Edward's time and after the coming of King William, as the Hundret (court) testifies, and this land taken by him (hane occupationem) we have taken (percepimus ${ }^{5}$ ) into the king's hands. The abovesaid manor including this (cum boc toto) was worth then, and when received, 6 pounds; and now it is worth 100 shillings; and what has been taken away from it is worth 20 shillings.

\section{HUNDRET OF HID(I)NGFORT [HINCKFORD]}

SCALDEFORT [Shalford ${ }^{6}$ ] was held by Godere, a free man, as a manor and as half a hide in King Edward's time. Then and afterwards I plough; now $1 \frac{1}{2}$. Then 3 serfs; now I bordar. (There is) wood(land) for 12 swine, fo. 93

(and) 7 acres of meadow. It was then worth 40 shillings; now 50.

\section{THE LAND OF WALTER THE COOK}

\section{Hundret of Hidingfort [Hinckford]}

SCALDEFORT [Shalford ${ }^{6}$ ] was held by a free

- See Introduction, p. 418.

6 This is one of the rare and interesting cases in which the Domesday Commissioners speak in their own persons (sec Introduction, p. 4 I 2).

- There were scveral manors in Shalford, and the identity of this holding has not been ascertained. 


\section{A HISTORY OF ESSEX}

man as a manor and as half a hide in King Edward's time. ${ }^{1}$ Then and afterwards $\mathbf{I} \frac{1}{2}$ ploughs; now I. Then as now (semper) I villein and 3 bordars. Then and afterwards 2 serfs; now I. (There is) wood(land) for 8 swine, (and) I I acres of meadow. Then (there were) 2 rounceys (runcini) and 12 beasts (animalia), and 60 swine, and 53 sheep, and 3 goats; now 10 beasts, and 8 swine, and 53 sheep, and 20 goats, and 5 hives of bees. It was then worth 40 shillings; now 50 .

In Assewella [Ashwell (Hall)] ${ }^{2}$ Felaga held half a hide as a manor; now Walter (holds it). Then 3 bordars; now 7 . Then I $\frac{1}{2}$ ploughs; now I. (There is) wood(land) for 60 swine, (and) I I acres of meadow. Then (there were) I cow, and 30 swine, and 5 sheep; now 4 beasts (animalia ${ }^{3}$ ) and 8 swine, and 53 sheep. It was then worth 40 shillings; now 60.

\section{THE LAND OF MODUIN *}

\section{Hundret of Berdestapla [Barstable]}

WICFORT [Wickford] was held by Eduin' Grut ${ }^{5}$ freely as a manor and as half a hide. Then as now (semper) I plough, and I bordar. (There are) 4 acres of meadow. It is worth Io shillings.

\section{HUNDRET OF WITHAM}

In WITHaM M[oduin] holds I hide which was held by Harold. Then as now (semper) I plough. Then I bordar; now 2. (There is) wood(land) for 12 swine. (There were) then 8 acres of meadow; now 4 ; and Geoffrey Baignard ${ }^{6}$ took away the rest (tulit alias). Then (there were) 4 swine; now 7 . Then 20 sheep; now 40. Then 4 beasts (animalia); now IO.

1 This is suggestive of the identity of this holding with the half hide of 'soke' recorded, under the main manor of Shalford (p. 431 above), to have passed into the possession of Walter son of Guibert, who would, in that case, be Walter the cook.

2 A manor in Finchingfield.

3 This seems to be one of the cases in which animalia represent cows.

4 This is an English name. A note below will show that its bearer had possibly held land in Essex under the Confessor.

5 The predecessor of Robert Gernon in a manor to the north-west in Chelmsford Hundred.

6 'This ' Goiffridus Baignard' must be the 'Gaosfridus Bainard ' who occurs in Norfolk as a considerable under-tenant of Ralf Bainard (fos. $247 b, 248$, $249,250,2513,253)$. We must infer therefore from this entry that he was under-tenant of the land held by Ralf Bainard in Witham (see p. 429 above).
(There are) now 2 rounceys (runcini). It is worth 20 shillings.

\section{HUNDRET OF WITBRICTESHERNA [DENGIE]}

Criccheseia [Cricksea] was held by Alward' as a manor and as $I$ hide in King Edward's time. Then 2 bordars; now 1. Then as now (semper) I plough. (There is) pasture for 40 sheep. (There are) now 85 sheep. It is worth now as then (semper) 30 shillings.

\section{HundRET OF WENSISTREU [Winstree]}

LEGRA [Layer "] was held by a free man as a manor and as 2 hides in King Edward's time. fo. $95 \mathrm{~b}$

Then as now (semper) 2 ploughs on the demesne. Then 5 bordars; now 4. Then as now (semper) 2 serfs. (There is) wood(land) for 20 swine. Then (there were) 32 sheep ; now I00. Then I cow with a calf; now IO beasts (animalia). (There are) now 40 goats, and 2 rounceys (runcini). Then 7 swine; now Io. It is worth now as then (semper) 60 shillings.

\section{Hundret of Lassendena [Lexden]}

Crepinges [Creping (Hall) ${ }^{8}$ ] was held by Alward' as 1 virgate of land. ${ }^{9}$ Now Moduin' holds (it). Then I plough; now a half. (There are) 2 acres of meadow, (with) wood(land) for 40 swine. It is worth 10 shillings. It was held by I free man.

In Dunilanda [(East) Donyland] Laghemann' held I virgate. Moduin' holds(it) now. ${ }^{10}$ Then as now (semper) I bordar. Then and afterwards half a plough; now none. It was then worth Io shillings; now 6 .

\section{Hundret of Tendringa}

Tendringa [Tendring ${ }^{11}$ ] was held by Alvric as I 5 acres. Now Mod[uin'] holds it as a manor and for as much. ${ }^{12}$ Then 2 serfs; now 1 . Then as now I plough. It is worth 20 shillings. (There was) then as now (semper) I rouncey (runcinus); now (there are) 4 swine, and 4 goats, and 10 sheep, and 6 beasts (animalia); this (stock) is on (in) the demesne.

7 This is one of the holdings in the Layers that cannot be satisfactorily identified.

8 A manor in Wakes Colne.

8 The addition of terre to virgate, as mere surplusage, should be noted.

10 "Moduin"' occurs below (p. 56r) as a former tenant of land here, which is in accordance with his possession of an English name.

11 One of the unidentified holdings there.

I2 i.e. the same assessment. 


\section{THE HOLDERS OF LANDS}

Dereleia [Ardleigh '] was held by Goduin' the priest as a manor and as $I$ hide and 5 acres." M[oduin'] holds (it) now. Then I plough; now none. It was then worth Io shillings; now 30 pence.

\section{THE LAND OF ILBODO ${ }^{3}$}

\section{Hundret of Berdestapla [Barstable]}

WICFORT [Wickford '] was held by 2 free men as 40 acres in King Edward's time, and is now held by Ilbodo similarly. ${ }^{6}$ Then as now (semper) half a plough was there; and (there are) 2 free men. ${ }^{8}$ It is worth 40 pence.

\section{Hundret OF Hidingfort [HinckFord]}

Listuna [Liston '], which was held by a free man as a manor and as half a hide and I virgate, is held by IJbodo. Then as now (semper) 2 ploughs on the demesne, and I plough belonging to the men, and 5 bordars, and 4 serfs, and 30 acres of meadow, and half a mill. Then as now (semper) 5 beasts (animalia) and I rouncey (runcinus), and 43 sheep, and 15 swine. And it is worth 60 shillings. And Ilbodo holds 7 free men, who held half a hide in King Edward's time; then and when he received (them) 2 ploughs (were there); now half (a plough); and 4 bordars (are there); then (this) was worth 20 shillings; now 15 shilings and 6 pence.

fo. 96

Dunilanda [(East) Donyland] was held by 4 free men as $1 \frac{1}{2}$ hides and 8 acres. Now I[lbodo] holds (it). Then (they had) 2 ploughs

1 This entry is not given by Morant under Ardleigh, to which however it clearly belongs. The normal Domesday form of Ardleigh was 'Erleia,' but ' Erlega ' occurs. The initial ' $D$ ' is found also in 'Dorseda,' the Domesday form of Orsett, and at Ardleigh itself on p. 54I above, where a manor of Ranulf brother of Ilger there is entered as 'Derleia.'

- The holding has not been identified.

3 Probably identical with Ilbodus, who held a manor in Oxfordshire as a tenant-in-chief, for the name is a rare one. $\mathrm{He}$ is mentioned under the king's manor of Witham (p. 429 above).

- One of the small estates there entered in Domesday.

b i.c. at the same assessment.

- This appears to be the right rendering.

7 Either the manor of Over Hall or that of Netherhall there. Each of them is assessed in Domesday at $\frac{?}{4}$ hide, and each had 30 acres of meadow and a moiety of the mill, and the same number of ploughs on the land. There had evidently therefore been a partition not long before the Conquest (see p. 552 above). among them; now I plough. (There are) now 3 bordars. (There are) 2 acres of meadow. It was then worth 10 shillings; now 7 .

\section{THE LAND OF H(A)GHEBERN ${ }^{8}$}

\section{HundRet of Berdestapla [Barstable]}

Nezendena [Newenden ${ }^{2}$ ] was held by Tovi', a tree man, as 54 acres in King Edward's time. Then 1 plough; now none. It was then worth 10 shillings; now 3 shillings and 4 pence.

Dunilanda [(East) Donyland] was held by Moduin' ${ }^{10}$ as half a hide and 12 acres. Now Haghebert (sic) holds (it) for as much. ${ }^{11}$ Then as now (semper) 2 bordars (were there). Then I plough; now none. It was then worth 14 shillings; now Io.

RAINEHAM[Rainham ${ }^{18}$ ] was held freely by a priest as half a hide. Now Hag[hebern] holds (it). Then half a plough; now none. It is worth 10 shillings.

\section{THE LAND OF THIERRI (TEDRICI) POINTEL ${ }^{13}$}

Trliberia [Tilbury ${ }^{14}$ ], which was held by a free man as a manor and (as) 45 acres in King Edward's time, is held of Thierri (Tedrico) by Hunald'. Then as now (semper) half a plough and I bordar; and (there are) 4 acres of meadow. (There is) pasture for

$8 \mathrm{He}$ is mentioned under the king's manor of Lawford (p. 435 above) as holding an estate appurtenant to it.

9 Now corruptly 'Nevendon.' This was one of the two manors there.

10 See p. 560, note 10 , above.

II i.e. at the same assessment.

18 One of the smaller manors there.

13 He occurs under several of the king's manors in Essex, having held land at Benflect, Latchingdon and Lawford, and still holding an estate belonging to Witham, and claiming one in Dengie Hundred 'pro escongio.' He was also, doubtless, the 'Pointellus' who held, in that Hundred, under Ralf Bainard at Woodham Walter and 'Curlai' (compare P. 522, note 5, above), and the 'Pointel' who held under the Bishop of Bayeux at Cricksea and at Wheatley in Rayleigh. He will further be met with below in the section 'Invasio Tedrici Puintel,' where further acts of annexation on his part are recorded at Thurrock, Burnham (adjoining Cricksea), Paglesham (opposite Cricksea), Little Stambridge (adjoining Paglesham), etc.

14 The mention of 'pasture for sheep' proves that this was Tilbury on the Thames, not Tilbury by Clare. The identity of this small manor is doubiful. 


\section{A HISTORY OF ESSEX}

50 sheep. It was then worth 7 shillings; now 8.

\section{Hundret of Witbrictesherna [DENGIE]}

F AnbRuge [(North)Fambridge] was held by Godric', a free man, as a manor and as 8 hides in King Edward's time. Now T[hierri] (holds it) in demesne. Then 12 villeins; now 2. ('There are) now Io bordars. Then Io serfs; now 5. Then as now (semper) 2 ploughs on the demesne. Then 4 ploughs belonging to the men ; now 2. (There is) wood(land) for 200 swine. There were here 2 free men who had 50 acres over and above (preter) the aforesaid hides. (There were) then 2 rounceys (runcini), to beasts (animalia), xo swine, (and) 150 sheep; now 2 rounceys, 5 asses, 8 beasts, 20 swine, (and) 200 sheep. It is worth now as then (semper) 7 pounds.

Thierri (Tedricus) holds $\mathrm{I} \frac{1}{2}$ hides, in exchange for Cogheshala [Coggeshall ${ }^{1}$ ], which were held by Tiselin'. 'Then 2 ploughs; now none. Then 3 bordars; now none. (There is) wood(land) for 3 swine, (and) 12 acres of meadow. It was then worth 20 shillings; now IO.

fo. $96 \mathrm{~b}$

\section{HUNDRET OF ROCHEFORT [ROchFord]}

Suttuna [Sutton ${ }^{2}$ ], which was held by a free man as a manor and as 2 hides and 30 acres in King Edward's time, is held by $T$ [hierri] in demesne. Then as now 2 ploughs on the demesne, and 6 serfs. Then I bordar; now 9. (There is) wood(land) for 50 swine, pasture for 100 sheep, and 4 acres of meadow. To this manor there used to belong (jacebant) 3 free men. One (of them) held half a hide, and could depart (abire ${ }^{3}$ ) without the permission (licentia) of the lord of this manor (ipsius mansionis); and another held 30 acres, which are (now) held of $T$ [hierri] by Grimbold, and are worth ro shillings; and the third (held) 30 acres, which are held (of Thierri) by Hunold and are worth ro shillings, ${ }^{4}$ and (these also) could depart. ${ }^{5}$

1 See p. 567 , line 15 , below.

8 Morant made this to be Temple Sutton alias Little Sutton in Prittlewell and Sutton; but I cannot find any evidence for this identification. It will be seen below (p. 566) that Thierri had laid hands on the holdings of freemen adjoining his own estates.

3 This probably means that he could place himself under the protection of another lord.

4 'The words' and are ... shillings' are interlined.

5 The words 'sine licentia domini ipsius mansionis' must be understood here after 'abire.'
$T$ [hierri] received on (in) the demesne 2 rounceys (runcinos) and 7 beasts (animalia), 6 swine, 100 sheep, (and) 6 hives of bees; now (there are) 2 rounceys, 7 beasts, 21 swine, (and) 106 sheep. It was then worth in all (inter totum) 4 pounds; now 7. Of this manor Robert holds of T[hierri] half a hide; and (there are there) 2 bordars, and 2 ploughs, and (this) is worth ro shillings in the above valuation (in eodem pretio). And to this manor there belonged I sokeman who could not withdraw himself (recedere).

\section{THE LAND OF ROGER}

\section{'GOD SAVE THE LADIES' (D[EU]S} SALVET D[OMI]NAS ${ }^{6}$ )

\section{HUNDRET OF Witham}

Ruenhale [Rivenhall '] was held by Ulsi', a free man, as a manor and as 30 acres in King Edward's time. Then as now (semper) I plough. It is worth 20 shillings.

\section{Hundret of Hidingfort [Hinckford]}

Felstede [Felsted] was held by Ulsi' under Earl Elfgar ${ }^{8}$ (Algaro) as a manor and as half a hide and 30 acres. Then as now (semper) 2 ploughs on the demesne, and 3 serfs. (There is) wood(land) for 20 swine, (and) Io acres of meadow. It was then worth 30 shillings; now 40 .

BAduUEN [(Great) Baddow $\left.{ }^{9}\right]$ was held by Ulsi', a free man, as a manor and as $I_{\frac{1}{2}}$ hides. Then I bordar; afterwards and now 3. Then as now (semper) 4 serfs, and 2 ploughs on the demesne. (There is) wood(land) for 40 swine, and 8 acres of meadow. It is worth now as then (semper) 40 shillings.

- It is no doubt only a coincidence that a 'William Godsave, Esq?' was a landowner at Cold Norton when Morant wrote.

7 One of the small estates there.

8 It is to be observed that both Felsted and Great Baddow (see next entry) had been held by Earl Elfgar and were given by the Conqueror to the abbey of the Holy Trinity at Caen. It is expressly mentioned however in Domesday (see p. 453 above) that King William had given ' 3 virgates' out of Felsted to this Roger. Thirty 'acres' went to the 'virgate,' and four 'virgates' to the 'hide,' so that these ' 3 virgates' are the ' half a hide and 30 acres' of the text.

9 This entry was omitted, under the Baddows, by Morant. 


\section{THE HOLDERS OF LANDS}

LXXIII. THE LAND OF GILBERT SON OF SALOMON ${ }^{1}$ 6. 97

HUNDRET OF HidingFort [HINCKFoRd]

In Felesteda [Felsted] a free man held 30 acres, ${ }^{2}$ which are (now) held by G[ilbert]. Then as now (semper) I plough. It is worth 20 shillings.

\section{LXXIIII. THE LAND OF WILLIAM SON OF CONSTANTINE ${ }^{3}$}

TaIndena [Theydon 4] was held by Suen' as a manor and as 2 hides and 40 acres in King Edward's time. Now W[illiam] holds it similarly. ${ }^{5}$ Then 5 villeins; afterwards and now 4. Then and afterwards 7 bordars; now 10. Then 4 serfs; now none. Then as now (semper) 2 ploughs on the demesne. Then(there were) 4 ploughs among the men; afterwards and now 3. (There is) wood(land) for 500 swine, 20 acres of meadow, (and) now as then (semper) I mill. Then and afterwards it was worth 60 shillings; now 100.

\section{THE LAND OF ANSGER THE COOK}

Alvilea [Aveley ${ }^{8}$ ] was held freely (libera) by Godeman as 50 acres. Then as now (remper) half a plough was there. In STIFoRt [Stifford] a free man held 25 acres; and what with (inter) this land and the aforesaid there is now as then half a plough. " And it is worth 10 shillings.

\section{THE LAND OF ROBERT SON OF ROSCELIN ${ }^{8}$}

\section{HUNDRET OF UdelesFort [UtTlesford]}

Haidena [Heydon] was held by Alwin',

$1 \mathrm{He}$ also held land as a tenant-in-chief at Meppershall, on the borders of Bedfordshire and Herts, and at Felmersham, Beds.

2 It is mentioned (p. 453 above) that the king had given Gilbert a 'virgate' at Felsted, but the whole manor is there represented as having been held by Earl Elfgar.

- He also held in chief a very small estate in Bucks.

4 Although this appears to have been a goodsized manor, it has not been identified in the Theydons. Morant seems to have overlooked the entry.

6 i.e. at the same assessment.

- One of the small estates there.

7 This is somewhat obscure, but the two holdings probably adjoined, and were farmed together.

$8 \mathrm{He}$ also held in chief a manor at Stepney, Midd., and was an under-tenant of Count Eustace in Herts and Beds. a free $\operatorname{man},{ }^{9}$ as a manor and as 5 hides and 15 acres in King Edward's time. Then as now (semper) I 8 villeins. Then 3 bordars; afterwards and now 7. Then as now (semper) 5 serfs, and 3 ploughs on the demesne, and 8 ploughs belonging to the men. And (there are) 8 acres of meadow, (with) wood(land) for 8 swine. (There were) 2 rounceys (runcini), 206 sheep, 40 swine, (and) 13 hives of bees; now I rouncey, 206 sheep, 20 swine, (and) Io hives of bees. Then and afterwards it was worth 10 pounds; now 12. And a certain Englishman, Goduin' by name, holds now as then (semper) I 2 acres; I bordar (is there) now as then (semper); and Lewin' similarly (holds) 5 acres; and (this) is worth 12 pence.

\section{THE LAND OF RALF PINEL}

\section{Hundret of Tendringa [Tendrino]}

Brumbeleia [(Great) Bromley] and WestNANETUNA [ ${ }^{10}$ ] were held by Brictmar ${ }^{11}$ as a manor and as $4 \frac{1}{2}$ hides; and there were 2 halls (balla). Now R[alf] holds (it). Then as now (semper) 5 villeins. Then and afterwards 25 bordars; now 23. Then 6 fo. $9 \mathrm{~b}$

serfs; now 9. Then 3 ploughs on the demesne; now 2. Then and afterwards ro ploughs belonging to the men; now 6 . (There is) wood(land) for 600 swine, (and) 16 acres of meadow. It is worth now as then (semper) 7 pounds. $^{18} \mathrm{R}$ [alf] did service for this land to (bane terram deservivit erga) $\mathrm{G}$ [eoffrey] de 'Magnavilla' because G[eoffrey] himself told him that the king had given the service of that land to himself; but on two occasions he paid of his own money (dedit de suo censu) to the king's officers (ministris), when the king sent his envoys to this land. ${ }^{13}$

9 'This was probably the 'Alwin' Stichehare' who had been his predecessor at Stepney.

10 This appears to be a lost name.

11 See Introduction, p. 352.

12 Yet the total number of ploughs had decreased from 13 to 8 .

is 'misit legatos suos in hanc terram.' The phrase is an important but obscure one. The word legati is used in Domesday for officers sent by the king, such as the Domesday Commissioners themselves. Under Alresford (p. 460 above) it is used for the envoy of a private landowner. The statement as to Geoffrey de Mandeville should be compared with that which is found under a manor in Suffolk (fo. 437) that Ralf Pinel had received it of the king's gift, but had done service for it (ex ea servivit) to Geoffrey de Magnavilla. 


\section{A HISTORY OF ESSEX}

LXXVIII. THE LAND OF ROBERT SON OF GOBERT

Belrsteda [Belstead (Hall) ${ }^{1}$ ] was held by 3 free men as a manor and as $I \frac{1}{2}$ hides and 40 acres. Then as now (semper) 3 bordars, and $I$ serf and 2 ploughs on the demesne. (There is) wood(land) for Io swine, (and) I 5 acres of meadow. It was then worth 30 shillings; now 50.

\section{THE LAND OF RAINALD} THE CROSSBOWMAN (BALISTARII)

Phenbruge [(South) Fambridge ${ }^{2}$ ] is held by $R$ [ainald] of the king $^{3}$ as a manor and as $3 \frac{1}{2}$ hides. Then as now (semper) I villein, and 7 bordars, and 2 ploughs on the demesne, and 2 ploughs belonging to the men. (There is) pasture for 100 sheep. It is worth now as then (semper) 100 shillings, but the monks of Ely claim it and the Hundret (court) bears witness in their favour (eis testatur ${ }^{4}$ ). And (Rainald) seized (saisivit) half a hide adjoining (juxta) that land after the coming of King William, and it (que) is worth 30 shillings a year.

\section{THE LAND OF GONDUIN ${ }^{3}$}

Hundret of Turestapla [Thurstable]

Toleshunta [Tolleshunt ${ }^{6}$ ] was held by Alric' as a manor and as I hide. Now G[onduin] holds (it). Then as now (semper) 2 bordars. Then 4 serfs; now 5. Then I plough; now half a plough. It was then worth 30 shillings; and when received it was worth 20 shillings. It is now worth 10 shillings.

\section{THE LAND OF OTTO ${ }^{7}$ THE GOLDSMITH}

\section{HundRet OF HidingFort [HinckFord]} fo. 98

GLESTINGETHORP [Gestingthorp ${ }^{8}$ ] was held

1 A manor in Broomfield. Morant seems to have overlooked this entry, for he only gives that which relates to the Warenne portion of Belstead.

8 In Rochford Hundred.

3 This expression is used to show that he did not hold it of the monks of Ely, who claimed that it belonged to them.

4 The interesting pre-Domesday plea printed in Inquisitio comitatus Cantabrigiensis (p. 193) contains the relative passage:- In comitatu Easexie tenet Reinaldus milis (sic) in villa que dicitur Fenbricge vi hidas et dimidiam' (belonging to Ely).

s 'Gondwinus camerarius' held in chief one manor in Suffolk.

6 An unidentified manor in the Tolleshunts.

7 See Introduction (p. 351). From his descendants Belchamp Otton derives its name.

8 i.e. the manor of Overhall there. by Earl Ælfgar (Algarus) as half a hide. Now Otto holds (it) similarly. ${ }^{9}$ Then as now (semper) 3 ploughs on the demesne, and 3 ploughs belonging to the men. Then 13 bordars; now 16. Then as now (semper) 6 serfs. (There is) wood(land) for 60 swine, (and) 25 acres of meadow. There are 80 sheep, 32 beasts (animalia), 88 swine and 3 rounceys (runcini). And there were I2 sokemen in King Edward's time-there are now I I-dwelling on (in) this manor; and they hold half a hide and 30 acres; then as now (semper) 4 bordars (were there), and I plough, and I serf. It was then worth 10 pounds; now 12 ; and when the king gave (it him), 15.

\section{THE LAND OF GILBERT THE PRIEST}

\section{HUNDRET OF HidincFort [HincKFord]}

Mirdentuna [Middleton ${ }^{10}$ ] was held by 9 sokemen of Earl Elfgar (Algari) as $\mathbf{I} \frac{1}{2}$ hides and 28 acres. Then as now (semper) $\mathbf{I} \frac{1}{2}$ ploughs on the demesne. (There are) $4 \frac{1}{2}$ acres of meadow. It is worth 20 shillings. He claims this land (as) of the Queen's gift. ${ }^{11}$

\section{THE LAND OF GRIM THE REEVE (PREPOSITI) ${ }^{12}$}

\section{Hundret of Berdestapla [Barstable]}

In BURA [Bowers (Gifford)] Grim has 2 hides, on (in) which was I plough, with (et) 2 serfs, in King Edward's time; but now there are 2 ploughs on the demesne, and half a plough belonging to the men, 3 villeins, 6 bordars, and 3 serfs. (There is) pasture for I 00 sheep, and half a hide and Io acres of wood(land) laid waste (vastate silve). ${ }^{13}$ And of these 2 hides one is that of (est de) men forfeited to (erga) the king, which G[rim] added to his other land after the coming of King William by means of (per) Robert Fitz Wimarc the sheriff, as G[rim] says, and all this was worth 40 shillings in King Edward's time; now 50.

In Celdewella [Chadwell] Godman, a free man, held 20 acres, and made forfeit (forisfact $[u s])$, and could not pay his fine (emendare).

i.e. at the same assessment (a strangely low one).

10 Part thereof.

11 See Introduction, p. 337.

$12 \mathrm{He}$ is mentioned, under the king's land, as holding 10 acres in Rochford Hundret.

13 See Introduction, pp. 376-7. This woodland clause is interlined. 


\section{THE HOLDERS OF LANDS}

But Grim gave the king 30 shillings in his place (pro eo), and holds the land by permission (licentiam) of Hubert de Port (portu) ${ }^{2}$, and it is worth 20 pence.

\section{LXXXIIII. THE LAND OF ULVEVA WIFE OF PHIN?}

\section{Hundret of Berdestapla [Barstable]}

In Picesera [Pitsea ${ }^{3}$ ] there were in King Edward's time 3 hides, which are held by Ulveva. Then 2 ploughs on the demesne, fo. gob

and I villein with (de) half a plough, and 4 serfs, and I mill. (There is) pasture for 60 sheep, (and) half a hide of wood(land)." Now (there are) 2 ploughs on the demesne, 3 bordars, and 5 serfs. It is worth 60 shillings. To these (3) hides there are now added 3 other hides with (et) 30 acres of wood(land), on (in) which dwell 8 free mes with 2 ploughs; there is pasture for 130 sheep. In all (inter totum) it is worth 60 shillings ; and these three hides remain in the king's hands (remanent regi).

\section{HUNDRET OF WITBRICTESHERNa [DINGIE]}

Lacenduna [Latchingdon ${ }^{8}$ ] was held by Phin, a free man, as a manor and as 5 hides and 15 acres in King Edward's time. Now

1 He held Mapledurwell, Hants, in chief, and is found in the eastern counties acting as an officer of the Crown (see p. 518, note 9). The mention of the Englishman who had lost his land through not being able to pay the fine he had incurred for an offence is of much interest.

- See Introduction (p. 348).

- This is satisfactorily identified as the manor which afterwards belonged to St. John's, Colchester, by the number of its hides. The cartulary of St. John's contains 2 charter explaining how it passed to Eudo, the founder of St. John's.

- The pasture and woodland (see p. 376) are here inserted out of place in the entry.

- The clause is somewhat obscure, but this valuation probably refers to the second ' 3 hides.'

6 The identity of this manor is obscure, and the obscurity is increased by Morant's confusion. He makes it to be Tiled Hall in Latchingdon, which, on his own showing, paid castle-guard rent to Dover, a proof that Montfort had held it. And the same proof applies to what he termed 'the king's manor' of Latchingdon (i. 353). Yet he assigned Montfort's Domesday manor of 'Lachentuna' to what he termed 'Lachendon Barnes' in Purleigh (i. 348), though it was not held of Montfort's Honour. Domesday's manors at Latchingdon are Ulveva's ( 5 h. O v. 15 a.), Hugh de Montfort's (3 h. 2 v. 20 2), Christchurch, Canterbury (2 h. 6 v. 6 a.), and the king's, which seems to have been under 2 hides.
U[lveva] holds (it). Then 6 villeins; now 3 bordars. Then 4 serfs; now 5. Then as now (semper) 3 ploughs on the demesne, 7 rounceys (runcini), 13 beasts (animalia), $3^{1}$ swine, (and) 245 sheep. It is worth now as then (semper) 4 pounds.

LXXXV. In the Hundret of CEFFEURDA [Chafford] Edward son of Suan held half a hide. $^{7}$ Now Edeva (who was) his wife holds it. $^{8}$ Then I plough; now half (a plough). (There is) pasture for 30 sheep. It is worth 10 shillings.

\section{THE LAND OF TURCHIL THE REEVE (PREPOSITI)}

\section{Hundret of Celmeresfort [Chelmstord]}

In WALFARAM ${ }^{\circ}$ [Walkfares $^{10}$ ] T[urchil] holds I hide less ro acres. Then as now (semper) 3 bordars, and I serf, and I plough on the demesne. Then half a plough among the men. ${ }^{11}$ (There is) wood(land) for 40 swine, (and) 6 acres of meadow. It was then worth 20 shillings; now 30 .

And a certain servant (famulus) of the king holds 8 acres, and (this) is worth 2 shillings.

LXXXVII. ${ }^{12}$ And a certain free man, Stanard' by name, held and holds of the king 30 acres, and they bclong to W ITHERESFELDA [Wethersfield $\left.{ }^{13}\right]$. Then as now (semper) 3 bordars. Then I plough; now half (a plough). (There is) wood(land) for 8 swine, 7 acres of meadow, and now as then (semper) 1 mill. It is worth 8 shillings.

LXXXVIII. And Goduin the deacon held and holds 9 acres, and (this) is worth 16 pence.

7 This entry occurs in the form shown in the text. The scribe must have taken it straight from the roll of the Hundred.

8 Sce Introduction, p. 355.

9 The final $\mathrm{m}$ is indicated by the usual abbreviation, but the scribe probably inserted it, from habit, in error after 'In.'

10 A manor in Boreham.

11 Presumably there was none at the time of the survey.

18 All these entries follow consecutively, without a break, from the land of Turchil the reeve to the bottom of the folio; but numerals are placed against those which relate to Stanard and to Godwine, and their names are rubricated.

13 There seems to be no allusion to this holding in the entry of the royal manor of Wethersfield on p. 431 above. 


\section{A HISTORY OF ESSEX}

And 1 man of William son of Grossa ${ }^{1}$ (grossee) holds two acres of the king's soke and pays the king's dues.

fo. $99^{\prime \prime}$

\section{LXXXVIIII. FREE MEN OF THE KING}

In the Hundret of Laxendena [Lexden] the king has 7 free men, and the reeve (prepositus) of the hundred has (charge of) them ; they hold half a hide, and are worth 8 shillings. And I free man held $3 \frac{1}{2}$ acres, and on (in) these is pasture for 100 sheep, and (arable) land for 2 oxen $^{3}$; it was then worth Io shillings; and when Robert de Montbegon ${ }^{4}$ (monte begonis) seized (invasit) it, it was worth Io shillings; now nothing.

And I free man held 13 acres. Now as then (semper) I plough is there, and (there is) wood(land) for 20 swine, (and) I acre of meadow. It was then worth io shillings; now it renders 20 shillings; and Richard, a man of Hamo, ${ }^{5}$ seized (invasit) this land and has its profits (spolia $\left.{ }^{6}\right)$ up to now (bucusque).

\section{ENCROACHMENTS ON THE KING $^{7}$ IN ESSEX (EXSESSA)}

In Horninduna [Horndon (-on-the-hill ${ }^{8}$ )] Goduin Gudhen has seized 2 'mansiones' belonging to (quee sunt de) the land which Hugh de St. Quintin holds of the king, ${ }^{9}$ and he has given pledge for this (inde dedit vadem). ${ }^{10}$ There also (in eadem villa) Goduin' has seized (invasit) 3 virgates of land, to the

1 He was an under-tenant in Witham Hundred (see pp. $429,45^{1}, 497$ above).

2 The handwriting changes sharply here and becomes smaller and neater.

3 i.e. a quarter of a plough-team. This is a good instance of a holding being assessed at an obviously nominal figure ( $3 \frac{1}{2}$ acres).

4 This entry is of great interest, because the name of Montbegon is wholly omitted in Ellis's Indexes to Domesday, and Dugdale could only begin his account of this feudal house with an entry on the roll of ' 5 Stephen' (i.e. 1130 ).

5 A ' Richard' held of Hamo dapifer at 'Totham and at Ovesey in Dengie Hundred (see p. 503 above).

6 This word is worth noting. It answers to the later 'esplees' of the proprietary action.

7 'Invasiones super Regem.' The phrase is a difficult one to render; it heads a record of those cases in which lands or rights belonging to the king have been encroached upon by his subjects.

8 See Introduction, p. 398.

9 See p. 557 above.

10 i.e. has given security that he will appear and defend his occupation when the case is heard (see Introduction, P. 412). king's wrong (super Regem), ${ }^{11}$ of the land of a certain free man, which land remains (remanet) to the king by judgment of the Hundret (court), and in this case also (iterum) he has given pledge (dedit vadem). ${ }^{10}$ In Dantuna [Dunton ${ }^{18}$ ] (are) I 5 acres which were held by Wulfwine (Ulwinus) and remain to the king undisputed (quiete).

\section{Encroachment (Invasio) of Thierri Puintel ${ }^{13}$}

In Thurruca [Thurrock ${ }^{14}$ ], which was held, in King Edward's time, by I I free men, (were) $I \frac{1}{2}$ hides and 42 acres; and (the same) now. Then 3 ploughs on the demesne; now 2. (There is) pasture for 30 sheep. It was then worth 41 shillings; now 20 . And T[hierri] Pointel seized this land; and it is in the king's hand(s).

fo. $99 \mathrm{~b}$

\section{HUNDRET OF WRNSISTREU [WINSTRER]}

LEGRA [Layer ${ }^{15}$ ] was held by Ulvric, a free man, as a manor and as 2 hides in King Edward's time, and this was seized by the same $T$ [hierri]. Then 2 ploughs; now none; nor (were there) when he received it (recepit). Now (there are) 2 bordars. Then (there was) wood(land) for 40 swine; now for 30 . It was then worth 60 shillings; and when received (recepit) 40; now 20. And in Burnham ${ }^{16}$ T[hierri] seized $15 \frac{1}{2}$ acres, and yet they were in the king's hands before these pleas were heard (bac placita fierent ${ }^{17}$ ).

\section{HUNDRET OF ROCHEFORT [ROCHFORD]}

Stanbruge [(Little) Stambridge ${ }^{18}$ ], which was held by a free man as a manor and as $1 \frac{1}{2}$

11 See note 7 , and compare p. 448 above.

12 Adjoins Horndon-on-the-hill.

13 See p. 561, note 13 , above.

14 It has not been ascertained in which of the Thurrocks this estate lay.

15 It is not known in which of the Layers this holding was situated.

18 Burnham was far away in Dengie Hundred.

17 This passage is of great importance as proving that actual pleas were heard in connection with Domesday (see Introduction, p. 41 I ).

18 This can be satisfactorily proved to have been the manor of Little Stambridge. Great Stambridge was held by Suain of Essex, and descended accordingly as part of the Honour of Rayleigh. Little Stambridge consisted, from the Conquest, of two distinct manors, which Morant confused by treating them as one, namely 'the manor of Little Stambridge Hall' (i. 320). The chief manor, with the advowson, was that of Thierri Pointel (as above), and is found in the 


\section{THE HOLDERS OF LANDS}

hides and 20 acres in King Edward's time, was seized by $\mathrm{T}$ [hierri]. And this manor is held of Thierri] by 3 knights. Then 3 villeins; now 2. Then I serf; now none. Then 2 bordars; now 5. Then as now (semper) I plough on the demesne. Then 2 ploughs belonging to the men; now I. It was then worth 40 shillings; now 100.

Pachesham [Paglesham], which was held by 2 free men as half a hide and 15 acres, was seized (invasit) by $\mathrm{T}$ [hierri]. Then as now (semper) I plough. It is worth 20 shillings. And Robert holds (it) of him.' $T$ [hierri] has held these 2 manors in (pro) exchange for (de) Cogheshala [Coggeshall]; and now they are in the king's hand(s). And in MIDEBROC [ 20 acres; I villein (is there) now as then (semper); and it is worth 4 shillings; and the soke belongs to the church of the $\mathrm{Holy}$ Trinity of 'Cantorbury,' as the Hundret (court) testifies; T[hierri] Pointel has held this also in exchange (pro escangio); and it is in the king's hand(s).

\section{Encroachment (Invasio) of Ranulf Peverel (PIPERElli)}

In Terlinga [Terling "] R[anulf] has seized (invasit) 5 free men who held (tenentes) 3 hides less 15 acres in King Edward's time. Of this manor Roger holds of R[anulf] 2 hides and 80 acres, and Ranulf 30 acres." Then $3 \frac{1}{2}$ ploughs; now 6 . Then 2 villeins; now 5. (There are) now 5 bordars. (There is) wood(land) for 20 swine, (and) 22 acres of meadow. It was then worth 75 shillings; now 4 pounds and 15 shillings. And in

thirteenth and fourteenth centuries to be held of FitzJohn and of his heir De Burgh, Earl of Ulster, as of the manor of North Fambridge, which was Thierri Pointel's in 1086. The smaller manor in Little Stambridge passed from Ralf Bainard (p. 437 above) to his successors the Fitz Walters.

1 This last sentence is interlined/It should apparently be inserted here.

2 This small holding has not been identified; but it was probably in the neighbourhood of Thierri's manor of Little Stambridge, as Christchurch ('Holy Trinity'), Canterbury, of which Ralf Bainard held the other manor in Little Stambridge, had the 'soke' of it.

a The manor of Terling was held by Ranulf in 1086, and adjoined his great manor of Hatfield (Peverel). Hence these encroachments.

4 The total of these two holdings would be 3 hides less 10 acres, which does not quite correspond with that given just before. There is doubtless a scribal error.
WidrTUNA [Widdington ${ }^{5}$ ] R [anulf] has seized 30 acres, which he holds in demesne; and they are worth 5 shillings. And in StanesGATA [Stangate ${ }^{\text {B }}$ ] $R$ [anulf] has seized I hide and 30 acres, which Ralf Fitz Brien ${ }^{7}$ holds of him, (and) which 2 free men held in King Edward's time. Then as now (semper) 2 bordars and I plough (were there); there is pasture for 20 sheep; it was then worth 15 shillings; now $10 .^{8}$ And in Henies [(Great) Henny] (are) $20 \frac{1}{2}$ acres which were held by 12 free men in King Edward's time; now Turold holds (them of Ranulf ${ }^{8}$ ); and they are worth 3 shillings. And in LAMERS [Lammarsh ${ }^{10}$ ] are 2 acres of free (libera) land; and they are worth 4 pence.

fo. 100

\section{Encroachment (Invasio) of Hugh de MONTFORT IN ESSEX (EXsESSA)}

Hugh de Montfort has seized (invasit) I free man to the wrong of (super) the king, and William son of Grossa ${ }^{11}$ (grossa) 10 free men, who, between them all (hii omnes), held 3 hides and 9 acres in King Edward's time. There were then there (in quibus) $8 \frac{1}{2}$ ploughs; now $7 \frac{1}{2}$. Then as now (semper) 13 bordars and 5 serfs. Then 2 mills; now I. (There is) wood(land) for 157 swine, (and) 30 acres of meadow. It is worth now as then (semper) 6 pounds and 2 shillings. And he has further (adbuc) seized (invasit) 4 free men with $(d e) 2$ hides and 20 acres, which are worth 30 shillings; and there were there then $2 \frac{1}{2}$ ploughs; now none. And in the Hund[ret] of Laxendena [Lexden] he has seized 3 free men holding 1 hide and 30 acres where (in quibus) there were 3 ploughs, (and are) now $2 \frac{1}{2}$; then I bordar; now 6 ; (there is) wood(land) for 100 swine, (and) 12 acres of meadow; it was then worth 30 shillings; now 50 ; and one of these three (free men) belongs to (jacet ad) the fee of St. Peter of Westminster

- In Uttlesford Hundred.

- In Dengie Hundred (in Steeple).

7 See p. 530, note 8, above.

8 Here, as at Terling, Ranulf held the manor, and had unlawfully annexed to it the holdings of these free men.

- Turold held the chief manor there of Ranulf (p. 529 above), so that the observation in the preceding note applies here also.

10 Lammarsh also was held of Ranulf by Turold, and it descended with Great Henny.

$11 \mathrm{He}$ held the important manor of Felix Hall in Kelvedon under Hugh (p. 497 above), so that this encroachment was probably in or near Kelvedon. Morant thought it was the manor of Easterford $\mathrm{Hall}$, but this was only conjecture. 


\section{A HISTORY OF ESSEX}

at (ad) Feering (feringas); ${ }^{1}$ and this is the testimony of the Hundret (court); but (the estate) was delivered to Hugh among (in numero) his manors, as his men assert (dicunt). And in Botrngham [Botingham (Hall) ${ }^{2}$ ] (are) 15 acres of land, which were held by a free man in King Edward's time, and are now held (of Hugh) by William son of Grossa (grossee), and are worth 32 pence.

In the Hundret of Ceffeorda [Chafford] is I free man with (de) 40 acres, who belonged to Havering (havelingas) in King Edward's time, (and) whom St. Peter of Westminster has now, because he came (venit) to the abbey of his own accord, ${ }^{3}$ and he does not render (his) customary due (consuetudinem) to Havering (bavelingas).

\section{Encroachment (InVAsio) of G[EOFFrey] DE 'MAGNa Villa'}

Masceberia [Mashbury ${ }^{4}$ ] was held by Alveva, a free woman, in King Edward's time, (and) now Ulvric holds it (quam) of the king's gift. And G[eoffrey] seized (it) to the wrong of (super) the king. In this (qua) land there is I hide; and now as then (semper) I plough, and I serf; and (there are) 8 acres of meadow. It was then worth 20 shillings; now 30. And in Canefelda [Canfield] are 8 acres of land which Geoffrey seized to the wrong of (invasit super) the king, and which Richard holds of him. ${ }^{6}$

\section{Wigghepet [Wiggepet ${ }^{6}$ ] was held by Boso,}

1 See p. 444 above.

2 A manor in Copford.

3 This is an interesting phrase which appears to denote commendation. On p. 445 above is mention of another free man in this Hundred who 'misit in Sancto Petro dimidiam hidam.' Possibly both cases were those of men seeking the abbey's protection for their lands.

4 Geoffrey held the rest of Mashbury.

5 Geoffrey had a manor of his own at Canfield, which was held of him by this Richard, and which may have been, as Morant held, Langthorns in Little Canfield.

6 A manor in Arkesden, which extended into Elmdon and Wendon, as Morant observed, and which is now represented, as I have shown, by Rockell's and New Rockell's farms (see Introduction, p. 391, and Essex Arch. Trans. [n.s.] viii. 376). Its identity is proved by charters in the [Saffron] Walden cartulary. On fo. 147 Robert (son of Robert) de la Rokele quitclaims, in 1302 , to the abbot of Walden his obligation to provide 3 masses a week ' in capella mea de Wyggefosse,' and on fo. 145 d Humfrey de Rokella grants the tithe of a mill saving the multure 'domus mec a free man, as a manor and as $2 \frac{1}{2}$ hides in King Edward's time. Then and afterwards 2 ploughs on the demesne; now $1 \frac{1}{2}$. Then 4 ploughs belonging to the men; afterwards and now 6 . Then and afterwards 7 villeins; now 8. Then 5 serfs; afterwards and now 7. (There is) woodland for 30 swine, (and) 24 acres of meadow. ${ }^{7}$ (There is) I mill now as then (semper). Then and afterwards it was worth 100 shillings; now 6 pounds.

fo. roob

WICGEPET [Wiggepet ${ }^{8}$ ] was held by I free man as a manor and as 3 hides in King Edward's time. Then and afterwards 2 ploughs on the demesne; now $1 \frac{1}{2}$. (There is) now I plough belonging to the men, and 1 villein. Then as now (semper) 5 bordars. Then 1 serf; now none. It is worth now as then 40 shillings. And in WendenA [Wendon ${ }^{9}$ ] a free man held (ten') $6 \frac{1}{2}$ acres, and (this) is worth 2 shillings. In PherneHAM [Farnham ${ }^{10}$ ] 4 free men held 3 hides and 3 virgates in King Edward's time; and now they are held of G [eoffrey] by 4 knights; then and afterwards 8 ploughs (were there); now 5 ; then and afterwards 6 villeins; now 3 ; then and afterwards 4 bordars; now I 5 ; then and afterwards 7 serfs; now 3 ; then and afterwards (there was) wood(land) for 60 swine; now for 50 ; there are 14 acres of meadow ; it is worth now as then (semper) 6 pounds. In Stanburna [Stamhourne ${ }^{11}$ ] a free man held half a hide in King Edward's time; then and afterwards 2 ploughs (were there) on the demesne; now none; then as now (semper) half a plough belonging to the men, and 3 bordars, and I serf; there are 12 acres of meadow; then and afterwards it was worth 40 shillings; now 50. In WesuUnic [ 12 ] in King Edward's

proprix de Wyggefosse,' in 1210. 'The 'fosse,' of course, is 'pet' Frenchified. The name survived at least as late as the seventeenth century.

7 This large proportion of meadow points to the manor lying on 'The Wicken Water,' which runs through Arkesden.

8 See note 6 above.

9 This small holding in the Wendons cannot be identified.

10 i.e. the manor of Earls-bury there, so named from Geoffrey's descendants, the earls of Essex, who held it.

11 i.e. as Morant showed, the manor of Moone Hall there, which was held of Geoffrey's heirs. Stambourne is in Hinckford Hundred, a good distance to the west of the manors among which it is here entered.

12 As these encroachments usually adjoined the manors of those who made them, I am disposed to think that this place was the 'Wenesuuic' in 


\section{THE HOLDERS OF LANDS}

time, (were) 6 free men with (de) I hide and 46 acres; then I plough was there; now none; then and afterwards (it was worth) I 5 shillings; now 10.

In Archesdana [Arkesden] Goduin' sech held I hide less 8 acres. It is now in the king's hand(s). Then I bordar, and I plough; now nothing. (There are) 2 acres of meadow. It was then worth 20 shillings; now ro. And this land was held by G[eoffrey] de 'Magna villa.' And 15 acres were held by Ulmar', as belonging to (ad) the fief of Ansgar, under G[eoffrey], and the county (court) does not testify (in his favour).

Hugh de Berners (berneriis) held 37 acres of the king, which he denied, and afterwards it was proved to be the king's (fuit derationata ad opus regis), and he has given pledge (dedit vadem ${ }^{2}$ ). Then as now (semper) I plough on the demesne, and I bordar. (There is) wood(land) for 40 swine, (and) 4 acres of meadow. It was then worth 10 shillings; now 20.

I1 Plesinchou [Plesingho ${ }^{3}$ ] a free man held I hide of land, which Humfrey Orescuil (aurci testicull) has seized to the wrong of (invasit super) the king. Then as now (semper) I plough on the demesne, and 7 bordars, and 2 serfs. (There is) wood(land) for 30 swine, (and) 7 acres of meadow. (There was) then 1 mill. It was then worth 16 shillings; now 23.

In Wigheberga [(Little) Wigborough ${ }^{\text {s }}$ ] Hamo 'dapifer' has added (to his estate) 2 sokemen of the king, with (de) 30 acres and worth 4 shillings, whom he has seized to the wrong of (invasit super) the king; and in Careseia [ ${ }^{6}$ ] 8 acres, worth 8 pence ; and in Stanburna [Stambourne ${ }^{8}$ ] 40 acres, which were held by Alestan, a free man, and 12 free men in King Edward's time, and they have (it) still, (and) then as now (semper) 2

Dengie Hundred, where Geoffrey had a considerable manor (p. 513 above). There is there entered, at the end of the survey of that manor, an almost identical holding of 6 free men who had 1 hide and 40 acres.

1 See p. 566, note 10, above.

- In Willingale (see p. $46_{3}$, note 2 , above).

3 Of which the manor was held by Hamo.

- This aggression has nothing to do with Geoffrey de Mandeville.

- An unidentified manor in Dengie Hundred.

- Hamo had manors at 'Carseia' (in Dengie Hundred) and at Stamboume. ploughs (werc there) and 3 bordars, and it is worth 40 shillings.?

In the Hundret of Odelesfort [Uttlesford] W [illiam] Cardun ${ }^{8}$ has taken possession of (occupavit) I sokeman with (de) 8 acres, and it belongs to (jacet ad) Cishelle [(Great) Chishall] of the fief of Geoffrey de Magna villa, and is worth 2 shillings.

fo. 102

\section{Half Hundret of Clavelinga [Clavering]}

\section{Encroachment of Suain (Suani) ${ }^{9}$}

Bolituna [Bollington ${ }^{10}$ ] and Bertuna 11] were held of Harold by Goduin', a free man, as a manor and as $4 \frac{1}{2}$ hides in King Edward's time. Now Alvred holds it of him (e0). ${ }^{12}$ Then as now (semper) 2 ploughs on the demesne, and 5 ploughs belonging to the men, and 7 villeins and 13 bordars, and 5 serfs. (There is) wood(land) for 20 swine, (and) 2 acres of meadow. Then and afterwards it was worth 4 pounds; now 6. Robert Fitz Wimarc seized (invasit) this land in King William's time, and it is still held by (his son) Suain (Suenus).

In Magghedana [Manuden] Aubrey (Albericus) de Ver seized (invasit) I t hides and 15 acres, which were held by 3 free men in King Edward's time. Then 5 ploughs; afterwards and now 4 . Then as now (semper) 6 villeins, and 6 bordars, and 3 serfs. (There is) wood(land) for 30 swine, (and) 9 acres of meadow. Then and afterwards it was worth 60 shillings; now 4 pounds. And in Smaltuna [ ] (are) I 5 acres of land, which were held by a free man in King Edward's time; then I plough (were there); afterwards half (a plough); now none; and it is worth 3 shillings.

In Mappesteda [(Little) Maplestead ${ }^{13}$ ] and

7 The words ' 40 acres . . 40 shillings' are interlined, and their construction is somewhat doubtful.

8 Geoffrey de Mandeville's tenant at Great Chishall (see p. 5 I 2 above).

- This heading refers only to the entry which immediately follows it.

10 A manor in Ugley, part of which was held by Robert Gernon.

11 If this was a local name, it appears to be now lost, being probably merged in Bollington.

13 Suain (?)

13 In Hinckford Hundred. 


\section{A HISTORY OF ESSEX}

in Pebeners [Pebmarsh ${ }^{1}$ ] the wife of Aubrey (alberici) de Ver seized (invasit) 5 free men with (de) I $\frac{1}{4}$ acres, ${ }^{2}$ which (quod) 'Tidbald' held (tenuit) under her, and (this) is worth 3 shillings.

Ralf Baignard seized (invasit) in HENHAM 4 half a hide and 10 acres, which were held by 2 free men in King Edward's time. 'Then as now (semper) I plough. It is worth 12 shillings. And in Celvestuna [ (are) 1 hide and 43 acres, which were held by 6 free men in King Edward's time; then and afterwards 4 ploughs (were there); now 3 ; (there are) 15 acres of meadow; it is worth 40 shillings.

In Bolintuna [Bollington ${ }^{8}$ ] i free man held 20 acres in King Edward's time, and holds (them) still, but has concealed (the fact), ? and therefore he has given pledge (dedit vadem). ${ }^{8}$ And it is worth $3^{\circ}$ shillings.

In Pherneham [Farnham] a free man held 30 acres. Now Ralf Latimer (Latimarius ${ }^{10}$ ) holds (them), but has concealed (the fact), ${ }^{11}$ and, therefore, he has given pledge (dedit vadem). ${ }^{12}$ And it is worth 10 shillings.

\section{In Liffildewella [ 13 ] I free man} held (and) holds still (tenet semper) 30 acres, and it is worth 6 shillings and 8 pence.

1 The mention of Pebmarsh enables us to say that 'Mappesteda' must be Little Maplestead, which adjoins Pebmarsh. Morant overlooked the entry under both these parishes. He suggested however that 'Nepsteda' (p. 457 above) might be in one of the Maplesteads (ii. 282), and, as it was held by the wife of Aubrey (de Vere), the entry in the text enables us to say that it was identical with 'Mappesteda,' i.e. Little Maplestead.

' 'I acra et quarta parte alterius.' The assessment is strangely low.

3 The words ' 5 free men ... 3 shillings' are interlined.

4 He held the manor of Henham Hall.

b See p. 479, note 5, above.

6 A manor in Ugley.

7 Perhaps this means that he had not sought recognition of his title from King William. Clearly his small holding had in some way escaped detection.

8 See Introduction, p. 412.

9 'iii.' is written above ' $x$.,' apparently as a correction.

10 The word means an interpreter.

11 See note 7 above.

12 See Introduction, p. 412.

12. This place has not been identified.

\section{Encroachment of 'Turold 14}

In Hanies [Henny] 4 free men held 18 acres in King Edward's time and hold still. ('They had) then as now (semper) half a plough between them. And it is worth 3 shillings.

fo. xorb

In LAmERs [Lammarsh] Turold seized (invasit) 47 acres, which were held, in King Edward's time, by 8 free men; and they have (them) still. ('They had) then as now (semper) half a plough. And it is worth 5 shillings.

\section{Encroachment of W aleram ${ }^{15}$}

In HENI [Henny] (are) half a hide and ro $\frac{1}{2}$ acres, which were held by 7 free men in King Edward's time; and they have now as then (semper) I plough; and (there are) 4 acres of meadow ; and it is worth 10 shillings. This is held of John (Fitz Waleram) by Roger. ${ }^{16}$ In HaLsTedA [Halstead] Ulwin' held Io acres, which Waler[am] seized; then as now I plough (was there); then I bordar; now 40.17 Then 3 serfs; now none; (there is) wood(land) for 16 swine, (and) 5 acres of meadow. It was then worth 20 shillings; now $30 .{ }^{18}$

In Branchetreu [Braintree ${ }^{19}$ ] 30 acres of land were held by 3 free men in King Edward's time, and (they) are worth 3 shillings. 'This land was seized by Ledmar' of Hamesteda [Hempstead] and held as part of (ad) the fief of Richard (Fitz Gilbert); and Richard does not warrant it to him (non est sibi tutor ${ }^{20}$ ).

14 Ranulf Peverel's under-tenant at Lammarsh and Henny.

15 Father of John Fitz Waleran, the Domesday tenant-in-chief (see p. 544 above).

${ }_{16}$ The under-tenant of his manor at Henny.

17 This ' $x$ l.' must, it seems, be a scribal error.

18 Morant identified this holding as Slow House in Halstead; but, as he gave 'Waler[am]' as 'Walter,' and states that the holding was given by the Conqueror to 'Albrey de Vere,' his account is unreliable.

19 Very possibly Sandpit Leet, as suggested by Morant (ii. 397).

$20 \mathrm{Sec}$ the other version of this encroachment on p. 573 below; also Introduction (p. 411 ). The double entry is due perhaps to the scribe's doubt whether to assign the holding to Richard or to his reeve. 


\section{THE HOLDERS OF LANDS}

\section{EnCroachment of Richard SON OF Count Gilbert ${ }^{1}$}

Almar of B[ar]lea [Borley], Golstan, Alvric of Alreforda, ${ }^{2}$ Ulvric of Branduna [Brundon], these hold half $a$ hide and 6 acres and held (it) in King Edward's time. Now Goismer' 3 holds them (eos) of R [ichard]. Then as now (semper) I plough, and I bordar, and 5 acres (of meadow ?). It is worth now as then (semper) 28 shillings.

In Phincingerelda [Finchingfield] Ernald"s holds of R[ichard] 80 acres, which were held by Brictic', a free man, in King Edward's time. Then as now (semper) 2 ploughs on the demesne. Then and afterwards I villein; now none. Then and afterwards 3 bordars; now 8. Then as now (semper) 3 serfs. (There was) then wood(land) for 40 swine ; now for 30. Then and afterwards it was worth 40 shillings; now 60.

At (Ad) Lacelea [Lacheley ${ }^{8}$ ] Grim, a free man, held half a hide, which is (now) held by Ernald'. ${ }^{6}$ Then as now (semper) 2 ploughs. Then and afterwards 4 bordars; now 8. Then 2 serfs; now none. Then and afterwards (there was) wood(land) for 80 swine; now for 60. (There are) 10 acres of meadow. Then and afterwards it was worth 40 shillings; now 60 .

At (Ad) Ersham [Hersham "] Brictmar', a free man, held, in King Edward's time, I hide. Wielard ${ }^{8}$ holds (it) now. Then and

I Alias Richard de Clare. Owing to the number of the places in which he encroached, fos. 102 and 103 are both headed 'Ricardus.'

2 This is the mysterious 'Alreforda' held by Richard de Clare (p. 478 above). As Borley and Brundon adjoin one another in the Stour valley, near Sudbury, 'Alreforda' should be in their neighbourhood.

8 Richard's under-tenant at Great Yeldham.

- An under-tenant of Richard at Great Dunmow and Wickham (see pp. 477,478 above).

- Now Lashley, a manor in Lindsell, which, says Morant (ii. 446), 'belonged to the Honour of Clare.'

But he does not give this entry under it.

6 See note 4 above.

7 Hersham Hall was a manor of which the Hall was in Bumpted Helion, but of which the lands extended into Sturmer, Haverhill and Castle Camps. Morant does not mention this entry under it, though he knew that "the manor of Hersham' (i.e. one of the manors there) belonged to the Clares and was 'holden of the honour of Gloucester' accordingly (ii. 533).

- For his other encroachment at Hersham see p. 573 below. He was Richard's under-tenant at Bardfield (p. 481). afterwards I plough; now 1 . Then 2 bordars; afterwards and now 7. (There are) 9 acres of meadow. It was then worth 30 shillings; afterwards and now 40.

In WeNINGHOU [? How Hall ${ }^{\circ}$ ] Germund holds $37 \frac{1}{2}$ acres, which (quod) were held by 1o. 202

Coleman, a free man, in King Edward's time. Then as now (semper) 3 ploughs on the demesne. Then and afterwards 2 ploughs belonging to the men; now 3. (There is ?) 1 serf. (There is) wood(land) for 4 swine, (and) 10 acres of meadow. It was then worth 60 shillings; now 4 pounds and 10 shillings.

In Geldeham [Yeldham] Burnart holds 40 acres, which (quod) were held by Goduin', a free man, in King Edward's time. Then as now (semper) I plough, and 2 bordars. (There is) wood(land) for 10 swine and 5 acres of meadow. It was then worth 20 shillings; afterwards and now 30.

In Barlea [Borley] Anschetil holds half a hide and 23 acres, which (quod) were held by Grim and Godeva, free men (bomines ${ }^{10}$, in King Edward's time. Then I plough; now $1 \frac{1}{2}$. Thell and afterwards 3 bordars; now 5. (There are) 9 acres of meadow. It was then worth 20 shillings; afterwards 30 ; now 40.

In Topesfelda [Toppesficld "1] Ralf holds 15 acres, which were held by Alestan', a free man, in King Edward's time. Then as now (semper) I plough. Then and afterwards 4 bordars; now 7. Then and afterwards 4 serfs; now none. (There is) wood(land) for 20 swine, and 6 acres of meadow. Then and afterwards it was worth 20 shillings; now 3 o.

In Topesfelda [Toppesfield] G. holds 15 acres, which were held by Duva (duua). Then as now (semper) I plough on the demesne, and I plough belonging to the men, and 3 villeins, and 2 bordars, and 2 serfs. (There is) wood(land) for 30 swine, (and) 8 acres of meadow. Then and afterwards it was worth 50 shillings; now 60.

- See p. 479 above for Germund's other holding there under Richard de Clare. The two holdings together made up 70 (geld) acres.

10 Godeva, of course, was 2 woman.

11 This and the next holding were probably represented by the manor of Scotencys there, which was subsequently held of the Clares by the Scoteneys. 


\section{A HISTORY OF ESSEX}

In NoRTuna [Norton ${ }^{1}$ ] Mascherel holds 55 acres, which were held by Brictric, a free man, in King Edward's time. Then I plough on the demesne; afterwards and now 2. Then as now (semper) I plough belonging to the men, and 5 villeins. Then and afterwards 5 bordars; now 8 . Then and afterwards 3 serfs; now 2. (There is) wood(land) for 40 swine, (and) 10 acres of meadow. It was then worth 40 shillings; afterwards and now 60.

In Brbenhers [Pebmarsh] Levecilt, a free man, held and still holds 3 acres; and Derolf 4 acres in Alfelmestuna [Alphamstone] and Holt, a free man, I acre (there); and Lewin' and Lemar' 5 acres in Bumesteda [Bumpstead]; and Algar 20 acres in SAlinges [(Old ?) Saling $\left.{ }^{2}\right]$; and Brictolf 30 acres in Olvituna [Ovington ${ }^{3}$ ]. These had in all (omnes) 3 ploughs in King Edward's time. Then and afterwards 3 bordars; now 8 . Then and afterwards 2 serfs; now none. (There is) wood(land) for 12 swine, (and) $8 \frac{1}{2}$ acres of meadow. Then and afterwards it was worth 30 shillings; now 45 shillings and 2 pence.

Of these abovesaid men Wisgar had only the 'commendation.' 1

fo. $102 b$

In Benedisc [Bendish (Hall) ${ }^{5}$ ] Wisgar, $\mathrm{R}$ [ichard]'s predecessor, seized (invasit) 30 acres after the king came into this country (patriam). ${ }^{6}$ And afterwards Ingelric had it (illam), and the Hundret (court) testifies that

1 This Norton must have been somewhere in the neighbourhood of the places among which it is entered, and this conclusion is confirmed by the fact that its tenant was 'Mascherel,' who was Richard's under-tenant at Bulmer (p. 479).

2 Morant appears to have overlooked this entry.

${ }^{3}$ Morant does not mention this entry under Ovington (which was usually 'Ovituna"); but one can hardly hesitate so to identify it.

4 Wisgar was the predecessor in possession of Richard de Clare, who, it is meant, claimed greater rights over these men than had been given to Wisgar by their 'commending' themselves to him in order to secure his protection. The entry under Colne below (p. 573, note 2) should be compared on this point. It is, unfortunately, by no means clear to how many of the 'abovesaid' holdings this clause applies, but, as no details are given as to the character of any of Richard's encroachments down to this point, it is probable that they are all covered by it.

5 A manor in Radwinter.

6 This is an important note of date as proving that Wisgar (the lord of Clare) survived the Conquest. it used to belong to Ingelric's fief ${ }^{7}$; but Richard has held it (illam) hitherto (bucusque).

In BYRDEFRLDA [(Great) Bardfield] Felaga ${ }^{8}$ held of Earl Elfgar (Algaro) I hide and 30 acres. And after the king came into this country (patriam), R[ichard] seized (invasit) this land, ${ }^{9}$ which, as the Hundret (court) testifies, was not held by his predecessor. Then as now (semper) 3 villeins. (There are) now 7 bordars. Then 3 serfs; now 1 . Then $1 \frac{1}{2}$ ploughs on the demesne; now 1 . Then as now (semper) I plough belonging to the men. (There is) wood(land) for 100 swine, (and) 27 acres of meadow. Now (there is) I mill. It was then worth 4 pounds; now 60 shillings.

In Hoosenga [ 10 Felaga held half a hide. Richard holds (it) now like the (land) abovesaid, and Walter (holds it) of him. Then as now (semper) 2 villeins, and 1 plough. (There is) wood(land) for 2 swine, (and) 4 acres of meadow. It is worth 12 shillings.

\section{In Hasingham [ 11] a free man} held $2 \frac{1}{2}$ acres, in the Hundret of Laxedana [Lexden]. Now R[ichard] (holds them). And there is now I mill there rendering 15 shillings ${ }^{12}$; and yet (the holder) was only 'commended' to Richard's predecessor. ${ }^{13}$

In the Hundret of Laxendena [Lexden] Luttin' held in Colun [Colne ${ }^{14}$ ] 40 acres. Now R[ichard] (holds them). And over (in) this land his predecessor had no rights (con-

7 The manor of Bendish (hall) had been held by Ingelric, whose successor, Count Eustace, was holding it in 1086 (p. 471 above).

$8 \mathrm{He}$ had held the adjacent manor of Ashwell (Hall) in Finchingfield, less than two miles to the east of Great Bardfield (p. 560 above).

9 Probably because it adjoined his large and valuable manor of Little Sampford.

10 This appears to be a lost name. As it had been held by Felaga, one would expect to find it in the neighbourhood of Great Bardfield and Ashwell.

il This also appears to be a lost name.

12 So in the text ; but the value is probably that of the holding as a whole.

13 The meaning of the corrective 'yet' (tamen) appears to be that Richard was holding the land, although its tenant's 'commendation' to his predecessor gave him no such right.

14 It would hardly be safe to assert in which of the Colnes this holding and the other just below were situate. 


\section{THE HOLDERS OF LANDS}

suetudinem ') but (such as) 'commendation' (gave him). Then 4 bordars; now 6 . Then as now (semper) I plough. (There is) wood(land) for 20 swine, 4 acres of meadow, (and) now I mill. It is worth 20 shillings.

In Creprnga [Creping (Hall) ${ }^{3}$ ] Alward held $68 \frac{1}{8}$ acres, $^{8}$ freely (libere), which (quod) $\mathrm{R}$ [ichard] now holds like the rest (aliam). Under him (there were) then 4 bordars; now (there are) 6. Then as now (semper) I plough. (There is) wood(land) for 20 swine, (and) 2 acres of meadow. It is worth 20 shillings.

And Alwi' the huntsman ${ }^{8}$ held freely (libere) half a hide and $26 \frac{1}{2}$ acres. Now $\mathrm{R}$ [ichard] holds (them), in BERcolt [(West) Bergholt], like the rest (aliam). Then 2 bordars; now 6. Then as now (semper) I plough. (There is) wood(land) for 15 swine, (and) 2 acres of meadow. (There was) then half a mill; now none. It was then worth 20 shillings; now 36 .

In Colun [Colne ${ }^{8}$ ] Ulvric' held freely (libere) 5 acres. Now R[ichard] (holds them) like the rest (alios). They are worth 2 shillings.

In Forham [Fordham] Tovillda held 3 acres. Now R[ichard] (holds them) like the rest (alios); and they are worth 7 pence.

In Bercolt [(West) Bergholt] Goding' held 6 acres; now R[ichard] (holds them). Then half a plough (was there); now 2 oxen. There is I acre of meadow. It was then worth 32 pence; now 5 shillings.

\section{fo. 103}

In HALstedA [Halstead] a free man held $2 \frac{1}{2}$ acres in King Edward's time; and they are worth 30 pence. Alvret, R[ichard]'s

1 Strictly, a customary due.

2 'Nisi commendationem" (compare Introduction, pp. 358-9).

A manor in Wakes Colne.

- He had also held the other portion of 'Crepinga' in which he had been succeeded by Modwine in 1086 (p. 560 above).

8 ' $1 x$. acras et iiii. acras et iiii. acras et dimidiam.'

B His name is one of the omissions in Ellis' Indexes to Domesday.

7 The name of the locality should have followed after 'acres.'

8 See p. 572 , note 14 , above.

- i.e. 2 quarter of a plough-team. reeve, has received these pence ${ }^{10}$; and he has given pledge concerning it (inde dedit vadem). ${ }^{11}$

In Hersham [Hersham(hall) ${ }^{18}$ ] a free woman held 30 acres. Now Wielard' holds them, as he says, of the king; but the Hundret (court) does not testify (in his favour); and Richard son of Count Gilbert has had the service (from the land). Then half a plough (was there); now none. (There are) now 2 bordars. It is worth 10 shillings.

In Branchetreu [Braintree] 3 free men held, in King Edward's time, 30 acres, which Letmar' the reeve claimed as belonging to (reclamavit ad) Richard's fief; but his (illius) men do not testify (in the reeve's favour). And he has given pledge concerning it (inde dedit vadem ${ }^{13}$ ). And it is worth 3 shillings. ${ }^{14}$

In Cenuride [Chawreth ${ }^{15}$ ] (are) 30 acres, which were held by Ulvric, a free man, in King Edward's time. Now Garner', a man of Richard, holds (them), and vouched to warranty (vocavit ad tutorem) Ilbodo, ${ }^{16}$ and afterwards failed to adduce a warrantor (non adduxit tutorem). And it is worth 8 shillings.

In the same vill 2 free men held half a hide in King Edward's time. Ailmar, Richard's reeve, seized this land, and vouched him to warranty (revocavit eum ad tutorem); but Richard failed (defuit) him; and he has given pledge concerning it (ex boc dedit ille vadem $\left.^{13}\right)$. It is worth 16 shillings. ${ }^{17}$

The monks of Canterbury hold in LALINGA [Lawling ${ }^{18}$ ] I hide, which was held by 3 free men in King Edward's time. Then as now (semper) I plough. It is worth 20 shillings. This land has been added to that manor ${ }^{10}$ in King William's time.

10 This passage is important as implying that 30 pence was the actual rent received, and not a mere valuation.

11 See p. 566, note 10, above.

12 See p. 571 , note 7 , above.

13 See p. 566, note 10 , above.

14 This is virtually a duplicate entry (see p. 570, note 20 , above).

16 Overlooking these entries Morant asserted that Chawreth was not mentioned in Domesday (i. 447).

16 See p. 561 above. It is not clear what he had to do with Chawreth.

17 Richard's encroachments end here.

18 In Latchingdon.

10 The monks had a large and valuable manor at Lawling (p. 437 above). 


\section{A HISTORY OF ESSEX}

In Colun [Colne ${ }^{1}$ ] Turbern holds 22 acres without (any) gift from the king and renders no customary due.

Henry de Ferrers (Ferreriis) has seized (invasit) I free $\operatorname{man}^{2}$ with (de) 16 acres in Stepla [Steeple]. And (it) is worth 2 shillings.

W [illiam] Levric ${ }^{3}$ has seized (invasit) in ScIDDEHAM [ ${ }^{3}$ ] I free man with (de) 6 acres. It is worth 12 pence.

In Bumesteda [Bumpstead] Robert Blund'4 has seized (invasit) 10 acres, which were held by Edui, a free man. Then as now (semper) I plough. It is worth 20 shillings.

fo. $103 \mathrm{~b}$

In Mildentuna [Middleton] R[obert] Malet ${ }^{5}$ has seized (invasit) 15 acres which were held by a free man in King Edward's time. Then as now (semper) half a plough. It is worth 5 shillings.

Frodo brother of the abbot ${ }^{10}$ has held up to now (bucusque) 2 free men in Staumtuna ${ }^{11}$ [Stevington (End) ${ }^{12}$ ], whom Orgar' his predecessor ${ }^{13}$ seized (invasit), (and) who dwell in the king's soke and have 20 acres. Then as now (semper) half a plough (was there); and it is worth 4 shillings.

In Cishella [(Great) Chishall] Lewin' held 5 acres; and now Roger de Otburvilla ${ }^{14}$ holds them, because (ideo quod) his predecessor was seised thereof.

In the Hundret of Rochefort [Rochford] lie I 5 acres of ANGRA [Ongar], which are held by Berengar, a man of Earl Eustace. (They were) then worth 15 pence; now 20.

\section{SURVEY OF COLCHESTER}

fo. 104

\section{Hundret of Colchester [Colecestra]}

In the same Colchester Godric, a free man, ${ }^{6}$ held, in King Edward's time, 4 manses (mansiones terra), ${ }^{7}$ and I church, and 4 hides in Greenstead (Grenesteda). On his death his sons divided the land into four parts, ${ }^{8}$ of which the king has two-to (in) which belong 2 houses in the borough (burgo) which have always rendered, and still render, customary due to the king. ${ }^{9}$ In (these) 2 hides (there were) then, and (are) now, 2 ploughs on the demesne; then and now 3 villeins; then and now 2 serfs; then and now 24 acres of meadow and marsh (maresc); then I

1 'This holding cannot be identified.

2 i.e. his land.

3 See p. 557, notes 4, 5, above.

4 Robert Blund was a tenant-in-chief, whose chief estate was in Suffolk. He, or a man of the same name, held some land at Castle Hedingham under Aubrey de Vere, but there is nothing to explain his appearance here at Bumpstead.

5 He held land at Goldıngham in the neighbourhood.

6 This must have been the Godric 'de Colx castro' whose small estate (' 25 acres') at (East) Donyland had passed to Count Eustace (see p. 466 above).

7 See Introduction, p. 416.

8 'Inquat dimiserunt partes.' As the 'inquat' is obviously corrupt, I have ventured to read 'dimiserunt ' as an error for 'diviserunt.'

- The Latin leaves it doubtful whether the due was paid from the houses or the 2 hides. mill; (and) now a moiety; then as (et) now it was worth 40 shillings. And of the two other parts Count Eustace has I hide, and John son of Waleram the other hide. And in the quarter of Count Eustace is the whole (of the) church, and a fourth part of the mill, and a fourth part of the meadow ; then 1 plough (was there, and) now none; and it is worth in all 30 shillings. And in the fourth part of John son of Waleram there was I plough in King Edward's time; now none; and (in it is) a fourth part of the mill, (with) a fourth part of the meadow ; and it is worth in all 30 shillings. And from these two parts the king has no customary due.

And the burgesses claim 5 hides of Lexden (lex sendena), which belonged to (jacuerunt ad) the aforesaid land that Godric held, (as liable) to the customary due and account of the city. ${ }^{15}$

These are the king's burgesses who render customary due. Coleman has I house in Colchester (de colecestra), and holds 5 acres of land, and renders to the king now as then

10 Of St. Edmund's.

11 A scribal misreading of 'Stavintuna.'

12 In Ashdon, the next parish to Radwinter, in which was Frodo's manor.

13 In his manor at Radwinter (p. $55^{6}$ ).

14 See p. 496 above.

15 ' Cootum civitatis.' Here again I venture to emend to 'compotum civitatis.' See the Introduction (p. $4^{16}$ ) for the meaning of the above entry. 


\section{THE HOLDERS OF LANDS}

(semper) customary due. Lewin' 2 houses and 25 acres of land. Ulvric 1 house. Eduin' the priest I house and 20 acres. Turchil I house and 9 acres. Ulstan eudlac 4 houses and 20 acres. Lewin' crist 1 house and 10 acres. Manwin' 4 houses and 30 fo. ropb

acres. Alvric 1 house and 5 acres. Herdedun $^{1} 10 \frac{1}{2}$ houses and 20 acres. Alfeihc the priest 1 house and 25 acres. Levot I house and 15 acres. Ulvric I house and 7 acres. Sucrtinc I house and 10 acres. Alwart I house and 2 acres. Eduin' I house. Goda ${ }^{3}$ 13 houses and 20 acres. Sprot 2 houses and 3 acres. Edric 4 houses and 15 acres. Godwin' I house and 15 acres. Godwin' wachefet and his sons 5 houses and 12 acres. Blanc' 6 houses and 20 acres. Alvric 2 houses and 14 acres. Stanart $2 \frac{1}{2}$ houses and Io acres. Goduin' I house and 9 acres. Ulvric 2 houses and 1 acre. Alsi 1 house and $3 \frac{1}{8}$ acres. Alward 2 houses and 23 acres. Manwin' 2 houses and 7 acres. Leffesse I house and $2 \frac{1}{2}$ acres. Lewin' 10 acres. Ulwin I house and $2 \frac{1}{2}$ acres. Godinc 2 houses and 10 acres. Goda ${ }^{3}$ I house and 7 acres. Ulwin the crier (monitor) I house and 7 acres. Alfgar I house. Uluart 2 houses and I acre. Alwin' I house and 10 acres. Alfgar the priest I house and I acre. Frent 1 house and 2 acres. Osgot 2 houses and I acre. Ulvric 2 houses. Artur 1 house and 4 acres. Eduin' 1 house and 4 acres. Salvare 1 house and 7 acres. Leflet ${ }^{3} 3$ houses and 25 acres and I mill. Alvric I house. Goduin' I house. Sprot I house and 3 acres. Grimolf 2 houses and 9 acres. Sagar I house and 10 acres. Alvric I house. Alwin' 3 houses and 9 acres. Ulvric I house and 6 acres. Sprot I house and 3 acres. Ulwart 1 house and 8 acres. Lewin. I house and Io acres 'consilio.' " Goduin' I house. Golstan $I$ house and 5 acres. Ulwin I house and 4 acres. Ulwart I house and 3 acres. Ulwin' 2 houses and 7 acres. Godwin 2 houses and 6 acres 'consilio.' Alfsi 2 houses. Lefstan I house and I acre. Godric I house. Alric fo. 105

I house. Not I house. Brictwin I house and 5 acres. Lefflet $^{8}$ I house. Alric I

1 So reads the Record Commission's edition; but I think we may read: 'Herdechin.'

: ' $\mathrm{d}$ d' et dim' $x \mathbf{x} a c$ '.'

3 A woman's name.

- This word, which occurs here thus, has not been explained.

6 A woman's name. house and $4 \frac{1}{8}$ acres. Edwin 1 house and $2 \frac{1}{8}$ acres. Scadebutre 1 house. Manwin' 4 acres. Goldwin' I house. Ulvric I house and 2 acres. Osiet I house. Edwin' I house and 10 acres. Ulvric 2 houses and 5 acres. Alwin' 2 houses. Edwin' I house and 3 acres. Ulwin' I house. Blacstan 2 houses. Manstan 2 houses and IO acres. Alvric I house and 1 acre. Lewin' I house. Alwin 2 houses and 22 acres. Lewin 2 houses. Edric I house. Lewin' I house. Wed ${ }^{6}$ I house. Ulsi I house. Goldric 2 houses and 22 acres. Goda ${ }^{7} 22$ acres. Calebot ${ }^{8} 7$ acres. Manstan 2 houses and I acre. Ulfeit I house. Manwin' I house. Winemer ${ }^{8} 1$ house. Sacrim 3 houses and 4 acres. Levric I house. Ulwart I house and 4 acres. Ulwin' I house and 1o acres. Lefflet ${ }^{10}$ I house and 25 acres. Godric I house. Dereman I house. Turstan I house. DuHel (sic) 1 house and half an acre. Godd $x$ (sic) 2 houses. Got cill' (sic) I house and I acre. Stan I house. Oriet' I house. Alfstan' I house. Tovi I house. Goldinc I house. Leuiet I house and 2 acres. Blacstan I house. Manwin' I house. Alwin' I house. Lefsun 2 houses. Alvric I house and 2 acres. Brumman I house. Alwin I house. Saulf $2 \frac{1}{2}$ houses and 10 acres. Lewin' 3 acres. Ulfric I house. Alfstan I house. Godwin 3 acres. Goldwin' I house. Godwin' I house and I acre. Wicga I house. Ledmar I house. Ulstan 2 houses. Godesun 1 house and 3 acres. Elebolt 2 houses and I acre. Godwin' I house. Godeva ${ }^{10}$ I house. Lefstan I house. Eduard the priest I house. Hacon I house. Ailbriest I house. Tate I house. Sawart I house. Berda I house and 5 acres. Ulwart the priest 1 house and 1 acre. Cullinc 2 houses and 7 acres. Alwolt I house. Filieman I house and 5 acres. Godeva ${ }^{10}$ I house.

fo. rosb, 2

Siward the priest I house and 4 acres. Pic I house. Ulwin' 3 houses and 4 acres. Leucva ${ }^{10}$ I house and $4 \frac{1}{8}$ acres. Alvric 15 acres. Alwen 2 houses. Ulvric I house and $I \frac{1}{8}$ acres. William Peche (peccatum) ${ }^{11}$ I

- 'Vued.'

7 A woman's name.

8 This strange name suggests an error for ' 'Talebot,' but one would hardly expect to find a Norman holding these " 7 acres."

8 This is a Flemish name.

10 A woman's name.

11 A Norman under-tenant in the three castern counties. In Essex he held at Gestingthorpe and at Belchamp Walter adjoining. 


\section{A HISTORY OF ESSEX}

house. Best I house. Rosell' I house and 4 acres. Lewin' I house and 2 acres. Goda 1 I house. Ulwin' I house. Leuesun I house. Golman I house. Pote 4 acres. Godric I house. Siric I house and 2 acres. Alric I house and 2 acres. Liuidi (sic) I house. Brictric I house and $9 \frac{1}{2}$ acres. Lefstan I house. Wdebil ${ }^{8}$ I house. Blacstan I house. Alflet ${ }^{3}$ I house. Ulveva I house and 20 acres. Goda ${ }^{3} 1$ house and 20 acres. Ascere I house and 19 acres. Godric I house. Brunloc I house. Alnod 2 houses and 4 acres. Godwin' I house and 10 acres. Lewin I house and 10 acres. Alvric the priest 3 houses and 2 acres. Roger I house and 4 acres. Godric I house. Alvric I house and 2 acres. Suertinc I house and 10 acres. Godid ${ }^{3} 2$ houses and 14 acres. Brunnin' 1 house and 3 acres. Ulwin' I house. Brungar 2 houses and 18 acres. Sunegot 1 house. Siward I house and $6 \frac{1}{2}$ acres. Ulstan II acres. Leffiuf 2 houses and 8 acres. Sagrim I house. Ulwin' I house. Lewin' I house. Leuric' I house. Godinc I house and I acre. Westan 2 houses and 30 acres. Ainolf 1 house and 15 acres. Tunric I house. Alstan 5 acres. Alfsi I house. Goldere I acre. Godsune $1 \frac{1}{2}$ acres. Ulwin' 1 house. Alvric I house. Godwin' I house. Pecoc I house. Alwin' I house. Brictric I house. Manwin' I house. Ulvric I house. Godsune I $\frac{1}{2}$ (?) houses and 6 acres. Brunuin' 1 house. Manwin' I house. Edric I house. Leueva ${ }^{5}$ I house. Owin I house. Alstan 2 houses. Alvolt $6 \frac{1}{2}$ acres. Manuin' I house and 5 acres. Alwart 1 house and 15 acres. Lemer 10 acres. The Abbot of St. Edmund(s) 2 houses and 30 acres. Stanhert I house.

fo. 206

Ulwin' I house. Sæwele I house. Leuret 1 house and 6 acres. Alveva ${ }^{5}$ 10 acres. Ulstan I house and 13 acres. Lewin' 2 houses. Leueva ${ }^{5}$ I house. Alvric I house. Godric I house and 9 acres. Ulric I house and 4 acres. Ulwin' I house. Alwen I house. Tescho 2 houses and 20 acres of land; and he owes customary dues to the king, and never pays (them). Ulvric 3 acres. Stotinc I house. Herstan I house. Leuric I house and 42 acres. Edric I house. Dela I house. Hunec 2 houses. Manwin' 2 houses. Alvric 2 houses. Got (sic) Hugh 6 acres. Lewin' I house and 25 acres.

\footnotetext{
1 A woman's name. 2 'Vudebil.'

3 A woman's name.

4 'Godsune et dim.'

5 A woman's name.
}

Miblanc (Dimidius blancus) ${ }^{6} 4$ houses. Lefsune I acre. Alveva ${ }^{7}$ I house. Leueva ${ }^{7}$ 3 acres. Sueno I house. Ulsi I house. Alflet ${ }^{7}$ I house. Ralf Pinel ${ }^{8} 4$ houses within the walls and 5 acres, and he has not paid (the) customary due, and has given security therefor. ${ }^{9}$ Orlaf $3 \frac{1}{2}$ acres. Walter 2 houses. Horrap I house. Alwin' I house. Stamburc I house. Ulstan 2 houses and 5 acres. Chentinc I house. Sprot I house and 5 acres. Edwin' 1 house and 3 acres. Got flet ${ }^{13}$ (sic) 20 acres. Mansune 10 acres. Godinc I house and 5 acres. Ulveva ${ }^{13} 5$ acres. Ulvric I house and $I \frac{1}{2}$ acres. Lorchebret $I$ house and 10 acres. Goldere 1 house. In addition to their land these burgesses have 5 I acres of meadow. Amo Hamo (sic) dapifer (has) I house, and I court (curia), ${ }^{10}$ and I hide of land, and 15 burgesses; and this was held by his predecessor Thurbert ${ }^{11}$ in King Edward's time; and all this, except his hall, used to render customary due in King Edward's time; and the burgesses still render it on their polls (de suis capitibus), but from their land and from the hide which Hamo holds the due is not rendered. In (that) hide (was) then I plough; now none; then and now 6 acres of meadow; and all this was worth 4 pounds in King Edward's time, and the same when he received (it); ${ }^{12}$ and now 40 shillings.

Mansune (has) 2 houses and 4 acres; Goda ${ }^{13}$ 1 house.

Eudo dapifer (has) 5 houses and 40 acres of land, which were held by burgesses in King fo. 106b

Edward's time and used to render all burgesses' due(s). But now the burgesses do not render due(s) save on their polls (capitibus). All this is the fourth part of the church of St. Peter ; $^{14}$ it renders 30 shillings.

Hugh de Montfort (has) I house, which was held, in King Edward's time, by his predecessor Godric, ${ }^{15}$ and used then to render customary due to the king. Now it does not pay and has not paid since Hugh had (it).

6 See p 534, note 11, above.

7 A woman's name.

$8 \mathrm{He}$ held in chief at Bromley in Tendring Hundred.

9 See p. 412, note 7 , above.

10 See Introduction, pp. 350, 417

11 See p. 500, note 10, above.

12 'Et quando similiter recepit.' Here 'similiter' and 'recepit' are obviously transposed by a slip of the scribe.

13 A woman's name.

14 See p. 578 below.

16 He cannot be identified as Hugh's predecessor in any Essex manor. 


\section{THE HOLDERS OF LANDS}

Roger of Poitou (pictaviensis) has I house which was held, in King Edward's time, by his predecessor Alflet ${ }^{1}$ and used to render the king's due. Now it does not pay and has not paid since Roger had (it).

Count Eustace (has) 12 houses, and one of which Engelric ${ }^{3}$ took possession (occupavit); and they used to render the king's due in King Edward's time. Now they do not pay and have not paid since Eustace had them; and they are worth 12 shillings. William, nephew of the bishop, (has) 2 houses, which were held by Thurchil, and renders customary due. Otto the goldsmith (has) 3 houses which belong to Esceldeforde [Shalford] and were held by Ellfgifu (Alveva) the countess, and used to render the king's due, and do not render (it) now. And this is of the queen's land. ${ }^{5}$

The Abbot of Westminster (has) 4 houses, which were held, in King Edward's time, by Earl Harold as belonging to Feering (ad ferigens) and used then to render customary due; now they do not.

Geoffrey de Mandeville (magna villa) (has) 2 houses, which were held in King Edward's time by Geni' as belonging to Ardleigh (ad erligam), ${ }^{6}$ and used to render customary due ; now they do not.

Suain (Sueno) (has) I house, which was held in King Edward's time by Goda as belonging to Elmstead (ad elmestedam) ${ }^{7}$; and then they used to render (reddebant) the king's due; now they only render on their tenants' polls (nisi caput bominis).

William de Watteville (watcvilla ${ }^{8}$ ) (holds) of Suain (sue none) I house, which was held by Robert (Fitz) Wimarc in King Edward's time, and used to render customary due; now jt does not.

Turstin Wiscart ${ }^{9}$ holds of John Fitz Waleram 3 houses and half a hide of land, which were held in King Edward's time by

1 She cannot be identified as his predecessor in any Essex manor.

' 'Reddit' for 'reddidit.'

3 His predecessor.

- See Introduction, p. 418.

- See Introduction, p. 351 .

- Geoffrey's manor at Ardleigh had been held by two brothers, and this 'Geni' cannot be identified there (p. 508 above).

7 Suain (of Essex) had succeeded, at Elmstead, his father Robert Fitz Wimarc (p. 491). Goda was probably an Englishwoman whose land Robert had obtained.

8 See p. 474 , note 6, above.

- This famous surname is among the omissions in Ellis' Indexes to Domesday. It identifies the Turstin who held of John Fitz Waleram at Saling. two burgesses, and used to render the king's customary due; now they do not. That half hide was then worth 10 shillings; and (o. 109 when received, 6 shillings ; (it is) now (worth) 5 shillings. ${ }^{10}$

Ranulf Peverel (piperellus) (has) 5 houses, which Ailmar ${ }^{11}$ held, in King Edward's time, as belonging to Terling (ad terlingas); and they used to render customary due; now they do not. One of these is without the walls.

Ralf Baignart (has) I house, which was held in King Edward's time by Ailmar melc as belonging to Tolleshunt (ad tollensum ${ }^{12} t c$ ), and it used to render (reddebant) customary due ; now not.

The Abbess of Barking (berchinges) (had) 3 houses $^{13}$ in King Edward's time, and then rendered (reddebat) customary due; now not.

Aubrey de Ver (has) 2 houses and 3 acres of land, which were held by Ulwin' his predecessor ${ }^{14}$ in King Edward's time. They used then to render customary due.

The king's demesne in Colchester (consists of) 102 acres of land, of which 10 are of meadow, (and) on (in) which are 10 bordars; and 240 acres of (inter) pasture and scrub (fructetam); and all this belongs to (jacet ad) the king's ferm. ${ }^{15}$

In the burgesses' common ${ }^{16}$ (In commune bur gensum) are 80 acres, and 8 perches about (circa) the wall, from all which the burgesses have 60 shillings a year, for the king's service if there should be need (for it), and if not, they divide it in common (in commune dividunt).

And (autem) there is a custom that every year, on the fifteenth day after Easter, the king's burgesses render 2 marcs of silver; and this belongs (hoc pertinent) to the king's ferm.

10 'The fee of Turstin Wiscart' is among the endowments named in Eudo Dapifer's foundation charter of St. John's Abbey, Colchester.

11 'This was 'Ailmar, a thegn of King Edward,' who had held Terling before the conquest.

12 This place has not hitherto been identified, and it was indexed in the Record Commission's edition as 'Collensum.' 'The entry gives us the surname of Ralf's predecessor at Tolleshunt (p. 526 above).

13 These are clearly the three houses mentioned under her manor of Wigborough (p. 449 above) as appurtenant thereto.

14 See Introduction, p. 343.

18 i.c. was included in the sources of revenue compounded for in the 'ferm.'

18 This appears to be the best way of rendering the above exceedingly difficult phrasc. The phrase probably refers to common of pasture. 


\section{A HISTORY OF ESSEX}

Moreover from each house (are paid) yearly 6 pence, which can be devoted (reddere potest) to the support (victum) of the king's soldiers (solidariorum) or to war service (expetitionem) by land or sea; and this does not belong (est) to the (king's) ferm. ${ }^{1}$ And let this be so (sit) whether the king has soldiers (soldarios) or calls for war service (expetitionem fecerit). ${ }^{2}$ And in addition to (propt $[e r]^{3}$ ) these (payments of) 6 pence the whole city (civitas) used to render from all dues (debitis) in King Edward's time, 15 pounds and 5 shillings and 3 pence each year, of which the moneyers used to render 4 pounds in King Edward's time. It now renders 80 (' iiii $\mathbf{x x}$ ') pounds and 4 sestiers (sextarios) of honey or 40 shillings $4 i^{4}$ and, besides this, roo shillings to the sheriff for fine (de gersuma) $;^{5}$ and 10 shillings and fo. rogb

8 pence for feeding (pascendos) the prebendaries. And besides this the burgesses of Colchester and of Maldon (meldona) render

1 See P. 577 , note I 5 , above.

2 For this difficult passage see the Introduction.

3 I read this as an error for prater.

4 'xl. sol. iiii.' The text is evidently corrupt.

5 Gersuma was an offering of some kind, usually consideration money paid for a lease.
20 pounds for the mint (moneta); and Waleram arranged (constituit) this; and they vouch (advocant) the king to warranty (ad turtorem) that he remitted to them 10 pounds, and (the holder ?) Bishop Walchelin ${ }^{6}$ demands (querit) from them 40 pounds.

In Colchester is a certain church of St. Peter, which was held, in King Edward's time, by 2 priests in almoine of the king (in elemasina [sic] regis), (and) to which belong (adjacent) 2 hides of land, on (in) which there were and (are) now, 2 ploughs; (there were) then 3 bordars, (and) now 4 ; then 3 serfs, (and) now 2 ; then and now 12 acres of meadow; then and now I mill; then and now 2 houses in the borough (burgo). Then the whole was worth 30 shillings; now 48 shillings. Of this endowment (elemosina) Robert son of Ralf de Hatinges" claims (reclamat) three quarters, and Eudo 'dapifer' holds the fourth ; ${ }^{8}$ and in King Edward's time they rendered (reddebant) customary due; and now it does not (non reddit).

6 'The word ten' precedes Walchelin', but here again the text is corrupt.

7 Clearly an error for 'Hastinges.' The MS. has 'dehatingis.'

8 See p. 576, note 14 , above. 


\section{INDEX TO DOMESDAY OF ESSEX}

\section{PERSONAL NAMES ${ }^{1}$}

A. (? Ailmar), $528 b$

Achi a free man, $488 a, 555 a$

Adam son of Durand Malsouer, $427 b, 558 b, 559 a$

Adelelm, 534a, $535 b$

Alfgar, 508a. See also Alfgar, Algar

Elfgar [Algar, Edgar], Earl, 336, $337,338,351,354,430 b$, $431 a, 431 b, 453 b, 474 b, 550 a$, $562 b, 564 b, 572 b$, notes 337 , $338,354,430 b$

Elfgifu widow of Earl Ælfgar, 351,5770

Flfric Camp. See Camp

Elfric son of Wisgar (Withgar), 348

Elfric [Alvric] the sokeman, $35^{8}, 535 b, 536 a$

Elfric [Alvric] the priest, 384, $482 b$

Ælfric Wand or Wants. See Wand

Ælfric. See also Alric, Alvric

Elfsige [Alfsi] (Colchester moneyer) $422,575 a, 576 a$

Ethelmær, $525 b$, note $443 b$. See also Ailmar, Ailmar melc

Æthelred, King, 340

Ethelric, 341. See also Ailric

Atnod, $470 b$

Agnes, $552 a$

Ailbriest, $575^{b}$

Ailet, Boidin, 392

Ailid, Ailida, a free woman, 347 , $467 a, 522 b, 523 a, 525 a, 525 b$

Ailmar, $553 a$

Ailmar a free man, $533 a, 552 b$

Ailmar a king's thegn, $452 a$, $526 b, 527 a, 577 b$

Ailmar melc, $526 a, 528 b, 577 b$. See also Æthelmær

Ailmar reeve of Richard de Clare, $573^{b}$

Ailric, 445a. See also Æthelric

Ainolf, $576 a$

Alan of Brittany, Count. See Brittany
Albemarle. See Aumale

Albert, $452 a$

Alcher, $498 b$

Aldred, $495^{b}$

Alestan', 506b, 520a, $531 a, 545 a$. See also Alstan

Alestan' a free man, $500 b, 514^{b}$, $515 a, 527 b, 546 b, 569 a, 571 b$

Alfega, $540 b$

Alfeihc the priest, $575^{a}$

Alfgar, 575a. See also Elfgar, Algar

Alfgar the priest, $575^{a}$

Alflet, $576 a, 576 b, 577 a$

Alfsi. See Ailfsige

Alfstan, $575^{b}$

Alftred a certain woman, $437 b$

Algar, $457 b, 480 b, 4^{81} a, 5^{1} 5^{b}$, $529 a, 529 b, 540 b, 572 a$. See also Ælfgar

Alger, $556 a$

Almar, $469 a, 487 a$

Almar a free man, $47 \mathrm{I} a$

Almar Holefest, $473 b, 558 a$

Almar of Borley, $571 a$

Alm(er)frid(us), Amelfrid(us), $469 b, 523 b, 525 a$

Alno, William de. See Aunay

Alnod, $576 a$

Alric, $524 b, 544 a, 556 a, 564 a$, $575 a, 576 a$

Alric a free man, $463_{3} b$

Alric a thegn of King Edward, $482 a$

Alric brother of Bund', 508a

Alric. See also Ælfric

Alsi, 47 I $b, 497 b, 575 a$

Alsi a free man, $458 a$

Alsi bolla, $539 a$

Alsid, $526 b$

Alstan, 576a. See also Alestan Althorne [Aledhorn, Aletor]

Walter de, 395 Wife of, 393

Aluric. See Alvric.

Alveva, $576 a, 576 b$

Alveva a free woman, $539 a, 568 a$

Alvid an Englishwoman, $487 a$
Alvolt, $576 a$

Alvred, $486 a, 489 b, 539 a, 569 b$

Alvret, Aluret, the reeve, $\mathbf{5 7 3} a$, note 364

Alvric, $432 a, 440 a, 440 b, 465 b$, $467 a, 470 b, 476 b, 500 b, 514 a$, $517 b, 525 a, 545 b, 555 b, 575 a$, $575^{b}, 576 a$

Alvric a free man, $441 b, 458 a$, $523 a, 557 a, 557 b$

Alvric a thegn of King Edward, $441 a, 461 b$

Alvric biga, $466 b$

Alvric cild a free man, $514^{b}$

Alvric of Alreforda, $57 \mathrm{I} a$

Alvric's father, $467 a$

Alvric. See also Ælfric

Alward, 440b, 457a, 458a, $530 a$, $560 b, 573 a, 575 a$

Alward Dore, 5586

Alwart, $575 a, 576 a$

Alwart a free man, $523 b$

Alwen, $575 b, 576 a$

Alwen a free woman, $482 b$

Alwi' the huntsman, $573^{a}$

Alwin, 467a, $467 b, 480 b, 536 a$, $540 b, 558 b, 575 a, 575 b, 576 b$

Alwin a free man (?Alwin Stickhehare), $44 \mathrm{I} b, 442 a, 458 b, 563 c$

Alwin a thegn of King Edward, $482 a, 498 b$

Alwin 'Godtuna,' $474 a$

Alwolt, $575^{\circ}$

Amelfrid'. See Alm(er)frid

Amo, See Hamo

Anschill, Anschil, 476a, 555a

Anschetil a man of the Bishop of London, 440a, $45^{8} a$, $553^{a}$

Anschitill, Anschetil, 438a, $514 a$, $519 a, 543 a, 571 b$

Anesti, Richard de, 379

Anselm, 47 I $a$

Ansgar [Asgar, Esgar] the staller, $341,343,352,353,358$, $504 b, 505 b, 507 a, 508 b, 509 a$, $509 b, 510 a, 510 b, 511 a, 511 b$, $512 a, 512 b, 513 a, 513 b, 569 a$, note 343

1 Including thuse of religious houses holding lands. 


\section{A HISTORY OF ESSEX}

Ansger the cook, $427 b, 563 a$ Ansgot, $489 b$

Ansgot a free man, $557 b$

Anunt the Dane, $459^{b}$

Arling', 5070

Artur, 494b, 575a

Ascelin, 486b, 487a, $514 b, 530 a$

Ascere, 576a

Asgar. Sce Ansgar

Asso, $519 b$

Assorin, 5506

Aubrey's wife. See Vere, Aubrey de, wife of

'Aurei testiculi.' See Orescuil

Aumale, Countess of, $427 b, 555^{b}$

Aunay, William d', $352,520 b$

Austruy, Seigneurs of, 344

Bacton, Leofwine of, Leofwine [Lewin] Cilt, 35 I, 54 I b, 548a, 5486

Baddow [Badwan'], Richard de, 396

Baignard, Geoffrey, 5600

Baignard [Bainard, Baignart] Ralf, sheriff of Essex, 346, 347, 349, $353,365,395,396,428 a$, $428 b, 429 a, 432 a, 434 b, 435 a$, $435 b, 437 b, 443 b, 444 b, 467 b$, $501 b, 521 b, 522 a, 522 b, 523 a$, $523 b, 524 a, 524 b, 525 a, 525 b$, $526 a, 532 b, 570 a, 577 b$, notes 347,5670

Balt, William, $440 b$

Bardulf, Thomas, 392

Barking [Berchinges] Abbey, 340 , $341,342,358,427 a, 448 a$, $448 b, 449 a, 449 b, 505 a$, notes $38 \mathrm{I}, 444^{a}$ Abbess of, 5776

Battaile, Aumari, 392

Battle Abbey, 341, 427a, $452 a$

Bayeux, Odo Bishop of, 342 , $343,352,387,395,427 a$, $435 b, 44 \mathrm{I} a, 448 a, 454 b, 455 a$, $455 b, 456 a, 456 b, 457 a, 457 b$, $458 a, 458 b, 459 a, 459 b, 460 a$, $460 b, 537 b$, notes $448 a, 518 b$

Baynard. See Baignard

Beauchamp John de, note $458 b$

Benefelle [Bendfield], Godwine $\mathrm{de}$, note $516 b$

Berda, $575^{b}$

Berengar a man of Earl Eustace, $574^{b}$

Berenger, 5240

Bernard, $376,463 a, 464 b, 465 a$, $470 b, 524 b, 525 a, 526 a$, not 5016

Berners, Hugh de, 386, 412 , $510 a, 569 a$

Best, $576 a$

Bigod, Bartholomew le, note 5 I 00

Bigots, the, note $535 a$

Bigot, Roger, 418, 420, 428a, $549 a, 549 b, 550 a$, note $543 a$
Binesle, Richard son of Peter de, Bury St. Edmunds, Abbcy of, note 406

Birches, William à, 389

Blacstan, $575 b, 576 a$

Blanc', $575^{\circ}$

Blois, Stephen Count of, 379, Caen-Abbey of Holy Trinity of, note 379

Blund, Robert, $533 b, 574^{a}$

Bodd' a free man, 46ia

Bohun, Humfrey de, Earl of Hereford and Essex, 374

Boidin. See Ailet

Bond', 5436

Bondig [Bondi, Bundi](thestaller) a free man, $350,504^{\circ}$

Borda, 5 I $9 b$

Borley, Almar of, 5710

Bosc, William de, 5406

Boso, $568 a$

Boulogne, Eustace Count of, 341 , $342,343,347,353,354,358$, $363,364,386,398,427 a$ $429 b, 433 b, 434 a, 435 a, 435 b$, $438 a, 452 a, 454 b, 460 b, 461 a$, $461 b, 462 a, 462 b, 463 a, 463 b$, $464 a, 464 b, 465 a, 465 b, 466 a$ $466 b, 467 a, 467 b, 468 a, 468 b$, $469 a, 469 b, 470 a, 470 b, 471 a$, $47 \mathrm{I} b, 472 a, 50 \mathrm{I} b, 574 b, 577 a$, notes $337,433 b, 435 a, 444 a$, $525 a, 53 \mathbf{I} b, 563 a$ a clerk of, $436 a$

Bricsi, 49 I $a$

Bricteva, 432b, $483 a$

Brictic a free man, $571 a$

Brictmar a free man, $571 a$

Brictnar, $462 b$. See also Brihtmar Brictolf, $572 a$

Brictric, $572 a, 576 a$. See also Brictic, Brictric

Brictulf, 47 I $b$

Brictwin, 467a, $575 a$

Brihtmar, Bricthmar, Brictmar, thegn of King Edward, 352 , $353,35^{8}, 460 b, 467 b, 514 a$, $526 b, 527 a, 530 b, 563 b$, note $462 b$

Brihtnoth, ealdorman, and wife, $34^{\circ}$

Brittany, Alan Count of, 350 , $427 a, 431 b, 472 b, 473 a, 473 b$ Brumman, $575 b$

Brun, 491 $b, 530 a$

Brungar, $576 a$

Brunloc, $576 a$

Brunnin', $576 a$

Brunuin', $576 a$ $38,340,427 a, 451 a, 451 b$, $452 a$

Abbot of, $452 a, 574 b, 576 a$ $337,342,427 a, 453^{b}$, note $562 b$

Abbey of St. Stephen of, $342,419,427 a, 454 a$, note 559 a

Caen, Walter de, $550 b$

Calebot, $575 b$

Camp [Campe, Campa, Capin, Capus, Cemp], Ælfric [Alvric, Aluricus], 353,520a, $524 b$, $543 b$

Camse, Henry de, 390

Camville, Thomas de, 372

Canterbury

Archbishop Lanfranc of, 342

Cathedral church and monastery (Christchurch, Holy Trinity), 340, 348, 427a, $436 b, 437 a, 437 b, 567 a$, notes $565 a, 567 a$

Monks of, $573 b$

Canute [Cnut], King, 339, $439 a$

Cardon, Cardun, William, 356 , $45^{1} a, 471 a, 512 b, 569 b$

Chentinc, $576 b$

Chien, Seiher le, 392

Clare, Gilbert de, note $478 b$

Clare, Richard Fitz Gilbert de, $348,355,363,388,408$, 4 II $a, 4$ I I $b, 4$ I 2, 427a, 43Ia, $43 \mathrm{I} b, 435 a, 477 a, 477 b, 478 a$, $478 b, 479 a, 480 a, 480 b, 481 a$, $481 b, 482 a, 508 b, 570 b, 571 a$, $572 a, 572 b, 573 a, 573 b$, notes $435 a, 535 a, 5716$

Clarenbald, $488 a$

Cnut. See Canute

Cola, $499 b$

Cola a free man, $558 b$

Colchester

Abbot of, note 393

Godric of, $415,416,466 b$, $574 a, 574^{b}$

King's burgesses of, $577^{b}$

Colcman, $480 a, 574^{b}$

Coleman a free man, $57 \mathrm{I} b$

Coleworth, Richard de, note 5 I $9 b$

Colfege a free man, $480 a$

Colo, 46 I $b$

Corbun, W., $515 b$

Bryanzun, Breanzun, John de, Cornhill, Henry de, 399 399

Buelle, Lambert de, 5106

Bund' a free man, $508 a$

Bundi. See Bondig (the staller)

Burcard a free man, $514 a$

Burnart, $57 \mathrm{I} b$

Burnel, Philip, 394

Bursigni, William de, 4496
Corp, $519 a$

Cudhen [Gudhen], Godwine [Goduin], 4J 2, 448b, $557 b$, $566 a$

Cullinc, $575 b$

Dapifer. See Eudo, Fulc, Godric, Hamo 


\section{INDEX TO DOMESDAY}

David, 4676

Dela, $576 a$

Derman, Dereman (Colchester moneyer), 422, $575^{6}$

Derolf, 5720

Dозi. See Douxi

Dodinc, $548 a$

Doding, 5036

Dore, Alward, 5586

Dot, Doth, $4836,519 a$

Douai [Dosi], Walter de, 350 , $427^{b}, 554 b$

Drogo, 5526

Du Hel, $575^{b}$

Duna, Duua, a free woman, 474 s. See also Duva

Duna, Thomas de, note 392

Durand, nose 4306

Durham, Bishop of, 337,364 , $385,427 a, 446$

Duva, 5716 . See also Duna

Eadgyth [Edeva], Queen, 351 , $461 b, 499 b, 548 b, 549 a$, note 4996. See also Edith

Easthorpe [Estorp], Edric of, $466 a, 541 a$

Edeva, 441b, 442a, 463a, 468a, $473 b$

Edeva, Eideva, widow of Edward son of Suan, $355,565 b$

Edgar, Earl. See Æifgar, Earl

Edith the Fair [Edeva], 350, $436 b, 472 b, 473 a, 473 b$, nobe 350. Sec also Eadgyth

Edmar, $462 b, 4886$

Edmund son of Algot, $427 b$, $55^{8} a, 55^{8 b}$

Ednod, 5246 . See also Ainod, Etnod

Ednod a free man, 5470

Edric, $4^{8} 4 a, 495 a, 496 b, 575 a$, $575^{b}, 576 a$

Edric a free man, $4566,4586,5430$

Edric of Estorp [Easthorpe]. See Easthorpe, Edric of

Eduard the priest, $575^{b}$. See also Edward

Edui' a free man, $574^{\circ}$

Eduin', 507a, 575a. See also Edwin

Eduin' the pricst, $575 a$

Edward, $4286,4576,4696,470 a$. Sce also Eduard

Edward (Colchester moneyer), 422

Edward son of Suan, 355, 5656

Edward the Confessor, 336,345 a reeve of, 4296

Ediward the Elder, 414

Edwin, 5756, 5766. See also Eduin

Edwine [Eduin] a free priest, 385,5156

Edwold, Edwolt, 440a, 4406

Edwolt king's reeve, $455^{\circ}$
Elebolt, $575^{6}$

Elinane, 4786

Elric, $469 a$

Elwi, 4506,4510

Elwin, $473 a$

Ely, Abbey of St. Ethelthryth, $340,341,342,346,350$, $427 a, 450 a, 450 b, 459 a, 474 b$, $495 a, 499 b, 509 b, 529 b$, note 5310

Abbot of, 346, 358, 359, $451 a, 459 a, 474 b, 492 b$, $493 b, 509 b, 512 a, 529 b$

Monks of, $429 a, 499 b, 564 a$

Engelric. See Ingelric

Enisant, 5340

Erfin', 358, 507a

Ernald, 477b, 478a, 478b, 5710

Ernulf, 386, $462 b, 526 b$

Esgar. See Ansgar

Essex, Geoffrey (de Mandeville), Earl of, $37^{8}$

Essex, Henry of, 344, nose 367

Essex, Suain of. See Suain, sheriff of Essex

Estred, note 4306

Etmar, $554^{\circ}$

Etnod, 4646. See also Etnod

Etsi, $473 a$

Eu [Ou], Count of, 337, 388 , $428 a, 513 b$, note 4576

Eudo Dapifer [Eudes son of Hubert de Ryes], 341, 347, $348,349,353,354,355$, $379,383,384,391,392$, $395,411,416,417,427 a$, $434 a, 435 b, 450 a, 450 b, 491 b$, $492 a, 492 b, 493 a, 493 b, 494 a$ $494 b, 495 a, 495 b, 496 a, 501 b$, $512 a, 576 b, 578 b$, notes $496 a$, $565 a$

Eustace of Boulogne, Count (or Earl). See Boulogne

Evrard, 5136

Felaga, $560 a, 572 b$

Fenna, Willelmus de, 394

Ferrers, Earl de, 388

Ferrers [Ferrariis, Ferreriis] Henry de, 350, $427 a, 503 b$ $504 a, 574^{a}$

Filieman, 5756

Frebert a thegn, 505a. See also Friebert

Frent, $575 a$

Frewin, $460 b$

Friebern a thegn, 2 free man, $343,410 a, 4106,512 a, 5136$

Friebert, $458 b$. See also Frebert Frodo brother of the abbot (of St. Edmunds), $427 b, 556 a, 574 b$

Fule Dapifer, note $492 a$

G., 5716

Galicer(ius). See Walicherius

Garenger', 543a, 549a, $549^{b}$
Garenne, William de. See Warenne

Garin, $527 b, 533 b$

Gamer', $410 a, 461 a, 477 b, 485 a$, $488 a, 488 b$

Garner', a man of Richard de Clare, $573^{b}$

Geni', $577 a$

Geoffrey, $462 b, 485 a, 5216,525 b$

Geoffrey (' Talbot), $552 b$

Germund, 395, 396, 479a, 524a, 5246,5716

Gemet, Richard, $506 b$

Gernon [Greno, Grino], Robert, $347,352,353,388,389,394$, $428 a, 429 b, 433 b, 436 a, 439 a$, $447 b, 448 b, 514 a, 514 b, 515 a$, $515 b, 516 a, 516 b, 517 a, 517 b$, $518 a, 518 b, 519 a, 519 b, 520 a$, $520 b, 521 a, 521 b, 527 b, 553 b$, notes $434 a, 569 b$

Gernon, William, 347

Gerold, $543 a, 543^{b}$

Gilbert, 4380

Gilbert a man of the Bishop of Bayeux, 458b, $553 a$

Gilbert son of Salomon, 350 , $427 b, 453 b, 563 a$

Gilbert son of Turold, $4276,557 a$

Gilbert son of Warin, 384,4316

Gilbert the priest, $428 b, 564 b$, note 337

Girald, Reimund, 354, $432 b$, 5176 , nose $55^{16}$

Girard, $521 b, 545^{b}, 547^{a}$

Girold, $4^{8} 5^{6}$

Gladiou, $475^{\circ}$

Goda, $575 a, 575 b, 576 a, 576 b$, $5770^{\circ}$

Godd $x, 5756$

Godebold, $4^{8} 4^{b}, 4^{88 a}, 490 a$

Godeman, 563a. See also Godman

Goder 2 free man, $442 a$

Godere a free man, $559^{\circ}$

Goderet, 5416

Godesun, $575^{6}$

Godet, $483 a$

Godeva, $5716,575^{b}$

Godfrey, $4^{8} 7 b, 5^{13} b, 547^{a}$

Godgifu. See Godeva

Godid [Goti, Gotil, Gotild], 350, $44^{2} b, 452 a, 500 a, 501 b, 502 a$, $502 b, 503 a, 509 a, 576 a$

Godinc, 575a, $576 a, 576 b$

Goding, 481a, 500b, 5730

Godman a free man, 5646

Godman a sokeman of Robert FitzWimarc, $489 b$

Godman. See also Godeman

Godric, $4^{10 a}, 44^{1} b, 459^{b}, 4^{8} 3^{b}$, $486 b, 488 a, 490 a, 490 b$, 5 I $9 a$, $522 b, 528 b, 575 a, 575 b, 576 a$, 5766

Godric a free man, $452 b, 455 b$, $471 a, 488 b, 559 a, 562 a$ 


\section{A HISTORY OF ESSEX}

Godric a king's thegn, $484 a$, Guibert, $474^{b}$ 4856

Godric dapifer, 35 I, 355, 436b, note 350

Godric of Colchester. See Colchester

Godric poinc, $476 a$

Godric scipri, $476 a$

Godsune, $576 a$

Goduin, 495a, $517 b, 519 b$, $550 b, 563 b, 575 a$

Goduin $a$ free man, $441 a$, $463 b, 492 a, 539 a, 543 a, 550 a$, $550 b, 569 b, 571 b$

Goduin king's thegn, $483 b, 492 b$

Goduin' sech, 569a

Goduin the priest, 561 a

Goduin. See also Godwin

Godun, $533^{b}$

Godwin, 575a, 575b, 576a

Godwin, Earl, 336

Godwin Wachefet and his sons, $575^{\circ}$

Godwine, 416, 428b, 441a

Godwine [Goduin], Cudhen or Gudhen. See Cudhen

Godwine [Goduin] the deacon, $506 b, 565^{\circ}$

Godwine. See also Goduin

Goismer, $478 a, 571 a$

Gola, $525 b$

Goldere, $576 a, 576 b$

Goldinc, 5756

Goldric, $575 b$

Goldwin, $575^{\circ}$

Golman, $576 a$

Golstan, 430b, $571 a, 575 a$

Gonduin, 427b, 564a

Goscelin [Goscelmus] the lorimer, $427 b, 429 a, 448 b, 559 a$

Got cill, $575^{b}$

Got flet, $576 b$

Got Hugh, $576 a$

Goti, Gotil, Gotild. See Godid

Gotra, Gotre, 5 I $6 a, 521 b$

Grai, Henry de, 388

Grapinel, $485 a$

Grapinel, Warin, note $485 a$

Gray. See Grai

Grim, 494b, $522 b$

Grim a free man, $544 b, 571 a$, $571 b$

Grim the reeve, $355,428 b$, $432 a, 564 b, 565 a$

Grimbold, $562 a$

Grimolf, 5750

Grinchel, $520 b$, $521 a$

Grosvassal, Geoffrey, 356

Grut, Eduin, 5 19a, $560 a$

Gudhen. See Cudhen

Gudmund, $501 a$

Gudmund a free man, 4690

Gudmund a king's thegn, 346 , $497 a, 497 b, 498 b, 499 a$

Guert, $439 a$
Gulbert, $475 a$

Guner'. See Gunner

Gunner, 491 $a$, 491 $b$, note 355

Gurnai, Hugh de, 428a, $552 a$, $552 b$

Gutbert, $509 b$

Guy, 464b, 465a

Guy the Angevin, 47 Ia

Hacon (burgess of Colchester), $417,470 a, 521 b, 575^{b}$

Hacun, $537^{b}$

Haghcbern, Hagebert, $427 b$, $435 b, 56 \mathbf{I} b$

- Hagra,' 499b. See also Hapra

Haldan' a free man, $537^{\circ}$

Halesdon, Robert de, note 394

Hamo the dapifer, son of Hamon [Amo, Hamo], sheriff of Kent, $350,383,395,417,419$, $427 a, 429 a, 429 b, 46 \mathrm{I} b, 500 a$, $500 b, 501 a, 501 b, 502 a, 502 b$, $503 a, 503 b, 559 b, 569 a, 576 b$, notes $412,429 b$

Hapra, Ulwin, 5586 . See also Hagra

Hardekyn, note $528 b$

Harduin', 5536

Harduinus, note 413

Harold (King), 334, 336, 337 , $341,352,428 a, 428 b, 429 a$, $429 b, 432 a, 432 b, 433 a, 433 b$, $434 a, 434 b, 436 a, 444^{b}, 445^{b}$, $446 a, 446 b, 460 b, 461 a, 462 a$, $468 a, 470 a, 500 a, 501 a, 507 a$, $511 a, 513 b, 531 a, 544 a, 553 b$, $560 a, 569 b, 577 a$, notes 337 , $433^{b}$

his reeve, $430 a, 433 b$

Hastinges, Ralf de, $544^{\circ}$

$\mathrm{Ha}$ (s)tinges, Robert son of Ralf de, 5786

Hauckestune, Geoffrey de, note 393

Helion. See Herion

Hempstead, Ledmar of, the reeve, $411,411 a, 411 b$

Henry, a knight, wife of, $543 b$, $544^{\circ}$

Herbert, $505 b$

Herbrand father of William and Robert de Sackville, 379

Herdechin, Herdedun, $575^{\circ}$

Hereford, Robert Bishop of, $336,427 a, 434 a, 460 b$

Herion or Helion, Tihel de. See Tihel the Breton

Herstan, 5760

Hervey 'de Ispania,' 350,356 , $472 b, 473 a, 473 b$

Holefest, Almar, $473 b, 55^{8 a}$

Holt a free man, $572 a$

Holy Cross. See Waltham

Holy Trinity (Christchurch), Canterbury. See Canterbury
Holy Trinity of Caen, abbey of. See Caen

Horolf, $431 a, 452 b$

Horrap, $576 b$

Hosdenc, Hugh de, 356, $550 a$

Houard, $443 a$

Hubert, $505^{b}$

Hubert (de Monchensy), 550a, $550 b$

Hugh, 424, 440a, 442a, $451 a$, $458 a, 458 b, 466 a, 466 b, 487 b$, $509 a, 512 a, 513 a, 513 b, 514 a$, $514 b, 516 b, 545 a, 576 b$

Hugh de St. Quintin. Sec St. Quintin

Hugh the son of Mauger, 499b, $500 a$

Hughling, 441a, 441 $b$

Hugolinus. See Hughling

Humfrey, 439a, 440b, 498a, $500 a, 526 b, 532 a, 538 b$

Humfrey Orescuil, $569 a$

Hunald' [Hunold], 561 $b, 562 a$

Hunec, $576 a$

Hunold. See Hunald.

Ilbodo, 41 2, 427b, 429a, 561a, $573^{b}$

Ilger, $515 b, 517 a, 517 b, 519 a$, $539 b$

Ingar the thegn. See Ingwar

Ingelric, Engelric, $432 b, 433 b$, $435 a, 435 b, 444 a, 454 b, 460 b$, $461 a, 462 b, 463 a, 463 b, 464 a$, $464 b, 465 a, 465 b, 466 a, 466 b$, $467 a, 468 a, 468 b, 469 b, 470 a$, $470 b, 47 \mathrm{I} a, 47 \mathrm{I} b, 472 a, 50 \mathrm{I} b$ $572 a, 577 a$, notes $433 b, 435 a$ the priest, $341,344,352$, $353,354,35^{8}$

Ingulf, $499 a, 520 b$

Ingwar [Ingar, Ingara, Ingewar, Inguare, Ingwara] thegn of King Edward, 352, $454 b$, $538 b, 539 b, 540 a, 540 b$, note 352

Ispania. See Hervey

Ivo the nephew of Herbert, $457^{b}$

John, $485 b, 487 a$

John nephew of Waleram, $427 b$, $559 a$

John son of Ernuc(i)un, $544^{\circ}$

John son of Guy de Rochford, 395

John son of Waleram, 342, 354 , $377,408,428 a, 430 a, 544 a$, $544^{b}, 545 a, 545 b, 570 b, 574^{b}$, $577 a$, note 337

Judith, Countess, $427 b, 555^{b}$

'Junain(us)', $462 a$

- Junan(us),' 4676

Ketel, 346, $532 a$

Kent, Countess of (Lady of Eastwood), 37 I 


\section{INDEX TO DOMESDAY}

Lagheman, $560 b$

Lambert, $468 a, 468 b, 510 b$

Lancaster, Aveline Countess of, 389 , nose 5206

Latimer, Ralf, 5700

Ledmar', $5706,575 b$. See also Letmar

Ledmar a free man, $464 a$

Ledmar the priest, 348,4716 , 4776

Ledmar of Hempstead the reeve, $4 \mathrm{II}, 41 \mathrm{I} a, 41 \mathrm{I} b$

the

Lefcild, 48 ta. See also Leofcild, Levechild

Leffesse, $575 a$

Lefflet, Leflet, 575a, 575b. See also Leofleda

Leffiuf, $576 a$

Leffstan, $482 b, 483 a$

Leflet. See Lefflet

Lefsi, $467 b, 47 t b, 492 a$

Lefsiu, $541 b$

Lefstan, $468 b, 47 a a, 554 b, 575 a$, $575^{\circ}$

Lefstan' the reeve, $554^{6}$

Lefsun', 506b, $575^{6}$

Lefsune, $576 b$. See also Levesun

Leftan, $4^{83 a}, 4^{87} b, 488 a, 521 a$

Lemar, $572 a$

Lemer, $576 a$

Leofcild, 5376. See also Lefcild, Levechild

Leofleda (ot Colchester), 417. See also Lefflet

Leofwine Cilt. See Bacton, Leofwine of

Letmar', 5736 . See also Ledmas

Leuard', $432 a$

Leuesun, $576 a$. See also Levesun

Leueva, $457 b, 480 a, 503 c, 575 b$, $576 a, 576 b$. See also Leveva

Leuiet, $575^{b}$

Leuild, $505 a$

Leuinc 2 free $\mathrm{man}, 5466$. See also Lewin

Leuret, 576a. See also Levred

Leuric, $456 b, 481 a, 506 b, 545 a$, 576a. See also Levric

Levechild, 556b. See also Lefcild, Leofcild

Levecilt a free man, 5720

Levecilt a king's thegn, $484 a$

Levedai, 5046

Levesun, 450b, 495a, 507b, $508 a$. See also Lefsune, Leuesun

Leveva, $522 a$. See also Leueva

Levid', $512 a$

Levot, $575^{\circ}$

Levred', 515a. See also Leuret

Levric, $575 b$. See also Leuric

Levric, William, $4276,5576,574^{a}$

Lewin, $466 b, 467 a, 468 a, 473 a$, $490 b, 496 b, 499 b, 506 b, 524 a$, $532 b, 548 b, 552 a, 572 a, 574 b$, $575 a, 575 b, 576 a$. See also Leuinc, Liwin
Lewin a free man, $430 a, 555^{b}$

Lewin Cilt. See Bacton, Leofwine of

Lewin' Crist, $575^{\circ}$

Lewin Croc, 5516

Limesi [Limesay, Limescio, Limesy], Ralf de, $33^{8}, 4276$, $429 b, 553 a, 553 b, 554^{a}$, notc 337

Lisois. See Moustiers

Linidi, $576 a$

Liwin, 4986

Loholt, Henry, note $525 a$

London

Bishop Maurice of, 334 $338,339,380,395$, $398,418,419,424$, $427 a, 437 b, 438 a, 438 b$ $439 a, 439 b, 440 a, 440 b$, $44^{1} a, 44^{1 b}, 44^{2} a$, notes $455 a, 510 a$

Bishop William of, 337 , $339,418,4376,4386$, 4610

St. Martin le Grand, 341, $444 a, 452 a, 465 a, 469 a$ Canons of, $427 a$

St. Paul, Church of, $36 \mathrm{t}$, $365,367,438 a, 439 b$, $557 a$, note $34^{\circ}$

Canons of, $34^{\circ}, 427 a$, $442 a, 442 b, 443 a$, $443^{b}, 444^{a}, 470 a$

Westminster Abbey. See Westminster

Lorchebret, 5766

Luci, Richard de, nose 392

Luttin, 5726

\section{Mainard, 4836}

Maldon, burgesses of, $578 a$

Maldon, Siward of [Seward de Meldona ], $346,358,386$, $449 b, 450 b, 527 b, 528 a, 529 a$, $529 b, 530 a, 530 b, 531 a, 532 a$

Malet, Robert, 428a, 550a, $550 b$, $574^{\circ}$

Malgerus. See Mauger

'Malis operibus.' See Adam

Mandeville [Magnavilla], Geoffrey de, sheriff of Essex and Hertfordshire, 34\%, 341, $343,349,358,364,374$, $383,384,386,390,394$, $410,428 a, 429 b, 442 b, 447 b$, $471 a, 494 b, 504 b, 505 a, 505 b$, $506 a, 506 b, 507 a, 507 b, 508 a$, $508 b, 509 a, 509 b, 5$ เaa, $510 b$, $511 a, 511 b, 512 a, 512 b, 513 a$, $513 b, 527 b, 554 b, 563 b, 568 a$, $568 b, 569 a, 569 b, 577 a$, notes $343,5016,502 a$

Mannic, $458 a$

Manstan, 5756

Mansune, 5766

Manuin', $576 a$
Manwin, 575a, 575b, 576a

Marci [Marcei], Ralf de, 356, $429 b, 46 \mathrm{I} b, 463 a, 470 a, 500 b$, $501 a, 502 b, 503 a$, noses $4 t 2$, $502 b$

Marci, Serlo de, 500b, $501 a$, $501 b, 502 a, 502 b$

Martel, Martell, Geoffrey, $505 a$, $509 a, 510 b, 511 a, 512 a$, moses 5016,5086

Mascarel, Mascherel, 479a, $572 a$

Mathew of Mortagne, 4276 , $555^{\circ}$

Matilda, Queen, $337,351,42 \mathrm{t}$, $431 a, 431 b, 433 a, 558 a, 564 b$, 5770 , nose 337

Mauger [Malgerus], 445a, 457b, $468 a, 547 b$

Maylande, Walter de la, 395

Melc. See Ailmar

Merc, Adelolf de, 344,356 , $462 b, 463 b, 464 b, 468 a, 468 b$, $469 a, 470 b, 472 a$

Merc, Enguerrand de, 344

Merc, Fule de, 344

Merc, Geoffrey de, 344

Merc, Henry de, 344

Merc, M. de, 344

Merc, Simon de, 344

Merc, Walter de, note 4926

Meruena a free woman, $559^{\circ}$

Miblanc ['dimidius blancus'], $534 b, 535 b, 576 b$

Modbert, $523 a$

Modinc, 493a

Moduin, Modwine, 355, 4276, $560 a, 560 b, 561 a, 561 b$

Moese, Margery de, nose $519 a$

Monchensy, Hubert de, 5500 , 5506

Montbegon, Robert de, $566 a$

Montfichet, Richard de, 394

Montfort, Hugh de, 345,346 , $389,39 \mathrm{I}, 395,427 a, 430 a$, $432 a, 435 b, 485 b, 497 a, 497 b$, $498 a, 498 b, 499 a, 499 b, 500 a$, $532 b, 567 b, 568 a, 576 b$, notes $430 a, 546 a, 565 a$

Morel, Ralf, note $492 a$

Mortagne [Mauritaniensis], Mathew of, $4276,555 a$

Moustiers, Lisois de, 348, 354, $492 b$, nose $492 a, 492 b$

Nigel, 499a, $517 b, 518 a, 546 a$, $547^{\circ}$

Norfolk, Ralf Earl of, $436 b, 473 a$, note 350

Norman, $432 b, 464 b, 472 a, 493 a$, 5246

Not, $575^{\circ}$

Odard, 49 ta

Odo, $512 b, 539 a, 539^{b}$

Odo a man of Suain, $449 b, 484 b$, $486 a, 489 a, 491 b$ 


\section{A HISTORY OF ESSEX}

Odo Bishop of Bayeux. See Bayeux

Oilli, Robert d', 5100

Oin the Dane, $459 a$

Olui, $53 \mathrm{I} b$

Ordric, $536 a$

Orescuil ('Aurei testiculi'), Humfrey, $569 a$

Orgar, $556 a, 574^{b}$

Orgar a free man, $452 b, 556 b$

Orgar the thegn, $514^{b}$

Oriet, $575 b$

Orlaf, 5766

Ormar a free man, $543 a$

Osbern, $455 b, 472 b, 482 b, 490 a$, $515 a$

Osbert, $507 b, 552 a$

Osgod, Osgot (burgess of Colchester), $417,575 a$

Osiet, $575^{b}$

Oslac, $53^{8 a}$

Oslac a free man, $460 a, 541 \mathrm{l}$

Osmund, $544 b$

Osmund the Angevin, $429 b$

Osward, $456 a$

Otburville [Otburvilla], Roger de, $427 a, 49^{6} a, 496 b, 574^{b}$

Otto the goldsmith, 350,354 , $427 b, 431 a, 431 b, 564 a, 564 b$, $577 a$, notes $351,477 b$

$\mathrm{Ou}$, Count of. See Eu

Owin, 576a. See also Oin

Payn, $482 b, 487 a$

Peche, William, $477 b$, 534a, $575 b$

Pecoc, $576 a$

Peter, $516 b, 521 a$

Peverel, Mathew, note $527 b$

Peverel [Piperellus], Ranulf, 346 , $347,35^{8}, 363,383,3^{86}, 388$, $392,428 a, 429 a, 432 a, 434 b$, $449 b, 450 b, 468 b$, 5 I $5 a, 526 a$, $526 b, 527 a, 527 b, 528 a, 528 b$, $529 a, 529 b, 530 a, 530 b, 531 a$, $531 b, 532 a, 532 b, 567 a, 567 b$, $577 b$, note $549 b$

Peverel [Pipcrellus], William (of Nottingham), 346, 388, 399, $427 b, 458 a, 552 b, 553 a$

Peverel, William, note $527 b$

Phin the Dane [Phin $4^{81 a}, 4^{82} a, 565 a$ Widow of. See Ulveva

Pic, $575^{b}$

Picot, $519 b, 521 a$

Picot sheriff of Cambridgeshire, $33^{8}, 430 b, 431 a, 431 b$

Pictavensis. See Poitou

Pincun, 5336

Pinel, Ralf, $35^{2}, 4^{1} 2,4^{2} 7 b, 5^{6} 3^{b}$, 5766

Pirot, 4 I $1 a, 493 b$

Plaiz, Richard de, note $519 a$

Pointel, 455b, $456 b$

Pointel, Thierri [Tedric Puintel],
$427 b, 429 a, 432 a, 435 a, 522 a$, $522 b, 525 b, 561 b, 562 a, 562 b$, $566 b, 567 a$

Poitou [Pictavensis], Roger of, $354,428 a, 432 b, 517 b, 55 \mathrm{I} a$, $551 b, 552 a, 577 a$, note 379

Port, Hubert de, $518 b, 565 a$

Pote, $576 a$

Quengeuet mother of Brihtmar, $35^{2}$

Rainald, 504b. See also Renelm'

Rainald the crossbowman, $427 b$, $564 a$

Rainalm, 5 I 1 . See also Renelm

Ralf, $437 a, 440 b, 441 b, 467 a$ $4^{8} 2 b, 4^{8} 7 b, 4^{8} 9 b, 494 a, 506 b$, $518 b, 520 a, 533 a, 536 b, 537 a$, $544 a, 551 a, 57$ 1 $b$

Ralf 'fatat(us)', $538 a$

Ralf Latimer, $570 a$

Ralf son of Brien, $438 a, 441 b$, $442 a, 530 b, 531 a, 567 b$

Ralf son of Turold of Rochester, $342,368,389,435 b, 454 b$, $455 a, 455 b, 457 a, 45^{8 b}, 459 a$, $459 b, 460 a$, notes $435 b, 459 a$

Ralf brother of William the deacon, 418

Ramis, Roger de, 349, 353,408, $428 a, 435 a, 445 a, 542 b, 543 a$, $543 b, 544^{a}$

Raner, $465 \circ$

Ranulf, $473^{b}, 475^{b}, 476 a, 47^{6} b$, $546 b$

Ranulf brother of Ilger, 352 , $428 a, 435 b, 446 a, 538 a, 538 b$, $539 a, 539 b, 540 a, 540 b, 541 a$

Rauenot, $528 a$. See also Ravenot

Ravengar, $448 a, 455 b, 456 a, 508 b$

Ravenot, 531 a. See also Rauenot

Redeswell, Master Robert, note $479^{b}$

Reimund. See Girald

Renald, $512 b$. See also Rainald, Renold

Renelm', 508a. See also Rainald, Rainalm

Renold, 536a. See also Rainald

Restolt, $544 a$

Richard, 386, 462a, 467b, 473b, $474 a, 475 a, 475 b, 476 a, 476 b$, $493 a, 493 b, 495 a, 495 b, 499 b$, $502 b, 503 a, 503 b, 506 a, 507 a$, $511 b, 5$ 1 $3 a, 514 a, 515 b, 526 b$, $527 a, 532 b, 538 b, 539 a, 540 b$, $568 a$

Richard a man of Hamo, $566 a$

Richard son of Count Gilbert. See Clare, Richard de

Robert, $465 b, 466 b, 470 a, 478 a$, $486 b, 487 b, 489 b, 490 b, 499 a$, $517 a, 518 a, 520 b, 522 a, 531 a$, $562 b, 567 a$
Robert Gernon. See Gernon

Robert 'invesiatus,' $445 b$

Robert 'lascivus,' 5 I $8 b$

Robert son of Corbutio, 390 $428 a, 430 a, 545 b, 546 a, 546 b$, $547 a, 547 b$, notes $337,430 a$

Robert son of Gobert, $427 b, 564 a$

Robert son of Godebold, 392, note $490 a$

Robert son of Ralf de $\mathrm{Ha}_{\text {a }}(\mathrm{s})$ tinges, $384,578 b$

Robert son of Roscelin, $427 b$, $563 a$

Robert Fitz Walter, note $479^{b}$

Robert Fitz Wimarc sheriff of Essex, 345, 349, 410a, 410b, $455 b, 482 a, 482 b, 484 b, 485 b$ $486 a, 486 b, 4^{8} 7 a, 487 b, 4^{88} a$ $488 b, 4^{8} 9 a, 4^{8} 9 b, 490 a, 490 b$, $491 a, 491 b, 564 b, 569 b, 577 a$ notes $345,358,489 b$

Robert the archbishop, 345

Robert the deacon, note 345

Rochester, Turold of ['Turoldus de Hrovecestria, Rovecestra], $34^{2}, 435^{b}, 44^{8 a}, 459 a, 460 a$, $460 b$, note 342

Ralf son of. See Ralf

Rochford. See John son of Guy

Roger, 461a, 480b, $4^{87 b}, 499 b$, $506 a, 52+b, 525 a, 536 b, 539 a$, $54 \mathbf{1} a, 542 b, 544 b, 554 a, 554 b$, $567 a, 570 b, 576 a$

Roger a man of the Bishop of London, 435b, 438a, 438b, 439a, $440 b$

Roger 'God save the ladies,' $427 b, 453 b, 562 b$

Roger of Poitou. See Poitou

Roger the marshal, $427 b, 507 b$, $558 b$

Rosell', $576 a$

Rykham, William de, note $519 b$

Sackville [Sachevilla], Richard de, $379,462 a, 491 b$

Sackville, Robert de, 379

Sackville [Sakevilla], William de, 379

Sacrim', 422, 575b. See also Sægrim, Segrim

Sxwele, $576 a$

Srgrim, Sagrim' (Colchester moneyer), 422, 576a. See also Sacrim, Segrim

Sagar, 575a. See also Segar

St. Edmund's. See Bury St. Edmunds

St. Martin of London. See London

St. Osyth, Abbot of, note $456 b$

St. Ouen, Germund de, $513 a$

St. Ouen (of Rouen), Abbey of, $34^{1}, 34^{2}, 4^{27} a, 454^{a}, 454^{b}$

Monks of, 419

St. Pauls. See London 


\section{INDEX TO DOMESDAY}

St. Peter of Mersea, $34^{2}$

St. Quintin, Hugh de, $4276,557 b$, $55^{8} a, 566 a$

St. Stephen of Caen. See Caen

St. Walery, Abbey of, 342, 427a, $452 b, 453 a$ Abbot of, 392

Saisselin, Sasselinus, $4276,556 a$, 5566,5576

Salvare, 5756

Samar, $492 a$

Sasselinus. See Saisselin

Saswalo, Sewal, $527 a$, nose $527 b$

Saulf, $506 a, 575 b$

Sawart, $575^{b}$

Sawin [Sauin] the priest, 358 , $507 a$

Scadebutre, $575^{6}$

Scalariis, Hardwin de, $338,430 b$

Scales, Robert de, $390^{\circ}$

Scal pinus [Scalpin, Sca] pius, Scapi, Scapius] a thegn of Harold, 352 , $507 a, 507 b, 520 b$

Scohies, William de, $428 a, 551 a$

Segar, 459b. See also Sagar, Sigar

Segrim (burgess of Colchester), 417. See also Sacrim, Sxgrim

Seiher le Chien, 392

Selva, 5196

Sercar, $547 b$

Serlo, 386, $526 a, 5266,5283$, 5416

Seward. Sec Siward

Sexi, $551 a, 557 a$

Sexi housecarl of King Edward, $352,554^{b}$, nore $554^{b}$

Sigar, 441a. See also Segar

Simond, $475 a$

Sired, $471 a$

Siric, 457a, 482a, 490a, 491a, $538 b, 576 a$

Siward, $503 b, 518 b, 576 a$

Siward a free man, $463 a, 473 b$

Siward of Maldon. See Maldon

Siward the priest, $575^{6}$

Someri. See Sumeri

Sprot, $518 b, 575 a, 576 b$, nose $447 b$

Stamburc, 5766

Stan, $575^{6}$

Stanard, 4286

Stanard 2 free man, $565 b$

Stanart, $575^{\circ}$

Stanhard, $452 a$

Stanhert, $576 a$

Stephen, King, 344

Stercher, $547^{\circ}$

Stille, Alwin, 5250

Stotinc, $576 a$

Stric, Alestan, $444^{6}$

Suad, $534 a$

Suain [Suan', Sueno', Suen'], $545 b, 563 a, 576 b, 577 a$

Suain [Suanus, Suen, Sueno, Suenus, Swegen, Swein] sheriff of Essex, 344, 345, 346, 349,
$365,374,383,384,386,391$, $393,398,399,407,408$, $410 a, 410 b, 413,427 a, 428 b$, $429 a, 431 b, 434 a, 435 a, 435 b$, $436 a, 456 a, 456 b, 482 a, 482 b$, $483 a, 4^{8} 3 b, 4^{8} 4 a, 484 b, 485 a$, $485 b, 486 a, 486 b, 4^{8} 7 a, 487 b$, $488 a, 4^{88 b}, 4^{8} 9 a, 489 b, 490 a$, $490 b, 491 a, 491 b, 508 b, 569 b$, $577 a$, notes $345,355,435 a$

Suen' Suart, $5366,554^{b}$

Suertlinc, $575 a$

Suertinc, $576 a$

Sueting, 4736

Sumeri, Roger de, $471 a, 471 b$

Sunegot, $576 a$

Sutton, Robert de, 372

Surrey, sheriff of, $433 a$

Swegen. See Suain

Talebot, Geoffrey, $552 a, 552 b$

Tascelin the priest, $431 a, 439 a$

Tate, 5756

Teher, $455 b$. See also Tihel

Tescho, $576 a$

Thierri [Tedric] brother of

Walter the deacon, $354,547^{6}$

Thierri [Tedric], Pointel. See Pointel

Thurbern. See Turbern

Thurchil. See Turchil

Tibetot, Henry de, note 392

Tidbald', 438a, $570 a$

Tihel the Breton [Britto], Tihel de Herion [Heliun, Heriun], $350,428 a, 457 a, 541 a, 541 b$, $542 a, 542 b$. See also Teher

Tirel, Walter, $349,+816$

Tiselin, 562a

Toesni [Todeneio, Todeni], Ralf de, $352,427 b, 554 a, 554^{b}$

Toesni [Todeneio], Robert de, $4276,554^{a}$

Tofig the proud, 343 note

Toli, $507 b$

Tonbrige, Richard de. See Clare, Richard de

Topi, 5196

Torbern, $468 b$

Tornindone, William de, 399

Torold, $440 b$

Tosti, $444^{6}$

Tosti a free man, $545 a$

Toti, $477 a$

Tovi a free man, 5616

Tovig [Tovi] (burgess of Colchester), $417,575^{6}$

Tovig. See also Tofig

Tovillda, $573 a$

Tunbridge. See Tonbrige

Tunric, 5760

Turbern [Thurbern, Thurbert, Turbert], 350, 417, 500b, $502 b, 503 a, 503 b, 574 a, 576 b$ Turchil [Thurchill, Turchill], $459 a, 4^{8} 3 a, 490 a, 505 b, 577^{a}$ 585
Turchil, Thurkil, a free man, 342 , $418,453 a, 453 b, 496 b, 559^{b}$ Turchil the reeve, 4286,5656

Turgis, $492 a$

Turgot, 4516

Turold, $483 a, 505 a, 527 a, 528 b$, $529 b, 530 a, 531 b, 532 a, 567 b$, 5706 . See 2lso Rochester, Turold of

Turstan, $575^{b}$

Turstin, $544^{b}$

Turstin a free man, $539 a$

Turstin the Red, 443a

Tyrel. See Tirel

Ulbert, $475^{b}$. See also Wibert

Ulf a thegn of King Edward, $462 a$

Ulfeih, 5126

Ulfeit, 5756

Ulfo, 4966

Ulfric, 522a, 575b. See also Ulvric, Wulfric

Ulmar, $44^{1} b, 4^{6} 4 a, 476 a, 476 b$, 48 เa, 498a, 499a, $551 a, 569 a$

Ulmer', Ulmar', a free man, $411 a$, $4 ! 1 b, 460 a, 492 b, 493 b, 494 a$, $494 b, 495 b$

Ulric, $576 a$

Ulsi, 443a, 500a, 546b, 562b, $575 b, 576 b$

Ulsi a certain freeman, $545^{b}$

Ulsius, noce $453^{b}$

Ulstan, $575 b, 576 a, 576 b$

Ulstan Eudlac, $575^{\circ}$

Uluin, 575a. Sec also Ulwin, Wulfwine

Ulvart, $5755^{\circ}$

Ulveva, $576 a, 576 b$

Ulveva wife of Phin the Dane, $348,355,428 b, 565 a, 565 b$

Ulvric, $504 b, 510 a, 568 a, 573 a$, $575 a, 575 b, 571 a, 576 a, 576 b$. See also Ulfric, Wulfric

Ulvric a free man, $460 b, 465 a$, $4^{6} 9 a, 473 b, 511 a, 537 a, 573^{b}$

Ulvric Cassa, 493a

Ulvric Cawam, 510 a

Ulvric the priest, $531 \mathrm{a}$

Ulward the priest, $532 b$

Ulwart the priest, $575^{6}$

Ulwin, $457 b, 458 a, 475 b, 480 b$, $506 a, 506 b, 510 a, 517 a, 518 a$, $520 b, 529 b, 537 b, 538 a, 556 a$, $570 b, 575 a, 575 b, 576 a, 577 b$

Ulwin the crier, $575 a$

Ulwine, 440b. See also Wulfwine

Ustan, 490b. See also Ulstan

Valognes [Valoniensis], Peter de, sheriff of Essex and Hertfordshire, $339,349,363,396,406$, $428 a, 428 b, 430 a, 432 b, 434 b$, $435 a, 442 b, 49 t a, 536 a, 536 b$, $537 a, 537 b, 538 a, 553 b, 554 a$, note 349 


\section{A HISTORY OF ESSEX}

Vaux, Robert de, 549b

Vere,Aubrey de [Albericus deVer], $343,350,367,383,386,396$, $428 a, 472 b, 473 a, 532 b, 533 a$, $533 b, 534 a, 534 b, 535 a, 535^{b}$, $536 a, 569 b, 577 b$

Wife of, $343,457 a, 457 b$, $570 a$

Verli, Hugh de, $410 b, 513^{b}$

Verley [Verli], Robert de, 389 , $516 a, 518 a, 520 a, 521 b$

Viel [Vitalis], 477b, $529 a, 529 b$

$\mathrm{W}[\quad], 483 a, 485 a, 507 a$, $538 a, 540 a, 546 b$

Walchclin, Bishop. See Winchester, Bishop of

Waleram, 342, 419, 435a, 435b, $454 a, 545 b, 570 b, 578 b$, notes 364,421 . See also John

Walicher(ius), Galicer(ius), $522 a$, 5236

Walter, $441 a, 474 b, 482 a, 484 a$, $486 a, 488 b, 505 b, 506 a, 508 b$, $520 a, 538 a, 540 a, 572 b, 576 b$, note $527 b$

Walter (de Caen), $550 b$

Walter Fitz Robert, 396, note $525 a$

Walter the cook [Walter the son of Guibert], $427 b, 431 a, 559 b$, $560 a$

Walter the deacon, 349,351 , $354,393,428 a, 435 b, 547 b$, $548 a, 548 b, 549 a$, note $499 b$

Waltham [Walham] Abbey (Holy Cross), 337, 341, 364, 375, $380,385,399,4466$, notes 334,365

Canons of, $427 a, 446 b$, $447 a, 447 b$

Waltheof, Earl, $555^{b}$

Wand or Wants, AElfric [Alvric], $355,35^{8}, 495^{b}, 496 a$

Warenne [Warene, Warenna], William de, 341, 393, 427a, $446 a, 449 a, 450 a, 473 b, 474 a$, $474 b, 475 a, 475 b, 476 a, 476 b$, $544 b$, note $501 b$
Warner son of Richard Petitsire, note 393

Watevill', Robert de, 481

Wateville, Watteville, William de, $474^{b}, 577^{\circ}$

Wdebil, Vudebil, $576 a$

Wed, Vued, $575^{b}$

Westan, $576 a$

Westminster, Abbey (St. Peter), $337,340,341,427 a, 444 a$, $444 b, 445 a, 445 b, 567 b, 568 a$, note $459^{b}$

Abbot of, $363,577 a$

Wiard, 4860

Wiberga, $542 b$

Wicard, $4^{89 b}$

Wicga, $575 b$

Widi, $501 a$

Wielard, $478 b, 48 \mathrm{1} b, 571 a, 573^{b}$ William, 437b, 438a, 441 $a, 44 \mathrm{I} b$, $44^{8} a, 450 b, 507 a, 508 a, 5$ I $1 a$, $511 b, 512 a, 519 b, 537 a, 540 b$, $541 a$

William nephew of the bishop, $418,577 a$. See also William the deacon

William son of Brien, 4409

William son of Constantine, $427 b$, $563 a$

William son of Grosse, Grossa, $429 a, 45 \mathrm{I} a, 497 b, 566 a, 567 b$, $568 a$

William Fitz Odo, $483 b$

William Fitz Oto, note $464 a$

William the chamberlain, 4450

William the Conqueror, 336,337 , $338,339,345,363,386,395$, $418,427 a, 428 a, 428 b, 429 a$, $429 b, 430 a, 430 b, 43 \mathrm{I} a, 43 \mathrm{I} b$, $432 a, 432 b, 433 a, 433 b, 434 a$, $434 b, 435 a, 435 b, 436 a, 436 b$, $482 a, 490 a, 490 b, 510 a, 511 b$, $515 a, 527 b, 564 a, 565 b, 566 a$, $573 b, 574 b, 577 b$, note $565 a$

Encroachments on the King's Land. See note below

Freemen of the King, $428 b$, $566 a$

\section{PLACE NAMES}

Abberton [Edburghetuna, Edburgetuna], $463 a, 489 a$, 529a, note 361. Sec also Badcocks

Abbess Hall in Great Wigborough, note $448 b$

Abbess Roding. See Roding

Abbess Warley. See Warley

Abbots in East Horndon, 399, note $552 b$
William the Conqueror (continued) -

Reeve of the king, $430 a$

Servant of the king, $565 b$

William the deacon, 418,4276 , 5596

William the brother of King Henry II., 392

Wimarc [Wymarc] (mother of Robert, sheriff of Essex), 345

Wimund, 5030

Winchester, Bishop Walchelin of, $419,578 b$, note 42 I

Winemer, $575 b$

Winge, $557 b$

Wiscart, Turstin, $577 a$, note $544^{b}$

Wisgar [Withgar] son of Elfric, English Lord of Clare, 348, $353,477 a, 477 b, 478 a, 478 b$, $479 a, 4^{80} a, 480 b, 4^{81} a, 4^{81} b$, 5720

Wisgar a free man, $472 b$

Wlbert, $475 b$. See also Ulbert

Wlward, $558 a$. See also Ulward

Wulfmar of Eaton. See Ulmar a free man

Wulfric (Colchester moneyer) 422

Wulfric, Abbot of Ely, 346

Wulfwine, $343,353,358,532 b$, $533 a, 533 b, 534 a, 534 b, 535 a$, $535 b, 576 a$. See also Ulwine Wulfwine (Colchester moneyer) 422

Wytenham, John de, 394

Wytenham, Roger de, 394

Note.-As it is difficult to estimate the amount of irregular 'encroachments' in the county (see p. 354 above), the following list of references to them may be found useful :-

Encroachments (Aggressions) on the king's land, 428b, 566a, $566 b, 567 a, 567 b, 568 a, 568 b$, $569 a, 569 b, 570 a, 570 b, 571 a$, $57 \mathrm{I} b, 572 a, 572 b, 573 a, 573 b$, $574 a, 574 b$
Abbot's Hall saltings, note $38 \mathrm{I}$

'Acleta,' 391, 395, 493 a

Acton (Suffolk), 346

Alderford (?) [Alreforda], $478 b$ note 5710

Alderton (Hall) in Loughton [Alvertuna], 4470

Aldham [Aldeham], $457 b$

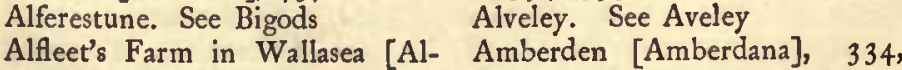
ford-nashe-Marsh], 37 I 586
Alphamstone [Alfelmestuna], 387 , $45 \mathrm{I} b, 479 b, 572 a$, note 408

Alreforda. See Alderford (?)

Alresford [Aleforda, Eilesforda, EIesforda], 342, $4^{11}, 440 b, 460 a$, $470 a, 480 b$, notes $435 b, 478 b$

Althorne ['Alestorn '], 387, 391, 394,395

Alveley. See Aveley $341,346,362,363,377,5290$ 


\section{INDEX TO DOMESDAY}

Amwell (Herts) [Emwella], 338, $429 b$

Archers, manor of, nose $514^{b}$

Ardern $\mathrm{Hall}$ in Horndon on the hill, 398

Ardleigh [Dereleia, Derleia, Erleia, Erlega, Herlega], 352 , $385,508 a, 520 b, 54^{1} a, 543^{b}$, $544 a, 552 a, 5610,577 a$. See also Bovills, Martells Hall, Picotts

Arkesden [Archesdana], 355, 391, $404,496 a, 496 b, 521 a, 569 a$. See also Eynesworth, Wiggepet and Wood Hall

Ashdon [Ascenduna], 347, $525^{6}$. See also Newham, Rothe (End), Stevington (End)

Asheldam [Aintune, Hainctone, Hainctuna, Haintuna], 391 , $392,393,410 a, 410 b, 488 a$, $489^{b}$, notes $394,457^{b}$

Ashen [Asce], 478b. See also Claret Hall

Ashingdon [Nesenduna], 4876, note 4876 . See also Beckncy Ashwell (Hall) in Finchingfield [Assewella], 391, 560a

Aspenden (Herts), 379, nose $495^{6}$

Assingdon. See Ashingdon

Assington (Suffolk), 346

'Ateleia,' 500a

Aveley or Alveley [Alvithelea, Alvilea, Avileia], 342, 419 , $457 b, 545 b, 563 a$. See also Kelington

(Aythorp i) Roding. See Roding

Babraham (Cambs), 338, 353 , notes $4306,431 a$

Bacton (Suffolk), 35 I

Badcocks in Abberton, note 4890

Baddow, 336, 337. See also Middlemead

Baddow, Great [Badewen], 337, $362,453 b, 562 b$

Baddow, Little [Badwen], 395 , $396,407,468 a, 524 a$, note 4420

Ballingdon, Balingdon [Belindune], 405, 406, 408, $537 a$

Bapthorne in Birdbrook (now Baythorne) [Babiterna], $540 a$

Bardfield, 380

Bardfield, Great [Birdefelda, Byrdefelda], $360,362,481 b, 572 b$

Bardfield, Little [Birdefelda], 4726

Bardfield (Saling ?) [B(er)defelda], 4816

Barking [Berchinga], 334, 364, $380,385,402,4486$, note 382

Barkway (Herts). Sec Newsells

Barling [Berlinga], 340, 366, $443 b, 456 b$
Barnston [Bernestuna], 343, $510 a$ Barnwalden [Borooldituna], 5230 , note $501 b$

Barrow ( $\mathrm{H}_{\text {all }}$ ) in Wakering [Berrewera], 348, 4820

Barstable (Hail) in Basildon [Berdestapla], 342, 368, 4550 Barstable [Berdestapla], Hundred, 369, 374, 376, $398,407,409,428 a, 440 b$, $442 a, 444^{a}, 44^{8} a, 452 a, 454^{b}$, $460 b, 473 b, 482 a, 497 a, 500 a$, $508 a, 514 a, 526 a, 545 b, 547 b$, $556 a, 558 a, 558 b, 560 a, 561 a$, $561 b, 564 b, 565 a$, notes 370 , $432 a, 455 b$

Barton (Norfolk), 347

Barton Hall in Great Stambridge, nose $486 a$

Barwick $\mathrm{Hall}$ in White Colne, notes $481 a, 5350$

Basildon [Belesduna, Berlesduna] 369 , 483a. See also Barstable (Hall)

Bassets in Baddow, note $442 a$

Bassingborns in Takeley, note 5166

Batayles in Stapleford Abbots, nove $518 a$

Battails in Bradwell by sea, [Effecestre], 391, 392, note 4996

Baynard's Castle. See Castle Baynard

Baythorne. See Bapthorne

Beauchamp Roding. See Roding

Beauchamp St. Ethelbert in Ovington [Belcham], 404,464b

Beaunnont [Fulepet, Fulanpettx], $381,396,5354$, nose 356

Beckney (?) in Ashingdon [Bacheneia], 388, 456a

Becontree (Bentry) Heath, 406 Becontree [Beventreu] Hundred, $406,409,429 b, 438 a, 444^{b}$, $446 b, 448 b, 497 b, 515 a, 527 b$, $536 b, 546 a, 555 b, 559 a$

Bedford, note 422

Beeches in Rawreth, 387, note $456 n$

Belchamp, 405. See aiso Beauchamp

Belchamp Otton [Belcham], 5496. Sce also Vaux

Belchamp Otton [Belcham], 356, $46+a$

Belchamp St. Paul's [Belcham], $334,366,4426$

Belchamp Walter [Belcamp], 383 , $386,405,5340$

Belcumber Hall in Finchingfield, 356

Belesdun. See Basildon

Belesham (Cambs), note $432 b$

Bellencombre (Normandy), 356

Belstead (Hall) in Broomfield [Belesteda], 476a, 564a 587
Bendfield, Bendfield(bury) [Benedfelda], 5166 , nose 407

Bendish (Hall) in Radwinter [Benedise], 348, 362, 4716 , $572 a$

Benflect, Bemfleet [Benflet], 337 , $340,357,363,373,428 a$, 4326

Benfleet, Bemfleet, North, 369 , nose 428a. See also Fanton Hal]

Benfleet, Bemflect, South [Benflet], 444a, $483^{b}$. See also Jervois, Southall

Bennington (Herts), 349

Bennington (Hall) in Witham [Breddinchou], 45 ta

Bentley, 350, 396

Bentley, Great [Benetleia], 381 , 5350

Bentley, Little [Benetlea, Menetlea], 473a, $480 b$

Berden [Berdane], $489^{b}$

Berechurch or West Donyland, 404

' Berewic,' 4590

Bergholt, West, Bergholt Sackville [Bercolta, Bercolt], $481 a, 5516$, $573 a$, notes $379,5176,5526$

Bermondsey Abbey, notes 5086 . $545 a$

Berners Roding. See Roding

'Bercuna', 5586 , ;69b

Berwick in Rainham (?), note $518 a$

Berwick Hall. See Barwick Hall Bigods in Dunmow [Alferestune], $356,377,387,510 a$

' Bineslea,' 405, 406, 478b, $537 b$, nose 406

Birch, 385

Birch, Great [Bricceia], 389, 402, $466 a$

Birch, Little [Bricia, Parva Bricceia], 389, 402, 518a, $55^{8 a}$

Birch Hall in Kirby, nose 4706

Birchanger [Becangra, Bilichangra, Blichangra], 377, $431 a, 453 a, 513 a$

Bircho in Kirby [Birichou], $470 a$

Birdbrook [Bridebroc], 352, 5396. See also Bapthorne, Hersted Hall

Bishop Stortford [Estorteford], $338,339,405$

Bishop's Hall in Chelmsford, note 4396

'Blacham', 469a

Black Notley. See Notley

Blackmore, 375. See also Fingrith

B(1)amsters Hall in Great Easton, 356,393 , note 4740

Blunts Hall in Witham [Blundeshala], $3^{89}, 4^{62 a, 5266}$ 


\section{A HISTORY OF ESSEX}

Bobbingworth [Bubingeorda], Bromley, Little [Brumlea, Brum362,5400

Bocking [Bochinges], 340, 369, 4366

Bocking Hall in Mersea [Meresai], $340,436 b$

Bockingham Hall. See Botingham

Bollington in Ugley [Bolituna, Bolintuna], $517 a, 569 b, 570 a$

Bonhunt [Banhunta], $557 a$

Bonnington (Kent), note $497^{b}$

Boreham [Borham], 390, 404, $468 b, 476 a, 490 a$. See also Culverts, Walkfares, Cuton Hall

Borley [Barlea], 555b, $571 b$

Borough Field or Fields. See under 'Colchester'

Bosmere Hundred (Suffolk), note 409

Botingham (now Bockingham Hall) in Copford [Botingham], $568 a$

Boughton (Norfolk), 347

Bovills in Ardleigh, note $552 a$

Bowers (Gifford) [Bura], 355, $356,374,376,377,444 a$, $526 a, 547 b, 564 b$. See also Richernesse

Boxted [Bocchesteda, Bucchesteda], $465 b, 494^{b}$

Boyton Hall in Finchingfield [Boituna], 391, 480a, note 4316

Bradenham (Norfolk), 347

Bradfield [Bradefelda], 353, 380, $543 b, 55^{1 b}, 55^{2 a}$, note $524^{b}$

Bradfield Manston [Manestuna], $380,544 a$

Bradwell-by-Sea [Effecestre, Effecestra, Duna], 346, 369, 391, $392,453 a, 499 a$, notes 391 , $492 a, 497 a$. See also Battails, Down Hall, East Hall, Eastlands

Braham $\mathrm{Hall}$ in Little Bromley, 388 , note $+80 b$

Braintree [Branchetreu], $41 \mathrm{I} a$, $411 b, 412,570 b, 573 b$, note $438 b$

Brandon. See Brundon.

Brantham [Braham] (Suffolk), 388

Braxted, Great [Bracchesteda, Brachesteda], 362, 379, 491 $b$, notes $497 a, 500 b$

Braxted, Little [Bracteda], 4416

Brentwood, 375

Bretts in Aveley, note 4906 . See Kelington

Brightlingsea [Brictriceseia], 334, $336,337,338,434 b$, note 382

Bromley, 348, 4I 2, note 385

Bromley, Great [Brumbeleia], $5^{6} 3^{6}$ leia], $35 \mathrm{I}, 4806,5486$. See also Braham Hall

Broomfield [Brumfelda], 343, 506a. See also Belstead (Hall), Patching(Hall), Patching(Hall Picot)

Broxted [Broccheshevot], 341, $450 a, 493 b$

Brundon [Branduna, Brumduna], 377, 408, 553a, 554a

Buckland (Berks), note 373

Bulmer [Bulenemera], 479a, note 406. See also Goldingham, Smeeton (Hall)

Bulphan [Bulgeven], 375, 398, $448 a$, note $508 b$

Bumpstead [Bumesteda], 362 , $407,572 a, 574 a$, notes $475 b$, $534 a$

Bumpstead, Helion('s) [Bumesteda, Bunsteda], 350, 356 , $535 b, 541 b$, note 534a. See also Bumpstead Hall, Hersham Hall

Bumpstead, Steeple [Bummesteda, Bumesteda], $464 b, 473 a$, Moyns

Bumpstead Hall, note $535^{6}$

Bures, Mount [Bura], 408, $543^{b}$, $551 a$, note $379,517 b, 552 b$

Bures St. Mary [Bura], 342, 408, 419

Bures hamlet [Bura] in, $408,479 a, 480 a, 545 a$

Burgate (Suffolk), note $534^{a}$

'Burna,' 469b

Burnham [Burneham], 369, 389 , $523 b, 566 b$, note 382 . See also Westwick

Burstead, 352, 369

Burstead, Great [Burghesteda], $376,454 b$

Burstead, Little [Burghesteda], 362,4410

Butlers Hall in Bulmer, note $479 \circ$

Butsbury [Cinga], 350, 369, 504a. See also Thyrstlinge Hall (?)

Buxhall (Suffolk), note $55 \mathrm{I} b$

Caldecots in South Weald, note $518 b$

Canewdon [Carenduna], 37I, 485b. See also Putsey

Canfield [Canefelda], 350, 568a, note $472 b$

Canfield, Great [Canedfelda, Canefelda], 378, 472b, $532 b$

Canficld, Little [Canefelda, Chenefelda], $384,474 a, 511 b$. See also Langthorns

Canterbury [Cantuaria], 415, 416 , note 418 $475 a, 479 b, 542 a$. See also

Camseys in Felsted, 390
Cantis in Horndon on the hill, 398 , note $441 a$

Canvey Island, 369, 371, 372, 373 , note 370

Cardens, Cardon's Hall, in Great Chishall, 356, note $512 b$

'Carseia,' 'Careseia,' 395, 502b, 569a. See also Northey (isle)

Castle Baynard. See London

Castle Camps (Cambs), note $571 a$

Castle Hedingham. See Hedingham

'Celvestuna,' ' Chelveston,' 479b, $570 a$

Chadwell [Celdewella], 342, 355 , $380,441 a, 455 b, 564 b$, notes $369,448 a$

Chafford [Ceffeorda, Ceffeurda, Cesfeworda] Hundred, 355 , $369,406,407,409,433 a$, $439 a, 440 a, 445 b, 447 b, 449 a$, $457 b, 475 b, 490 b, 505 a, 518 a$, $545 b, 553 a, 554 b, 556 b, 565 b$, $568 a$, note 370

Chalk (Kent), 338

Channels in Little Waltham, note $45^{1} b$

Chardwell, note 4766 .

Charsford (Suffolk), 352

Chatham in Great Waltham [Cetham], 506a

Chawreth [Ceauride], $412,573^{b}$

Chelmsford [Celmeresfort], 385 , $439 b$, notes 374,406 . See also Moulsham

Chelmsford [Celmeresford, Celmeresforda, Celmeresfort] Hundred, $389,390,406,409$, $433 b, 443 a, 445 b, 449 a, 451 b$, $45^{2 a}, 453^{b}, 458 b, 468 a, 475 b$, $490 a, 495 a, 499 a, 504 a, 505 b$, $518 b, 524 a, 531 a, 540 b, 546 b$, $555 a, 565 b$, notes $433 a, 442 a$

'Chelveston.' See 'Celvestuna' 'Cheneboltuna,' $479 b$

Chester, 415,416

Chesterford (Great) [Cestreforda], $334,337,33^{8}, 4306$

Chesterford, Little [Cestrefort], 334,35 I, 549a

Cheswick (Hall) in Chreshall [Cesewic], $554 a$

Chich, Chiche. See St. Osyth

Chich-Ridel in St. Osyth, note $53 \mathrm{I} b$

Chichester, 415

Chicknal. See Chignal

Chickney [Cicchenai], 385,5276

Chignal [Cingehala], 343, 358, $506 a, 506 b, 507 a$

Chignal St. James, 404, note $519 a$

Chignal 'Tany,' note 5190

Chignal 'Zoyn' [Cinguehella], 5190 


\section{INDEX TO DOMESDAY}

Chigwell [Cinghewella], 387 , 5536,5546 . See also Wolverston

Chigwell Hall, note 5536

Childerditch [Ciltendis, Ciltedic], $369,433 a, 482 b, 556 b$

Chingford [Cingefort], 340, 375 , $380,514 b$, nose 368

Chingford, Earl's, nose 5146

Chingford (St. Paul's) [Cinghefort ], $442 a$

Chipping Ongar. See Ongar

Chishall [Cishella], 362, 4966

Chishall, Great [Cishella, Cishelle], 476b, $512 b, 569 b$, $574 b$, noses $451 a, 471 a$. See also Cardens, Tewes or Lisles

Chishall, Little [Cishella], $471 a$

Chishall, Over, note $496 b$

Chreshall [Cristeshala], 352, note 362,4706 . See also Cheswick, Crawleybury

Clacton-on-Sea [Clachintuna], $334,339,380,405,439^{6}$

Clapton ['Dotone'] (Northants), 395

Clare (Suffolk), 335, 382

Claret (Hall) in Ashen, 361, 4646

Clavering [Clavelinga], 334,345 , $362,377,4^{89 a}, 4^{89 b}$

Clavering [Clavelinga], Hundred, $406,407,409,494 a, 502 a$, $513 a, 523 b$

Clavering [Clavelinga] Half Hundred, 475a, 489a, $516 b$, $533 a, 556 b, 569 b$

Claydon Hundred (Suffolk), note 409

Claydons in East Hanningfield, nore $524 a$

'Cliva,' 5440

Clopton (Suffolk), note 4776

Cocket Wick in St. Osyth, 373

Coggeshall [Cogheshala], 363, $377,385,461 b, 562 a, 567 a$

Church of, 344

Coggeshall, Little [Coghessala], $436 b$, nobe $497 a$

Colchester [Colecestra], 335, 350, $351,385,386,412,414$, $416,417,418,419,420$, $421,423,424,440 a, 445 a$, $449 a, 454 a, 462 a, 465 b, 466 a$, $527 a, 574 a, 574 b, 575 a, 575 b$, $576 a, 576 b, 577 a, 577 b, 578 a$, 5786 , notes $363,4326,477 b$

Borough Field or Fields, 423

Castle, 418

Headgate [Havedgate], 424

'Portmannesfeld,' note 423

St. Andrew, Chapel of, 424

St. John, Abbey of, 347 , notes $4966,565 a$

St. Mary's Church, 424
Colchester (continued) -

St. Mary Magdalen, Hospital of, note 419

St. Peter's Church, 384 $419,423,424,5766$, 5786 , nose 414

See also Greenstead, Lexden

Colchester $\mathrm{Hall}$ in Takeley, nose $494^{\circ}$

Colchester [Colecestra] Hundred, $406,414,5740$, nose 409

Cold Norton [Nortuna], 376 , 522a. See also West Whetenham and Flambards

Colne [Colun], 351, 451b, 481a, $572 b, 573 a, 574 a$

Colne, Earl's [Coles], 367, 5346, nose 5306

Colne Engaine [Colun, Parva Colun], 351, 356, 403, 466b, $5486,550 b$. See also Overhal Colne Miblanc, note 5346

Colne, Wakes [Colun], 550b, note 466b. See also Creping Hall

Colne, White [Colun], nokes $534^{b}$, 535a. See 2lso Berwick Hall, Ingledesthorpe

Coleness Hundred (Suffolk), 370

Copford [Copeforda], 439a, note 406. See also Botingham Hall

Cornard (Suffolk), 351

Corringham [Currincham], 44 Ia

Cowbridge in Mountnessing [Cubrigea], $540 b$

Cowick Bury. See Quickbury

Cranham [Wocheduna], 375 , 4400

- Craohu,' 4586

Crawleybury [Crawelæa], 4716

Creping Hall in Wakes Colne [Crepinges, Crepinga], 5606 , $573 a$, note $481 a$

Creshall. See Chreshall

Cricksea [Criccheseia], 4566, 5606

Culverts in Boreham [Richeham], 391,5196

'Curlai,' $522 a$

Cuton Hall in Boreham, 390, 5076

Dagenham, 406

Dagworth (Suffolk), note $497 b$

Dale Hall in Lawford, notes $435 a$, 4706

Dalham (Suffolk), note 4776

Danbury [Danengeb(er)ia], 407, $507 a$

Dangeybrigge in Dengie, nose 372

Dansye, Dansing, Dauncing Hundred. See Dengie

Debden [Deppedana], 346, 362, $383,529 a$. See also Amberden

Debden in Loughton [Tippedana], $447^{\circ}$
Debenham (Suffolk), 351

Dedham [Delham], 353, 5436, nose 5246

Dengie, Dengey [Daneseia], 369, $453^{b}, 457 a$, nose 373

Dengie, Dengey [(then) Witbrictesherna] Hundred, 342, $369,372,376,384,388,391$, $393,394,395,406,409$, $430 a, 432 a, 437 a, 438 b, 442 a$, $442 b, 453 a, 456 b, 457 a, 462 b$, $465 a, 4^{8} 7 b, 4^{8} 9 b, 492 b, 497 b$, $499 a, 502 b, 504 a, 512 a, 513 b$, $515 b, 522 a, 523 b, 528 a, 530 a$, $540 a, 548 a, 560 b, 562 a, 565 a$, notes $382,394,442 a, 567 a$, $569 a$

Dikeley in Mistley [Dicheleia]. 5200

Doddeswich in Tillingham, 373

Doddinghurst [Doddenhenc], 5456 , nose $547 a$

Donnington [Cloninctune] (Sussex), 395

Donyland (East) [Dunilanda, Dunulanda ], 355, 466a, 466b, $560 b$, $561 a, 5616$

Donyland, West, or Berechurch, 404

Dover, nose 497a, 498a Constableship of, 389

Dovercourt [Druvrecurt], 362, 396,5350 and rose

Down, Down Hall in Bradwellby-sea [Dona, Duna], 391, $493 a, 530 a, 530 b$

Downham [Ramesdana], 4970

Downton (Wilts), noke 419

Dunmow [Dommaua, Dommawa], $375,385,462 b, 474 b, 4^{88 b}$, $494 a, 501 a, 511 a, 512 a$. See also Bigods, Merks, Southall

Dunmow, Great [Dommaua], 360, 4776. See also Bigods, Merks, Newton Hall, Shingle Hall

Dunmow, Little [Dommawa], $346,347,5106,5226$

Dunmow [Dommaua, Dommaiva] Hundred, 393, 401, 406, 407, $409,430 a, 450 a, 462 b, 4^{6} 3 a$, $472 b, 474 a, 477 a, 488 b, 492 a$, $493 b, 496 b, 501 a, 503 b$, 509a, $522 a, 527 b, 532 b, 555 a, 558 b$, notes $401,452 a, 452 b$

Dunton [Dantuna], 455a, 566b, note 369

Duxford (Cambs), 353, nose 352

Eadwulfsness (now the Sokens) [Eldulvesnasa], 340, 366, 405,4436 , nole 4700

Earlsbury in Farnham, nose 5686 Earl's Chingford. See Chingford Earl's Colne. See Colne

Earl's Hall in St. Osyth, note 4696 East Donyland. See Donyland 


\section{A HISTORY OF ESSEX}

East Hall in Bradwell-by-sea ['Effecestre'], 391, 392, note $453 a$

East Hall in Paglesham, $476 b$

East Ham. See Ham

East Horndon. See Horndon

East Mersea. See Mersea

East Newland. See Newland

East Thorndon. See Thorndon

East(t)horpe [Estorp], 405, 466a

East Tilbury. See Tilbury

East Whettenham, Whytenham. See Whettenham

Easter, Good [Estra], 341, 362, 4520

Easter, High [Estra], 34 I, 343, $384,509 a$, notes $354,505 b$

Easterford (Kelvedon), note 406

Eastlands in Bradwell-by-sea, note $493 a$

Easton [Estanes], 5 II $a$

Easton, Great [Estanes], 362, 377, 474a, 555a. See also Blamsters

Easton, Little[Eistanes], 349,375, $377,384,391,393,548 a$

Easton Park, Little, 375, 393

Eastness, 405

Eastwood [Estwda, Nestuda], 37 I, $484 b, 487 b$, note 382 . See also Alfleet's Farm

Edwardstone (Suffolk), note $550 a$

'Eiland.' See Nayland

Elmdon [Elm(er)duna], 362, 47 I $a$. See also Leebury

Elmstead [Almesteda], 360, 381 , $385,491 a, 577 a$

Elsenham [Alsenham], 375, 377, $521 a, 559 a$

Elsenham Hall, note 5210

Empford (Stanway Bridge), note 406

Epping [Eppinges, Epinga, Eppinga], $378,407,446 b, 472 b$, 539a, note $44^{6 a}$

Epping Forest, 370, 375

'Esthodelesford.' See Uttlesford

'Estoleia' ['Scoleghe'], 395,498b

Evreux, $507 b$

'Ewenemersh' in Walton, note 373

Exeter, 4I 5, 422, note 422

Eye, Honour of, 379, note $550 a$

Eynesworth in Arkesden [Eineswrda], 391, $476 a$

Fairstead [Fairsteda], 378, 388, $527 a$

Fakenham (Suffolk), 406

Falkenham (Suffolk), 352

Fambridge [Fanbruge, Phenbruge], 394

Fambridge (North) [Fanbruge], $562 a$

Fambridge (South) [Phenbruge], 341,5640
Fange. See Vange

Fanton (Hall) [Fantuna, Phantuna], 34I, 376, 377, 444a, $444 b, 448 a$

Farnham [Pherneham, Phernham], $377,502 a, 517 a, 568 b, 570 a$. See also Hertisho-bury, Earlsbury

Farther Wick in Canvey Island, 373

Faulkbourne [Falcheburna], 350, $417,500 b$

Feering [Feringe, Phering $x$ ], 337 , $385,444 b, 568 a, 577 a$. See also Prested

Felix Hall, note $497^{\circ}$

Felmersham (Beds), note $563 a$

Fclsted, Felstead [Felesteda, Felsteda, Phensteda], 337, 390, $453^{b}, 562 b, 563 a$, note 335 See also Camseys

'Fenna 'or 'Phenna.' See Stow Maries

Fincham (Norfolk), 347

Finching field [Fincinghefelda, Phincingefelda, Phincinghefelda], $337,350,351,358,377$, $404,431 a, 464 b, 465 a, 472 b$, $473 a, 478 a, 478 b, 479 a, 479 b$, $57 \mathrm{I} a$, note $43 \mathrm{I} b$. See also Ashwell, Belcumber (Hall), Boyton, How Hall, Spain's Hall

Fingringhoe, 34 I, 342, note $454^{\circ}$

Fingrith in Blackmore [Phingheria], 4330

Flambards in Cold Norton, 394

Flamstead (Herts), note 554a

Fobbing [Phobinge], 334, 342, $344,353,358,360,380,4606$ Fordham [Fordeham, Forham], $476 b, 481 a, 552 b, 573 a$

Fordwich (Kent), 4I 6

Fornham St. Genevieve (Suffolk), 404

Foulmire (Cambs), 353

Foulness (Island), 37 I, 405

Foulton in Ramsey [Fuletuna], $491 a, 547 a$

Marsh and Chapel, note 372

Foxearth [Focsearde], 479a. See also Weston

Frating [Fratinga, Fretinga], 346, $383,469 b, 532 a$

Freshwell [Frosscewella] Hundred, $409,541 b$, note $452 b$

Freshwell [Frosscewella, Frossewella] Half Hundred, 436a, $450 b, 47 \mathrm{I} b, 473^{b}, 48 \mathrm{I} b, 495 b$, $525 a, 535 b$, note $534^{a}$

Fresling in Butsbury (?) [Festinges], $449^{\circ}$

Frierning [Inga], 5 I $8 b, 5$ I $9 a$

Frinton [Frictuna, Frientuna], $470 a, 5080$

Frowick Hall in St. Osyth [Frorwica], $469 b$
' Fulepet.' See Beaumont

Fyfield, Fifield [Fifhida], 334, $353,400,403,467 b, 545 a$

Gaines in Upminster, note $554 b$

Garemundecote, marsh of, 392

' Geddesduna,' 445b

'Gerham,' 473a

Gernons in Great Oakley, 5200

Gernons in Tolleshunt Darcy, $389,521 a$

Gestingthorpe [Ghestingetorp, Glestingethorp], $337, \quad 348$, $35 \mathrm{I}, 354,362,405,4776$, 564a. See also Overhall

Gibcrakes, note $498 a$

Ging - Joyberd - Laundry (Butsbury), note $504 a$

Gloucester, 4I 5, 422

Goldhanger [Goldhangra], 357, $38 \mathrm{I}, 469 a, 499 b, 532 b$

Goldingham in Bulmer, $550 b$, note 406

Good Easter. See Easter

? Gravesend [Gravesanda], 4०9, $461 a$

Grays ('Thurrock). See Thurrock

Great Baddow. See Baddow

Great Bardfield. See Bardfield

Great Bentley. See Bentley

Great Birch. See Birch

Great Braxted. See Braxted

Great Bromley. See Bromley

Great Burstead. See Burstead

Great Canfield. See Canfield

Great Chesterford. See Chesterford

Great Chishall. See Chishall

Great Dunmow. See Dunmow

Great Easton. See Easton

Great Hallingbury. See Hallingbury

Great Hazeleigh. See Hazeleigh

Great Henny, Heny. See Henny

Great Leighs, Lees. See Leighs

Great Maplestead. See Maplestead

Great Marsh Farm. See Marsh Farm

?Great Mulsham. See Mulsham

Great Oakley. See Oakley

Great Parndon. See Parndon

Great Saling. See Saling

Great Sampford, Sandford. See Sampford

Great Stambridge. See Stambridge

Great Stanford (Rivers). See Stanford (Rivers)

Great Stanway. See Stanway

Great Tey. See Tey

Great Totham. See Totham

Great Wakering. See Wakering 


\section{INDEX TO DOMESDAY}

Great Waltham. See Waltham

Great Warley. See Warley

Great Wenden. See Wenden

Great Wigborough. Sce Wigborough

Great Yeldham. See Yeldham

Greenstead (next Colchester), $378,415,4^{16}, 574^{\circ}$

Church at, 423

Greensted (Ongar Hundred), $362,375,5026$

Guines Court in Tollesbury, 357

Gurmonds in Bradwell-by-sea, marsh of, nose 392

' Hacflet' [Hackeflete], 380, 384, $395,457^{\circ}$, note $457^{b}$

Hadstock [Cadenhou], $450 b$

Hainton [Haintune] (Lincolnshire), nose 394

' Halesduna,' Hailisdune, Haylesdon, $393,498 a$, noses 393,394

Hallingbury [Halingheberia], 405 , $4416,509 a$

Hallingbury, Great [Halingeberia], 496a. See also Wallbury

Hallingbury, Little [Halingebia, Halingeberia], 377, 488a, 5086. Sce also Monksbury

Hallingbury Hall, Litrle, nose soga

Hallingbury-Nevill. Sec Hallingbury, Little

Halstead [Halsteda, Haltesteda], $412,419,475 a, 479 b, 570 b$, $573 a$, nore 364 . See also Hipworth Hall, Stanstead (Hall)

Ham, East [Hame], 385, 444a, $515 a, 527 b$

Ham, West [Hame], 378,385 , $515 a, 527 b$

Hambleden (Bucks), note 337

Hamford Water, 381, 396

Hampton on the Thames, 425

Hanningfield [Haningefelda], 342, $358,359,368,369,416$, $524 a, 5466$. See also Claydons

Hanningfield (South) [Haneghefelda], $458 b$

Hanningfield (West) [Haninge[elda], 341, 390, 475b, 476a

Harkstead (Suffolk) [Herchesteda], $338,434 b$

Harlow [Herlaua], 340, $451 a$, $462 b, 4916,5386$

Harlow [Herlaua] Hundred, 397 , $406,407,409,452 b, 462 a$, $472 b, 477 a, 488 a, 496 a, 501 a$, $508 b, 514 b, 536 a, 538 b, 554 a$

Harlow [Herlaua] Half Hundred, $407,429 a, 441 b, 448 b, 451 a$, $473 b, 491 b$

'Hasingham, $572 b$

Hassingbroke, Hassingbrooke, in Stanford-le-Hope[Hasingebroc, Hasinghebroc], $342,361,455 b$, 4826
Hassobury. See Herrisho-bury

Hatfield Broadoak, Hatfield Regis, $334,337,338,350,363,365$, $375,378,402,405,412,429 a$, 501a, note 363. See also Matching Barnes with Brent Hill, Rise Marses

Hatfield Forest, 375, note 4940

Hatfield Peverel [Hadfelda, Ha[elda], $356,362,376,386$, 456a, 5266 . Sec also Marshalls

Haverhill. (Suffolk and Essex), 335 , $350,376,408,409$, note 5710 Havering [Haveringx, Havelingx], $334,337,363,429 b$, $497 b, 546 a, 568 a$, notes 363 , $365,545 a, 546 a$

Havering-atte-Bower, Liberty of, 406

Hawkwell, Hawkswel] [Hacwella, Hachewella, Hechwella], $411 a$, $411 b, 487 b, 493 b, 495^{b}$

Hayes in Stow Maries, 393, nose 394

Haylesdon. See Halesduna

Hazeleigh [Halesheia, Halesleia], 346,5286

Hazeleigh, Great, nose $528 b$

Hazcleigh, Little, note 5286

Hedinghams, The, 407

Hedingham (Castle) [Haingheham ], 343, 362, 383, 385 , $386,407,5336$, note $574 a$

Hedingham, Sible, Sibil [Heding ham, Hidingham], 377, $543^{a}$, 549a. See also Grassals

Helions in Helion Bumpstead, note 5416

Helion('s) Bumpstead. See Bumpstead

Hellesdon [Heilesdune] (Norfolk), note 394

Hempstead [Hamesteda, Hamsteda], $362,4816,5706$

Henham, 347, 362, 407, 5256, 570a. See also Pledgdon

Henham Hall, note 570 .

Henny, Heny [Hanies, Heni], $377,544^{b}, 570 b$, nose $529^{b}$

Henny, Heny (Great) [Henies], 5296,5676 , note 5496

Henny, Little [Heni], $549^{b}$

Hereford, 415

Hersham (Hall) [Ersham, Hersam, Hersham], 341, 377, $452 b, 534 a, 571 a, 573 b$

Hersted (now Herksted) $\mathrm{H}_{2}$ ll in Birdbrook, noke 5590

Hertford [Herefort], 338, 4296, note 413

Hertisho-bury (now Hassobury), nore 5170

Heybridge [Tidwoldituna], 340, $366,372,381,443^{6}$

Heydon [Haindena], $451 a, 563 a$

High Easter. See Easter
High Laver. See Laver

High Ongar. See Ongar

High Roding. See Roding

Higham (Kent), nose 369

Higham (Bensted) in Walthamstow [Hecham], $537 a^{\circ}$

Hinckford [Hedingfort, Hidincforda, Hidincfort, Hiding Ford, Hidingaforda, Hidingeforda, Hidingfort, Hidinghafort, $\mathrm{Hi}$ dinghefort, Hidingforda, $\mathrm{Hi}$ dinghfort] Hundred, 348,376 , $406,407,409,431 a, 438 b$, $442 b, 451 b, 452 b, 453 b, 454 a$, $457 a, 463 b, 472 b, 475 a, 477 b$, $498 b, 502 a, 503 b, 517 a, 523 b$, $529 b, 533^{b}, 534^{a}, 539 b, 54^{2 a}$, $542 b, 544 b, 549 a, 550 a, 552 a$, $555 b, 559 a, 559 b, 561 a, 562 b$, $563 a, 564 a, 564 b$, motes $553 a$, $5686,569 b$

Hipworth Hall in Halstead, notes $475 a, 544^{b}$

Histon (Cambs), 338, note $430 b$

Hitchin (Herts), 336

Hockley [Hacheleia, Hocheleia], $362,371,449 b, 484 b, 487 a$. Sec also Plumborough

Hoddesdon (Herts) [Hodesduna], $338,429^{6}$

Holland [Holanda], $554 b$

Holland, Little [Hoilanda], 4700

Holton (Suffolk), nose 343

Home Salicoats in Stow Maries, note 382

'Hoosenga,' 5726

Horkesley [Eil and], 408, 489b, note $489 b$

Horkesley, Little, 392, 393

Horkesley Priory, Little, note 4900

Hornchurch, 404

Horndon (formerly Thorndon), E2st and West, 369, 376, 387

Horndon, East (formerly East Thorndon) [Torindone, Torinduna, Torrindone], 398, 399, $400,552 b$, note $456 a$. See also Abbots

Horndon, West (formerly West Thorndon) [Westorendon, Torninduna, Thornyndon], 398, 399, notes $400,456 a, 482 a$, $491 a$

Homdon on the Hill [Horninduna], $369,380,384,385$, $398,399,412,416,441 a$, $460 b, 482 b, 557 b, 558 a, 566 a$. See also Wythefeld

' Horstedafort,' 559a

Hosden's Farm in Great Maplestead, 356

Housham (Hall) [Ouesham], $473^{6}$, $554^{\circ}$

? How Hall in Finchingficld

[Weninchou], 479a, 571b

Howich in Tillingham, 373 


\section{A HISTORY OF ESSEX}

Hubbridge Hall in Witham [Hobruge ], 441 $b, 514 a$

Hutton [Atahou], 34 I, 375, $452 a$

Icklingham (Suffolk), 346

Iclinton (Cambs), note $432 b$

Ilford [Ilefort], 380, $559 a$, note 406

Ilford, Little, note $448 b$

Iltney in Mundon [Altenai, E1tenai, Eltenhey], 388, 39I, 393, $462 b, 487 b$, note $457 b$

Inga, $526 b, 538 a$

Ing(atestone) [Inga], $449 \circ$

Ingledesthorpe in White Colne, 405 , note 5350

Ingrave [Inga], 342, 368, 376, $455 a$, note 400

Ings, The. See Butsbury, Frierning, Margaretting, Mountnessing

Inworth, note $497 a$

Ipswich, 348, 414, 4I8, 420, $42 \mathrm{I}, 422,423$, note 368

'Portmens meadow,' note 423

Ipswich Hundred, note 409

Ixworth (Suffolk), 382

Kedington (Suffolk) [Ketton], $347,408,409$

Kelington (afterwards Bretts, now Kenningtons) in Aveley [Kelituna], $475 b, 490 b$

Kelvedon [Chellevadana, Chellevedana], $346,363,444^{b}, 497 a$, note 406

Kelvedon Hatch [Kelvenduna, Kelenduna, Kalenduna], 341, $3^{86,445 a, 457^{b}, 503 a}$

Kenningtons. See Kelington

Kensington, 383

Ketteringham (Norfolk), 346

Kewton or Cuton Hall in Boreham [Keventuna], 390, 5076

King's Meads at Oxford and Canterbury, note 418

King's Wood, Colchester, 419

Kirby le Soken, 340 , note 4436 . See also Bircho

Knights Wick in Canvey Island, 373

La Waule in Bradwell-by-sea, 392 , note 392

Lacheley in Lindsell [Lacelea], 5710

Laindon (wrongly 'Langdon Clay ') [Legenduna, Leienduna, Leindone, Leyndon], 369, 398, $437 b, 441 b$

Laindon Hills. See Langdon

Lambourne [Lamburna], $467 b$

Lammarsh [Lamers], $5296,530 a$, $567 b, 570 b$, note $529 b$

'Landuna,' 395, 493a

Langdon (wrongly 'Laindon Hills') [Langedon, Langedone,
Langenduna], 369, 398, $482 a$. See also Lee Chapel

'Langdon Clay.' See Laindon Langdon 'Hills.' See Langdon

Langenhoe [Langhou], 360,369 , $381,463 a$, note $501 b$

Church of, 344

Langford [Langefort, Langheforda], $521 b, 525 b$, note $443 b$

Langham [Laingaham], 348, 349 , $360,376,481 a$

Langley, note $489 a$

Langthorns in Little Canfield, note $568 a$

Latchingdon, Latchendon [Lacenduna, Lachentuna, Lessenduna], $346,376,391,430 a, 437 a$, $497 b, 565 a$. See also Lawling

Latton [Lattuna], $362,384,385$. $451 b, 462 b, 536 a$, note $492 a$. See also Mark Hall

Lavenham (Suffolk), 383

Lavers, The, $352,353,402,404$

Laver, High [Lagafara], $401,467 a$

Laver, Little [Laghefara], 40I, $4^{6} 7^{b}$

Laver, Magdalen [Laghefara], $401,554 a$

Lawford [Laleforda, Leleforda], $334,336,337,412,413$, $419,434 b, 470 b, 480 b, 525 a$, $541 a$, notes $364,435 a, 435 b$, 460a. See also Dale Hall

Lawling [Lalinge], 380, 437a, 493a, 530a, 546b, $573 b$. Sec also Ulehams Farm

Lawn ? (Old) [Laghenberia], 4590

Layer [Lega, Legra], 339, 362, $368,377,388,389,402$, $432 b, 454 b, 498 b, 528 b, 556 b$, $560 b, 566 b$

Layer Breton, 356, 401, note 5566

Layer de la Hay [Legra], 356, $389,401,4636$

Layer Marney [Legra], 356, 401, $438 a$

Layham (Suffolk), 353

Layston [Lefstaneschurch] (Herts), 404

Leaden Roding. See Roding

Leavenheath (Suffolk), 408

Lee Chapel, West Lee [Lea], $340,369,442 a$

Lee Wick in St. Osyth, 373

Leebury in Elmdon [Lea], 361 , 4716

Lees. See Leighs

'Lega,' $516 a$

Leicester, 415, 422, note 422

Leigh (on the Thames) [Legra], $380,388,532 a$, note $434 b$

Leighs (formerly Lees) [Lega, Legra], 343, 376, 495a, 507a

Leighs [Legra], Great, 352, 388. See also Mulsham
Lexden [Lessendena], 406, 416 , $417,419,4326,574^{b}$

Lexden [Lassendena, Lassendene, Laxedana, Laxefelda, Laxendena, Lessendena, Lexendana, Lexendena, Lexsendena] Hundred, 406, 408, 409, $432 a$, $444 b, 45 \mathrm{I} b, 457 b, 465 b, 476 b$, $480 b, 489 b, 494 b, 504 b, 517 b$, $530 b, 534 b, 543 a, 548 b, 550 b$, $551 a, 552 b, 558 a, 560 b, 566 a$, $567 b, 572 b$, note $523 b$

Leyton [Leintuna, Leituna], 378 , $380,384,444^{b}, 497 b, 515 b$, $536 b, 546 a$, note $430 a$

'Liffildewella,' 570a

'Lilestone' (Middlesex), 355, note 355

'Limpwella,' 4586

Lincoln, 4I 5, 422

Lindsell [Lindesela, Lindeseles], $385,452 b, 492 b$, note $431 a$. See also Lacheley

Lisles in Great Chishall, notes $476 b, 496 b$

Liston [Listuna], 552a, 561a. See also Netherhall, Over Hall, Weston

Little Baddow. See Baddow

Little Bardfield. See Bardfield

Little Bentley. Sce Bentley

Little Birch. See Birch

Little Braxted. See Braxted

Little Bromley. See Bromley

Little Burstead. See Burstead

Little Canfield. See Canfield

Little Chesterford. See Chesterford

Little Chishall. See Chishall

Little Coggeshall. See Coggeshall

Little Colne. See Colne

Little Dunmow. See Dunmow

Little Easton. See Easton

Little Easton Park. See Easton Park

Little Hallingbury. See Hallingbury

Little Hallingbury Hall. See Hallingbury Hall

Little Hazeleigh. See Hazeleigh

Little Henny. See Henny

Little Holland. See Holland

Little Horkesley. See Horkesley

Little Horkesley Priory. See Horkesley Priory

Little Ilford. See Ilford

Little Laver. See Laver

Little Maldon. See Maldon

? Little Maplestead. See Maplestead

? Little Mulsham. See Mulsham

Little Oakley. See Oakley

Little Ongar. See Ongar

Little Parndon. See Parndon

Little Sampford. See Sampford 


\section{INDEX TO DOMESDAY}

Little Stambridge. See Stambridge

Little Stanford (Rivers). See Stanford (Rivers)

Little Stanway. See Stanway

Little Thurrock. See Thurrock

Little Totham. See Totham

Little Wakering. See Wakering

Little Waltham. See Waltham

Little Warley. See Warley

Little Wenden. See Wenden

Little Wigborough. See Wigborough

Little Yeldham. See Yeldham

Littlebury [Litelbyria], 334, 340, 4506

Loft Hall in Orsett, note $+38 a$

'Lohou,' 5586

London, $364,385,4466,448 b$, 5136

Castle Baynard, 346, 347, 396

Loughton [Lochetuna, Lochintun2], $375,397,430 a, 4466$, $447 a, 515 b, 537 a, 537 b$, note 406. Sec also Alderton (Hall), Debden

Magdalen Laver. See Laver Maldon [Malduna, Melduna], $335,341,346,385,386$, $409,412,421,432 a, 434 a$, $465 a, 491 a, 531 a$, nose 393. See also Sayers, Southouse

Maldon, Little [Meldona], $528 a$

Maldon [Melduna] Half Hundred, 407, 434a, 491a, $531 a$, note 409

Malgreffs in Horndon on the hill, 398

Manhall [Monchala, Munchala], $350,358,4730,5130$

Manningtree [Sciddinchou], 5556

Manuden [Magellana, Magghedana, Menghedana], 516a, $517 a, 523 b, 569 b$. See also Payton Hall, Pinchpoles

Manuden Hall, nose 5170

Mapledurwell (Hants), notes 5186 , 5650

Maplestead, Great [Mapledested2], 5 1 7 a. See also Hosden's Farm

Maplestead, Little [Mapledesteda, Mappesteda, Nepsteda], 377. $384,457 a, 544 b, 569 b$

Margaret Roding. See Roding

i Margaretting [Ginga], 369, $404,4330,5550$, note $433^{\circ}$

Mark Hall in Latton, 344

Marks in Margaret Roding, note 5010

Marks or Merks in Dunmow, 344, wose 4626

Marks Tey. See Tey
Markshall [Mercheshala], 346, 499a, nose $462 b$

Marlow (Bucks), note 337

Marsh Farm, Great [Marsh Farm or Dairy-house], note 372

Marshalls in Hatfield Peverel, 380 , note $546 a$

Martells $\mathrm{Hall}$ in Ardleigh, note $508 a$

Mashbury [Masceberia, Massebirig], 343, 507a, 568a

Maskelsbury in White Roding, note 5110

Matching [Matcinga, Matcinge, Metcinga], $452 b, 509 a, 514 b$, 558a. See also Housham (Hall), Stock Hall

Matching Barnes with Brent Hill, note +526

Mayland, 394, nose 391

Mayland Hall, 395

Melton Constable (Norfolk), 346

Meppershall (Beds), 350

Merks in White Roding, note $492 a$

Mersea, East [Meresai], 380, 4886. See also Bocking Hall

Mersea, West [Meresaia], 34t, $380,385,418,454 a$

Mersea Island, 341, 369, note 4566

Merton (Norfolk), 347

Messing [Metcinges], 5236 , $543 a$, notes $444^{b}, 445 a$

Michaelstow in Ramsey [Michelestou], 5246 , nose $525 a$

Middlemead in Baddow [Mildemet], $442 a$

Middlewich in Tillingham, 373

Middleton [Mildentuna, Milde]tuna ], $4796,564 b, 574 a$, notes 337,406

- Midebroc,' 567a

Milton Hall in Prittlewell [Mildentuna], 437\%

Mistley [Mitteslea], $380,544 a$. See also Dikeley

Monkswick in Canvey Island, 373

Monksbury in Little Hallingbury, 384 , nore 5086

Moone Hall in Stambourne, note 5686

Moreton [Mortuna], 362, $551 a$

Morris [Mareys] Farm in Stow Maries, note 394

Mose. See Moze

Moulsham in Chelmsford [Molesham ], $445^{b}$, nose $459^{b}$

Mount Bures. See Bures

Mountnessing [Ginga], 356, 375, $5406,541 a$. See also Cowbridge

Moyns in Steeple Bumpstead, note 4756

Moze, Mose [Mosa], 381, 396 5076
Mucking [Mucinga, Muchinga], $342,380,448 a$

Mucking Hall, note 4560

Mulsham in Great Lees, 403

Mnlsham ? (Great) [Melesham], 4596

Mulsham (Little) [Molesham] 4596

Mundon, Munden [Munduna] $334,383,393,394,4926$. See also Iltney

Mynchens in Elsenham, nose 5310

Nasing. See Nazeing

Nass, The, note 405

Navestock [Astoca, Nasestoca, Nessetocha], 340, 375, 403, $443 a, 502 b$

Nayland (Suffolk) [Eiland], 408

Nazeing [Nasinga], 378, 380 , $4466,539 a$, notes $380,446 a$

Ness Farm, note 405

Netherhall in Liston, note 5610

Nevendon, Newendon [Nezendena], 5586,5616

New College, nose 392

New Hall in Tendring [Tenderinge], $44^{\circ} b$

Newendon. See Nevendon

Newham, Newnham, in Ashdon [Newenham], 358, 362, 4716 Newland, East [Niweland2], 5400 , note 5400

Newland, West [Niwelant], 404 $437^{\circ}$

Newland Hall in Roxwell [Newelanda], 468a, note 4336

Newnham. See Newham

Newport [Neuport], 336, 337 , $338,362,411,435 b, 436 a$. See also Shortgrove

Newsells in Barkway (Herts), note $495^{6}$

Newton Hall in Great Dunmow [Niwetuna], 5100

'Niuctuna,' 5536

North Bemfleet or Benfleet. See Benfleet

North Fambridge. See Fambridge

North Ockendon. See Ockendon

North Thorp. See Thorp

North Weald Basset. See Weald Basset

North Wick. See Wick

i Northey (isle) [Carseia], 395, 5026

(Nor)thorp in South Church [Torpeia], $405,485 b$

Norton [Nortuna], $\mathbf{5 7 2 0}$

Norton, Cold [Nortuna], 376, 5220

Norton Mandeville [Nortuna], $34^{\circ}, 35^{6}, 375,44^{2} b, 503 a$ 


\section{A HISTORY OF ESSEX}

Norwich, 4I4, 415, 416, 417 . $419,420,421,423$

Notley [Nuthlea, Nutlea], 360 , $369,377,378,488 a, 500 b$, $556 b, 558 b$, note $527 b$

Notley, Black [Nutlea], $508 b, 544 a$

Notley, White [Nutlea], 377. 461a. See also Slamondsay

Oakley, Great [Accleia], 334, $353,381,396,520 a$, notes $382,395,524 b$, note $543 b$

Oakley, Little [Acle, Adem], 380, $395,396,5246$

Oburnes in Finchingfield, note $479 a$

Ockend on [Wochenduna, Wokindone], $337,369,433 a$

Ockendon, North [Wochenduna], $445 a, 445^{b}$

Ockendon, South [Wochaduna] $364,505 a$

Ockendon Episcopi, note $440 a$

Old Dairy-house, note 372

Old Hall in Rayne, 349, note 5426

Old Hall in Tendring, notes 4696 , 4706

? (Old) Lawn. See Lawn

(? Old) Saling. See Saling

Old Windsor. See Windsor

Ongars, The, 375

Ongar, Chipping [Angra], 347, $467 a$

Ongar, High [Angra], 407, $545^{6}$ Church of, 344

See also Passelow

Ongar, Little, note $545 b$

Ongar [Angra, Angre, Hangra] Hundred, 397, 401, 406, 407, $409,432 b, 442 b, 445 a, 447 a$, $451 b, 457 b, 466 b, 473 a, 490 a$ $494 b, 502 b, 504 b, 518 a, 531 a$, $545 a, 551 a, 553 b, 574 b$, notes $492 a, 537 a, 540 a, 554 a$

Orpington (Kent), note 4450

Orsett [Orseda, Dorseda], 339 , $375,416,437 b, 461 a$, note 56 Ia. See also Loft Hall

Over Chishall. See Chishall

Over $\mathrm{Hall}$ in Liston, note $56 \mathrm{Ia}$

Overhall in Colne Engaine, 35 I

Overhall in Gestingthorp, note $564 a$

Oresey (isle) [Uveseia], $503 b$, note $502 b$

Ovington [Olvituna, Ovituna] $404,549 b$, 572a. See also Beauchamp St. Ethelbert

Oxford, 415, 417, 420, note 418

Paglesham [Pachesham], 34I, $371,386,445 b, 476 \vec{b}, 525 b$, $547 a, 567 a$, note 382
Panfield [Penfelda], 342, 360, $362,419,454 a, 478 a$

Papworth (Cambs), 353

Parndon, note 5386

Parndon, Great [Perenduna], $344,462 a, 539 a$

Parndon, Little [Perinduna], 378. 5366

Passelow in High Ongar [Passefelda], $447 a$

Patching (Hall) in Broomfield [Pacingx, Pacinges], 459b, $506 a$

Patching (Hall Picot) in Broomfield [Pacinga], 5 I $9 b$

Payton Hall in Manuden [Pachen Hou], $475^{\circ}$

Pebmarsh [Bebenhers, Pebeners, Pebenhers], $479 b, 549 b, 570 a$ 572a. See also Polhey

Peete in Mersea and Peldon, 34l, notes $454 a, 456 b$

Peldon [Peltenduna], 378, 381, $412,418,489 a, 559 b$, notes 385,4566

Pentlow [Pentelawa], 347, 5236 . note 4796

Picotts in Ardleigh, note 5436

Pinchpoles in Manuden [Pincepo], $556 b$

Pirimers in Tillingham, 373

Pitsea [Piceseia], 376, $565 a$, note 358

Pledgdon in Henham [Plicedana,

Plichedana], 494a, $513 a$, note 407

Pleshy, Pleshey, Mandeville castle of, $341,343,383,387$, notes $356,509 a$

Plesingho in Willingale [Plesinchou], $4^{6} 3 a, 569 a$

Plumberow, Plumborough [Plumberga] in Hockley, 4766 , $486 b$

'Plumtuna,' $531 a$

Polhey in Pebmarsh [Polheia], $377,475^{b}$, notes $475^{b}, 544^{b}$

Port Meadow at Oxford, note 418

'Portmannesfeld.' See Colchester

'Portmens meadow.' See Ipswich

Powers Hall in Witham [Witham], 5140

Prayers in Sible Hedingham, note $543 a$

Prested in Feering [Peresteda], $358,530 b$, note $534 b$

Prior's Hall in Lindsell, notc $452 b$

Prior's Hall in Prittlewell, note $485 a$

Prison Hall. See Pledgdon

Prittlewell [Prittewella], 458a, notes $367,369,486 a$. See also Milton Hall, Prior's Hall
Prittlewell Priory, note $485 b$

Purleigh, Purley [Purlai], 346, $35 \mathrm{I}, 376,39 \mathrm{I}, 393,394$, $462 b, 497 b, 498 a, 515 b, 522 a$, 548a. See also 'Curlai,' Gibcrakes

Putsey in Canewdon [Puteseia], $487 a$

Quendon [Kuenadana], $495^{\circ}$

Quickbury, Cowick Bury, in Sheering [Cuica], 361, $474 a$

Radwinter [Redewintra], 355, $358,37 \mathrm{I}, 407,495 b, 535 b$, $54 \mathrm{I} b, 556 a$. See also Bendish (Hall)

Rainham [Reneham, Renaham, Reineham, Raineham], $45^{8 a}$, $518 a, 554 b, 561 b$. See also Berwick

Ramsden [Ramesdana, Ramesduna], 369, $514 a, 538 b$, note 5086

Ramsden Belhouse [Ramesdana], $438 a, 441 b$, note $455 a$

Ramsden Crays [Ramesdana], 4559

Ramsey [Rameseia], 353, 362, $380,524 b$, notes $525 a, 543 b$. See also Foulton, Michaelstow

Ramsey Abbey, 370

Rawreth. See Beeches

Rayleigh [Rageneia, Ragheleia], $360,383,484 a, 484 b$. See also Whatley or Wheatley

Rayne [Raines], 500b, 542b, 5434. See also Old Hall

Rayne (Hall) [Raines], 346,438b, $498 b$

Rettendon [Radenduna, Ratenduna], 334, 340, 346, 390, $450 a, 495 a, 531 a$, note $4599^{\circ}$

Reydon (Suffolk), note 343

Richernesse in Bowers Gifford [Richeresnes], 372

Rickling [Richelinga], 436a, note 367

Ridgwell [Ridewella], $4^{6} 3^{b}$

Ridley (Hall) in Terling [Retleia], $508 b$, note $527 b$

Rifthams in Danbury, 387

Rise-Marses in Hatfield Broadoak [Siriceslea], 501a, notes $412,429 b$. See also Siriceslea

Rivenhall [Riwehala, Ruenhala, Ruenhale, Ruwenhala], 363 , $379,461 b, 462 a, 488 a, 514 b$, 562b. See also Felix Hall

Rochester [Rovecestre], 342, $4 I 5,416$, note 4 I6

Rochford [Rochefort], 371, 486a, 4936 , note 367 


\section{INDEX TO DOMESDAY}

Rochford [Rochefort, Roches- St. Mary's, Shrewsbury, 345 fort] Hundred, 369, 371, St. Melaine of Rennes, 350 $372,376,406,409,432 a$, $437 a, 443^{b}, 445^{b}, 449 b, 456 a$, $472 a, 476 b, 482 a, 484 a, 495 b$, $525 b, 532 a, 539 b, 547 a, 562 a$, $5666,574 b$, noces 370,382 , 4556

Rockells in Arkesden, note 476a

Roding [Rodinges, Roinges, Roothings], 341, 343, 358, $384,397,401,402,407$, $412,496 b, 511 b, 512 a$, nokes 401,4920

Roding Abbess [Roinges, Rodiges], 340, 358, 401, 494b, 505a, note $492 a$

Roding (Aythorp ?) [Rodinges], $401,450 a$, note $492 a$

Roding, Beauchamp [Roinges], $356,401,473^{\circ}$

Roding, Berners [Rodinges], 356 , $401,510 a$

Roding, High [Rodinges], 401, $474^{b}$

Roding, Leaden [Rodinges], 401 , $474^{b}$, note 4500

Roding, Margaret, 401, 404. See also Roding Marci

Roding, White [Rodinges], 401, $430 b$, $511 a$, $512 a$, note $492 a$. See also Roding Morell, Maskelsbury

Roding Marci [Rodinges], sola

Roding Morell (Morel) [Roinges,

Rodinges], 480a, 492a, note $492 a$

Rodings, The, 343,350

Rok Hall in Little Totham [Toteham], 440a, $440 b$

Romford, nose 406

Rookwood Hall in Abbess Roding, note 5050

Rothe End in Ashdon [Roda], $473^{b}$

Roxwell, noke $433^{b}$

Roydon [Ruindune], 352, 378 , $407,538 b$

Rudham (Norfolk), note $536 a$

Rumilly - le - Comte (religious house), 344

Runwell [Runewella], 443a, 468

Saffion Walden. See Walden

St. Alban's Abbey, 406

St. Albright (Æthelbricht), Stanway, Chapel of, 403, 404

St. Clere's Hall in St. Osyth, note 5316

St. John's of Clare, $34^{8}$

St. John's Abbey. See Colchester

St. Lawrence, 352, 404, note 391 . See also Newland

St. Mary Magdalen, Hospital of. See Colchester

St. Mary (? Barking Abbey), $444^{\circ}$

St. Mary's at the Walls. See Colchester
St. Osyth [Chich, Cice, Cita], $339,344,346,373,376$, $383,402,439 b, 469 b, 531 b$, rove 4396. See also St. Clere's Hall, Frowick Hall

St. Peter-on-the-Wall, Chapel of, Bradwell [Ithancestre], 392

St. Walery's Hall in Takeley, 356 , more 4530

Salcott (Saltcot), 381

Salcot Verley or Verli, 389 . $516 a$, note $456 b$. See also Virley

Salcot Wigborough, note $516 a$

Salcots at Brightlingsea, note 382

Saling, Great [Salinges], 377 , $384,544^{6}$

Saling (? Old) [Salinges], 5720. See also Bardfield Saling

Salt Coat Marsh at Burnham, note 382

Saltcoats in Ayrshire, 382

Salters field and Salters 10 acres at Great Oakley, wote 382

Saltpan Marsh at Paglesham, note 382

Saltreachfield at Eastwood, nose 382

Salts at Barking, note 382

Samanton. See Sampsons

Sampford, 360

Sampford, Great [Sanfort], 355, $407,436 a$, note 350

Sampford, Little [Sanforda], 4816

Sampsons, Sampton in Peldon [Samantuna], 342, notes 394, 4566

Sampton. See Sampsons

Sandford, Great. See Sampford

(l) Sandon [Bedenestede, Bedenesteda], 341, 346, 390, $499 a, 546 b$

Sandpit Leet in Braintree, note 5706

Sawston (Cambs), 353

Sayers in Maldon, note $491 a$

'Sciddeham,' 5740

'Scilcheham,' $557 b$

Scoteneys in Toppesfield, note 5716

Secqueville-en-Bessin, 379

Shalford [Celdeforda, Scaldefort, Esceldeforde], 337, 351, 385 , $431 a, 559 b, 577 a$, notes 365 , 4316

Sheering [Sceringa], 536a. See also Quickbury

Shelford [Scelfort], (Cambs), $338,436 c$

Shelley [Senleia], 400, $504^{6}$

Shellow [Scelga], 4936

Shellow (Bowells) [Scelda, Scelga], $341,356,400,4300,5106$, $511 a, 512 a$
Shenfield [Scenefelda], 344, 4616

Shimpling (Suffolk), 347

Shingle Hall in Great Dunmow, nore 5110

Shoebury [Essoberia, Soberia], $456 b, 485 b, 486 a$

Shocbury, South, rote 4856

Shoeburyness, 405

Shopland [Scopelanda], 334, 344 , 358,3714720

Shortgrove [Scortegrava, Sortegrava $,{ }_{4} 6_{3} b, 520 b$

Shouldham (Norfolk), 347

Shrewsbury, 415, 416

Sible, Sibil, Hedingham. See Hedingham

Siriceslea. See Rise-Marses

Slamondsay in White Notley [Slamondesheia], 438a

Smalland [Smallant], 546a. See also Marshalls

- Smaltuna,' 5696

Smeeton (Hall) in Bulmer [Smedetuna], 4650

Snoreham, notes 391,4980

Sokens, The. See Eadwulfsness

South Benfleet. See Benfleet

South Fambridge. See Fambridge

South Hall in Paglesham, note 4766

South Hanningfield. See Hanningfield

South Ockendon. See Ockendon

South Shoebury. See Shocbury

South Thorpe. See Thorpe

South Weald. See Weald

Southall in Rainham, note $458 a$

Southall in Dunmow, note $474^{b}$

Southall in South Benfleet, note $483^{6}$

Southchurch [Sudcerca], 352, 380,4376 . See also (Nor) thorp, Thorpe

Southhouse in (St. Mary's) Maldon, notes $49^{i} a, 498 a$

Southminster [Sudmunstra], 334, $339,369,395,4386$

Southwold (Suffolk), 380, 424

Spain's Hall in Finchingfield, 356

Spain's $\mathrm{Hall}_{2}$ in Willingale Spain, 356 , nose 4726

Springfield [Springafelda, Springinghefelda], 380, 404, 519a, $531 a$, nole 4686

Springfield Hall, noke $531 a$

Stambourne [Stanburna, Stanburne], 383,502a, 5686, 569o

Stambridge, Great [Stanbrugc], $362,371,456 a, 486 a$. Sec also Barton Hall

Stambridge, Little [Stanbruge], $371,4376,5666$

Stamford, note 422

Stamford Bridge, 386 


\section{A HISTORY OF ESSEX}

Stanford-le-Hope. See Hassing- Sturmer [Sturmere], 542a, note broke

Stanford Rivers [Stanfort], 364 , $466 b$

Church of, 344

Stanford Rivers, Great, $4 \circ 3$

Stanford Rivers, Little, 403 , $467 a$

Stangate or Stansgate Priory, note $530 b$

Stansgate in Stceple [Stanesgata], $346,530 b, 567 b$

Stanstead Abbots (Herts), notes $474 a, 538 b$

Stanstead Mountfichet, Stansted Montfichet [Stanesteda], 347, $356,362,375,385,407,5166$. See also Bendfield

Stanstead (Hall) in Halstead [Stanesteda], $377,550 a, 551 a$, note 5166

'Stantmere,' 556a

Stanway [Stanewega, Stanwega], $337,354,362,386,403$, $417,419,4320$

Stanway, Great, 403

Stanway, Little, 403

Stanway Bridge, note 406

Stapleford Abbots [Stapleforda, Staplefort], 358, 451 $b, 518 a$. See also Batayles

Stapleford Tawney or Tany Staplefort], 356, 490a, note $491 a$

Stebbing [Stabinga, Stibinga], $346,383,388,5036,5296$

Steeple [Stepla], 350, 39I, $432 a$, $493 a$, 504a, 574a. See also Stansgate

Steeple Bumpstead. See Bumpstead

Stepney (Midd.), notes 510a, $563 a, 563 b$

Stevington (End) in Ashdon [Staumtuna, Stavintuna, Stevituna], $473 b, 536 a, 541 b, 574^{b}$. See also Waltons

Stifford [Estinfort, Stiforda, Stifort ], $3^{84}, 449 a, 45^{8 a}, 45^{8 b}$, $563 a$

Stisted [Stiesteda], 376, 437a

Stoke (by Nayland), 408, note 367

Stondon Massey, Stondon Marci, 356 , notes $501 a, 503 a$

Stone ness, note 405

Stow Maries [Fenna, Fenne, Phenna, ? Weneswic], 391, $393,394,410,512 a, 513 b$, $548 a$, notes 382,391 . See also East Whittenham, Wellinditch, Witham

Stratford, note 406

Stratford Langthorn Abbey, note 5150

Strethall [Strathala], 334, 362, $450 b$ 571a. See also Kedington

Stutton (Suffolk), 352

Stutton ness, note 405

Sudbury [Sudberia, Sutberia], $335,35 \mathrm{I}, 385,405,480 a$, $529 b, 533 b, 545 a$, note 408

Sutton [Suttuna], 359, 371,4866 , $487 a, 487 b, 562 a$

Takeley [Tacheleia], 342, 375, $377,453 a, 494 a, 516 b$. See also Bassingborns, Colchester Hall, St. Walery's Hall, Warish Hall

Takeley or Hatfield Forest, 375 , note $494 a$

Taunton (Somerset), note 419

Temple Mills in West Ham, note 5154

Tendring [Tendringa], 4696 , $470 b, 520 a, 531 b, 560 b$. See also New Hall, Old Hall

Tendring [Tendering, Tenderinga, Tendringa, Tendringe] Hundred, $34^{8}, 372,373,376$, $380,381,395,396,406,409$, $434 b, 439 b, 443 b, 452 a, 460 a$, $469 b, 473 a, 480 b, 491 a, 495 a$, $499 b, 507 b, 520 a, 524 b, 531 b$, $535 a, 541 a, 543 b, 547 a, 548 b$, $552 a, 554 b, 555 b, 560 b, 563 b$, note 382

Terling [Terlinga], 343, 369, $385,527 a, 567 a, 577 b$, note 5296. See also Ridley (Hall)

Terrington St. Clement (Norfolk), note 404

Terrington St. John (Norfolk), note 404

Tewes in Great Chishall, note $476 b$

Tey, Great [Teia], 385,4656

Tey, Marks [Teia], 344, 5046

Teye Maundeville. See Tey, Marks

Thaxted [Tachesteda], 348, 362, $363,364,365,377,402$, $477 a$, note 365 . See also Yardley

Thetford, 414, 418, 420, 421, 422

Theydon [Taindena], 563a, note 406

Theydons, The, 375, 402

Theydon Bois [Taindena], 356, $397,401,5376$

Theydon Gernon (or Garnon) [Taindena], 356, 358, 401, $494 b$

Theydon Mount [Teidana], $359,401,490 b$

Thorrington [Torinduna], 4600

Thorley (Herts), 339

Thorndon, 399, 400

Thorndon Woods, 375

596
Thorndon, East. See Horndon, East

Thorndon, West. See Horndon, West

Thorp. See Thorpehall

'Thorpe,' 405

Thorpe, North. See Northorp

Thorpe, South. See Thorpehall

Thorpe-le-Soken, 340, 365, 405, note $443^{b}$

Thorpehall Farm in Southchurch, 405 , note $539^{b}$

Thorrington, $342,387,389$. See also Marsh Farm, Great

Throcking (Herts), 339

Thunderley (now in Wimbish) ['Tunreslea], 334, 377, 385, $404,533 a$

Thundersley [Thunreslea], 369, $407,484 a$

'Thunreslau,' Half Hundred of, $396,397,405,407,534 a$, $537 a$

Thurrocks, The, 407

Thurrock [Thurruca, Turoc, Turocha], 407, 457b, 458a, 5666 , note 369

Thurrock, Grays [Thurrock, Turroc, Thuruc], 356,380 , $388,553 a$, notes $457 b, 458 a$

Thurrock, Little [Turruca], 362, 4406

Thurrock, West [Turruc], 337, $364,380,385,388,5136$, notes $383,457 b$

Thurstable [Turestapla] Hundred, $376,380,381,401$, $407,409,436 b, 439 b, 443^{b}$, $449 b, 460 a, 468 b, 491 b, 499 b$, $503 a, 521 a, 525 b, 532 a, 547 a$, $564 a$, note $521 b$

Thyrstlinge Hall (?) in Butsbury, note $449 a$

Tilbury, East [Tiliberia], 373, $374,377,380,390,473 b$, notes 369,5616

Tilbury, West [Tiliberia], 373, $374,376,473^{b}, 4^{82} b, 508 b$, notes $369,561 b$

Tilbury-by-Clare [Tiliberia], 362 , $373,542 b$

Tilburyness, note 405

Tiled hall in Latchingdon, note $49^{8} a$

Tillingham, 340, 366, 369, 373, 380,4426

Tilney All Saints (Norfolk), note 404

Tilney cum Islington (Norfolk), note 404

Tilney St. Lawrence (Norfolk), note 404

Tilney Smeeth (Norfolk), 370

Tiltey [Tileteia], 378, 5036

Tiptree Heath, 370 , note 370 


\section{INDEX TO DOMESDAY}

Tollesbury [Tolesberia], 369, Wakering, nose 382. See also $380,381,4496,469 a$. See Barrow Hall also Guines Court, Tolleshunt, Tolleshunt Guines

Tolleshunt [Toleshunta, Tolleshunta], 341, 381, 385, 401, $402,404,4600,4696,4916$, $526 a, 564 a, 577 b$, nole $525 a$

Tolleshunt Darcy [Toleshunta], $346,401,5000,5200,5210$, $532 a$, notes $449 b, 516 a$. See also Gernons and Virley.

Tolleshunt Guines in Tollesbury [Toleshunta], 4686

Tolleshunt Knights, 401. See also Barnwalden

Tolleshunt Major or Mauger, $356,401,547 a$

Tolleshunt Tregoz in Tolleshunt Darcy, note 5320

Toppesficld [Topesfelda, Topesfelde], $383,465 a, 502 a, 5716$. See also Scoteneys

Totham, Great [Totcham], 350, 5036

Totham, Little [Totham], 380 , $491 b, 499 b$, nose $480 b$. See also Rok Hall

Totham with Goldhanger, nose 4996

Tottenhill (Norfolk), 347

Twinstead [Tuinesteda], 4796

'Udecheshale,' 5336

Ugley [Ugghelea], 334, 377, 378,5336 . See also Bollington

Ulcham in Lawling, Uleham's Farm, 442a, 465b, nose 394

Ulting [Ultinga], 5216

Ulvestone in Debenham (Suffolk), $35 \mathrm{I}$

'Ulwinescherham, 391, 395, $432 a$

- Upham, 4736

Upminster [Upmonstra, Upmunstra, Upmunstre], $447 b, 457^{b}$, 554b. See also Gaines

Uttlesford [Odelesforda, Odelesfort, Udelesforda, Udelesfort, Wdelesforda, Wdelesfort, 'Esthodelesford,' 'Westhodelesford'] Hundred, 342, 406, $407,409,430 b, 435 b, 450 b$, $453 a, 463 b, 470 b, 473 a, 476 a$, $494 a, 495 b, 496 a, 496 b, 512 b$, $516 a, 520 b, 525 a, 529 a, 533 a$, $541 a, 549 a, 554 a, 557 a, 559 a$, $563 a, 569 b$, nose 5676

Vange [Phenge], 342, 358, 368, $376,380,398,454 b, 526 a$

Vaux in Belchamp Otton, note $549^{b}$

Videlews in Baddow, note $442 a$

Virley [Verley, Verli], noses 356 , $516 a, 521 a$. See also Salcot
Vakering, Great [Wachelinga], $485 a$

Wakering, Little [Wacheringa], 371,4866

Wakes Colne. See Colne

'Walda,' 397, 536b, 539a, nose 4476. Sec also Weald, North

Walden, Saffron [Waledana], 343 , $362,377,512 b$, note $509 b$. See also Manhall

-Walfara." See Walkfares

Walkfares in Boreham [Walcfara, Walfara, Walfaram], $391,447 b$, $459 b, 5656$

Wallasea Island, 371 , nose 370

Wallbury in Great Hallingbury [Walla, Hallingeburia, Hallingebiria de Walla], 396, 397, $477^{\circ}$

-Walla, nose 406

Walpole St. Andrew (Norfolk), note 404

Walpole St. Peter (Norfolk), nose 404

Walsingham (Norfolk), $34^{6}$

Waltham, Great [Wa]dham, Waltham], 343, 358, 383, 402, $505 b$, 506a, note $509 b, 546 b$. See also Chatham

Waltham, Little [Waltham], 340, $451 b, 468 b$, nose $546 b$

Waltham Forest, 375

Waltham Holy Cross, 334, 337 , $400,446 a, 514 b$, nose $539^{b}$

Waltham Hundred, 406, 407, $409,442 a, 446 b, 514 b, 539 a$

Waltham Half Hundred, 407 , 4466

Walthamstow [Welcomestowe, Welcomstowe, Welcumestou, Wilcumestou, Wolcomestoue, Wolkhomstowe], 375, 378, $380,400,5556$. See 2130 Higham (Bensted)

Walton-on-the-Naze, Walton-leSolken, 340, 365, 405, noses 373,4436

Waltons in Ashdon, notes 536a, 5416 . See also Stevington

Wanstead [Wenesteda], 375, 381, $438 a$, note 340

Warish Hall. See St. Walery

Warley, Great [Wareleia], 369, 449a. See also Warley Franks

Warley, Little [Wareleia, Warleia], 339, 369, 375, 439a, $557 a$, note 370

Warley Franks in Great Warley [Warlcia], 4906

Warwick, 420

Waulc, La, 392

Weald, South [Welda, Walda], $447 b, 5186$
Weald Basset, North [? Walla, Walda ], 356, 396, 397, 407, $538 a$

Weeley [Wileia], 369, 495 a

Weld in Harlow, 397

Well Wick in St. Osyth, 373

'Wella' 440b

Wellindisch [? Weneswic], note 394

Wenden, Lirtle [Wendena], $476 a$

Wenden Loughts or Lofts [Wendena], $525 a$

Wenden [Wendena], 5686

Wenden, Great [Wendena], 5166

'Weneswic', 'Wesuunic,' 391, $394,513 b, 568 b$, note 5686

'Weninchou,' 'Weninghou.' See How Hall

Wenington [Wemtuna], 4456

West Bergholt. See Bergholt

West Donyland. See Donyland

West Ham. See Ham

West Hanningfield. See Hanningficld

West Horndon. See Horndon

West Lee. See Lee Chapel

West Mersea. See Mersea

West Newland. See Newland

West Thorndon. See Thorndon

West Thurrock. See Thurrock

West Tilbury. See Tilbury

West Whettenham, West Whetnams, West Whetenham. See Whertenham

West Wick. See Wick

Westmill (Herts), 352, note 5546

- Westnanetuna,' 5636

- Westnesse,' nose 405

Weston near Clare [Westuna], 4646

Weston in Foxearth and Liston [Westuna], 5500, note 4646

Westwick in Burnham, 391

'Wesunnic.' See Weneswic

Werhersfield [Westrefelda, Withcresfclda], $337,338,384$ $431 b, 480 a, 565 b$, note $431 b$

Whatley or Wheatley-in-Rayleigh [Watclea, Wateleia], 369, 376, $380,455^{b}, 4^{8} 4 a$

Whettenham, Whytenham, East [Whitmans Farm, 'Witham' (?)], 388, 393, 394, 5156

Whettenham, West, West Whetnams, West Whetenham or Flambards, 394

White Colne. See Colne

White Notley. See Notley

White Roding. See Roding

Whitmans Farm. See Whettenham, East

'Wicam' (Wickham St. Pauls ?), $377,478 a$

Wicks in Canvey Island, 'The, 373

Wicks in St. Osyth, The, 373 


\section{A HISTORY OF ESSEX}

Wickford [Wicfort, Wincfort], $34^{2}, 37^{6}, 455^{b}, 4^{8} 3 a, 4^{8} 3^{b}$, note $508 b, 560 a, 561 a$

Wickham (Herts), 339

Wickham Bishops [Wicham], $439^{b}$

Wickham (Bonhunt) [Wicam], $377,557 a$

Wickham St. Paul's [Wicam, Wicham], 365, 377, 442b, $478 a$, notes 367,368

Widdington [Widituna], $453 a^{\circ}$

Widford, note 406

Widington [Widituna, Widintuna], $520 \bar{b}, 567 b$

Wigborough [Wigheberga], 365 , $529 a, 557 b$

Wigborough, Great [Wicgheberga], $378,381,385,418$, 448b. See also Abbess Hall

Wigborough, Little [Wigheberga], $376,501 b, 569 a$

Wigborough Wick, 373

'Wiggebruge,' note 393

Wiggenhalls, The (Norfolk)

'Wiggepet' (now Rockells in Arkesden) [Wicgepet, Wigghepet], 391, 568a, $568 b$, note $476 a$

Wilby (Norfolk), 347

Willingale [Willingehala], $488 b$, 558b. See also Plesinchou

Willingale Doe [Willingehala], $346,528 a$

Willingale Spain [Ulingehala], $350,472 b$. See also Spain's Hall

Wilton, note 422
Wimbish [Wimbeis], 347, 348,

Winstree [Wensistreu], Hun-

Winstree Hundred, Court of, 342

Boulogne, Honour of, 343,357 , note 4686

Clare, Honour of, 348 , notes $479 a$, 4806

Hatfield Peverel, Honour of. See Peverel of London $377,385,404,523 a$, note $533 a^{\circ}$ Windsor, Old, 337 dred, 376, 380, 381, 406, $407,409,438 a, 448 b, 454 a$, $456 b, 463 a, 488 b, 498 b, 501 b$, $516 a, 523 a, 528 b, 556 b, 557 b$, $559 b, 560 b, 566 b$

'Winthelle,' $556 a$

Wissant, 344

Wissington or Wiston (Suffolk), 408

'Witelebroc,' $525 a$, note $525 a$

'Witesworda,' $481 a$

Witham [Witham], 337, 341, $344,365,378,394,428 b$, $462 a, 560 a$. See also Bennington Hall, Blunts Hall, Hubbridge Hall, Powers Hall

Witham Hundred, 406, 407, $409,428 b, 436 b, 438 a, 441 b$, $444 b, 451 a, 456 a, 461 a, 491 b$ $497 a, 500 b, 508 b, 514 a, 521 b$, $526 b, 544 a, 546 a, 556 b, 560 a$, $562 b$

Witham Parva, note $514 a$

Witnesham (Suffolk), 351, note $54^{86}$

Wittenham [Witeham] (Berks), note 394

Wivenhoe [Wivnhou], 5176

Wix [Wica], 351, 499b, 548b, note $499^{b}$

Woburnes or Oburnes in Finchingfield, note $479 a$

\section{HONOURS}

Wolston Lodge, note $433 a$

Wolverston in Chigwell [Ulfelmestuna], $432 b$

Wood Hall in Arkesden, note $476 a$

Woodford [Wdefort], 334, 375, $446 b$

Woodham Ferrers[Udeham], 356 , $376,504 a$

Woodham Mortimer [Odeham], $334,346,356,376,528 a$

Woodham Walter [Wdeham], $357,376,522 a$, note $522 b$. See also 'Curlai'

Woolwich, North, 409

Worcester, 415

Wormingford [Widemondefort], 354,5176

Wrabness [Wrabenasa], 334, 380 , $405,452 a$

'Wringehala,' 395, 4930

Writtle [Wiritela, Writela, Writa], 336, 337, 347, 362, $385,433 b, 434 a, 468 a, 460 b$, note $433^{b}$

Wythefeld in Horndon on the hill, 398 , note 4826

Yardley in Thaxted [Gerdelai], $377,541 a$

Yarmouth, 414

Yeldham [Geldeham, Geldham], $540 a, 571 b$

Yeldham, Great [Geldham], $478 a$

Yeldham, Little [Geldeham], 36 I, $464 a$

York, 415

Haughley, Honour of, 345, 389, 390 , note 392

Mandeville, Honour of, 374

Peverel of London, Honour of, $346,388,392$, note 5316

Peverel of Nottingham, Honour of, 346,388

Rayleigh, Honour of, 344, 345, $392,398,399$, notes 398,399 , $456 a, 487 b, 493 b$ 





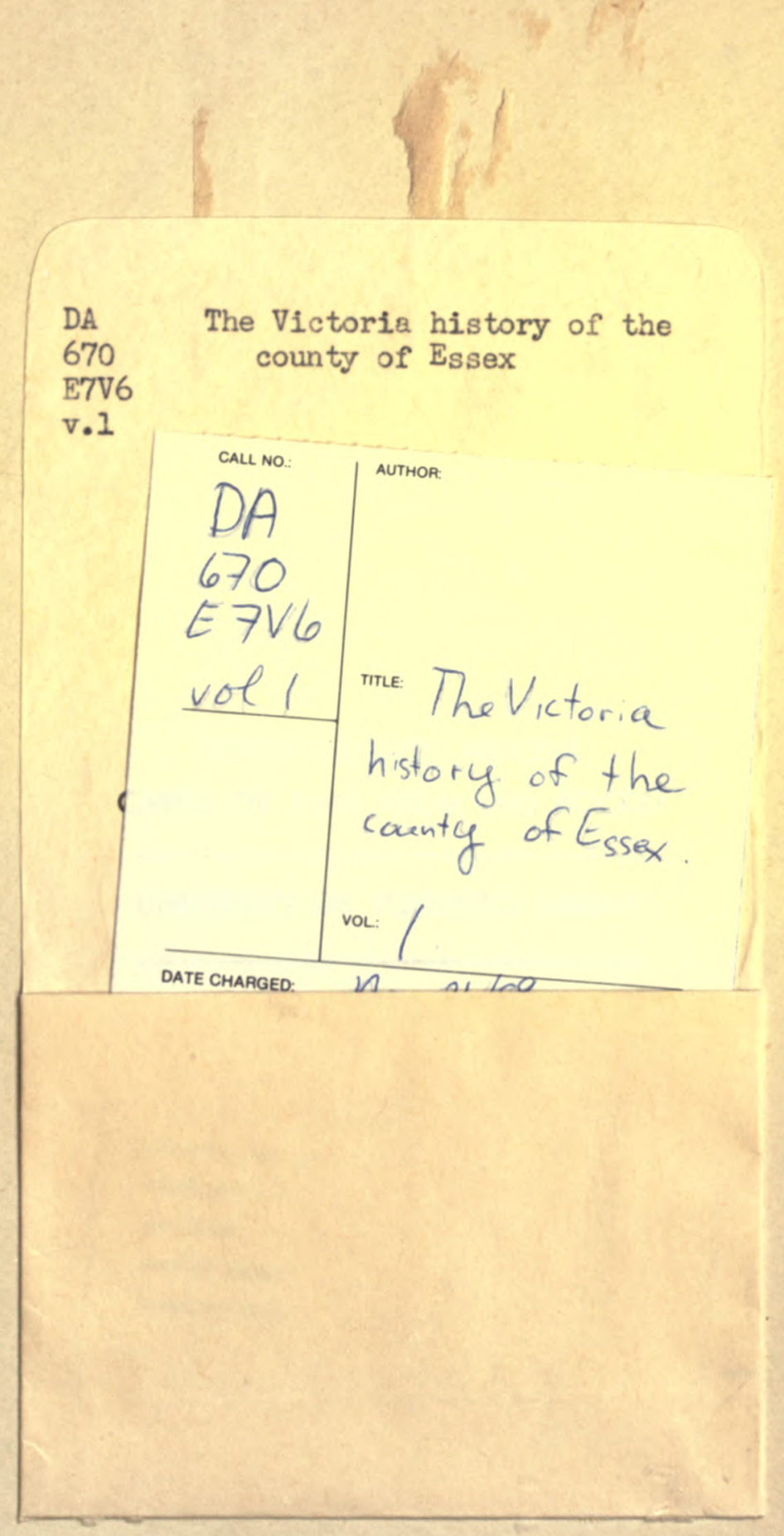




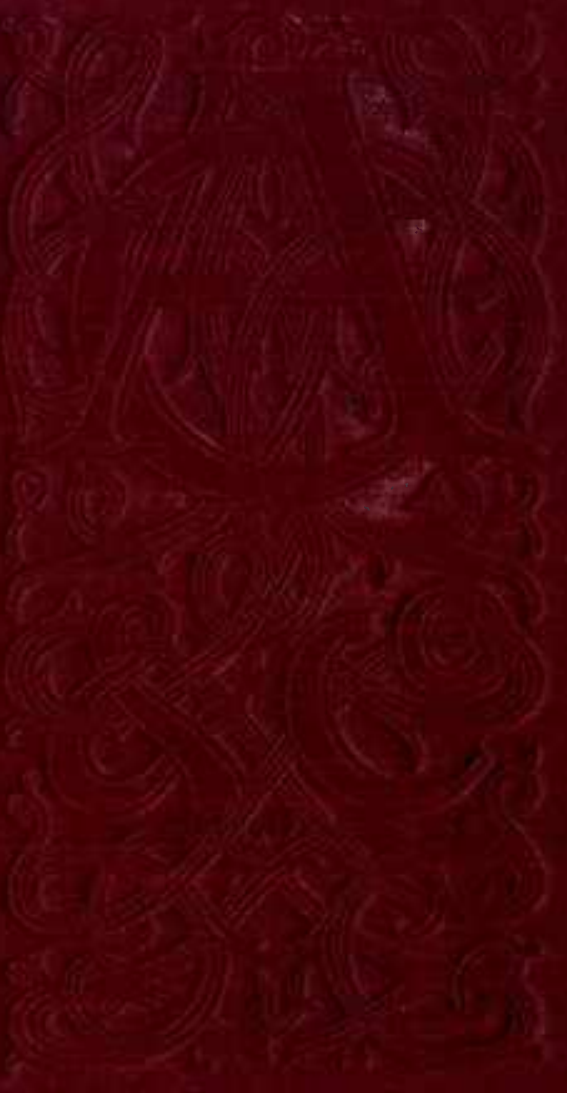

